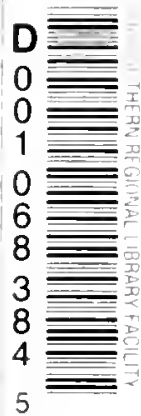

of Califorr.

Regional

Facility 


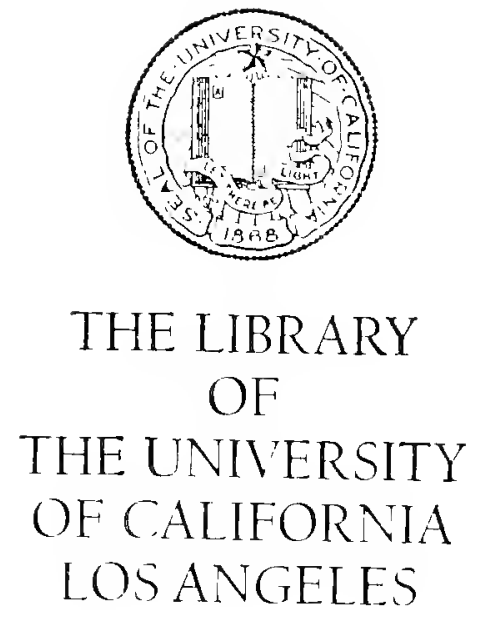




$$
\text { i }
$$

4. "

4 
Sotuthorns 


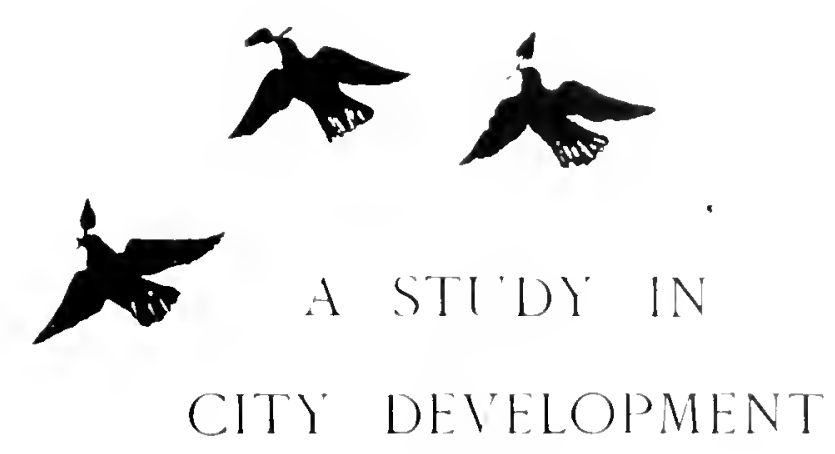




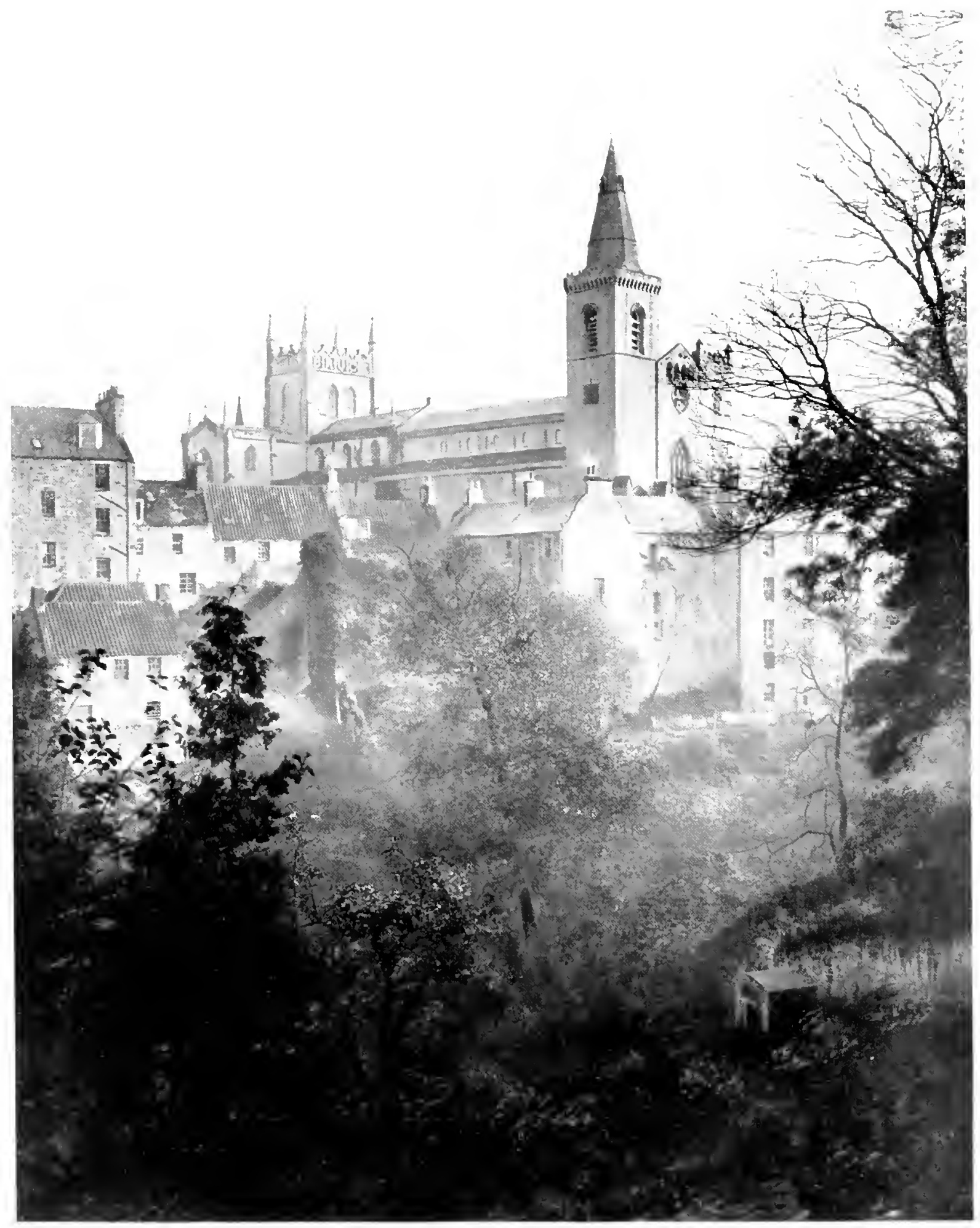

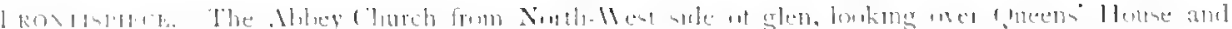

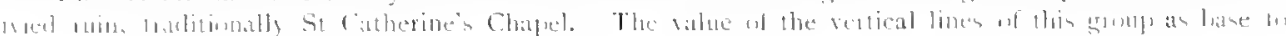

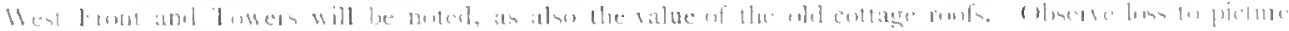

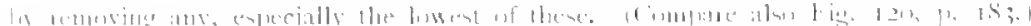




\title{
CITY DEVELOPMENT
}

\author{
A STI'DY OF \\ PARKS. GARDENS. AND \\ CULTURE-INSTITUTES
}

A REPORT

TO THE CARNEGIE DINFERMLINE TRLST

1:i

PATRICK GEDDES

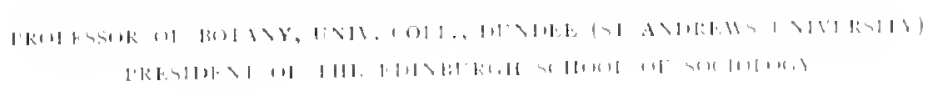

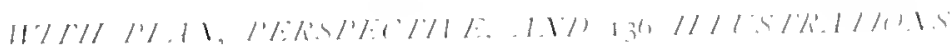

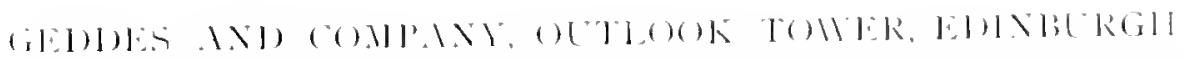

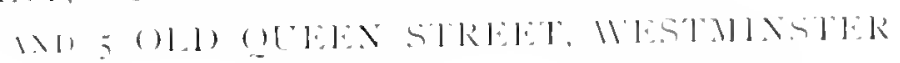

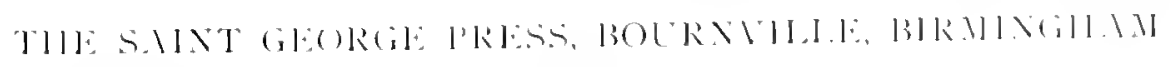





\section{PREFACE}

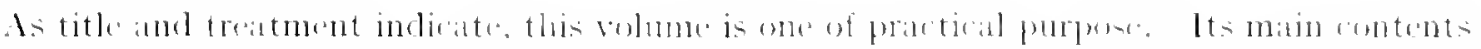

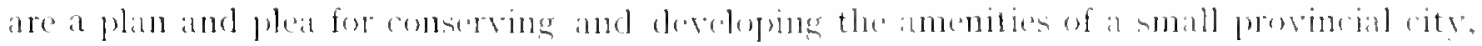

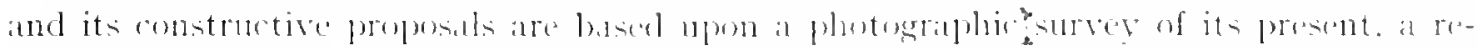

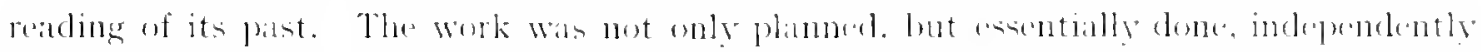
of publications, but unexpectedly numerous induiries from many centres, british and foreign, have slown that the ideas with which it deals are fully stirring. and that the deminds it is here somght to supply are widely folt. I hase. therefores to return

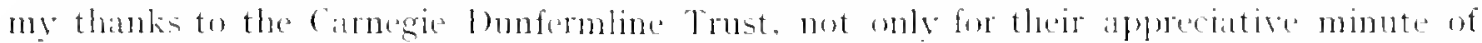
reception of the volume, bit for following this up be acouding permision for its being now mate accessible to the priblic.

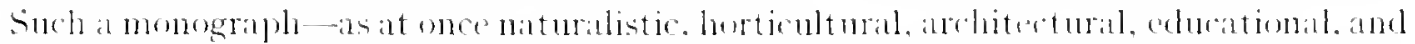
strial, and in all these respects having to utilise past history amel present resoures, frankly. to discuss needs, and boldly to indicate possibilities-cannot be prepared withont wide incpury and general retlection: in fact, its lowal questions inevitably ratise the general ones of eity life and derelopment. and these from well-nigh every point of ves. The preservation of natural beatuty. the ordered gardening of art and of seience. the intelligent conservation of the surviving relies of the past. can only be attempted in proprortion as we

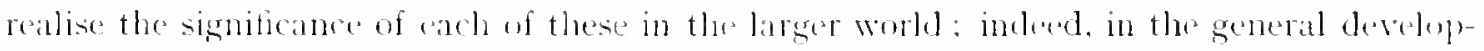
ment of civilisation. Still less without such wide surver can future developments be ontlined, for the needs and problems of health, leisure, and recreations, of educition and social betterment, are becoming much the sime for all cities. The purpose of the great gift. towards utilising whele this lieport has been called into being, has been from the fir-t explained by its donor to his trustees as not only a local but an experimental and general one: " the rety problem you hare to solve is. "What can be done in towns for the benefit of the masses by money in the hands of the most public-spirited citiens'?" Again, in the words of a reecut announcement of the Cniversity of London of its inaluguration of sociolugical and civic teaching: "With the comsideration of life in any one of our towns of to-dity is csentially commerted the puestion of what this life may beome if intelligently directed by men who are clearly cons ions of the ideal to be desired." To offer answers te these great questions, at once ideal and practiral, for any one city, a comparative study of others is neecseary, and the volume begun and planned in this olel Fifeshire cappital hats thas

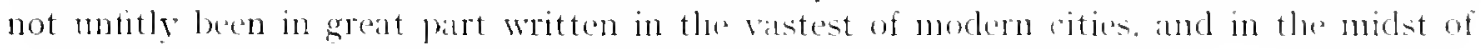
university and other teaching and study of "Civics as applied sociolugry." *

* Ar this more general treatment of civics has been lately bitid hetore the sociological society

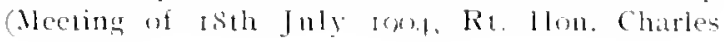

Bootle, fiks., in chair I mat bere me a tew wergluly passalgen from the comments of the

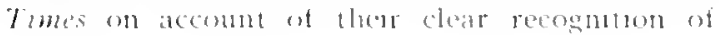


The world is now rapidly entering upon a new era of civis deredopment, one in which "progress" is no longer described ats in mere quantity of weallh and increase of population, but is seen to depend newn the guality of these. The last generation hats had to carry ont great workis of prime necessity as of water supply, sanitation, and the like: elementary education, tow, has been begme so that to some, even pionecers in their day, oms city develonment may sem well-nigh complete. but a new phase of civie derelopment has become nrgent that of ansuring healthies onditions of providing happier and mobler ones.

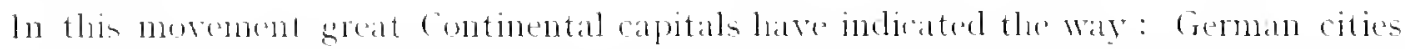
are now leading: Amerian rities are actively astir. Where one mall soutish burgh maly

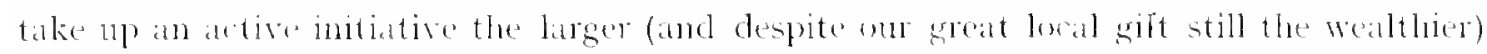
industrial and moversily eities ammot lag: nor will the great English municipalities, least of all Lomden itself, long be content to follow. In fact, social and municipal artivities, hitlerte mainly un utilitatian or remedial lines, are now increasingly progressing towards cultural lesterment alsos.

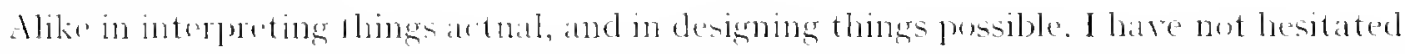
to be definite, even at the risk of critiosm. Holding a a luaturalist a brief for "regional

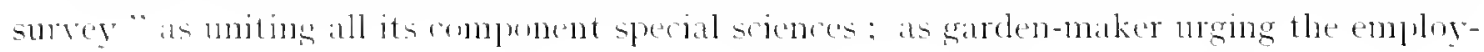

civic beterment as now bencelorth $m$ pon the plane of practical polatico, as well as of there substantal endorsement of the views here enomed.

"In the puper ly l'sufessor Gedeles-an abstract of which we print-are contamed ideas of practical value to be recommented to the study of anbitious muncupalites. Thits is the age of cities, and all the worlel is coty bulleling. . . In a dim sort of way many persoms understanel that the time has come when art and skill anel foresiglit should control what so far has been left fo chance to work out; that there shomld lxe a more onlerly conception of civic action, that there is a real art ut city making, and that it lechores the generatom to master and practise it. I'rofessor creddes truly said the land is already full ut preparation as to thes matter: the heginings of it concrete art of c1fy making are rishble at rarums founts. But onj city rulers are often among the binlest to tlese consideratums: and nowhere probulsty is to be seen al muncuplaty fully and comsistently alue to its duties in flus respeet. Lomelon may be bett ont of the questun . It wall be sone time betore it can le deall with as an organic whole. but the rulers of such communifues as Manchester and veweastle and lork roght long ater to have realised, much more than has freen clone, that they are not so much lrick and mortar, so much rateable area, so many thousands of people fortuitously bromght logether. They hate all a regional environment of thear own which determined their orgein and surowth. They liate all at rich jast, the mumuments of which, generally to le found in afmulime by caretul, reverent muluters, ought to be preserved; at past which ought to be known more or less to all the awellers therein, and the knowledse of which will make the present more interesting

such prote. . Such 'estowth of civic conseinusness and consctence, Ine awakening of cituzenship towarlscirie renascence, will he the best securty tor at worthy city of the future. . At present those who are most zealous are too often indifterent either to the past or to the true interests of the tuture. They snatch at passing. popular schemes, nestecting what would permanently beatufy their cily. .

joufeson fickles shlanced at the opening civic tuture, the remoter and higher jssues which a city's meletintely long lite and correspondingly needed forestint and statesmanship involve, the possbiblues which maty be eally realised it only there be true cric pride, toresight, and unflagging pursuit ot a reasonable ideat. It yet remains to be seen what our cities will hecome when for some generations the same spirit of pride and reverence shown hy ald families as to their puscessions has presuled over atl cive changes and developments. . Soncthng nore than open spaces, music in the protes, municipal trams anel stembats, and a senerots enployment of the rates is needed to builu and develop cities as they ought and might he. Kiskin somewhere points out the medireval love of cities. . Aftection miglit with more reason attach to the molern city if its people knew what it had been and stcadily strove to make it better, if there were in every large community fatriotism and a polity." 1 mes. 2 th fuly 104.4. 


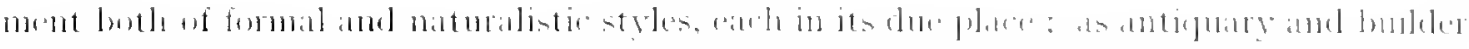

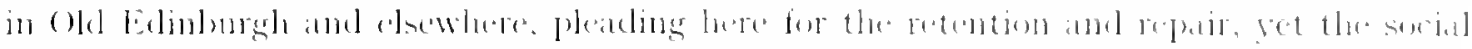

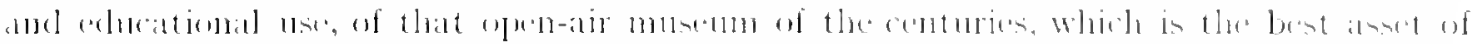

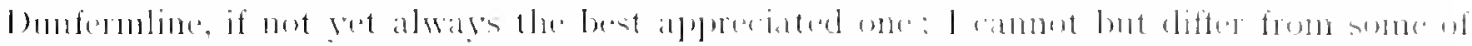

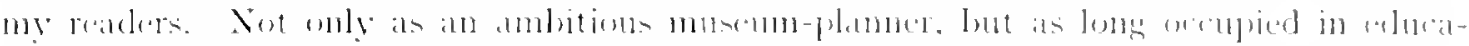

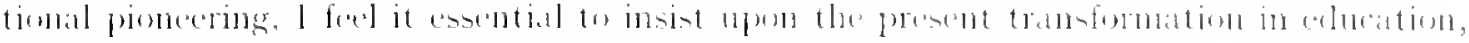

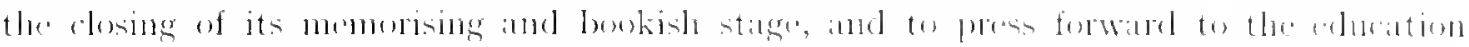

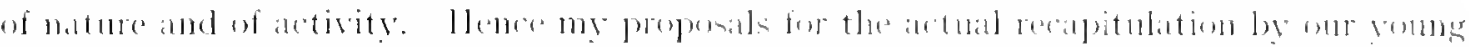

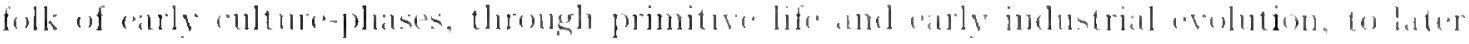

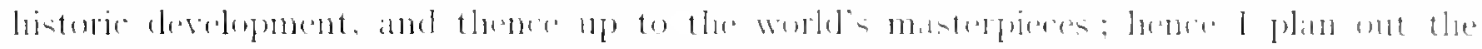

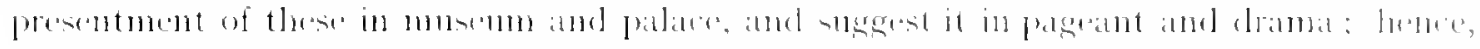

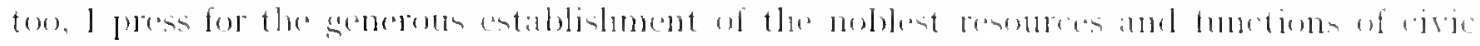
life.

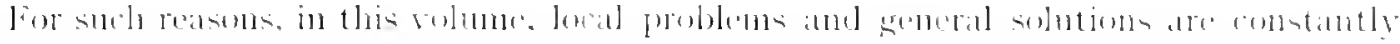

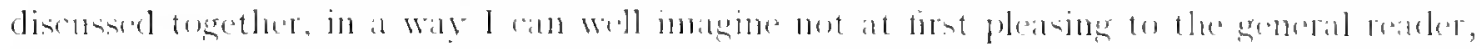

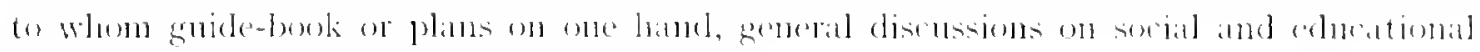

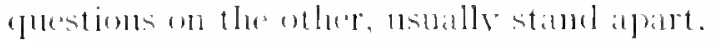

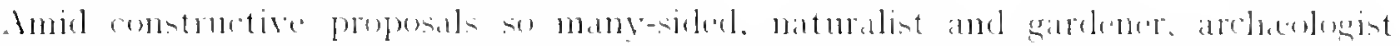

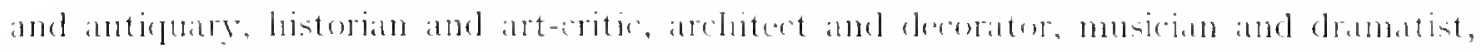

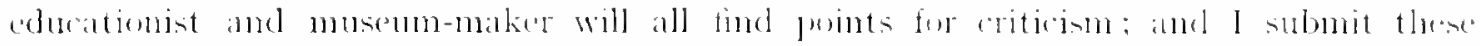

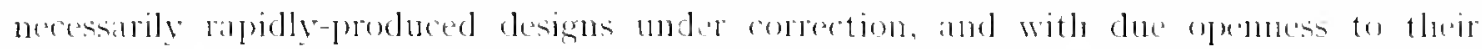

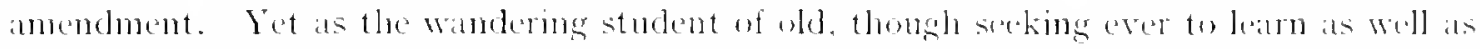
teach, was wont boldly to nail up his theses agranst all comers, so do I here. First of all I press the conception of the literature of rities as anstituting a vast " Enegeloperelia Civion." having for catel city its Book of the last, its interpretative gude-book, geographical and historical : its Bonk of the P'resent, a stecial survery and its bouk of the Future, the rity's book of lupe, in which it should be attempted to discern, to plan ant and to suggest its incipient or potential derelopment. (Grics as an art, a polity lats thus to do,

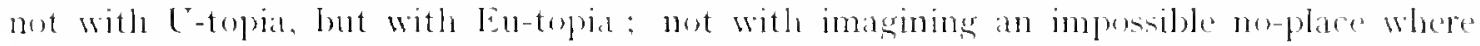

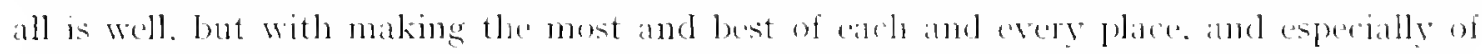
the rity in which we live. Here, then, is such a Eutropia for lounfermline, witle its present-

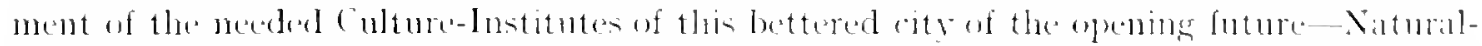

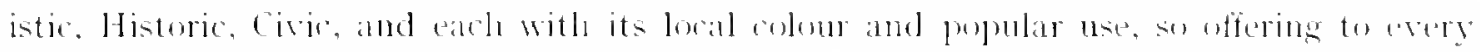
sonl full and living contarts with Nature and with llumanty, and relating individual tankis to the social whole.

Furthermore. I submit that the time has ene to be fully setting abunt the same thing

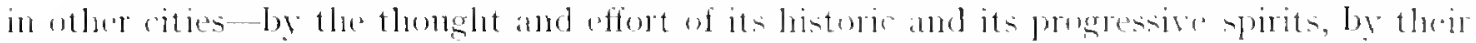

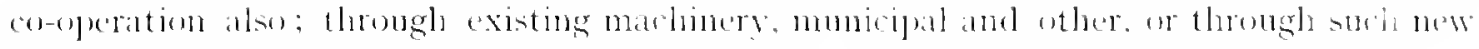

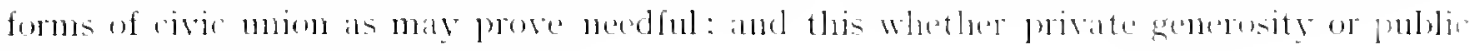
wealth be at tirst arailable or mo. 



\title{
CONTENTS
}

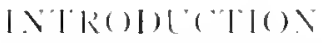

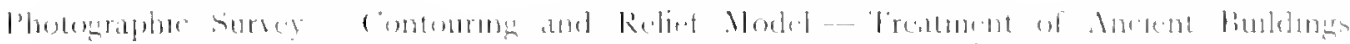

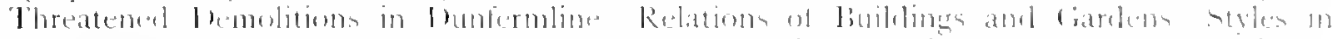

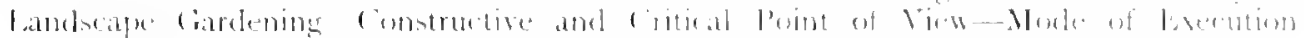

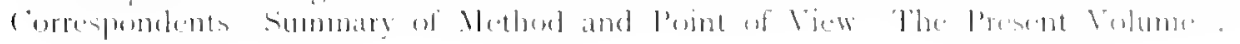

\section{$\mathrm{BOCK}$ I}

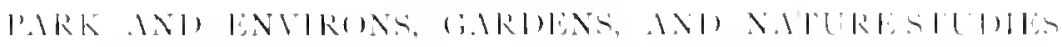

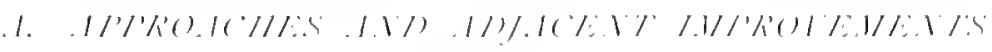

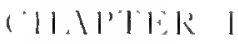

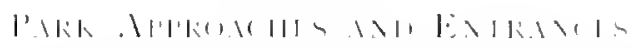

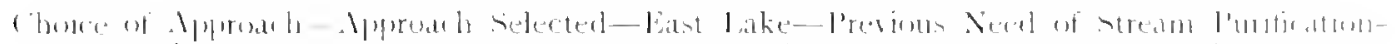

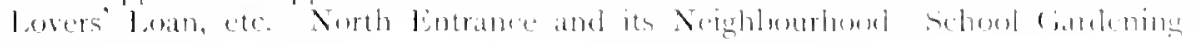

('JI'IFK I

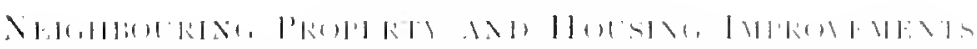

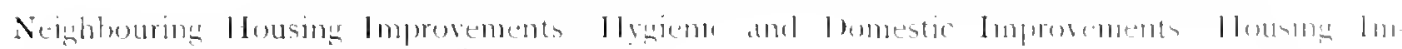

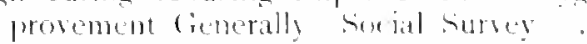

('IIIPTK 111

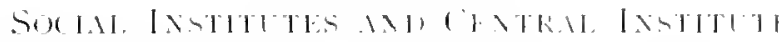

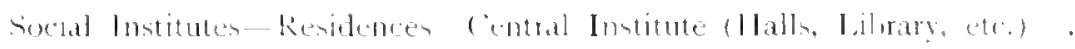

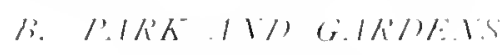

("1) INTER II"

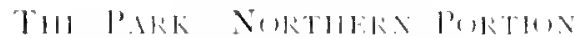

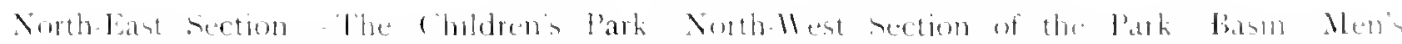

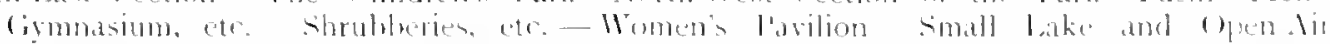

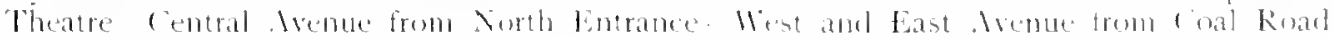
lintrance

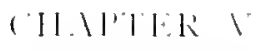

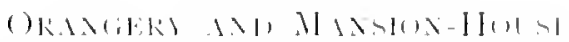

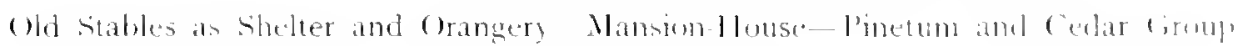

\section{('ISTEK II}

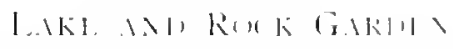

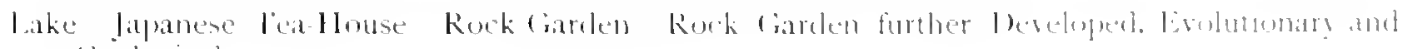
(ieological 
(ONTENTS

CHATTER VII

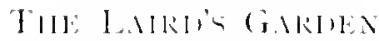

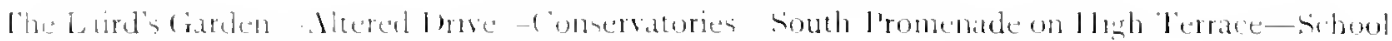
cialdens

\author{
('IITIR VH

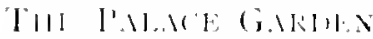

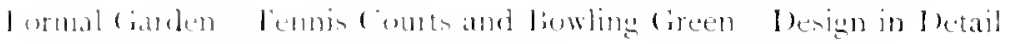

('HATEK I

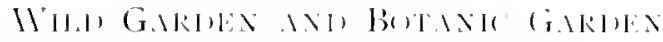

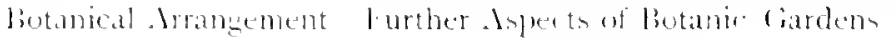

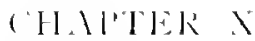

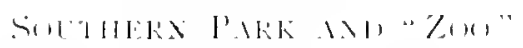

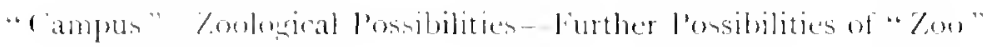

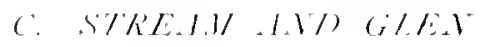

(IIAPIEli

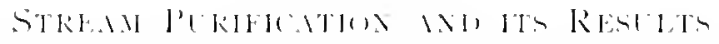

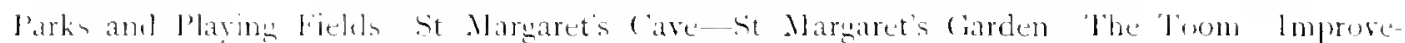
ments Uj stream - lark Extension suothwards liurther Mrantages

('IITIFR NII

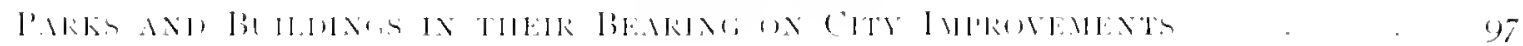

\title{
(HA'TEK XIII
}

TIII: GI,I:N

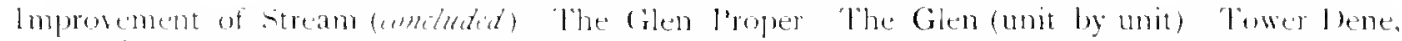

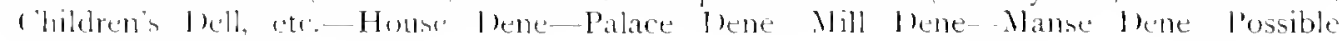
llermitage (irotto

\section{1). I.ITLKE HCSEL HS \\ (HATIRK XIV}

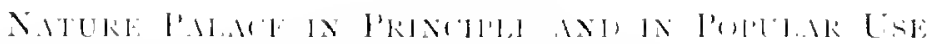

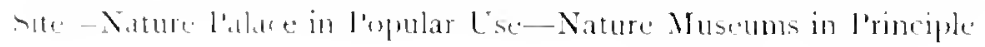

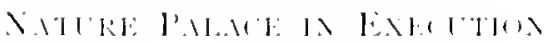

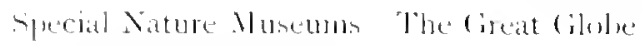

\section{CHAVEK XV}

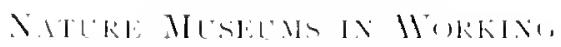

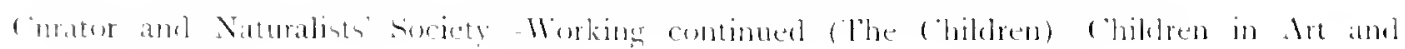
Neture. 


\section{BOOK II}

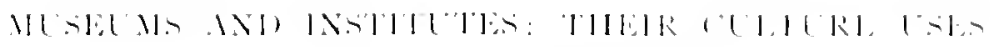

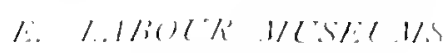

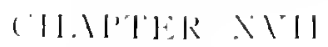

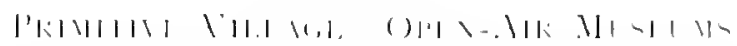

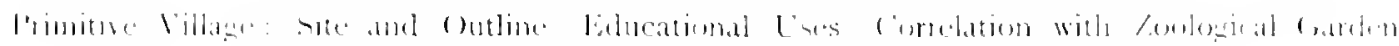

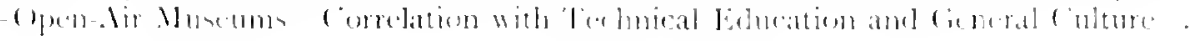

('II.MPlik XIII

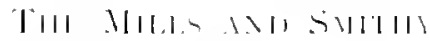

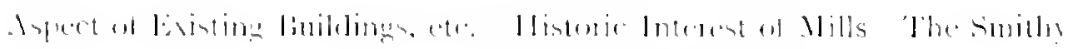

121,

('II.IPER XIN

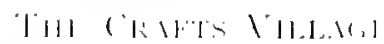

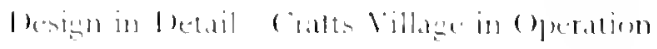

1,32

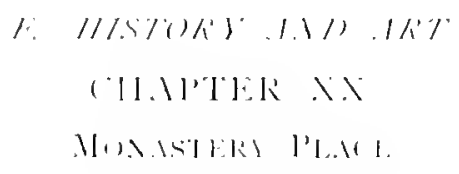

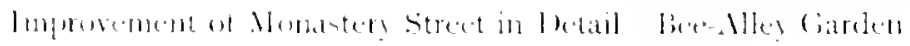

1,311

PIIIPER XXI

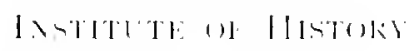

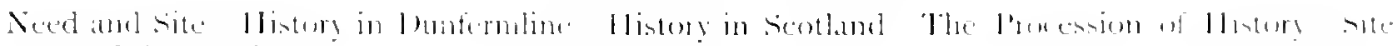
and Ipprath .

\section{(IIIIIER XVII}

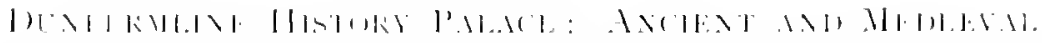

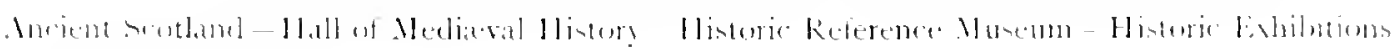
aml the ir lises.

\section{('II.1\%HK XIIH}

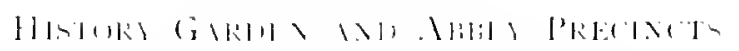

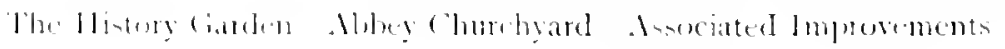

\section{(IIIIER XXM}

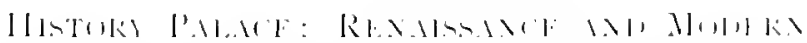

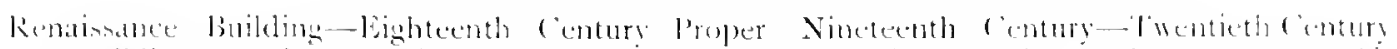

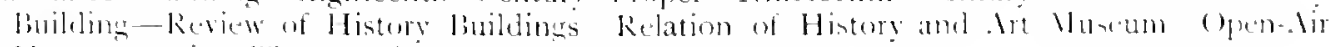

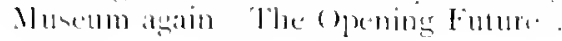

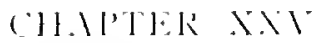

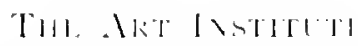

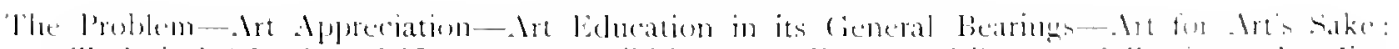

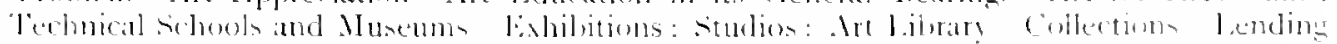

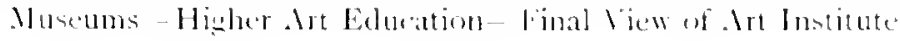




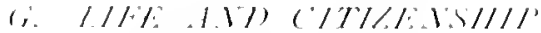 \\ ('IISIEK XNI'

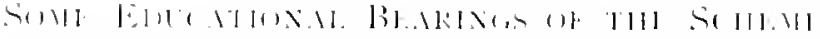

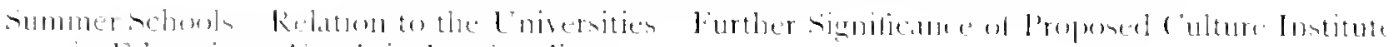
in Euluation-bouth in lombermline.

I W. F 1,70

('IATHE XXII

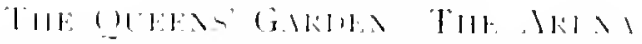

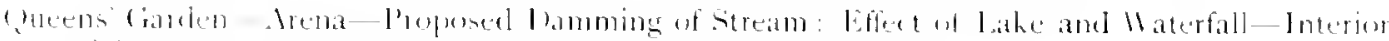

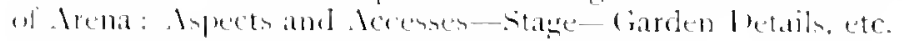

(IIPTEK XNIII

$$
\text { MI:4C II.11.1. }
$$

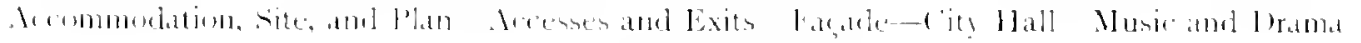
187

\section{(IIPTEK XXIN

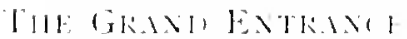

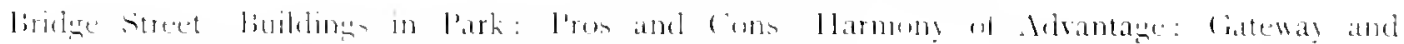

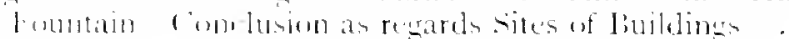

113

\section{(III'THK XXX}

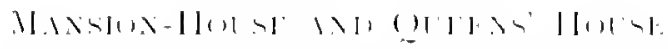

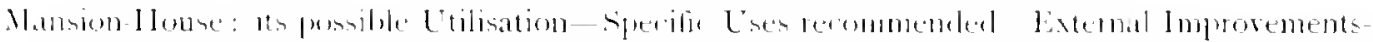

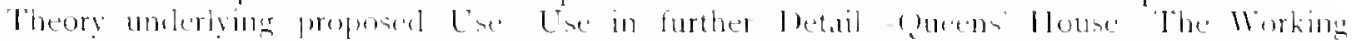

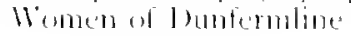

\section{ＩIIIFK XXXI}

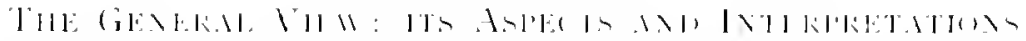

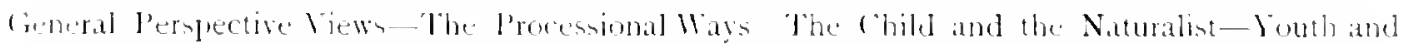

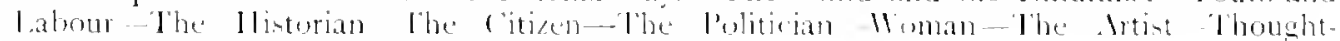

\section{CIAPTER XXXI

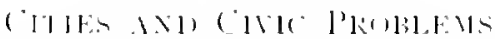

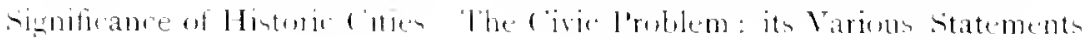

\section{('IIITER XXXIII}

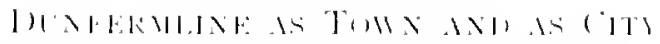

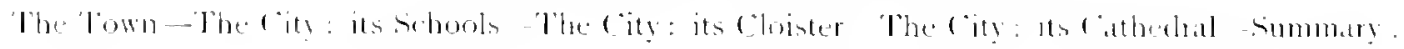

\section{(11.PHIR XXXI}

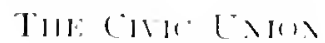

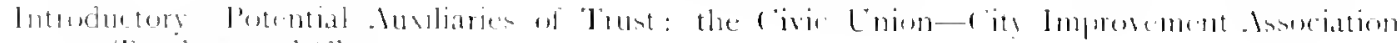

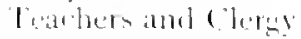





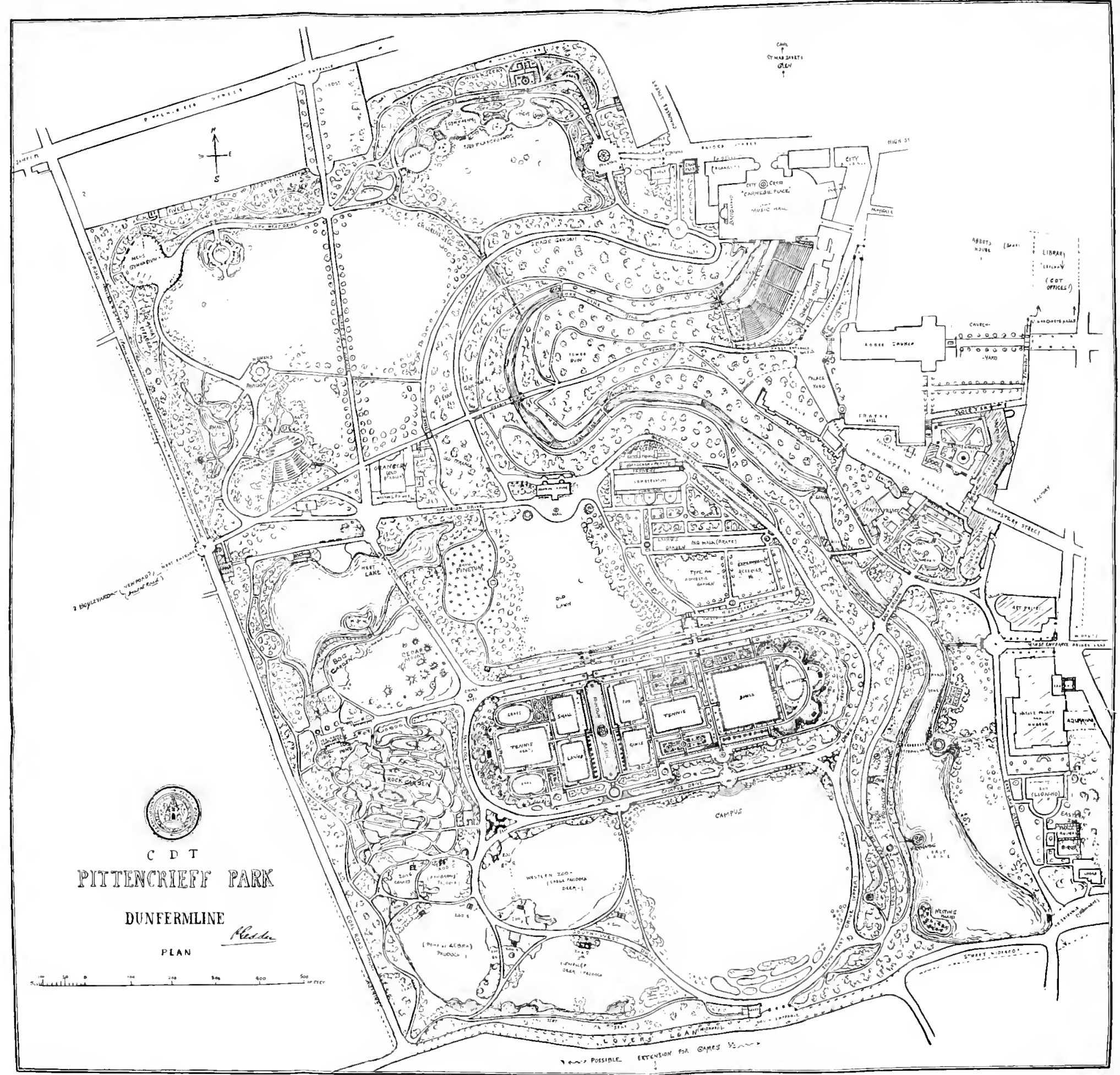

Fig. I37. GENERAL PLAN OF PARK. (See note, page 20.) 


\title{
PARK. GARDENS. AND CI'LTI'RE-INSTITI'TES
}

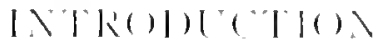

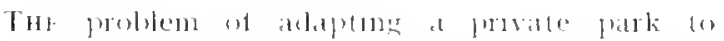

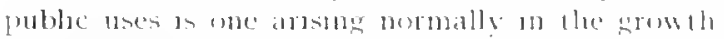

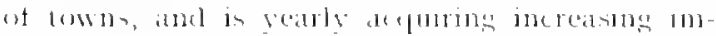
portance, llere, beweser, the preblem tats peculiar adelitumal elements at meterest first,

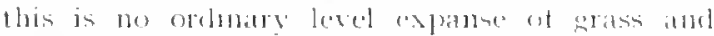

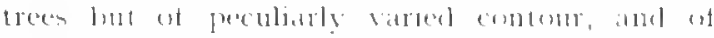

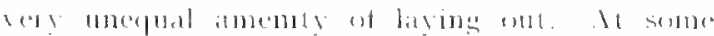

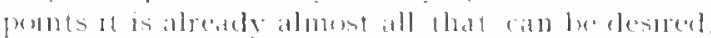

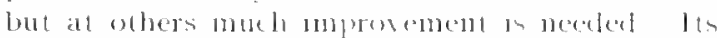
principal teature a the Gilen penter, at ravine perhaps only roalled an regards scemery among pullic parks by that of Jommond bene at few castle; while in weallh ancl ratieds et architer tural views and remans and of hatere mterent

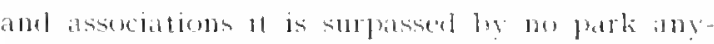
where.

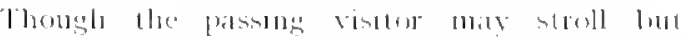

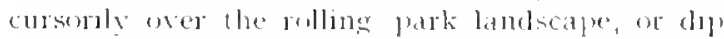
here and there inco the shaty lell, the parti improver must jom with the geograther in laying down tirst of all a therougle survey of the whole contom, and whth the gentegist an sturlying the rocks molerlying and expresed, inul not only the

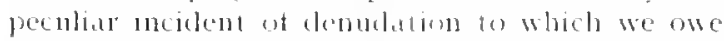
the Tower Hill but the strean ilkelf which lelis done the work. To find this enternge the part baten with every torm of pollution, mechanical, chemical, and organic, is me donht a partial ex-

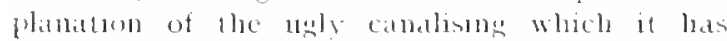

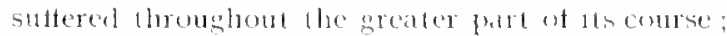

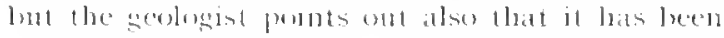

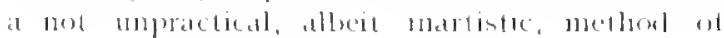

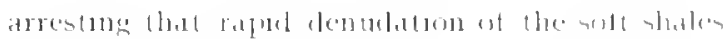

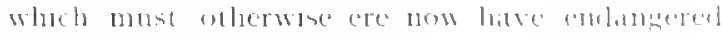
lonle ladace ansel mansian.

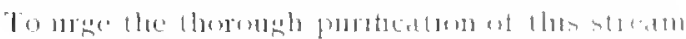

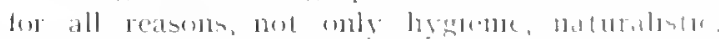

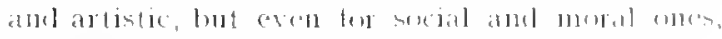

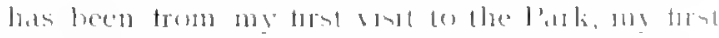
furefomal, and stoll is ars.

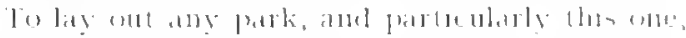

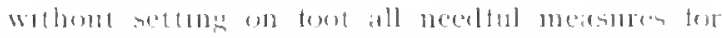

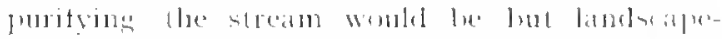
satrelenung whal is all present il dratn, and in.

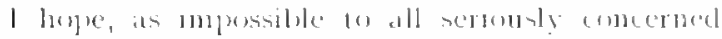
ats would be the taçadurg ot at slum, or the sfreate

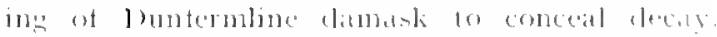

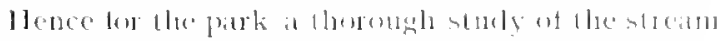
and ats tribulaties aluse bats leen newessaty

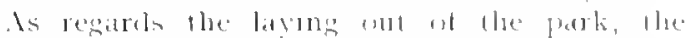
ordmary complitions and repuirements of exalmon

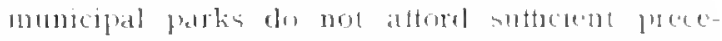
dent. These refurements as lor gumes, eten, atl exist, and can be partly nat npon a peneroms

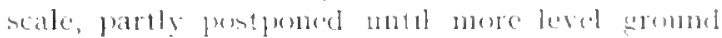

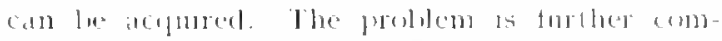

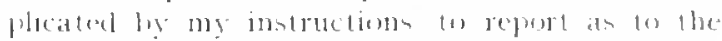

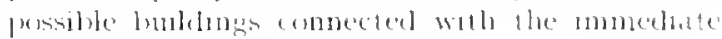
atul tuture work ot the Trust.

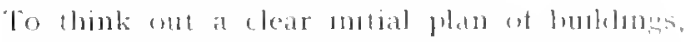

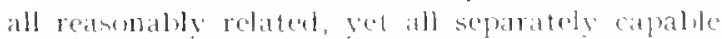
of extension with the esereferelophe replute

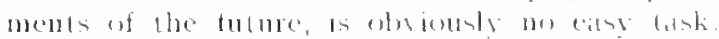

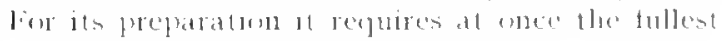

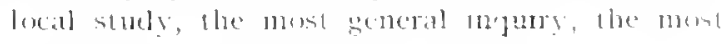

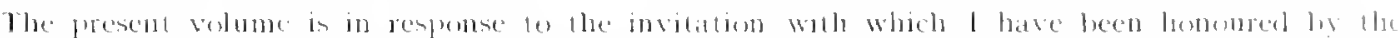

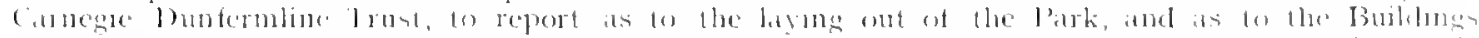

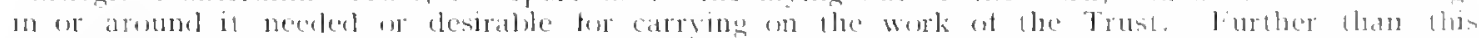

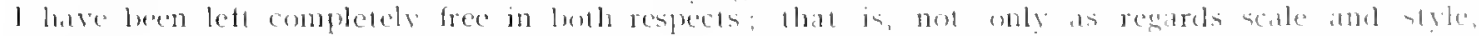

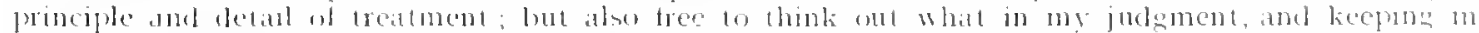

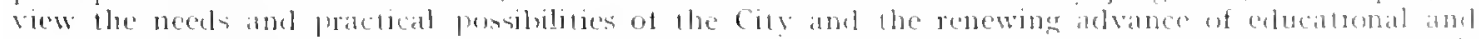

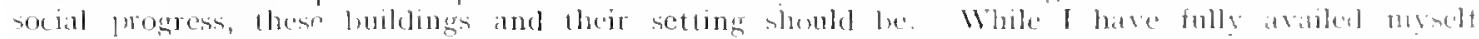

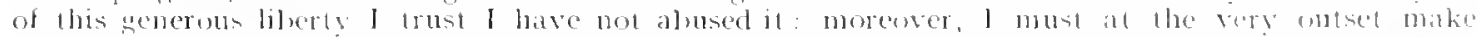

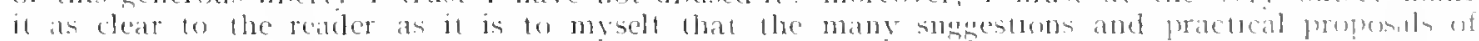

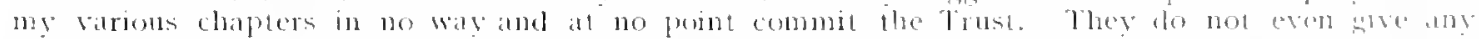

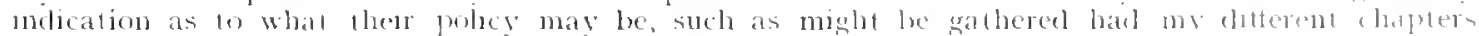

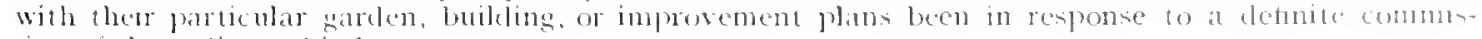
won of the ordinary kind. 


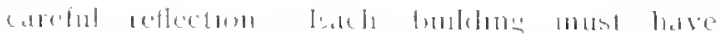

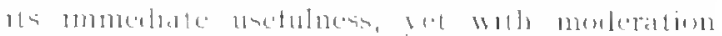

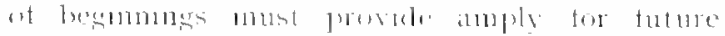

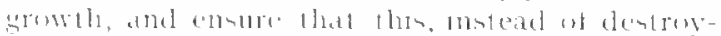

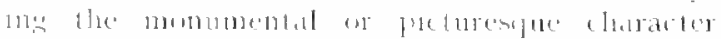

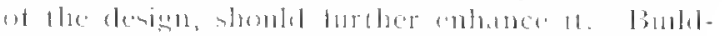

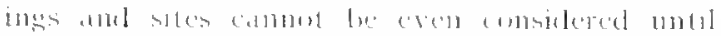

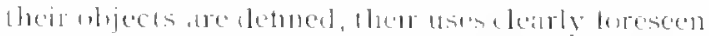

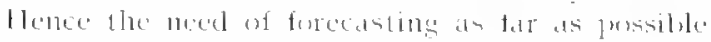

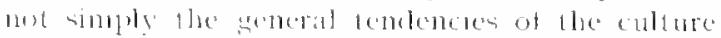

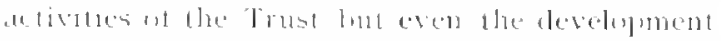
in the letsulte branches ot thene, and of call

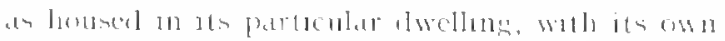

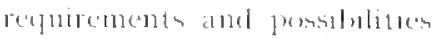

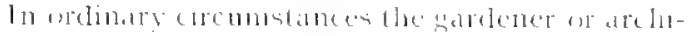

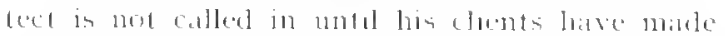

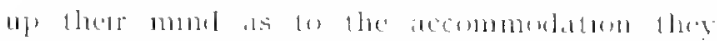

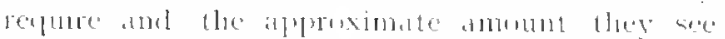

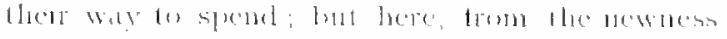

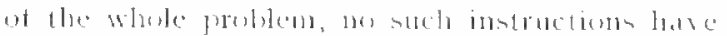

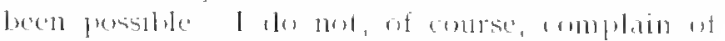

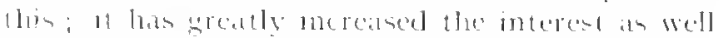

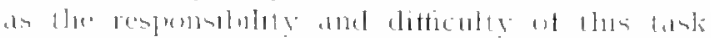

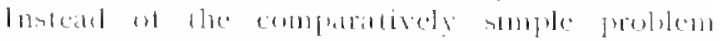

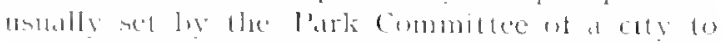

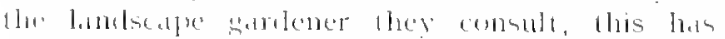
undwombly developed into that of thinkin: ant, and comeretely expessing in plan and perspective

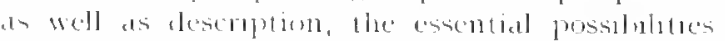

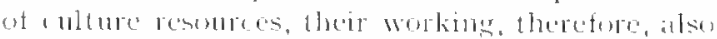

that is lo sily, the problem compels its omo

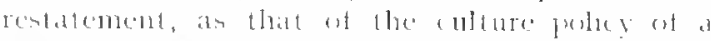

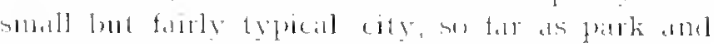

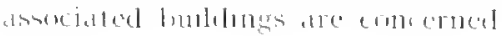

\section{A. Photographic Survey}

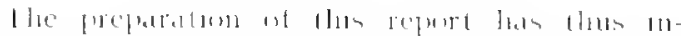

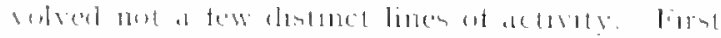

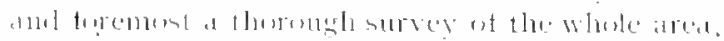

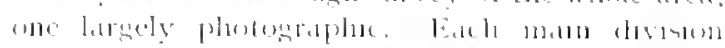

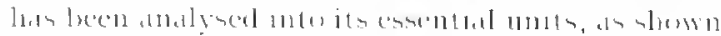

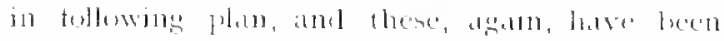

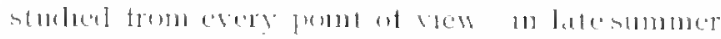

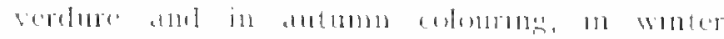

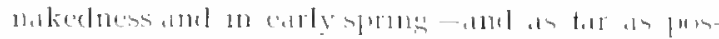

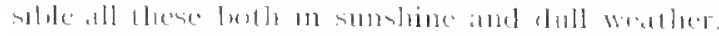

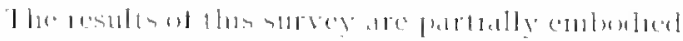

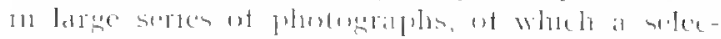
tion enly are repunduced here. At these only

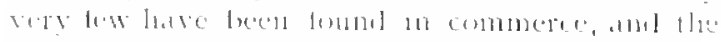

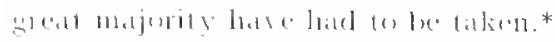

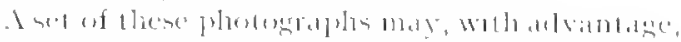

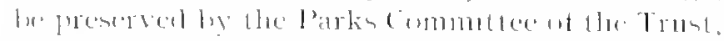

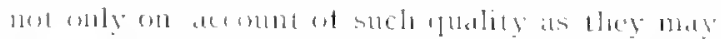

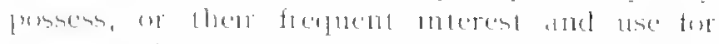

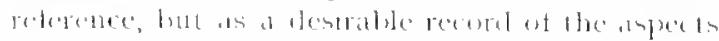

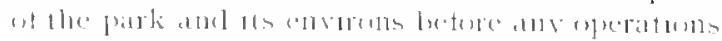

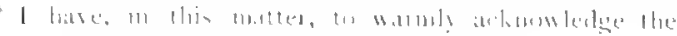

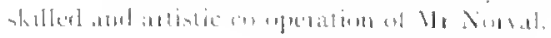

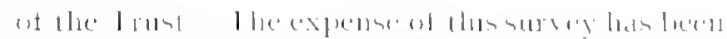

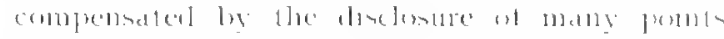

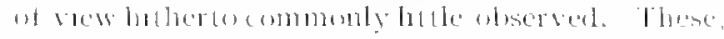

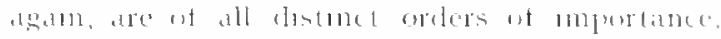

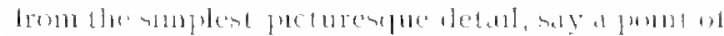

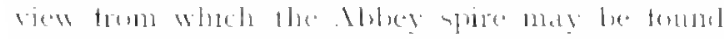

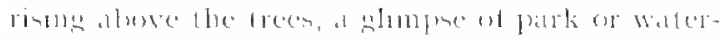

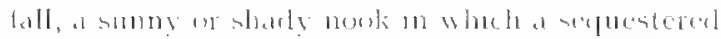

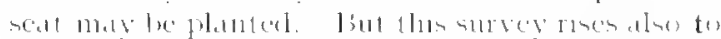

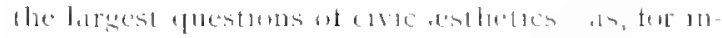

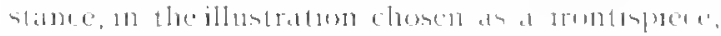

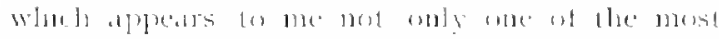

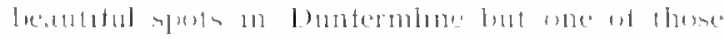

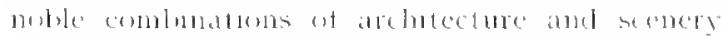
wheh are rate anywhere. 1 gureater abley

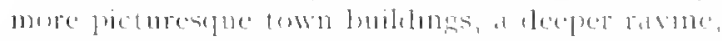

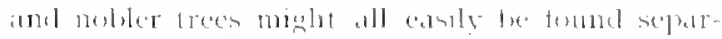

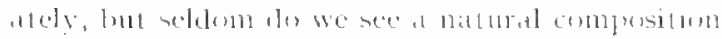

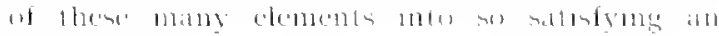
artantse $11011 \mathrm{~s}$

\section{B. Contouring and Relief Model}

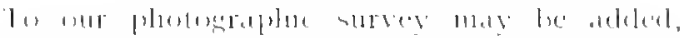

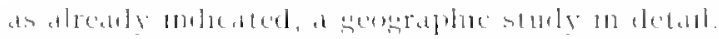

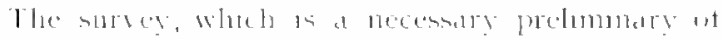

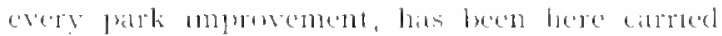

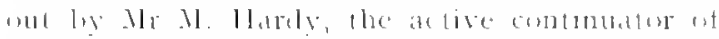

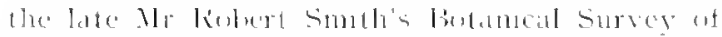

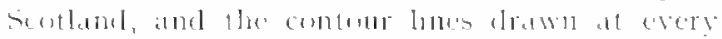

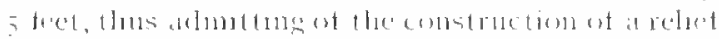

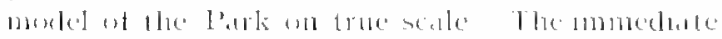

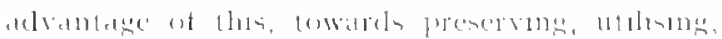

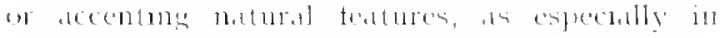

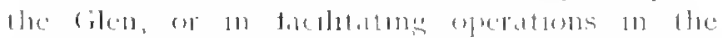

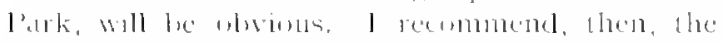

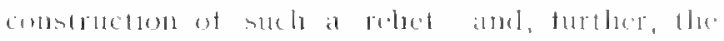

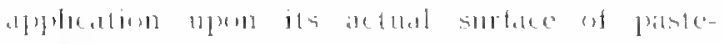

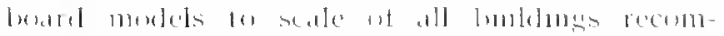

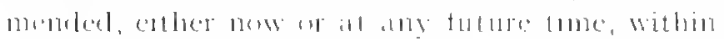

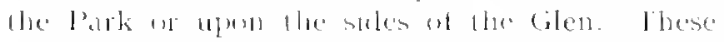

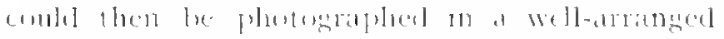

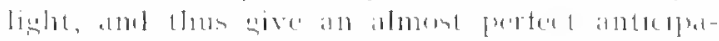

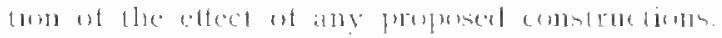

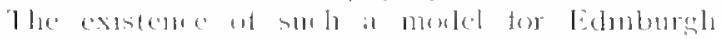

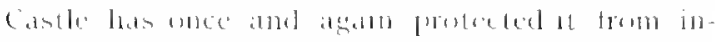

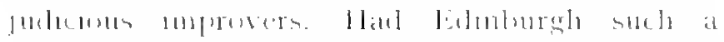
menlel, the recent destructeon of its matin bew

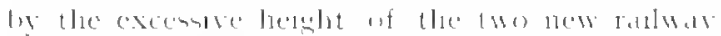

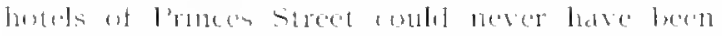

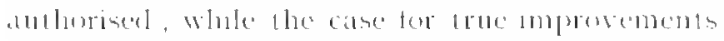
would le ereatly strenstremet, the propulat

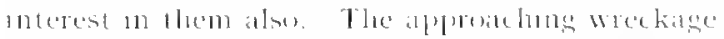

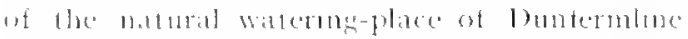

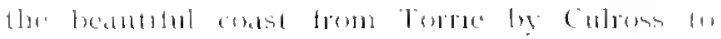

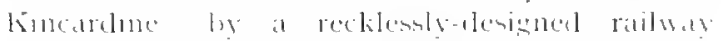

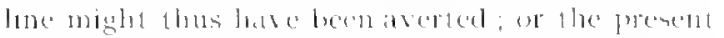

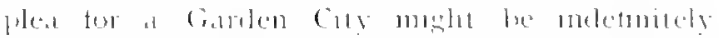

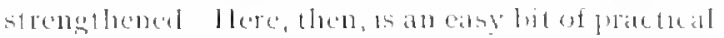
fonecring it the very tirst the comstruction of 


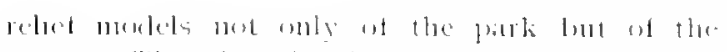

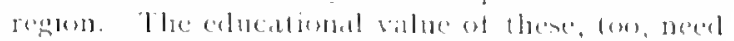

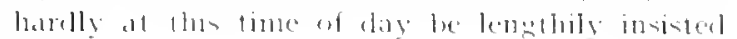
แ’)

\section{Treatment of Ancient Buildings}

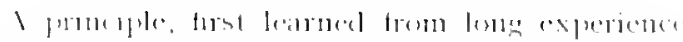

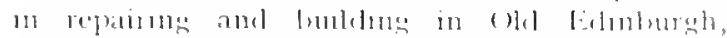

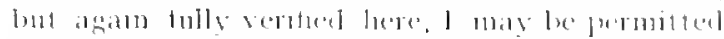

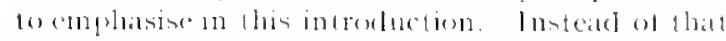
merely andighatian respere of the seanty sur

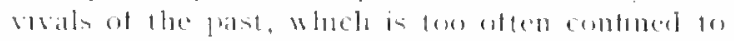

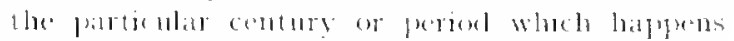

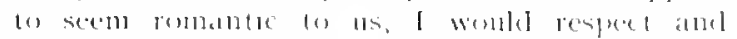
preserve examples of the bonest and thateteristic work of eate and crery perrod, whether frem an present jusint of vere also a presing

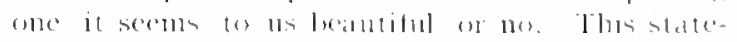

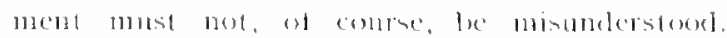

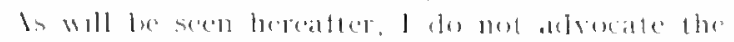

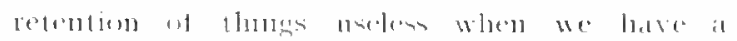

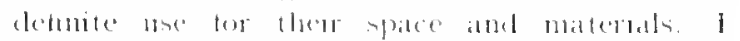

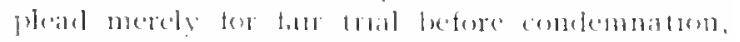

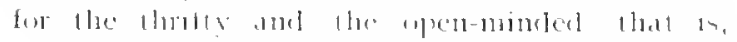

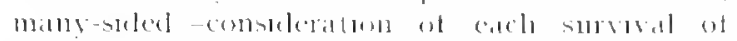

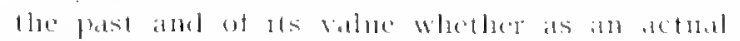

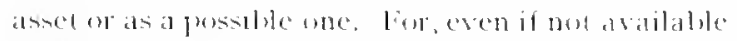
in 1 ls present form tor immerlate use, I have

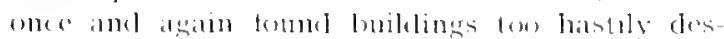

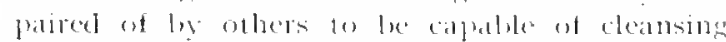
and repair, or of alteration and incerporation

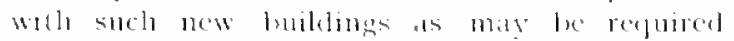
in shorl, of renewerl nsetulness and eren heatuls

Ally meastre at success which maly helve allended my fersomal imporement work of the lase serenfeen or cighteen years in sume three domen closes

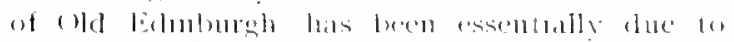

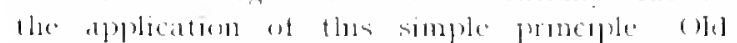

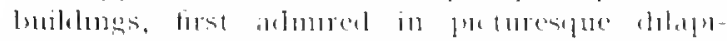

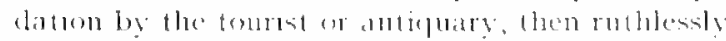
concemned as ent of date hy the miltentan, on mondolesome by the tens corme illor, were often fomel caftelle of handhang trom a pout which hatrmonised the partide truth of all these stamelpesints

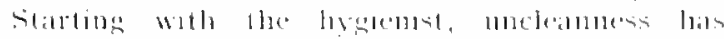

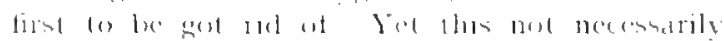

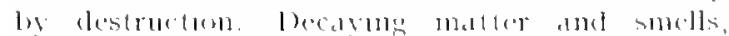

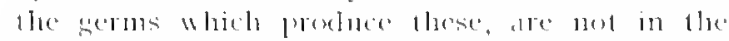

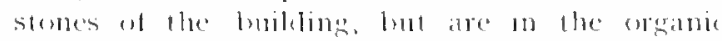
dirt superfictal to these Cleathe and desinfert in this wats, and the old building maty then tre wholesmer than the averase ninetenth-century one, who dis mpertect dranage and onher defects ()d masol-wotk is not discredited he weathered suldace; cren cracks often indicate a loug past sellement, not an increating weakness, and 11 any case are more easily reprated labu perple generally suppose. After cleansing and mending. the antique bulkling is frankly adapted 10 its molern uses, with sanitation, electric light, and

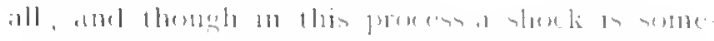

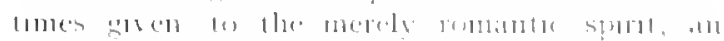

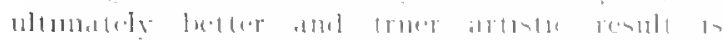
reachel, espechlly when, whth whe and weatheralla.

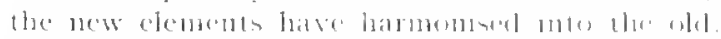

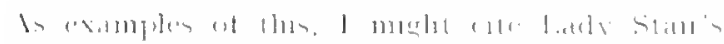

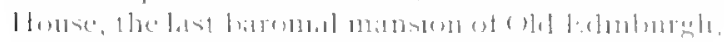

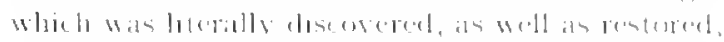

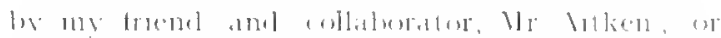

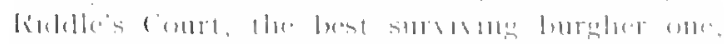

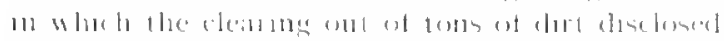

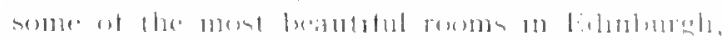

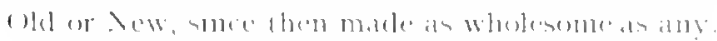

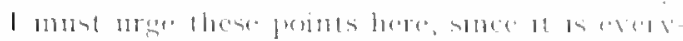

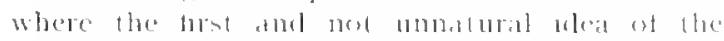

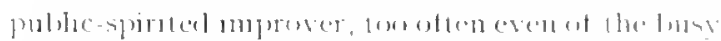

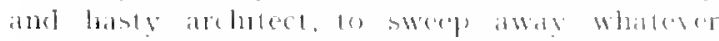

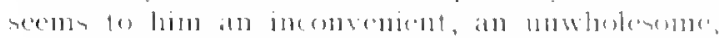

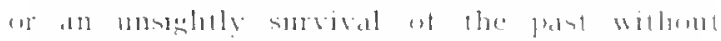

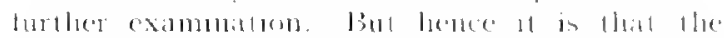

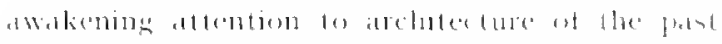

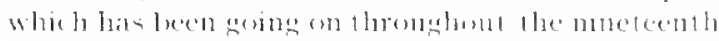

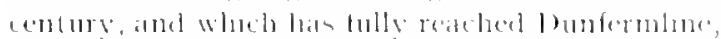

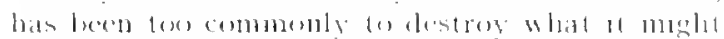

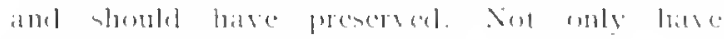

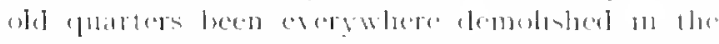

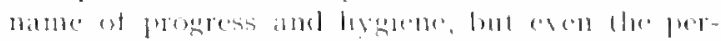

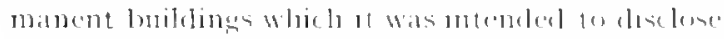

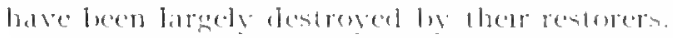

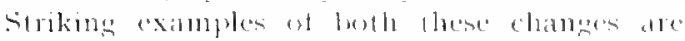

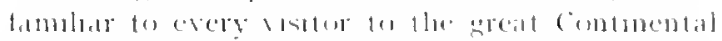

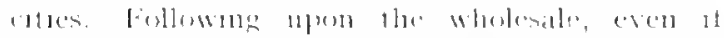

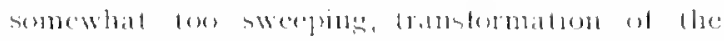

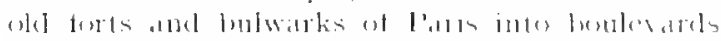

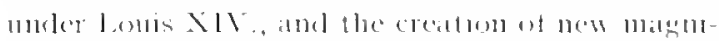

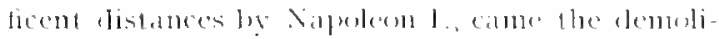
(jom and recenstruction of the erregulat laternth

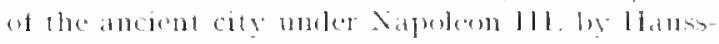

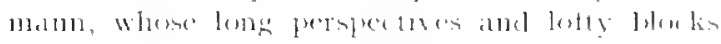

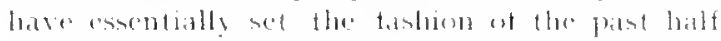

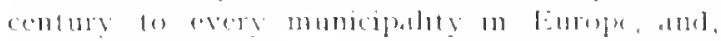

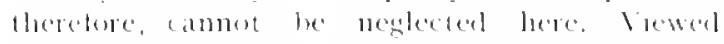
from the street, the aplereme advalutage in

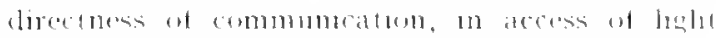

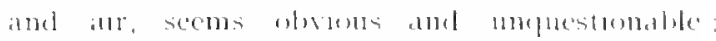

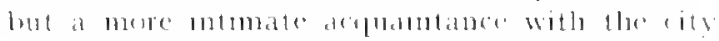

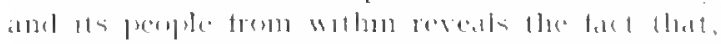

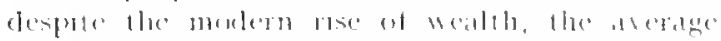

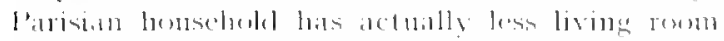

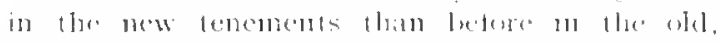
and this at tar greater cont her rent and lases.

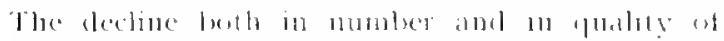

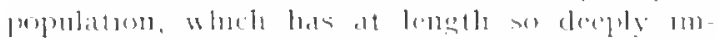

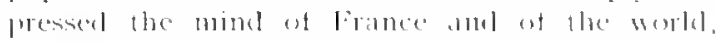

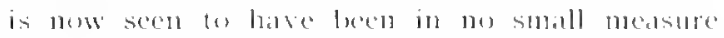
accolerated by these conty impromemonts Moreover, wh thlle knowledge est the city and ats

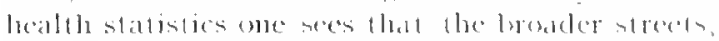

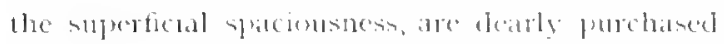
by llue loss at the ample coutes the old gardens,

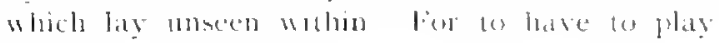




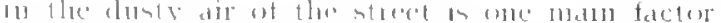
un the Weakness of tomn thlilen

lhe moral of all the as the verg sinmple one.

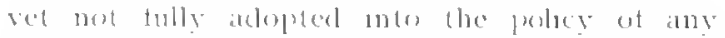

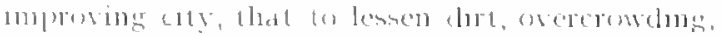
ded the rest we shomld not merely relieve our

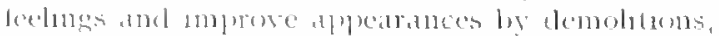

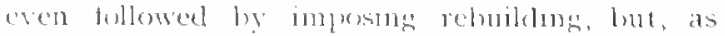
lar at may he, improve the old and buld new

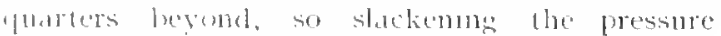
ot fopolation npom halitalion, not mercasing it

Commenext to the steat surviving monuments,

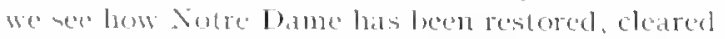
at the crowded old bublungs which chusered about jts feet, and now stimas detached upon

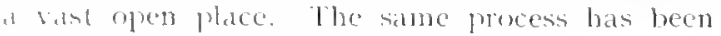

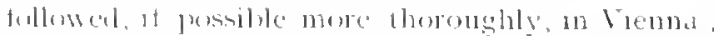
most of atl tor the eahexlral of colones, at wheb

\section{Threatened Demolitions in Dunfermline}

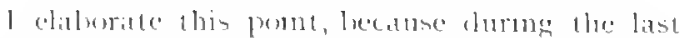
six monthe l hare not amly cemsantly hearel,

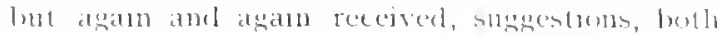
ly worl and letter, ats lo the desigalulate of demolishome thes and that past clement at ald

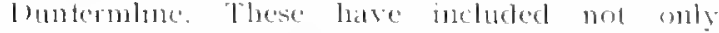
the mont chardeteriste abl leatutitul teatures of the old tomm, such as the Mhluet's llonse itselt,

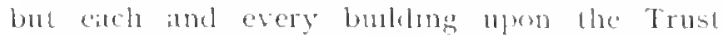

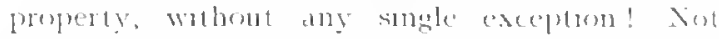

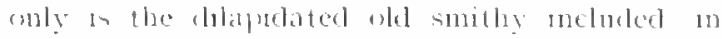

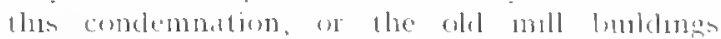

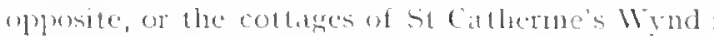

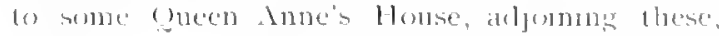
more momedately below the Ahley, in spectally

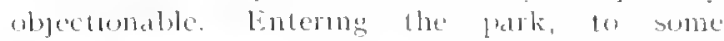

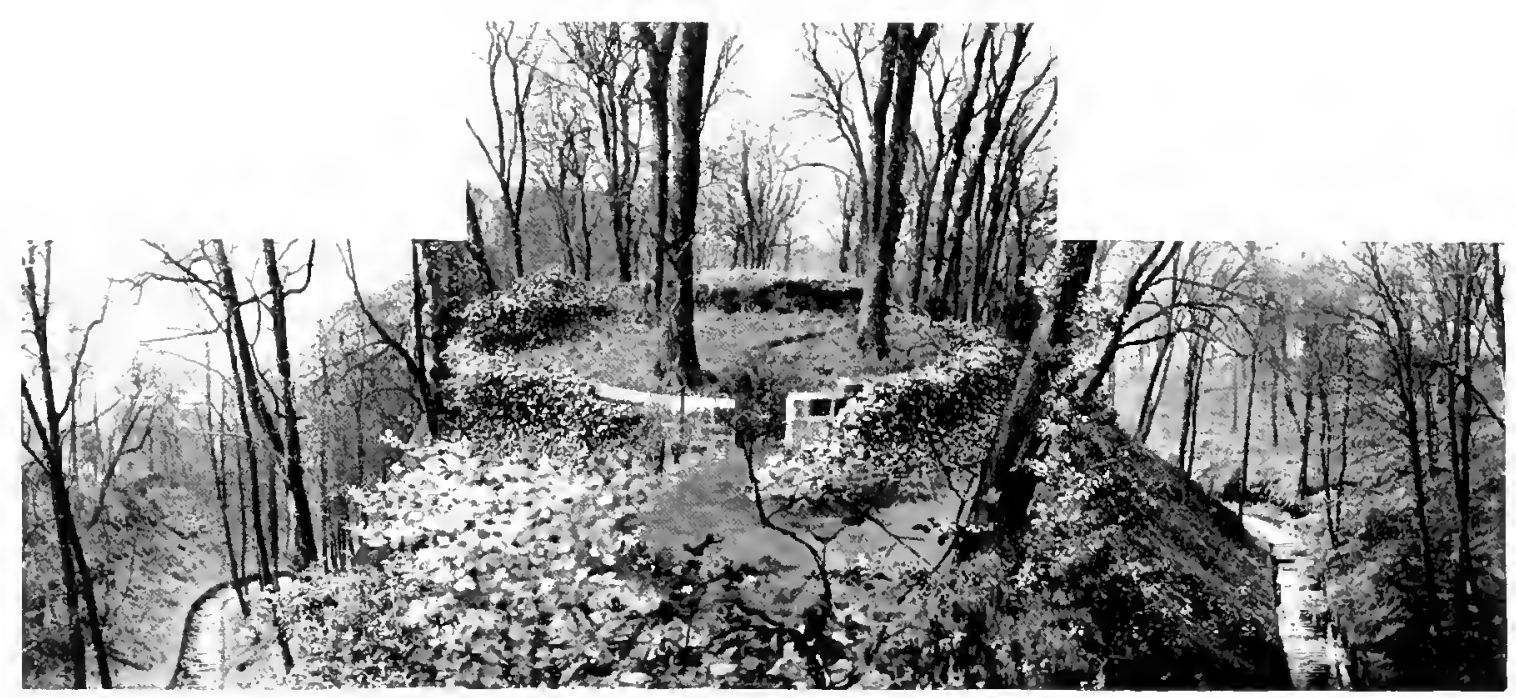

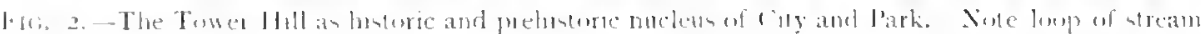

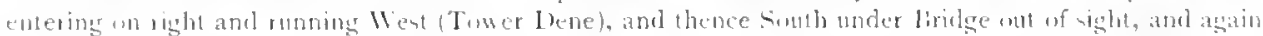

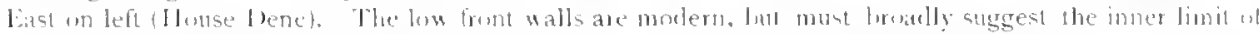

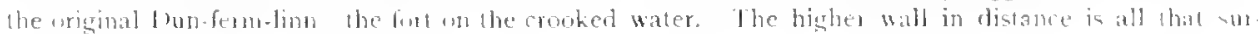
bive of the eally neeli,utial twer.

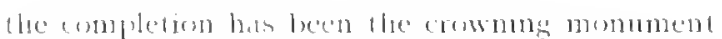
of froman tonty. Ind all whth what result?

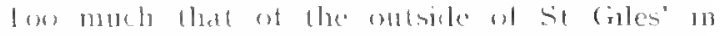
fidmburgh, whth its ancent exterior destroyed

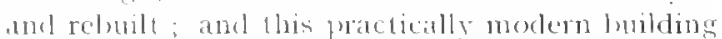
loblued eren al its ancient loluness by the removal of the clustering bublings wheh, thomgh seeming

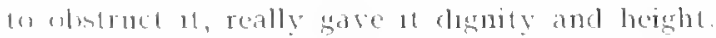

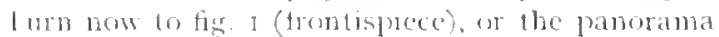

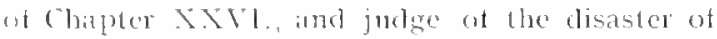
removing the oll coltages and houses helow the Albey tomest and spirce comsider, ton, the disater lo Dunfermbne and Soothand, trom the fise that the accompanying figure ol ont fower Hill has nothing mole of lts ancicent hublings (1) shent!

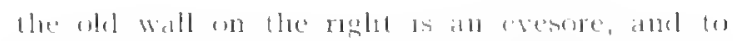

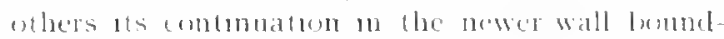

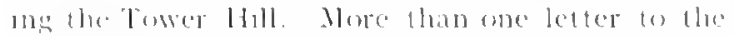

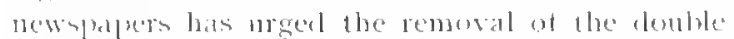
bralge, or its replacement by some more modesn piece of empineerings. To smove the plan and buty bak ot the old mansion-lanse maduly decpens the permanent shadow of the slen at this pont; while the dulness al the west aspere of the

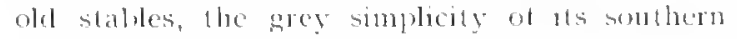
front, turnish conclusive arouments to others

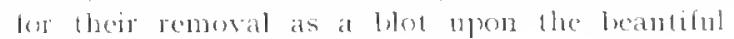
pate labdscale around.

() bler correspontents, it is tair to note, find theil special abhorrence not in the work of the fiftermth, sixteenth, serentermth, and einhtoenth 


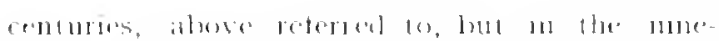

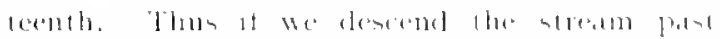

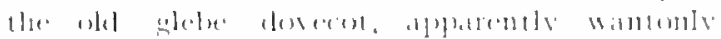

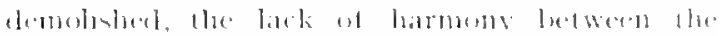

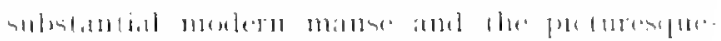

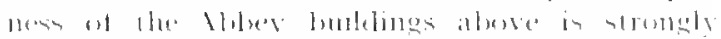

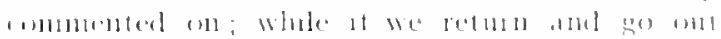

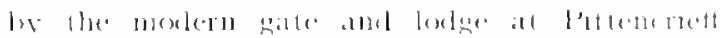

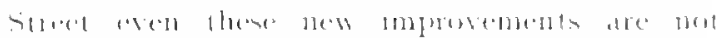

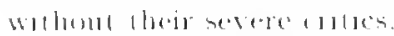

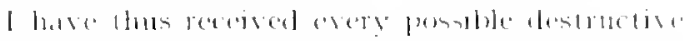

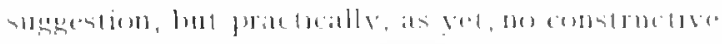

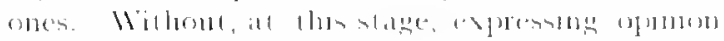

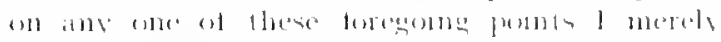

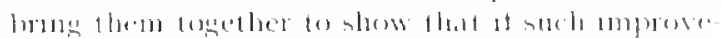

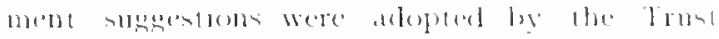

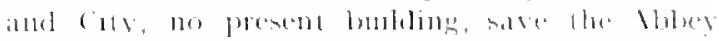

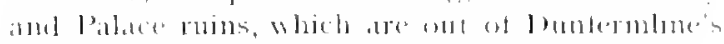
power, wombl hong remanth.

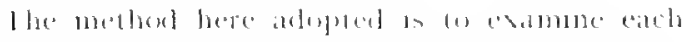

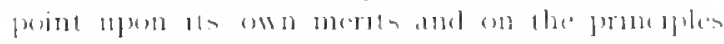

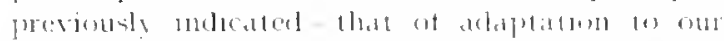

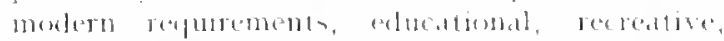

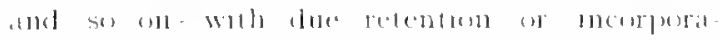

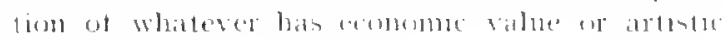
fintuess.

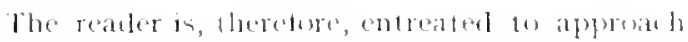
this question with an open mond, ats flue writer

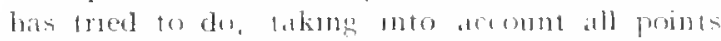

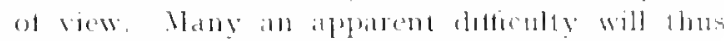

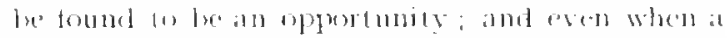

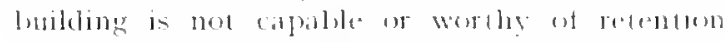
as it stamels, it may serve at any late as all che

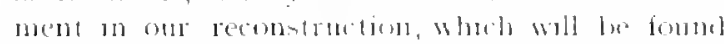

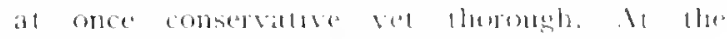

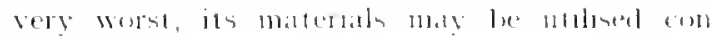
structivaly

\section{$E_{1}$. Relation of Buildings and Gardens}

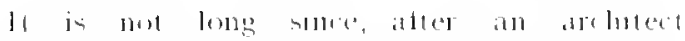

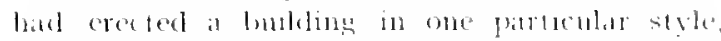
the cheme called on at huse-pronter, whe there upon decordted 11 in anomber: whle a nursery

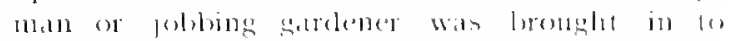

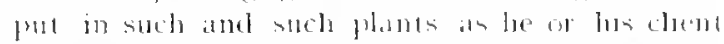
pledsed, withesut rederence to edther of his pro.

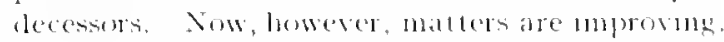

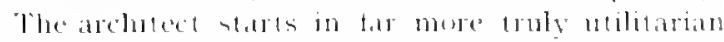
tashion, and wotks ont the specitic pratedical

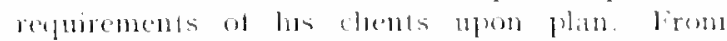
thin the desaton naturally arises, The efted of thes clevatum defents primanty upon ats masses; the proportion and the light and shate atre alse trom this, ats does the colour sebeme from the appropratle materid: whe the trati-

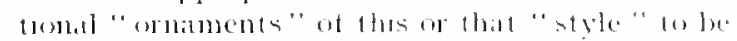
foumd in hooks, and tollowed ats a " puredente,"

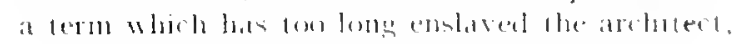

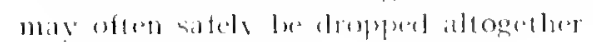

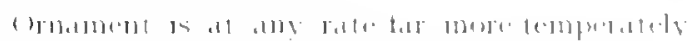

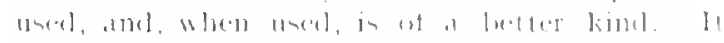

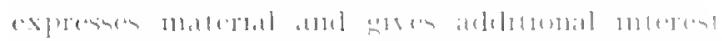

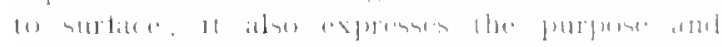

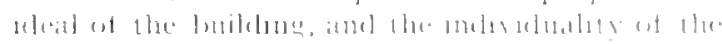
at $1114 t$

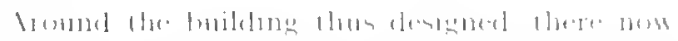

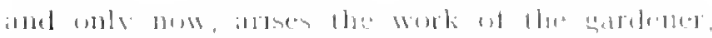

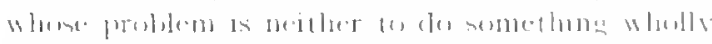

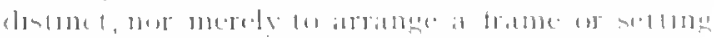

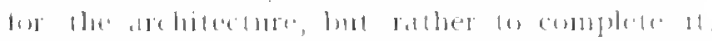

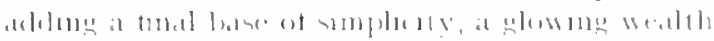

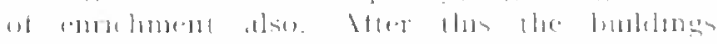

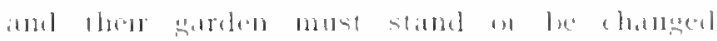

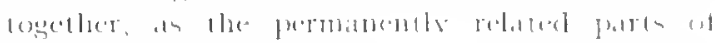

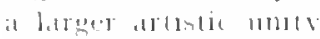

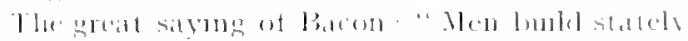

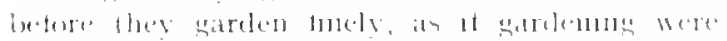

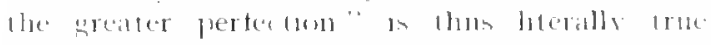

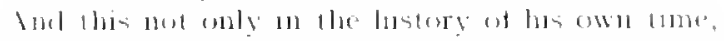

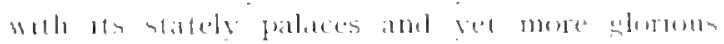

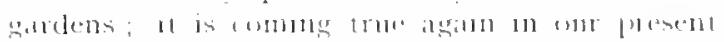

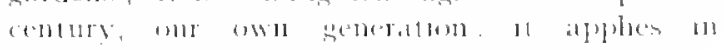

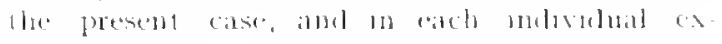
perienes

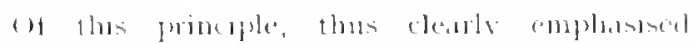

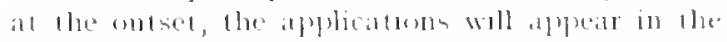

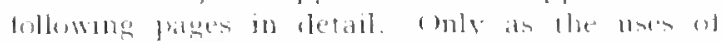

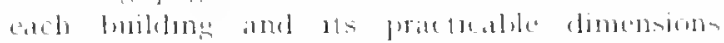

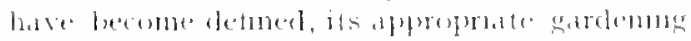

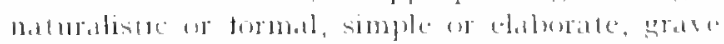

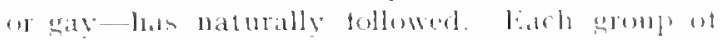

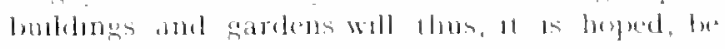

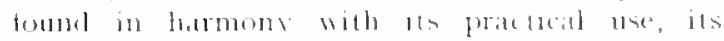

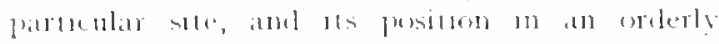
st hembe, an which the varouth atspects and nexts

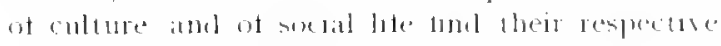

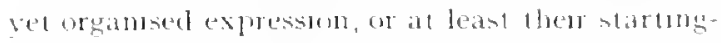

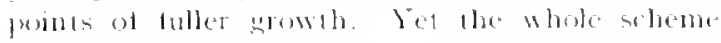

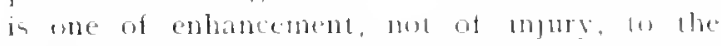

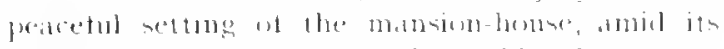

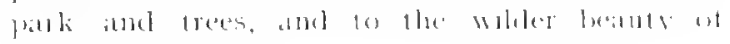

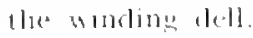

\section{E2. Styles in Landscape Gardening}

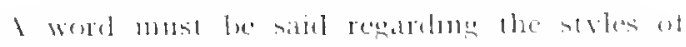

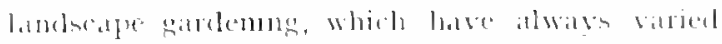

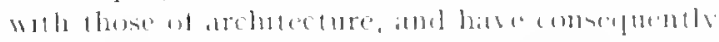

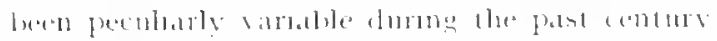

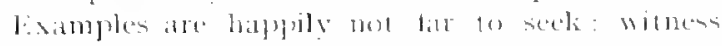

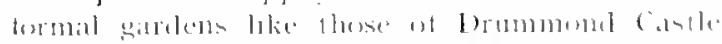

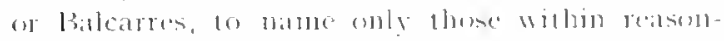
alle destance : while molern naturalintic work, hlis

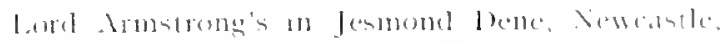

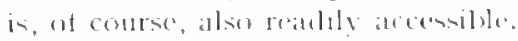

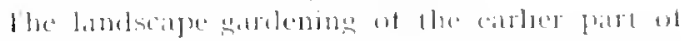

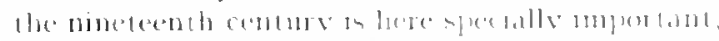

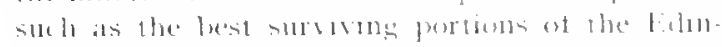

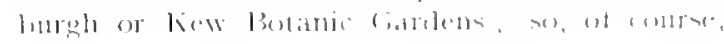




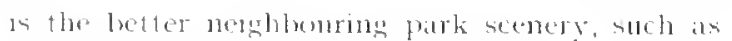
that of Broounlall, Blamalam, ete, *

The confluce of styles is sharply indrated fy the many wolumes of Mr Rohinson, a great noturalistic gardener who wall have lit the or notheng

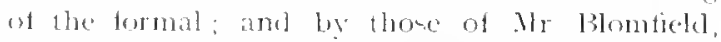
who, whle an emment tomat getrelen-archect. serons to have toro litte interent in nature or exen in flants. but later maturalutic writers, such as Mins fekyll, have animulated much from the alrowates of formal gardens; while recent arclutects, hke Mr seddug, are not unmindful

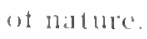

some bate tele the orianility and sublets

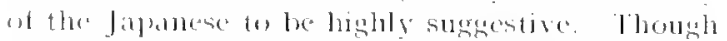
a first soght of pictures of Jabaneste gardens may give an mpression of quaintness and remoteness, 11 som lecomes flan that the Jildanese is really emphasing the characteristic teatures of his own envomoment, alike in notural land-

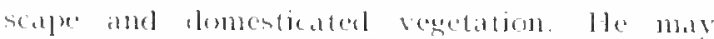
thus on some way be clammed for the naturalistic school, yet in the clathorate ateptation of his arehitectural conditions and domestic needs he is alse amomg the formal sardeners. Ilis formalsm and comsention are so difterent from our own that we cannot reproduce it whlusul lis a thal aid, nor should we wish to ro so sive, at most, al some one definte point of deluleratedy rentic intreat.

What, then, is the conclusion of this matter? While afprectandy all styles, we must laere follow

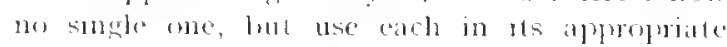

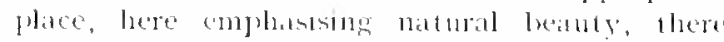
acatumg such ordered and tormal beanty ats we mat fet finally barmonismo all into a lareer muly, a lontein ine tor only thus call we appeal fored h level ot ange and culture, and meet the many Jefurements of recreative and colucature use, of

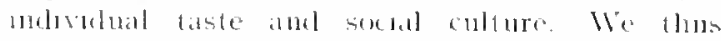

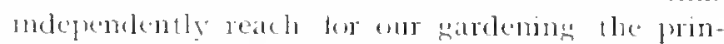

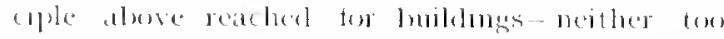

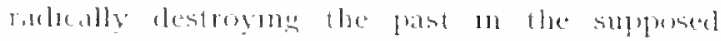
interent of the present, nes ton conservatively allowug the past to hmot this, but incorporating the liest resulls of the past, whth the lest we can

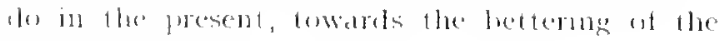
1)

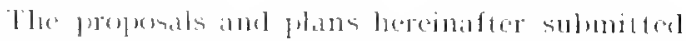
whl thus, it is hopeel, he tomed to grive seope and

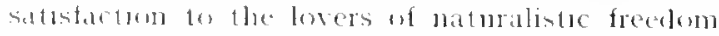
and exuleratuce, breatlh, variedy, and detals ; yet also an thene due place they nithe the many and stately resomeses of architecturat amd fomal

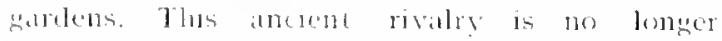
mutually destructue; an age of coleration has

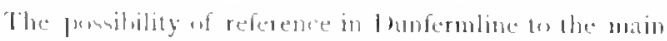

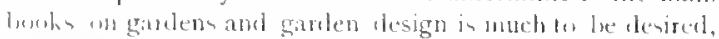

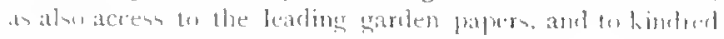

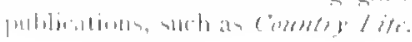

arrved for architecture and tor garelening alike and losthereat styles, the classic and the romante, are seen not only to deserve continumere lut to anlunt of mutual colnancement, exent to lomel themsetves to new developments In a word, Hen, cach stylo has its om place.

\section{F. Constructive and Critical Point of View}

since, after seven monthe prepration, the followus plans and proposals have mew to face the criticism of many, and the lest of yeats, 1 maty be permitled to bfter a worl of explantion-the more so since this is not ly way of mitigaturg or evalung criticiom, lut of assurne that it le just and keen. I assume then, that siner the froblem hadd leen set trom the first, not only upon the best usual fevel that of utilising and athating tho best that low been thought and dome in the worled but levonel the where it in prateticable upun the most ambitom leeight that of "fnoncers ilways ahead"-there is one fluestom, one implied conticism which must be extuded from the outset as ontside the rule's of the present pame, and this the commonest: "Very jorty, nu doubt: but can you show me where this has been triel hefore? Where has it suceceded?"

sucl conticiom, il sometimes less dearly expressed, is generally what each and every concrete attemple at carting out into the needtul applicittions any gencral coumsel of promeering usually gets; as I know an the present case, even from mos of the frients ufon whom l batre oceastonally tried this of that poposal. l inderstand, and sit far sympathose with, lhis attoncle. I lowe the old somgs best, and have selelom cared for any new ones at first hearing: stoll, knewing my own bias agimst new compositons, J do not eriticise them. a new picture, however, or a new flower is quate a defterent matter, since here $I$ and more ale customed to the pietoral or horticuldural stand-

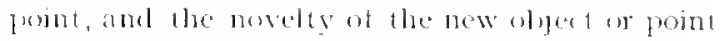
of vew beomes to its ablantage.

In short then, I plead that the unconventional nature of some of the tollowing proposals must in fairness be set to their credit, at anyrate mot need as an argument against them.

After warding oft this one crificism I wonld now aid all oflers, ly disclosms the print of view needed to sluare the standpount of such designs abst to overlook them. It is me casily actuired, in some moasme, ly anylumb who will take the pains, or rather the pleasure, for it is a child's onc.

Angone who is not wholly unobservant kmows that he is often partally so. The ditficulty of dreatns of describing any lamilar objeet, say the church steeple, from memory, or the like, ju a simple prout of thus, llere, too, the cameral, still more the view-finder, is an aid: with this the 


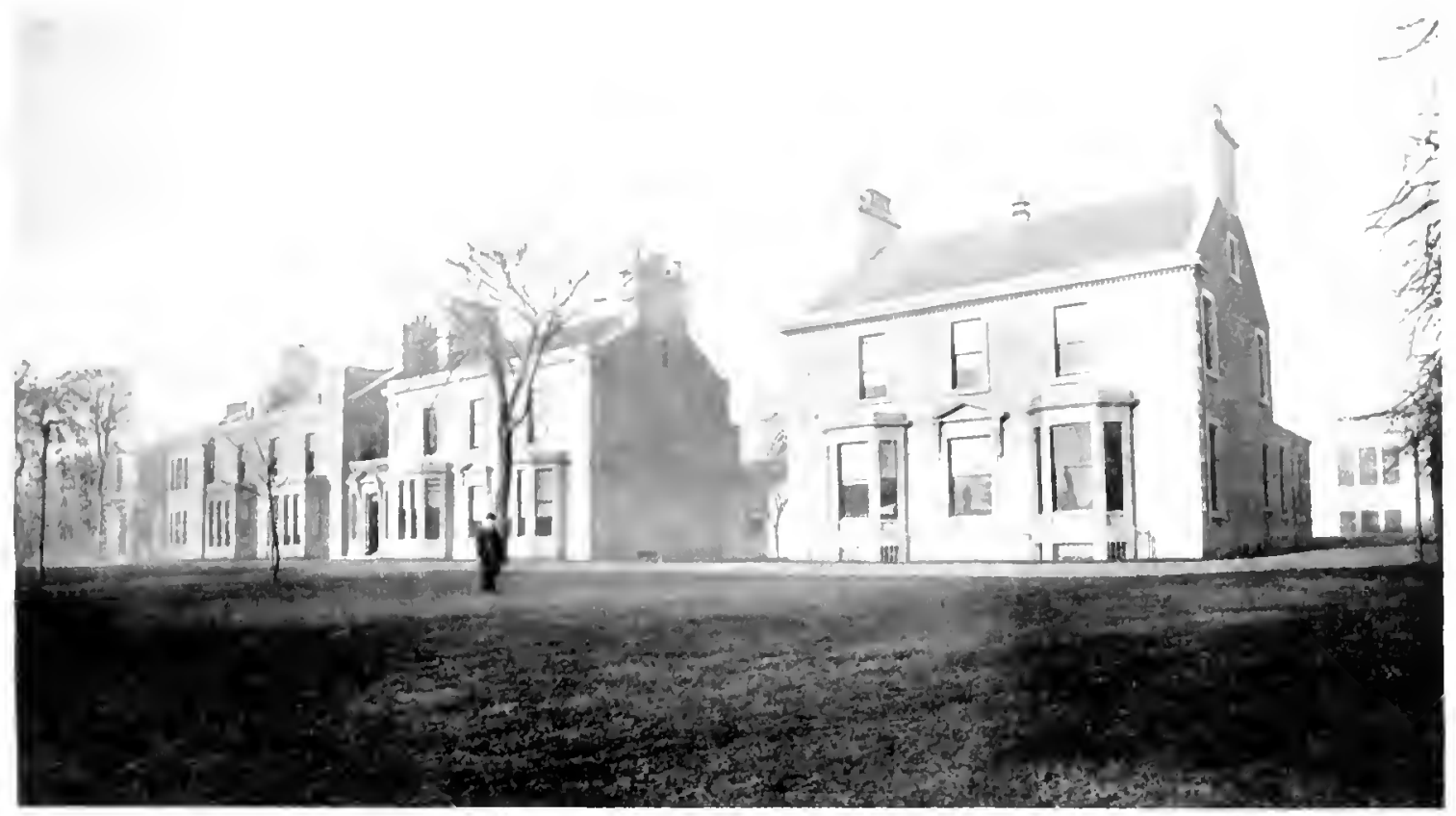

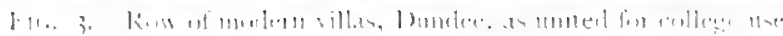

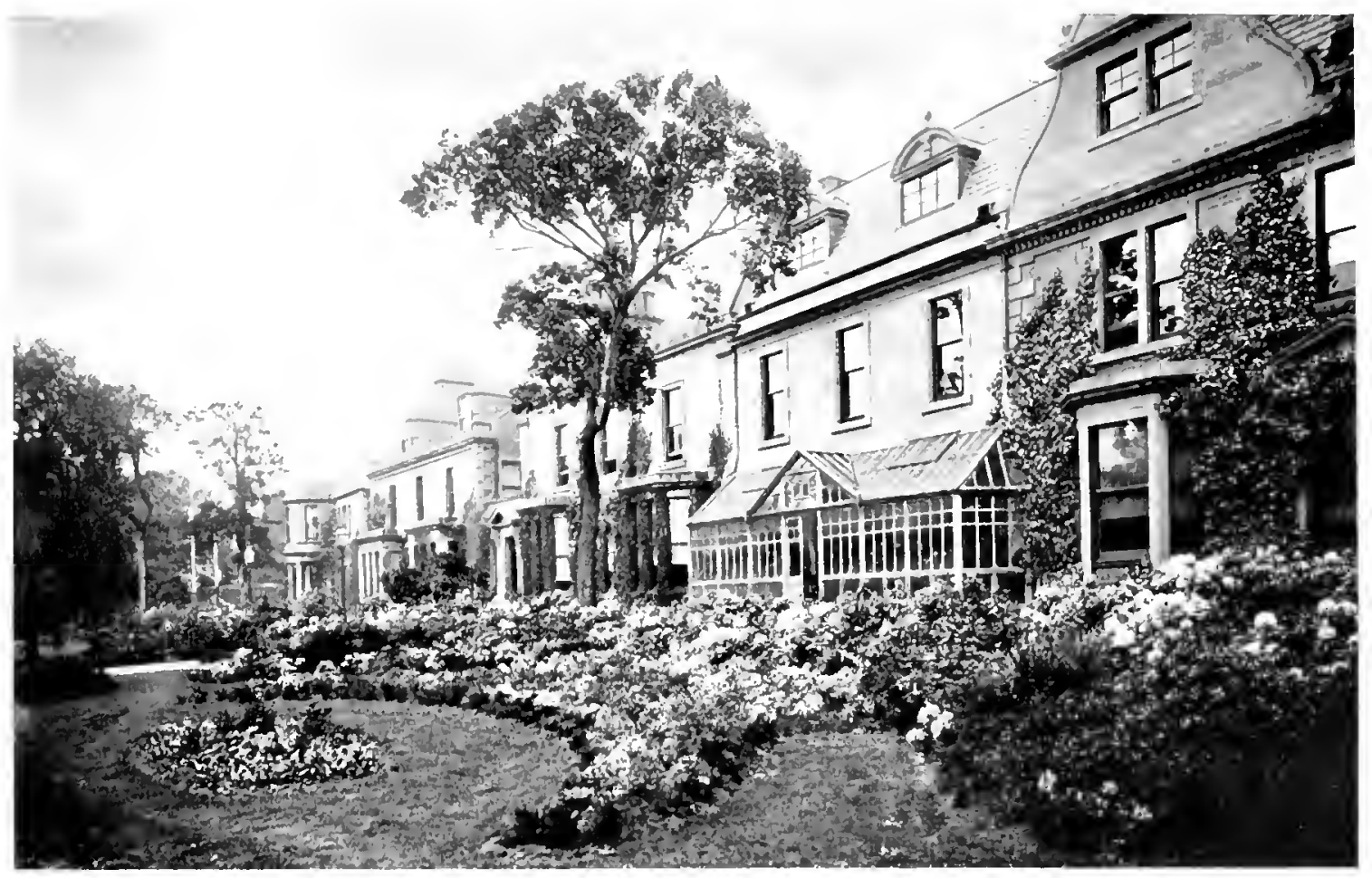

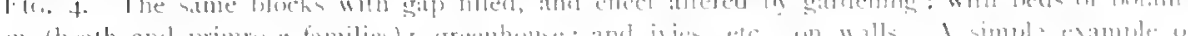

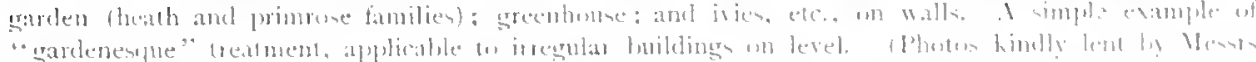
litentius. \& soms I.tri.\} 
most unobservant may rman culurate the art ot secing.

For the ardinary purposes of life we need generdly go no furtler. We have no call w bring imaginatan to our aid, and wo balve grounds, by no means wholly arratumal, for distrusting any who do

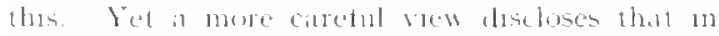

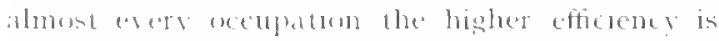
connecter wall the exereise on some torm at the imaguatre powers.

The physelan we chome ar consult is he to whom the trame is most transparent, the lurkmg death-shadow most plan. The sucuesslul merchant foresers llwe comong marliet, the stitled otticer as be who "seces through the hills"; and sol on, similarly, then, for the gardener, the ald hited.

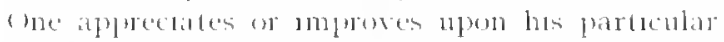
plans as one acquares his eneneral point of view that of not only first seeming the thung as 11 is, 130 also as 11 maly he. Hedeal stolut amb nosight are anduired by nurses, and miluary moghta by moldies and whonters, and thes oftem in a high lowe nu sughestums in offer-one, the pessimint. whe can see unly the dreary streed preture: the other, who likes the pretty one, but "llues not we how il can be done."

So mueh for buildings chosen as of the everyday streed style, and ol thes inmedtate pus sibulutes with a monmum of outlaly In illustratom of the converate problem-that at more ambitious and romante design l nuly and my lomecontunued, thomgh still tar from completed, attempots torescre and carry on the essential artaste motive of old belinburgh, th proturesifuely puleal-up masser and ronts, chimneys and funnucles, and 10 axpress this sporit an new prompingts.

If the recosery of picturesplue slums, of the

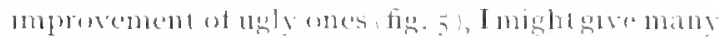
mstances. Keepong, however, 10 garten problems, let me guve, 1 concluston, a single ellubtration of a simple cathe of the formal terrace gardening 1 projose liekw Chap. VI11. whon a greater scale in its appopmate place, and as a further alluntration of

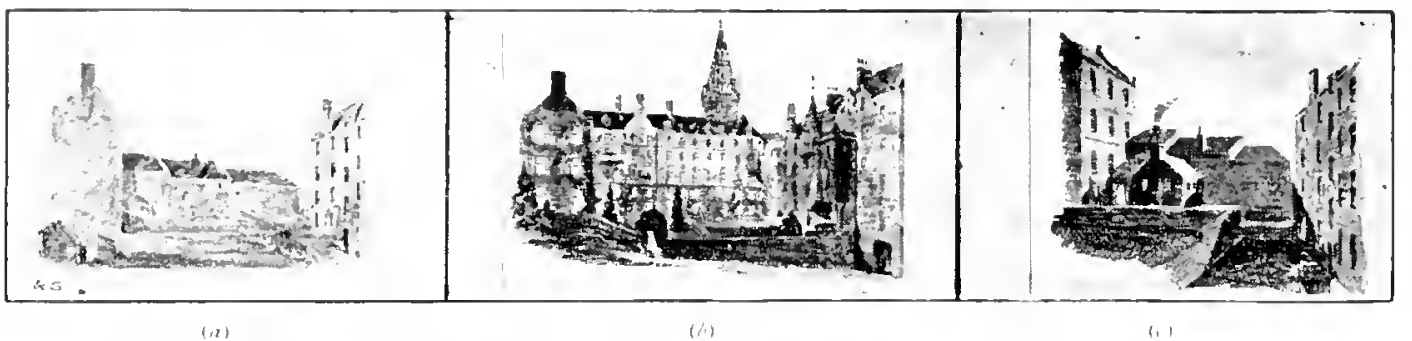

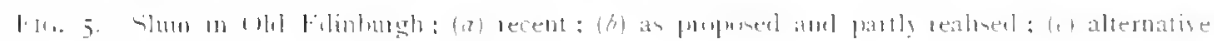

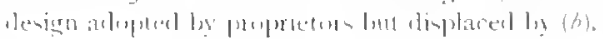

legree, one which fistifies their hathl of criticism even al spectalst and reteran. So 11 is with the intellgent amaterir an exery suljert; and 11 in hence no small use of plans such als these for serve as exereses for the more rencril culuvation of this spluth

take a comerete and smple llustration of this mole of inagining improvements and of judghng them. I linel that some at lirst glane hardly recognise on llee lwo llustrations, figs. 3 and $f$ that the houses and promml are the same; meded almoxt, though not exally, the plostographe bewpont also. lowk, then, at the bare blocks not cholbel and comsider low these late blextis

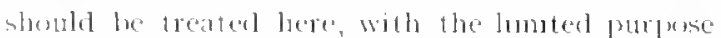
of a college lawn and the severe restrictions of a butante garden

The skilled are, protesciond or amateur, will now deteet the weati prints on my second pieture,

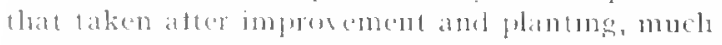
as does my ow 11 will know also which of these

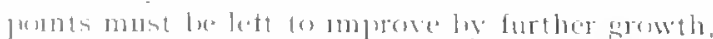

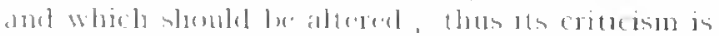

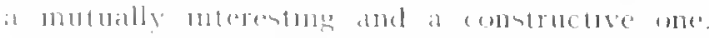

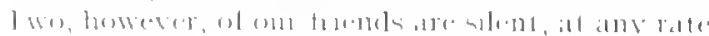

the halut of mind required both tor a design and lts chticism two states ot a garden entrance in Mal lanburgh betore and atter operatuons, the whole change bemp the lowenns and balustradngs

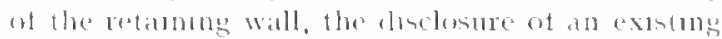
slatrease, and the provelsom of railing and shmbbery on thear dere places figs of and 7

fiurther tlustrations of the same principle that of clear obmervation of the thumg ats it is, and tesign of $1 \mathrm{t}$ as it may le, are grven homphom

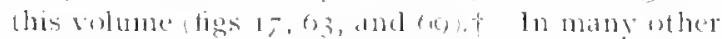
cases also my illustrabum exposes an eval without any ampanom 10 express its accompranomg

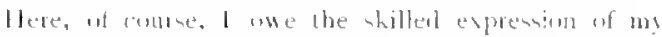

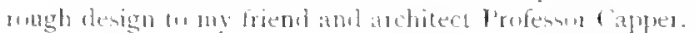

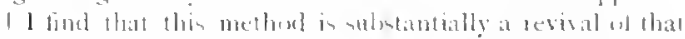

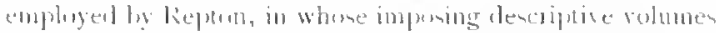

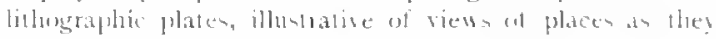

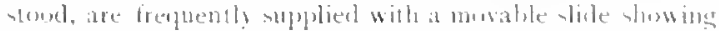
the effert of hin propmed imponements. thin nethul ran

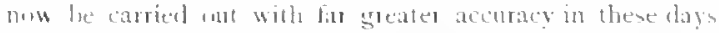
of plontography, and its wides application would le of sed bee alike in the preparation of designs and in the appratie.

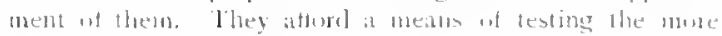

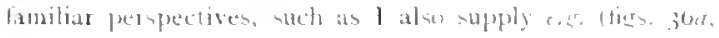

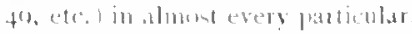


remedy. "lo de this consistently far more tume womld base leen needed: but my reater whll now, I trust exercise humself upon supplying this, als, of course, also in muprosing the sugenestems actually offered. Some, I well see, are only toos capable of this, while others are stoll but indifferent. Of these illustrations I slatl here venture (o) matutatin only one as leeing, so far als I can rel sea, in imnciple and on the whole. the best that can lee done under flue ciremmstances Fig. (1)5), thought for this alse I nuvite cinendation.

The reader will, of conrse, allow tor the lifficulties of this adaptation of the retouthing process, and the impertection or orer-finish in the thgures which have alternately resulied

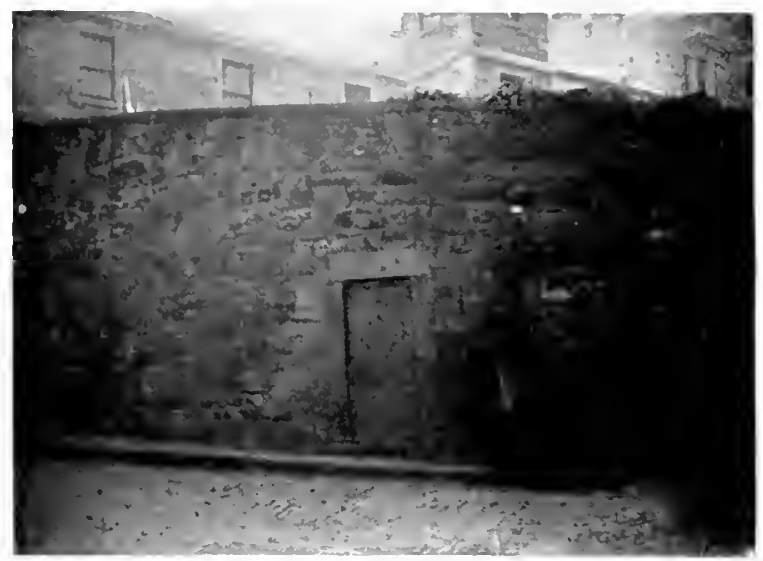

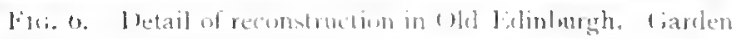
entrance beforce imporement.

\section{G. Mode of Execution}

While we would not leave things untidy hecause untimshed still less without a gencral design to be steadily carried ont, the eommoner converse error must also be guareled against-that of leaving nothing to future develepment. For parti and buildings are not in themselves the end but the means towards an ever healthier, happrier, and more cultivated communily, and towards this end the cilizens and their enviromment must ever be progressing together The following plans have thus been drawn up with the idea not of finishing the place once for all as a nine days wouler, lut as indicating a comprebensive policy of improsement. which would not only occupy the constructive labour of years, but could ever le lurther and further developed. I rock garden, for instance, maly he made and extended gradually. while its collections are never completed. Yet, 10 aroid confusion, we need a plan upon which extensions are provided for. On this principle of comprehensive, yet continually progressive improve- ment, interest will be contumally renewed, and pullic tante mprosed. Xiag, more, the whole. younger generotion maty thus le deeply and truly intluenecel towarels beatuty and knowlerge, with the no small reatction upon lite and houne.

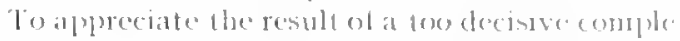
tom lat us redurn onee more to Jesmond Dense Whale we admire the completed cifects produced ly as master hand, we soon also discoser some want of adepuate alpreciation in the communny to which this great park hats been hamed over Close beside the lovely mill cottacre, the pietur-

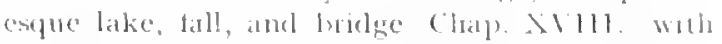
wheh lord tromstrong's whole construction culmuntes, the present park authorities are buildng in slecter, choulutess m itself neceled. but architec-

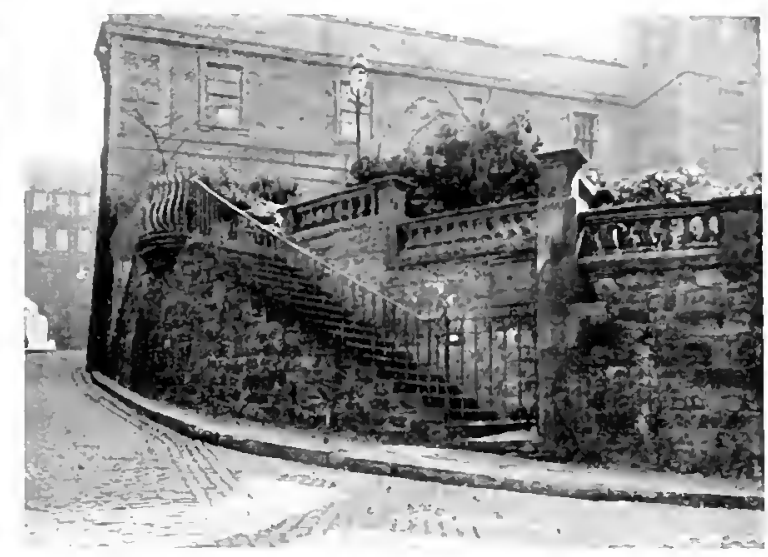

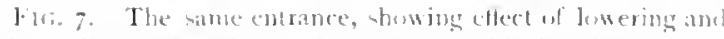
balustrarling wall. and exposing claiciate wilh shrublery almese. I simple evample of detitil of formal gardening applicatole lu varying level.

mally as porot ats poor can be. Down-stream aljacent parks and their buldings disclose an unexpected deficiency of civic asthetics; while, outside the park lomit altogether, the mannificutsty widening valley fasses through increasing nestect and pollution and desolation into the utmost squalor and slum. One almost wonders whether this great gift may not in some ways be harmful, since it not only fails to serve as an incentive and start-point wo the contumed improxement of the valley, but secms too much reluced to a spot of refuge from the neiglobouring neglect or continued dertruction.

My proposal involves the precise reverse of this. It is, hat while aclopting a comprehensive design I trust the present one, and having this stull further elahorated with all neelful completeness, the Trustees should utilise its gradual execution for the corresponding education of its community. Thus, the place of needed trees once tixed upron plan. their planting might largely be made at matter of social and educational interest, ntilis. ing, for instance. " Irbor Day"," that aldmirable 


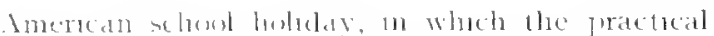

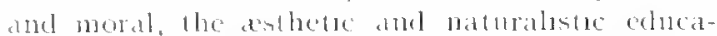
toon of the younger generathon, and the needed attorestation of the commtry atre bemp helped (m) together,

smolarly tor the development ot partens, and thett of all kmols- seloblate and gencral, botante, naturalistic, and tormal, of contse 31 varyng

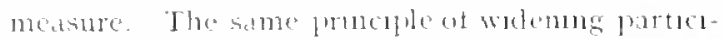

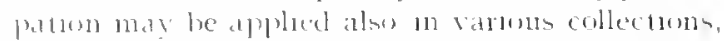
luth lowng in sodelens, preserved in museums, lobaries, ete. Towatrels sucle derelepments the respectue worlan staff maly acturely co-operate.

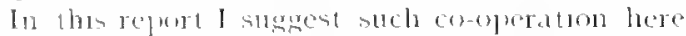
and there: and th pussiblutes should be everywhere kept an vew, the lontermbence pulsic thus

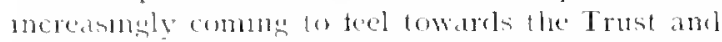
its soup of culture resouteres and institutions as do the members of a ereat college not only gealously caretul ot lher common wealth but active towards moreasung $1 t$.

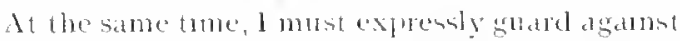

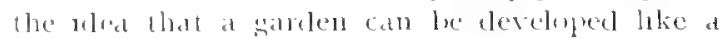
conrm, trom the sum of melependent contributions. Jlus wonld he hake having rival pelinters on the same canvets, roval decerators or musteras in the sume reom, of a eaumed ot war conductung at hatte-tespote all aluhty and gonel intentions only descosel and materlal disanter can result.

\section{H. Correspondents}

At thes stage 1 lute ter express my corthal thankis to wer two hundred correpponelents 10 many pluaters of the old and new work, whose sugrestums 1 inviter at the mulset ot the repurt. seven months age, and trom whom l have reecred at very larse number of reples, alwaty muerestung or enconrats?ng and sometimes hohly suggestuve. Were I atuthorved loy the writers ta print these, they would matie up a volume if ne mean in terest. Nomy of these sugaestions, of conrse, touch maters leyome my sane: espectally do many of the latere wromps dealing with educational problems and tasks and whth sochal bettement extent begomel the lombont the present rolume. fint all have heen tratumbled to the Secretary of the Trust for uts resprecture commottees, so that no suscestums walt thus tall to recerve the sermus combletatuon they mest. I trast that many correponelents whe may not timel then partucular vew expressly represented mus still teel that its spont is mol wholly lationg.

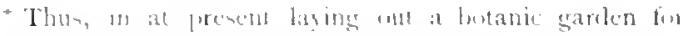

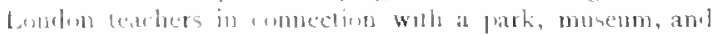

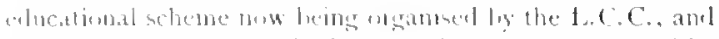

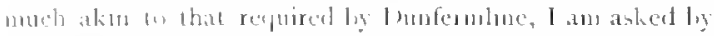

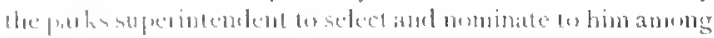

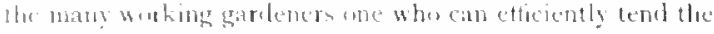

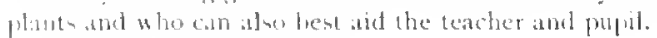

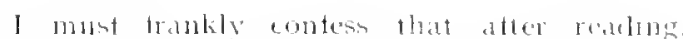

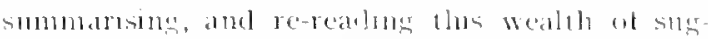

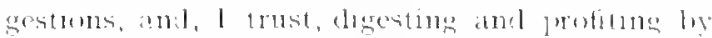

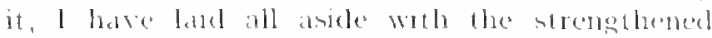

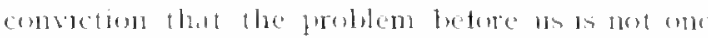

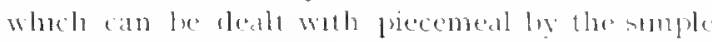

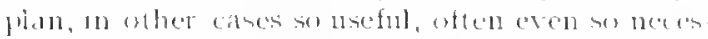

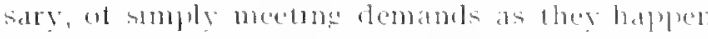

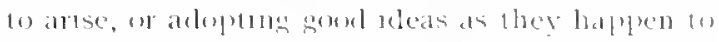

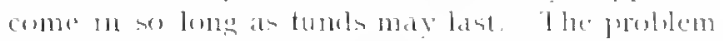

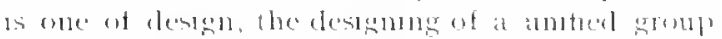

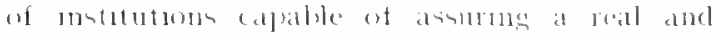

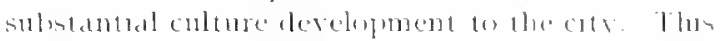
assured, all susegestuens may ancw le emsidered. and wall le tombal laredy wh tall nate thede nattural paces.

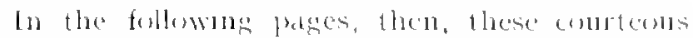
correspundents wall find the seneral vion at the

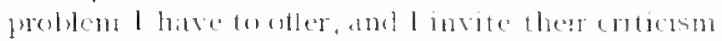

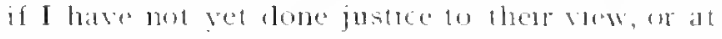
any rate left place for 1 ts subsedpent onsideratuen when the time of detaled executuon thpuraches.

\section{Summary of Method and Point of View}

In simmary, then, the preparation of the reprotet

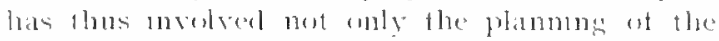
inmeroxement at a park, and the leymer met of armens upun a seale worthy of the cily and ot the acasson, lmt that of an extensive serien of

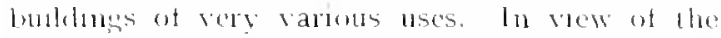
extreme irresularity of the sites, and their peculiaty complex relition both to parkind city, these bave hat a te planned out with expecial care, meleed whth pratteal completeness, salce to ntdeate such stees whthont positure certanty that the preposed lublanes conlel be folled into them would have been worne thall hos suegestion at all In this comnectom, two, I have had to deywant myselt whth the history of Duntermbles, and.

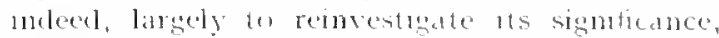
whach aptears to me to exceed that chaned even ly th many lowng amnalists to To tho problem I hat alrealy, fortunately, siven seme attentmom, as atore for many vears pust to dhe vast merlem question of musoums. lint here, asatin, tresh plaming and replanmog has heen necessary, slloce precedents latre avaled bute. The requnements

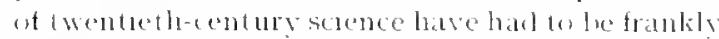
recomstered, and this from that more comprehen

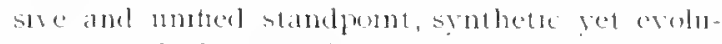

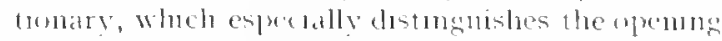
perwel from the recent ine, which has been, in the man, so comtent with its muluphaty of modated specialisms. Jgain, beyond the dettenly of tue presentment and worthy housing of serence and artis in evolution is that of the rast exlacitional problems which these raise, and this on erery

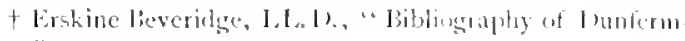
line." Inntermline, 1003. 


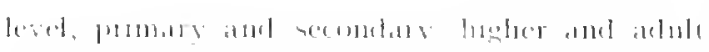

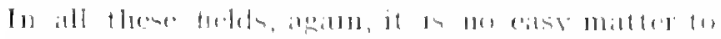

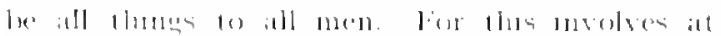

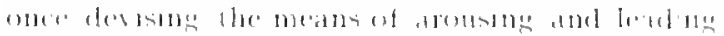

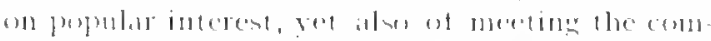

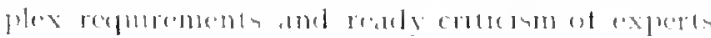

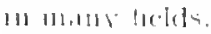

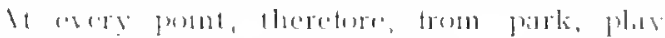

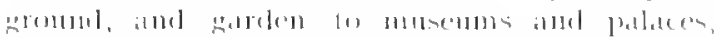

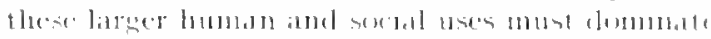

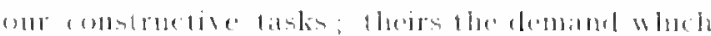

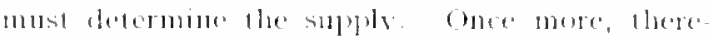

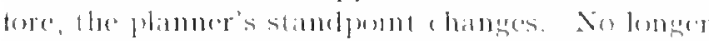

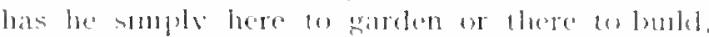

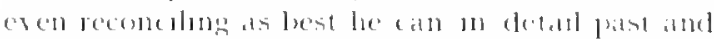

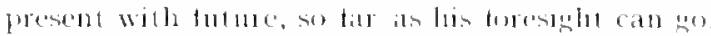

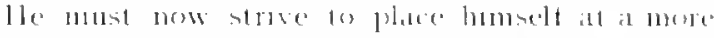

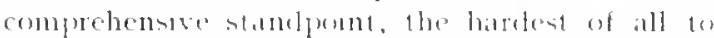
reach that of the city as at whole ated the not

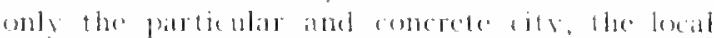

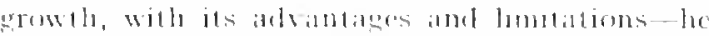

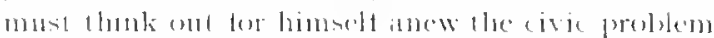

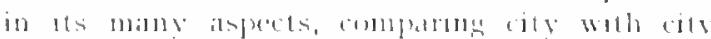

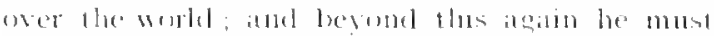

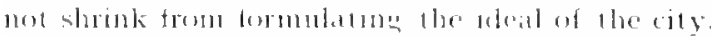

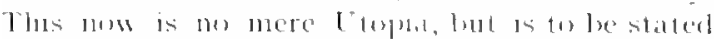

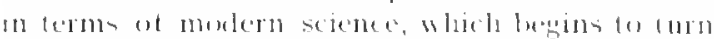
trom deciphermes the past at esolution to secking

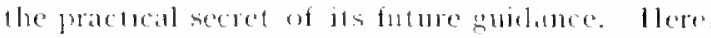
then, is the list and lugher plane of soctat and

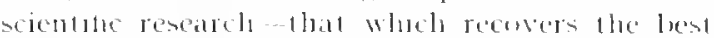

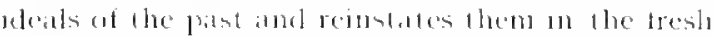

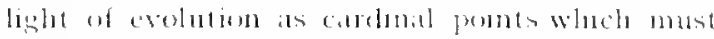

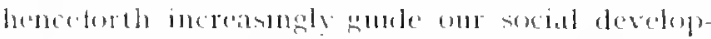

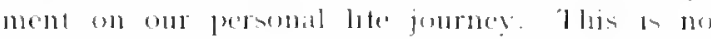

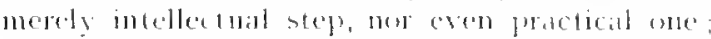
it involves the wholde life, the whele being, and that of the community evern more tully that that of the inclustluel. Beyond the exolutionats symbesis of the thinker, or the remewed universits of the reather, there thum arises a comecplom, abeady naseent, not only on books hut in cities, that of park and gatrelems and culture institutes as becommer the Cattedral of the People and of the apenumer time. We now sese the modern town evolving ancy towatrets the culture city-city of

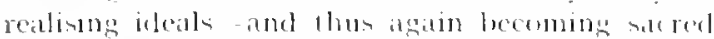
in a new sense, yet one which maty have withon it mucle ot what is lest in the olde.

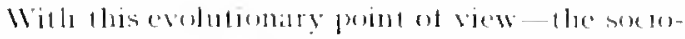
logical, the elducal our whole perspectue changes

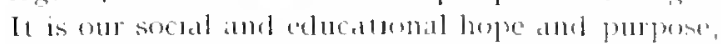
our conception ot cive progress, which must determune our selection amicl the many possibilates of lufe; and if non consciously and tor higher ende, then unconsciousty and bor lower ones. These deals now stated, them heusing maty be protitabs considered that is, their hublings lity constructed and planned; inut, thus concluded, their parden sell1ng, withm the whole cily, park, and handseape, becomes praticable.

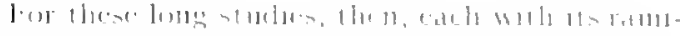

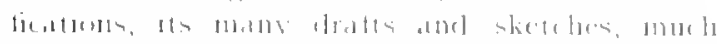

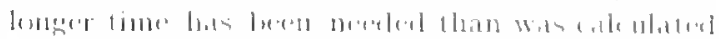

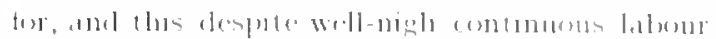

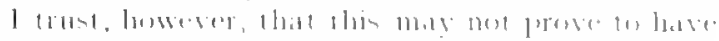

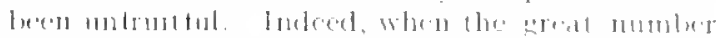

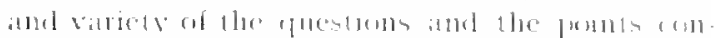

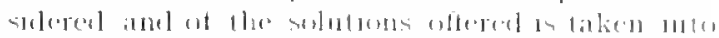

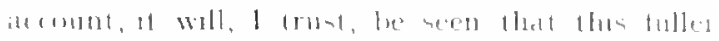

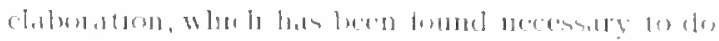

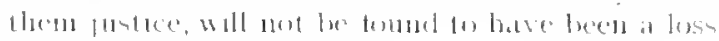
of time in 1 he bor: rom

\section{J. The Present Volume}

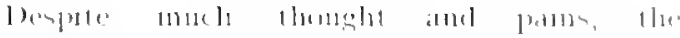

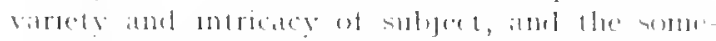
tomes needtul abstrictuess if thought, make the volume less reathathe than I hatel hoped. I would

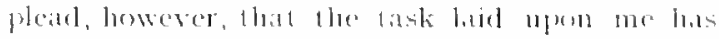

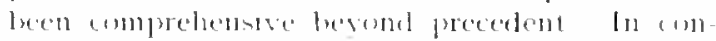

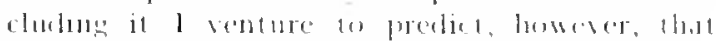

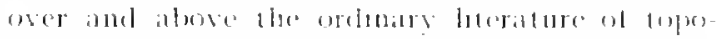

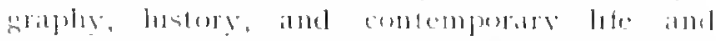

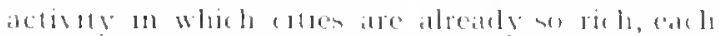

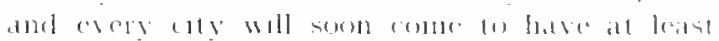

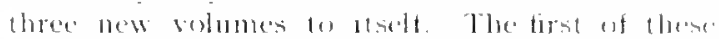
with offer the geographic and histore taets ot a

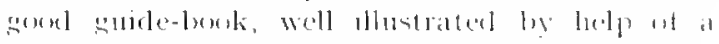

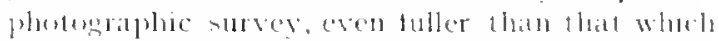

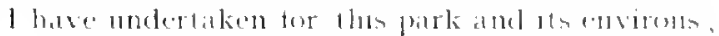

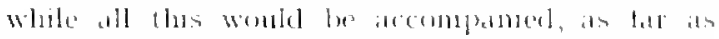

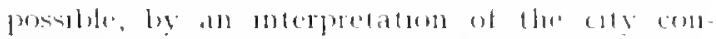

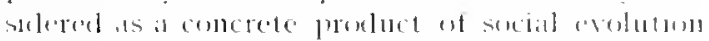

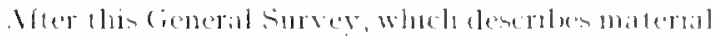
envorument and historic derelopment, conten

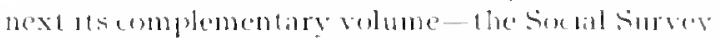
proper This setsont from the standpoint of the

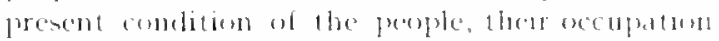

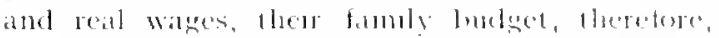
and culture level The first of these trooks 15

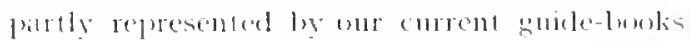

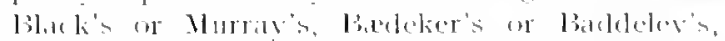

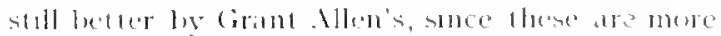

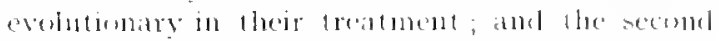

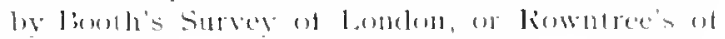
rork

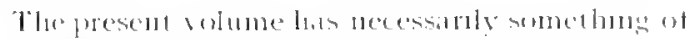

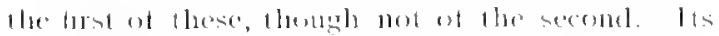

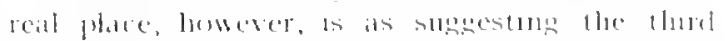

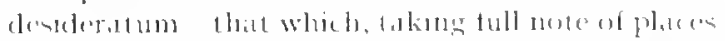
anel thongs ats they stand, of preople as they are,

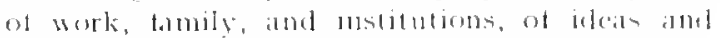

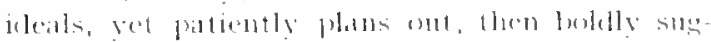
gents, new and prateticalole devolopments: and these mot only tor the innuediate future holl tor

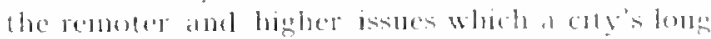
lite and its correspondingly mexted foresight ansolves. In therl, it keport such as the prenent inteed. har more complete and more extersive than 


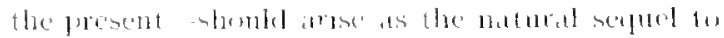

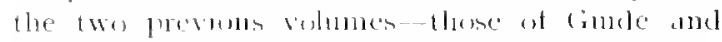
Sixlal siltrey

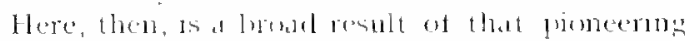

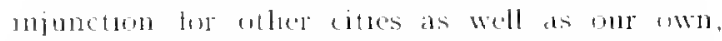
Whate in the inted kevnete struck for the Trust

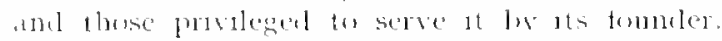
Here we reach 1 he duecourljustment of thomght and

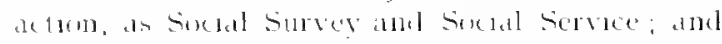

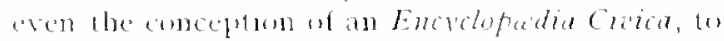

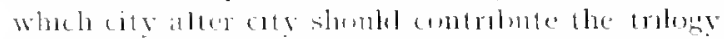
of its paist, present, and future Better far, as late fromseands lunks, we may see, yed more fore-

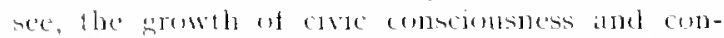
sence, of awolening and reniscence. Thes the production of sold volumes would at ance imply

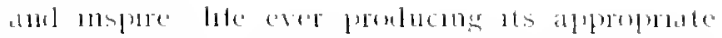
expresion on herature, and herature reactuld upm lite.

Aprot allowether trom what may be the ipuatilins atuel deferts of particular volumes such an the frement, we see lus the very concepturn sot steh a threefolu berdes mat lectme ut sersiee, sme comhoning the view and the renources of the edued-

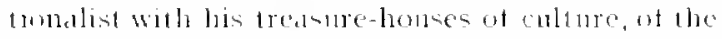
man w allom with his mastery of mmellate aftiris, of the thinlier with his vision of the "lpening future, and all int the matcral of the artst Even lis mifying dergen, its wrothy realusition, is thus preparatury on the real problem of the Trust, Hedt al moral aturl social leadership, at once inspiring and orclestrating all.

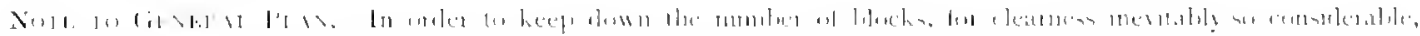

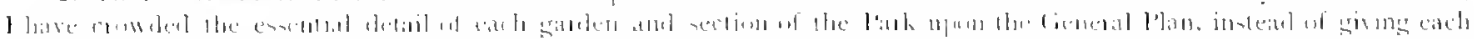

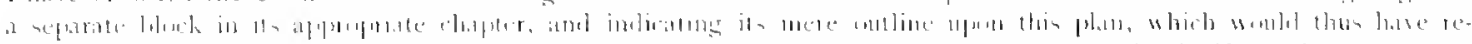

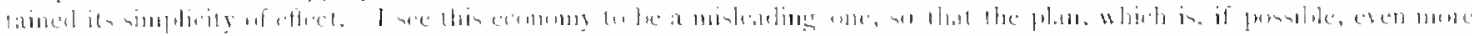

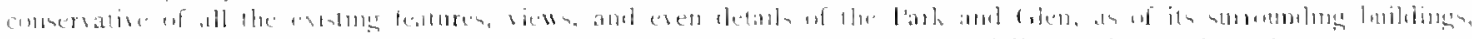

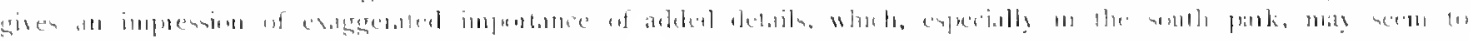

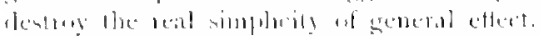

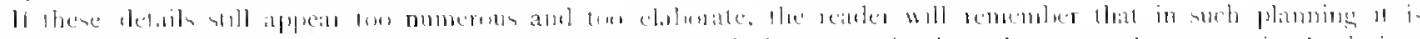

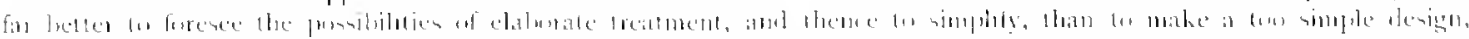

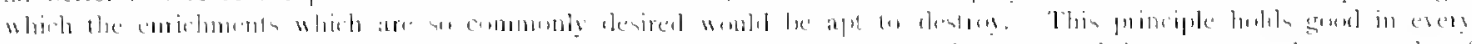

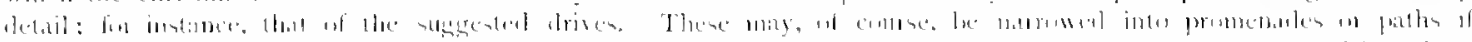

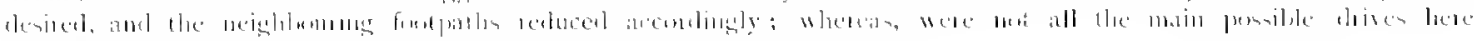

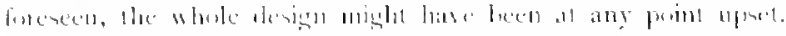

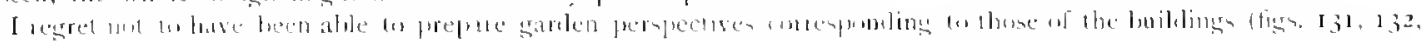

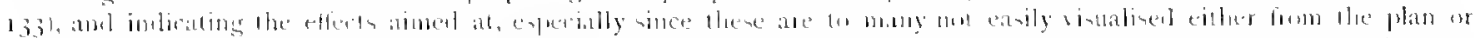

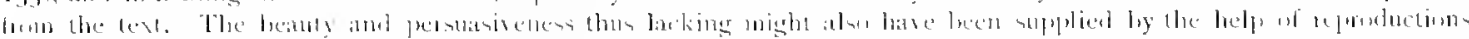

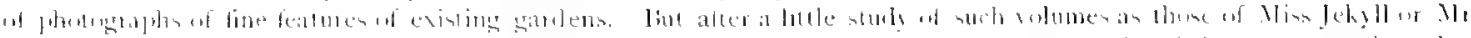

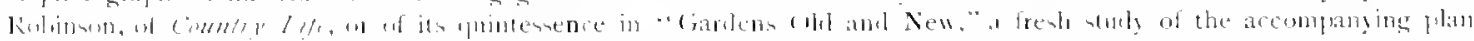

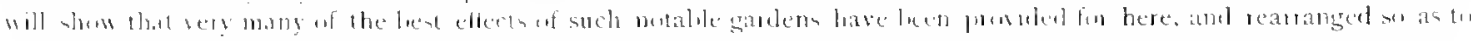

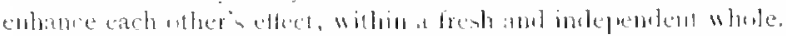

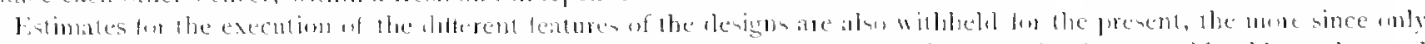

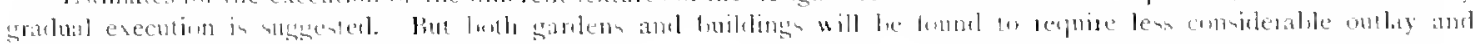

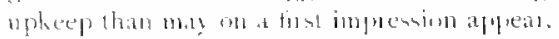




\title{
$\mathrm{BOOK} \quad \mathrm{I}$
}

\section{$A$. APPROACHES AND ADJACENT IMPROVEMENTS}

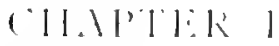 \\ PARK APPROACHES AND ENTRANCES
}

\section{A. Choice of Approach}

13E FORE as is lle plan of lle whele park. I ask

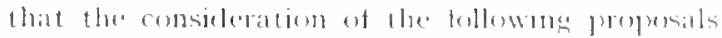

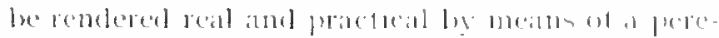
gritution, one actual for the remblent and at bast

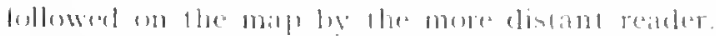

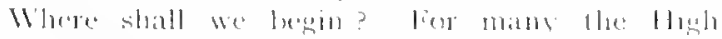

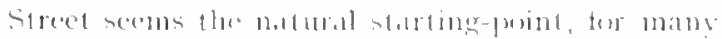

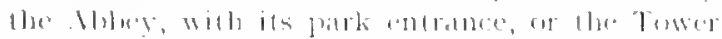

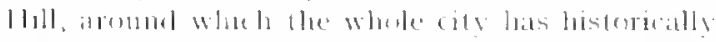

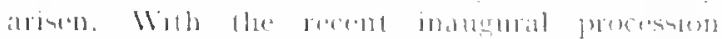

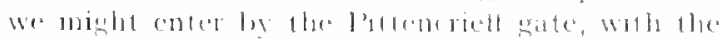

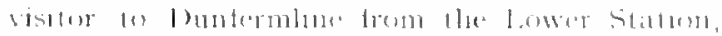

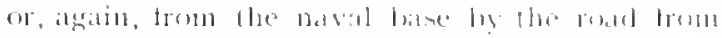

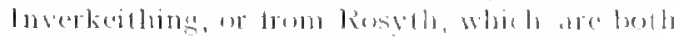

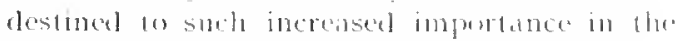

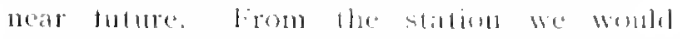
naturally alportach ley l'riory lane and Monastery street, whale ly lhe last we bluam our first view trom the Keethertown. There is much wo he satid lew each of these promen ot rew, ald the plan of the present repurt hats

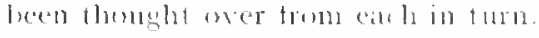

from the stamelpoint alike ol serreratphe atmel common-sense we must apprould a litl-city trom its lottom, now trom its lop. Wente we bere at the standpenint of the tourtat we shemble naturitly molie al onee lor ats

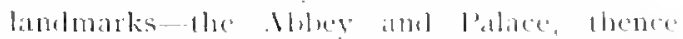
pass to the filen, ind thence to the funest

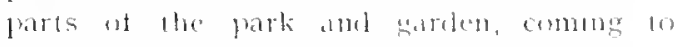
mmor elements only later it ture allumed. Sn this repurt, however, it 15 expedient almont (1) reverse thes prowess, and lexpin with lese salient abpects tirst. Sheret these there is less (langer of diterence of opmones, so that not only

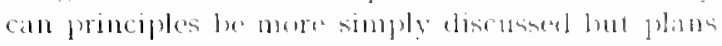
of aretion more casily settled.

for further concreleness, lol las imagine ont

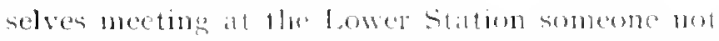
unacylutinted with surdening and arelutecture. and bringing with him that tresh age which mily

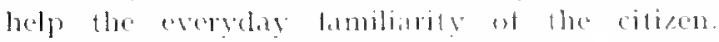

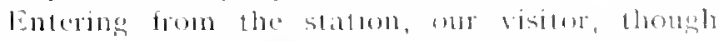

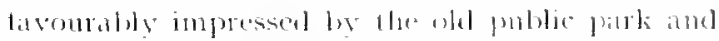

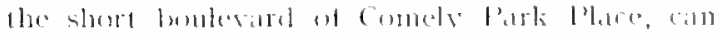

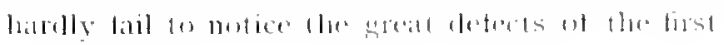

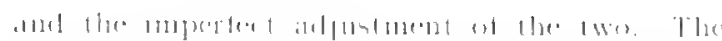

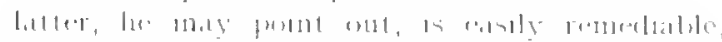

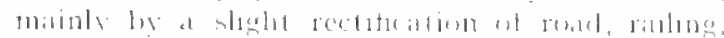

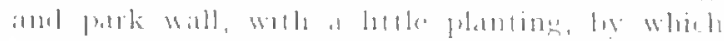

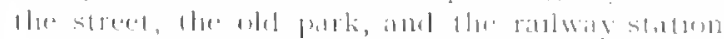

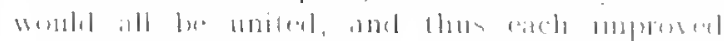

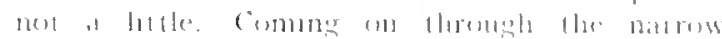

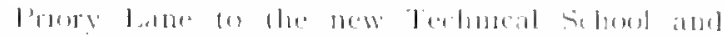

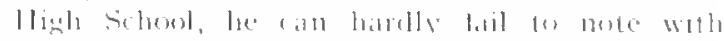

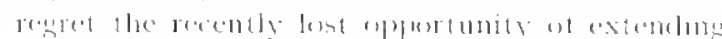

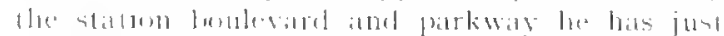

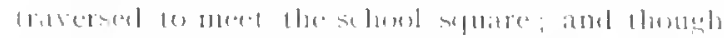

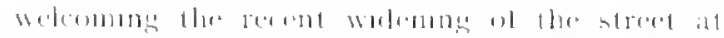

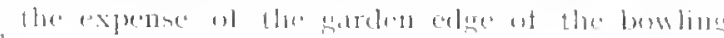

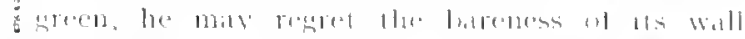

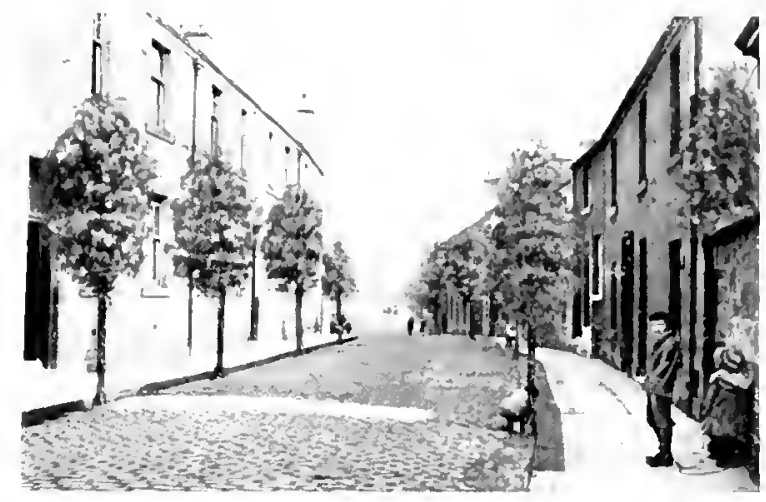

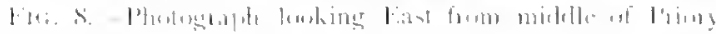

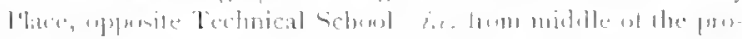

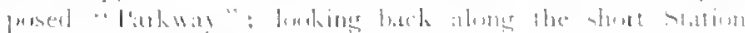

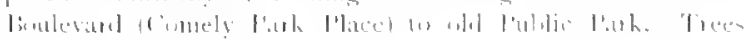
hew intruluterl.

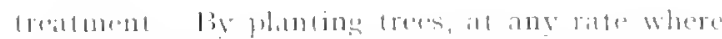

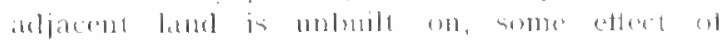

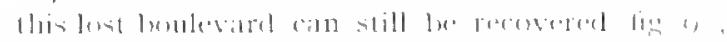

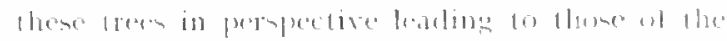

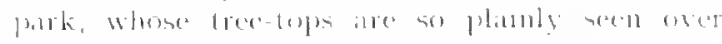

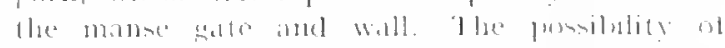

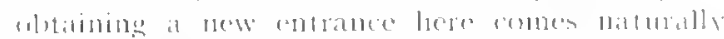

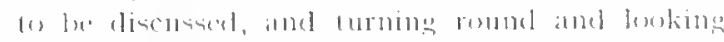

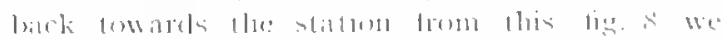

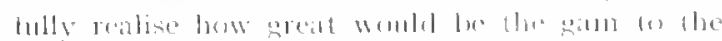

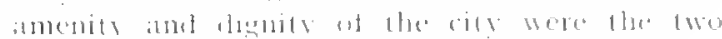

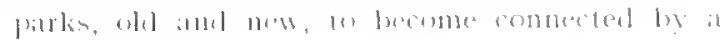


continnous lwolevard, il "l'arkway." lience he camnot but urge that this be put upon the city"s plan, evon though it con only at once be reabled by these tew trees, and perhatps not fully for a generation. For tree plabting involves paticece as no other athon rloes.

the disastrous loss to the improvement of a rily through tookung al each ot its puldic parks ats at well-detined "property" enclosed within its own boundaries is here at once reabsed. In any and exery city exen in those omparatively

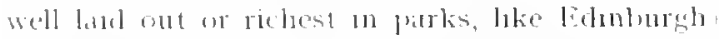
we mole reatily see low ats present bealaty moht

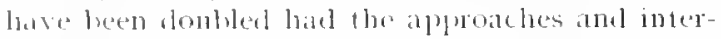
comnections of its parks leen adeduately studiod, msteat of molependenty comblucterl, on one side w a larks Committee, in the wher by a streets and bimldouge commetere, and se, practically, ly

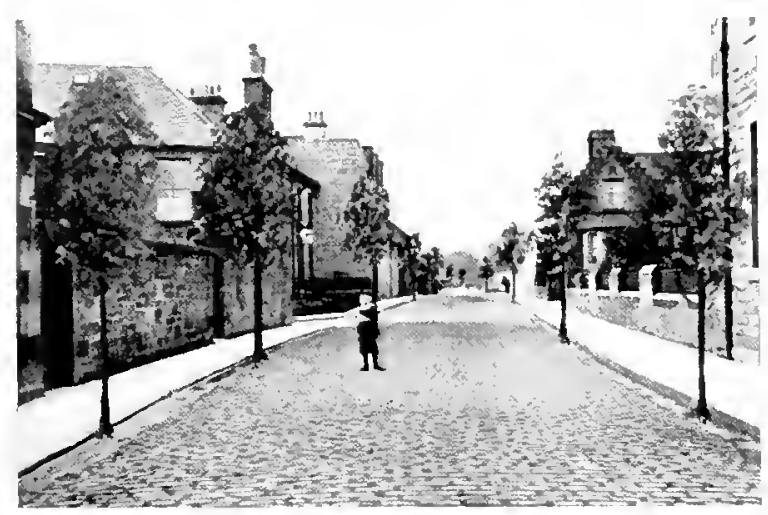

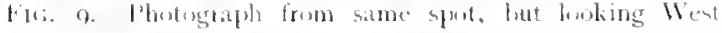

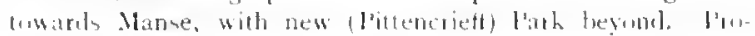

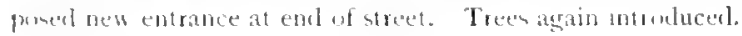

untucky chance. Here at the very outset the landscape satdener mat at once define his habituai viewpoint - that of combining into picture, comolinating in literal perspective, the standfroints of these two civic committees, and of helping, so lat as lue catb, towards contjusting the immediate fied of the park superinfemelent with those of the city architect and of the burgh engineer. To luetuicut in his task he must take note of all that comes into his park petures, which necessanty include parli approaches and enviroms, momore avoling the point or that fatme, becanse af fropretary or onher differences, than does the hygiense in his way, hut entubly fres with lim to sily what in his julgument is wrong, and sugergest what may still be fone, or, at any rate kept in view, to remerly it.

\section{B. Approach Selecied}

Since this Manse entrance is not yed arquired, and smoe, moreover, we andeed at the outsed in begin at the lowes lavel and to dispose of simpler matters before entering npon diffeulues, we leave this, and also the present liats entrance,

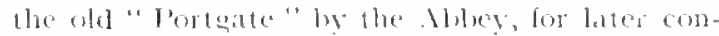
sideration Chaps. XIT and XXlll. respectively" and descend ly Mosdie Street fowards Netherlown, notins for preservation Mr Carnegie's early home, and below thas, for improvenent if possible the fatureless galde of the adjacont house and the present unoceupled ficlel-an excelient site, it may le noted on passing. tor a possible future School ciarelen. of this the necded gardenersmperinterdent's conttage worlel cover the gable alowe relerred 10, and murove the strect. See Fig. 11 .

lieathing Nethertown streed, we have fortunately bese stech brealth ats ofters the possibility of pluming it as a bullevard like comely l'ark l'lace indeed why not with the mprovement of grass verges as at llelemsmmb? liig. II.

Here, in fact, would be at first-late immeshately realisable larkway, which wombl be pratedeally in line with a new entrance to the park at the fout of the filelese of which the acpurement is abviously of steat importance. l'ausing at this point, we note the varous clements of the landscape, the fine tree-clad west bank of the strean, the pleasantly rising hut baked manse hill with the valley narrowoms upwarls, the irregular grouping of the old mills, the tower of the Alibey Clutuch. Fins. 12 and 13 .

Again and algain along the slepges to forth "Try we find such a "ten" or dell, a more or less beep-cut, tree-filled ravine widening out inte an enlatrged valley of more fertile aspect in short, passing from dell into orchard amel field. This leing the seneral and notural character of a lundscape of this kinel, ont lusiness as sardeners - taming Nature, yet developing ber natural resources of beaty - is 10 plant upwarts, thus continung trees tum the innlevart and from our proposert Nediertown entrance to the lop of the manse hill. Large and lotty trees at the highest points atomer this ascendung cast sile ot the Gilete, som wh the the elge of the park, are obviousty desirable to frame the valley in trees on luth sites, the present hich and mosighty Wall tigs. $1 . t$ enc] fo, beins, of conse, remuved. common natple scots "plane" would here do well, and immediately west of these should he planterl thwering trees-tirst the wikt gean, white in spring blessom and orange-scarlet in antumm follage ; withun these again a variety of erabs and other apples, so interesting in fruil as well as un flower, and acpuiring with age a gnarled picturesclueness of form and heanty of bark all their own. Kowan, servec tree, and hawthomest sorts would atso be atelerl, the common 


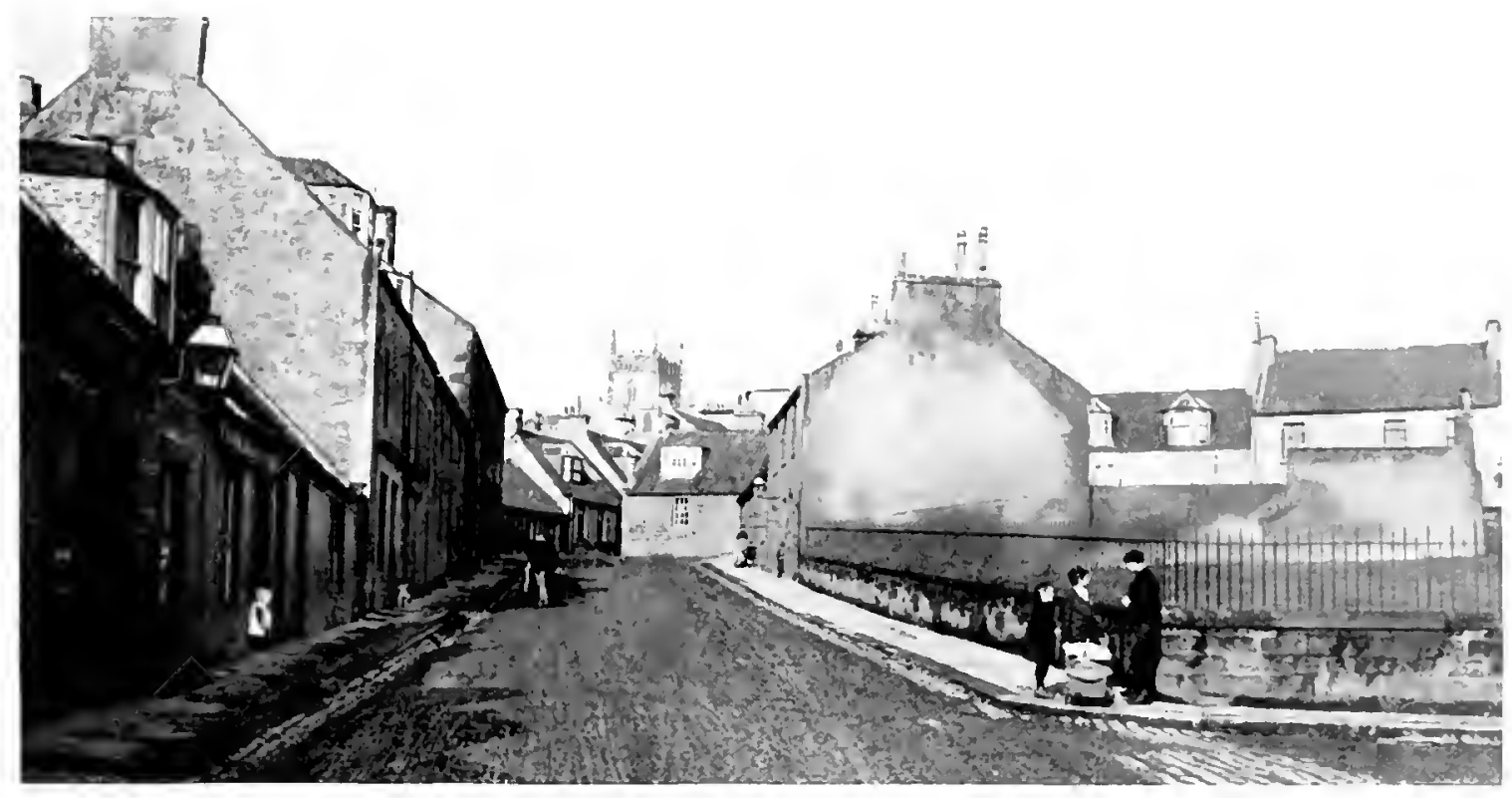

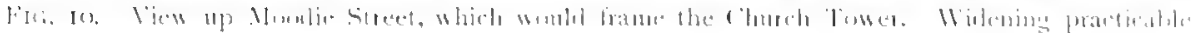

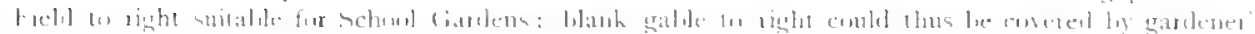
collitge.

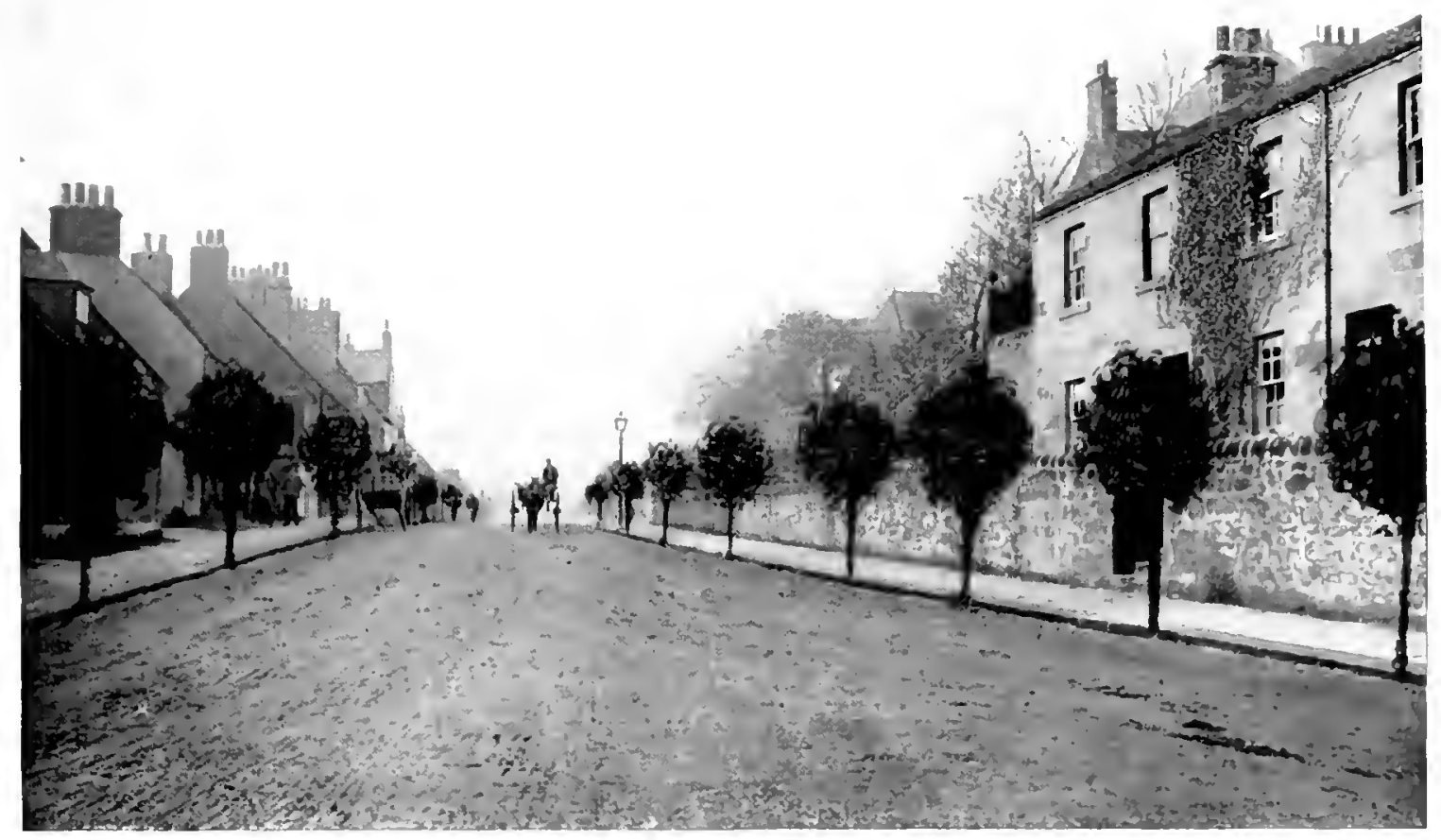

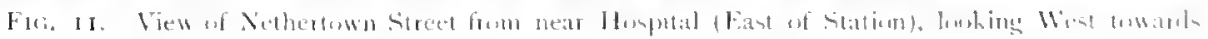

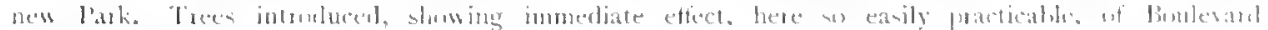

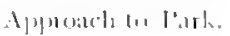


hawthorn necupying shate thrown lyy the larger trees.

With the shelter thus provided tine varieties as of louble cherry, and even of almond, with its early pink llosson, mas be planted; while even where the Glen narrows into shadow thorns will still hossom, hurnishing a "Hawthornden " transition from the orchard eftect below to the deeper terny shade above. On the future gatelodge clumbing shoubshe the blue-hush Ceamothus, the orange llorn. C. proamtha, the dart-foliaged and scarletherried coloneasters, would all tind place. The man effect oblained ly the acquisition and imporemest of the Gilehe would thus he that of a weil-sunned orchard slope, shellered by trees from east and west with grassy hank rmmong down to the dowerote and the strean.

shomkl the arljacent ficli to the cast he acquired.
The general principle of the needed rearrangement will be understood from a glance at figs. It and 15 , tor, as inspection of the ground will show, it is need ful and easy to widen and straighten the present connection between the Nethertown foulevart and the avenue of Lovers' Loan. To do this we must, of course, push the stream northward, and here rises the possibility, as the contours show, of altering the present artificial course of the stream, chiefly ly excarating to northward of its present course, along the roadside, so as to fumbsh a not inconsiderathle esturarlike lake or pond, of which this south side would still be straight, lut the outlines to easi and west would be quite natural ones, Any excavated material would tre partly used to fild up the deeper portums of the present comse, and so leave no spot which might be wo deep for children wading.

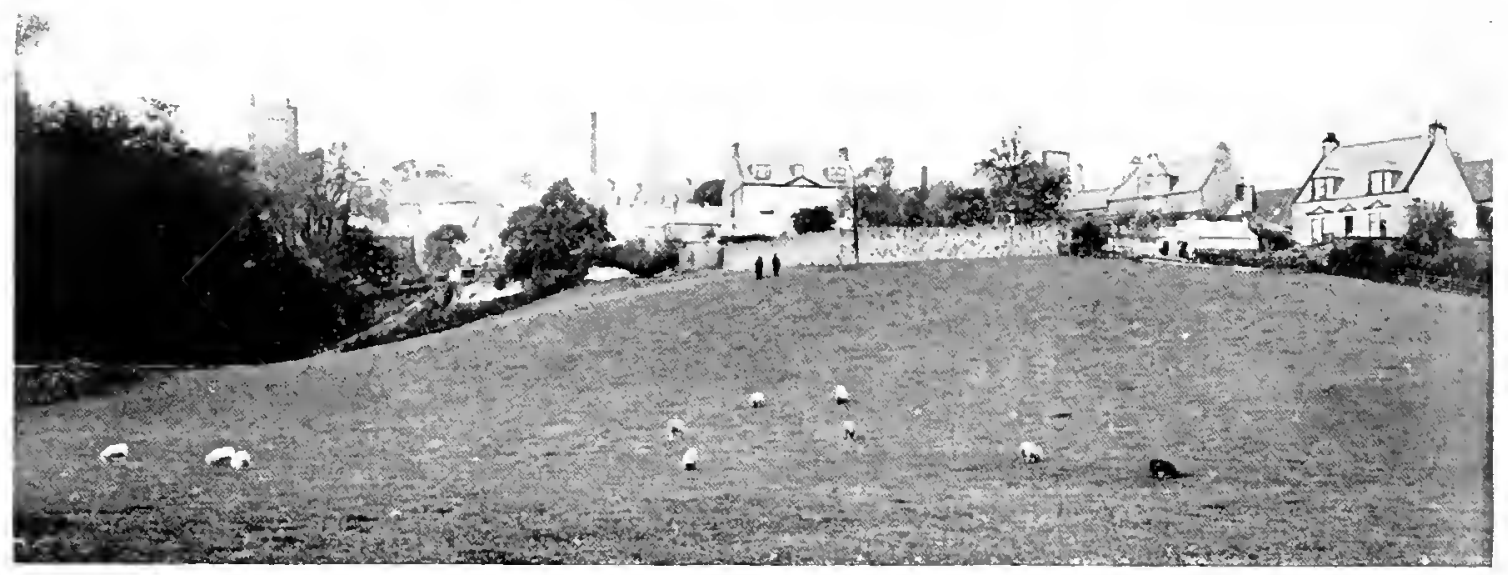

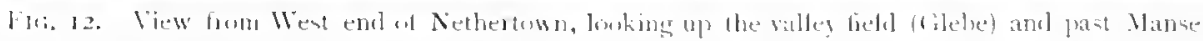

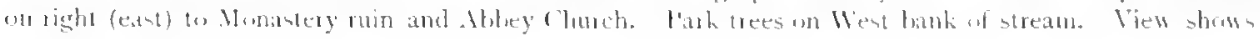

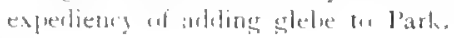

the proposed planting maly le readily adjusted to this; or if buldings are erected in it ly other proprietors of sucls a character as to enhance the amenity of the park, peeps of mutual adrantage can he arranged.

the design tor this somth-east Nethertumin entrance lodge must maturally tre determined ly the arelitecture of the buldings in be erected allowe, and su cannot be discussed at this stage. In any case it should be simple and unohtrusive upon the larger view. Imposing gates and lodges are only neeted where the lablseape otherwise lacks interest, with sreat arrhitecture as here within sight, they must be licple as simple as possible.

\section{East Lake}

The puestion of roads from lhis antrance next falls to be consiclered, and some compoint understanding between the public anthorities, adjacent propretors, and the trust is here plainly desirable. and, further, to construct a small hird islant, where nests would lo secure from molestation. But some material would he needed for raising the roat and unproving the slope also from ligit street. A small slating-pond, though one not very rapully treezing, whing to the trees shetterung it on the western side, is thus provided. This will twe of leanty dmins the whole year, and afford a natural home for swans and for a considerable number of arpatic lirels, of which an interesting selection may easily be maintined at very molerate expense.

The ruined dovecot should, of cenrse, also be rebuile hig. 17, and would turnish a picturesque foreground whed, composing with the picturesque masses of the old huildings alove on the hull, Thin doveent permonsula might also afford lodging for a seal, or eren seatlion, on its sonthwarl side, a duly protected hear-cage or hear-pit and pole to the northwart. The pustion of the different animal horlses ot thr propused small "Kor " lats 
been carefully consitered, with the kind hetp ot one of our most eminenty successful anthorities, Professer Cumbingham, R.K.S, Late Drector of

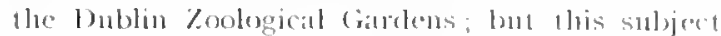
will be returned to bater.

(hat). X.)

It will be noted that this slight raising and extension of the stream woukl sacritice a certain number of trees along the west elge of the present stream. These would be more than compensited for by judicious planting along the edge, and atso by planting new ones upon the other side of this belt of trees-i.e. upon the east side of the main park beyond.

The effect of the proposed changes may be realised from figs. 17,18 , and 10 .

\section{Previous Need of Stream Purification}

The polluterl state of the stream, however, renders this whole proposed improvement -i.e. the very first park inprovement we come to, and one of obvious beanty-quite impracticable for the present. We therefore latve the glen and its stream till we have discussed its thoromgh purification in a lates chaptes (XI.), and in the meantime acklress ourselves to such park improvements ats are practicable independently of this. though not therely recummending these, howevel in themselues desirable, as worthy of precerlence. This is indeed the fumdamential condition both of the nitluralistic and the artistic improvements which lie before us; a condition closely connceted.

not only as symbol hut as practical help or hindrance, to the whote task and prolnem of material and moral betterment njum which Dunfermline is entering.

\section{E. Lovers' Loan, etc.}

Proceding atong the widened road shown in fig. 15, we now reach the arenue of lovers' boan. Fig. zo shows not only its beauly but its defect. The existing tootuath on the south side is low narrow, while on the morth sede there is mome, and the park wail, untertumitedy, hiefes the sterus and roots of the trees. The tollowing

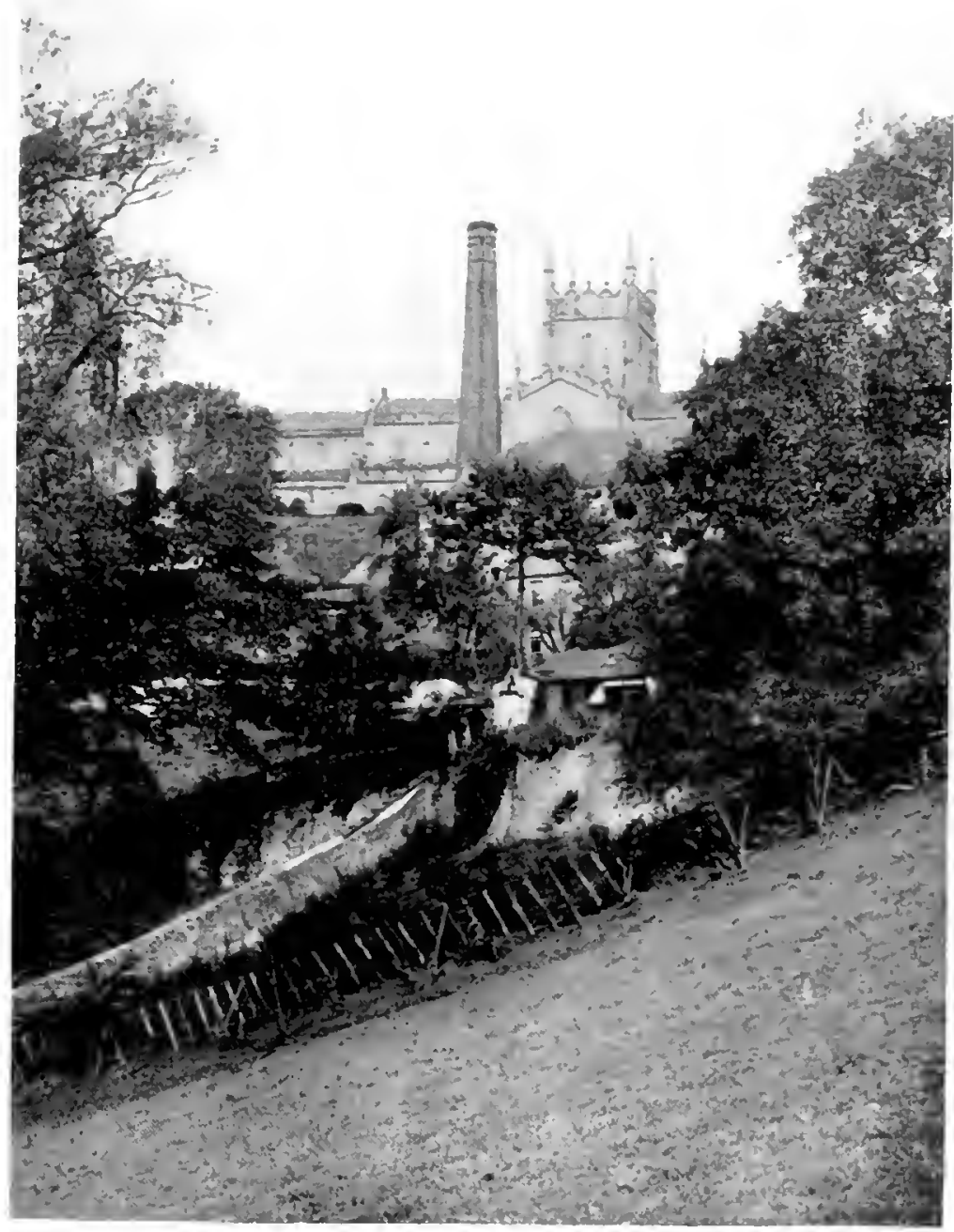

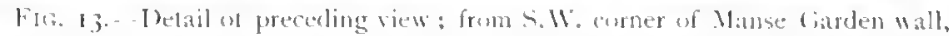

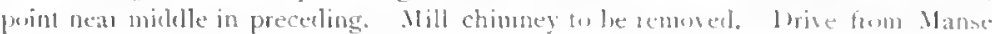
lintrance to proposed new East bridge (Chap. Xllt. and plan) womkl an along

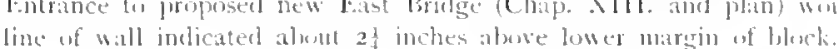

illustration shows the improvement of remosing the pats wall to the smuth and carrying a light fence behinet fig. 21 . Is shown on plan, the main drives proposed around this sombern portion of the park should have an entrance and issue here, and a new lodge at this point wouk athmit scope for a somewhit more omate arelatectural treatuent than that al Nothertown.

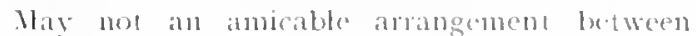
the roul authoritios and the aldiacent proprietors 

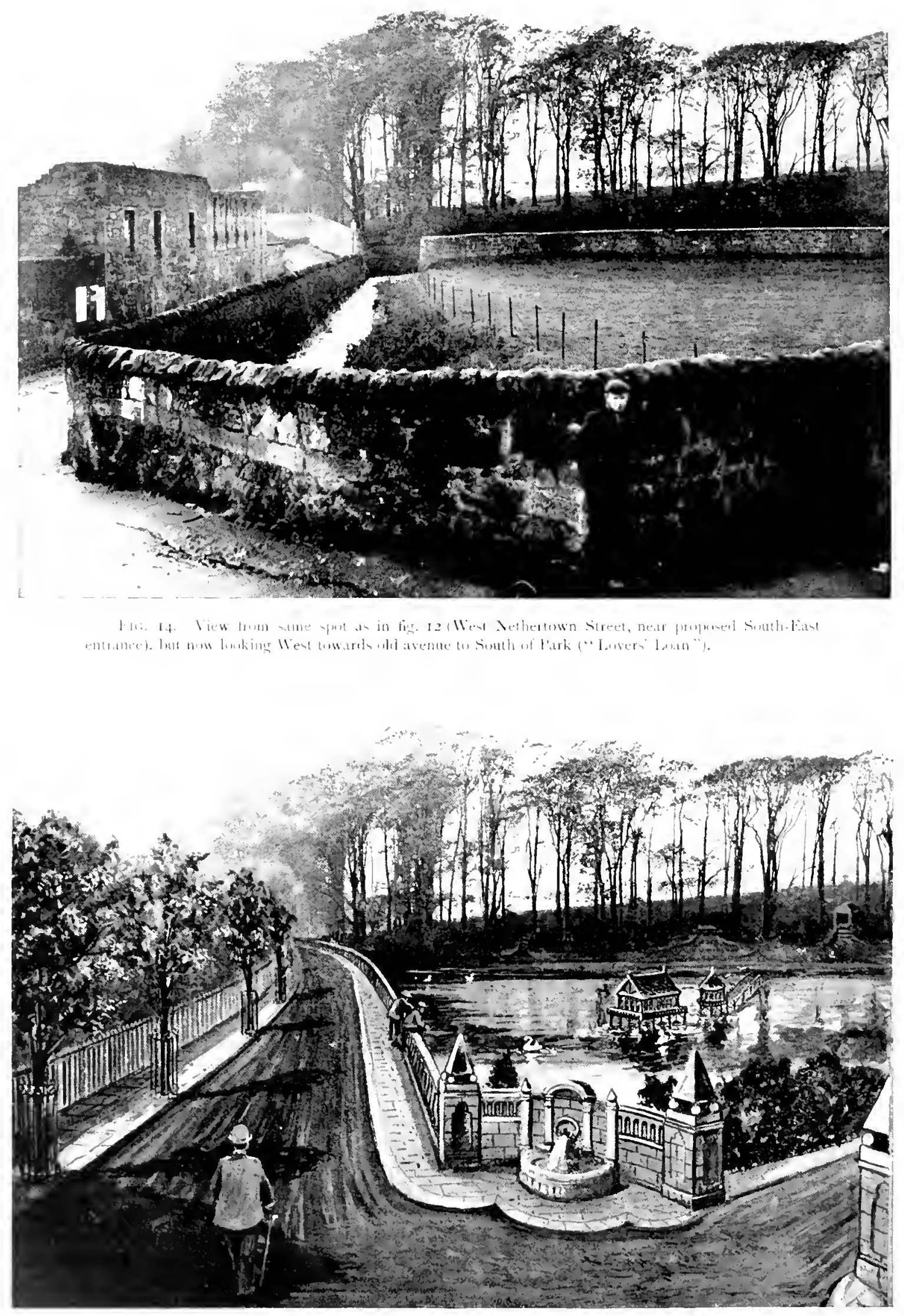

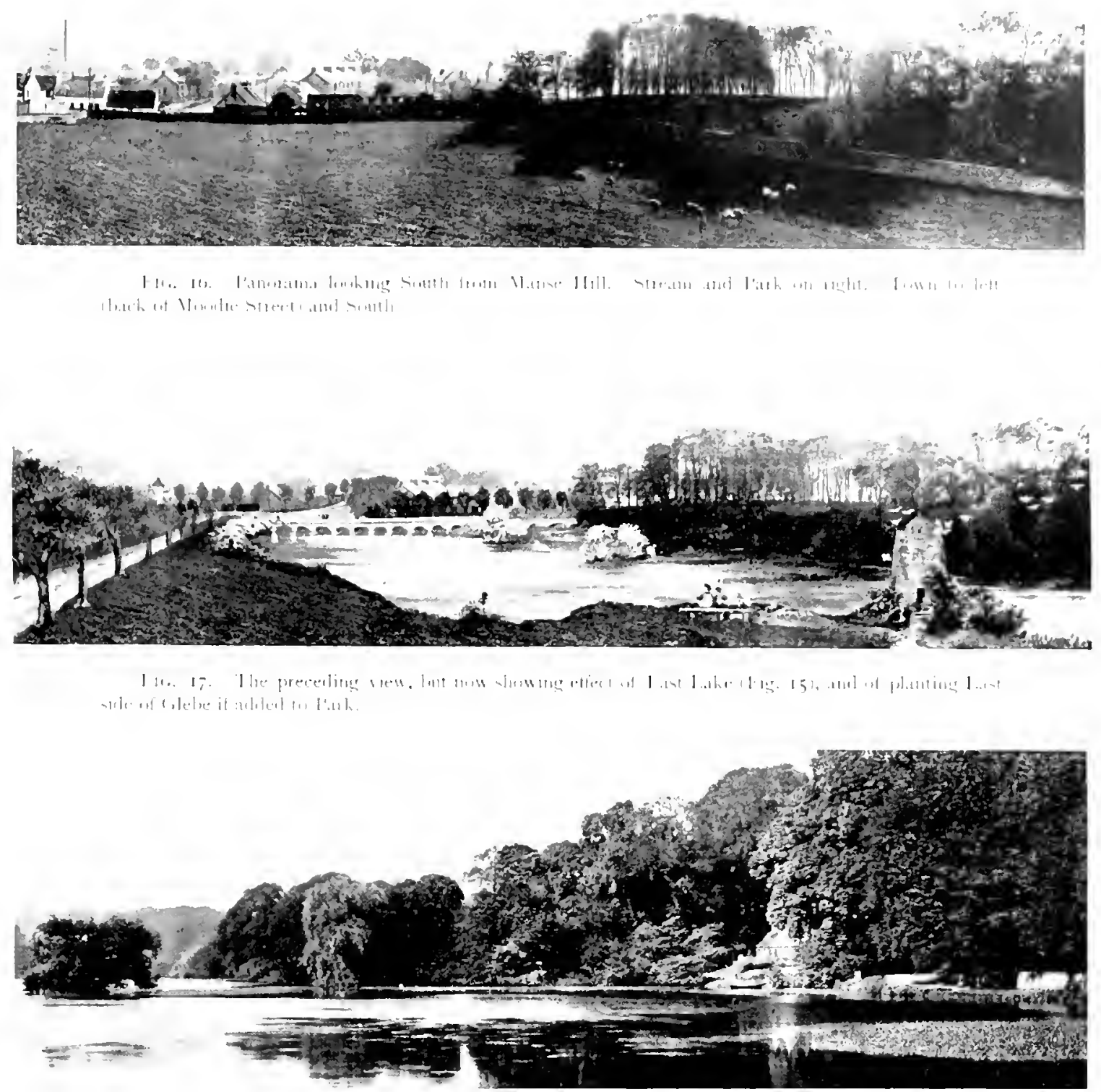

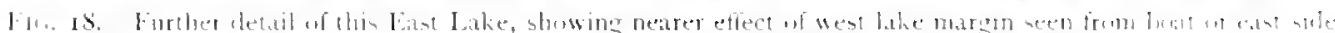

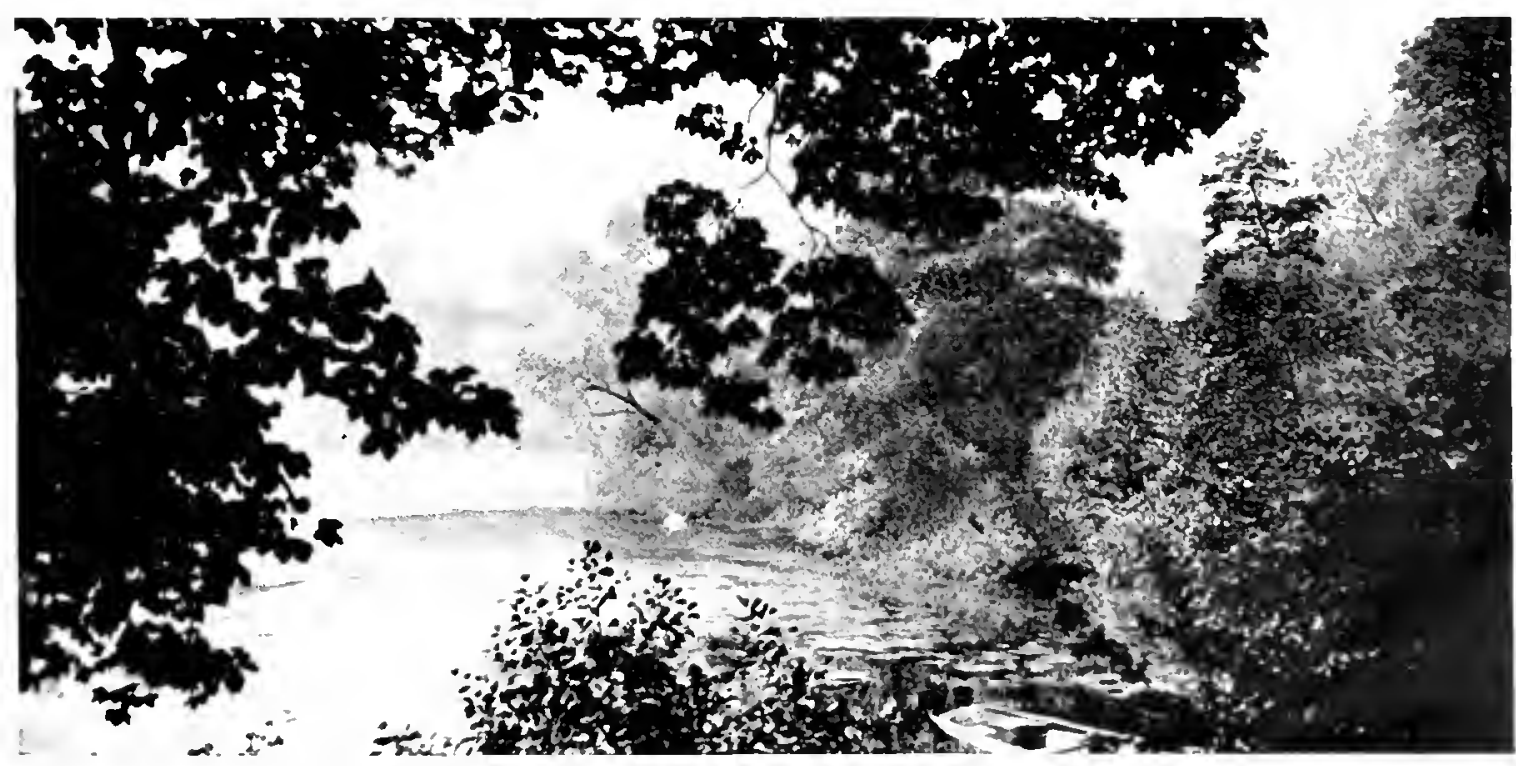



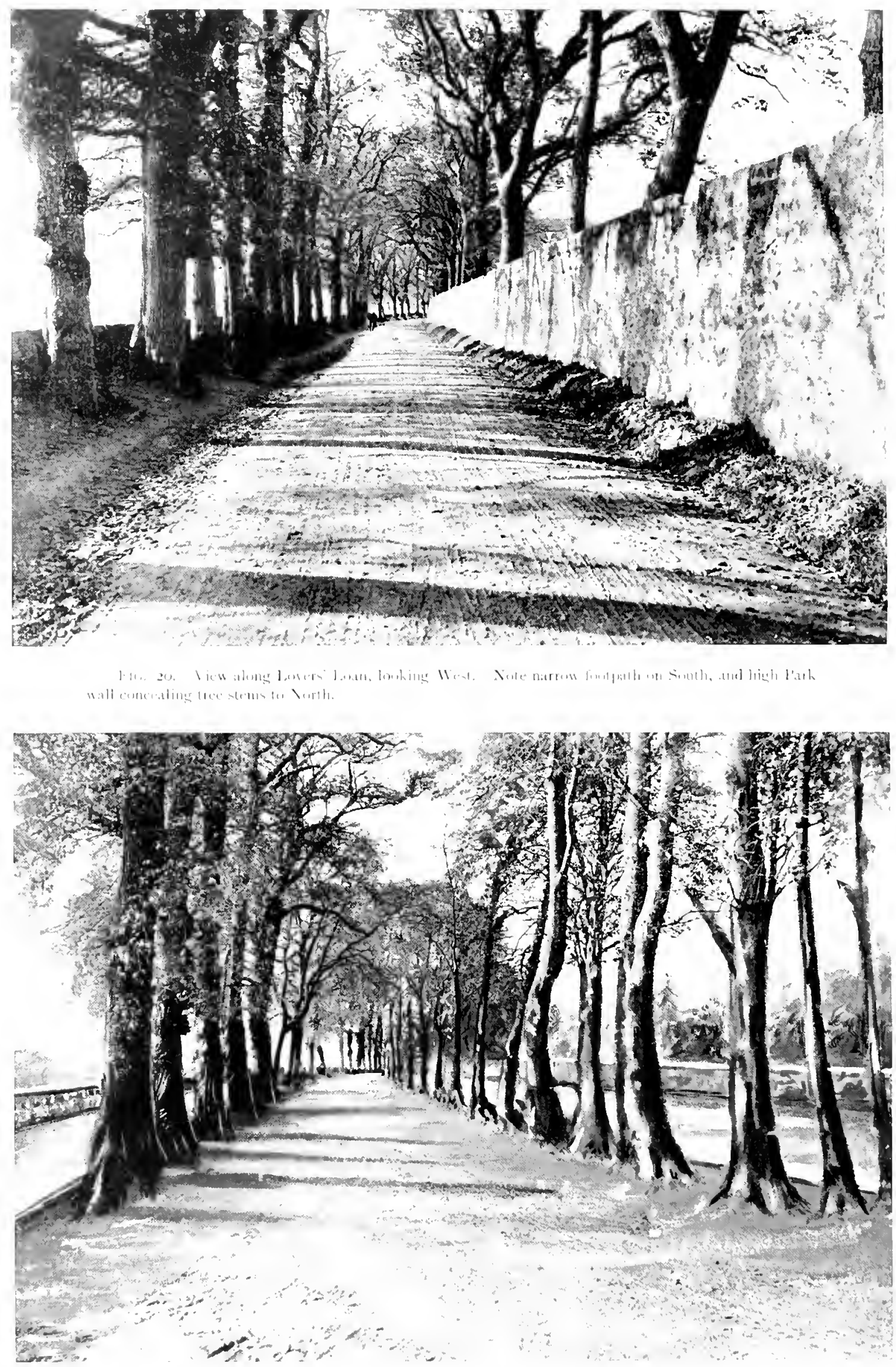
be pussible lace? Whallt met at strip of gromel he conceded by each propreter, nerth and somb of the present roat, so as to grive at bonlevarel proper, with a tomplath on either sicle of the

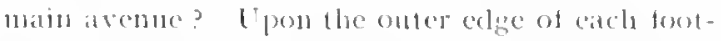
fath a new row of trees might also be planted: while the gatps in the matin alvenue would of contse lese supplied.

furning northwards np the coal koad fig. 22, is not at similar arrangement pussilse, laus continuing our mitial Parkway along the sonth side of the town and park up the west sirle also? Why

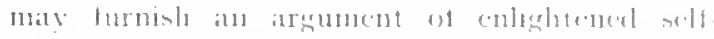

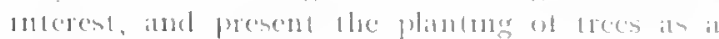

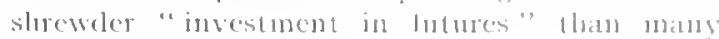
more common ones.

\section{F. Nortl Entrance and its Neighbourhood}

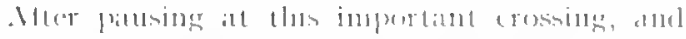
moting flat monotonous street perspectives np and down, we pass eatswatrle, atud soon feacli the forth entrance, with its new gates and loclge

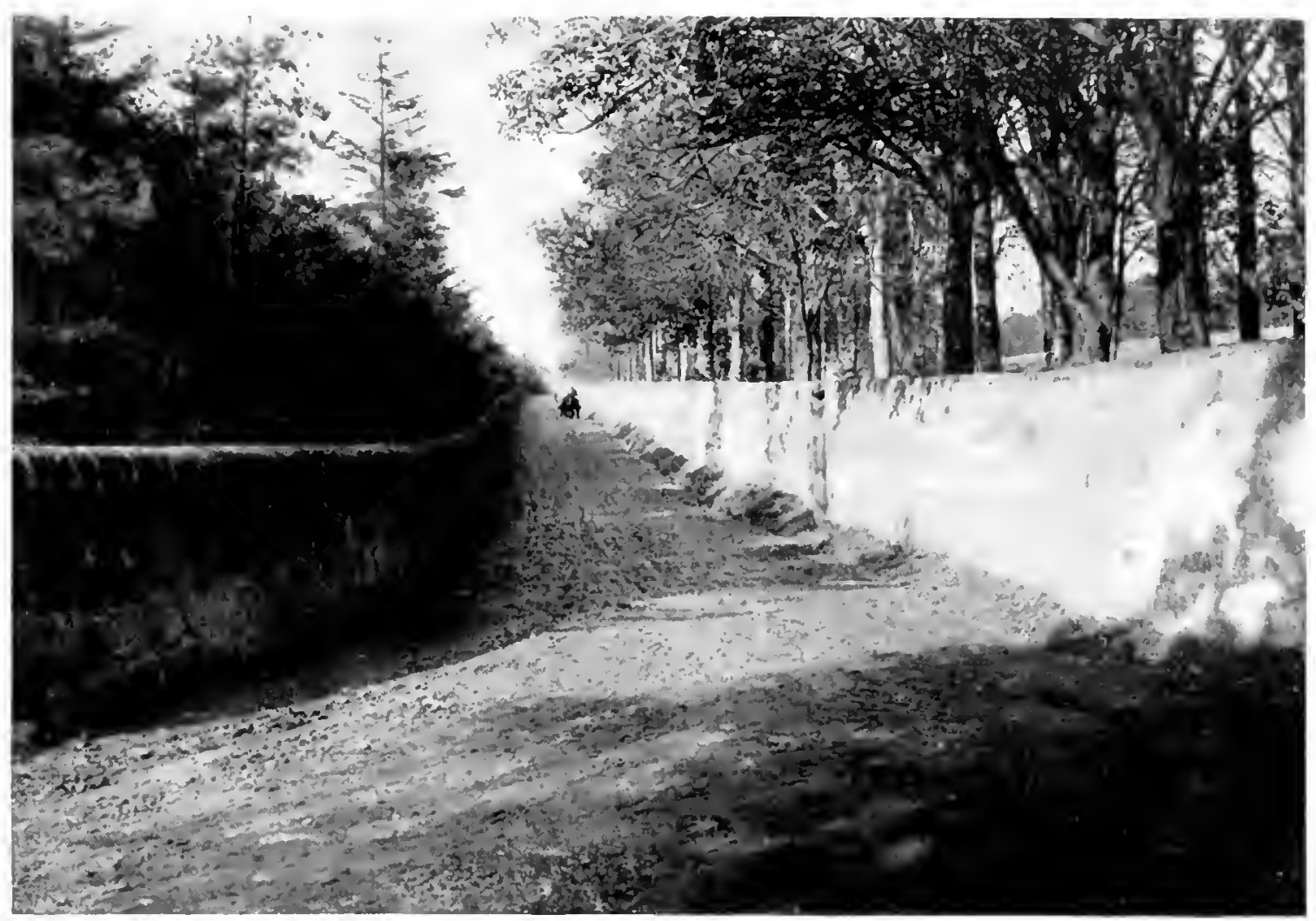

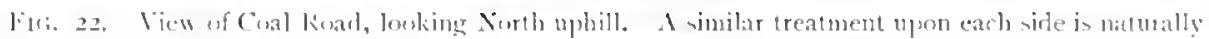

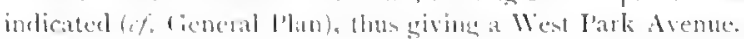

not continue the alenue still farther, so improving the new sulurb arising to north-west of the park? For this some trees alreally exist on the way to Gricre street and folfelumi, and serve to indicalde how great would be this improvement

$\mathrm{ll}$ is the clear and increasing policy of all parti inprovements really worth the name, ly duc development of such approaches 10 sencl out at any rate the beginning of bonlevards racliating into the actual city or the future suburbs in every direction possible. That difficulties exist is obrious, but this class of improvement is so obviously needed for the alproaching future that it cannot be neglected: while the substantial economic gain to proprietors, as well ats to the city,

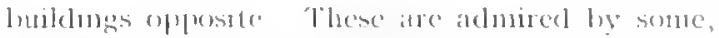
severely criticised by ofhers, but at any rate are sol new, effeient, and sulstantall ale to male no alleration justifialule, salse by the planting uf ivies, roses, jessamine, and the like upon benth lodge ant railing. Is representing the style of our own times, they also tatke as olutous at place in our opertair musenum of architectural styles ats any of their predecessors.

l'ausing again for a moment at this crosing we note the destrability of areain improving at park apprateh by planting a nortloward avenue up) Matland street and of pulting in trees alongr the ederes of the adjacent school playground. In all such matters of planting, even in comparatively 


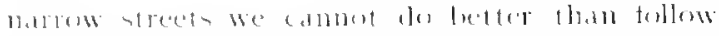

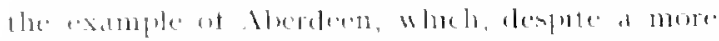

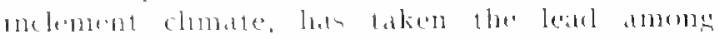

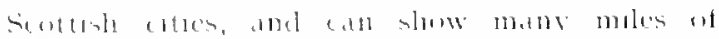

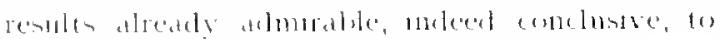

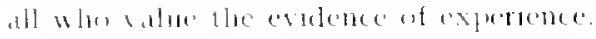

\section{G. School Gardening}

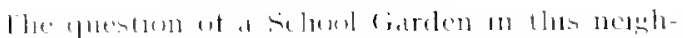

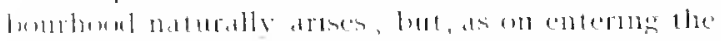

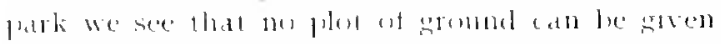

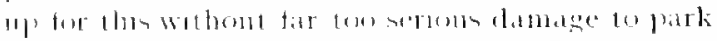
amenity, I stangly recommend lhat any grommel

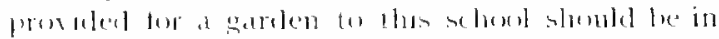

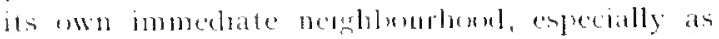

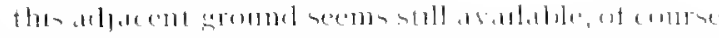

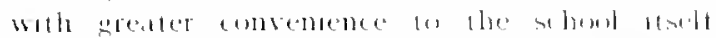

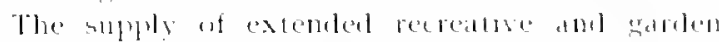

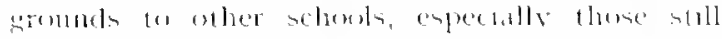

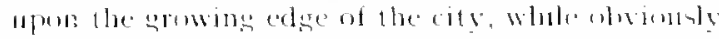

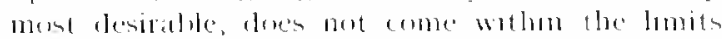
of the present rement. I sulmot fin, luswerer

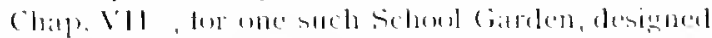
to moledte the pusbluty of combinme lush re-

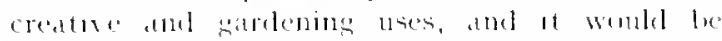

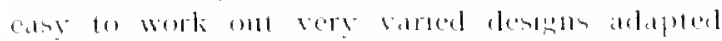
11) respeetise stles thene womble enalde eath

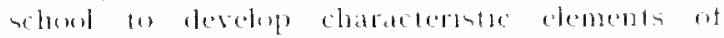

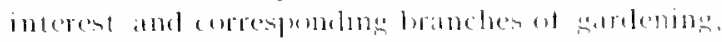
so that eath might be tert in come wat . Mll

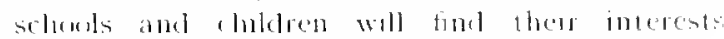

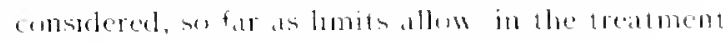

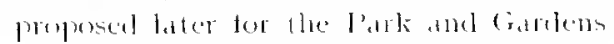




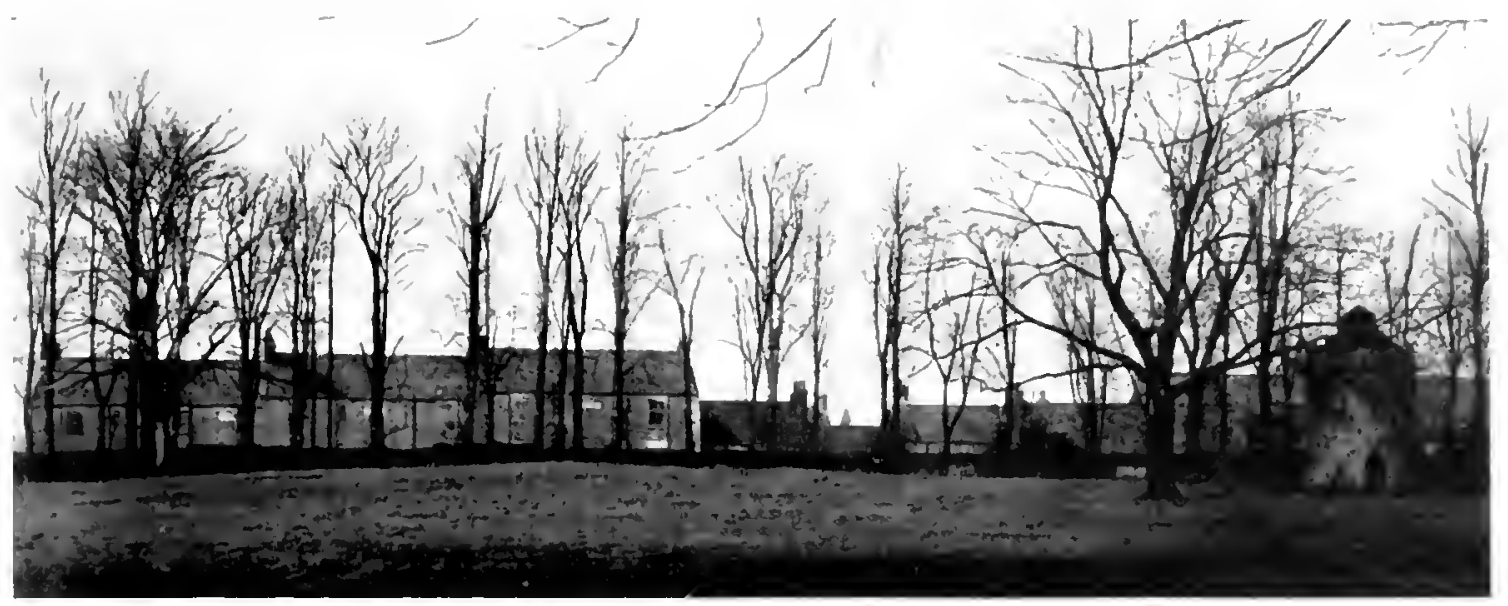

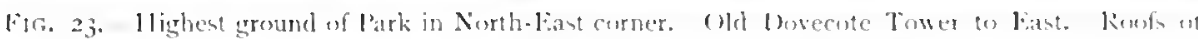

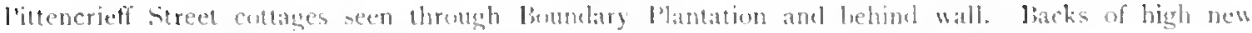

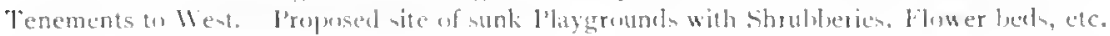

\section{CH.APTER H}

\section{NEIGHBOURING PROPERTY AND HOUSING IMPROVEMENTS}

\section{A. Neighbouring Housing Improvements}

WiтHotet entering upon the general Inusing ()uestion or the housing policy of the Trust in relation to it, the present problem, that of the park, its approaches, and adjacent buiklings involves some brief discussion of the subject within these limits.

Returning to the North entrance, possible sites at once sugrest themselves, not inly as well adapted for improving the approaches by open spaces, bousiner improvements, or both, hut also on accomnt of the serions risks of permanent injury to the amenity of this important entrance, as of others, should they be built upon in the ordinary tenement tashion, of which examples are not tar to seck. It is minifest that such sites can be used not only more picturespuely but more conomically ly the lrust than by at private speculator, for the former can more lully utilise them.

From the northern part of the l'ark, east of this main entrance, the uninterestiner backs of new and complatively lofty tenements form a regrettable intertuption of the picturesulue lines and pleasing colour of the red-rooled cottages which elsewhere predoninate, especially westwards. These bale brick walls and low-pitched, slated roots, so well seen during the long months while the trees are bare, give an oninous indication of the possible future aspects of the lark boundaries. The ugly and monotonous high boundary wall of the l'ark is atso fat 100 much in evidence. See fig. 23 above.

There is nothing necessarily undesitable in baving houses looking into the park. On the contraty, the more windews with the pleasame ontlock the better. Nom is there any objection to tenements in themselves: some such lofty buildings, at due intervals, the wrter himself responsible at Jdinburgh lor the lofty temenents of University Itall, with their ontlook upon West l'rinces Street Gardens, would naturally rather wetome than oppose, provided due architectural care be taken in their gromping and design

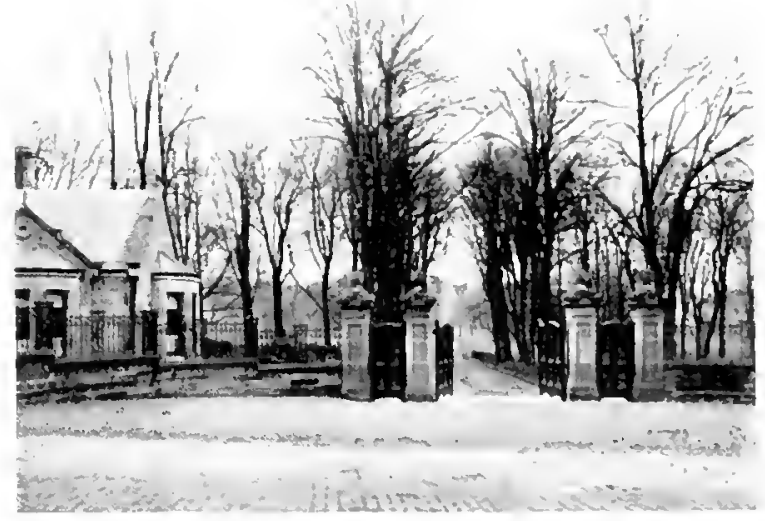

Fir. 2zis. North lintutuce.

Here, then, is at suggestion: that the Trust let It be openly understorl to all surrounding proprietors that where they are willing 10 make their present back a pleasnge frontaleve, in any way, however simple, whether ly loulding, loarhng, or verduring, and where tenants keep their garden so as to make this presentable and pleasing from 


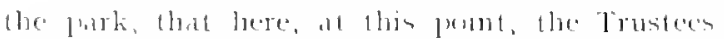

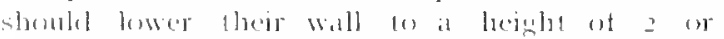

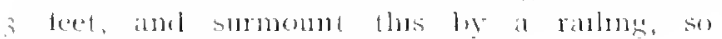

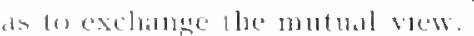

The trees, montly lomes, wheld fromed the

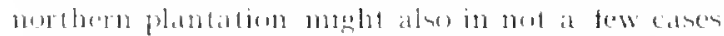
be lowered, in tied be polldeded, with sain ot

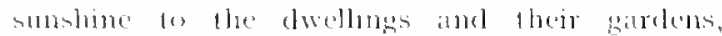

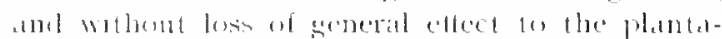

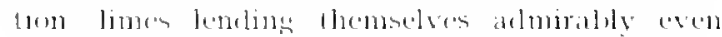
(1) the seresest freatment. Per contra, where the backs of bublemes are objectionable, the Trust shomlel leave its exsinns lrees and wall, and stall further shut wht the vew of any buildun: they abject to as of the rrregularolies of them

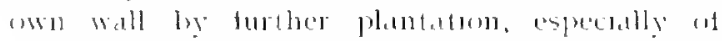
tall-growang varieties ot yew and lably, ob ats increannels for conceal them in wher

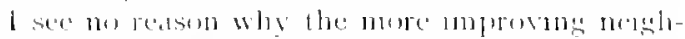

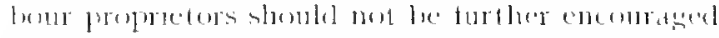
by a problese which womld give mereased value

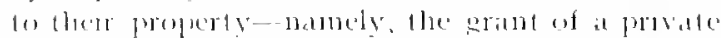

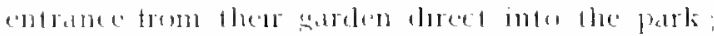
of comrse, controbled at nteht-time hy an over-

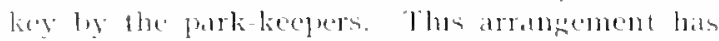

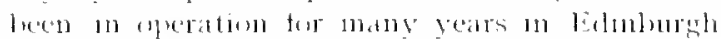

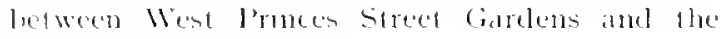
abacent butses.

\section{B. Hygienic and Domestic Improvements}

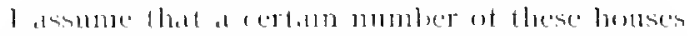

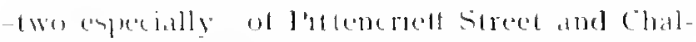

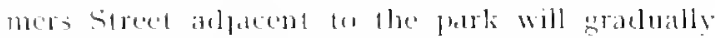
fidse nute the possession of the Trust, ls $11 \mathrm{mit}$

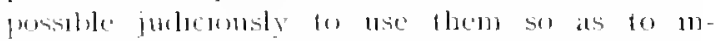

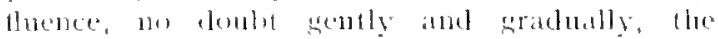
neneral housurge of the town apart from lasper bubleng selemes fo wheh my present mblouc-

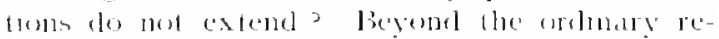

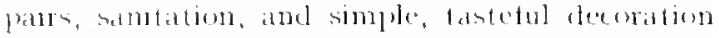
wheh maly le all taken for granted, what else can be done? I sumbit that there are at leats lwo

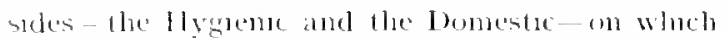
these Trust properties shonlel exhibit a defunte and comspicuous atvance. first as regatels liserene, I would urge that the foust attempt an moltutive, wheh would mo doubt like every

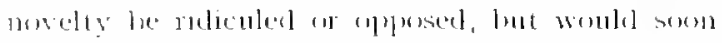
be justitiod by heable statistucs-namely, loe

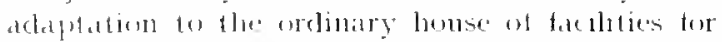
that chen-atis lite which the open-air freatment for comsumptem is tenching fo maturahse atmeng us.

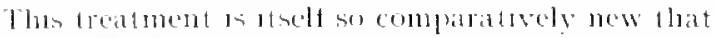
few reallse that 11 is mow passing beremel the task of curatere medreme altogedlee into that of pre-

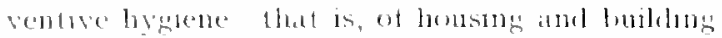
gencreally.

The old dreat of apen wambows, particularly al bugl, is now known to be a storvival of earlier tomes, when atgue and malatia were nete cren in

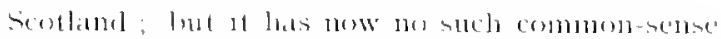

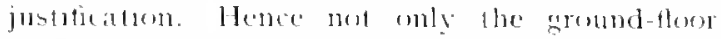
verandele summer-house, but next the opentall

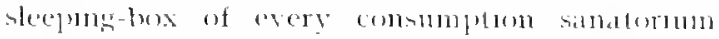

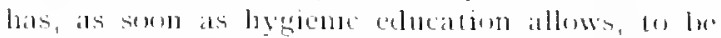
incorporated an part of the orelnary and reabenable simutary standare of the intellyerent home: the feder edluated house-mother havang hencetorth lo expend the sime conscontious solucitule in

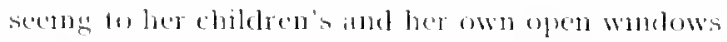
that ste has tomerly expended upon closing them: incleed, by-amel-ly feelong the sime sting of slatue at noteong a closed whelow that she already does were a dirty one. And stree it is naturally the more domestre and seclentary sex that sulfers, espectally trom censtumption, the provestem of that mestelirs bulcony wheh is a mann hygenic

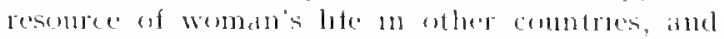

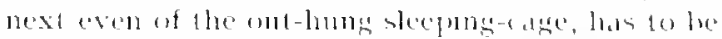
hencetorts mere and mere latgedy comsulerod.

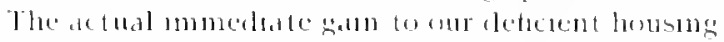
accommotelton from this casy supply of atuat

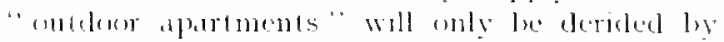
that sectom ot the pullse whom the opentar trealment han mot bet conserted.

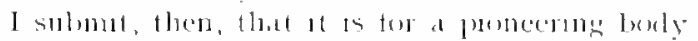

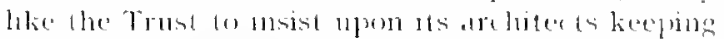
in verw thes combleratem thromglome its whole

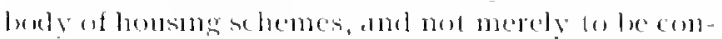

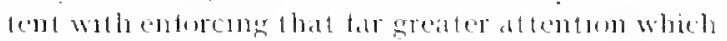
may be expected trom them as wo due plateing of

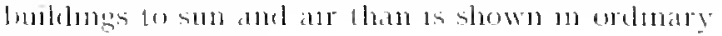
ferumeschesues.

The domeste point of bomsing mupurement wheh l press tom all propertien acporred by the lrust in that it improwng kitchen and seullery accommolatkm. This may reem a small matler.

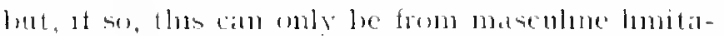
toms or from temonme molesty. After spending more fome su Ameraca than many more prolitic wroters d maty mbentatumgly set doswe my adherence to the view that those Amernan superomates whelo beerin to surjorise and dusconcert old Europe, very hargely 1 urn, inderecty as well ats doectly, upon the superom culture atuel status of womedi. Thes is no doubl commonly known: fut it is net sufficiently realsed flut the beisure for thes culture and thes mproved status is to an enormons extent elerwerl from that dimnumbon in domeste druduery whoh dostugnushes the

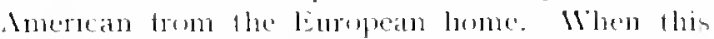
begsun fo be realised melsedine chivalry will hake the form of mprowng the kitchers and th alppurtenances, alike for cinclerellats sake and for her motress's. 11 is thiskessening of drudgery, lessening of fatiene and worre, that leaves the women of the homsehole-mistresses, danghters, and makds alike-tume, anel conseptemtly stremgth and inclination, for the culture atctivites of the llomen's Club, whth its wide and widenng in- 


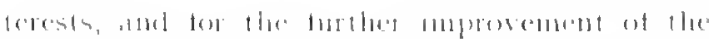

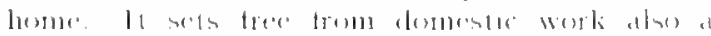

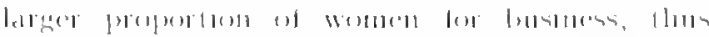

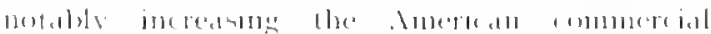

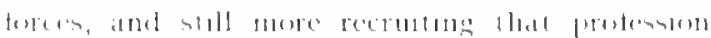

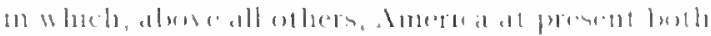

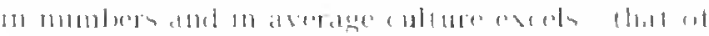

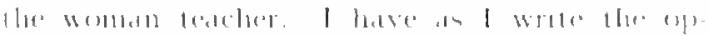

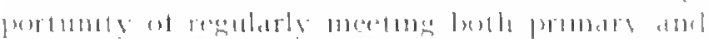

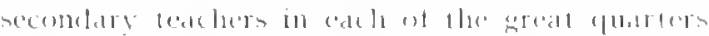

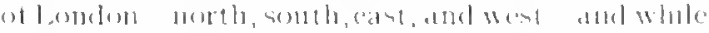

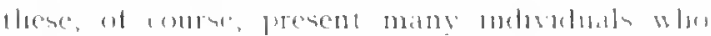

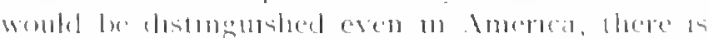

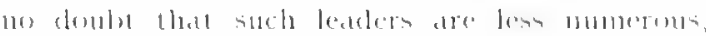

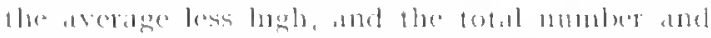

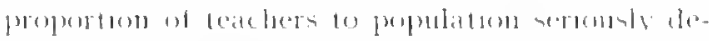

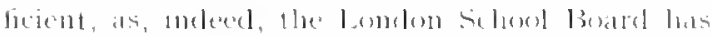
bately been recommongen

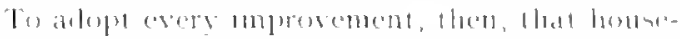

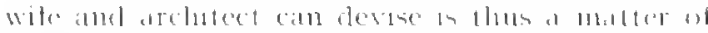

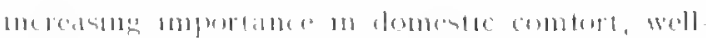

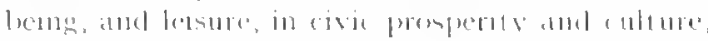

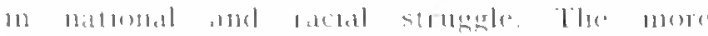

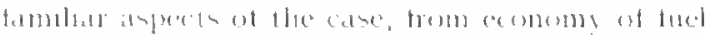

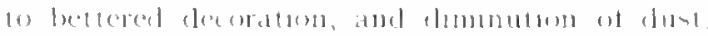

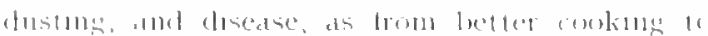

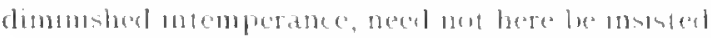

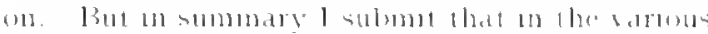

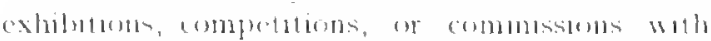

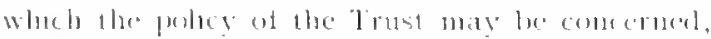

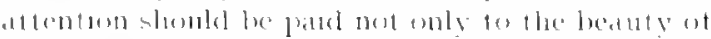

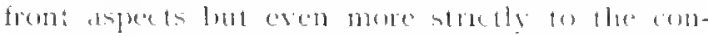

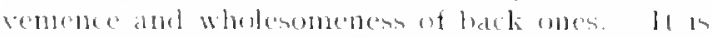

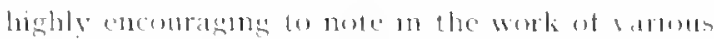

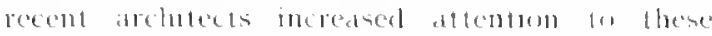

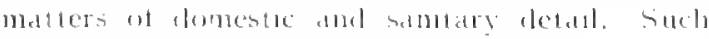
moprovements have artante value also

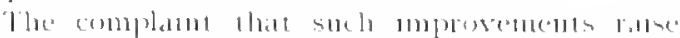

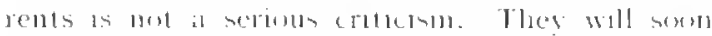

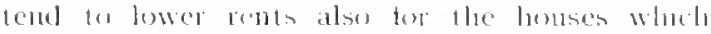
reman behomet the age. The ensential problem at

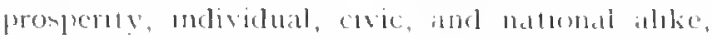

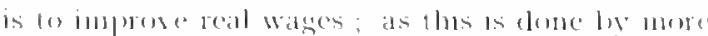
and more touly prolucture molustry lac meney Wager must, amel do, tollow

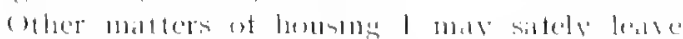

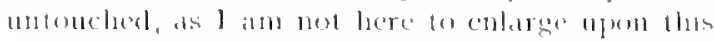

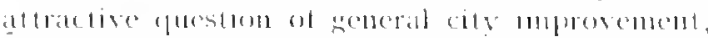

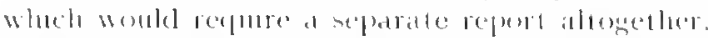

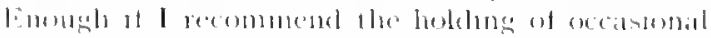

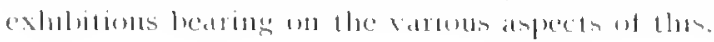

\section{Housing Improvement Generally}

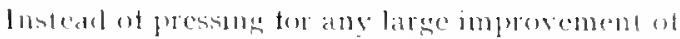
thas or that pont, imolvang extenstic purchases

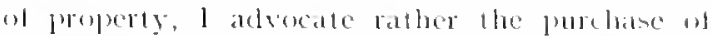
properties al many proints alome the matrents of the park, where, in the natural oreler ot llings, presperties are changing hands every yeatl. Thus,

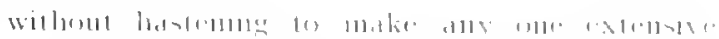

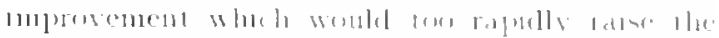

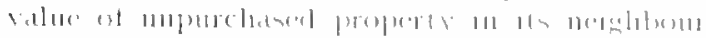

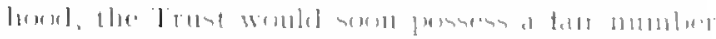

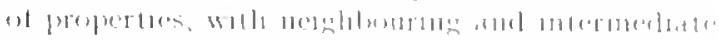

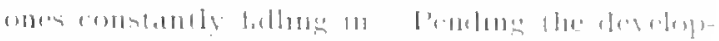

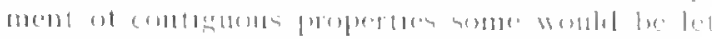

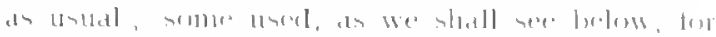

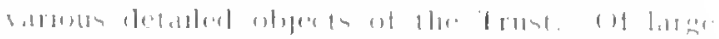

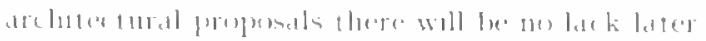

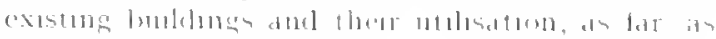
mat le, are the tarnt ate

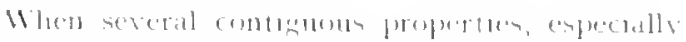

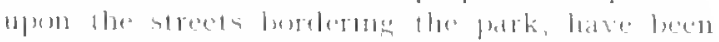

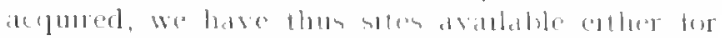

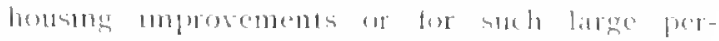

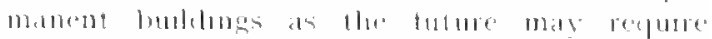
These would tre wedl boun from the park also le

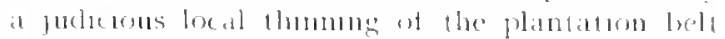

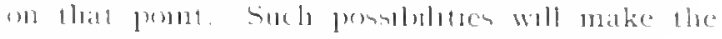
Trust increasingly indepentent of pressure trem

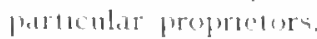

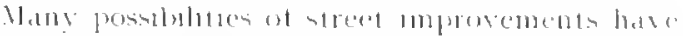

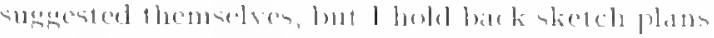

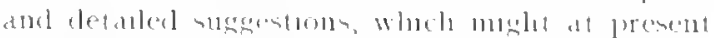

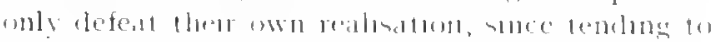

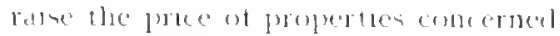

The progess at buntermbe muposements

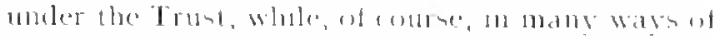

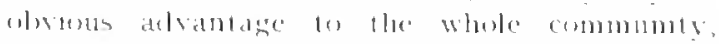

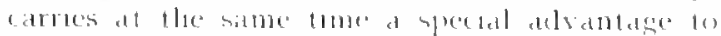

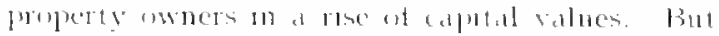

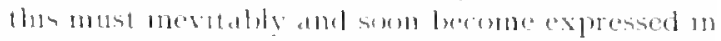
demelency lowards a rese of rentats mene com-

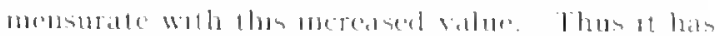
ecome about betare men that an lomporement

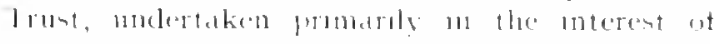

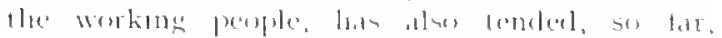

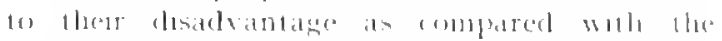

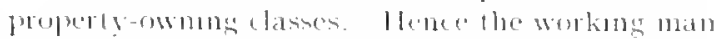

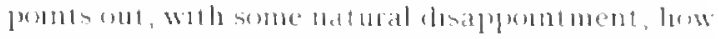
amprovements an ratse lus rent hut cannet ralse lus wages. P'er contlat, lare property awner boulls

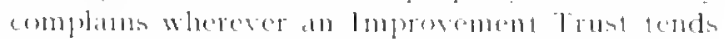
to cheapen dwedlones by mereasing the number of

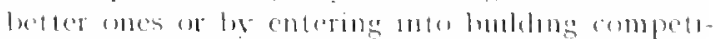

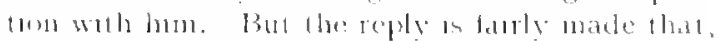

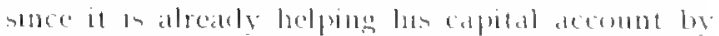

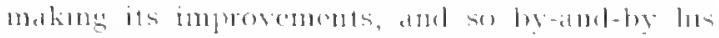

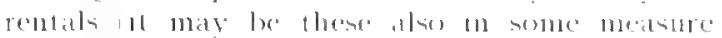

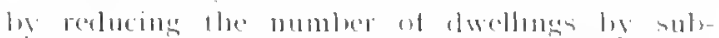

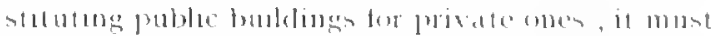

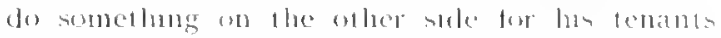

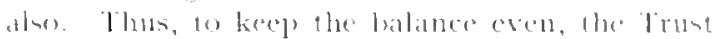

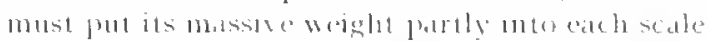

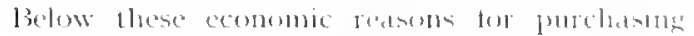

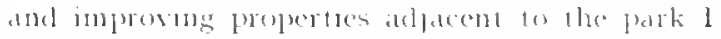

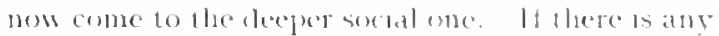

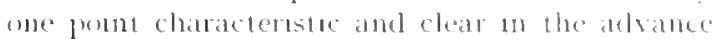

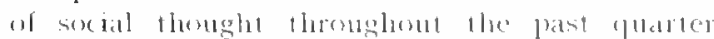
century it has leen the return from the pareely 


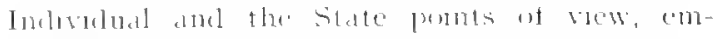

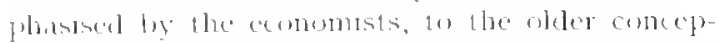

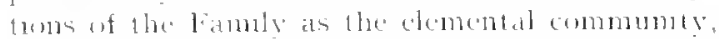
anel with flum of the Coly, as bu many purpeses, if mot mont practual ones, the true State, and not

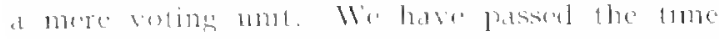

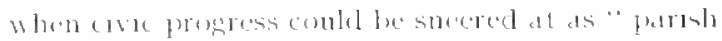

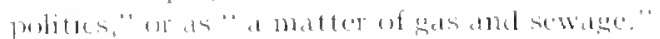

With thes point of veres, in tact contral to it,

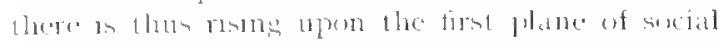

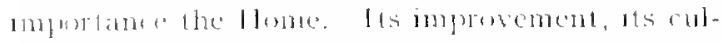

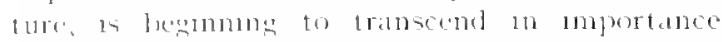

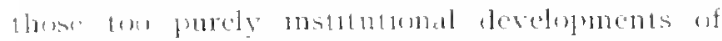
the precelong humberl years wheh hate leeen so

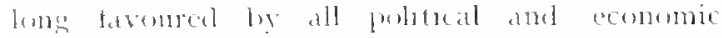

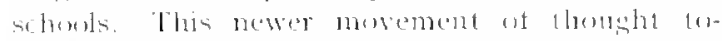

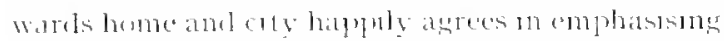
the pustum wif wombon, and thes no lomger as at mere puldeal "melivelual," a mere "econombe man," Hut agsur as home-maker, choliser, an all sules, theretore, as atigens.

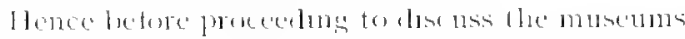

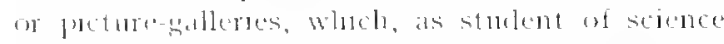

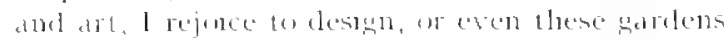

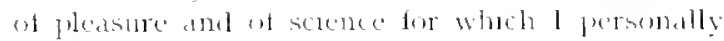
care most it all, I presis this fluestoun of lome

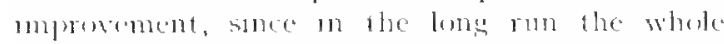
culture proluc at the Trust will be measured in terms of the comfort, culture, and chatacter of the lonfermbue lume.

but low is a Trust fo modefle woth homes?

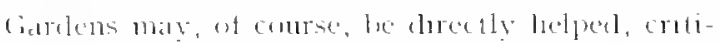

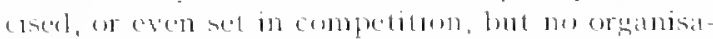

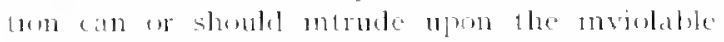
privace, the alselute melepentence, ot the m-

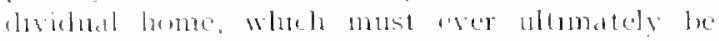

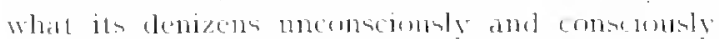
make 11 .

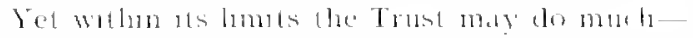
tirst, as that most needed sort of model lamellenel

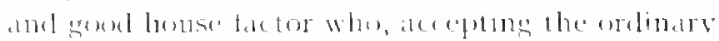
eveting rules of the lusiness fintme, yet sees 10 11

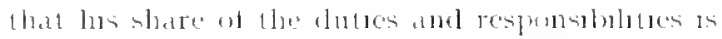
fulthled to the utmost. But 11 is not the problem of a mold fanderel lo supply more houses morely of the average foulaty, still less to mereane at mommum atcommentation tor mommem rents. thengh there are many pholdnthogists who thank

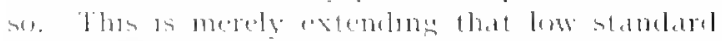

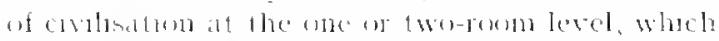

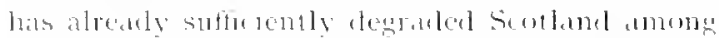
the peoples, ald which temels we kner watres as well. The lask now ledere us is a forte dolterent

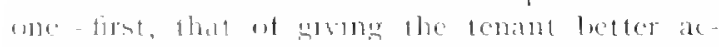

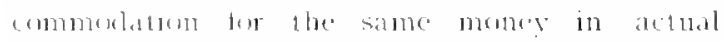

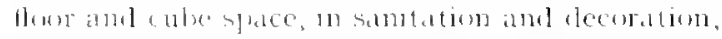

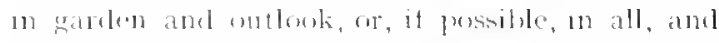

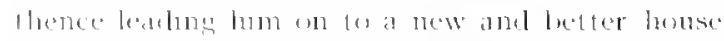
altugether this must nocessitily be a dedred ane, lut the encreate of wage-earning pourer

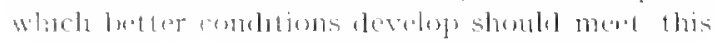

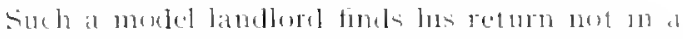
lusher purtecntage but in chence and fermanence of the lest tenants, wab comseptuent regulatily of letamg and maintenance of property. It in, thereture, wh the simple evervaly lusuness metherds of Mliss Octarda llill, wheh have lueen

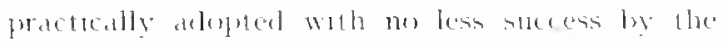

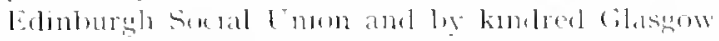

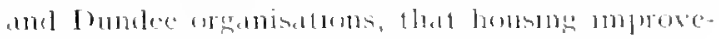
ments may reabomalily begin.

Thes somd fousmess, at first mose of tactoring

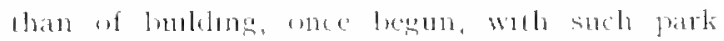

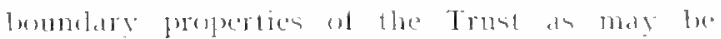

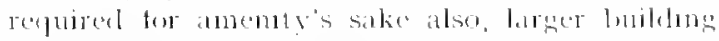

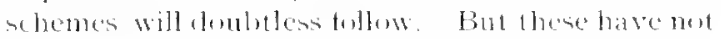
wo be considered within the present lomis

There are mmotiate uses te whoh such ald jacent

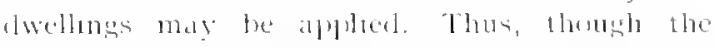
existing and firospective linderes will house some of the wotking salf of the Thust, more louses may be repures. Though the bothy, customarily suppliced tor momarted sardeners, woulel bes, naturally, near

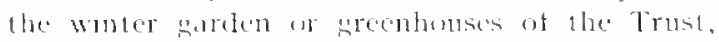
al least one such cottage mught sull be usefully found on this nejeshourhous

Thombly gomng men ate alwaty free 10 find

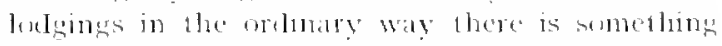
to bestid tor their living together ; and experionce of houses of resulence for studenth who are much ble non-students slowes that common lowng is of atromtage to a majorty. Experrence also preves that though the provision ot restence for women wothers is less dereloped, becuste nore diffecult of soluteon, 31 is yet perhaph more needtul and thes not only on ecomome srounds but on

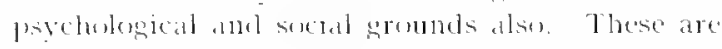
mol bemes, ret, beskle their immerliate usetul-

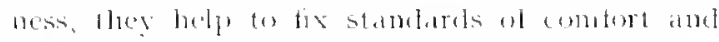

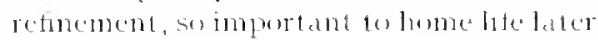

\section{Social Survey}

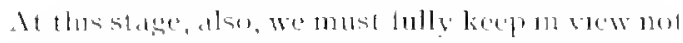
mly the mmediate stes fun the use whe con lx make of them towats serial hetterment.

The current change in ecomonnd thuling, from acaleme there and wotkmedase strmgele tor money wates, for he olservallon and amprosement of real wases, centres essentally upon thes housing

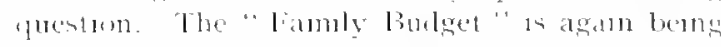
secon to be as essentall lo the theory as to the prac-

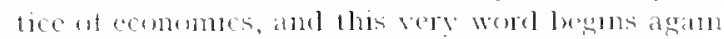

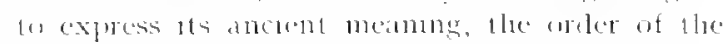
homses.

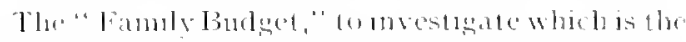

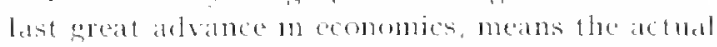
fluantity and puality of home syace, of clothing and foedeng, ot wameng and lighting, of celucatron and reading, of covlisme or debasing pleasure. 


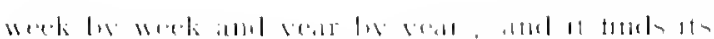

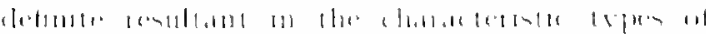

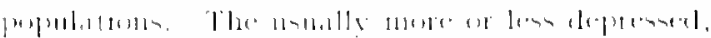

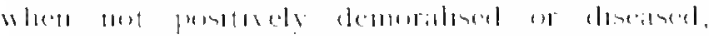

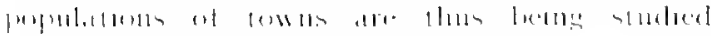

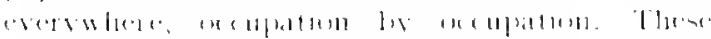

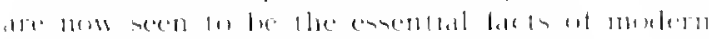

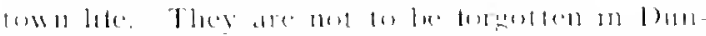

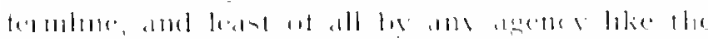

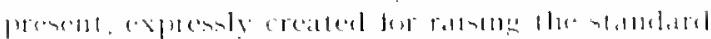

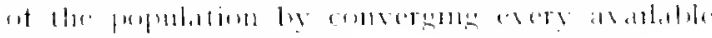
renomare of crilimatlom

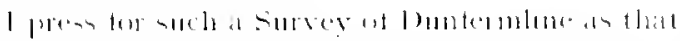

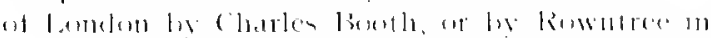

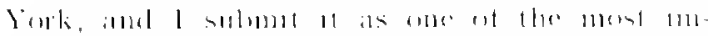

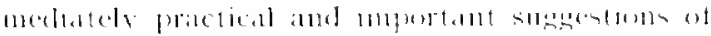

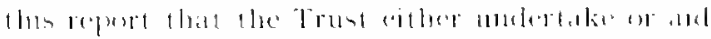

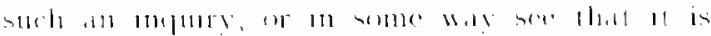

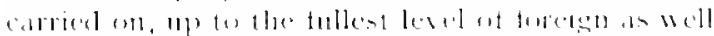

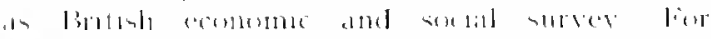

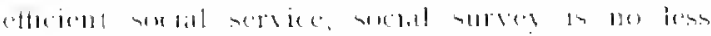

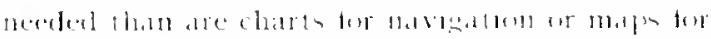
win

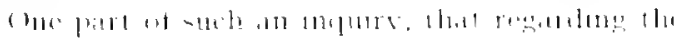

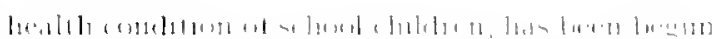

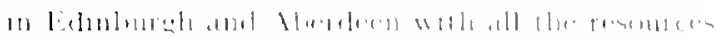

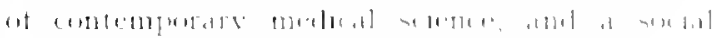

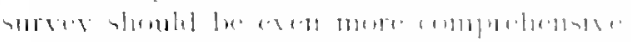

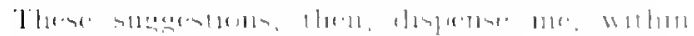

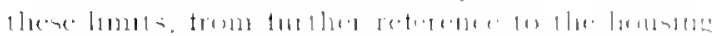

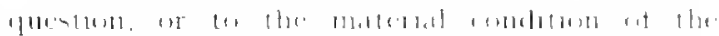

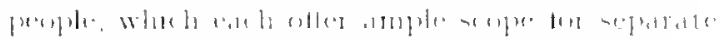

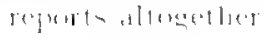

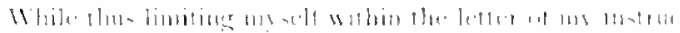

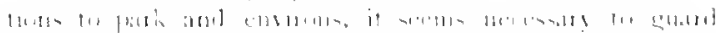

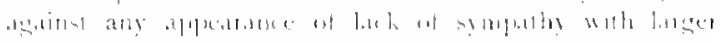

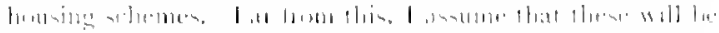

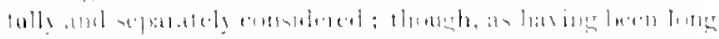

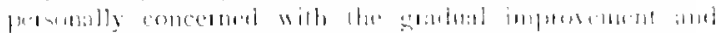

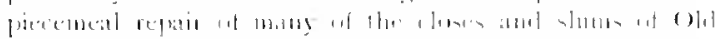

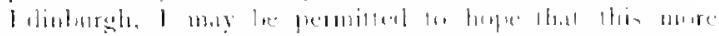

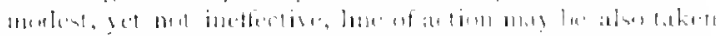

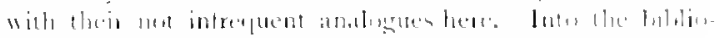

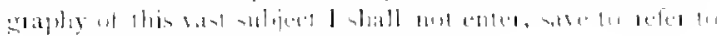

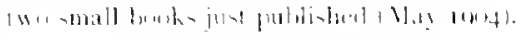

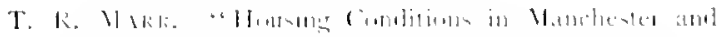

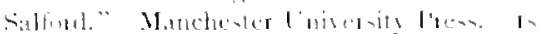

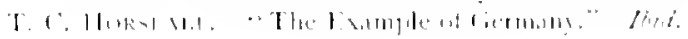




\section{CH.MPTER II \\ SOCIAL INSTITUTES AND CENTRAL INSTITUTE}

\section{A. Social Instilutes}

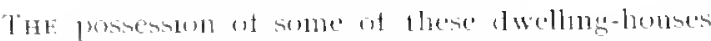
neere the parte woulel alse gree the Trust an

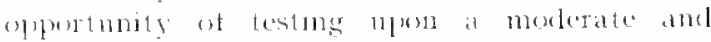
experimental scale one or two if the soctat in stlutes which latue of late been so strungly recommemeded low the Res. I) l'atun, Mr Arthur

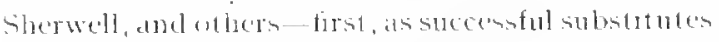
for the puble-humes and secomel, ats reacting usefully upon homes on then districts. To give thes pronciple farr trabl it must le tested, tor young women and tor youmg men, for alder preople also,

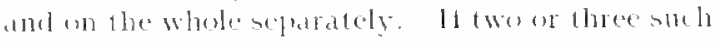

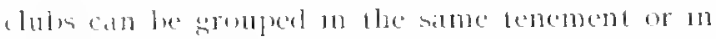

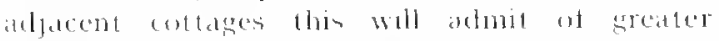
ecomomy at management-teg. 12 heatings, re-

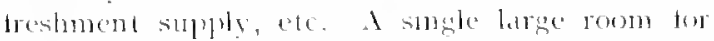
entertanments and other speetel acasions woth thas suffice for the whote group, and other ecome-

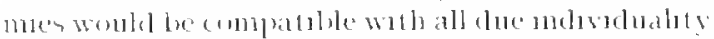

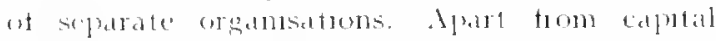
mivestment, the expenses of a mexterate start, hor

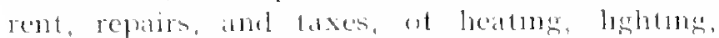

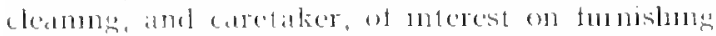

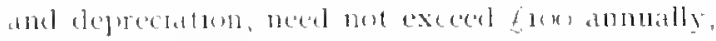
while a subutantal frertuen of thim moght be

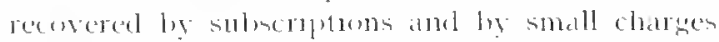
(n) sames and entertabments, learmes only the hatence therefore an be med ley the Trust. It is

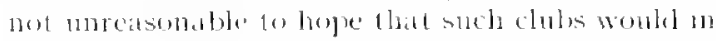
tume become self-smplusting, it net even vield at margm of profil, whoh moglut be cmplesed to rellee the mblat deticit upen starting new ones.

I an aware that many prefer to begin wan a

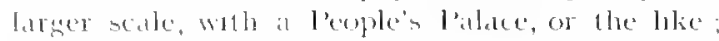
fut 1 sulmit that lesth types are neceled, ame the smaller first. This small type of instutue, where

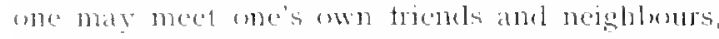
hut not the whole awn, is a neceled element of temperance retom, of che peresess, and, hast but men least, of that educateon in social lile, $11 \mathrm{re}$ spensbolnty and almumatratue experience which

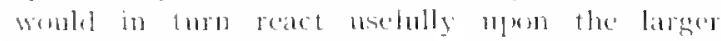
cillzenship,

llere anan everything must ultmalely deperel not upon the Trust directly but mon qhe vital personal inithave llueg can tmel for management. and this nust lee of that rorest kind, whet can

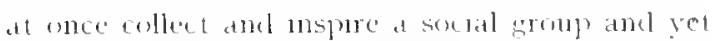
provide tor the own replacentent from within its ranks

Dr l'aton's anel kindred sexial lustitutes dre

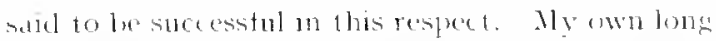

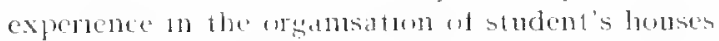

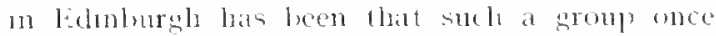
started soun heomes, and on the whole thoroughly rematns, worlhy af the ulmost contidence wheh

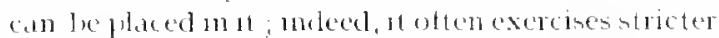
regulation trom wathin than could possthy be

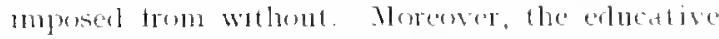

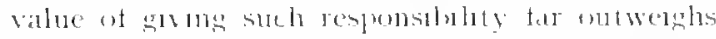
the ecentence of acedsional melestrable incelents. while eren thene are tound movathly to provelie a bealthy reactom, which is the best sategatrel areanst thedr recurrence in the future.

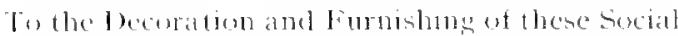
Institutes 1 womlel attale much mportance, pleadms tor the atdeptum ot at standart 10 ad-

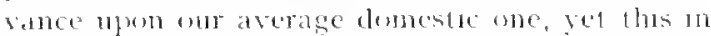
the directurn of smpliesty no less than of $1 \mathrm{~m}$ prover alernment. Simply staned anel waxed flows, whth only the tewest and smplest of ruses

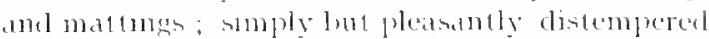
walls decorated wath those gend and cheap repore ductoons of misterpeess wheh may now be no less wotho the reach even of the poor than are the cheap papers simple tahles and cane chairs, and some of those chear but restful deck-thairs

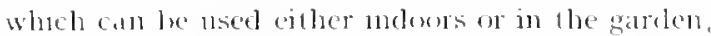
complete the essentuals at an expense sulstantally betow that of the orelnary turmshung of the corresponding lume. This eombination of ecenomy and heanty in fumblong, actuatly known as the "Iniversity settement siyle" in Whitechapel. in New lork, anel Chucasu alike, is lwoming adopted m the homes-especially, of course, of the newly matred -and it serves as an exeellent beatse upen which the further atorument, se instinctive to the home-malking sex, maty be carted om. The reaction of all this upon liome lite anel fanmly ideals has still to be sutficiently realised.

This ecomomy in furnishmes will help towatrels a more hberal outay mpen an essential to calch of 


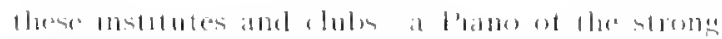

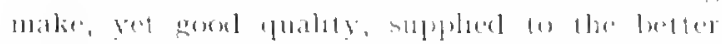

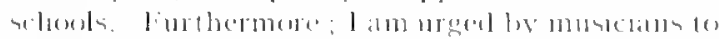

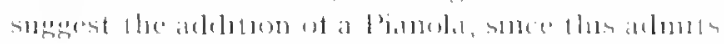

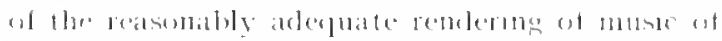
bu higher quality than comes withon the range of

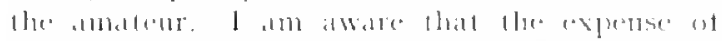

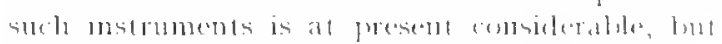

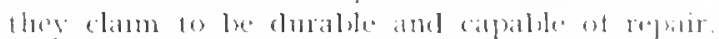

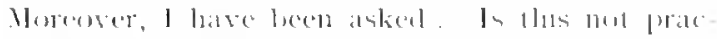

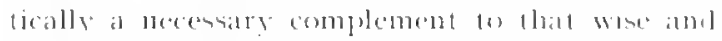
generens encombagement lo muse upull whols the

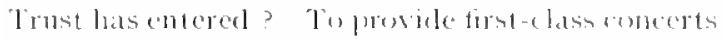

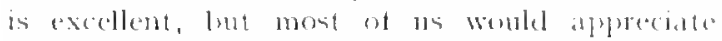
them and protit by them tall mole it we comld first frepare tor them, and also recall them ly hearing

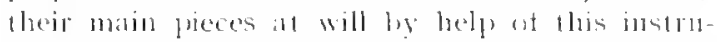

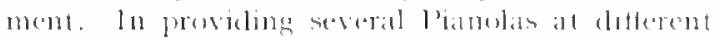
contres of the lewn the Trust muht alsuerenumbe

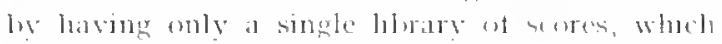

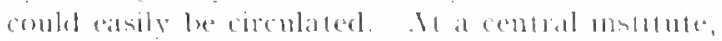
at least, the cxperment might atsily lu make ol

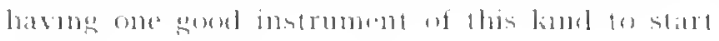
will.

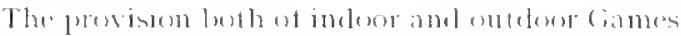

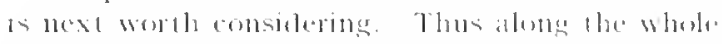

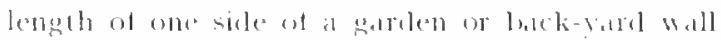

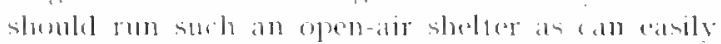
and cheaply le erected lo carpenter anel steres, and of wheh the pents can le wreathed wath roses for stumber and gessamine tor whter. Thestuder. well bollomed whth ashes, wombl serve as an outdeser apartment, amel would thes help an that

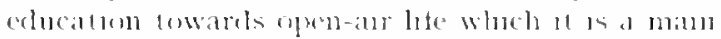
the of this whole repore to instigate. The seats

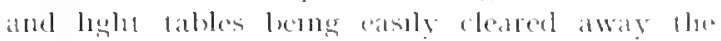

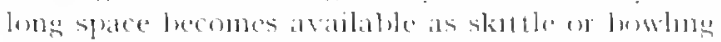
alley, an admirable resomed for enther sex and . 1ll ages, in wel weathere espeesully.

With all this should get the supply of one (1) (wo)

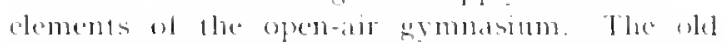
impression that grmmastics are only for poung men has leen dispelled by girts" achersh, and ats the better-educated generatlon has leen growing up some have continuel its gymmastes, so that we are beginning fo have gymnasts of all ages, just as we have cyclists, pedestrians, and riders 11! (o) olel age. In the puthic gymuasia of advancert cities like boston there are large regular classen for elderly men; and the gentle, yet atetise, and upertatir hygene so essential to vigerour old age is also in actise progress. Such institutes wrll not intertere with the great public symmisia, ofe, any more than do privale haths with pulbe ones: they will in the main help each other.

I lwh very strongly that these mitial trincal units of the social institutes of the operumg tuture are, and should he, of a modest and homesuc eluellarter; in advance certainly of the average lome,

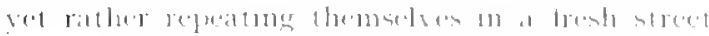

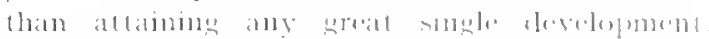

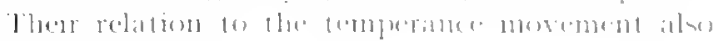
molucatus thus

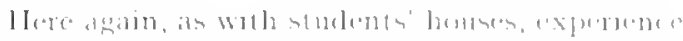

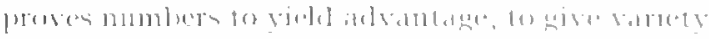

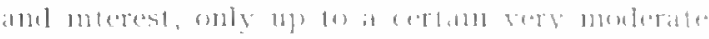

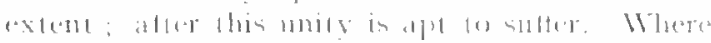

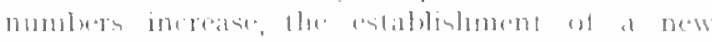

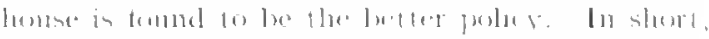

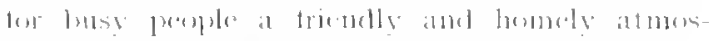

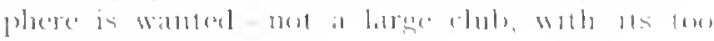
pasulng aceprantance.

\section{B. Residences}

Acertan natual growth, hemerere, is lestimate ame destrable, Residener, primarily tor the unmarried, but sometimes 11 may be also the maried, may noturally arme an conjumetion woth

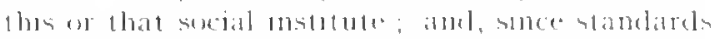

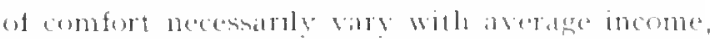
like groups tend to lue tomed, lore of working

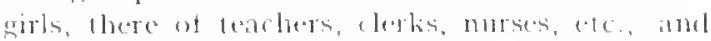
simblaty tor mens of deterent incomes and crecupations.

ln conjunction with abch of these homent the

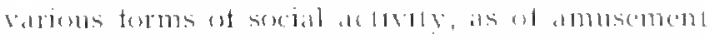
and entertainment, whelel atrise fust als they kn in larger cires. There the small univereldy seflements and the like are steally growing up

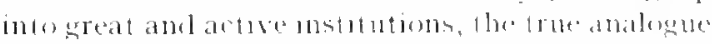

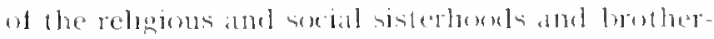
heods of the past. With this growth ness lonita

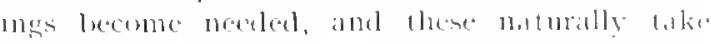

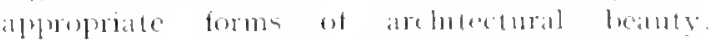

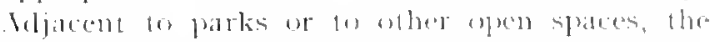
value of suct inctutules is maturally ereatly

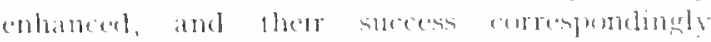

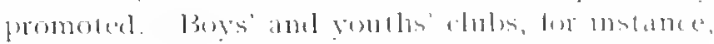
cant lous especially be jurmoled.

Wre mass of lmidelings, fortunately already the

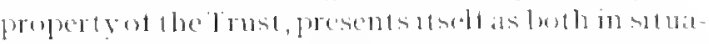

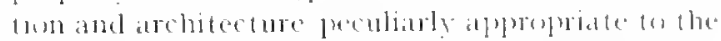

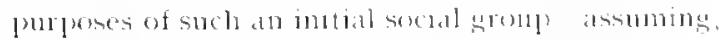

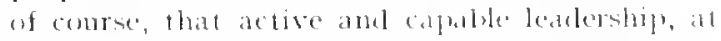
ance moral, practical, and mollectud, whols is refuired. Starting with one on the dwetlmes of

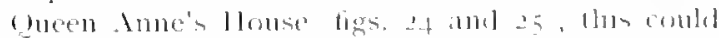
metude others as requirexl, and grabually now-

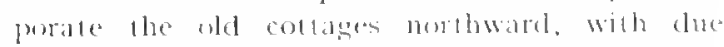
repair, or rather, on this case, relmblomeg of the beanty and fineses of these old huldungs I have alreacly spoken; and llougl these, as I constantly find, are fas tom lump whtomenty aptreciated in Dunfermline, l can omly s.ly that 1 know

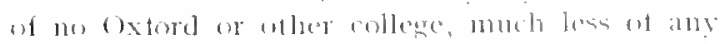
unisersty settlement, whith womld nos be prond

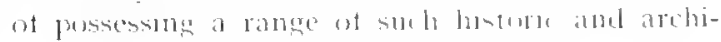




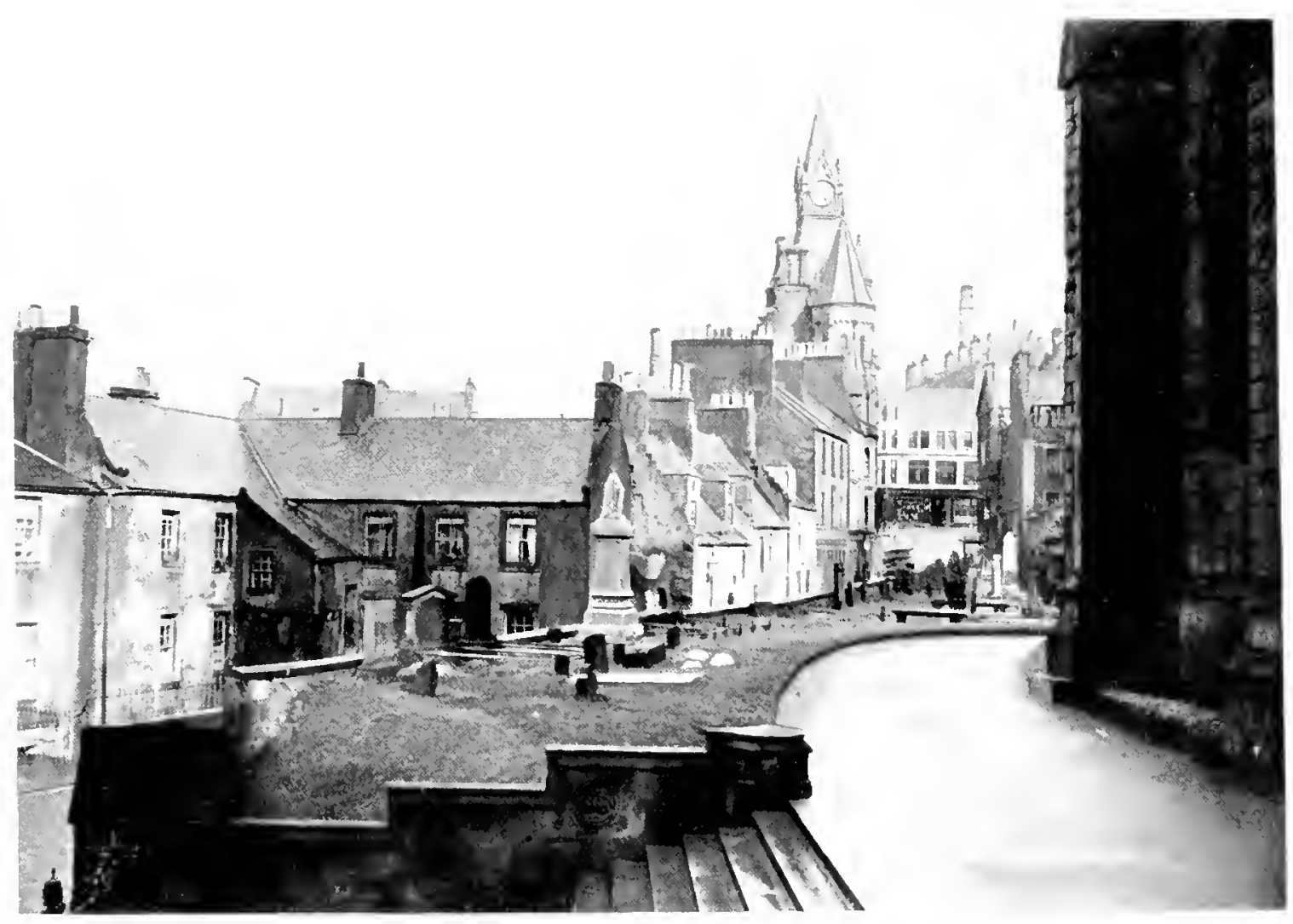

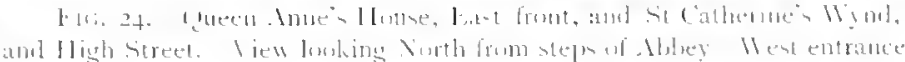
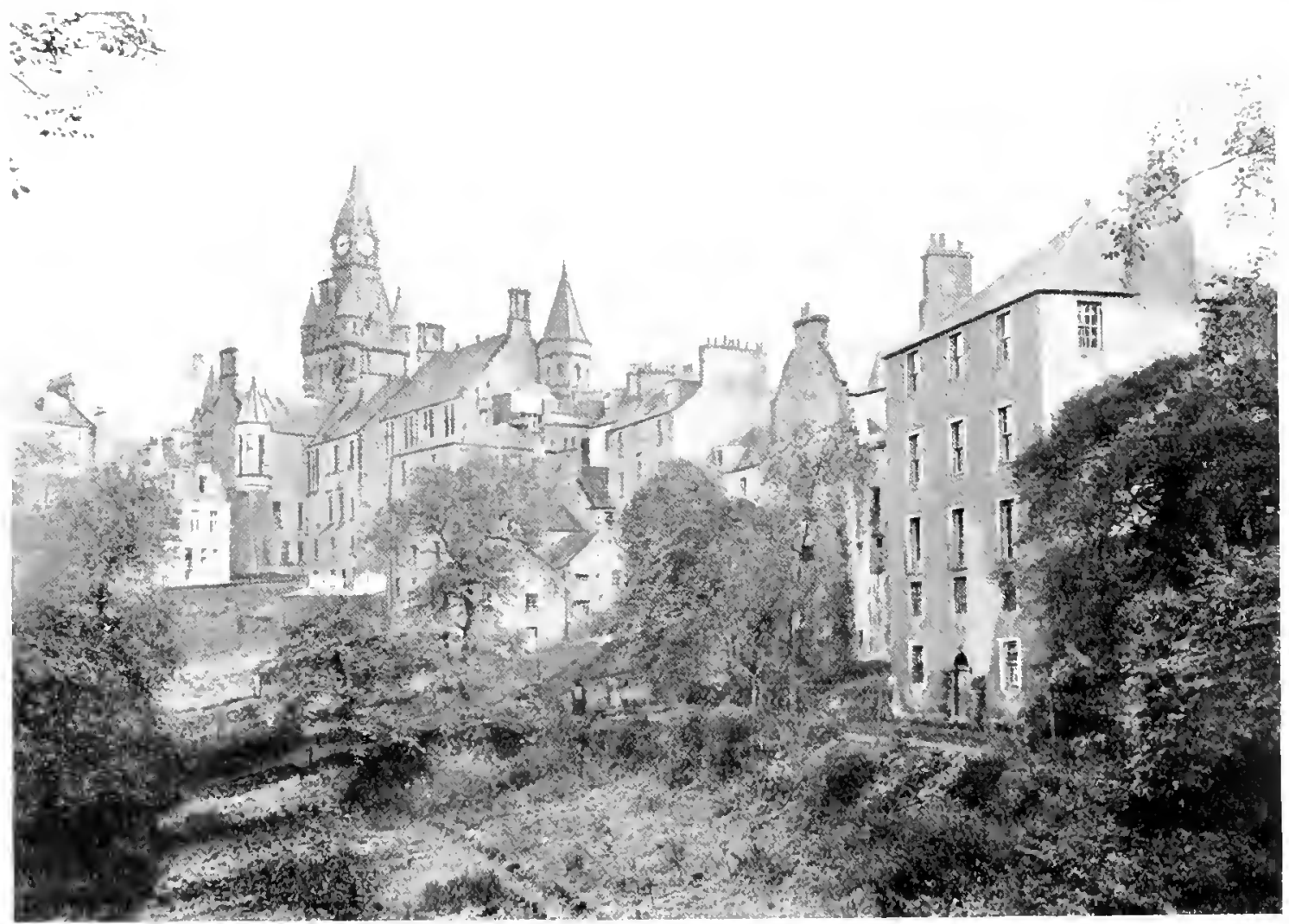

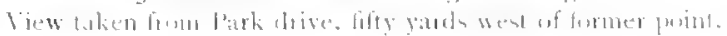




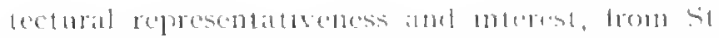

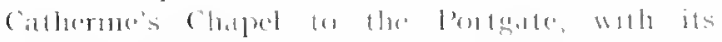

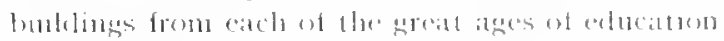

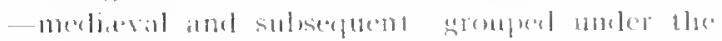

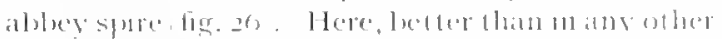

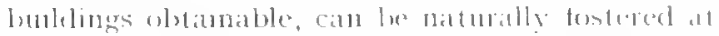

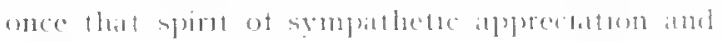

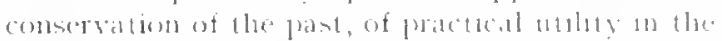

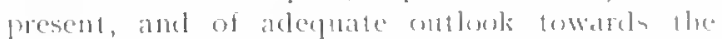
future, which is essential not only or a liberal culture but to a fully sympathelis and usetul life. Such a eroup of houses mould reathly idapt itself to restedence for buth sexes, the methol which works so atrumbihly 19 some ot the lowst Imerican sethements as motally llull House, Clricago. If a sepatralle antre moler

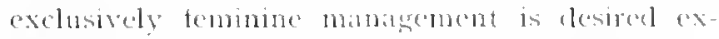
cellent sites atre obtanalyte enen in this neighlomehored. In this comnectem I womld stromety press

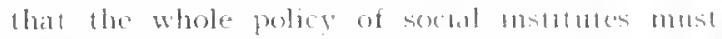

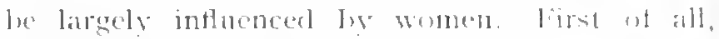
therefore, the relevant committee will have to lind the meht whisis.

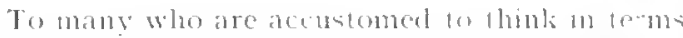
of lirege political changes rallue than of small social

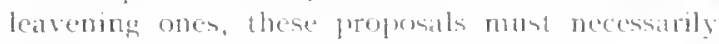
seem "pety " or "indelinue." tee whe camnot as yet simply mal out a town inte districts lake municipal warels, or schorbleneld areas, and there plant lown a sockal imstutute and capect it to work. It any rate, l am not alwate ol such methods having succected andwher whereas that sporatic, irregutar, and unsystematic som th trom many inclivilual centres, and of as many kincls, is stcidily transforming the slume ot

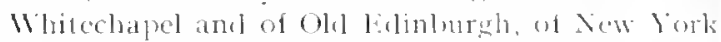
and Chicago. Thus Towmee Ilall and lts atssociated group have puidy gone on and pospered. and in less than twenty rears have spreal into activilles, influences, and results which would need this whole report to do them justice: whle the famous l'eople's Palace, stateded from the first upon a far ereater scale, and with apparenty. everything in its favour, lats enrmbully settled down into litule mose than a local technical seboul. There, as so often, the most generous of phiblinthropic foundations from willoul is but litle compared to that which struggles up from an ideal within. But here in Dumfermsine maly we not have the combination of botts advantages? May we not hope to see living personal swomps, generously, yet wisely-that is, sraduatly - enceuraged (1) enlarging growth and uscfulness? My conceytion, then, is of the rise of one after another of these gradually growing centres, each naturally selecting its own memberslip and lines of activity, and its inclividuals griving some portion of their tme to the work of the institute, and thence titking part, 11 maty be, in wider social service. It is in this way that in the course of at few rears the settlements

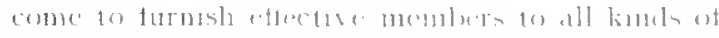

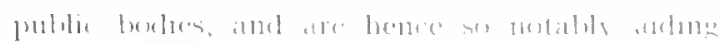

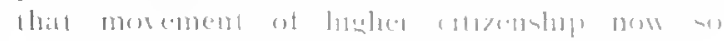

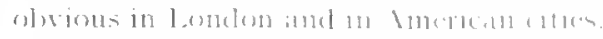

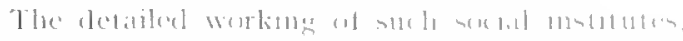

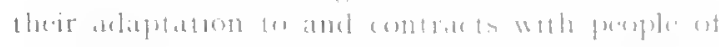

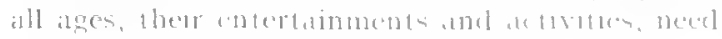

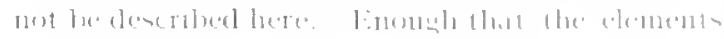

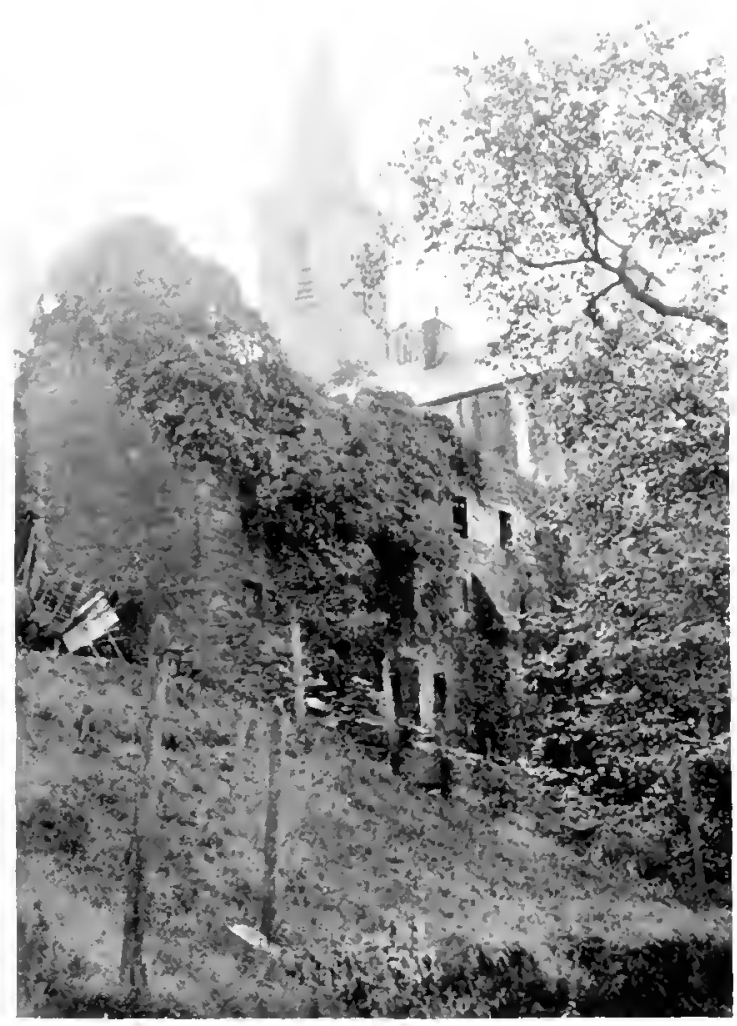

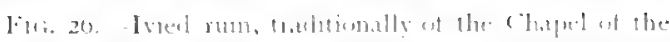

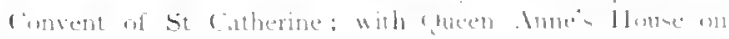

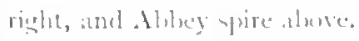

are alrealy present in lountembne, like ofher umons, indeed almundanty, |xoll in connection will churches and with ha malmsaluoms, greneral and spectal while acthisindence wath the worts of moversity sentements and knded furles can

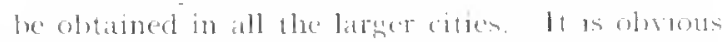

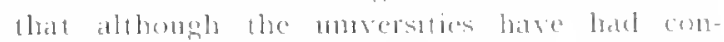
silcrable share in their establstument there ts no

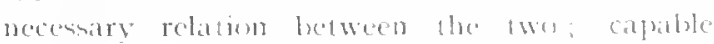
workers and bealers constanty eppear inde pendently af educational mutilutumis allongether. See the pecularly entral pusition of Duntermbe

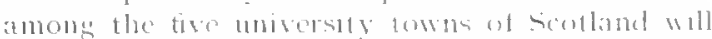
nuake it easy to ntilise this comnectum in mam ways. No greator ambmalon ol alvintiges

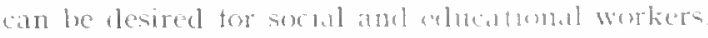

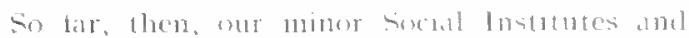

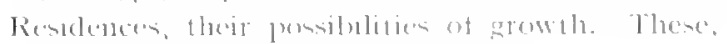


lumever, mext replute, al least will be ereatly trenefited by, the estallishment and correspomeling

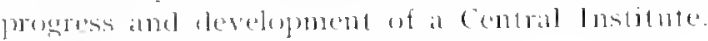
lect menow allempl to sketed thes.

\section{Central Institute (Halls, Library, etc.)}

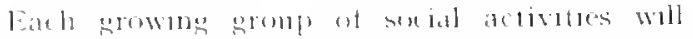

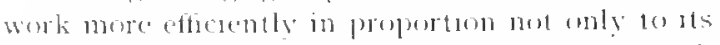

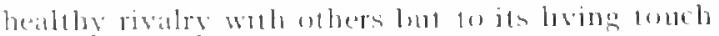
and interchange of kleas, an far als possible eren its actual conperaton wolh flese. The simples

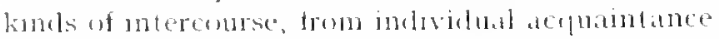

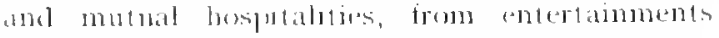
amel mate hes of all kunds, woll natmally atrise, lut beround this we need a Meeding-plite of persoms,

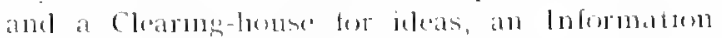
Burean of many kinds this in turn recpuires efficient Reterente lobsaries of varmos definte kinds, so grime us a Iteral Mbentem, a home ut social anel infellectual life, al rathant centre ot

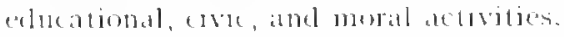

This, then, wext repuires a convenenty situated

-thar is, as nearly as posolute central group of lublilugs, and now upon a barge and pulde seale. What are als elements? In the furst place, both smalt aml latrge llalls tor meelings, entertainmonts, leetures, of all kinds; and, on the other hand. an adepuate lothary.

(Hximsty the elements of both of these alreaty

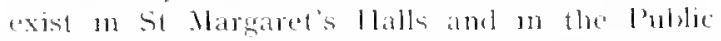
lolmary, happly aljacent, and it would he in my jurlement shere watste 6 h hold new ones for replace

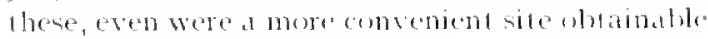
which I tail to see

Whale Dunfermline lats the bomourable clisfunction of possessing flu first of the great sertes

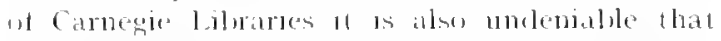
- dembless in greal part tor that very reason-

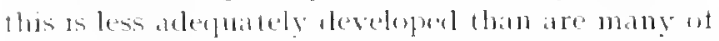
lts successors. New surely is the time to brong il up 10 date, whel in thus case meame not only atreast of the molern average, but amain serving ats an example and intiative. For this purpose 11 requires in the first plater sulmtantial structural extension, and thes is pratedable on the present site by moderate alderation and ardition. The present librarian's bumse should be lhrown into the bhrary. No dwelling should be placed here, so that the whold avaluhte space up to st Margarel's Halls and the Bank garden molat then sately be built over, thus makmer one contumuous

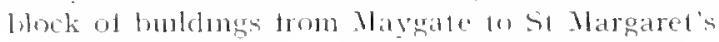
Halls inchusive.*

I have mot thought it mecessary or desirable to

* I am aware that this would regunire the special sanction of the magintrates, but if the dwelling were comoved the matal reservation of open goumd from lailding space might safely be relaxed just as it has been with the site entirely covered by st largared ilalls. mlmot any delailed plan for this, since lhe lwo

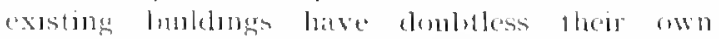
arehileds. The simplest inspection of the lwe buildengs and the vacant ground will make 11 olvioms that they can tre easily and economicably comected, the present gromel plan of si Margatrel's tlatts, whth their existing passigges on east amol west sile allie, making such commections easy wothoul any serous structural alteratime upon

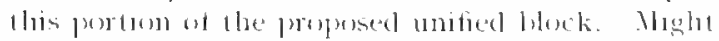
mot the Trust oftices bere absis conveniendly fimel accommolation, so giving a vel more extecture combenation

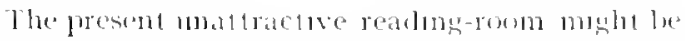

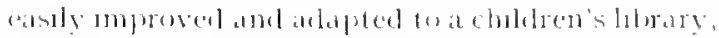

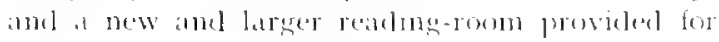

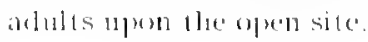

I can well magne that the time is ripening for the estableshment of branch librares, at any ralle 1n the remuter suburls, such as Townhil and Baldriclue Bum, but these lic beymel nuy limuts. Nor need I bere enter mon the olswous need of muposme the existing reneral libars, or remlering 11 accessible thongh a laser porlow of the day and week than al present, as of impresang and increasms the sounty supply uf corrent literature accessible in the reathonrom. but l must le permilted for whe the clesibatibity in fact, 11 appears (1) me the urgent neressly - ot alerpatte departmental lieference collections in these departments of atelivity which the existence of this Trust anvolves. I to not prepose that Duntermbe shomlel atlempt

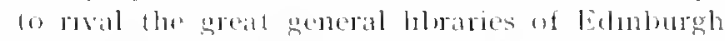

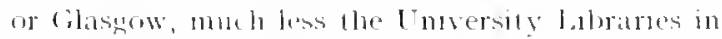

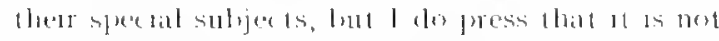
merely clestrable lut inclapensalble, it the Trust is to rams out any poluy of poneerneg, thalt it

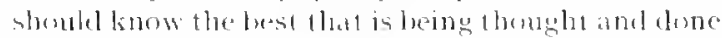
at the wolle in its varions depertments. That in

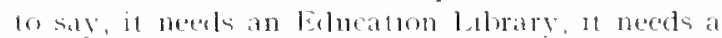
Secial science and Social Betlement librar.

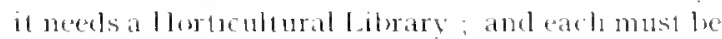
first-rate of its kind - that 1s, 11 must moluele not only the essential books and seral publications of Ciseat Britam anel America lout also those of the greal contmental combries, since to pioneer in education or an sorial beterment without knowing what is being dome in Germiny or France, what is

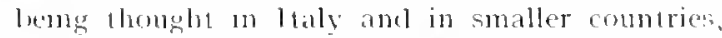

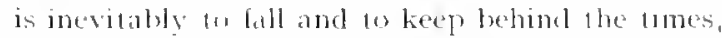
as on the whole has been the pusition of attairs in Scotlatel during the past generation, it not betore. Much lost gromul has now to he made $11 \mathrm{p}$. In short, these 1 hree hibraries at least are no less necessary for the work and future of the Trust than is a meclical library for an artive meelseal institution, a law library for a legal omen', a thenlogical bibrary tor a clerical one.

I am aware llat these proposals involve large 
capilal expendilure for the spatere and bosks, and

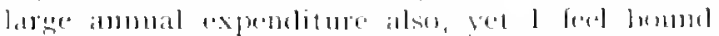

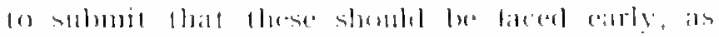

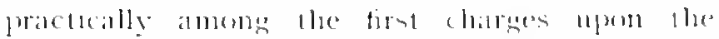

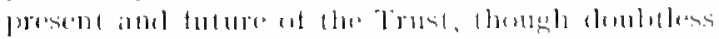

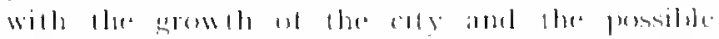

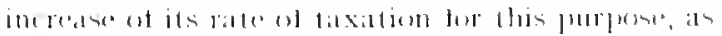

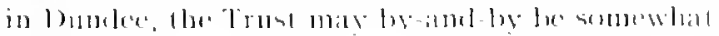
redreed

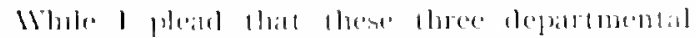
librames lne develuperl lo an extent which would

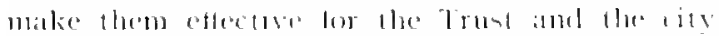

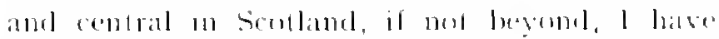
also fo plead tor other reterenee collectums upou

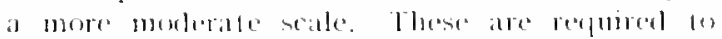

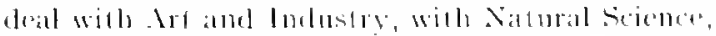

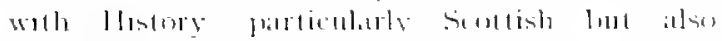
enencral, and wilh Musje; in l,al, it male le :

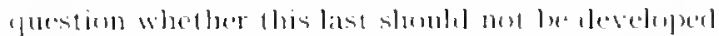

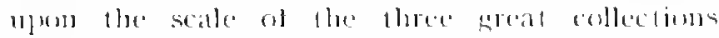
aforesibl, but this is nollually for mote expert counsel flan mine

These secomblary eolleetiens, howerer, will natur-

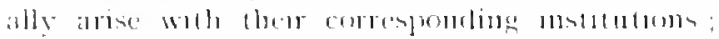

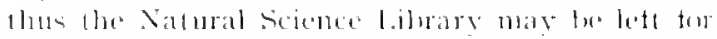
romsteration with the Xature boulding hereatter

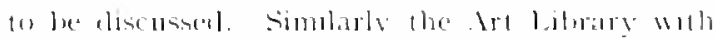
the ste Bublumes, the Music lobraty with the

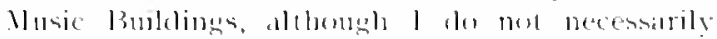

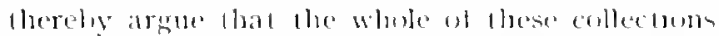
should be kept ajast trem the main one that would sette itsolf an pratede. The esential thing is that non only the Trust but any entizen should be alble ripully and etticiently to work up any of

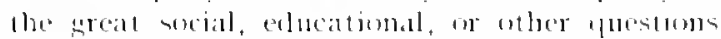
which are now so fully before them.

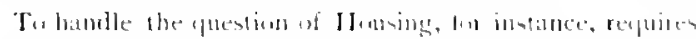

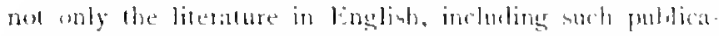

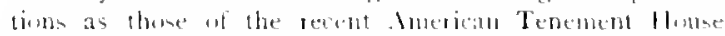
l:xhilition, but the bat amenut of inlormation which in 1 .

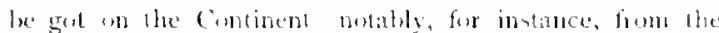

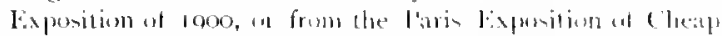
Jlousing last year, of which farticulam seem mol ewen ols.

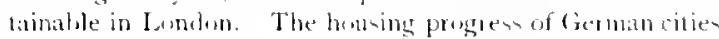

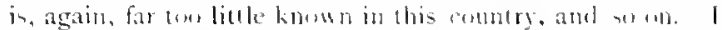

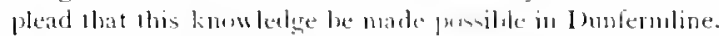

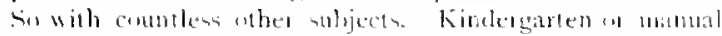

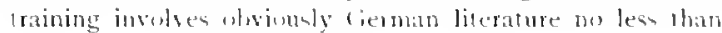

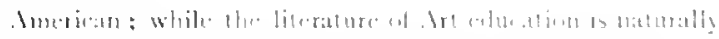

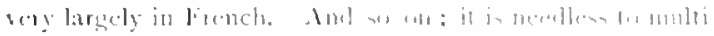
fly imblater.

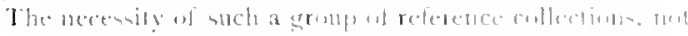

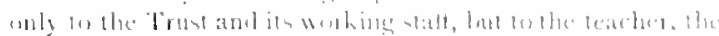

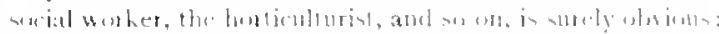

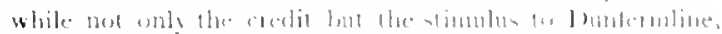

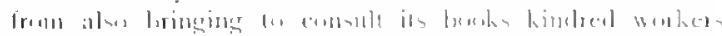

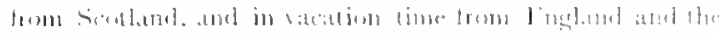

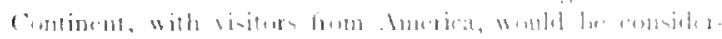

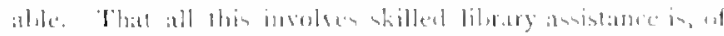

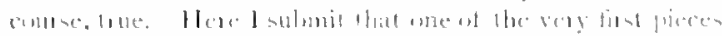

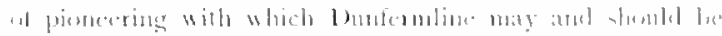

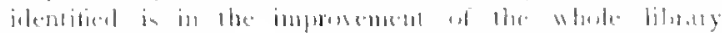

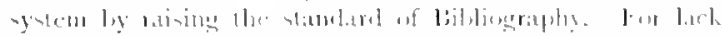

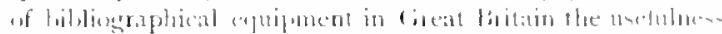

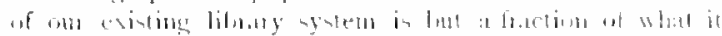

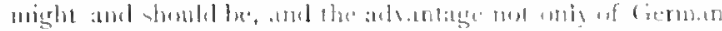

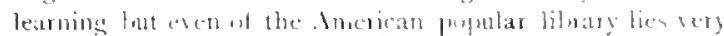

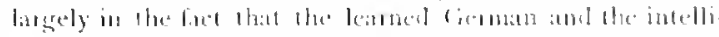

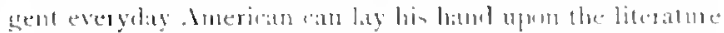

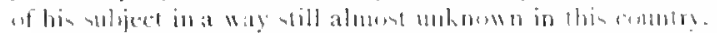

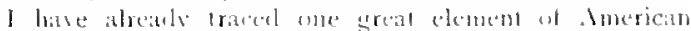

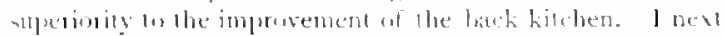

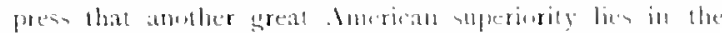

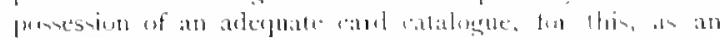

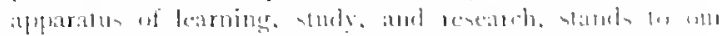

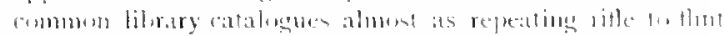

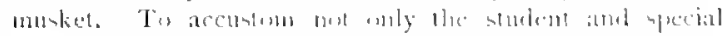

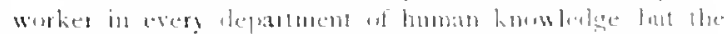

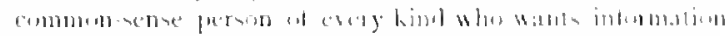

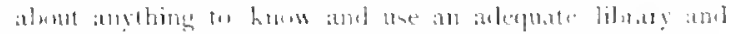

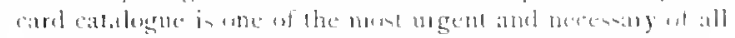

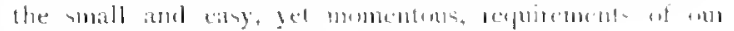
present colncinim.

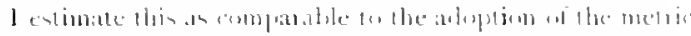

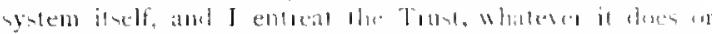

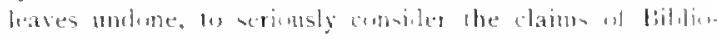

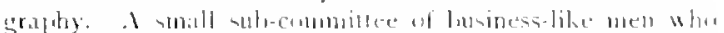

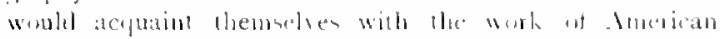

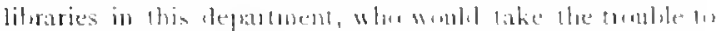
realine the immene urefulnees of the Internatisnal Institute

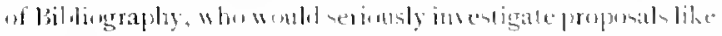

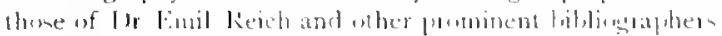

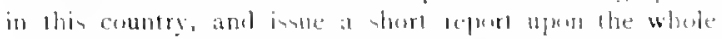
morement, womld render an immense service te cullute in

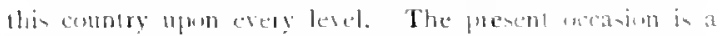

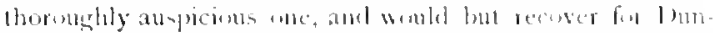
fomline it historic initiolise. I therefore forwarl will this regurt the decumentary milerial I have seceived foom

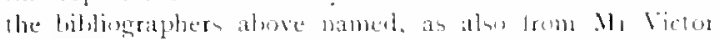

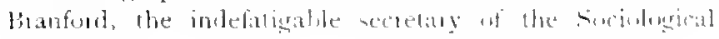
siciels. 


\title{
$B \quad$ PARK AND GARDENS
}

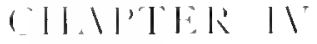 \\ THE PARK NORTHERN PORTION
}

\section{A. North-East Section The Children's Park}

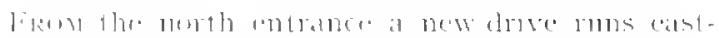

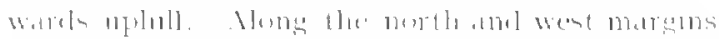

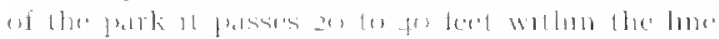

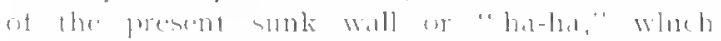

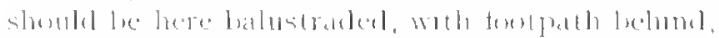

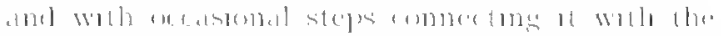

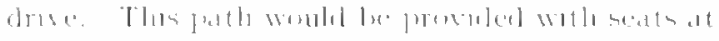

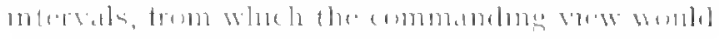

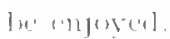

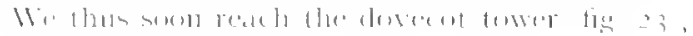

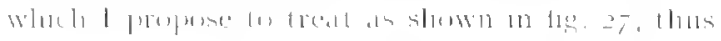

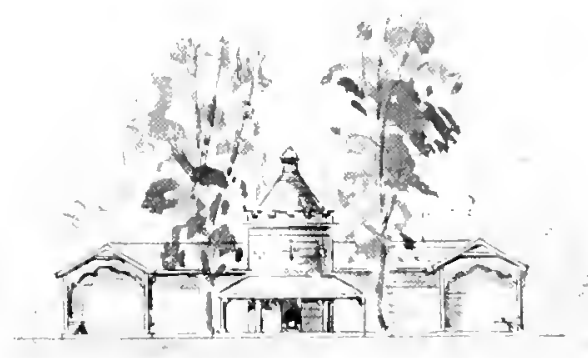

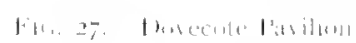

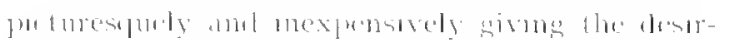

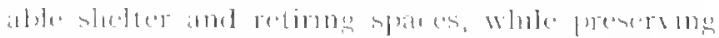

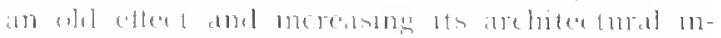

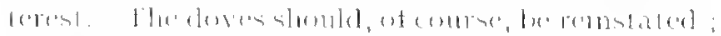

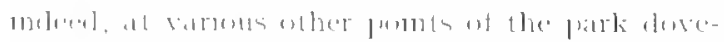

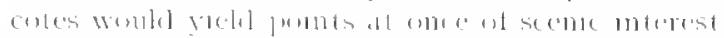

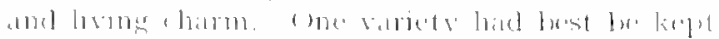

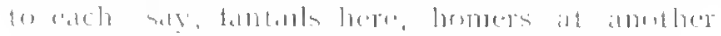

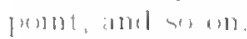

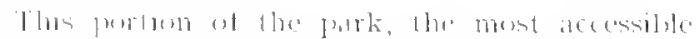

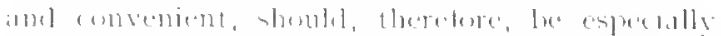

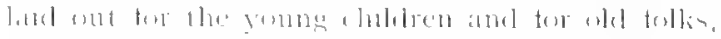

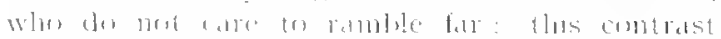

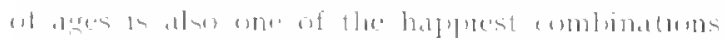

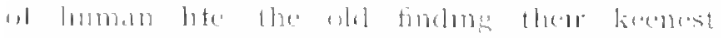

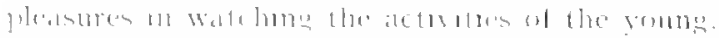

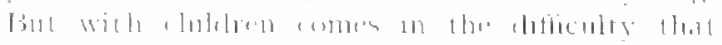

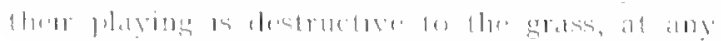

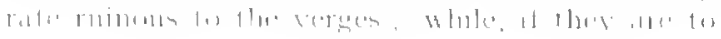

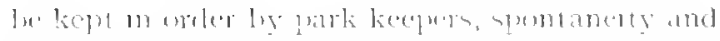

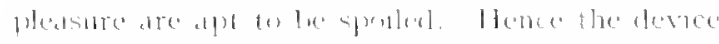

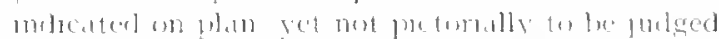

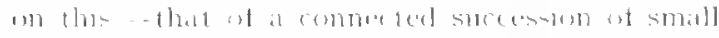

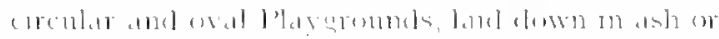

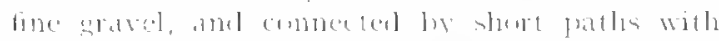

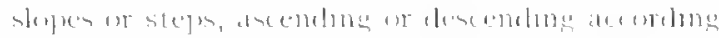

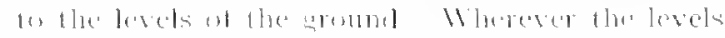
allow, and where momertant trex ronts would not ly entertered molh, thene playeromele would be

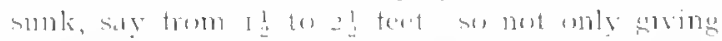

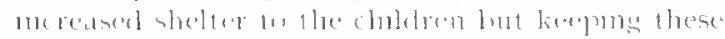

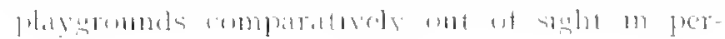

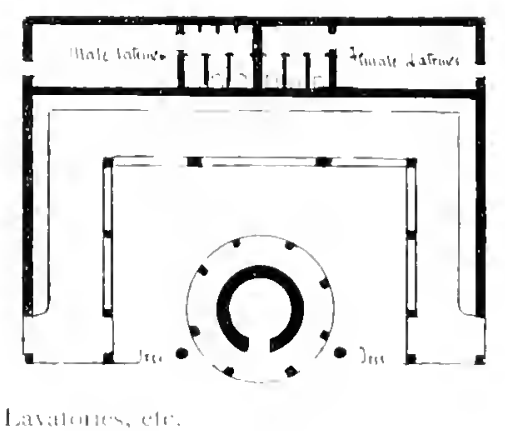

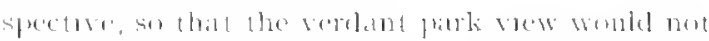

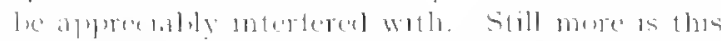

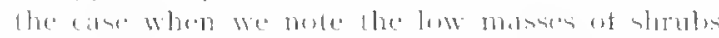

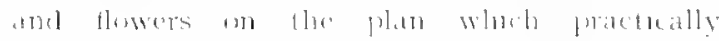

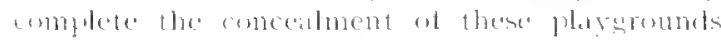

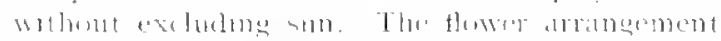

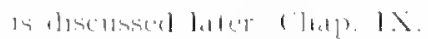

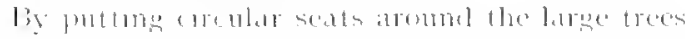

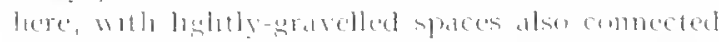

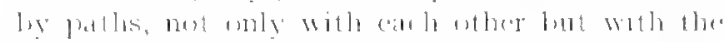

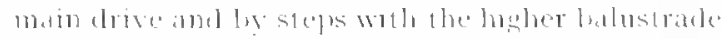

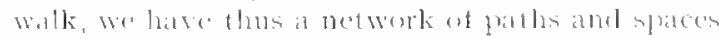
upon which the clolefen wruld race and thase

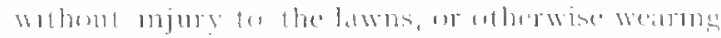

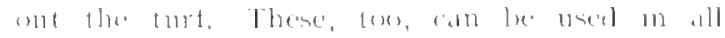
weathers, and wollomt wet feet, whobe, ot course,

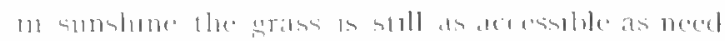
$1 x$.

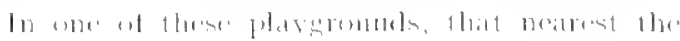




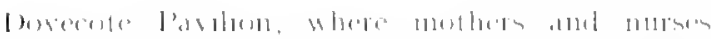

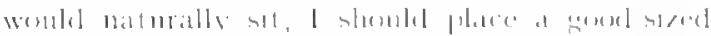

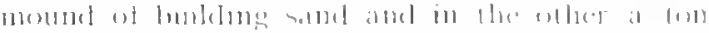

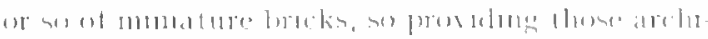

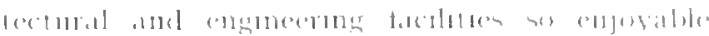

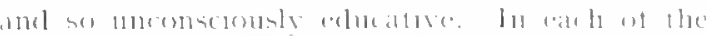

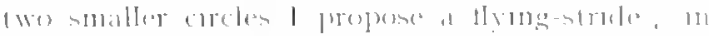

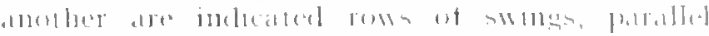

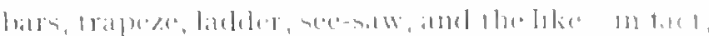

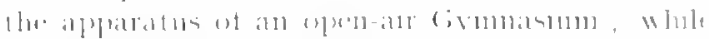

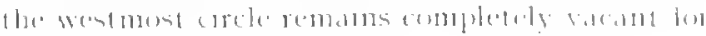
roume gedmen and the lake

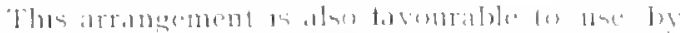

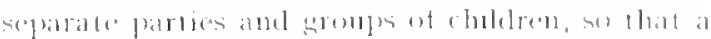

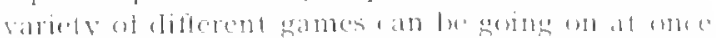

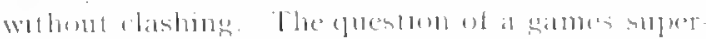

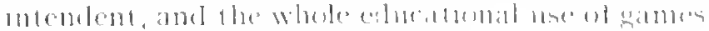

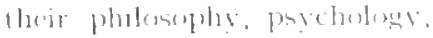

allel morats, are not to lwe

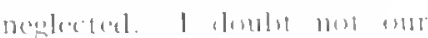

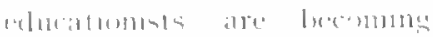
ither [e all thes: val theme mbects hase ot late mamly been worked at in onher conntries and languasen. Ileres.

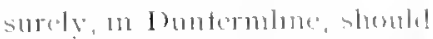
lee the weal omblitume ter at besh expermental reinsestrabltion of the whole sulfject, surely mol the least important io a punering trust tom promotumg the greatest halph mess of the rreatest number lios 11 is the childrem whe ofter the mumbers, and thene happli-

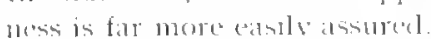

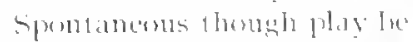
(c) the voune, nowhere may it trace educationat have a greater intluence than als plas leater, ant that sten exprerto are still sor searee ts testmoms

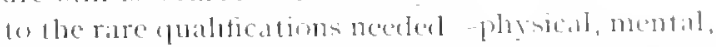
anel moral, temperamential mose of all ll in me

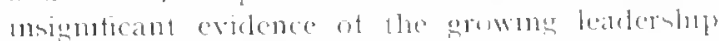
at Americat that plav teachors are there becomeng

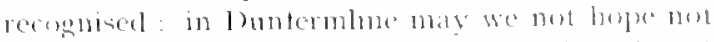
anly first for find ane lowl next to tratin others?

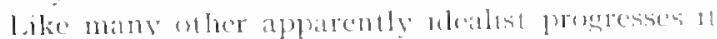

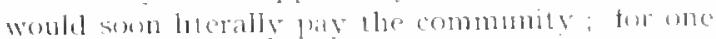

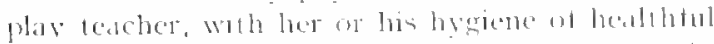
acturty, would anon tar more than hate costs in

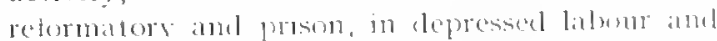
apally most of all. We have lately harmet that the consumptive is generally only so tor late of the services of that preventive hygensist whos sow rapidly approaching power. Hhe llwellgan stell

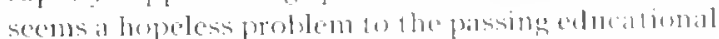

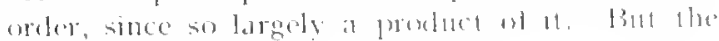

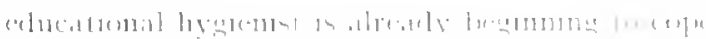

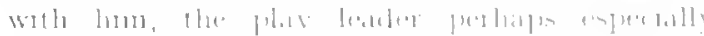

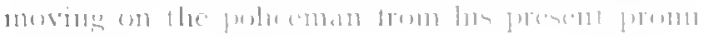
mence.

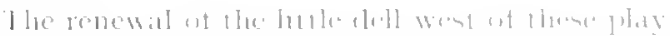

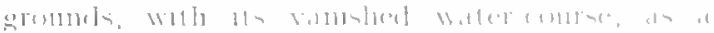

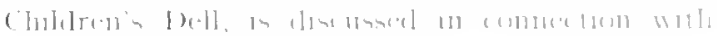
1he (ilene ("hill. Xl11)

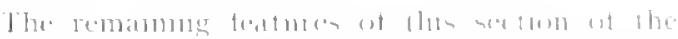

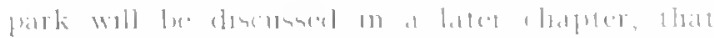

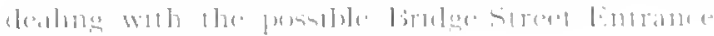
it. die.s. and (hat) XX1X

\section{B. North-West Section of the Park Basin}

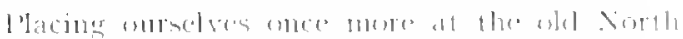

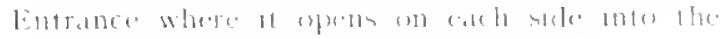




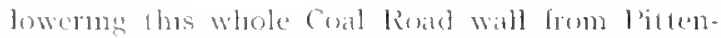
criedt sireet lo lowers lown and by carrying along ats upper alge the new forlpath shown om plan. For smplicily's solie this is drawn ats a straght lute. 1ut it would of course spare any drees ol value. The adrantage of this maty be judged trom photograph of Coil Roud at present fig. 22

The lowering of the wall will be foumbl to be a

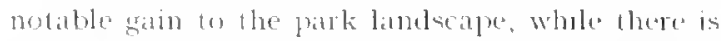
no serious loss of shelter, this heing increasmely given by the elenes phantation belt on the apposite sicle of the roat.

\section{Men's Gymnasium, etc.}

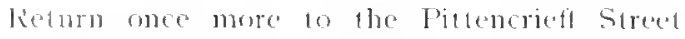
entrance. Hening proveled in the northerest sectlem for young choliten and uld folks we may bere constler the requrements of the roung men. turnishing of the open-air gymnasum on this seale lut an indicalom is grven, as also ot heats for performers and spectators

This north range thus ofters a comsideralde range of intereat to the yomm men and buys.

\section{Shrubberies, etc, Women's Pavilion}

Coming out upom the hatha its more sumby protions can be picturesquely treated ly plants like the madenticent sea-holly, ele. Besteles these in trent the leatutulul flewerng turant family can berlisplayed, with mock-orange and other floweding shrulus for spring, and alon hrdrangeas and onber leanties of autumn the main buly of the hatha would be cushiomed with stone-crops, sempervivums, and saxtrages, thus continuing that combination of wild garden and shrublery, Woll girrelen and hotanic garden heern in the last

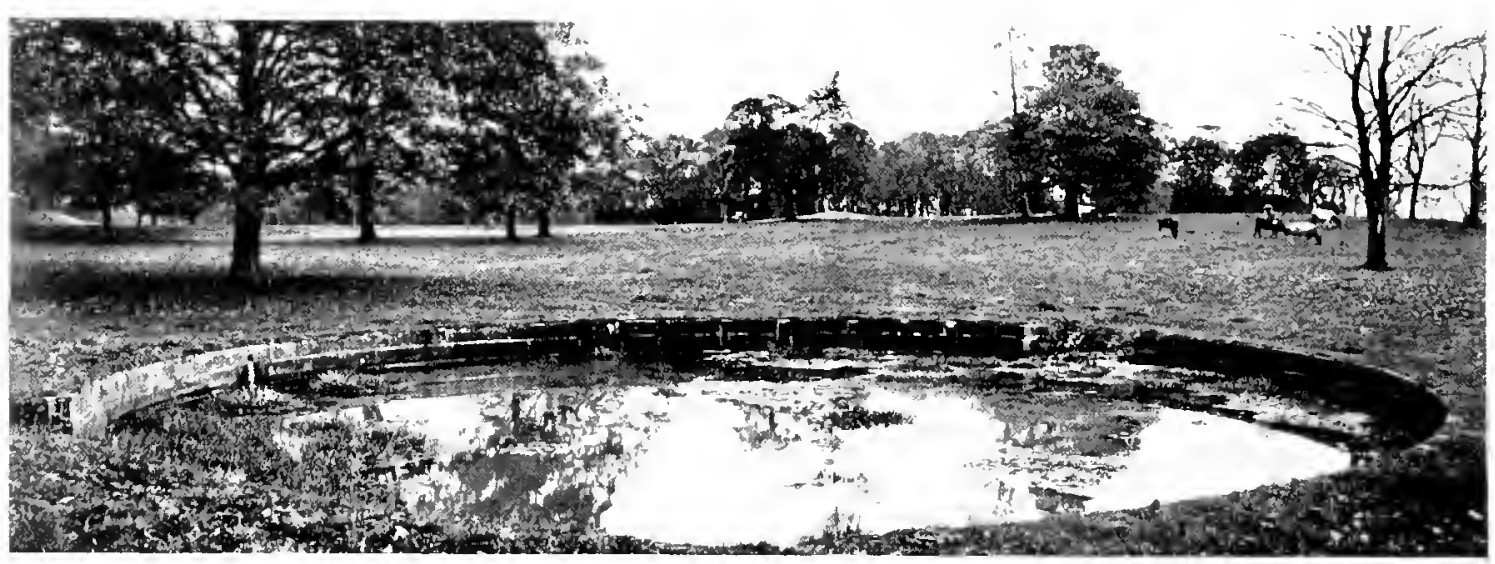

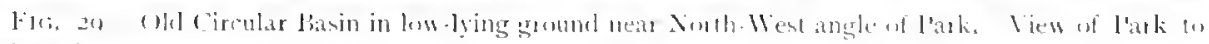
Nuthwatis.

Is elsewhere ponted ant, there $1 \mathrm{~s}$ in this park no stutable level ground for the greater games, but a Buwlong they and Fives Contrite provided along the noth wall, whthout any loss of prark space or undue thmning of trees. These huldings might alon be very flam and inexpensive, herng ealsily screened by wy trellis, dogwools, and hage umhetliters, which womblall throe perfectly walt in this shaty region.

Passing the trasin we now reach the croner feature so plandy inclicated on plan, intended not merely for exeputional use as a spacious furo of wating-place for carrages but as a youths' "pen-lur fymmasimm. For simplicily's sake the trees are left on on plan, but the better ones

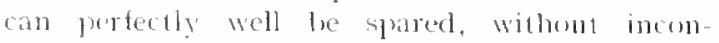
venience. The hatha being here eftaced the surface can be sently sloped down to meet the level of the man drive. Fonnd this space seats are hown. It is unnecessiry to slow the detailed portion. Around and west of the Basin the same general principle continues, so providing an meresting heasomal succession of flowers and shrubs along the whole north of this section.

Coming unw to the rest side, it will the seen on pan that lresiles retaning the good trees of the plantition as nsual 1 show new bits projecting from zo to fo treet heyond the present hatha. (I) these I would plint the more northerly with leguminous trees and large shrubs psendacacia, labunum, ete : and the southerly one with rosaceous trees, thus again combining picturestueness and variety of ettect with botanic unity of interest.

Contunuing southwards from the gymmatsum our new dove sweeps southward letween these new patches of rees on the west and a corresponding mass uf shrubleries on the east, on which crabs, the larger cotoneasters, flowering cherries, thoms, e.tc, wonld be planted so as to repeat that magnuticence of flewer which was silggested at the 
very antsed of lhese park sturles at the cileixe, seen on entering from Nethertown, ats the most comspicuous and chataleteristic teature of our whele seasonal design. These rosacenus trees in all their sariely and beaty I propesse to carry sonthwards to the Coal Rual lintrance of the man cast and west abenue, working ond as bat als space allews the varied resoureces of this most beatuful order of plants, ats regards shruls as well as trees. Hexe is, in fact, the possibulity all once of creating one of the most beantul and constantly improsing teatures of the whole park, and of a not inalequate arboretum selection suggestixe to houltulutists and students alike, no less also (1) designers, whose interests lave constanty leen remembered thromghout the park by the selection of the more decorative species of all kinds, herbs included.

Our path now rises gently to the highest point of this section, nearly ins ratrls south of the lasin. This height I propuse 10 crown by at

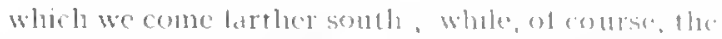

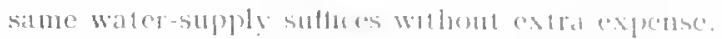

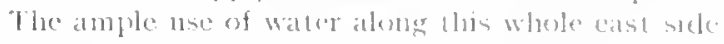
and foot of the park is, in facl, relseveel of all ex-

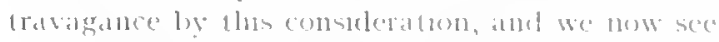
on the exeneral plan that this system of lakes and smalt intervening watercourses mot moly gives the whole west and south sirles an moterest in which they are al present deficient, but also lurnishes the right contrast to the leep lem on the cast ste ot the park. This thus lies belween lwo watercourses, sreat and small, and si) doubly inviles the visitor, first 10 a more prolonged walk, and then to a fuller enjoyment of thr hatracteristic beanties of each. Could the custom on a freefuent ramble of this kind, from a mule and a hall to two miles in circuit, be induced, the usefulness of the park woukl soon be decply telt in many way. Go form this habit among an increasing number the ordinary attractions of the areredge aly patk hase

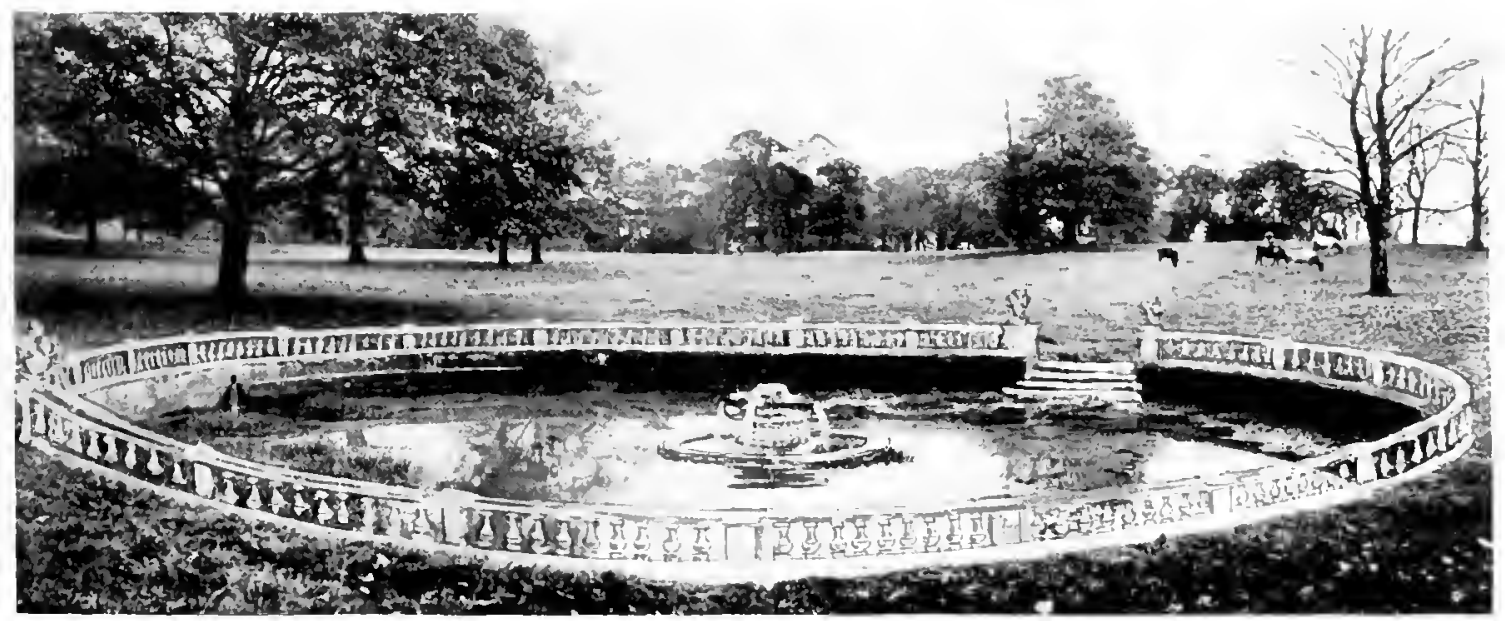

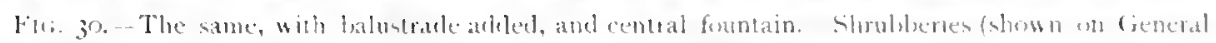
l'lan) are next needed, Lo reliese the olherwise momotonoms efiect of this.

square l'avilion, with fonr pediments and central dome, the arrangenent which woths out ats most compenicut from the standpoint alike of accesses, of riews from withoul, and from within. The eflect must be imagined in the accompanying figures zo and 3o, and by help of the gencral plat. This might be reserved for women, and furnished somewhat more daintily accordingly, especially with ample reclining seals, ats befits al rest-house.

\section{E. Small Lake and Open-Air Theatre}

In the litale Lake, wheh is shown in plan in the natural depression at this point, we have here a feature not only of interest and teanty as an uncxpected feature in what is otherwise a comparatively insignificant spot-it also performs the artistic service of giving scale to the larger litie to to be increased in such waly its this, cepjectully. since for one who appreciates the latrege atspects of landscape, here of course present and not to be interferel with, there ate many whe are attracted by the variety and interest of details. Hence lle justification of the present design, that of ratricl enrichment of the margins of the park, white leaving all its present fine general alspects undestroyed, indeed developed also by muroved foregrounds and the like.

Return to the Women's l'avilion and its soutleastern portico steps: a patth runs ap the litte height to a spuare space with seats, from which pleasing views are obtaned. Amost dne south of this the peculiat dispesition of shrubleries shent in plan indicates a proposed small open-air theatre of the simpleyel ettective kind sugaested by the theatre of the Villa Gori at Siena Centwy . Magdame, 1(x) The various amatcur dramatic compantes, both 


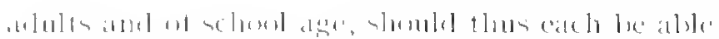

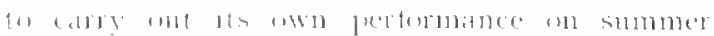

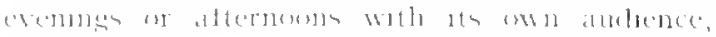

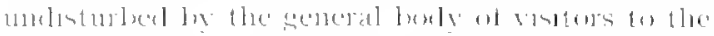
1.ark.

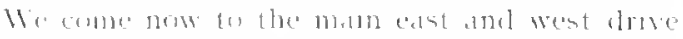

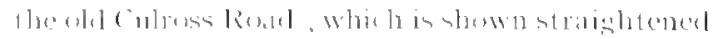

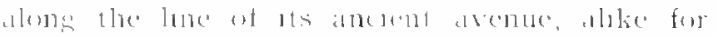

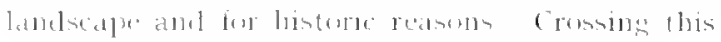
we see the lastere lake.

\section{F. Central Avenue from North Entrance}

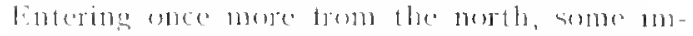

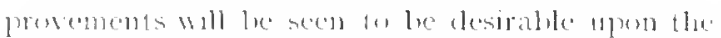

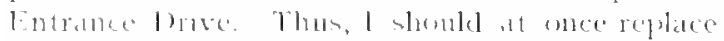

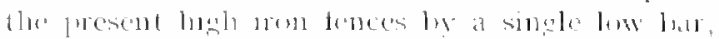

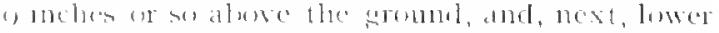

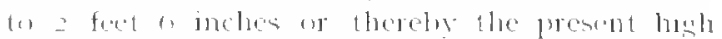

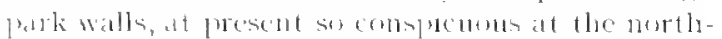

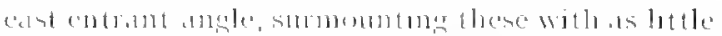

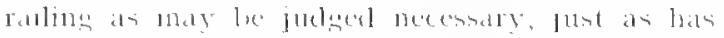

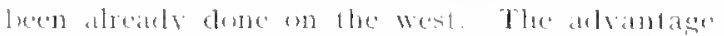
ut these tritling changes an the first mumessum

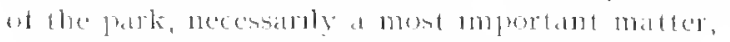
wall reably le apperated.

The present ofen central brove may be wuleneel at leats a foret on each sale with alvantage, and

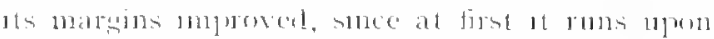
an olvions melge abese the ald acent parti level

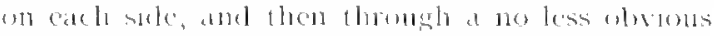

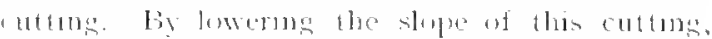
and using the catth to fill up the aletiesendeges to

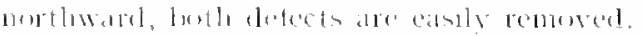

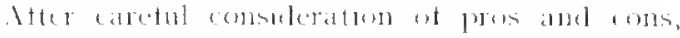

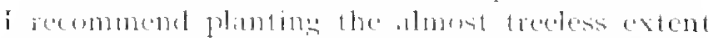

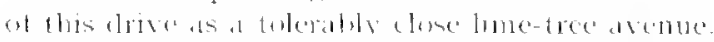
This as the anly plate on the park where unch a

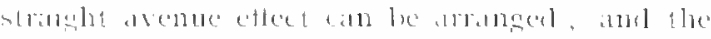

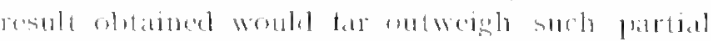

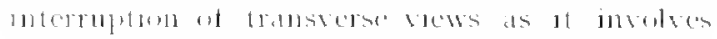

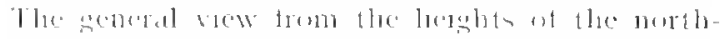

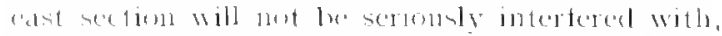

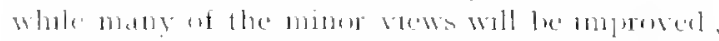

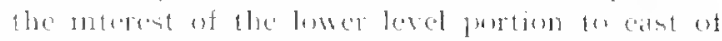
the arente espectally, the more when we neste

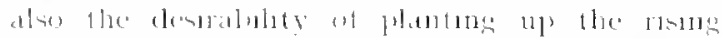

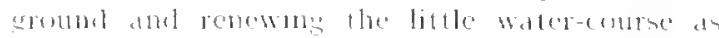

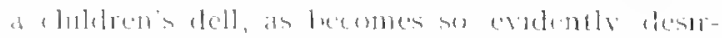
whe trem the stody of the main sten to whele we ene later (h.1p. X111

\section{G. West and East Avenue from Coal Road Entrance}

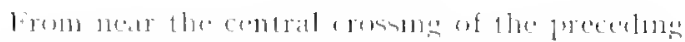

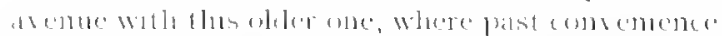

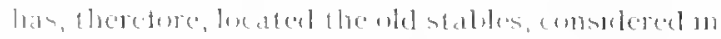

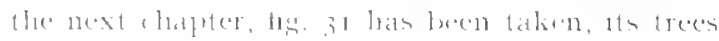

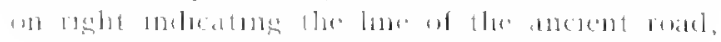
from the Tower llatl and Coly westudrts. In the

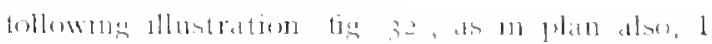

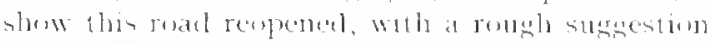

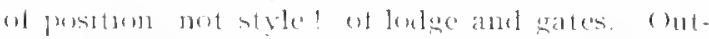

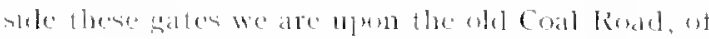

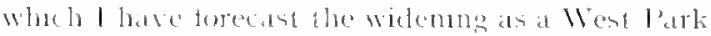

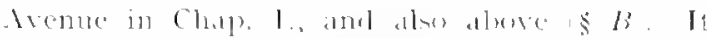

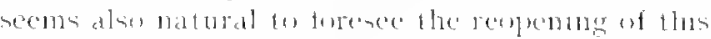

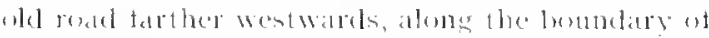
the fiedele trom the lodece on to jun the existing

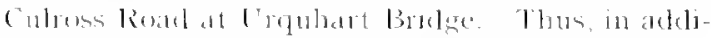

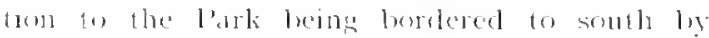

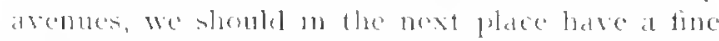

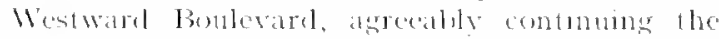
fark trom the city point of vew, ame tumblung

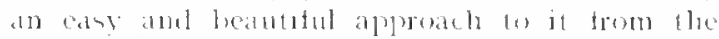

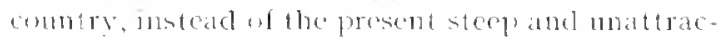

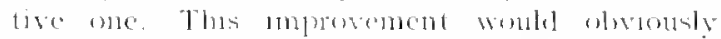
reat we tabmably upon the westem derelopmont ot the olty, and is, in fact, an exectlent llus-

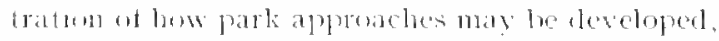
alule tor the lenetit ot the aty and at propreters.

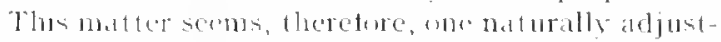
alle a an ordmary matter of street or rather suburloplanmuse, and not one which abectly mbulues the trunt

keturmeng now thom llus entrance westwards, we

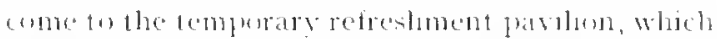
mant pustpone, during its gears of servece, the foll

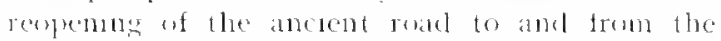

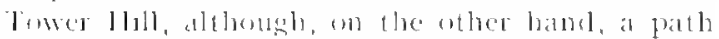
on this line liceomes moliepremsalde, so restoring the hinterie route, with nu small gain to the inaginat$110 \mathrm{nt}$.

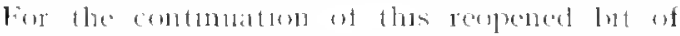

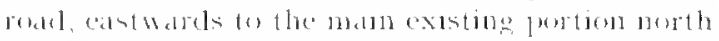

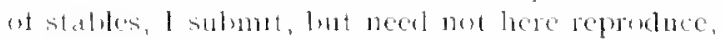

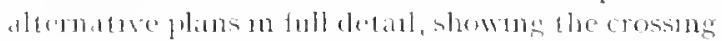

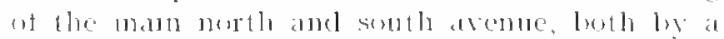
brelge and on the level, and mat leave these to

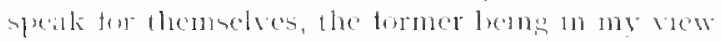
the more fleturesfur. and the latter certanly the minte cast.

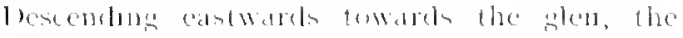

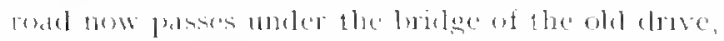
firtung the citen methwarl, and we mats here neste the destabluty, both of artste and sugres. tore prefuresiguenests, at recallong in some way the old tortancation and onthesk whit h must for mam centures lathe stend here an ho needed ontwork

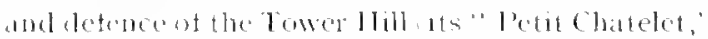

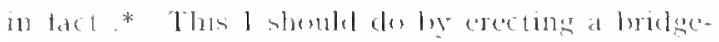

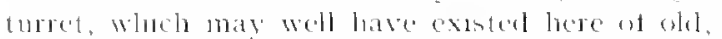
since the roat it artes is mo mere pleastuc-walk,

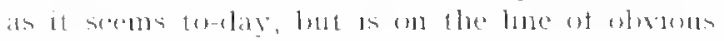

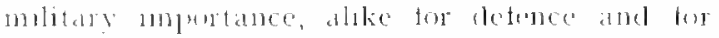

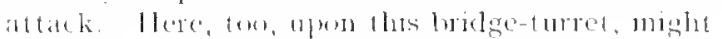

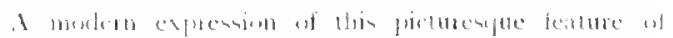

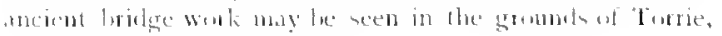

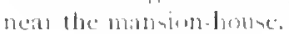



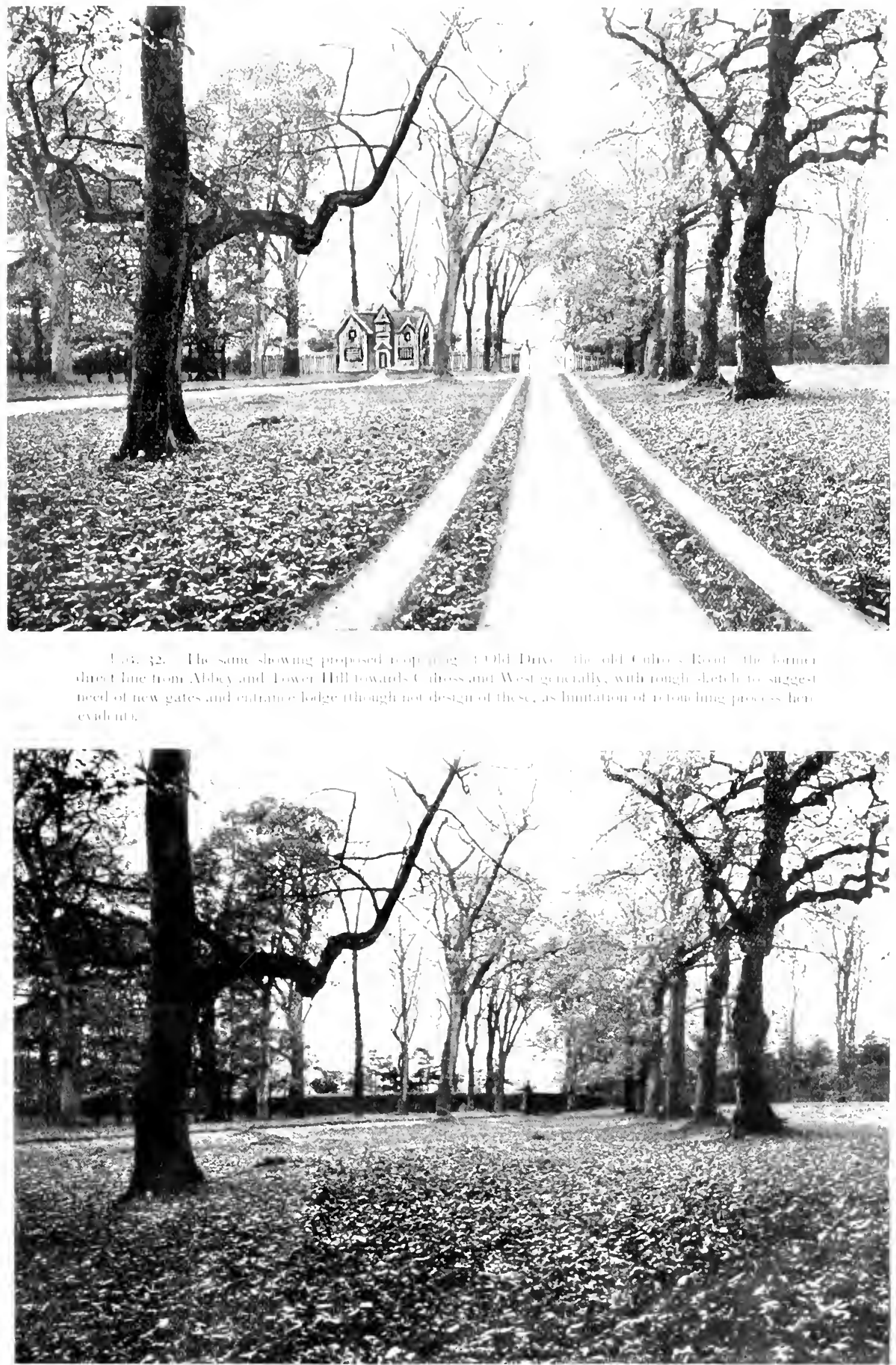


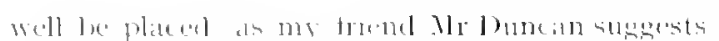

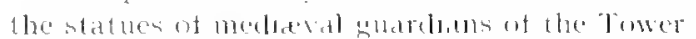

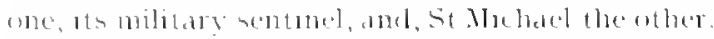

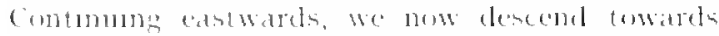

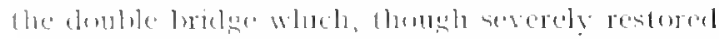
In the late eighteenth and anty nuneteenth centures, strikingly sugents that arolution from

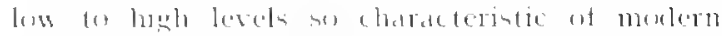

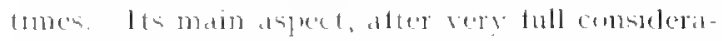

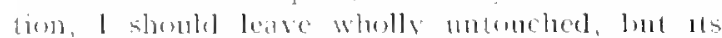
weak and maternly ware balustraleng should be

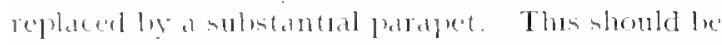
wt the simplest, wholly wothent ornoment, but

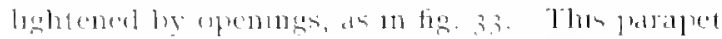
wall I should continue, wah buttresses at mtervals uprom the present retamme wall of the Tomer Hell, whech also refutres a sateway entrance at each end. These, as an the ilhustratum, recall the fort-

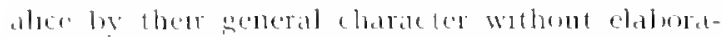

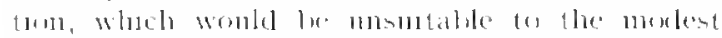
slze of the olde fower and the rugeed smplesty

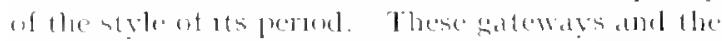

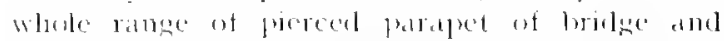

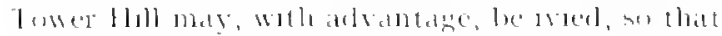

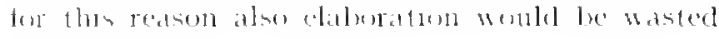
upentl them

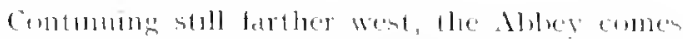

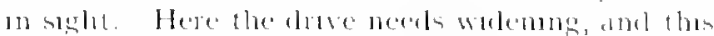

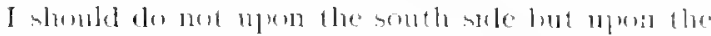

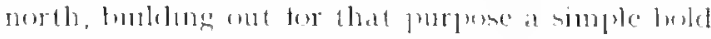
series of round atreles, rosing trom lhe old gatrelen ledew. The effect of thes smple, matsive, curved

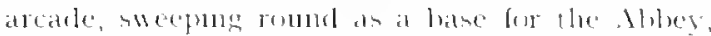

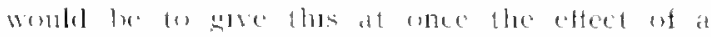

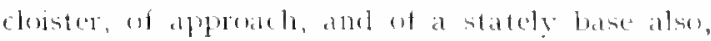

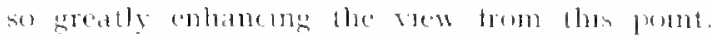

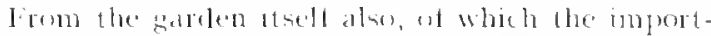

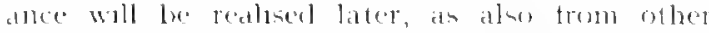
ponts of vew, such as that of the fromtispiece thes areale would be a most mportant mporement.

In the present rodwaty entunuen castwards, it unfertundtely sweops 60 the lett. and thum loses it ancient and approprate aldument to the west

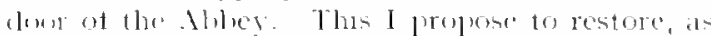
stemen in plan. The increase of stecpness, which this will be seen to invelve, can, if course, be

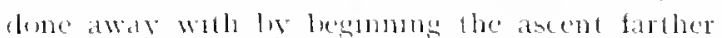

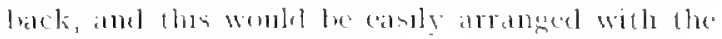
welemeng just referred to.

The further imperement of thes entranece and adpuraches wall be dencunted later chapter XX:
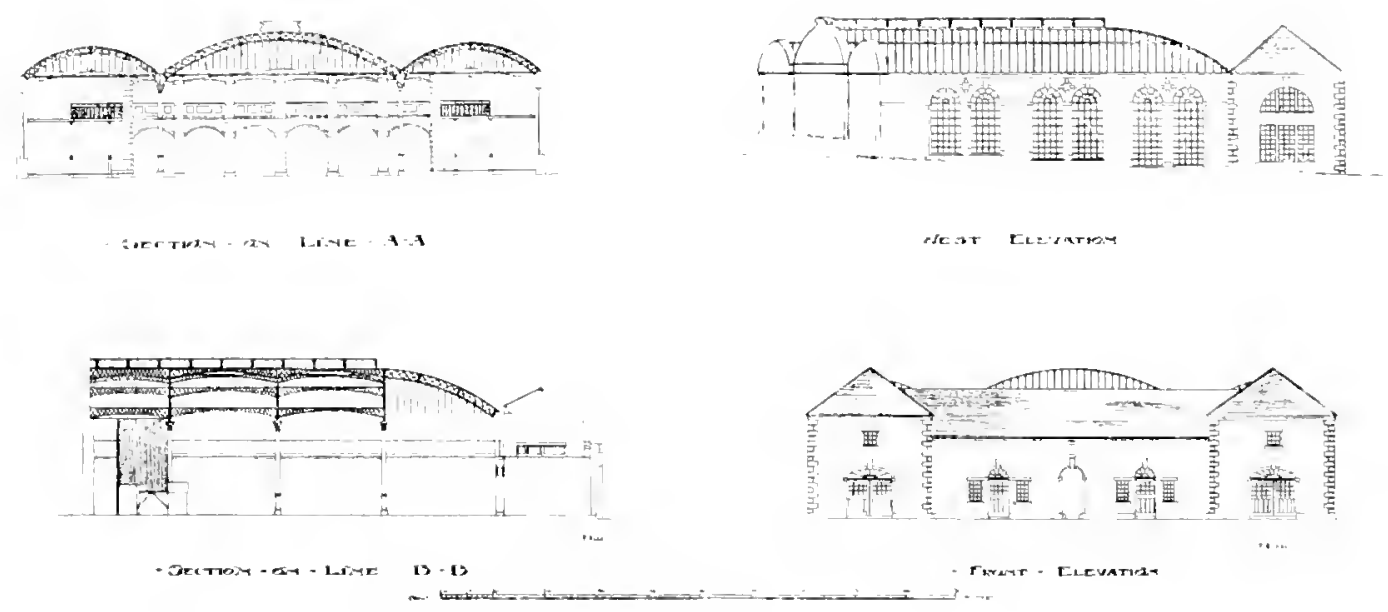

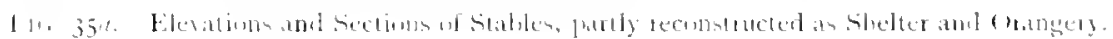




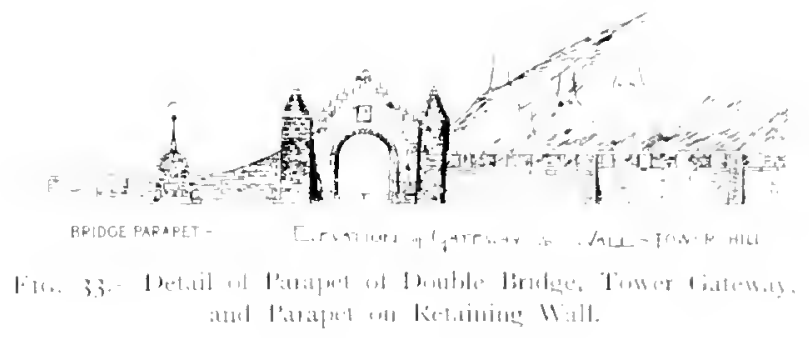

CHMPER V

ORANGERY AND MANSION.HOUSE

\section{A. Old Stables as Shelter and Orangery}

T111 (9)

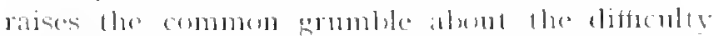
and uncertainty of our seathere, a complatut grievoubly exagneratled, sine erergme who

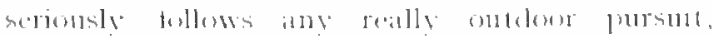
sport of athletes, sardeming on lutans, buows how verg few tomes, atter all, wh the feat hin pursuits

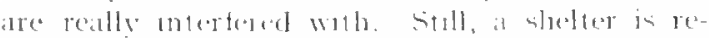

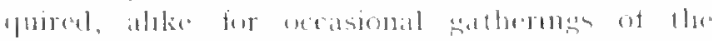

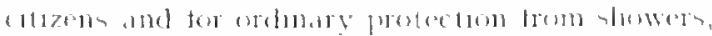

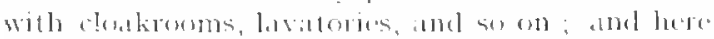
I am bully onsinced that there in nos swa sorentral and so comsentent in the whole park as that athorded ly the present old stables the it llence the acomplanving pletse tig. $35, a, b$, shom the old frome hulding retanted atmol the moth wall also, whole the cast and went sules are rethult, the

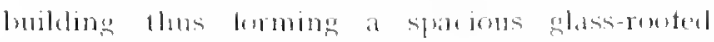
hall, with a platterm at the morth end, which wall also serve as a bandotand. Internal alecommonta

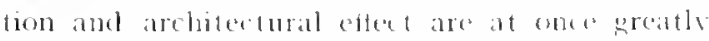

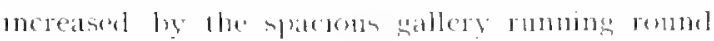

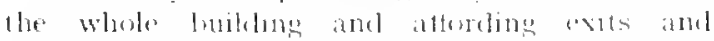

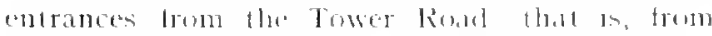

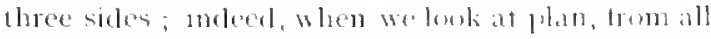

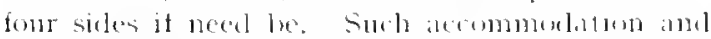

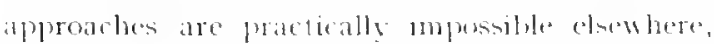

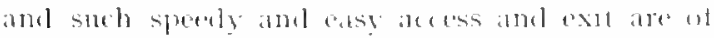
real importance in prosiding for crubels and tor excursionists.

The needful closkromes and retrestument rowns are provicled for in the ohel trunt portem ot the building, the bater atso on the uplete storey an

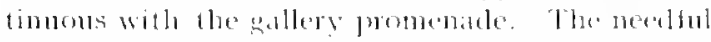
lavatories are slusin an two well-separated higks, both 10 the eastwant, and thoremehly conceated on either hand.

While the praticabluty of lluese proposals will harelly be dieputed 1 imagine objections on grommls of amenisy Grim, dull, mineralle, dirty-loskins, ditapidated, esen stgualid, are the usual deljedives, and the first instinet of the park reformer is 1 luse to sweep the whold thing away. But, let me ank in return, does the critic apprectate stols altvantages as loe lmbleng has? Denes he see, tor mstance, in this stern and smuple buldeng the style,

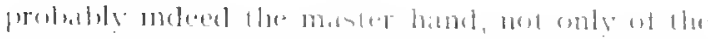

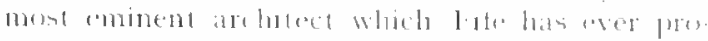

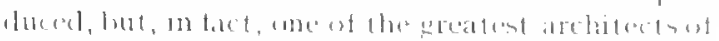

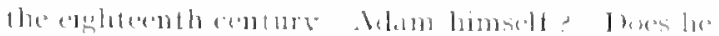

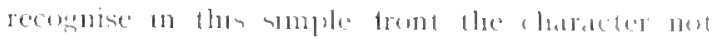

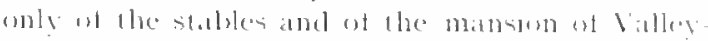

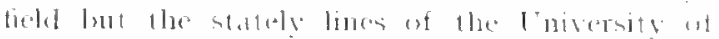

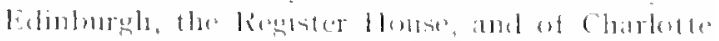

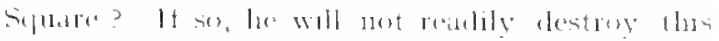

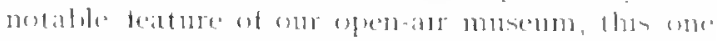

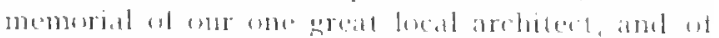

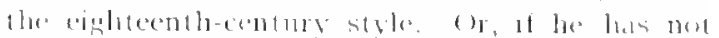

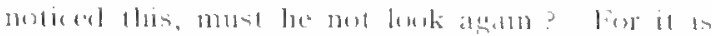

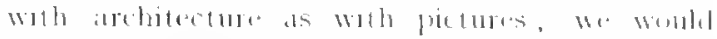

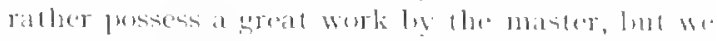

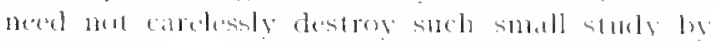

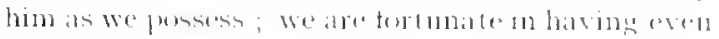
(c) $\mathrm{mols}$

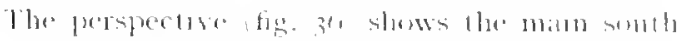

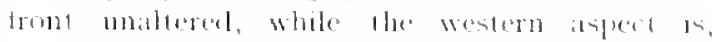

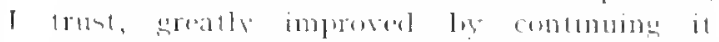

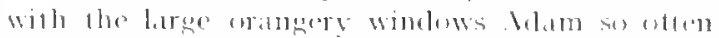

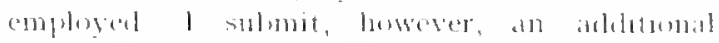

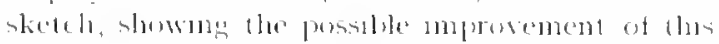

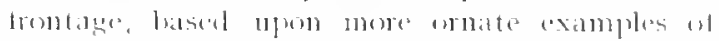

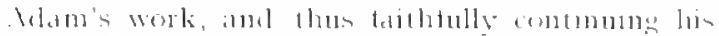
tration Tlese tront is thus emphed, whome

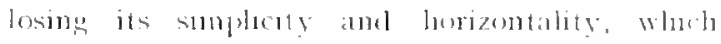

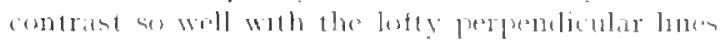

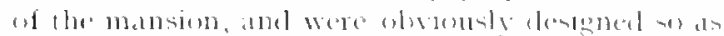

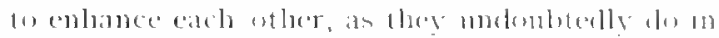

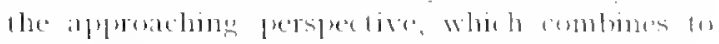

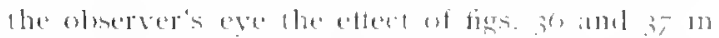
at watr I comnot repuresent here

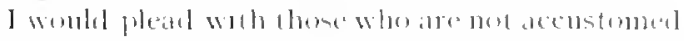

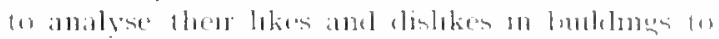
sive llis pome a tresh tair trial on a tew of thest

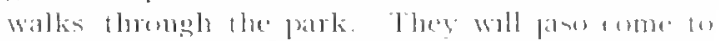

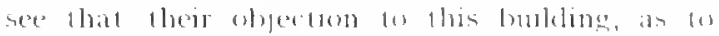

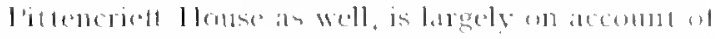

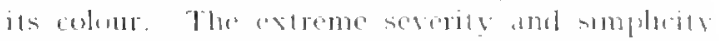

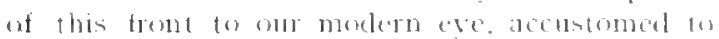
that extreme oxeremrichment of letabl whith a

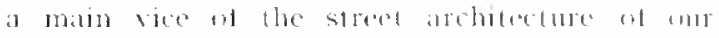

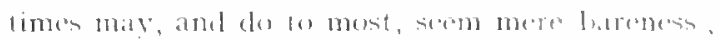

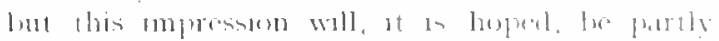

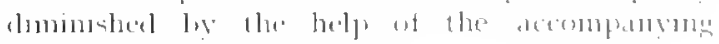
photographs and drandens. 


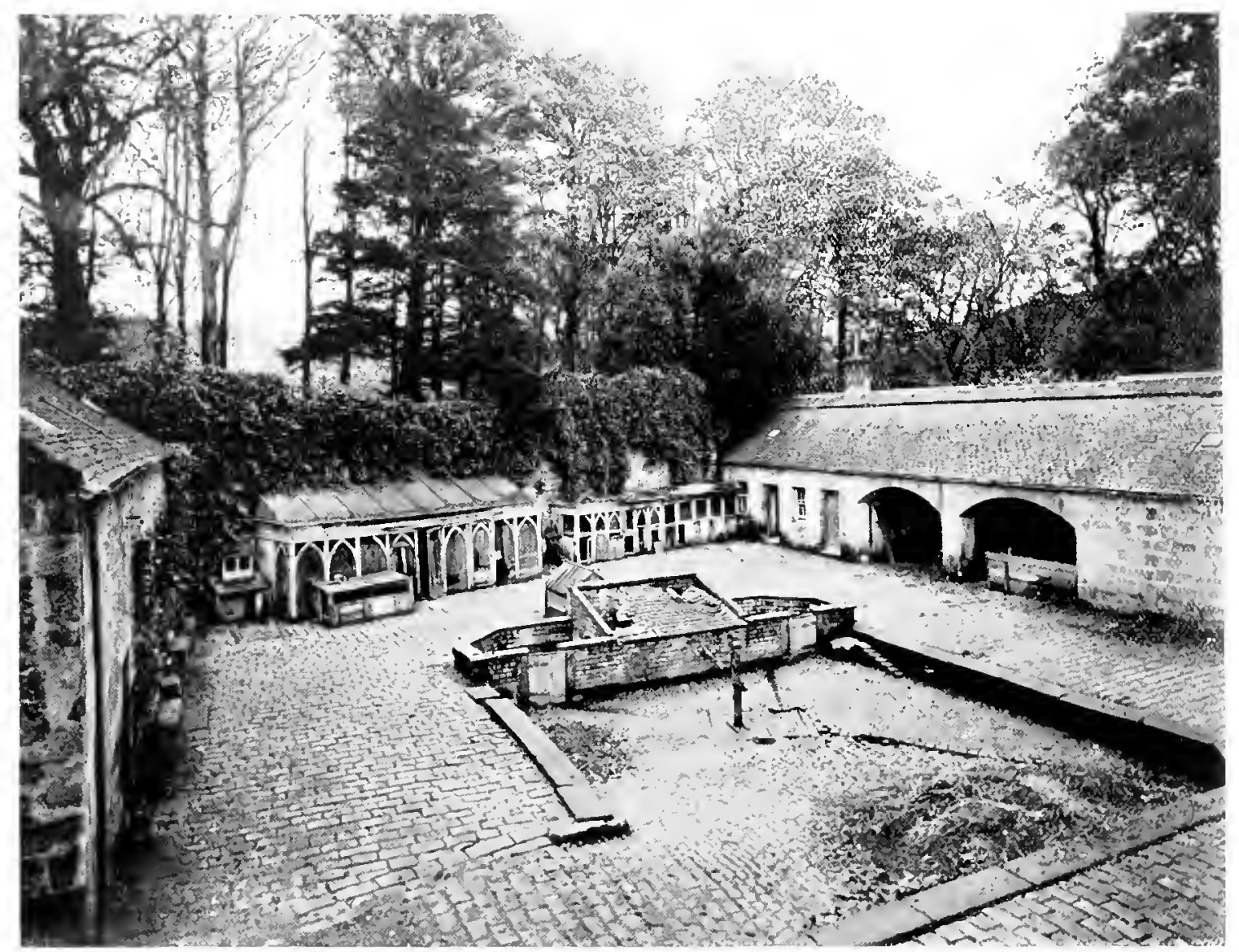

Fic. it. Interior of ohl Staldes at prenent, showing extencive area and pereibility of further increane an helter and orangery ly taking in area of contages to left and sheds toright.

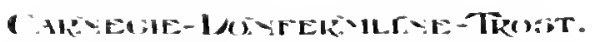

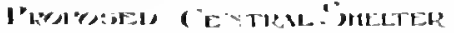
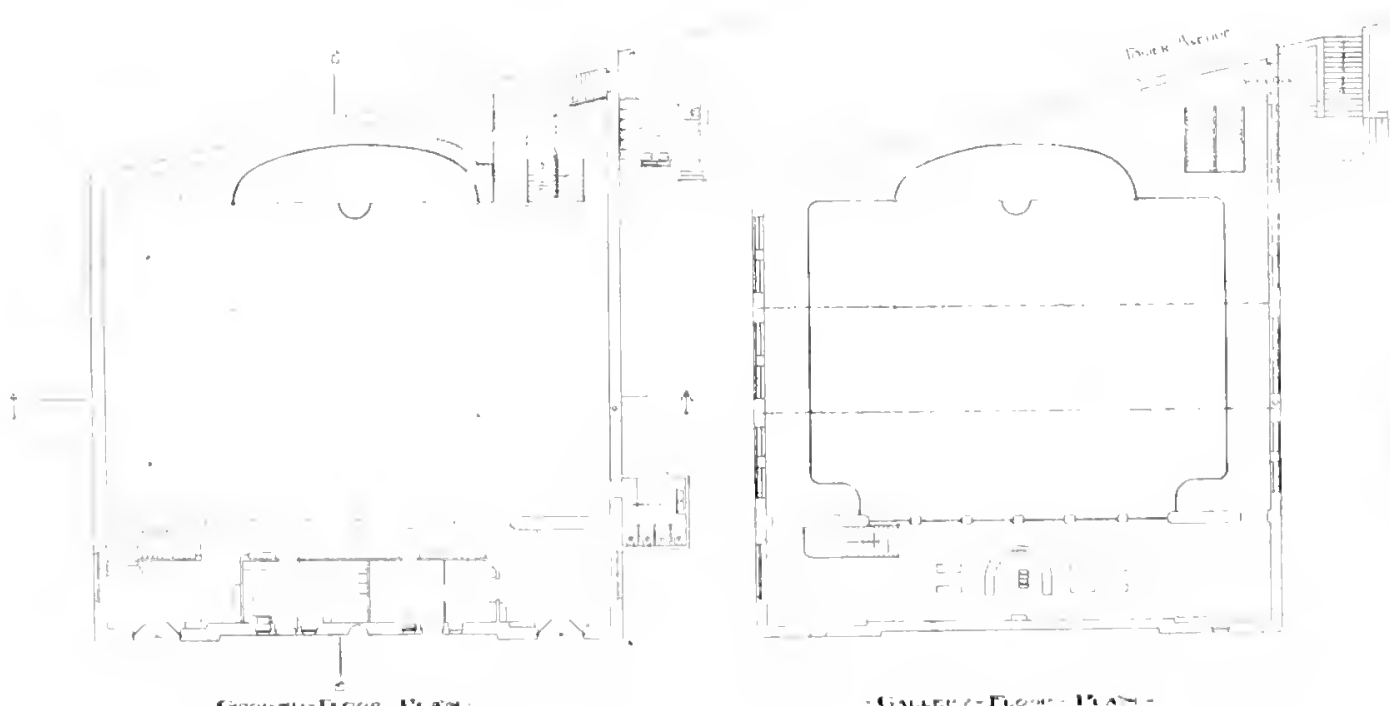

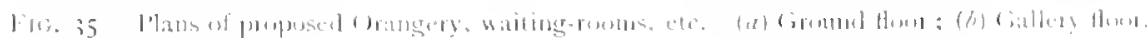




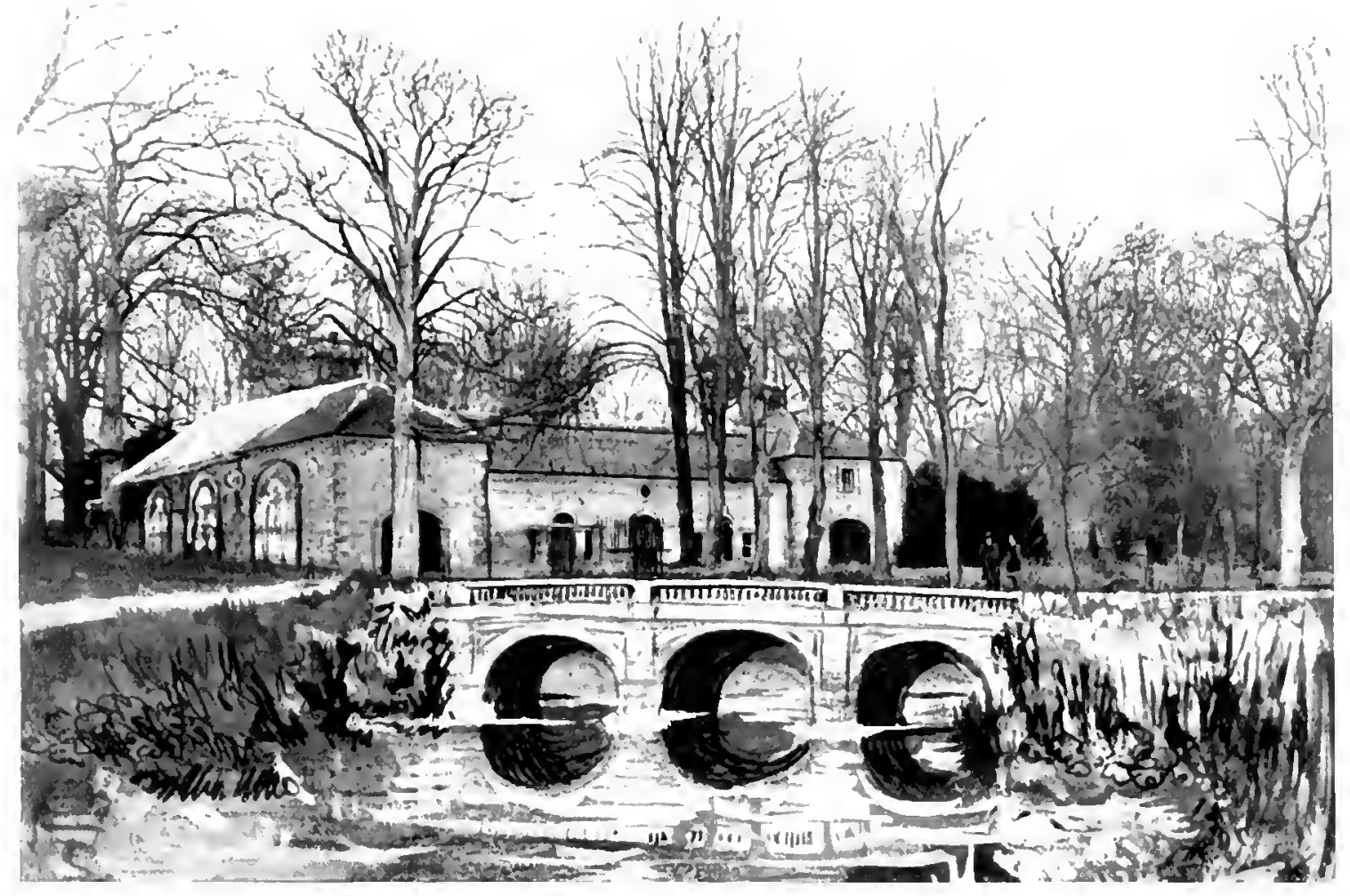

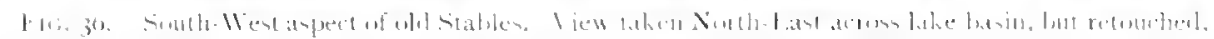

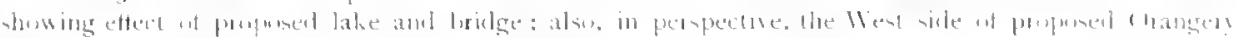

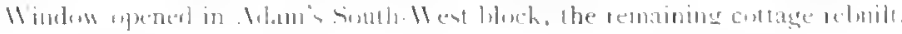

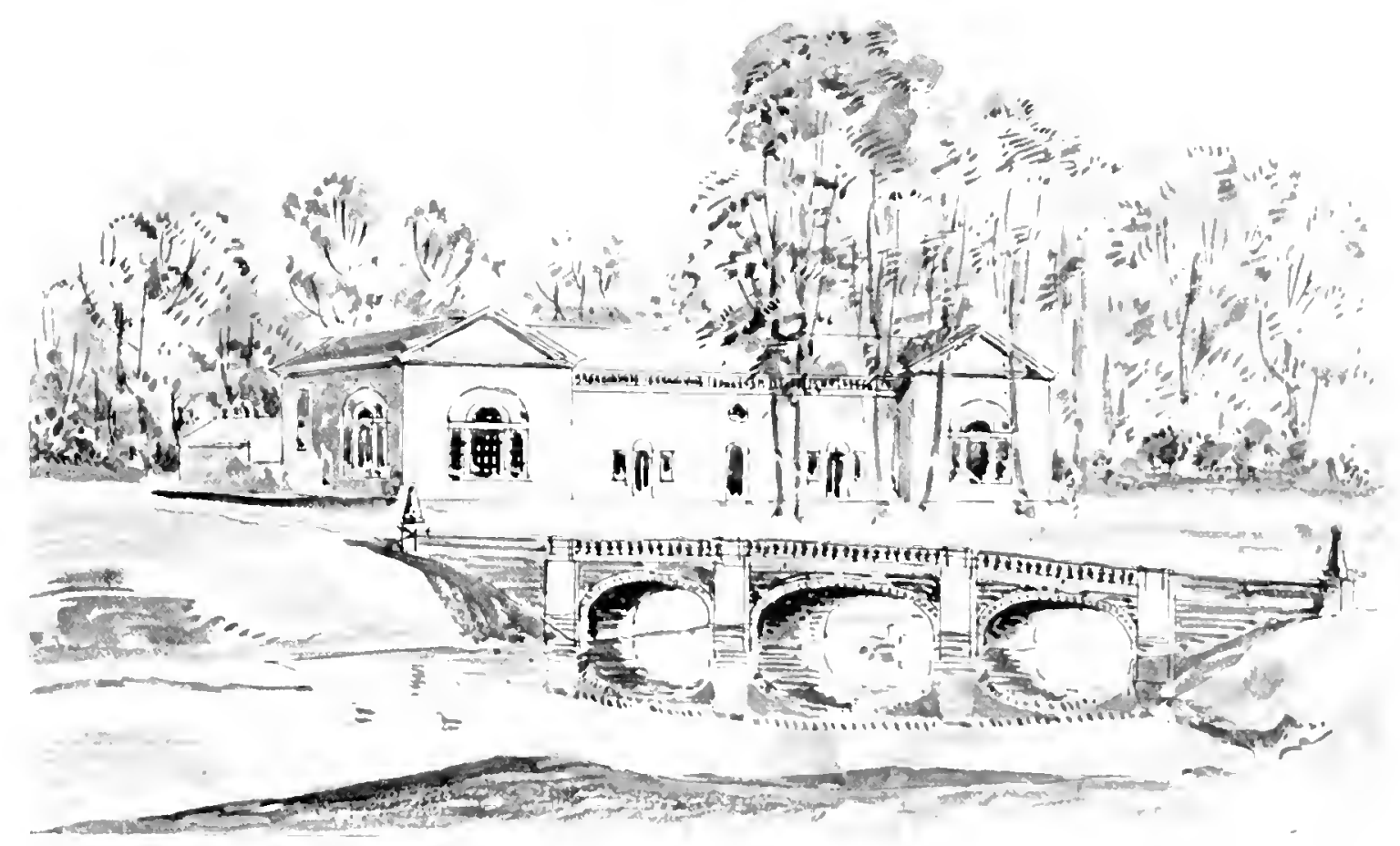


Let it be clearly understum, then, that my plea 15 on no merdy listoric grenund; this old block is a real and useful element of the composition, a genuine beatuty to the liske scene I propuse to create; anel I appeal from its hasty critic to the archited and artist of every school. llere is a clear case of the unison of historic and artistic considerations with economual and practical ones. The survival ot at tew huldugs which depend for their eftect mpon proprotion and simpliculy, not name really expressive both of its essential proportions and its architectural style ats now reflanned - the (rangery-and invite the realer to comprate this with the orangeries of Alam at varuus great mansim-houses, or even in its present state with the musemis of kew. Surely What is vilued as gonel arehitecture there cannot be sn despicalle here. As for the dark and sharlowed irontage, this may be partly relieved at the west angle, hut not as it whole, since it is too

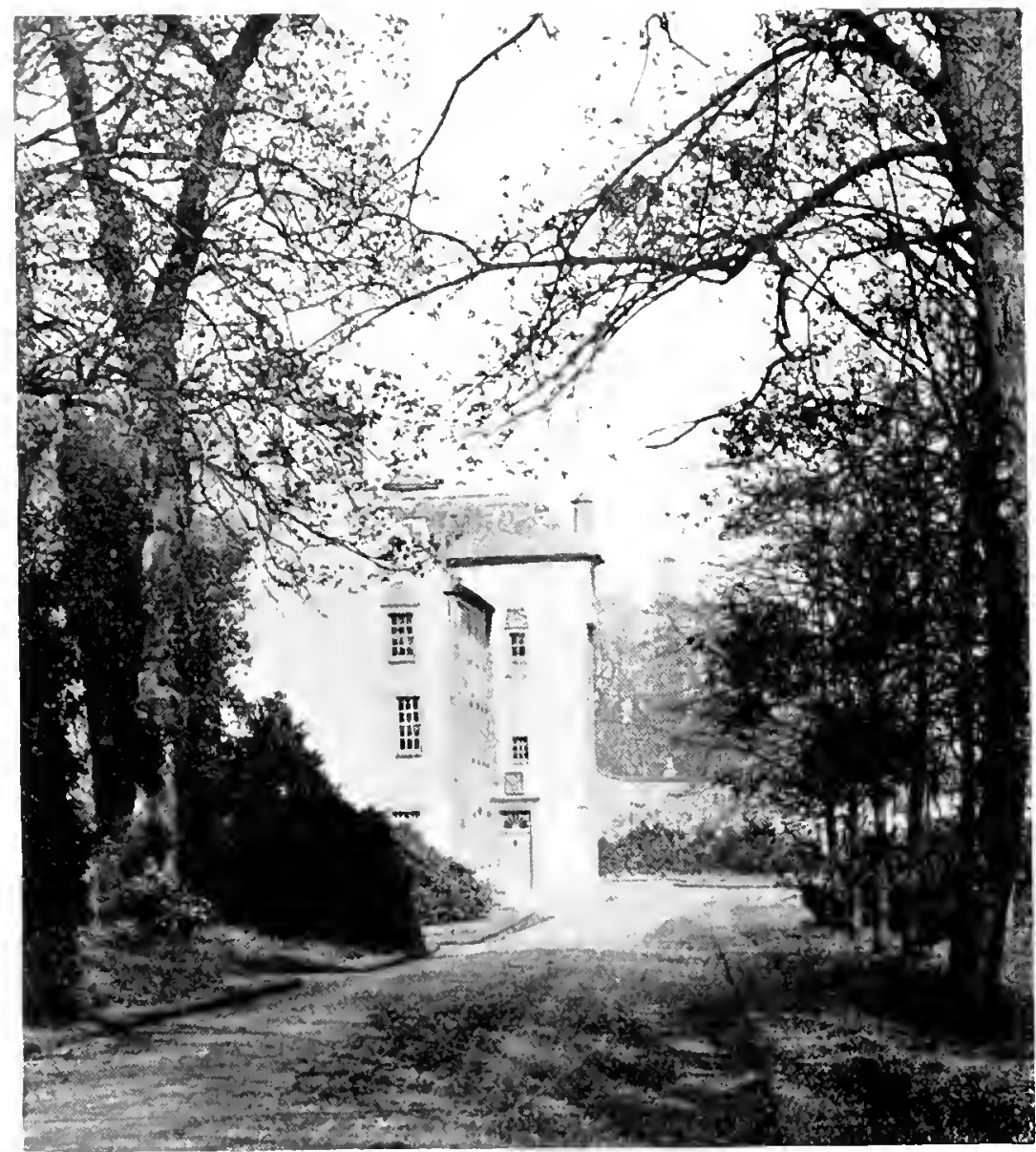

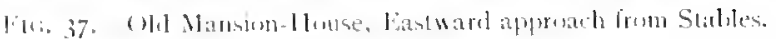
useful a shadow tor the lake picture to which we are now commong for the greater fortion of the interior, as will be clearly seen, is pertectly well smmet, while the shady portion of the interior, that ol its south wall, will fecilitale a contrast with lerns and other slarle-boving srowths

The main beanty of this spacions park-lall womll be as an eximple of the possibilaties of a Conl Creenlususe, which need not he healed all all save during the pxtreme frosts of winter learing aside any detailed enumcration of the ton selfom utilised resonrces of this type of garkeming. I may point out its possibiluties as a Camellia House, not rnly beantitul with evergreen foliage all the year romul, but glomous beyond deseription in the early spring, just when flowers are most rnjoyed. Thrously the stummer and autumn the galleries would be [estomed inexpensively from ent to end, as a pullared avenue

upon ornament, is something to be thankful for amel to be guarleal. In such a case it is the duty of the gardener and architect to resist popular sentiment, with the clear conviction that it may" be the passages of his repert which give lutle satisfaction at the monent which may he atterwards seen to le of most value; especially when, as in the present case, they may help to prevent the irreparalle astruction of teatures and elemints of beanty which may be all the more needed because they have tor the time fallen but of gencral appreciation.

Jet me propose, then, for this central shelter a of flowers, with creepers of every kind traned upon them, testooned and swinging from the ronol.

We set free also within this great enclosure a [ew well-plumaged birds We arrange tor a small aviary of song buts in the gallery, and sur dingy old stables have become a tropic paralise. Sindlatly the clange from exterior dulness is emphasised by placing a statue in the central nuche and loy ung the little piaza within the new external halustrate as a convenient and natmal place for tea taliles and seats. From thus balustrade the gnests of the refreshment rooms would 
feest the peacocks, and atso reaklyly attract the picturesplue bord life of the adjacent lake.

\section{B. Mansion-House}

Whule thus dealme woth old buildings 11 is

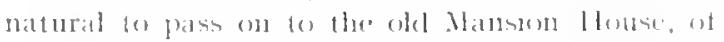
wheh the fate has so bong hung in the balance. Xo one will dispute the pteturestpurness of its approach lig. 37, : and it may be safely assmued flat the many protests during the past winter. not only of antiquaries but of arlists and anchifects, have awakened the Dunfermline fublic to a eneater sense of its real merits. lixternal muprosements are easy, whluml serious elatrge fendung repairs, and the presumable clearing out of bedrooms and garrets as a bong gallery, the pessible imprevement also of the clevations from the outside, I would sugerest that the bunlelune lee washerl anew a pleasant cream colun insteat of the present orange, here too sinsh, Here too dirty. It is to this and its contrast will the dull purjle grey of the window tacinges that the freguent dislike of this old bunklung very larecely depenels: and the eflect of this small and inexpensive change would, therefore, be sencrally apprecialed. Ilence the suoner this slight improsement can be carried sul the better

It now rematins to consider the treatuent of the shrubberies on erther side of the old lawn : that on the east, already with many rhododemelons, should the developed further and tringed with a heatle collection, wheh would give thower throush eight of une months of the yeat. Two small decorative hedding-out masses, comventently again round the small fomtans, occuly the angles of the lawn on enther side of the erravel sweepl in front of the house.

It the southwarl apex of this gravel sweep is also shown on plan at sun-dial: this might best be of the lype at Newbattle, perlatps the noblest in Scotland, indeed one of the fincest anywhere.

The comtrast of these enrichunents whth the panu old tower of the mansion whll be found grvilly to enhance the cifect of both

This stemmess I propose to rehere furlher by a due planting of climbers, from the early clematis to the winter cotoneaster, and to than high 4 fou the wall the lig and vine, whth tall climbing reses. thon the east and west ends ivies and yellow jessamine may be mixed. liog the recent perom grarden seat have already been substituted two betfer ones. Finally, if, as seems not unlikely before long. whe present roof has to be renewed, the old-fashioned attic windows of the original design might be advantageously replaced, the grimuess of

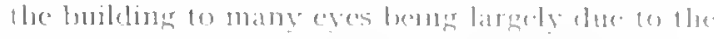

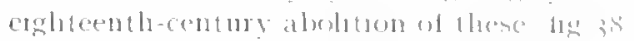

Is to the use of the lrounce, I tust inereest it ats primarily part of that hesterse muedams in wheth this park shoukt excel all ofluers. Withen it

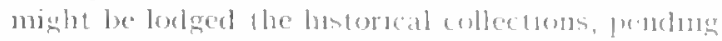
the creation of that large lustome museme we which I come bater perhales the naturat hestory

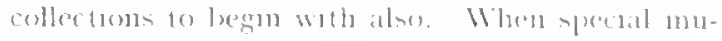
seums, as bater sugrested, are comstructed ofled use whll readily be fouml (hit). XXX.

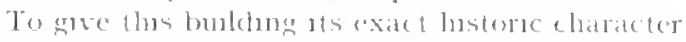
and interest, that of the f'urtan and cavalier period, we late happly at titheng and olventus resonrce in the splended stalues of "The l'urntan" and "The Cavaher," In Macmomumes, whel were so prominent at the l'aris Expmition of exens, and

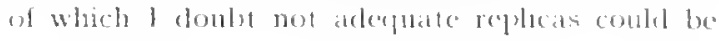

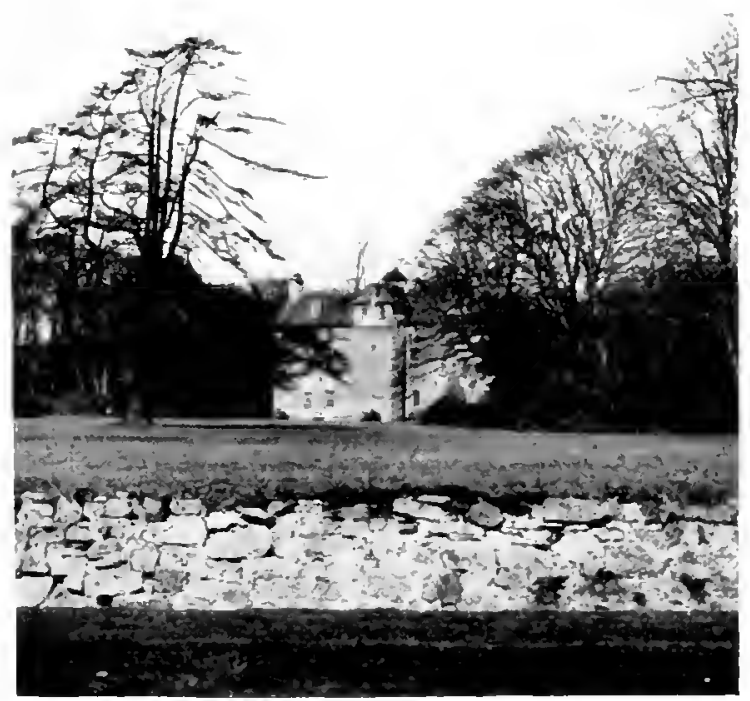

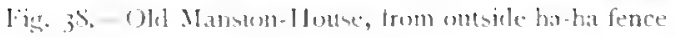
of lawn to sioutl.

obtanded. Or, faing these, mmmo statues of kindred type would give lask to this hulking a historical character in all "yes harelly less distinct thatn that of the medreval buldung themselves. The statues of Scott's characters moun the Waserley monument in l'unces street slow that Scottish sculptors only await the opleotumly to give us work of individuality and inferest. The statues of the Nattonal lortrat Cablery may also be retered to. These statues would readily tind their places to cast and west of the heruse.

\section{Pinetum and Cedar Group}

Learing now the mansion we may enter the lutle wood upon its right or western stle. Here at path leads to an old well, probably that of the 


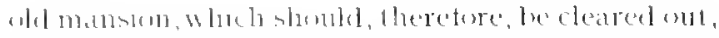

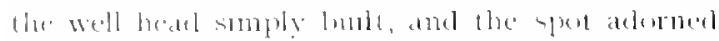
whth seat and shade. Thes whole phace, despite

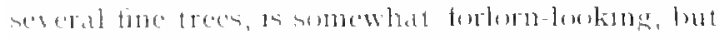

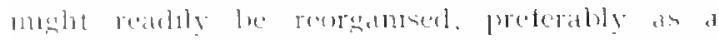

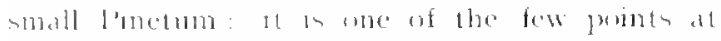

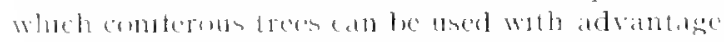

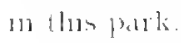

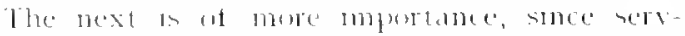
mo to compleve eate and all at our whelle

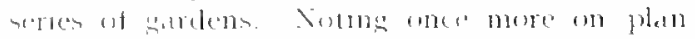
pmetum and lake, lhe reck garelen, and tormal surden what final doment is needed whels

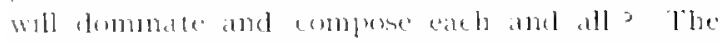
answer in that the can bent be done by a soromp o! cedars at lechamon, wheh wall be equally vilualle trom and tor every one of these pents of vew, and woll steatily increase in beanly for comturbes lo come. The compallatue exposure to

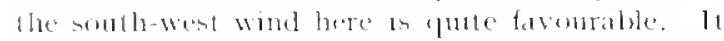

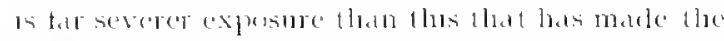

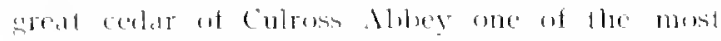

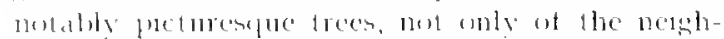

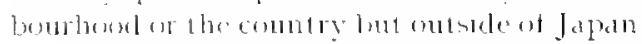

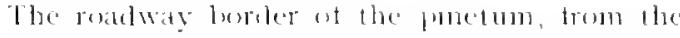
lawn w the lake and stables, shomld be borkted

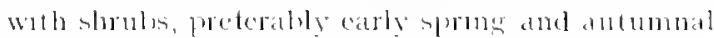
ones, steh as witch-hazed and mezerom for the

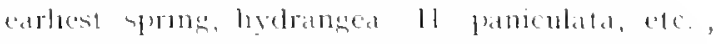

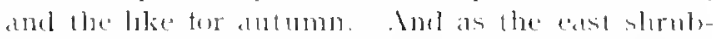

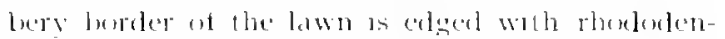

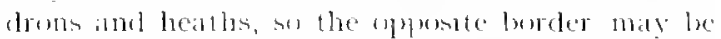
tromed whth a loly gerden, lonked fo lts shrublery by rucods and the like, and ats leele keple bught, not only with hloes proper but wath theor kindred. the season roumel, trom snoweloms and crocus to

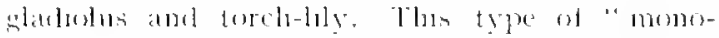

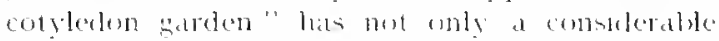
botanical interent but an artistic fualuty and charater of its ousu, a pepular interest even, as I bonew be expertence .11 l)undere, where 1 have camed out thas stye of bedelung for decoratue porposen throughout the scasoms, trom the show-

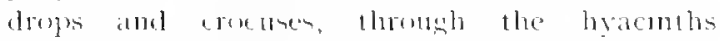
and tulpes of later spmes, and the day-lutes and fucluas of summer, to the forch-lilies of ant umon. 


\section{( HIIII:R I I \\ LAKE AND ROCK GARDEN}

\section{A. Lake}

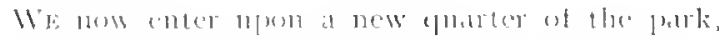
the western, wheld is here shown oechumerl by it

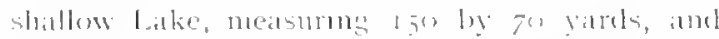

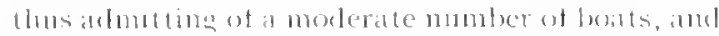

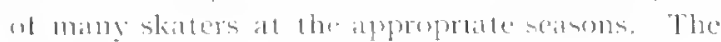

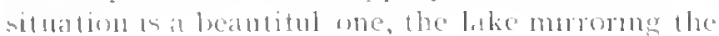

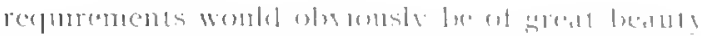

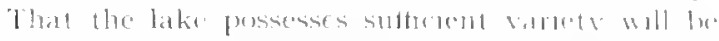
seen from plans, process blexks, andel, heme of all

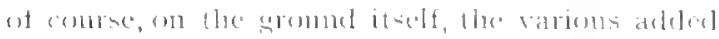

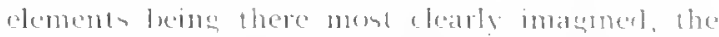
western wilow-ereen frumbug the explung belt

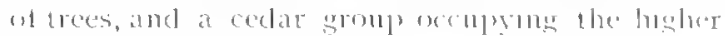
ground to south-east. Fo thin reclat whoup I

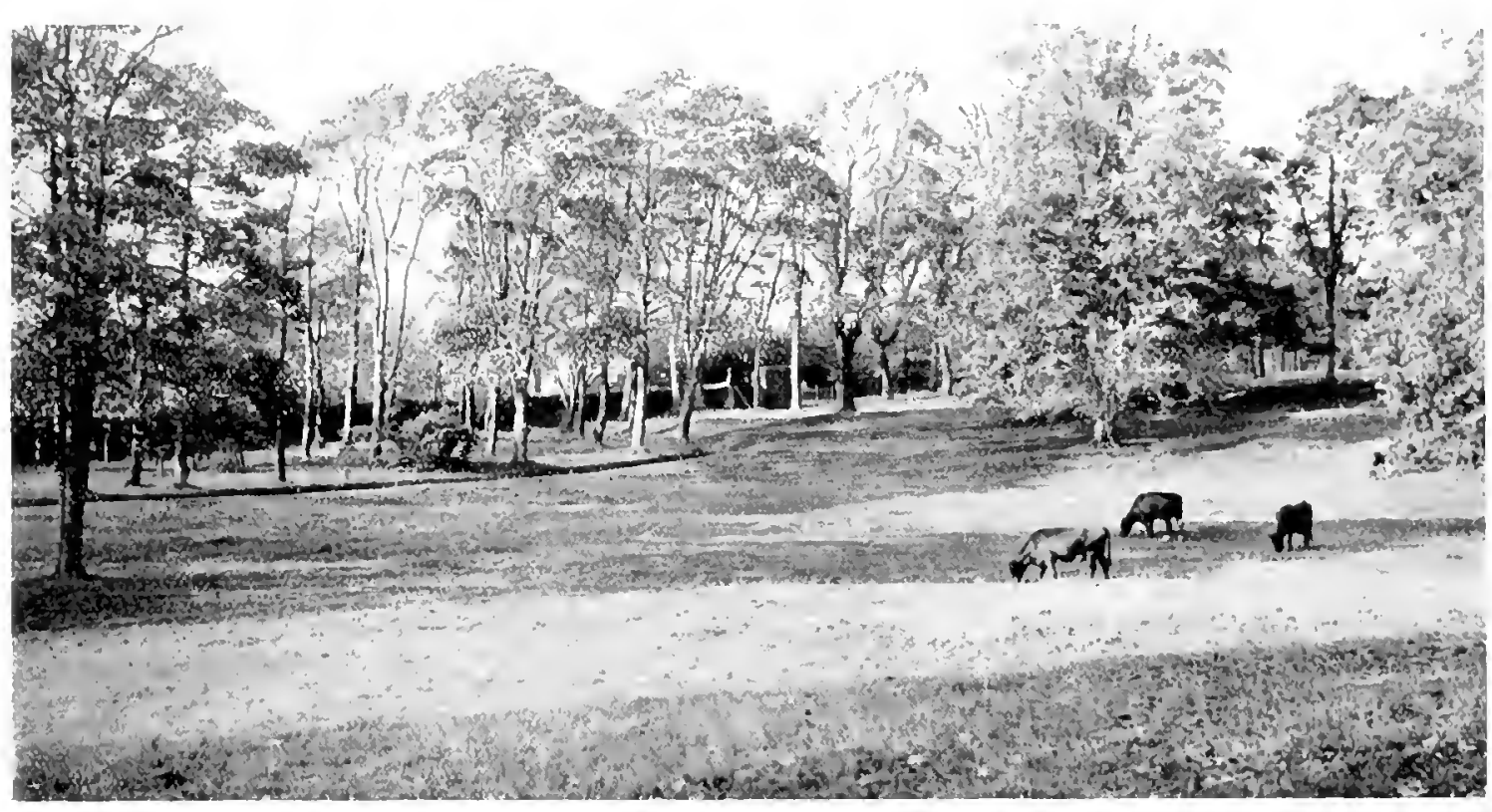

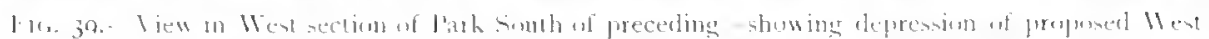

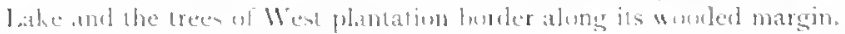

trme trees to enst, west fig. 28 , and moth, while it groul anchitectural eftect is given by the necestaty

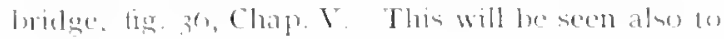
compuse well with the old stables, and I mout fully convince ther severest critic of the nexd tor retitining them. The loss on this picture whold womld result from the removal of the stalles will bo obious from a study of the illustration

Ilere, then, is a man element of our arehteotural composituon, hut this, agam, fombsits completion and contrast in the Bout-house, comvententy usable above watter level as a lea homse and rest house This, again, is al burleding of which the attach oreatl tmportance, as wall be seen tully. later. It is to the whols smroundung lesen- of lake, rock garlen, minsion-louse lawn, funetum, and tomal garlen-what the kerstone is to the arch see chap. Vill

The general form of the late is in accordance with the contour lines; ind where escavation hat been necessiry beyond theme. enpecially at the norlh-west, the eonsepuenty steeprer shore adapts itselt 10 a poturesine rock treatment

thout the muklle of the not th shore utatnalis a bat-house, with retreshment rom atme. The 
adeliom to tts northward shady siele of a prosible rain awmon would ereatly increase shelere in showers.

The pomontury as left smply grasty, with a mere stony edge, so as to allow the cye to travel across the gath up to the trees, some distance behmol. On the cast sile the present roal passes wer an entholiment, wheld at this pount is rephacel by a bridge, as shown m plan and perspecture fig. 3 ho, Chatp. I"

The bridge thus divides the lake nuto a large, lorght, and sunny west portion, and a small, clark, shaty cast one. The arches stanel between " and f teet above water level, thus making it posilbte not only for buats to pass lut for skaters (1) run througly in tull career. But though the whole lake would le kept shallow, nowhere axecolng 3 feet, the ustual frectutums wall naturally fall to be taken ly the patk-liceper of closmig these arches unth the trost as therementy atsisurert.

Here the allustratuon fig. 3n indicates the elfect poduchle ly the constructuon of the belie and bulge. It atch end of the hridge are tisposed erreat clumps of picturestue water plants, such as hulrushes and reeds, their natrow toliage contrasted by the glomtic leatege of Gumeras and other decordabe plants. One or two w the finer whlows might also with advantage be planted here

l'roceedeng now sublhwart atomen the correspondmeg path we come to a smatl sianel with nestmog clomp, arranged again with a foothrege, flus time simfly worlem, and lingli enough not to obstruct the sliater

Eastwarts are huih a serice of "pockets,"

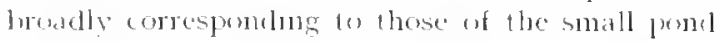
at the Edmingl Besanc Gasden, for the culture of water plants, intermelate in size lectwers the rankest forms at the lowige and the finere ones aroum the prods of the rock garelen to be contsidered later.

Behund these, south of the dry gath alomg the adge, runs a bog garden anel bug shrublery, will beatutitul plants for numerous for mention.

Towards the somtl end of the latie is the ontled, whth th mecessaty dam conceded by the planting ut a thicket of willows. This is continuerl along the west sitle northwards to the rocky shore, thes wllum plantalum thus shading into the existung pldntation belt lis. 3(3), so that sufficient lluckness is assurcel and the desired eflect realdsexl. The lat-ha would here be eltaced

\section{B. Japanese Tea-House *}

licturmms to the outlet, where the clam is crossed by a butge there would naturally be a fall of

* Thir pasnage was writton lefore the opreningt of the present war. ahoul \& o wo feed, which, by economy all night, could le run will sutficent quantuly for picturexplueness. I poul is shown helow. Thus brings us abmost down to the row of noble old plane-trees

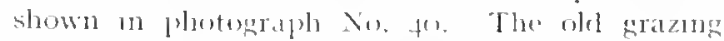
park shanty shown in tront of these I propose lo replace by at Japanese "Tea-l louse

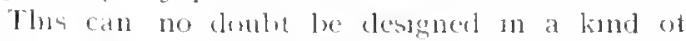
way by limopeas hands, but I sulmme that it would the more saldstatedory to bare, nest indeed

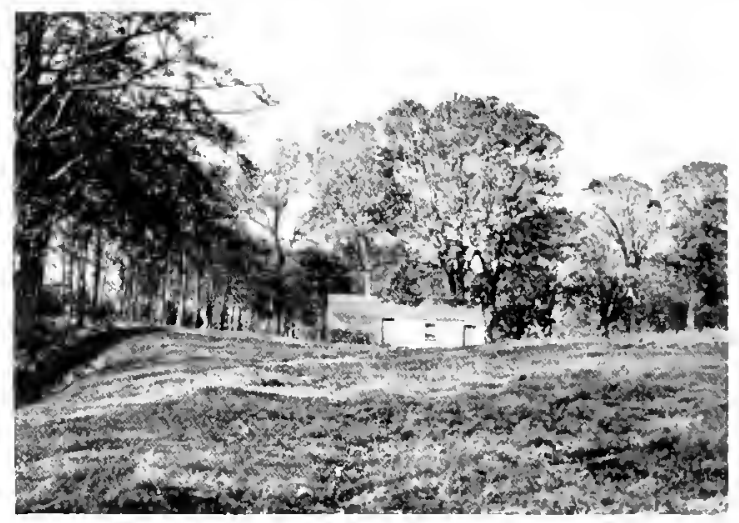

Fiti. 4". Site of propused linck (iarten, separated from lake (n) Nonth loy high trees. The hatha fence in deep shalow under West lumulary plantation th he effaced, and the eviuting natual depression deeprened as watercourse and main valley of linck firmlen. Jafunese tea-boutse sng sesterl on site of present sherls.

the tramework of this louldeng lout bls essental detail and adomment, executed 11 Japan, the experience of Mr Mempes and whers hasing alrealy poved that this is moll practicable and ceonomical.

I have later suggested many thungs for the techmeal school and for the local at tist, but this is nut one of them. Ne can nu more produce Japanese ormanent than cireck statuary, and in this ease if is not even desirable that we slmuld try, the imilation of Japanese art in Europe leeng mere clumsy foretry.

Why, then, do l sugerest a fapanese bulding at all? Irmmarily because the park is intended fo give a secteative and complete thange from our daily envionment, and clabnge of scene ancl dissociatom is one of the most real sources of such recreation. Very few of those who are to use the park will ever see Japan, and I therefore ask tor ons litlle genuine bit of it here. There are ofluer reasons. If all nations the Jafinese have suc-

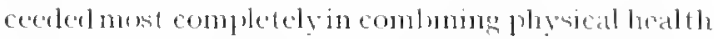
and strengll, necessarily theretore the essentrals of hygiene and comfort, with the ntmost simplicity and comomy; yet all these again with many of the very hishest elements of personal refinement, and with that mavelous art whicl is at once the noblest of huxuries and the most enduring of comomices. 


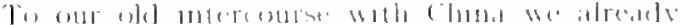

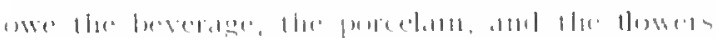

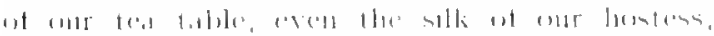

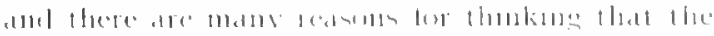

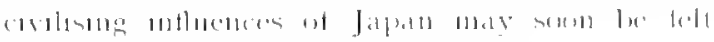

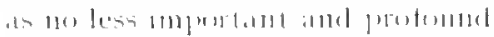

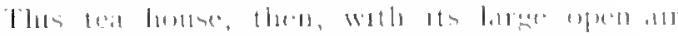

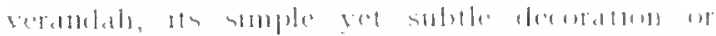

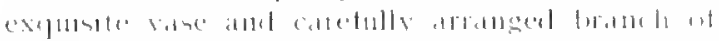

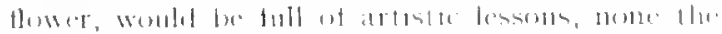

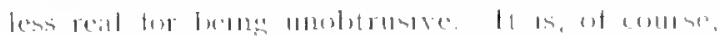

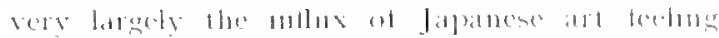

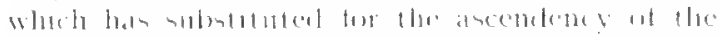

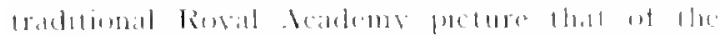

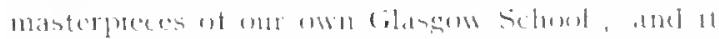

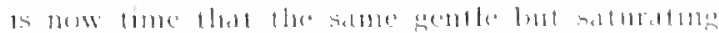

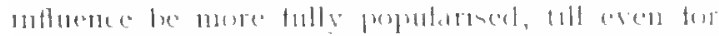

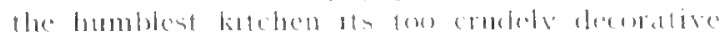

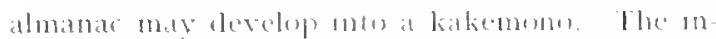

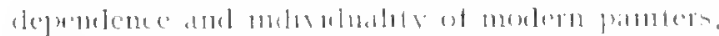

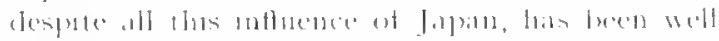
illustrated be the chetracter and worts of Me

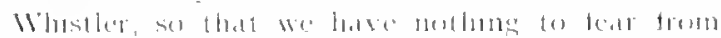

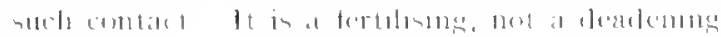
(1)

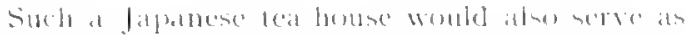

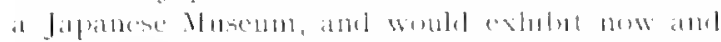

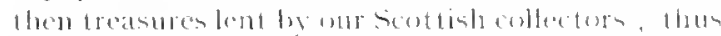
agan the park woukd constantly to tomplong the mally art lowers of lounfermline to a healthiful excurbion to its farther extrembly llere, alas, is one of the many Ways in whets an these parts

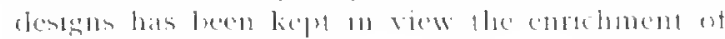
the statple molntry

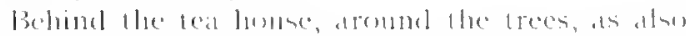

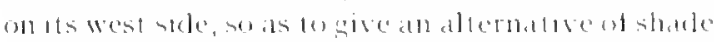

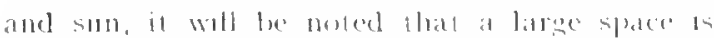

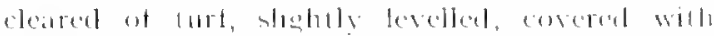

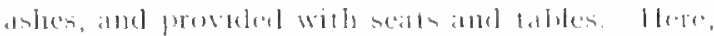

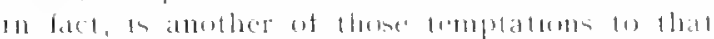

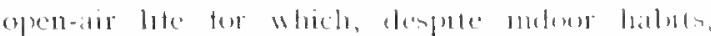

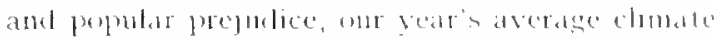
atfords a very comsteralle rame of elas and hours.

\section{Rock Garden}

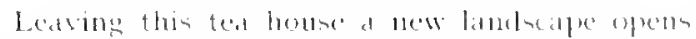

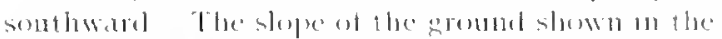
plotograph ties. fth meleaten that cultivatum

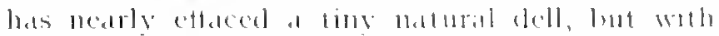

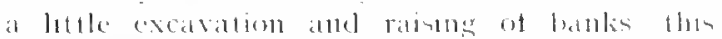
may be easily recosered inds a litle waterenutar. the water being provided srom the outles of the lake. At thes point, then, naturally arises the

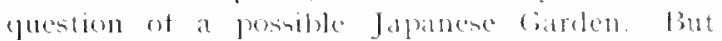
while we can lring over Japanese carpents and

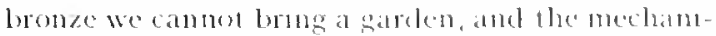
cal imitation of the Japanese style wutd here le even more impraticable than exer

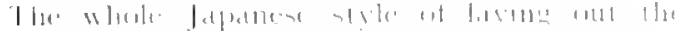

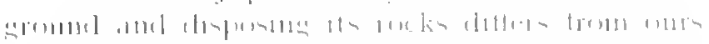

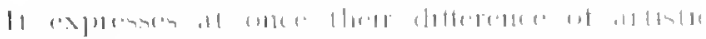

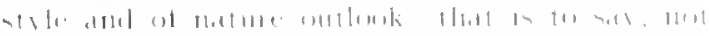

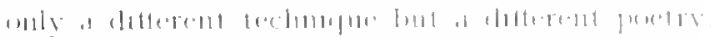

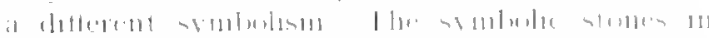

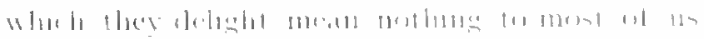

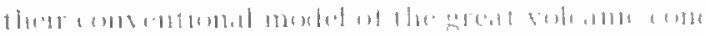

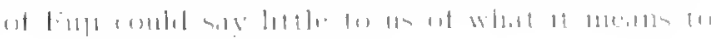

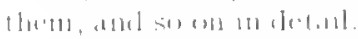

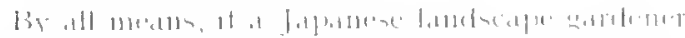

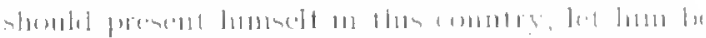

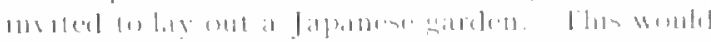

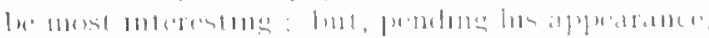

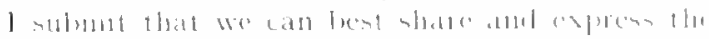

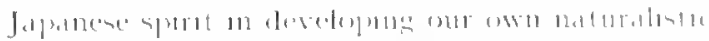

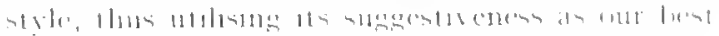

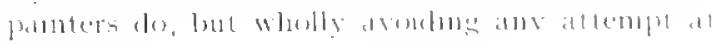
(i) 191110

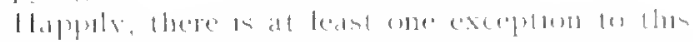

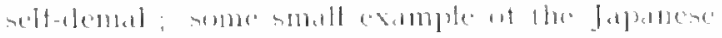

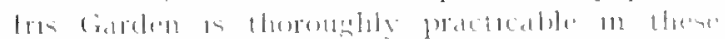

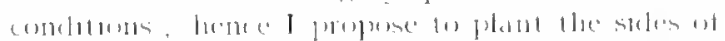

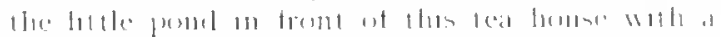

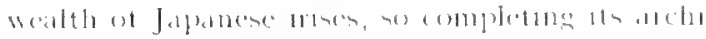

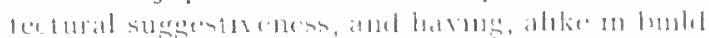

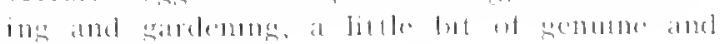
1ypulat Jay,d11.

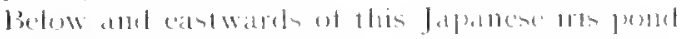

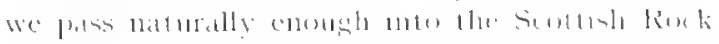

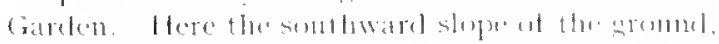

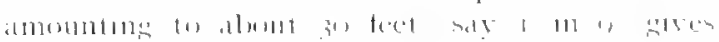

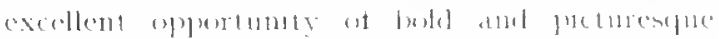
treatmente I take comsiderable upater tor that

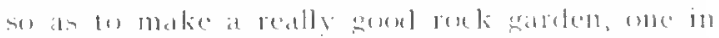

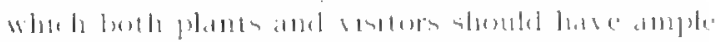

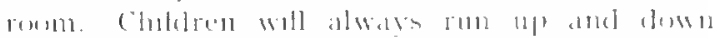

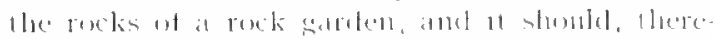

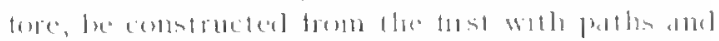

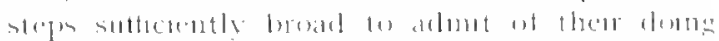

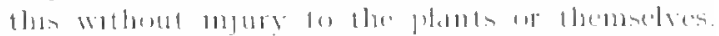

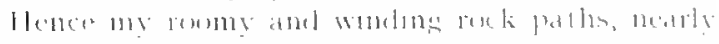

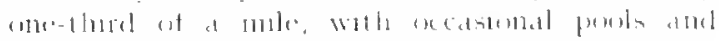

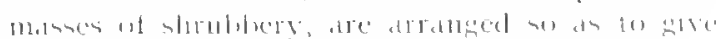
combinul vancty and tresh pronts ot rew anel intriest

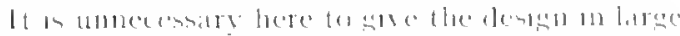

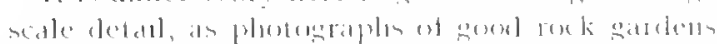

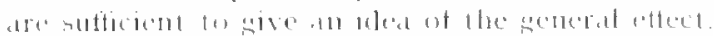

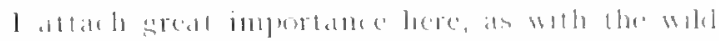

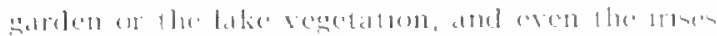

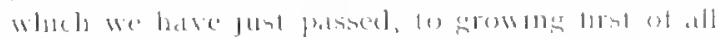

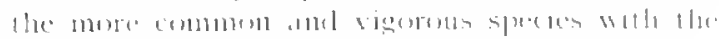

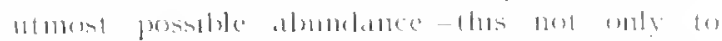

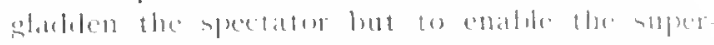

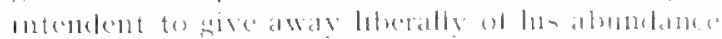

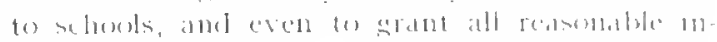

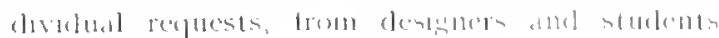
especally.

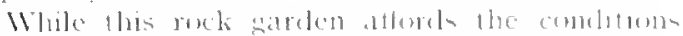

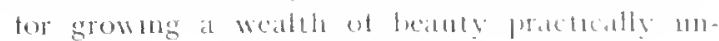




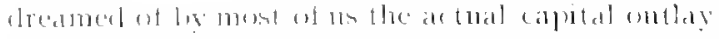

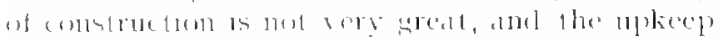

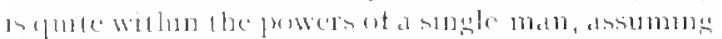

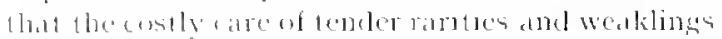

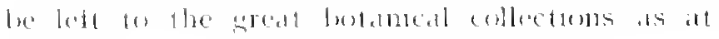
hincisent

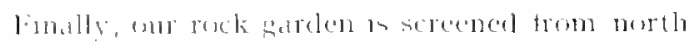

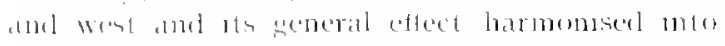

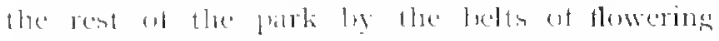

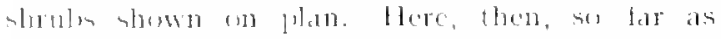
ontalum sordenung is comecrned, we leave for at tume the lolamst.

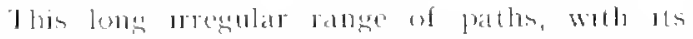

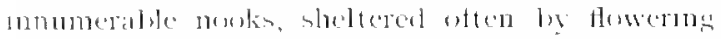

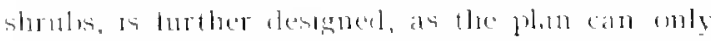

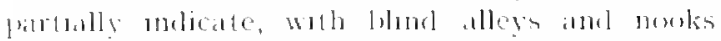

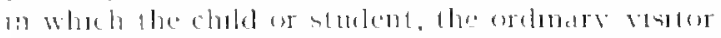

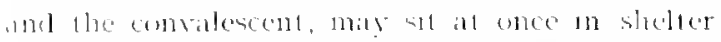

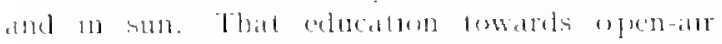
freatment, wheh as a math hrgiense itspeect of the

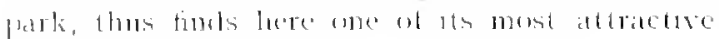
and chective punts.

\section{Rock Garden further developed Evolutionary and Geological}

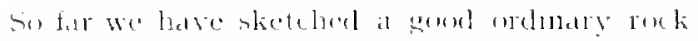

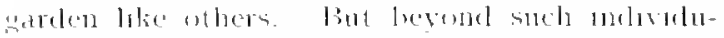

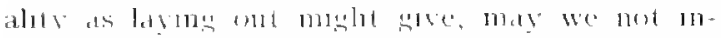

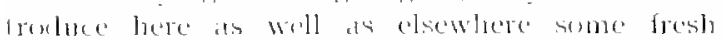

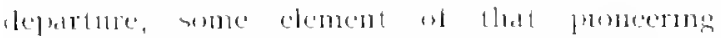

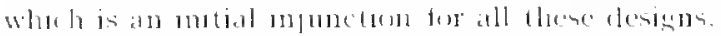

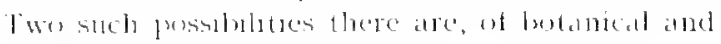

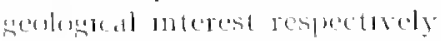

Whate it in the tirst merst of a rock gurden lo

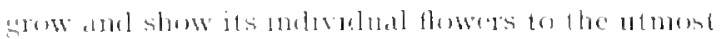

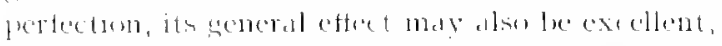

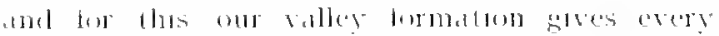

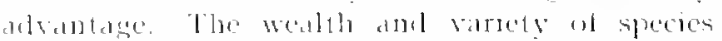

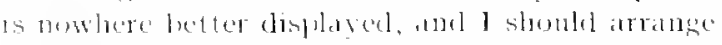

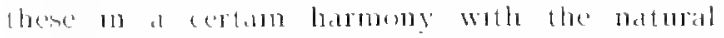
orders aleponed later aromind the park clatp. 1. and also wath that aencalesgat tree stretch-

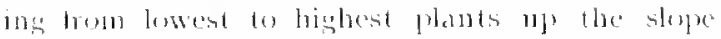
of the "shate garten" of the Tower bene (liap. . Yll.

The interest, not merely to the technical student

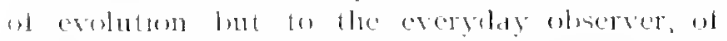

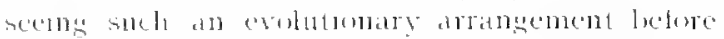

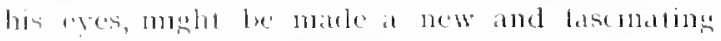

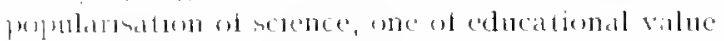

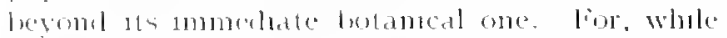
escrome is nowday familat with the idea of the

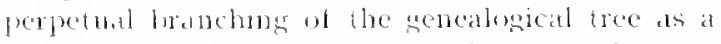
simlol of evolution, wh such comprehenswe

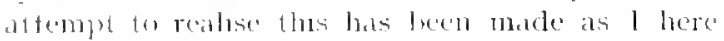
poprose. I an well aware that, with the alfance of our knowkeres, rearangement would be necessaly : lut do met and plants repuire just such presolue lifting and aveling?

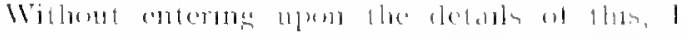

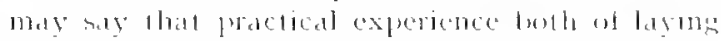

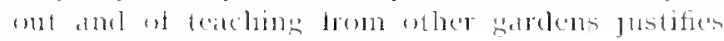
what lasis lecen propused

Wore mencrally motestine and mpressive

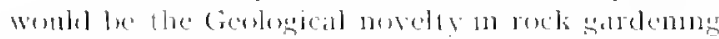

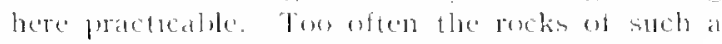
garden are joresular, exen chatutu sometimes, as with the foplonese, picturesplue arrangement is atcmpted; but wur better bublers atm at

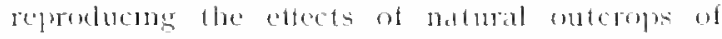
rock. Here, then, are the adrantages these

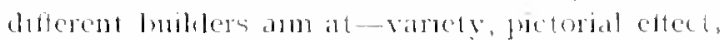
and reprofuctum of nature: can we not cany all thee turther here? Science with ber plans

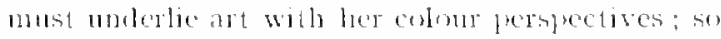
let us ask the fecologist the fundamental prestion What is the ideal of seolosy - its fullest am-

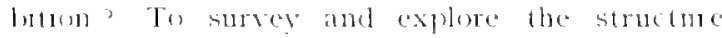
of lle world, to bere and lore its crust until the stacension of strata from the carliest times ul) to onr swn can be thplayed, and, again, to loxk back from the smple crerghay proceste (1) change (1) the woll-makmg which is then sum.

All this the perslogent strives to combense into his surver, to set torth in his musem with its succesion of cases, and to leath in description

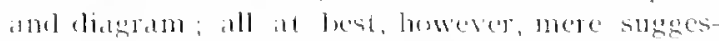
toms or symbuls of the morenificent reality Can

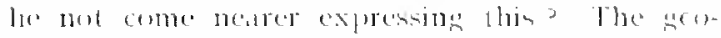

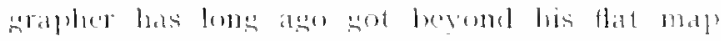

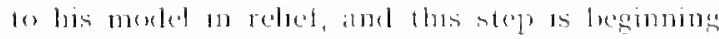

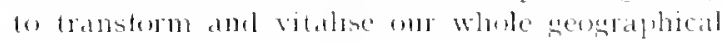

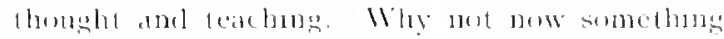

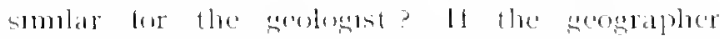
has a worle-model, surely he maly have a Worlet section? lod us on to work, them, and prepate under his direction such a sectum, or mather theesfold series of sectums-the central one tor ont own intands, complaratuely on well-known, whthm

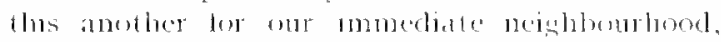

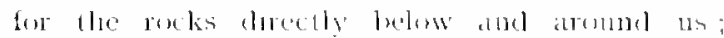
and ontsicle all steh an onthere of the world for-

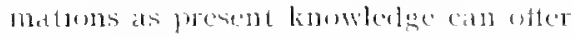

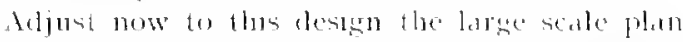
(1) our rock gurden. This may lxe consulerest uot so mucle now as brablly rectangulas, hut

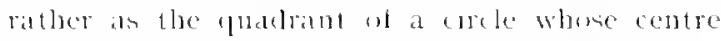
is all the south-western cormer. Aromed the walest sweep ot hlus large are we arrange for the worle formatems, alome the midelle the Bansis enes; while near the centre of the curve -i.t', at the gaden's castern terot - comes the pre sentment of our immediale strata.

Here, then, is a fatsenating problem tor our Naturalists Soctety, one for whell they will need atl the help that gerolugical survegor and teacher can sive them, but whoh with this is not impracticalle. We have to allot so many yardo 


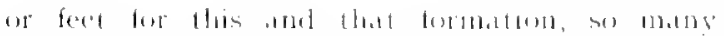

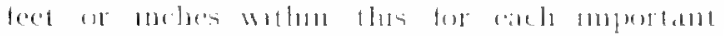

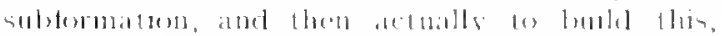

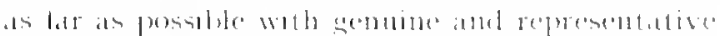

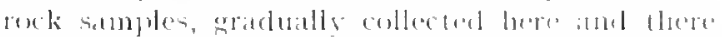

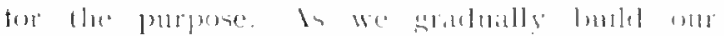

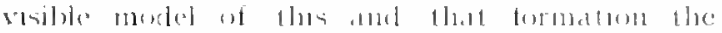

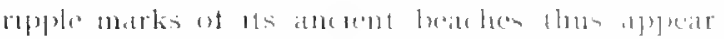

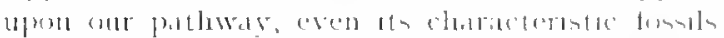

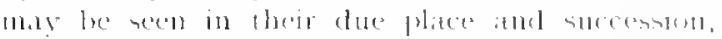

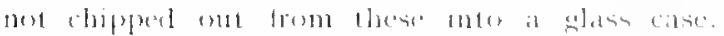

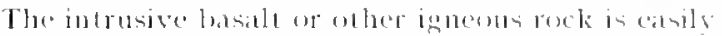
supplieel, the glaciated surtace alses. Even dassical sections and chardeteristio exposules moty sometimes be sugrested, it mot reprostucest in miniature. In fact, the more one brings to bear on this problem the expertence of the serographical mexlel an reliet the more one sees its splemelul possibulitues

It may be justly satid that sheh a model is not easily mate, ret that is surely another reason why it should here be attempted. The rock

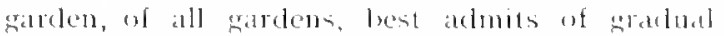
growth, and even, where need be, of wataled

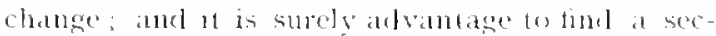

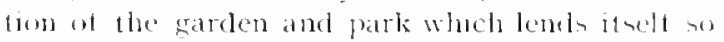
pertectly to elabotation and improveneme, which are so desirable for continued interest

The collection of the neediul comblituctue material-rocks and stomes, muluerale and tosits-may at first sight atprear difficult; fet thus is the husiness of musemms, and that upom at tor more elahorate seale. These amm at eomplattive coms. pleteness: while here we shomlel he sittsfied will sood types. The expense at carridere in mothing serious; a somel deal ut the refunter material comes to our ports an ballast, whle the frateded transportation even bl tarese stomes ka all exeryday matter of hulders expentence.

lienuning to our plants, we have here an excellent mode of exhibuting that characteriste relation to appropriate sols whuld ha comblatum of pertect culture. The geogralincal destrubutum

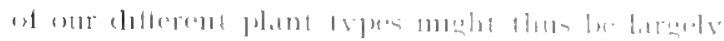

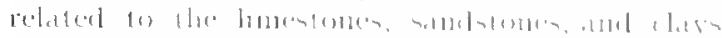

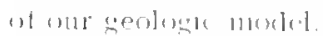

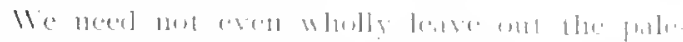

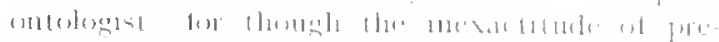

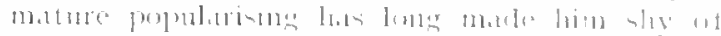
reconstructing the creatures of the poret in all

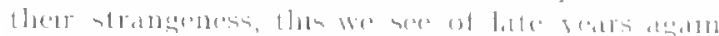

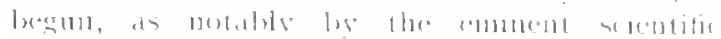

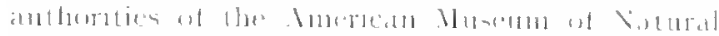

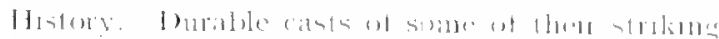

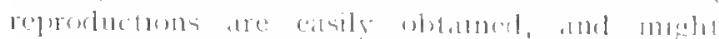

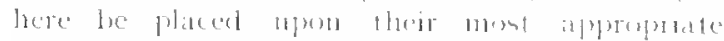

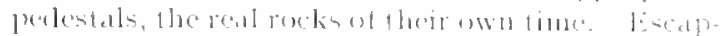

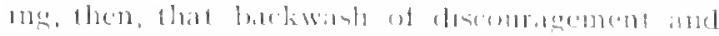

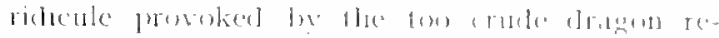

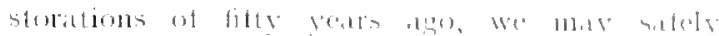

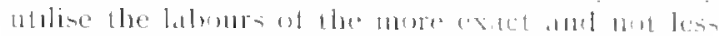

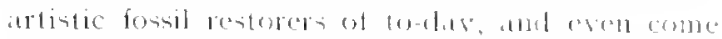
to thare them

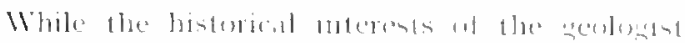

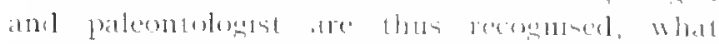

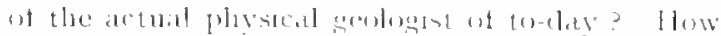

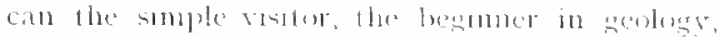
the helped to see the areat precenses of worke

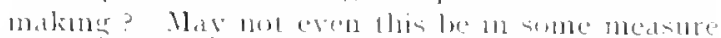
contrued in munature by the latp of cur little

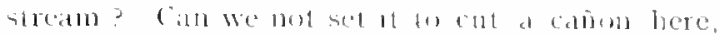

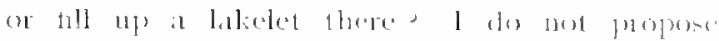

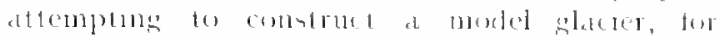

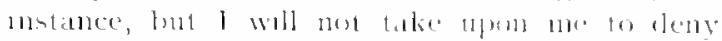

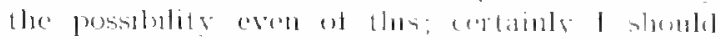

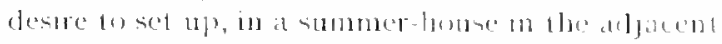

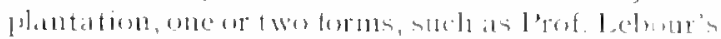

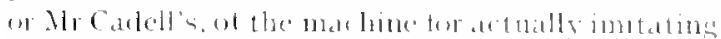

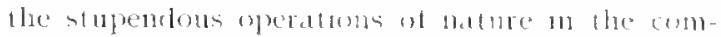

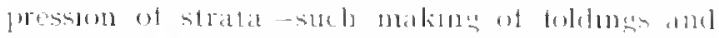

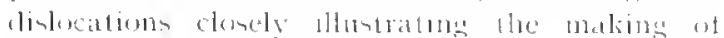

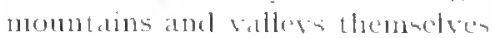

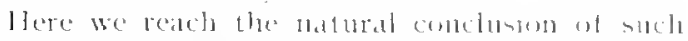
proneering propmats-that he whe wothl see the world mas loterally de wore than come ter Lomtermintere 


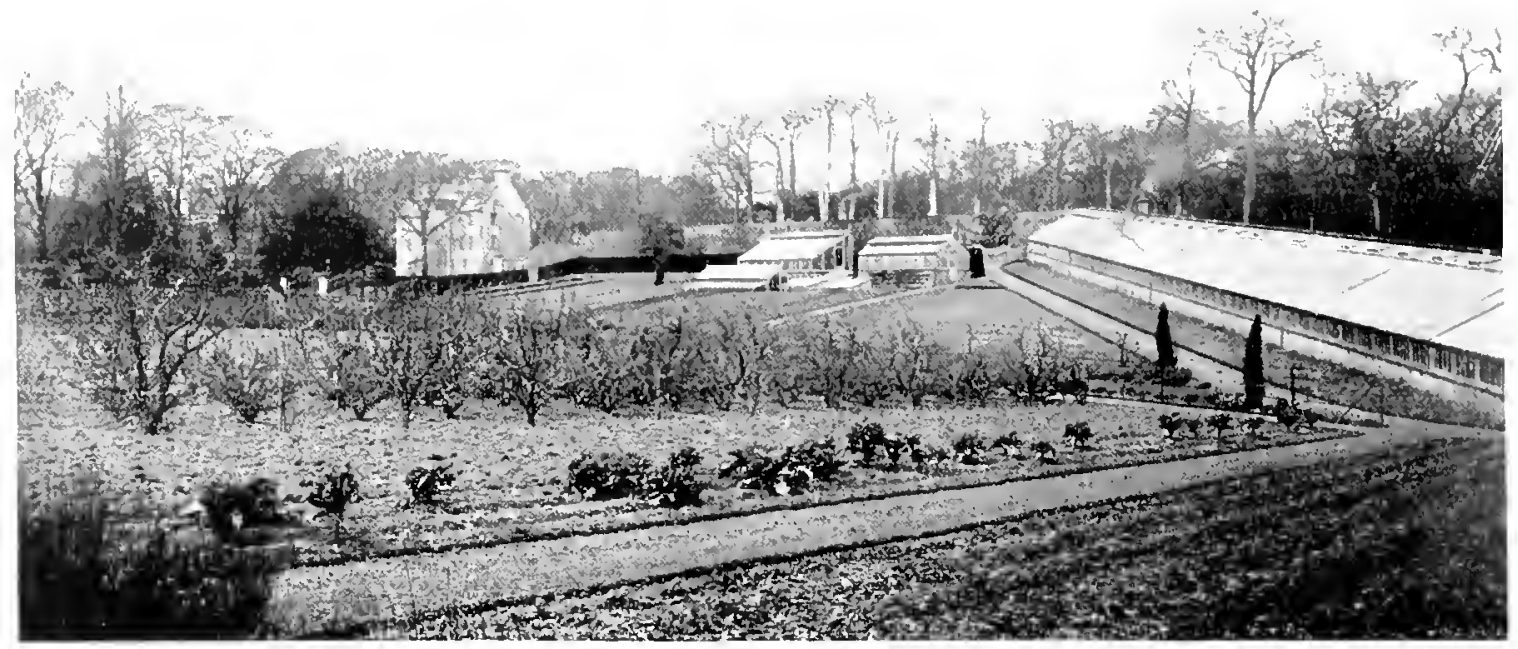

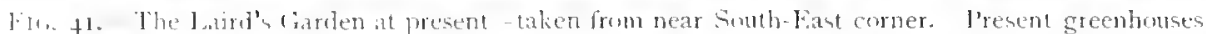

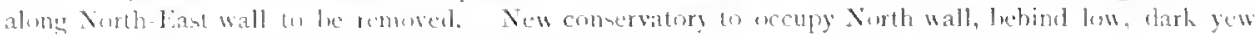

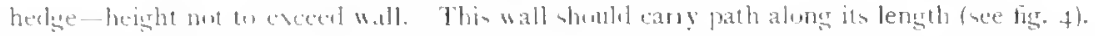

\section{CHAPTER VII}

\section{THE LAIRD'S GARDEN}

\section{A. The Laird's Garden}

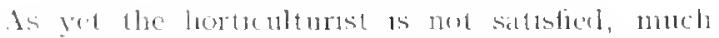

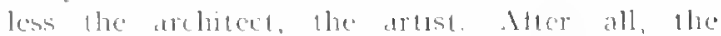

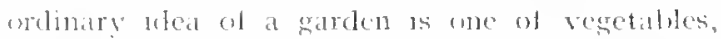
flowers, and trmit, and from thé melispensable,

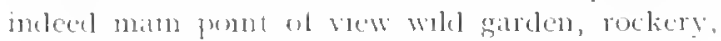
and the rest are munor attars

It ts tume, then, to betake ourselves to the

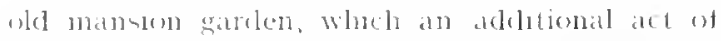
generosity has now thown also into the common wealth. The general aspeet of the garden has

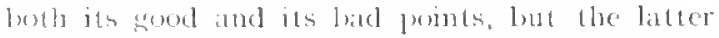
figs +1) maly be sently transtormed without lesing the tomer. The princeple abcaty applecel

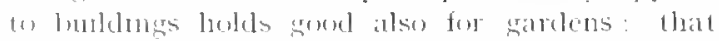

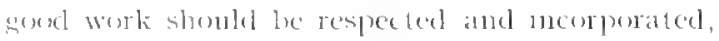
not destroved

The decoratse feature of the garelen, sts long contral grass walk, whth linplocens border on

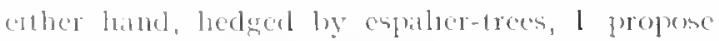
pretically to leave alene, merely improving the at prexent unsatislactory olduge crats, as shown on plen. I should also lengloen this man wall by setho bate the entrance gate for teet westWillels. The small curculat lasuns showen at each (mel of the walk will ereatly improve each extremity. I assime the future rebuilding of the ereenlanses, but for new ones the more natural and adratutageous situation is, of course, at the north wall, not dhe north-edst as at present. At present alse these. from ton many ponts at view, uravely interlere with the magnificent view of the Alsey ancl palace, fig. Ht

But belore enterno norn dedals let us ask: What in common-sense is the best pulbe use that can now be made of thes old private sarden? I submit that thes should not be laticl out as a pleasure garden smply, for which its onthe and present chatracter do mot very well adelest it, thomels these diffoulties conld, ol comse, he gat over Bul, as we shall see, we can make at tar belter pleasure garden elsewhere; anel, in my view, this old one should stoll practically remann, and cren be called the "Iotird's Gatrelen." It should be permanenty used te show what any gool ordinary sarden, in our conclitions, maty reasonably be expected to produce. lts tuture, in fact, like its past, should le entirely determined from the homely pont of vew-using "homely," of courte. in its lull significance. And since the firth cent-

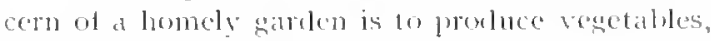
let us have kale, lecks, and all the rest, cach 1 its best varientes as well as its best culture. Thum the well-to-de villa resident who keeps a skilled gardener whl see what he mity tairly expect to gruw, whle con the smplest and pourest citzen who has a plot ol ground at all, and who has to use it (o make both ends meet, will see here the best vatrieties of vegetables and flowers, talie note 
of their lituels, and lity in luis pacliets ot seed, or buy his young plants from the nuseryman.

Most important and most instructive to act.

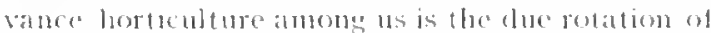
crops in the garden, and so at convendent points should hang the cropping plan of lles detterent phots ot the garden for thee or four years, so that the visitor may again in thes respect go home in structed, and aroid his common mistakes of grow ing the sitme crop seatson after season th the salme gromund, or of maling haplatarel or umbutable successions.

Another important lesson should also lo put up monthly or formingtly the diars of satrelen aperations for Duntermbine-so that we slumbl he shown, sed I have pleaded for the reenention ot the fune old

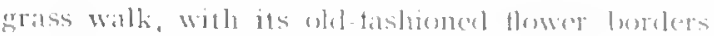
atal espaliers. by all menos lot us inprose the selecuon ot these, looth as regards tout a mol thowers. Inat let us keep theme on the main, erenthe small rock garden also. Which is new theromghly antaly-

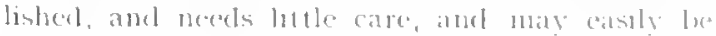

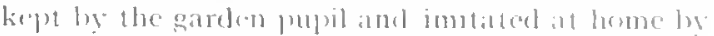
the intelligent anmatem

There in not rom lare for a great trume collection; lareace all the more calre shomld be given to the salestion of a small typucal orcharel

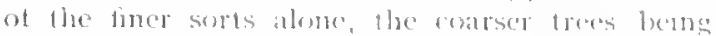

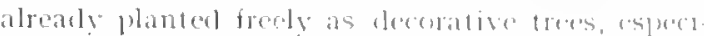
ally at the grebe and north-west she of lhe parlo

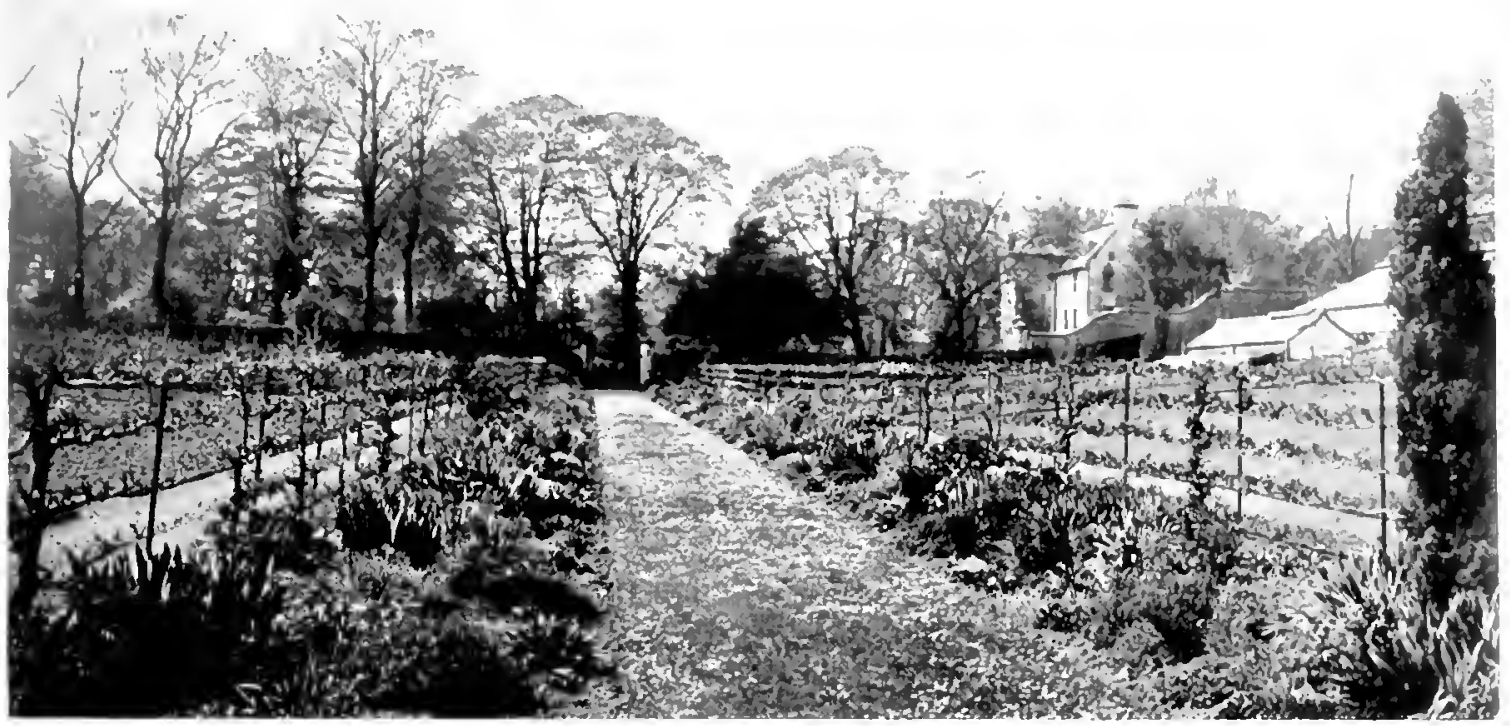

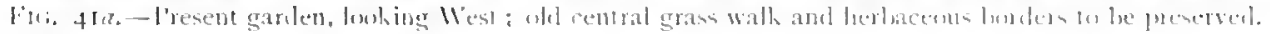

not only what in grow and how to grow it, but reminded when to sow, transplant, pme, ambl so on a no less important matter.

Here, then, our gartener would beomo a teaching lorticulturist: under arangements easily framed he would becomo a natural leater in tho regional horticultural socielies and the like, and, st course, be in ever-increasing touch with the schools. It might reatily become an honour and a pleasure to the best pupils in the schools to be allowed to assist him in particular operations, or even be gramted the responsblility of some particulir garden plot for the season. A selection of more advancel pupils would be admitted into the inmost and secret penetralia of the sartenes-his propagating houses at the back-and there, hehind the scenes, would be intiated into the finil secrets of preparation and stage management of the floral drama. The same principle, of course, holds good for flowers and truit. Hence at the very on-
At present it is right lo sily frout trees alre usually. discouraged in public parlis and sarclens, and curators are more prone to teats them up than to plant them; and red in face of this I plead for the reverse policy. Here, in tact, is one of those opportumities for Dunfermbine pronecrong, which is needed if we are to become the truterewing combry we might and should be; the simple remedy against bovish depredations being to in terpred these intelligently, as showing the need for more and more fruit planting still, wntil not only the towns and villages but the roidsules of sentland are as fruitulat athose of Germans

Igain, of course, the untortunate prejuclice against our own climate elisguises the face that the good scottish girdener is eserywhere producing results of which his countrymen rarely (lram. . III the more since the dimensions of the patk are not sufficient to atmil of any substantial departure in the matter of forestry. I press thatt here, in 


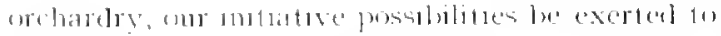
the full.

sime of the srommel will be neceled tor reserves

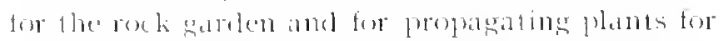

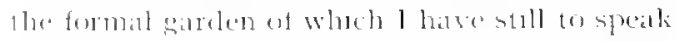

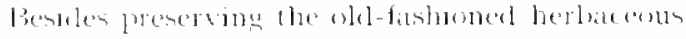

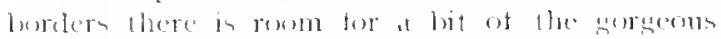

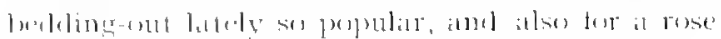

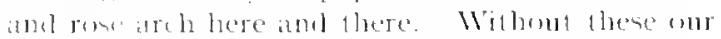

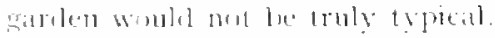

W flus pome, fox, a worl may les satel of the

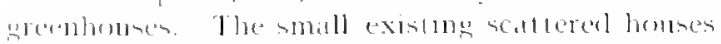

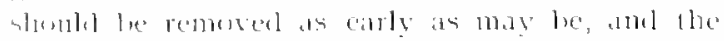

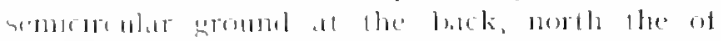

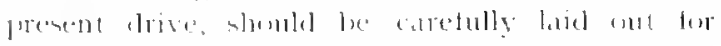

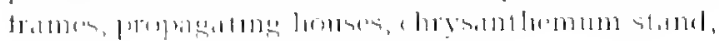
1.11

\section{B. Altered Drive}

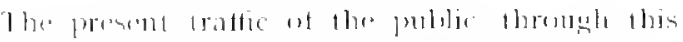

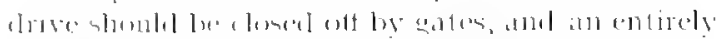

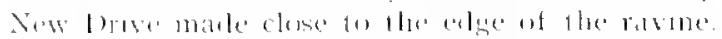

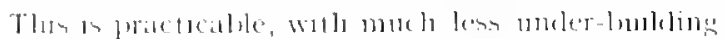

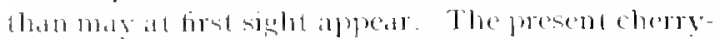

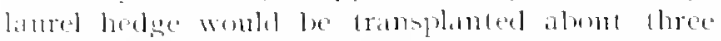

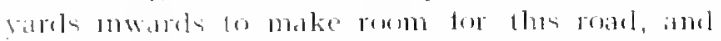
werling space therely so moch curtaled. The womld be practically compensited by the pracent

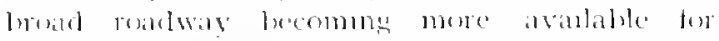
working purpones and also by a botter arrangement of sjace, which I denot plan here, the this will tall nalurally to the general superintemelent of the sorrlens, The gain to the lriwe by the sulb-

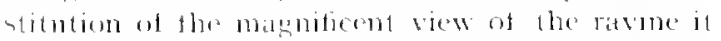
at present loses womkl alone more than rompen-

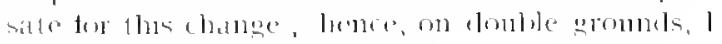
strongly ronmmend it

\section{Conservatories}

I nese combe to the eflestum of the conservat-

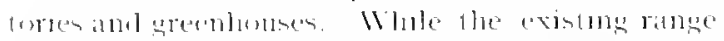

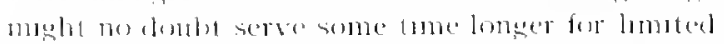

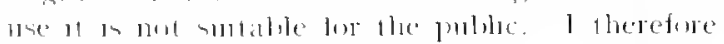

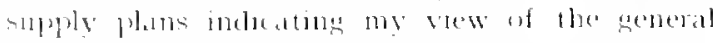

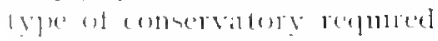

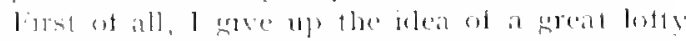

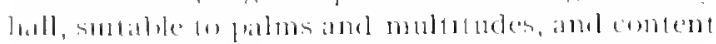
mbell whll smolling mose molest, yet more

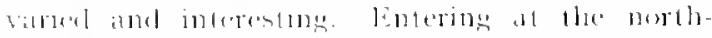

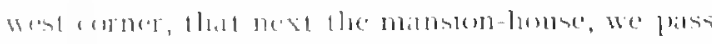

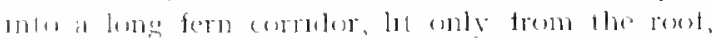

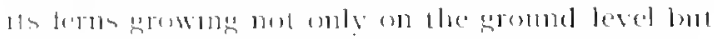

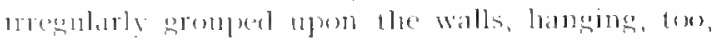

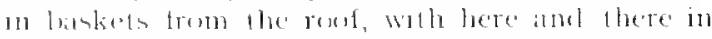

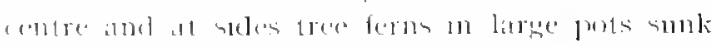

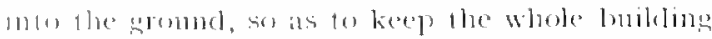
lus from a root walk abure thes, wheld comlel

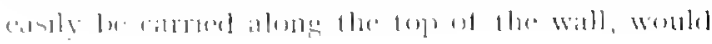

be obtancel that fines bew of the palate and

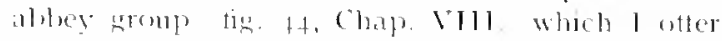
me place of the more fumbliar one, and alos smmbaly improsed views in other llarectums.

(1) this corrolor to the nerth, if a roum an lue spated from the working range and the lesthes lechind, I would comvert it inter a bimy ferm

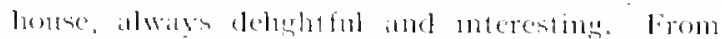

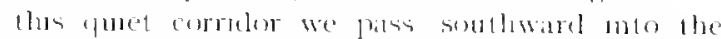

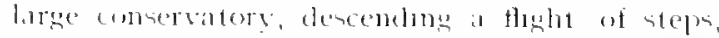

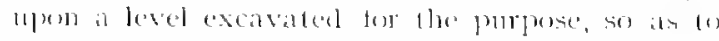

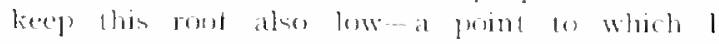

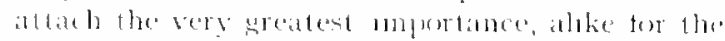

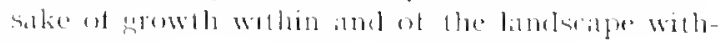
111

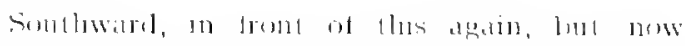

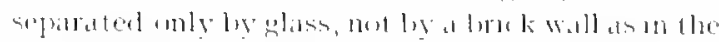

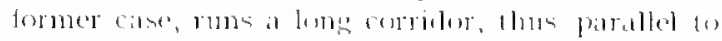

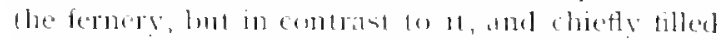
with the fince climbers of all serts. This triple range of houses- fernery, conservilury, and cor-

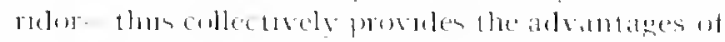
at winter soldele, being excellently sumblble for is premenate, even for attermon meptents, or with electro lowh tor evening entertamments firom

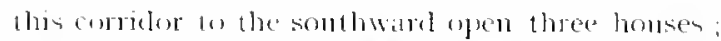
sty a masellaneous homse in the midalle with a steculent home and orchicl homse on ellher hamel. If fubde allow, a "Victoria regle Honse" womld be

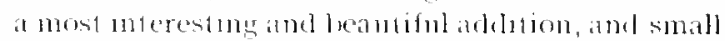
collectons of aseful plants, insecturorous plants, ete. monld be easily provided. These three may again le comnected fy transerse passages. These are not shown on devation, as on the whole 1 think the very shellered space enclosed ly these

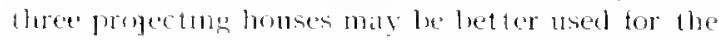
growing of delicate plants, otherwise defficuld 10 cultivate om of loors. Examples of the success

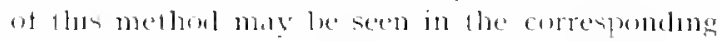

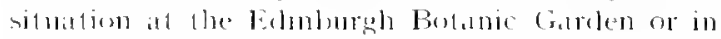
the seatedy more farentable clmate of that of Cimbritge, In sim, then, omr range of houses combunes the escental atvantanes of course, mon a smoll scate-ot the winter sarden of a ereat cily park with the sreater beanly and vanety of botanic simben lonses.

1 need not speak further of the plant arrangement of thin comservatory, a maller of more letall than need bo entered inter here: trut neither proded examples nor fresh ideas are lacking. *

lexpe now this comservillory and look at it

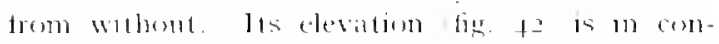
ventional style, and whlle 1 stand by as interior

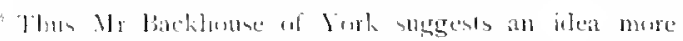

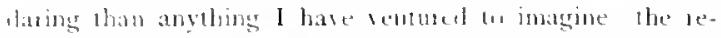

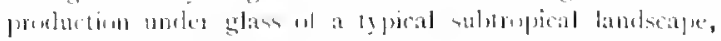

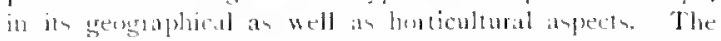

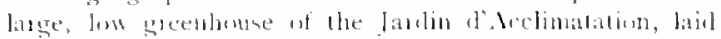

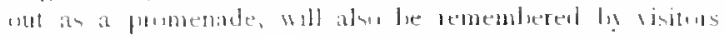
1+1 lativ. 


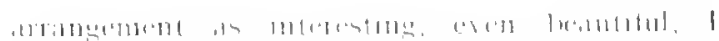

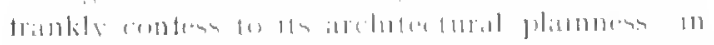

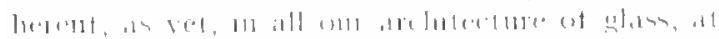

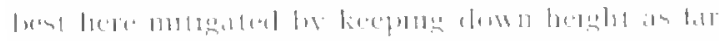

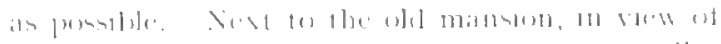

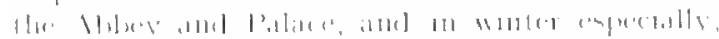

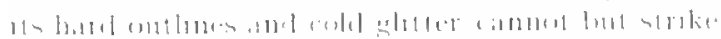

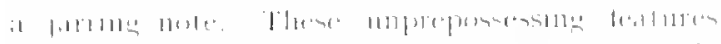

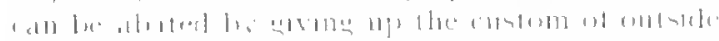

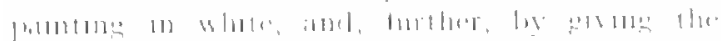

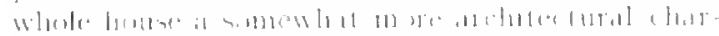

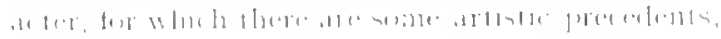

\section{South Promenade on High Terrace}

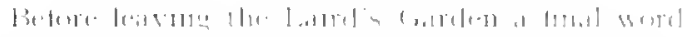

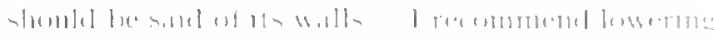

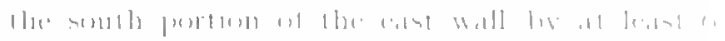

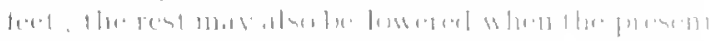

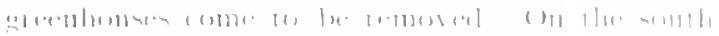

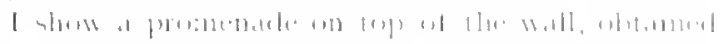

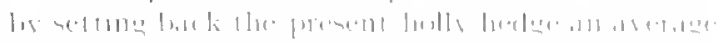

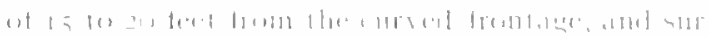

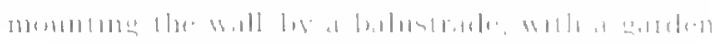

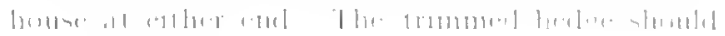

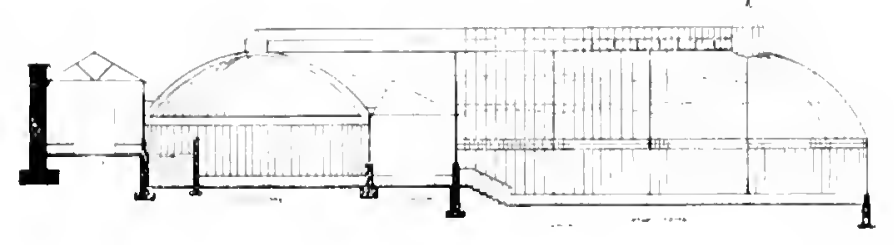

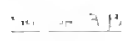

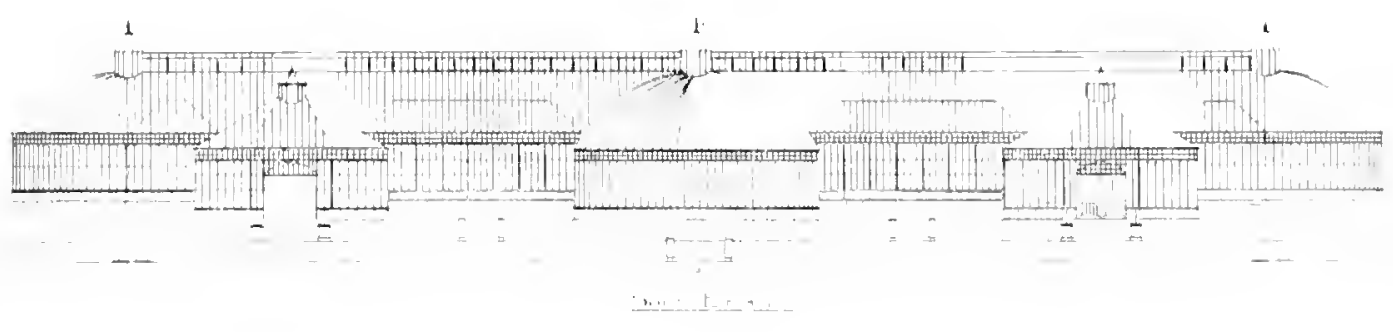

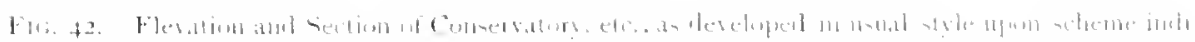

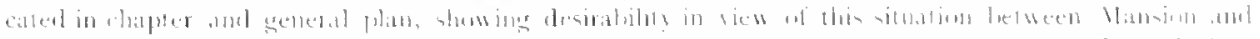

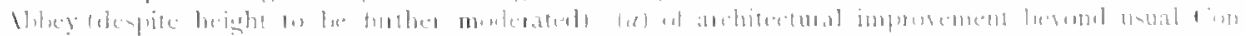

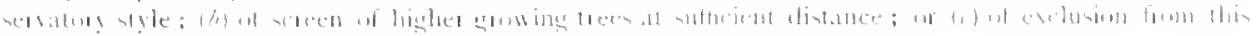

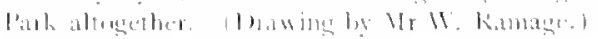

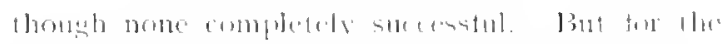

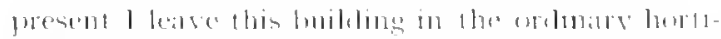

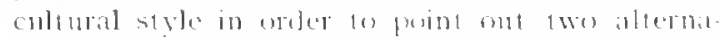

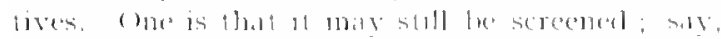

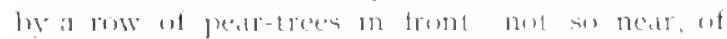

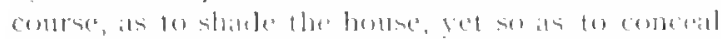

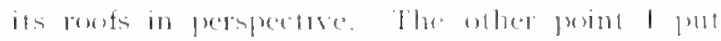

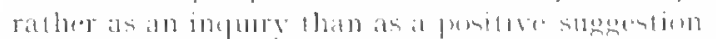

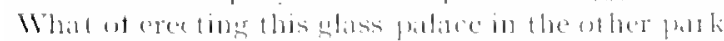

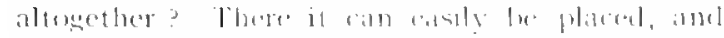

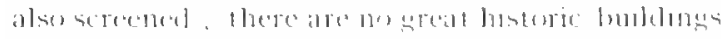

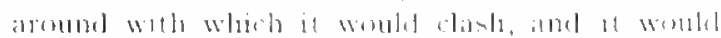

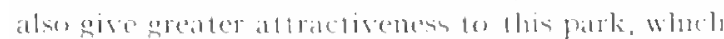

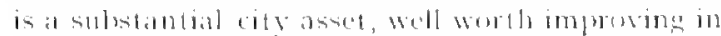
its tarn. In any case there should still be al smatl

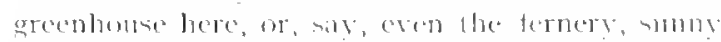

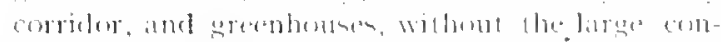

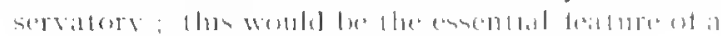

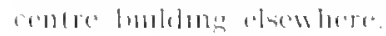

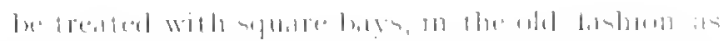

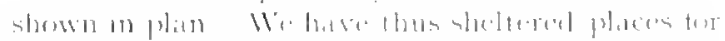

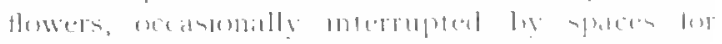

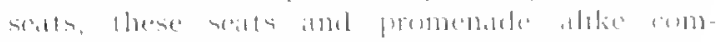

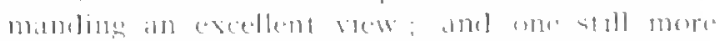

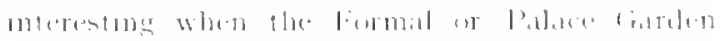

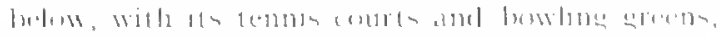

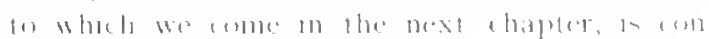

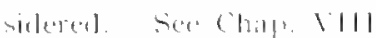

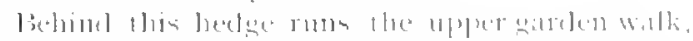

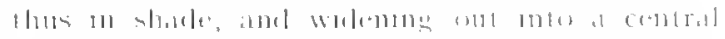

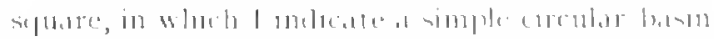

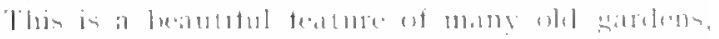

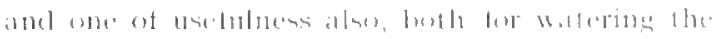

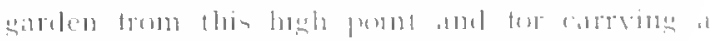

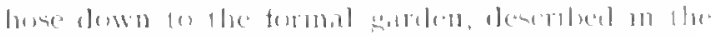

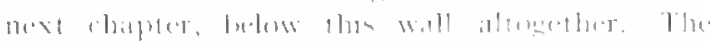

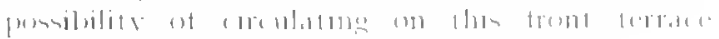

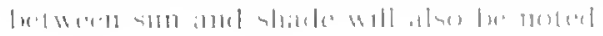


Below thes promenade and npon the wall helow

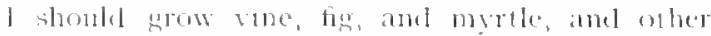

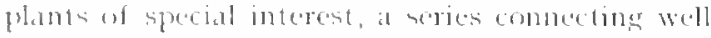
with the formal getralen alsis. This woulel be a little Medoteramean terrace marten, tor with a

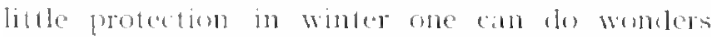
upur such is well-summel and well-shelterenl wall

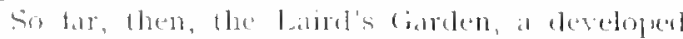

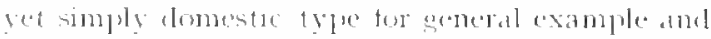
tor horticulture.

\section{E. School Gardens}

The relation of the garclen to the schomls will noturally langely depenel on the horticuldurist m charge of thes tepartment, and 1 wonlel submit that the reguarment slould be taken fully ande acount in algusting the staft. Few gardenerscan

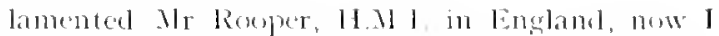
trust being continued ly the many cultivatome of the Nature stuly monement, as notably by Mr I. C. Meld and others, elucatomal opinion thes ineen on some extent awakened, lout for practioal purposes we maty see the morement even mow landy lement

I have lately lenen privileged a prepare for the

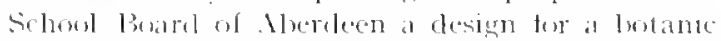
garden on a larger scale than customary. This is tor the we of the llish sichond, where botanical and horticultural teaching has long leen ably

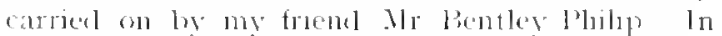
progress also I maty mention a birger garten for the London comme Council, thes as situated at the flomiman Xusemo, and is spectally intended

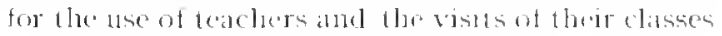
sher examples might les given

In this matter os Sclurol

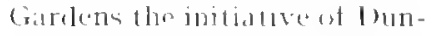
fermbine is an ollel story: witness the ohl anel charming flewer loreler of the llospinal llill schose, the lwanic sarren of the Techomeal sichool, and the sumall sarden laid out in connection witls severill ot the newer schools. In this renpere, however, there is stoll much to lex done, and at ble presont periol of educatonal transition a further acture milidtre wonld the of peculiar value. Fspecially is it not realined how much more has beren dome in foreign commories than at home.

bere I canmot do beller than cote trom a recent American pamplilet.*

The Austrian pullic sehoul baw realels: "In evers.

teach and few leachers can warden: the problem bere is to find a man or wesman whe can do lestle

With this gearden shomld be, of comrse, relatid the sebond gardens, nuw in the near fotmes and of which l sulmut ond of combless allernatives plitus fis ti as a type attractive fo beginmers

In our own country the school warlen movement is still in its infancy. (O) the fotal number at seluol parelens in the British Istande l hate no

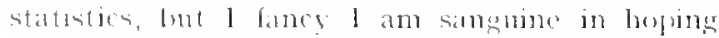
that there may he by this time as many tens as on fromer there are thousands. The whole matter is as yet in a phase of sporalic mitiative: thus for many reats I have recasionally found a scherelgowerning borly or a poneering teacher willins to

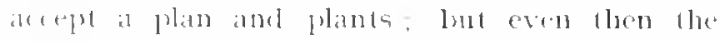

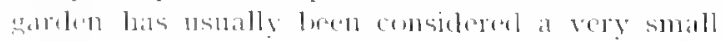
mol secomblary attar, in no wise taken ipe will the theroughness we have seen on the Continent. lispectally throsgh the exertions of the late sclund a grmmastic sroumu, a garden for the tealuer accorling to the enommitances of the community, and a flace tor the purposes of agricultural experiment are lo be ereated. School inspectors must see fo it that in commters schools selowel gardems shatl be provided for corresponding agriculumal instruction in all that relates to the soil, and that the teacher shatl make himselt skilful in such instrucum. Instruction m natural lustory is indropensible to suitalily entablished schom gardens. The teachers, then, most he in a comblition to conduct liem."

"len fears aso Iustria hat eight thousand school gardens. France has mu more than thirty thousand of these schools. Nearly all of them betomg (o) the primary and elementary grales. Inderel, in liance a man who lacks a necessaty knowledse of horticulture and the aluluty 10 teach * I. V. Cinde. "The Ilos of Improvemene Wirk."

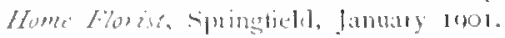


it amot recere an alpuntument at master of an elementary school moler any consideration. siweden srafted the selsool getrelen upun her pullie

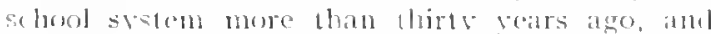
cich of her public schools has lieent allotted from

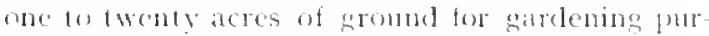
poses. Russia has taken "ly the school getrelen work witle enerery. In löog the two hundred and twentr-seven garden sehools of une proxince cum. tained one hundred and eleven thomeand fruit trees, and nearly two hundred and fitty thousand forest trees The schond garden itear ariginated in Cermany-lle nation to which the worlel is indebted for lhis and mant oher arlsanced educational ideas. In the city scloests the pardens are confined to lotanical and decorative thwers. In the country schools and gardens rival the agricultural collexes in the scope of their work. In large cities, where land is very valuatsle, it is usual to have a large contral schosil sirten ontside the citr, which supplements the small garten about eath scholhouse. This rarten supplies the schoul with all the thowers neexled for stucly. I recitation hall is luilt in this garden, to which the teachers and their pupils come ene week. the worle is comfined to the hidn scluol grades. During sturly hours silence and order are mainfained as in other classwork. I'upils are recpuned to take notes, wite essass, etc., and receire diplomas at the enduclusion of their crurse."

from a very concrete statement of the case for school gardens-accompanied also ly an excellent bibliograply of recent American literature of this subject - which 1 have just received from a valued correspondent, Mr Warren 11. Maming, Secretary af the Anerican lark and ()uldror Mt Association, I camol retrain trom citing a lew pussases

"The school garden movement will lead, as it has in cermany, to a much more practical educaltion than that now in rogue. It is the kind of education that has more to do with the evervidy life of a majority of the students than that of a more academic character previously in rogue. it is the kink of education snpplemented, as it is being and will be, by industrial trainug alons other lines that will make students producers almost immediately on their graduation from the jublic school, instead of compelling them to drift abont in great inclecision for a mumber of vears, until they finully find an opening, or of leading them into clerical positions or professions tor which they are not fitted, and from which they can have little opportunity to beome really progresive or valuable citizens.

"This work has dereloped into a trpe ot schont gindens hatring two distinet purposes in view One is that of making the grounds more attractive by the use of hardy sines, shruls, and trees fromed about the base of bublines and aramst fences in positions where they would shut out mattractive views and screen undosirable structures.

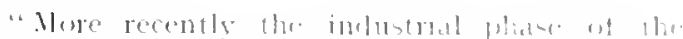

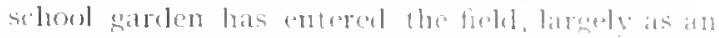

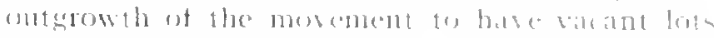

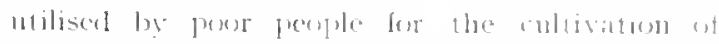

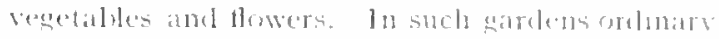

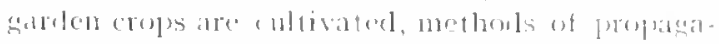
tion are tanglat, some attemion is given to interel

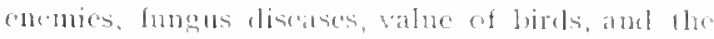
like The most inferesting recent derelopment in

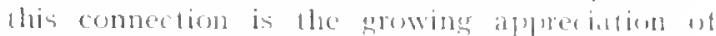
those who are responsulde for the rarre ot on

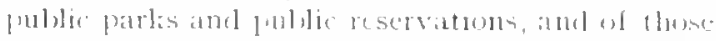
who are restonsilde for the chluational syatems ot communities, of the improtence of it clemer an. uperation hetween these two interests. Blrealy in l'itsing extensive areenhouses have beent crected in connertion wath schenley lark, in which childien of the publir school are given an opportunity to study the growth and development of plans under diess, firthermore, they are encomriged 10 ta'ie alsiantage of the park as as place for matme sturly."

These citation might easly be muthplied aml cmiched he refernce, for instance, 10 . Arbor low. in frut-inlure, 10 wndow-gardenine, for-keotmis. and so on, as also to popular instruction in lanclseape gatrlening They might be supplementer also by evidence ot the moral and social results of suldens upon their cullwators; and this, asin, he comcete evilence su h as that of their reforming eflet upon the active hooliganism, and the even more deally lobting habits, ot town lite, aczinut which our current schoul education an do so litlle, for which, indeed, it so largely lisposes, il not actually prejares.

(1) my own plan herewth figr ty only a word need be said, that it is intended mot at all wa a typical sehool garden but as a Trial caren, in which chilsen mint have tins indivilual gatdens allotted to them for culture, as well as some general tratuing in dealing with breger beds, and in which a plasing ereen, available for cropuet, lawn tennis, ete, is alst supplied. From thas trial gatrelen it would be a distinetron to be dratted oott In the schuol fimlens proper, or, hest ot all, tor the hishest instruction and responsibility at the Laind's Garten and oller gardens of the l'ark. For a large development of rardening then, this Trial Garden would lu not only the best argument. lut the means of at once preparing the children and their parents, the pullic and the anthorities. for a vigorous adoption of Continental and Anerycall caimple in this matter. Nor does the intlu"nece of snch gardens end with schuol life. It will be the child who has passed a due proportion of hajpy and busy honrs in its tim garden lure whe will want a house in a ciasten city later, or who at any rate will be ready for that provismon of allotment gardens in the sulurls, which might here so easily be provided for lhose whose homes may still be in town. In every wa. therefore. the proposed plan is largels one for sowings. 


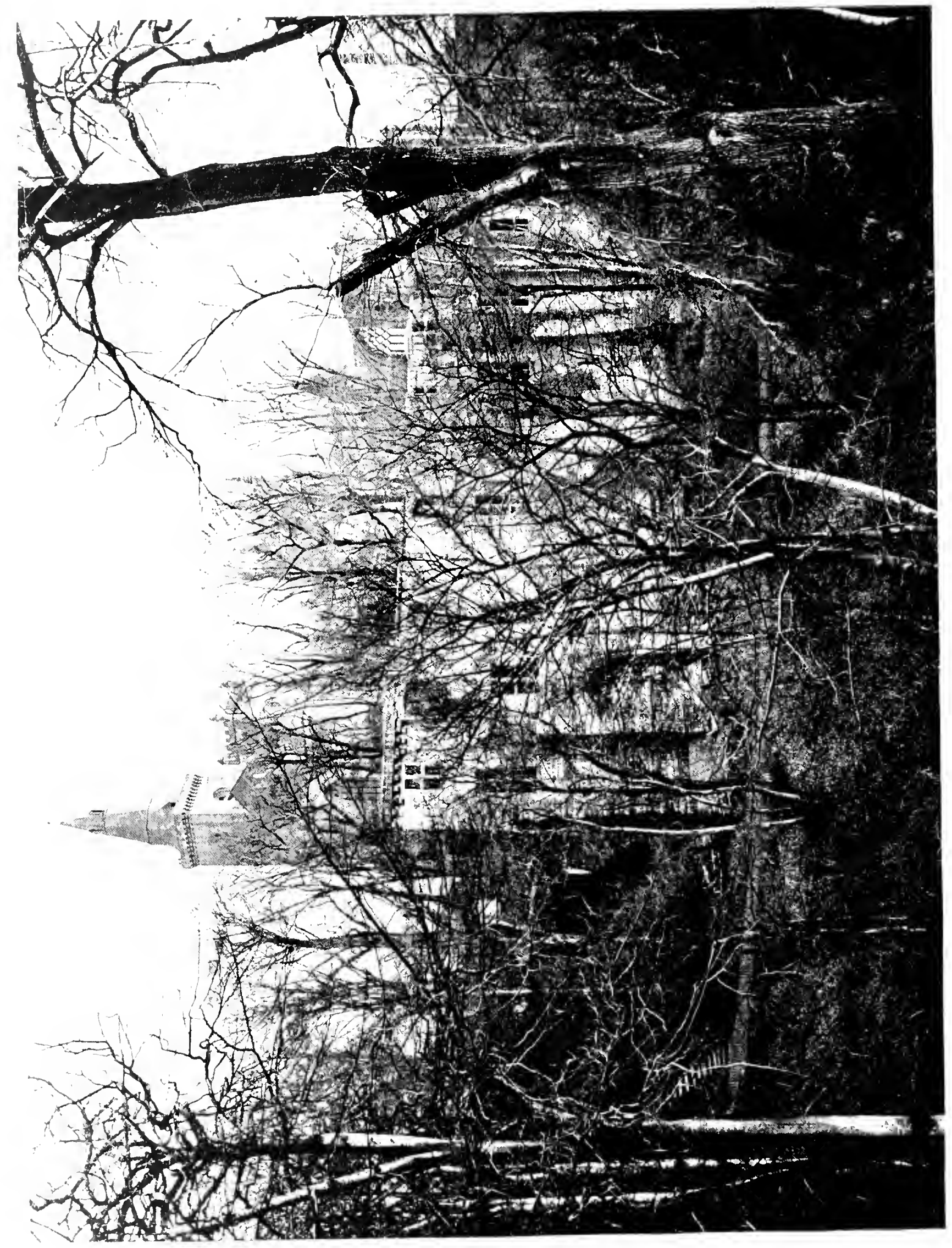




\section{・H.MPIK III}

\section{THE PALACE GARDEN}

\section{A. Formal Gardens}

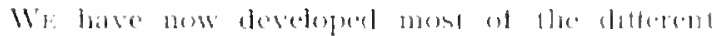

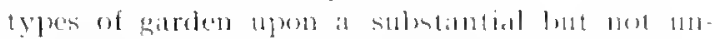

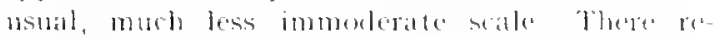

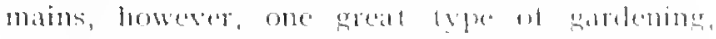
inclecel in mot a tew ways the erreattent at all the

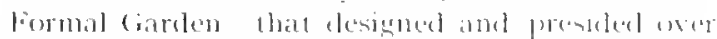

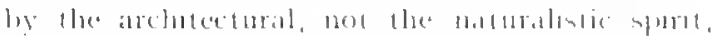
by urban art instead of be nature, nthlys, or

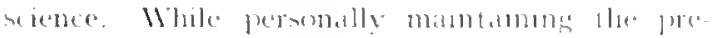

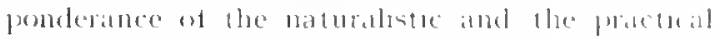
points of vere I must recognise that the diams

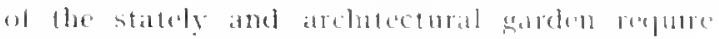
also to be reasomably consulered, "sale trankly

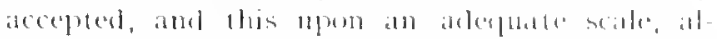

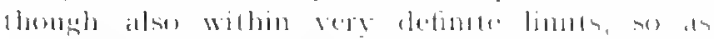

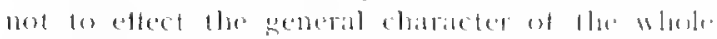

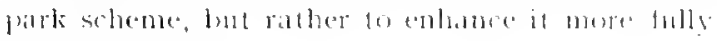
be its contrast

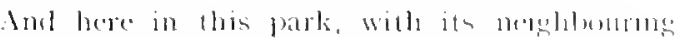
historic palace of the lienatissance, ats well at ats

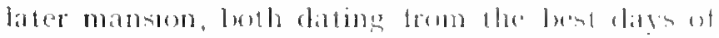

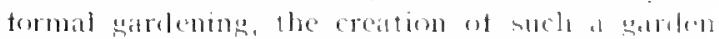

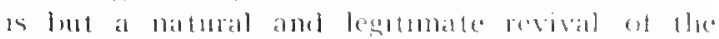

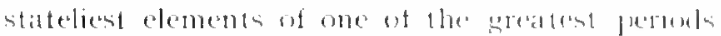
of art. That this has once and ingen flomomed in Serotianel masnificent examples lake thome of

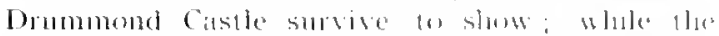

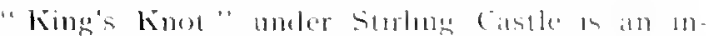

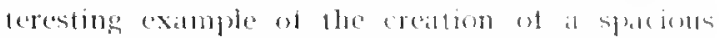

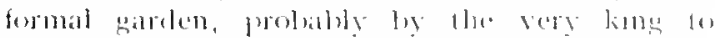
whom the present taçade on the patale is dawe

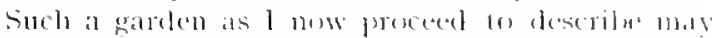

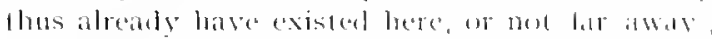

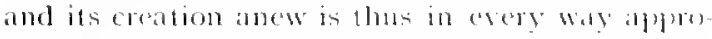
priate to the surroumdengs. Is due indication of the dignity and heably ot these, and comberguently of the ive of sarden refuired, I lare msert

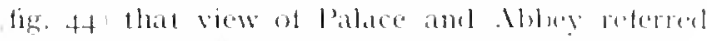
to in the precethe chapter

What are the elements of steh a l'alded dimelent?

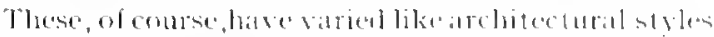

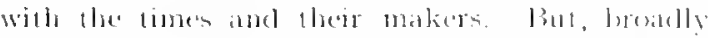
speaking, we recesnise in 1 hem all the matsmitecence

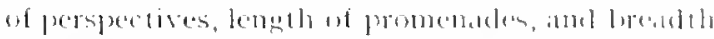
of bevelled lawns, well-trimmed atmel monumental

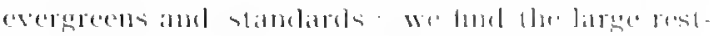
tal shaces of lawn comtranted wath amplexly07

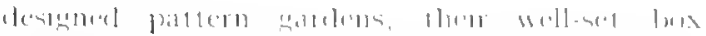

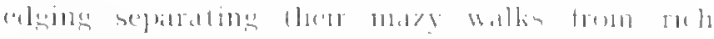

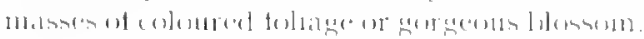

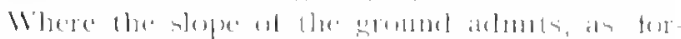

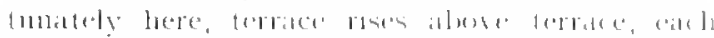

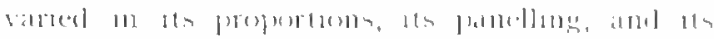

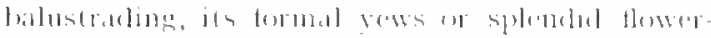

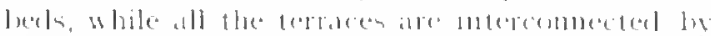

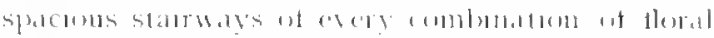
alornment ujon architedural design.

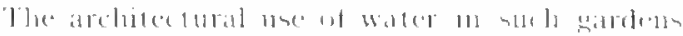

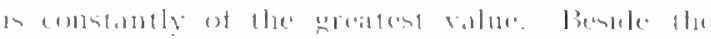

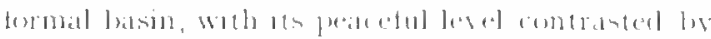

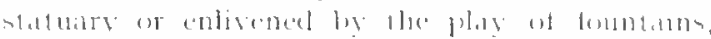

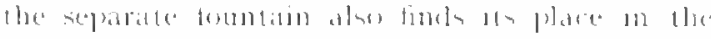

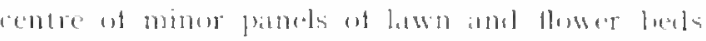

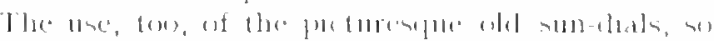

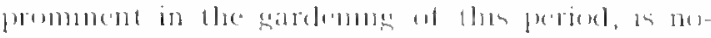

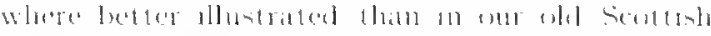

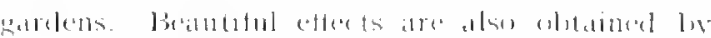

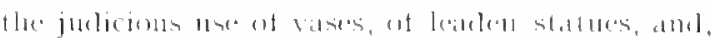

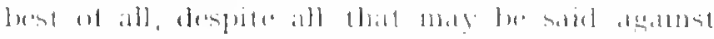

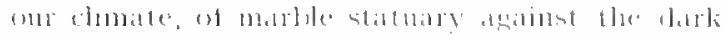

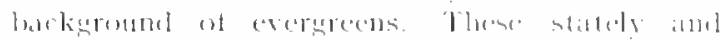

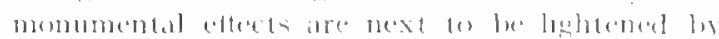

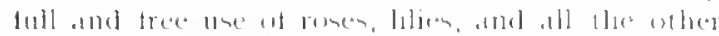

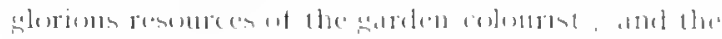

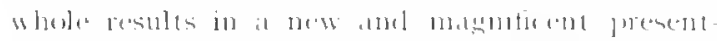

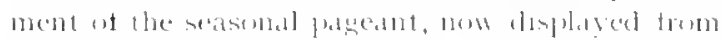

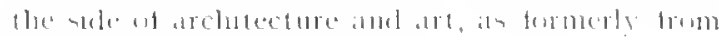

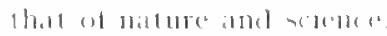

\section{B. Tennis Courts and Bowling Green}

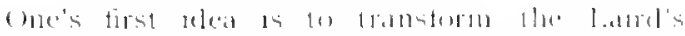

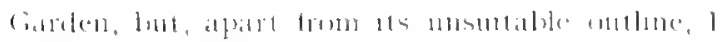

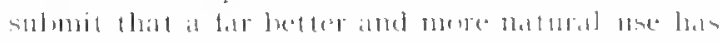

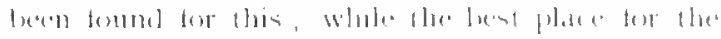

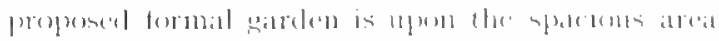

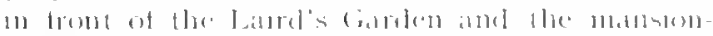

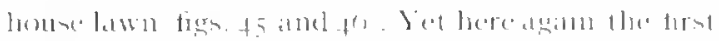

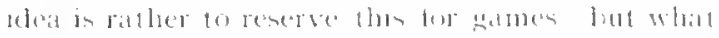

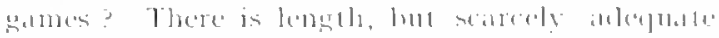

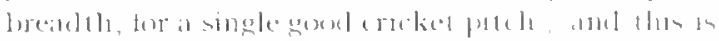

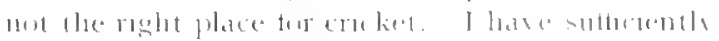

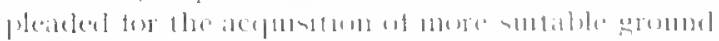

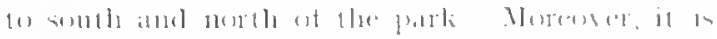

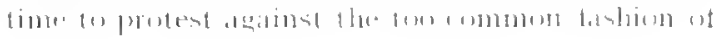


lanmg out parks for hoys' and men's games al we Ilence, just as I have proposed reserving the nou w east corner ot the park for childen and okl tolks 1 submet the level space shombl primarily be understond as the ldavgromen of the older girls and roung women of the fewn and reserved for such games als they can fully take part in. These wames, then, are primarly tenus and crofued, to wheh we maty adrl buwls; and the laying-nut of this linge space with temus courts and lowlung greens is thus, it seems to me, the most practical and unetul purpose to which it can lo applied but temns courts ate not in themselves sutficiently lxamtitul to sitisty the eye, and to plot down surle conrts in the ordmary way would be to sumil
Horeover here, as at so many other points, we may thus reconcle the claims of wealth and art. of traditon and culture, with those uf simple popular pleasure, and even play. ()ur latace Garden is thes fully at l'exple's Garelen also.

\section{Design in Detail (see General Plan)}

Hence, then, the present plan is a conbunation of both requrements and principles just mentioned. Referring to the plan, $1 t$ will be seen that this shows one full-sized grass bowling green anel two tair-sized temis comts, which had better be asli-lotlomed for all weatlers; tour small grass

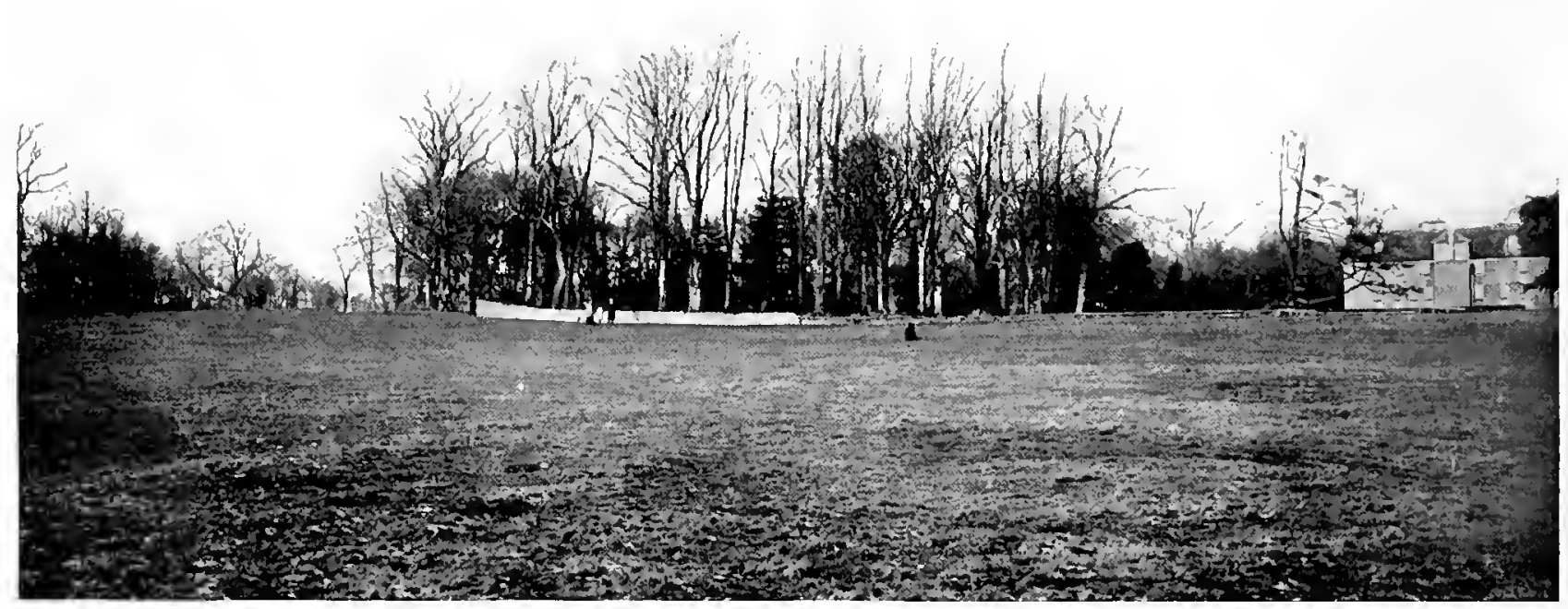

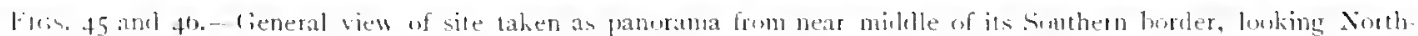

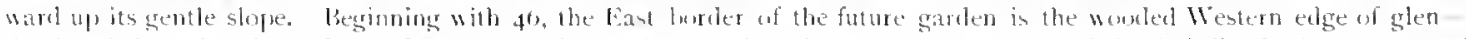

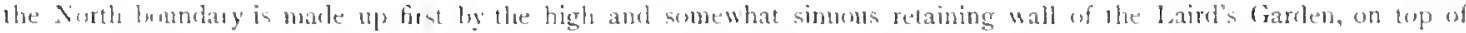

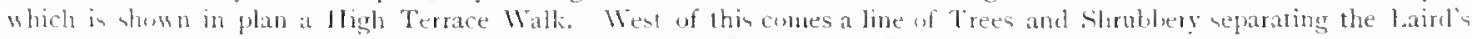

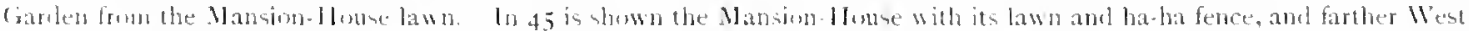

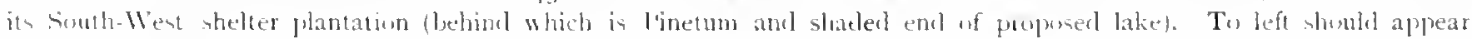
the main entrance drive, mited from those of all three emrances to Nonth. Last, and West. (See Genernl llan for derign of propused fiamal Girilen.)

the most complicumus point of the whole park, a real waste of the beatuty uf this splendid public property

Shall we, then, give this up, and return to the omdinary tomal garden of promenales alone, as at Drummond Castle, giving up games altogetler ? Not so: the diffoulty is an oplowetunity; we may "xclurle neither, but combine them hoth. J.et us have our tennis courts anel hewling preens but arrange lheir necessarily straiglit paths with flower borders and the like. Thus we have our formal equrden also, and that of the hest type, in which that fere sreat rispersion of interest, the too claborate deval which is the defeet at Prummond castle 1 s

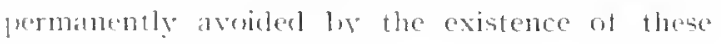
uscful ogen spaces. lawns for tennis or croqued, and three small oxals, one larger and two smaller, all large enough for children, making ten play spaces in all.

To all these the formal garden gives a centre with its basin and fountains, a frame for them also whll its leelges and lawn borelers, its terraces and standarl yews, its four small fomtaned and boxelged panel gardens. Of these, the wo larger are to westward, the two smaller to eastward, of the basin: while a long flower borker completes its soullem foot.

Anng the whule suthern front runs a loner wall, with central circular foul and tomtain or statue, while mun tountains, or possibly small garden lumses with view platforms on topl, some what in the model of a city eross, occupy the centre of the 


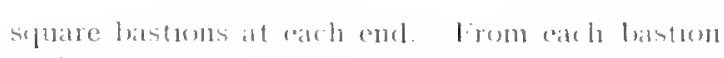
projects a rombled baleony seat. East and west rume a walle fowatels the semicorember emels of the gardent de cast and west. On the lomger eastward hall of this path preject two other semuedreles. agam with sats, one with a central dial, the

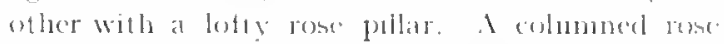
perendia here ofters beanty and shate

The precliminary contous sursey shows a latge of about 20 fort on this whole with of getrelens. bence two g-feet ferraces are slown upon the moth sicle next the hatha and garden wall, thus leaving other 10 fect, of which o woulel be accounted for by lle southward terrace wall, leaving + tor a terrace farther down on the other side of the bung

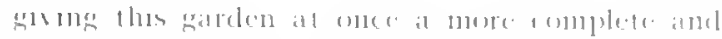

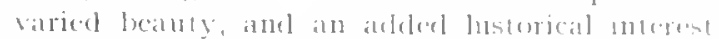

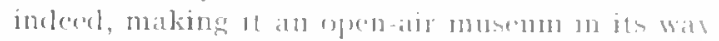

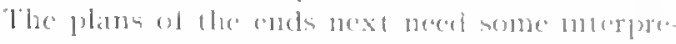

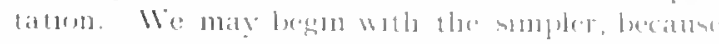
less livomably sunued, western une, Ifere the path romenger roumel the sefuate and oval lawn

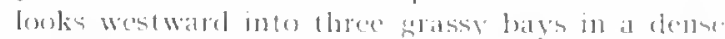

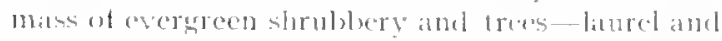

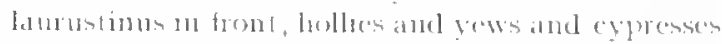
bebme. The plan of the two smatler batys shows at perlestal for a lumt or small leaten statue. In the latrecentral bay a latger statue and pedestat is tanked by a fleswer bed on either side, and hals a small thower berl in fromt alsos.

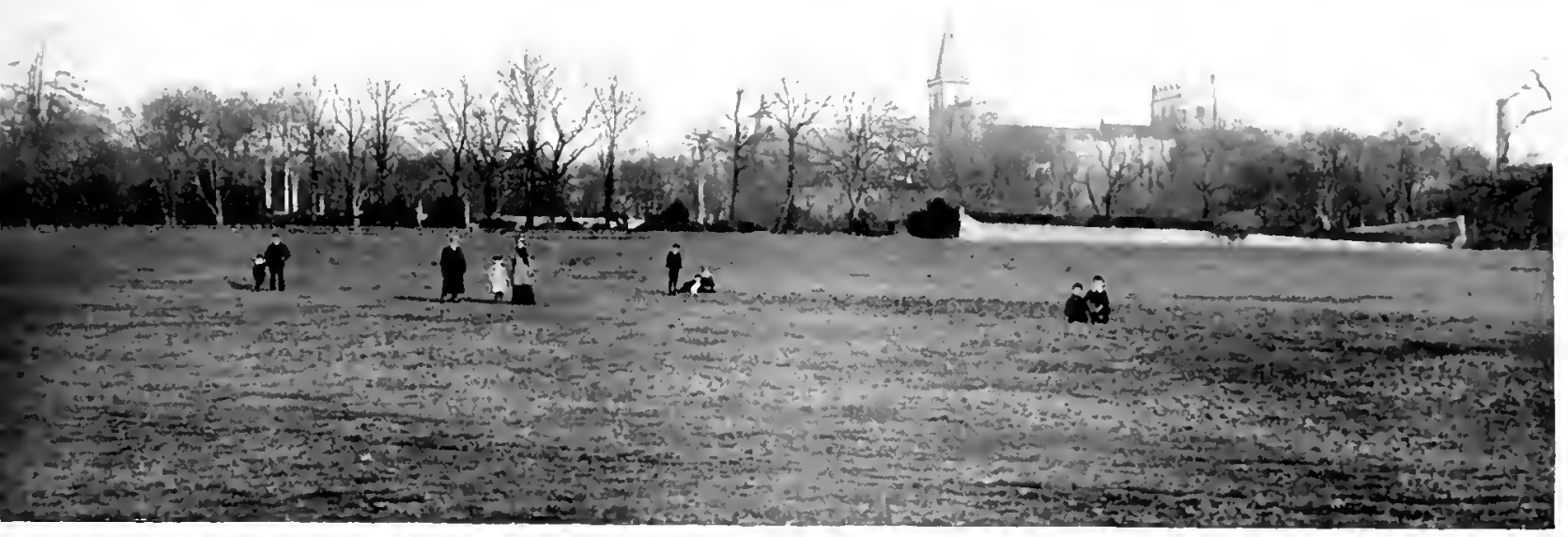

elliptical drive, which now encircles the whole. This will be useful also als casily furnishing a halfmile running track-while on either side of this drive also races 11$]$ ] to zox yardi can be watched by a fair number of spectators, though of course athletic "events" would not le admissible here.

Different methrels of treating the long horrers are indicated in different parts of the plan, cillees with regulal few's, rows of thower heds, or the like, or largely lett racant an grass. Short and gentle stairwalys lead lown into the lawns, since these are slightly sunken, d method loth beatutitul in itself and sheltering to the players, tor to this depression we must ad the height of the hedges above

In the detailed treatment of these borders, and of the other ditferent units, an attempt would $x_{x}$ made to express the characteristic merits and effects of the ditferent styes of formal gardening from the Roman, so plainly indicated in P'omperi. as well as clearly described ly classic authors, through their varions renaissance developmentsltalian, Fench, Dutch, English, and Scottish- latsing now to the east end a smilar prunciple is carried out, but on a latrees scalc, with tive semicircular bays onertonking a sunk wal hwn, woth small triangular flower locks alt its extremities. Of the five bays three latre here statues. now of marble, with an arrangement of flowers besicle and in tromt of the pedestals, as at the other end: while the two minor bats may have busts or rases. From lhe derep crergreen mass, at this end some fo lect at its thickest, should rise large irresular erroupes of cypresses, so in a lew years beginning to probluce one of the sreat ettects ol ltalian gardens, and leading back the eyo gratually to the high trees of the decep ghen immediately behind. It will he noted that the main drives on both sides of this garden wnite lere in the wood, and thence rum wh towards the back ot l'itrenerteft llouse or down to the hottom of the park. This again aftords an arrecalble yet not violent contrast hetween the naturalistic and the formal styles; the two are so arratned that they cannot come simultancusly into view at any pront. In the sime waly at the west side the 

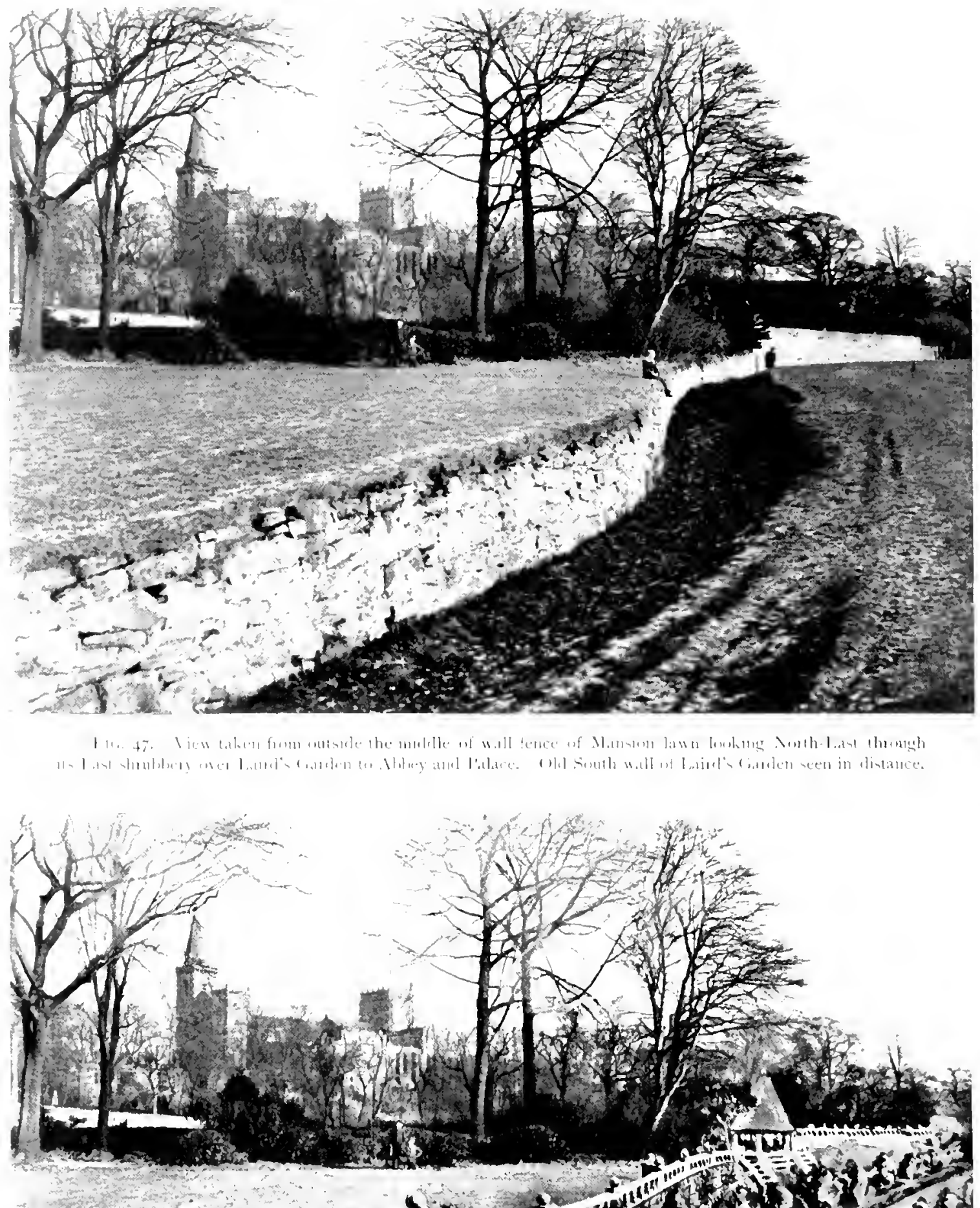

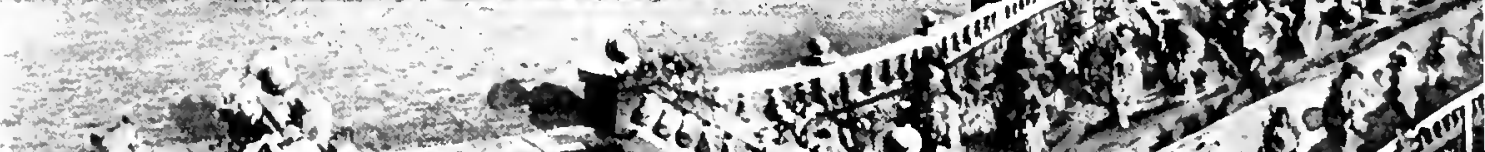

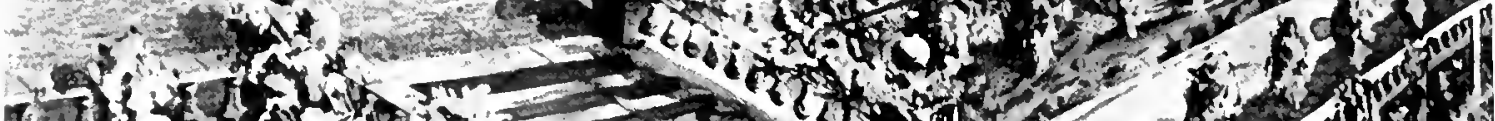

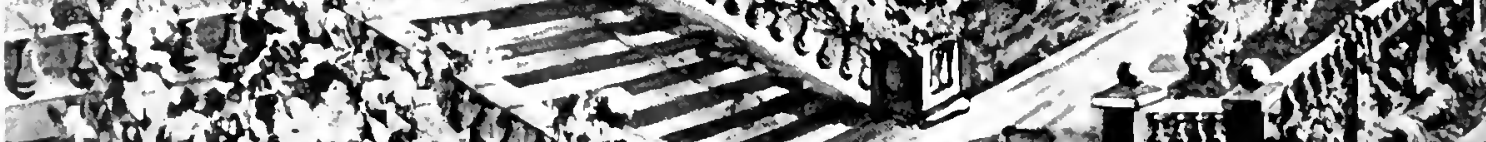

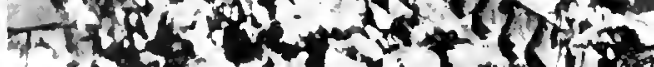
T 4 (

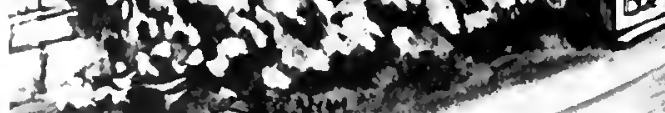




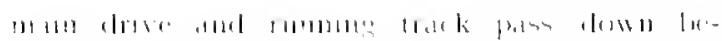

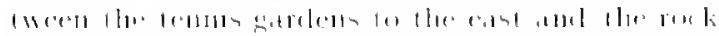

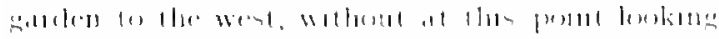

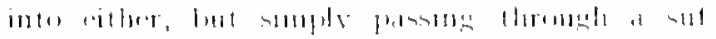

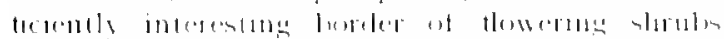

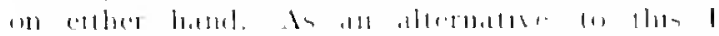

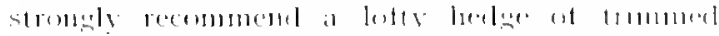

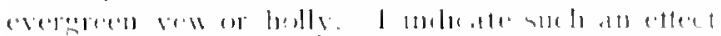

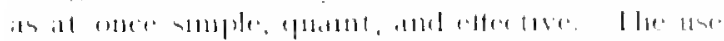

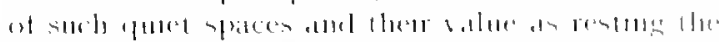

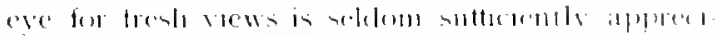

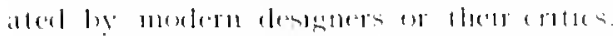

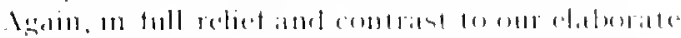

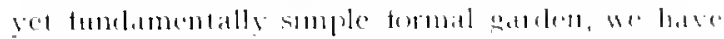

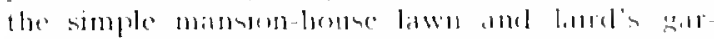

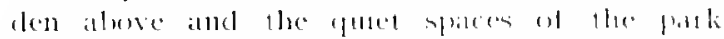

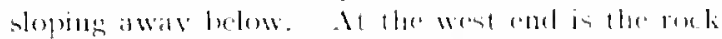

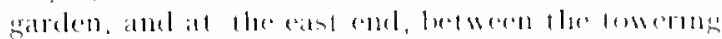

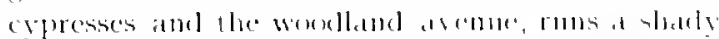

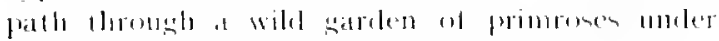

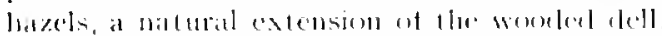

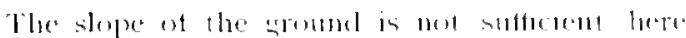

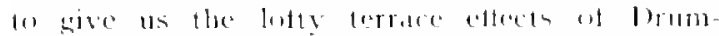

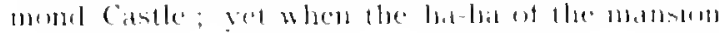

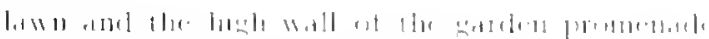

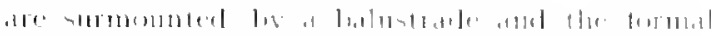

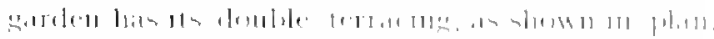

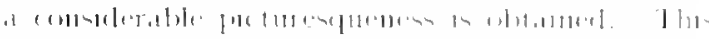

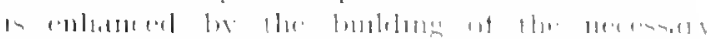

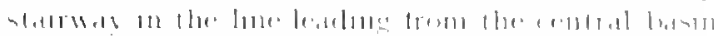

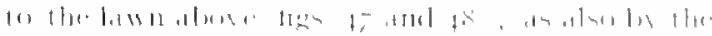

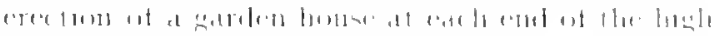

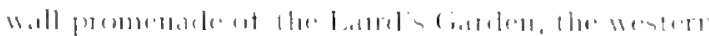

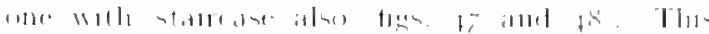

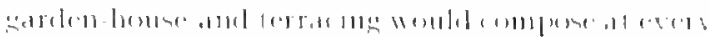

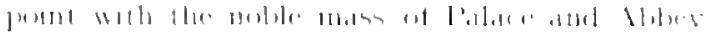

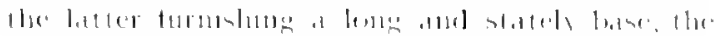

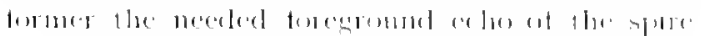

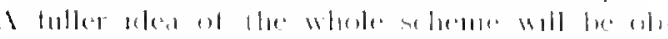

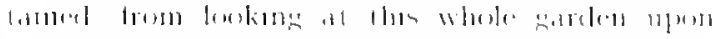

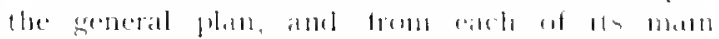

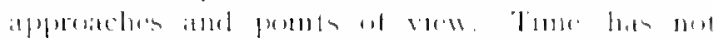

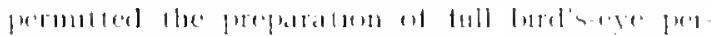

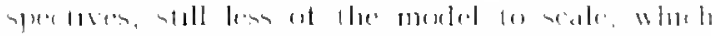

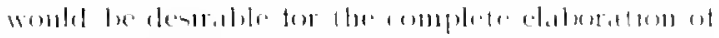

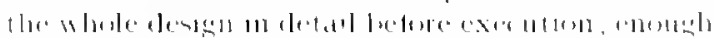

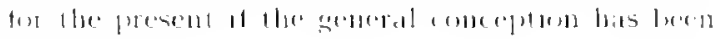
mate cleatr. 


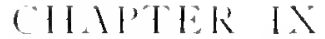

\section{WILD GARDEN AND BOTANIC GARDEN}

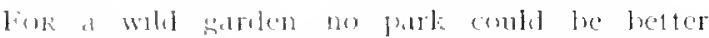
adelpted. The ghen and the plantation borders awat us, and attord the opportunity of working ont this teature mon me orelinary scale of perfectom, al any rate so far as lhe more slate-foring spectes are concermer.

but what of the sun-konng toms? (I) these the fince thoral sorts are provedol for lin the thower sardens at difterent punts, nutably the tulips and hracuthe of sprong, the roses, hlies, and carbetions of summer, and the chrsanthemums of antumn Water-horingspedes haveample brome an the exten-

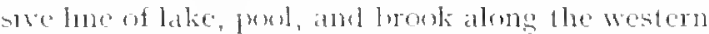

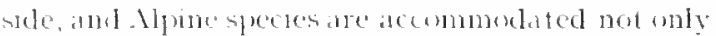
in the large rek sarden fout will find admirate

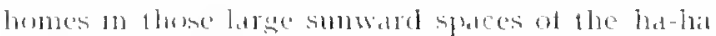

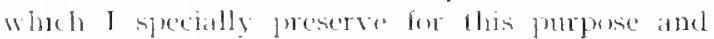
propuse for atorn in this waty. Ilere the reater

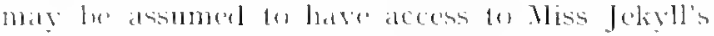
heallitul rolume of "Wall aml Witler Crablens,' which disperses noe trom a more detaled expositjon of the possibilutes of this sufject

minteacl, theretore, at eilluer preserving or destrosung the existme hathat as a whole. I have male each punt of its circumberence the subject of careful study, and its preservation at some ponts, as removal at onthers, will thus become

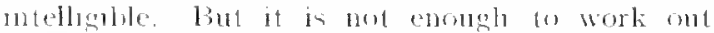
with the gardeners the approptate stykes, the stes of shade and sun, nor even to work out whth Miss fekyll or the painters the appropriate seasonal eftects. for as red, in all this garden, the

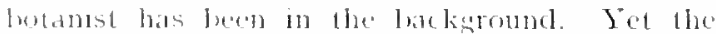
problems of lavne onl a bulanc gardon have been.

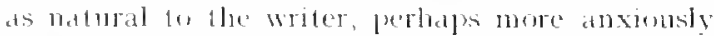
constered than any other prortion of the scheme. lor the repurements of the lutamist are nou situstied by the mere latrellons of species, nor even by deposing them sn some measure in their

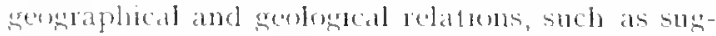

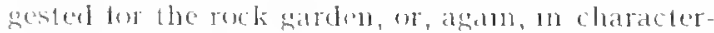
iste grenps such as the Meditcranean plants pror-

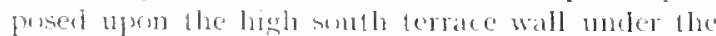
laird's Garden. Ilemust havelus plantsaranged wh their natural orders. Tomany the at once stugests laping ant memolenums tomal lines of beds suchas meet the ristor tothe great botanic gardens, If not a merecat's grateyareflect of epitaph labels.

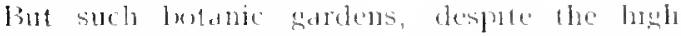
athornties whe arrange and mantain them, are really survivals of tradtion rather than the last word at selence. For they are pre-codutionaty

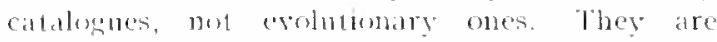
avowedly made from books, notably " Bentham and llooker," not the broks from them. That therr so-called natural system is pre-erohntonary Is evidencel by their gennetrical arrangenent, so that this freer one would le tar more truly sciontitic

In this way I lo not hestate (o) say that the small folduc garden arranged ly ny famented fremel and astistant . Mr lowert smolh, in frome of the lechnical scherel, as superior to most of the

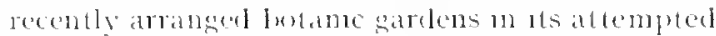
presentment of the athmites of the natmeat orders. And since thes sarten is tound sufficient for the refurements of elementary teaching, and sonce, moremere the bonhurgh and Glasgow collectons are st atcessible on advanced students, there is somedhing fo le satid for gromg no further, es pectally as mo portun of the farte remains which

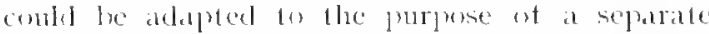
lotanic garden whthut injury to what-botanist

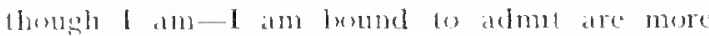
neneral noeds.

Is at sor mony ether points, the dificulty here

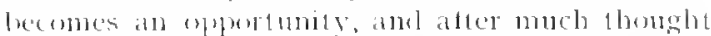
l renture to think that I have sebred the protslem. fior, instead of as specific butante gedrten at one spol. the whole place is a botanic sarden; and the mot me gedy of that simpler, freer arowng type which preceled the hard and hnear arangement at present prefommant, Lut alse in its rery treedom more colutionaty lenth in general arrasement and detail than any botanic satelen has been before

ll is an old and still tho common experience that 1 becknes linowledge we may lose beanty ret 11 is not mpossible also to use our knowledge in service do lecatuly, varsing it and entancing it

To the oflenary vistlor the succession of plants will still appear naturalistic; indeed, if artistically designed they may aplear almost accidembal let nel only the lexpinner in hotany will soon find the naturat orders in their most easily grasped succession but the professed evolutionst, I trust 


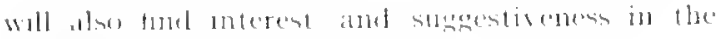
merle of treatment allopted.

\section{A. Botanical Arrangement}

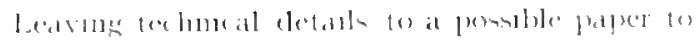

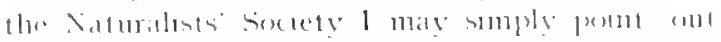

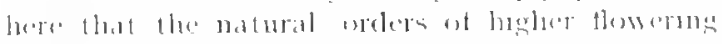
plante whould becrin, on the righ thanel trem what

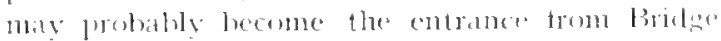
Street, with the simple ranunculus tamaly and there alles, peomes, magnolias, and laterties, peppleses, cruciters and lumbores, hypericums, resedes, and violets, resamums, with the pink tamly and their picturespely veredative allies, the rhubarts, and spinaclo of this whole serien the sum-lowing varietes occuly wath prekets in the hatha, smath fecls in advance of thes, or accasionally on lop of the wall; while the more slade-loseng speckes rum back into the plantalken ledt.

This methel of grataluom from sumpy plants in

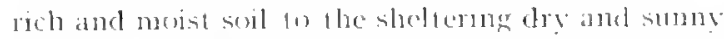
wall, and thene agan behmel to the sharliest sloubleries, altords an clmost icleal vartely of

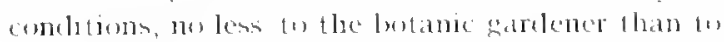
the ordundry flower lower. Their interests and metholis are lous bere reconcilet.

By a careful selection of spectes it is putte

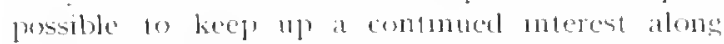
this whole rengon for the greater part of the vear,

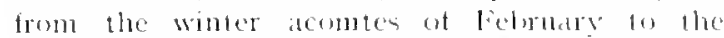
Chromas rose, and the like in considerable measure alse for many of the ot here orelers.

White this sectlon of the park, then, Bllustrates and includes the large enonp of natural orelers bent known to most naturalists as "thalamitlorals," of which the huttercus is the mitial lype, the next section of the park, the north-west, has similaty its whle garelen and wall garden, its plants and shouls around the hasin and elscwlere, drawn trom the next greal sroup ot orders, the "calycitlonals," * of which the rose fambly is most familatr. Hence beatuluful eushions of saxifrages may draje and adorn the hatha wall, whith the allied hombelects and stone-crops: whle the shrublery sitxitrages, like flowernge currants,and mexk-orenge, will atford

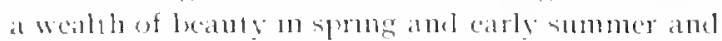

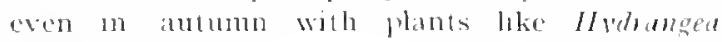
peniculate.

In shmbleries around the basin the beatutut

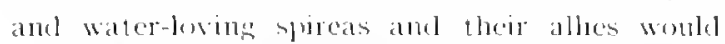

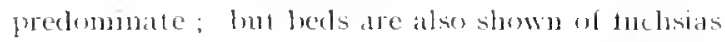
and evening primoses, etc : whle be mere shadefosmg umbelnferous plants acupy the plantation belt behinel the saxifrages, yet with the splentel sea-bollies coming forwarl into the sun.

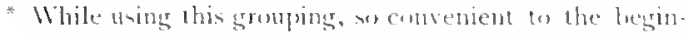
ner, the tercher will. of crume. proint wat that thin at los is traditional and partly artificial, and that the order of nature is not so simply eliscuvered.

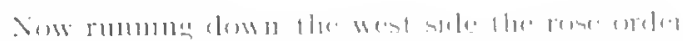

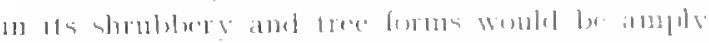

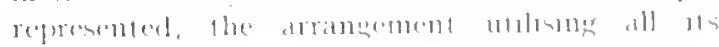

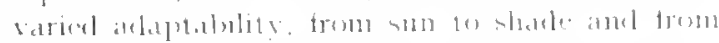
waller 10 wall.

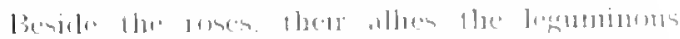

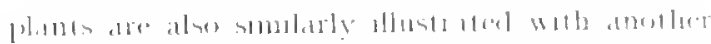

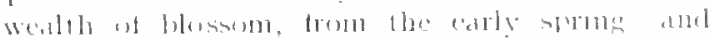

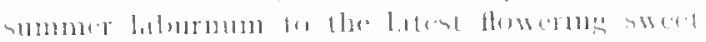

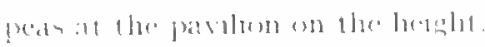

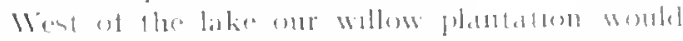
smularly be es an smatl lestanical meterest. and this without incertering wabs its aftert, in facl, whaneing 14 , and sol on with the water plitilin.

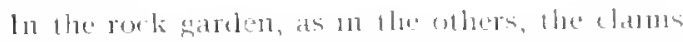

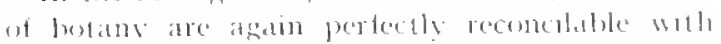
those of beanly; and esen in the tormal garden

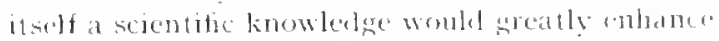
the interest of its displays of spring luthe, of atmmer and atutumn flowers. Tulpps or chryanthe mmms are not less beantiful to linose who linom

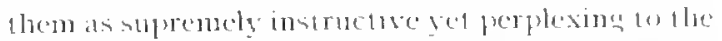

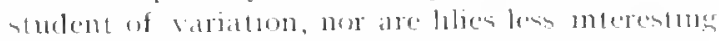
10 those who are wont seriously to consider how they riom.

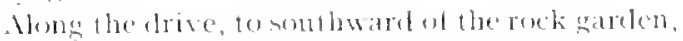

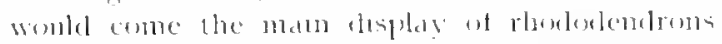
and araleats, hat excechne in thoir splembour these of fier t, and rumning oth inte these the whole heath famly, of matked interest alike to partener and bolanist, slumbl be illustrated here.

for the promese tamily loth sharly grate and

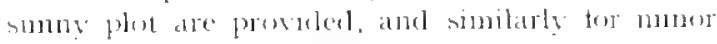

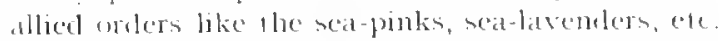

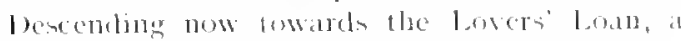
seredt teature ss mate atong the eant sale of the chive and the fringe of the der platstation of the campanulat tamily and their leveloped allies the compostles. Ilere, 11 fact, in perhapenthe colmmont mg cxample of the possibte combunation of seasemal

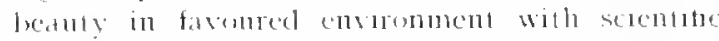
mereat. For ample successem at flomers is most casily kept up from the sprong deronicume, whe b

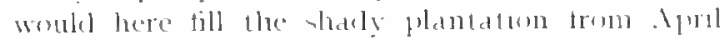

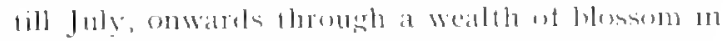

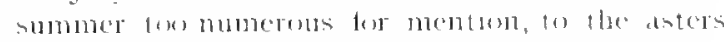

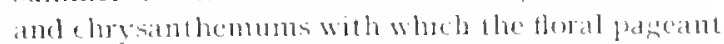
("mils.

The comection at the trees of the plantatem wath the herbage of the boreground is prosided

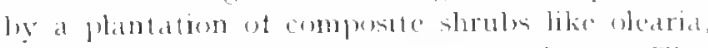
eic, behond the kindred lerbaceour plants. The

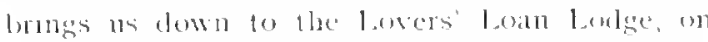

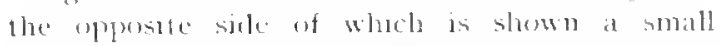
group of alled melers matclers, valcriams. scabiolls, and teatads. the latter, of course. recalling the composites, and almost excecolnos them in picturespluenesis.

In front of the lenge entrance ate sroupent the lablates, in masses of lavender, rusemary, thyme, 


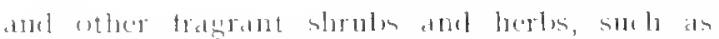

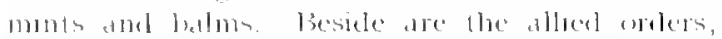

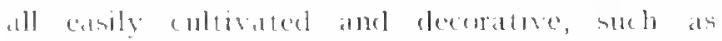

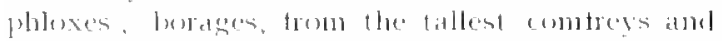

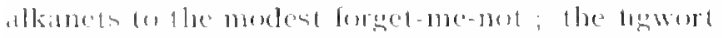

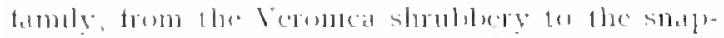

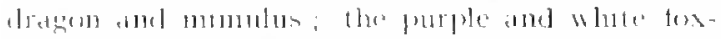

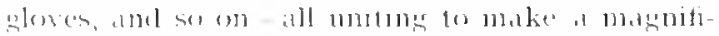

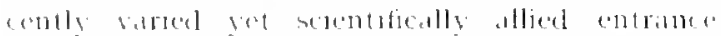
:2rilit

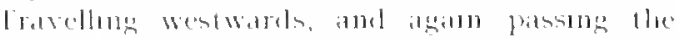

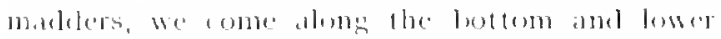

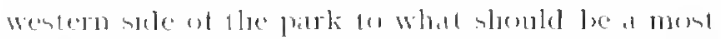

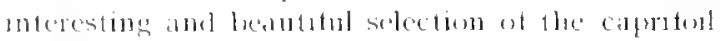

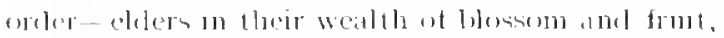

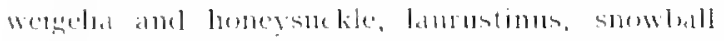

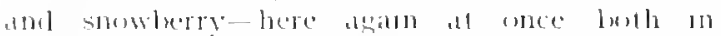

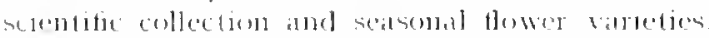

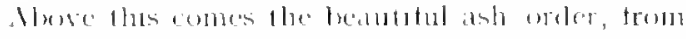

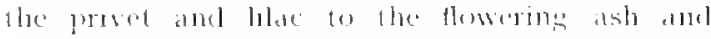
thickest forese tree.

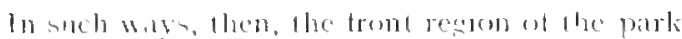

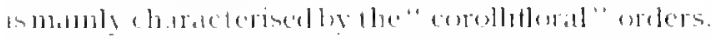
Xext, alter the willows alleaty mentioned, come

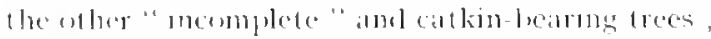

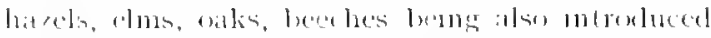

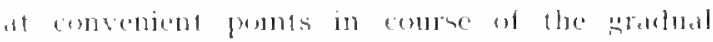
inporement of the plantatum borter to the

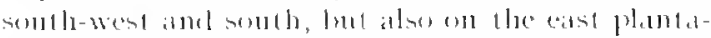
lam ledt leatlong to the den. So tar, then, a

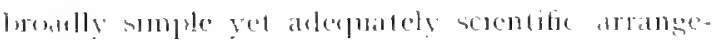

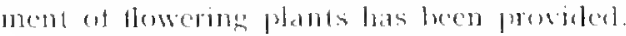

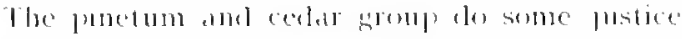

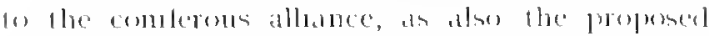

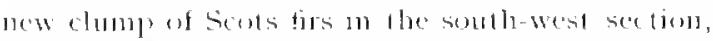

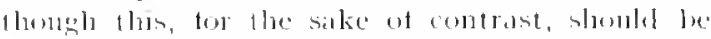
maxed with burehes

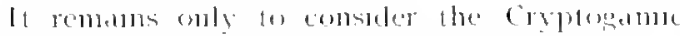

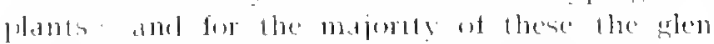

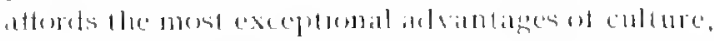

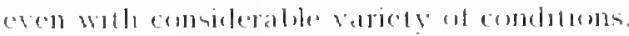

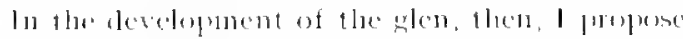

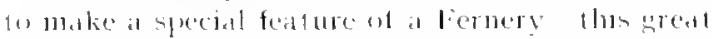

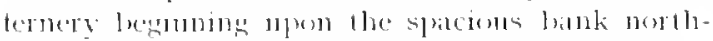

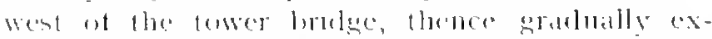

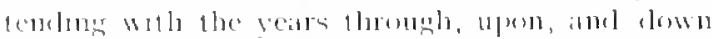

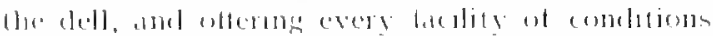

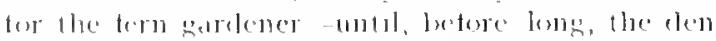

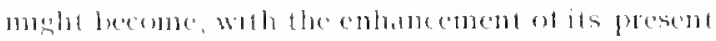
thellms, and whloul serions cepense ane of the now remarkible fern surtens ter be seen any-

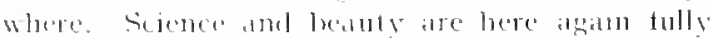

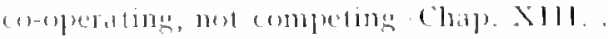

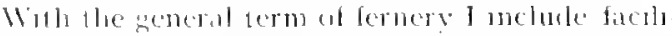

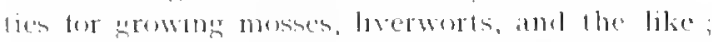

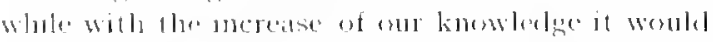

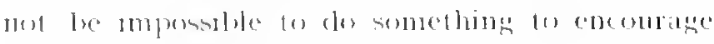

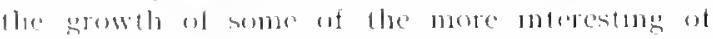

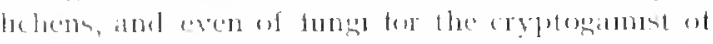
:111 $110 \mathrm{~m}$

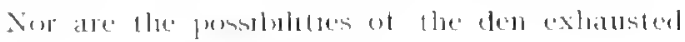

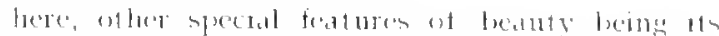

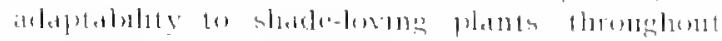
the seatsons, from snowelopps, celemelune, amt

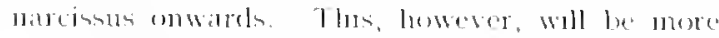

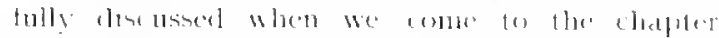

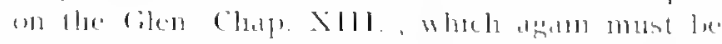

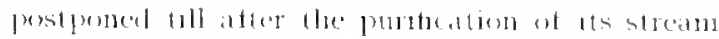
(1), >il.

\section{B. Further Aspects of Botanic Gardens}

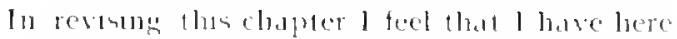
perhaps more than anywhe, come short at expresing either to the general reader or to trother lotamst, that malny-sided presentment of plant lafe, alike in 11s profean beanty and its manfold intellectual interest, wh wheh ance more this

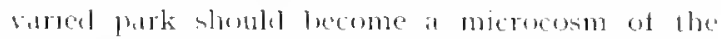
letger worlel-the worle of Nillure, the worlel of Science. In such loriet space it as mpossible

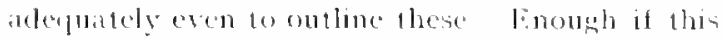
pratetical possibility has leen supesested here of

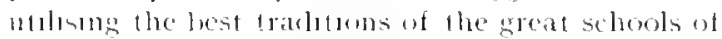
lutins ret of proceding heyond these toward at rel fulles and more chimacterstic presentment of the phant wotel. That is of the urder of lis evolu-

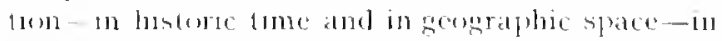
atdeftation of soils and climates-in arlaptation, tor, to wher torms ot lite, and to man hinselt, and alse in some indication of that natural order ol desecnt and kinship wheh sis now party de-

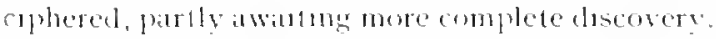

by such linging out ats I have propered fer the gardens of this patk moln might be lone, me only lor locil exlucatom and lor resiomal naturatists, but eqen for the larger world at science. The greal metropelitan gatrems are necessiuly hampered ty their latying ont in the past, which it

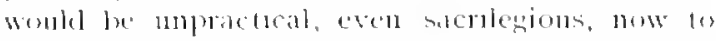

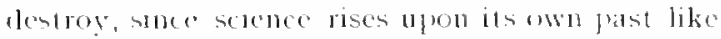
antal reet or wall, and thus grows upwatrel inter the tolure. The present opportunity as thus ane of real inpertance on motural seience everywhere. Where hetore has there been such a chance est convergme the resomeces of science, at once systematic wnol esolutionary, whth these of lostre ulture, from

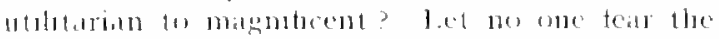

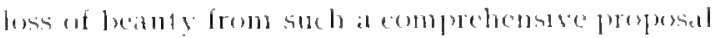
of scientife layng out, at bewing lle whele park as a dreat lostame gatelen. licall how, with one

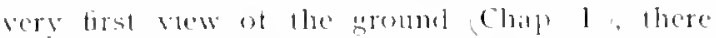
appeared the prepesal for the appopriate planturg

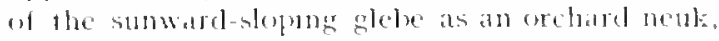
narrowing into a hawhorn den, and for ceboing these with a kindred arrangement wion the mothwest sicle of the park also, each, then, wh an effee at one Japanesplue and lwancly But the sprong paradise of blessom trees alore the latice, this blaze ol atulume shery ledes the ancient towers, wlll only be all the richer for having tecl- 


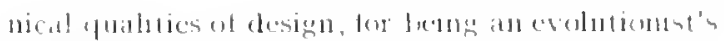
rype-sedectson of characterstic varleblums of the liessitcents

The dikl proing among the humblest liserwoth

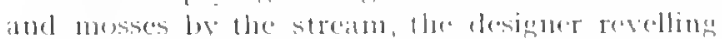
andel the verdure mazes of the dell, will atgitin hut be the richer when the naturalast-gatretenes hat

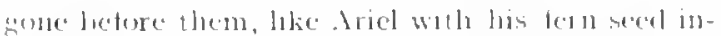

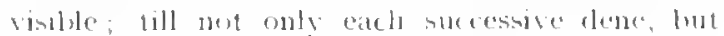
cach difterent pount of exponure and moisture, of reck and soil. Whthin these has its distinctive pent op mass of heituty, vet all secming mere natural than helore. The nareissns ghades, the ris palches

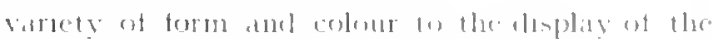

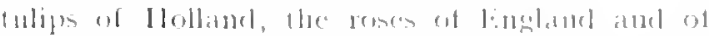
Fiance.

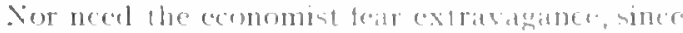

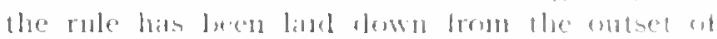

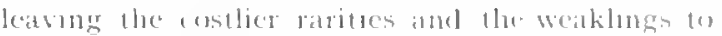

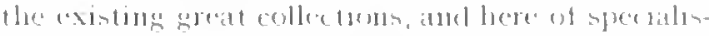

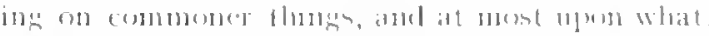

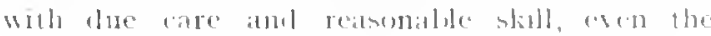
amatcur cultuatur maty grow

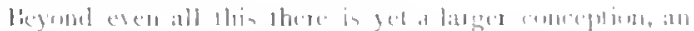

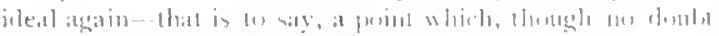

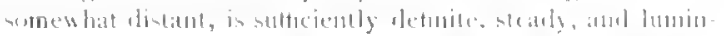

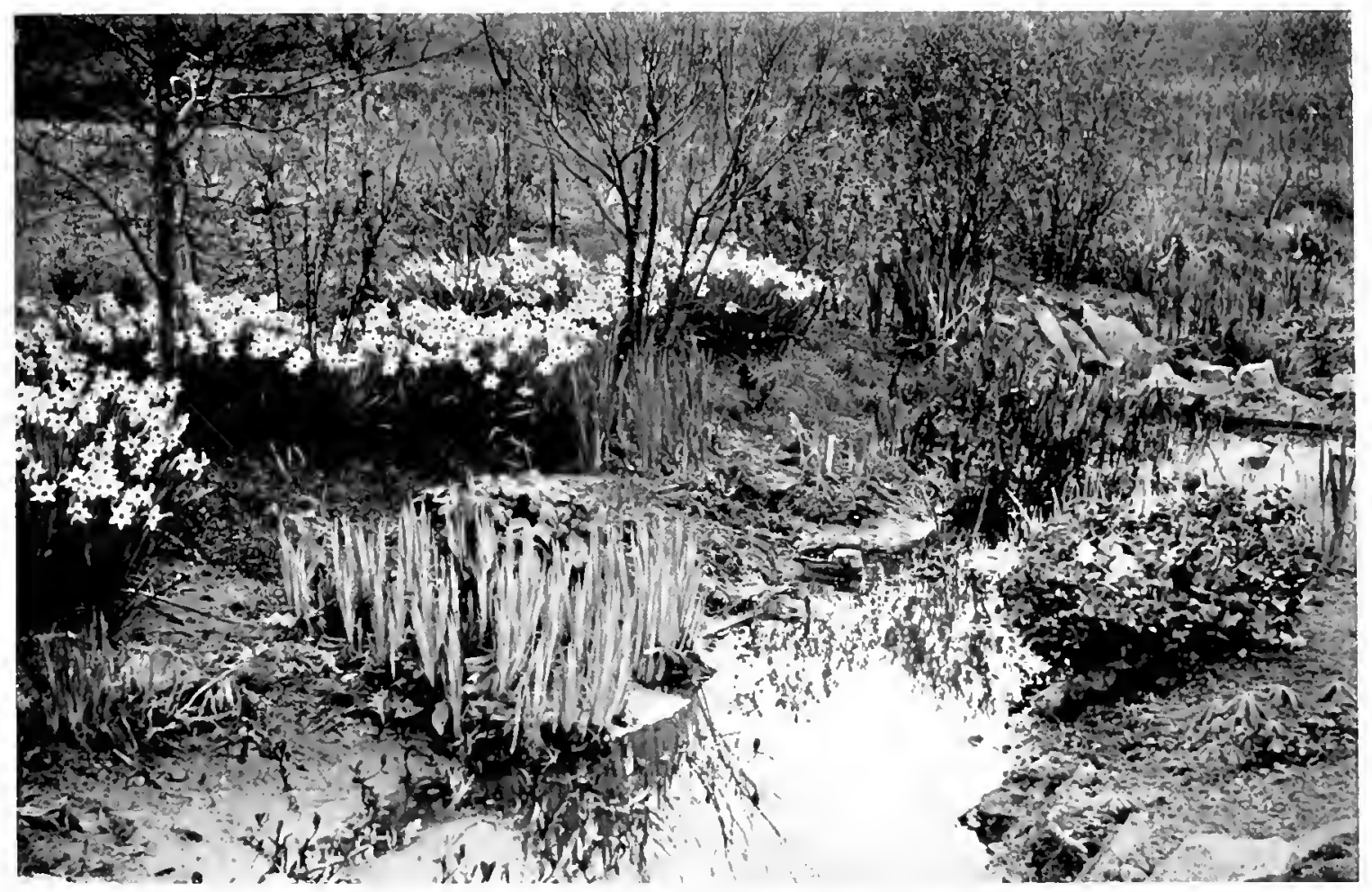

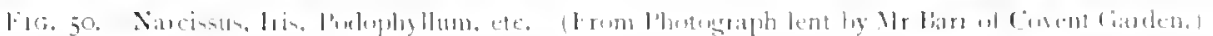

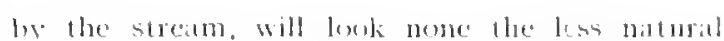
fecause their arrangement has lreen he at selection from the treasures of the specialist in this maller. it is to the comresy of the very foremost if these that I wwe the acompanying flgure tig 501

Passing to that contratst and complement of Niture at her greenest and wildest in the shitly. detl to the stately terraces, the thral manniticence of the palace garden, which should give this park such rare pre-eminence over the vaster pleasances of greater cities, our sumward parteres will he all the richer that their annual pageant has been rostudied from the monograplis and collections of snowdrops and crocus species, rounct to those of the chrysanthemum and Christmas rose. Such fresh presentment can but give new wealth and

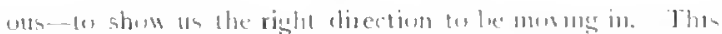

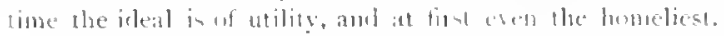

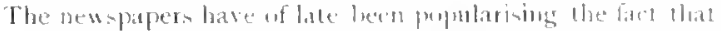

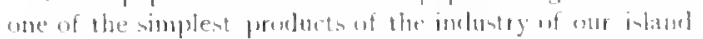

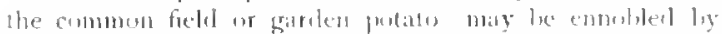

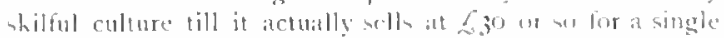

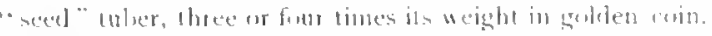

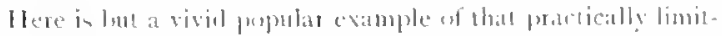

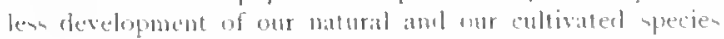

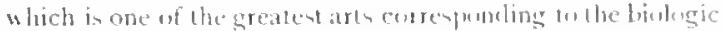
wiences. Here, in lach, is a deselupmem ol imblumplater than those of chemical or physical sciences of mechanio or

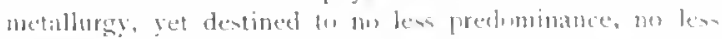
Iras-formation of civilisalion in is approblhing toun. It is strely none the lew utilitarian lucaume. invesid uf destruging Sature, an with tou mang recent prongresses, it develop ber. in our Giken (Chap. XI., high. 57 and 60 ) we see mort than enough of ahes where, till our uwn doy. there was beauty: 


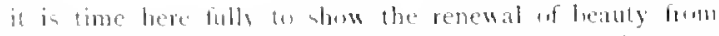

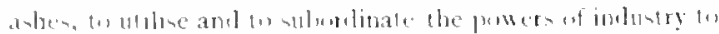

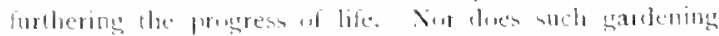

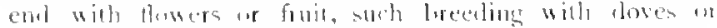
lamber hut leagine anew fo have human and weial applica.

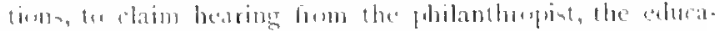

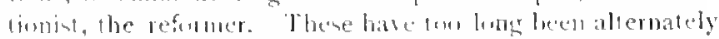

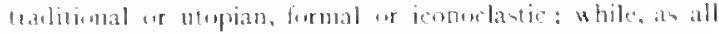

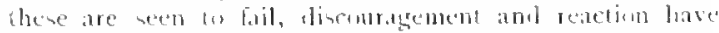

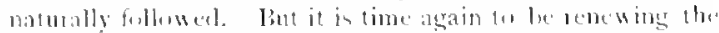

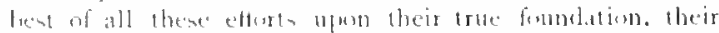
litedally natural one that of a heter comblitioning of the deselopment of life. The sucial ethert of the opening future

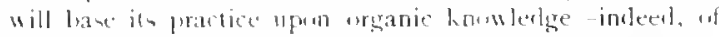

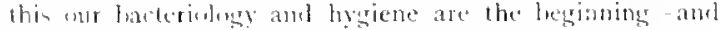

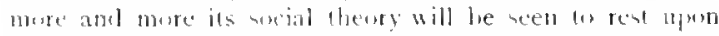
sital experience. Hence the great histuric teachers have ever solght 10 turn mell again wo nature, and have chemen mure than theis furalles from the Hower : while our molern

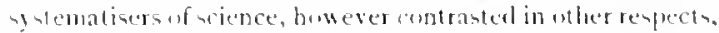
like Comte and sipener themadres, are yet unammondy

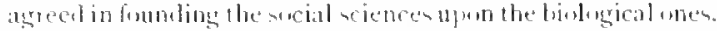

l'utting this more definitely still, the epening genctation. for whome sake it in that we are here plaming and preparing. has nom to correlute the respertive ats asontedated with

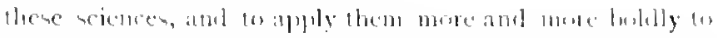

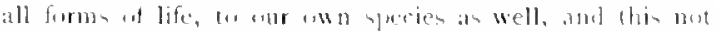

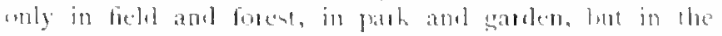

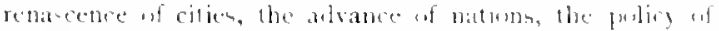
races. This alvance is lecing seen nu longer merely in

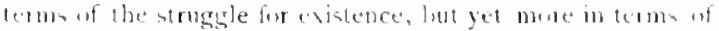
the degree in which we mat laibe thin wrogerle into the culture of existersed bepile the appatent predeminance on

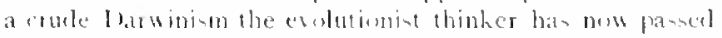

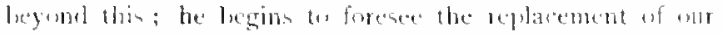
furrent weial pulicien and polition with the ir crmbe nutural-

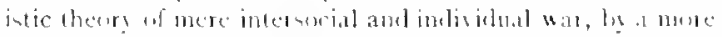
complete, a muk human view, in which hunger heoumes

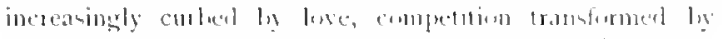

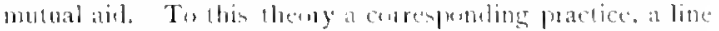

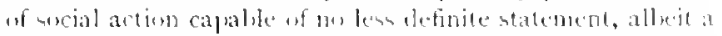

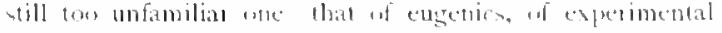
ewhlutum, stgatnic and human, ant this and only in ensiunment lat in lereed anel race. Tomarts these great uscial cnds, then, of evolution, not unly in tauture lout in human

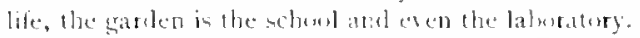

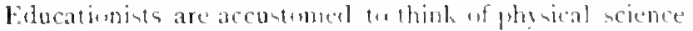

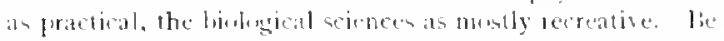

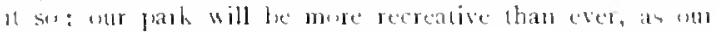
gardens lecome re-creative inleded. 


\section{('IHAYTKR}

\section{SOUTHERN PARK AND "ZOO"}

Wr: may now flam to have satfistied the demalmala of the wilel gatden with musual tulness, so that at should not only be possilde but increasingly attractive to walk up or down the glem, and still more of go roumel the park almome every day of the vear, anel not only weloome ald triends but

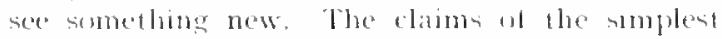
loser of nature, of the teacher, and of the tranesl naturalut, of the landsatge lower and gardener.

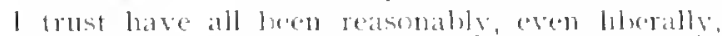
met.

The landscape aspect of the park to southward bas now to be completed

lintering once more trum the volp bate, passing the mangery, hake, anel cerlat monnt, we descend leetween formal garden and rock gatrom. Gur main drive descents an a sweepung curve between the rock garden and formal sardon, earl best closed trom the other by a yew hed we, which I should recommeml to be grown by to the vastest scale and trmmed in the platint fathion of our foretuthers, althomb in some new oumbination of their tratitionat dextess, such ats that indicated in plan fige. 135-2he smple sweep of curvalure of the omsex side lexing liere contrasted with the stroner light anel shate of the concave side. This lroal and simple treatment, besides its own mpressiveness, is designed here to give the necessary repose and comtrast with the rich detail of the rock garden and of the ample lanelscape mto which it presently opens somthwarl. llere we are, in tact, upon the present open space of the park, a very minferesting one, comparing unfarourally with the much nore picturestucly planted northern half.

Th appreciate the treatment necessary here we may best follow the western drive downhill, now nearly upon the lines of the ancient roatway, to the new loxlge and gatewa shown to occupy the present breate in the arenue of lovers' lomon.

looking upwards, the lack of interest is now more manifest, our plotugrapls figs. 52 and 53 showing that the problem of planting hats never lee'n grapleal with at all, and that here much

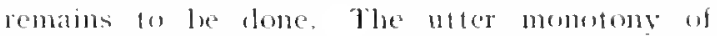
this expanse is as yet lithle interfered with, even when the formal garden and rock gatrten

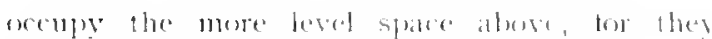

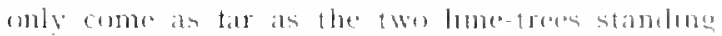
weat the centre of lle park.

\section{A. "Campus."}

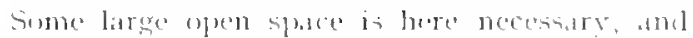

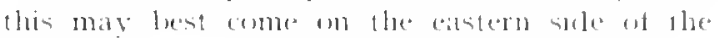
jalk.

The necessity, tom, wh sme smoly harge of ene spate

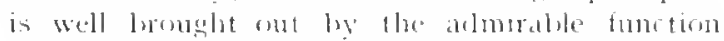
wah which the park was epened lat Sorember.

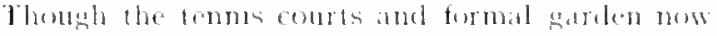

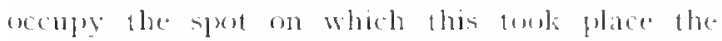

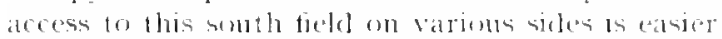
than ever, and the space sutfices for at ereat concourse. Thes also explanus the dejumition of the large circulate platform which the formal gatrelen projects moto the tichl, so that an openair meeting on a great scale, so fat from bemp

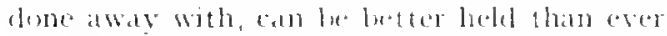

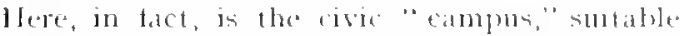
tor larger fites, ceremonies, we gatherings than can be acommolaterl on the Irena, to which 1 come later Chap $\mathrm{X} \times \mathrm{V}$ l

It is possible that some alteratum of levelhng may be desired on this field, but the would easls he managed, especially in view of the shrublemes at sts foot, and thos would present nu herions difficulties, practical or artistic.

We now come to the south-west protion sit the park; lut first a combideration of the neoded "Zoo."

\section{B. Zoological Possibilities}

Goologiat and lootanist will, l trust, almit that thea repurements have leen carefully onsideret, but they must not forget that a smolat responsibility exists to the zonkegist. With all this varlety of wild ant tame gatelening cannot smething similar be done for the even more facinating interest of anmal life, both witel and tame? since we have gandens of all kimble, pratenterly exen a Botanie Garelen, why not alos a ret more atractive "Zoo"? 
Let us beam with ammal as with the vegetable lite, taking nature ats we timel it, or rathere ats it

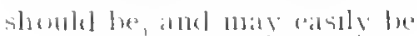

\section{Fish}

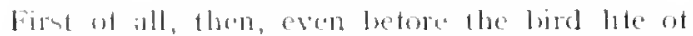
the glen and plantatum, comes llue fish bite of the stream. Astuming the aecessary purtication, a great deal may le dome lo restock the stream, espectully stoce its enlarement 1016 more spacious pould anel the creation of the proposed lakewomld secure tlus. It is no ielea ol mine, but

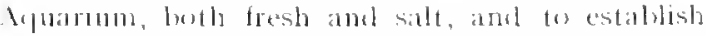
flus on a moderate seale there is on serious ditfiwhy. limom great and costly mulertakings lake the Brightom departion or the elefunct one of

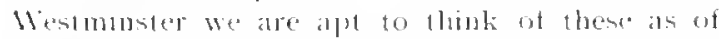
areat expmense and ditficulty. But the metherts of acration of tanks ale now sa simple and so perfeet that there sis not the sleshtest difficulty in liegring moderate-sized alluaria flowrishing without change ot water even tor vears. In a Londen museum with which 1 itm well acquainted, whl grest and well-displated zoologual and anthropological collectons, it is still the small aquarid which are ohiously far most allactive (1) vinitors old and young. Yet this alpuarum lats oret tewer bun-

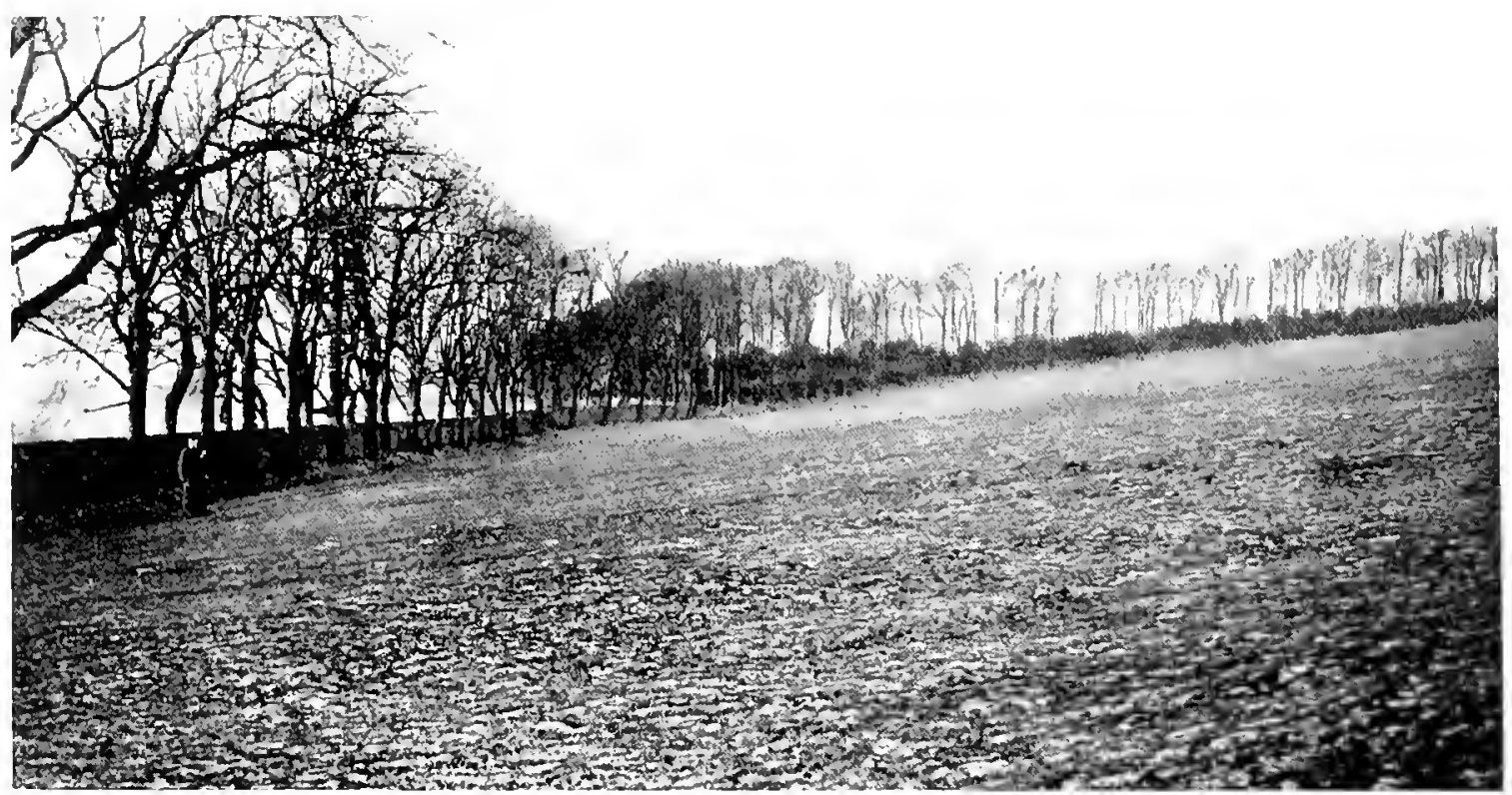

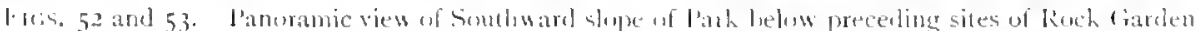

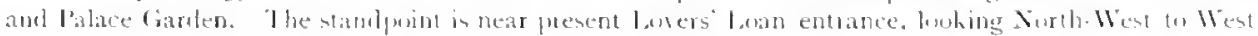

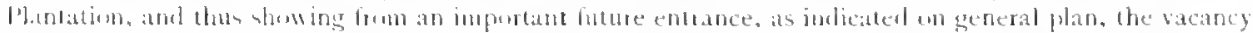

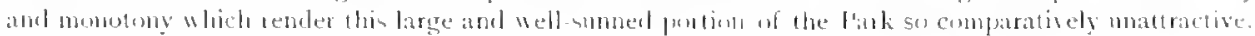

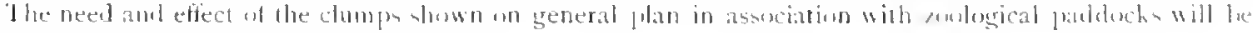
realinesl frum this paums.man.

a pratical and independent suggestion 1 awe 6 two of our leading souttsh fishery experts, that a small installation of hatchine troughe might be sed up, convenitently towatals the heald of the

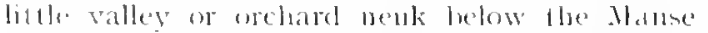
and, even though it he long lefore the stream atu

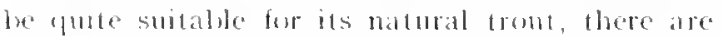
less exacting species. We may them look torwarl to anglers, dit and young.

\section{Aquarium}

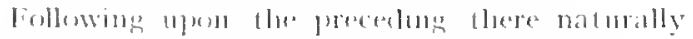
arsese for comsideration the provision of an breds than the rest ot the musemm seojes of Humsands.

Mith this can easily he associated, if not a ponal. at least small vivaria, with tortoises and hatmless smakes, frogs, and their kudeded; also an inseretarium, in which the marellums flimsformations of inseds eall be easily shown and followed. The povision for schools of small ayparia, and the reveral of the old tatsion of keeping silkworms, calerpillase, and the like will again accompany the spreading lose and educative use of natural history among the younger ereneration. This afwarim may also conveniently be associated with the Nature lalace, and is sngesestest in the

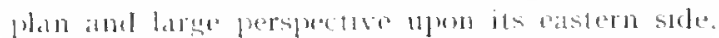




\section{Bird Life, Aviaries. Poultry yard}

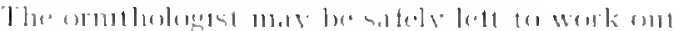

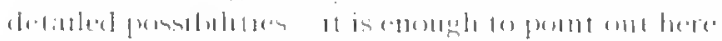

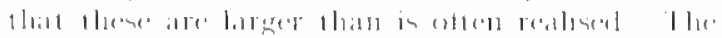

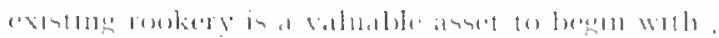

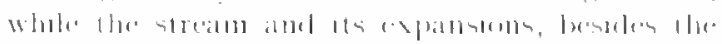

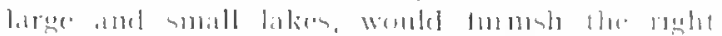

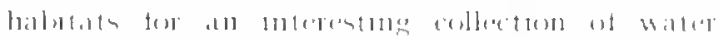

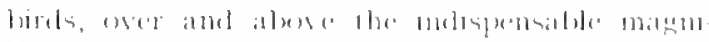

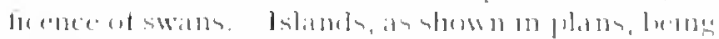

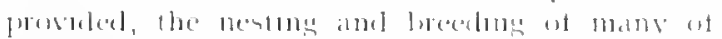

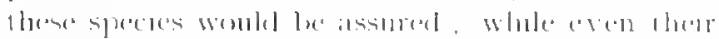

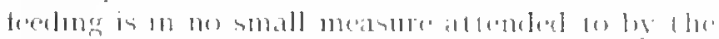

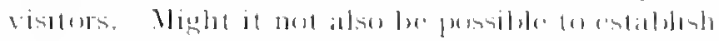
a small heroms, of which there is at leant ande

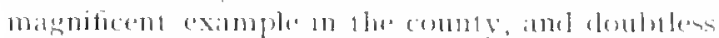

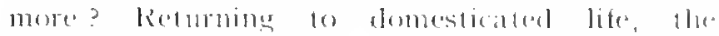

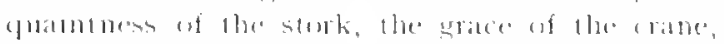

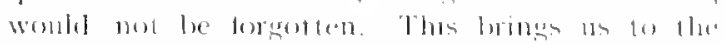

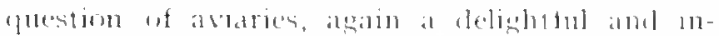
cxpensive resoluree sich ample spence an be

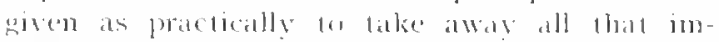

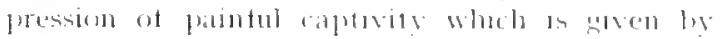

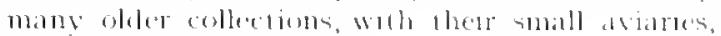
of lex close continement

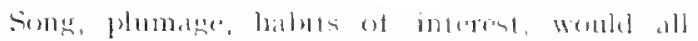
guide the formation ot sule a small reprenentatise

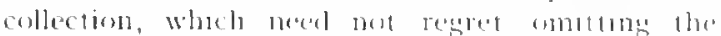

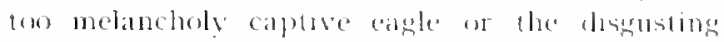
sulture; the fords of prey may le tor practical purposes sutficanty reprenemed be tawls, 10

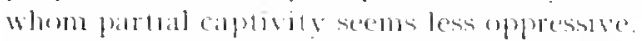

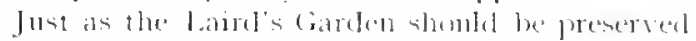

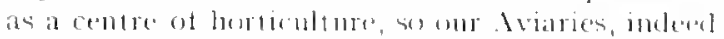

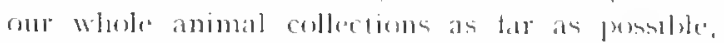
womld have a smilaty fractual amel buman interest that is, ther shombl primarily laderegard lo the creatures we call domesticaled, lom whoh have had so valst a share on civilising allul fomesliealling man. Just as 1 gress tor a molel kanl-

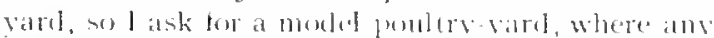
visitor conld see and be alvised ats lo the best sort

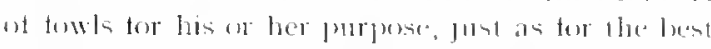

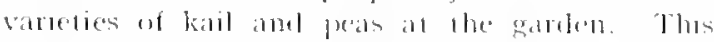

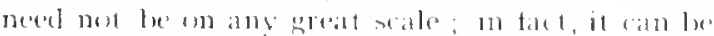
mosi netul upon a mesterate one.

\section{Keepers}

lasteat of the ordmatry male keeper of a zun-

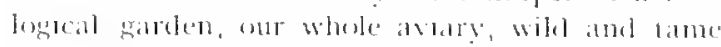
and, inderel, why not the man zoulogical matnagement? might well be in the lamelest an melligent and sympathenc woman maturiltst and pultry "xpert. Such women have alway existed in the

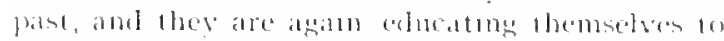

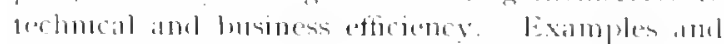

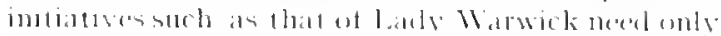

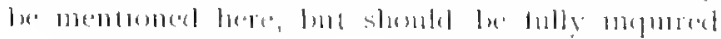

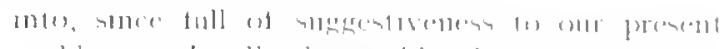

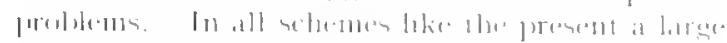

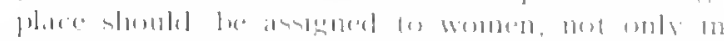

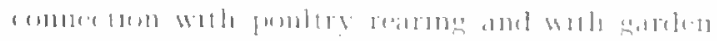

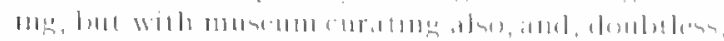

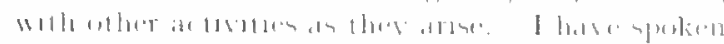

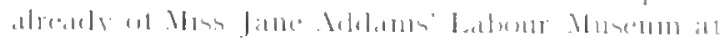

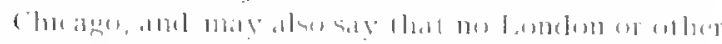

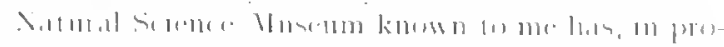

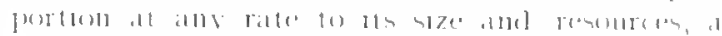

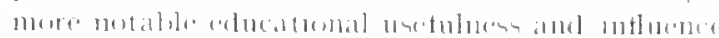

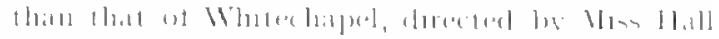

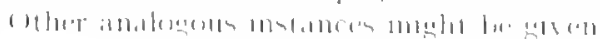

\section{Larger Domesticated Animals}

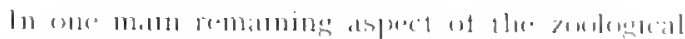

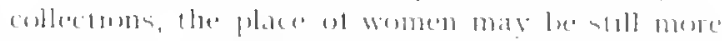

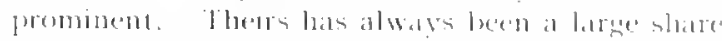

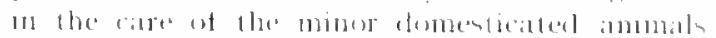

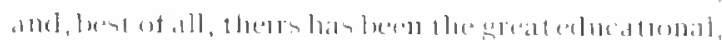

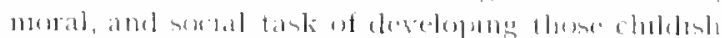

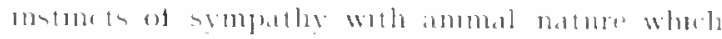

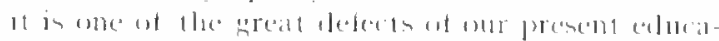

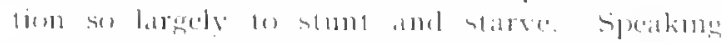

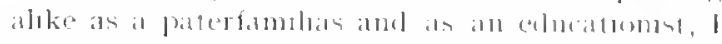

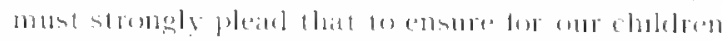

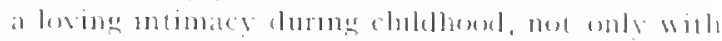

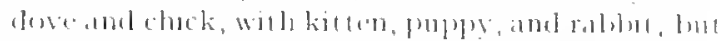
woth tamb and alf and all wher accesshole germlle

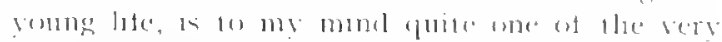

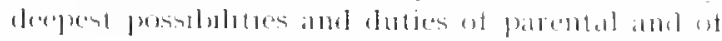

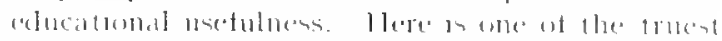

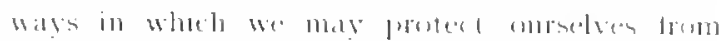

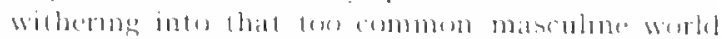

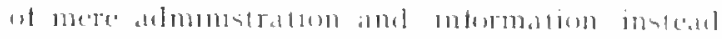

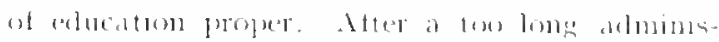

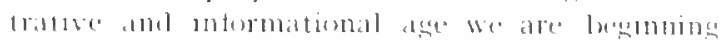

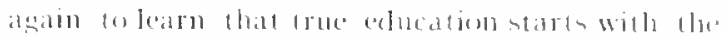

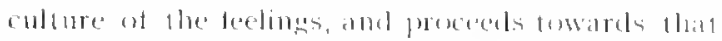

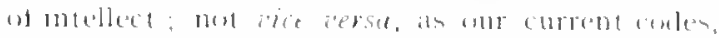
fromary, secondary or higher, hase hesen teso loms

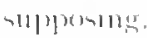

Witle stuele womanly intluences al work the

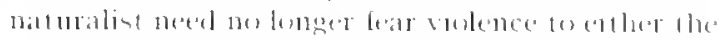

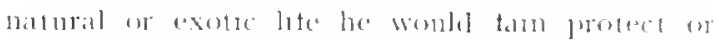
naturaluse. Just at the single typeal sebul

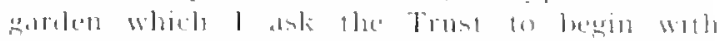
(hatp. VII. E. will in time be tound 10 arte at

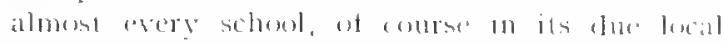

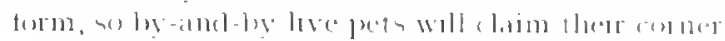

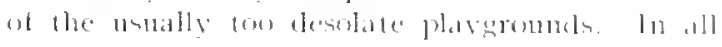

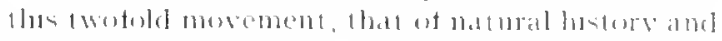
bume late fosether, ons woman corater would lxe invalıilul.

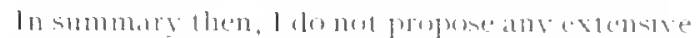

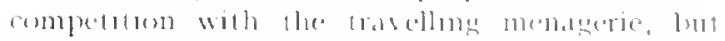

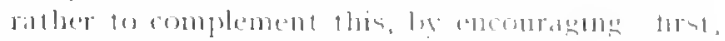

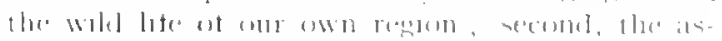

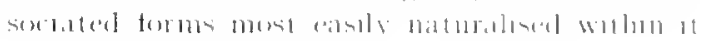


and thitlly, alowe atl, those domestic animals, not only on acount of their material usetulness, lut still more on accome of their sympathetse and moralising value which is so urgent it fresent-dely

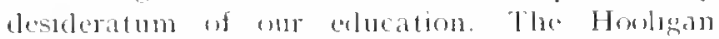
has been for hong treated be punishment and repression: wo hegin to understand lim as bargely the product of our educational machine, the starveling of its stony lisedel. It is time, then, to give woman-gardener and nuturalsst a cluance of tair competition with school-colle maker and proliceman.

besides, fhem, that literal annual poxision of hamb and calt for our choldren to which I lowk terward on the nearing future of education by experience and reility, why not also more permanent pels? Why not only a dos or two. a whole tomily of l'ersian eats, but even a troup of donkeys, another of Shethand pomies? Chulden would pay their halt-pence tor rules no leso reacluly than tor swcets; so here, again, one on the greatest chlucatomal resources of humanity might be smply and inexpensively demoratised, and the literally chisalrous thus begin agatin to replace the merely horsey. Since such children's steeds par the provate speculater al every summer waterug-place, there is surely no risk at their not reasomalily earning their living in llas place of resort, open and atctive all the year romme

\section{South-West Paddocks}

The plan clearly shows the mode proposed for breaking up the vast western protion, upon which the impression of hankness principally depenels. Here the phan must be th uwn explanation, since time has not permuted the preparation of perspectiris.

It will bo seen that this western space of about five acres is lmoken up into large and small paddocks, barbing from 2 acres fo $f(x)$ sef. yels. liere. fluen, alle many spaces, applicalle to one of the most desirable interests of this park-its "Zoo" and with due aceommodation suitalde to difterent sperties, from the small deer park to the mere cage run sufficient for the smallest quatrupers. A detailed stmely of the plan will slusw that this caretul antention to the repuirements of a Zoo has not prevented the composition of the tree clumps into lirge and unitied masses, nor their disposition so as to give vistas, but has rather lacilitated this. I sulnmit, in short, that here, as chewhere, the reat repuirements of useful work and general picturescluemess are nut separate.

following llye contour lines, dye oullet of the lake above gives us the opportunity of continuing it, not only dewe thromsh the rock garden, but thenee down along the areses of a number of the ammal parkocks, where it call when out into ponds, sometumes cemented, wh as in prevent trampling and soilung of the elge while rumning in and out from the general courses of the little stream. This astain gives opportunity of picturestue gardening with water-loning plants, and also ot showing the animals in their tullest beauty of reflections and at convenient nearness to the spectator, so that this soulhmost walk woukl become a liwourite haunt of that truest sportsman who has exchanged hus gun tor the camera.

The partal sepatation of this protum ot the Zoo trom the rest woult not occasion ans serious incomvenience in work, since, after all, the distance is so slight. Yex the pirturestue connection can be kept up by accosionally furning sheep, or even cattle, into the main Campus, which I leare, for the present at least, untouched, save for beds of shrubs ancl flowers opposite the entrance, which are easuly detended by a light, meonspucums fence along the north siele. Thomgh a very tew specimen trees, or even small clumps, would probably be cesiralule, these slould he lett till the main mprovements are finished, and then put in as finishng touches with the mont aretul design.

For donkeys and sheltes a moderate puddocts sparce is provided in this sonth-west corner ot the park. In others of these pradtocks shomb be displityed some of the supremely leandiful members of the Acer and antelope tribe. I picturesque rocky prominence woukl be constructed in one or two if the smaller padiocks, me for the display wf antelese or deer and the other for a lamily of woats, which are thus seen to incomparably greater alvantage than imprisoned apon the level. Even of the common sheep such a climbing rock gives an altogether new ieleat while wo see the play of lambs in such condetions is one of the greatest seasmal debryts possible to a bealthily simple human lite. Set huw tew balse ever seen a really first-rate tournament of lambs, much less provided them with the needtul hillock for thes game of "lings of the Cavile."

\section{Exotic Animals}

To these varons trpes of shere, gout, and oxen, deer and antelope, mightwell le ateled some strange untermediale forms, like the yak, w other species aclapted to on climate. Ancl besicle the pony padelock, why not a zelora? It these thrive and pait at lenicuik they might also thomsts here.

We are thus coming to athmit some of the animals of the menagerie and permiment "Zon," and among these, no dould, those quantert of creatures, the kangarous, would chetim ore of on pathocks. The great canivora, the monkers, and oflue thotoughly exotic types, l shoulel personally prefer to leave to the menagerie: lut I recognise that many fed in these the very kednest interest, and that some molerate representation of such types mav lairly be considered. In this 


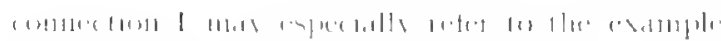

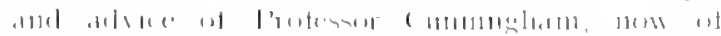

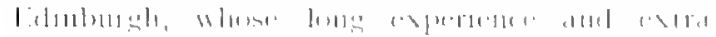

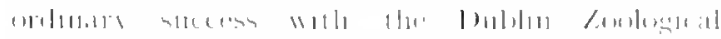

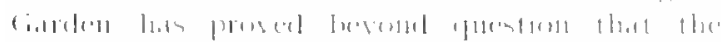

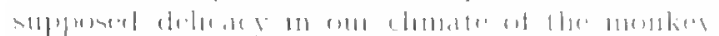

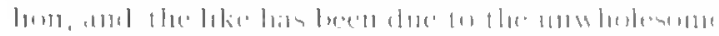

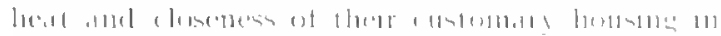

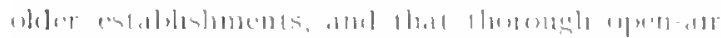

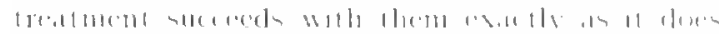

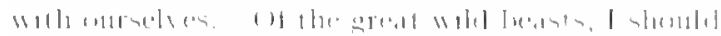

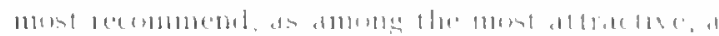

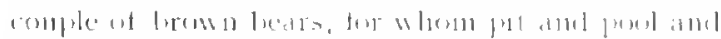

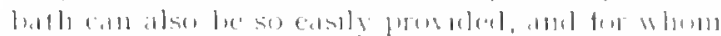

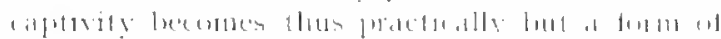

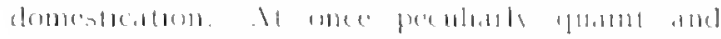

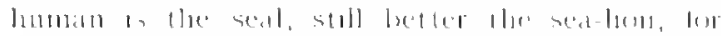

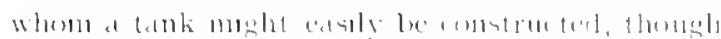

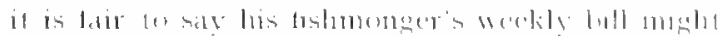

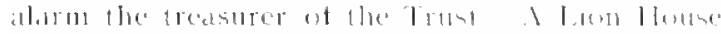

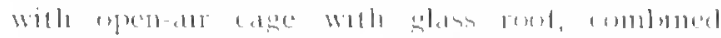

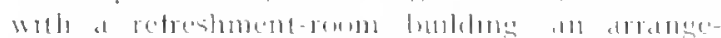

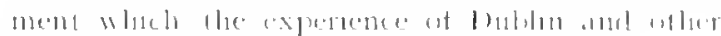

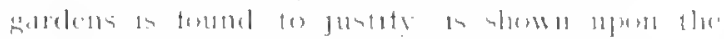

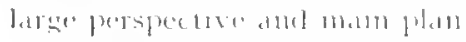

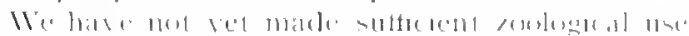

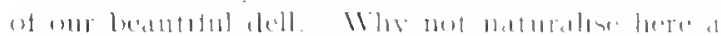

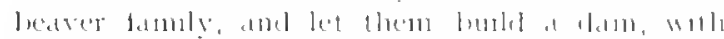

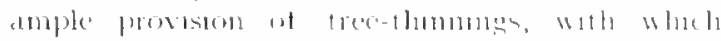

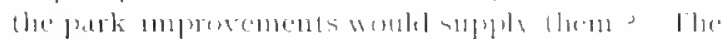

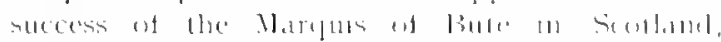

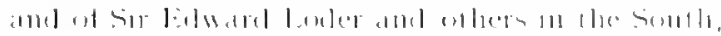

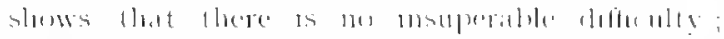

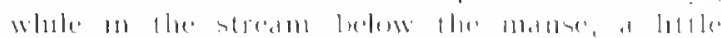

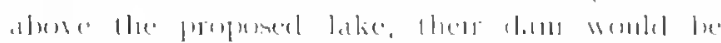

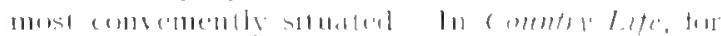

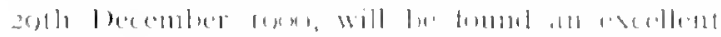

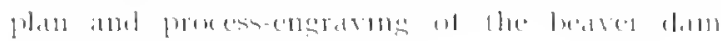

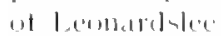

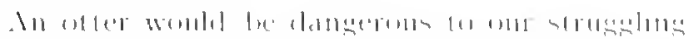

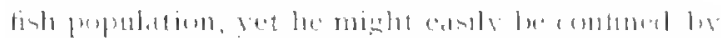

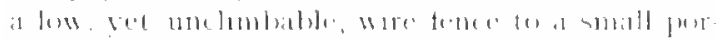

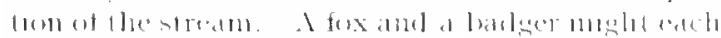

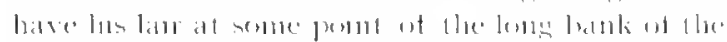

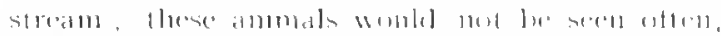

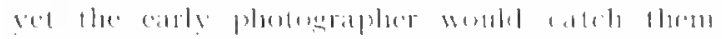

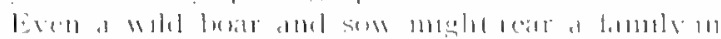

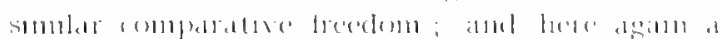

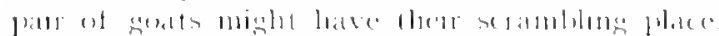

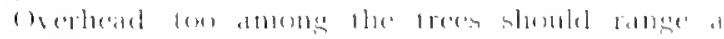

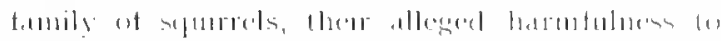

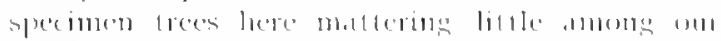

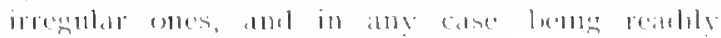

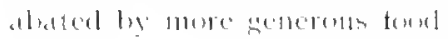

\section{Further possibilities of "Zoo"}

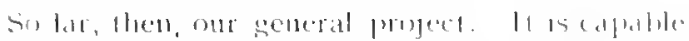

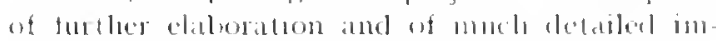
prosement, lut I trost is detensible in the main

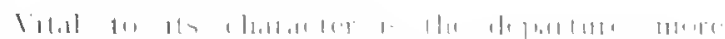

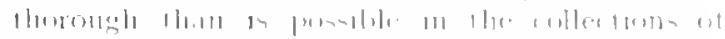

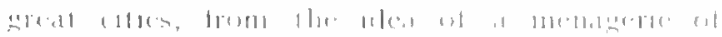

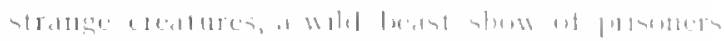

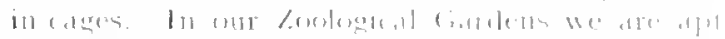

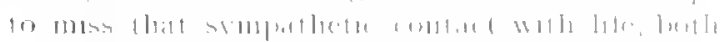

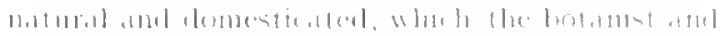

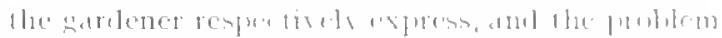

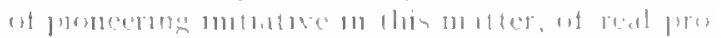

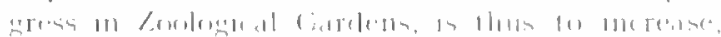

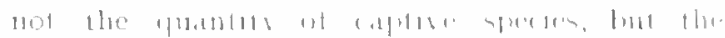

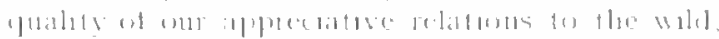

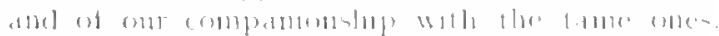

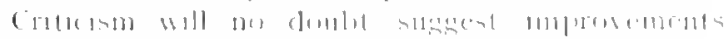

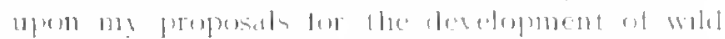

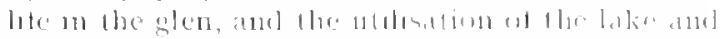

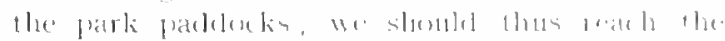

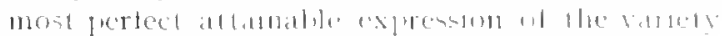

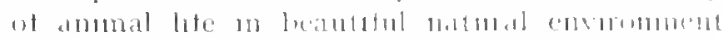

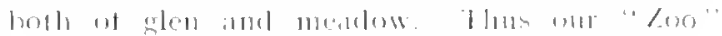

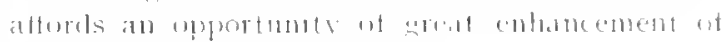
our naturalunte partemeng.

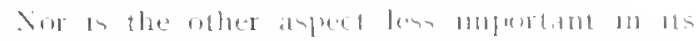

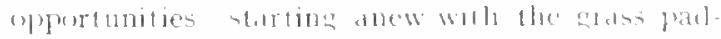

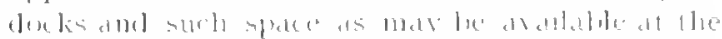

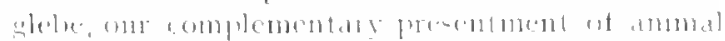

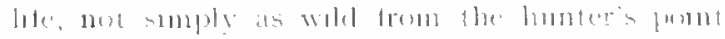

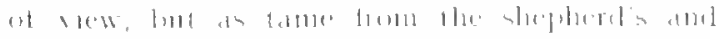

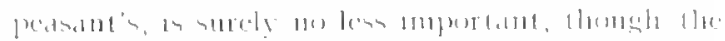

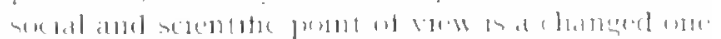

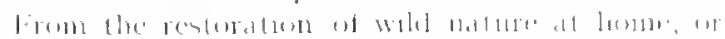

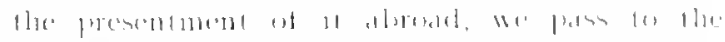

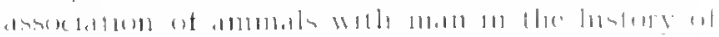

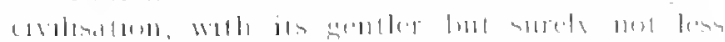

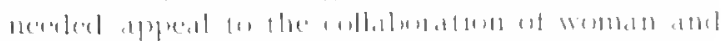

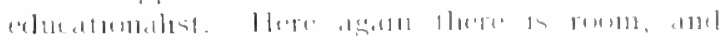

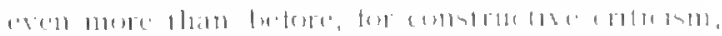

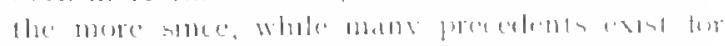

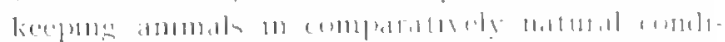

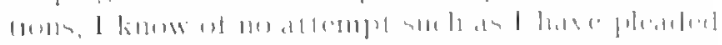

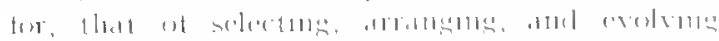

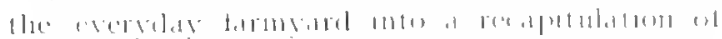

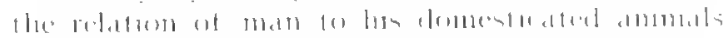

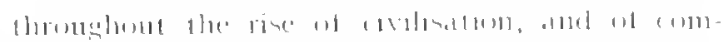

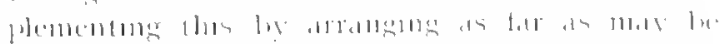

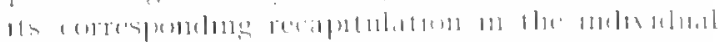
(9)

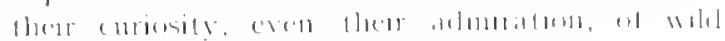

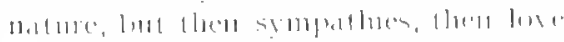

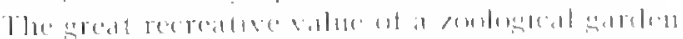

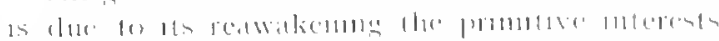

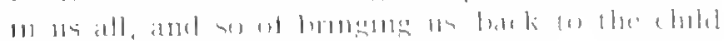

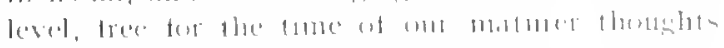
antel cilles

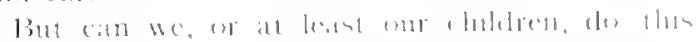

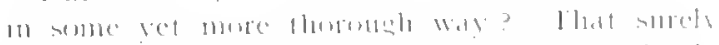

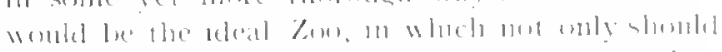

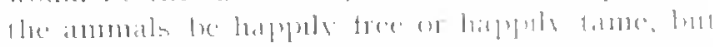

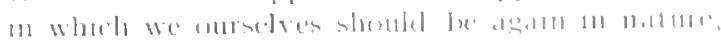

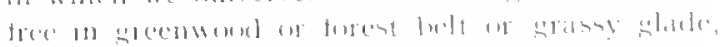

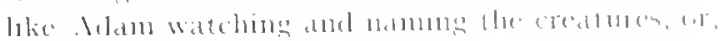




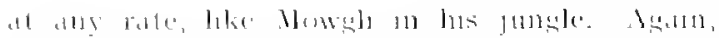

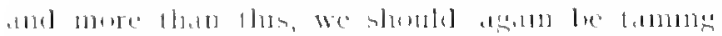

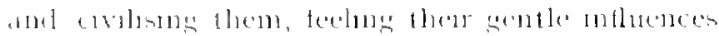

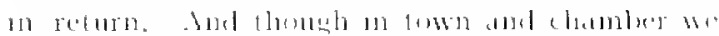

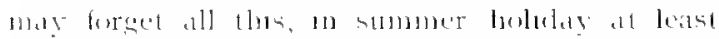

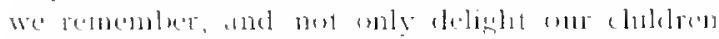

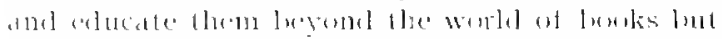

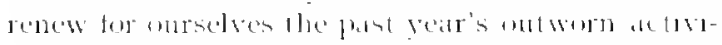

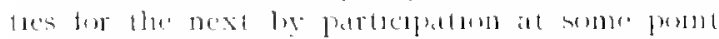

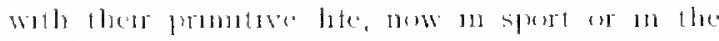

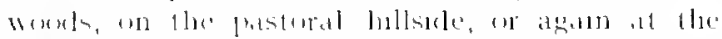
form. To smplyty somedhug of llese clements

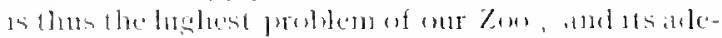

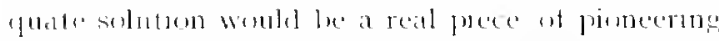

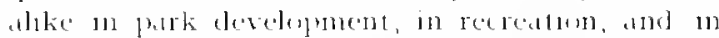

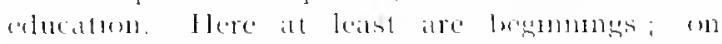

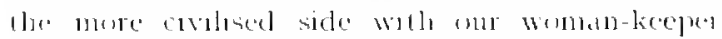

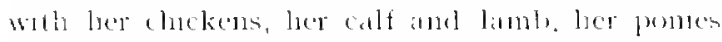
and the rest. But tor the mone prometure sole, the

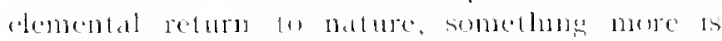

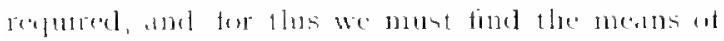

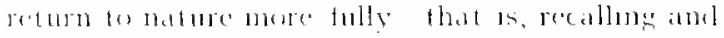

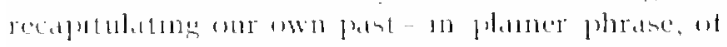

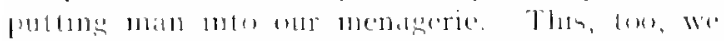

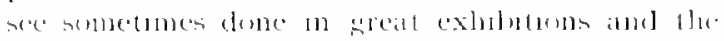

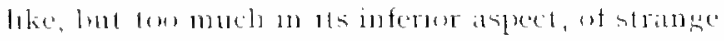

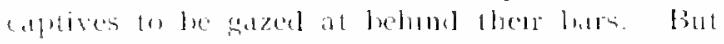

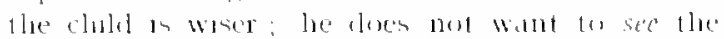

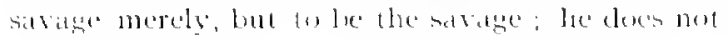

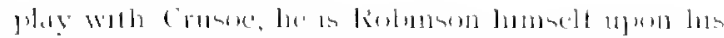

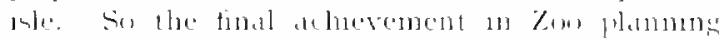

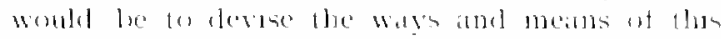

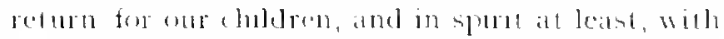

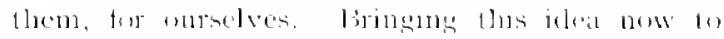
practece, we need the promblue eare, the latr, the

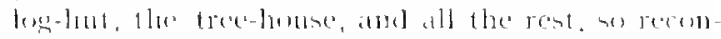

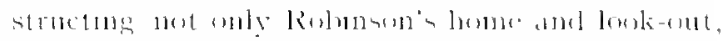

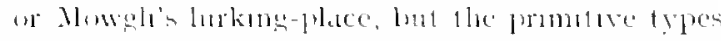

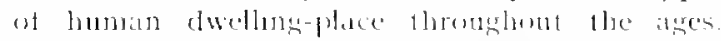

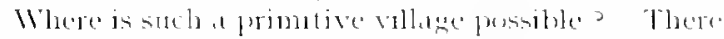
sis the vere place fore at on the west bank ot the

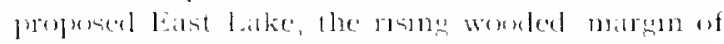
digs. if or 1 -

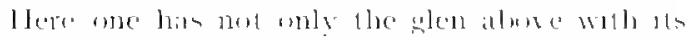

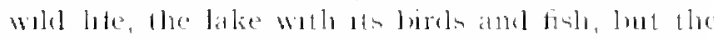

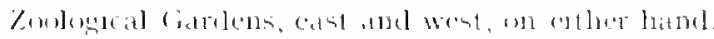

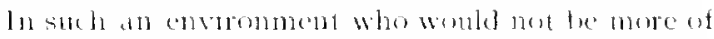

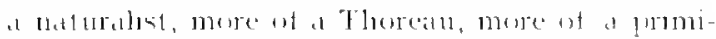
tive, more of a clude . Anel woulel nent thes be

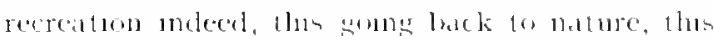

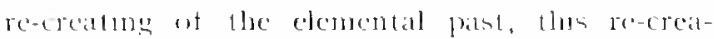

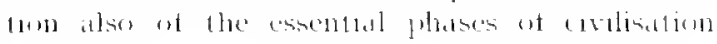
ancw?

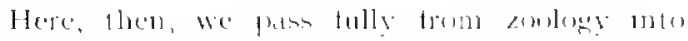

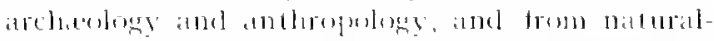

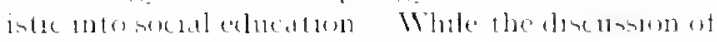

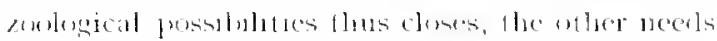
t. If $11=$ freatnent a tresh chepter Xill. 


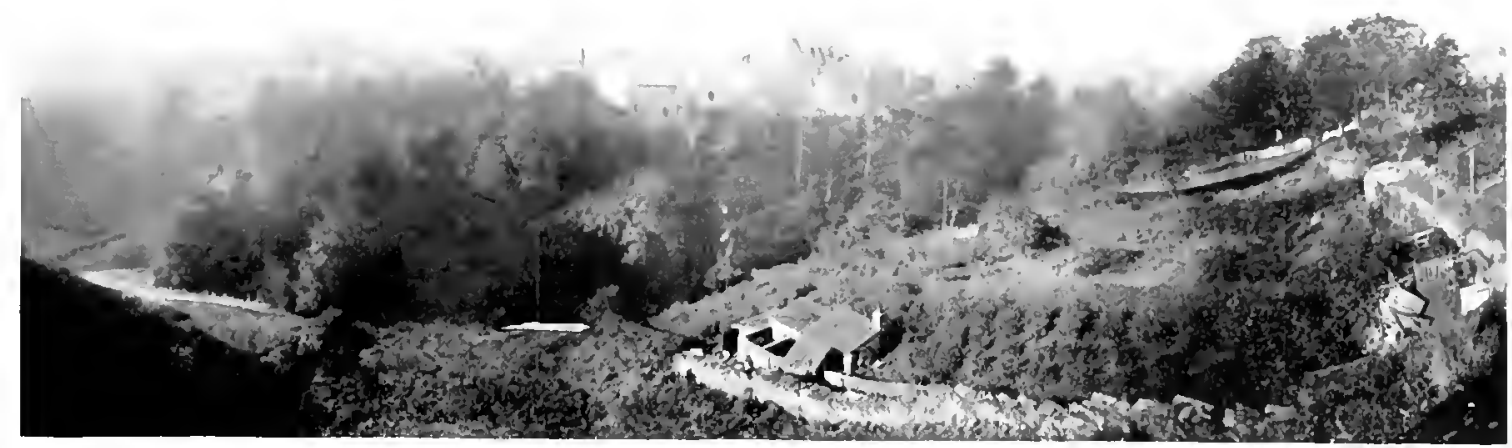

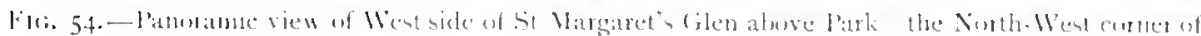

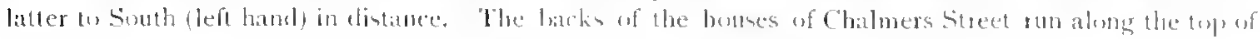

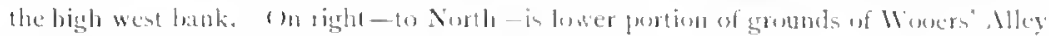

\title{
C. STREAM AND GLEN
}

\author{
CHAPTK XI
}

\section{STREAM PURIFICATION AND ITS RESULTS}

It whth be rememlered that the inirial polle inprovement of our approuch was of the widened stream Chap. I., figs. It to 10 ; but that this was seen to be impracticable-indect, all cilen improvement impossible- without the purificition of its central essential element, now so deplorably contaminated, the once pure and beantiful hill stream. To treat this, then, we must overleap our park walls and follow it, if need he, to its scrurce. This ctear, we can then, and only then. speats of improving the cilen at all. but as we bave already seen that at least hall the value of a park lies in its approaches, here is, of comse, the main, the natural approach; more than ever we must leep our eyes about us for sucl collateral and convergent improvement as its banks may afford, mow in pleasant nook or in spot of moble associations: or agatu, in larger epen spatces of rest of play, the more sime these are necessitrily. connected with our main park ly the finest ot natulal parliwys, the varied cource of the stream itself, with its incessantly changing landscapes. Thus, then, we are not leaving oul l'ark, but llatually continuing it along with us upstream, realressing its present sadly depreciated value, and enhancing this with each practicable extension. We are not expencling our wealth, therefore, hett investing it in real estate. and this in the fruest increase of heanty and use, of accessibulity and varicty, of recreation and health to the generations of the future. Here it is again possilles, and surely, if anywhere, it is desirable. to he pionecring ahead of the wants of those to whom the present molest limits of our existing l'ark walls may seem sufficient, or who may be satistied with this present improsement of t15 own quatres of the enty without similar concern for the larger yuarters to northwarl.

\section{A. Parks and Playing Fields}

()n our first umpression Dunfermlne may well secm amply suppled with publac parks, and this cren as regards consulerable future extension of popplation. Yet if we look again trom the stanelpoint of playing-fickls, avalable especially for the games of loys and young mon a matter obriunsy not only of recreative unterest lut of the mest definite hygenic mpertince, of ceonomeal sigmencance also to the working power of the pepulation, imelispensalsle tore as at safety-valve for encrgies which otherwise fimel less desirable channels-we sec that Innfermline as fet has practucally hatelly any park at all. for neither

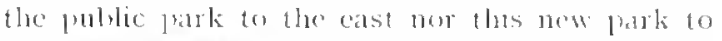

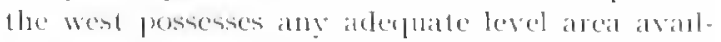
able for games. To level such spreces would, mereoser, cost a great deal, anul would sertesusly deteriorate the new parti for ather purpuses.

the ambignous term of palk may, mefeed, tor the moment be usetully absumened. We have pleasure grounds of the rarest extent and heabty. but these are really leisure grounds, not playngfields, and they should be as far als pessitsle preserved tor their watural uses. Therr alpleal is 10 childhood, to maturity, to age; and stech fevel ground as they possess should be preserved for the grentle games and recreative atctivities of the garls and the large working-woman populition of the city, and practically not offered to the young 


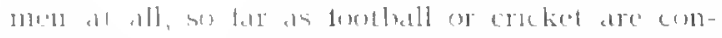
armed.

Even trom the fonnt of view th the jocsent ent much more from thett of als explublenes onc, thes lareger park problem must he speetsly laced.

Betore dome the let us notice the actud re-

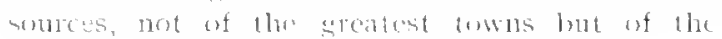

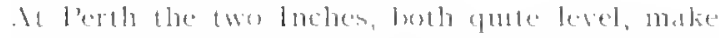
lup an atea of tully 175 acres, and at surting the park area is just uncler 20 . In this way at will

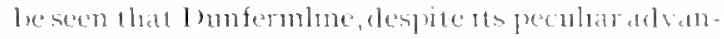

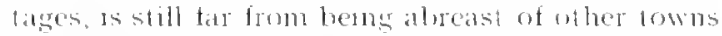
as regatrels gratis, moch less ahead, an the real

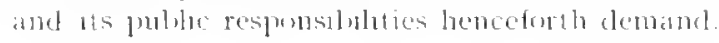

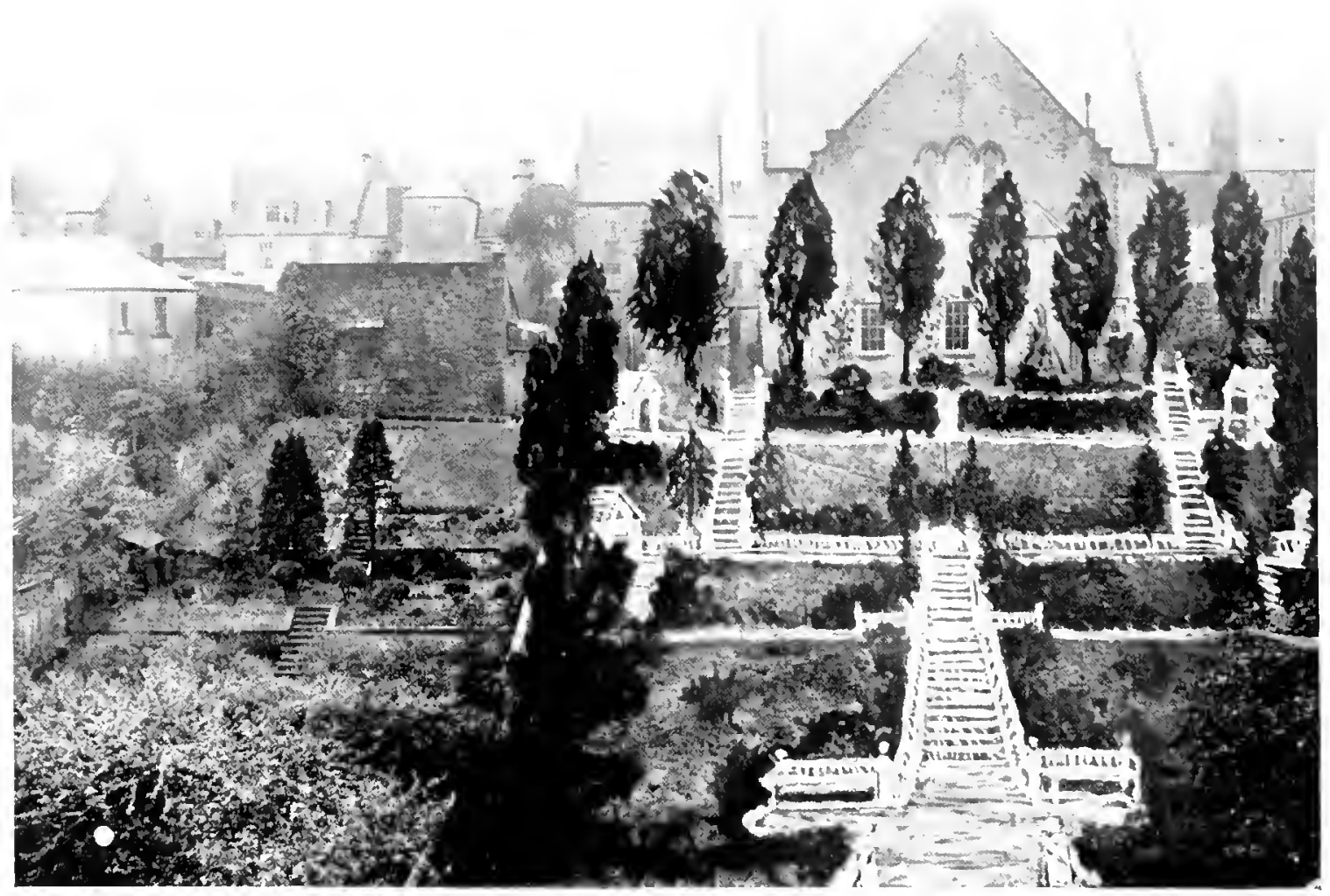

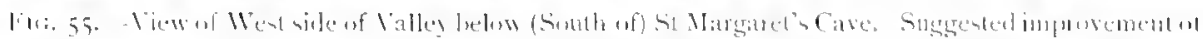

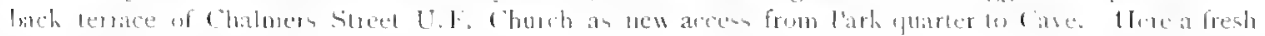

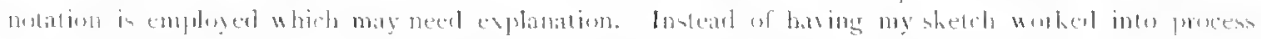

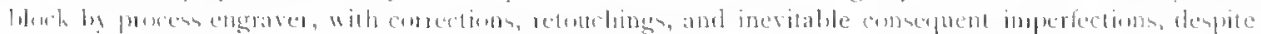

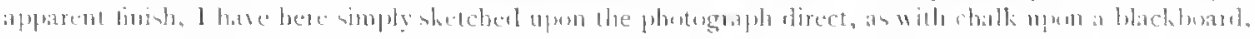

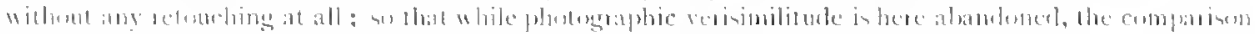

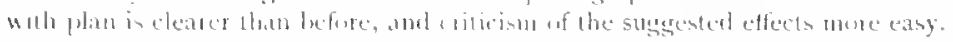

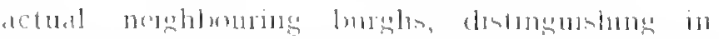

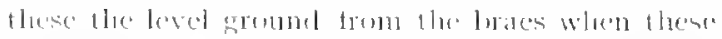

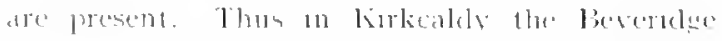

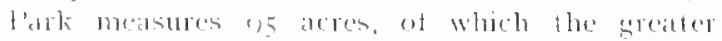

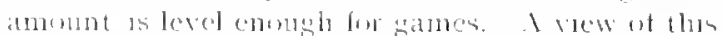

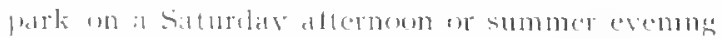

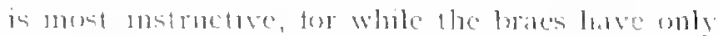

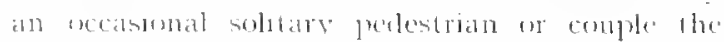

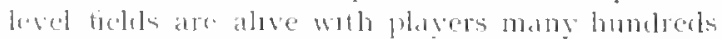
stromer. In short. lever sround is for athletic purposes alome of reat use, greatly thomeh undula-

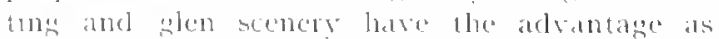
resinds beantion,

latssing of st incliews we find the lonks amombing 10 neatyly 3us atres, whth seatshore wallis an luth eliredioms fractically witlout end.
D) t them, in vicw of this greatl public actuistuon so recently mated venture of propuse yet further extensinm, whl corresponduner responsililities,

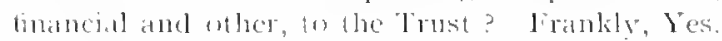
I see mo sacape frum this. I camot hesitate to urge thes in twe dereeterns, luth north and soutle of the present now park. Let us begin nothwat,

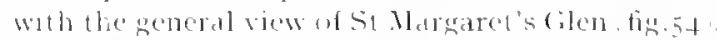
lu the tust place, I strongly uree the acquistion af a path, as far as possible doulde, on carlo side of the stream abure bribgestreed indeed, thas as tar as pussible alone its tributaries; also so suplyoung prabually improving accesses to the district of Baldridge Bum, as well as Brombland and heyond. I plead for the acquation also, ats opportunty may ofier, of ground on either sifle of this proposecl 
path. This would fumish, here it mals lo only space tor a seat surrounded by a fow trees, w there for a drinking fountain or the like. Igain, a bank may be plinted, or a level sile reserved from buikbng for a bowling green for men, or a tonnis court or cropuet lawn for girls. It some other point a small field may he reserved tor school or ocasional music, and so on, an lorm the habit ot coming ont of dorots a little more largely for in with her little ones and rould loring lure nocellework or knitung in luer hanel, yed with the cor latiaty al casily returning withoul fatigne we prepare the midaly or eventing meat, the game of bodlily health and mental serenity womld be wreat

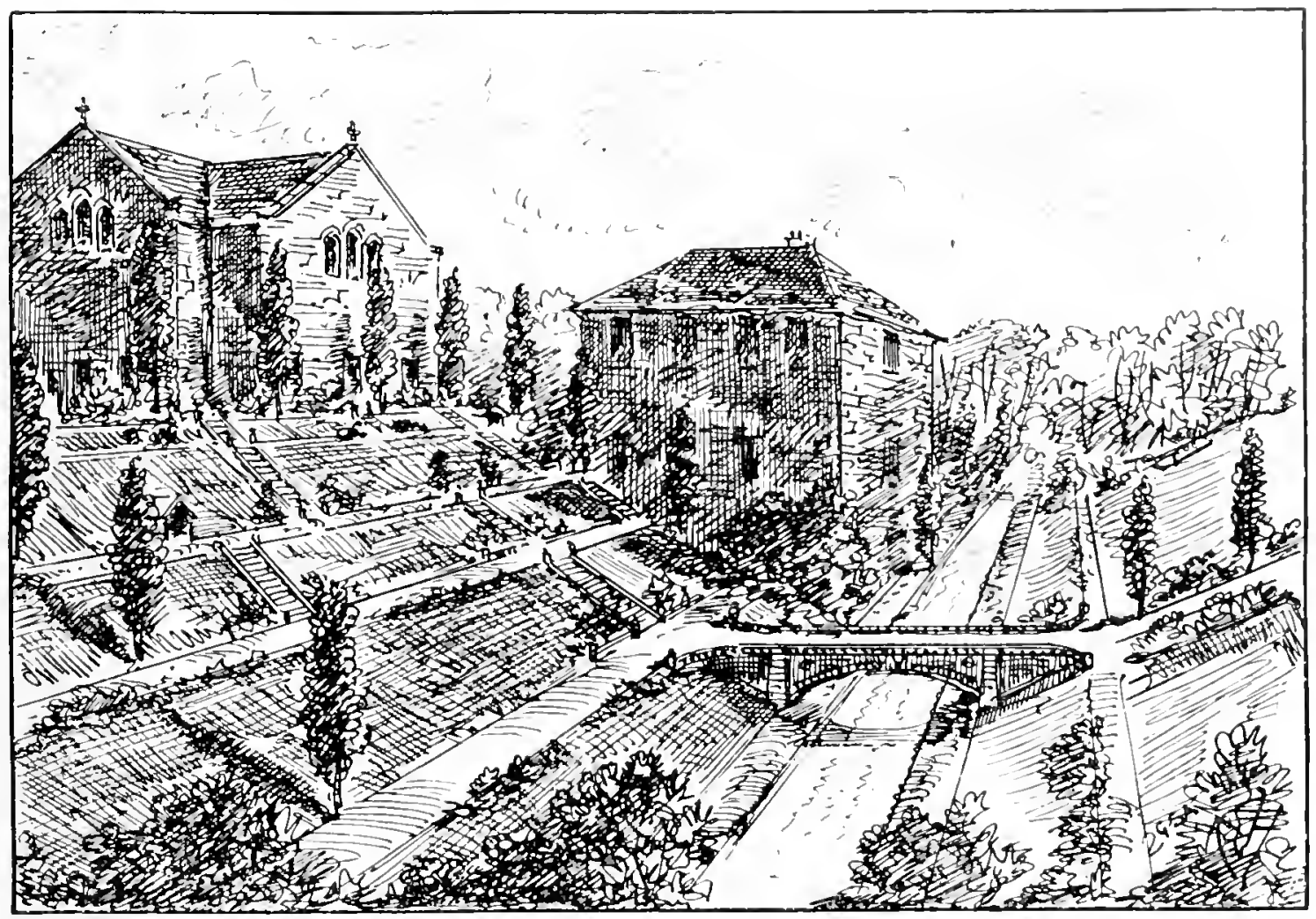

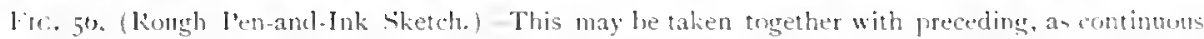

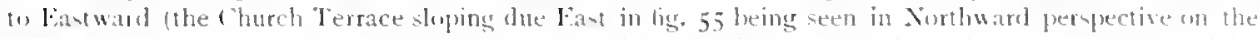
lefi sile of fig. 50). To the right of the strean and in the distance lies the Saint"s care, emvinoned l,y

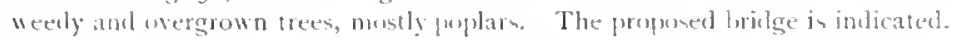

for allotment gardens, while a larger ficld should now and then be obtained for recreative purposes for the games requiring ampler ground. Theso are not parks, however, of any grcat acreage. "The multiplication of a large series of open spaces, bowever small, will be increasingly fouml to les of greater lyogienic value to populations than is the mokern system of large patis at comparatively great distances. These the bulk of the population practically reaches only on summer eventings or on Saturday afternoons; whereas, 10 raise the general standard of health, we need many more open spaces easily accessible 10 children and within easy hail of home. Such spaces, ton, would be of immense value in tempting out the worlsing mother anch elder sisters with the smallor chiblren, and the provision on such spaces of ronferl yet open-air shelters, with comfortable seats, woult] be founcl of immense value in such wass. If the housewite conld be induced by juflicious example, and the home happiness notally increased. the proportion of illness dimmislyed also, (ven the actual hife expectation appreciably improsed. Not even all medical men adequately realise, much less the general public, of the too exchusively masculine municipal and governing hodies, how very large a proportion of the detective elements in our cily life, particularly in scotland, is due to the too great confinement of mother and hairns within the narow limits of what is actmally or practically a one-roomed home. with its leterionated air and its deficient sunlight and leauty, even where cleanliness and order are maintaned, and mach more when these, through aserewaling or the like, becme leficient.

\section{B. St Margaret's Cave}

I submit next that besides the donble path in

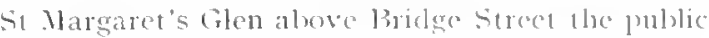




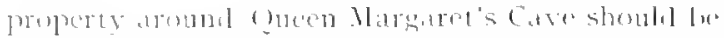

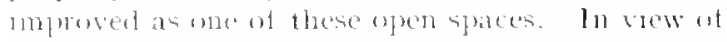

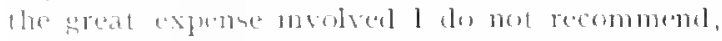

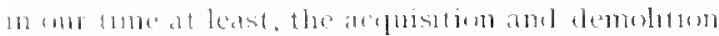

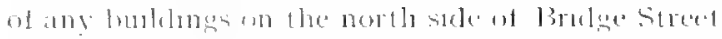
or "ren of Chalmers Street or Brme Street lt, ats

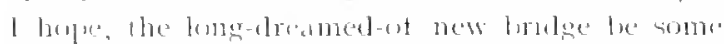

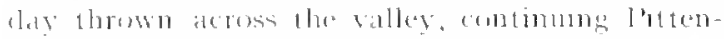

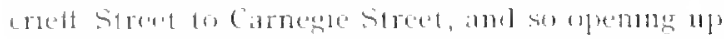

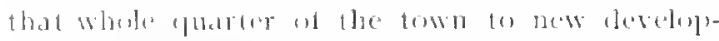
ment, alecesses at ear he end tor descent to the glen

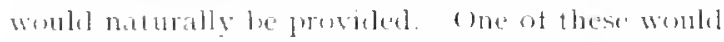

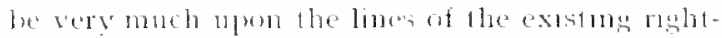
of way, the bate on which the choldren are chomber in my photograph fig, 5 . It as, af course, un-

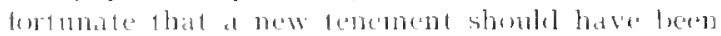

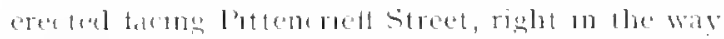

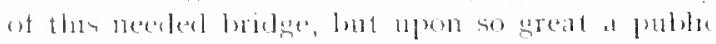

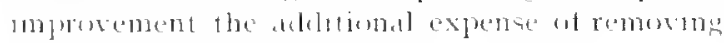

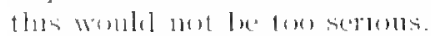

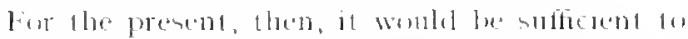

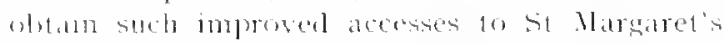
Catre and bilen ats follows. - That the Trust should acture from the chalmers street l'muled firee

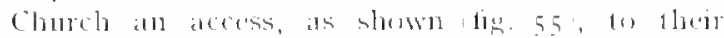

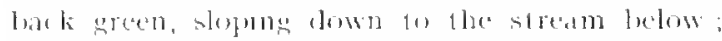
that the shomlel be terriced much at is the exist-

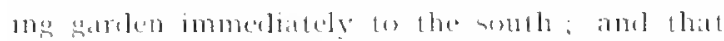
thus ly stoping pethe and stepsone should deseend

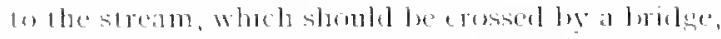
ethere communcaturg with the prommel of sit Margated's Cave already on possession of the cily. or leeller as tollows.

I truther uree that a simbar alpplicaldon be mate ly the linst to the liree church oplusite,

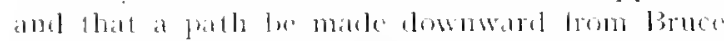
street thromgl their betek srommet to the stream, and that this new lorelece at the buttom be mate

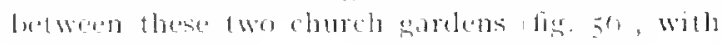
patle to cirve.

The result at this simple and comparatively mexpensive imporsoment womld be thatl the

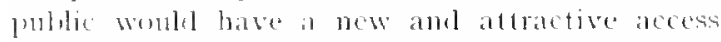
trom buth sules for one of the most inferesting and himferic spots within the city, one at present

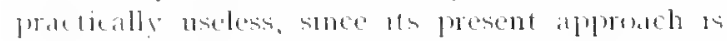
nos only obscore, lint sepualid amel reprellent

In this way, (x), we hould have loterally united

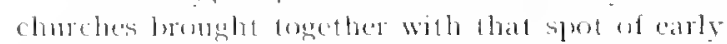
tratlitols on which all the various denominations

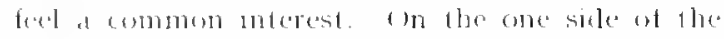

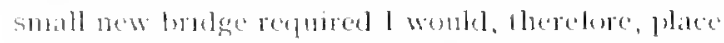
a carved pand, learines on ane ste the emblem of

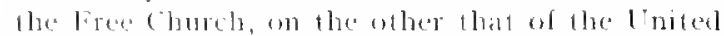
l'resherertan, and in the malder there present conjoint symbel. on the north sicle. towards st

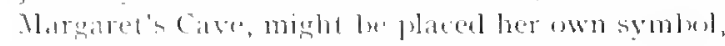

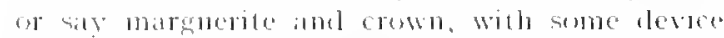
commenumative of the celtic Clauch on the one

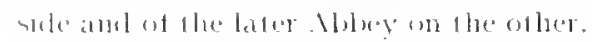

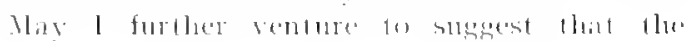

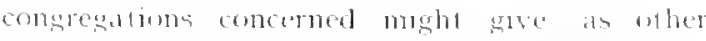
riparan prepriefors bave alreaty expressed their

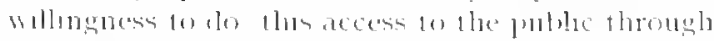
the Trust without charge? The woulal themselves

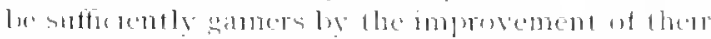

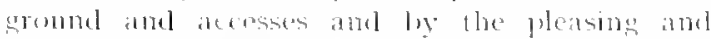

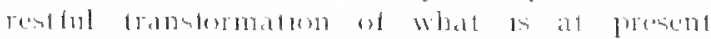

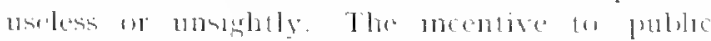

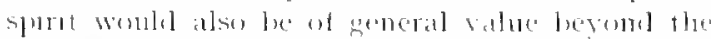
congregatems concerned, and might latel to other

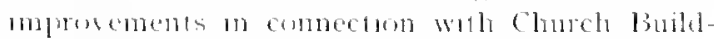
mos promed throughout the fown, such as vill

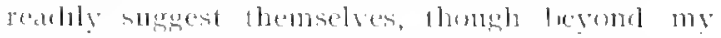
linuts bere

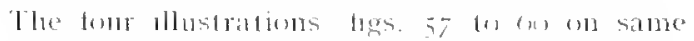

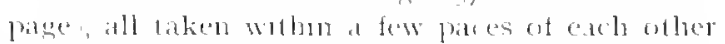
on the west bank oppusite the cave, will here interest the reater. That supply of clust lo chaldrend lunge, ly wheh our present urban

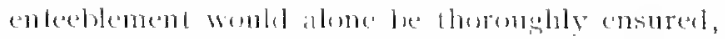
will be moled on the lett above: whike of the stream treatment the two stapes of development

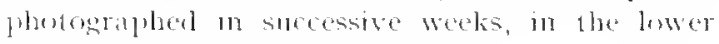
tinures, surely neerl no comment.

\section{St Margaret's Garden}

l'asing now northwarl of the cave we note luw the tall trees of this grouml have completely spuled the gatren atjacent, whech now les waste. Thus might surely be casily alefured, and slould lx platuled with elder and olher shadeloving shrulus, thus derenenimg ret further the

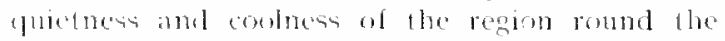
calve. The brings wh to the square-walled rum, that of an old weaving factory, now long disnsed amel rontess, whth a natrow lane to the south and some tumble-town omblouldangs to the east Surely this minht be acepured for lithle or nothing What shonld be dome witl it?

I whe the rotention of thin rum practically as il stamble and its trealment as tollows:-The walls 16) the pointed with cement, the tope especinlly cementerl so as (1) prevent firther dibupilation. Iry then should be planted on the ontsides of thes. The natrow alproach might eassly be witened, of comrse by clenublishing the wall on its south. Epom entering now low the extsting forway a spectacle of tesoldton presents itself, yet here are elements of ercat pieturesineness amel subtability when franstomed as melicaleel me plan. The valle upen the mutrot show the recesses of winlows now walled nu, and these migha casily be adapted in bedige wall fllants a method ot ereal

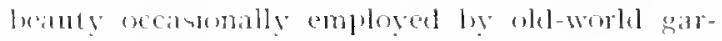
demere mo less tham lig molern ones, wimess Ealedl castle near brechin.

The interos space might easily le lombly into culturalion as a fluwer gatrdem, amal this l propose to treat in sigecial commemeration of our leal

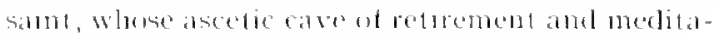



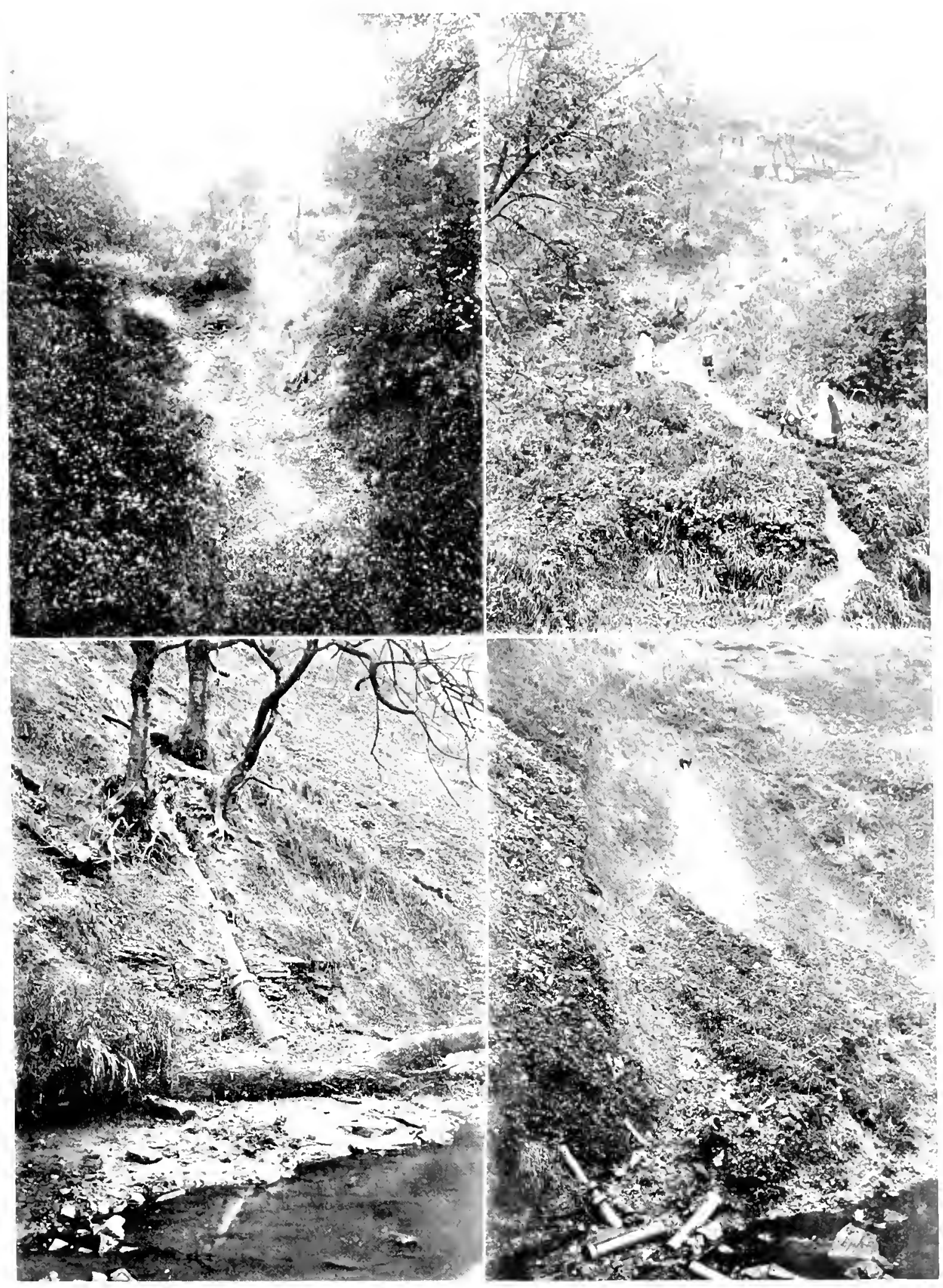


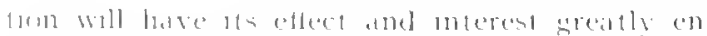

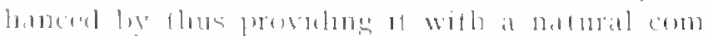

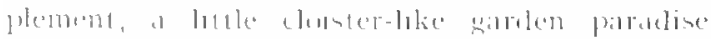

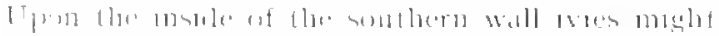

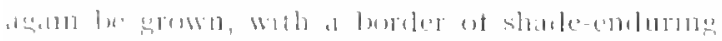

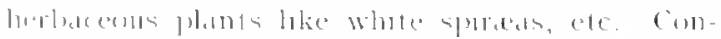

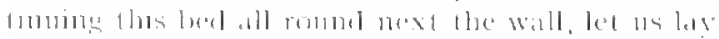

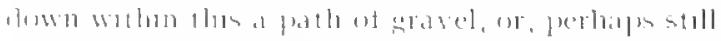

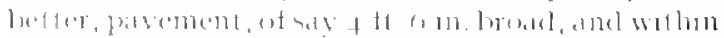

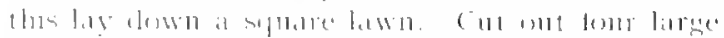

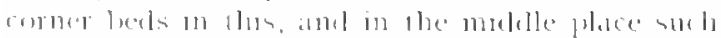

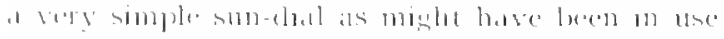

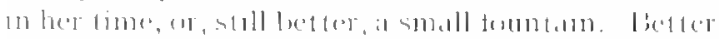

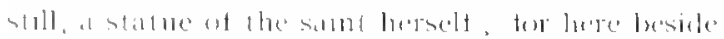

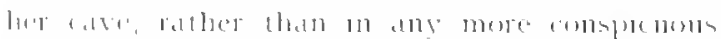

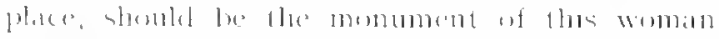

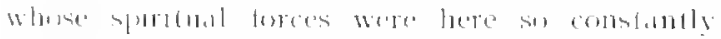

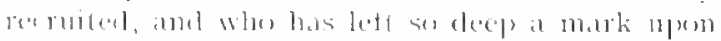

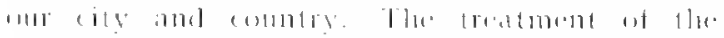

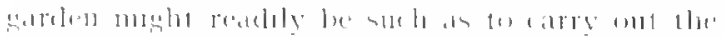

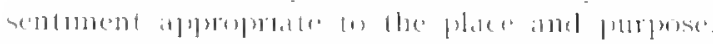

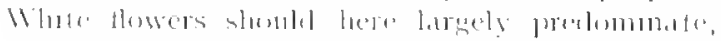

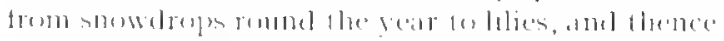

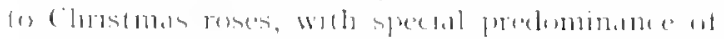

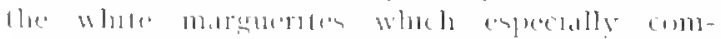

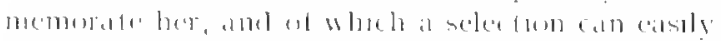

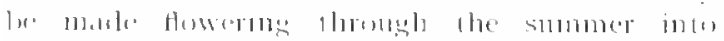

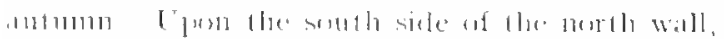
which o.

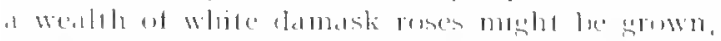

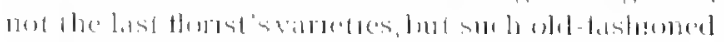

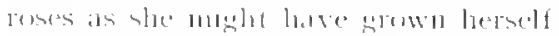

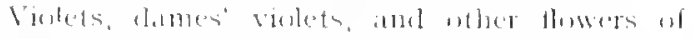

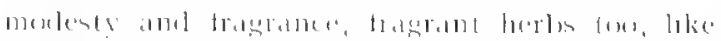

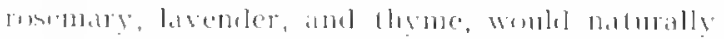

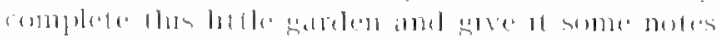

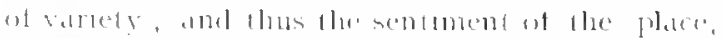

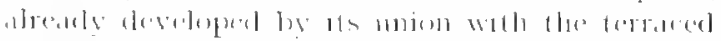

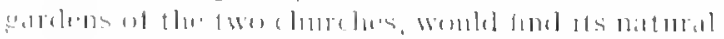
inmpletwin, and inax

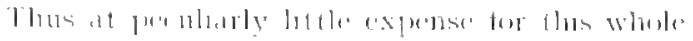

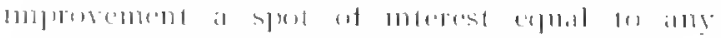

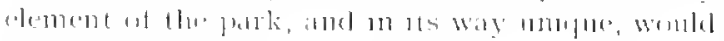

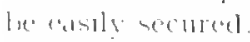

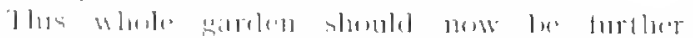

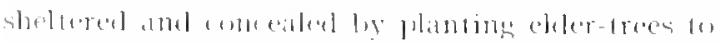

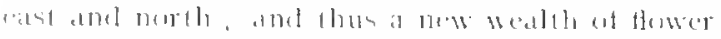

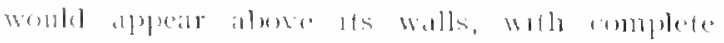

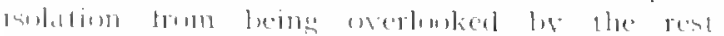

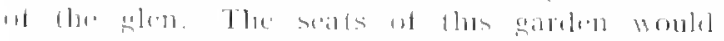

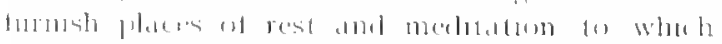

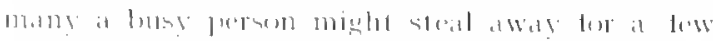

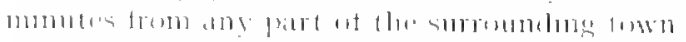

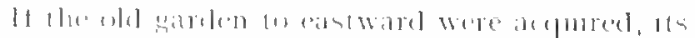

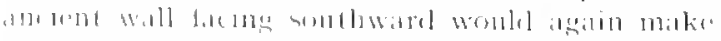

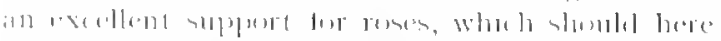

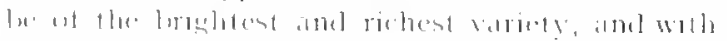

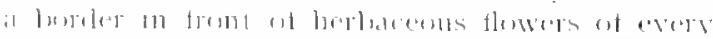

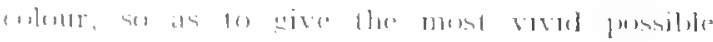

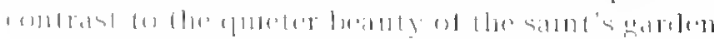

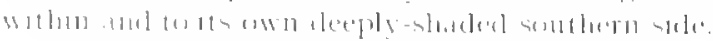

\section{The Toom}

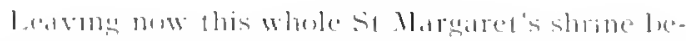

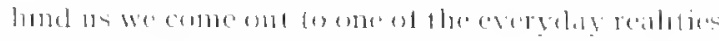

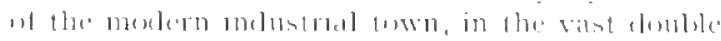

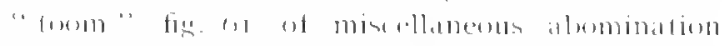
and rublush whell is all present, perbalph, the most destessing anel discredilable teature on the whole

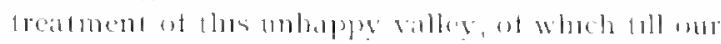

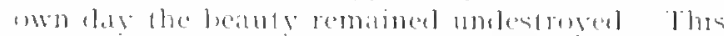

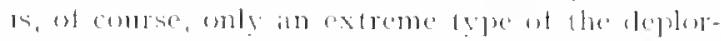

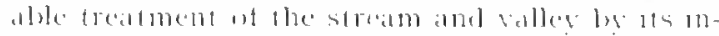

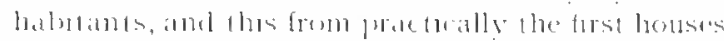

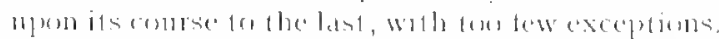

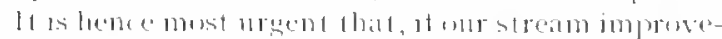

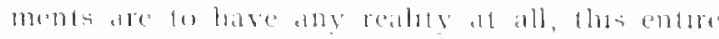

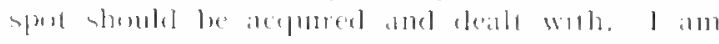
aware that this form meens a real moed ats a plare

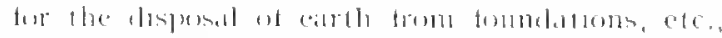

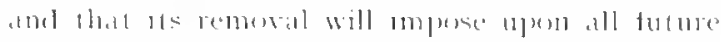

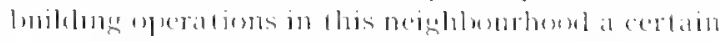

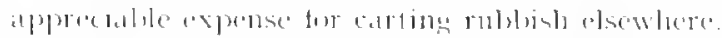

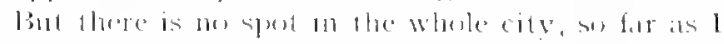

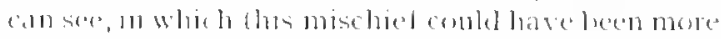
deststrous, or of whide the imprestement wenth

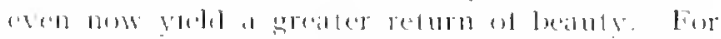

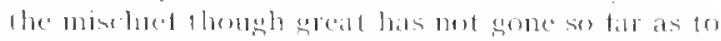

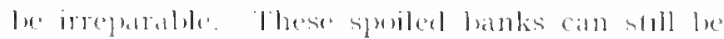

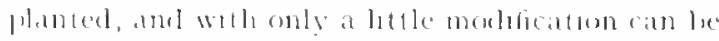

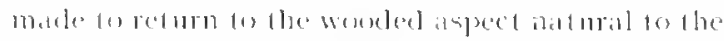

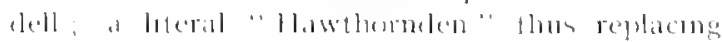

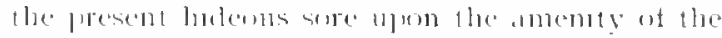

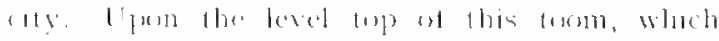

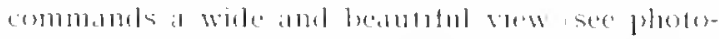

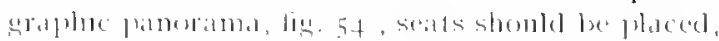

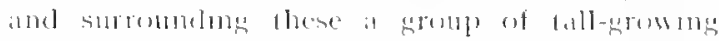

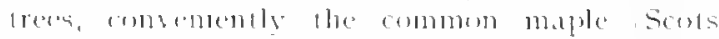

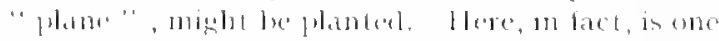

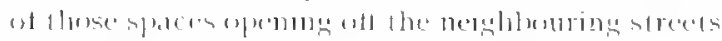

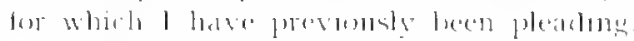

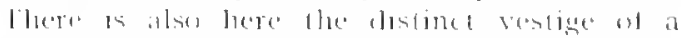

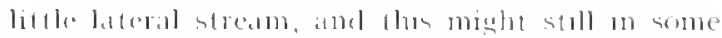

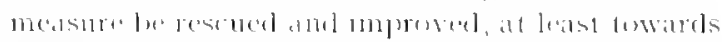

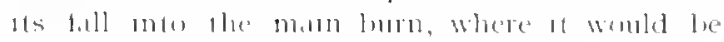

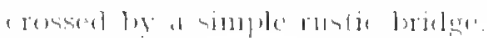

\section{E. Improvements Up Stream}

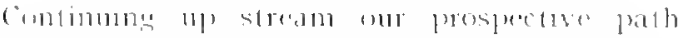

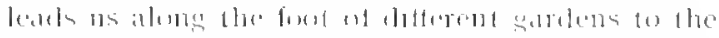

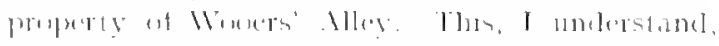

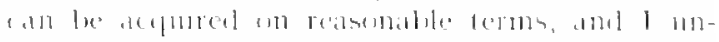

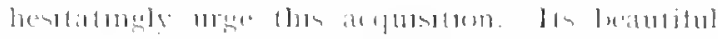

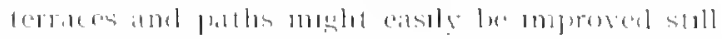

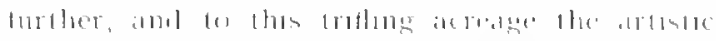

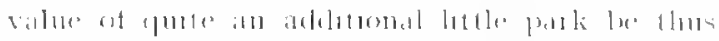

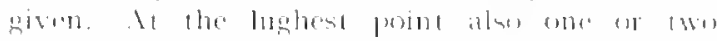

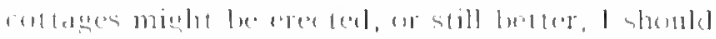

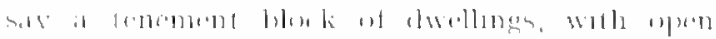

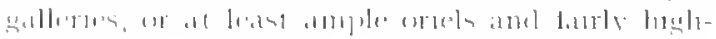




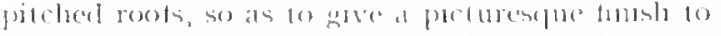
this otherwise at present rallue combused rotner.

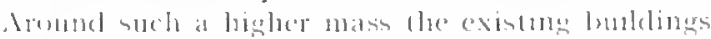

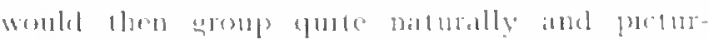
(sicpusty.

l"pon tlase opposte sicle l have ventured to converse whth two notghbouring proprietors. The ome

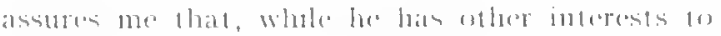

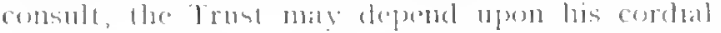

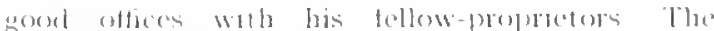

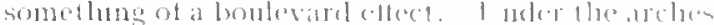

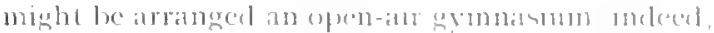

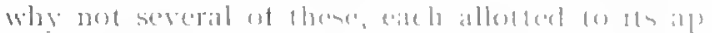

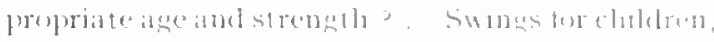

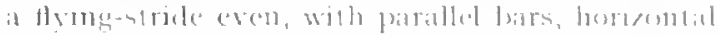

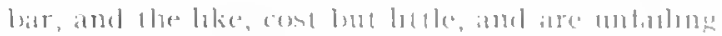

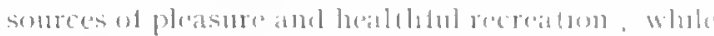
a tew seats at the marem wombl be wheome, not

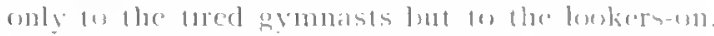

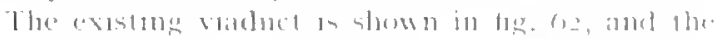

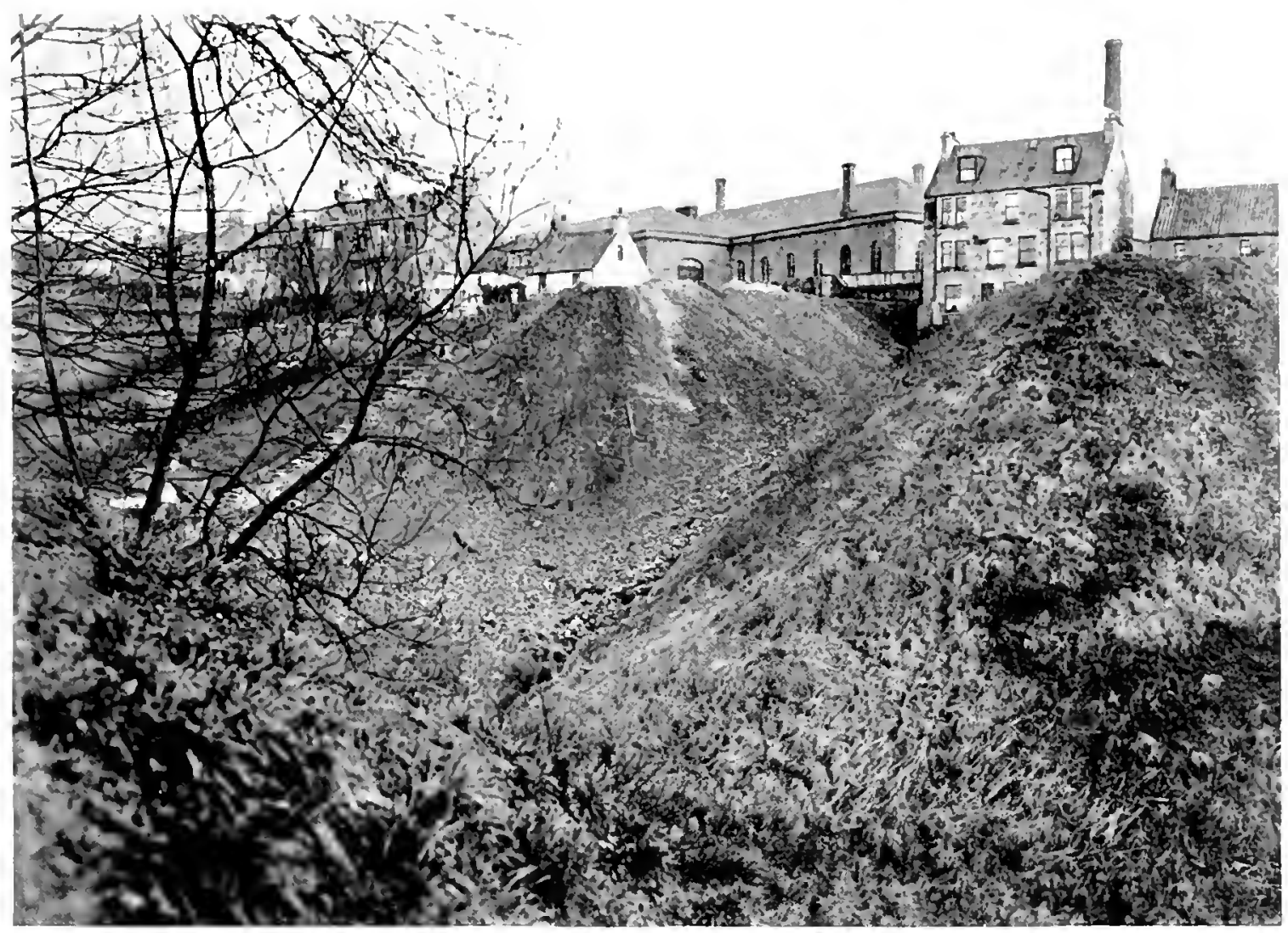

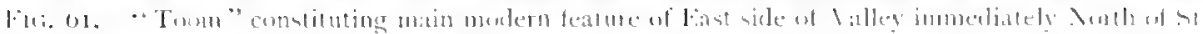

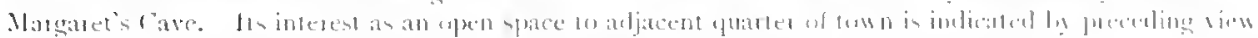

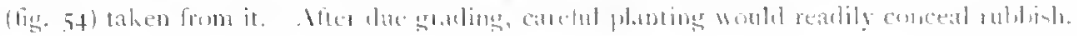

next proprietor at once anthorises me to inlorm the Trust of his cordial willingness to give ouf such a pall as is desirable along the whole botwom ot his property, simply upon the natural condition of the Trust comstucting ats path wilh such relaining wall ats may be needed to keep his garden above from sliding oft into llye stream, ancl to protect him trom numbited rinitors.

Leaving Wnoge' Hev we cross the strot at Buffe's Brae, and mote opposite the fine ratwir vialuel, with the underlyng aromel bappily already the property of the cily. This ground I urge should be partly employed tor widening the streel, with trees planterl so is to give at least improvement bere so easily pussblate inclionted an the tollowing figr.

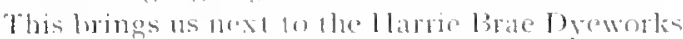
and ther outying grtsumd, at region of many pictur-

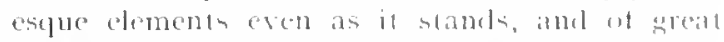
pussibilities. I must agalin strongly mane the are quistion of this property, alike ats at grealt element

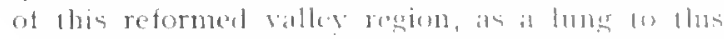
whote neighbourhool, and, of comse, also as a means of removing the almominable pullution which constanly surprises the vistor of Inllen criefi latk helow - the stream sudedenly coming

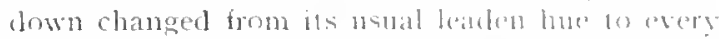

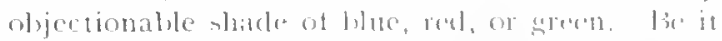

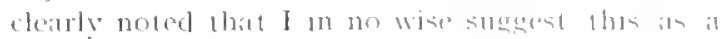


mere unremunerative outlay to the Toms ty"

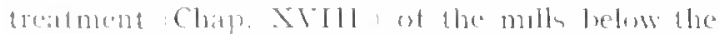

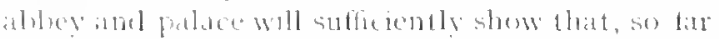

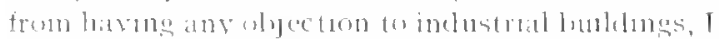

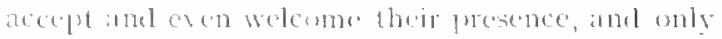
prese tiret employment on wayn combistent watl

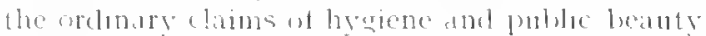

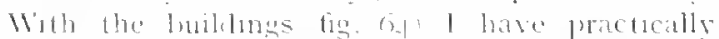

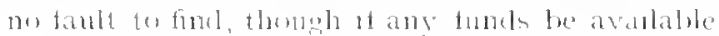
for there inpormement l should reathly undertalie
This now leats us to the groment of anel street ot

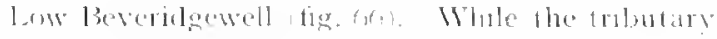

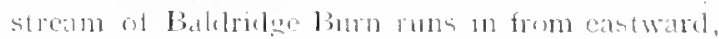

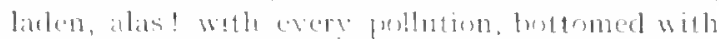
froken crockery and askes, and intermoted hy ton

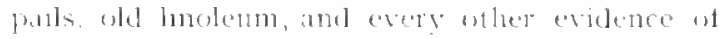
latereal cirilisation, here the math stream is curered

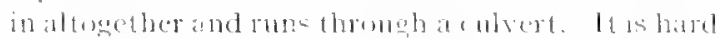

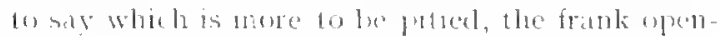

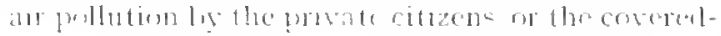

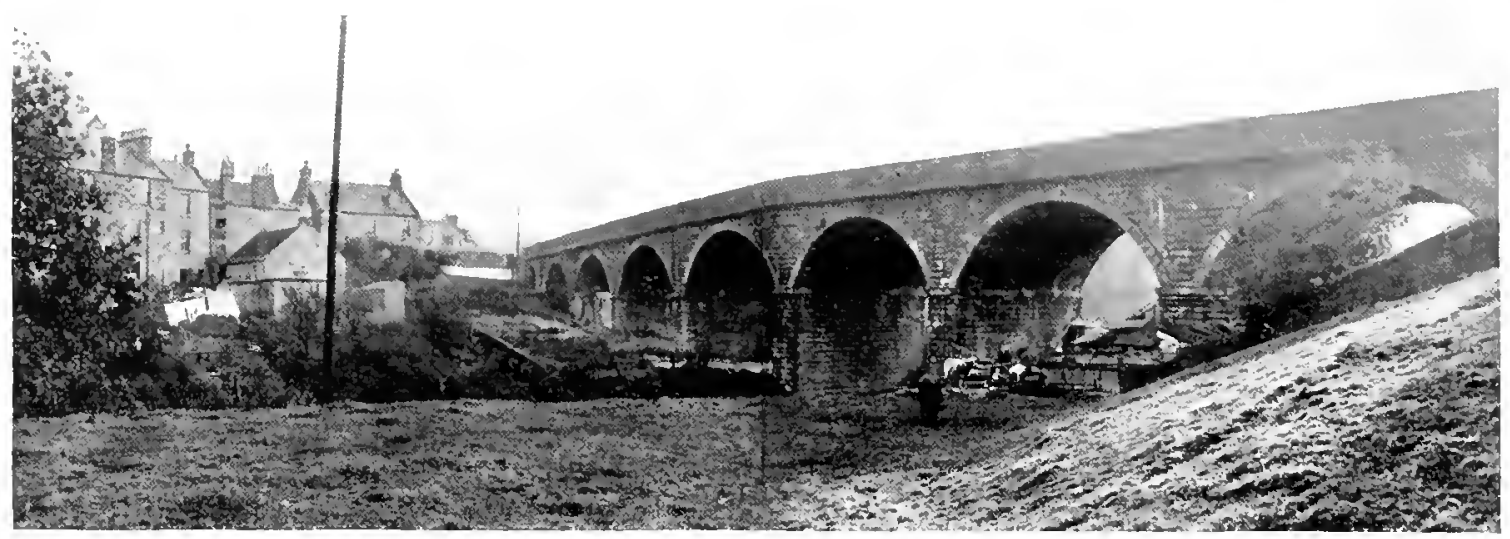

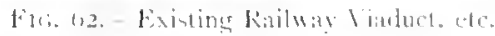

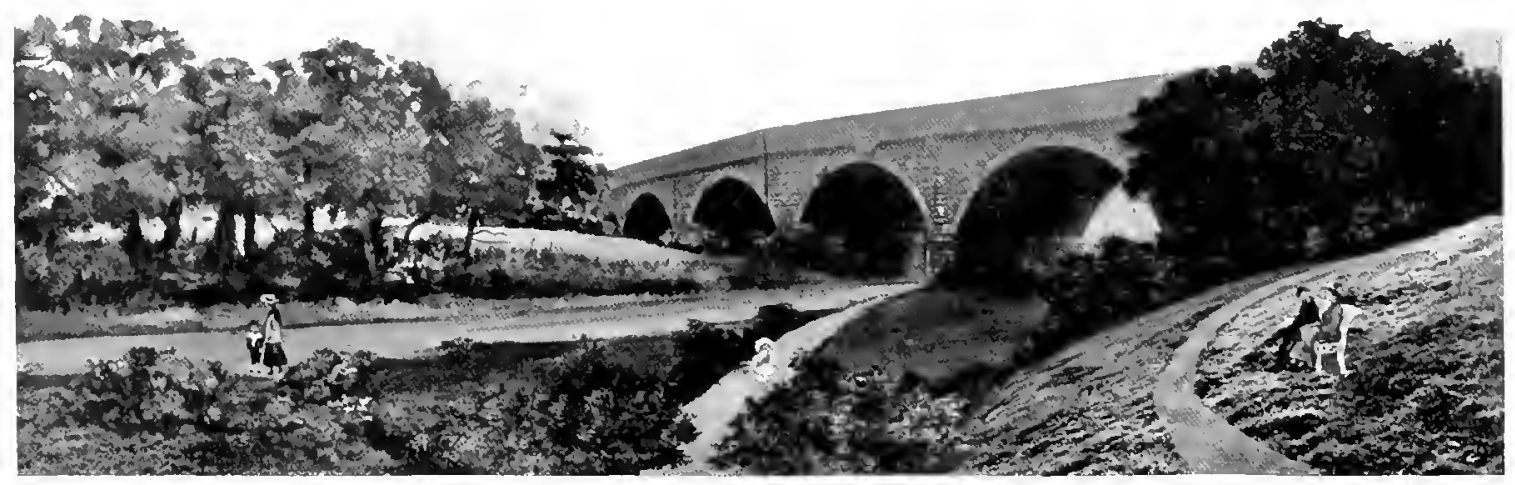

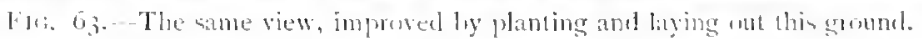

to merease thetr picuresqueness, as I trust my destens de, for the mills of Momasters Street; non neerl the various spets of bullelung eround which thas property might yelel at speculative proprietor be neslected by the Trust. I would recommenel their buikling on them much as he would do, yet ger increased picturesplueness with it all.

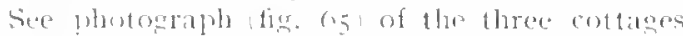
tor the "ast of these dye-worts. There is no romestic groul more picturestue in Dunfermline, red theer is nothing to which any arehtectural expense or ormament has been aldial. in scwer treatment which we owe to muntelpal art litte matter if, as is obrionsty of elementary necessity, we correst both. Ip Baldridge

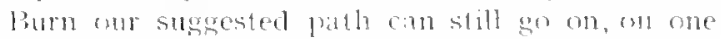
wele at least-that of the iron worlis-amel farther "1) perhaps on hoth again The cleansing ot the stream here as elsewhere is of no great difficuly w expense, since the remural rublish need not even be carted away, lut can be decently luried in deep luses due temporanly for the putipose along the bank. While the stream is so utterly dirly noborly need have the smatlest mompundion about 
adeling more dirt; but, per contra, let the lrust cleanse the stream, in due co-oferation, nos douln, with urban and local atuthortese, and thereafler the better citizens at least would think lwice before they wemlel again do anvihing to pollute it. leon the arcatomal oflender the continutal passers aleme the proposed fath would latre at ertian morill etfect, while even the hardened oblender might be reatily dealt with without legal or polsce interterence by the simple vet jungent experlient of phote. grapling her or him in the act (see my preceding fig. 58 ). The polite communication of a copy of such a photograph by the secretary of the Trust to its subject would generally be sufficient: if not, more pultlicity might be readily given.

coming now to the man stream in the culvert, I arlive that this be reopened and the stream condiretel no longer in the natural course, which is filled u1 for good, but along a regular and formal basin. The street is here loroad enough 10 give a sufficient boulerard, and with this should the undertaken the improvement of the loneneglected-looking hank, which, I understand, has been actually offered ly the proprietor to the cityon condition of some such general improvement. I understand that the expense at the time deterred the city from undertaking this, but the Burgh Engincer's plans exist, and might he readily revived - it may be adjusted to the larger scheme 1 am now advocating. The Trust need not, of course, relieve the city of the whole axpense. I an far from suggesting any violation of its fundamental instruction in the owner's letter: but only that in view of the resultant public space at 1op as well as bottom the Jrust mugh fairly undertake that difference of outlay over and above that of ordinary street improvement, which detcred the city on a former uccasion. The (1)portunity here presents itself of a fine piece of formal houlevard, a sheltered yet sunny promenade also. On top of the bank a small open-air gymnasium, a band stand, or holl, might also be crected with great advantage 10 the neighbourhoud. For the present, however, I leave my pholograph fig. ofit of the existing desolation io speak for nteple, and whbhold its natural compatnion-that of the scene transformeel.

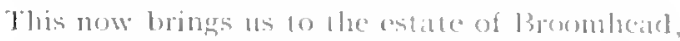

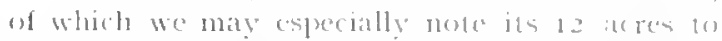
somth of the strom, its acre ar sis accupreal by stream and banks. The a acres of gardens and grounds around the mansion-louse, and the large field behimel, up to the conl-pit, maly tor the lime

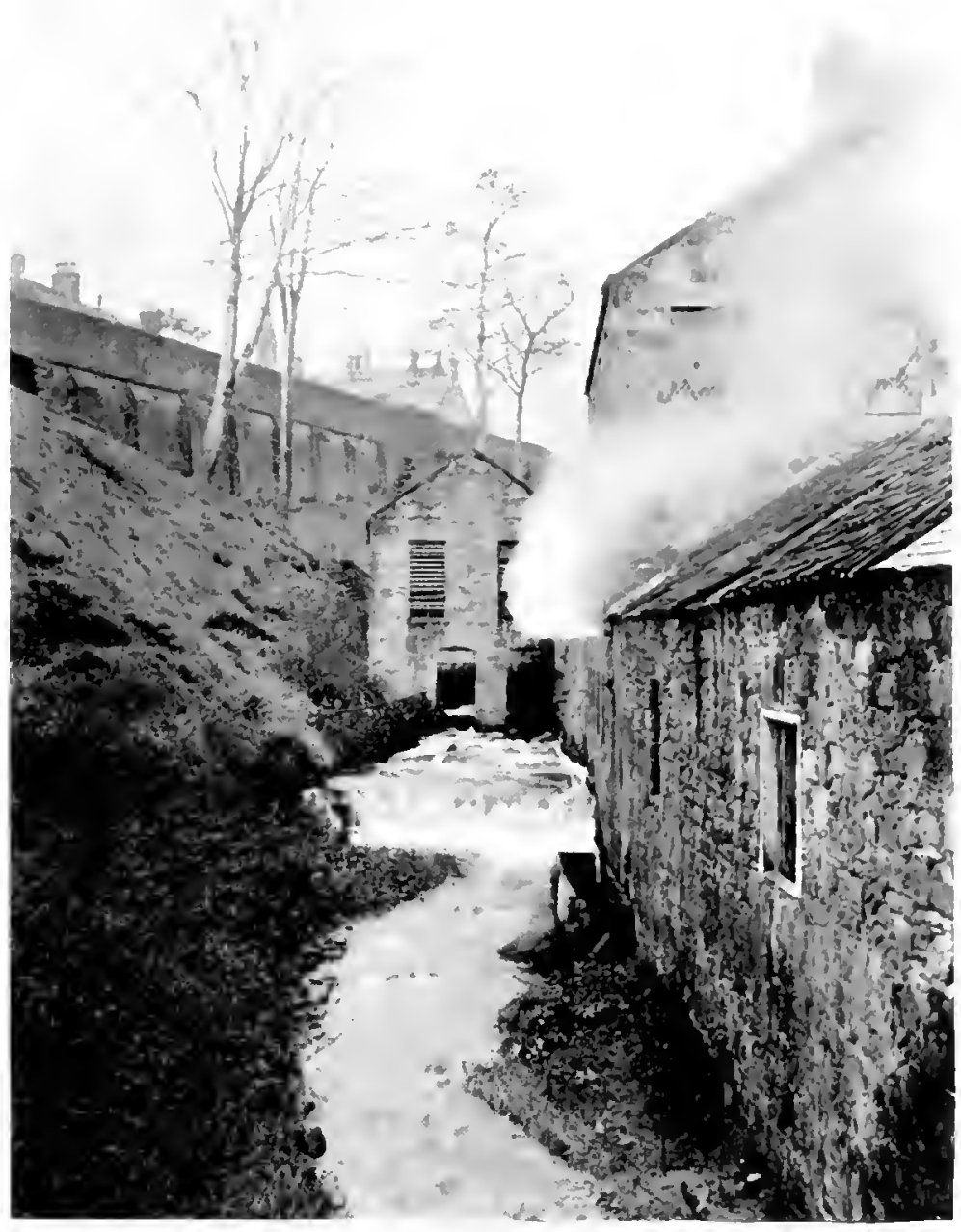

lin. 64. Ola l be-work atul Mills on stream. be left out of consideration, though any ludilding scheme in which the Trust maly entrige would naturally look at these among uther sites. (If these 12 eomparatively level acres of Bromhead, with at least one side of the stream, if possible both, I strongly urge, luwever, it not the inmediate acquisition, at any rate llwe olnatinine of an option upon these, so is 10 present their passing in to the hands of the speculative builder and lecoming irresocably lost to the Thust. fin luere, nearer the centre of working population than the 


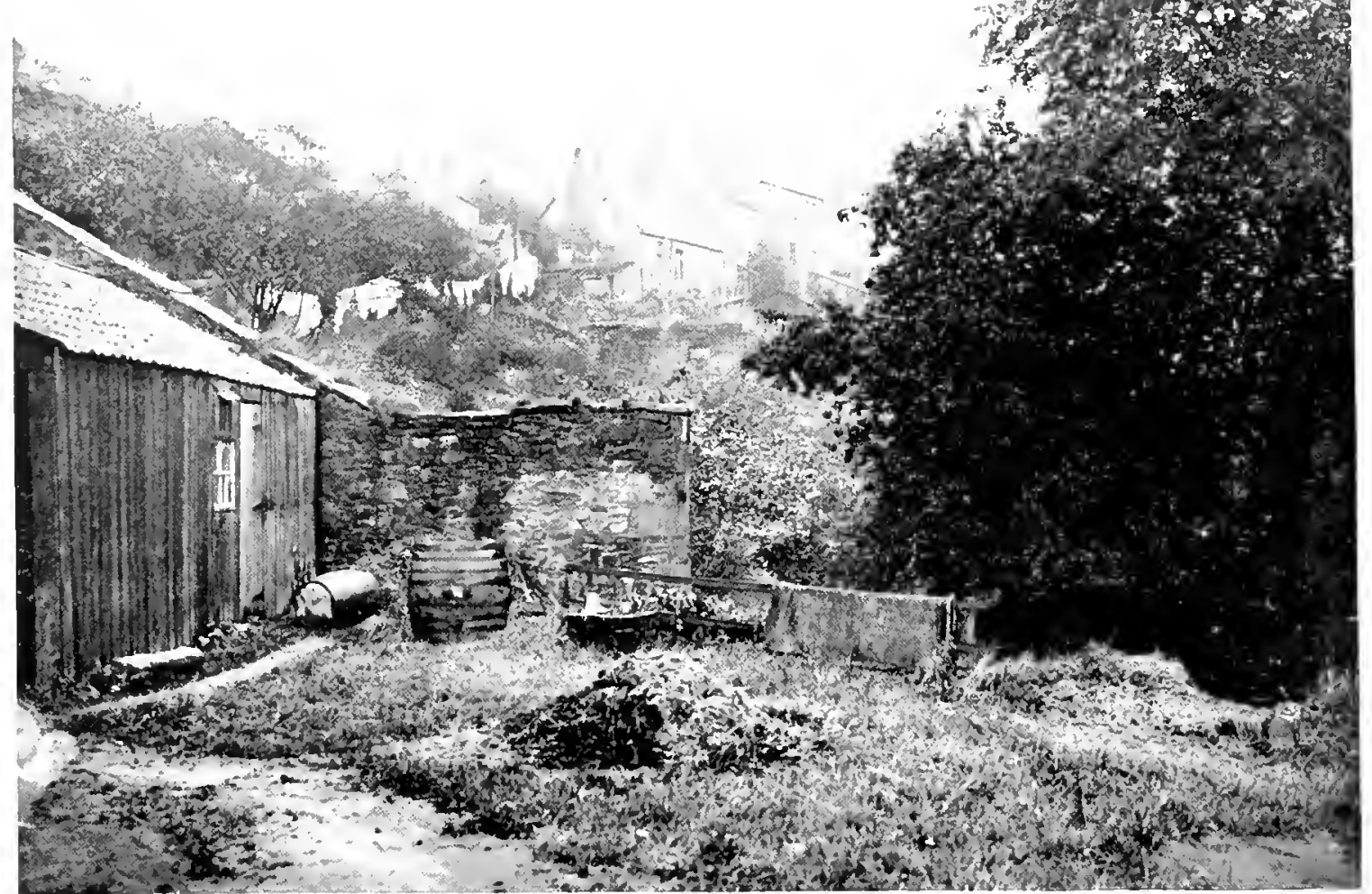

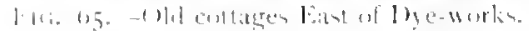

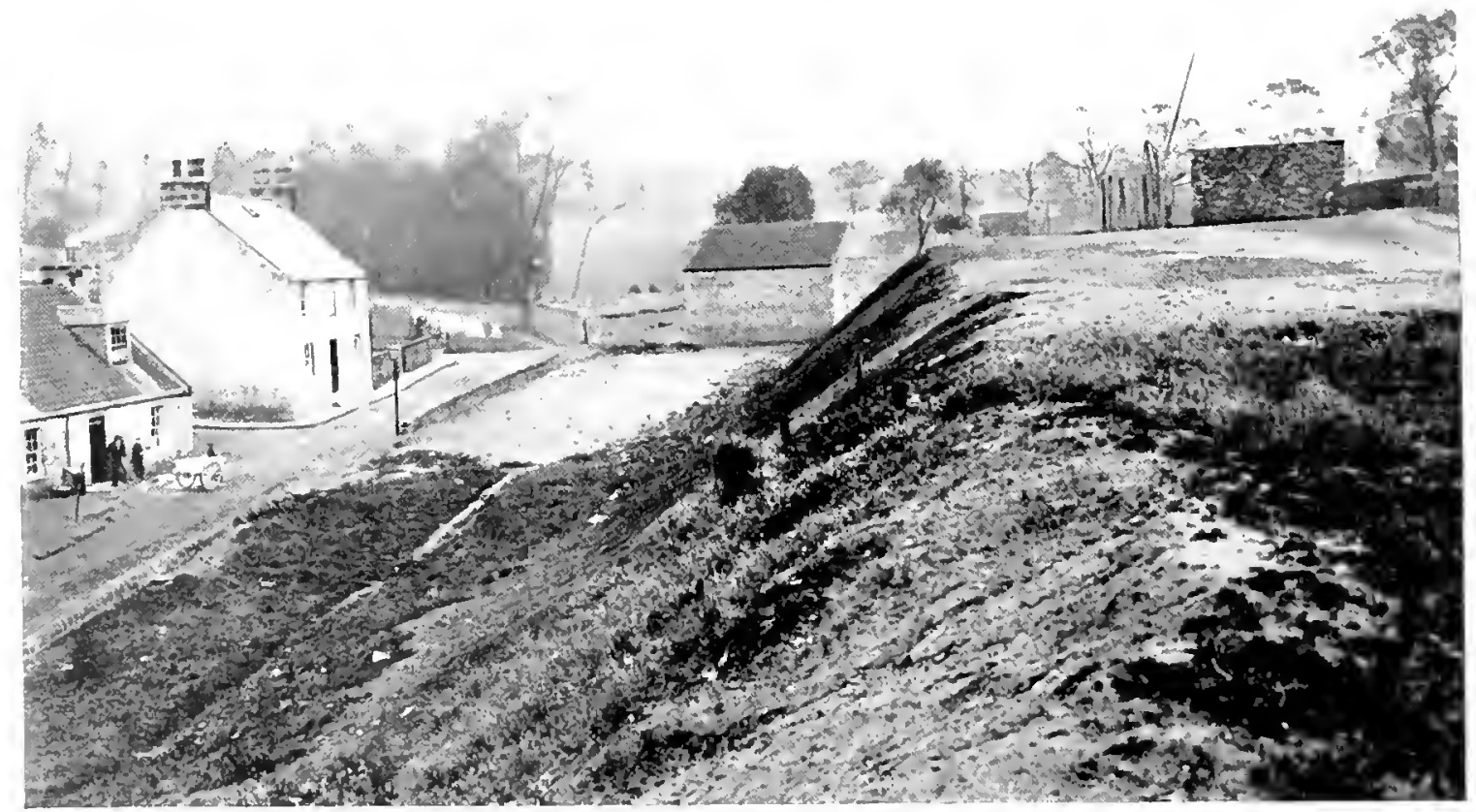

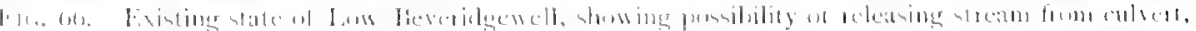

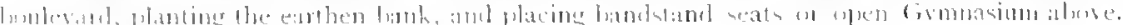



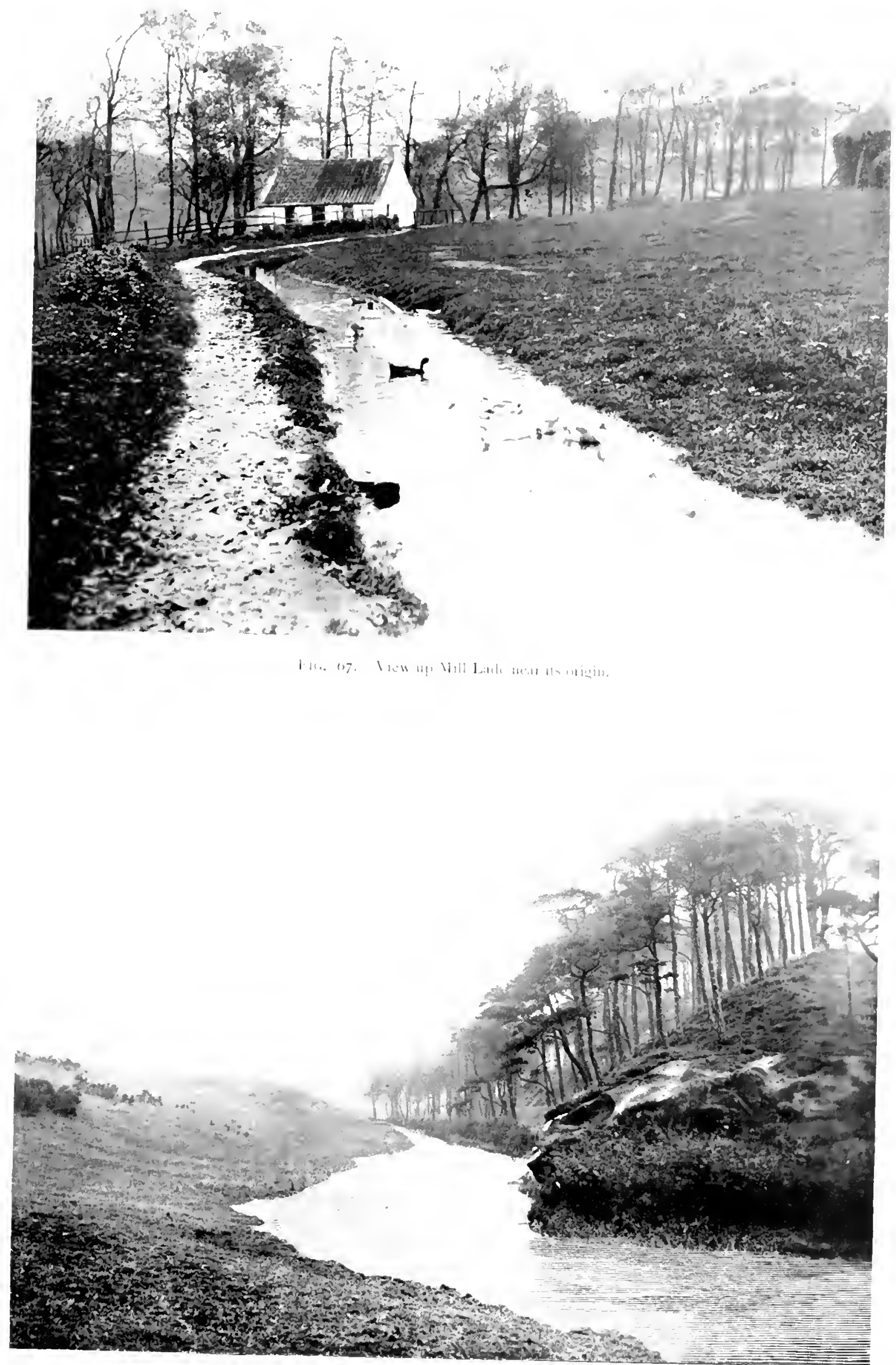


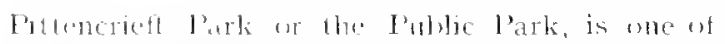

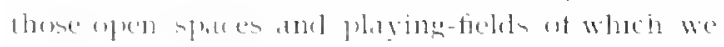

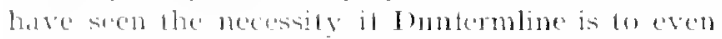

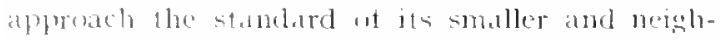
bourine atics. To mutieate the expense of this stound at certatin number of sillas might be teucet alt the Wellwoxh linacl to easward, and also one or two more, or exen a block on two of tenements "reetert on the level gromml at the south-west. thengh I must almol the ecomomy of such curtiuhment is open to puestiom.

leaving lorombeal, crossiner the Wellwoul Roul, ant continums up strean, we mole ly the

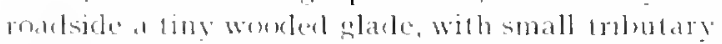
strombled, whoh might he maste a picturesque teature upon our double path. On the north side we come to the solt links, atong the tere of wheh omr path shomld surely easily le secured; white on the south we have the blendhing-worts of Messts Marslatl. These gemelemen allow me to report that they wall be hapyy we gront the Trust the

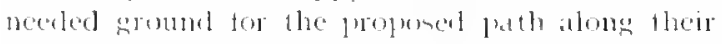
ten from just obure their water tank to their

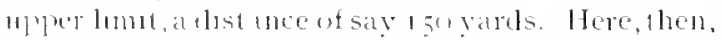

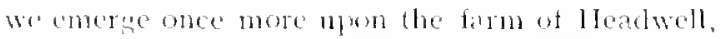
with its fine avenue leading eastwats to the Townholl Rord, an avenue which it is earnestly to be hopert may be bems preserver and matintaned. The care of all such spots would baturally become. me of those puble interests which might conveniently be undertalen by that citizens' union towhels which 1 ofter sugecstions Chap. XXXl11

ficepme, buserer, to the stream, or rather strik1n: up to the bate wheh rons through the town. and rejoms the matin stream in the glen below the Ahrey llobs, we fimel a chaming picture upon ats

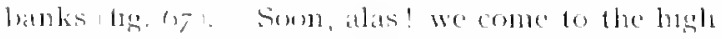
buted tences and notaces commonly sugeresting an ancent but desputed right-ol-way, the natural path from the city up to the Town Lach. Here,

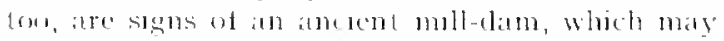

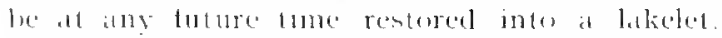

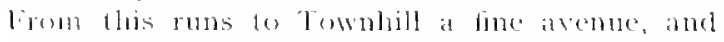
beyoud thes the preturestue and roky hank, with its seots pines, the tirst eximple of this movaluable

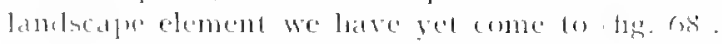
Thes hatle portuon of the valley an etselt contains more clements of leaduly, not lo speals al funsi-

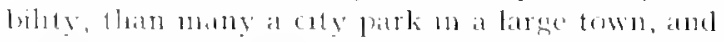

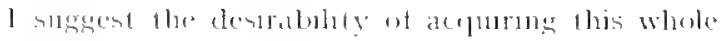

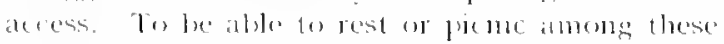
seons birs mould be a provilege many would i1)'l'cellte.

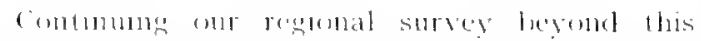

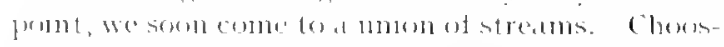
me terst the smaller, that fomates the vollage of

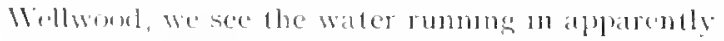

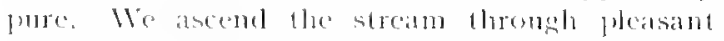

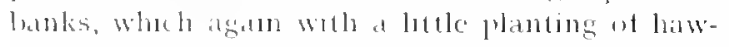
therns and roses would beatutululy contenue orr

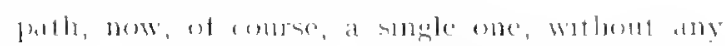

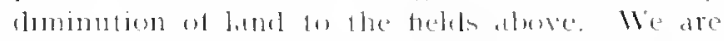
som struck ly an anmestatioble presence if seware fongers in the water, which thekeles and

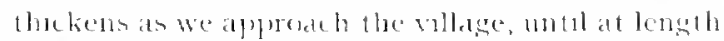

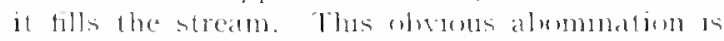

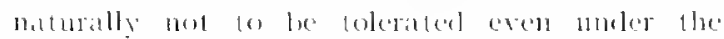
exsting low state ot public opinisus, atul the

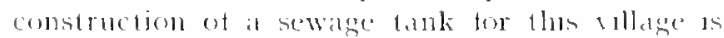
clearly a mater tor its local anturity. The furough of Tontermline is certanly justitied in ashing, and I am assmed pussesses all the lenal power for entorcing, some such eftecture measure ol pusticatum trom the counts. l thust that the Comnty will compensate itself and relieve any natual teohnes fowateds such an attack, and

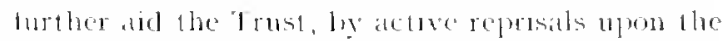
City, at the other and lowes and of the lown, where

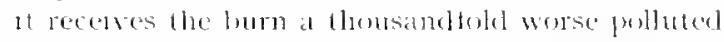
than here. where it is the mmonatialile otlender.

lieturning now onde more to the main stream we maty tollow this ny to the fown lach itselt. That this should lex, on ammalble arangement wht the fropredor, mpmed hy planting, and that paths and seats les set round it, surely should

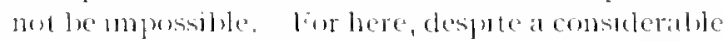
lemetle of country walk from the main londy of

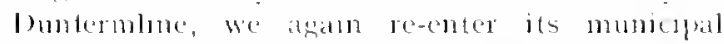

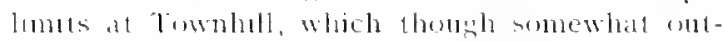

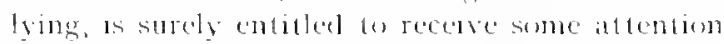
and emprovement on the pist of the Trust. In emojumetion wath the neglected woul to eastwarel, also a clty poperty, the lmaks of this loch should, in tact, attorel the public latk of lhes quatere, and the citrens of Townhill should be able do watli uje and down lo town along this path a by either of the two likerat avenues which we have seen communtallng with 16 . It

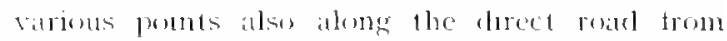
jownhll of the city-that is, fractically to the

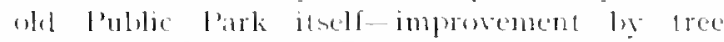
phating wherever posible might go wh, ind we

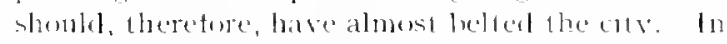
bict, when we rementher how easy 11 would lyc stell do restare something w the old aremes of

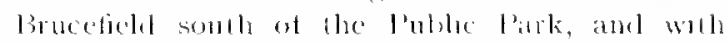

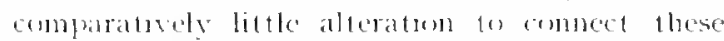

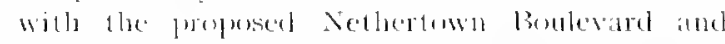

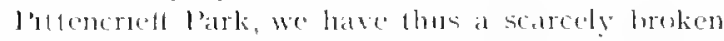

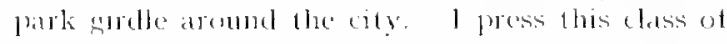

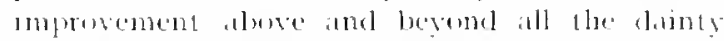

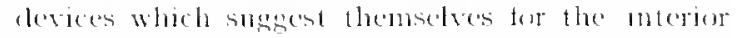
wh the palk itselt. These can he lome at any lime: whereas this proposect imporement must be

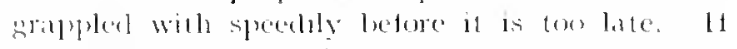

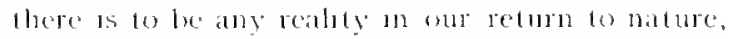

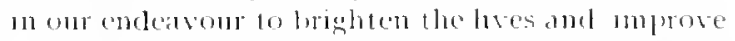
the hoalth of oms working cilizens, it is cmpliate-

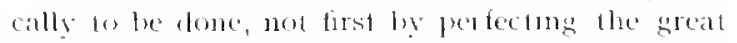
puble parlis, wheh are atter all mainly accessible 


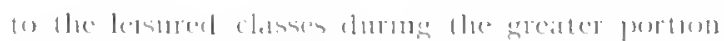

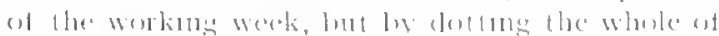

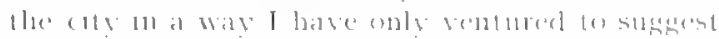

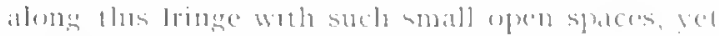

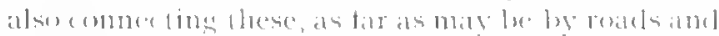

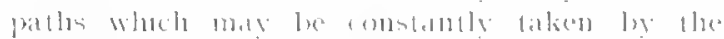

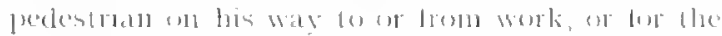

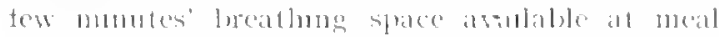

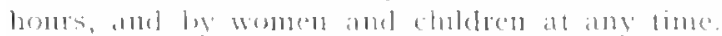

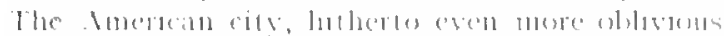

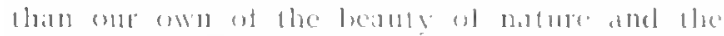

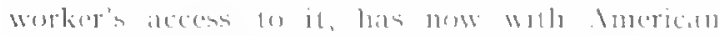

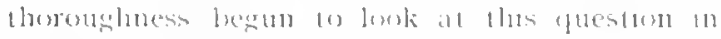

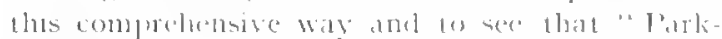
ways" atre almost more tmporthol than partis themselves. Ind it we are really determined, at any punt whatever, to taithfuly and heldly carry

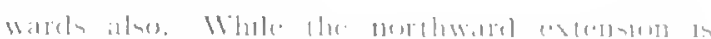

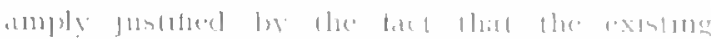

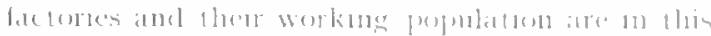

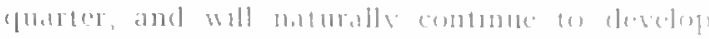

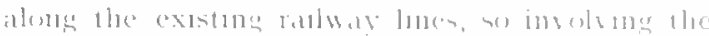

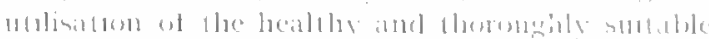

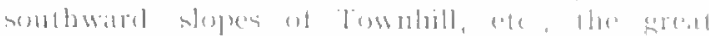

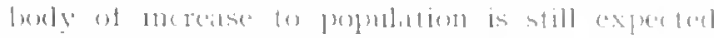

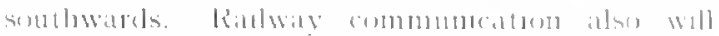

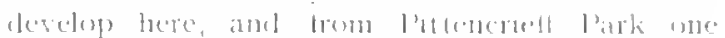

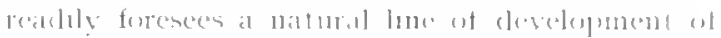

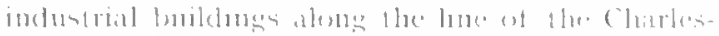

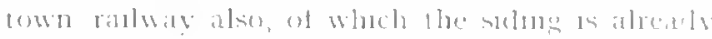

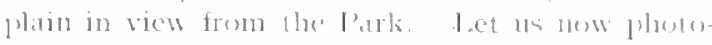
graph this view i.e trom the gas-werke and the:

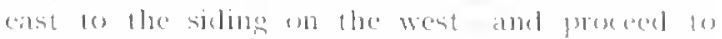
fill we the picture the on with the mothrol and

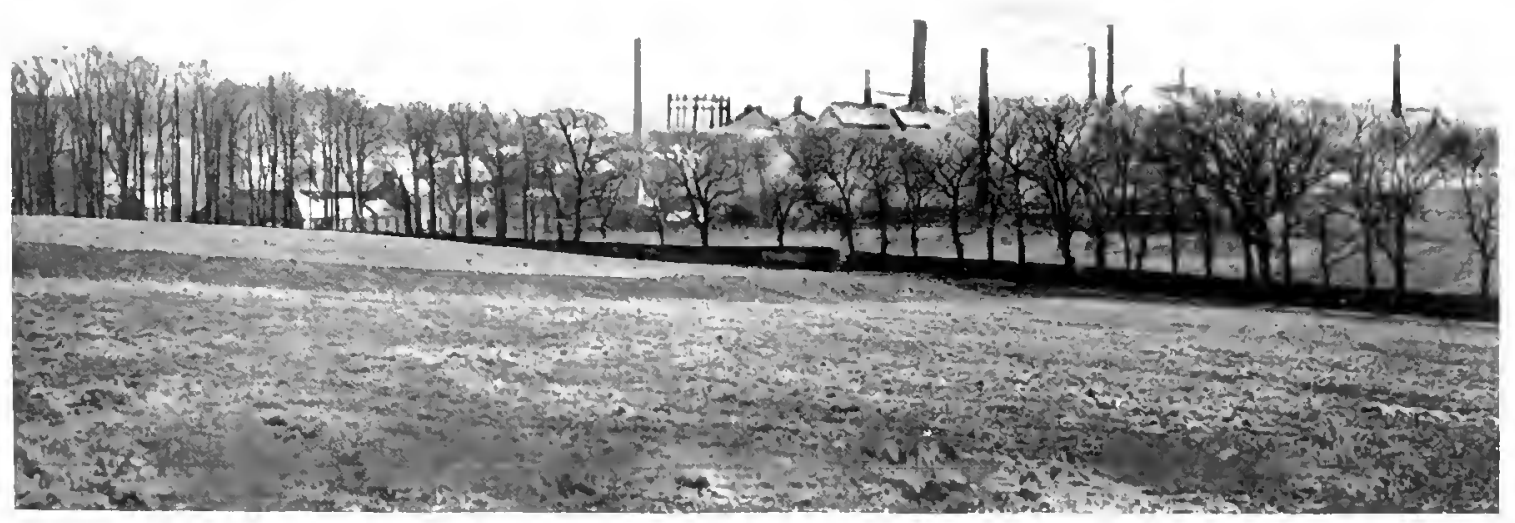

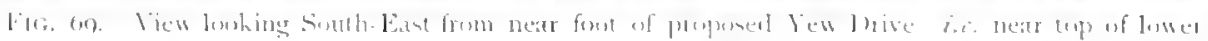

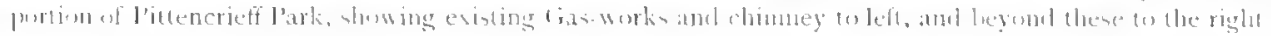

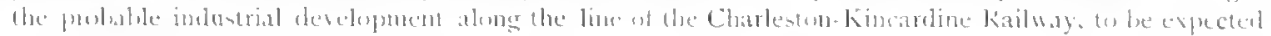
with the covansion of the cily.

Out the bistruetions of ant domer's letter and to

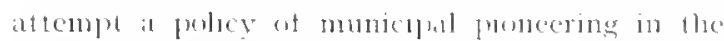
interests of the people I submut that this thapher of my report ts the fubelamental ene, since it is the ane yeldung the most definte returns to the health and happluess of the entzen and the mest useful and uresently needed example to the towns and wlies

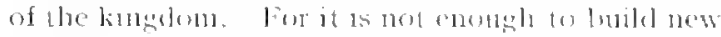
garden cites: we must firce the lat more dethrult lask w makmu gatrlen cines of our existing oldones.

Yed al lownhill the oppottunlues are almost mitge in Britain, since the coty is atready its om

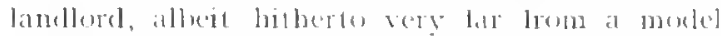
one. Why net a molel one heneetomard?

\section{F. Park Exiension Southwards}

Will cren thes proposed tarly comprediensibe frelt of open spaces northwards sulfice? Certainly not without seme corresponding extension soutl- momal develepments whide must be expecterl. say on a molerate allenandere a dozen somel lorge industrial buldengs of valrous kuds, with not less, theretore, thath eight or ben arerage

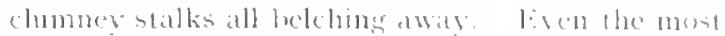
ardeme enthustast of lounfermlune progrems will

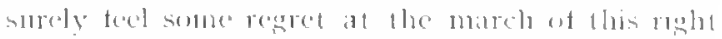

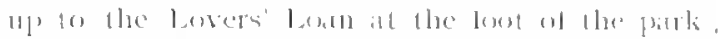

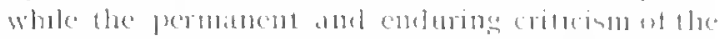

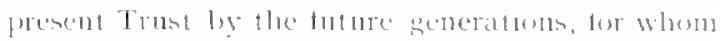
the park will thus have been praterally ankl

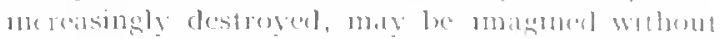

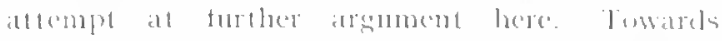

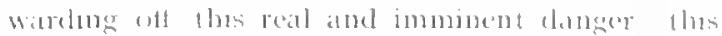

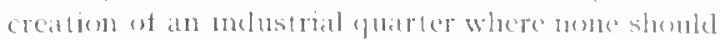
lx, the billing up of the present leatultul sallex with at vist hudelle of fatedories and temements corresponding to, in best, the distret of thatre mow funming west along the corresponelung valley from lidinburgh-what is to be done? 


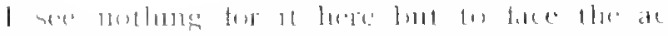

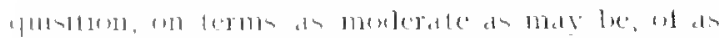

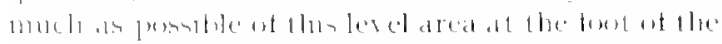

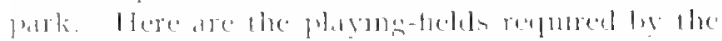

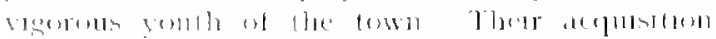

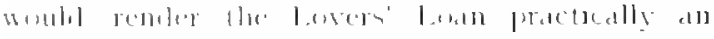

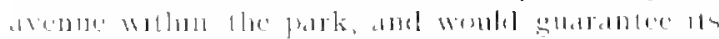

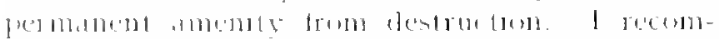

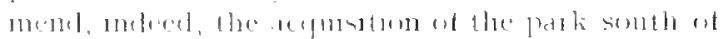

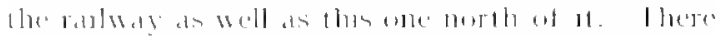

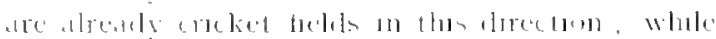

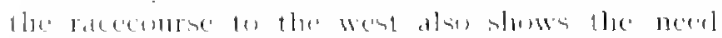

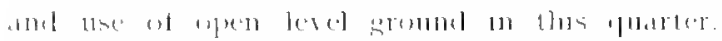

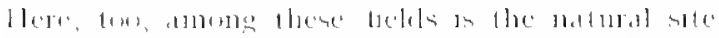

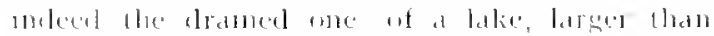

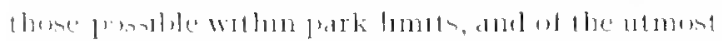

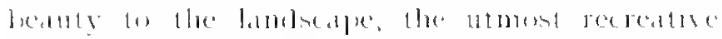

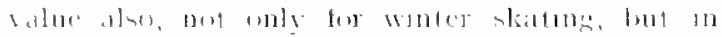

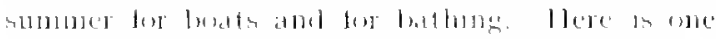

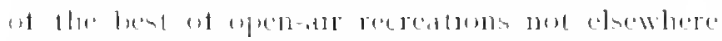

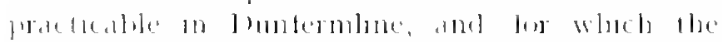

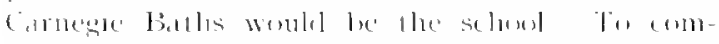

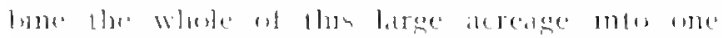

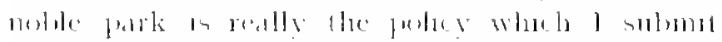

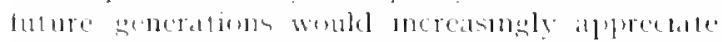

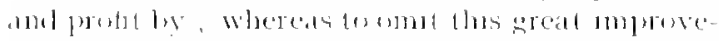

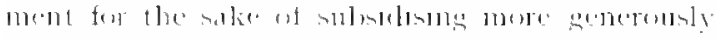

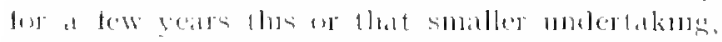

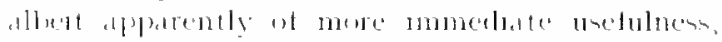

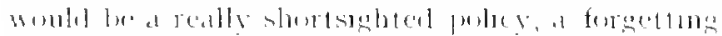

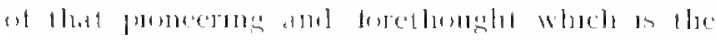

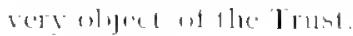

\section{G. Further Advantages}

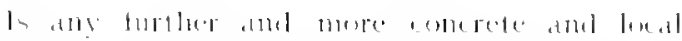

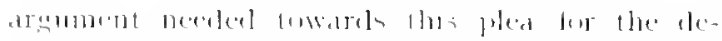
selepment of the herduly al the whele villey.

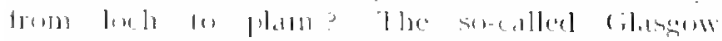

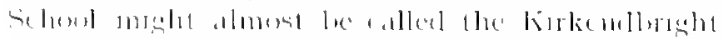

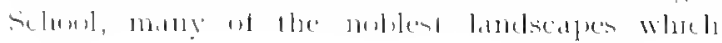

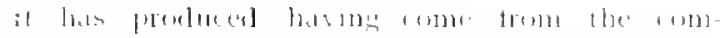

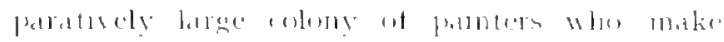

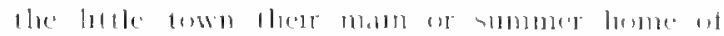

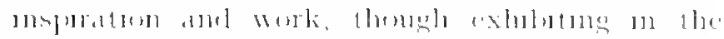

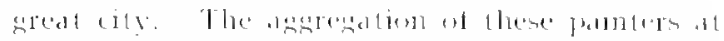

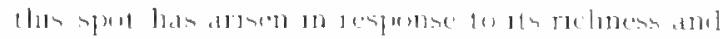

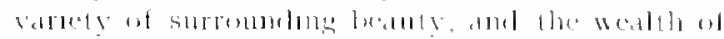

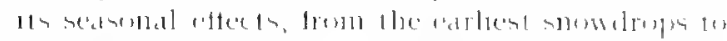

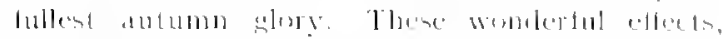

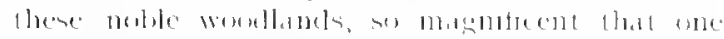

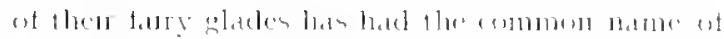

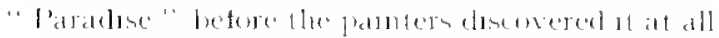

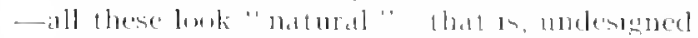

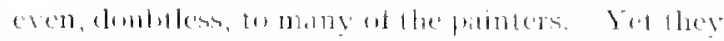
are really well known to be the createne of the

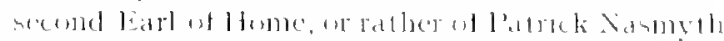

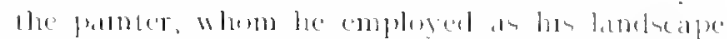

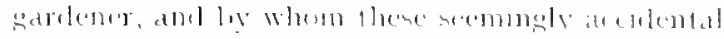

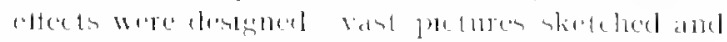

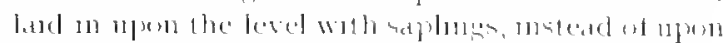
the upreght wath thanced

sre we tolnt that we thell mest and the trees we

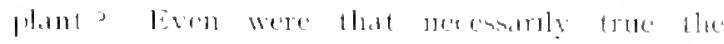

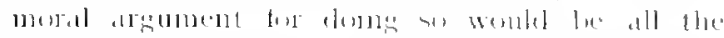
stronger.

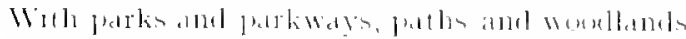

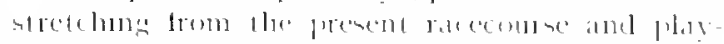

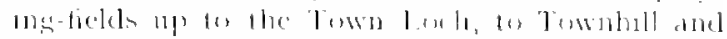

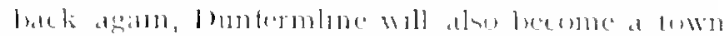

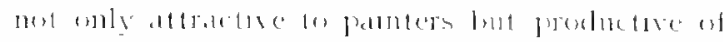

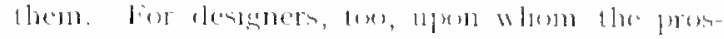

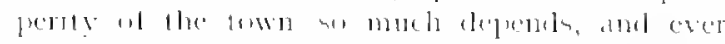

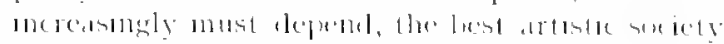
and example a enotantly alestalde. These two

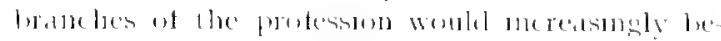

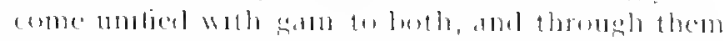

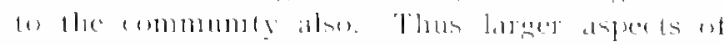

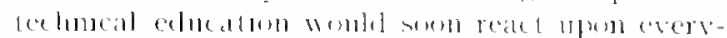

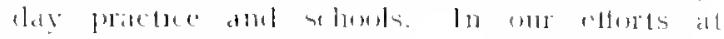

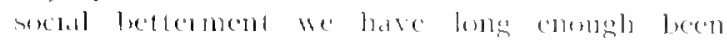

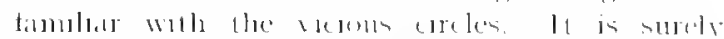

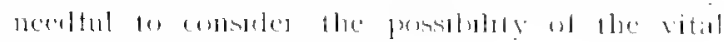

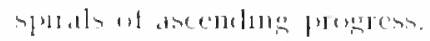




\section{(11.M'llK XII}

\section{PARKS AND BUILDINGS IN THEIR BEARING ON CITY IMPROVEMENTS}

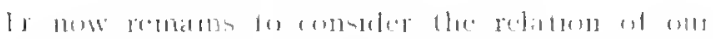

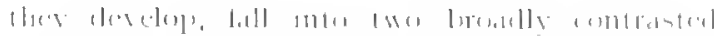

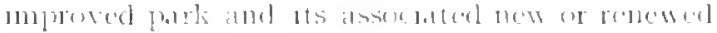

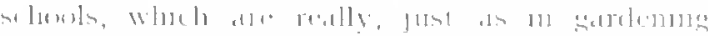

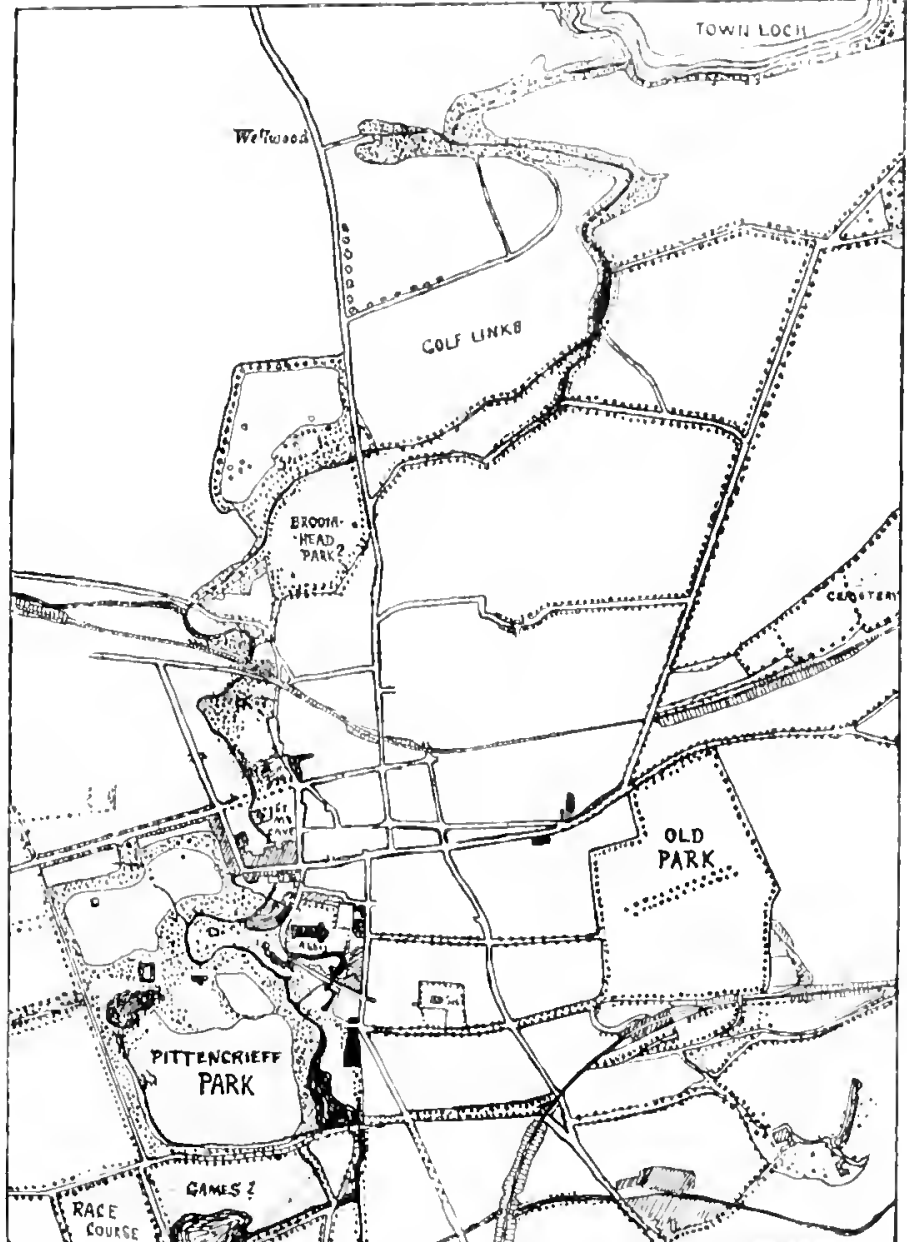

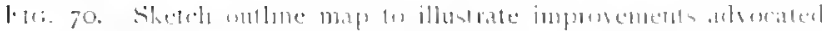

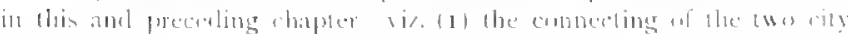

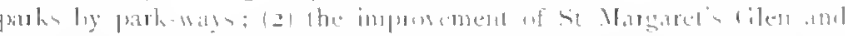

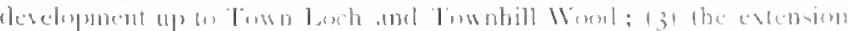

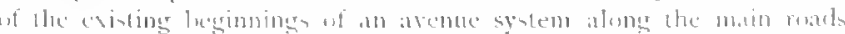

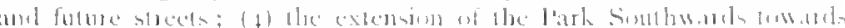

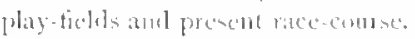

buthlings to the general improsement of the call City impovers, lake the surteners trom whom

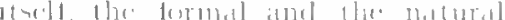

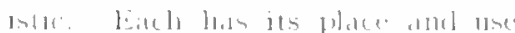

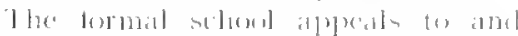

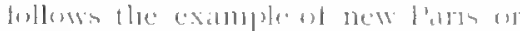

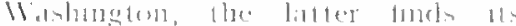

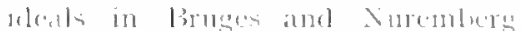

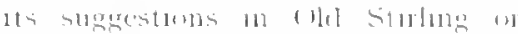

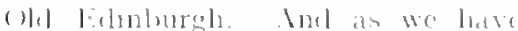

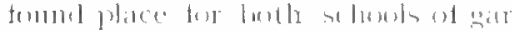

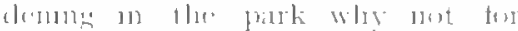

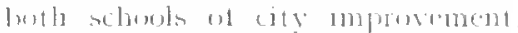

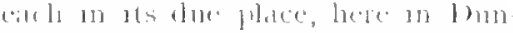

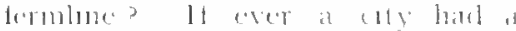
elance of aldomenge its future for

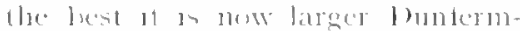
lane, wheh to the sponortumber ot

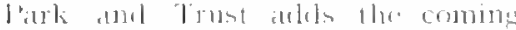

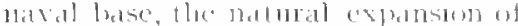
its mann molustry at smeularly

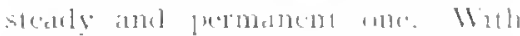

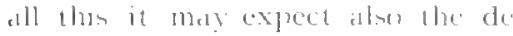
velpgment of ats cultural amal rest dental aspere and the aremello mew industress, stech as prontung, in deed, monmerable subsidury molun

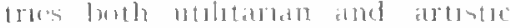

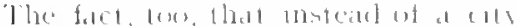

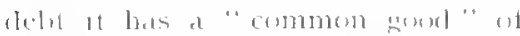

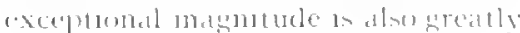
111 its telvolnt

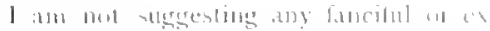
.

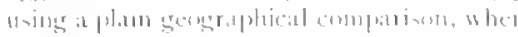

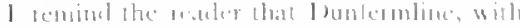

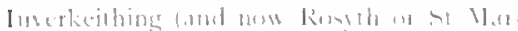

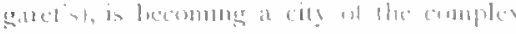

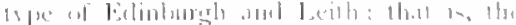

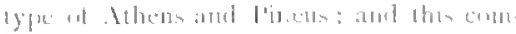

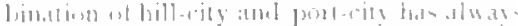

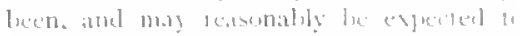

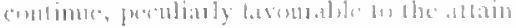

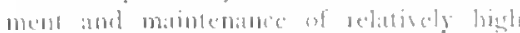

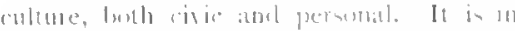

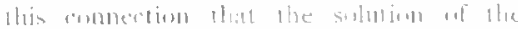

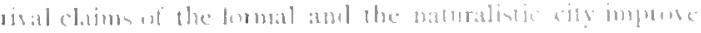

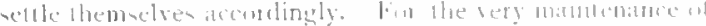

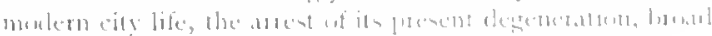




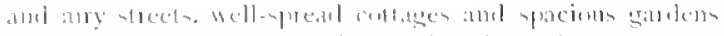

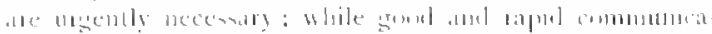

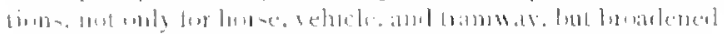

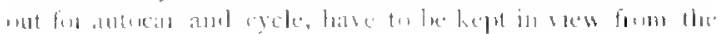

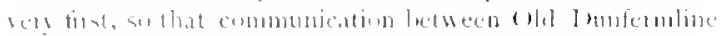

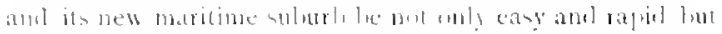

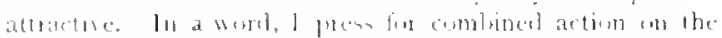

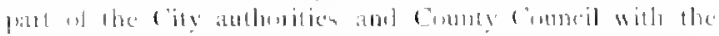

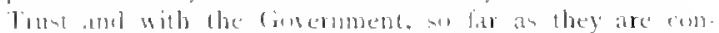

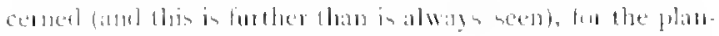

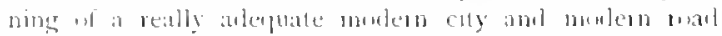

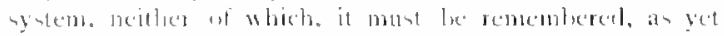

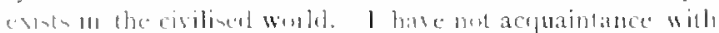

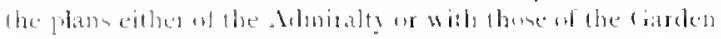

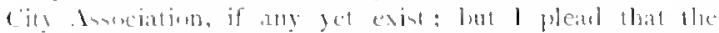

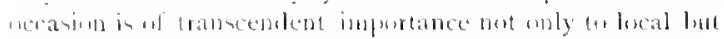

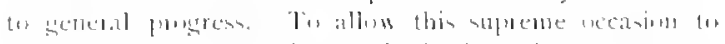

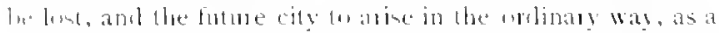

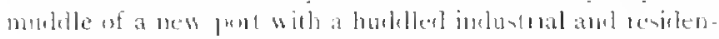

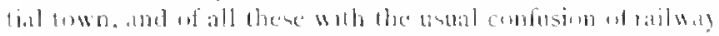

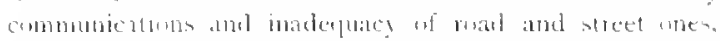

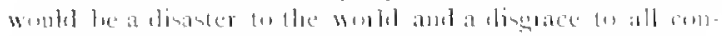

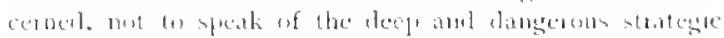

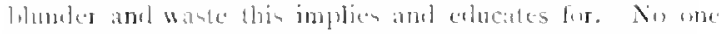

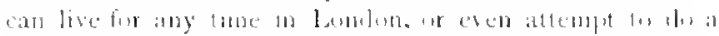

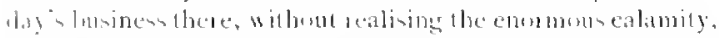

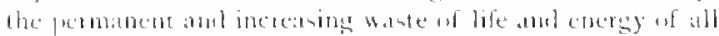

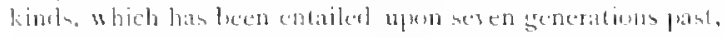

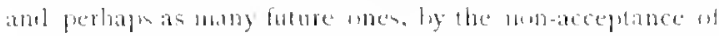

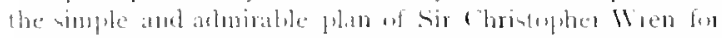

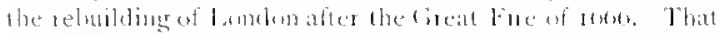

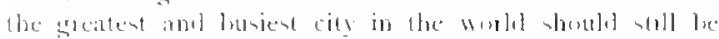

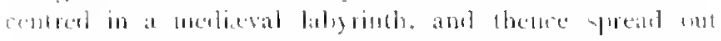

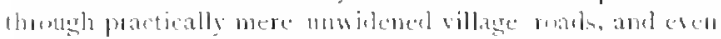

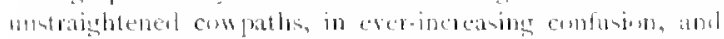

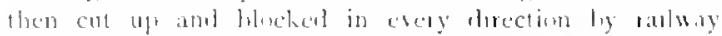

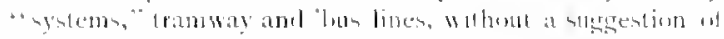

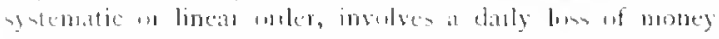

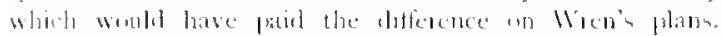

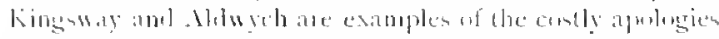

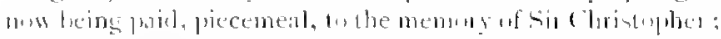

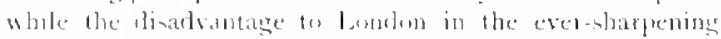

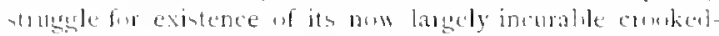

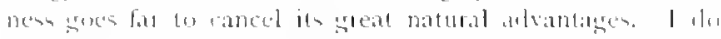

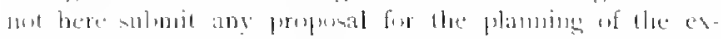

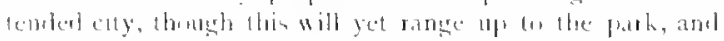

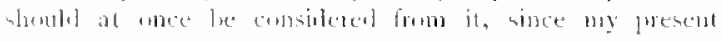

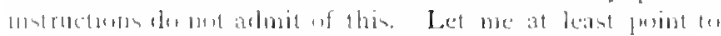

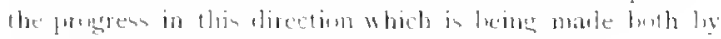
Amerivan and hy genmass cities.

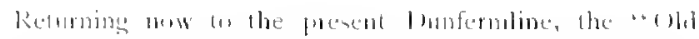

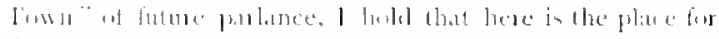

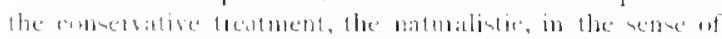

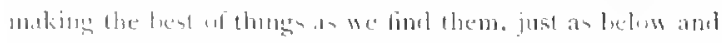

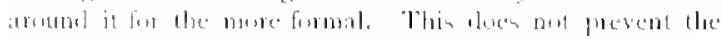

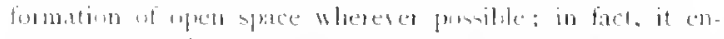

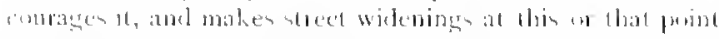

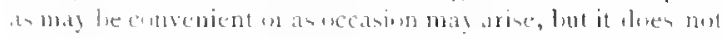

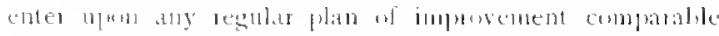

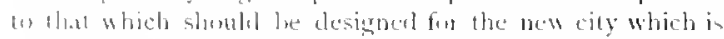

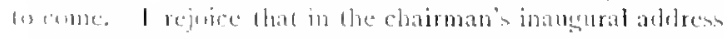

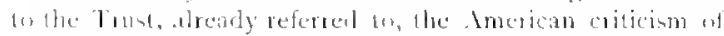

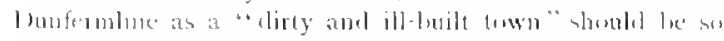
lazkly combdered: yet to make it well-1,uilt, ansl esen

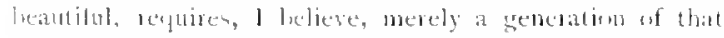
compraratively gratle and gradual trabsfomation which hat

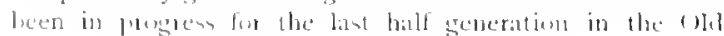

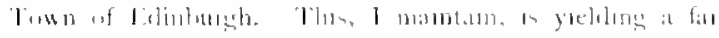

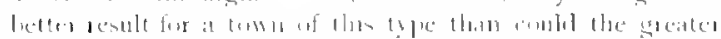

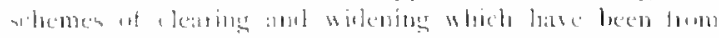

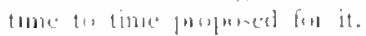

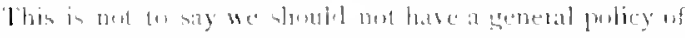

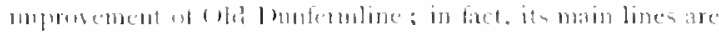

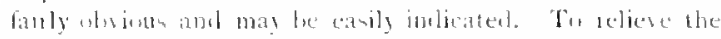

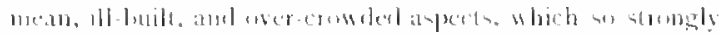

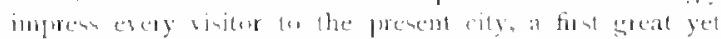

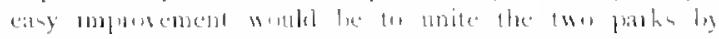

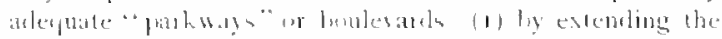

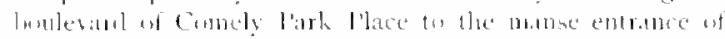

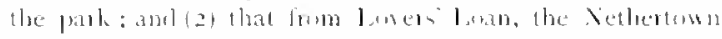

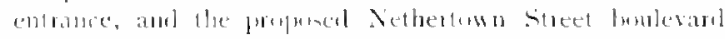

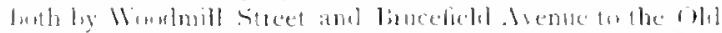

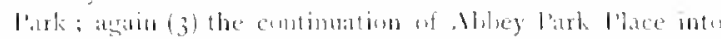

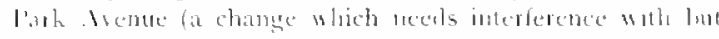

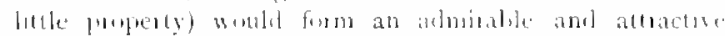

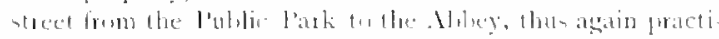
cally connection the twe partis; (f) combers tor the lligh

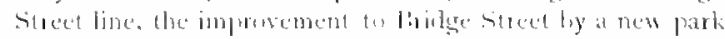

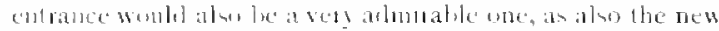

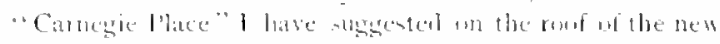

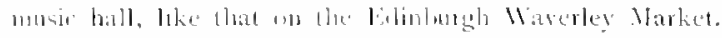

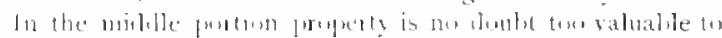

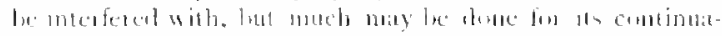

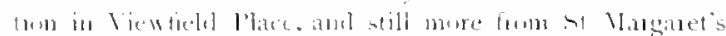

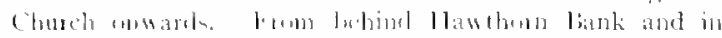

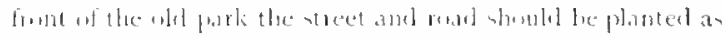

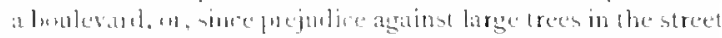

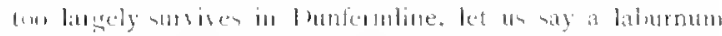

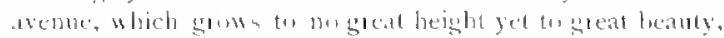

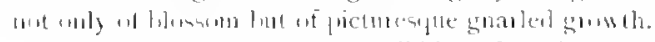

In this way we ace the pussilitity uf awe lens than four

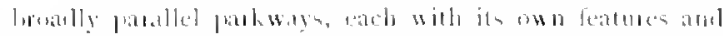

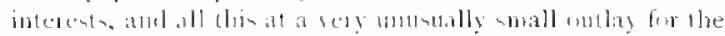

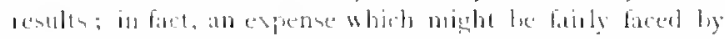

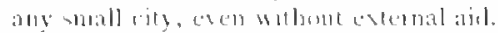

So much, then, fin the wathen half al the cums : what

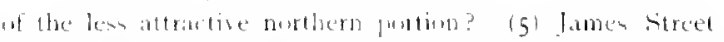

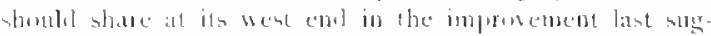
gested, and withrut any geat eyene lond this street and

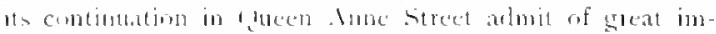

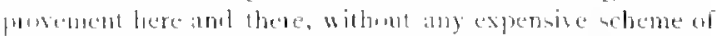

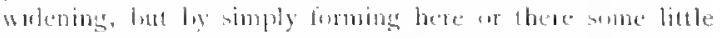

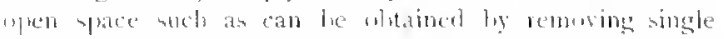

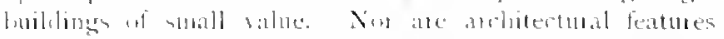

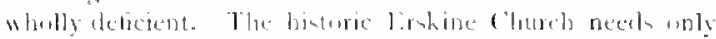

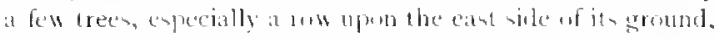

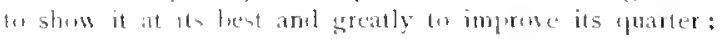

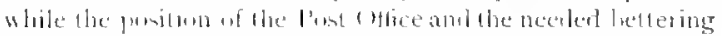

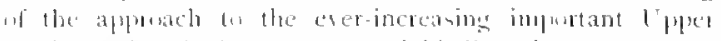
station makes the improwemest of thin line of strect a matter if plactical reltaints in the future.

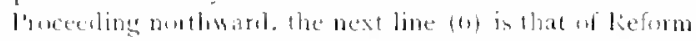

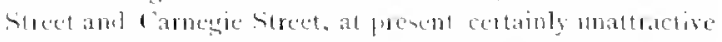

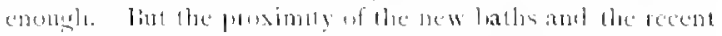

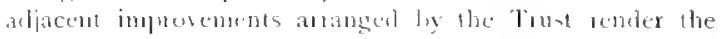

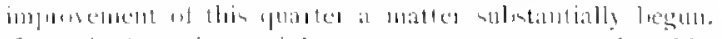

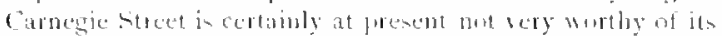

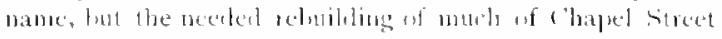

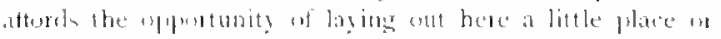

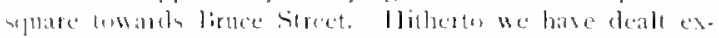

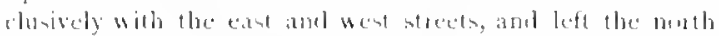

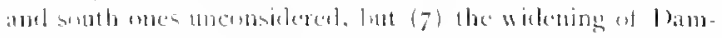

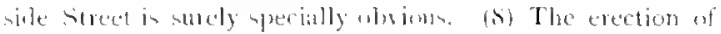

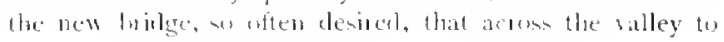




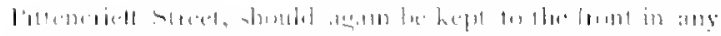

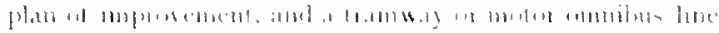

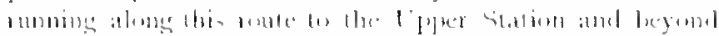

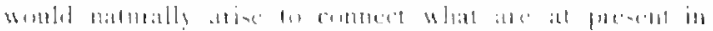

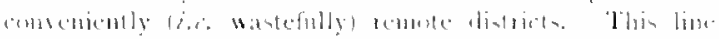

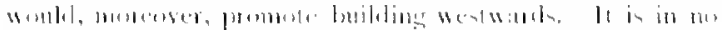

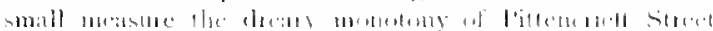

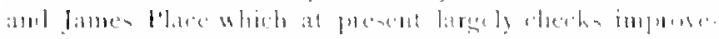

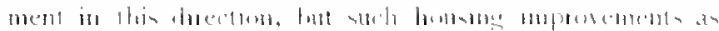

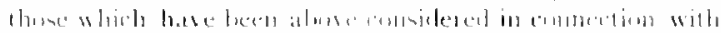

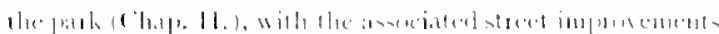

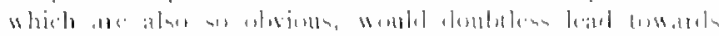

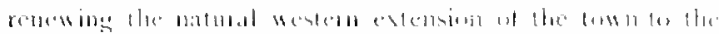

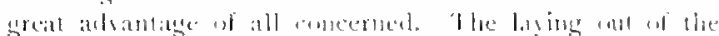

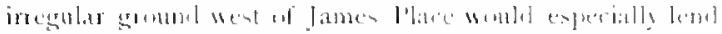

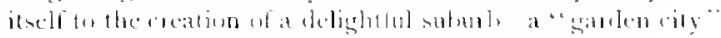

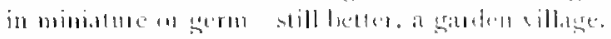

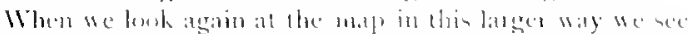

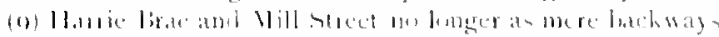

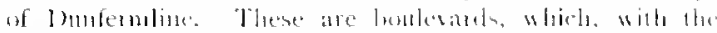

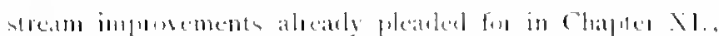

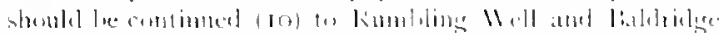

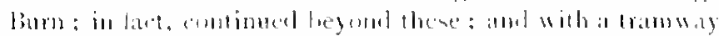

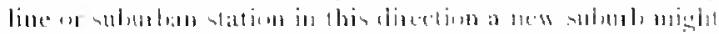

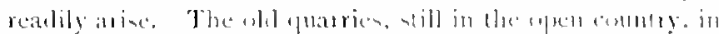

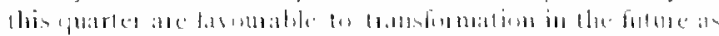

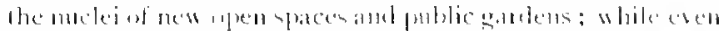

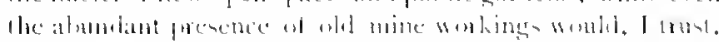

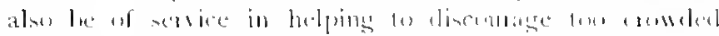

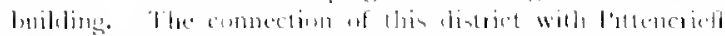

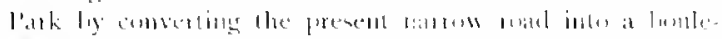

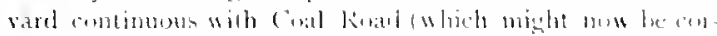

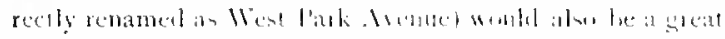

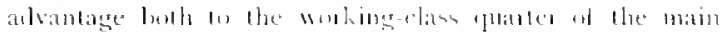

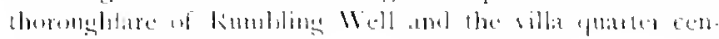
ming in cirese singert.

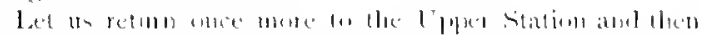

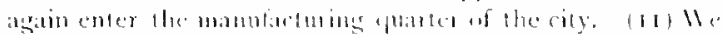

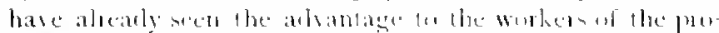

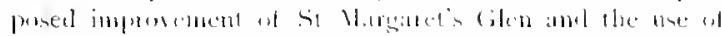

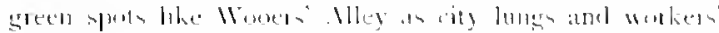

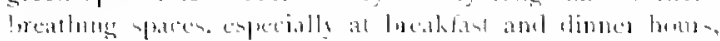

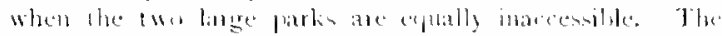

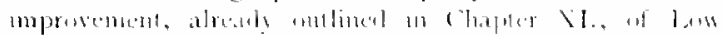

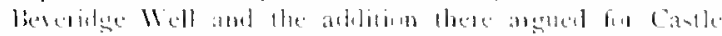

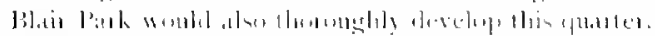

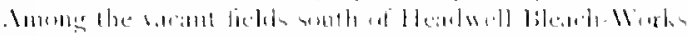

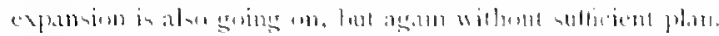
l]

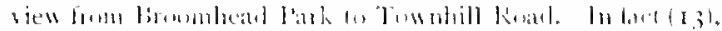

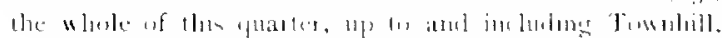

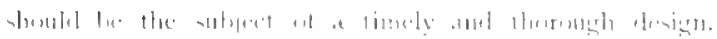

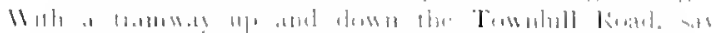

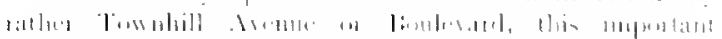

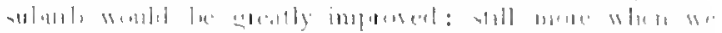

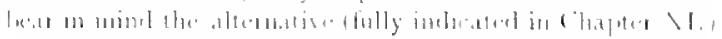

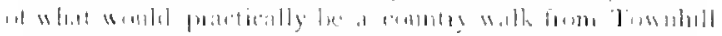

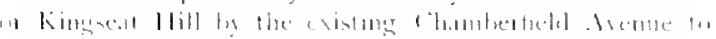

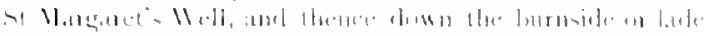

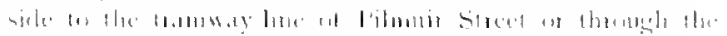

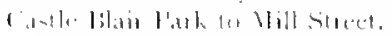

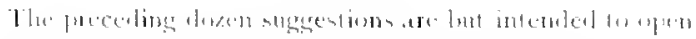

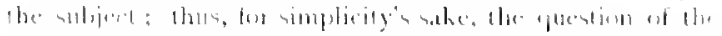

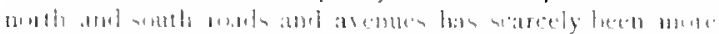

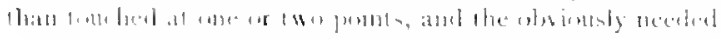

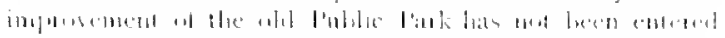

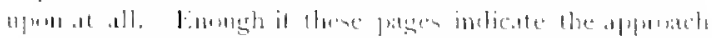

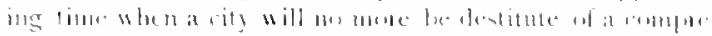

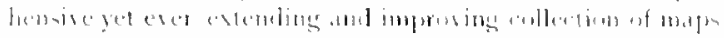

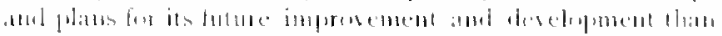

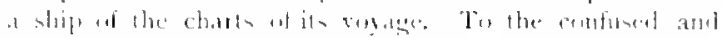

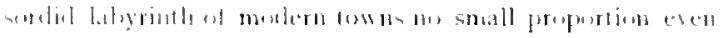

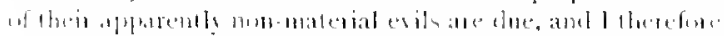

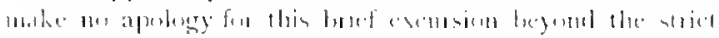

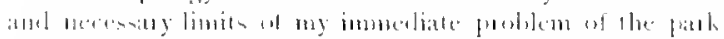

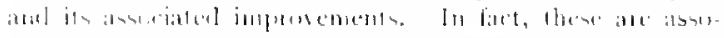

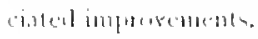

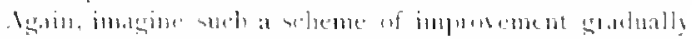

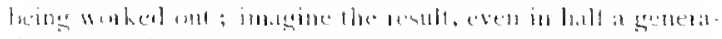

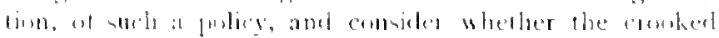

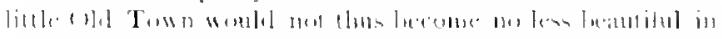

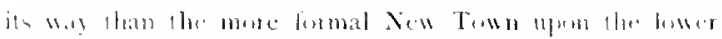

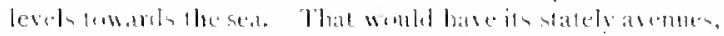

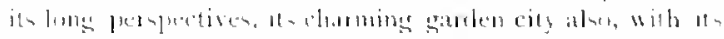

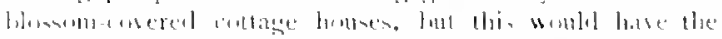

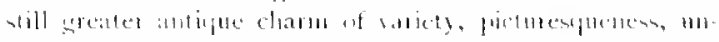

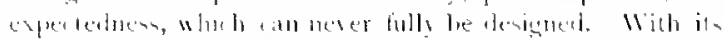

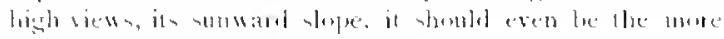

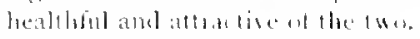

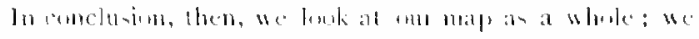

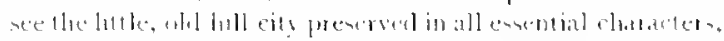

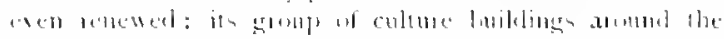

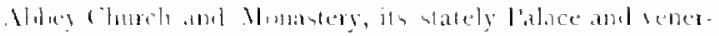

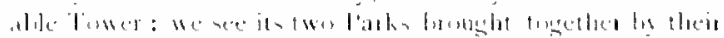

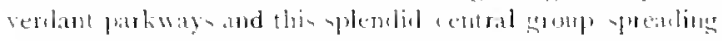

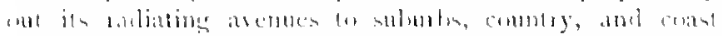

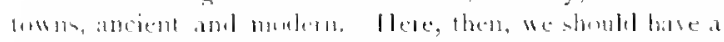

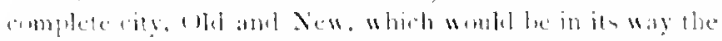

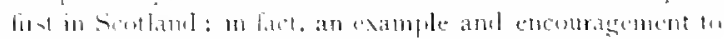

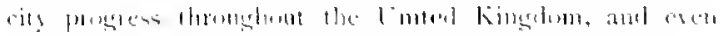

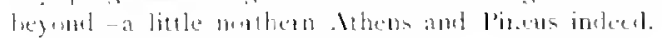




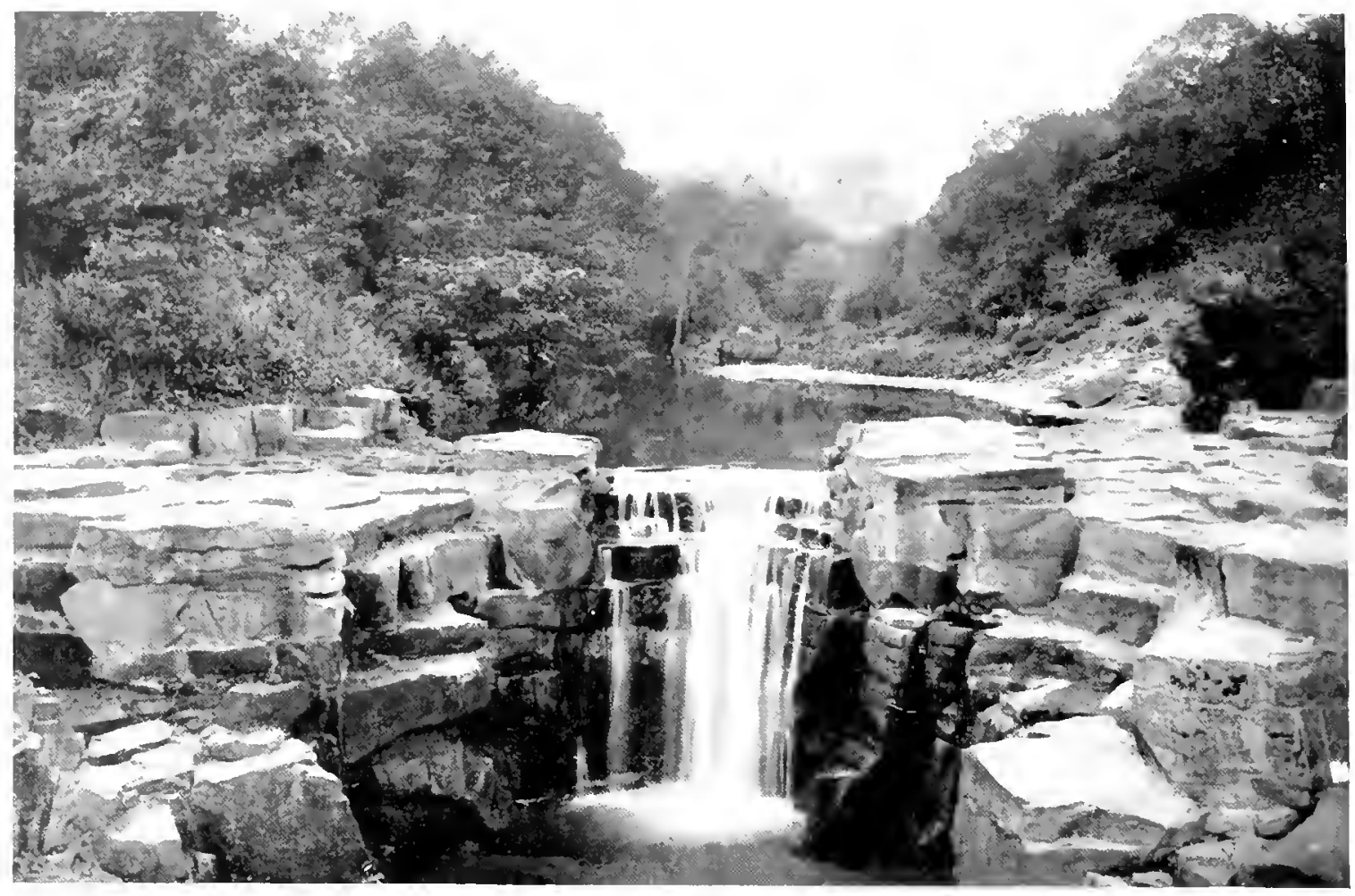

F16. 71. Waterfall of lesmond lene, Newcaste, windicate pusililities of an artificial fall of atrout the same heinht an that proponed, even without planting. (Ihoto kindly lent ly Mesus Valentine d sons.)

\section{('HXPTEK XIII}

\section{THE GLEN}

\section{A. Improvement of Stream concluded}

We now start ingun from the Town boch and return down stream. Some day this locle ats ahrady suresested, will he the centrall lake of the Townhill bark, the comosure of a hitle Garden City. Enotght, however, for the present it thes water be pure and its elluent be kept so; with reconered respect for this, the essentid comblition at once material and symbolic, all else that enher hysienist ancl landkcapist an desire will assuredly tollow:

1 rery practucal puestion is the utulismg of this loch more fully" for its practucil purpuse as al reservor for the stroum, and of economing its How ats tar ats may the so as to aroid noly and unwholesome drving up (th the strean in smmer. Thue pusstulitics here sumesest thembelves-the first, the bomeing in of adelitional bouks, is trom the combur of the country most diftendt, and may, 1 tear, for the time be practically elisregarded. But is at not pussible to hetp the conse of the stroam lrom water pumped or mu from the diflerent mines? I helieve 1 am correct in stating that sulstantial increase might he thus gren (w) the stream at more than one point aboue the burk withent any great expense. Especially maty this be the case if nuy large pumping scheme the set anong for the town's propurty in conpunction with adjacent proprietors. I third method, and one also reconcilins amenity and utility, is the constructum not of any new latge reseroir hut of as many small clams as possible along the course of the stream. This method would redel charmung stecessions of lakelet and watertall, and woild give an agregete acomolation of water of considerable value towards sur present purpese. In this conntry people are too apt to thmk of a stream as something visible in its comse, but anyone who thinks nu terms uf genlogy, or who has hat experience of liastern Irtgation, 15 accustomerl to reatise that the great bolly of the stream is "the undertlow" out of sobt below the visible bed altogether by increasing thes such ponds are of much more vidue than their storage capseity would inclicate

The advantages of setting impurities and giving a pellucial stream through the park, of supplying fish-pools also along the whole course, will be obvions. If any loubt the picturespueness of such artitictal tants, with their pools and falls, I need only pout to the many eximples aftorded 


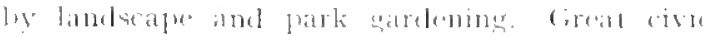

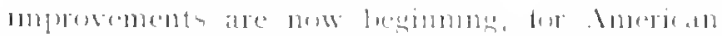

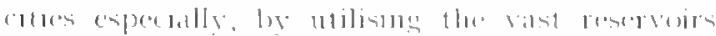

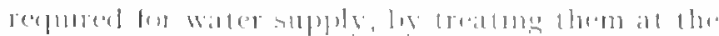

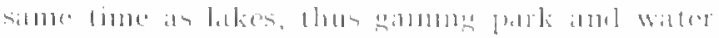

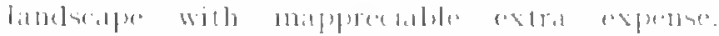

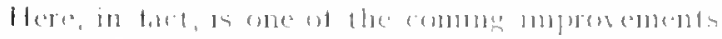

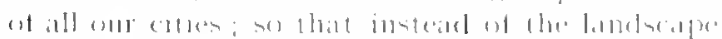

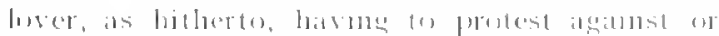

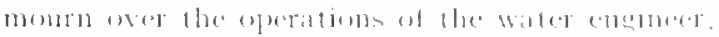

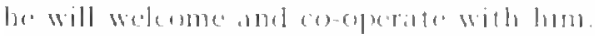

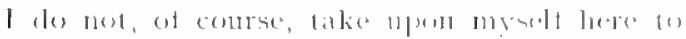

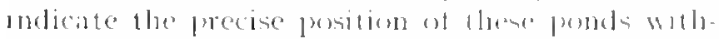

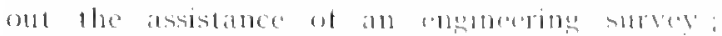
enombly it we note the existence of at latat ane now

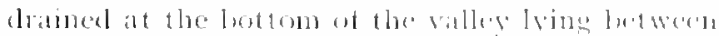

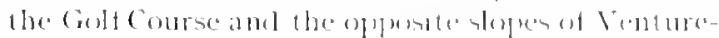
tair; in fict, lying between the atemes slown in

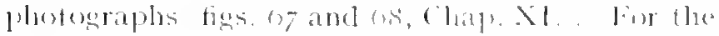

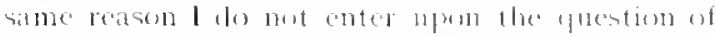

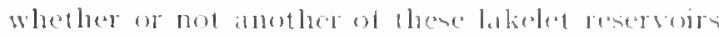

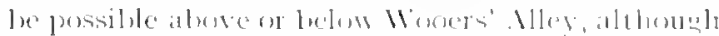

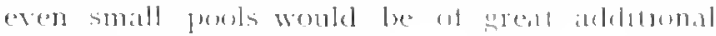
beatuty.

In the case ut sterm and ypate the presence on

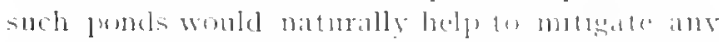

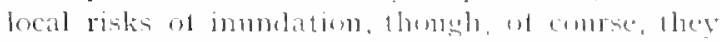
could not be sufferent la eompletely remese these. That womld be a matter tor the anginerer south of the town, inter wheh we need nest fee enter begond pointone ond how almiratily the existong contours of the ground near the fharleston rant waly and sidns south of the park are adepted

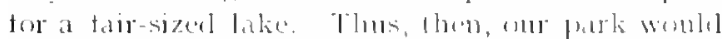
again claspe together new expanses ot lwatly on

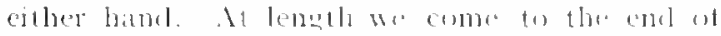
this long insintence mpon the stream improsement external to the park. This has beren nenessalts and justifialde, since the streatu as stall the satal

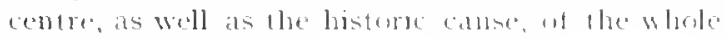
fark and eity allate.

\section{B. The Glen Proper}

Entering now the proti itselt, we hate lane as its central anel hintorionl portion, thit estrotedronaty lonp ugem the stream fig 2 to which the Tower llill owes its axistence the lonn and tower the refore, and the city itselt. Here, asesin, the creatlon

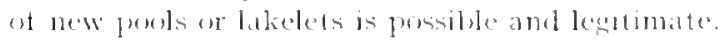

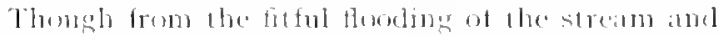
the friatle nature of the shales thromels which

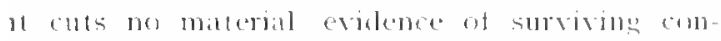
structions cam be expected, l think at not impessible that in eatly times the stream arembl Tuwn llull may have been artificially rathed so as to lumish an alequate moat, greatly stremplonang the derences of the Tower. Be this as $11 \mathrm{may}$, the present ditchlike walling of the stream is intolerably ugly, and must le deale with. But

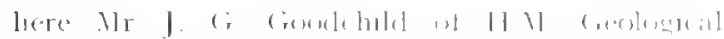

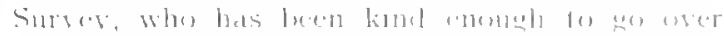

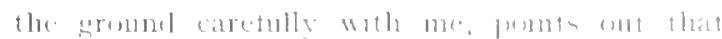

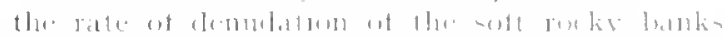

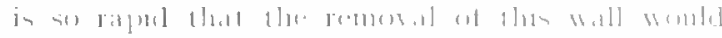

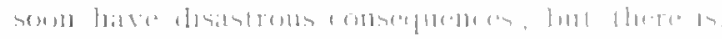
buseret, no (b)

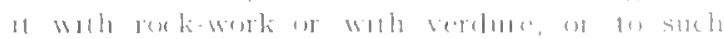

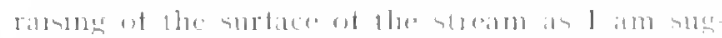

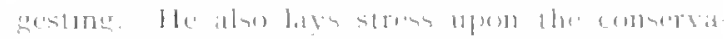

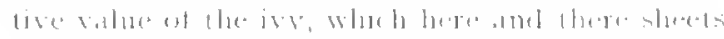

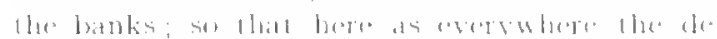

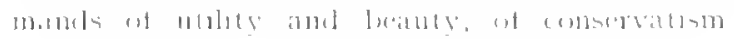

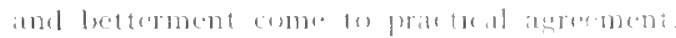

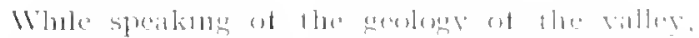

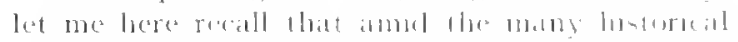

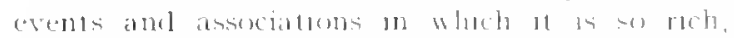

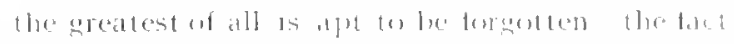

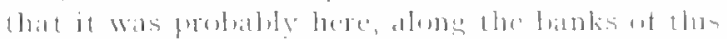

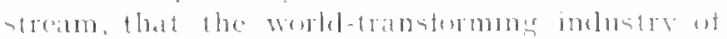

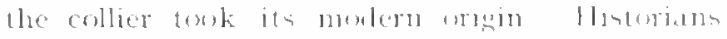

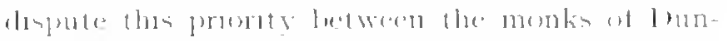

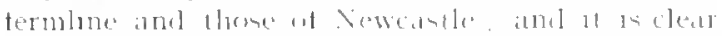

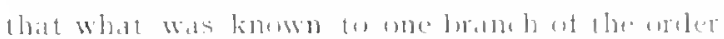

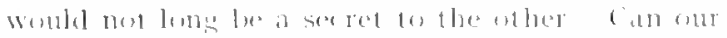

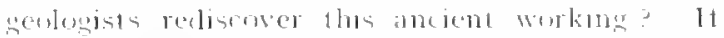
s), 11 dererves the most corroful preservatum,

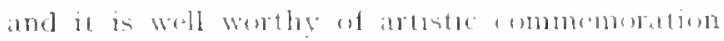

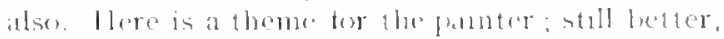

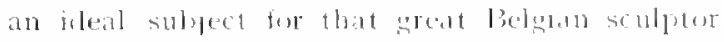
who has so often fombl hic mopratton in the

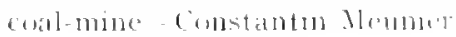

\section{The Glen unit by unit}

Fin comsentence salse, let us divide the comrse

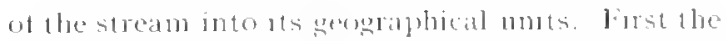
cueen's Gatelen, which in at suberpuent chapter XXYI. we develup as the trena Even indepemelenty of the constructuren of thes. the existence of a lakelet as a reflection mirror womld be it great grith to beauty, while its fall below sures us the needed centre and tows of a new picture lowking

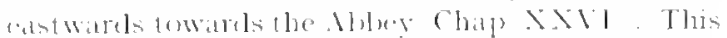
is, in tace, our seconel wat, the hesmoning ot the best part of our winlong when or elede den or

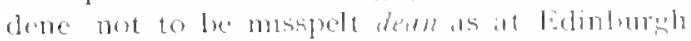

Sot only fur cleaness in the present ondlume, but wor the consenience of those whing the park.

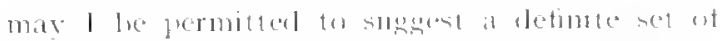

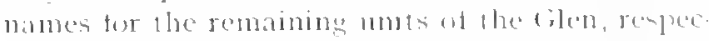

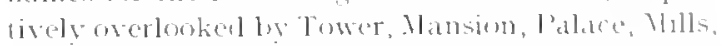
and Mance, as, therefore, He Tower Dene, llouse

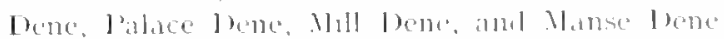
respectively latels is a matural unit will tealures of ils own wheld have now lo in turther eleceloped.

starting. then, at the log of the lower bene 
which may here for the time being lw roughly sugresterl by that of Jesmond Dene, fis. 7 i witls our new watertall from the drenat hake, we bate lailt way down the hall-natural, laalt-artfficial makings of another waterfall fig 72 , and lows a bitte more art will easly render much more natural-fosking. (1) the right is seen the nearest

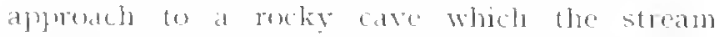
afforels; in a dangerous and nearly (b) latsung state, it is true, yot eafuble of lremgr casily pro-

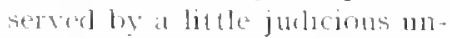
derbuldiag, wheh shomle be suppled wathout delay for tear of an acculent. Which misht easily be fatal to anrone sheltering wthin $1 t$. It several other rocky points along the stream such skilted mulerbuildlng is needed, notalyly under the Tower approacls oprosite. and there is no reason why

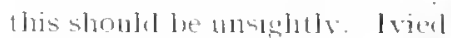
strength cannot onfenes ans eye.

Here the stream begins an urn somblhatels towards the loridge, and here, again, another lakelet is possible, with smatl fall below

\section{Tower Dene, Children's Dell, ete.}

Thongh the serpentine sweep of the Glon gives $i t$ an evernew and undivilual interest wo still miss onc feature which wotd be of great value - the coming in ol some smaller tributary stream of which the minor valley wonlel grve a new scale ame dignity to the ravine a greater cifect of hreasth and deptly. llere above us is the one point where nature ithough apparenty nut unaded by the deturs of the muter's art has of akd supplice] these, though on no wroat scale-the tiny dell in the north-eatst section of the park, though waterless and completely dammen ofl trom the b]en ledow fir. 73

To enve this, howerer, something of ats possible beaty and continuity with the math valley, and again, if possible, ling down a little stream whl its opportunites of picturesplue fall, is bere mest destrable, and fortunately ensily practicable also. The hollowng ont of this ats at waterenurse, the slight heightenung of ats banks, their planting these are all olvious, and though a lrive whome comrse we cannol now alter appears to mterfere, this difficuly again becomes an oppotunty of new ettect ly smoly earryug the streanlet in a short tunnel below the patls-this, on firct giving us the always picturesigue eflect of a single-arched bridge. From lubu this the strean would ile scend in a succession of small tajls ancl juols to the main stream, so suing a fresh interest to the whole lower Done. The water woll come

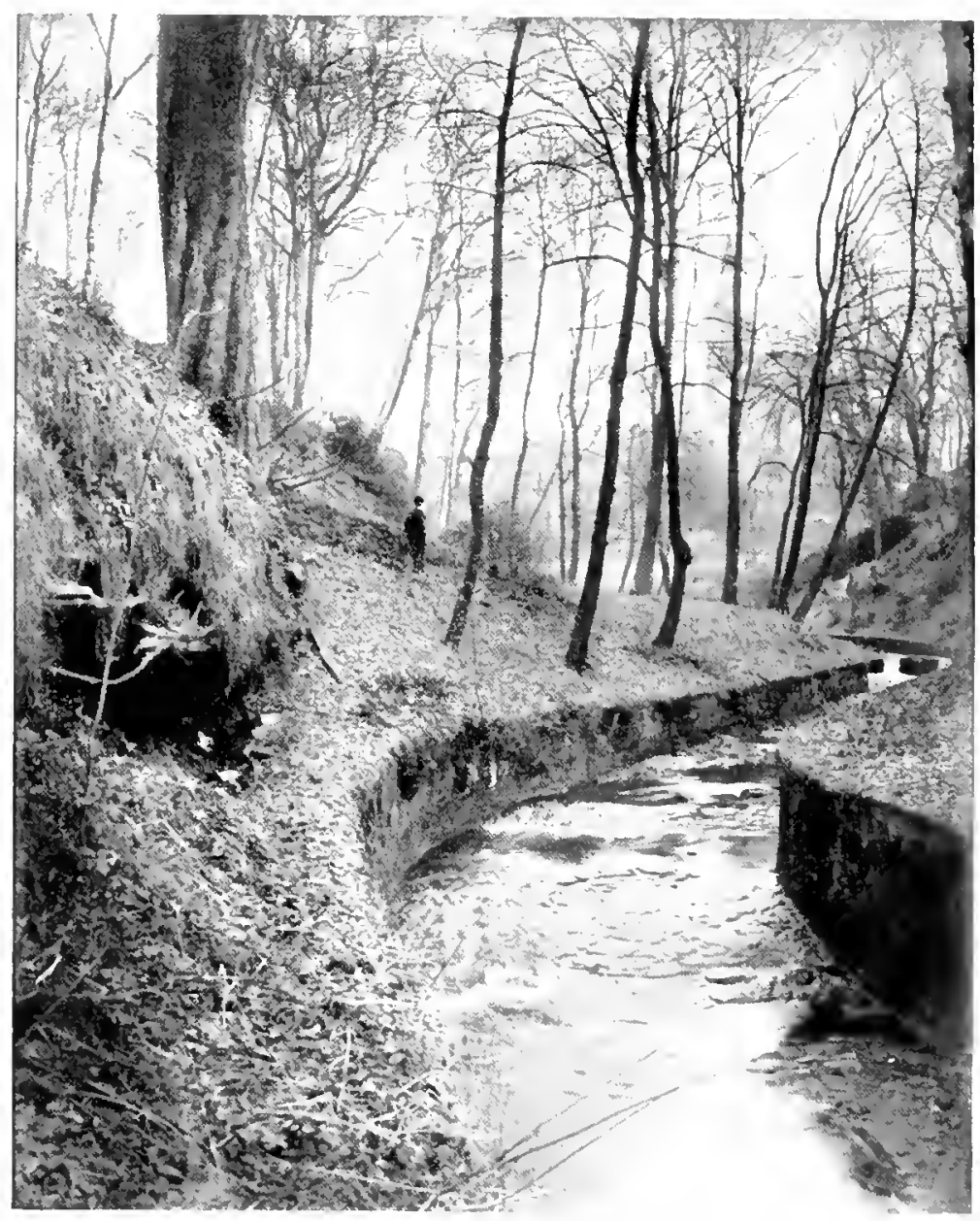

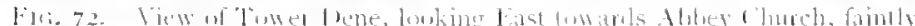

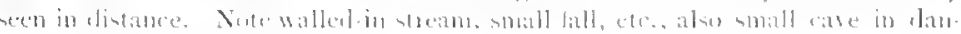

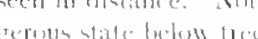

naturally trom the large fommain of the main entrance (lesp XXYII and Ceneral lant. The association of thes as a Chibren's Iboll with their

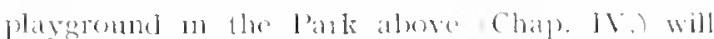
alsi) bo noter]

lim this whole water sulply a 2 -in pipe would suffice, easily supplied from the city malins, or more economically wolked from a ram concealed at the now Juber lall below, or posily also

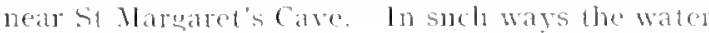


supply of the laree and small west liskes, its continution throush the kork Garken and along the west and south of the park, would all lo easily managed without any serions withlowal trom the existing strean for elry wather, lowerer it would be destrable to have the town siplyly to bill back monn, and unless the matin stroim can be sulstamtially reinlored the alusilutsy had better he provederl from the tast. Even axsming the purification of the stream a suectal

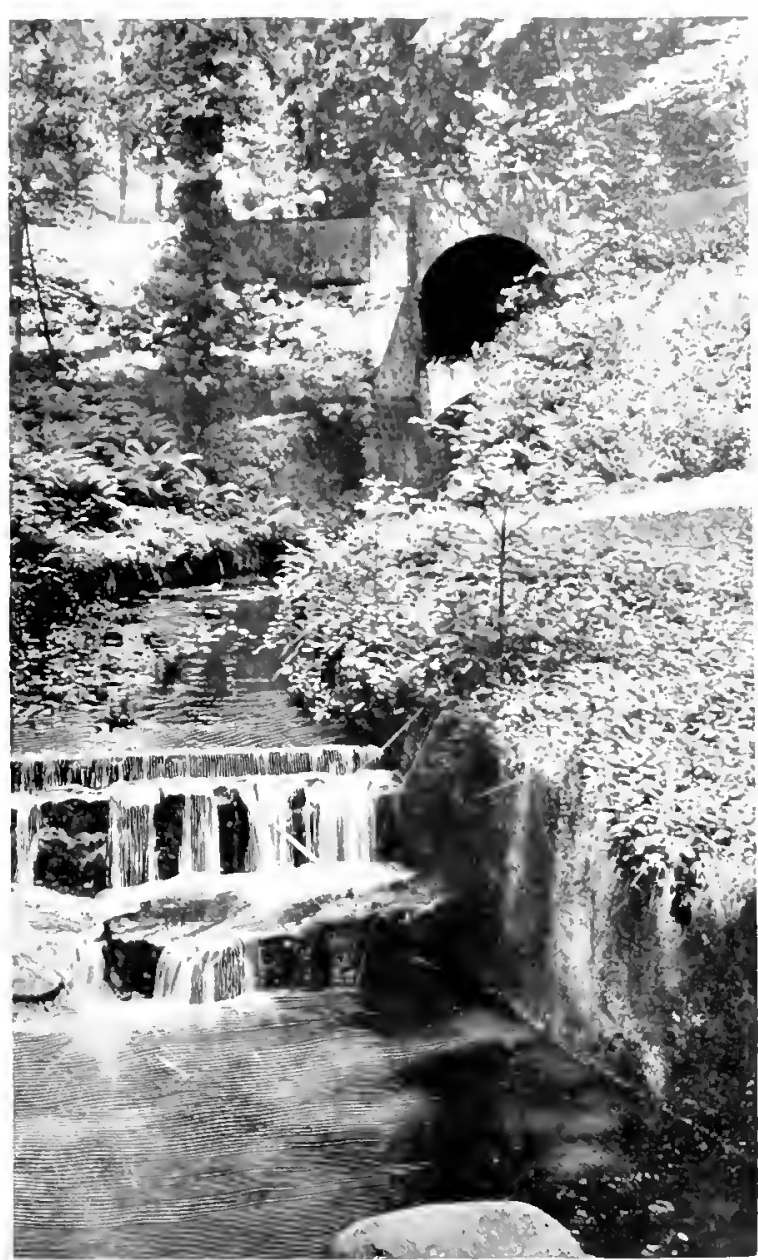

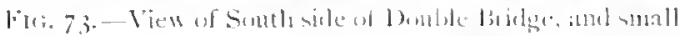
fill in Ifome frome. Note that thete are at pesent pactioally

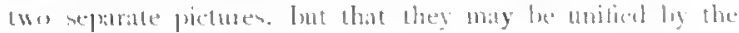

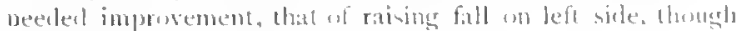
lese forntally than present efouching indicater

filter should also be supplied in connection with the liting ram, thus guaranteeng the greatest possible purity to this ornamental water.

\section{Shade Garden, Spring Garden, Fernery, etc.}

The spacious southward slopes above llus upon the noth side of this Tower bone aclumit of simple yet beautiful treatment. Aftor re- moving a few wrollylus trees, mere werely pules,

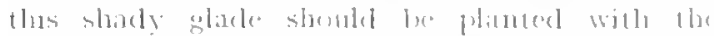
richest wealth of disforlik, sluereed in dritis of blussom, not merely delted, catle main vartety amply represented of as lo give mol ondy greater

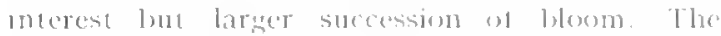
higher wooked lanks shendel be more lully planted with terns, of which the growth is lacre pecularty pertect, and alder sown loreadeast wath primroses and foxglores and other shate-lowing wikl flowers.

This wild wealth of spring and summer lwatuly shomld next glodually pass westward

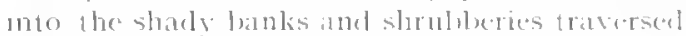
by the axisting paths, amel also be well seent trom the double brigge and its drive. Fom these, northwates, I would carry out and develop a smggestiom which l owe io the liev. Mr George, and which, theough long a puzpling difticulty, I now sere to tre reablisable at this pount, that of a liernery and Shirle Garden. which sloukl at the sinne lime express some thine of the development and clissification of veretable lite from the smplest cryptratame plants upwarels to the flowering ones. Towarely working this ont I hate atgain lately studied the collections of Kin, and more espectally the famous Spring fiaden at Belroir Castle. White protiling ly these examples, I would combine at once an orler ol planting expressive of the present stamelpont of the systematic and of the evolutionary botanist, so that we shombl literally ascend the tree of vegetalite hite. Starting from the stream level, with its humblest water-weels, we should cultivate upon the rock-work of its banks the werworts and other simplest creptogamic land plants; then the musses, the ferns, and their congeners: and lhence pass (o) a simular outline representation of the sord-beating and flowering plants. By" introlucing here and there anid the nealful rock-work the example ar reproduction of the alynguriate tossil form, and by putting out an summer-tine some of the more delicate plants such ats cycals which are needal w complete our ombline of the vegetalule kingtom, it very fit general irles of plant lite can he oluaincel. I literal birt's-eve view of the vegetable kinghom would flus set forth, whll perluaps unprecedenter] simplicity and cleaness this Tree of livolution fitly completing and inslexing that general presentment of the main orders of the vegetable kingdom which is disposed throughout the piath especially along its lorders.

This witt also complement that display of the essential succession of geological formations which I have proposed alowe Chat, V1. as the essential sulstructure of the liock Gatelen. Here, then, once more we reach the propesition that wheever wonld see the world most dearly and most simply I do not, of conrse, sily most richly thin 

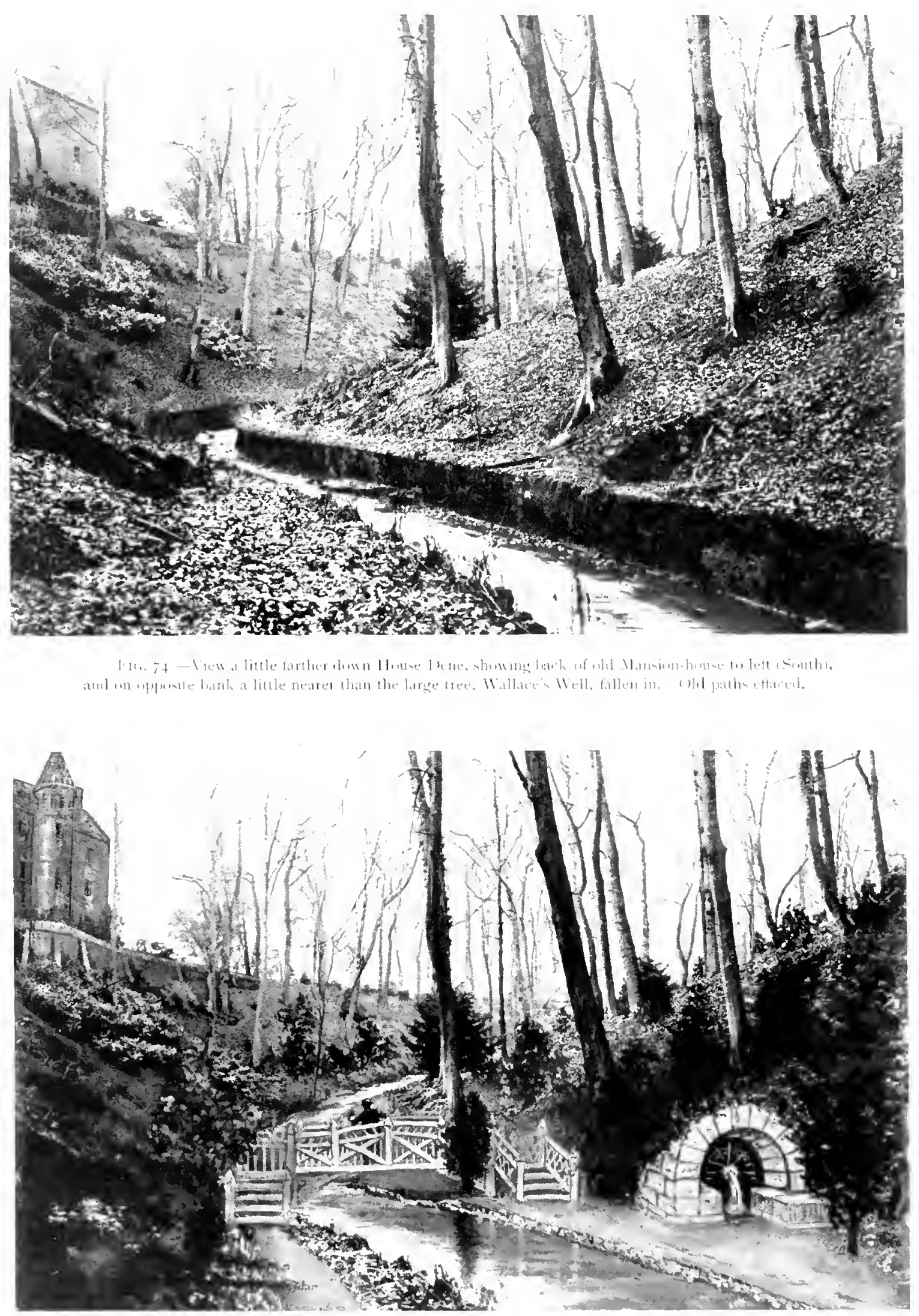

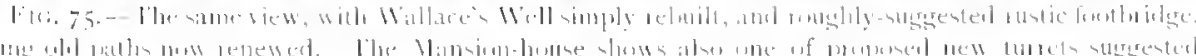




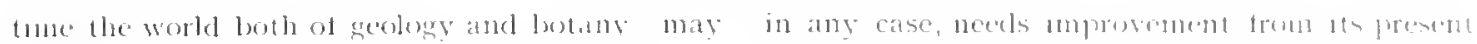

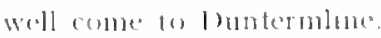

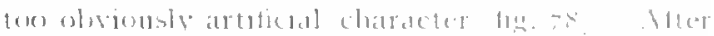

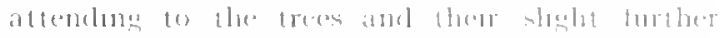

\section{E. House Dene}

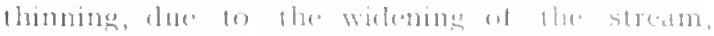

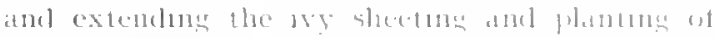
the banlis, there es here little to be dene on elther sicle.

Jissing now south ot the louble fundere to the

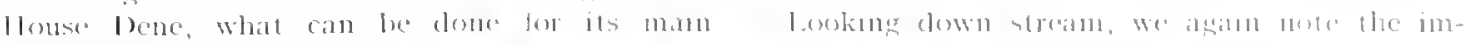
featlues? The bridge is slowill in tign. 7 , and this from one ut its lesest points of view, that of the exist ing sumall tall. This shomld, again, he somewhat heightened and improverl, the resultant pool above this tall then mirroring the bringe, and so doutuling its present beatuty.

Tpon the mprovement of the mantion I enter clsewhere Chites. I and XXIX. is regards the stream, the banks need litte more fluan iry and enlargement of ils masses of bays, yews, anct elders. I propose to renew the path along the bottom, and connect it by a light wooden bridge will the renewer footpath leading to " $\mathrm{Mal}$ lace's Well" upon the nortl sicie figs, $; 5$ and 7 , Whatever be the connection with W'allace, if any, this Mell may probally have been connected with the water supply of the Tower, but its tradition ot medicinal value must also be kejt in view. If after cleansing it turns out to be hrinkalle, we liave here an interesting little feature, an adolional attraction.

\section{F. Palace Dene}

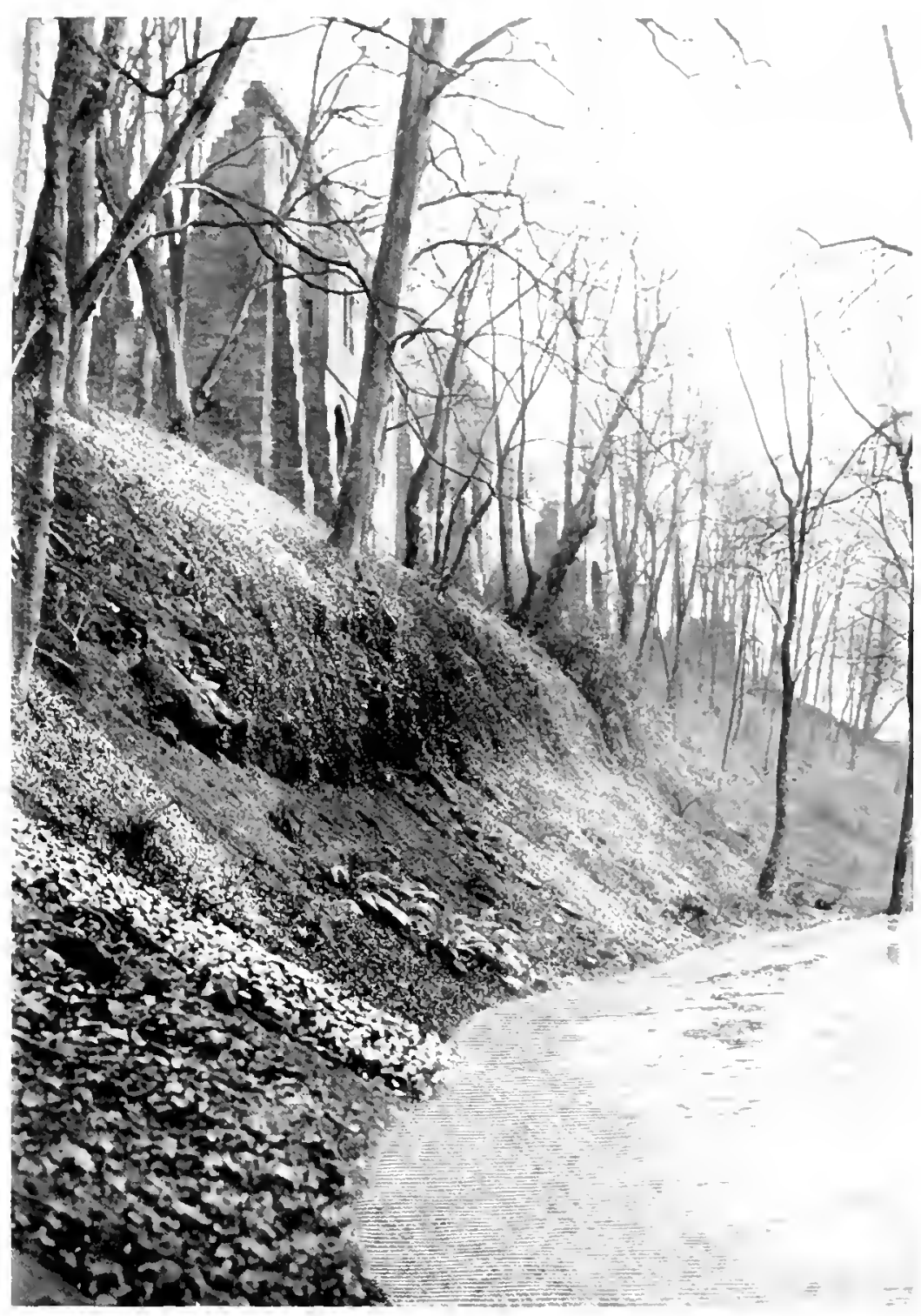

This [rings ns practically to bur next unit the Palace bene. To rase and to widen out lae stream is liere of all places most imjwrtant to attord the reflection mirtor needed to perfect the picture of the Palace ruins, and more fully justly that comparison to Warwiek Castle whoch is otten male ing. 77). This le easily donte by raising the level of the existing linn, which,

porlance of the old mill lumblumes as extendung

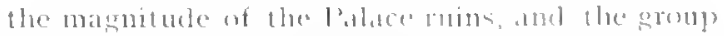
it forms with the Mbes abose. on thes whole mass 11 now hehoves us to tind the lest view points. Better than the familiar ones from the 
west side ot the Dene will be found the view oflered alowe, owing to its letter displaty of the

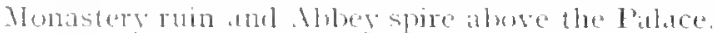

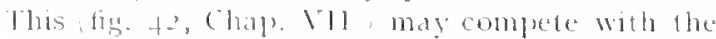
frontispeet on the thim of leting the best view in buntermline. It as taken trom the un of the north garden wall, and hence surely justefies the construtum of a logh stair atse, leadung to it rallat walk, replateng the present cope, or at least (1) at belvedere turred-why not both

lisy thinnmg ont the worthless trees, and ly a bitle jutlewos proming of the remaining ones, bemish is obvionsly the arom rather which at present proterts the path figs. +2 and ond

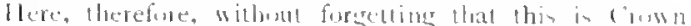

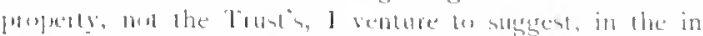

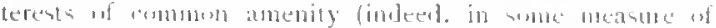

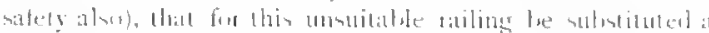

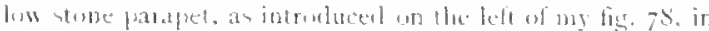
place of the prevent ailing in lig. 76 . An insection st this

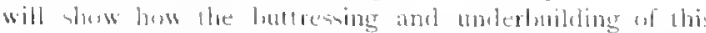

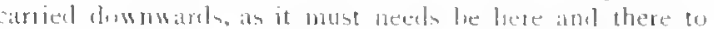
the rack ledsu, will further ais the pricturespuenes of the whole compusition, and ahe prevent andy danger of homblip willin an atprectalole time.

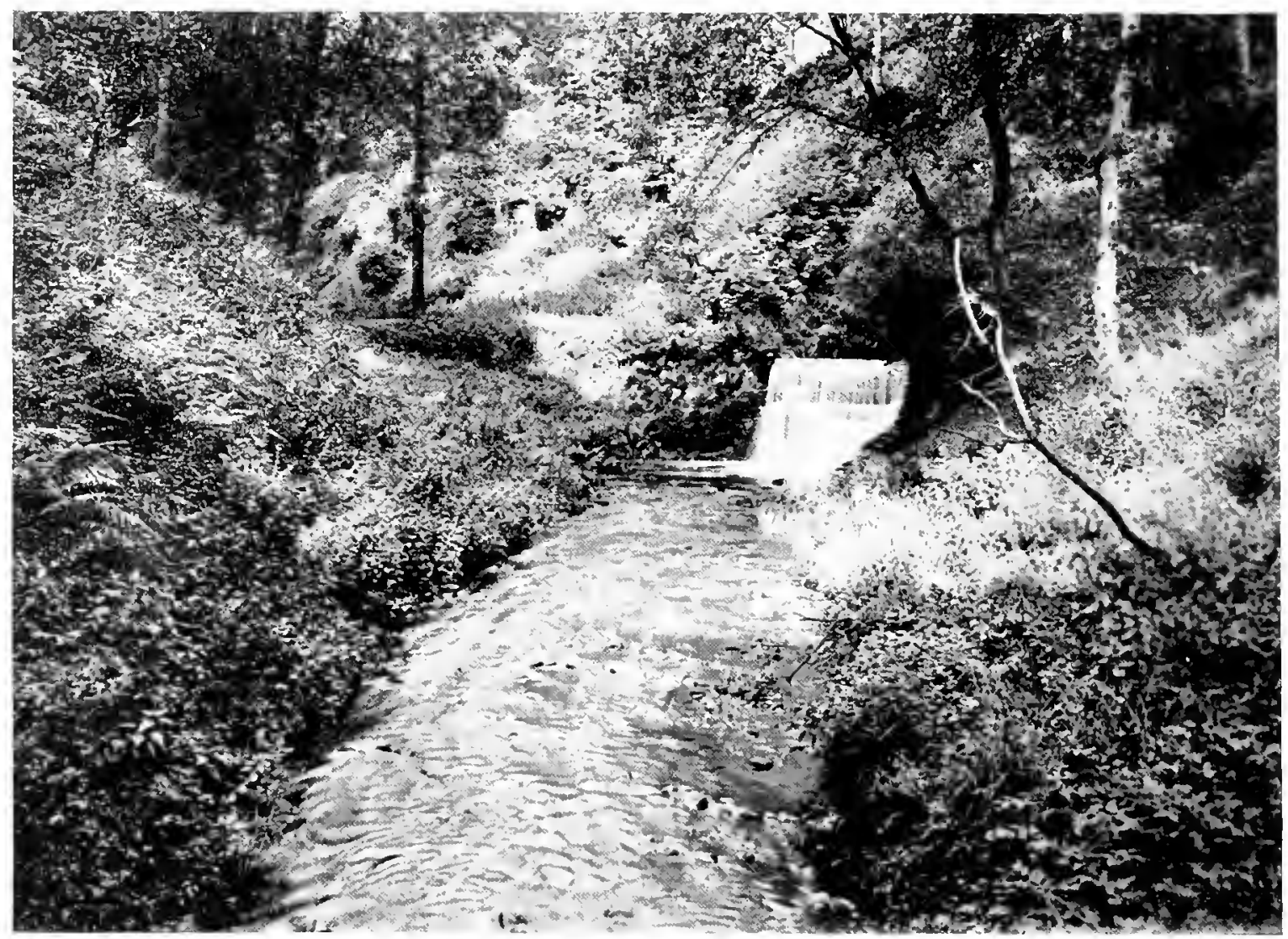

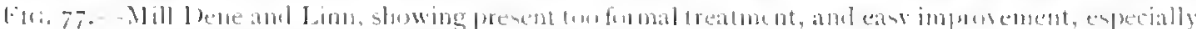

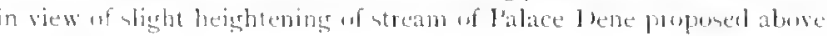

this whole pricture may be considerably improverl, since parts of the lubleling would then be visible thromgh openings in rerlure, and not merely, as at persent, throush the winter branches akone. The slight thinumg of trees at lontem, insulved by the widening of the stream, will also be an alvantiage. In extonding the ivy sheeting and planting of the bank there is also a litte luther momprement to be lone

Stulling this l'alace vew more closely, we note huw laregely 115 noble eflect depends upon its massive buttessmb, while the corresponding
While spe:alking of the crown property I may alow renture to siy that the present rough earthen separe an in lieep

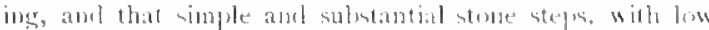
parapet of latublate on one vide, would lo at sulmandiat improsement to the whele architertural empusition. The

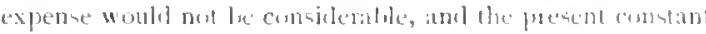

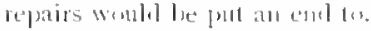

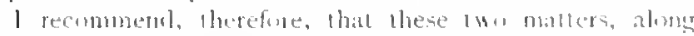

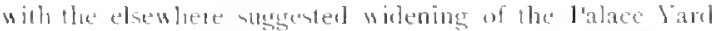

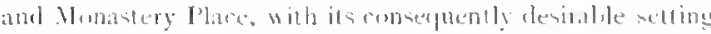
bick of the wall and railings in the fonuser flace, and

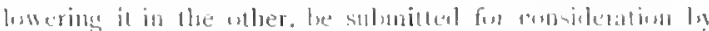
the Trus to the crown atuturitien. The apenting of the late proprieten arcesen to the l'alace. which hat presum

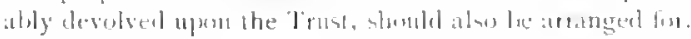




\section{G. Mill Dene}

of the Mills I shall speak at length in Chapher Sillt; while of the picturesture interest it the Mill bene, with its two lills beth improwed, its fresent brigge rebuill, and a new one thrown atcross from the foot of the .lill Ciarlen westwards. nothing more need be sand than that this section of the slen mould obviously be one of the most interesting and varied of all. The milt strcam 1 also leave for consiclention in Chaps. Nitll and $X 1 X$

New and interesting views both of Mill Dene and Manse Dene womld be obtained from the proposed new bridge sec fig. 70 , of which the usefulness as connecting the lwo sides of the glen for driviug puposes will readily be a preciated. At other points this would be impossible without much greater expense, and, indeed, serious alteration of the landscape, but luere the levels readily admit of $j$ ts presence as an improvement not a transformation. We drive from the future Manse Entrance to the low of the Will Garden, then acrosis lhe stream and down a wide old path, easily renewed as a clrive, to meet the cast lrive of the main park, and thence turn uphill or go roumel. . little stucly of the plan will show how greatly this luilge will increase the extent and the variety of the possible Park Drives, This bridge I have sketched in but the slightest way, hut its comparatively long span indicates steel as lere the suitalole material. Ipart altogether from any preculiar fitness here on fersonal gromuls, this would obviously be the most characteristic constructive adelition we can make in onr day and generation whe open-air architectural museum of the Park. Why not make its construction an occasion and a stimulus for the engincer as artist? In our still compuratively early sted age, he has hitherto been mainly occupied with the more elementary problems: let him now express lhe funest capabilities of this nost marvelious of materials.

H. Manse Dene

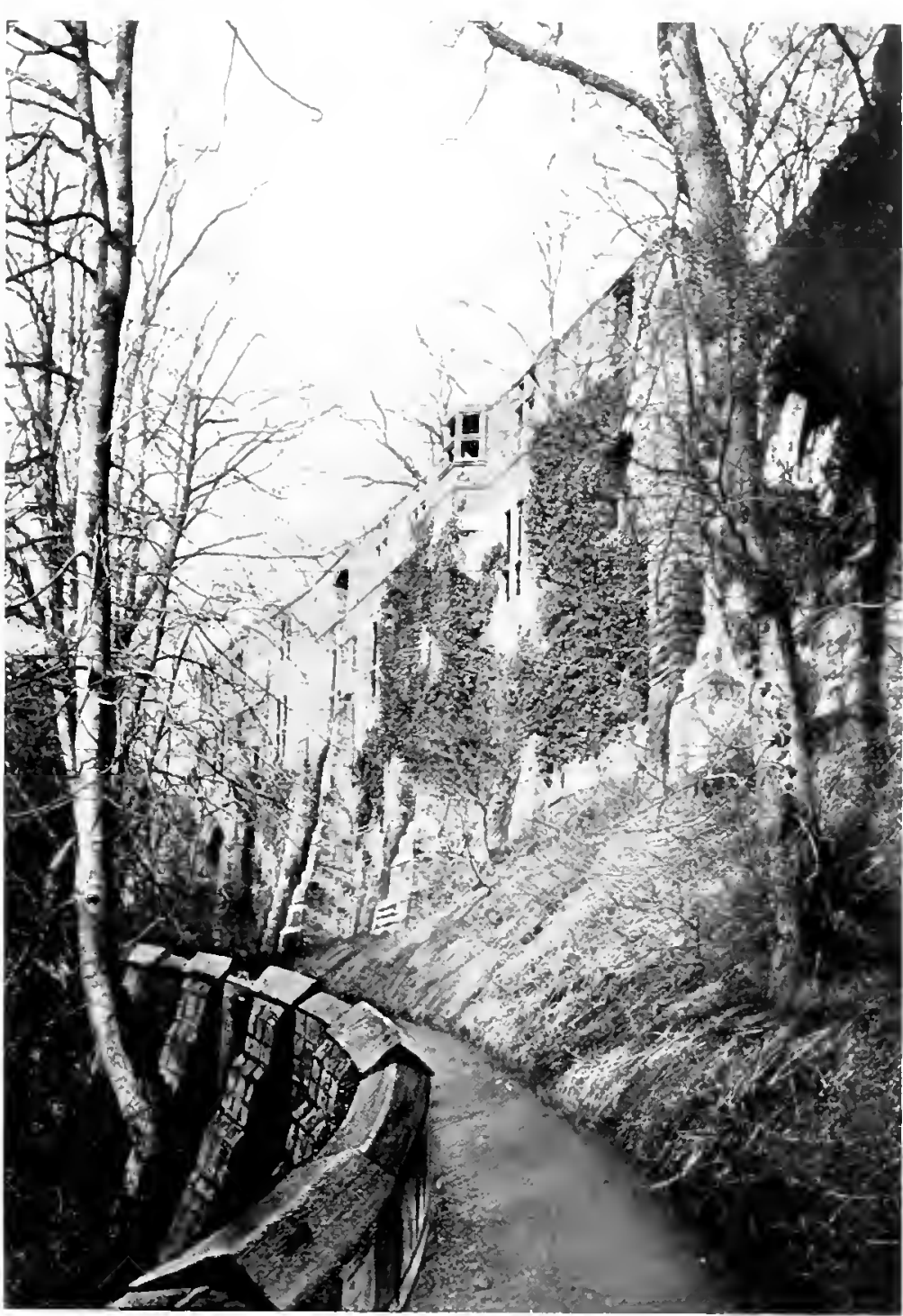

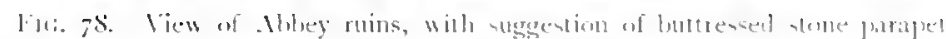
to replace present imo raling. The paraped is here us prominent, and the cupe

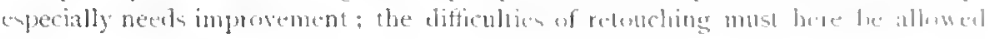
firt.
(I) lle Manse Inene widening anto the lake

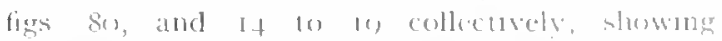
the possible improvements, are suffuerent. The whole study of this propesed muperement, in relation especially w the Nodhertown bumberat 


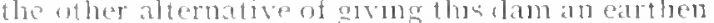

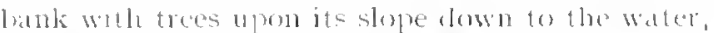
though I fully admit there is alon much to tre sabt tor thes nuturalistic licatment.

Herca at length wo have returned to the improvement wh whell these parle sturies fregan, in

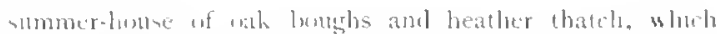

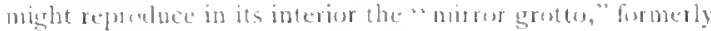

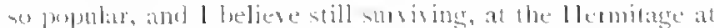
Inulielel and eluewhere. I ans sell awate that thin is not

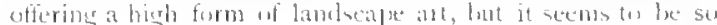
real a resunge of delight to ehildren and other wimple ab. servers that it seems reandable to styply it.

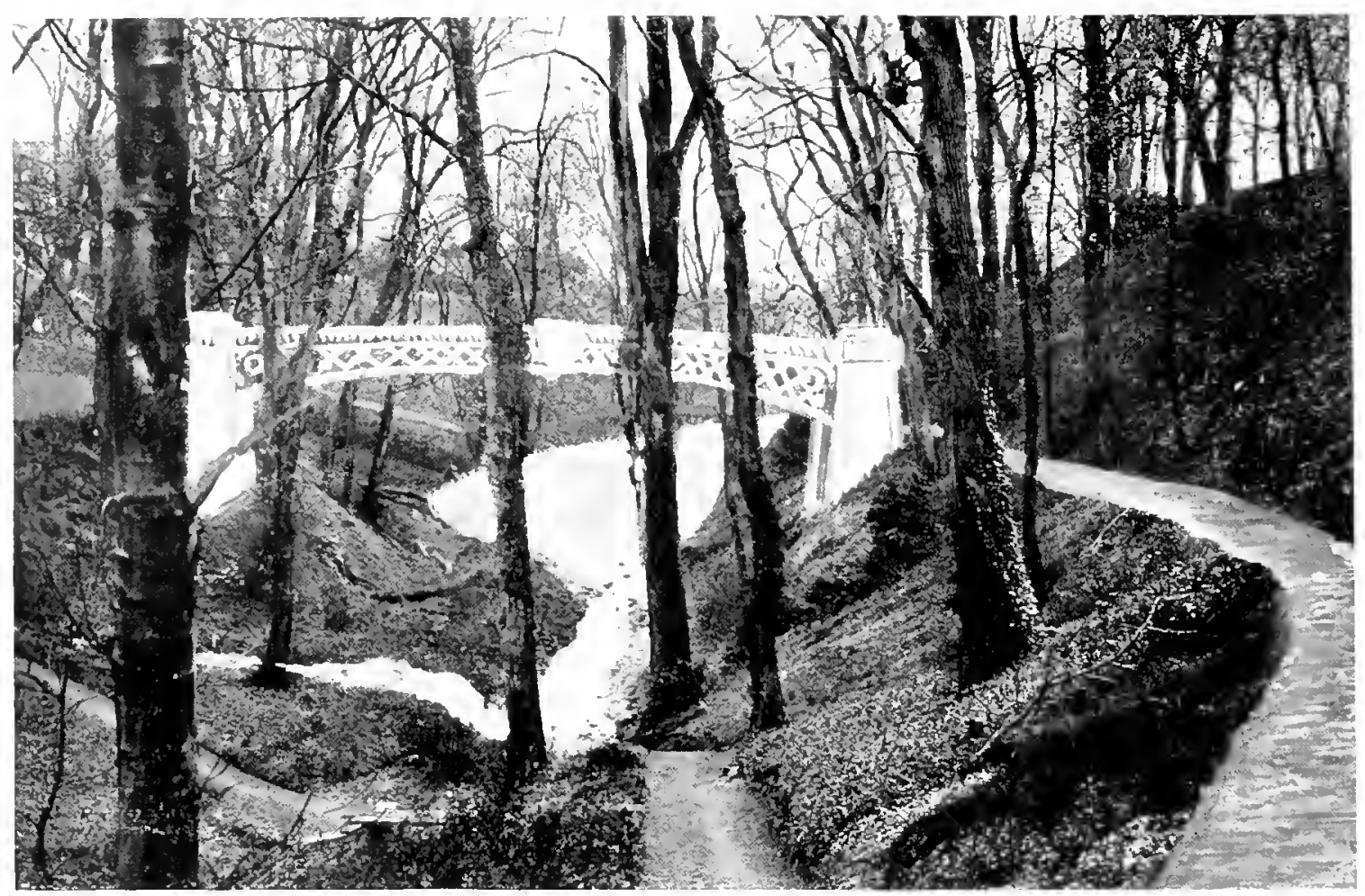

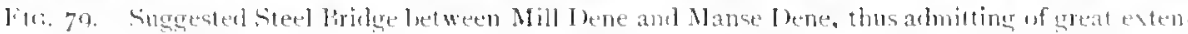

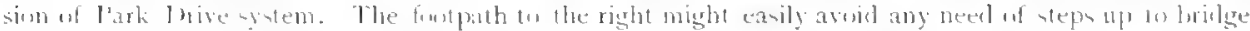
and dive by a ligbt increave of graslicont.

Chaptor I that whlening of the stream into a lake at the fort of the Glebe which gate us the whole series of fios, It to I d but which we were then whiged to atandon as impracticable, pending the purification of the stream. This now exhatustively treated, this propused seheme can be reatised; indeed, some day, I trust, continued southwarl, as already adrocated in Chap Xl F.

\section{Possible Hermitage Grotto}

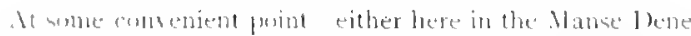

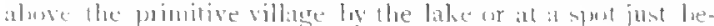
low the propmed nes Arena fall-1 would erect a rustic

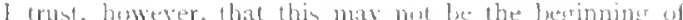
any sulangueous sroutus or other custly cumceits, for in such ways the arts have ton often wandeded away intw may

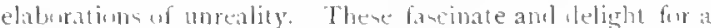
season, but a reaction som appear. The waste of habour. of wealth, needed elsewhere, beromes volutenly mantest, and a utilitatian age thus follow. To othess the unreality is most painful, and scientilie I'hilivinism results: shile te whers, itrain, such elaburation of lewe interents in prefertace to bigher ones a walke"s the putests alihe of l'uritan and iromedast. (1) all grounds. then, it in safte to dos as I have tried in these pagen: and, while fearlessly thanating

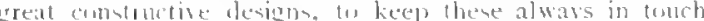
with the reality ut labsur, wilh acience also, and, alneve all,

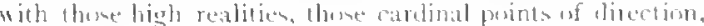
which we call iale:ils. 


\title{
D. NATURE M USEU M S
}

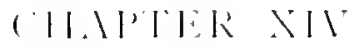 \\ NATURE PALACE IN PRINCIPLE AND IN POPULAR USE
}

\begin{abstract}
A. Site

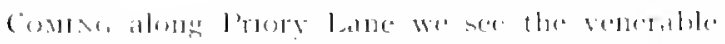
fraghent of an anclent gateway whald comber

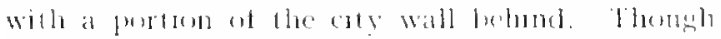

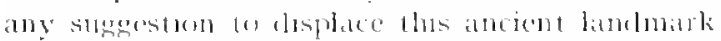

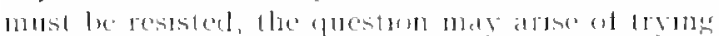
(1) adapt to this, ar harmonise whth at, the gatte

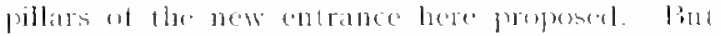

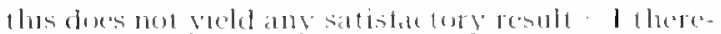

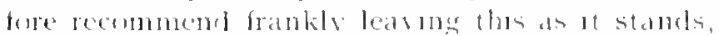

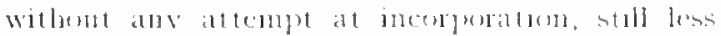
restoraton. An ify plant may be plated on the

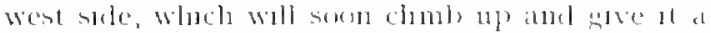

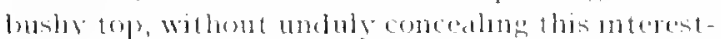

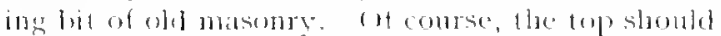
be cenented and any weak joints well pronted. but atter the tre.tument iry can do mo harms its

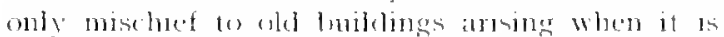
allowed to conceal actual dibaptedtion and to throst its shouts between the jomts of stomes, which its growth then, of comrac, bursts asumeler and may even bunder lown.
\end{abstract}

$1 \mathrm{t}$ is licre at the manse thet atter tull comsteferit-

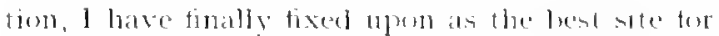

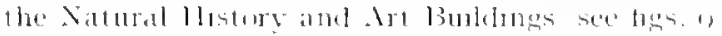
and I2. The choce has heen determmed mot only ly the eratdual exclusion ot the one or two wher

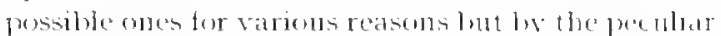

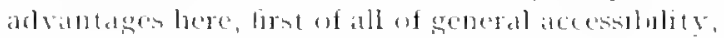
and thes, ot eourse, not stmply from the ratway statem or the Teebmeal schord but ats the mont conventent entre between the present old Town

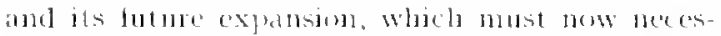

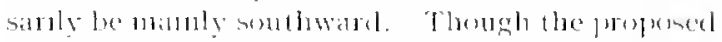

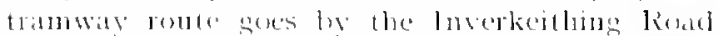
this will still be rery conventent, and there is every probalulaly that before many reats at Hew line may le lad, pashing this entrance.

The harae tolerably level site destrable tor a

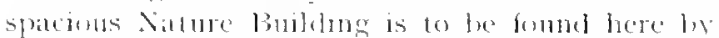
uthlsher the manse garden, ot which the slope so a gentle ande. I, theredere, recommend the acolutstion of manse and garelen ats well ats glele, erpuratbent accommostaten being readily found for the present manse elsewhere.

To replace thes an existing, posibly historic homse, saty the dhbot's, moght, perhape, be purchased, or one of the existing vallas, say in comely

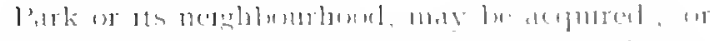

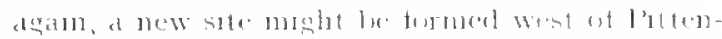

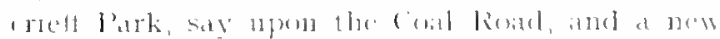

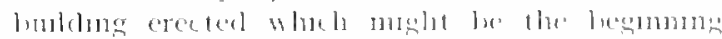

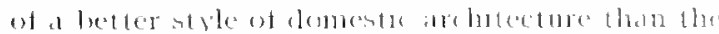

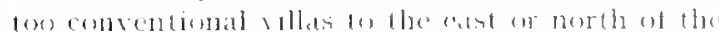
t)พIt

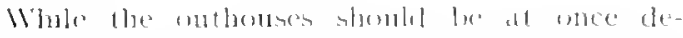

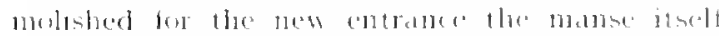

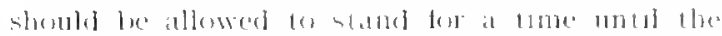

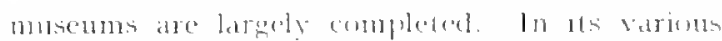

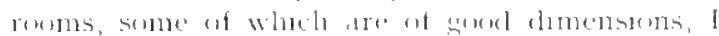

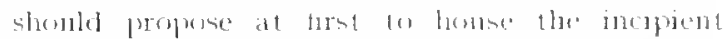

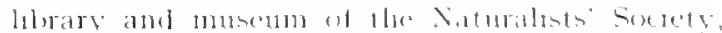

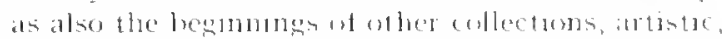

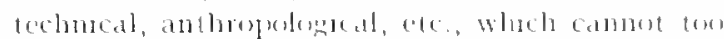

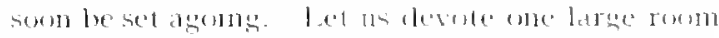

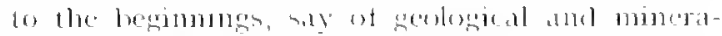

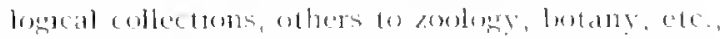
eatch wath ith hemorary curallor, an official whe

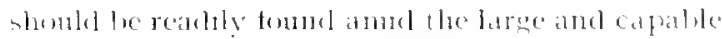

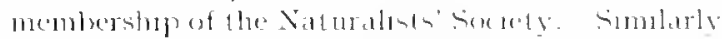

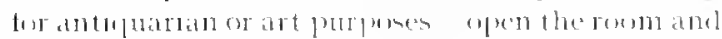
find the curator, and the colled tom and spectment wall sine be commens 11 .

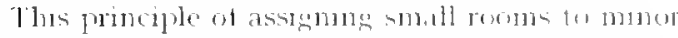

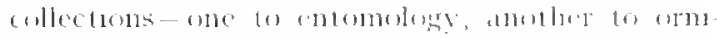

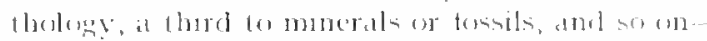

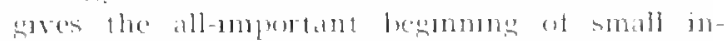

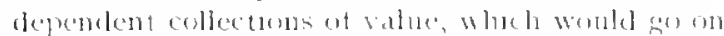

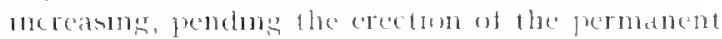
museum buldug.

\section{B. Nature Palace in Popular Use}

We now come do ble at the mont amportant and

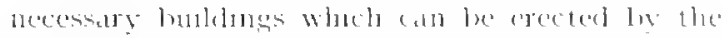

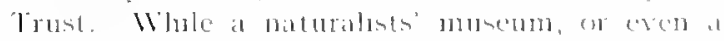
muale ball or art sallery, can only appeal to, or

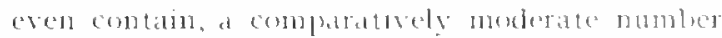
of entrens, there is uroently nereled on our colles some spacious and attracture plece es recreateon allul meeting.

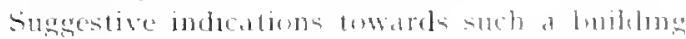

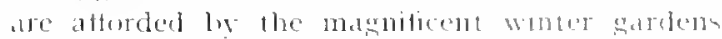

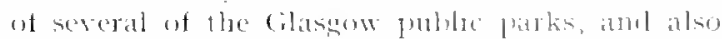

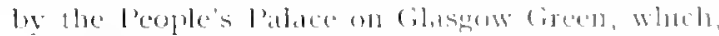
in ahlution to a conered promenalde, serves as at 


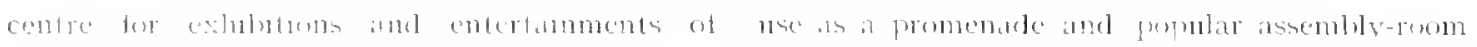
virume kimely.

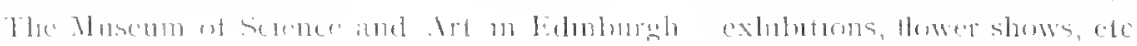

fur lingats, perondic undundral
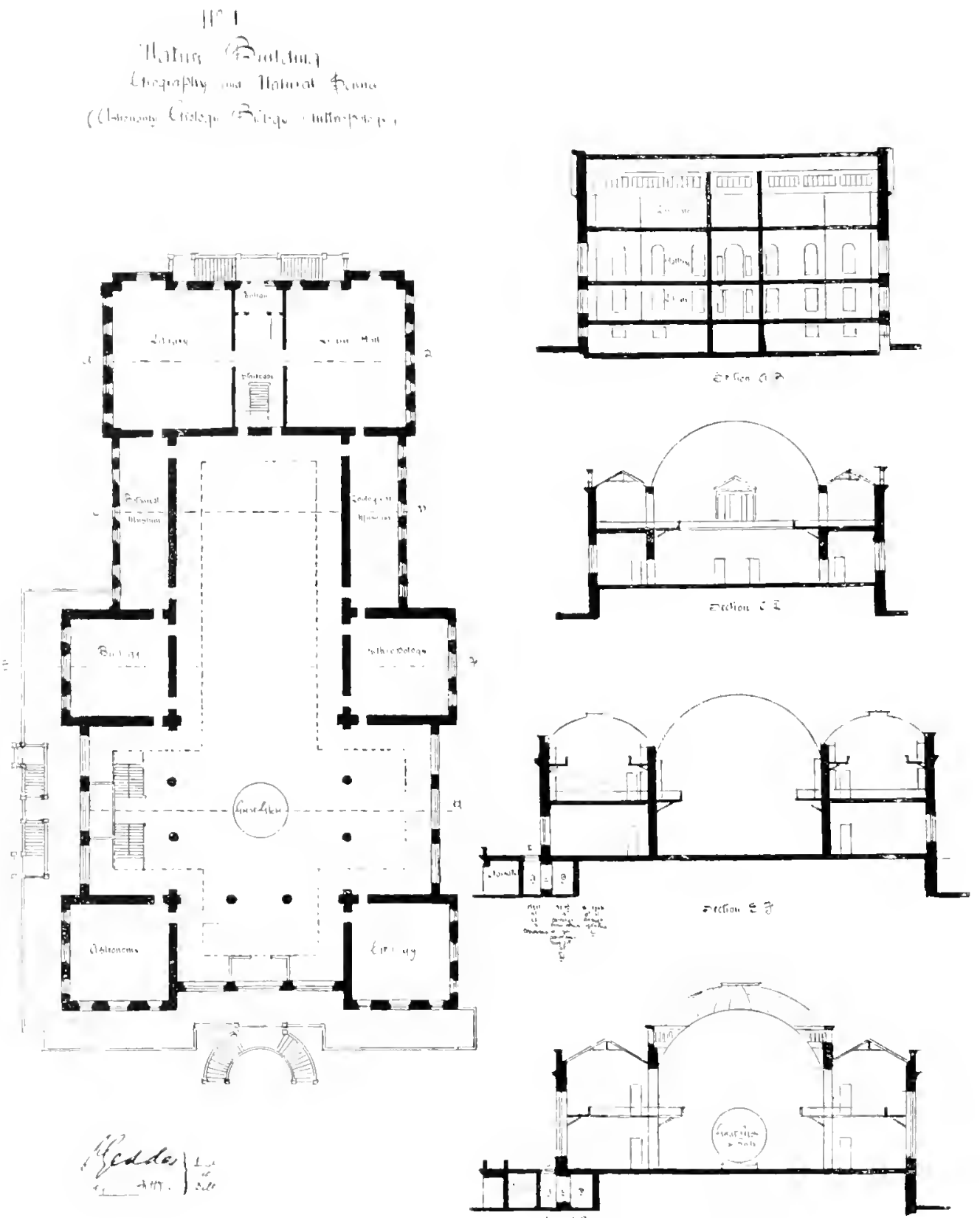

$\div$

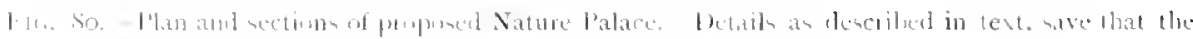

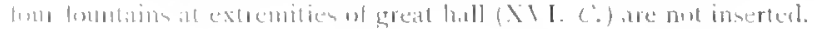

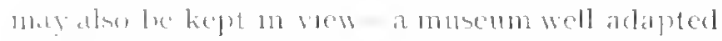
atse ar rectulioms and comversaziones The Winerley Market al Ednuburis is crmstantly of
What the cication of an example of each and all of these types of motitution is obvinusly borond our needs, the puestum at moe arises: May we not 


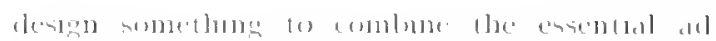

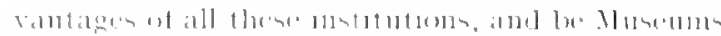

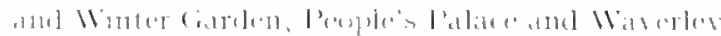

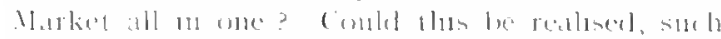

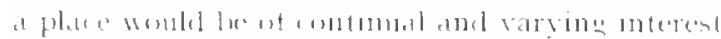

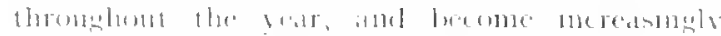

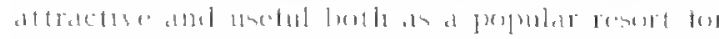

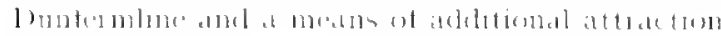

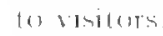

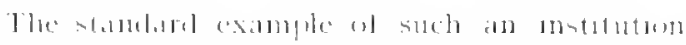

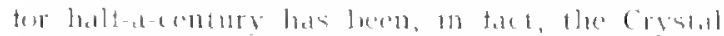

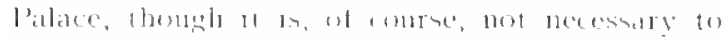

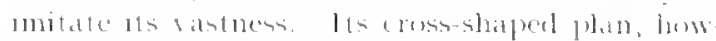

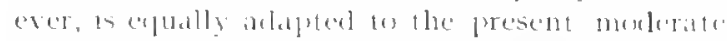
scale, woth the impertant ditterence that i

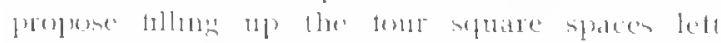

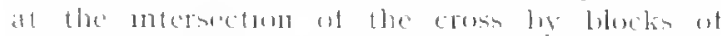
muscum huldimg and of amtommeng these fo form the ent

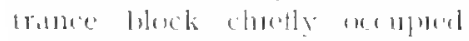

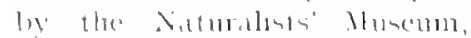
cte. which monlel replese the

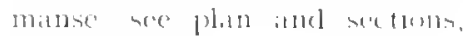
fig. Sis

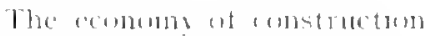
chlecters by the combundurn, and the pomstality ot arehlecturat elteet, espectilly in the north, west, and sollth, and also trom a destance through the prompinges of llue lom small domes aroumel the lurge ecentral one, will lese sern trom the accompansme pleme, elevatuons, and perspective it will le

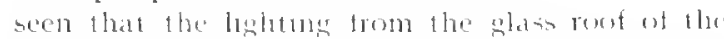
man buldug is supplemented by the preat wndows of ats eant, milth, and west tronts. The

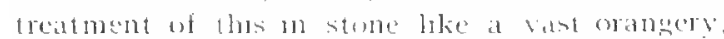

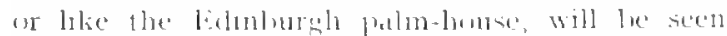

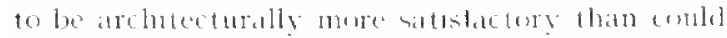

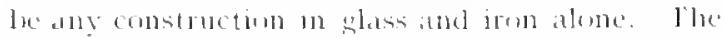
posiblitity of ront-lishtule of the appere storey ot each of the tour angle-blocks completurn the sefuate aromel the cross allowe of utilising then whele wall space and of amitting texternal

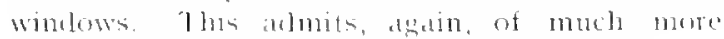
monumental treatment fiest si and sz.

Whole on bublunges ot hosturical character we may naturally empley the oleler architedural stries, ats will be sech later, at frankly modern

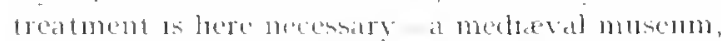

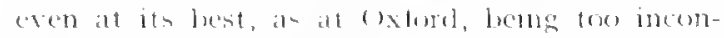

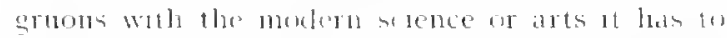
house. Atter combleletelun of the varions stras

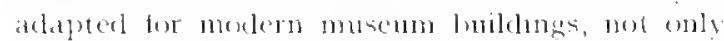

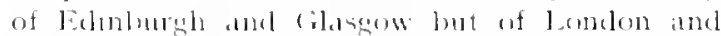
Smerican citest, l think we camnot do better. espectally here in liste, thatn adenst what we are

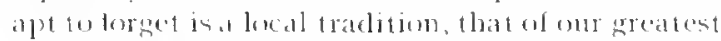
native artist, perlidps the most mmportant arelitect

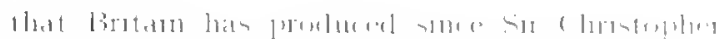

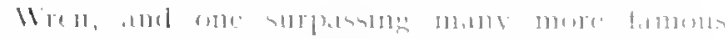

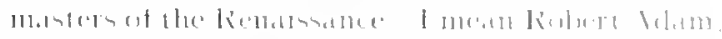

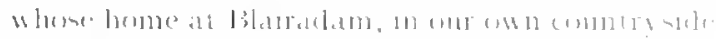

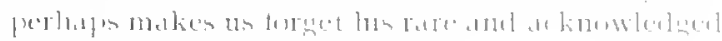
e'In⿴囗十)

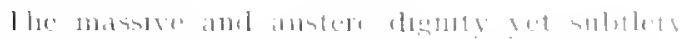

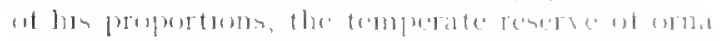

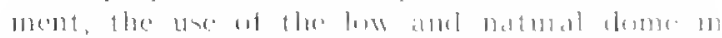

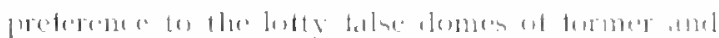

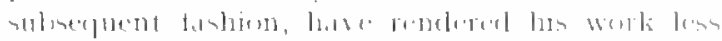

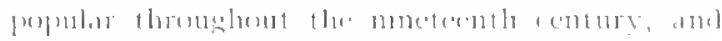

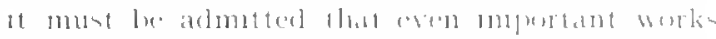

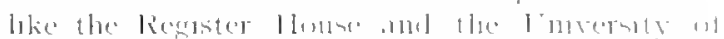

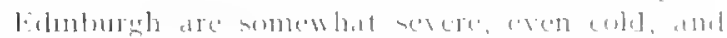

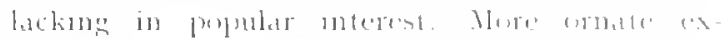

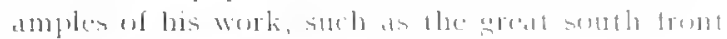

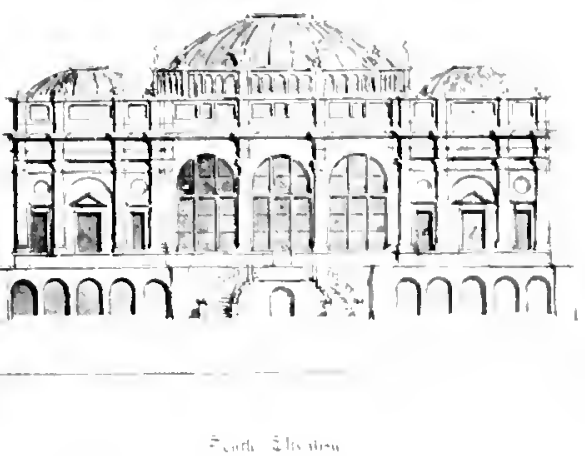




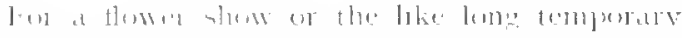

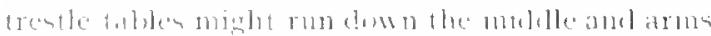

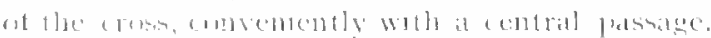

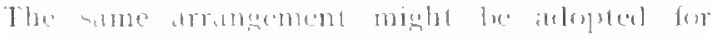

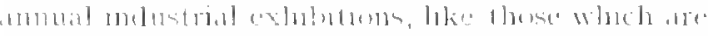

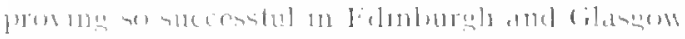

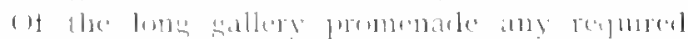

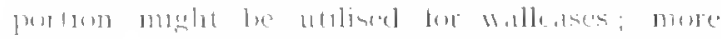

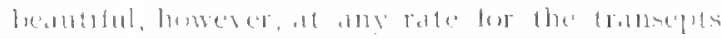

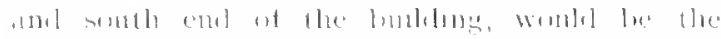

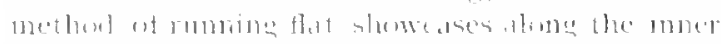

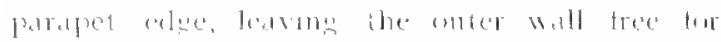

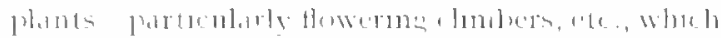

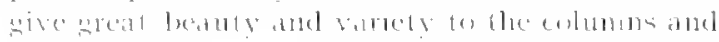

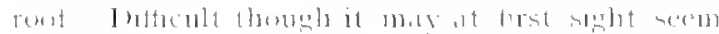

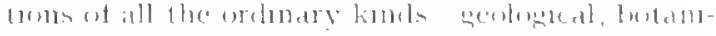

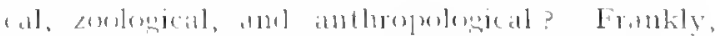

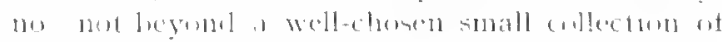

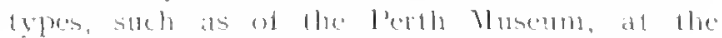
very largest. Thomple fersmally stremgly in-

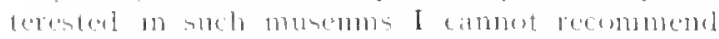
the reduplicathon of at set of these in Lonterm-

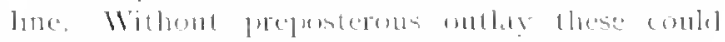

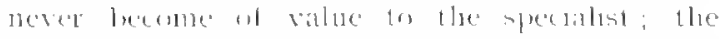

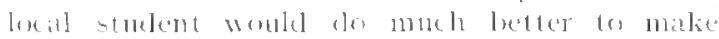

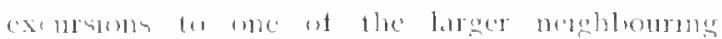

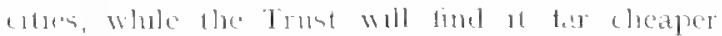

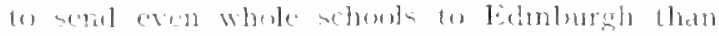
(1) weate anch musemos here. Even were

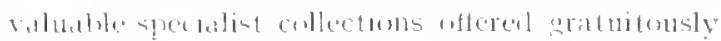

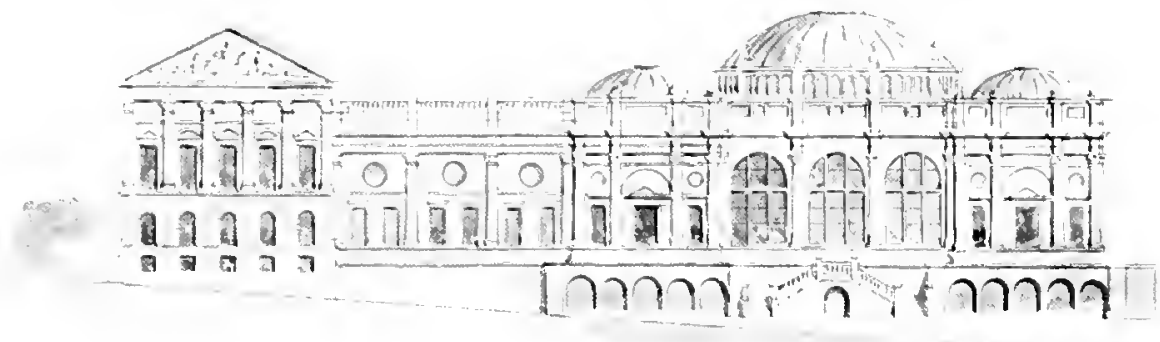

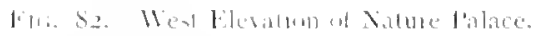

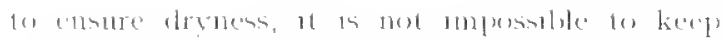

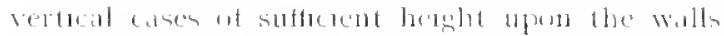
and yet lave the plants atuse lleme on the wall-

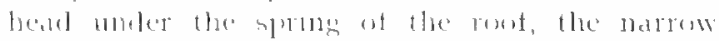

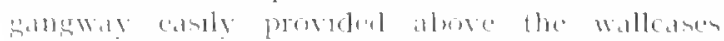

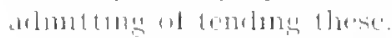

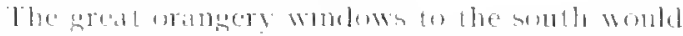

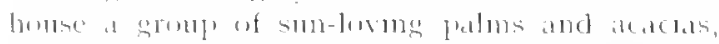

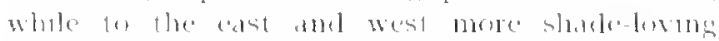

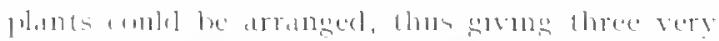

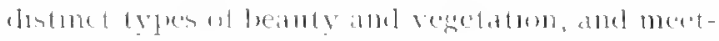

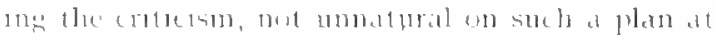

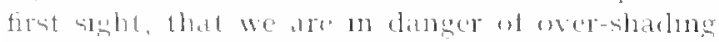

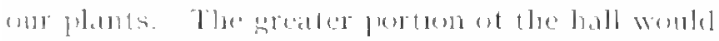

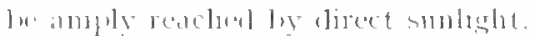

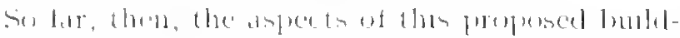

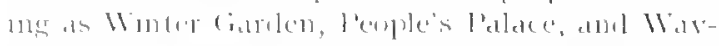

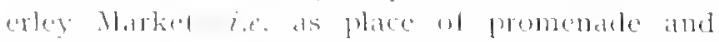

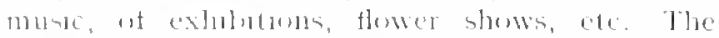

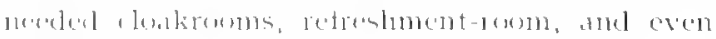

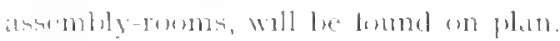

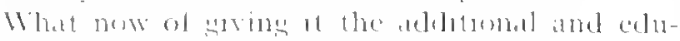

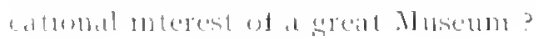

\section{Nature Museums in Principle}

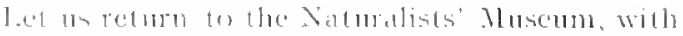

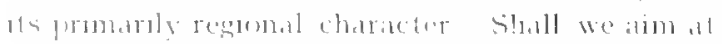

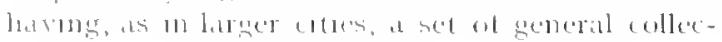

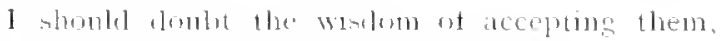

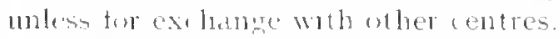

While 1 , therefore, woungly presin the abandonnume of any ambution to porsese the sath best

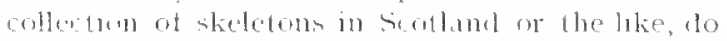
I therefore propose hutung up our knowlerge

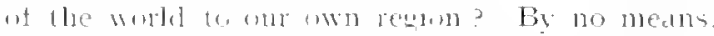

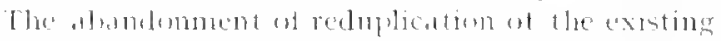

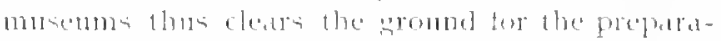
forn and the woth less andlay-ol at tar mome

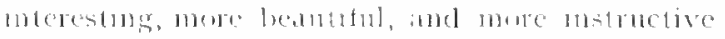

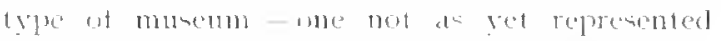

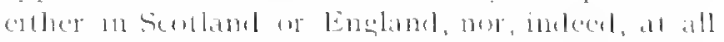

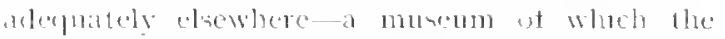

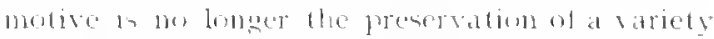

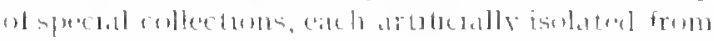

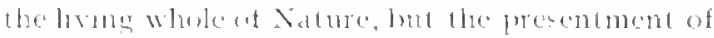

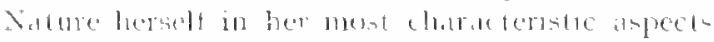

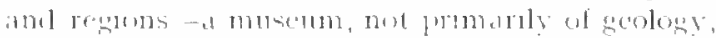

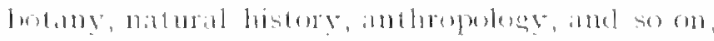
yet of the whole of these withen the laven anity

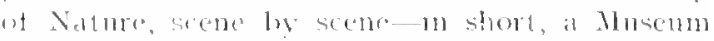

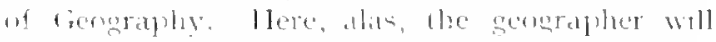

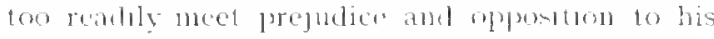

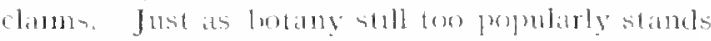

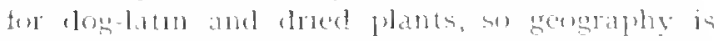

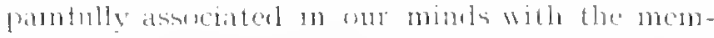

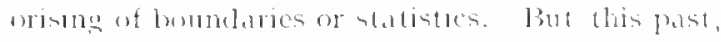

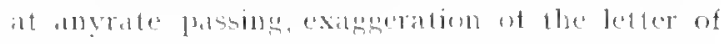

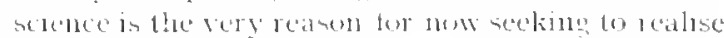


How artintio everession of its living rablits and ofurit.

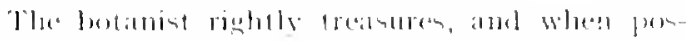

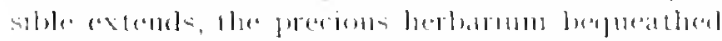

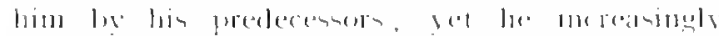

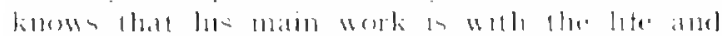

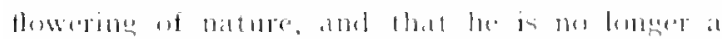

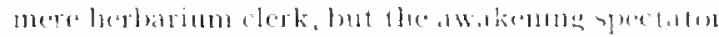

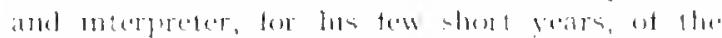

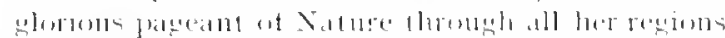

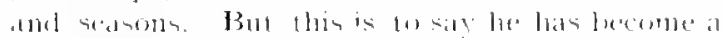

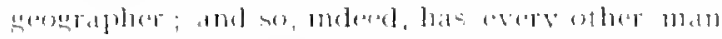

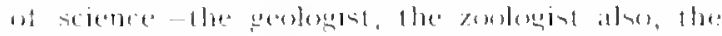

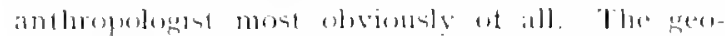

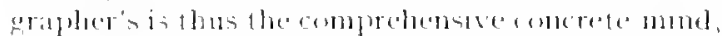

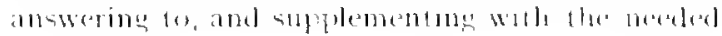

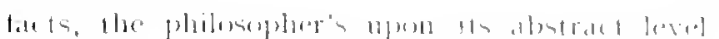

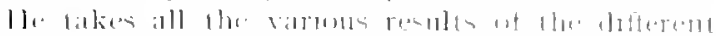

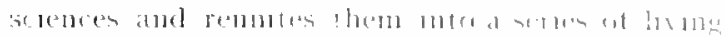

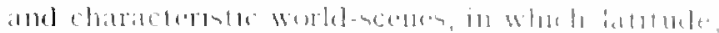

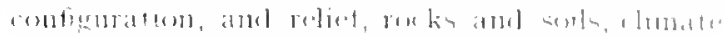

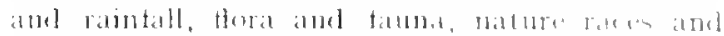

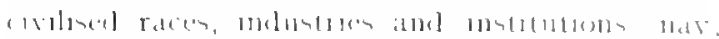

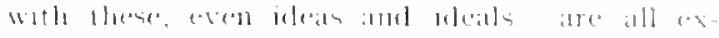

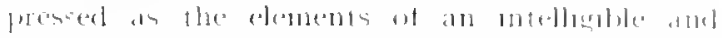

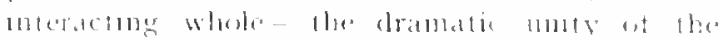
Winla and man aty, also, we llat in lik

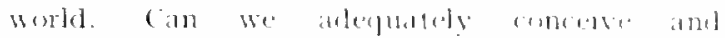

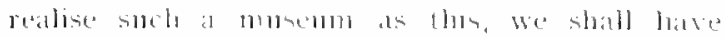

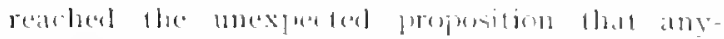

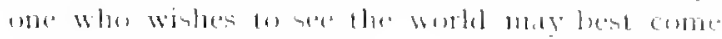
(1) Dontermbine. 


\section{CHATER XI}

\section{NATURE PALACE IN EXECUTION}

lluw ans such a project as that antlined aluse

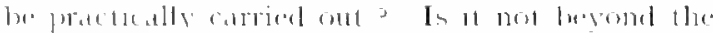

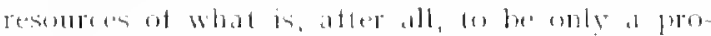

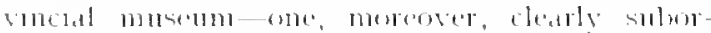

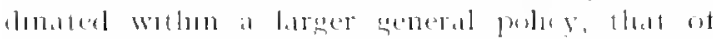

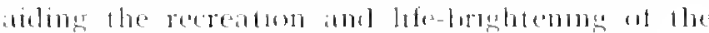
workers and buletere of the communuts"

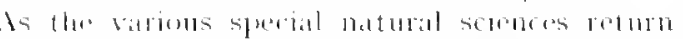
into that geoseraphe, that general presentment of the world an evolutum, of which they are lont lle

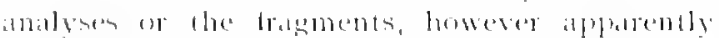

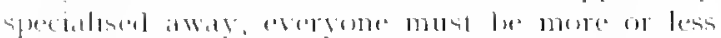

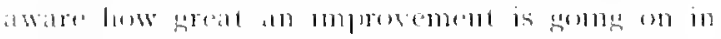

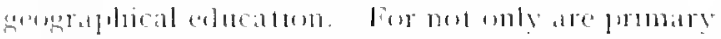

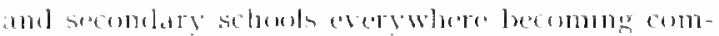

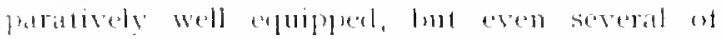

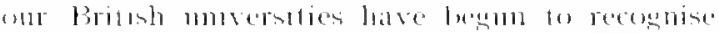

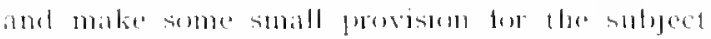

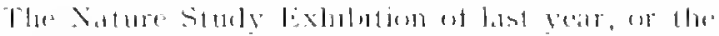

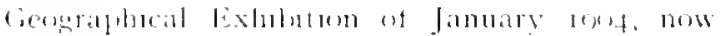
arablable to lomponers why nol, theretore, in

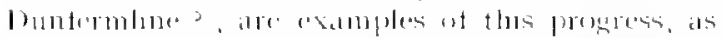

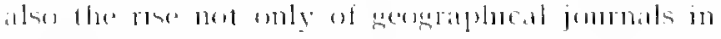

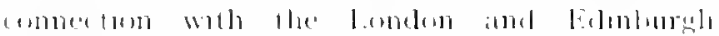

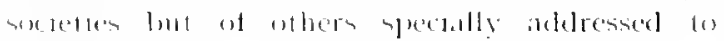
feacheres

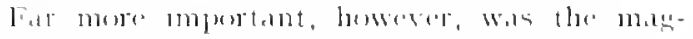
nifuent laris lixpostan of lese, from which,

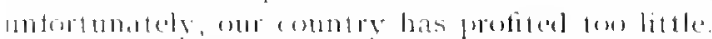

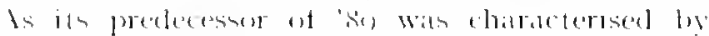
the teetmeal marvel of the litled Tower, so thes bxpmitum wombl its alpeal of freshest interest

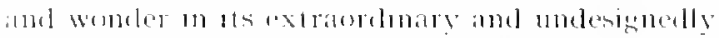

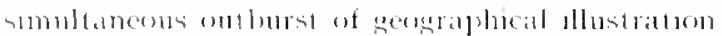

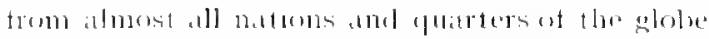
The wats not only on reled, collerton, and porture, lut mose of all in lamoramats, these embleang

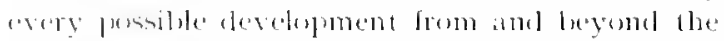
awe lypes more or less tamiliar in this commtry

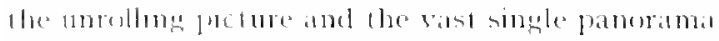
wempeng an enture hall. Mloving panoramas were developed woth rematkalle eomlinations of artustir and merhanical skall--witness the "sterre-

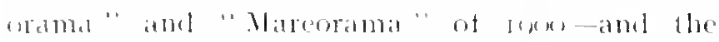

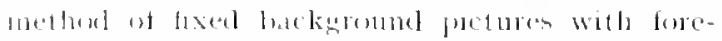

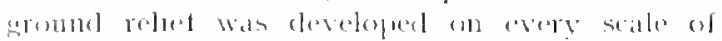

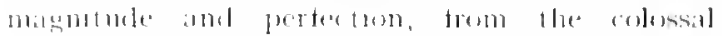

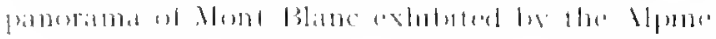

(labs, to the diny perse blows of defterent minos scenes which atcomplatied this. The same methul was also unetully and siccessfully applied for the olluntration at arthituture withess flue

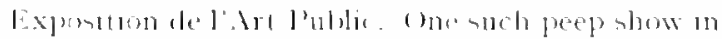

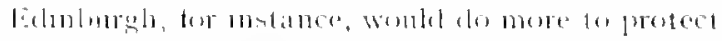

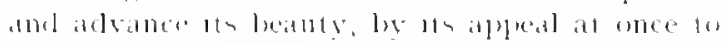

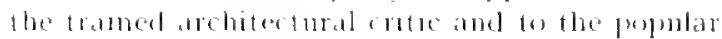
mond. Hatn is fosishle lo the entire litelume of at

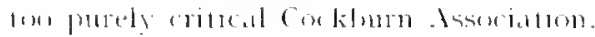

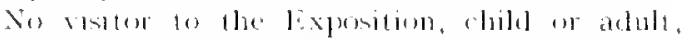

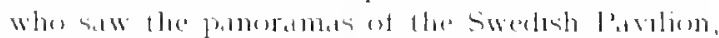

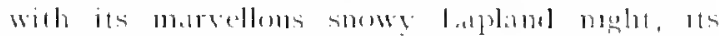

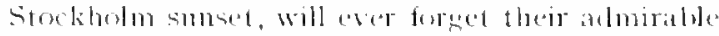
fidelaty and leatuty, thete combinatum of reatism ame of art, whle on mans ofher natonal and Fremeh departments at the Exposition searcely less skill was deplatyel. A chmax at union of

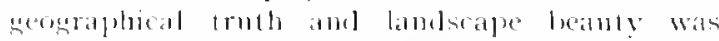
resched in the shome models, like these of the

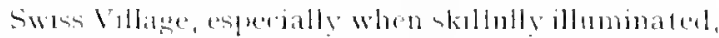

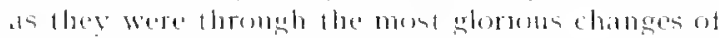

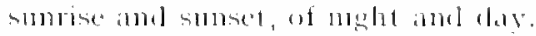

these, in thet, was developed, from lomer familion

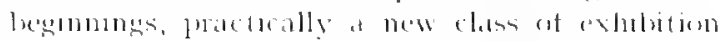
and musedum one, in which the serepan exploter

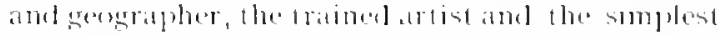

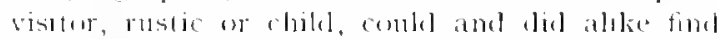
the most been and active pleasure, will gentome

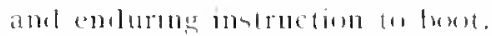

In all that enomoms waste of gexul work wheh gaes on at the lreakung 11] of an Expostum nothing was more lamellathe than the seatterng ot these panoramas; ret thas was meratable, sinco they hat been prepared trom all sorts of reparate pomls of vew, whont any apprateh ar mity.

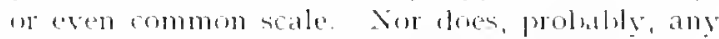
existing musem possess aldefuate fachlites for showing panoramats, small or latpe

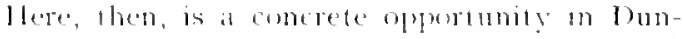
termbine: the knowledge, lae skill, and experience which problued these panoramets is largely stoll aviulable, is practically nuemployed. let us import some of it here; in fitce, let the curatere or assictant curator of the propened musem be one

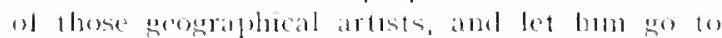

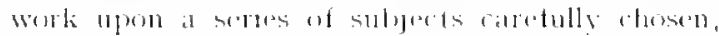

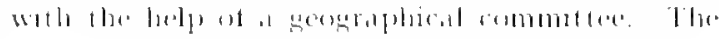




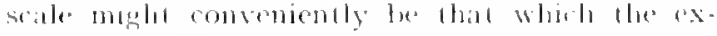
ample of sweelen, alose referred wo, hat esperidly

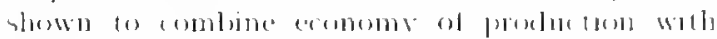

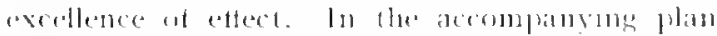

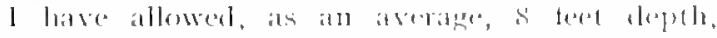

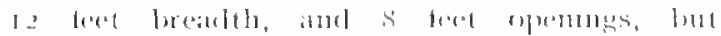

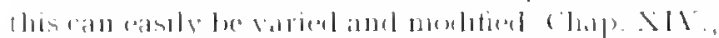

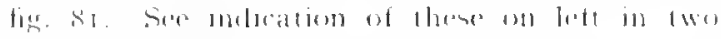
lower seetions

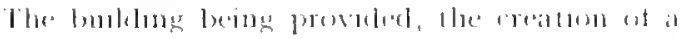

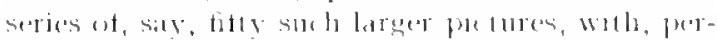
hapes as man smaller ones at balt or duarter that

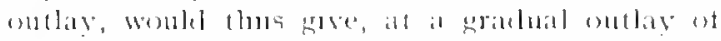

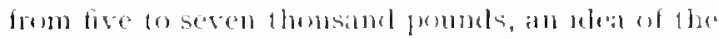
workl, such as not aven the traveller like llumbolal, he deseriptise geograpluer like lieclus, has ret possesined.

The expense of such small paluritmas would be molcrate, chetly for "lime and lime." I $1,1 \mathrm{ke}$

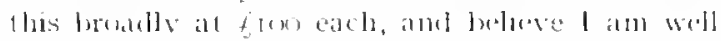
within the matk. The ompletwe of ats pano-

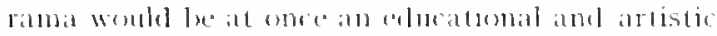
erent in the city; ambl the growing collection would not only command the attentson of exeographers

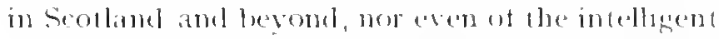
public, holl be at once attrative and educallive

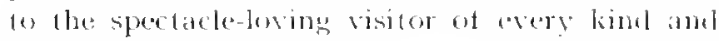
age amblevel.

leaving precine defimum (1) a speetat puper, more suitable to a greopraphacal wociety than for the present purpose, it is enomple here to gree at first rough indeation of posslule and clesirathe panoramas, selected bo as 10 comber an impresiom of the most chatacteristic regums of the worlal, especially these which may be regitoled as at mose mberest to us on reneral scientific armumls, or those of national intercourse.

The senes should naturally le arranged rummor from north to south, with dere attentust alses fo east and west. The sicitor enteriner at the moth. and keeping bus lett babel lo the cast, se as 10 travel with the sum, would thus pass throunh the characteristic lamelscapes of the ohl worke lle would legin, say, whth Namsen's seat of ameient iee:

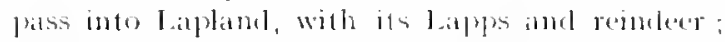
descend of the prove forest of Norway, whl ats

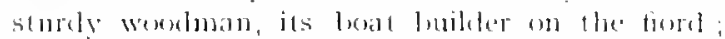
thence threngh Denmark or north dermingy to the Alpine landscape; thence asain fo lably.

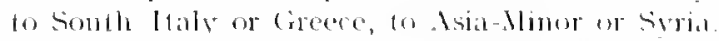

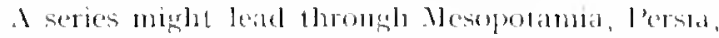
the Homalayas, and Imdia to ceylon; atmolleer through Mtanchuria, kinea, anel japan, through China, Burmah, asul the Malay l'ommsula; vel another to and through dustrallat and New Babland.

(). coming dows agan from the north men the westere hand, he would similarly stite with a Geentanel or Alaskan slacier, amel the liskimo cocompunent at jis fom, and pass, ly a canalian forest and lake scene, with ita halt-breed triplerer,

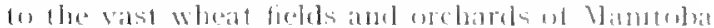

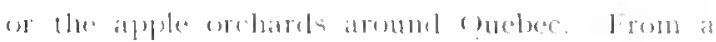

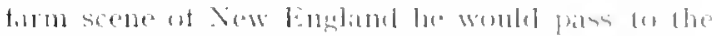

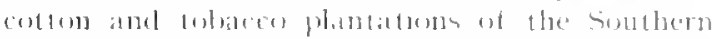

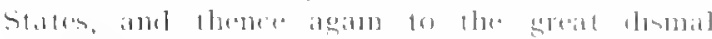

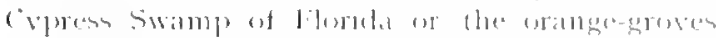

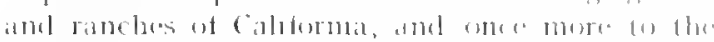

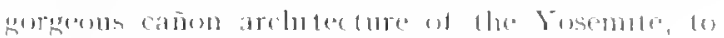
the mably trees, the ato tus desert

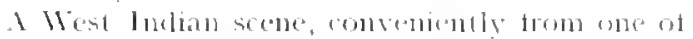

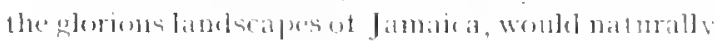

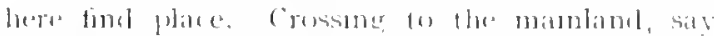
all Vira come, we shombl see somethime of the

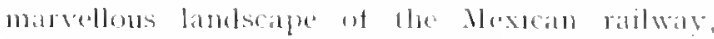

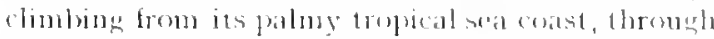
a clanging forest, ap a the temperate platean orertopped by aternal snows steppong solthwatel the l'anamal lsthmus, the ledetic and the

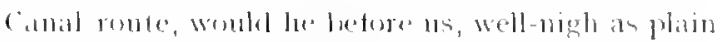

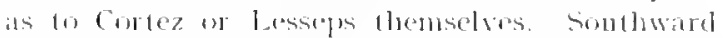

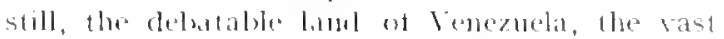
plotins, the mighty dmatomian forest, the pastures

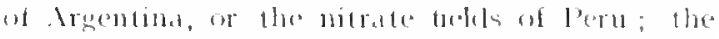

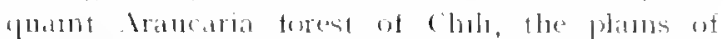

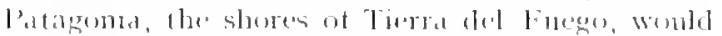

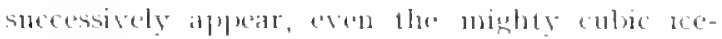

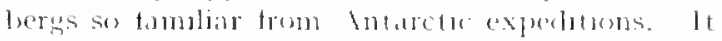

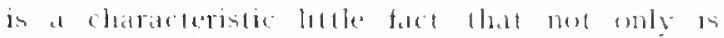

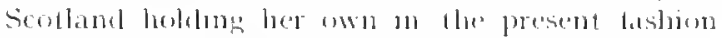

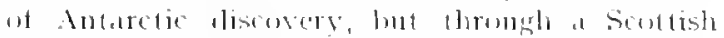
explorer she actlolly intulted them. ()ur scotisste patriotic prible lists ben tor purety com centrated upon the leating hatels and their heroes tew know that, aking, say, aren a toredgn history of some lepartment of gerographeal exploration, there are mentioned as many sontiols travellers of mese and producturity an from the greater

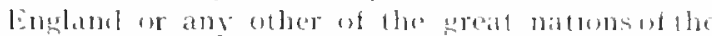

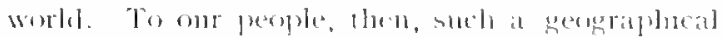
musemon must espelatly appreal.

such a range of pambamas mas, l repeat whlout any undue expense, and whthe a very

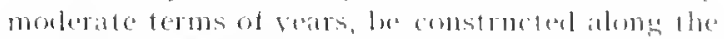
east anel west sinle of om lombling; whle alomg the south might to arramed at smilar serres of

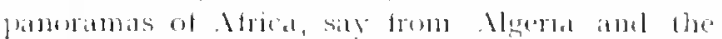
Sidhallat, with a charactelistio oasse; through the

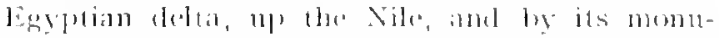
ments to the greal dam ; onwabls still to . Abysintal

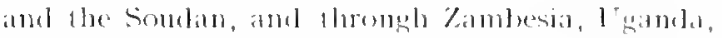

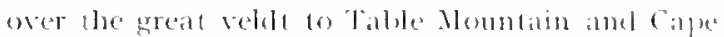
Town, and thence oser to a seene ar lwe in Matel-

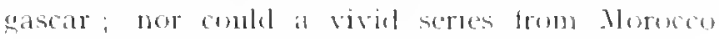

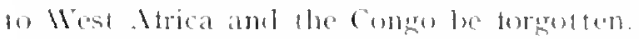

The completion of each palmorima wonld, 1 say agan, be an apprectalde geographeal exemt and the remporary moled partally permanesul exhobtion of the gengrapheal and alleste materal,

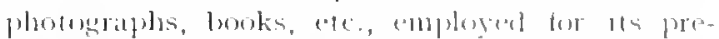

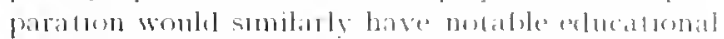
value and interest. I do not lecilate 10 ram 
that, were such wote once tamly in progress, it

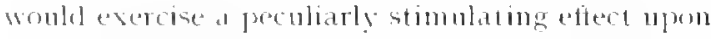
the seluxh, and this for more than merely geograt phical studes. Exen those whom most bethere that

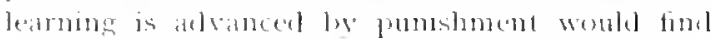
it mol mettective lever on exclusion from the

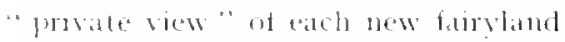

l attate momportance also to the broally correct wentallon w sieh funoramas as have been oul-

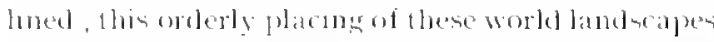

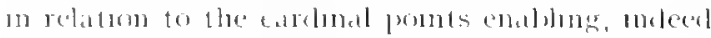

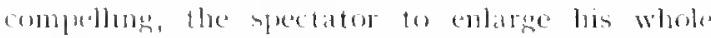

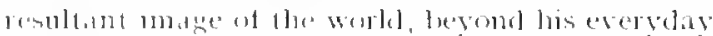

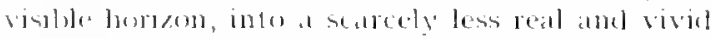
presentalion of the embere world in all its matrs

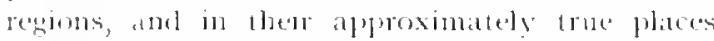
arouml hom. Thus, as the series besame comprethenise the vistor would not only know more of the workl than any one mortal bats exere seren,

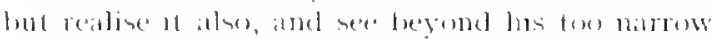

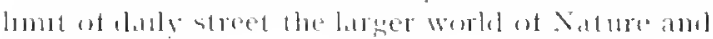
Ilumanity

\section{A. Special Nature Museums}

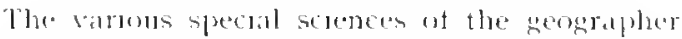
the geology and belany, the zedology and the andhopolong of the work - woukd thus be prepated tor, their large aspeets being imprinted upon the spectator's mind in a way which no musems,

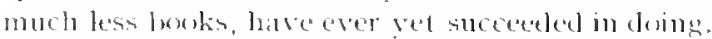
Morewer, 11 is atler such a compreluensive prepuratum, steh is generally untelligent oullowk upon the world its a whole, that we can best succeed 10 torm a reasonably seprote idea of its geolugic a bohere comstituents. Thus we come into a

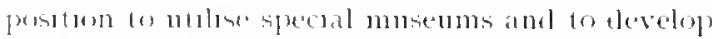

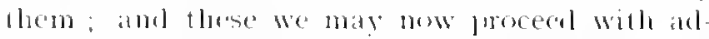
simtage to consteler, so fillug up the tour angles of the eross, and eath muler its respective minos dime.

ln the first of these led us place the Istonomo

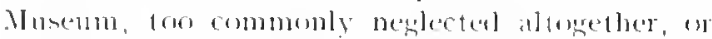
represented by some poor orrery, commonly ont

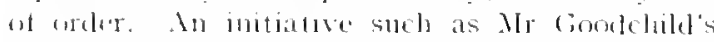
in lhe limblurgh Museum, and a reductions ot

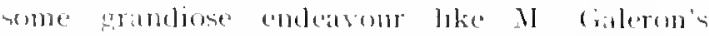
"Globe Coleste," woulal show its possilnhtices

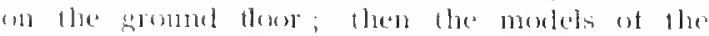
solia and stellat systems, in which such eminems and organd teachers should lave then saly buse world be the observatory itself, with

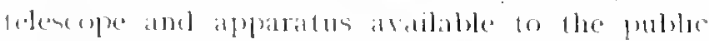

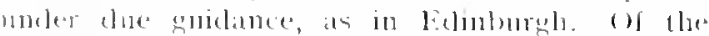
supreme entucational atrintage of astronoms

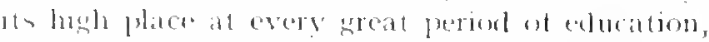

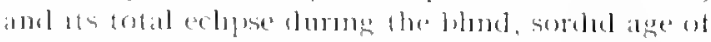
udes, exammatums, and payments he result the

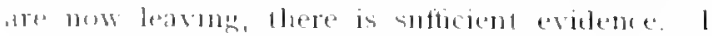

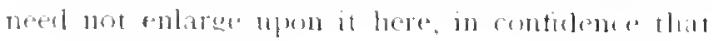

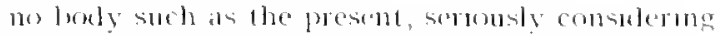
the best provisom of the clevating resources ot culture, can wmit the clams of astromoms.

The value of some new attempt upon alegulde seale of all astronomo presentment of the murerse,

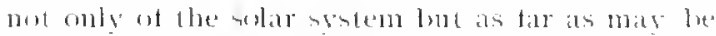

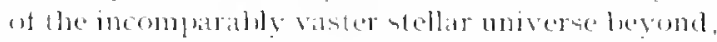

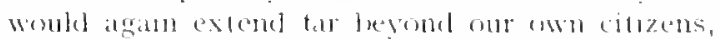
and gove a real impulice to the truly llgher beratuse aceper bilucation of the worlat

Coology with its long part, biolong woth its protedn bite, even anthropology, whlh its searce less forotedn valuely yet unity if human nalure, con

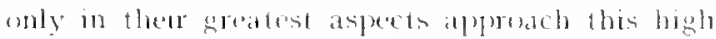

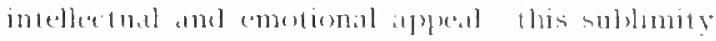

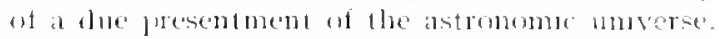
Every seheme of education throushout the remotest past of mankind, thomgh all its great constructive culture periods, lats recogmised the need of friblung, dorecting, and developing men's interest in the stare. It is true, I reperill, that in the ronventional primary, secondary, and hugher colucation of the ames atromomy has come to occuly" a less flace that at any presious period en hintery ; but this l toke as me smatl element in the explanatom of the moral and philosophic interiosity of our current meelley of imperfect specialioms. In the eflucation and the recreation, in the whole up

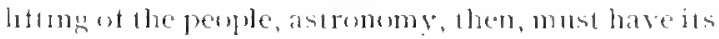
liberal place. 1 am glacl to bearn from . Ir l'eck. the astronomer whe of all others best enmbines will scientific work the wilest educational and croce appeal, that the realisition af such a project by establshung a small but efficient observatory uprom an aldefuale scale wombl mate no very alarming lemamel upon the tinancial resources of

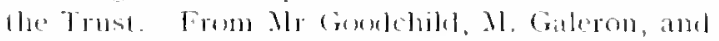
whers I alos find flate llue establishment of an

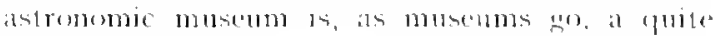
minem matter.

In our second dome let us represent the Geological aspect of the world m ils wolest sense, inchuthe weanograply amd meterologr, or, in pertaps less tomblar yet really more visid phrase, "the account

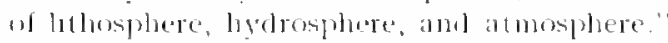

The lowe and upper storeys of the atjacent dome might be similarly allotted to the Biological workl-the presentment of the " biosphere," with its plants and antmals, lis " phytospluere and zoo-

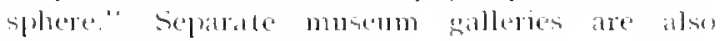
shown 11 pon plian

The fourth back might onventently atter in its lower storey the presentment af the simpler Jluman world - that of prehistoric and of anthropelonical researth: while its upper sterey might le devoted to a new panorame presentment njun smaller soile corresponding 10 the atmorable

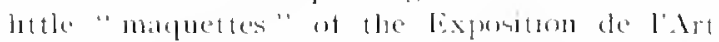

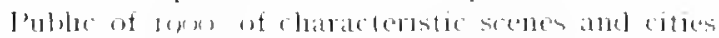

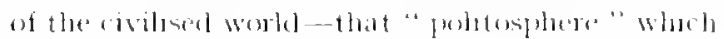

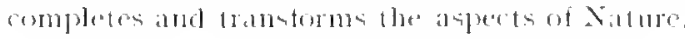




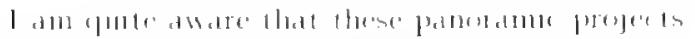

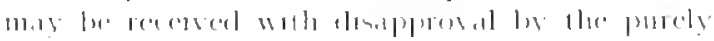

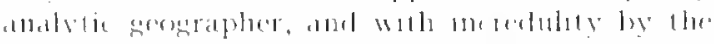

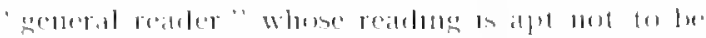

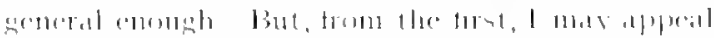

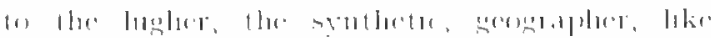

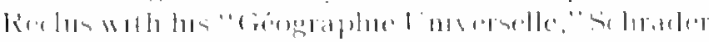

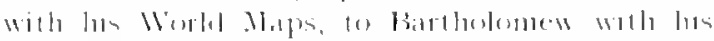

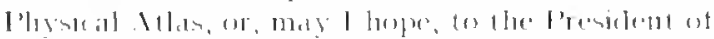

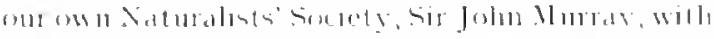

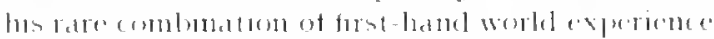

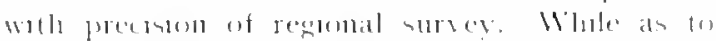

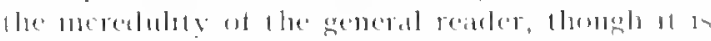
(os) lithe tor him to see the atetual wealth of the

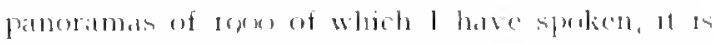

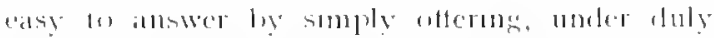

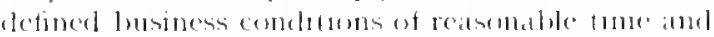

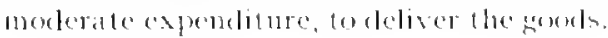

\section{B. The Great Globe}

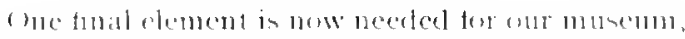
red the contre and starting-pmant of the whole the

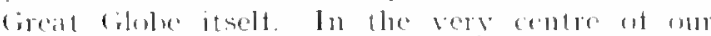

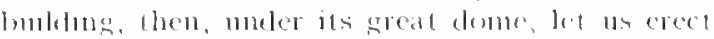

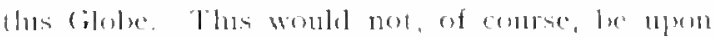

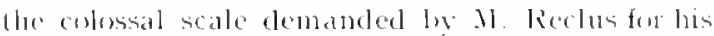
stmpendous temple of the bioth, whith will whe day le realised, and wheh will make the chy

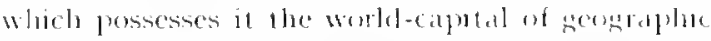
selence: it would not even be on the seale ot that National lostitnte of fecography, reecently propused

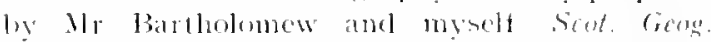
Mag, Irxe, but on the moderate and cisisly

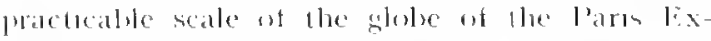

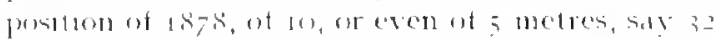
or of teet in diuneler, the lather the very smallest upon which a true rebet at llse steater teatures

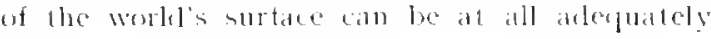
showit

Both the chlucational wes and the perpulat onferest of such a globe have been so often and sol fully demomstrated, and the detals of its comstruction are w) wedl known, that I need not here repeat thens, suttice it merely lo say that mot (mly the due rolation, the effective lighting and desplay, but the detaled inspection of any repuired purtom of its sutace may all be easily provided tor : as also that, liy simply placing the stand npen rals, the

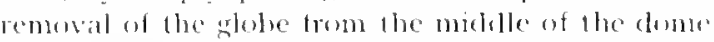
(6) the erlge of either transept molnt he edsily and instanty eftecter whenever, for other purposes, an unintermbled view of the entire labine would be reppured.

I repealt, then, that, pendmer the creation ot at

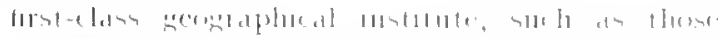

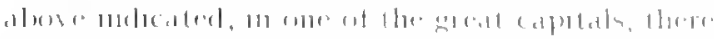

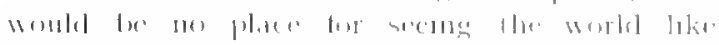

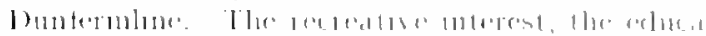

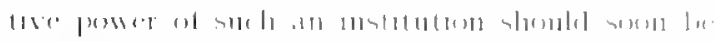

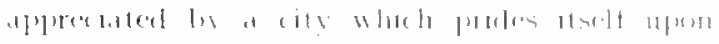

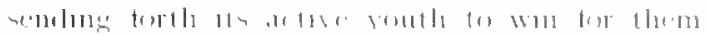

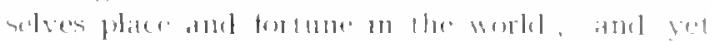

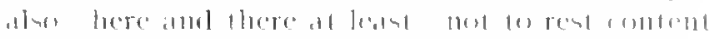

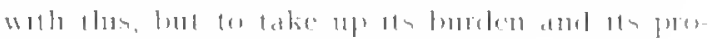

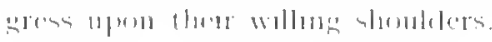

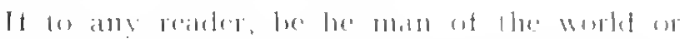

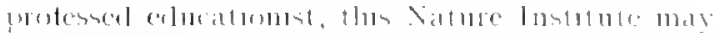

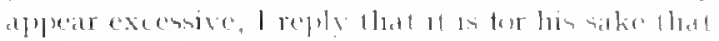

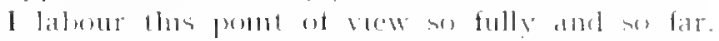

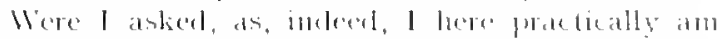

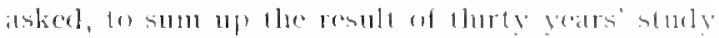
and trased abse reflection mpon nature of mans

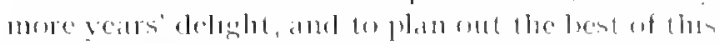

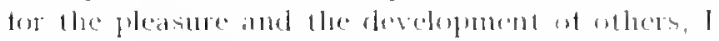

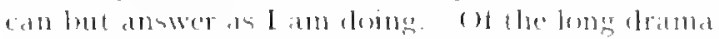

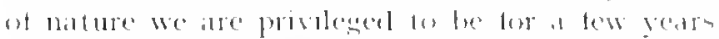

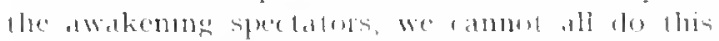

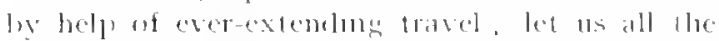

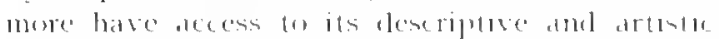
resuld, so loringing lefore ourselves the secenes and regions of the worlal, the prleries of them ; and

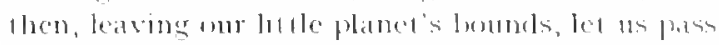
(1) the solat ststem whl copernicus and ballen. and thence extend our eyes thromenome the stellar system with the contumal atratuce of astionomy

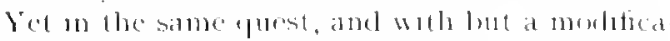
fion of the same epte prowers, we may, and must, make an mensive, a literally photrepraphe and meroseopes surey ut on immerliate region that one wheh it is natural to kmow and to lowe best. and which, be common coment of exerestaphers of the world, here possesses al one pecultall weath

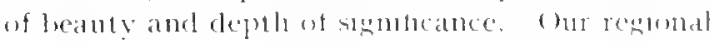
sturles, then, hate for extend me their laregest lenelseape and seologic aspects trom clousl and

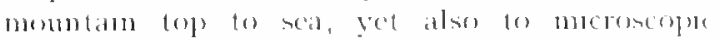
serulumy of rock and earth, ot verelure and life nay, of every peopled water-alop by the was Polescopes, microscopes, steresseopes atre all now

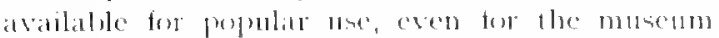
vesiter's mont inexperieneed hathdlins, and shonle] be sencrously supplied - llat is, increasmosty as the demand rises for them.

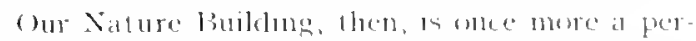

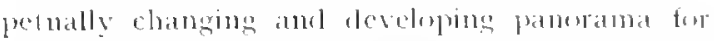
childhoex, and in all these stuleses it is no moxlent metaphor of Xewton's or Darwin's, but the simple fact, that we are chilelren all. 


\section{CHAPER XVI}

\section{NATURE MUSEUMS IN WORKING}

\section{A Curator and Naturalists' Society}

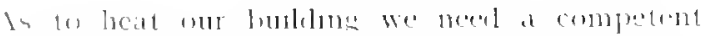

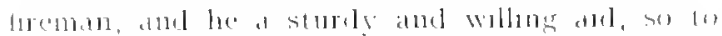

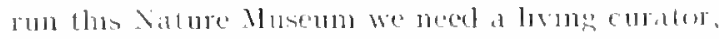
well secomeled by hliemenderl venuer men is

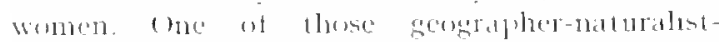
artests for whom l have so spectically askeel

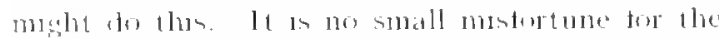

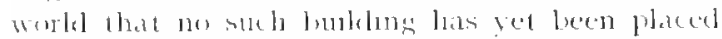

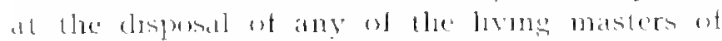

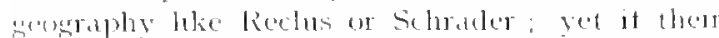

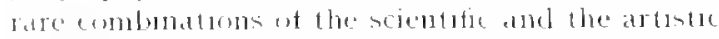
pawer canmen wten be toumb in one man, these

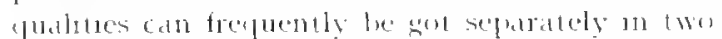

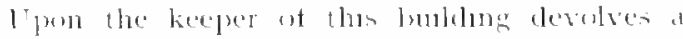

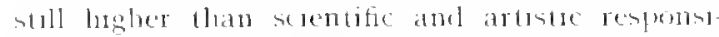

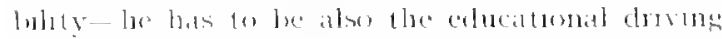

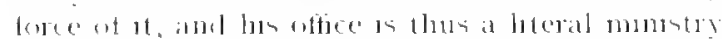
of culture from the nathathe punt of vew: 1

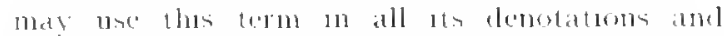

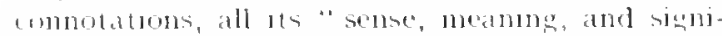
tacane." Whale he must hase due permatuent stitled assostance, a larerer foluntece statt will ont

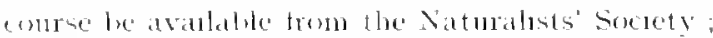
"very such sorety, and thes farticulaty mo the east of Sontand, contanme not only mdruduals of consterable experieme and even aceurate know-

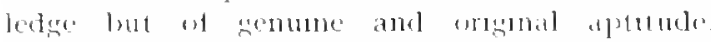
bermat me, then, a word of thes: 11 touches the holuest policy and usetulnese of the Trust

It is not sufferently reatised, enther by educat

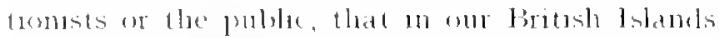
there are ehadereristic regiomal aptotudes, almost

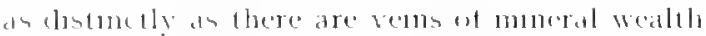
let we know of the songtulness ut Wates: and 11 we explan thu merely by as element ot historic smovel we are undecerved by an expert hae

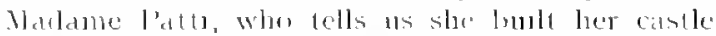

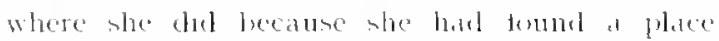

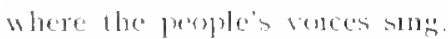

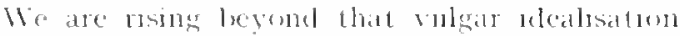
of Guantity of limpire, which lis but the expression

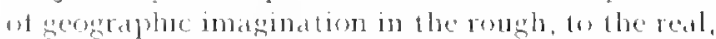
the urgent, fuesteon of pritedical pelitics that of the Guality of Race-and of wheh eren the stuggle is 1 terms of culture. Soon we shall see a psychological survey ot the chulden of scothand

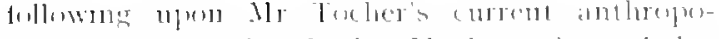

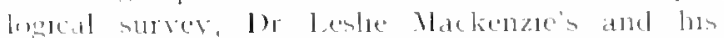

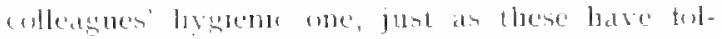
fomed apen the gendengeal survey or that upon the orelnence survey amel the politeal malp

I submit, therefore, that so tat trom grome peromel the pratical problemen of the trunt Im fressing one of the mont vilal and edtucational of

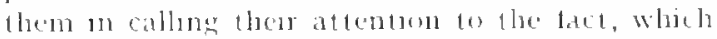
every hostortan woll confirm-that is, every student of ndtural seience who knows anvelung ot ats

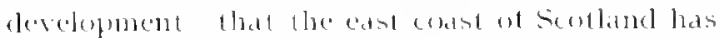
tommsleet momy and marked examples of men of

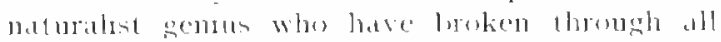

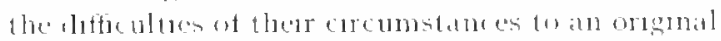

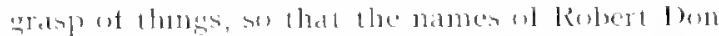
ar llugh Mlefter, of Themas liflwarl or liobert Drek are but the popular examples trem a lint whele might le amplitled, porbably at least toristolel.

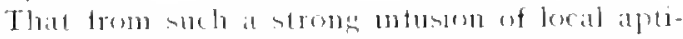

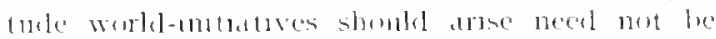
womlered at ot luese sir fohn Walzell, one of the

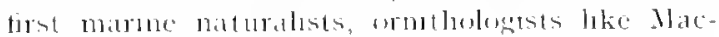
Gilluray or Wibom, butancal explorers like

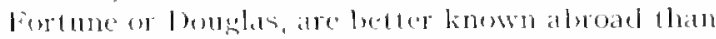
now at lame, though of these men of wirlely ackowledged cminence sume names, llke those of Murchson and the burnhers fielise, have become fombar when countrymen.

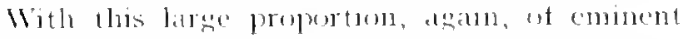
ablity it in not to be wemelered at labt this region sluould agxin and achan lave produced the man of supeme abluty and mithated an the whele world at some fartucular slage and tame. () sueh names these of llutum and lolvtarr among the

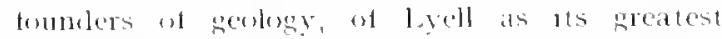
organuer, are surely well linesun, whole with lotte luther study we tinel Humbelde's facte pranceps botamentem in kobert Brown at Mentrose.

l an well aware how lons to some redelers maty seem awdy trom the pount. I reply this is the

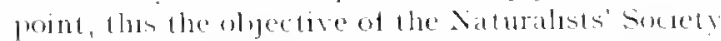
of buntermline o mprose flumselves as naturalists on the smplest level I have cited and to educate therr sucessors as hedter naturalists, and among these to search out and find and encourdge 


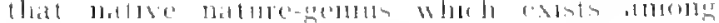
us.

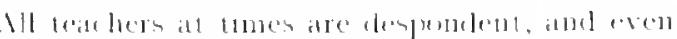

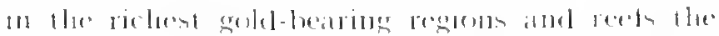

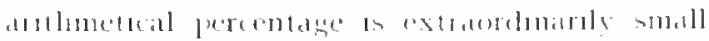

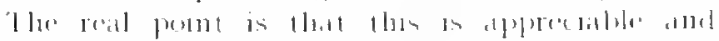

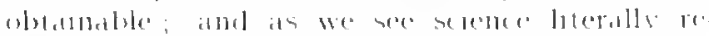

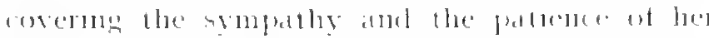

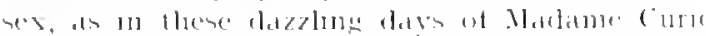

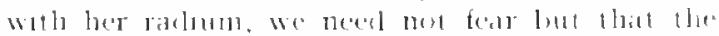

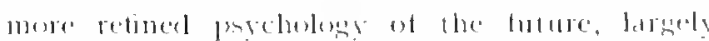
thromeh the women teathers who woll best alply

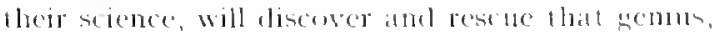
which is as yet the most wasted of atl lunmoln resoneres, the most deeply hidalen, vet the mest wately dostribuled, of treasures.

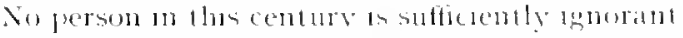
trankly of deny the ancreasung importance of seicnee, ret no educational anthority ats vet

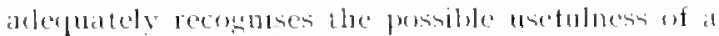

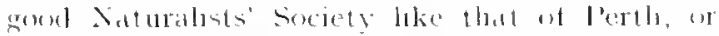
the greater possible usefulness of the easily better one of buntermble--casily better now, nut only becaune more richlo emlened of more mumerous. but becisue of the relaxatuon of that deademing

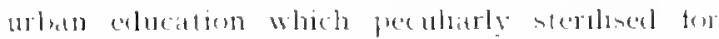
mature studies the whote generatum torm lson (1) $1(x)$.

Desple snch reservatum we owe moch to the pophlarisation of the thee lin; get we may mow set much more from that return w nature of which our very park and its purpusesl naturebuikline here are but the begminne

I have treated thes butding al spectal lemeth. partly hecause I am bere withon the feck of my

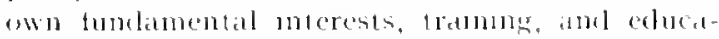

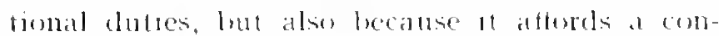
ventent example of that treatment wheb prevales the entare report. Just as one dees mot bist malie gratens and then erect builemus 10 spont them.

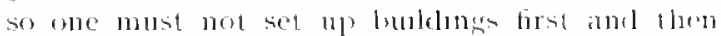

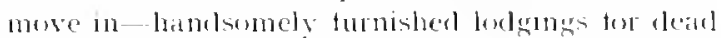
institulions are common enougle aldeady. We mmst bean in this case, and in exery ofher, whth the active life and progress of the sulpeet. ant consieler its plate in the general progates as well ats an the loeal weal. To forged the eneneral

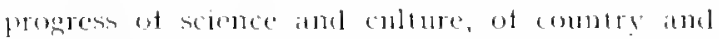
humanity, and build only whth the stumted interests of lle present fountermbne in view would be 40 entinue bat narow prosineblasm Which has blighed ho many of hes endearours already; just as her public litrary reaclung-rom, which is not worth at stranger comong $6 x$, is lathe wortle a citizen goiner io.

litule retlection will slus llyat the one and only funlelms wheh can le constructed from external measurements and financial estumate alone, independently of living use, is a cottin. To this class no doubt many instututions leelong; bence so many speak, and so many more feel,

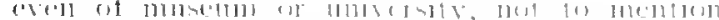

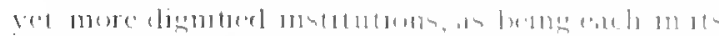

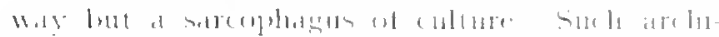

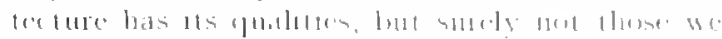
eecli bere tir moline.

\section{B. Working continued The Children}

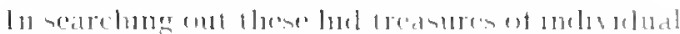

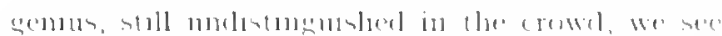

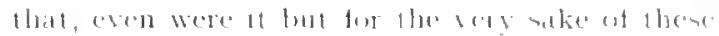

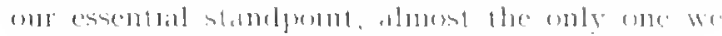

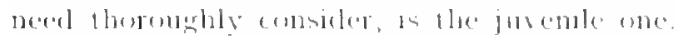

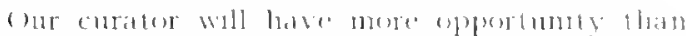

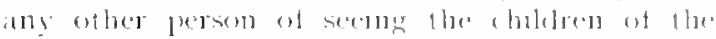

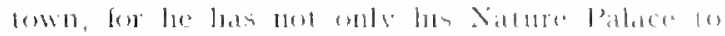

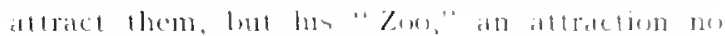
(c)uld can withotame.

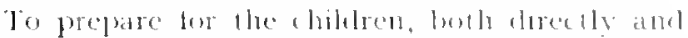
through theor teachers, smatl exhathtums, loath collections, picture and louk colledtums, on thes

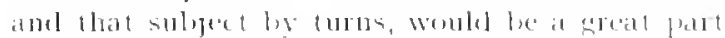

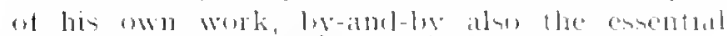
work of a skilled absintat, mant consentently at

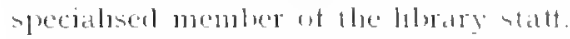

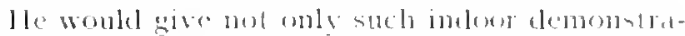

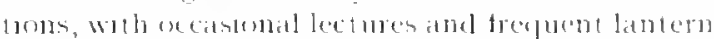

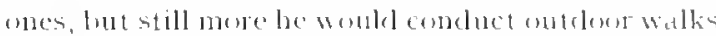
in the $Z$ exo and the park; lue would thence enceurage

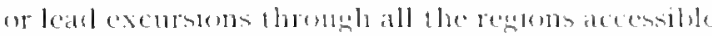

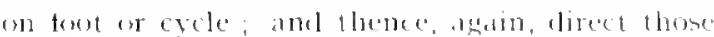

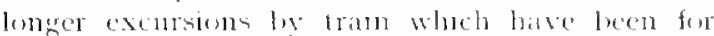

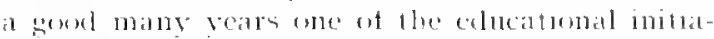
tives of Duntermline selusels.

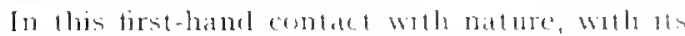
stimulating find of forsel or thesere comes alse

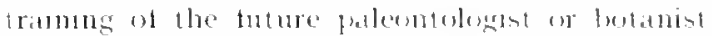
the historian of clasifier. Complicuoss examplos

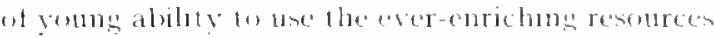
of their aty for thembelses might lhus rathere be

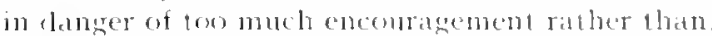

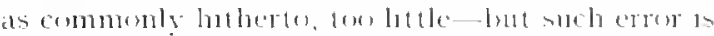
serm currected

llatherto we have opelien of this lubleling athorst

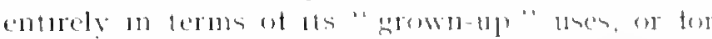

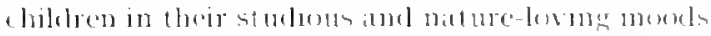

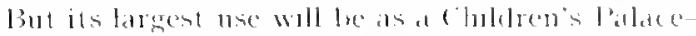

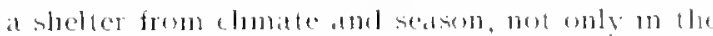

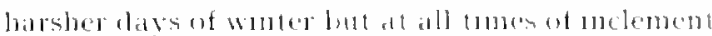

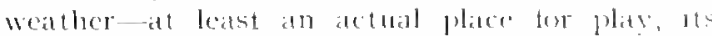

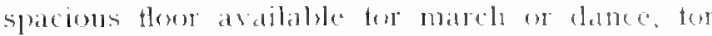

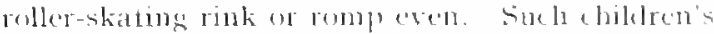
flay, which hats natural lomets of tome, necel not deteriorate its other usetulues the Naturaluth Librare and callerice, the leventeresem, the

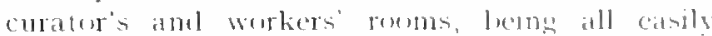
protected ly louble doms from nome. lin many elder adults of the lown surh phat hours would incleed be chosen for vall; whate if any shrink wholly from them batrel, interests ate prosuded in the park elsewlore 


\section{Children in Art and Nature}

All thin foung aletwe late munt brolle in dust

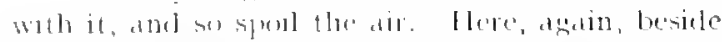
ample ventalation, these tountatms which our

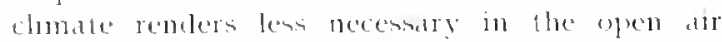
mat here he introluced, and I sugrest, athe for

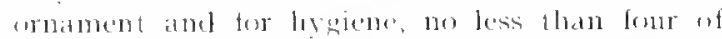
these, one at eall axtremity of the cross, then

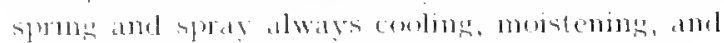
cheansing the all.

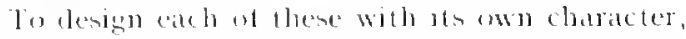
and in remer the ald that tomntan form of each varialle at woll, is an easy lask; while, with smple and inexpensive installation, the groreons eftect of electre tombans agan varymo in colour and brinhlness at in torm at will-mar realily be smppled. Such a specterle would itsclt ablorel a source of visul pheasure- an erening attractom "certan to d1, aw."

shall we destern there still further? (rowel examples are not wanting. the lienaissince lesigners

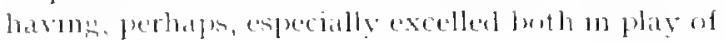
tancy and an perfection of form. Yet spoutum

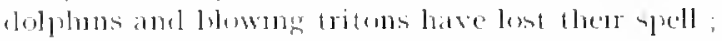
we need a smpler, directer, fresher motwe, and here in the chaldeen playime aremel the fountan

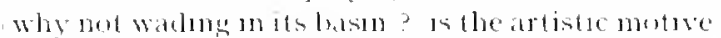

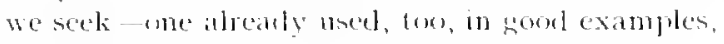
Renatsinance and moxlerm.

Let us take, then, llus smple motive, whlits popular, its motrersal, alpeal. Yet, applymg this, as arehecture must do, with the whole conception of the lubleling lefore as, what follows? (Jur four fountans atre an the toner puaters of the world; so, moteal of repeating one type, our own, toconsentionality, let us give to each formetan lts individud thateder, nome the bess inferesting

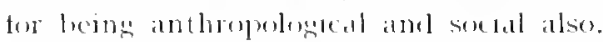

It the mesthern tommtan, them, the tall scandi-

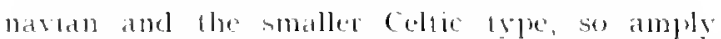
represented on our wan lonselodels, naturally prerommate, but to lls somth the declitemanean chilu. In the eatsern formtan, bestede the now essentially Aryan lye of l'ersan and Turk, woulel come the

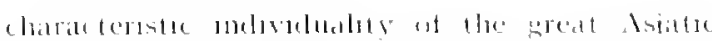

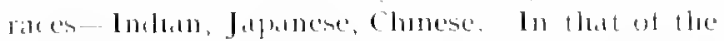
south the contrast would be ret more distonet

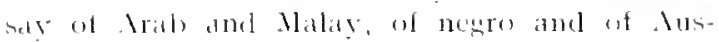
tration: whle on the west the hatt-lneerl Cantdian, the Indian, the Mexican, conclueleng woth the

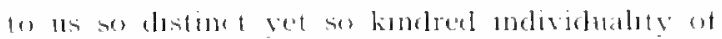

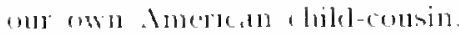

for unch se ulplute, seience has of combe ample materials; but what artist hats laken arlsantage

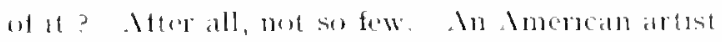
hats hately travelled the world, pabution ats fypes of rectal beatutr, form morth to south, from cast to west I vivid example of rood seulpture of this lind, satisfactory alike to artist and to anthropwherist, mily be seen any day on l'nunces street,

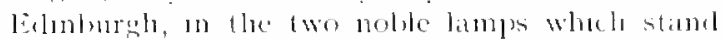
Iretere the buteding of the Lite Association of sentland. The mont ambitums example of thin

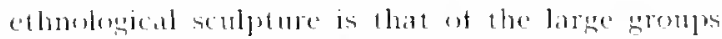
symbolic of the combents which acemps the ingles of the Lombon . Whert Memormel.

Fet the awe street limps aforesalid turmsh,

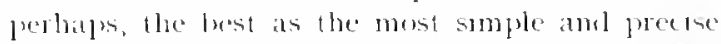
eximple: and here, tom, we see the trace fumetion of this alliance of ant and science sn the dlumbat tum of the everrolat street - the help of the prisserby. Here, in this example, is the actual srmblel

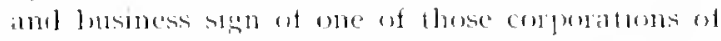

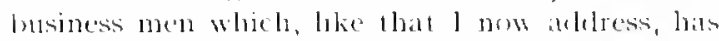
for its tatsk merely that of hemp at litte forthersighted than les neighlouts; and so has the contage to express as ambition to the everyeluy worlel.

For the educational and moral purposes of the Trust, lls secial atuel collural ambitions, such as atsinclateon ot atet and seience has many possibulptien. The symbile slogestions of such founfains would loe at mantold as their asprects; and even those who least catre for art amd its gentle ministry mat most need to be reminded by 11 , as here, of the varcely amel interest of humamity as of nature, and helped to see there fellow-man of ditterent land and race and colonr, no lomger an "ball-devil" but as touly chuld. 


\title{
$\mathrm{BOOK} \mathrm{II}$ \\ E. LABOUR M U SE U M S
}

\author{
CHATIR NUII
}

\section{PRIMITIVE VILLAGE: OPEN, AIR MUSEUMS}

\section{A. Primitive Village: Site and Outline}

THE high hank of the stream upposter the filehe now chams our attention. Ilere, above the foot patls which would run along the west sicle of the stream, widened as lake, is a wold bank peculdoly attractive to the acturities and incturets of chiletren, and particularly of hoys, whe might lace be allowed larger freedom ancl latitule than ipussible al other places, where damatge misht be more easily done, and where notise womld be more disturling lts main roud of access would be controlled trom the new bridge up-stream (that from the Mill Gitrlen, whle its existing thickets of holly, ete., should be extended so ats to form a practical but not apparent hedge of shrubluery.

led it not he supposed that either dimuge or moise is th be encourdged ; on the contrats I propose liere 10 organise and utilse some of that constructive energy of boylund of which boy mischef is mainly but the leakige or the exposion, and to devote it io the construction of what might lee nrade in course of no lome time at once a not inconsiderable attratem of the l'ark, as well as an immediate adhlitum for tos educitional resources. What I propuse for dhis spot is that our boys gradually construct for us a noteworthy part of the whole apen-an musem by reproblucing as far ats posible a number of liese dwellings of early man in which sootland,

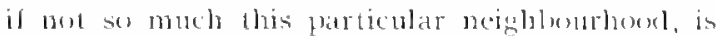
so rich. In the exposed escatpment of clift we shoukl hew out, under due direction by a mining expert, one or more cires. In the mure level portion we should excavate and buikl one of these underground "l'acts" louses" which itr Mathitchic especially has shown to be the homes of those ancient possessors of the lind, who have been transformed by tradition and fancy into lrownies and faties.

A combenient spot exists for the erection of a larger rude stone dwelling abore ground, with its surtace cosered with earth and turt; practi- cally, theretore, at tumulus, ret lomeing out the

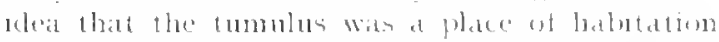

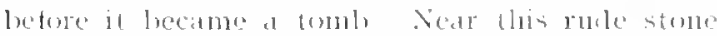
hute mirht he erected, one whth promtive orer-

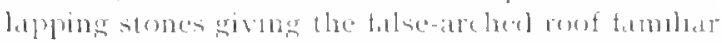
(1) vistors to the bermulate on lachouln, the

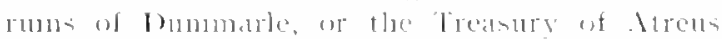

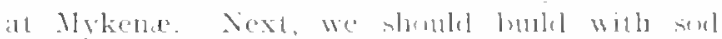

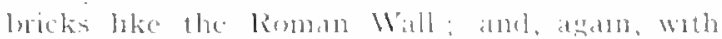
brathes and clas in "wattle and blatul," thens

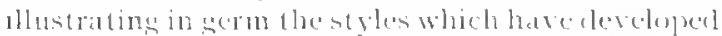

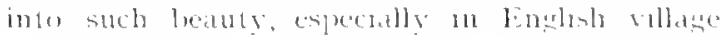
and mansion

Coming down the lalie matrin, thas attorels a comvenient stuation ter the artafical istand platform and hutsot one of the "croburges," which

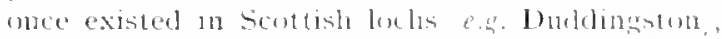
if wot even for the more developed latie-dwelling proper-that of the swion latie in which the platform wats ereeted on plos in flecper water

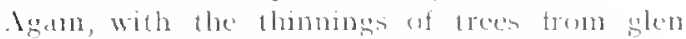

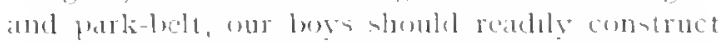
log-huts of varous arpes and syles, and so on. Fhis whole scheme thus at once tulntisters at

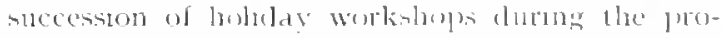
gress of each constructum, amel a play-louse and a picnic-room afterwarls, the sirls here commer in tor then turn to fimisle and to atomen, and to prente over the lumplatilues of this or that primitue home. Still, in the matin, the first log-lwuse constructed would serbe ats a joiner's worlishop for the next; and hy-and-by tor many kindred activities, such ats the construction ot bird-houses and bast-hutches which would naturally be carried on here. With lo leaderslup of a sympathetic and ansentive worlimanteacher there is no limut to the valiety on interests which might be provided for.

Every visitor to the farourite surbunban resort known at "Robnson," ontside l'arls, with its many summer-houses, perching largely even in the trees, has seen that such play-houses are full of attraction and cham, eren to chuldren of a larger growth; whle it any scepticism remans 
an to the educative usedulness, or the local applacalibly of thene proposils, 11 mat surely become secptical of thell upon the retlection that the mmmortal Rohnuson . Vexander Selkirk was a liffer. Why mot, therefore, let his elassic home Le atan reconstructed licre?

The unterest of such a return to nature, imel in such a spon, in worlland bonk and glen, and lutween lake and park, between the two halves

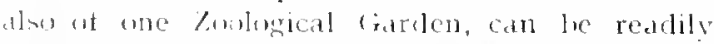
manined. Sincth a group on the stde of the seine wats a main teature of the laris Exposition al 1s;

\section{B. Educational Uses}

There ale doubtless smo so severely gromn up,

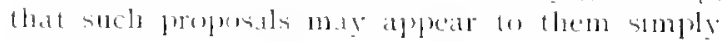
chmerical, but these con surely have never lived the late of the for-rambler or the field meturellst, much lins roughed at with traveller or explurer. Not only trom some personal

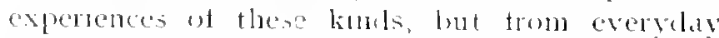
later and present lite, ds pulfertamblas, and as leacher sometnmes of hos and fouthe as well as young men and teachers, the writer liceps well withu what he lits espermentally prover in solying that undertakings such as thoic sugerested are not only pratetic lole but as with boses such alsount in all seluols, whth youtles such ats are at present rennong to waste at street corners. lam told that bos prefer mischet and dombtless so did mony wit us till we enet the chance of doing somcthing ixeter. (moly is this true in the tow common case where they are lete without leadership capable and resedred to lead them to that construtive aletivity which sluoulel be, if 11 is not, the very implatse and reality at a luy's education. bur present exasseration of mere classroum metes or drawness, mere workshop exercises, however skilful, leaves flis unsitistied, evelu where it does not, as foo commonly, ponotic permanem distaste of work altogether l'uttins this stoll morectearly let mos sat this : that whle?

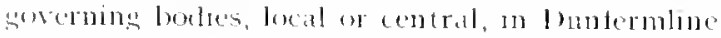

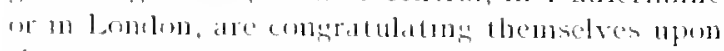
the enod reports, the high mates, and bouldy

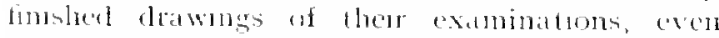
the models of their exhotions, the lact rements, an anyone who gets an terms al friemelly conttrdenee with seloollows on witl technical students mat somen discoser, that much of the most skilled pratedical teathugr is leaving as its mann result

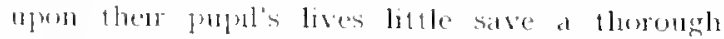
dratelste for lts entimued exercise. from the latin or Frencle or arithmetical "excrcises" which wasted so large a proportion al our own lmylumbl, we, at the older generation, conlel at least escape in ablolescence to ant or science or incluatry, and take up one or other of these with vrein interest and trente eve but now that

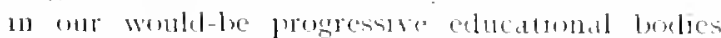
and ofticial ones we have laid our hedds tosether. and rlissected our irt intu " iraden." Siciences

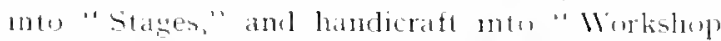
Exerctsen" ie. the whole of these nute a mere variant of ledtin gratmmal and exeresses once more-the result in that fbe sprone of the vounes worker, artist, or scentest is leeing broken. They have had far too much of mere exercises for apfrotumties which came tor late, if at all. What we mow need in pplostunity. In a word, the modern education of Exercises has asain to be replaced wy the past and future edacatum of lixperiunce;

I am not bere speculating on smesesting, but cmphassing the truth, every where beng vertied by expresence, that 31 is rough activitues like those of the loys' camp, and of open-air play construction enenerally, that are the hest preparatom tor that hishor technical education to which we sluall cone turther on Simularly to utilise that strong destructive impulse which is one of the signs of the commen it sigoroms manhood, I would fout wonteers to help to demulish, when the tume comes, the unsiolitly wall between stele and fark: melect, to move the stomes to any peint where they maty be refured. I whallass, tor instance, is a marvellous and erer welcomed eregine for at ince relesing anel utileing surplus loy encruy, even disciplenmen and socialising itcollectuc action helving here such a ratrely obvious and immediate collective result.

Son l foled that longe wall mulue the lited and animal life of the l'alk? Doulntess, il, ats at present, tou often lett meducited with regird to it. Hut 1 may here ate the expertence of my

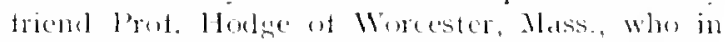
(wi) or thee vears congeration wath the teachers of the town in the nature studies now prominent 11 Anencal and incipuent here, has so transformed buy concluct and boy intluence throughout that large manufacturime ofty that instead of the numemos complatuts of best destruction and tree minury whe here tomally mede on all lands, pullic and priate, only one complaint was heand at in that comederm last year, anel that trom the parents of a boy who

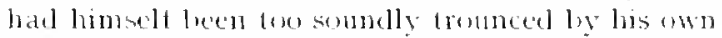
comraten tor a hiol-nesting attempt of the very lind to which the same gang were in prem vious rears devested. Fin m the meantime they bad learned to make hird-boxes, anel take a triendly meterest ar the nests mstead ot a destruetive one

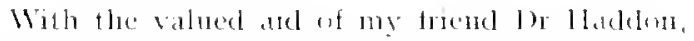

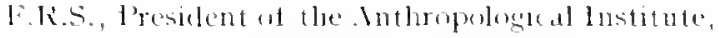
and with the advantage also of eriticiom and sluggestion trom Dr Mlumro, whose recent tascinat- 
iner latper * wall, 1 trust, recente the attention at deserves, I lave drafted a sclume of allustratuon not only of the various types of habutation of the palieolithic age but of the neolithic and the earler and later loronze ares also, with blucir respective momuments. This, lowever, I may keep in reserve until it can be more tully claborated-llo aluxe descruption, whth some suggestion in fig. 83 and on the latege perspective facmg p. 228 , being sufficient tor the present, since the scientitic interest and the educational value maty be best considered apart from the details. To complement and continue this general presentment
I may, howese content myedt by jolcatung that any to whom this elunatomal scheme secmo unpractical maty refer to stech recent blerature ol pratical education as we owe to Parker ancl Jackman, Stanley llall. Deply, and mluer writers. or at least note that these emanate from bmericat and most of all from Cheage-surely not the city lakely to be wer-reverent of mere anchaological strrivals, he they in material form or in extucational practice This conception of ecluation by furesessive experience, and this of dureet action and reaction with the completest attanable environment, is, in fact, the needed comple-

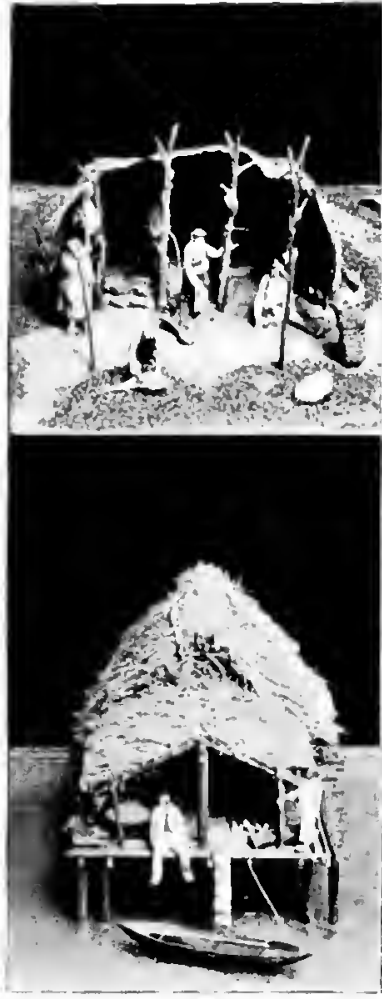

Prinisive Ludi:un shelter. Lake l wellings (Venezuelan)
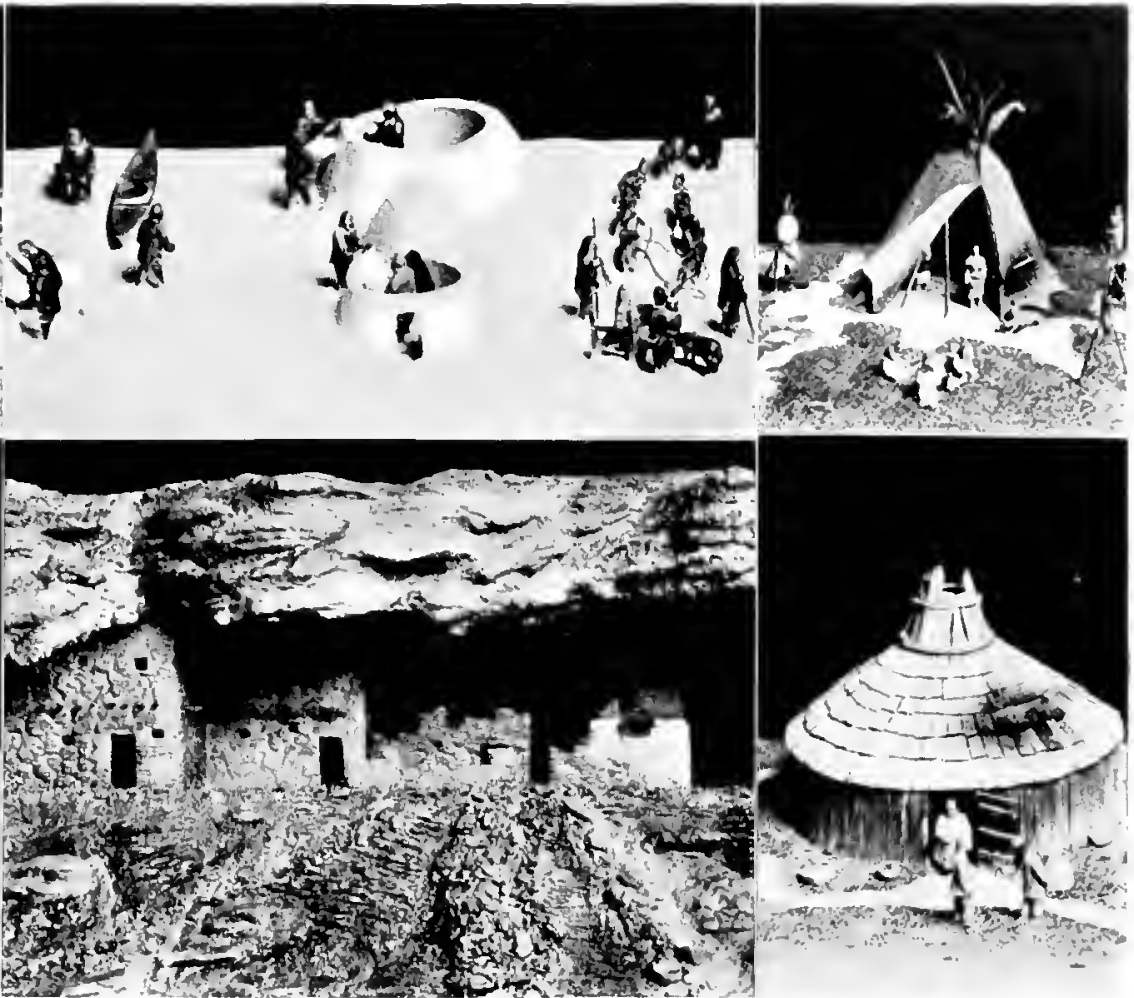

Enkimw Snow Hut, Sleqinc, and Kayak

Cliff llwelling (Arizona),

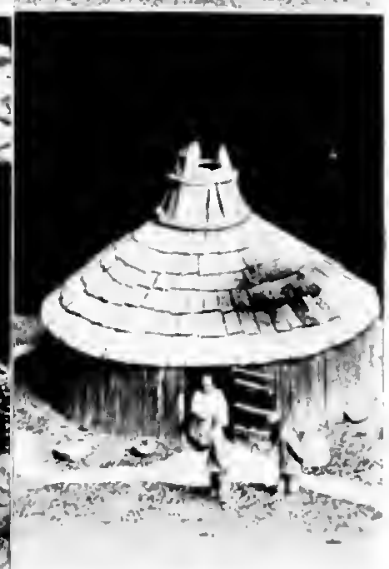

Sioux I ent.

Round Hu Colifortit.

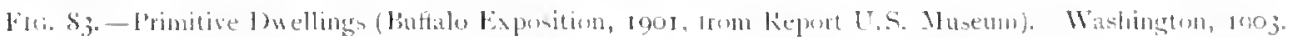

of the world from various points of view, astromomic and geographic, gcological, botanical, ancl zoological, which we have atready consicleres in previous clrapters, by the correspondingly simple yel bivid and comprehensive exposition of the early relations of man to nature, and of some of the main phases by which he has risen to his present mastery, is surely of value too obvious to need argument.

lis educational value might also be mucl more fully argued for, if of this any doubt remains.

* "Yan as Artist and Sportsman in the I'nlecolithis l'ericul." l'roc. Kog. Sor. Lollinburgh 1903: itnd Grant, f'rinces Street, fidinhureht. ment of the tere purely subjectuce educatronal thenries and pratice of the past; and when we observe that the leaders of this return to nature are among the foremost of living psychulugists, as well as of pedagogues, any dread of a return in barbarism, or of a mere imitation of Diogenes or "lhoreau, may be clismissed.

Again, since rapidly to recapitulate the main phases of the past is nature's way of passing bevond these, even of acquiriner the impetus for passing in thrn beyond the present plase, it may well also be ours. Or if a concrete proot be needed, that this very inquiry intes the remotest past may be associated with a forelook into the future, I may mention this fact, for little 


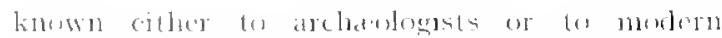

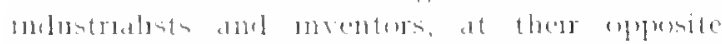

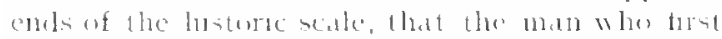
merpreted thent mulements and exedvated

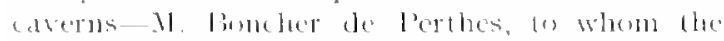

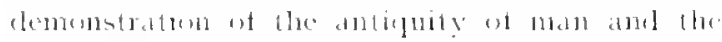

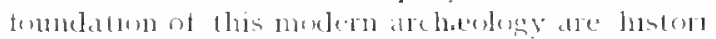
cally alue-was alor one of the meme ardent alvo-

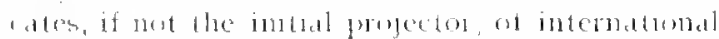

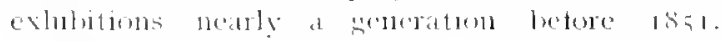

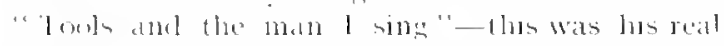

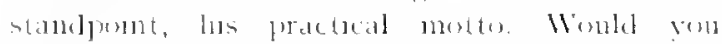

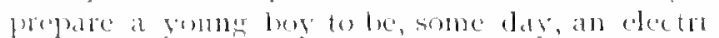
cal emeneer-msenter 11 naty be? Set him tes rediverer the fire-drull of the salvage-the sected uf l'ronethets.

\section{Correlation with Zoological Garden}

Here then we hate readed, trum a tresh pomb of rew, therery sante practical proposals as these u which we came at the nowed final development of the Zonlogical Garien Chap. X. Each fold has, I trust, its own weipht and cogency ; and surely when now considered together their alpeat must le tas stronger. Naturalist and archadogist have of late hat commonly tou little to say io each ollere, though the "Satural llistory of selburne" is a classical cximple of the thorough larmony of these pronts at view; and now this "pen-iur schorl amel museum of anthopolugy untes the essential standpoints and results of lesh; crattsman and adventurous hoy do not ustatly cornperate, yet here they are at one; exen fisclologist and pelagogue are not olten so bull: anreod, yet here all meet and co-operate We sec, (w), that this scheme develops an otherwise unused and unmurostant fringe of the parti inte a new unit, and one in its way as interesting as any, one enhancing the ronlogical gatelen by climax, the horticultural garlens by contrast, and turmsh1ng, for, the needed link leetween the wild glen and cultivated levels, the civilised park and city aromm. We realse, in slort, more and more of its mantold atsrects and interests, from those of manguation at play to those of science and morals conveyng upon ibilustry. It is to be remembered, tow, that the whole scleme, here necessarily unlike most others, is almost a costless one. jor it is of the very esence of the seleme that it the realised, be it slowly or yuickly, by the voluntary and lanpad labour of boys and yonths, with no outhys, therefore, from the Trust heyond tools and supervision, linder all the corcunstances, then, I venture to hope that the besimings of exccution mily lie at least made the subject of a sufficiently undused and patient experiment ses soon as the right man or wonan to insplete and superintend it call be tound.

\section{Open Air Museums}

(1) on the most notable of recent contributions (1) on knowledse of museums and their possibilutes will lo touml in the admirable article ly

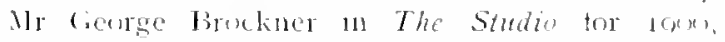
antitled "( "pen-ir Museums for London: I Sugnestron." Thu is easily accessible, as also Mr B.dlur's recent invaluable Presidential Iddress to the Iluseums Assuciatuon Meeting at Mherdcen

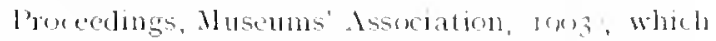
is indespensuble to every seruous consderation of llue subject of Museums in seneral. llence it sulleces bere to give a smmple idea of the open- lir Wuseum trom the accompanying figure 8 ; $a$, which I owe to the courtesy of The Studio, and which represents the nodel of the design now bens executed for the open-air Nuseum of Christiania. lt will he seen that this expresses the types of simple domeste and puldic arclitecture of town and country in Norway; and this as far as possible from surviving examples, and with due sarlen setring and appropriate interor turnishing, so that the exat material conditions of civilisttion in the past can be here precisely realiated.

from this illustration, and still more trom the whole paper trom which it is borrowed, my repeated insistence upon lyis comparatively :mfamliar idea will be better inderstexd, as also the even greater corresponding value of these survinine relice of (1) Duntermline, upon which l have so repeatedly insisted in this comection. Like my preceling plea for Scliool ciardens, for a Great cilobe of the like, however my proposals may seem in atrance of public opinion or efucational practice in this comntry, they are but to utilise the experience or the scientific outlook clsewhere at tained, and if posslbe to overtake the successful educational pionecring of other comntries. the absurd in ritution, or even accusations of "lack of fatriotism," of "tudulism," or the like, so tamiliar to wery one who has endeavoured during the past decale or two to inferm his comntrymen of foreign advances in elncational lheory or practice has at length abuted: Lut the practical difficuly of having these modern resomees and leas cren farly tested in detal, much less introducel, still reminus. For in the present phase of elucational tramsition, ats the writer well knows. nealy crergone readily grants ine's general appeal but is afrad to sive trial to any of its particulars.

Epon such lines, then, there is no small fiekl and oppotunity, even of natronal pionecring, hefore Dunfermline. And in ases such is the present, where fioncerng is but the ald atation and eomhination of ideats and methods of proved efficiener. the period of prelminary consideration may nuturally be shofter thin in cases where frecelents, home or foreign, camot be trought torward 


\section{$E$. Correlation with Technical Education and General Culture}

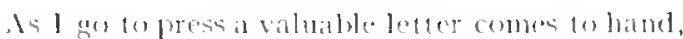
this time trum one of the pioncering alucationists

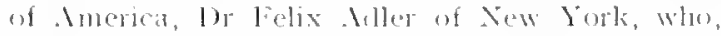

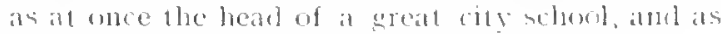
the inspiring leater of the allical movement in Amricil, naturally approaches the educition problem trom a very difterent pule from llat of naturalist and gardencr, which predonsinaten in these chapters.

"What I have to say mow may be inalplucille to the local conditions, or perhaps 11 is alleady embracel in voul seleme, It ats rate this is my* thought: A policy of culture tor a small yet typical city is what you have in vew. It seems 16) me that culture should contre alout peoples vocatioms: that it should he gained mot atter ome's work but in and through one's work. The lalow problem to me is essentially the problem of so reconstituting the conditions of mandill labour that the work shall hecome mentally, iestretically. and morally stimulating. Hence I struld sug-

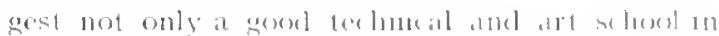

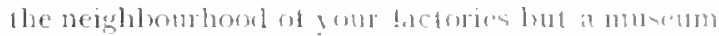
of inventions, illestratung to the eye the prostese ot inventions from primitive numes 101120 presemt, and helping to create the historice spint. I reatly

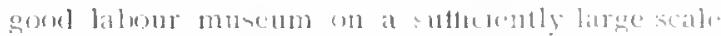
does not yet, l think, anywhere exint. It yom can build one you will be a pioneer.

"I hope that the time will ame when a part ot the manual labuter's daty worktime will be spent in educational study, and the time so spent will not be deducted from lis paty. The elhool and musenm will then be recounised as an integral part of the factory system."

(In erery sille, lhen, I maly take it that these proposits for a primitive village will, in promethe.

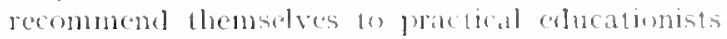
both technical and hooretic ; anel mur next problem is, therefore, for carry an the line of plimning beyond these primitive benimines, to the simpler mammat arts and industries, and thence agatn 10 the complex mechamsm, lhe finel at of later civalisation and modern repuirement. as unitin:

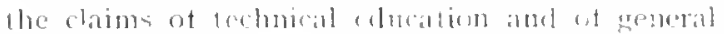
culture.

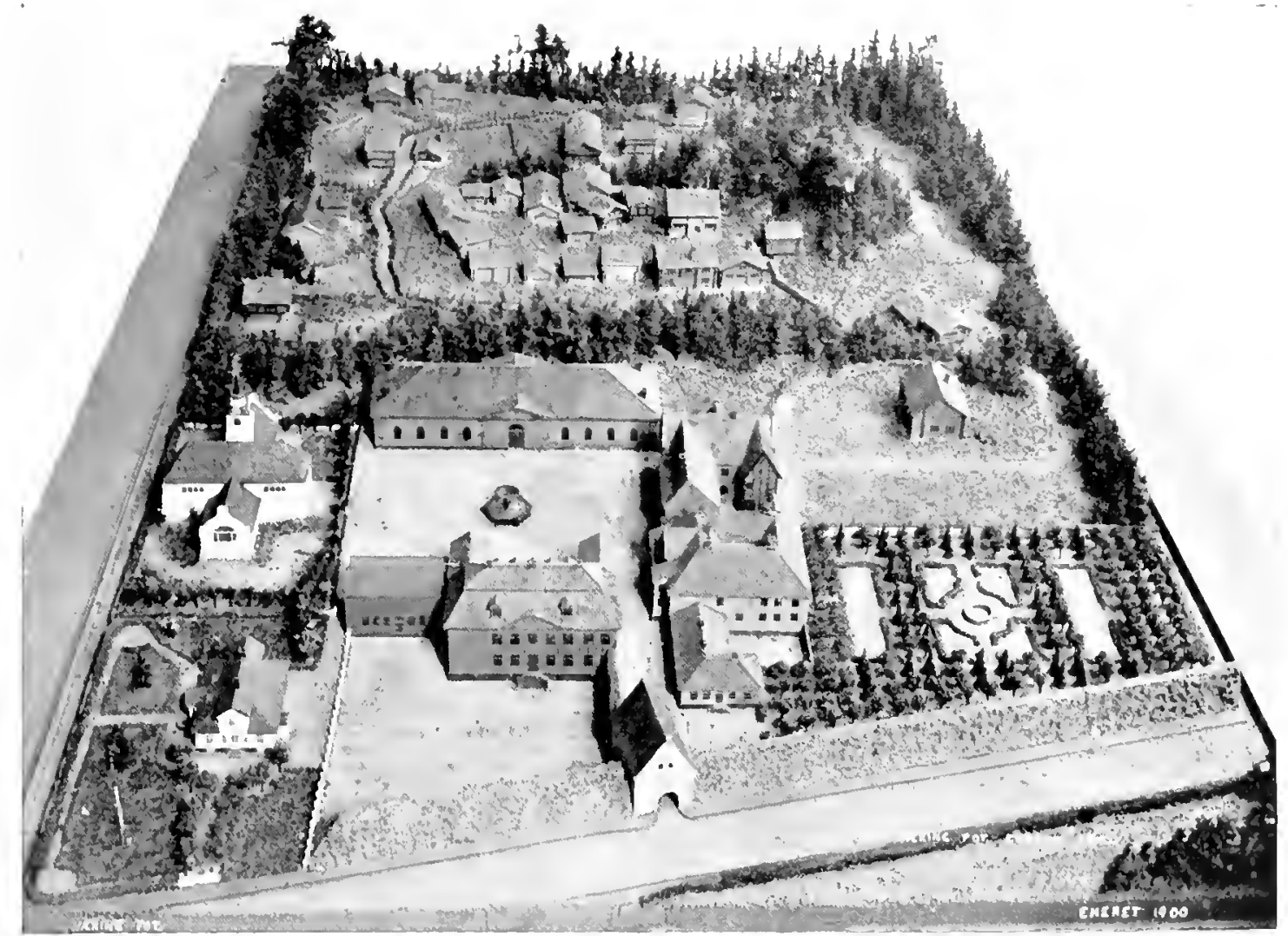

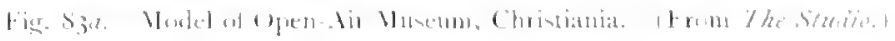




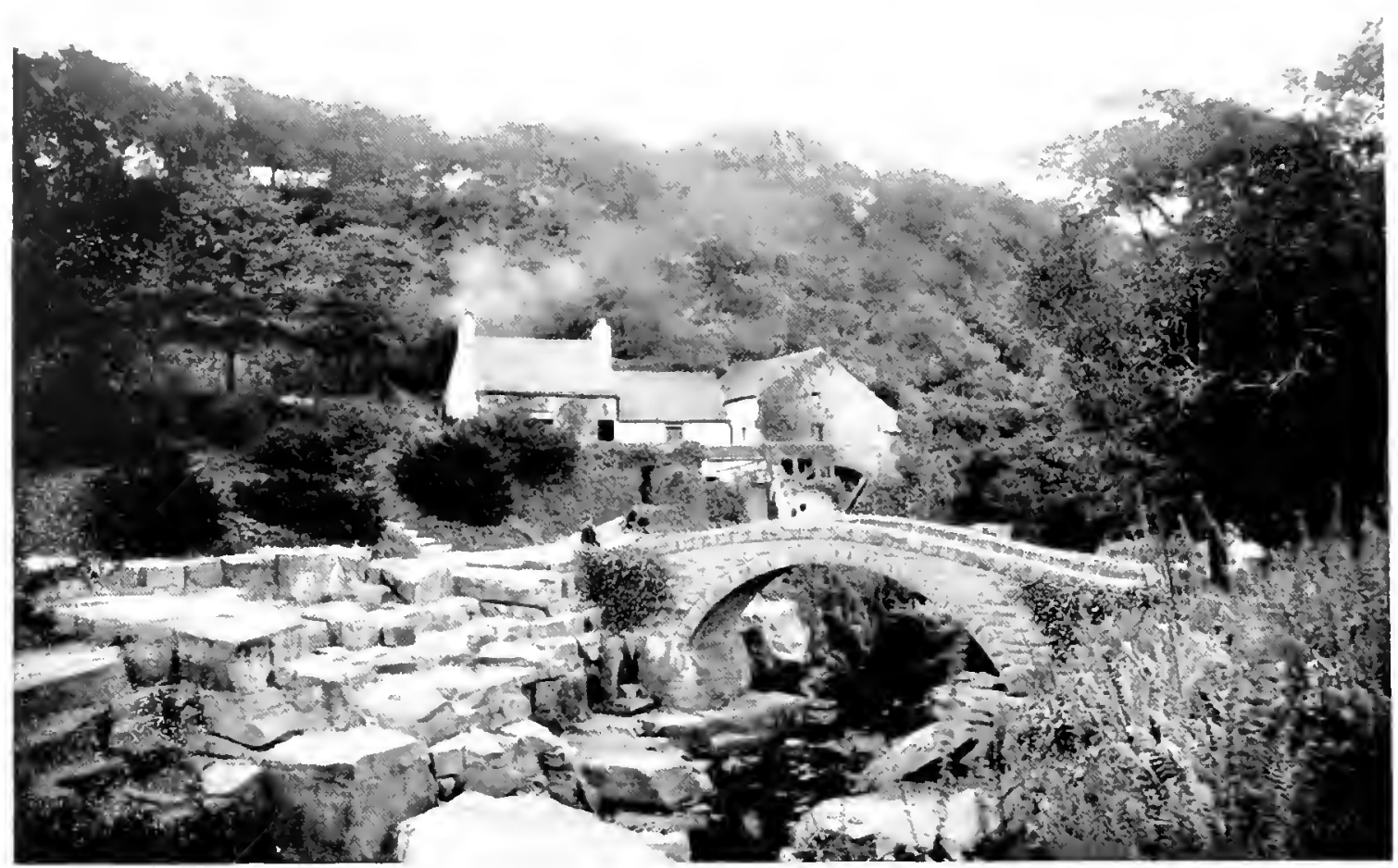

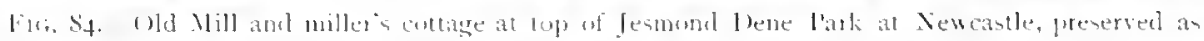

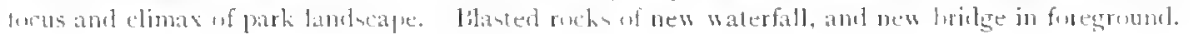

\section{CHAPTER NIII}

\section{THE MILLS AND SMITHY}

\section{A. Aspect of Existing Buildings, etc.}

Is alreacly salu, there is probably no park in Britain so olsiously interesting to the visitor from Dunfermlane as Jesmond Deme at Newcastle. since there we habe a larger and bonally similats "den "or "dene," with the alvantage of greater scale, more water, and finer trees. It is also at remarkalule picce of maturalistic gardening, the work of a fresh and original mind aecustomed to operate both upon the greatest and the finest scales in various fields of industrial activitythat of lord Armatrong, who personally desigued and superintended the whole work before handing it over to the Conporation of Sewcastle

As we aseend the dene and atmire its many beanties these culminate in a concluding scente, or rather gromp ot scenes, which is the pride of Neweastle, and deservelly so, as fig. - i chap. SIII and the accompanying fig. st inclicate. Yel what are the main teatures of this? A small lake, from which the stream issues in a tall perlatys 12 or 14 feet high, like the bim in the glen; artificial lake it, but better lone. And secondly, a little ivied cottage grond the old mill anel its humble dwelling fir. st

Coming nom to onr awn Gilen, I am surprised by the indifference displayed to the heauty-the real and remarkatule beanty, the still greater possibility-of the falls along the mill late. downwards to its joining with the main stream of the Glem. The idea of suppressing llus fall in the interent of the main lumn, or tor any nther reason, is an much like those which I have tow often heard for destroying each (and therefore every one of the whel buldings of the Trust, and is similarly to be protested against on esery gromel. I yield to no one in my demand for a purified stream, and, of comse, I quite aj)prove tuming the lade nto the main burn, as is perfectly easy, whenever that may be neeessary or convenient; but that is a very difterent matter from adnitling proposals for loing away with it allogether. I stecp mill race, avalable for forty teet of falls, is tor precions an asset to part with easily !

I ask comparison of the accompanying photographs of this tall with those uf the Linn of Corrymulzie, a fall familiar to every visiter to Braemar -indeed, famous throughout the Highlands With little alteration, practically the rearangement of a tew stones and some planting. the essential charm ot such a lovely litte tall could lx reproblnced liere; this clespised lacle thus furnish- 


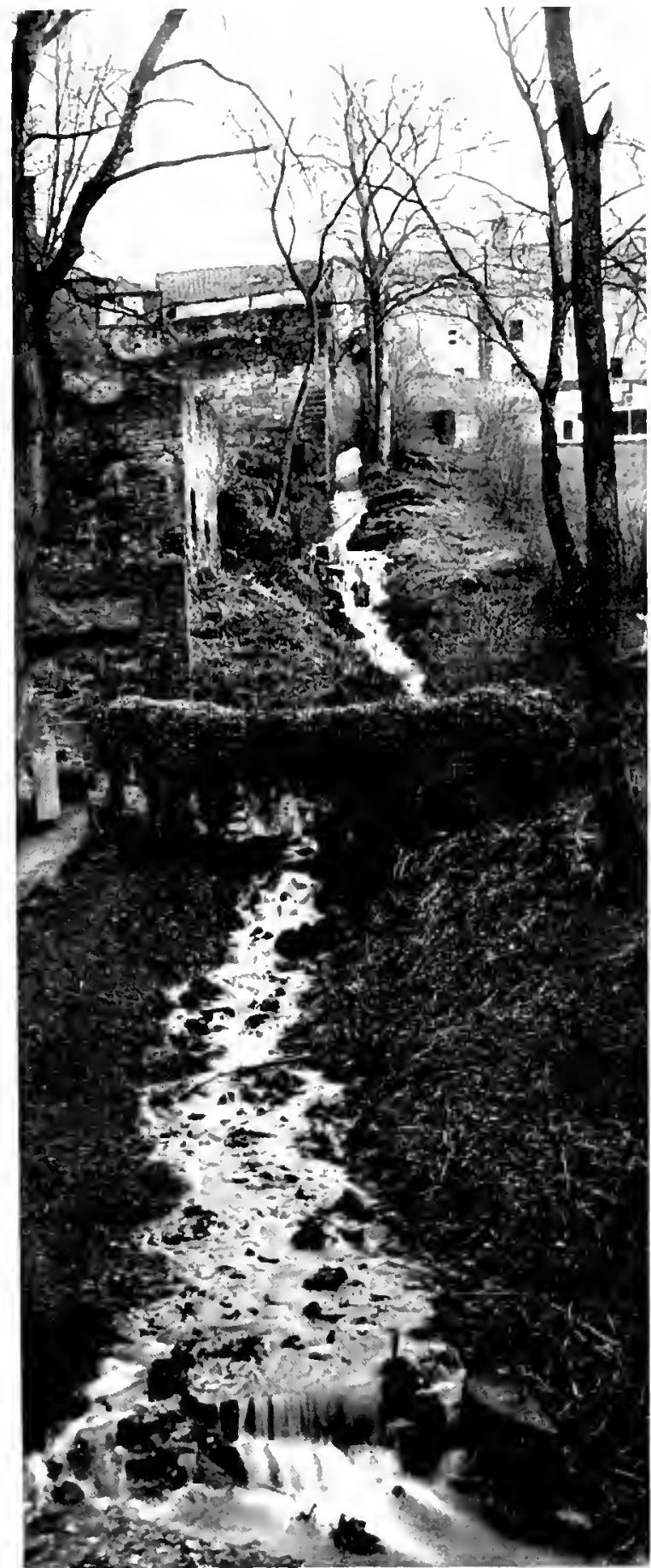

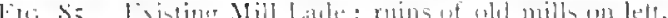

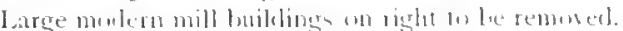

a proncipat naturaliste feature and heanly al the entire park, estate, and exen rity! This ks at

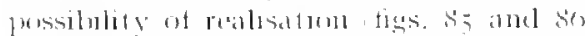

castle, ind then relushs to Dontermbine, to tomel

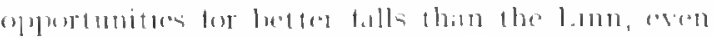

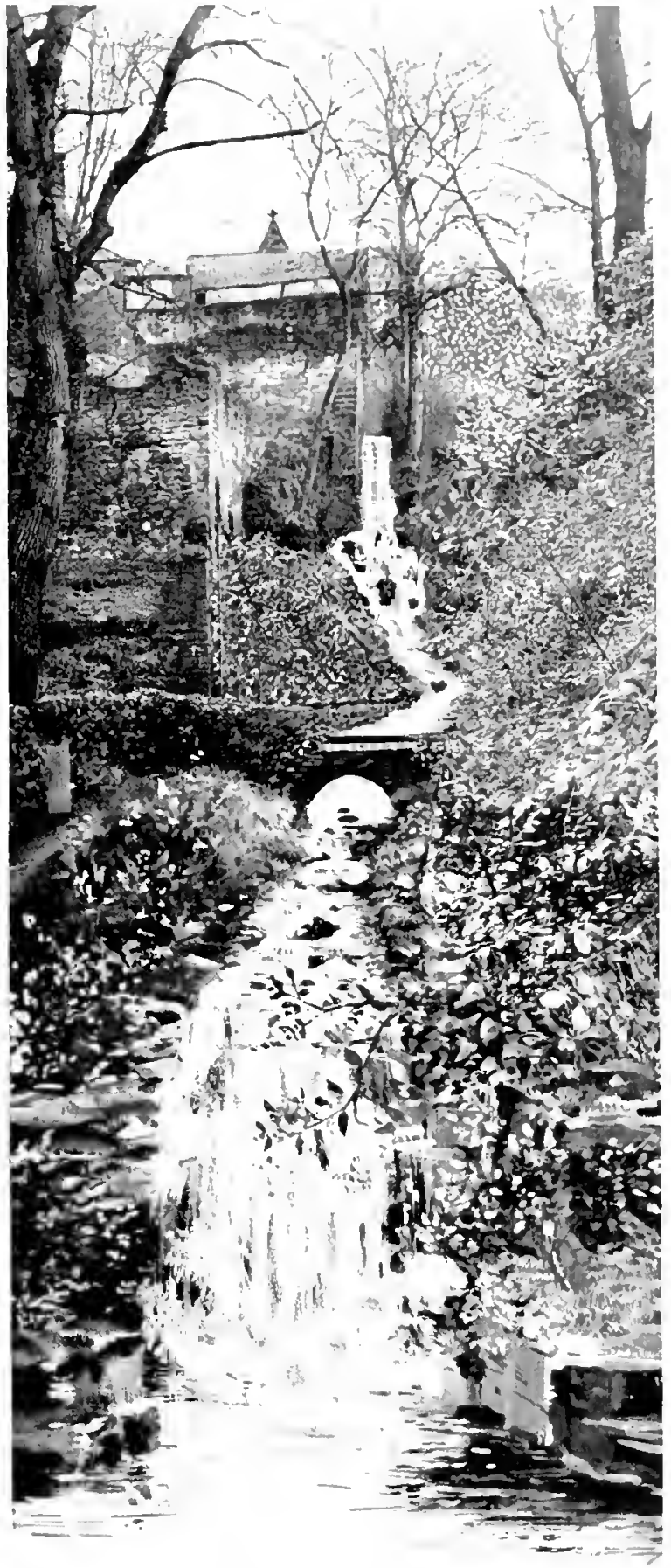

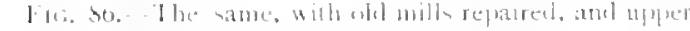
toutc)

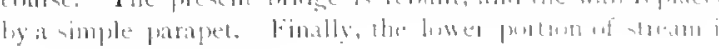
cul bach into a umall fall. 
skiltully ullused here, and even now are more picfurestue trom their lest ponts of ves than is the completed picture at Newcaste. but fo note also hor gate is the appreciation of this in Donfermlane is ofotain striking prost ol the way 11 which

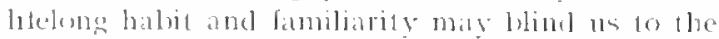
leambes al our vely dours; witness also 1 lere commom indifference to the mernts of other and more mupsung lunklings 1 an only stating what

snce row to confirm the idea, that the preservation ot all these hitdings can only be in the vers teeth of the mpinion of a majority of the puldic But, it so, here is the use of such at repert as the present. lts new constructive proposals can wan, hul destruction is mreparable: it is necessary. therefore, to modify public opinion in this matter wr il may be (ow late.

some help may he got from the conservative pleadings of many who have been ancerned will conslrucfive improvements in Scottish cules, our toremost living architects, our illists and art lovers as well atis antiquaries. We may cite ton the warmeth if appreciation, not only of these traned astheles, but of the passing tomrist will his eamera, whose snapshots not anly of the fratry llall, of the dblut's Ilonse, or some other jewel of old Duntermline, hat his views of the Mills or dueen sinne's llouse, of the mansion or stalules aforesaid, wring from the citizen at least the atmission that these, after all. "look not so bael in the pholograph," vel somehow not well in reality. It is, of course, an alswrd itlea that the camera image or the eye of the trained and critical observer is not a test of reality; while imfifference or at any rate non-training to composition, to light and shade, is so: or that an off-hand fecision that an old hulding should be destroyed is a fair preparation tor discussing its merits. Iet though I have heard this sentence of Jecldart justice for each and every one of these old buiklings not once nor a dozen tumes, l must yet press for trial anel reversal now

l.et me begin by conceding that photographs of drawings

"very tresh eve sees: that in these mills, ins in the okl houses muler the alber, or, arain, as in ald Initenerieft llonse, eren in its very stalules, there are features whele would be the makmg ol a farti in many as greater city; ams, further, that it is on the unlisation and improvement of these features that the real success of our parle design must

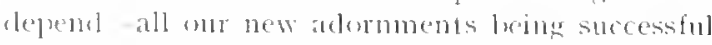
at they group around, lead up 10, or ontrast will these essential frotures.

I am creably informed, and mo own experi- are sin for perplexing to the phain obserser, since they express fleliberate selection of the best points of view. Yea why should these best points of view be usually unknown to the destructive critic, who has in the majorily of cases frankly to aumil that be hals never seen these prints att all; imleed, would often le puzzled to find the spots from which hloy were taken? It is a morlest and a practical proposal that paths, when necessary, be made or cleared to these spots and that seats be flaced at them, so that our critics may in futiness be able fo go there and reconsider their former verdict. 


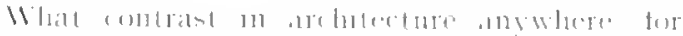

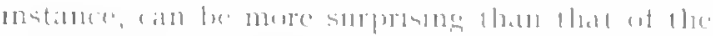

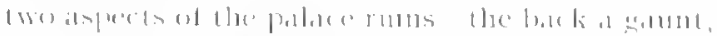

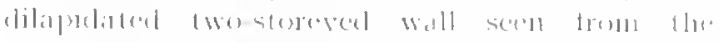

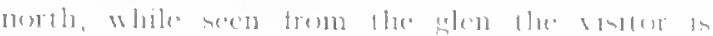

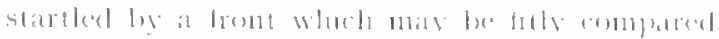

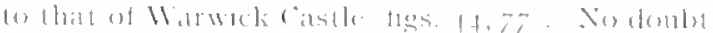

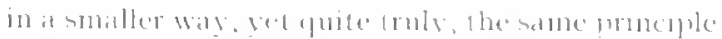

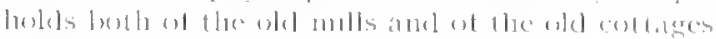

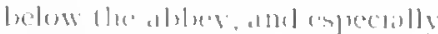
a) the tormert

Will lhe Duntermline realder who catll ser patsily (lo the frankly and open-muledly make this expretment on the spot? That is, ol compsortus in suecession the views trom the level, and then from the hollow, of palace amel ablece, of

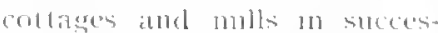
slon, betere redusing foronstedes

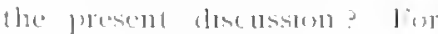

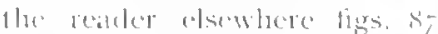
and so wll dombless sulfice

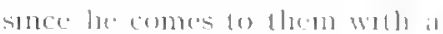
fresh 100

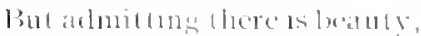
is there mot allow undiness? Cerfaimly res: sranted al oner. The north site of the palate wall, and esprectally the moth devation of l'ittenertell llomse.

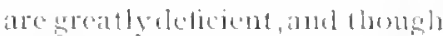
even here lhe trancel ere mush urgeextenuatumedretumstances these misht not be stofticient to gatin ils case. The Mnnastary streed aspect of the mills is at

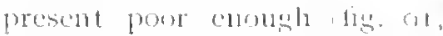
Chays. X. : while the photoreraphes of the monalstery asedt show lle lumble olel white washed smithy as on the whole a bot mon a sereat arditer. lural onmensition fig. (1) Chatp. $\mathbb{x}$; : inel on phan tig. 115, (hap). XXl1, it will be secoll that l propuse wholly remosing luth wh these, whth the result of oprenter up ale strect into at fine public

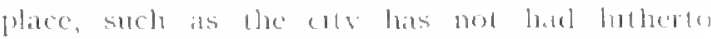
Chal $\mathrm{XX}$

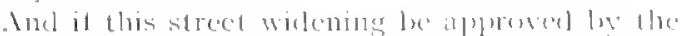
medern spirit, as surely 11 must, I tmet that it

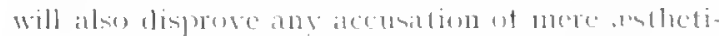

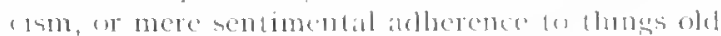
for old are's sake, independent of hutoric vilue

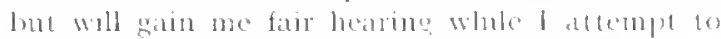
show the real reatsons of my apparent conservatism.

Leatring now this puestion of beatur, I am next

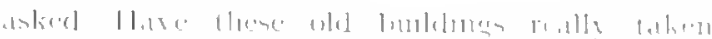

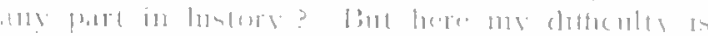

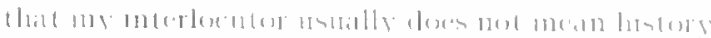

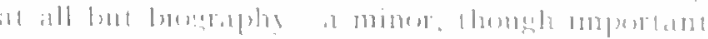

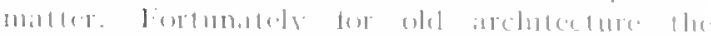

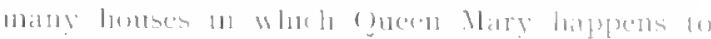

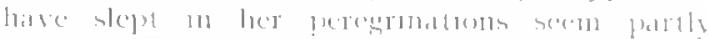

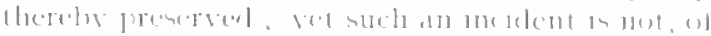

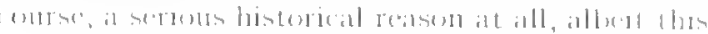

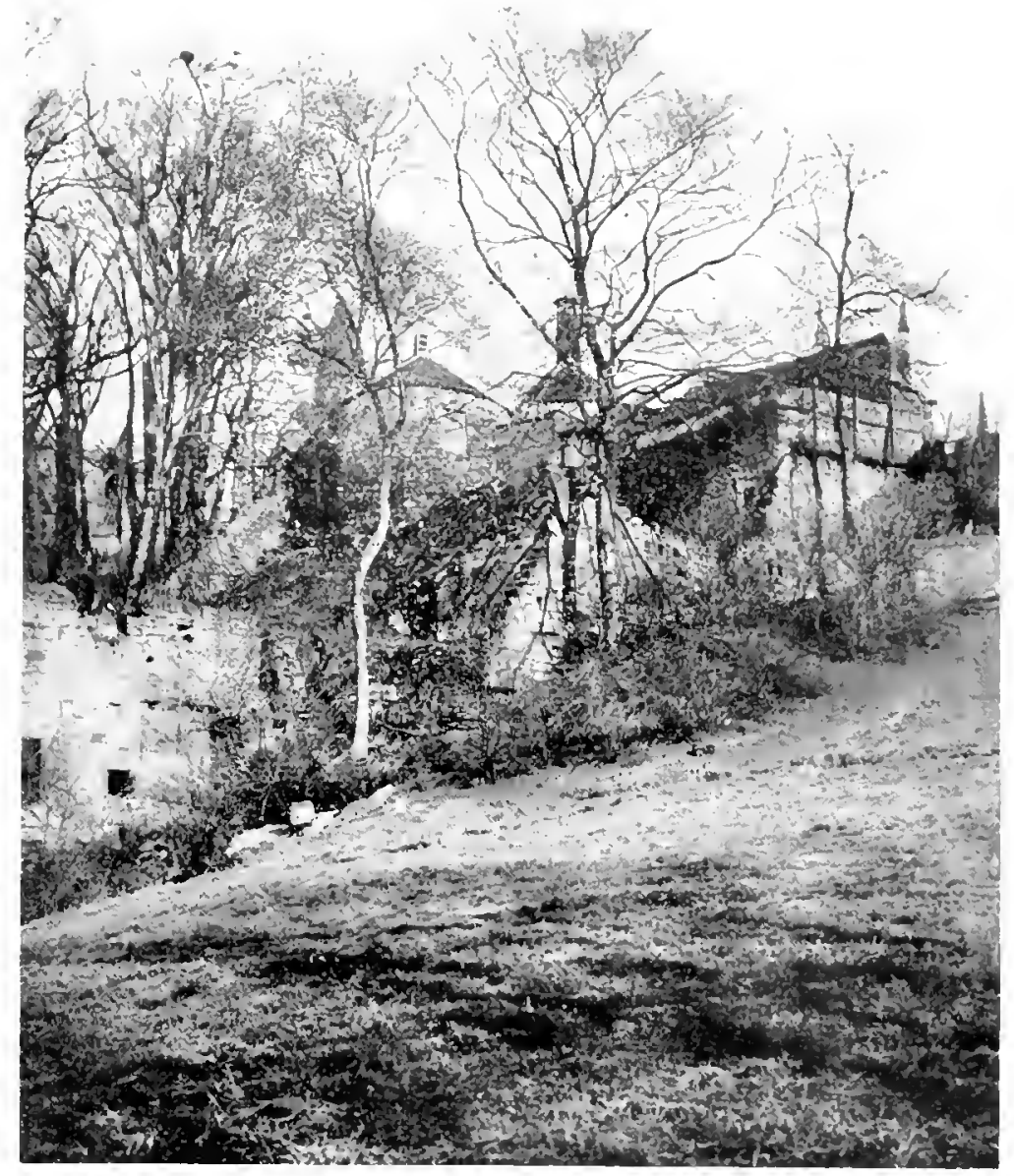

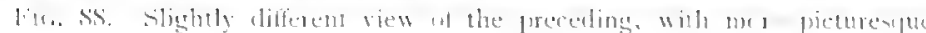

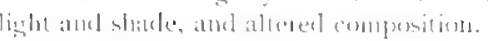

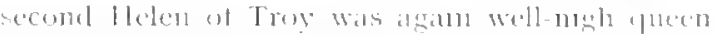

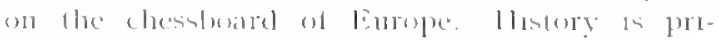

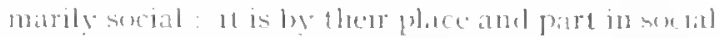

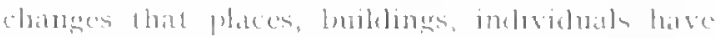

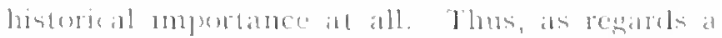
greall church, 11 gilins greathe of contse, 11 interest from its fllustrious foumdation and jts hosteric sepulchres, but surely all will anger that its main sinnlicancecomes trom its place in batrere history that at thomght and teelong, fathe and cull, and lheir apression in architecture.

Non here is the point that to wherere lats once 


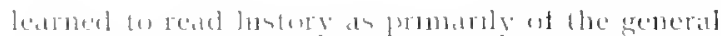

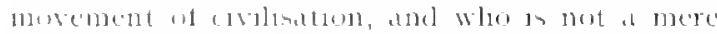

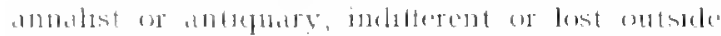

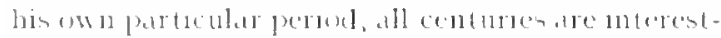

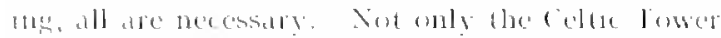

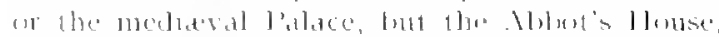
so well sererencel from the streed, and woth its

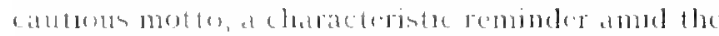

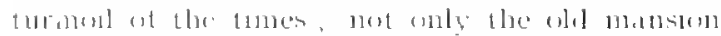

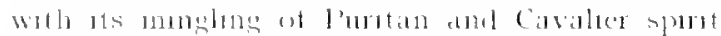

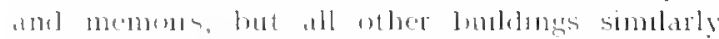

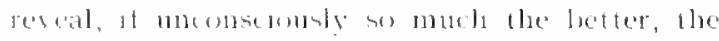

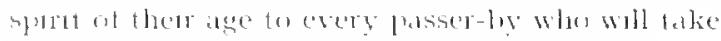
the frillis tor teitl.

Thus the extreme seenness and simplicity get

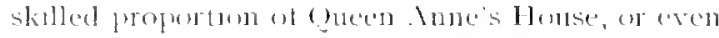
of liobert Adim's stibles, express the dear, cold

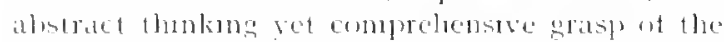
"rohtrenthe contury, gust as do the luoks of llume

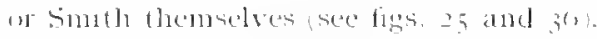

lo pussess ole buldungs which allustrate the

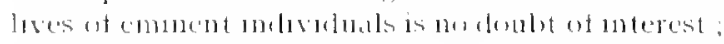
but of tar more value is a suffictent series to fllustrate the semeral development of the anes, the sue -

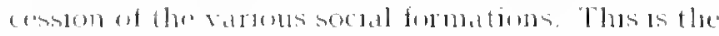

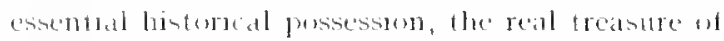
any city This is not a guestion of indivelual

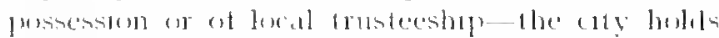
these on grust for ats natem, for the lorger world.

\section{$B$. Historic Inlerest of Mills}

Sluntting some conency, some attractueness.

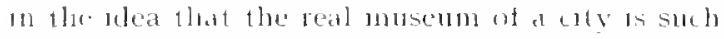

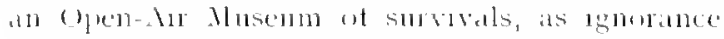
or torpolity or gerel antentions exen, maly have lett undestroyed, why all thas hother over some

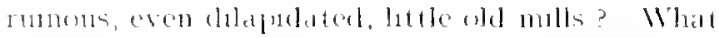
pumsibe cham have they to histome comsideration any mure than the smothy a have propused to aloumlan?

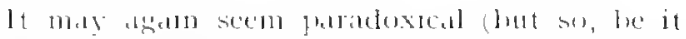

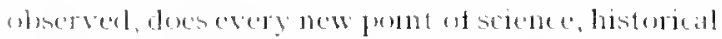

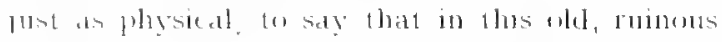
(a)n mill is a historical centre, and ance ceren more

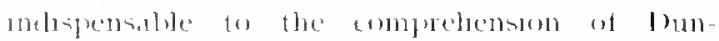

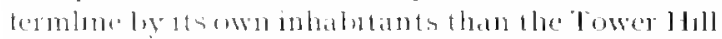
ltaelf. Tlus bill, defencled by ats ravine and commanding the great north rout and the western

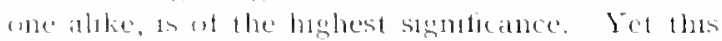

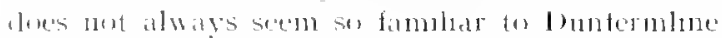

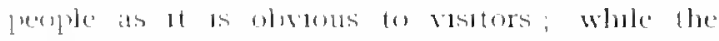
interent in the colte Tower, despite 115 central flace upon the city arms, has bean tors lately revered to solve almost at stone aluse its mere

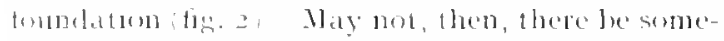
Henng to bean about these mills whele it 15 not yet (ax) late?

Jlere, then, is the pond : that the feudalisment the pratace, the ece lesiastecsm ot the monistery, verwed

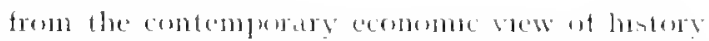
whels now takes prededence of the common romante pictures of swort or cowl, are the two

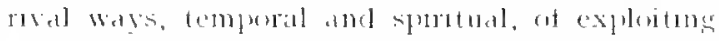
the moller amel his mill. In shert, the exonome

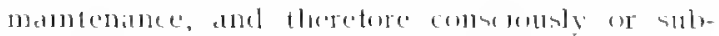
combenomsty the poley ot tower and abey ot mediaval (houreh or state, was very latgely in

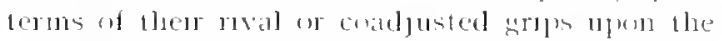

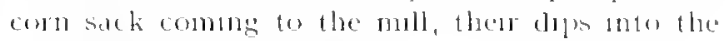

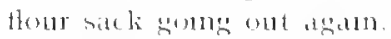

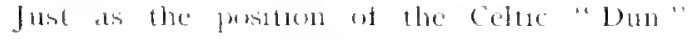
and ats aljacent roals attords ane of the tinest ofject-fensons in miltary gengldphy in scotland

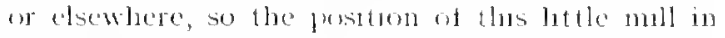
relatum first wo Tower, then to abluey and palace. is the corresponding abject-tessen in economic listory. To destroy the mills now would tlas be a less excusable vandalism than was the destruction of the celte fower: that wats done in tomes of general ignorance, whlte the wher could anly newadeys be fone by mere linal persistence in ignorinee, chougl to evolse the molngation of students of history erergwhere.

'The muprtance of this mull was symbolically reconnsed ly trustees and cituzens allice in the recent aldmirable mangural ceremeny of intettment; and to destrog the aneent moll mow womld le to convert that admorable tunctuon from at great tmotatse cermony into a mmmmery a traglc tarce. Whereas thes ceremony of the acceptance of these great gutts involved a pledge to the future, even more than a spectacle to the present. We mey ahus be comblent that however frequent be indifterence for the value of this or that element of thes great heratge, mothing is now likely to be swept awe whach posterty would certanly dephore.

\section{The Smithy (fig. 13, ('hap. XX.)}

Why, then, do l prepuse to destruy even the old smithy, confielent ats 1 an that every Instorse clement will be requared at us by our succesors? for the pesitum of thes, agdtu, is no mere accident, thasgh not so detintely fixed to one precase point, like the old moll by its wheet to its lade. And, thomgh the present building is obvously ot he sreat antiguty, there must hate been a smolly herealouts throush onnumbered centures, hestoric and shadowy. It as not only that the peatant whe hat to cart his grain to hes ford's mull mogh naturally have liss horses shod at the same tane, lut tor a reason wher ats well as more romente: the king's commers from Eelunturgh and the boreler, the athut's messenger trom lione, all would come up from Ouceusfery ly Mnnastery Street to the l'alaceyard and startung back they all naturally needed the services of the smith. The too was not only horseshoer and toolmaker of peace, hut armonrer of war. Long before 


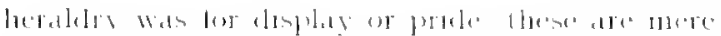

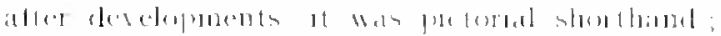

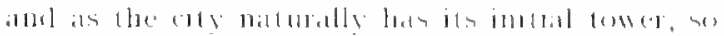

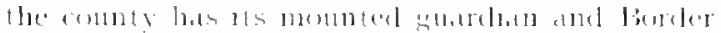

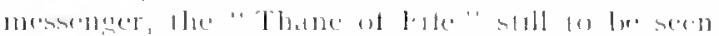

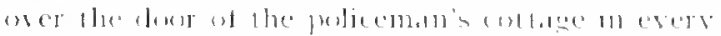

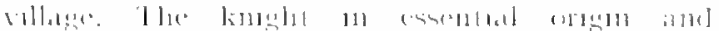

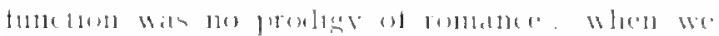

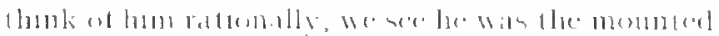

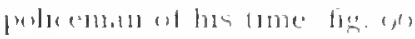

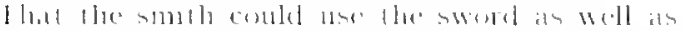

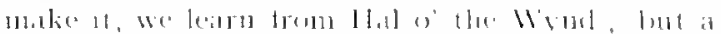

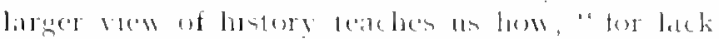

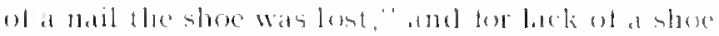

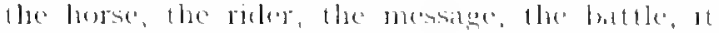
maty le the kingelom atselt. Sis it is thatt, as lue kntg's servants ever lecomme the kme's ministers.

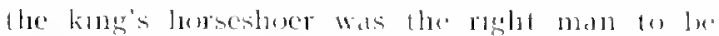

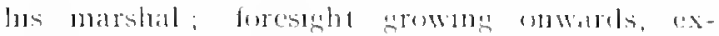
pressed and appleed bere or locre be individud

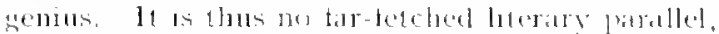
lout a dereed secindogical deredupment, wheh

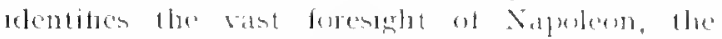

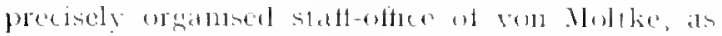
the dexeloment if the humble paldec-smolat:

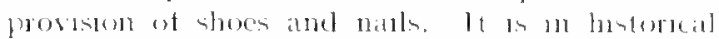
educatem as me ether matlers, thus the fown child al torst boums cral as a fletached ubject

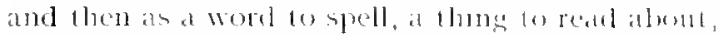

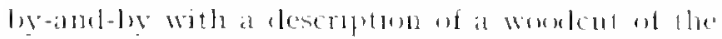

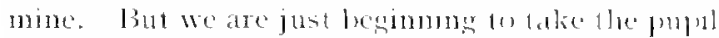
to the place where it as expesed, 16 he mone thell.

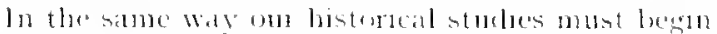

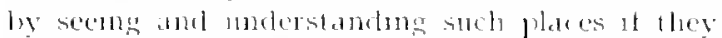

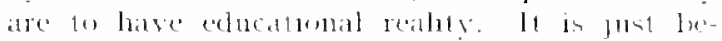

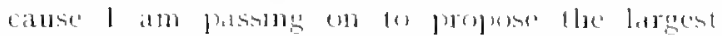
seope tor llee laterary and artiota treatment of the history of Duntermline that l seck to put all this now that elementary bask of everveldy experience atrise.

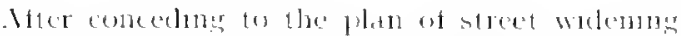
and to the due expresure of the ablere walls, flue demolitum of the old smothy, we noted its hostore unterest: but 100 ats erervilat unctulness, nor the rate fucturesefueness at shates with exery smothy

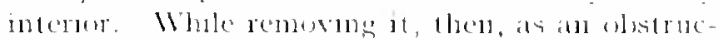

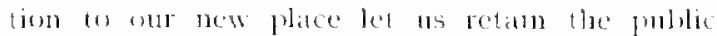
ulatity and remew the picturesefueness ly buldomer at new snothy, tig. (x) on the excellent site shewn in plan fig. I 15 on the opposite sile at the l'tace.

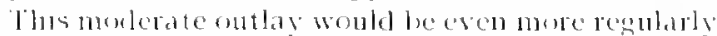
amel immedately remmeratue thatu the retreshment goms and crafts Vilhate, 10 whele we shall come in the neat hapter, and esen the carnesse Trust will sexn lind use for all tis rent-roll, Externally, (x), trom every aspece, the escoup of

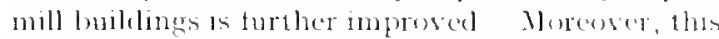
old-establshent business is not displatered tor more asthetic reatsons; the very ideat of stele at thing

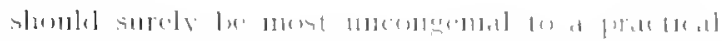

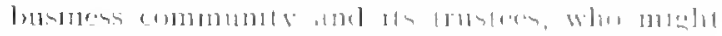

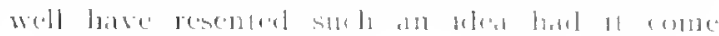

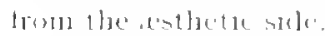

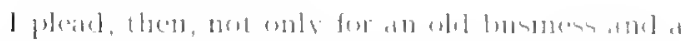

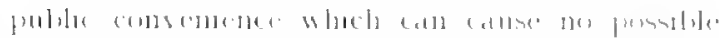

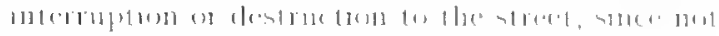

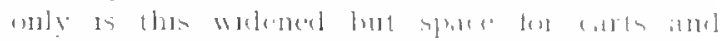

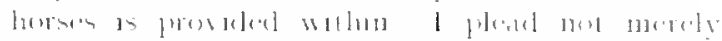

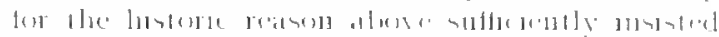

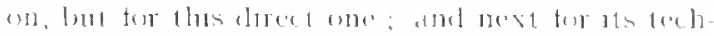
meal moterest also

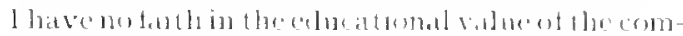

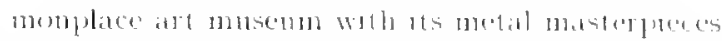

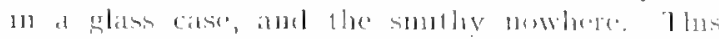

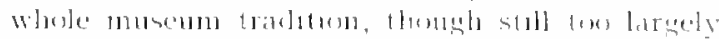

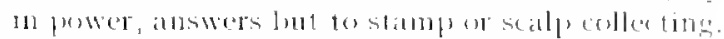

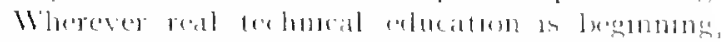

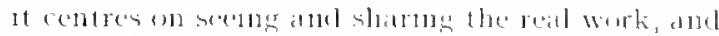

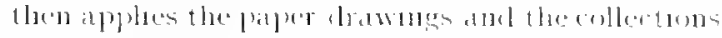

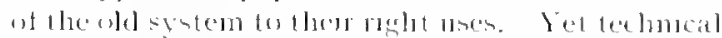

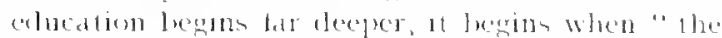

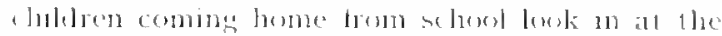

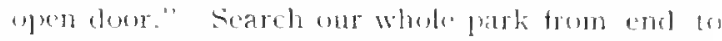

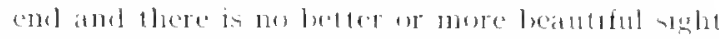

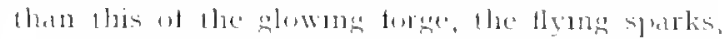
nes mese elemental stull of future muse than the

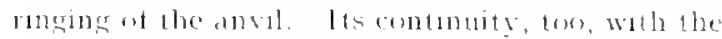
prominte sillage of the stome and lirenze teren, by here presentang the exsenthel workhop of the

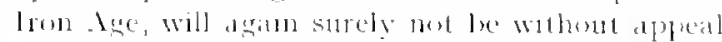
in many. But this also is the link to the present. The one more plea and l lase done. lowkmg wat trom ont hill-set cal we see how notaloly

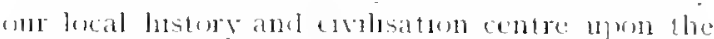
mastery of mon and steel. Xearest us the fintla

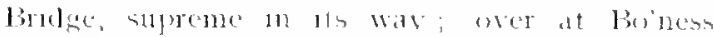
Lumald stewart's home, where Jemess llate

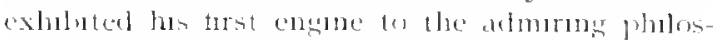
mplers ot Edmlurall. Turnmer west we recall the

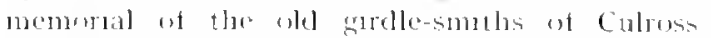
leyond glow the fumaes of balkat and Camelom, the foreses of camom. So that here ls the very fistory of iron an peace and ware, from the sharpening of the limman swort, trom the only latt

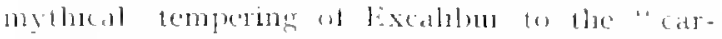
romades" of onr old wars, for farmen was mot so

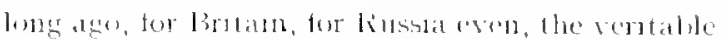

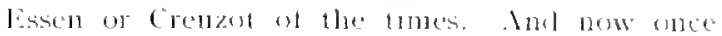
more the war centre is returnmg. Whl its thating fortrosses of steal.

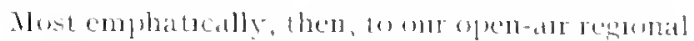

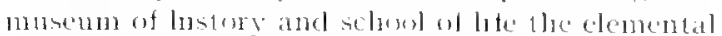
torge is molispentable. Fisen were the preceding arguments less strong we should shlt remalcl the smithy as a no less characternte memorial of ond facling cotrzen and generous fommeler than his collage home. Feleh is, an fict, the natural complement of the aber. Whe retertum of the smithy leing on this ground alone alluwset ats desiralle ats that of the cottage an Moude street 


\section{CHMTER XIX}

\section{THE CRAFTS VILLAGE}

\section{A. Design in Detail}

As linte as the last century, as ohl engravengs

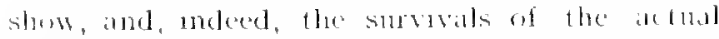

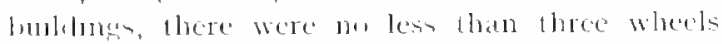

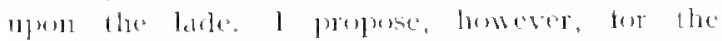

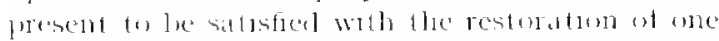
only, the uperomest and promenal one. (1) the lustory of this mill at literal tume record mat be

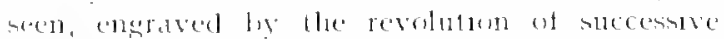

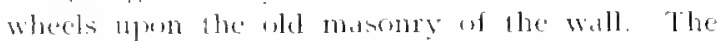
whed slusuld be atrain an overshot ones, so giving increated beisht to the fall lekow, which, ats

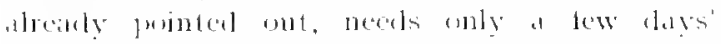
coretul work to develep it mon the finest snele feature of the slen; thas l frust doing away whth the suggestion of suphressing thes lade altarether.

but what is an le dome with this null lon-

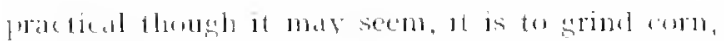

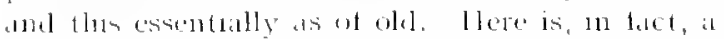

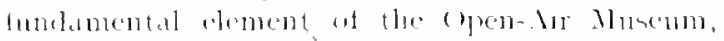

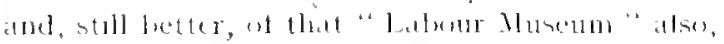
for which engincer, fechnical aducationist and artast, ecomomist and socologist, cren mondist, are increatengly lowking, and wheh the intiative

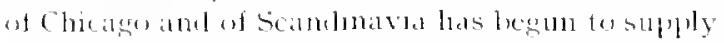
16) thest (ommunuties.

Wegrind, then, our gran here, ind in the repedired

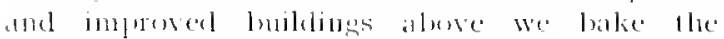

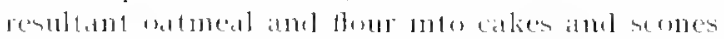

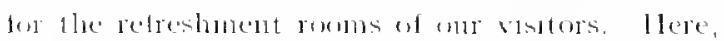

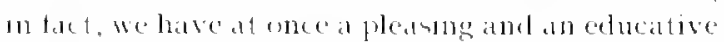
feature-the restoraten of the fundenumbal

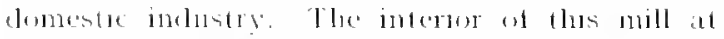
work, supplicel with the ald and smple molemery at ine foretalleres, would be ane of the most

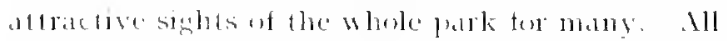
the more when belew this, upem the cerurse of the utream, we put un a sucecision of notched stones, in wheh beys moly fut their ewn little water molls and rig up then molets of primitive forms like the Nirse me

Now to this smple mstallation let me artel ome pher. lion the water mill may at pleasure drove nut merely its mollstones but, detatred trom these, transmot its motion to a little roont levent, in whele shonle stand the smplest and nust pomi-

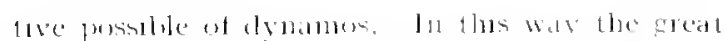

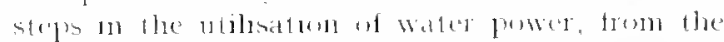

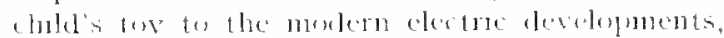
could be bromeht togedlere, and the progeses of

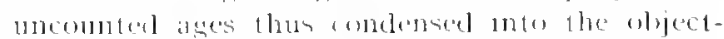

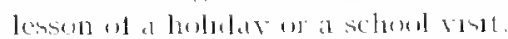

Turn back to the two plostonguples of the mills

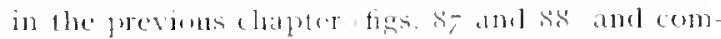
bare the present perepectue sketch of them as

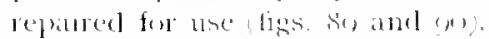

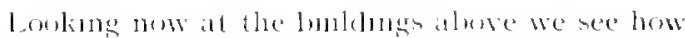
the corcular-emeles stable las somedhing of the

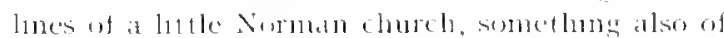
the stomt smplenty al a castle tower. From 1 ts

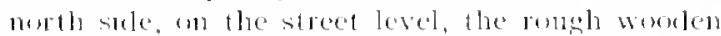

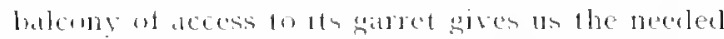

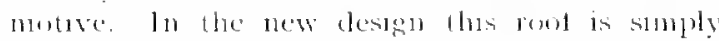

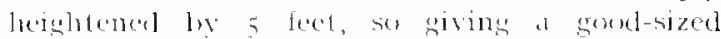
refreshment rom, wh ample and beatutiful ontlexk anter the den ; and ats wolndows, seen from the

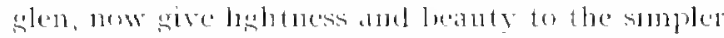
walls ledus. Thes upstairs refeshment room is next extended minte the old encular malt harn

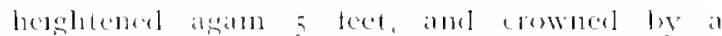

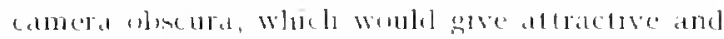
varled fletures at the whole seche aromel, almose

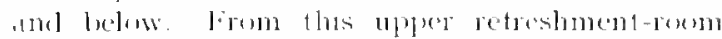

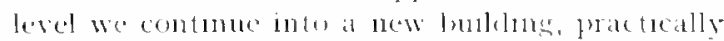
pepresented, however, at present be an old tiled

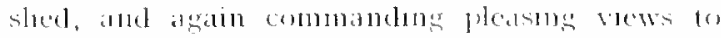
smethward and to cars and worth

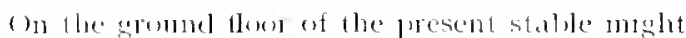

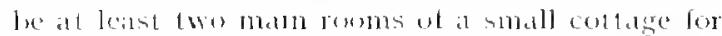
the mulles and lus wife; or, suce it is not neecsisaly that anyouse should live mpon these premises, they whold les better cmpluged as the kitchen of the

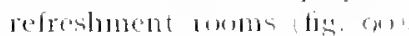

This kitchen shoukl be at the smble ald-

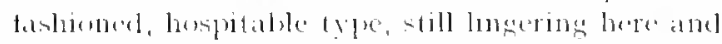
there in a santish farmbone or mansion, of in an

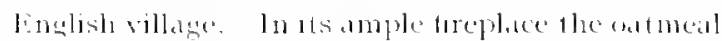
and bentrom the mill beks would le baked into

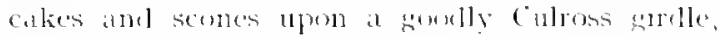
and the ervests homely tables amel sedtes would fill up the rest of the rom

In the smatl reme to the and shomld be placed a modern kitclen and senllery, with gas and all 


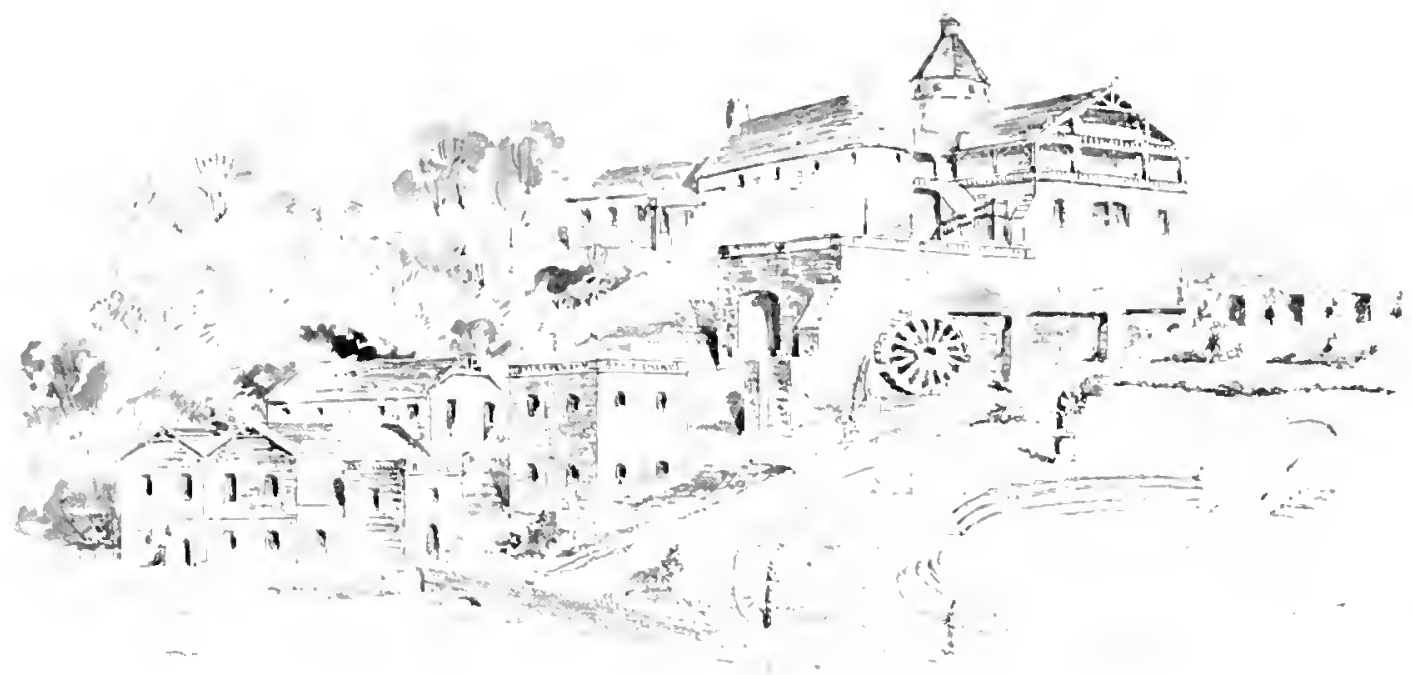

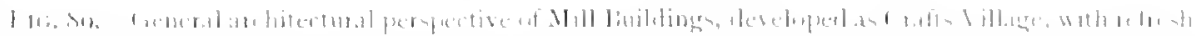

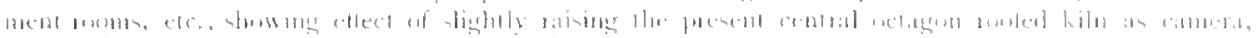

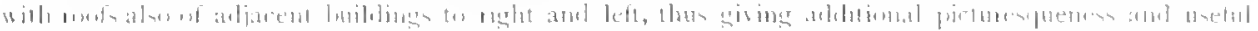

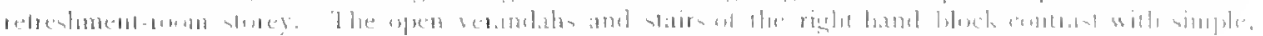

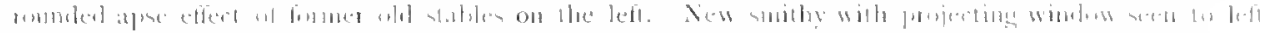

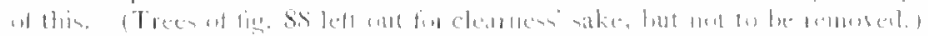

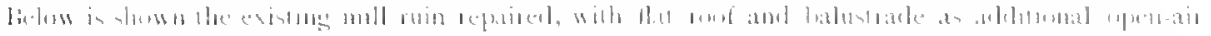

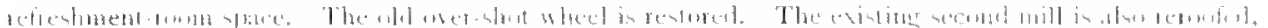

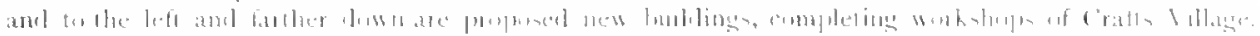

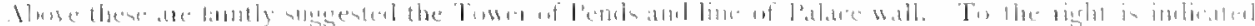

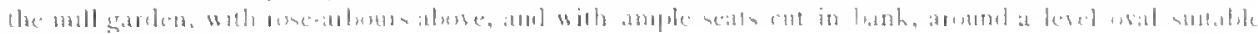
lar lineinger ente.

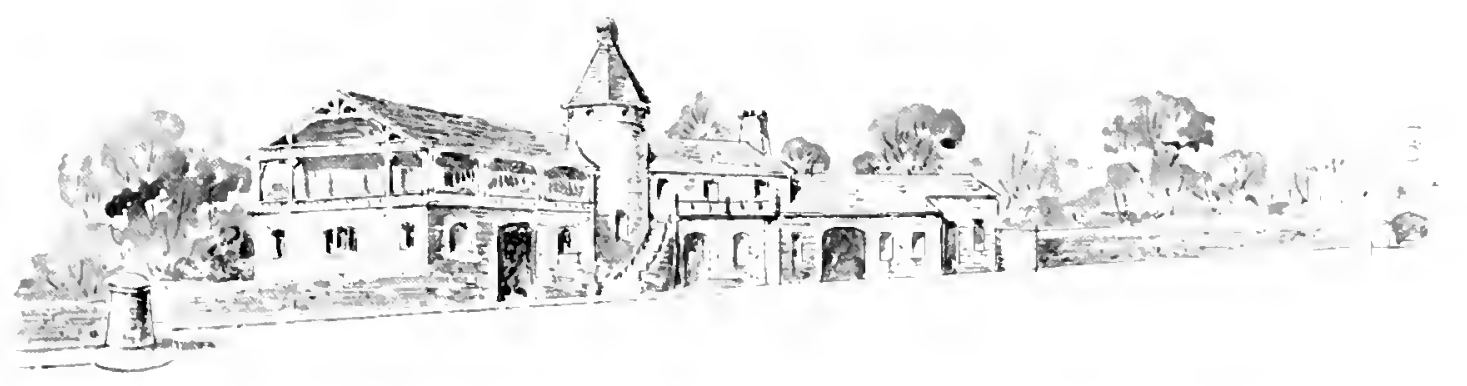

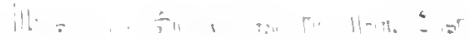

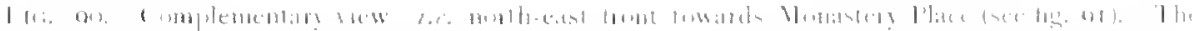

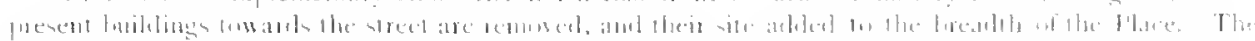

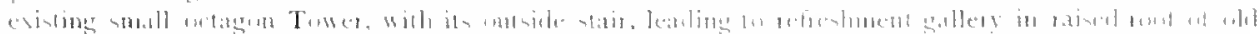

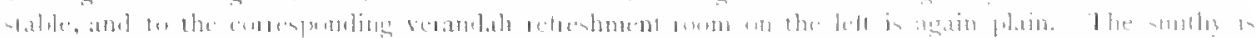

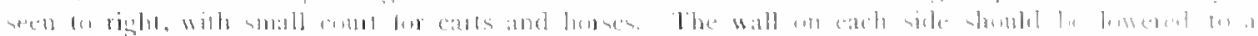

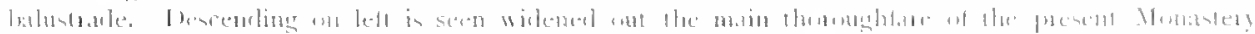

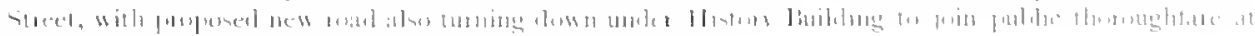

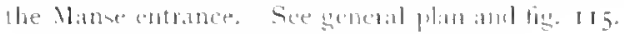




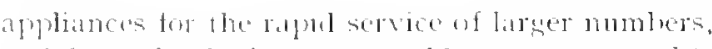
and from thes hette rom would pass a servere litt tor communcatom woth the how aluse. Fnterng

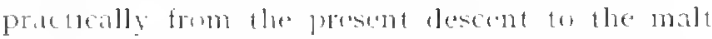

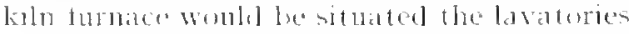

In these two storeses, then, we have thus com fortable atcommolation for sity for guests in the uppere storey and : 5 m the lower

Vote now on the south fies. Sie in adclition te this the littlo stan leading from the street level

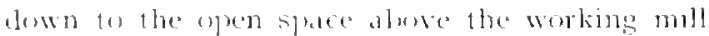
Here, asain, in reom tor not only a wall bench weth table lont for seats acommondatung a gumel bew additional pervons, Igand, we may extend this phatorm ly using the flat root of the mill itcelt thas can late an awmug stretched rover it in smmer it desned. Ilere, then, we have com-

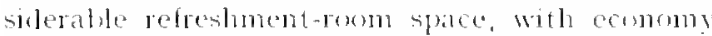
and puturestuemess; one uld molls are again

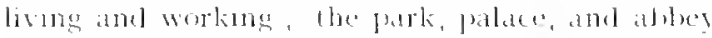
effects are netably mprosed wathout any loss of

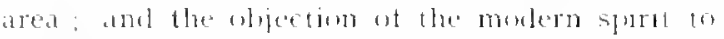

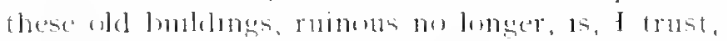
completely and findly remoned tigs. s; and sis. Chath Xill

What of the recomel rumed mill, of the rumed wall of the thirel, stall standing at the torot of the fall? And what ot the present nettle-gum

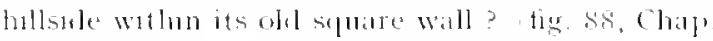
xill

Begin with the lowest hit ot rum mot shown in figures, and see agatin how thus, doubthes fo many a worthess frogment, is agdin when we vew $\mathrm{st}$ with artistic are a foreground element of the highest puctumal value on an whole mpression of the palace lunes. Not onls so, but it greatly extends the effect of these. Now looking at the whole range ut ruins, from mills to palace, from every pount, across, up, and duwn stream, we see that the tormer are imeliepensalde to the extent as well as to the dignits of the hatter, so that thetr demolitum would llwat the gulace an a way wheh even the least olvervant whild apprecate. thomgh when 1 t was tom hate. Imotosraphs, however, trom ranous points of view will show thin iof fig 7), Chap) Sild.

Thas kowest he ot rom, then, must be left practicaily as it stands, all mont with such slight repuir, mainly of cement pointins on top amel nogth as 1 s necessary to sturanted lls permanence. butt atong the wall, neat the site ot the samshed "Kings Barns," the acompanying plan shows the proposed erention of a furtlor stoup of onestorey fomblangs, whancuner the importance of the mills above, which thus crown a more complex composition. With dhe aldatum w these tew simple and inexpersite lomblums we maty now complete the essentials of a further element ot the whele scheme, brablly answering to the " Irts and

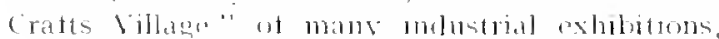

to a turther development of the latherr Museum, to a very real development therefores of tee hmoal

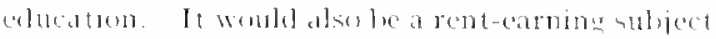
to the Frunt and a means of lestimate inclustry (1) 1 ț t:ollatits

\section{B. Crafts Village in Operation}

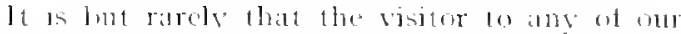

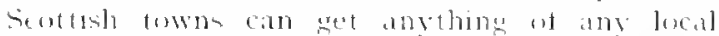

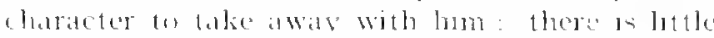

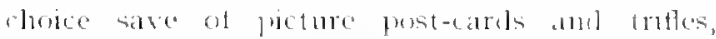
pothlily problacel elsewhere. Why should the vintor mot lave the meterest and ploastre of seeng the artist-crattsman at work and latills awat something from hom as a somenir of his viste? Why shombl not one or two nf thene new worls-

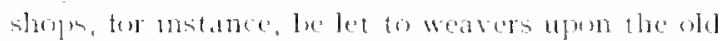

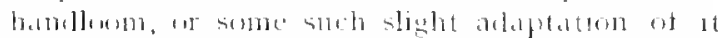

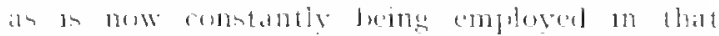

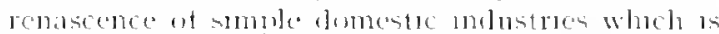
now realpearms in so many parts of brotan and

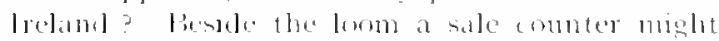
dropley dratacterestite examples of the many

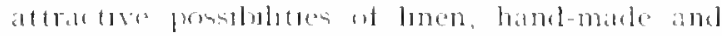
menutacturesl allise. The retreshment-roums of

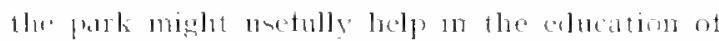

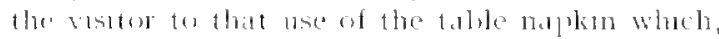
were 11 developed to eren a slight groportwot of that seneral me comtunental onmeries, would sion tar mome than fouble the staple industry ot buntermline The alpetrently perverse mithides ot liukin, and their deselepment in the lash vilage industres of Sir Horace l'lunket, chus lead us on la molern londermbne ance more.

Agath, lesule the weaver, why not the loras anel coprer-worker, with a raricty of probuctom from the sumplest maplin rug on the beaten salves

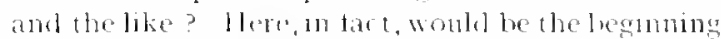
rif what, in the tar smaller, less farcourably-situated and hutomally less art-proulartive community of keswels, lus spread inter a lazge and flouristumg artestic induntre of wide educational usetulness

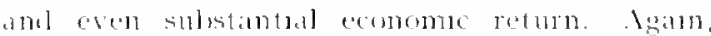
in anothere of these beroths might be the silverwomker, the geweller, met, as fou much an ledinlough, retailing ar "Scottish jewell"ry" South American agales cot in bavaria and mounted in firmingham, lunt the designer and executant 10 ome. For the worl-carrer there should, agint naturally tre at place. Why andeed, should there

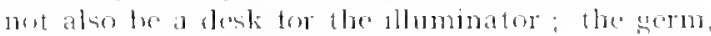
isean, of a renewal it the listoric seriptorium?

it would lue easy to multiply these supuestions still further. The prent is emougle it the general princelle be enduated that of torming agam a

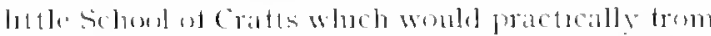

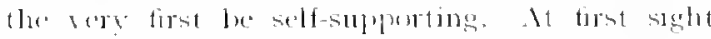

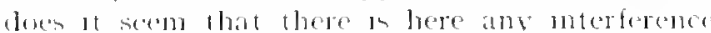
wath private entroprese? Not more thats in ans 
exhlution, of wheh the stalls are surely tar more corretly descruluel as extensoms of privale enterprise. Their perelucts, if sucecesstul, would

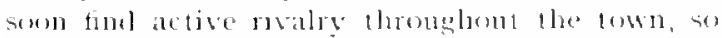
that pasing aloug the streets the visitor would fimel mans thones chatacteristie of the plater aluel eacle wall its own beatly or bectulnesis. Is the scheme developed other industries would be adeled, or rather would and lhemselees. Why

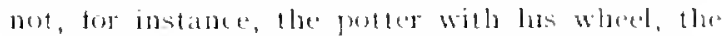
florist; even the bagpipe maker, anel an mo

That an everveldy village hatesmilh has in lus apparenty homely eraft-matstery a latent artastic skill only needing opportunty for its arousal 14 well shown by the marvellowe reprostuelion ot that Sealiger ralingr. which is ant once one of the sights of feromil, and one of the masterpieces of the forse. A Sention tomriat, the late Mr lenner. brombla lome a photogrildh of lhis, and showed it fo his village smols, with the halt-jesting question Can ron do anvihng like that? "led me" see! May I tre" "Was the answer-and the present reprouluetom wath the result, whe well re-

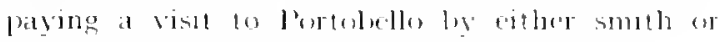
sceptic.

Thus around the renewed molustral nucleas of mill and smithy, the finer arts would again naturally arse. Such a scheme is, it course, really nothing new; it is only what hay leeen arosing once and again on many palds of these datule, following

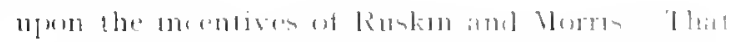

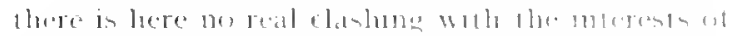

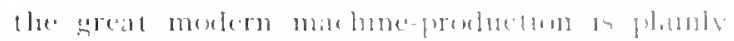

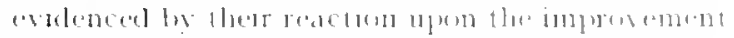

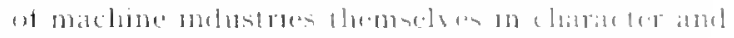

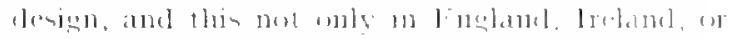

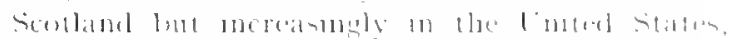

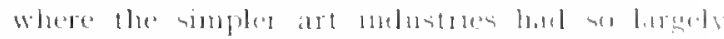

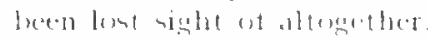

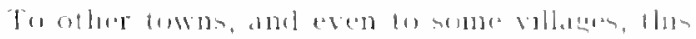

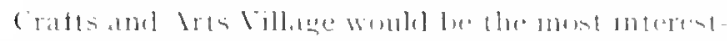

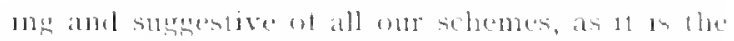
most selt-sustining and least costly. Its reactur

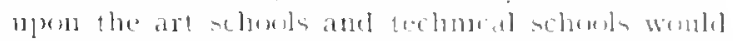

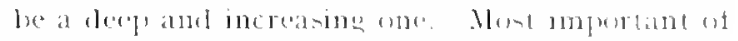

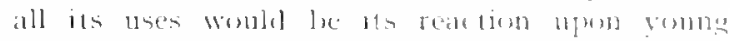

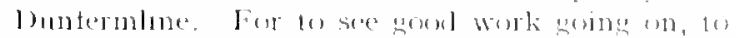
mutde 1t, to belp in 11 , was the very enenese at

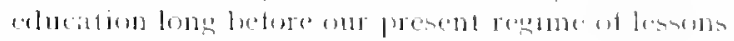

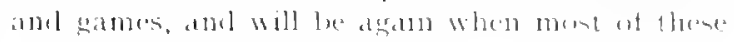
are formeltent

The presenter, fen, of this lithe hive of induntries

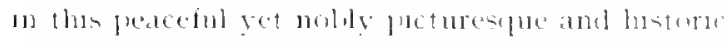

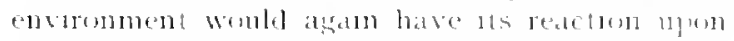

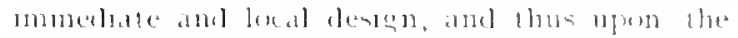

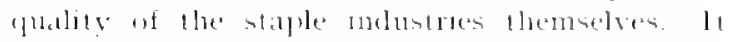

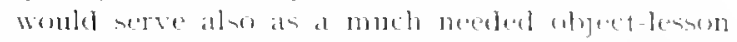

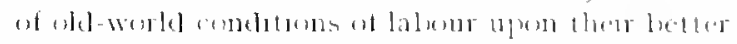

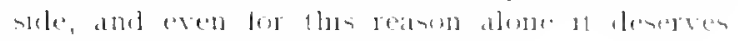

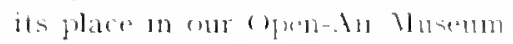




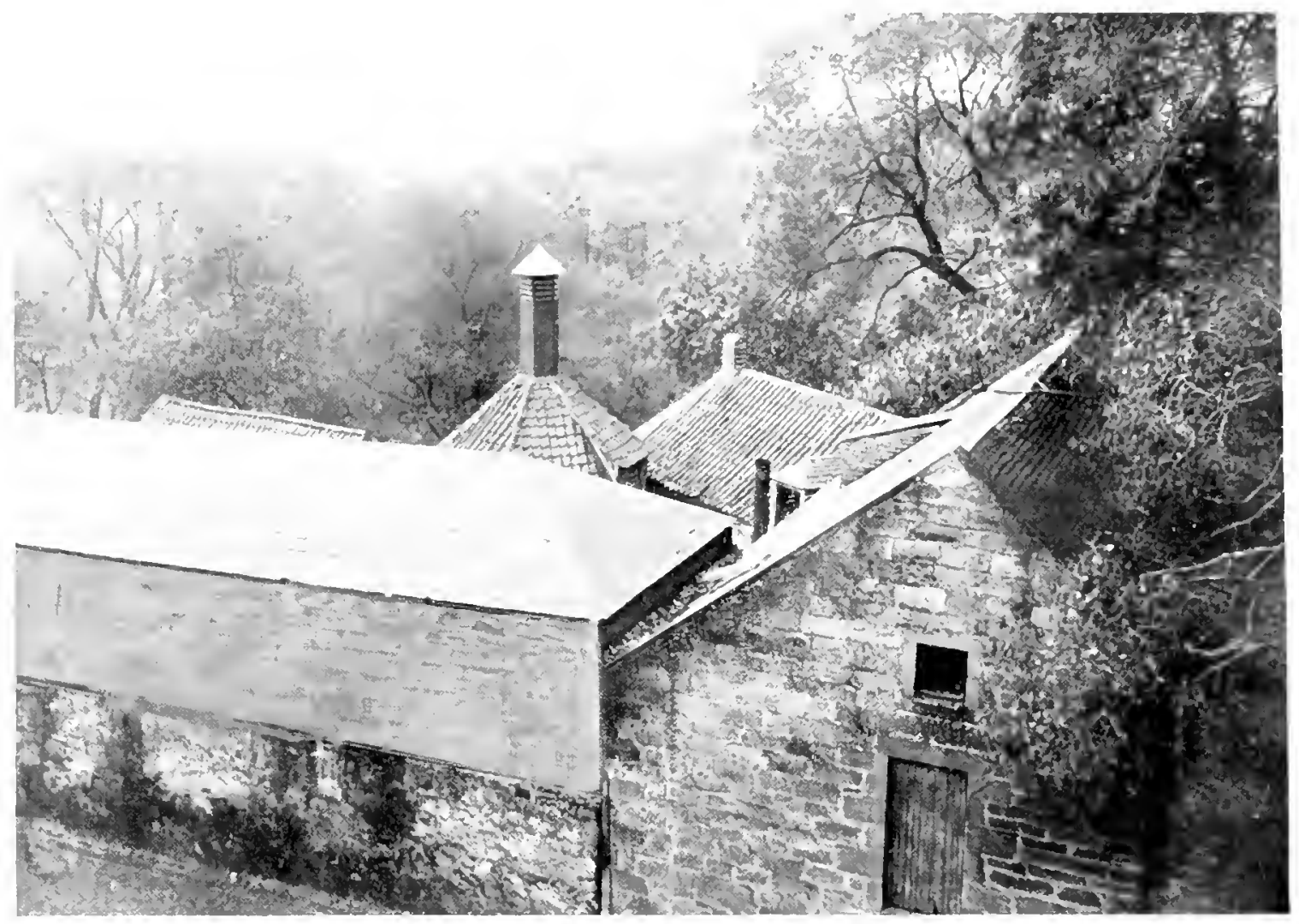

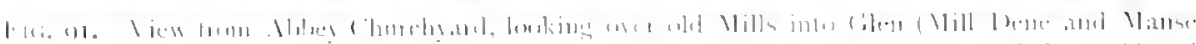

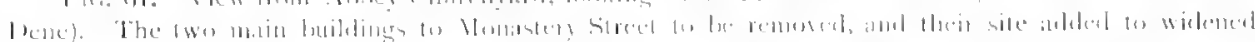

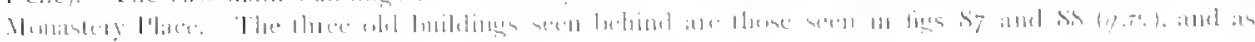

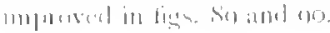

\title{
F. H I S T O R Y A N D A R T
}

\author{
('IIIIIK XX \\ MONASTERY PLACE
}

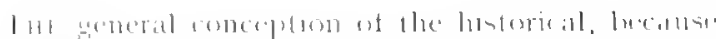

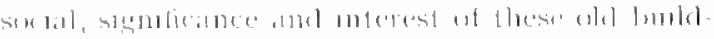

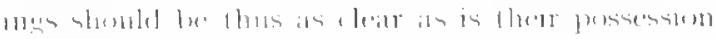

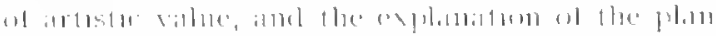

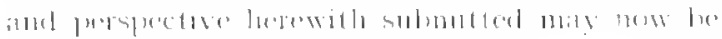
princerenter waln

\section{A. Improvement of Monastery Strecl in Detail}

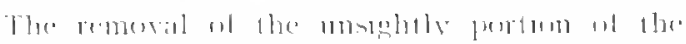

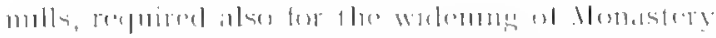

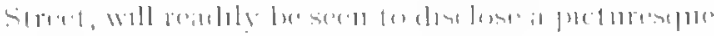

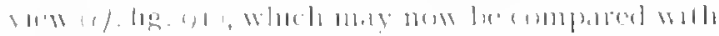

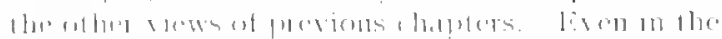

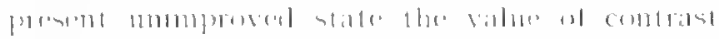

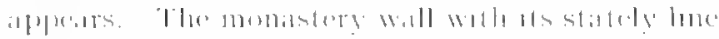

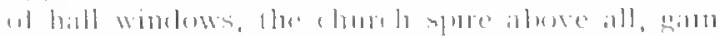

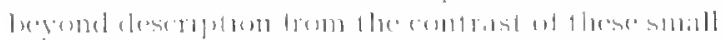

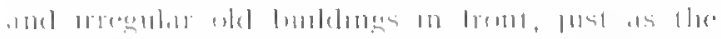

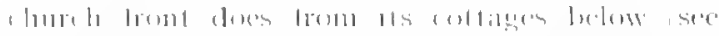

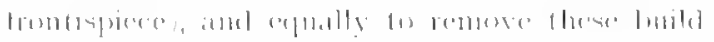

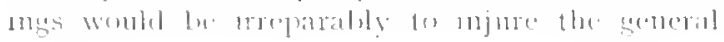

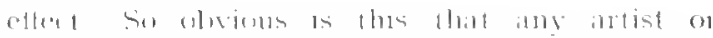

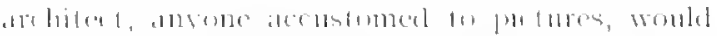

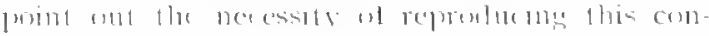

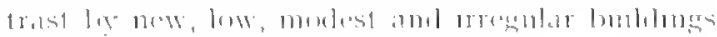
were the present unos destroserel

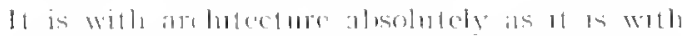

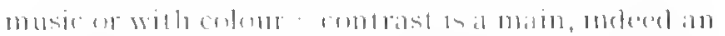

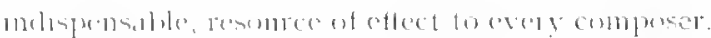

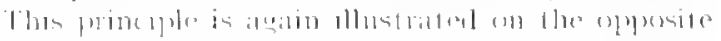

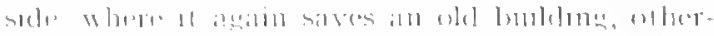

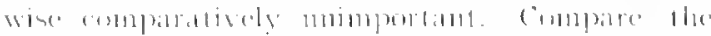

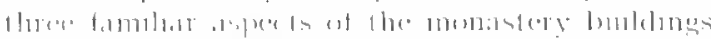

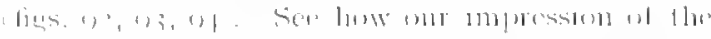

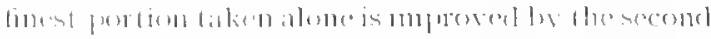

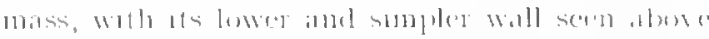

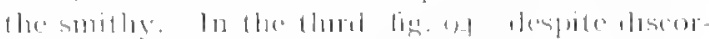

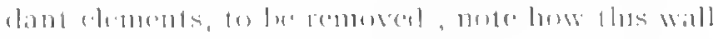

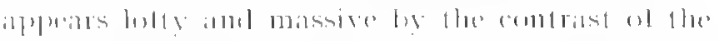

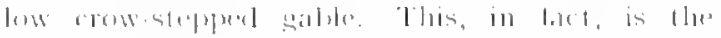

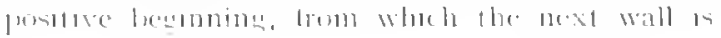



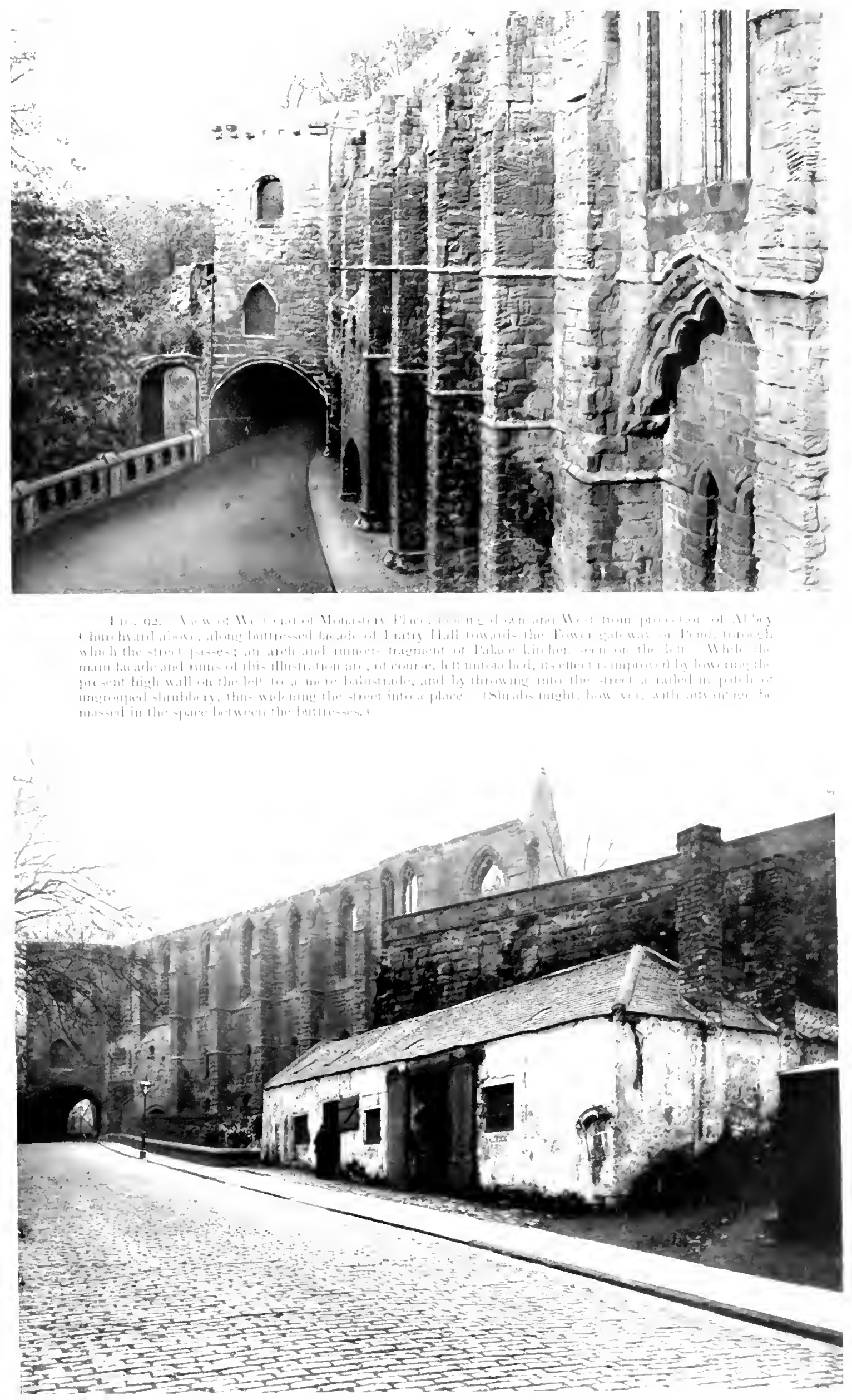
comparatively erreat, anel the last superlative in dignty anel heatuly. The spectator commen up the streed may not hate been consciens of this source of efter, but it has helpeel his impression all the sibuce. It $1 \mathrm{~s}$, in fact, the presence of this little old bulding wheh enalikes us antustically to dispense wath al elematnd for some low structure in the place of the olls smothy compare tigs. of amel os

Next, follownge up this consideration, we see the smoths away and this piece of graveyard wall expused, its stermuess relieved by windowe which aclvantageonsly repeat those of the liratry wall. of death and vantsherl greatness alove is at equestrian statte. Here this would be no merely. decorative teature, but the needed symbil of Man and Tature, of life on Joy and Power, of Youth amel Enerery Mr Watts" statue of Enersy, or lus stutue of Itugh l,mpus at fiaton llall, are here noble and suggestive precerlents. The acompanying sketch on Mr Donean's has also 1 ts own chollacter and litness, especially shoutl a has-relief he all that lunds mats allow hig. the

From this centrat feature of thmastery l'lace we

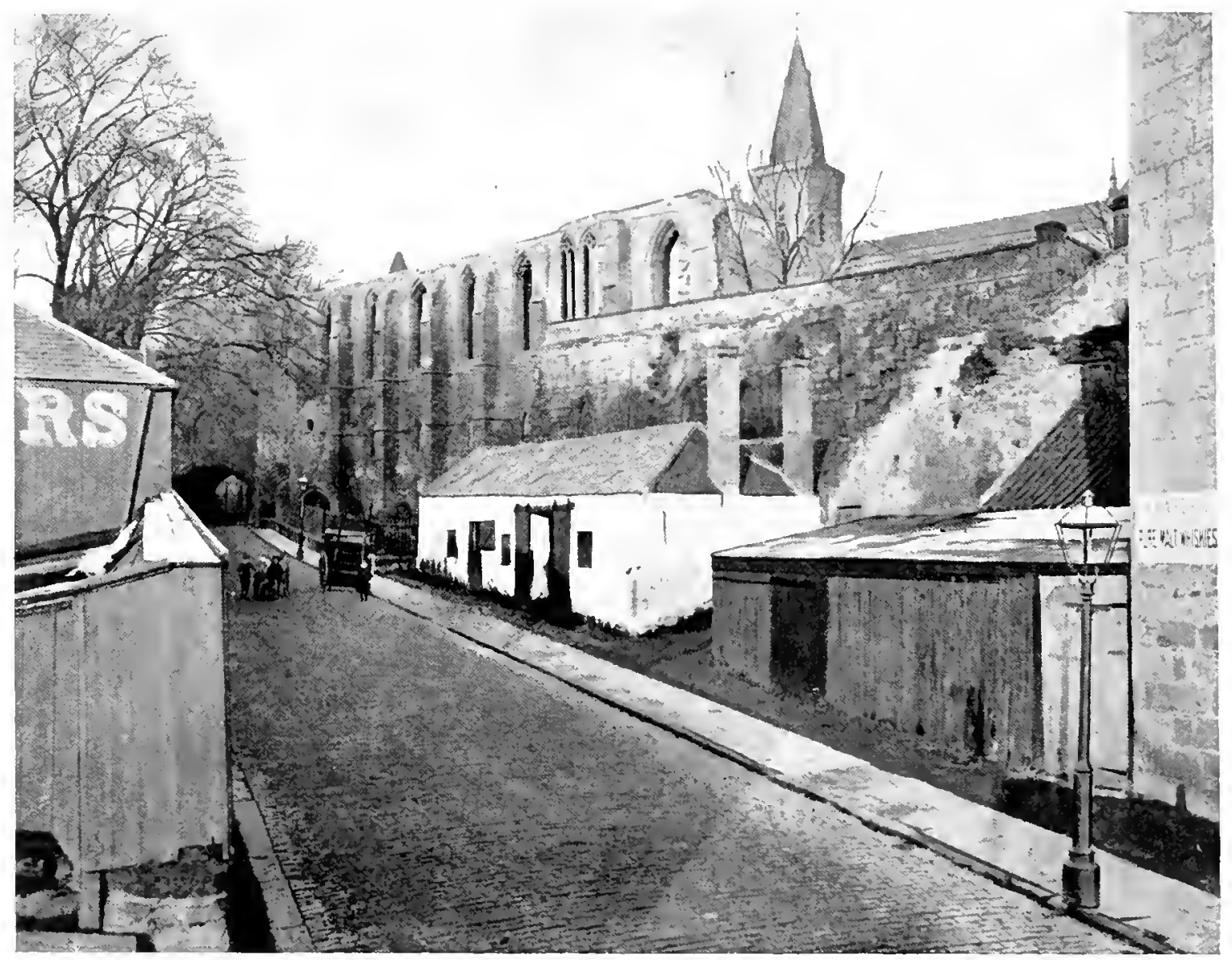

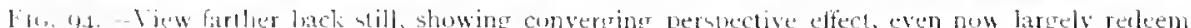

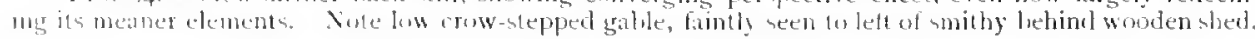

The urly and calreless masunrs of the modern paraned is num replaced by a simple lout subtable balustrate. The smple sipuare projection, however. necels somethung in front to continue and romplete its sabence. This should be done not by a building but by a monument and the monument appropriate here has been already practically, by our discussion of the smithy, sundested-some commemoration at smith or ot liniglitly ider, or of both together, in bals-relief lout what would give the whelle line a new picturesqueness and an ahled lite, a medel comtrast with the associations proceed tupuads to the Pents. In the large triangular railed-in space, which 1 ask to he cleared of shrubs and threnen into the street, should stand a drinking fountain for man and beast, whth a range of massive and simple seats under the western wall of the spuare projection of the gravefard above tganst this broad, plain wall the natural contrast with the statue would he a vertical line of some sort; a pillared or storeyed fountain, therefore, of some height, say at least I 2 feret, or aven up the the ground tevel alove, from which the new balustrade rises. But this 


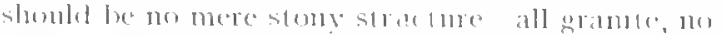

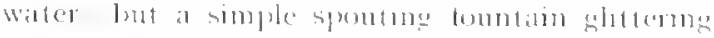

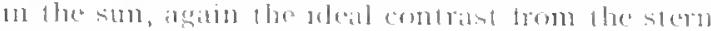

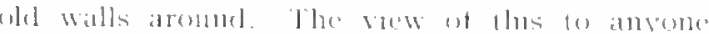

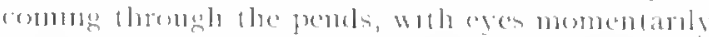
rested and then pupts anlarged by these tew

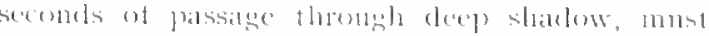

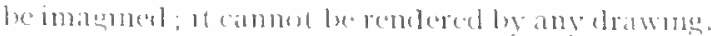

Nisw returning downhll we pass once more the equentrian statue, and then ame to the linke

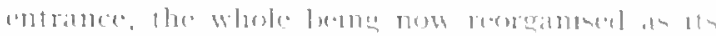

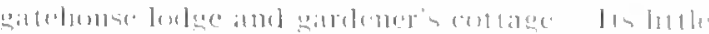

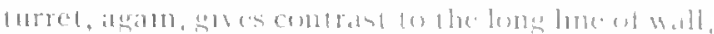

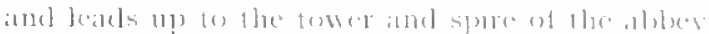

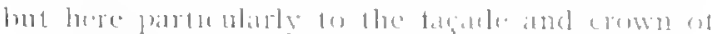

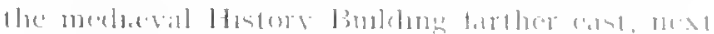

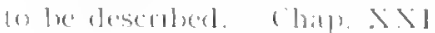

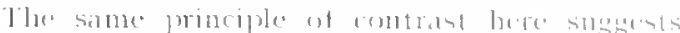

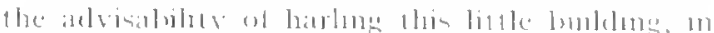

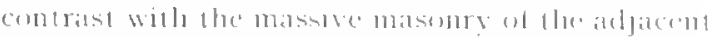
lones of wall and th the ereat lullelinges allowe

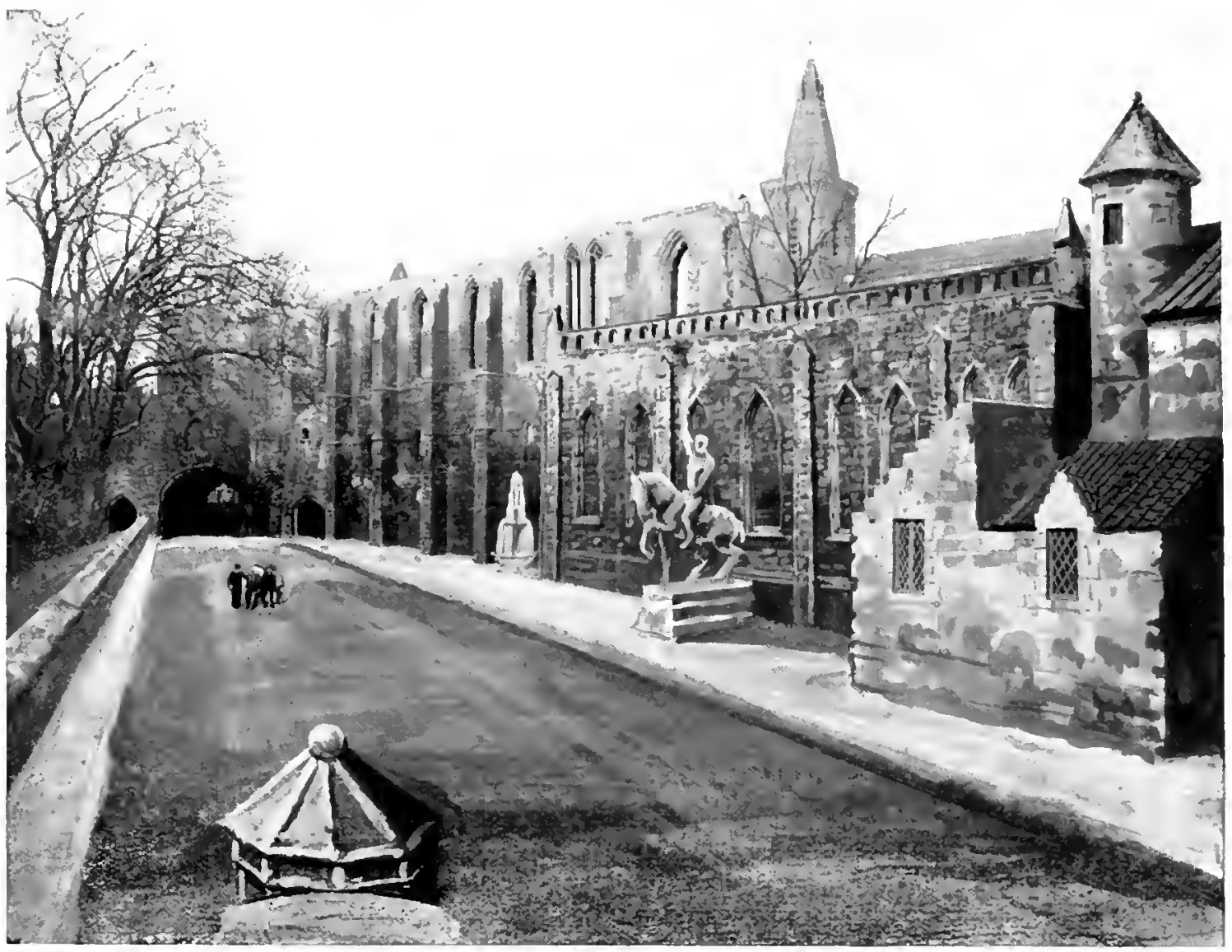

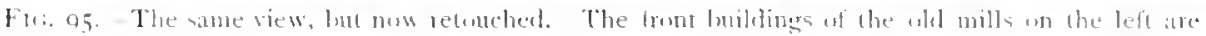

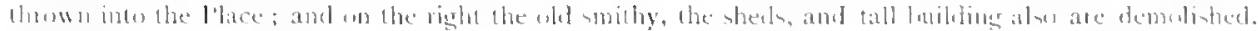

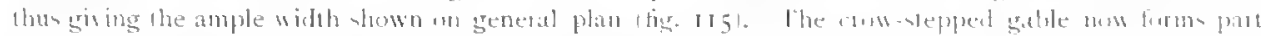

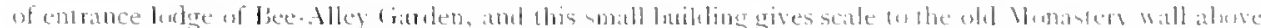

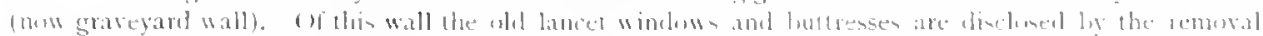

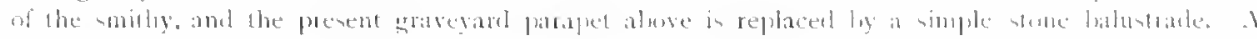

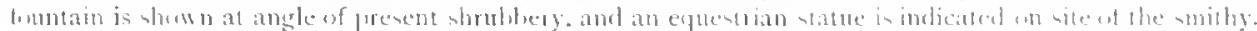

red-ronfed building, that of the crow-slepped gable alteads mentioned. Lis long, plain, how wall bere gives agilin foth parallel and contrast to the graverard wall we have just passerl, and serves as the east backgromel to the statue, just as the formor wall did to the tomntin.

This olel bulding is shown on fig. 155 , retained let improvel, along with the lumens bitte fower-

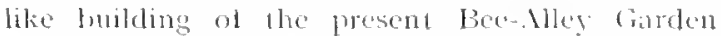

\section{B. Bee-Alley Garden}

There remains now for consideration on 1 hus

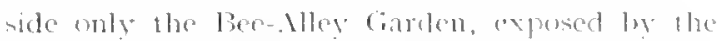
removal of the hatge mill and chimney stalli. If will now bo seon that this projecting gitehomse cannot be removed, since it lithle more than

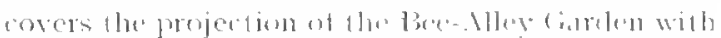
its retaming wall. When llis present chommey. 
stalk and large mull are remosed the retaining will of the garden wall come into view. It should

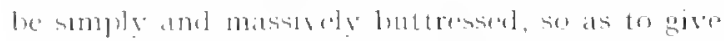

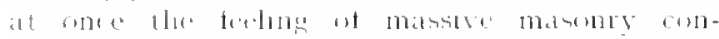

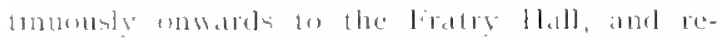

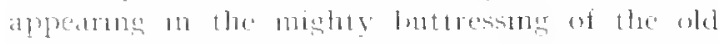

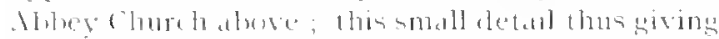

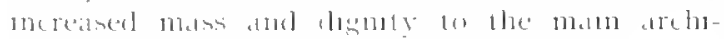
fectural teatures ats we ande to them.

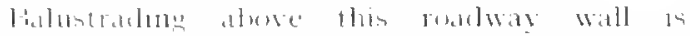

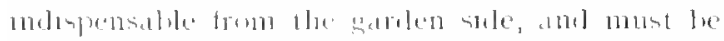

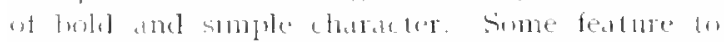

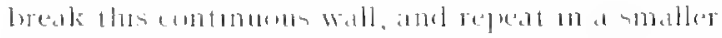

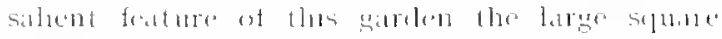

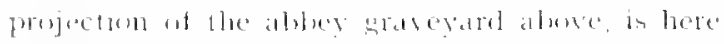

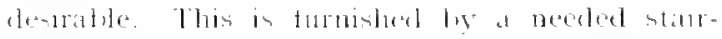

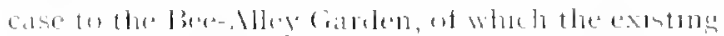

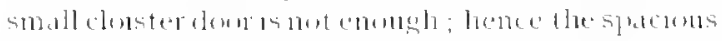

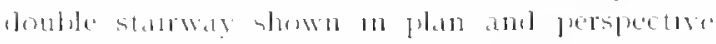

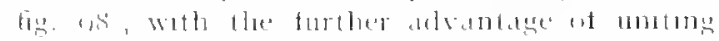

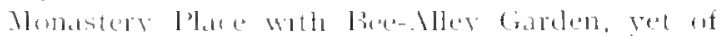

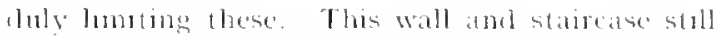
need a trature of life and contrast, and this mats here tre beat glven by the use of water. Ilow is

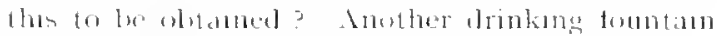

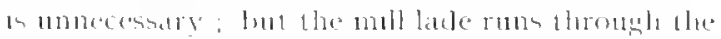

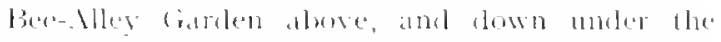
street frelow. To, lorng this ont, then, from an

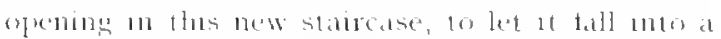

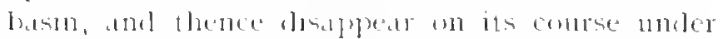

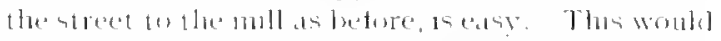

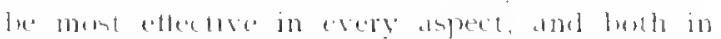
basmomy and comtratat wath the tountatin farther in). Cot defornment thes rash of trombled water

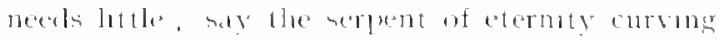

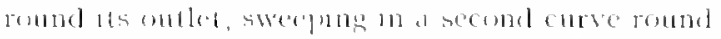

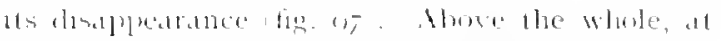
toj) of the etall, ant thus recesed from thas

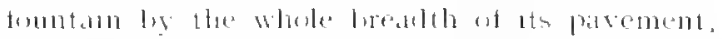

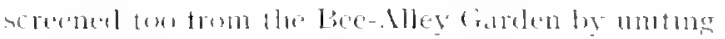
manses of preets lourel and golden vew planted to right and lett, shoull sit enthromed a notse

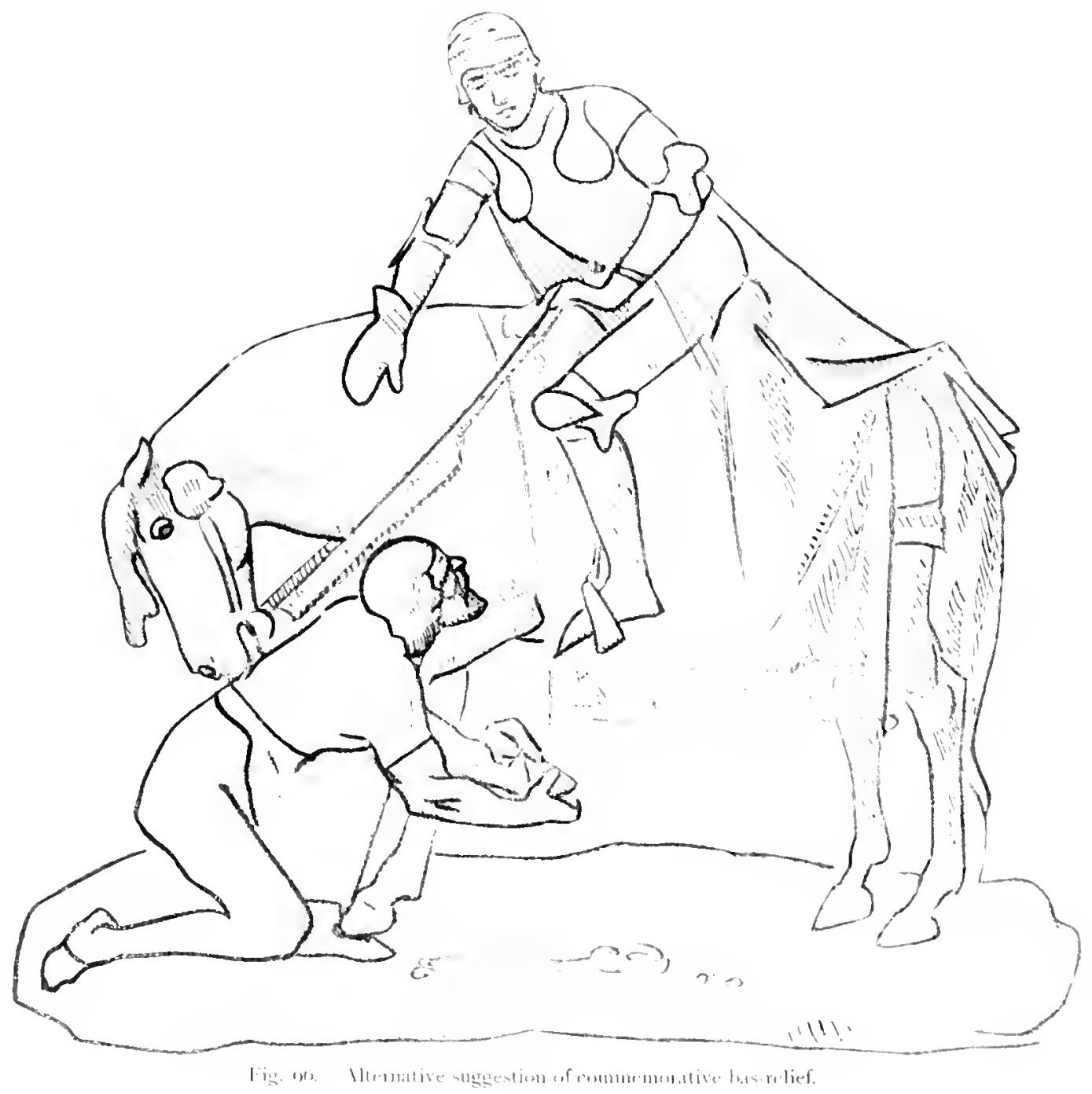




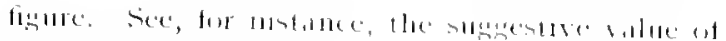

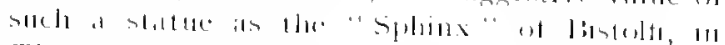
The siluter.

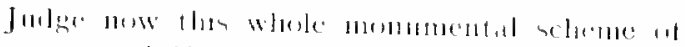

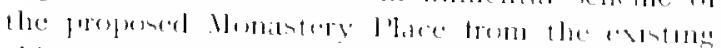

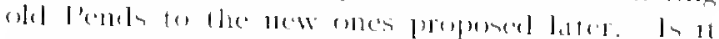

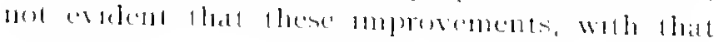

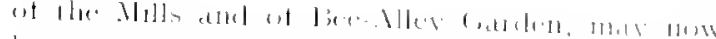

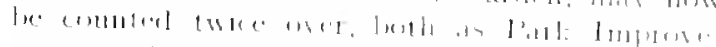

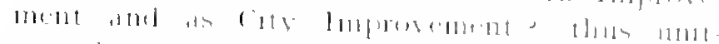

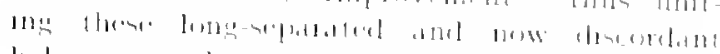

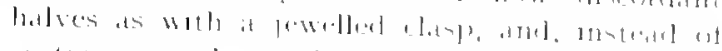

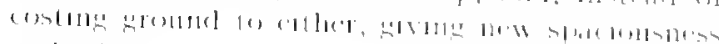
(1) Ixilh?

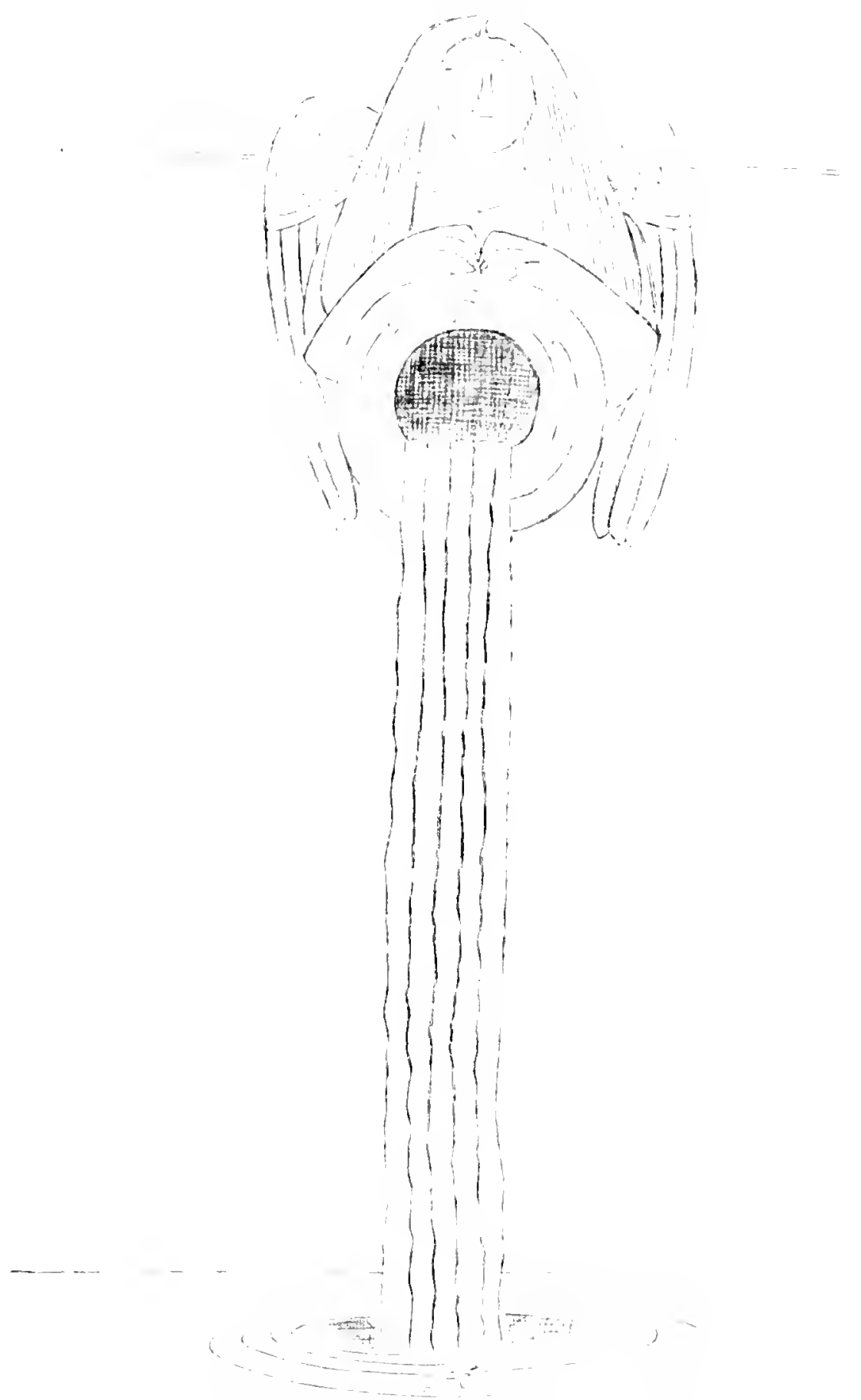

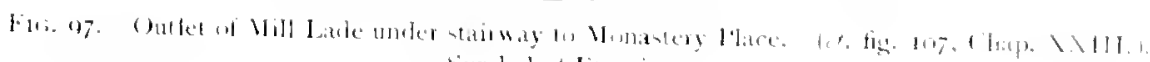
siminil al Eleanis. 


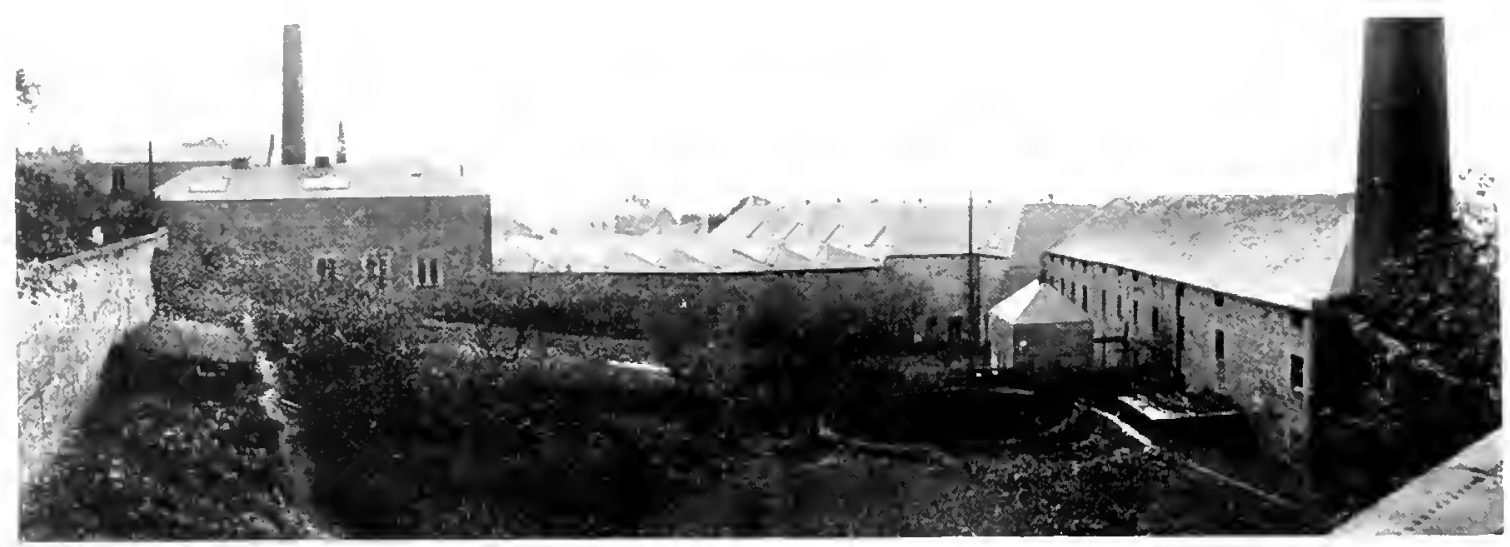

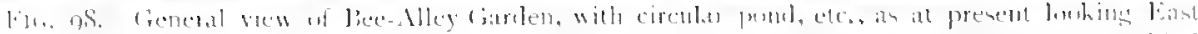
Im

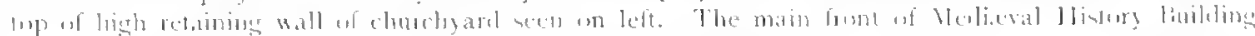

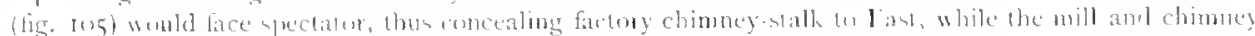

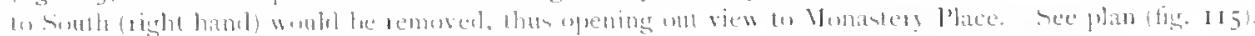

\section{(II.TPER IXI}

\section{INSTITUTE OF HISTORY}

\section{A. Need and Site}

(1)

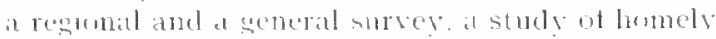
letals fet ol vastest wald aspectr. Simblaty

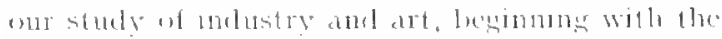

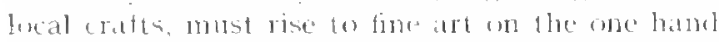
and must lescend on the simplest begmmmes

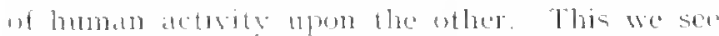

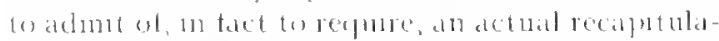

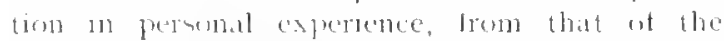

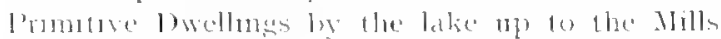

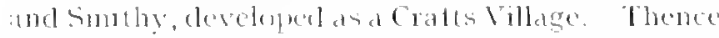
and later we shall come to the Art Gallery, 11 which this ant actives and at educalum shoulal

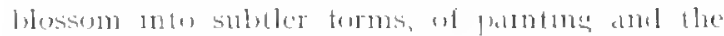

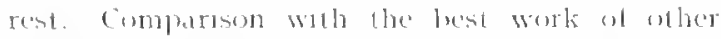
flaces, cxhobstoms, and permancont collectums

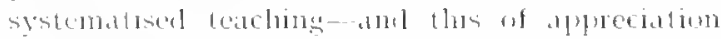
as well at of poolution would all and in taising

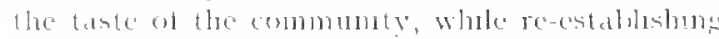
11 mpond its tumelementals. Those uneluele contace weth nature and woth materall, dereet first-hand experrence of abserving and woring: and also

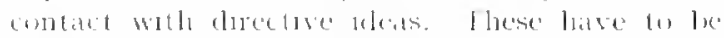
stated, mot only as regarts solentule law and

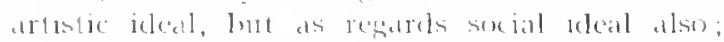
for art is service

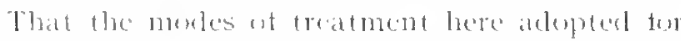

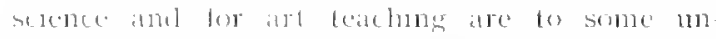

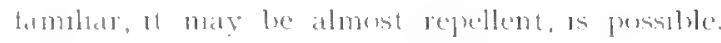
liut, if so, I sulmut bery seruotsly, as mell as conthdently, so muth the wore for the present, or rather the declunner oreler, eledicient as it is in evervone of these elements of reality just indeated, and cx-

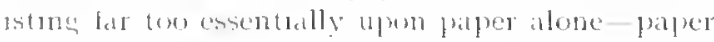

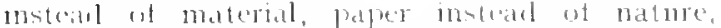

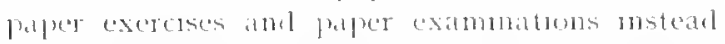
of real esperience, paper certiticates and rewards. and finper reports to the puble. I lo not ask the

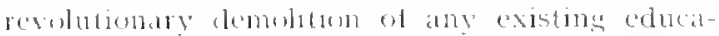

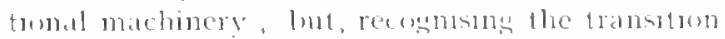
in thoterlot and action now happly in progress, 1

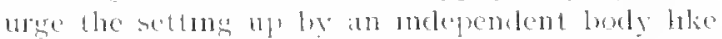
the linst of an equipunent uf real resources for contale whth natue and with art sich as l have

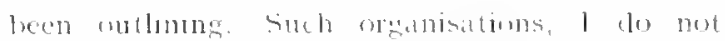
hestate fo say, would le welemer ly all the

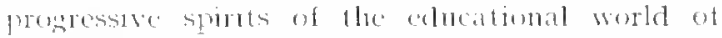
Great britain and ol Anerica, whether local. govenmental, or Leneral. fiof the fact is that,

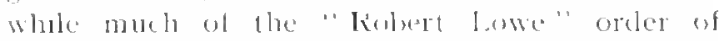
educatoon strll survires in trom, o new life has

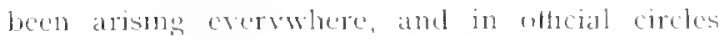
no lomerer least ot all.

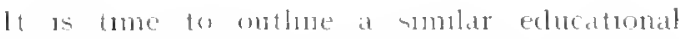

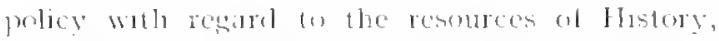

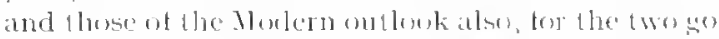

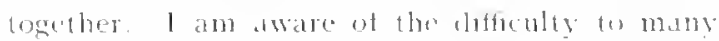

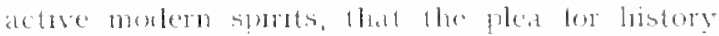
sis apt to be complicater wath an unduce conservatisn of classical and tratitional stmelies, and. therefore, es to be looked bipen with distrust.

It is the wealiness alsu of the bintorand to seem a nere antugary of the past wrthont dequate reterence to the present, much lese the future; but is it met "the wealiness of the prateteal man to look at the worled thrombe the suste chonk of the present," and so to menumerstand this an has turn. perbaps not less seriously? Agitn, the mere Itepust foils also, ly striving a sec torwinel 


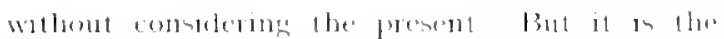

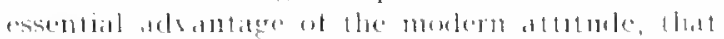

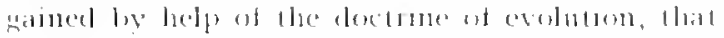

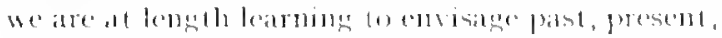

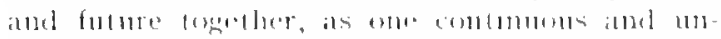

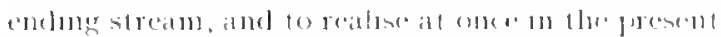

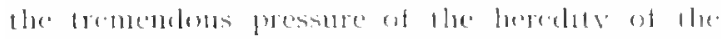

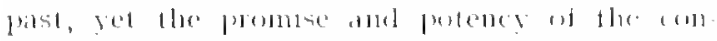

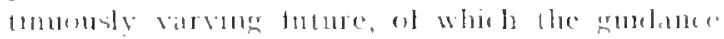

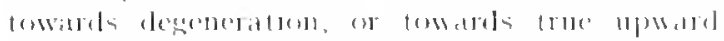

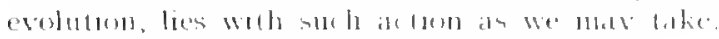

\section{B. History in Dunfermline}

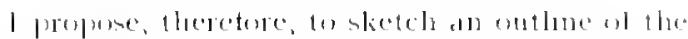

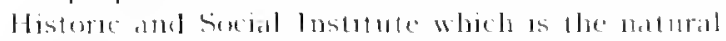
complement of the Nalure Instumte abeady ontluned, and the art Institume an le consulered liter. For this ayan bunfermbine has many. advantages as well as pessiblinlutes, so thatl here

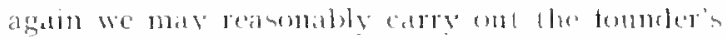

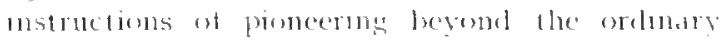
level of other mirs.

The inmortality of the hastoric pitst is not comls evirlenced by the Temer llill of Maleolm, the cise

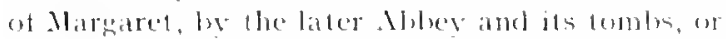
the yet later l'aldee, lut fry the atmosplere of the city itselt; and the non only richly m literature

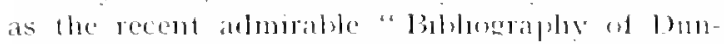

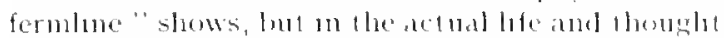
of its inhalutants. Fin sedelom elly soul is so completely deat ats to formet the atsoriatums of lum mative city; assuredly none returns whlostl some feelug of how lle beart mat burn

The tany herinumes of an archeolongal and hustoncal muscum now monldering walun the Abley cratehouse Timer, the collectoun of the

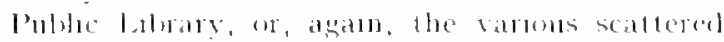
obyeets in private collectons, are all evedenes of

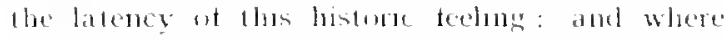
mose appepriately than an Donfermbere can we now consteler the adeptate development of thisthat ss, upen at sole worlhy of at once an ancent and historic apdlal, and of its present rejuvenescence?

lint historical exlutallon, I moly be told, in

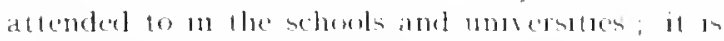

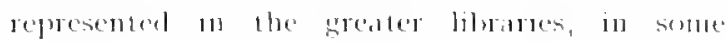

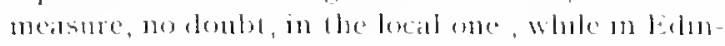

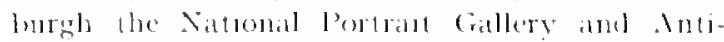
quarian dusem should le sufticiont tor mor higher requirements. I regret to traverse all

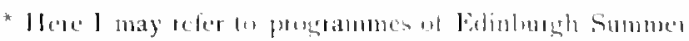

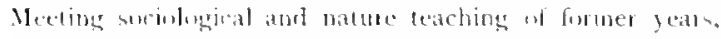

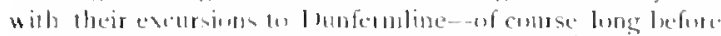

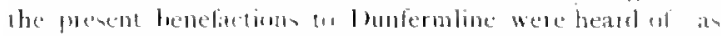
crideme that mol mly the hintoric interest ot the rity lant it present signilicance, ant exen its l.tent reasalicuing, hase tang leen matlers of ancial prevision and enlucalional exprension.

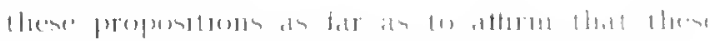

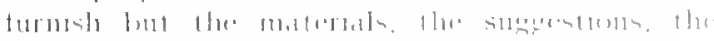

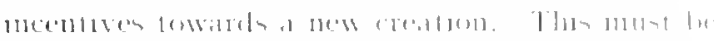

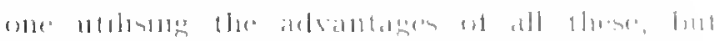

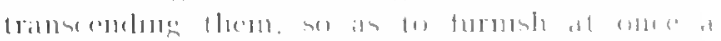

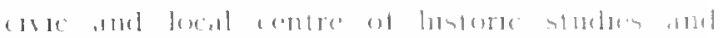

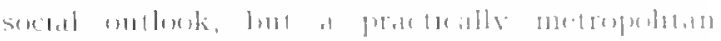

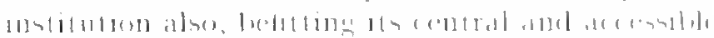

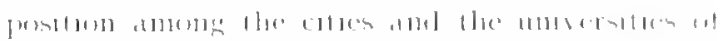

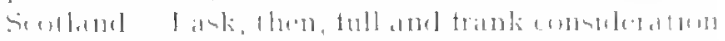

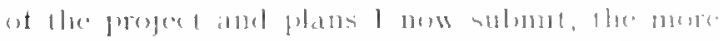

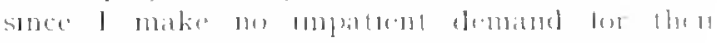

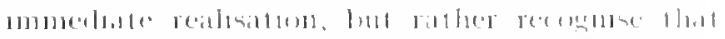

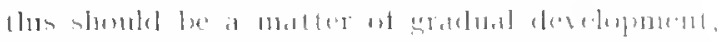

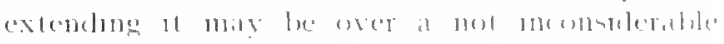

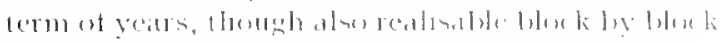

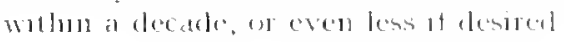

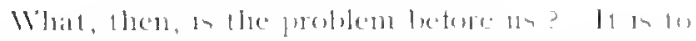

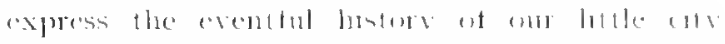

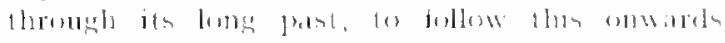

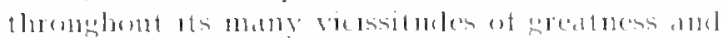

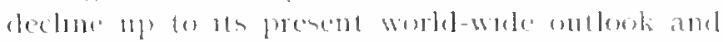

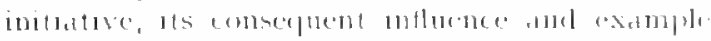
Thes cily it mol merely at regumal of promened

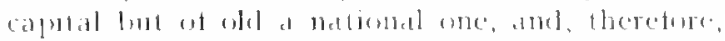

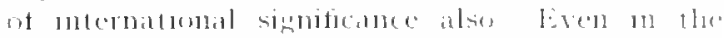

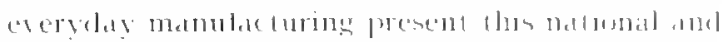

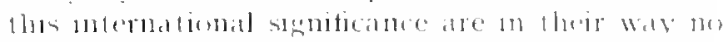

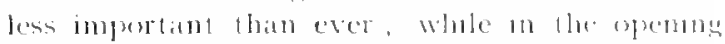

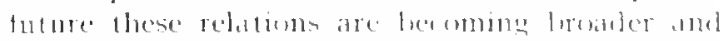

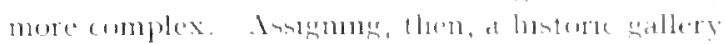
16 Dontermbere and ats history we see that thes

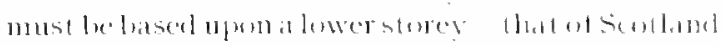

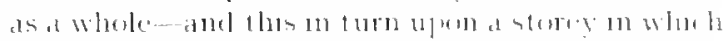

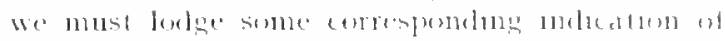

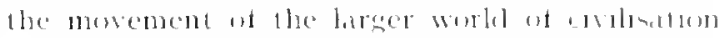
in all ots wrer aspects. For as we haw seen that

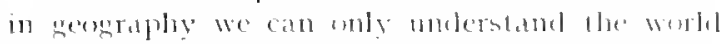
when we hate a eleas comeptum of ons awn

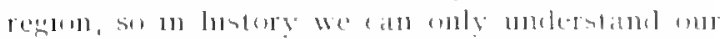

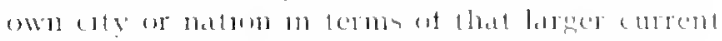

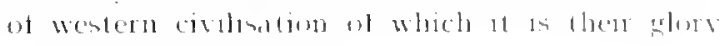
10 hate formed at bat

\section{History in Scotland}

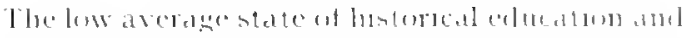

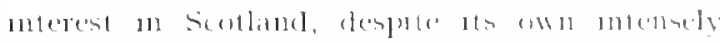

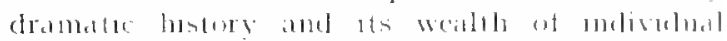

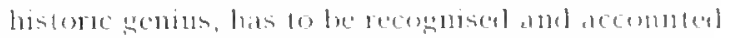

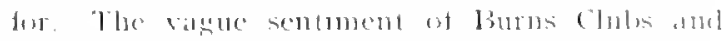

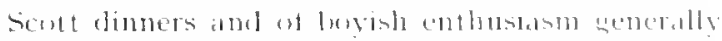

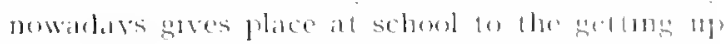
of " perends" sul has that of the Norman fompluest of Finglend, the police of llensy VIll or some

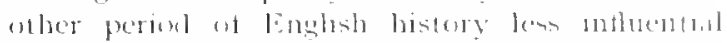

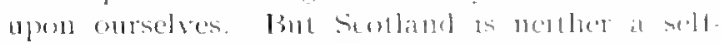
suffictent nationaluy, as she once thompht, not the

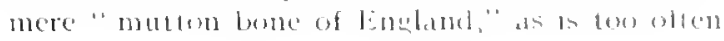




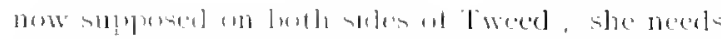

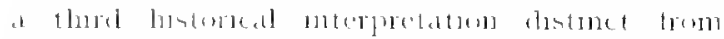

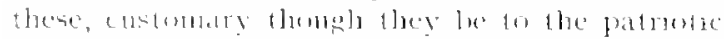

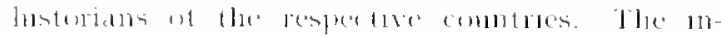

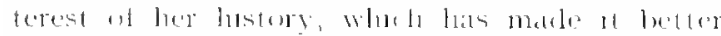

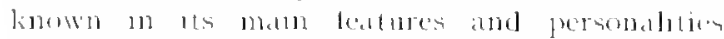
la the whole worlel than that of any other bmall

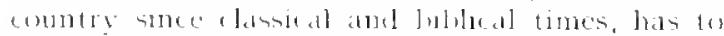

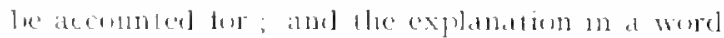

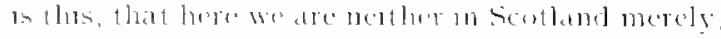

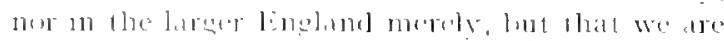
nowh-wentern lingere. It 15 at the fide marli

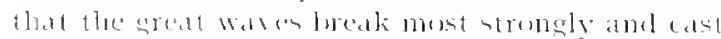

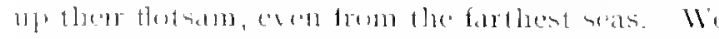

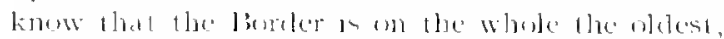

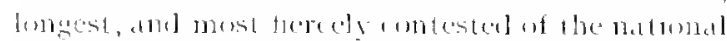

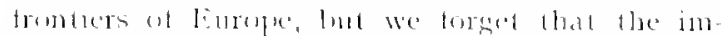

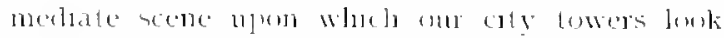

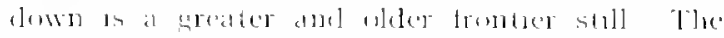

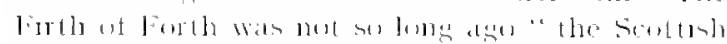

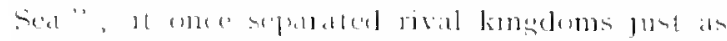

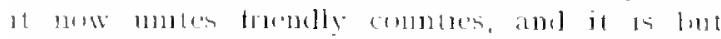

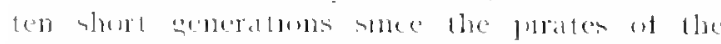

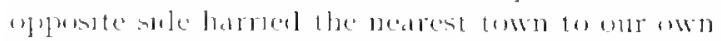

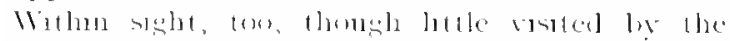

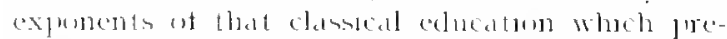

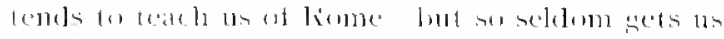
muth nearer at than the lecals of the Remalssatne -stander whal is on the whole als most motalde momument ontsue linme ltorlf - lle northmost

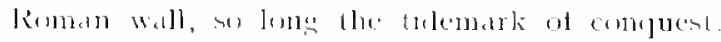

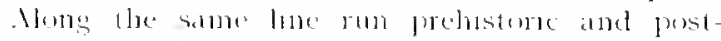
kimmen forts and memeries almoxe withoul number. Thus, 11 fluse lomes permited the

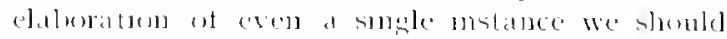

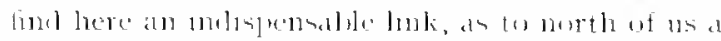

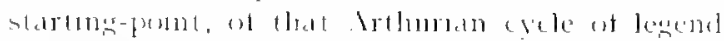

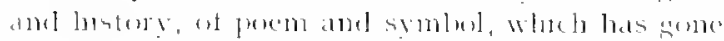

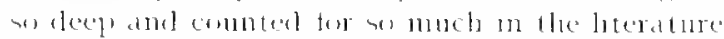

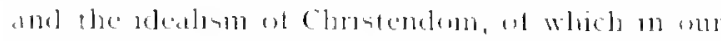

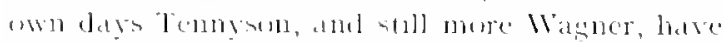

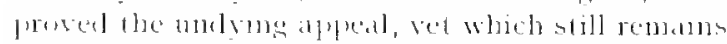

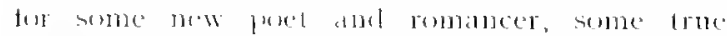

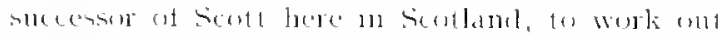

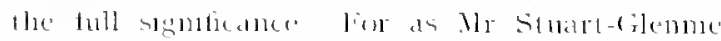

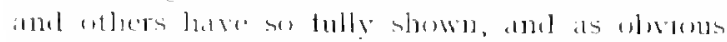

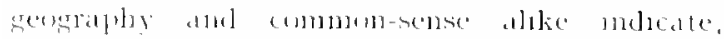
11 was eleaty upun Sindand that the Northoman

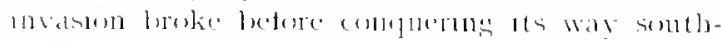

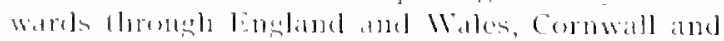

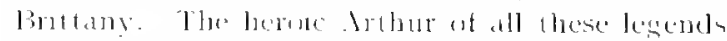

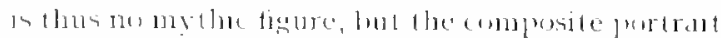

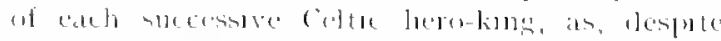
sallant fetence and hard-won thetors, he tell alt

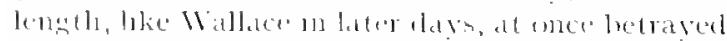

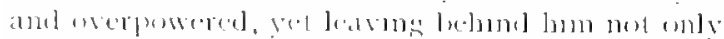

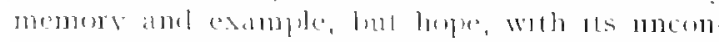

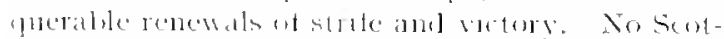

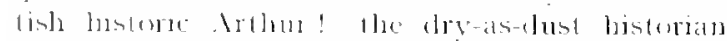
a) mere recorts lelly us, as if lastory were not

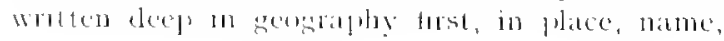

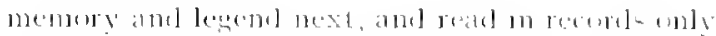

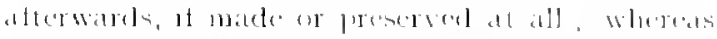

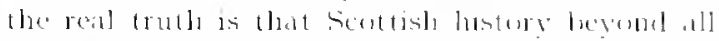

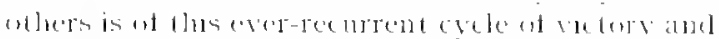

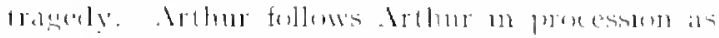

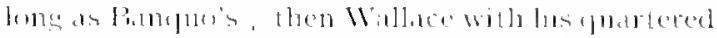

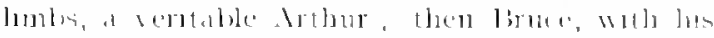

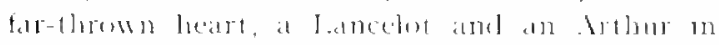

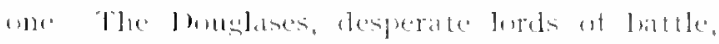
ret terneler and true, are of the some stuft; the

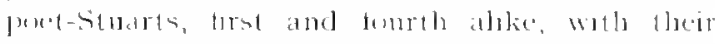

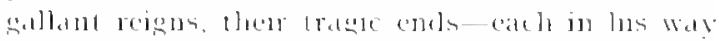

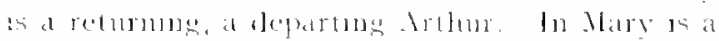

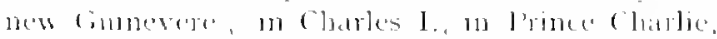

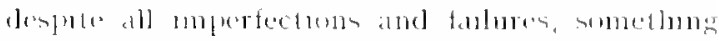

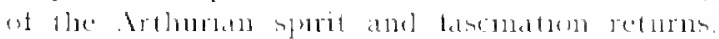

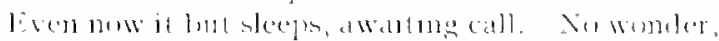

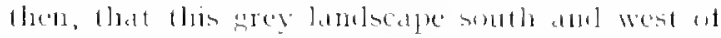

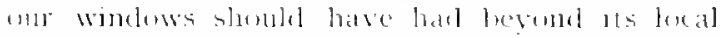
thomelers and bards a veritable lated llomes, al true Merlon, reandkening the delled world wo the

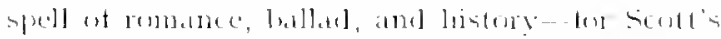

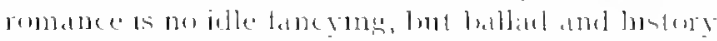

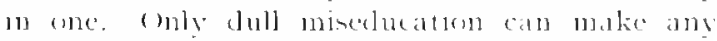
thomk that magle and romane are oser ; molem

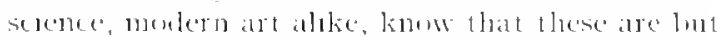

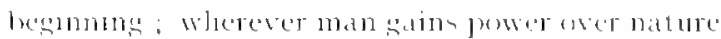

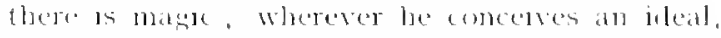

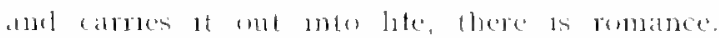
Where, then, were more of enther han are openings

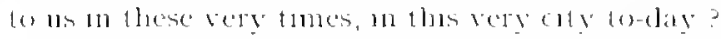

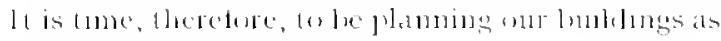
homes worthy al calde.

\section{The Procession of History}

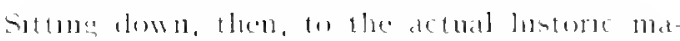

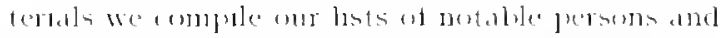

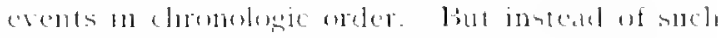

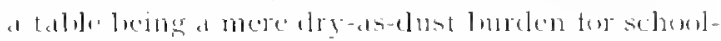

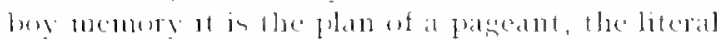

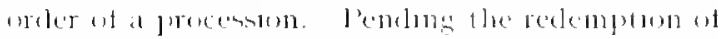

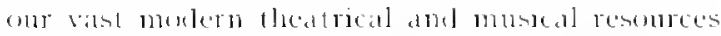
mom them transtory degratatums, then temporary

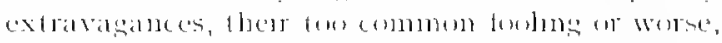

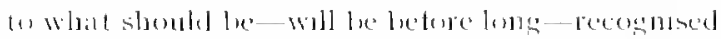

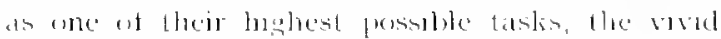

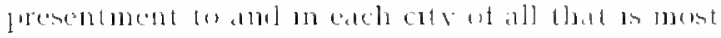

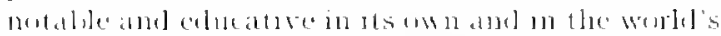

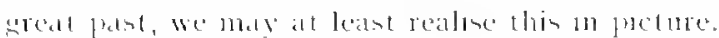

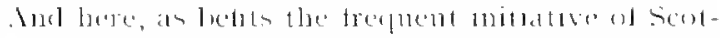

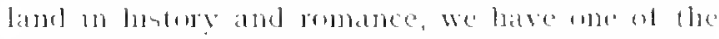

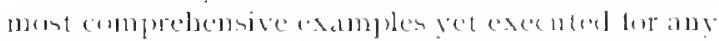

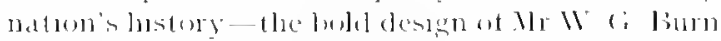

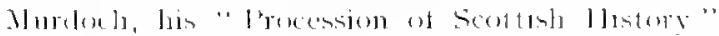
for seven hondred yeass, from louncin and Mate-

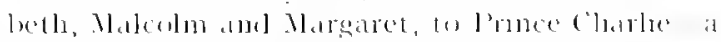

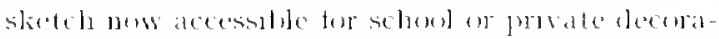
tion or for libary reference in a complede loll, and so aratiling filling reallotion on sculplure, in 


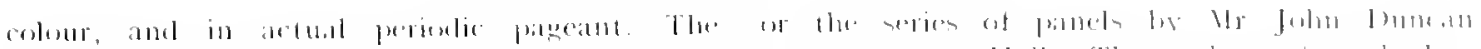

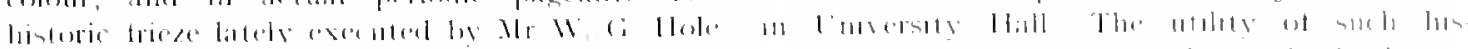

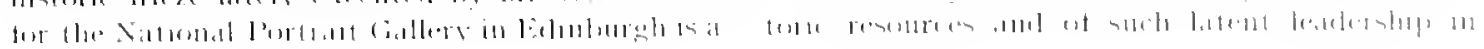

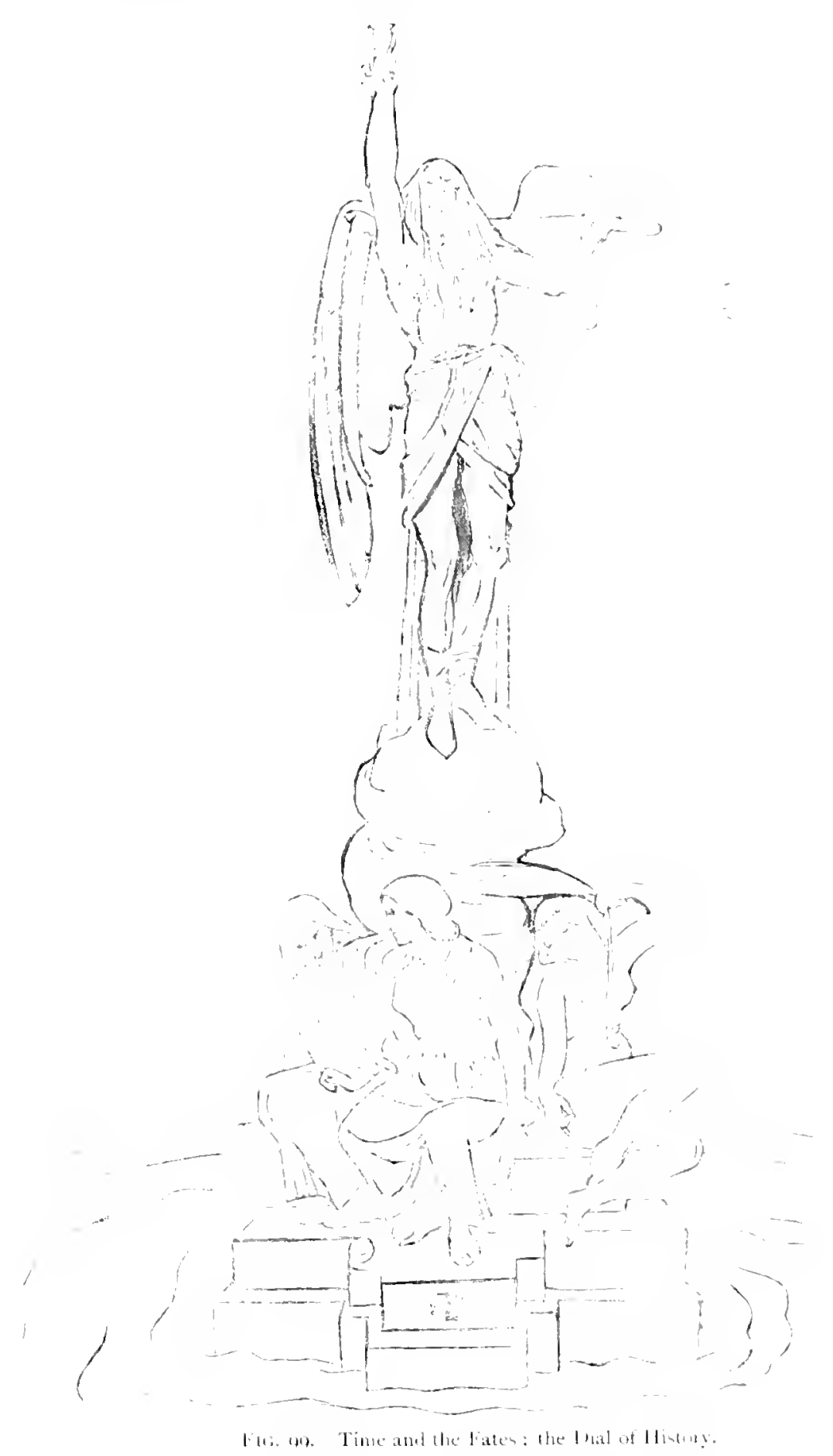

similat example, with which may be laken hes listoric freserses in the same Imiding. The decorative franele of the lastory of cilasens, executed for its Municipal Bublings be tour at its most eminemt artents, mas also bo ibed:

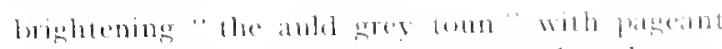

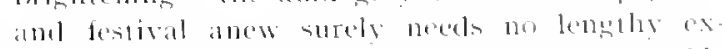

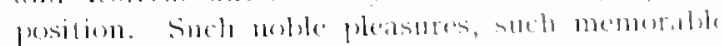

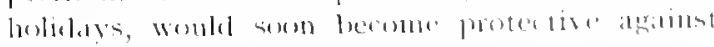
coarser ones. 


\section{E. Site and Approach}

Where shall we flace and historic hulding I need not spend tome arguing sul all ble reatsom wheth hase determined my selections of the ancient garten of the momastery the pratintly-named "Bee-hlley Garten." below the hbley Graveyard, as the convenient centre and starting-posint of this, smee this thesee may be best justified as wo proceel fig. of . See also plan fin. 115

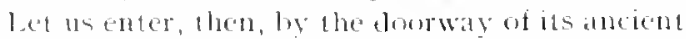
chuster, plainly moleated, though long demolishert fig. Ir)2 . We consibler and work out designs tor the recoustruction of this closeter; ind then upon matures judsment repert and brop them ras

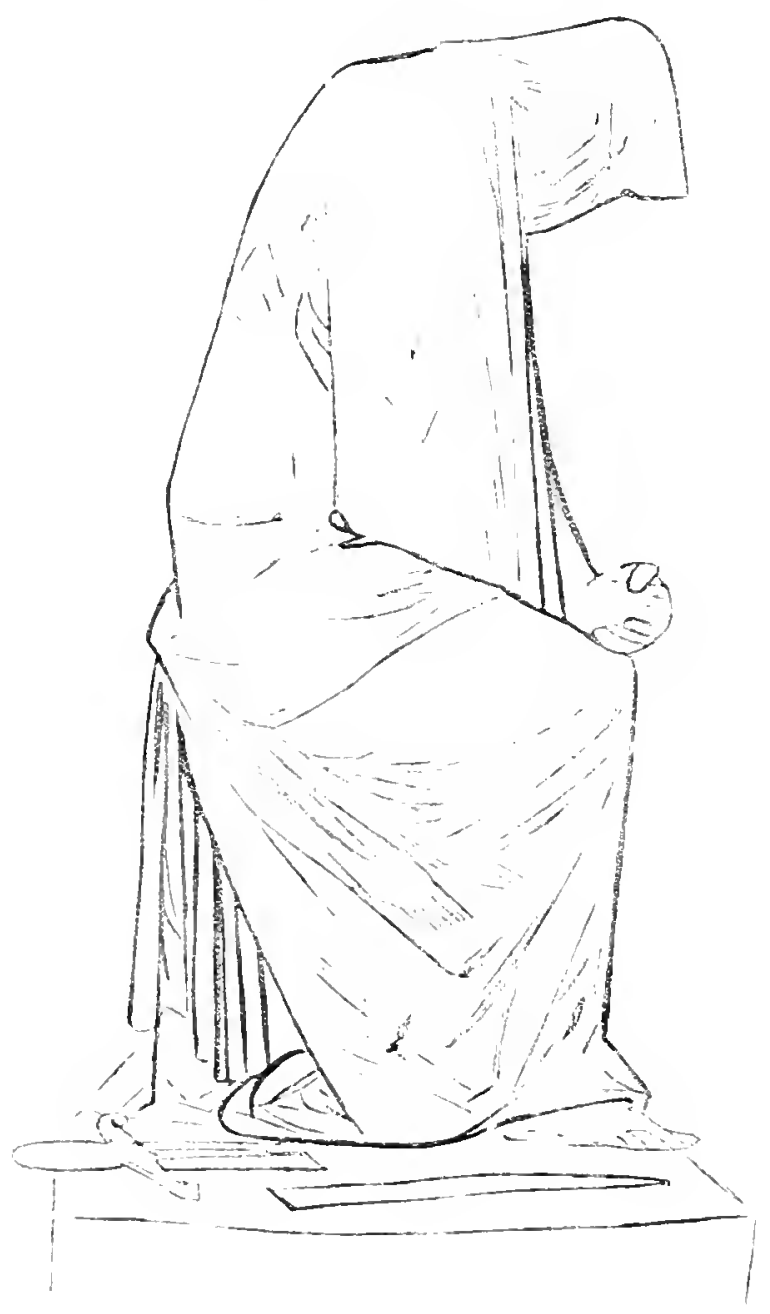

Jili, roo. Sitatle of Sinnm, whing whelointer entrance w llintury Garlen.

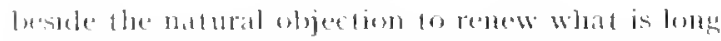

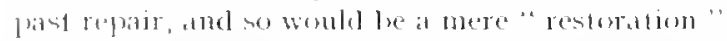
ill the worst semse, amet for me particular usetul

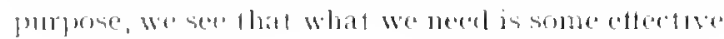

antine of the hastors whole, some clear remunder of 11 s arents and persons, some mterpetatuon of their results and services, some memorial of its plory, its ever-returmong alpeal to the present.

first of all we need at wothy symlol at Time. for as 11 on Xoture Buikling the everyelaty at thosphere ol collecting, deseribing, and analysulg was raised to the highent level at science by its rivid central reminder of the unity of the worts in the Great Gobe, 1ts remmler, too, of the sublime infimtudesol space buplopriate astronomucterices aromind 11, so now hege we need a corresponeling symbol, to give the scalle of thrombt and atmosphere amel teeling to our hustoric lubleling. For if these we to have the eluc allse ratue we seck, each must struke its characteristic note of idealism, each must awaken matgination and teelong, wen before is can impart real knowledge.

What, them, is this needed milual Time symbol, and where shall we place it? What symbol better than that wh the waters of a fountain, seeming to stand, yed exer on flow; What better than the unnelial, with ats passme shadow, yet its immenomal fears? Here, then, in the old garden

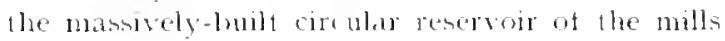
needs but litte modificatum to sutt this purpose. To renew its waters and raise the lotfom to dangerlem depth in, wf wurace, easy. Next in the contre we set up a pillar pedestat, and on lois the statue of tume, whth his trathtional sovthe and lonteglisis, it may be the sreater symbol of the astrommic circles atso, lut alxuse all the stern, high

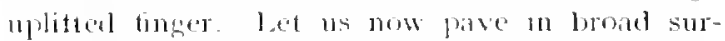
roumblone pallways the lunes of the diat, and at this long distance the solemn shadow of this

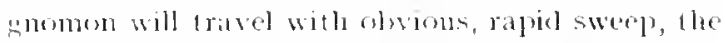
pitsong it the hours mate visulle fig. (x)

Round the pillar base let us at the Thee Fates ber of luth fowarls the morning, of life-mainfenanee to the midalay sum, ambl her of the shears

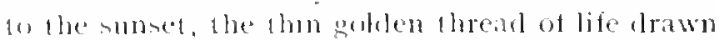

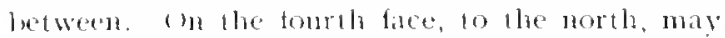
the carved the stern tratitional mothe, wetl fitted for such a diat: "Pereanl el imfutantur" - "l'erishing, rel reckoned." Or this minht be sunk betwen the hour-lines startugy from the fountain elge, so making room for another symbolic sculpture - cither that of Splunx and Babe, which would filly precede the serpes of the fattes; or that whe hathratly sums up the whole place and puspose-the Muse of History meditation.

From thes symbel of tale and Time bo its garden

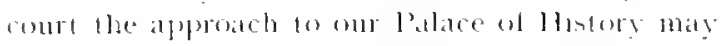

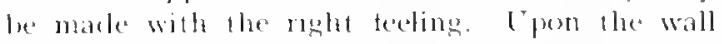
led us clear the old walled-up lee niches and house the hives anew; again an their midst setting spon the wall at simpler dial, this time with vertical moonward lace, and legend: "Work while it is

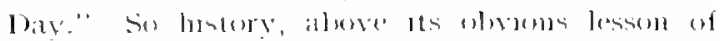
tramsunt lute, sets the practical one, of strenuous

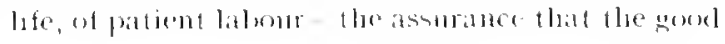




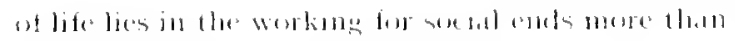
111 is results.

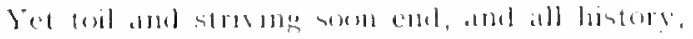

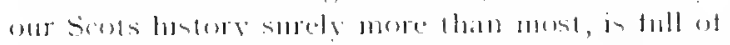

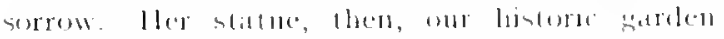

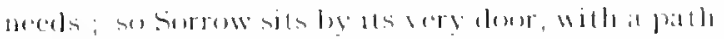

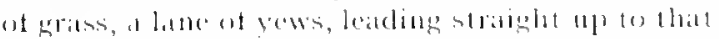

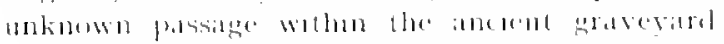

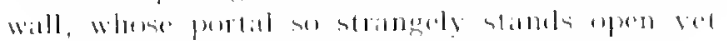

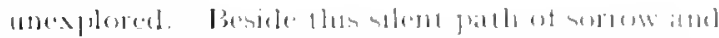

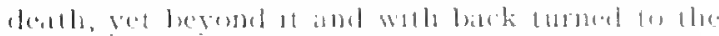

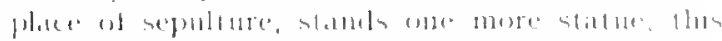

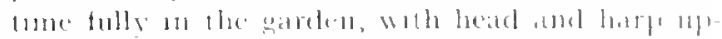

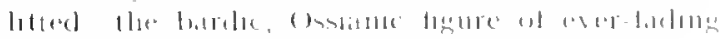

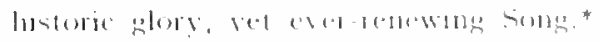

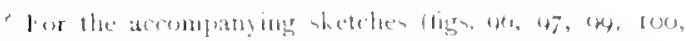

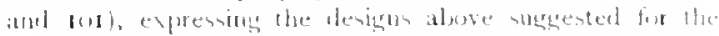

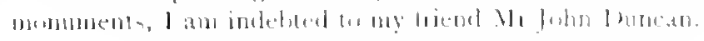

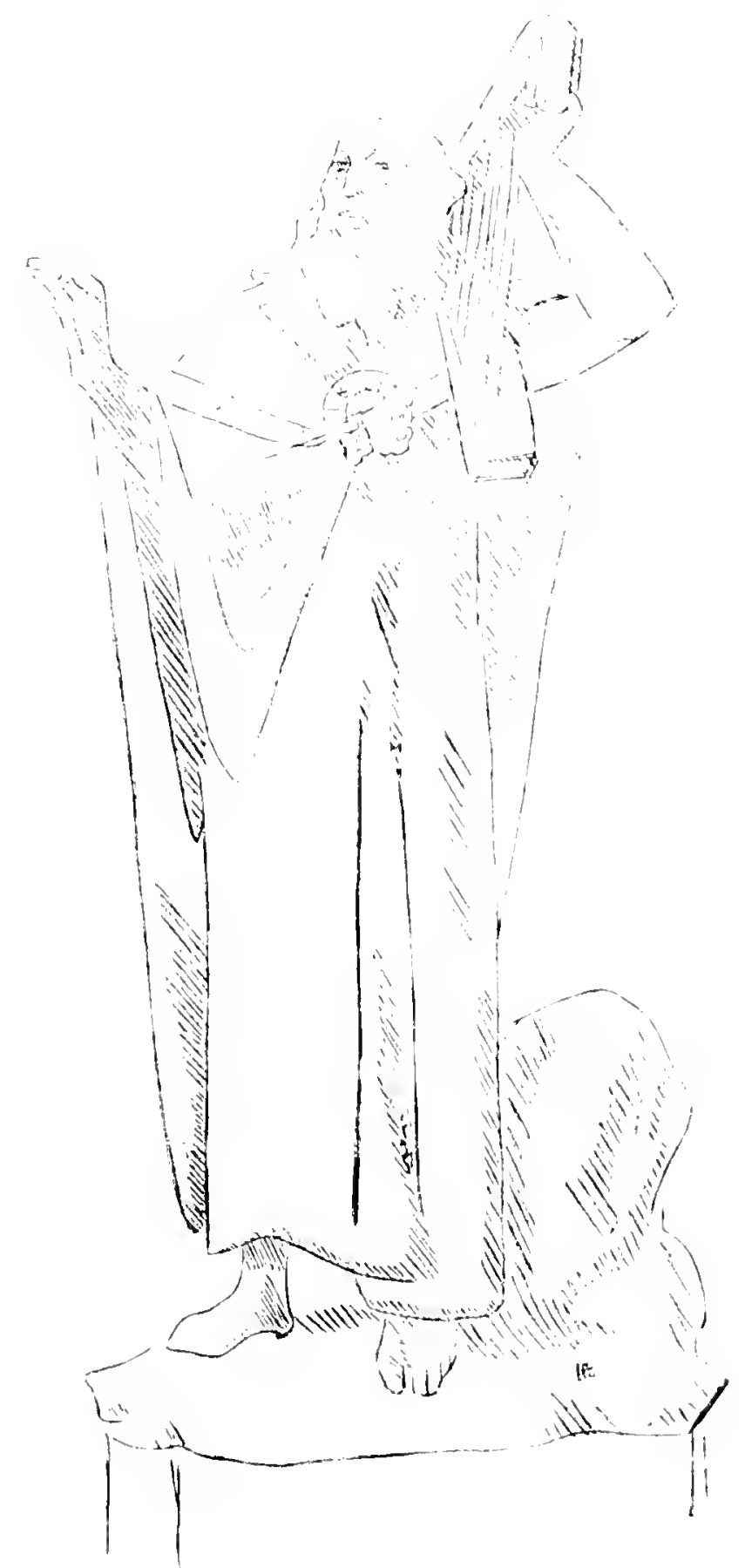

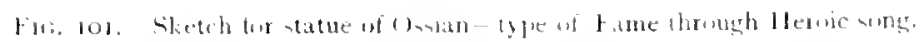




\section{CH.IPTEK XXII}

\section{DUNFERMLINE HISTORY PALACE (ANCIENT AND MEDI/EVAL)}

\section{A. Ancient Scotland}

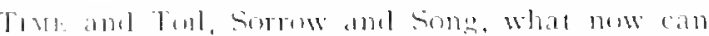

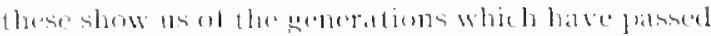

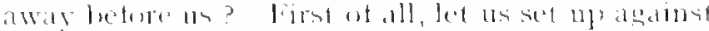

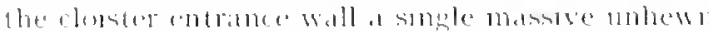

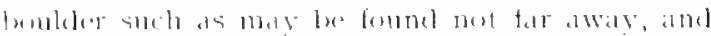

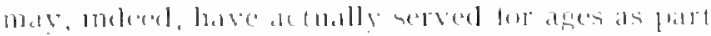

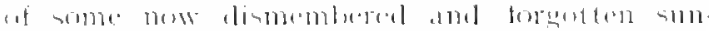

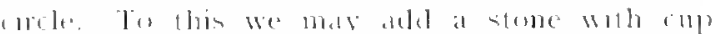

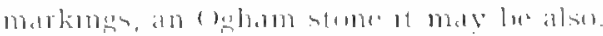

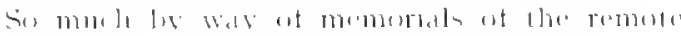

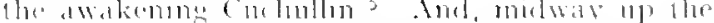

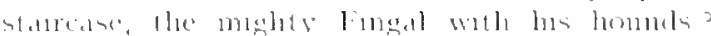

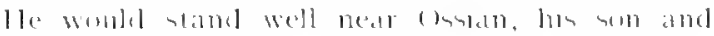
sherer.

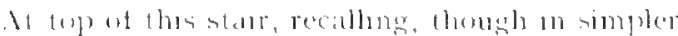

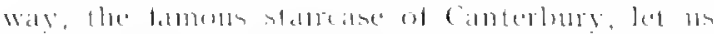

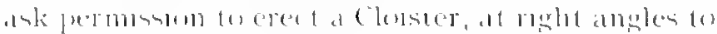

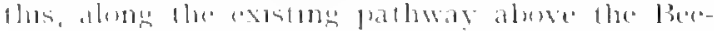

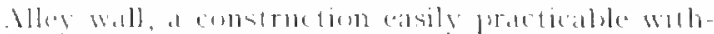

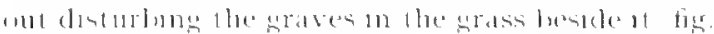

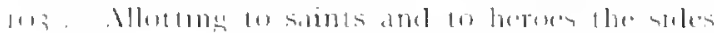

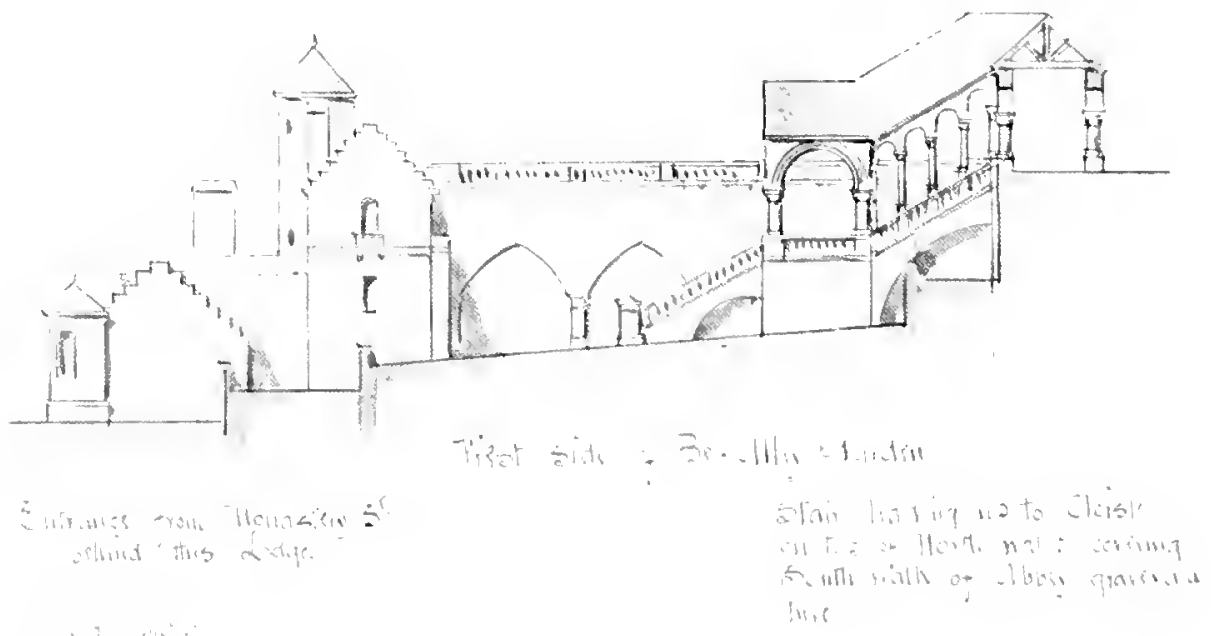

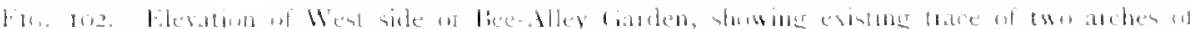

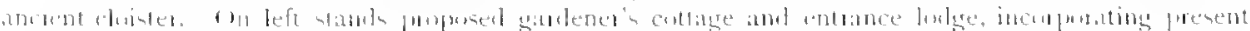

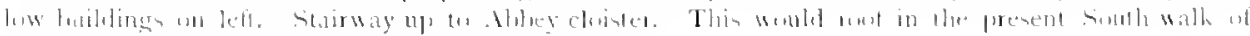

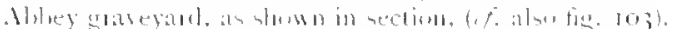

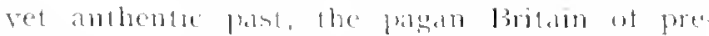

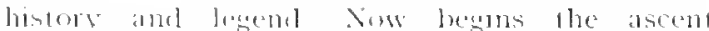

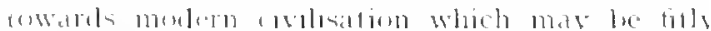

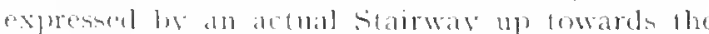

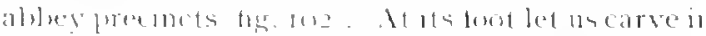

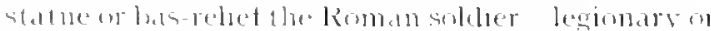

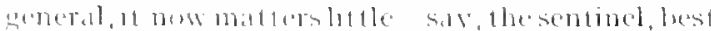

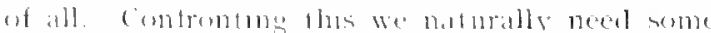

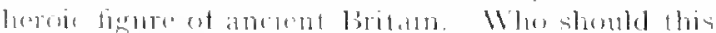

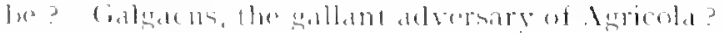

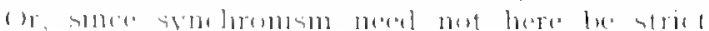

at this wheh bate towards church and world respectuely. Columber will naturally stand first

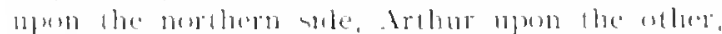

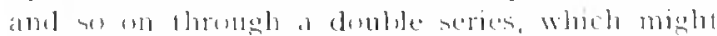

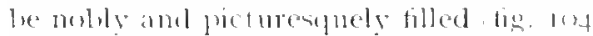

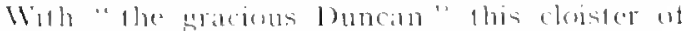
celue hustery-wheh we see is more elesely con-

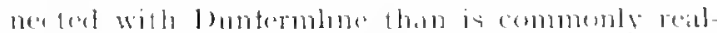
inel may draw lo its end. I enters a komond

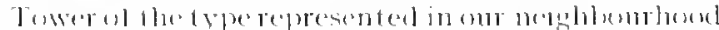

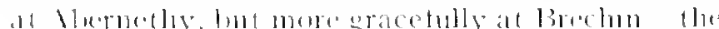




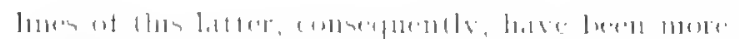

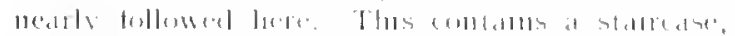

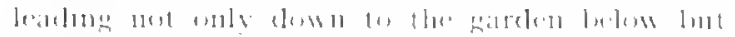

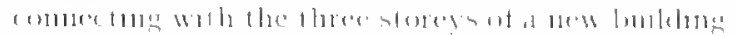

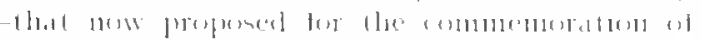

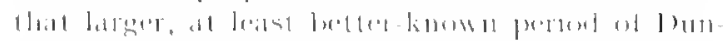

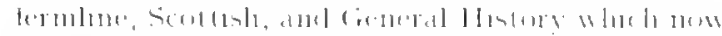

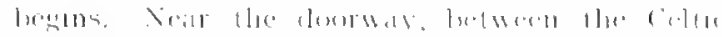

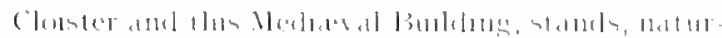

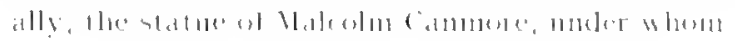

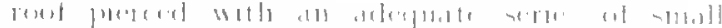

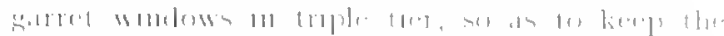

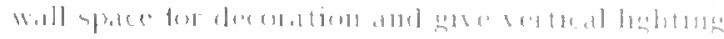

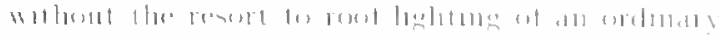

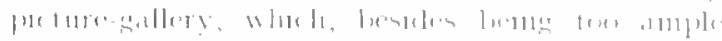

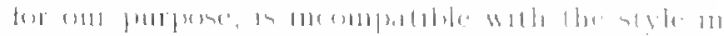

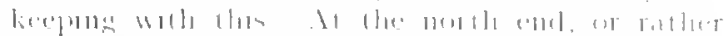

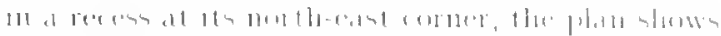

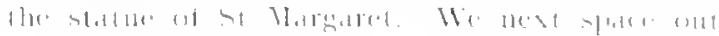

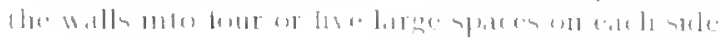

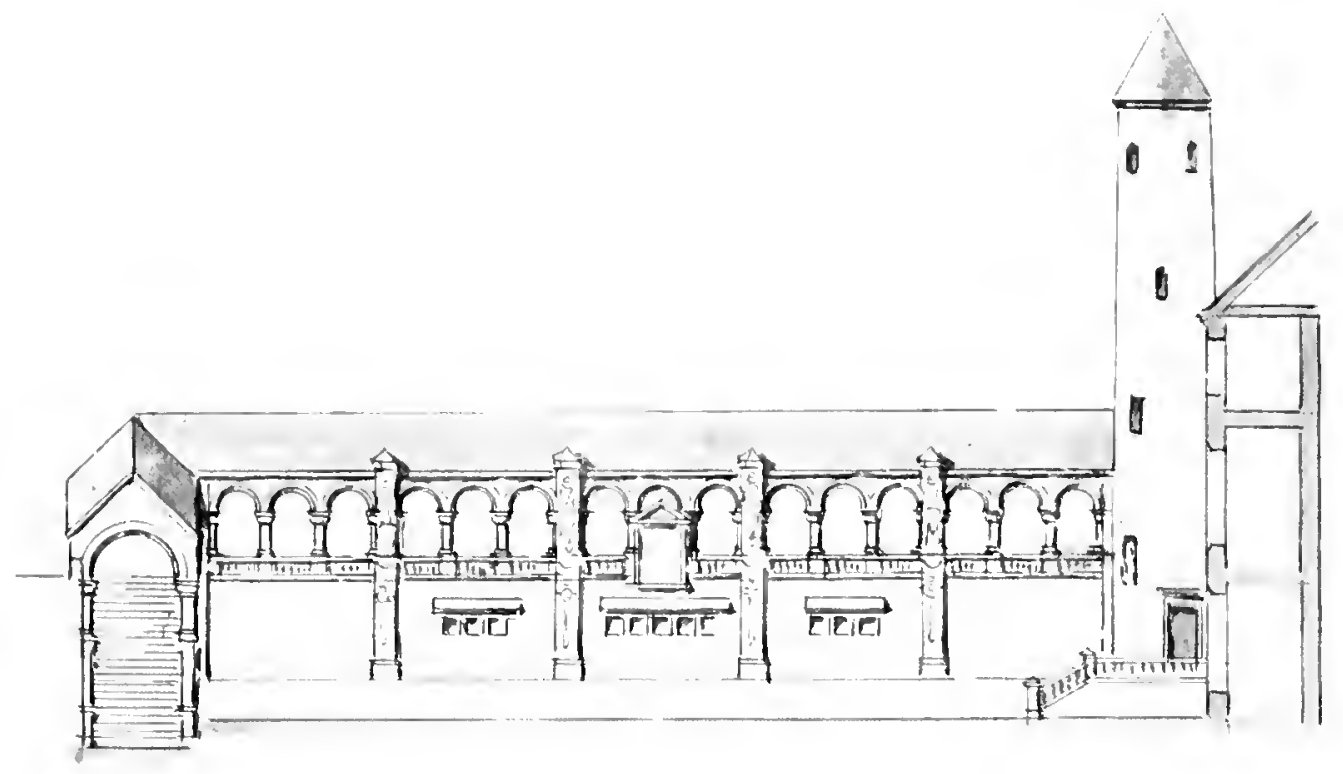

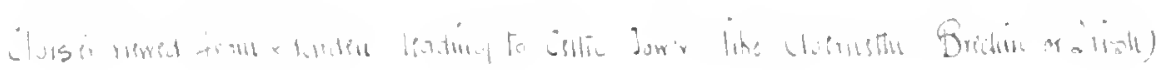

$$
\begin{aligned}
& \text { Cillie Exants und Hiros. }
\end{aligned}
$$

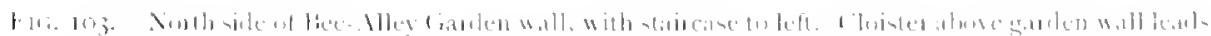

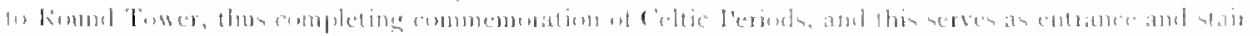

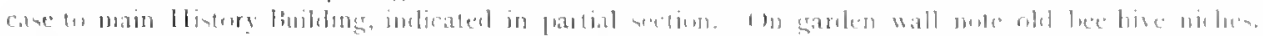

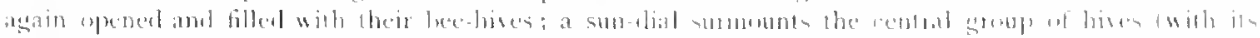

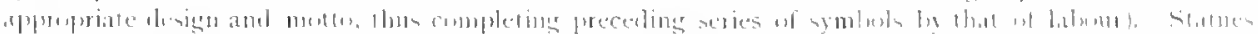

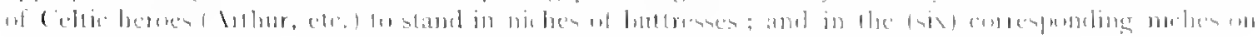

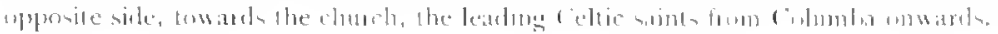

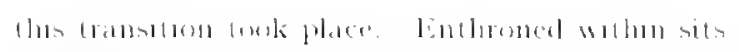

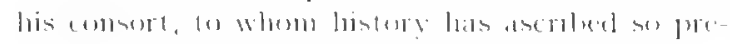
demminath a bhate 11111.

\section{B. Hall of Mediazval History}

(Sice tigs. $105,100,107,11$. .)

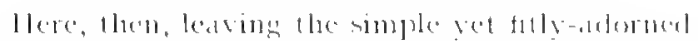

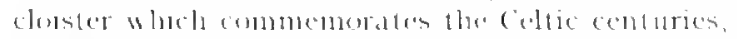

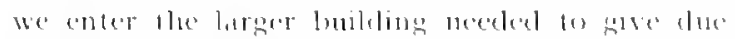

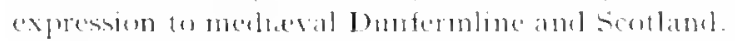

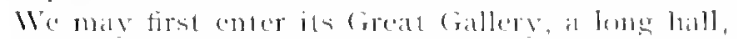
partly lit from the north hy a latere romol-arched

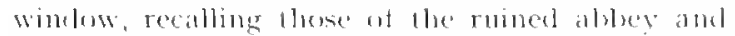
of 11s kindrect cathedral of burham; Its timbered

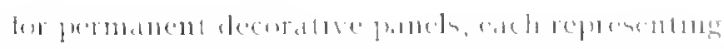

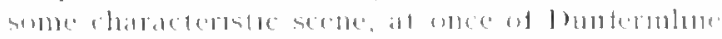

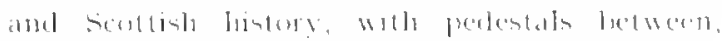

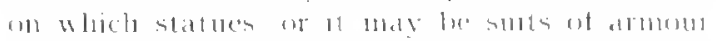

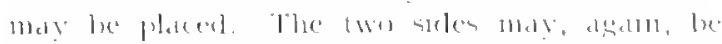

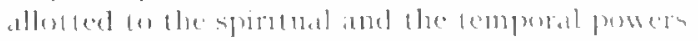

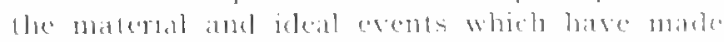

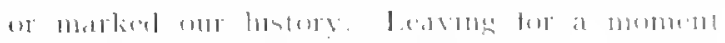

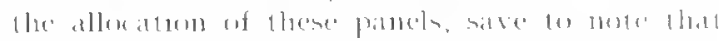

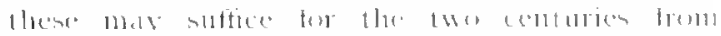

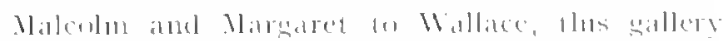

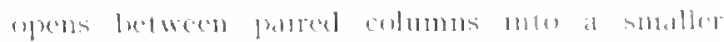

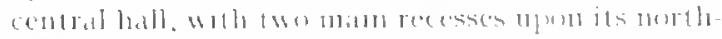

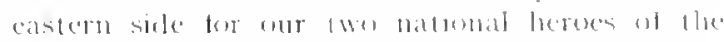

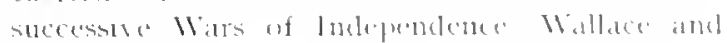




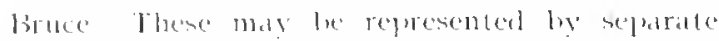

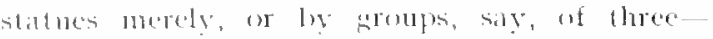

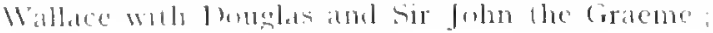

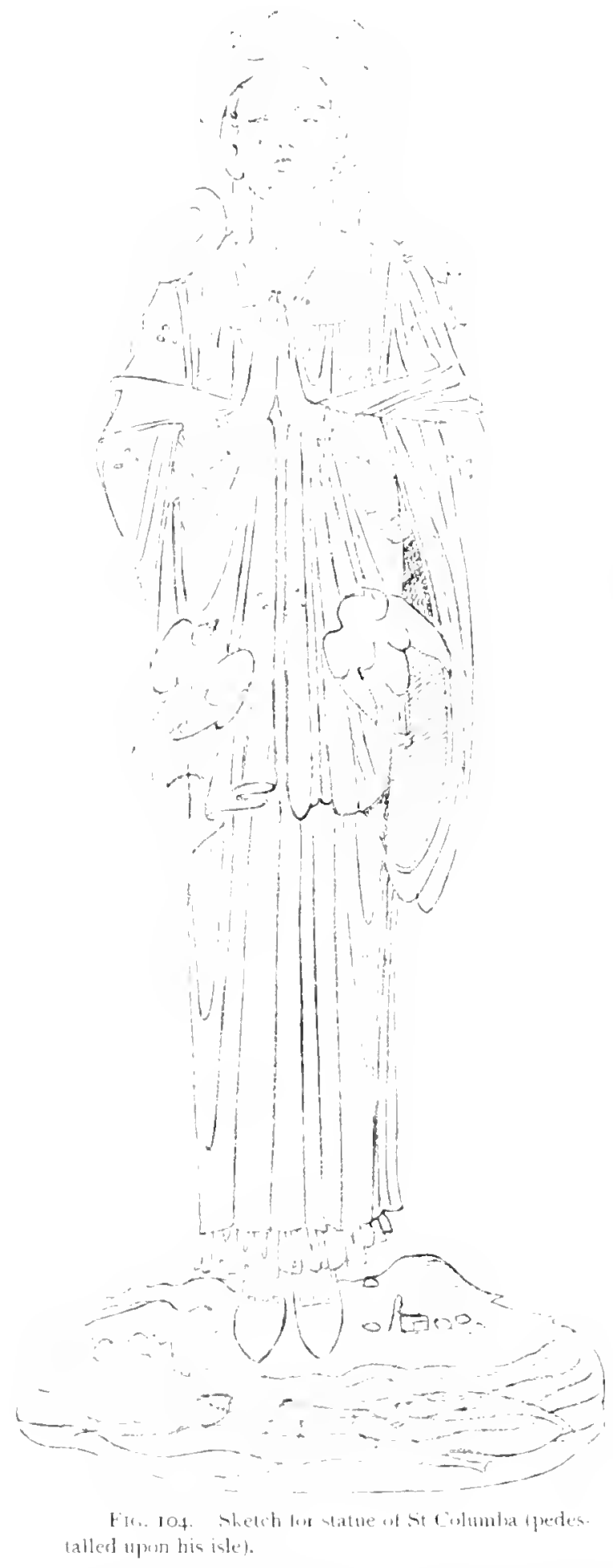

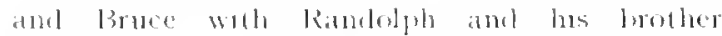
Eilwarl, or his own pueen. Alove them stands filly the Central Tower. Its Crown, se chatale- teristic ot our sentlish enchotecture, is surely dembly appreprate here.

lirom this llatl ot luckependence the sallery

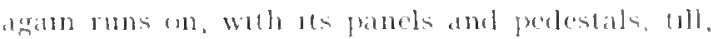

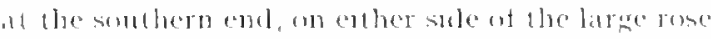

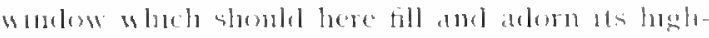

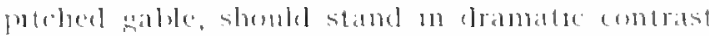

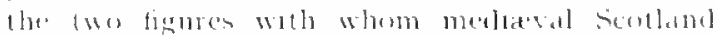

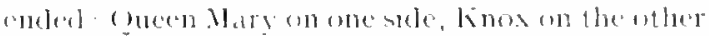

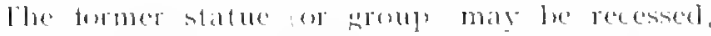
more ar less ats was queen Margated's, the batter placol just bevomel the gatlery in the recess of the

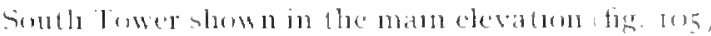
llus arelutecturally balducing the culdee Towe

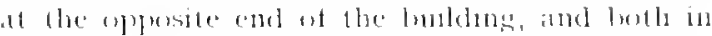

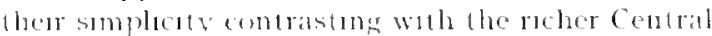

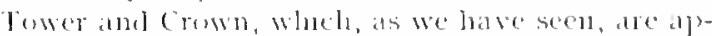

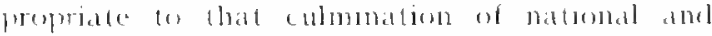

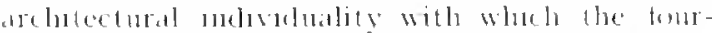

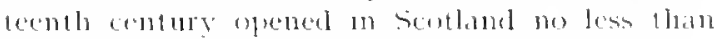
in other lands

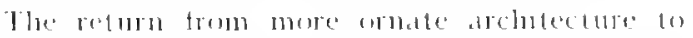

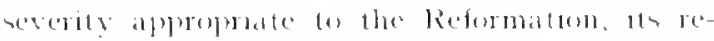

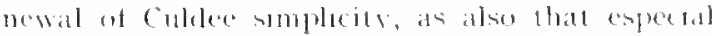
coldat wats the french rather than will the Corman or Enghth retormers which the very name of Cilumom commemoralles, are alow expressed 12 the architecture of this lieformation Tower,

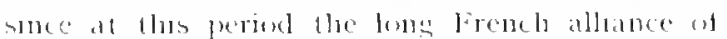
sernlame culminales with llary, and comes 6 an end with the Reformatum.

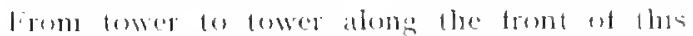
mededeal louldung, and on the some level as the triple hall wo have junt eleseribed, runs an open Clonater walk, its columns nore ornate than that alwere the bee-1lley wall, since in kecping wath

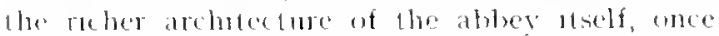
and dsann so greall, as chromicles and sumbing ram allie proctam. This twofold range of

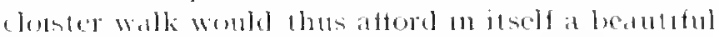
ame] allatedive ambulatery, with shelter in sll weathers a changhng succession of vews, also, of faralen and buldings, abley and park berend,

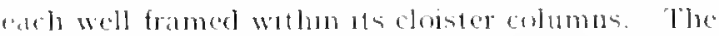

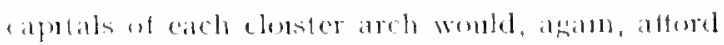
almurathe sone for vared and aphoprite desern, and for wotime out more tilly the historte staceession of architedural and decorative styles, nf erente, and of symbulisms. And it any fear

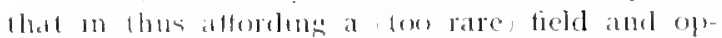
pertunity tor destener and carrer excessue espense maty be incured, is maty be well to recall here the fact that in the comstruction of the ( Xateri Jusenm -amel of later lubldums, in whels such treelom has heen allowed the artist and workman the actual expense of earving hats positively fallen below that customary for the medantical repeditum of at single design throughout an arcate! for the carver can only put pirit and energy into woth whol, interests him, and which puts him 


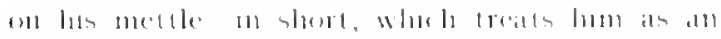

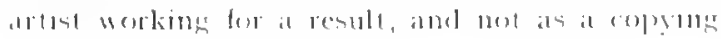
mischine lor waters.

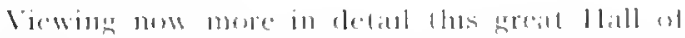

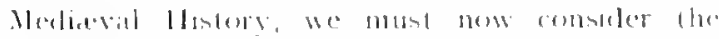

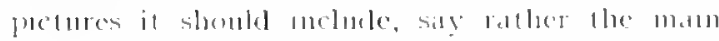

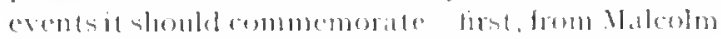

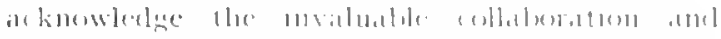

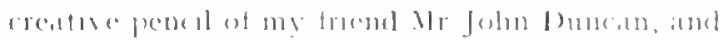

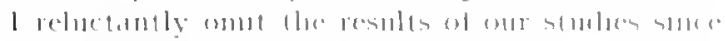
these exceed the present completsis

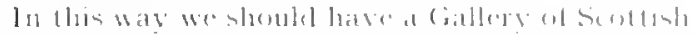

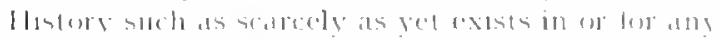

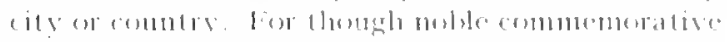

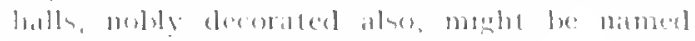

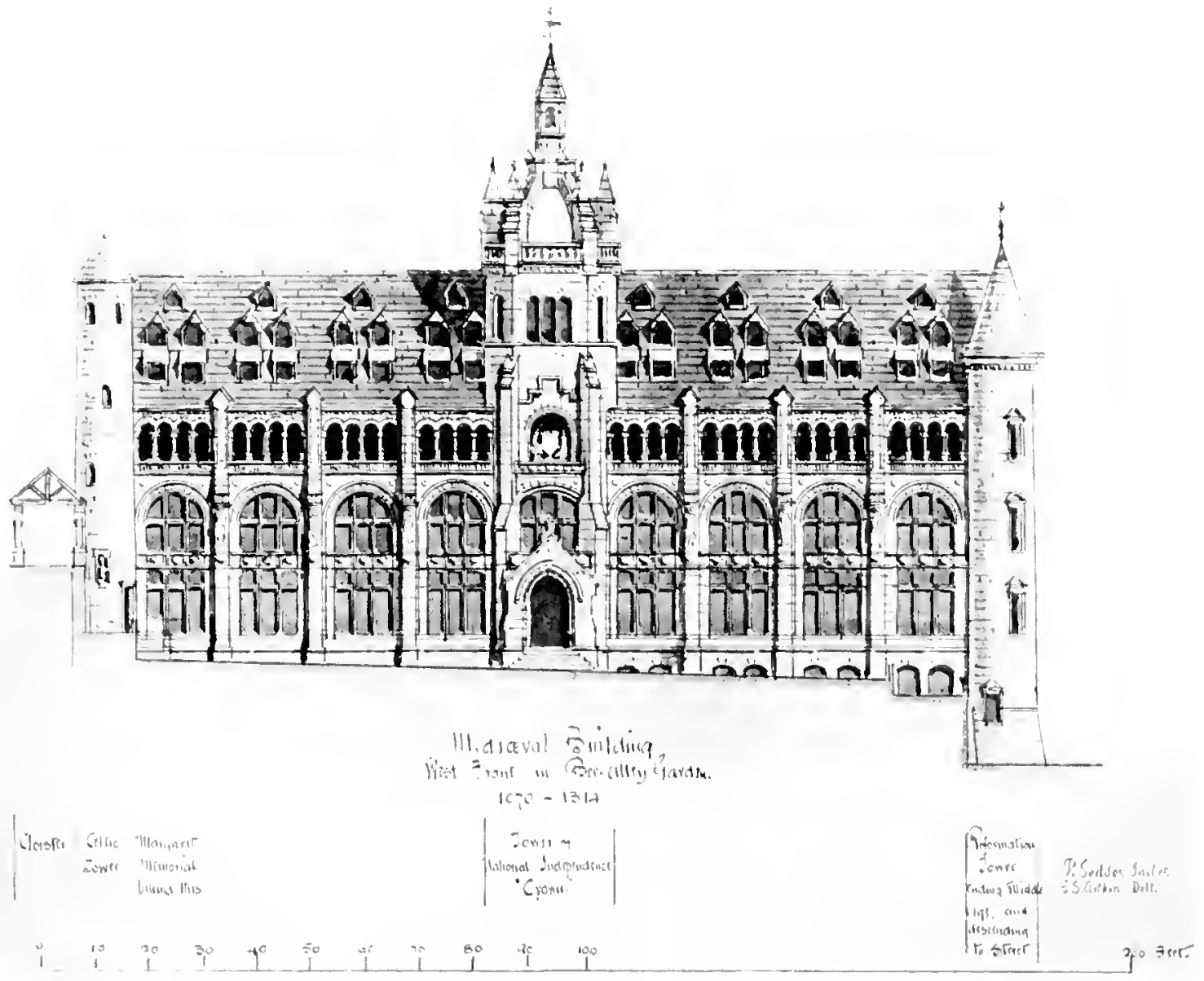

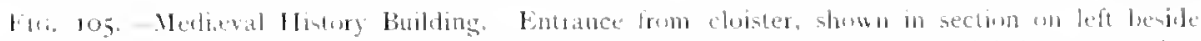

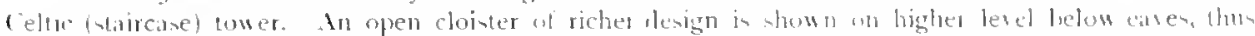

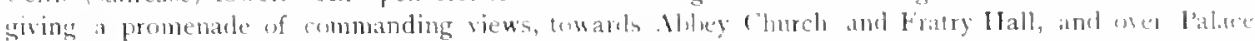

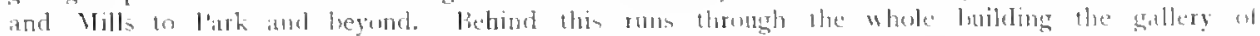

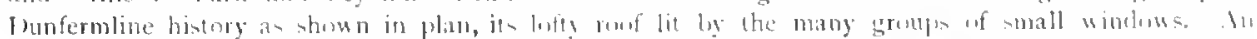

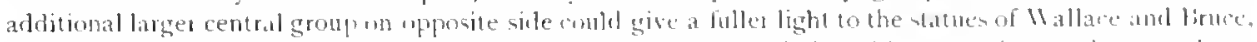

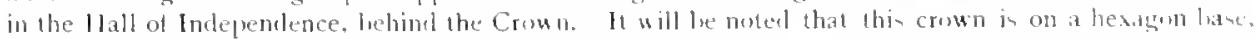
at departure from precenlents.

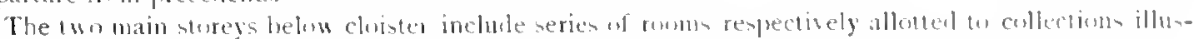

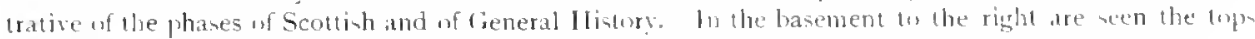

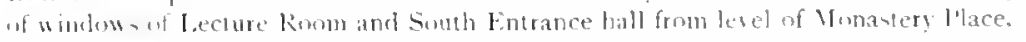

and llatgated to the Mars of lotependence, ind Here trom these to the Retormation. Broblly allotiner, as in the celtic doister, opposite stoles to the temporal am the spiritual evolution of our commlyy, ats fill as these may be distuguished, a worthy series of sectes mat readily le suggented lin the study of this problem I have especially to motable, for anstance, the coronatom 11 all of the

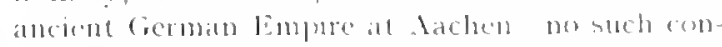

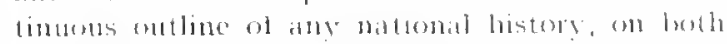

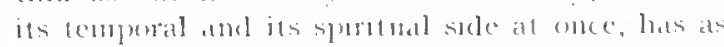
yet been attempted. This deficiency of precedent might, of course, be regarded ats a drawbick in more ordinatre circumstances, bus in rew of the 


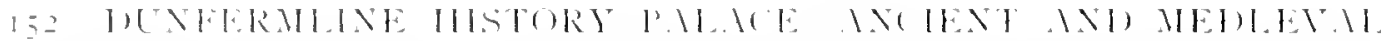

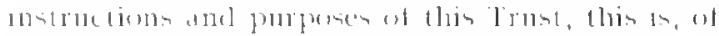

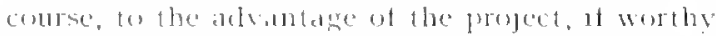
mpen 115 own merits.

Can any doubl the inspurng value of such al

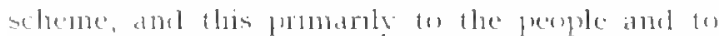
the young, for whom, as l an not tor one moment forgetenge, this joust promarily exists? The

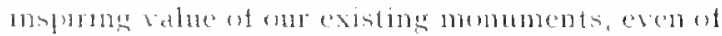

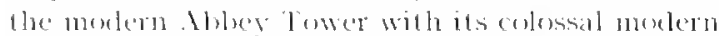
mecriptem, despite its mere than questionable art.

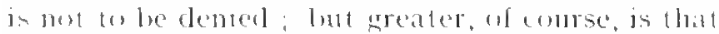

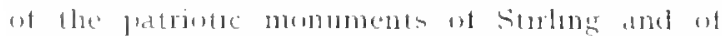

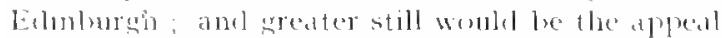
of the present edefice, whth its slottless and pictures

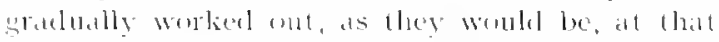
hagher level ot pountung and sempture whels so

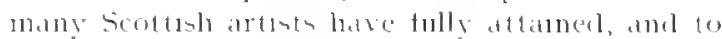
expers which they only need such opportunty and emernatgement, such place and songe as l am lawe proposing

The Trust would tultil one of its bighest prosthitities in thas concentrating upon ats cily and propulation those highent powers of having

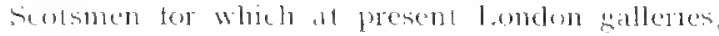
aml still more foreghn ones, are almost alome offering any aledpute appeciotion, get less worthy and congenial opsurtamety

lo lung together such a suremp of artists anel art workmen in and for lontermline would reated upun the seneral culture, and event the melustrial

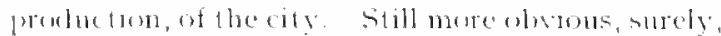
is the ommedhate eflect wheh steh a grouls and work wruld have upon educatem anel upen the tormetron of eleals. That incentive to ofler

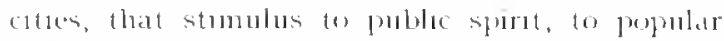
culture, and to grivate semeresty aluke, whels it

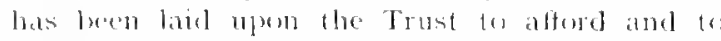

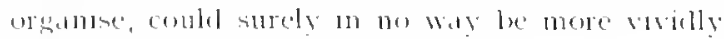
awiliened or more welely dittured

\section{Historic Reference Museum}

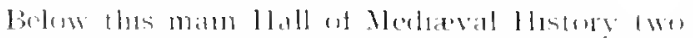
storess are moleaterl. That momedately ledew

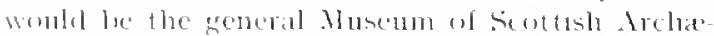
where and llistory trom the earlese times to the

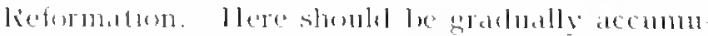

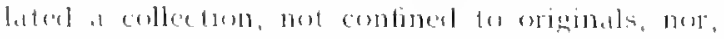

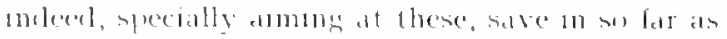

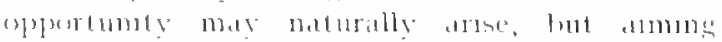

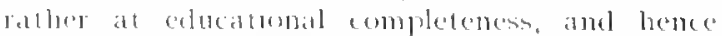

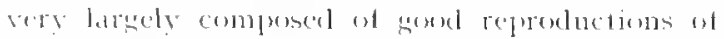
all kinds pluotogriplus, casts, ete. The essemtial value woule tie an the educational arrangement Casto of the man treasures of lishonburgh, Lenden, and onther collectoms are, for all practical proposes,

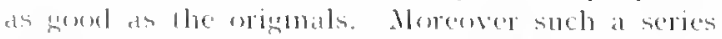
selected from the sreat collections, which are all so ineomplede, and here arranged so as 61 be studed an historic orefer, would really te of tar
Heatere chlledtomal value than anv extant collectom; and trom its completeness at representa-

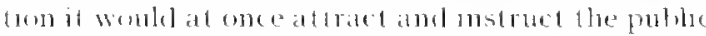
and the mpectalists

In velea of the stone, bronze, amel tron leses that is, of then essental haracterstes of primuthe uvilisation should beattempted here, meleed, why not with some of the same panuamic ompleteness

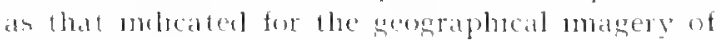
the Nature bulding? The elucatre value of assembluns steh collections, in wheh eprectally the des elopments of the arta in lite, frem their rude becinninges up to those marvellous refinements to which ancent stones or jewels of ithmmations beat whess, slould all be llustrated by wellchosen lypes of reporaluctions and phestographs

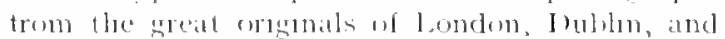

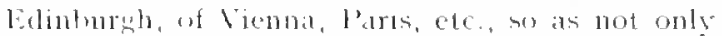
to fit the Inontermbne stulent to poht by vistung any of these, yet for practeal purposes to elispense with them also.

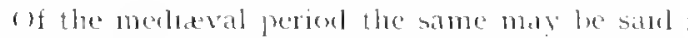
inclecel, whth stall greater force. Thus, though it womkl have been statifyng in every wal to place apon the pertestals of our ereat hall suld a col-

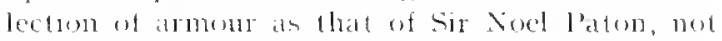
only an esinemtially blentical eftect, hut at still more reprexentatue educatomal serien for all ordinaty purpuses, historical, educational, and attistic, cath be ollaned by trankly ententing ontselves with the perfect efectrotyped facsimiles now readily

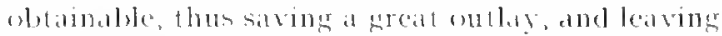
the origituds to the weder problic of the national collections in Eelinburgh.

In the same way, were pluotographs and eolour pronts at such pictures as we pessess of the historic prersomages of Soutand, of eath epoch, phacerl each in one room with those of the buakings and places assoctated with them, with tacsmoles of the books and elencuments of the tmene, and so am, eateh of these mexpensue lathe museums momld have at comblative eftee tar esceedmg that of orelnary allections of oldginals, in which pretures, books,

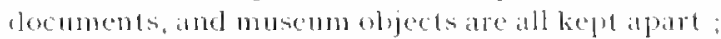
in tact, in difterent collectums, protede and public, and when public in dofterent lowhlines anel manderement allogether, and this in an arrangement usmally not clomological at all. little womeler, then, that themeh many goter and tres, and know-

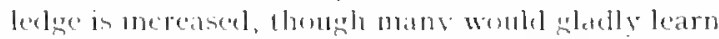
amel many aladly terteh, we yet linow so lithle. live us here, are history andwhere one such collectom ; and we shall learn and teated to some juipore.

\section{Historic Exhibilions and their Uses}

I aldeall, them, not only to all who are interested in Duntermlune, or even scollanel, but 11 art, in hterature, in celucation, to consider this project, 


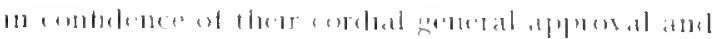

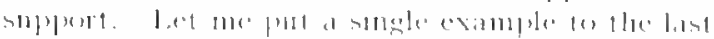

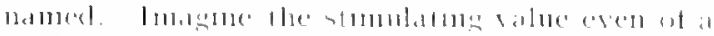

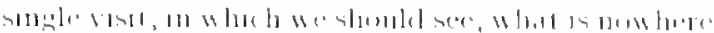

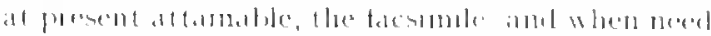

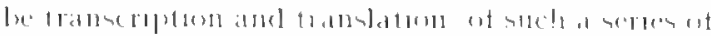

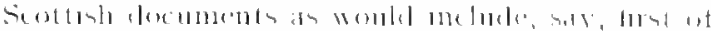

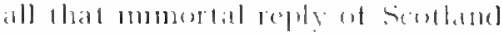

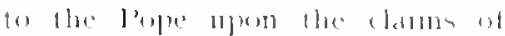

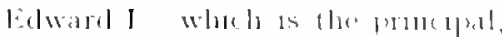
yol pratically unkmown, reasmo of lhe licegrater llome - wheh

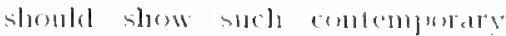
documente als we have of Wallace and of Bruce, stele memerrals ut the early situals as we ath saller shew seme of the ledters of .llare, whech have so leses perplexed hom torians: shom, low), a letter of linos. acopy of the soleme levague and Cosenant: to wheh mans womlal aldel as mo mean clumax the mant-

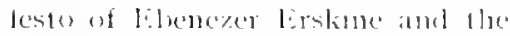
Dissent and l'rotest of the lmatup-

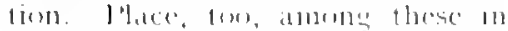

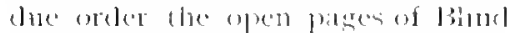
Hatry and al bathom and theme of sir Jovel lomelsiy: slaw, low, the characterntic setrly dreuments

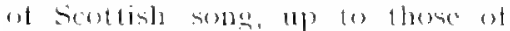
ladely Nairne, of bomms and Seont.

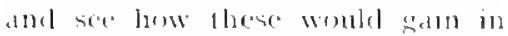
cumblatue elfect, espectally when we bear in mind the astoredated wealth of alecompaniments and sol roundmen we are outluning

()t boltivh Histore Exhabitame

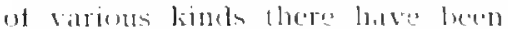
not a lew whtun the last lwenty

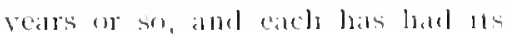
interest and its value. Reall, tor instance, fuestede the establishment of permanent collections, of piefures, furmotures, and aljects en per-

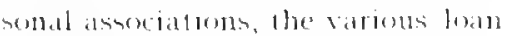

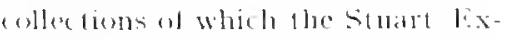
holution was lee chect, and of which

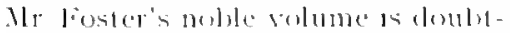
tess partly an outcome. liecall, 10u, the serveces of varions anternational exhlulioms in thas regard.

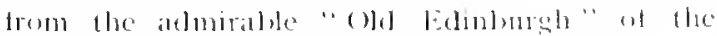

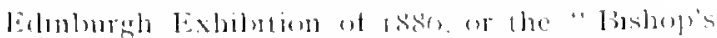

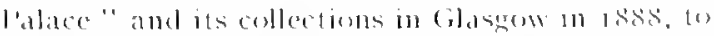
the great show of Glaseme in $1001-$ an exhibitmon

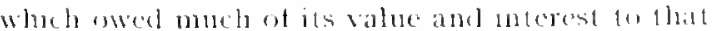
tree use ot reproductums recommended here.

What a poprose, an fact, is that we now millse the very catalogues, the onmmemoratre volumes, the reprobluctions of ath these exhlotions and collections, which collectively make ne a vers

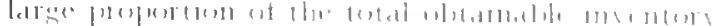

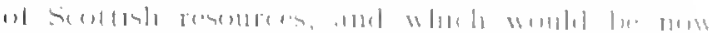

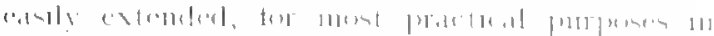

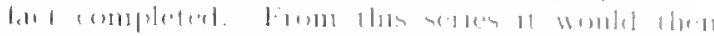

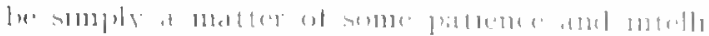

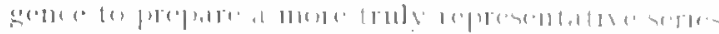

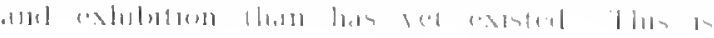

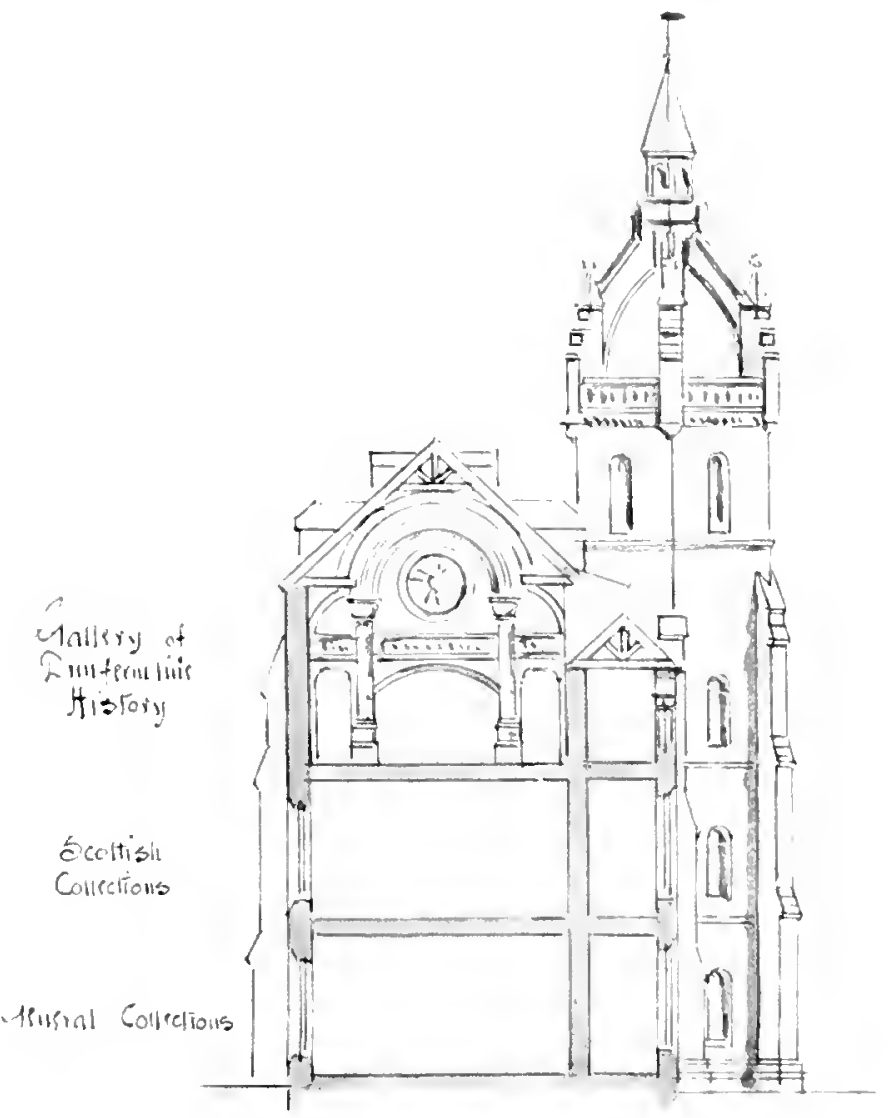

$\because 2116$, ant

Tertiol Section of Tisonic Ending " Mliedinal Black.

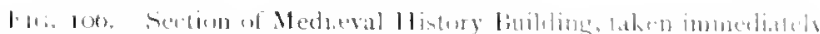

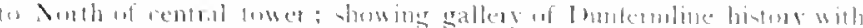

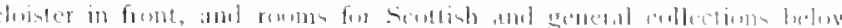

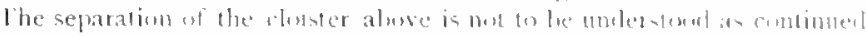

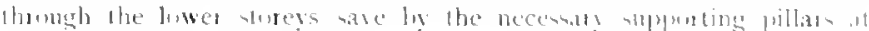
intertals, w lece emplatinat.

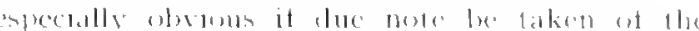

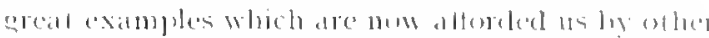

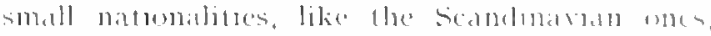
like these of the low Countres, and some of these

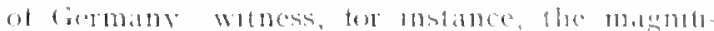

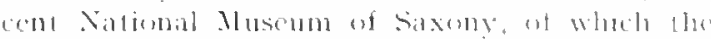

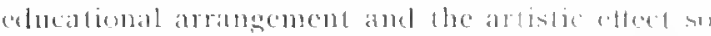
incomparably exed the contuset anel conturang

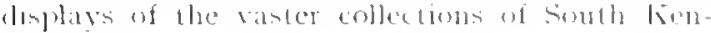
$\operatorname{sing}\{a n$ 


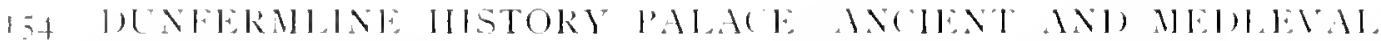

While the eommenourative historic gallery wemkes alepend tor its eftect went its long, almost cathe-

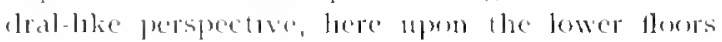

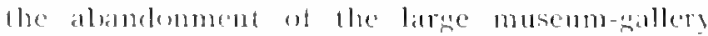
methorl, fal lox persistent an this country, in

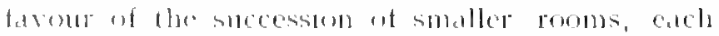
devoted for a monor persent, is strongly recommencled I beit fer the south kensingten or

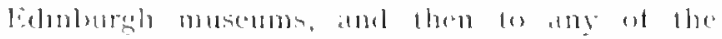
comtunemtal moseoms arransed on the latter prin iple, will fully confirm this

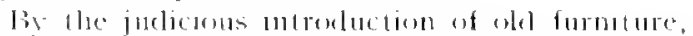
the natural varialem to size and decoralerm, and ot the stall mecessary museum cases, ete, with sliblul anel sympathete treatument gencrally, much

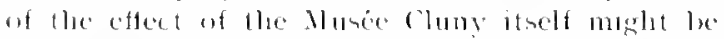
realised- llat 1s, an atmesplace in which historyt cmphastses atr. and art hastery.

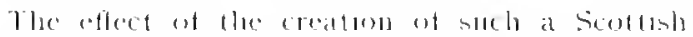

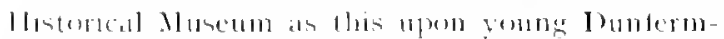

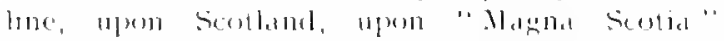
througlesut the worlel, wablal be speeds, yet en-

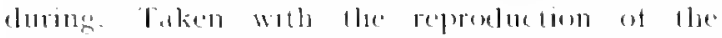

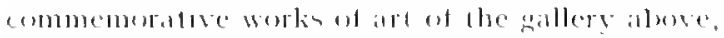

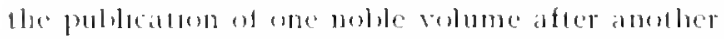
weuld naturally result, whele, again, molst he perp blarted on welcly aceessible forms. The rise of

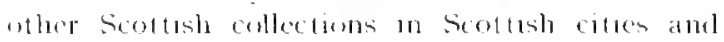
exen bermol, the attracton to this Dunfermber

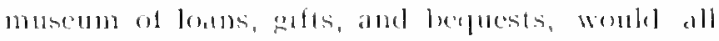
nuturally follow; whle the teatehing of seottisls hastery and sontish literature womld gitin trom this shatal natural, yet new and actue, eentre a frest stumulus, let us lope a bencefortls enduring life.

the curater and assistant curaler of solch a collectem would thes pratetically lecone the mont

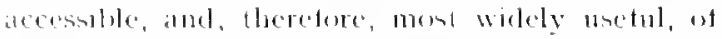

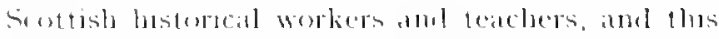

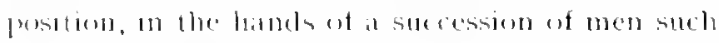

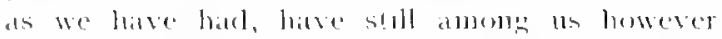

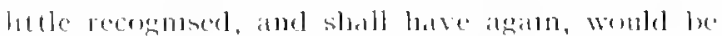

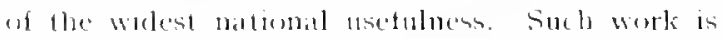
needed to complete the remascence of pholerm-

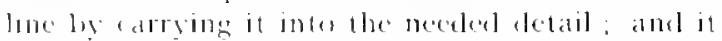

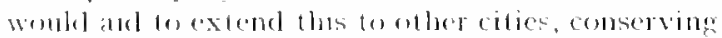

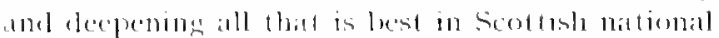

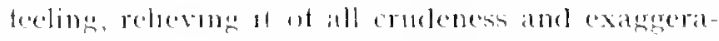

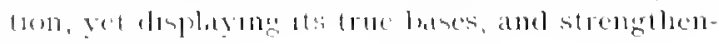
in: these.

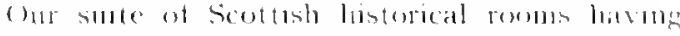
flus enmpleter and complemented the grealt gatbery alwere, the enound floor remans for consuleration. Here we base lo work out the relea alleaty slegerested, that of seotland nexher complete an

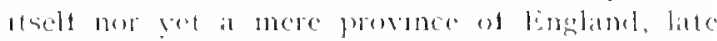
ind reluctantly united, thomgh now satistacterdy

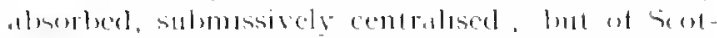

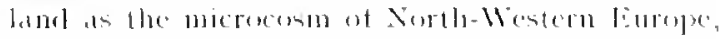

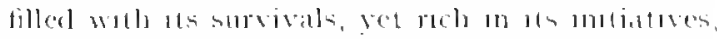

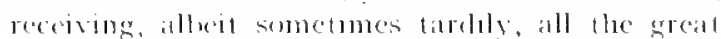

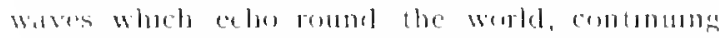

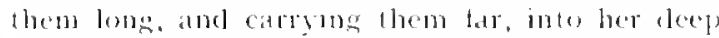

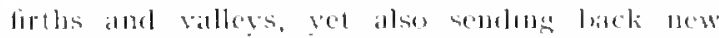
wares, new terees, whels have on then forn modtfied mankind.

Why deres the histony of Soothand show at shate

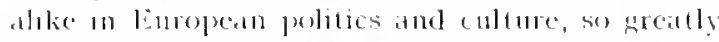

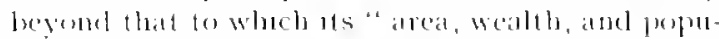

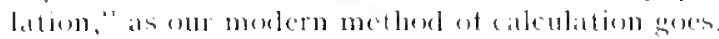
wesuld seem fo entille it? Does it mot indicate

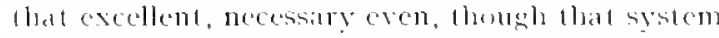
of calculation may be, it remaine not only urorally

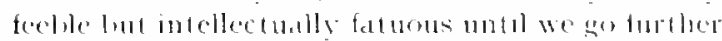

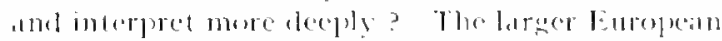
fict whet explains the medieval mometance of Seotland, just as the achantages of her molitary

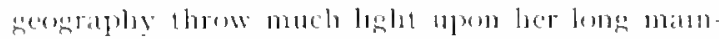

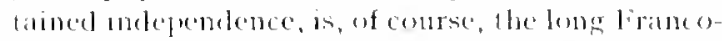
seottish allanee, which is the prectse historte equivalent ef the lual Bltancent vesterday; while

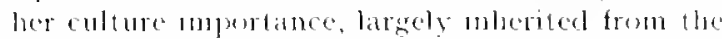
ancient, bratel, and deep culture of treland and lonal, was contumually renewerl and atranced by a fuller and mole sympalletic comata wilh Contomental peoples than was that ot her larger neiglolutur, whese mistortune it has been to be

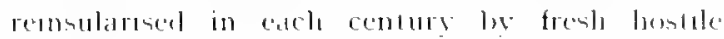

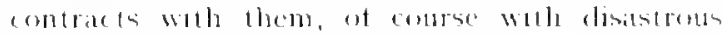
reatetion upen Scontiand also

Hence, then, the need in our lustertacal muscoum to express ont pist relation with the culture of oflue conutries, and to recognuse the anceasing

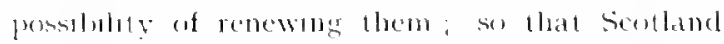
matye mone recover her plater, as the small contimental conntres bave already lome, anonge the finropeatu lowers of culture. In this movement

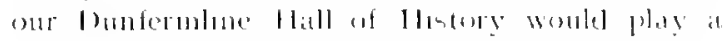
worthy latt. 


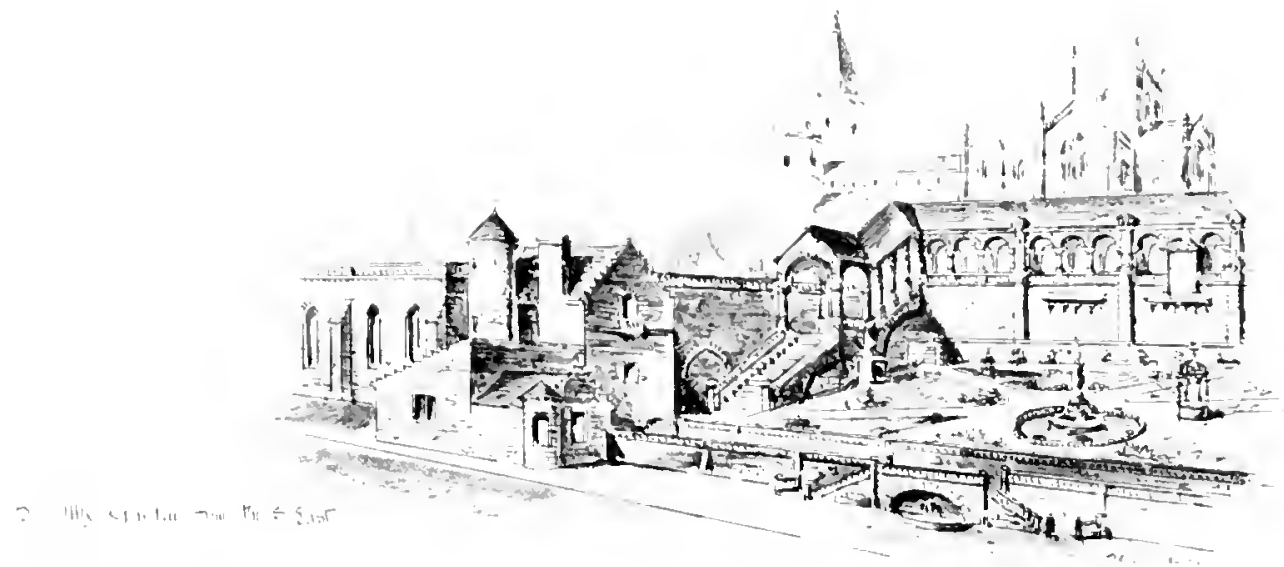

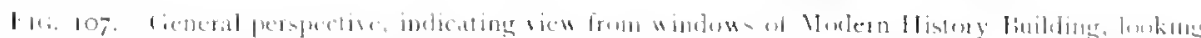

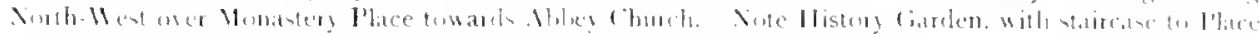

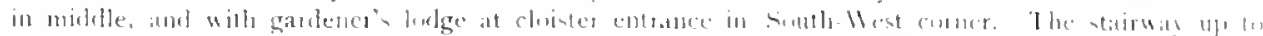

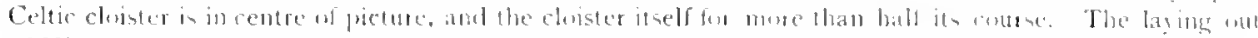

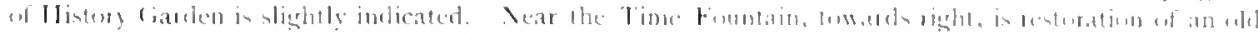

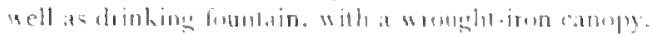

\section{('H.MPIR XXIII \\ HISTORY GARDEN AND ABBEY PRECINCTS}

\section{A. The History Garden}

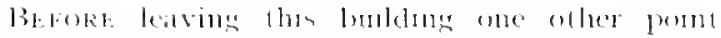
rembins. With ats design and lases tully before

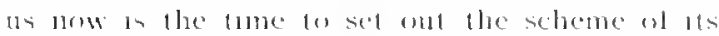
sedren, nut betore: 10 sllustrate, low, the whole standpont in gitrlenng which the repert mainlains.

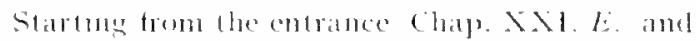
its path fo the statease, whth bls patralled path et Sorrow, its lume of gews on either hand, we pitses

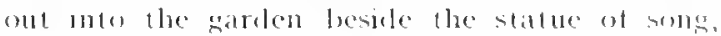
whose pedestal should rise from a mound of heallos, chosen for ample thower both on sprong and attomu, through wheh shosuld rise an summer

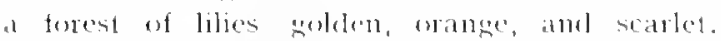
the moin walls shmale he paverl will lold mesalle devices ne coloured pelblues, regularly varying as we preceed the matrenerite and ferect-me-not, the Deruelis heart, the bruce's crest, the sluat chepuer

The olel apple-trees may manty remant, and lwote lons will beeome venerable ones, but the formal character of the sitreten should be matintamed, ancl its spirit clearly expressed, ly the planting of regular masses of Inats, of course the

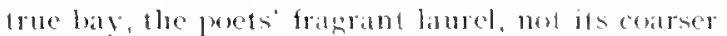
substitue of the Roman trimmph and the modern shrubluery.

In addition 10 these laroe dark masses thore should be introduced in regular foustom alomg the

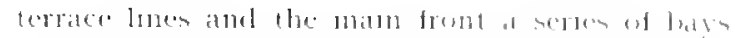

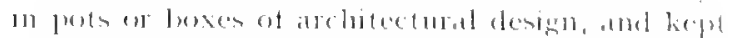

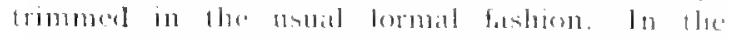

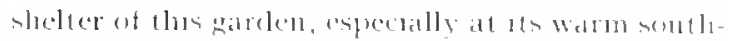

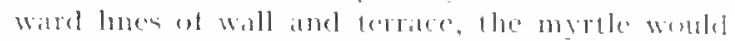

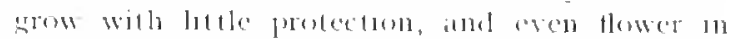
exeeptional stmmers; whle lavemler, mesuary, and thrme, with rue, fors, anel ditlans. womld

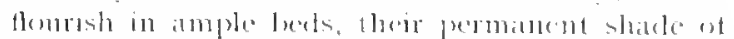

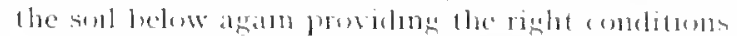

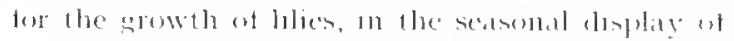

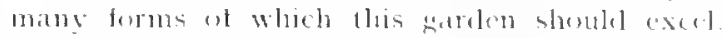
Twe of the elde wall aphle-trees womlel remedn

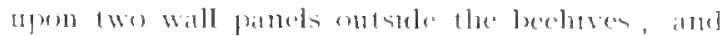

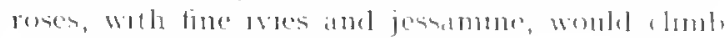
the buttresses lig. 10:

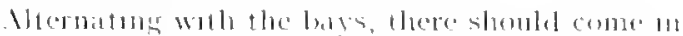

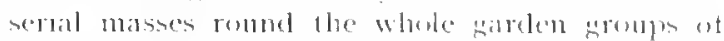
grant thistles, thromgh and aroumel whome thomy mass should grow whote lolues, bordered lw dwart thutles. In the smaller contral beds womld be

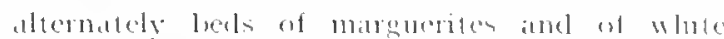

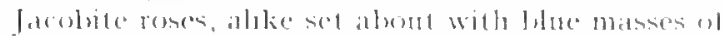

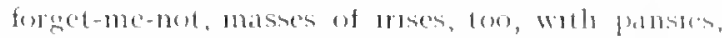
and so on. Winot detals, tore muncrous tor menton, and sometimes chandurs wats fle seatsons and vears, woukl furthere empholstse tlocse

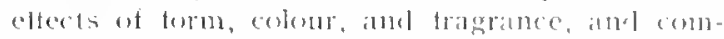

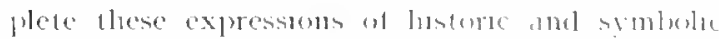
tecling Thus the reater, saty of funlsart "The throsel athe the liose" nould tind here 


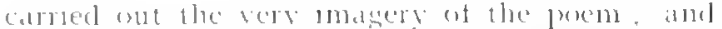

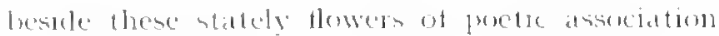
the monk hertrary, the queens smples, woukd find then maxlest place.

\section{B. Abbey Churchyard}

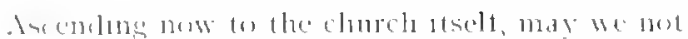
(a) somethrng here? Sere what moble pumbulaties! -what puor lane made of them ! - for the hintoric frees, once the prele of Duntermbne, have hallen, ancl their sucessiots are but (1) haphazard Hathung.

Hore, howerer, st the deleal spot an all loun-

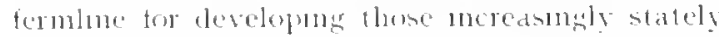
and solenn eftects which the judicious use of the

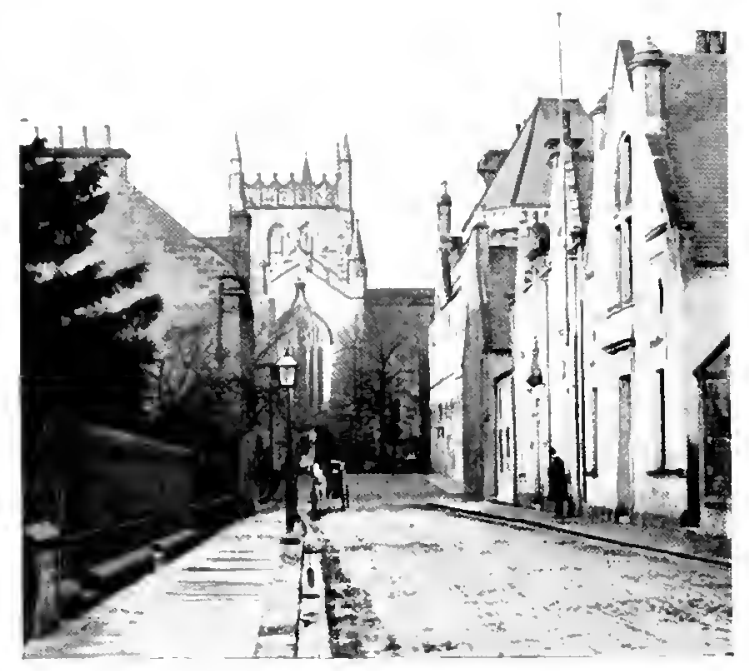

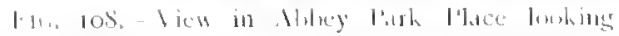

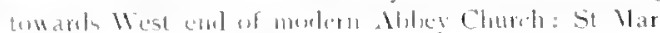
satet" 11.211 seen 11 , risht.

rew atforels, and thas monumental plant therefore

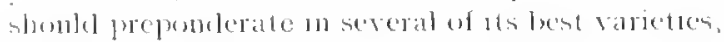
chethy the spreathes and the pullared, the fotter

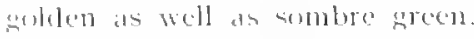

one such atemese would naturally commed the

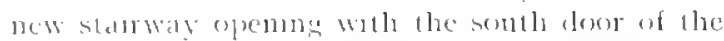
Alley Clumeh. The weedy peplar-taces fowatrde the senth-east should be remosed, and the limes

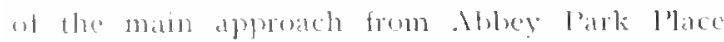
moved inte nue regular positon and aligument. sifll better, they slusuld be lifted, as is still quite fracticable, large though they are, and planted ontside the alshey wratseyal allogedher, mpen the aratselted rodulwy ontsile, contunous with the street; whole whthm the gates should then be planterd an areme of the latreent spreachng yews 11p to st Margated's tomb withn the ruins of the lady chelpel, trom whels the present monghtly and useless rablum should be remosed. Thus whole apperesch woulel thus alogn with sbley l'ark l'lace, whel, as the acompanying photo-

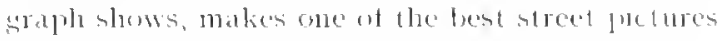

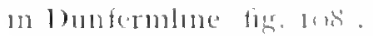

The main walk, rumbng east and west on the south side of the churely, should aluo be yewhordered, lut whls smaller golden pyamuls, ats also the watk rumning due somth from thas of the cast end of the fratry llatl. On the north side of the ehurch the sraveyard is momotomons and mestected hoking; the lgly coment-topped wall to the east shomld be both ivied and screened hy shrublere, including a tew spreading yews, conneeted by more cheertul evererems, and hightened by thwermy hawthoms above and masses wif white rose lecher.

A smular tratmont would satistatorily sereen

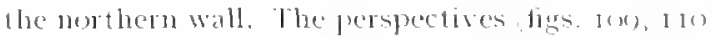
melate how easily this whole view might be improved by the picturesplue rebulding of a single lolock, an shown, and the improving of the ngly

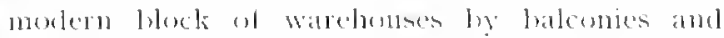
creepers or the sereenmer it he trees. For this purpese one or more of the easily removed limes and polats might also be cmployed, thus improsins the sarous pretures aftorded by the churchvart, and emphasising its solemen denty an the stractest approprate way-an olel style, rif contse, not the molent cemetery excess of Califormian coniters. Let this is somewhat tor somber and,

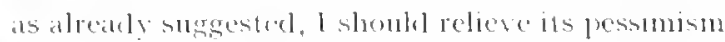
of eleath hy thowering strubs and clmbers, adding especially those of joyous and sacterl associations -the rose, the almomel especially, the smaller shrubs also: claphnes, for instance, especially the white nezereen and its congeners; the honeystecle also. One or lwe of the smaller flowering whlows night alse find place, and close to one or lwo ot the entrances a weephng willow.

It may, ne dombt, he asked. Why do I vemture 10 fropuse these mumorments ly the Trustees of

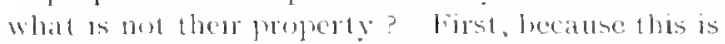
a prot of buntermbere, and the rely lest, the most sactert part; and second, leatuse it needs imbrosement. The heritors, the congregatom, the public, are all alvantaged hy this imporement withomt expense fo themselves: the aheady ponpused stairway though bee-slley Garelen to

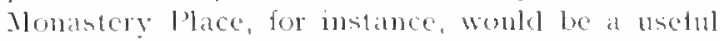
and agreedle aceess and exit on Simderys and week-dats alike; while the Trusters, even trom the natrowest pousilake standpoint of their own parle interest alone, are still more advantaged. fir these propusils, it carried ont, wonlel pratetrally entarge the parts and its gardens, by includmg, within their general treatment and perspective. the nothest feature of the whole city, the parts thus fractically hegiming at and with the abley. 
Conversely, the abley, which hat once as its parti the large area castward now huilt over, would thus be truly restored, since now within a parls again. The estape trom the mutual exclusivenest of sequate uwnerships to this proposed co-operation ter common anenity is surely not beronet public-spirital bolies surli as those here con-
C. Associated Improvenents

I neve submit elevaton and perspective showm:

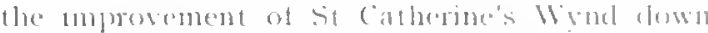
(1) the lents. Finst of all, the prenent nomtlewest salteway entranes to the abber graberatrd, neal

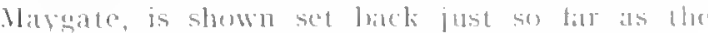

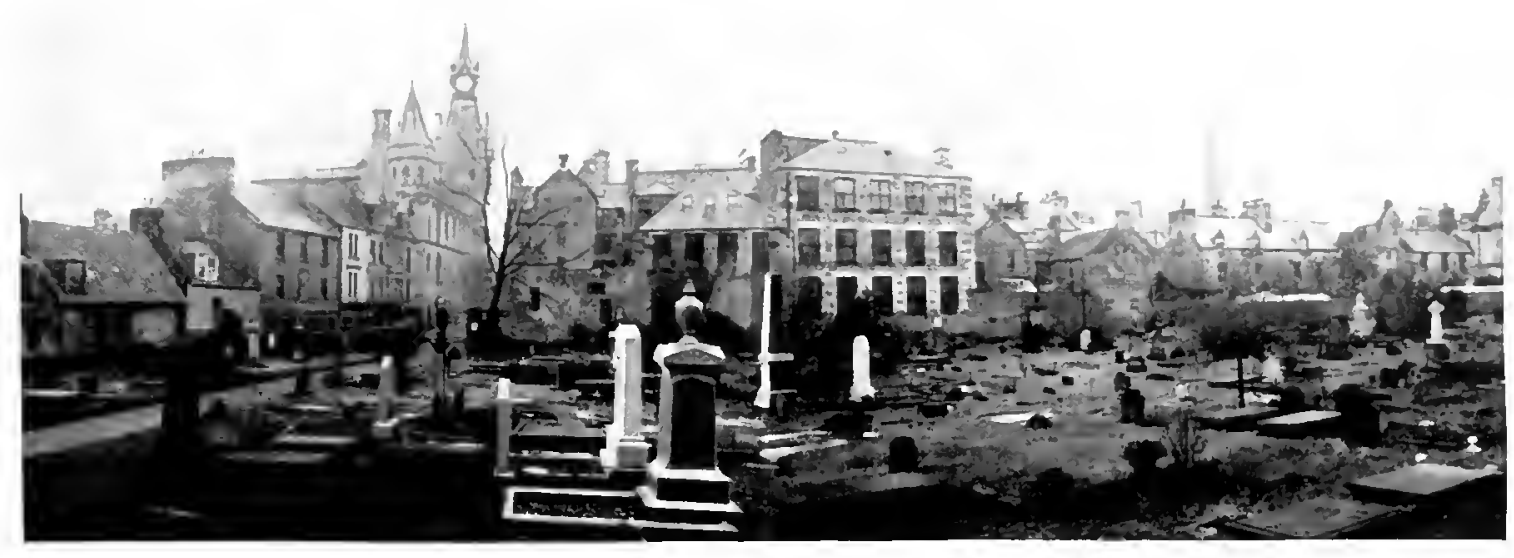

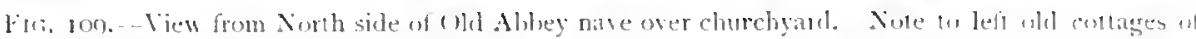

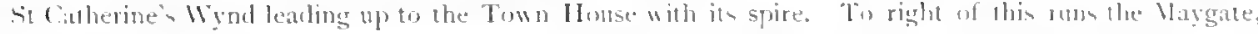

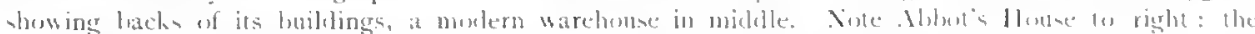

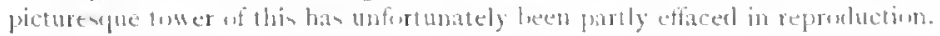

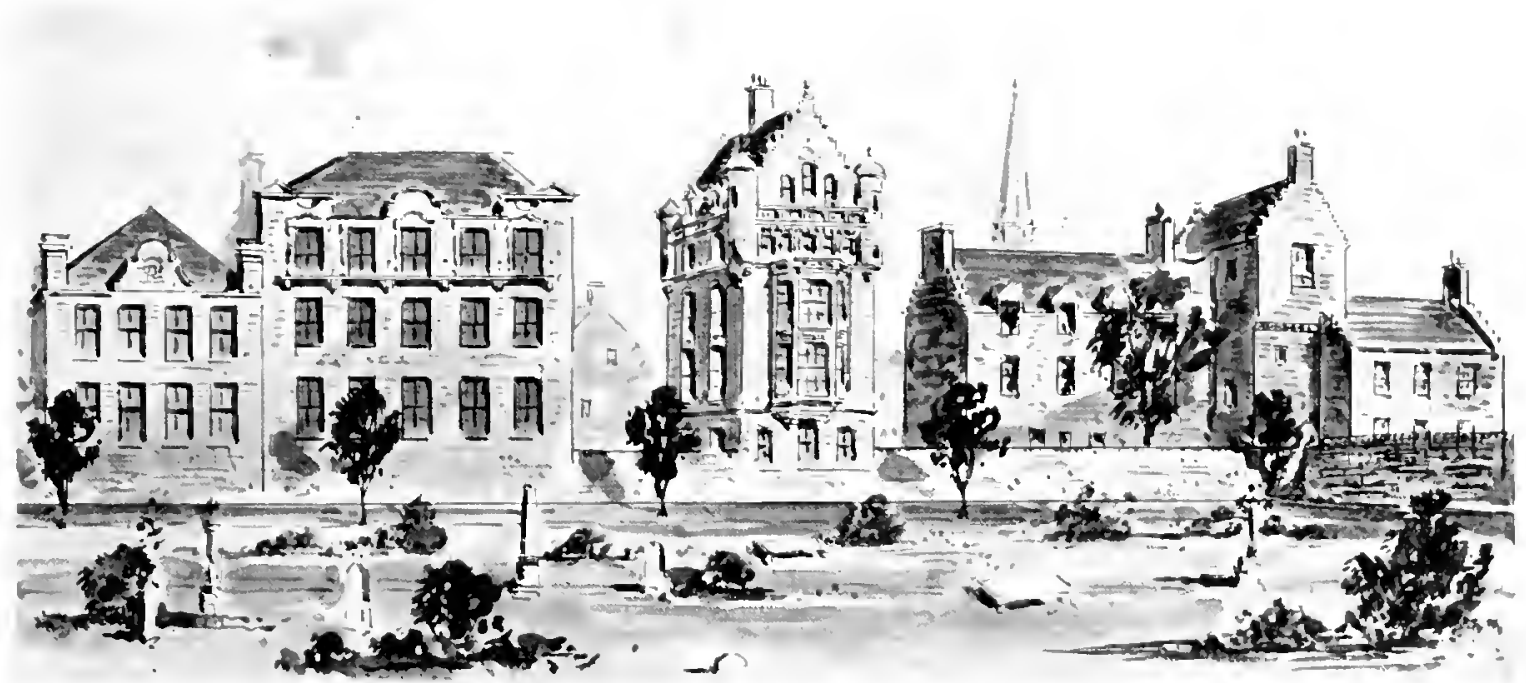

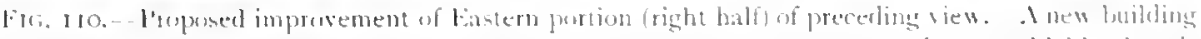

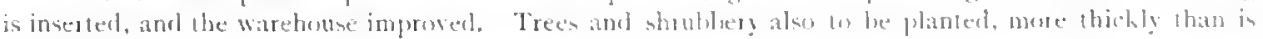
hete buwn.

cerned: the civic eximple is atso in the right tine of development.

I continue, then, to strggest that the whote west side of the graveyatit be next improvel ; of contse, as everwhere, without interference with a single grave, though even tree plinting does not go nearly sn deep. principle of non-interterence with graves allows, thus giving the much-needed eftect of a smatl public place outside, below the tlunicipal Buile. ings, a space useful, moreover, ats we shall see bitrer, to the proposed Mtusic llall

Deseending to the main west entrance of the okl thbey church, we note that its modern gate- 


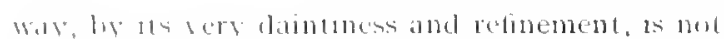
alelefuate sor the soltation. but thes cannost,

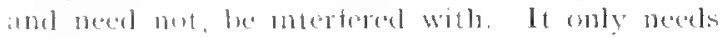

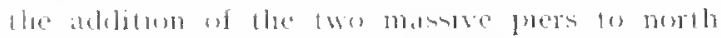
and south, wheh are acomolngely shown in perspective, amb wholl, as wh be seen, harmomse arul compune with the pinnatele north of the ereat womlow ot the firatry llall, as with the proposed treatment ot lle park entrance and Tower Hill limal fign 111

The small enclusume of cartelesty planted ever-

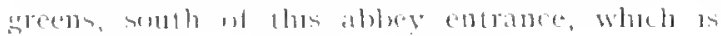

of wall lo si Catherine's Wrod on either hand, whole thas is timaluet ly the simplest pierced masoms balustrate thromghout ats length, the whesh being then planted whth costoneaster and ixy. on the northern halt espectally, where sto hats aceess, I would ardel white Jacolite and Arrshire romes and homersuclite.

Tha brongs as back to the north-went entrance of the graverarl at Maysate, which I should mow propesse to treat with new sateway piers of stmple character, hamonsing wath the architecture and massive luttressing of the churrh

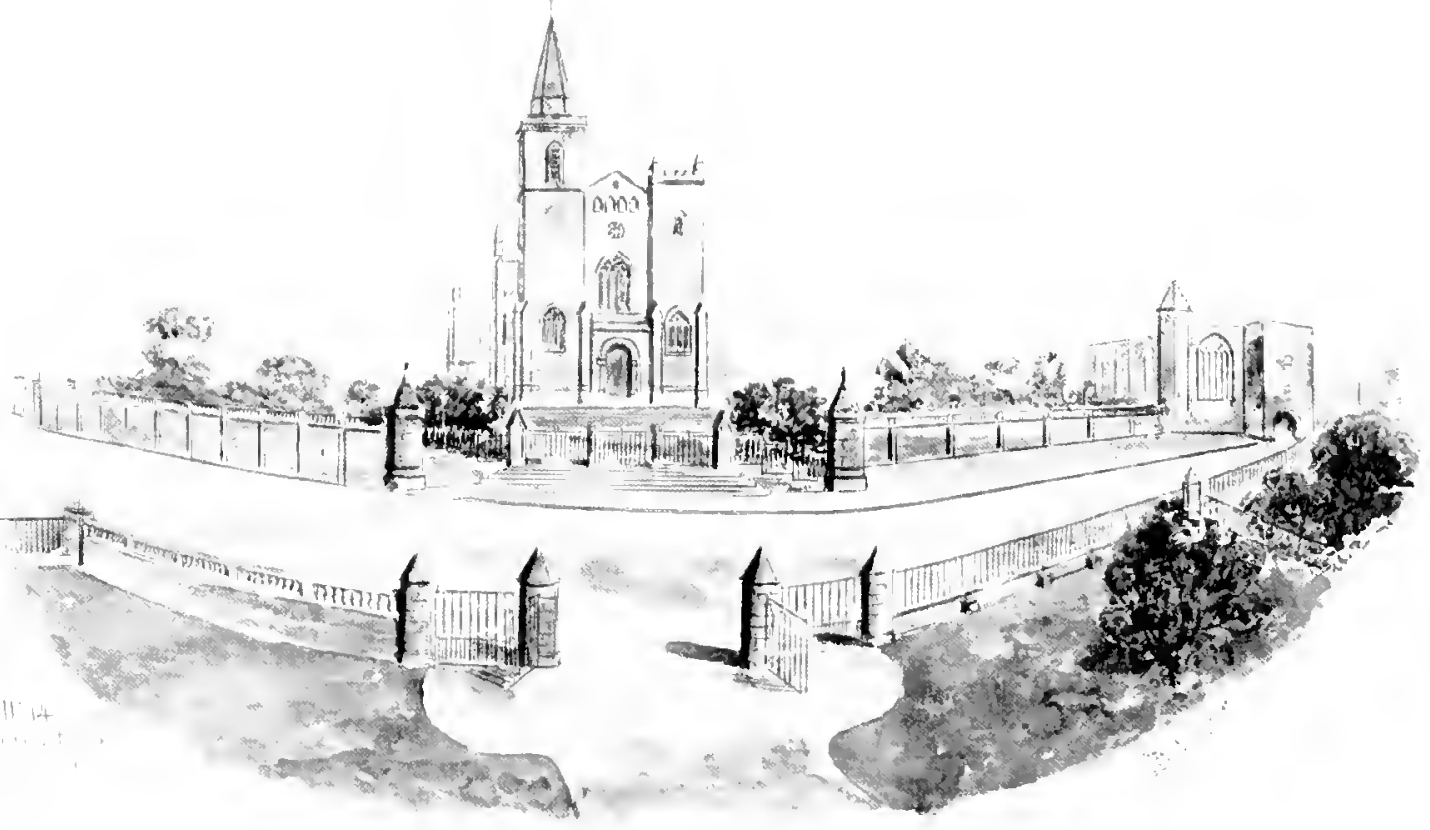

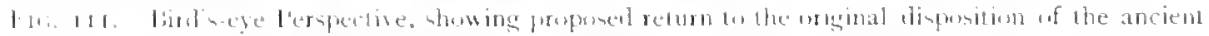

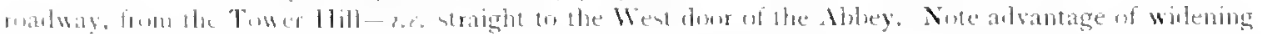

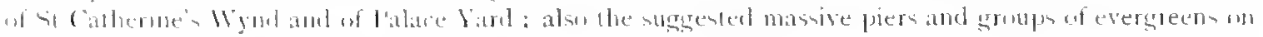

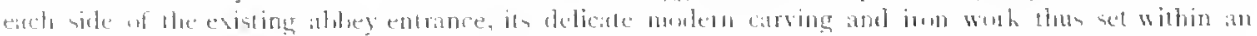

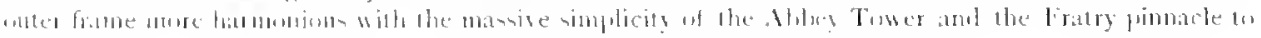
right.

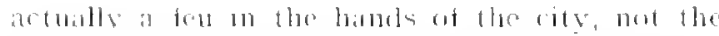

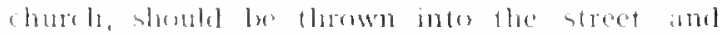

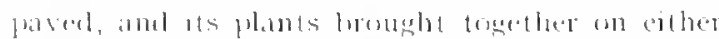

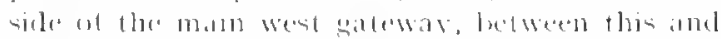

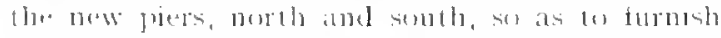

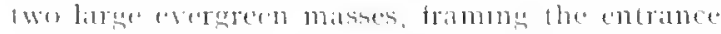
on edher band. The improsed ettect to the ablers, seen from the streed and from the park, will easily le reillacel.

1 sules af smple pilanter buttresses, much at along the lower llall liakl withon the park, are shown treakine the momoloms of the tone ranese

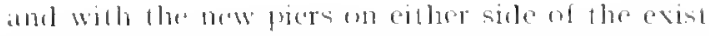

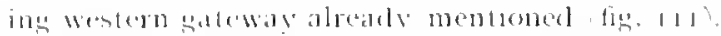

Bis next rettums back the "l'ort gate" of the park, and lumping this into its ancient aturl

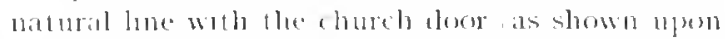
pan and resattom, we recover the efteed of the anciont lablece Yarel and almost its extent: while this may be completed ly oblaining the neecestry permissom from the Crown authorities on set back Aluedr lommolare alas

l'assing thrmoh the Pends, we requirs similar

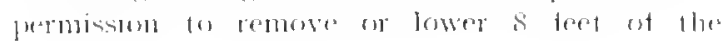




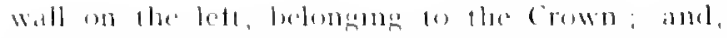

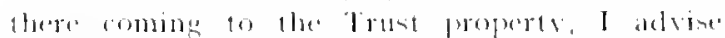

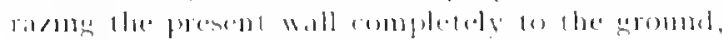

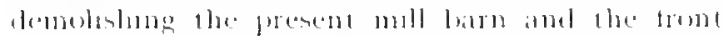

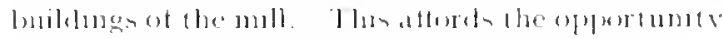

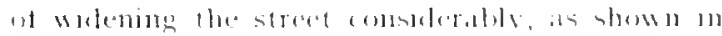
the gemeral plate big. 115.

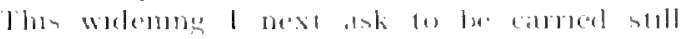

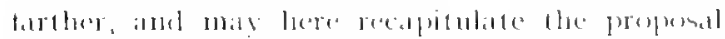

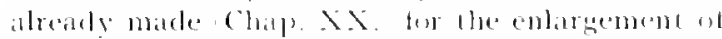

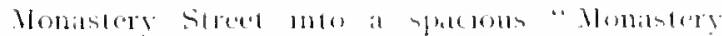

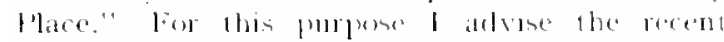

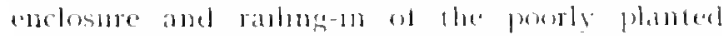
triangular space between the strees and the momastery bulding to be turkeme, and the whole

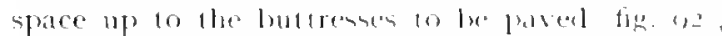
a simple rablutg-bas at most beime placed to proted a couple of teee tit areen turt extging, or a smgle mass of shrolm hedween each hutress. I of comrse assume the inclesting respect of the public tor these improsements, and the natural prevention of ant ballual calue for their inpurs

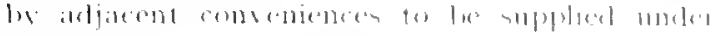
milli

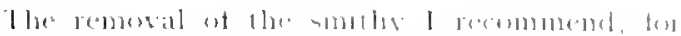

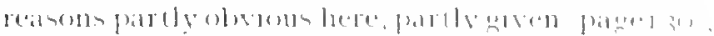

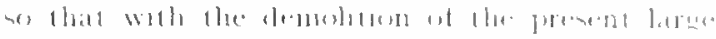

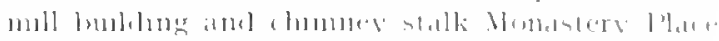

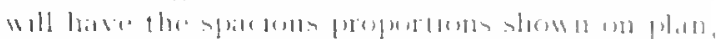

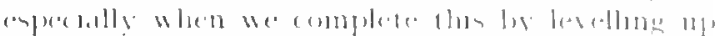

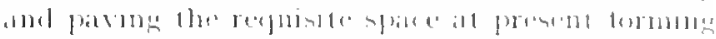

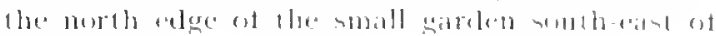
1he, 11114

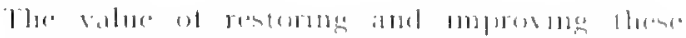

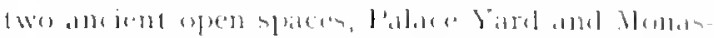

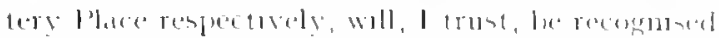

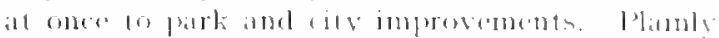
this new place would be breatly impromal ho

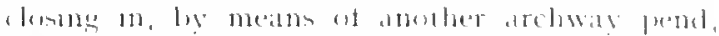
suld as wats one the galle tarbler down at the

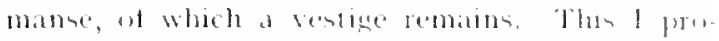

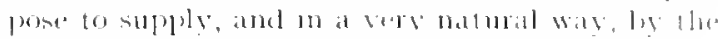

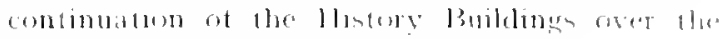

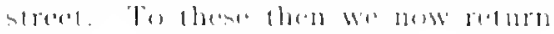




\section{CIITTER XNI}

\section{HISTORY PALACE: RENAISSANCE AND MODERN}

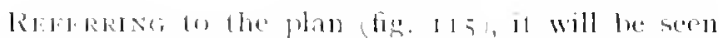

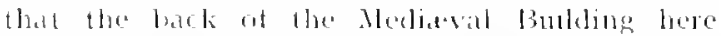
projorts easturale to meet the aljacent factory

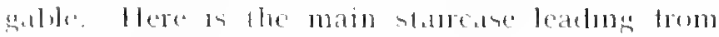
atl 11 s storess down to the level of the stroet, whlt

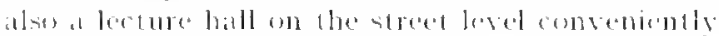
utllated tor pulblic atecess

\section{A. Renaissance Building}

To resume our hutorical plan ot exponition we atecond l, this startate and enter the Great llall ones more. firom this the thorough revoluton in religion and enture, pollates and ceomomic lite. In alt therefore also, which is marked le the surcession (1) Marr of James VI. and 1 , is malurilly incleated le the change of charactes if the buldinge, from Merlieval to lienatissance. The molive of design ardopted here in given by varions memorials of old belinhurgh, ote. but best of all

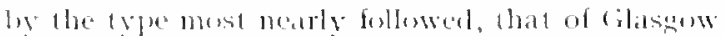
college, demolished scarce a Exeneration abs tig. 113

The style of this Renaissance buikling lemels atselt wall lwath to the eneral purpose and to this particular stuation, and when sieswed in perspectuve, on whach 14 is shown as it atctually woll lee soen trom the street, it wall be seen to compose

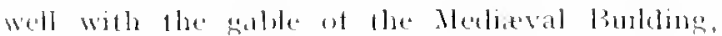
leehinel which it is recessed. Mlso in its hostorie sennlicance the desten will be seen to hold. Kims James's departure over the furder is, it whll be

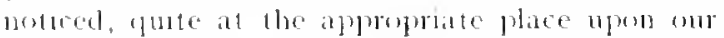
plan, that wer the erosing wer the mothere patement of the street; whe the last notable ronnections of Dunfermline with his dyasty, thoush the furth ot Chatles 1. and the liestorat

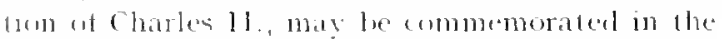

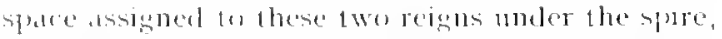

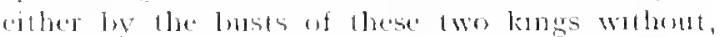
or Ix protrats or pietures within the Tower and sine chamber, which continnes npon a simbli

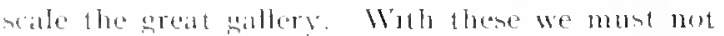

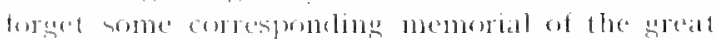

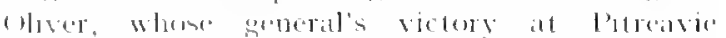
lountermbne slill remembers

Givas latte space at the Restoration and to the hriet and wetched resgn that followed it the somthmont portion on thes side fige I I belomes to the periol of William and Mary, and to the unsucesstul, vet all the more heroir, "lifteen" anel "Forly-five," really, of course, the belated endiner of the serenterenth centurs, sunce the last efterts of the sontlidn Cavaliers.

\section{B. Eighteenth Century Proper}

Belime this the huldoug shoult again recede a step eastwarels, assuming, of course, that the site can le in bue time actuired. Here our next historie callery, that ot the later lighteenth Century faces north, and loxks wut only a the mill oppostle. But here is surdy the right pusition for the clear but posair outlents of the pust-Jacohite ball-century, that charaterised for seotland and the world allke by baviel thume, yet more by anoflue name no less immortal -in lact, that of the most world-trinntorming man of genins whom Iifte has ever produced-Wham smith of the "Weallh of Sations." Besicle him, our Senttish minore worthies of the periosl womlel naturally" tre cormmemoraterl.

\section{Nineteenth Century}

From dhis rums somblusad agan, and in elevation once more recessed so as to retam its own dostinctive character while composing all the better with its predecessor. the larese building desoted to the historic commemoration of the Nineteenth Century. It will be noted in plan how it continues on the hue of the later fighteenthCentury Hall, vet unems also from that of the earles facobite ase, so clearly experessing the inHerence vet strile of rivil dements, dulitarian and romantic, which have so deeply marked the century's fistorv, and in which our seotlish romaneer has as fully led the world ats did our great utilitarian figs. 112 and $11+$ t.

The laree representature rencretions of the nineterenth centur are herse commemorated w distinctive thanges of style first comes the

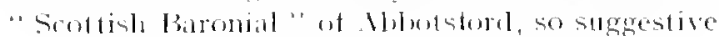


ol all il stomel for. This leads, seconel, tu dhe litrges

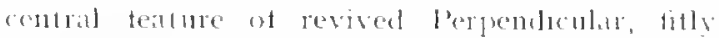
another stabrase Fowe and, tor the tume, the

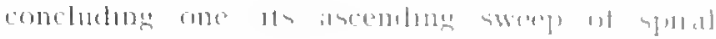

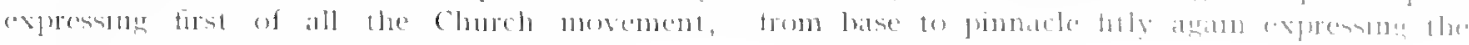
wheh dol atchatly atej) this style m seoulatul als in England - withese the

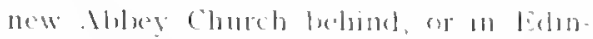

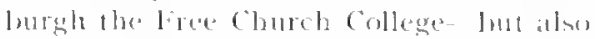
that aldrancing anglicing of the seot,

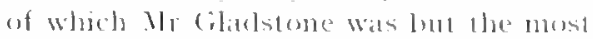

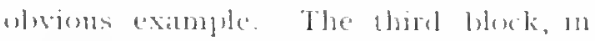
contemporary bank or affice style, (xpresses the ardatecture of the current periods of finance and Emplite. Ser despite tle apparent incongruity of styles in detiul, intentomally recalling our nine teenth-echtury street ettects, il will le
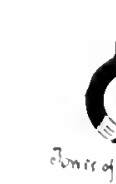
110110 seen that a certain unity not only al alimment but of comproition has been preserved.

Thromghout the upper storey of this latock the Donfermline fallery luns on, full it is now natur ally still further deproed of its former matruticence, and reduced from monumental gallery 10 the molest scale of the monary musemus sirred yed the would not be withoul a wealth al interest ing memorials, and these particularly of its working people, many of whom are well worthy of remembrance through an individuality of the ratest kind. It would indule moleds, too, of their loxms and insentions a recond of the rue from isolited looms a collective tactory, assuredly one of the mightiest changes in the hutory of civilisation, and one for which il is not too late to compile a record which would be of inestimalule value to the tuture: some memoricts, fore, ot the ecclesiastic and scholastic lite, ut the lateras production of Duntermline alsu-in shart, the fullest possible recurd of the century which has su lately closed. In this way the actual comtrists ot treatment of our long Gallery of lountermbine brings out the vicissitules of the fown, whet had ly the nincteenth century practically tergetten its once high estate, its lialace fallen, 1ts Mibey mostly quarried away.

\section{Twentieth-Century Building}

But now from this modest musem sirred (1) homely molern lite and labour we come out upom our Nodern olltowk, that of this cily with the opening century. Thiss expressed architecturally by the spacous upen gallery of a cirenlar umer (tig. $11+$. form which we may lonk back to the old historic city and forwad into its future, whelening as this is on every sille.

The lofty arcate of this Outlonk Ciallery will atoo attord, arch by arch, the space for at least the symbol, indeed otten for the athal instrument, of each ant every one of all the arts and seiences: it expresses, 100, their sociald possibilites most of all. From the ground to this kebel rises
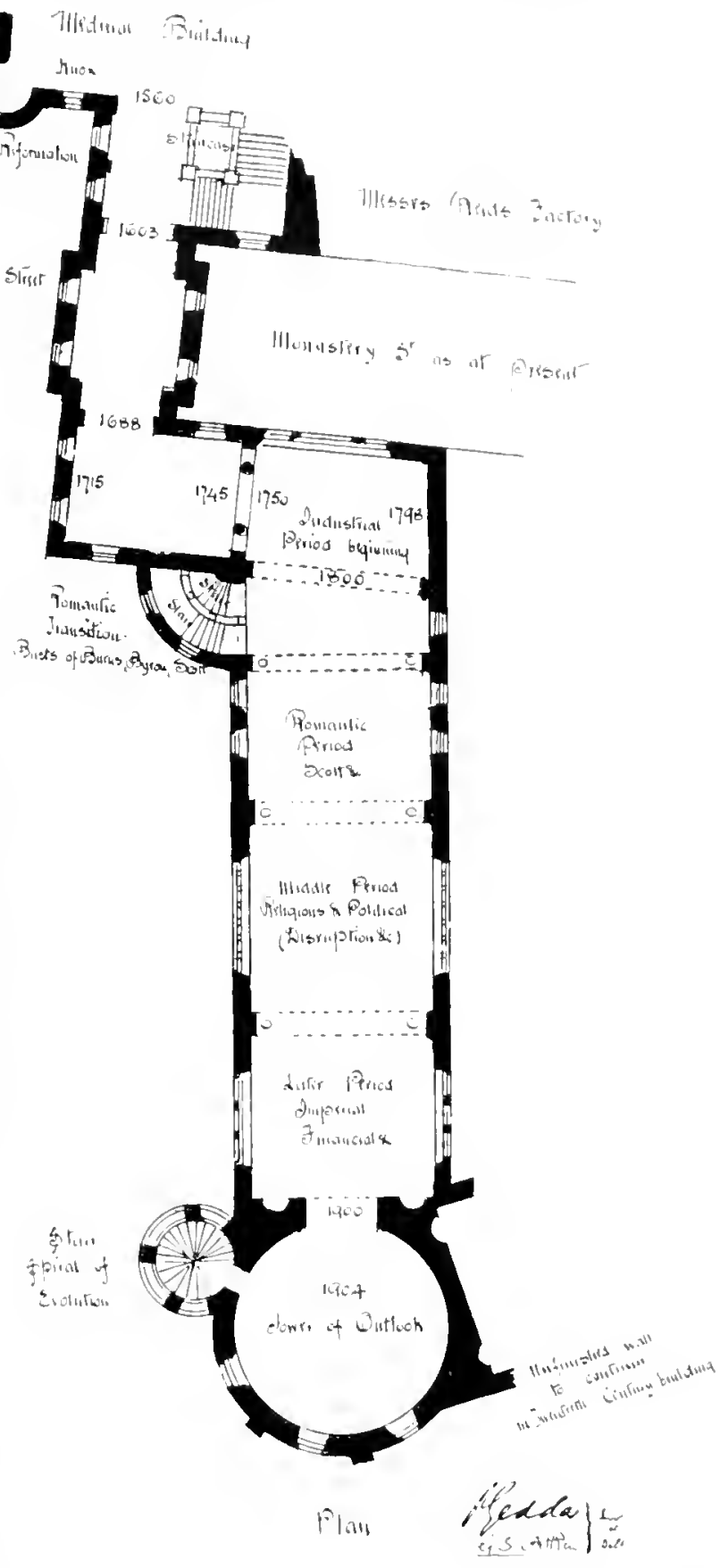

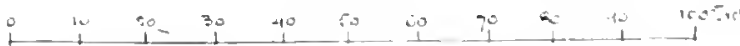

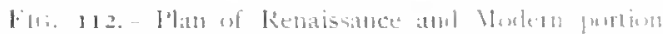

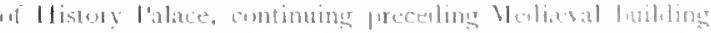
whthwarilo.

spiral of evolution, and in detail infentunatly

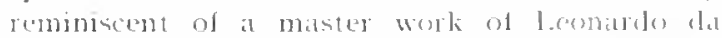

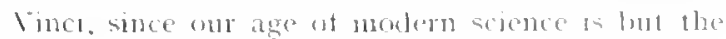
remassance of the licmassance. 


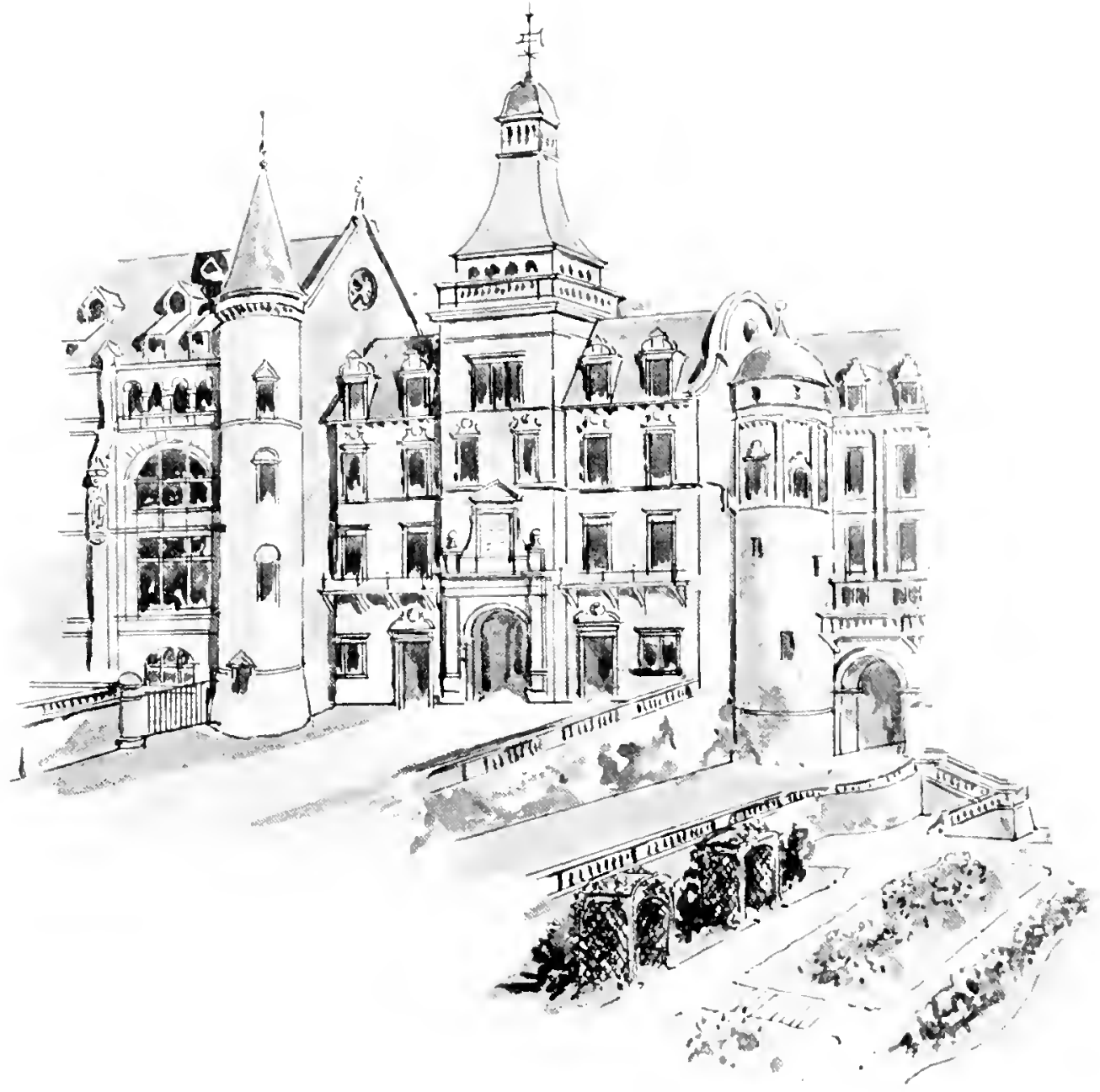

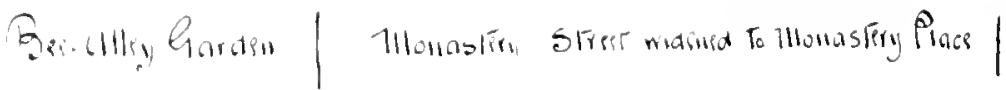

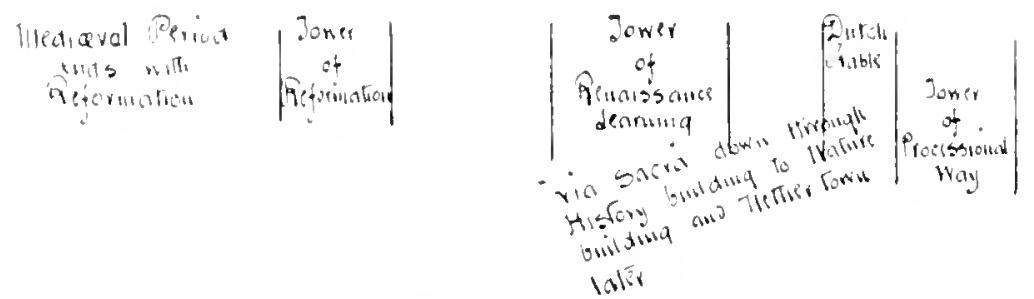

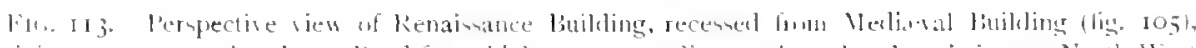
and giviur a new centrat archway l'end for sehicles curenponding w that already existing at Nuth- Went

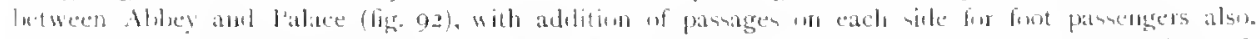

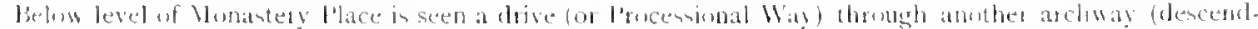

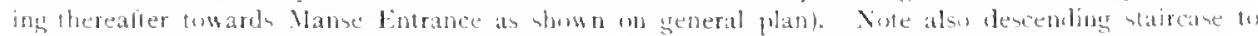

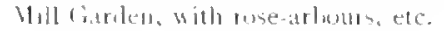


E. Review of History Buildings

Review now the whole elevitum once more from first to lavi, and note how as its strle

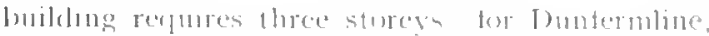

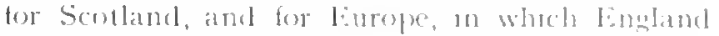
wats too often the most foremen ut nations.

Witly the mion of the English and trontish

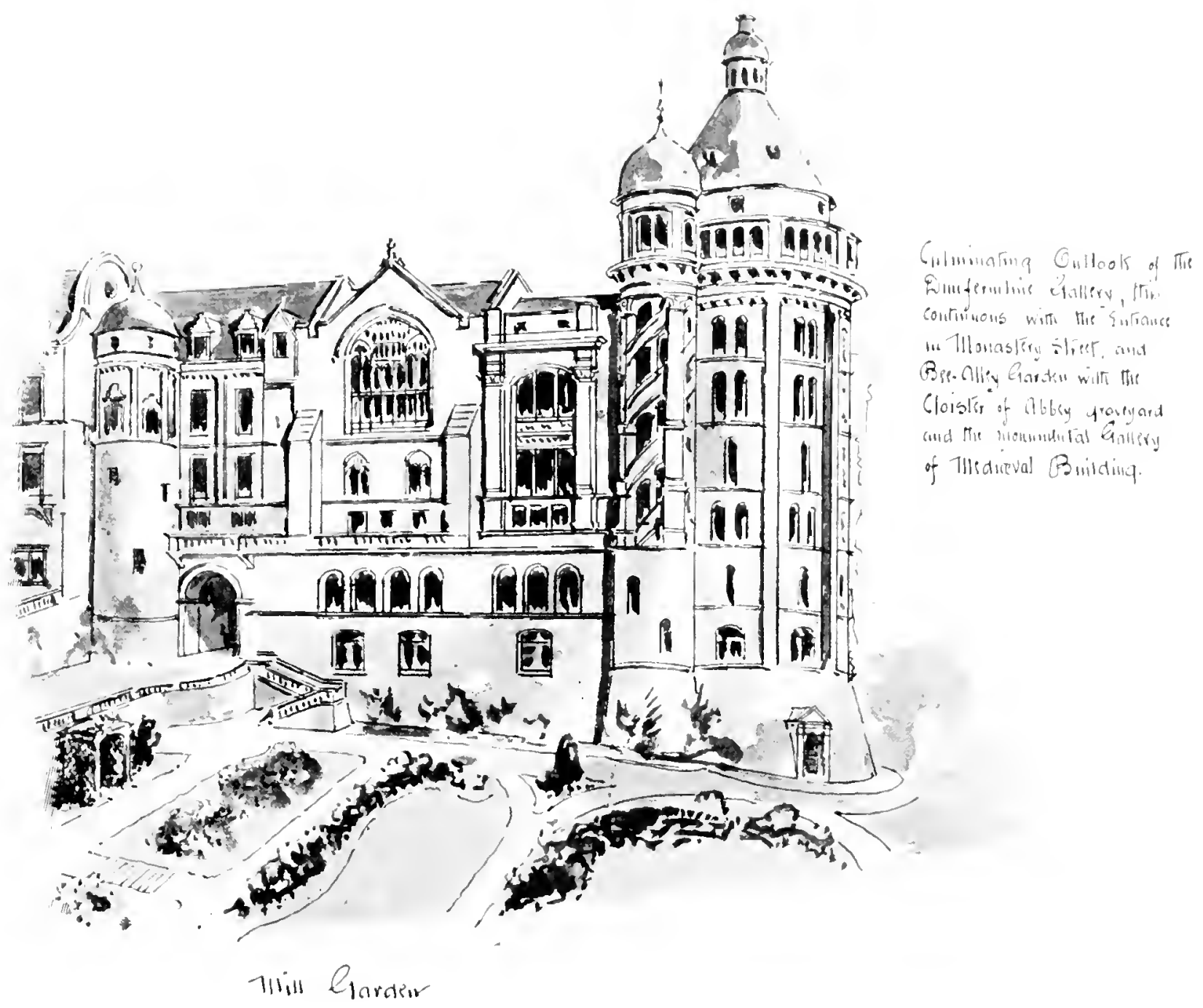

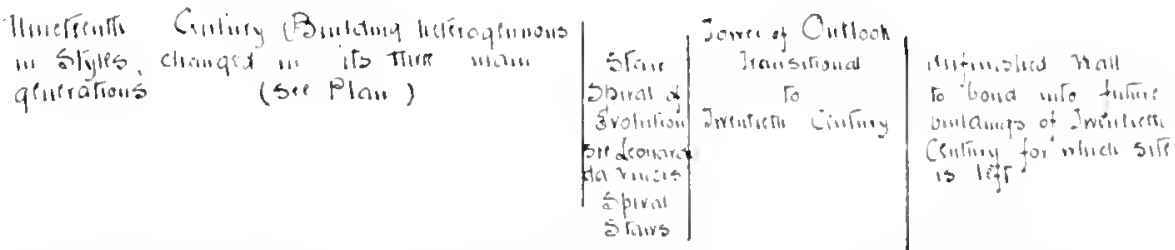

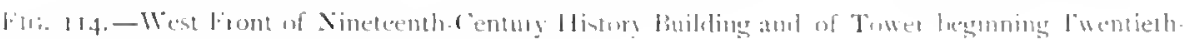

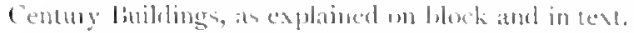

expresses the change, so its leight, the increasing complexity of the wold. The comparative isolation and mits of the coltic world is represented by its simple closter, lut on Merlicial crowns, indicated at the heginnme of our Renassince huildung, a new storry is introducedllat oof English history, hencetorth fundamental to Scottish, al any rate far more important to us 
Jencetorth than the neneral whole of Emope re-

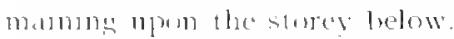

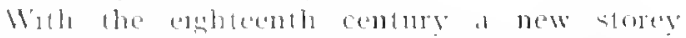

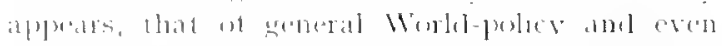

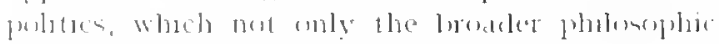

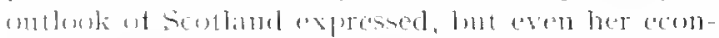

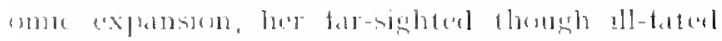
barken paliey

Nitl the nimelecuth antury a new storey is astan introbuctel that of Empure: while an the

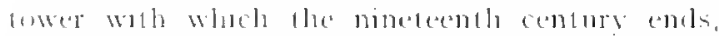

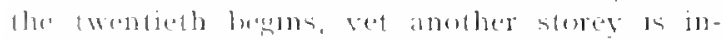
stred that one deroted to the lonted states. whll wheh our fortunes, Impertal, british, Seche

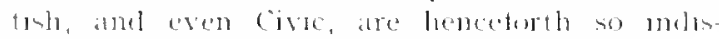

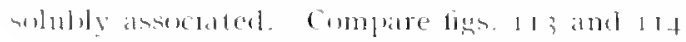

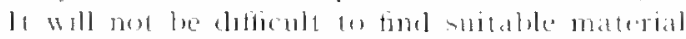
fo till all these storese, and thus to suve the range

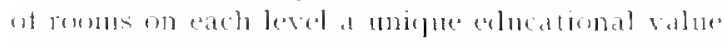

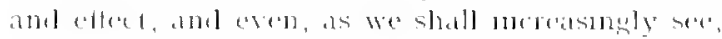
a motably artionte durater

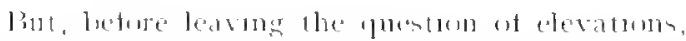

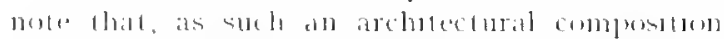

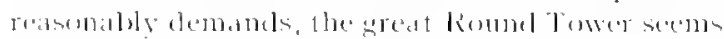

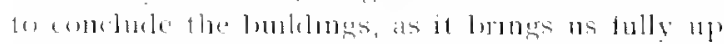

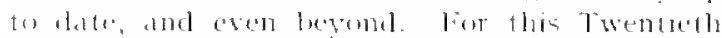

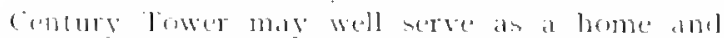

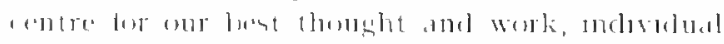

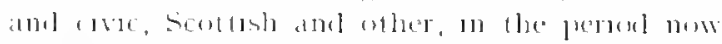

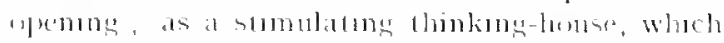

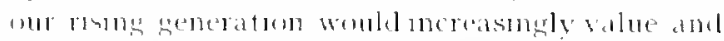

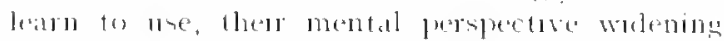

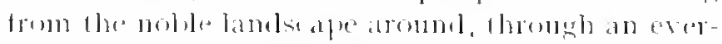
deepenong concoloneness ot an entarems world of

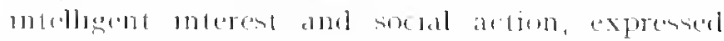
storey by storey, from persomal ontlume to Cits. and flemee to seotlame and Britan, 10 Empure

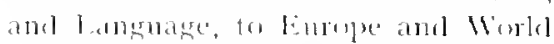

such an actual labuatory ot thomeht, in the hands of even a smete mbelligent uberver and mdever, whldel soon lecomse a centre of reterence and smpury of reil and exer-mereasme value to

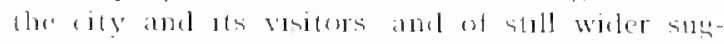

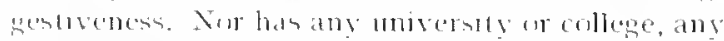

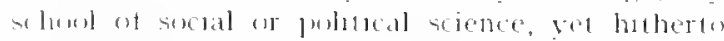

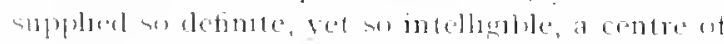

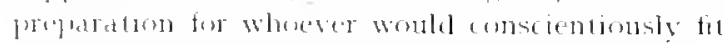

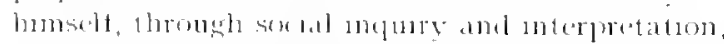
(6) take ng that fersomal respensilibty tor a share

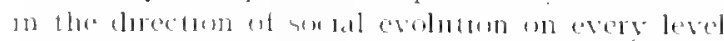

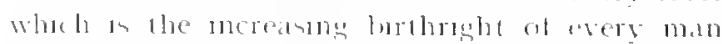
and womem, lut whe hour politual developments

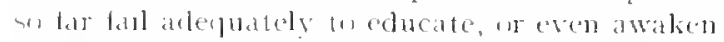

Is mol this antlents ande from whels we maty

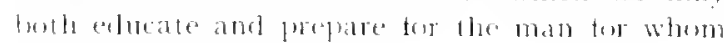
Finising ralls

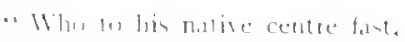

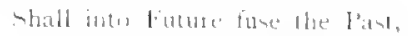
And the walde thowing later

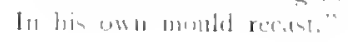

Note tinally how the whole range of hubluns,

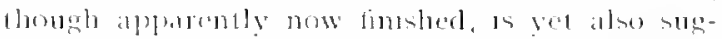

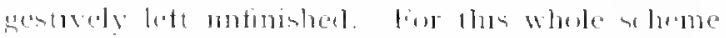
would be menmplese wrete 11 completed, It is at

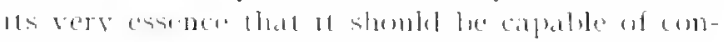

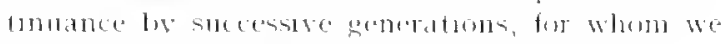

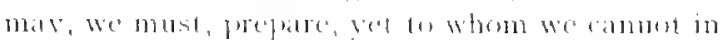
anv wise betale.

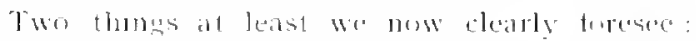
that the tuthe wht need space, and will hare a

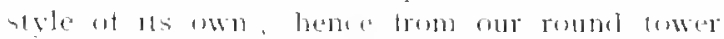
flere projects eastwarl an anfinislied edere of wall whth whele the next buldung com fee bemeled, ats

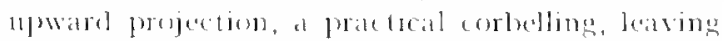
spece at the top for the ane symbol we may tarly

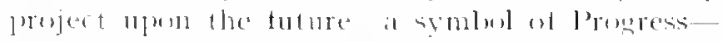

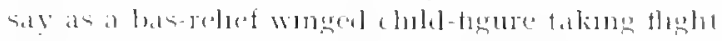

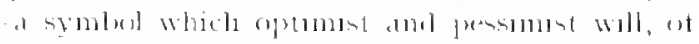
entere, each read on his own way.

So tar them the seneral scheme of and historic louldeng: and were it execoled mont we not

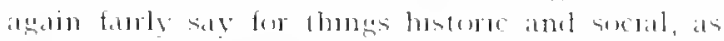
we ded for theme geoseraphe, that whosere woukl

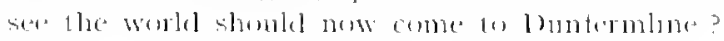

\section{F. Relation of History and Art Museum}

But here is non yet the whole sockal world? ll

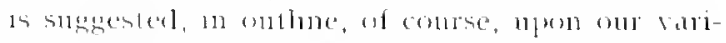
uns floms and always withen the moderates and

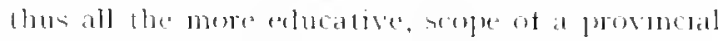
muserm, and here, fors, is the explanateon why

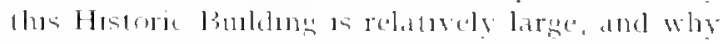

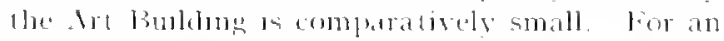
art bublong is, or at least shomlel be essontally for masterperese of the and of all time, in there

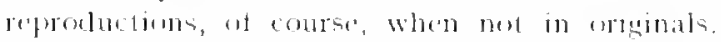

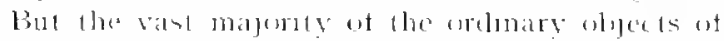

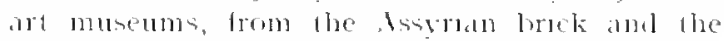

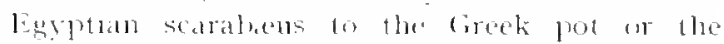

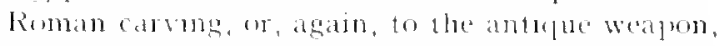

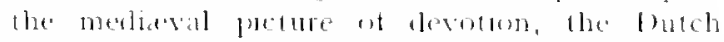
meror or sod piece, are like the conventumal

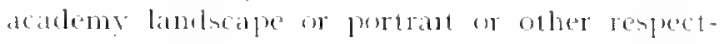
able prece of turnture or decoration-that 1s, ach is primanly so much historical materat, It is not

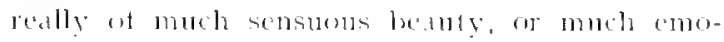
temal salue, 14 se promarily an ebjeet of matrue troeness, of motumatumal or ellustratise molerest. What we use an enr so-called Art Muselums to bach the "hustory of omament" or the haee is thus, arowedly, Bstory first and leatury atterwatels, it at all. Whereas, thement the Irt ciallery must and shonld contan examples ot all tomes, it should only allmat these examples whel trons-

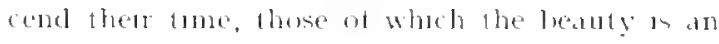
entiuring ome. The applacation of the enterion

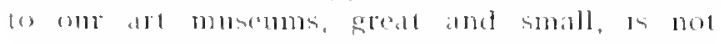
only what is mereded ter relere then congrestion, 


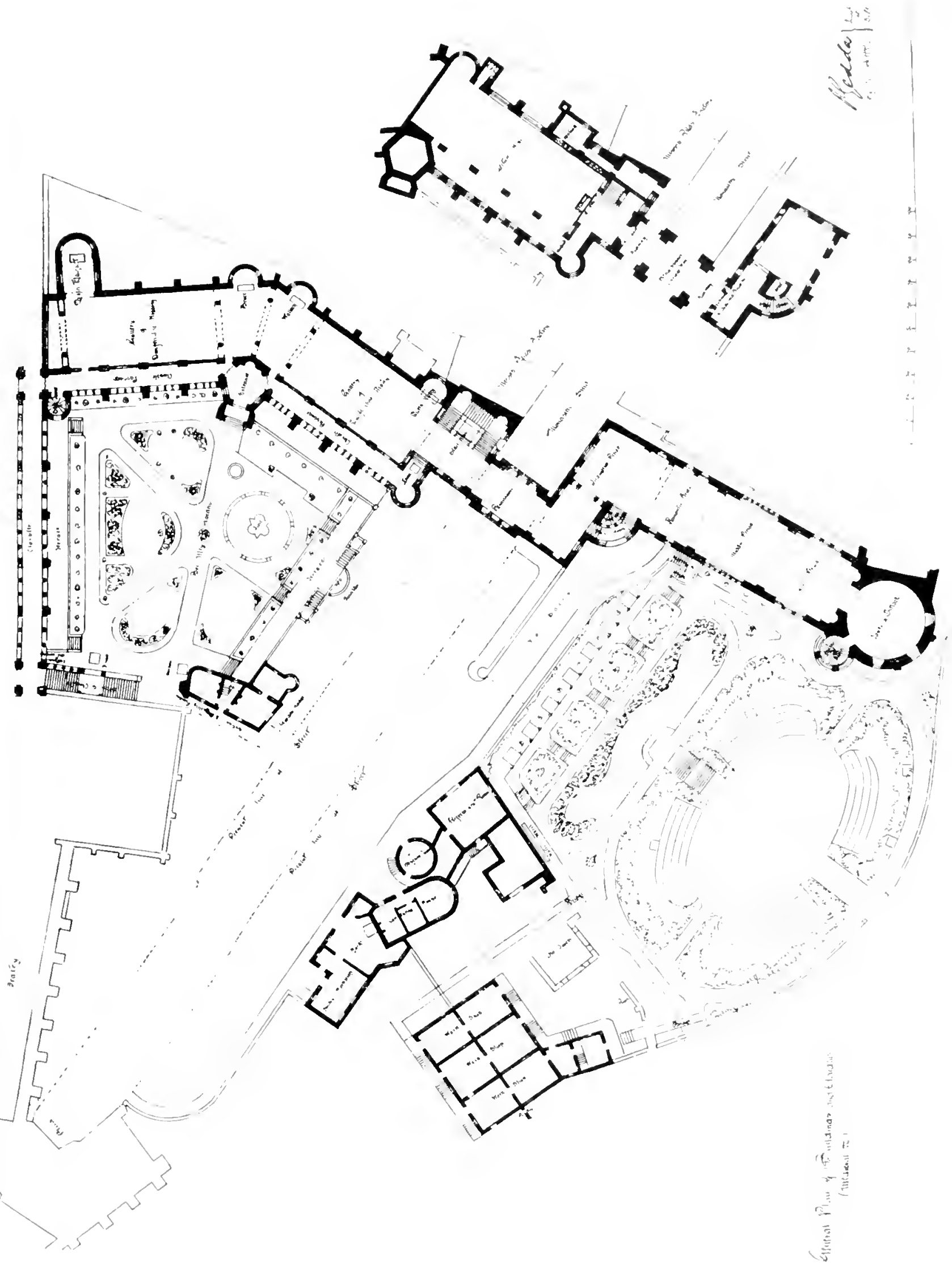


but is molespensible to relieve the pulde gonorance of both all and history tosether. Were

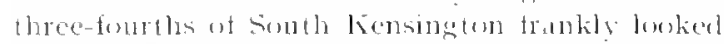

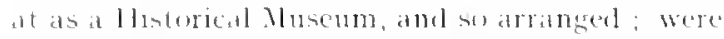
its numberless dupleates distributed to the minor

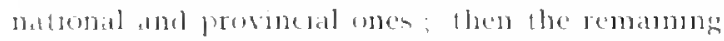

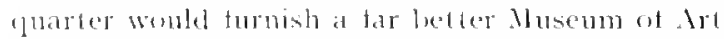
preper. We should thus hase lwe first-tate

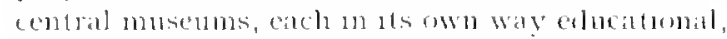
mstead of une ratst and contusing pantechneon.

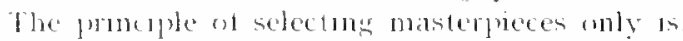
of conre, to at very large extent applued loth m the Nationat frallery of lendon and in the Luxem-

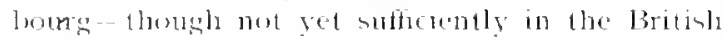
Juseum and lla loruve; nom is it as yet butficrently extended leyond pietures.

\section{G. Open-Air Museum again}

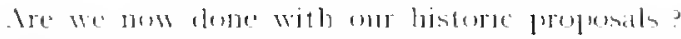

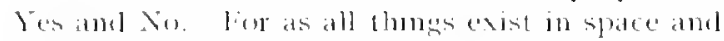
flace, se all things exist $m$ thme, and the eflucittion of at sane and stroms untellegence requires the continuolis grisys ot bolh.

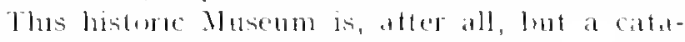

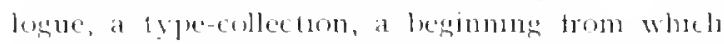
the sturent mar go out to unclerstand hus everenlarging world. First of all, he will aplrecinte his own chy and comntry; he will see the whole

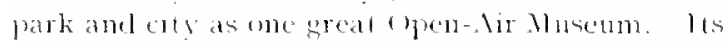
primitise divelliness, its renesved ole molls and their simple yet atristic worlishepse, onwards to the esent molem tactory industry of our awn tume, are one continuous historie developunent. m which past and present and totture are hence forth a contenuous and bring whole.

From the promitue dwellings we pidss really

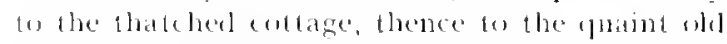

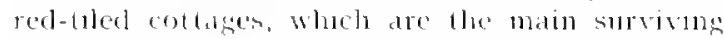
leanty of lountermbue; thenes lo the dull or

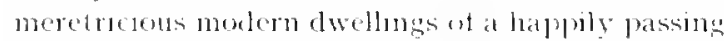
atyle may we mo hope a practually obsilete one

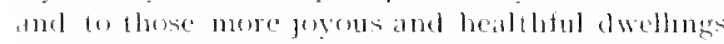
to which we mat mo bok forwarl. Why not then de Romblh, for an motiatue and representative

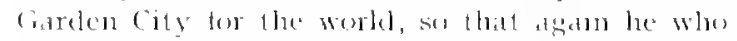
wonld study, as dalse pitrt in, the better houstos whe people should come to lontermane?

(), leegmones ance more, and this time with

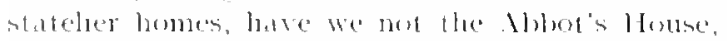
which at some tuture tame maty tall 10 to the hand of the Trust, then to be doubless tept in repair and fumished woth what can be sot together ot the bistorie tumbture and lecomation on the an tme, as the Musee Cluny of Jumtermbne?

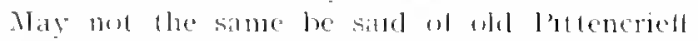
flouse, so representative of llee l'uritan amol Cavalier permed? And agan of the cighteenthcentury house by the loort fille, near the sblecy. whth its sternly simple exteruer, lts pleasant

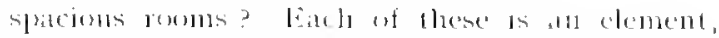

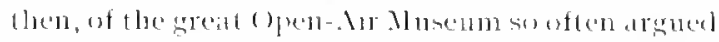

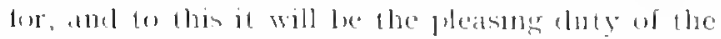
Trust, and of indepenteme coldens, fo carry on at generoms rivalry in arje deselopment, sh that

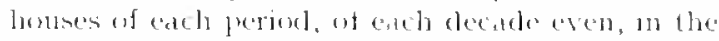

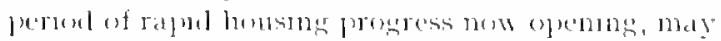
be llought worthy at presersation by our successons. llere, them, as a tubler derejopment of

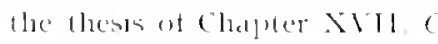

\section{$H$. The Opening Future}

Will this complete our histurie museum? Nol yet. Hotomy is no more study of the past, as unvelum the orgen and development ot the prenemt, it moreasmgly also foresees the future dis continuthe that development, be it tor better "1t tor wose. Thus I understand the improvement of the Abley churel is at present heing seriously consiclerest; and at some time, if not now, the relunling of the Liuly Chapel over Gueen Margiret's tomb whll reptice the present miserable arection agitnst the east wall of the Church, thus lengthening ant the whole perspective and latrely recomposing the present foo meongruoms matsies (1) the ancent and moxlern halses of the clubch bulding, whle the natural weatherme of time, to wheh should be itdded the juelicions plantume of isy, will latgely do the rest, thus agitur restoring harmony of the whole alitice.

But this is not all. This union of the historic and the molern sprit, al reverence for the past yet of pratedeal resiganimatun in the present, will not only dear out the basement of the Monastery of the rubbish prtehed in two generations agn by the morestorer of the abley, but will some day relould the destroged north and east walls of the great firitry Hall, and romet this anew.

Yei mose: some day also the l'alace itselt will be rebult; thensh all this will be nesther tor monk mor prest, for king nor moble, hui ats 111 all and lialace of the Commoms, as a fratry I I ill indecd. In Seotland of ohl, there were phin foll who linew thembelves" Holdes by roht ot an eatrier creation, prests ly the mingsition of a mightiel hand."

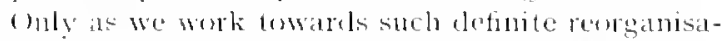

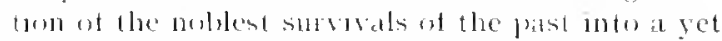

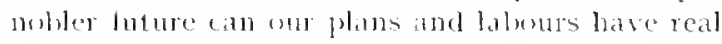

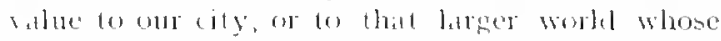
best thonght and work we have to share, and, it it may be bere fo stomulate and lead.

Here then is a scheme of poliey stretehing

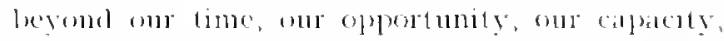
and for that rery reason a Culture-l'alay indered That the besinumgs at any rate are praticable wall not be denied; and if any do not thunk this of its ultimate ones, of roofing of palise and hall, he may see all thus and more in progress from Edinburgh Castle, whl its resiored larlament 


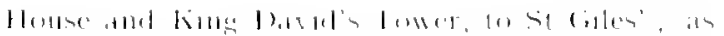

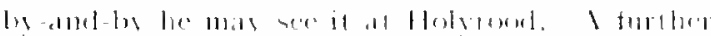

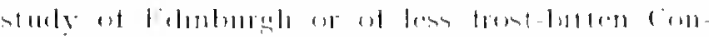

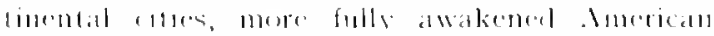

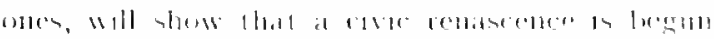

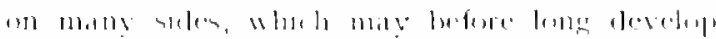

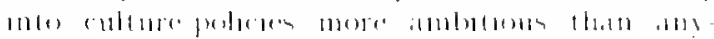

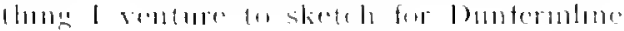

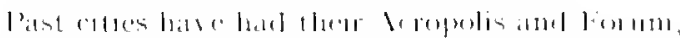

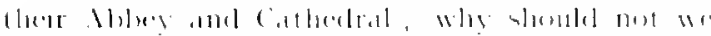

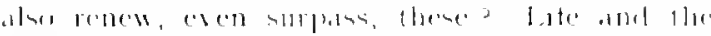

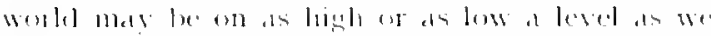
chome to make thems: hence the entere of the

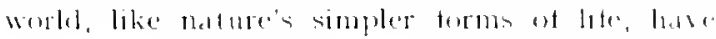

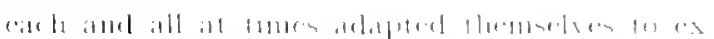

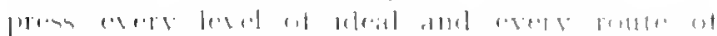

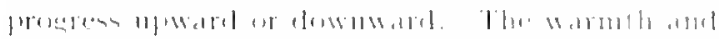

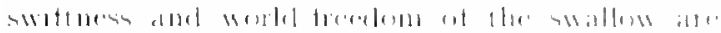

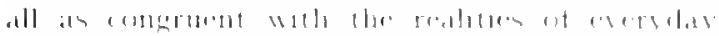

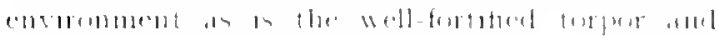

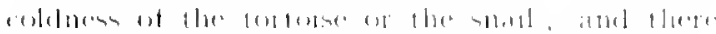

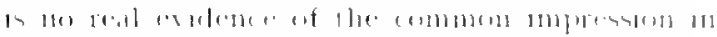

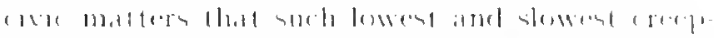

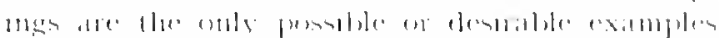

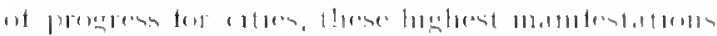

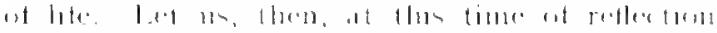

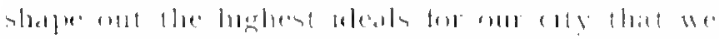

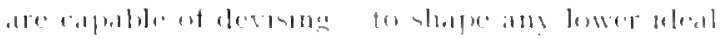

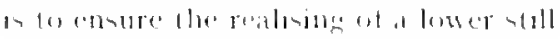




\section{CH.MTER XXI}

\section{THE ART INSTITUTE}

\section{A. The Problen}

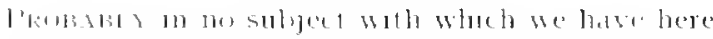

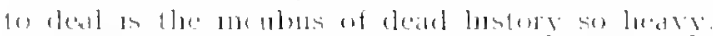

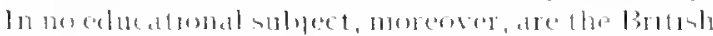

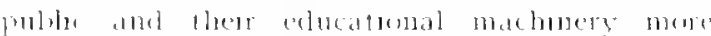

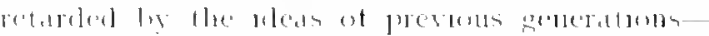

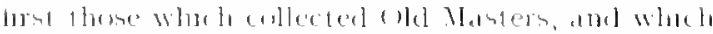

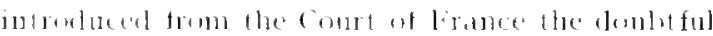

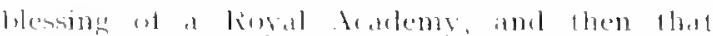

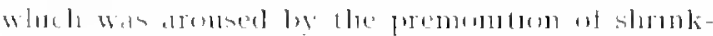

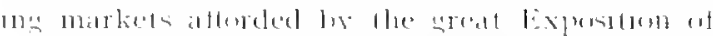

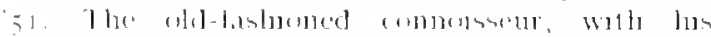

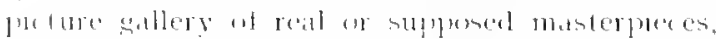

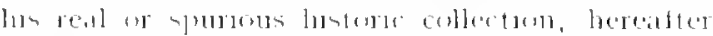

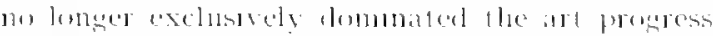

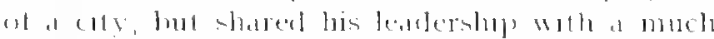

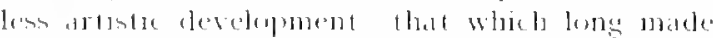

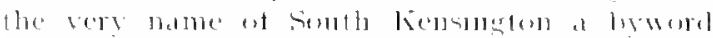

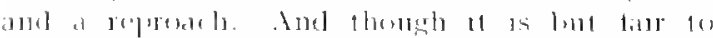

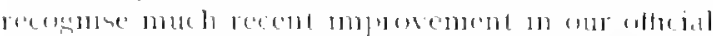

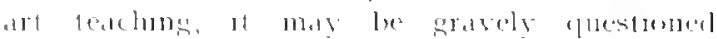

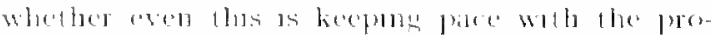

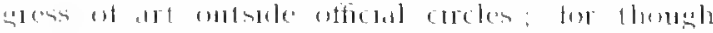

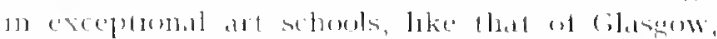

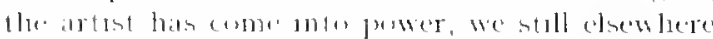

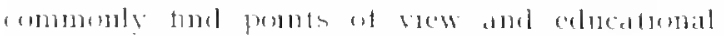

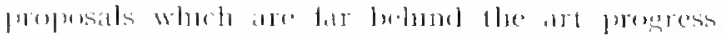

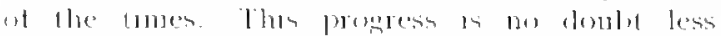

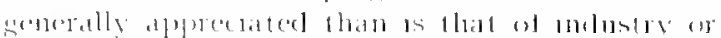

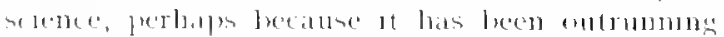

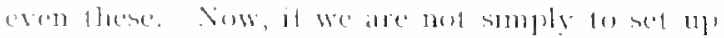

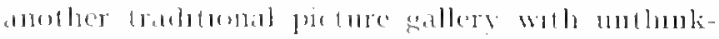

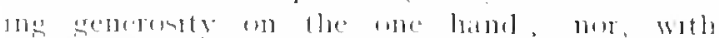

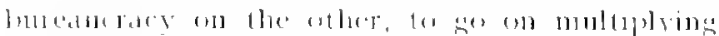

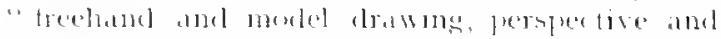

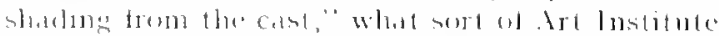

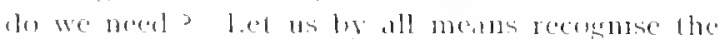

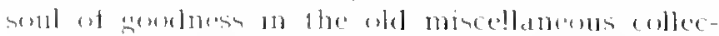

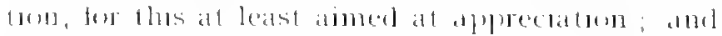

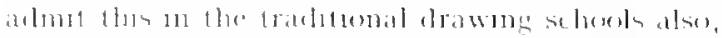
sme these al any rate base sobught to atel in artprestuctem, but surely lewe is the place and

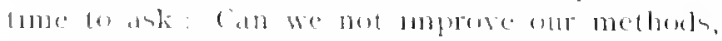

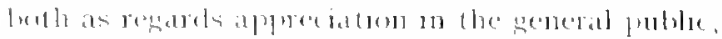

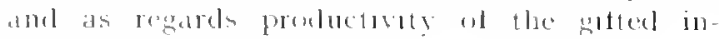
(livilual?

\section{B. Art Appreciation}

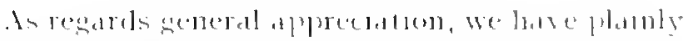
turst et all fo commumbate the Art of Seeme, esen fefere the seener ol tre Here our park ex-

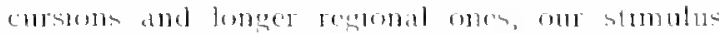

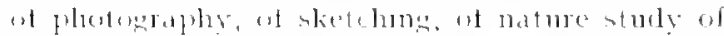

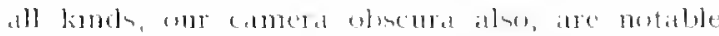

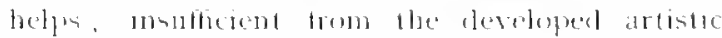

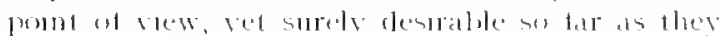

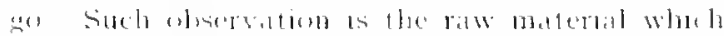

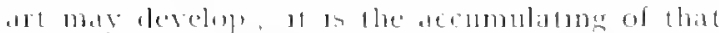

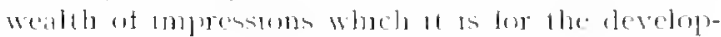

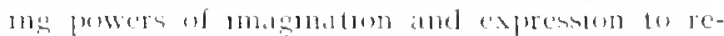
atrithese.

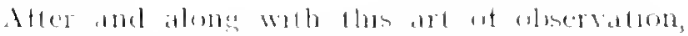

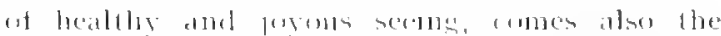

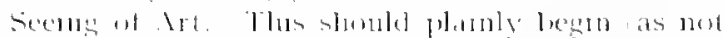

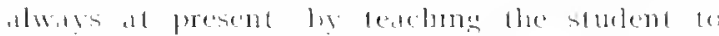

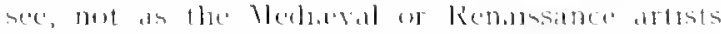

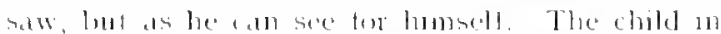

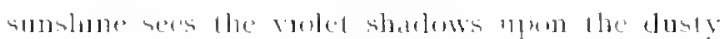

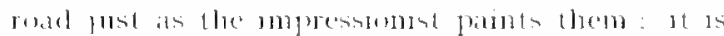

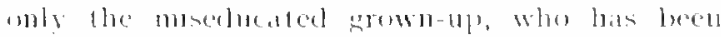

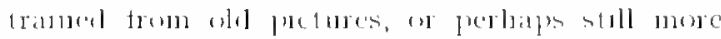

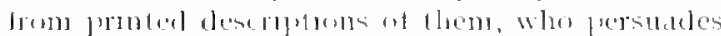

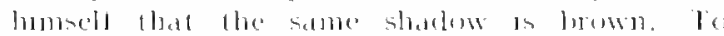

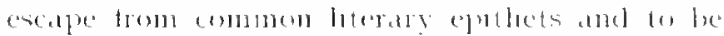

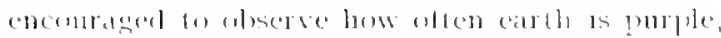

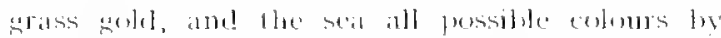

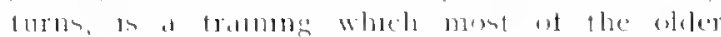

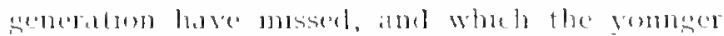

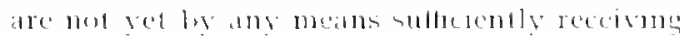

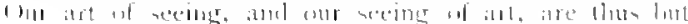

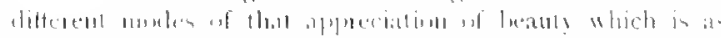

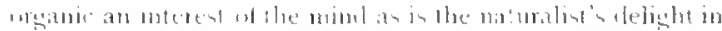

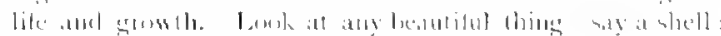

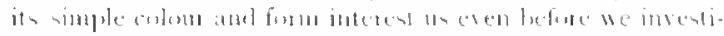

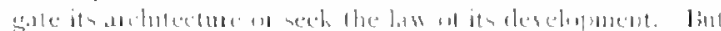

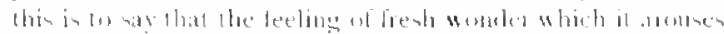

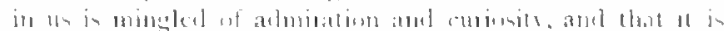

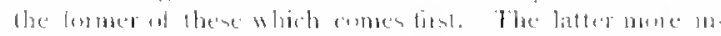

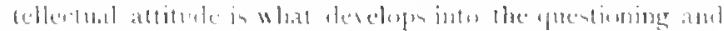

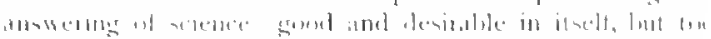

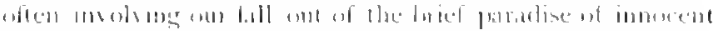

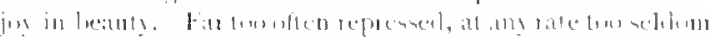

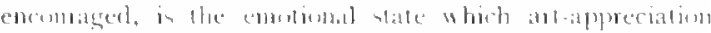

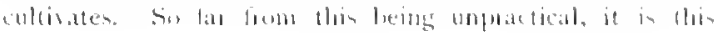




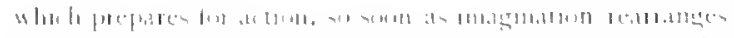

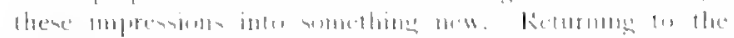

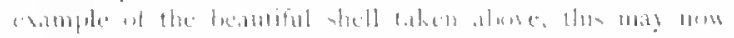

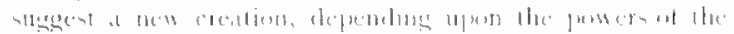

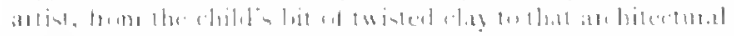

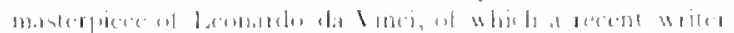

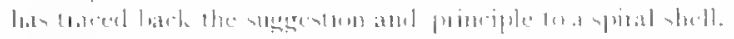

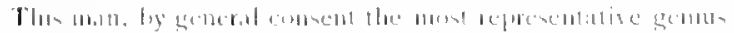

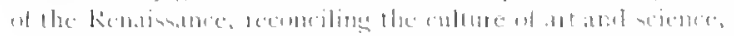

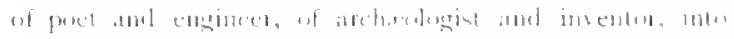

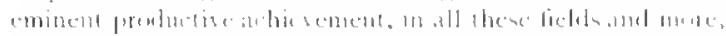

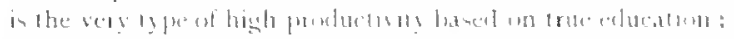

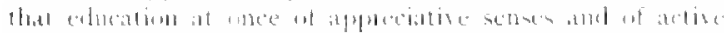

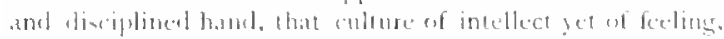

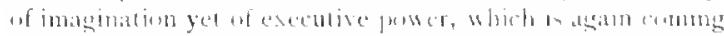

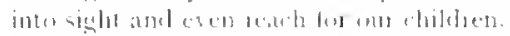

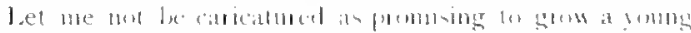

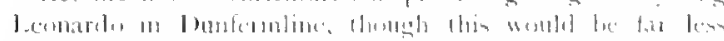

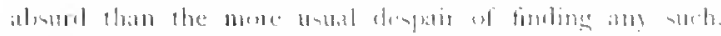

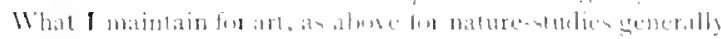

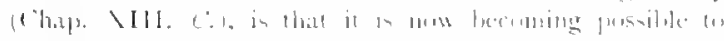

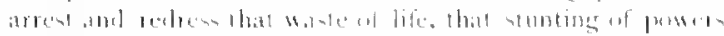

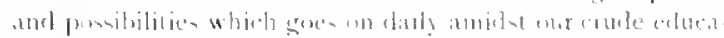

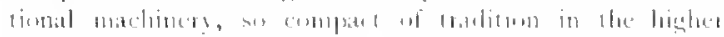

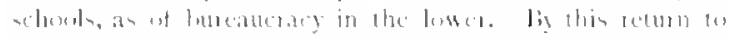

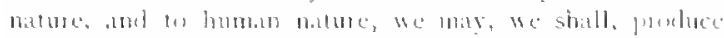

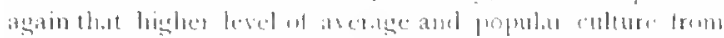

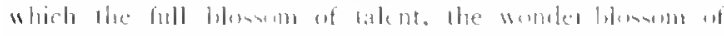

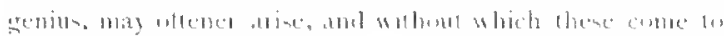

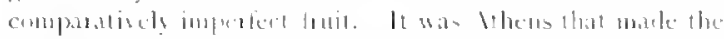

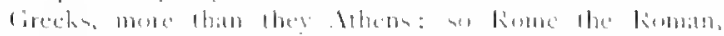

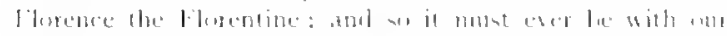

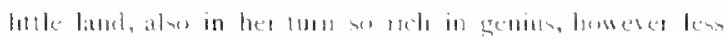
sucecunful in he renting af it.

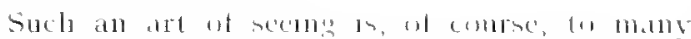

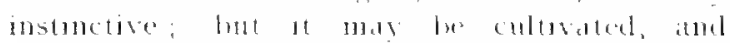

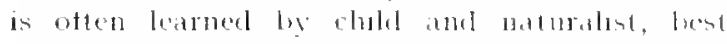
of all by those whe hate the somel tortume to

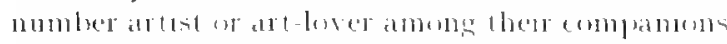
and finents. My pount ls that it an now possible

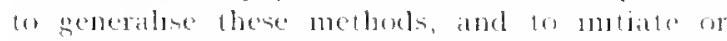

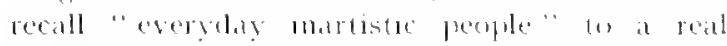

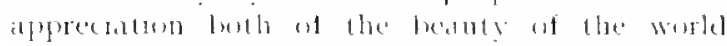
and ot the artiste rendereng al at. The can and

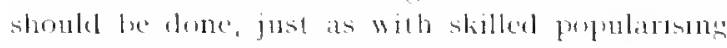

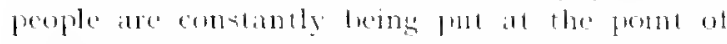

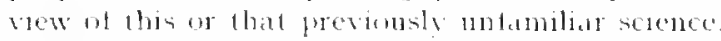
Everyoly kmows hy this tome that to walk ant

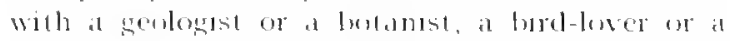
legester, ds to hatre his cyes mened lo things be

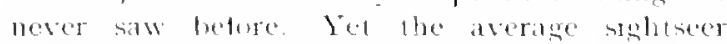

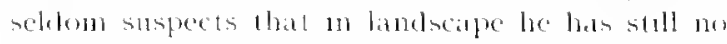

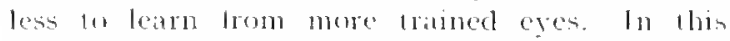
comnection I venture lo speak with a gomel deal ot exprimental certiture, alike as learner and ats teacher-in tate trom experence as dedinite as Whl seientufic nature-teaching, and of the sande kind, alike as gride an the open field and in line

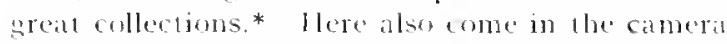

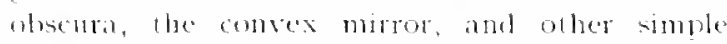
cyuteal devecs, which are of nowable aid to sering to the lewinner and cren to the artist. I'reesedy

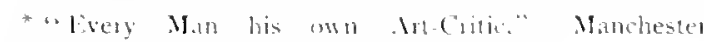

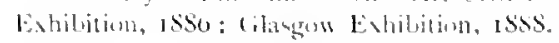

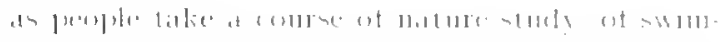

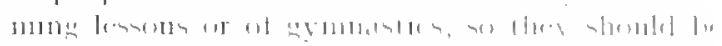

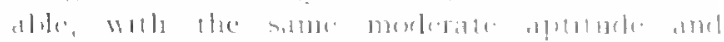

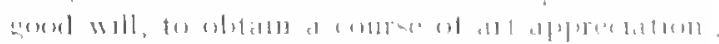

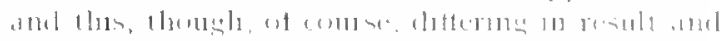

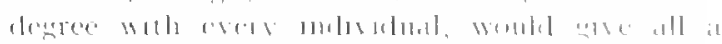

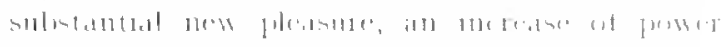

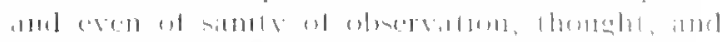

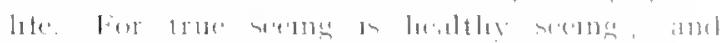

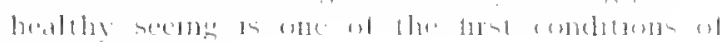

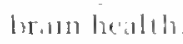

\section{Art Education in its Gencral Bcarings}

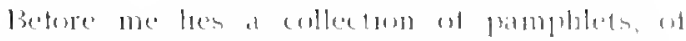

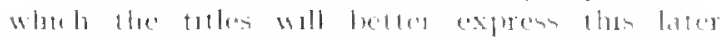

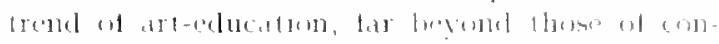

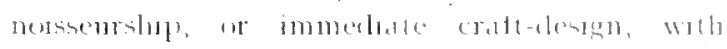

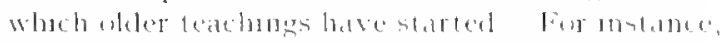

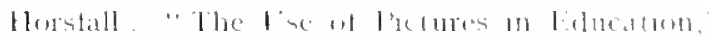

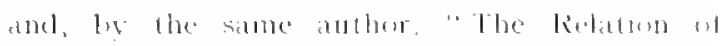

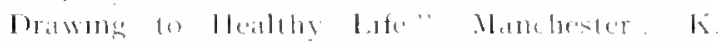

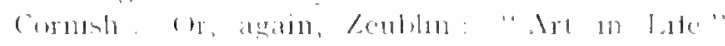

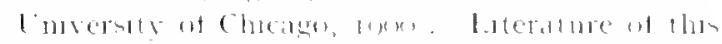

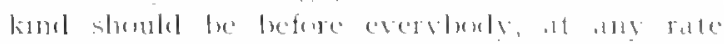

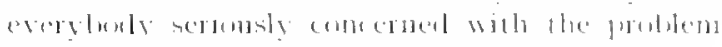

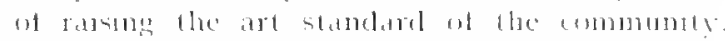

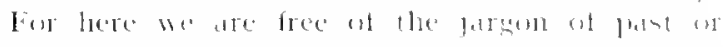

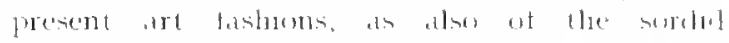

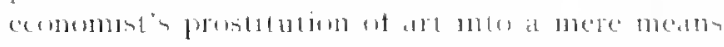

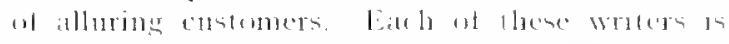

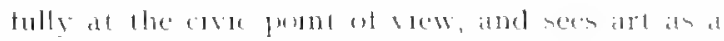

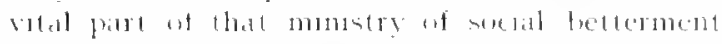

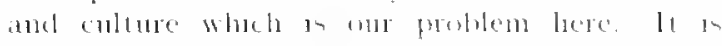

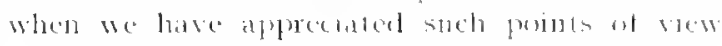

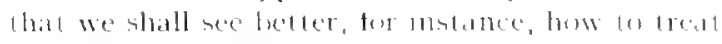

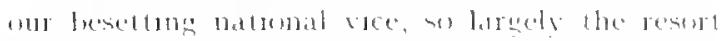

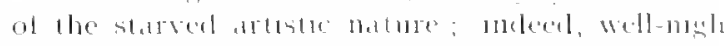

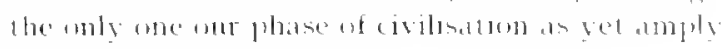
provides tor the freatile.

\section{Art for Arl's Sake Technical Schools and Muscums}

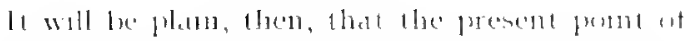

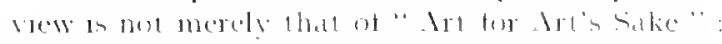

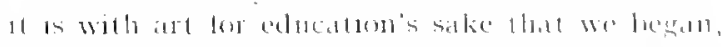
and woth are for the eny's sulke that we would

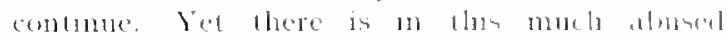

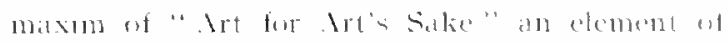
truth which needs nem an be reconsued. The element is that at technoal qualitien, anel m.1s

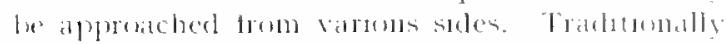

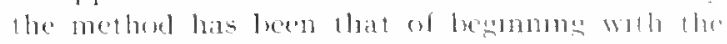

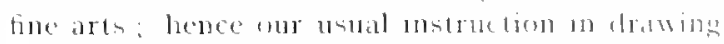

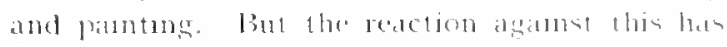
mow fully leegun, and the rise of arts trom cratle is now in progress. Thus, insteact of teaching crergbedy to draw more or less betally, and pros- 


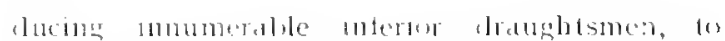
whom cratiomanshy) fluen serms d descunt m the social and artistic sale, we besin to supply at general basis of crafteducation, from whels special artistic tolents will far more realily arise. Hence asain the justrication of ont lamitive Villige, our Cralts Village. To dais recapilulation of the simpler craftexperience the more developer activities of a Techncal School proper woule] naturally be lintien. is such schools develup, thoin student will le less and less content withont preducing a geod job es jumbey. man, and sracluating with a masterpices, as of old: nu mere drawings or exercses will content bim.

Into the matter of Techncal schook I do not thinli it relevant here fo enter-not hut that at great development of both schouls and muscums, ete, m commection will the leading industres of the City and meightumbol may be expected. It appears to me, howerer, that such improved resources, in so tar as drectly bearing upon the staple industries af the caty and neighlourberl, moly pute faily be lett he the Trust to the ordmaty combe of educitional devolopment, such as would have been nutural and necessary in the city whthout any lrust at all ; otherwine, it the Trust step in to supply these, slatl we not merely have a case of that indirect relief of rates whim has been so expresily provided deainst? Local technical de velepments are to be expected in connection with the edncatumal changes now penting; and cren if these do nut tully satisfy lueal industrial needs, it is not the Trust which need be tirst callerl upon. Would not this le overlooking the natural organisers of sucle artwances-the local captans of indualy? If anything whatered is to be lett in their spectal knowledse and enlightenes ald-interest. 11 in surely such technical developmente, is of Texule Museums, Scluols, and the like.

I refrain, theretore, trom muluatus any purely technical musemom It my point of vew le nos approved, and the Trust see it desirable u establus or lo and stretly techneal muneums, these would dombtlens be sithated at or near the present Technical sehesl, and need not therefore, he cumbeled upon the present site.

\section{E. Exhibitions-Studios Art Library}

I leturn, then, (1) these possibilities of general at' turtherance, wheh are the main problem betore us here. The true way to foster the highent posshle development even of purels technical exedlence in our industries is, there can be no doulut, that which also takes part in the larger art movement of the world llance the inelirect but truly educative value of such an Art Exhabition as that reconly lude, presumbly only one ot many exhibuthes lo come.

Xlay I pleal that these Exhibitions ahomla be frepuent, small, and of specialised purpuse, rather than anmul, luge, and general, lake the too miscellaneous exlubitions of other lowns? lixhilutions at best are but museums of the mment, and neet to be vitalised ly relation (1) the real work of the world. Hence, then, ambler characteristic feature of our irt Institute ferond its exhibitiner and ith tearebing wh becomes tear. It shomld contain at least one stustio, it possible a proup of several; and in these should be contmually in prostess this or that piece of deconative worts for a buiklung of the Trust, a school, or the like Here, in fact, would be the true continuation and eulnination al the wortishope of the Cratts Village.

With the painter at wots, why not the sculptor also? Why should not an artist, instead of recoving a commission for a picture, he rather ensaged by lime-salary for specific tasks? This principle, whicl applacs sombiously for decorative panting, anel which hals been once and again found to be satisfactury to all conrerned, might also fatirly be applied to the elaburation of other undertakings of the Trust, at any tate to the fitting detail of their execution, as in wood-carving, mosaic work, ete. In this way the fullest possible comlact of arts with crafts, as of smith, weaver, embroidcrer, would he effected, and the artistic impulse deepened in the community. The existence of sucle a livine art school would not only interest the destgners and amateurs but through them stmulate the whole town: while it would aid in liecping up the artistic quality of the panoramic creations I have already indicated for the Nathre Buldung (Chap $\mathrm{CV}^{\circ}$ ). In this way we see, is a main tunction of the Art Institute, the carryng on of the task of the present volume, the development of park, sardens, and culture institutes: in lact, the improvement of Dunfermline in all its esthetic and technical aspects. Of the malerial atvances ut civlisation lhrongh Irimilive Villane, Cratts Village, llistory Buildungs, and Ilusenm of Mastepieces, here, in fact, is the flaming-room, the studio, and the sehoul.

As already suggested, a small lut well-chosen Art Library might convenently here he centred; at any rate an art Bibloghaphy : this should inclute furlance to the art books not only of Duntermline but of Edinburgh and Glasgow, so as to sive time to all concerned. I table with Art Journals and Magizines would be also greatly appreciated, and would relieve that pressure upon the ordmary library readng rooms which may be reasonably expected to arise as sonn as these hecome adequate. (ne of the olfires indicated on the accompanying plan would naturally be that of business administration; the other would serve for meetings and deliberations connected with art 


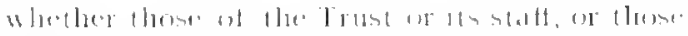

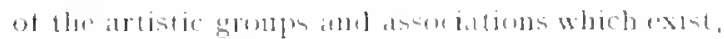

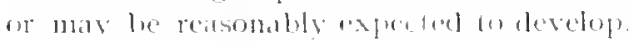

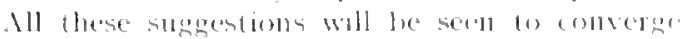

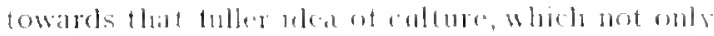

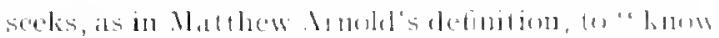

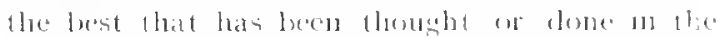

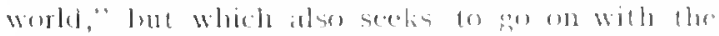

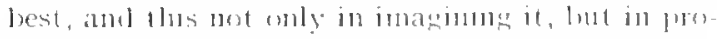
ancing it ln short, here is another cane of 1 he education ot experiences reflacing that of evercises.

\section{F. Colleetions}

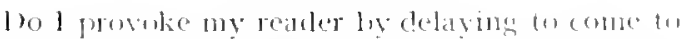
what is commonty consulered the essential matter of atu . Irt fustitute its collections a I must ander more refer to the puston taken np in precelme

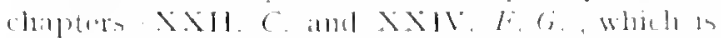
practically this that the art oljects of mast ardinary collectons shumlal le distributed into threeserin-ane llat of llistory, for which we halve blerally pustifed secomily, that of the lathology of Int, which we slould not here provide at all for; and thrily, that of the Husterpeces; ant it is for these masterpiece lluat I would tain plead that our gallery space should the reserved. The disinction of materpieces fron historical specinen" is, of course, not always easy, yet often punte practicable. Thus, for instance, it is olvions flut at collection of cyones art is of notalle hindoric interest but of hote artistic merit; while conversely, a selcction of Tanagra ligures, a goof breek vise or 1 wo, are masterpieces indispensahle to the smallest collection. The masterpiece should be approached with admiration that 1s, cmotion ally; the historic illustrative specinen is approached with interest and curiosity-that is, intellectually; and to use the one lor the other, as is $k$ o commoniy fone, in om museums - South kensugron and its nunor institutions for thorce-is to combine luo enth on one hand a training in almution of the merely curnus-that 19 , the unbeautitul; will, on the wher, a merely informational--that is, inartistic-use of things leatutiful. It is this use of science to spoil art, Which is at the ront of the comparative melessness of what should he our greatest educitional treasure-hounes Thus eatu museum, begun as a paralise of lreauty, lets in its serpent, and prepares its rum

Just after lesigning a temple to the muse of history, such as she has never in this world possessed, I may le pardoned lor refusing to surrender to her impartial serial presentment the master. pieces of heauty also; these neel surely a un less distinct temple of their own, smaller yet not inconsiderable, and not necessarty neglectul of historic gromping, though kept apart from ordinary presentment of it An l thereby neglecting the

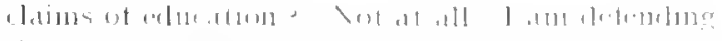

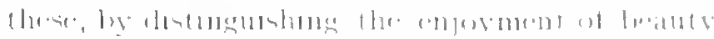

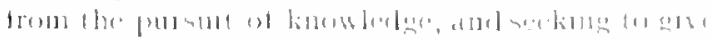

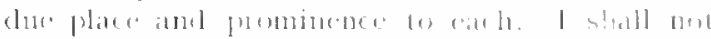

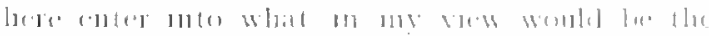

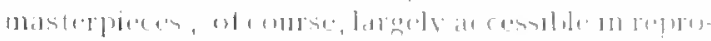

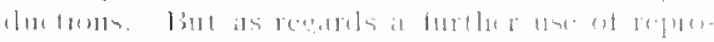

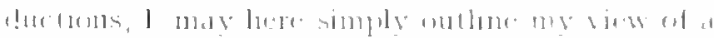

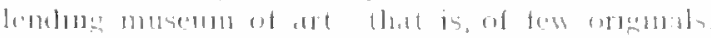

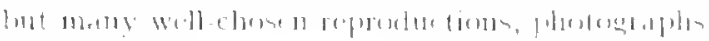
atill lomslis.

\section{G. Lending Museums}

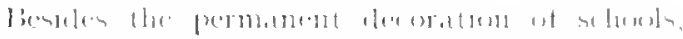

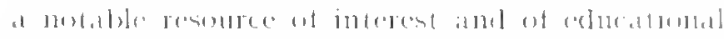

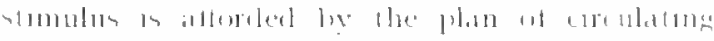

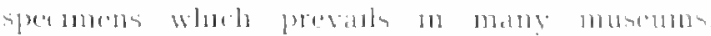

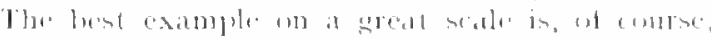

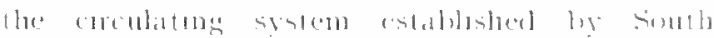

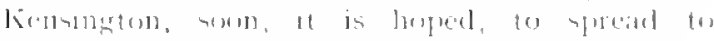

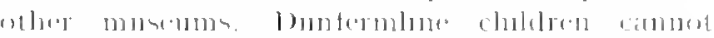

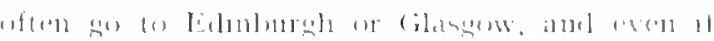

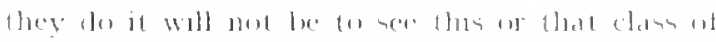

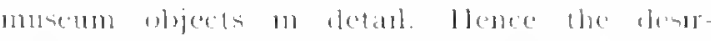

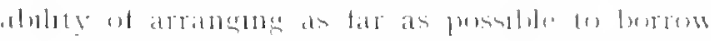

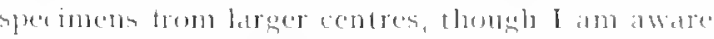
that on many astos parliamentary powers would

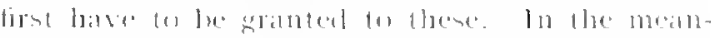

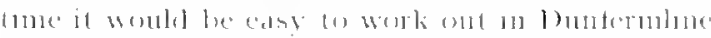

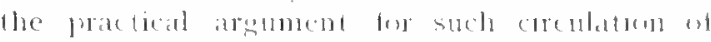

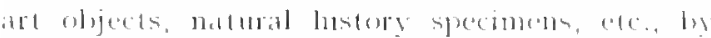

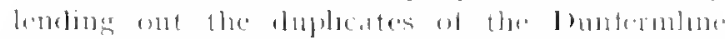

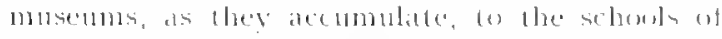

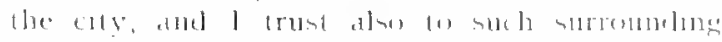

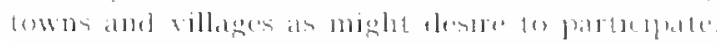

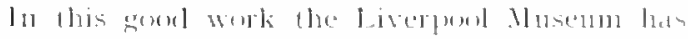

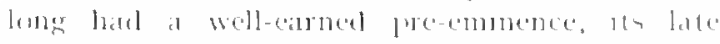

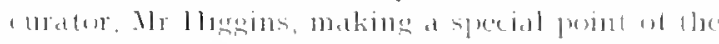
trealuty of the collectums which he wath acenstoment

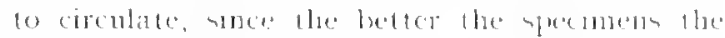
more impressom they create lla was wont le mantain, and whth erealt justece, that the interion

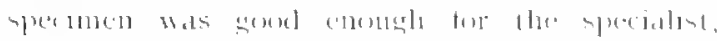

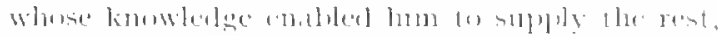

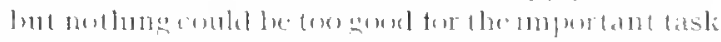

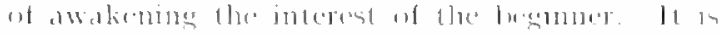

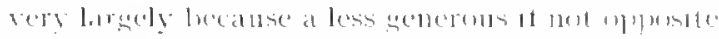

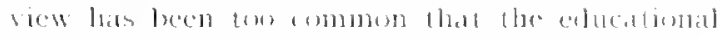

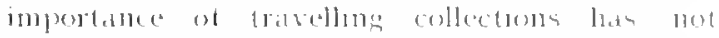
already lecen more fully entalblialied.

Amerour traning collegess also corry this

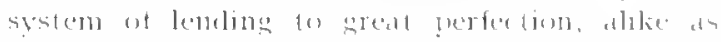

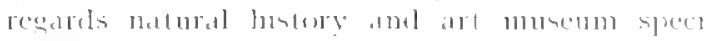

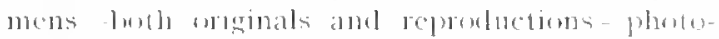

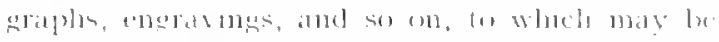

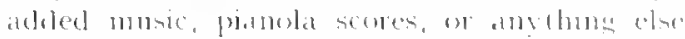

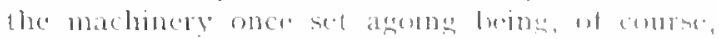
adaptable 10 all sorts of refpuremente Cireal

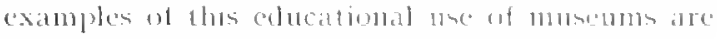

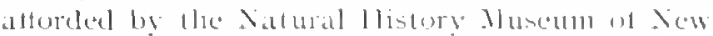




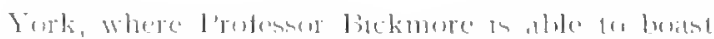

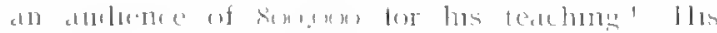
magnifuenth bllustrated lectures at the contral

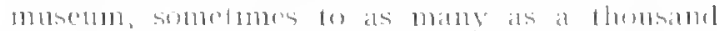

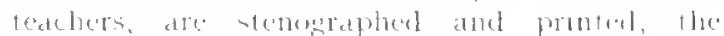

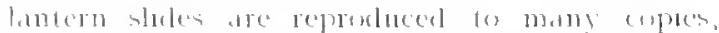

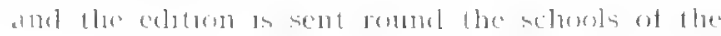

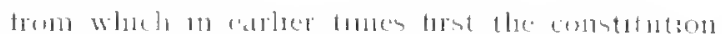

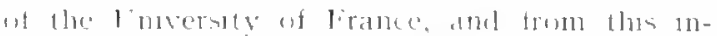
duretly, m turn, that of the lonversty of london

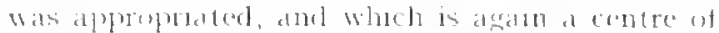

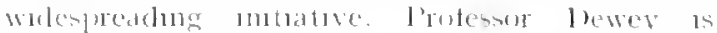

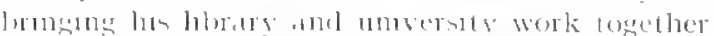
nuto an extending sistem of l'nveresty lixtension,

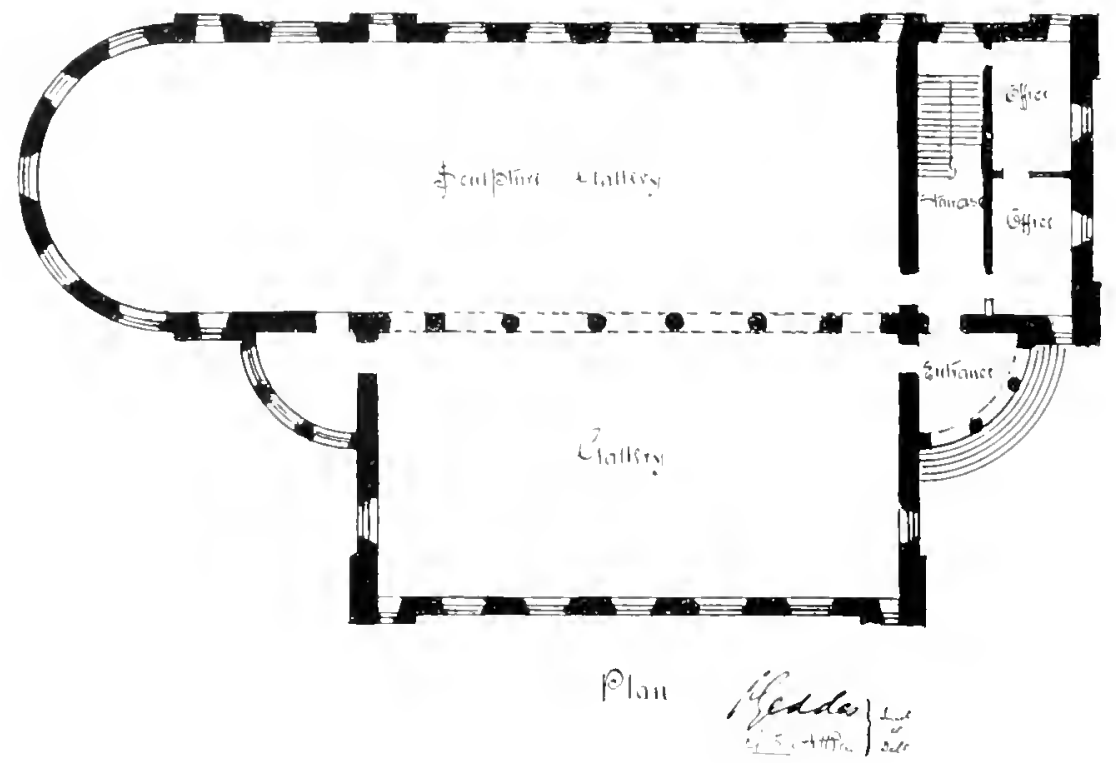

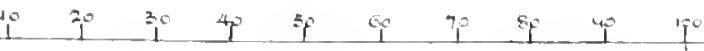

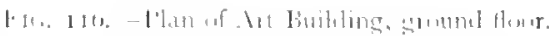

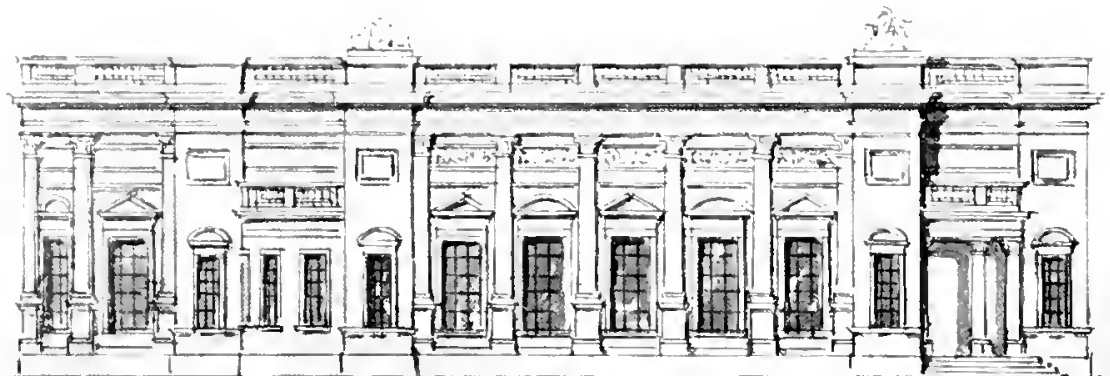

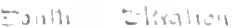

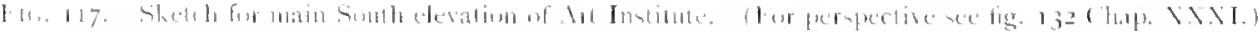

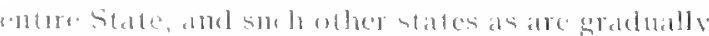

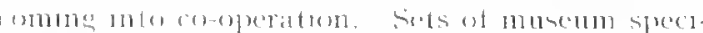

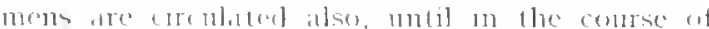

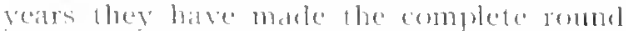

In even more axtrarelinary organisation, at veltalle statl-otfice of thes atgresesive colture, is

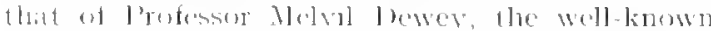

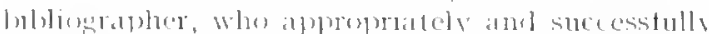

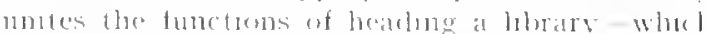

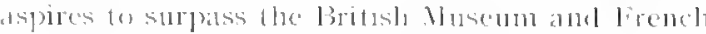

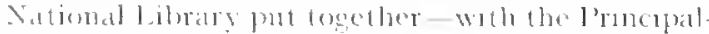
slup of that remarkable lonverstg of lien lork

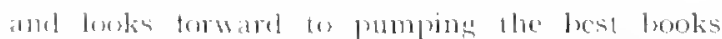
and conteses of reating trom has central reservoil into evers one of the million households of the sitate. This, astum, we may assocrate with the at mosplere of chantaluplat and its kinelred mosements, which, however, maty he more conveniently descussed elsowhere.

1 press thes prometiple of circulation for a reason obrens to all, vet constanthe foreotten that an denent of change is constantly needed to reatwaken merest. Even actasinnally to alter the hanging of puctures in the same romn groes them a new 
freshness. It is largely by the fuller use of the plan in the Japanese luestseholel that the cospusile sensitivereses we mature ant art alike, which is 40

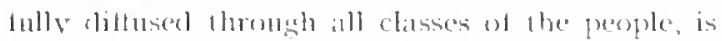
develeped and maintatmed. The new hook trom the library is more likely un be reat than that upon unt shelves, and so the small consignment of fresh sperimens trom the balrge musem will be looked more keenly it by leachers and pupils alike than any jermanent treasure. I have lately visited the fincs school musem I have over seen, one lull of oljects ut which any greater collectuon might lu promel, vet practically unvisited he rither box w masters, who, ferling they relucation in art I mean the inoreatsugle general

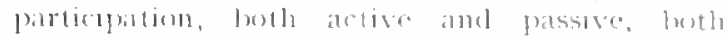

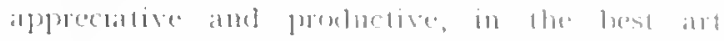

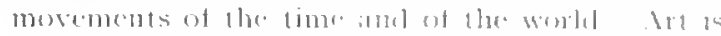

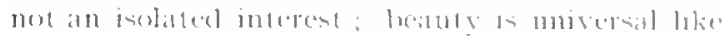

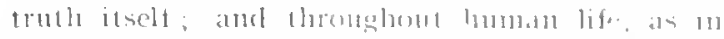
mature, there is at contimual strusgle of beanty lo

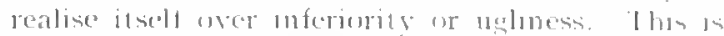

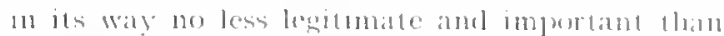
is the strofe of truth wath error an the world wit

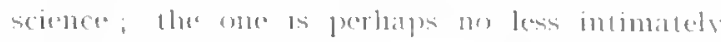

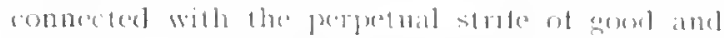

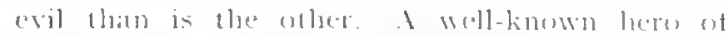

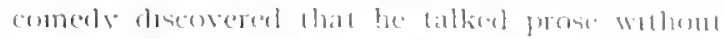

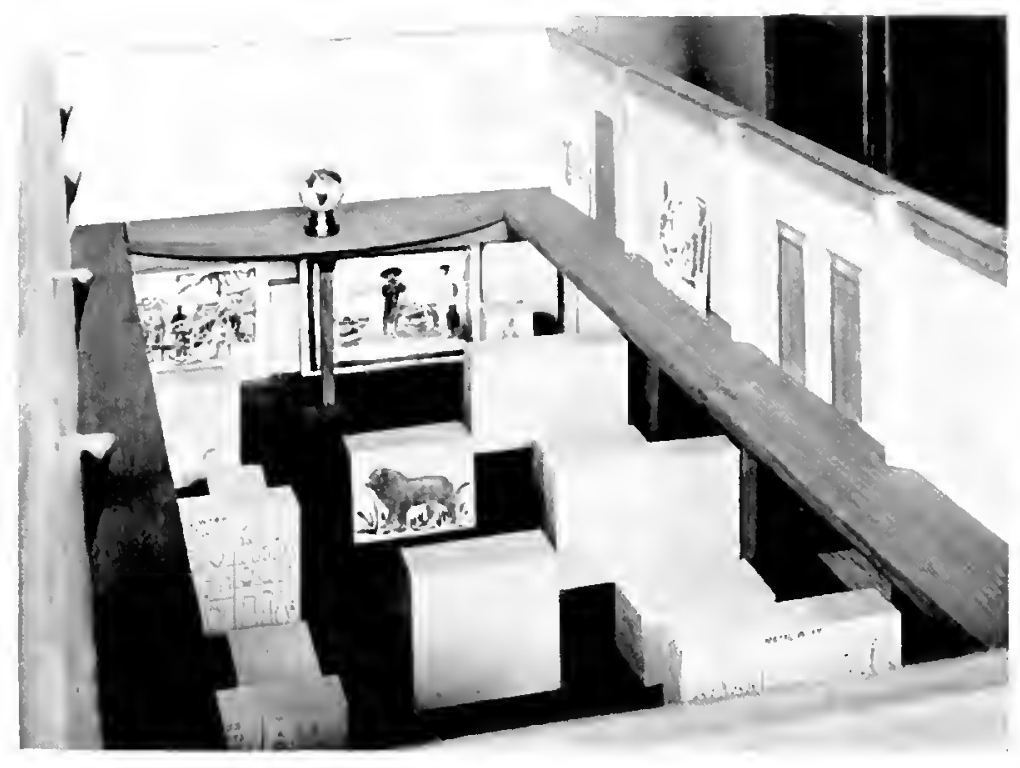

Far. ats. Indication of the methend recommended for the furthes

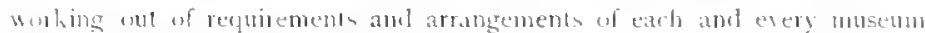
building lefore completion of plan-i.e. by mean of an actual medel. with

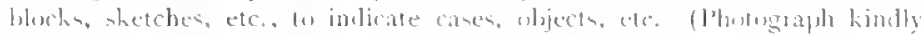

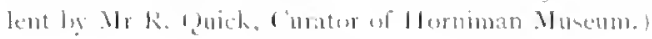

can see them at any lime, hardly look at them at all. The same is true of university and cren national collections. Let Duntermline, then, begin to act more and more fully, as the regional cullure. capilal she is again becoming, and lorighten up her surrouncling towns and villages or gencrous and regular circulation of her ever more aloumbling best-so pioncering all once in cultural advance and educationil helptulness.

\section{$H$. Higher Art Education}

"Higher art elucation." Mhat is to he understnol ly this? Xot, of course, more grades. examinations, and certificates. Sot alone the encouragement of individuals ol nore developed skill, more genume productivily. By ligher linowing it: so, whether we notice it of no, wh arc each and all expresing our preferences and giving onr influence-that is, taking nur part-in this or that erolution of art we are realists or comventionalsts, idealists or symbolists. These atje clitterent altitudes of mind which appear on each and every level of culture-nay, are aldedely batent to evervone who has bech arouseal io ubserve them-in the play of children, on reverk. m even consersation, and in current literaltur. most plainly of all

l.et no one think that these artistic allitudes may be all verv well in l'aris, or exen in Glasgom, but are not necessary for Duntermline. Surely no culture problens in interests are foregn (1) us bere, least of all one so mtilitarian, practical, inclustrial. 11 is a motional aftectation at present not to take art seriously: hence, even at its rare public appearance, an tcalemy dimner, the gllests 
Me wont to beture the artist npon politics, insteit of learning from lam to see.

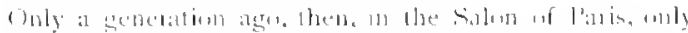

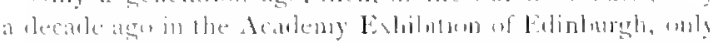

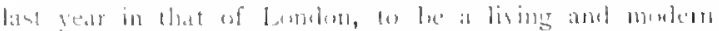

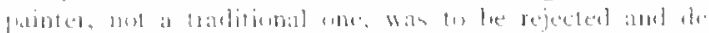

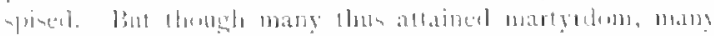

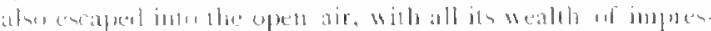

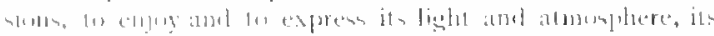

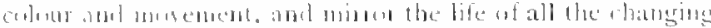

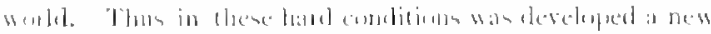

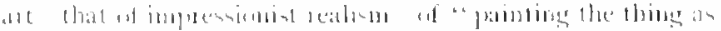

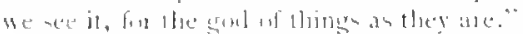

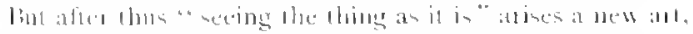

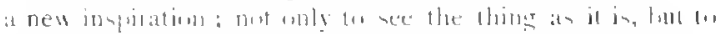

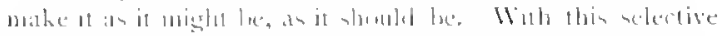

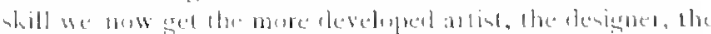

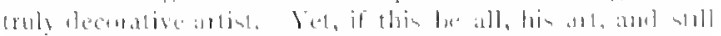

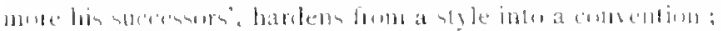

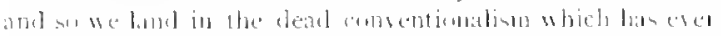

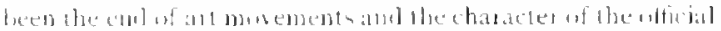

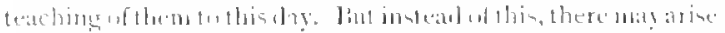

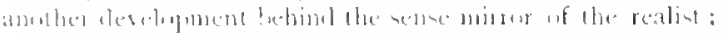

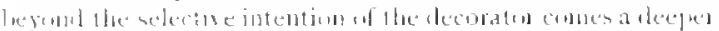

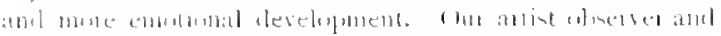

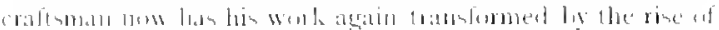

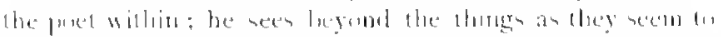

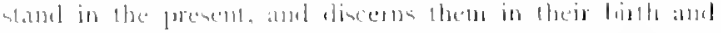

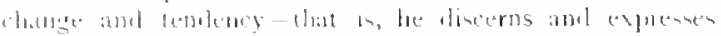

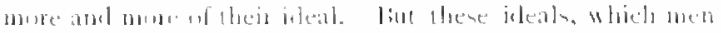

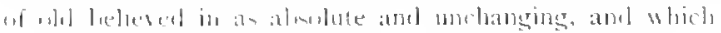

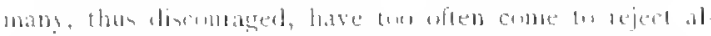

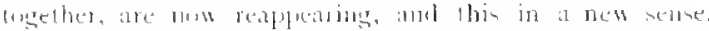

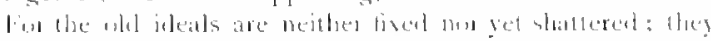

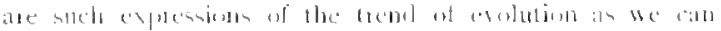

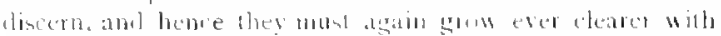

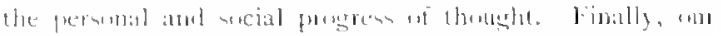

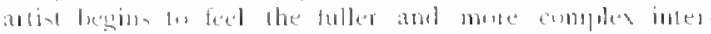

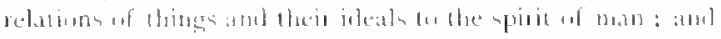

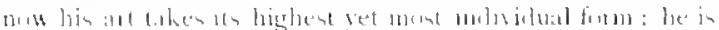

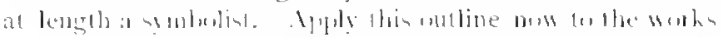

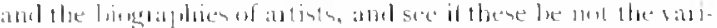

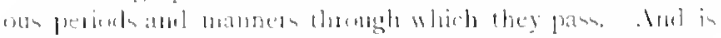

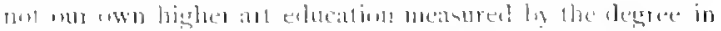

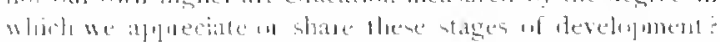

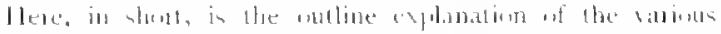

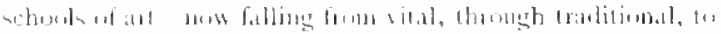

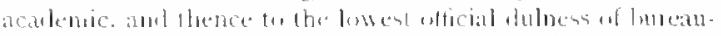

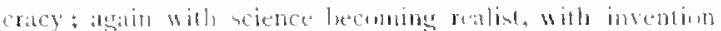

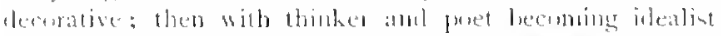

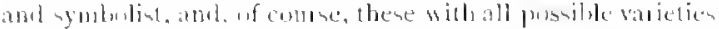

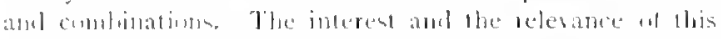

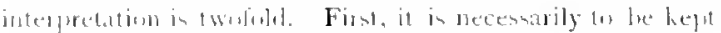

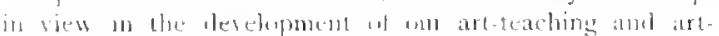
treatationg:

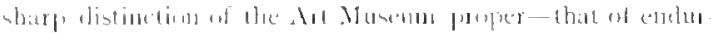

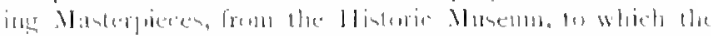

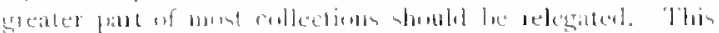

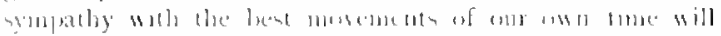

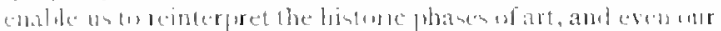

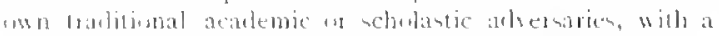

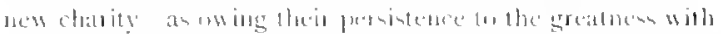

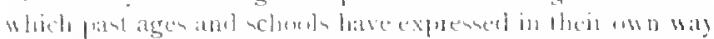

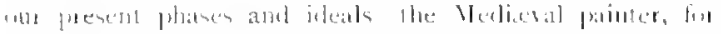

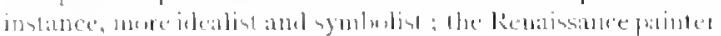

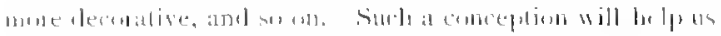

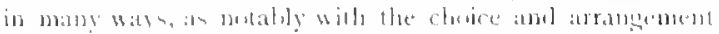

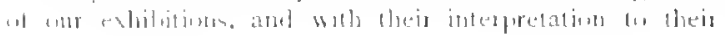

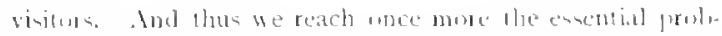

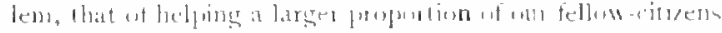

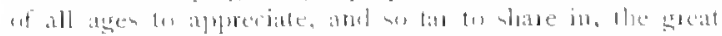
mesemesila ar arl

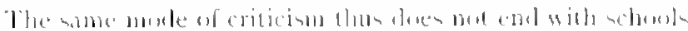

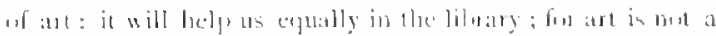
mete syceial colucation, an perlant thisk, it in a general

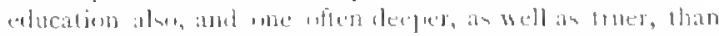

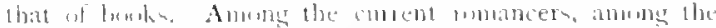

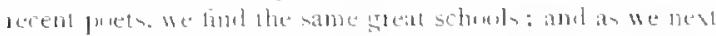

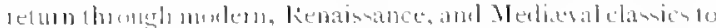

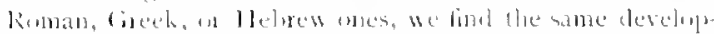

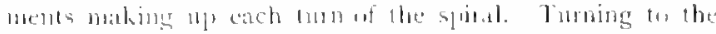

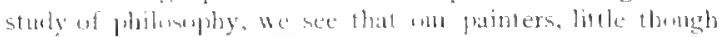

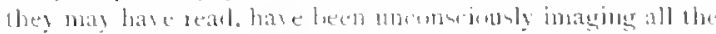

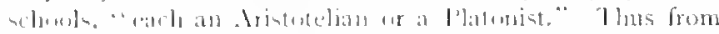

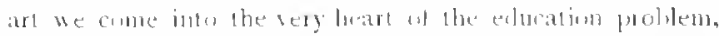

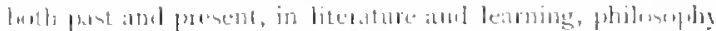

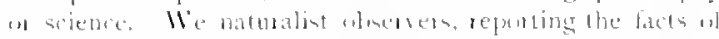
natuse or life an we find lown shether for the reichitio

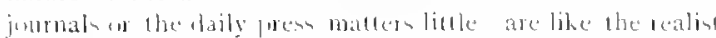

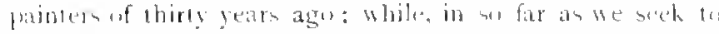

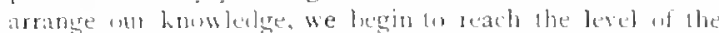

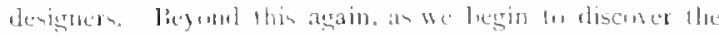

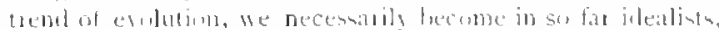

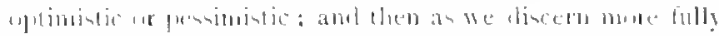
the comples inter-gelation arul unity of things, and their

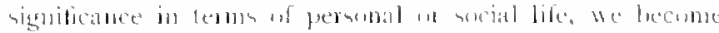
so far broululinto.

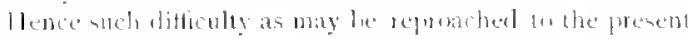

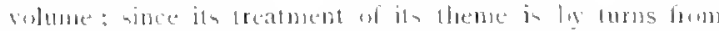

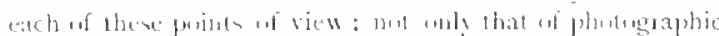

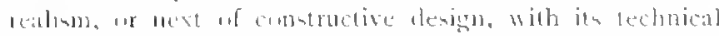

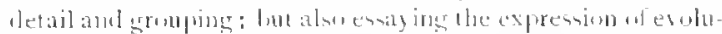

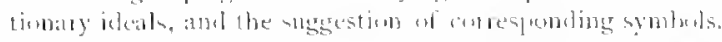

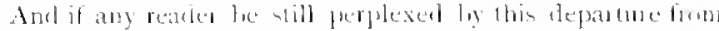

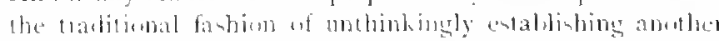

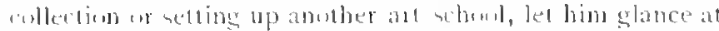

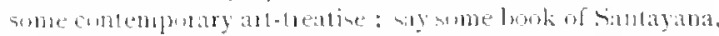

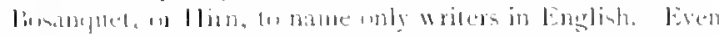

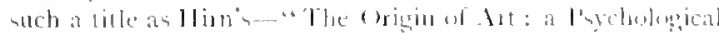

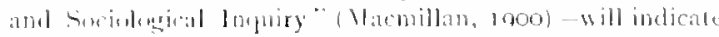

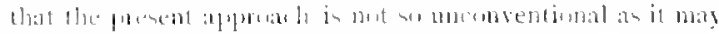
aํ.

\section{Final View of Art Institute}

Lease now art for science, which is commonly taken more seriously. Nin one any longer doubts that the current social evolution is one which science is slowly but surely transtorming, alike in war and peace. But what of the details of this? Jlunt it not soon become olvious that just as the stone age is divisible into two very well-marked and distinguishable periods-the "l'alumblhic," with its coarsely-chipped inplements, and the later "Xeolithic," with its finely polished ones- so two such phases are hecomins recusnisathe in un modern technical iviltsation ${ }^{2}$

In ong loimitive Villuge we shonld sce and show how the rude stone age with its ronghchipped thints became repliced not only by the culture of a finer age lint hy the man-one not only of adranced knowledsu, but ol higher industry, of nore develped art. In this 


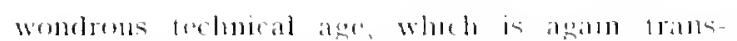
torming the world and histors, do we not recill

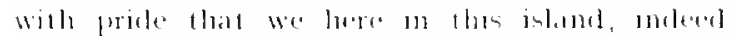
in the partionlar central region ot at, have leen

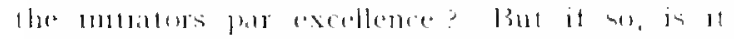

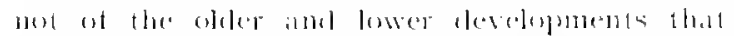

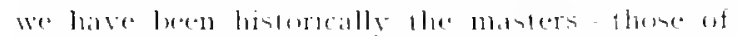
conl and steam rither than these of electricity and at? Must ne not, therefore, call thin earlier

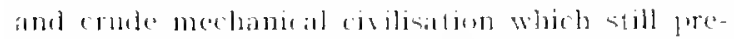

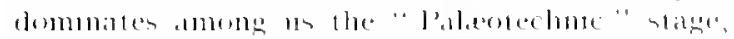

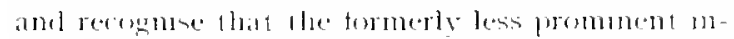

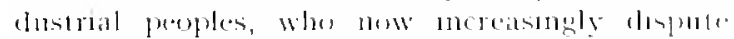

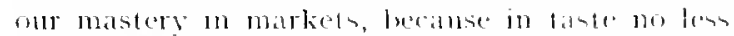
than in secence they are excellung us, alle passung more efuckly than we mot the "Noutehnic"

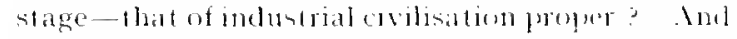

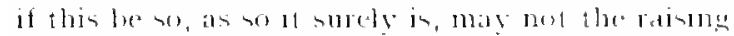

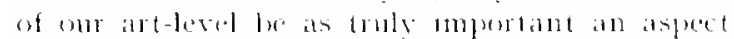

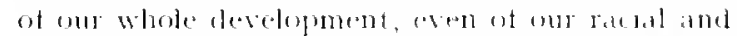

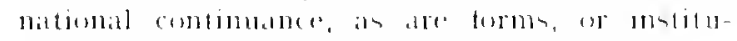
tions, or policies at present more pominent?

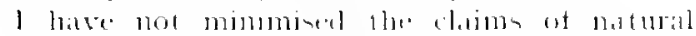
science, ot history, or of sochal semenec ; yed l colle not refrain trom expresing the combotum that

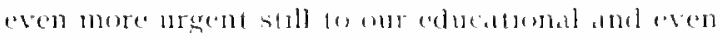
ont social hetterment is lhe poblem ol a real

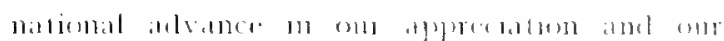

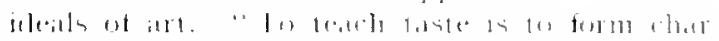

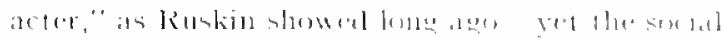
retormer, steetalemp

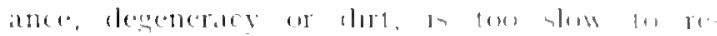

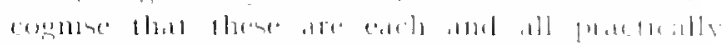

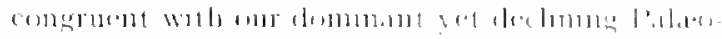

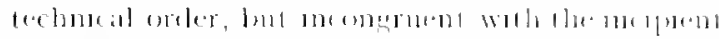

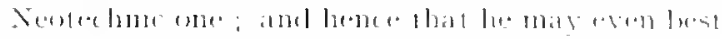

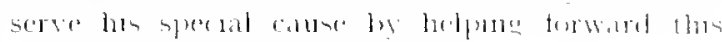
latreer morement of the athe

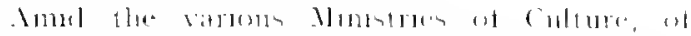

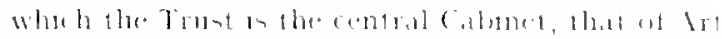

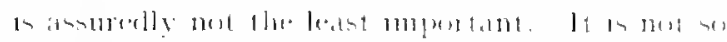

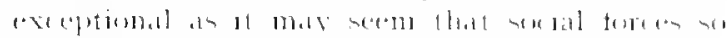

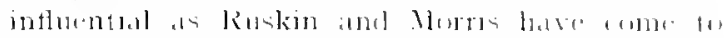

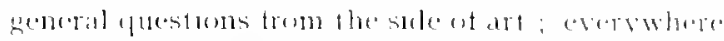

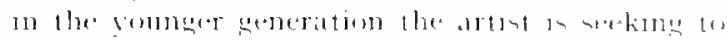

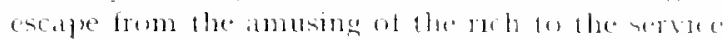

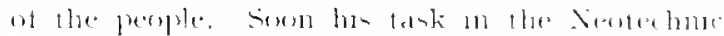

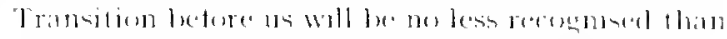

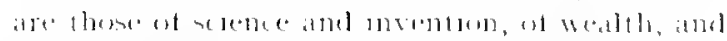

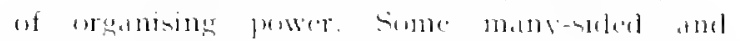

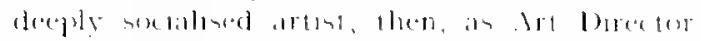

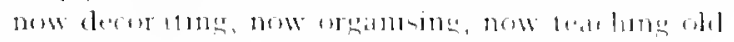

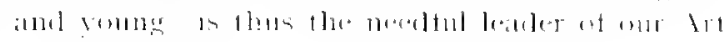
nurement. 


\title{
G. LIFE AND CITIZENSHIP
}

\author{
CHAPTER XNII \\ SOME EDUCATIONAL BEARINGS OF THE SCHEME
}

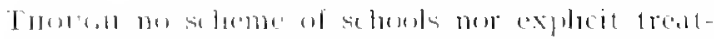

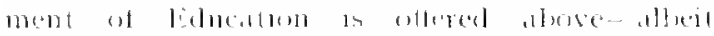

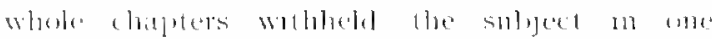

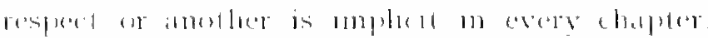

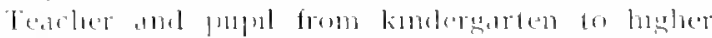

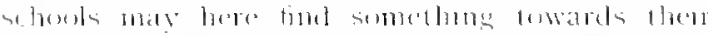

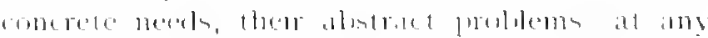

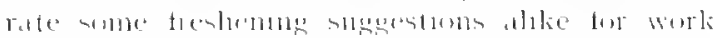
and platy.

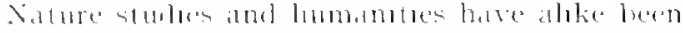

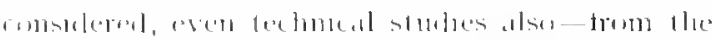

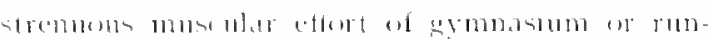

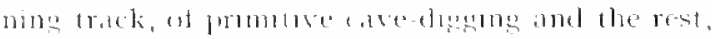

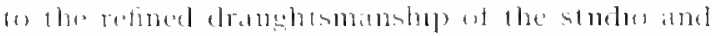

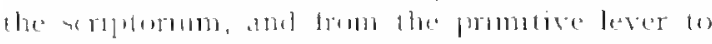

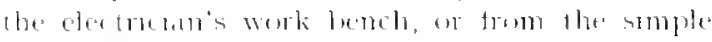
the the complex $610 \mathrm{~m}$

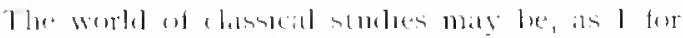

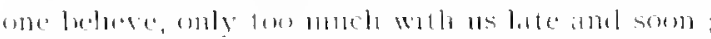

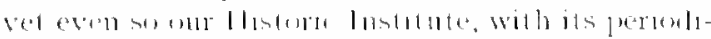

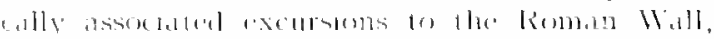

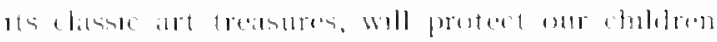

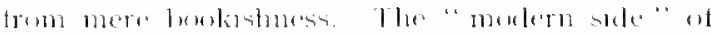

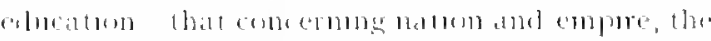

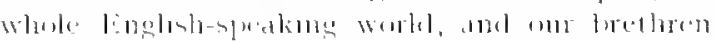

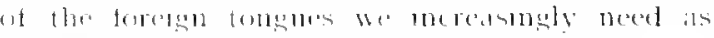
well- is all presented more tully than ever to

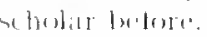

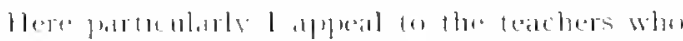

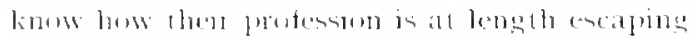

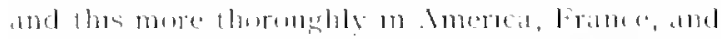

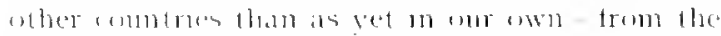

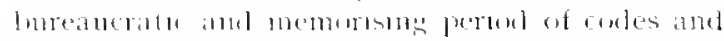

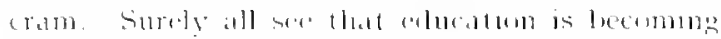

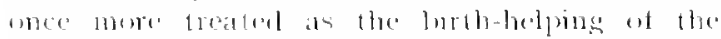

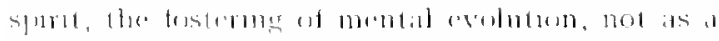
maller of mere aredenule exereises and official

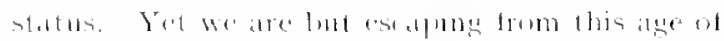

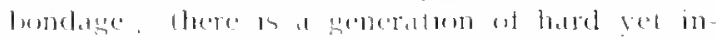

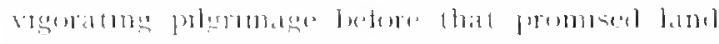

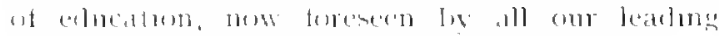
sponte, can $1 x \cdot 111,1110,1$.

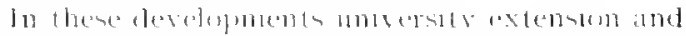
such morement play thetr part, and the opportombles for at are bure. Gur new nowsems or

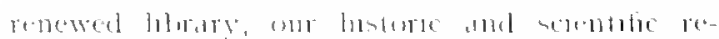

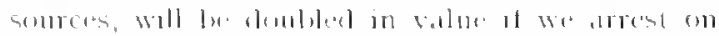

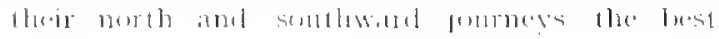

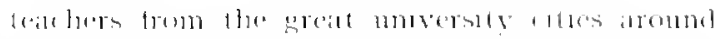

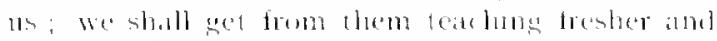

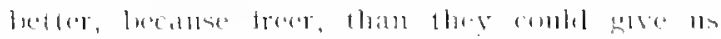
tome that ow thats

\section{A. Summer Schools}

Mont mportant of all, we teachers, as we trans-

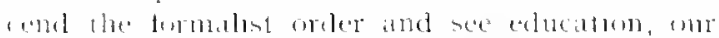

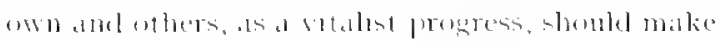

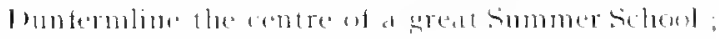

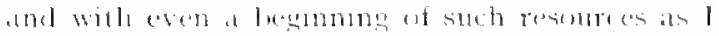
am stegersong absse we comblend womb do so.

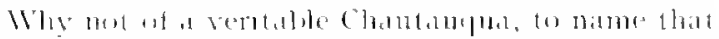

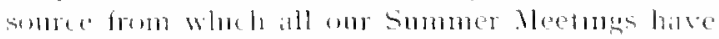

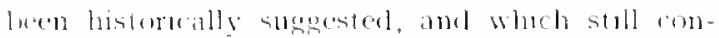

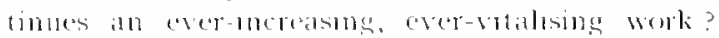
lome expersene of a small and early begmnme ol

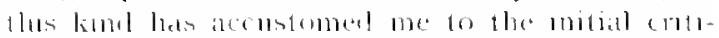

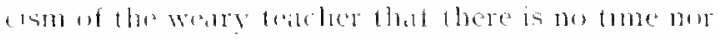
strelugth lett on the summer salcation for more work but thuse wh renture to try th swon appreciate the new sprit, and unterstand with a new freshoness low the ancient, the true and perpetual meanng

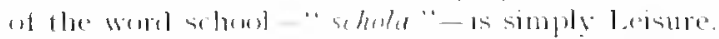

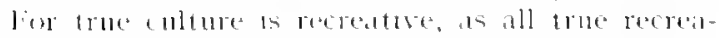
tom is cultural, develephng not only the ludy or

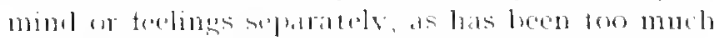
the citse m our own tome, lout umbine all tegether

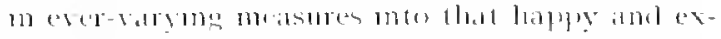
fomelong mity of tometorn, whete is Late.

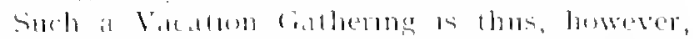
mol so muld tor the bexly of the teatelers ot Dinfermlane. (hange is needed, and to them the

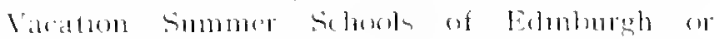

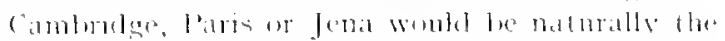

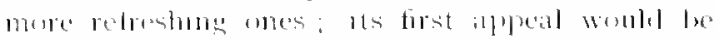

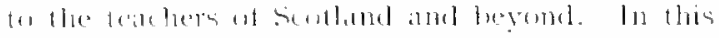

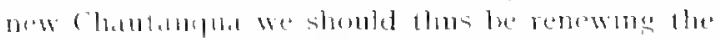

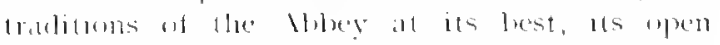

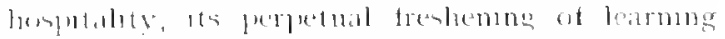

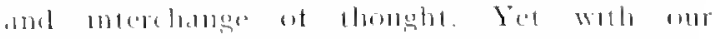

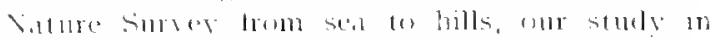

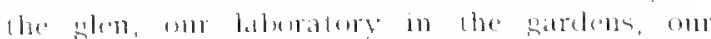

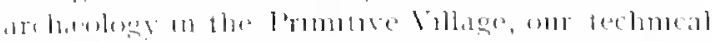
metrut tom on the gardens and at the molls, our

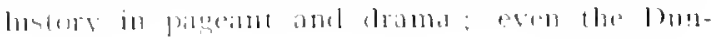




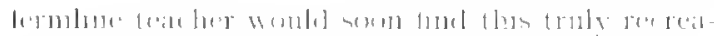

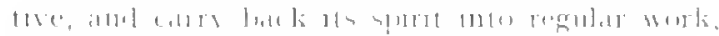

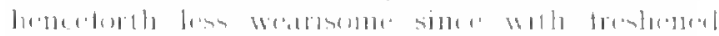

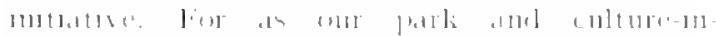

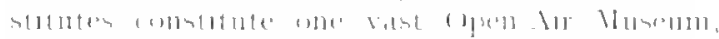

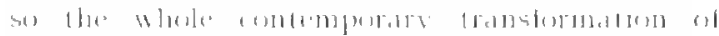

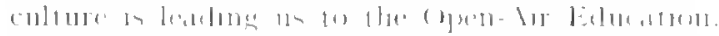

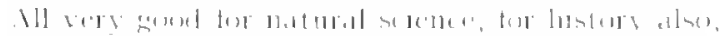

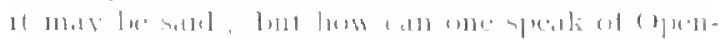

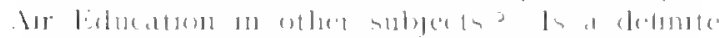

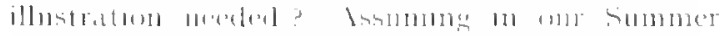

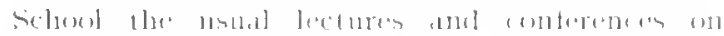

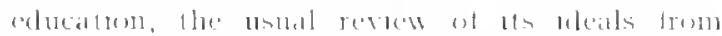

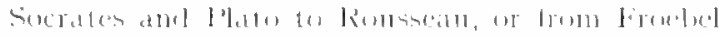

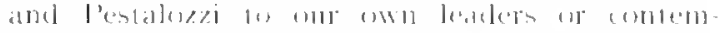

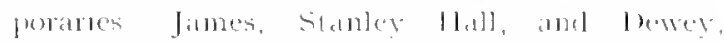

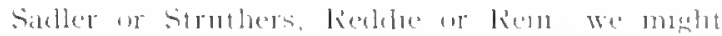

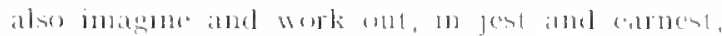

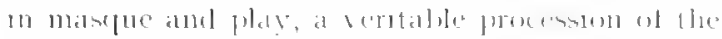

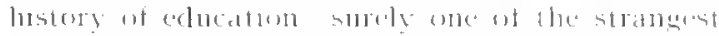

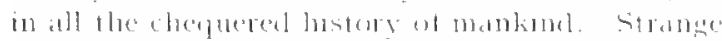

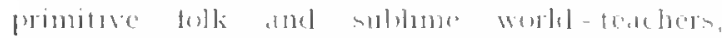

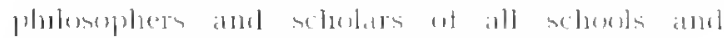

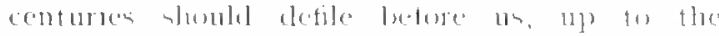

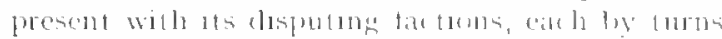

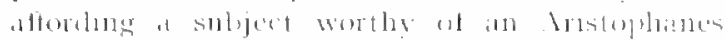

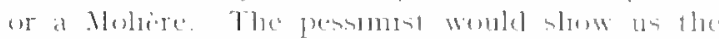

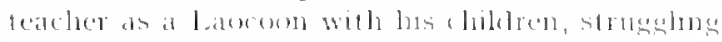

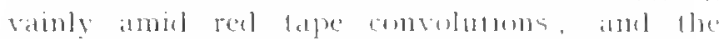

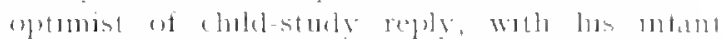

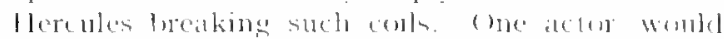
popularise the atr ot alternate suallowing and

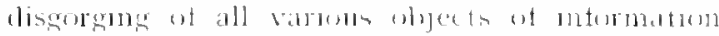
in als smpler conjurtur lorm, amel amother solemuly awarl fertificates and dplomits for proficency in thes with all the sellenunty at alder

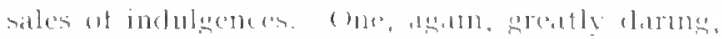

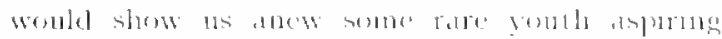

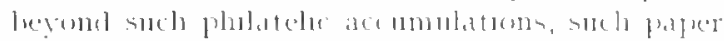

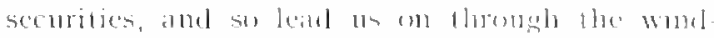

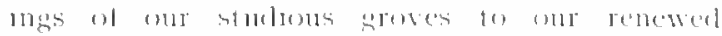

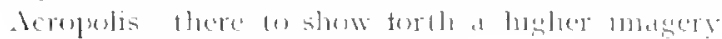
than I dare onthe here.

\section{$B$. Relation to the Universities}

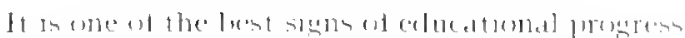

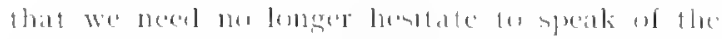

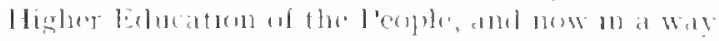

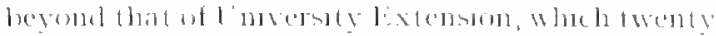

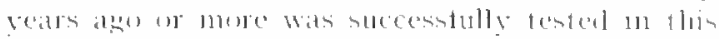

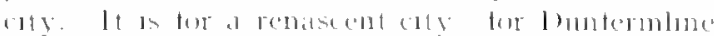
then, lust at all to malie ber reture tor all the

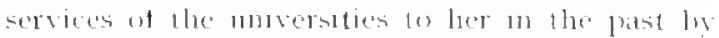
helping to vidise these andew, W worting ont tor thems, even ahered of theme tor a seasm, thes and llat element of that lelucatumal kevolutum which is an progress thronghent the worlal, and which the weight of insular trathtoms, est present resjunsibilates, makes se peculatly detterent for them.

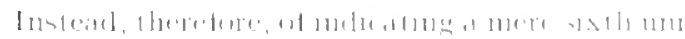

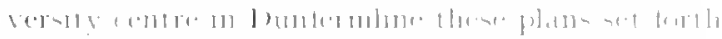

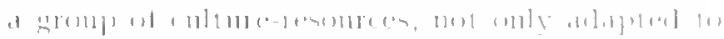

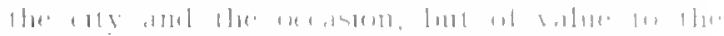

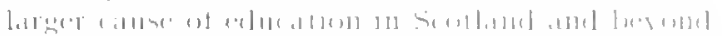

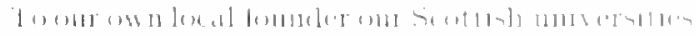

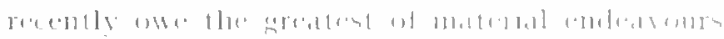

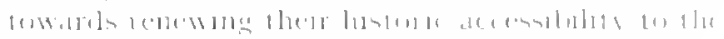

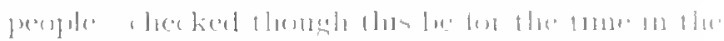

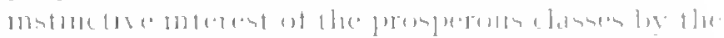

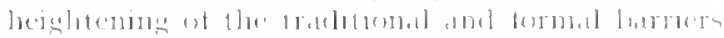

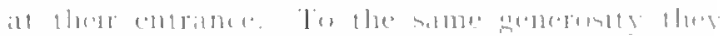

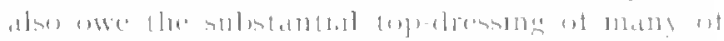

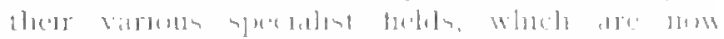

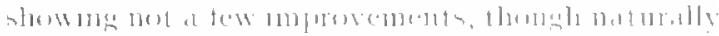

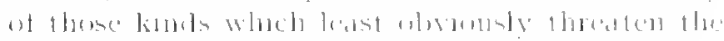

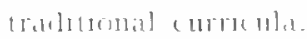

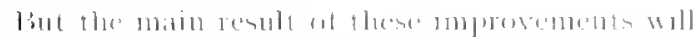

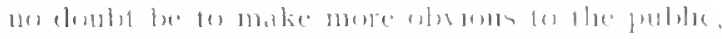

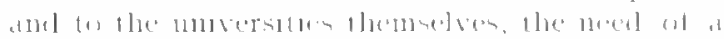

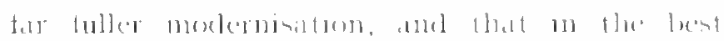

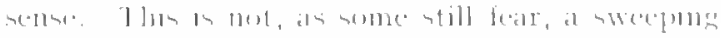

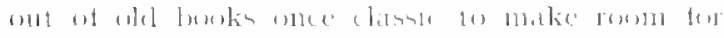

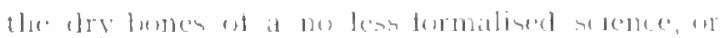

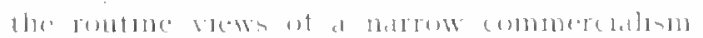

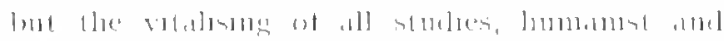

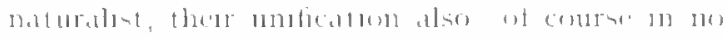

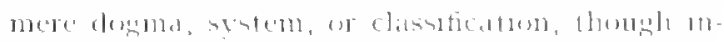

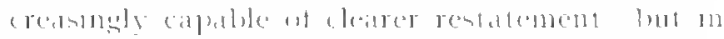

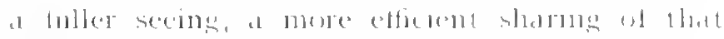

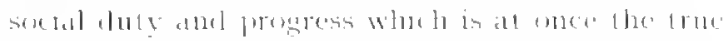

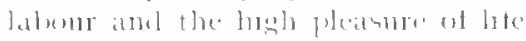

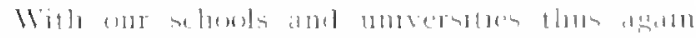

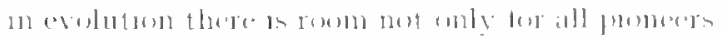

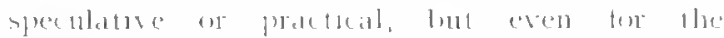

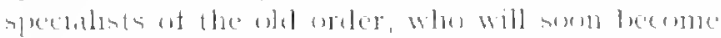

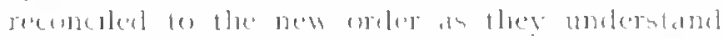

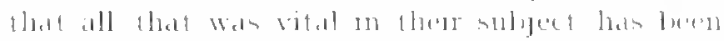

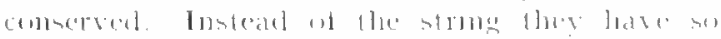

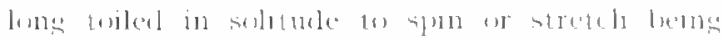

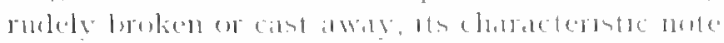

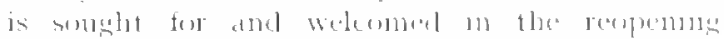

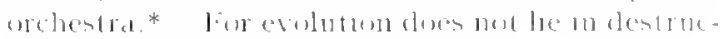

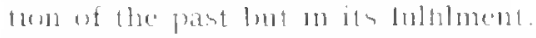

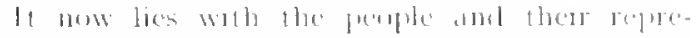

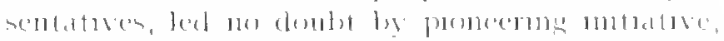

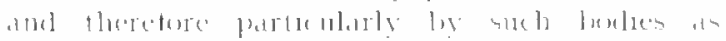

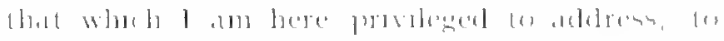

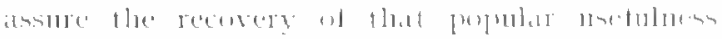

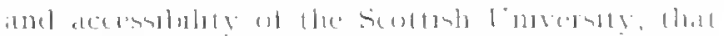

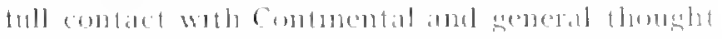

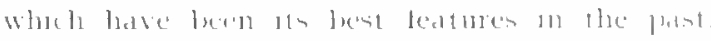

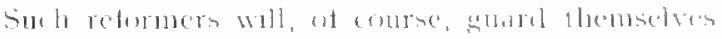

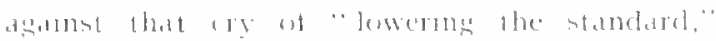

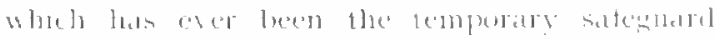

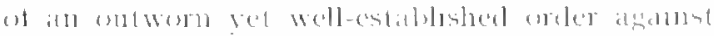

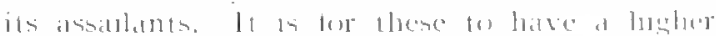

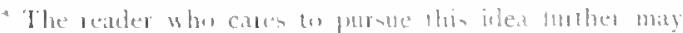

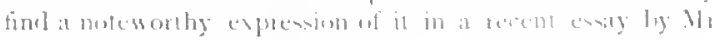

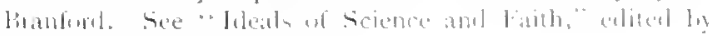

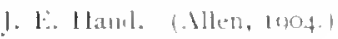




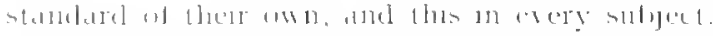

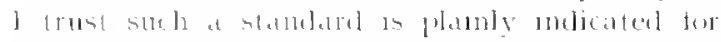

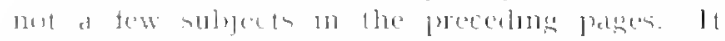

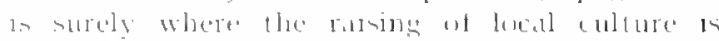

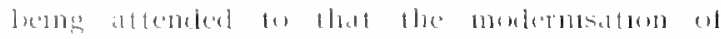

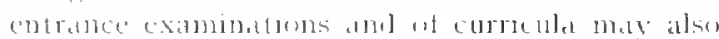

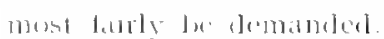

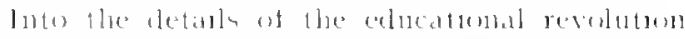

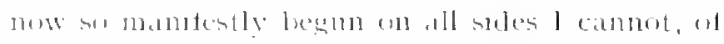

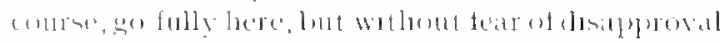
trom any ] ] ar promary, I maty debme them as a change from

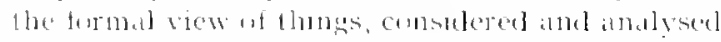

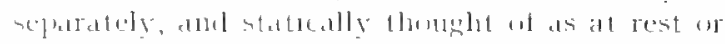
deald, towath the vital or kimple vew-the sonthete correlateon of all studes, henceforth

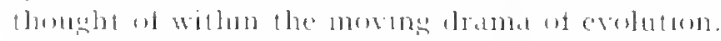

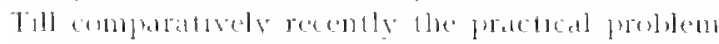

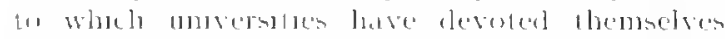

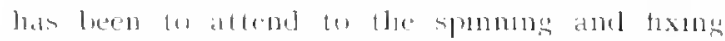

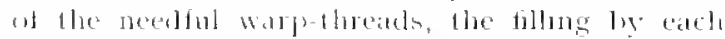

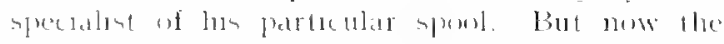

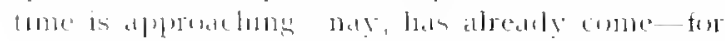

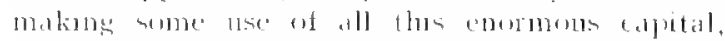

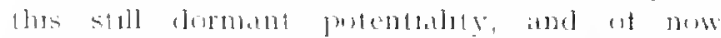

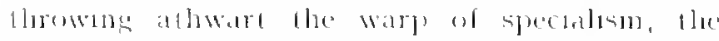

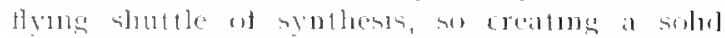
fellore buste at warps and wowt.

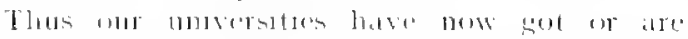

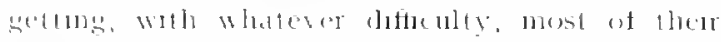

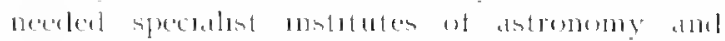

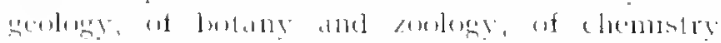

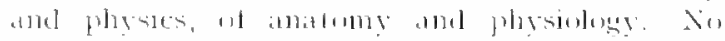
fombt all these need tuller derelopment; yet it

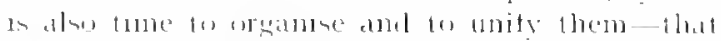
15, by the corespentung development of these

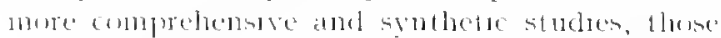

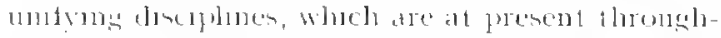

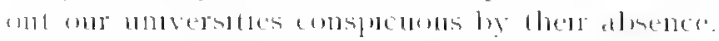

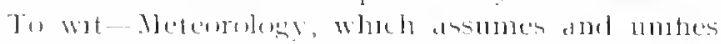

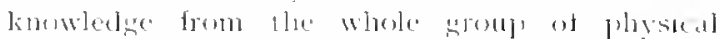

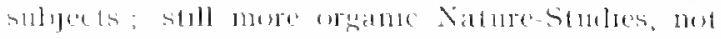

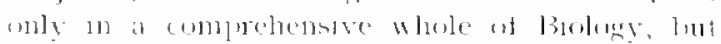

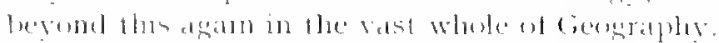

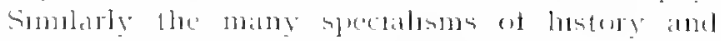
langragere have now an he ampleted ly at com-

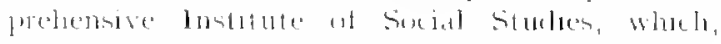

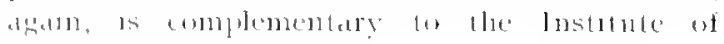
(inometply

Vow, one at these synthete mathlutes as entr

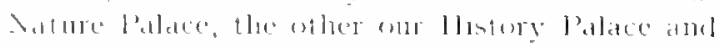

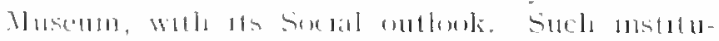

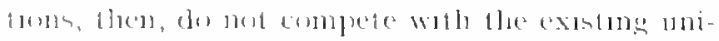

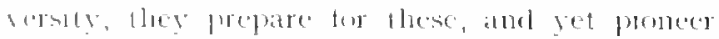

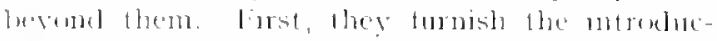

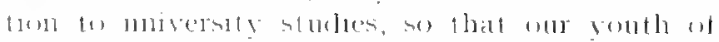

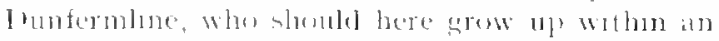
almoplese of mature and of history contimued

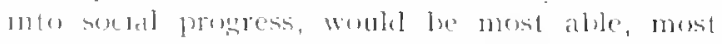

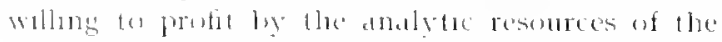
spectal sclences ats terekped in the varnous univer-

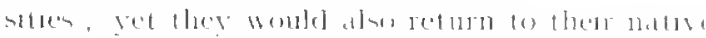

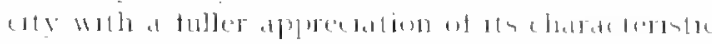

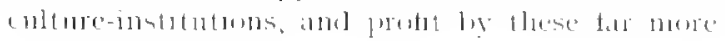
tully than luture

\section{Further Significance of Proposed Culture- Institute in Education}

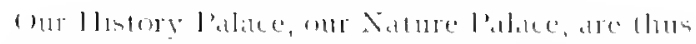
mo mere persinal dreathe They arre presented ats approxmete stutums, open, therefore, to exery

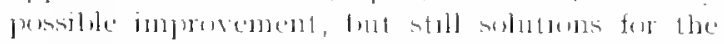

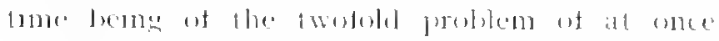

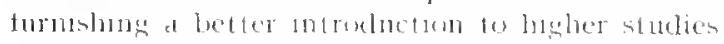

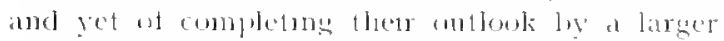
and more modern evolutmonty culture - that is,

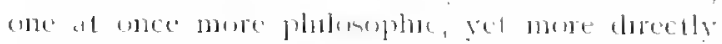
human ind sochl also That sirele an educatom

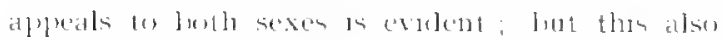

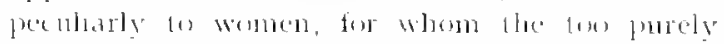

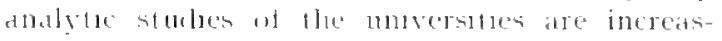

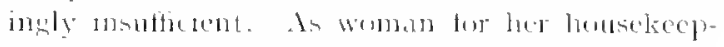
ing must combere the results af many arte and

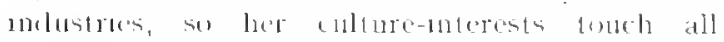
speedeltsms. The monersity, it is true, offer's its

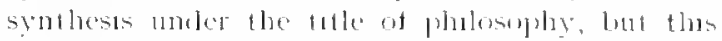

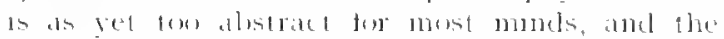

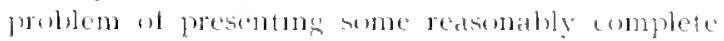

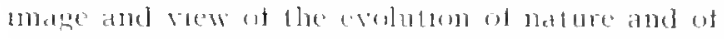
lommanty has, theretore, to be deall whth. Henee

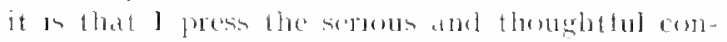
seleration of the present aroup of anstitules as the appoximate solutuons recpured.

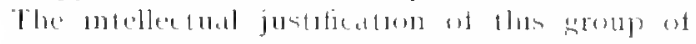

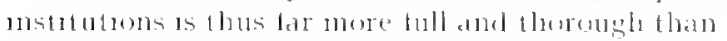
maly appear at first steht. yet at must le put

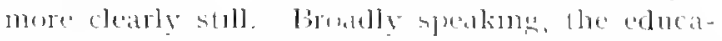

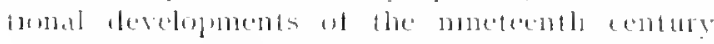
maty le exprested no two all these meth mone-

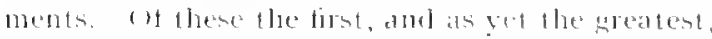
is the magnificent develepment at the ciemant

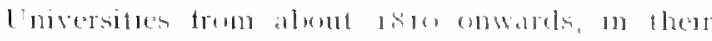

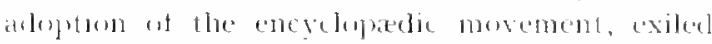

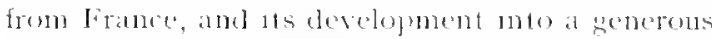

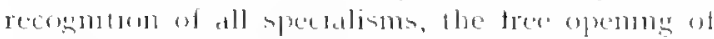

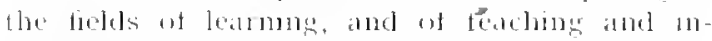

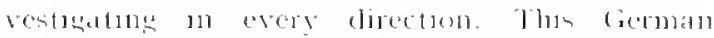

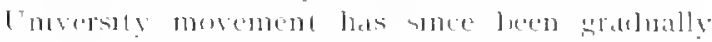

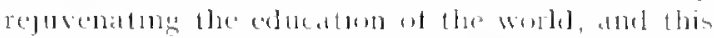

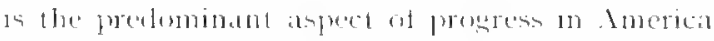

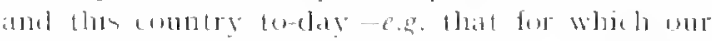

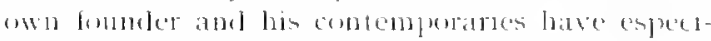
ally deplayed then munficences.

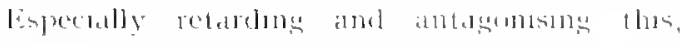
flecre bas jecen, and I tear I must saly in Cireal

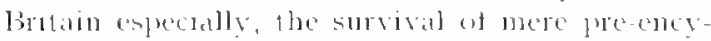

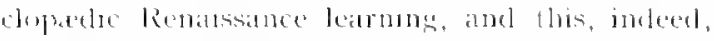
fou otten redapsing mo mere monlash trathtumalism, as of grammat ly rote. Besides thes, but tully profitung by 11 , there has gene on the 


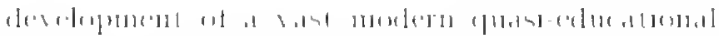

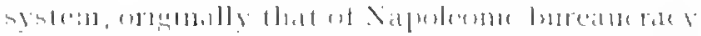

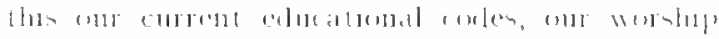

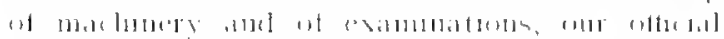

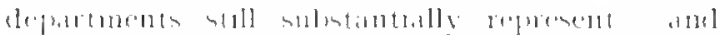

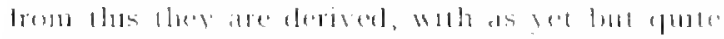

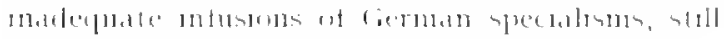

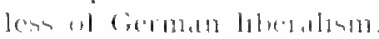

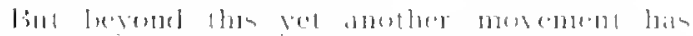

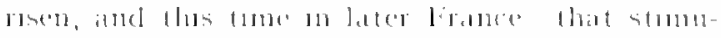

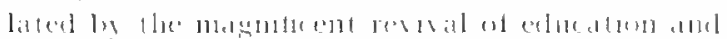

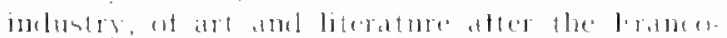

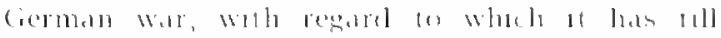

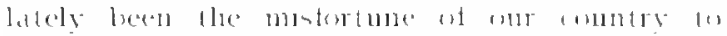

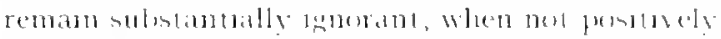

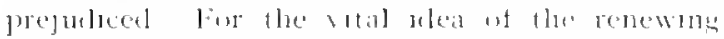

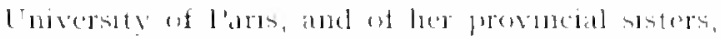
in now a levelopment leymol current ferman on

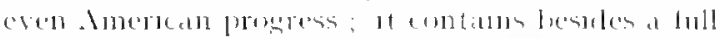

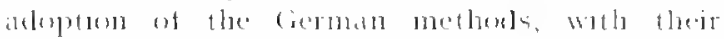

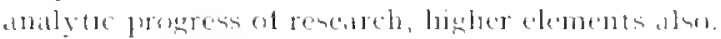

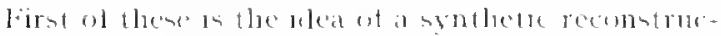

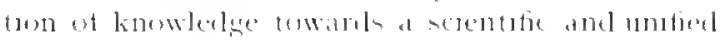

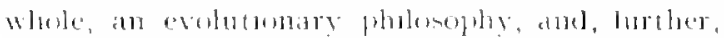

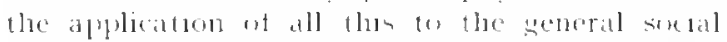

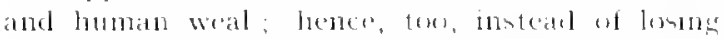

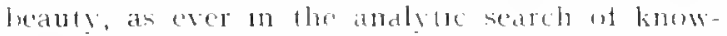
ledere, it strues fowdrels the comprehenswe carry-

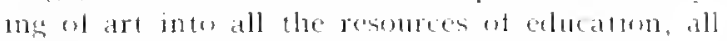
the aspects and atctoritics of life

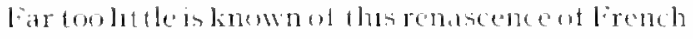
educatum in the conntry or inteed in imerted

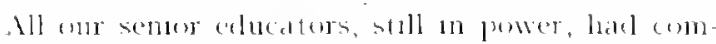

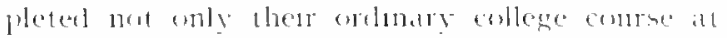
home but their "wander-vedr" in fermany also

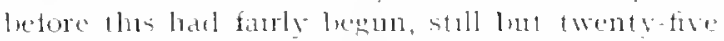

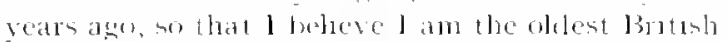

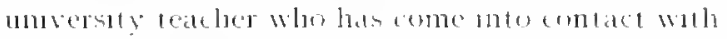

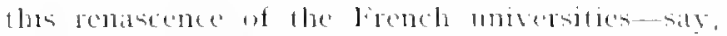

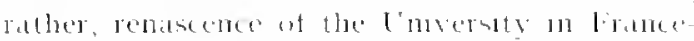

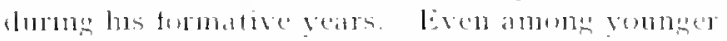

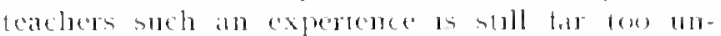

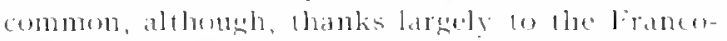

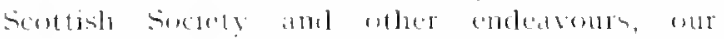

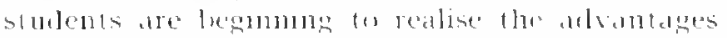

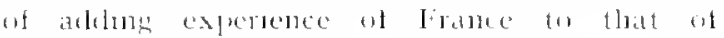
Ciermentus

lows nemer morentent is, af contse, far torm

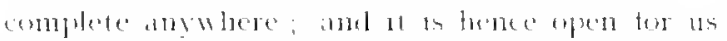

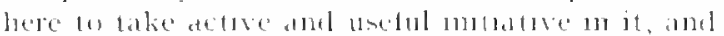

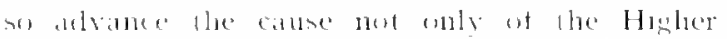

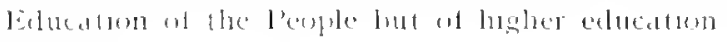
for all.

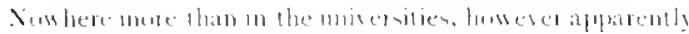

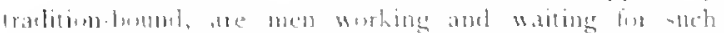

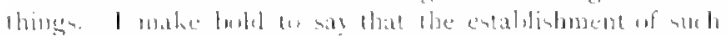

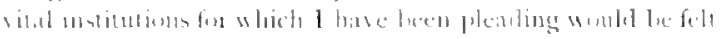

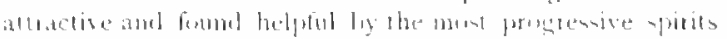

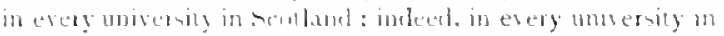

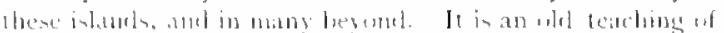

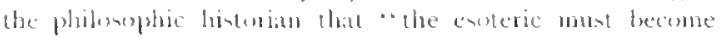

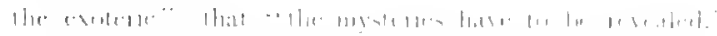

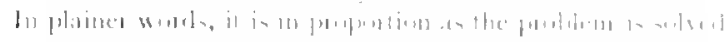

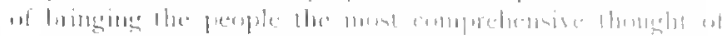

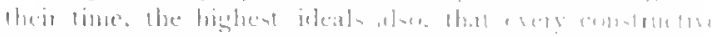

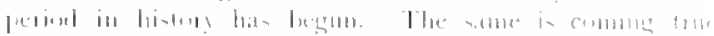

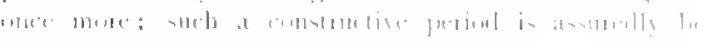

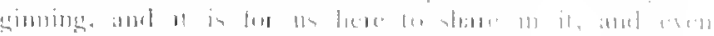
lie pinitiecte

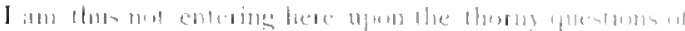

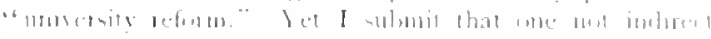

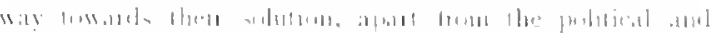

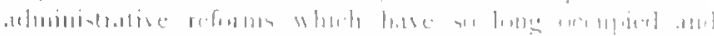

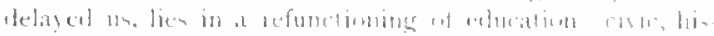

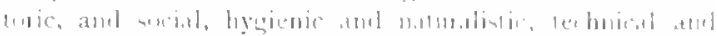

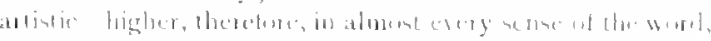

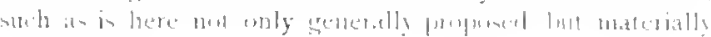
pliturnent lin.

\section{Youth in Dunfermline}

Firmeh, then, wh the most seneral wew of thesest propusals and elesens trem the standpont of the fresent eluedtum mesement su the worles. I word now of thes appeal to the inclumlual, the Inontermlene vouth and chulel.

That the immerlide surrommlangs of home and

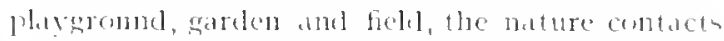
of air, earth, and water set a deep and emoluring

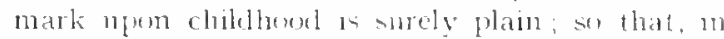

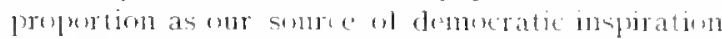
passes from urator to hyglenist and eusemint, the

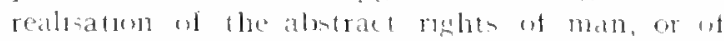
woman, is seen tor reguire a buller reemenitum w the concrite rights of chilrluxul to the hest at tamable environment. Hence the weohty

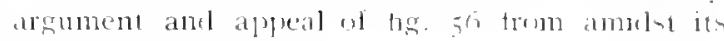
nelahbourumer ones

The andiridual type and stamp, the measue uf educalulity and productive power sem precommanty a resultam of the particular tomoly stock and of its home and mmediate conditom but we still largely frowet the importance of that new thle of life which sets an whth athlescence The view is becming prevalent among some of our foremost educationists that it in to mur renes.l

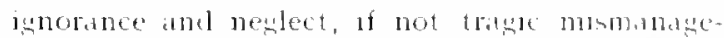
ment of thin eratical phase of human development, that the manulature of our bast eriminal, theased,

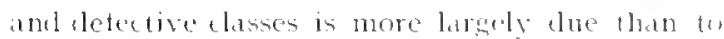
any taults of parentage or of early home-mploring-

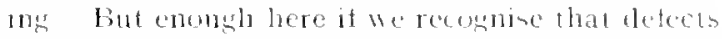
of nature may at the phase he harely corrected

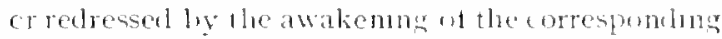
ylualitios

That "yperal to the moral am soual mutuncts ont

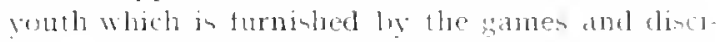
pline of the average linglish public schont, alleit fo my mint ton crute ant too exclusue, has yet been extromdinarily rewated in teveloping the present type of governing Fonglishman-ine to which the governing Scotsman has aluo for the time conformed. It rematins now for the truly democratic reformer who would redress the pre 


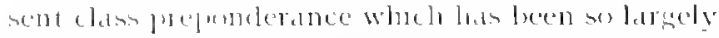

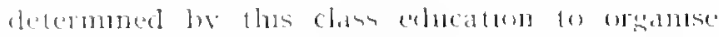

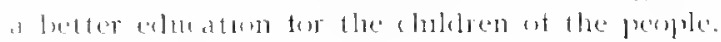

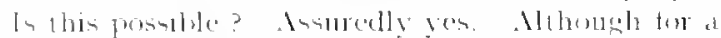

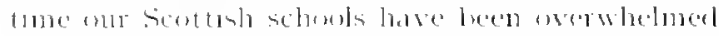

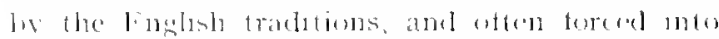

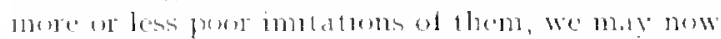

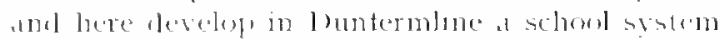
whieh, whle retaning le dements of entellectual

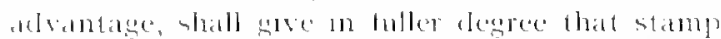

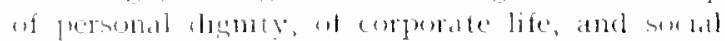

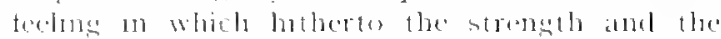

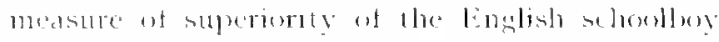
amel miversity man has lan

With the improvement of homing. imel the

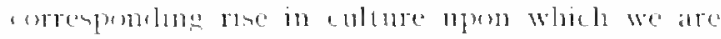

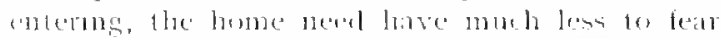
Irom flie competition of any artificial applom

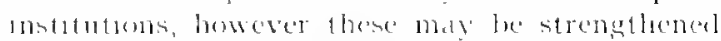

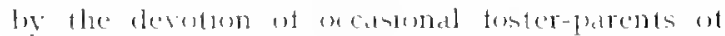

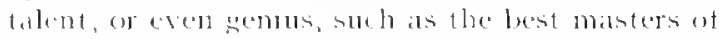

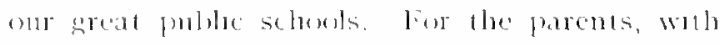

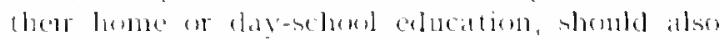
be able we demand the serveces of specialuste no less emment, and mere willng to to-eperate whth them than hase been the leaders ot the dominant $x \ln (x)$ stostenss.

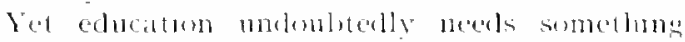
more than home. (ircell though be the mprestance of immeralte bome stroumblangs, we constantly see lhat children, and especially giffed unes, are more sensiture fo the larger nutluences of

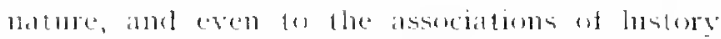

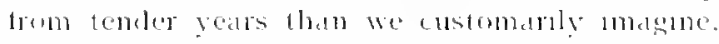

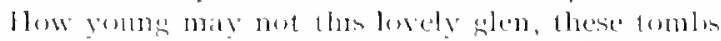

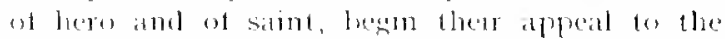
awakening spurt?

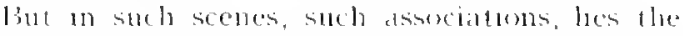
lest strensth of at greall linglish schenl, still

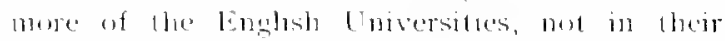

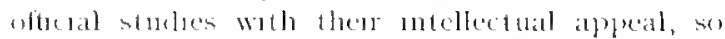

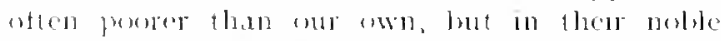

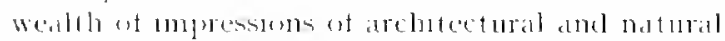

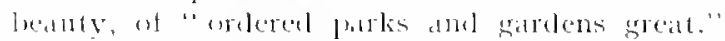
The Hegh street of oxterd, the "Backs of the colleges" all Cambrilge are thus two of the supremu assets not only al lingland but of Elucatom, of llumanty ; ans leside the ener-

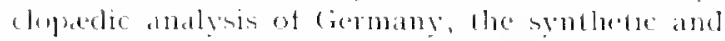

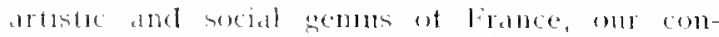

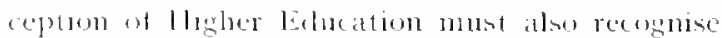

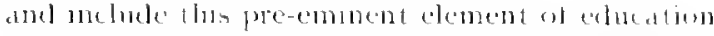

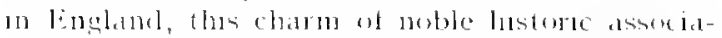

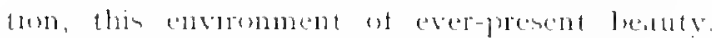

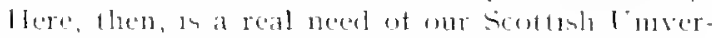

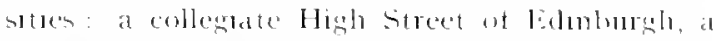

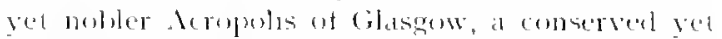

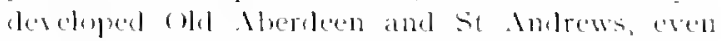
a bumer lonmere.

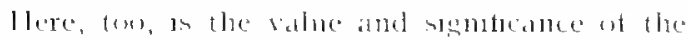

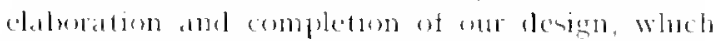
womld tumish lece, in some respee ts mo less than

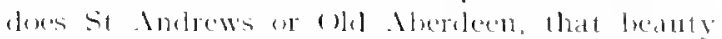

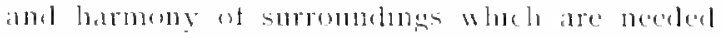

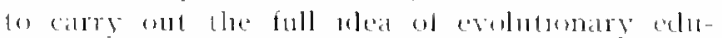
cation-an conothement. For as in our labbour Muneum we have plearled tor the nee esity of completws: the stment through the vital reality ot lalume as man, so an the other at neede thas rech envirenment of beatly and culture ne all its aspeets an make oll man and scholar a gentlematn an the true semese also.

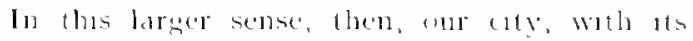
manituld culture mstiluter, its vertable mexlern cathedrat, must appeat as an princtule and germ not only a nuthern bayreuth but as much of

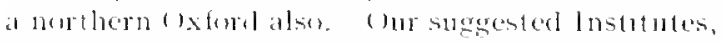
onr Summer Schomb and Assembly, have thus more posshbilities than we at first assumed, and make mere apreal even to the mniversites than they yet kinm.

let me conclude ly now insiting the very critictsm wheh I somplut to ber at the ontsed Introlucturn, pitge 14, the prestion of where have such things been lane betare tor now there is the smplest of answers here in this sery buntermbere. Thes ablery had the mingue hisforic drstuncturn amid all wher culture-centres (1) the direct parentage of the (wo metropmitan culture-capitals of the north-loma and Canterburs; and in its fime it had a corresponding intluence also: so that, on now pitching high our rleal and onr pioneerne, fo the ntalisation of the best culture movemente aromal tus, 10 the establubment of a grenp at Sinthete lnstulltes, to a policy of ealucatom at ence neturalest and humanist such at phlumpluers lave dreamed trem Comentus ar spencer, and such as the lmoversities, cren the sreatest and meme progressive, have not yed fully redised-we shall hut be returning to the early past upon our molern sporal 


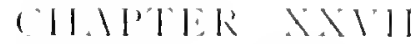 \\ THE QUEENS' GARDEN THE ARENA}

\section{A. Queens' Garden}

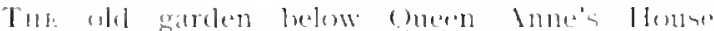

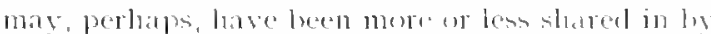
the old comvemt ot si catherme, whese magne

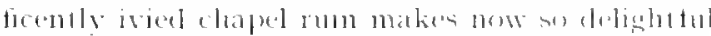

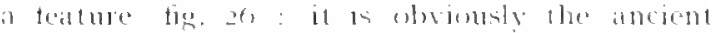

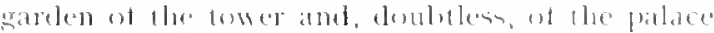
alse. Almont trom time emmenumal, in tact, the

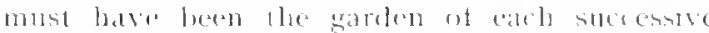
queen, and only since the ontortumate hlling 11 .

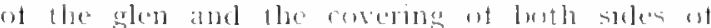
Brolge street has the anctent path of connetion with st llatrated's Catre and beronel become

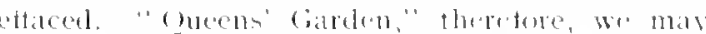
tarly call it, esperally sine its speciell name serme to have lalsed.

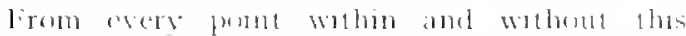

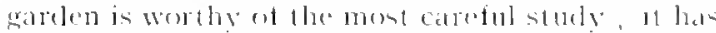

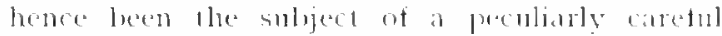
photographic survey, of which some results are given figs. 1211, 122, and 1 2t

Bll posiblitity ot splenelum in treatment lefitting a palace garelen is, homerer, eseluderl by the deep shate monter which thas lies; while the paldue sarden proper is now represemted la the sums

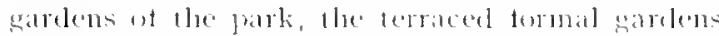
especially.

Amother possibility is that of a puint clobster garden, one of snowehop' and nareisolls, hlies mol marenerites, befitting the tratition ot st llatratret; but this I have sugested more applepriately near her cave, and something alim alse at the llistors Garlen. The herles and simples ot the olld nuns garden next sugarest themselyes, but these are for various reasons musmialde. Jel another aldernattive would be to aecept the shady situatum, to

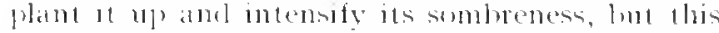
woukl merely be continumg what nature alreatly otfers as in all the rest of the glen below Nor as a formal treatment stutable, the more so since we can oldain the far more impressuely ly the improvement wt the Abley Churchyod, as surested above

tnother idea, only partially suggested aluse, is (1) make this a hulb atorlen tor early spring, lut this 15 also proxided on t.11 greater scale and woth

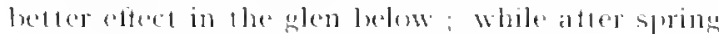

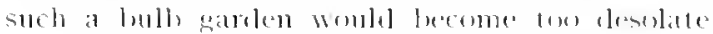

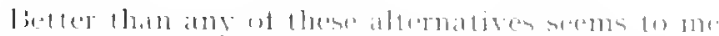

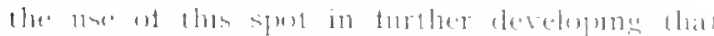

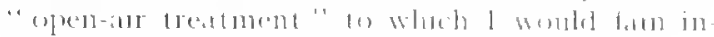

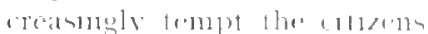

\section{B. Arena}

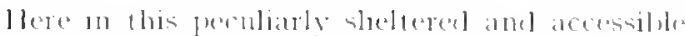

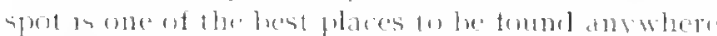
tor a groat open-air arend. 1 say antwhere in the

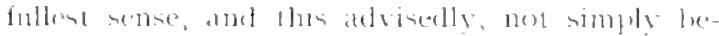

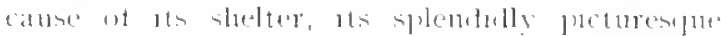

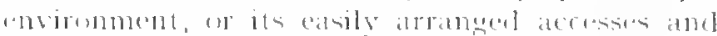
exits, lout heranse of he extratordinarly pertent aconstics. I have expermentally proved this, not

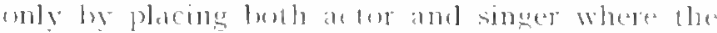

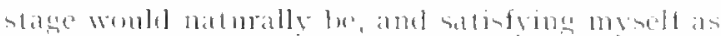

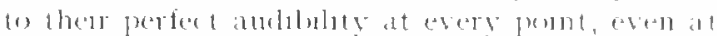

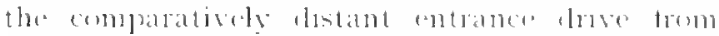

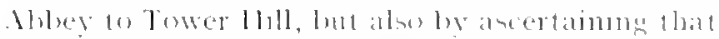

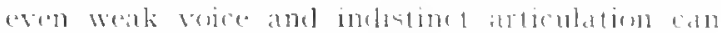

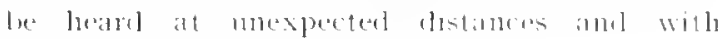

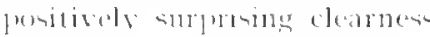

\section{Proposed Damming of Stream: Effect of Lake and Waterfall}

llence, then, the present desten of this arena. which ranges from below the existing tertate of the olel huldeluse neatly tor the present elge of the hurn. I sily nearly, lecalue here l propuse de ritive the stream at present rumning unseen at the luttom ut what is practically a hiph-watled ditch

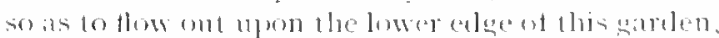
mow arena, thus producing the effect, it mot ot a small lake, at any rate of a mosterdes and

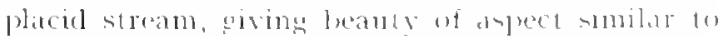
that already sugrested at the Vethertown, lut also the adelonenal charm ot reflections of the buildings and trees around trom everechanging points of view.

This proposed damming of the stroam most not

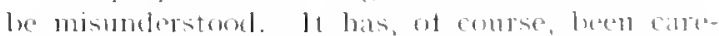

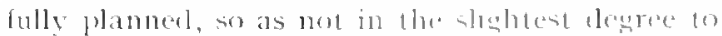
merfere with the present waterwar under

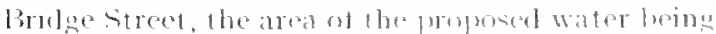




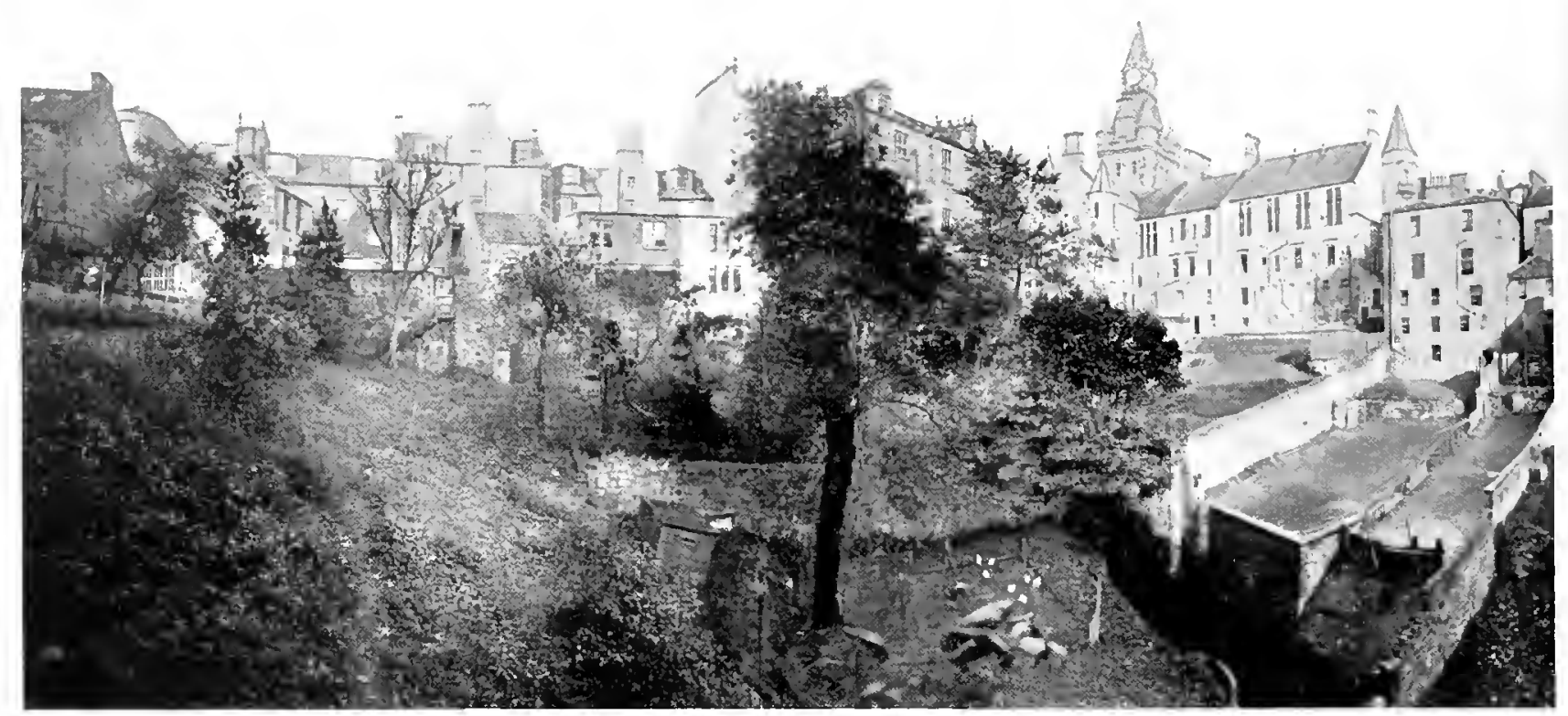

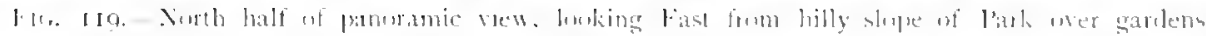

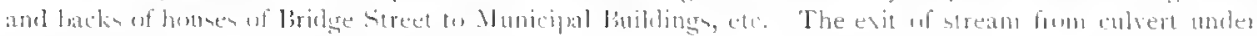
Bribge sireet is in deep hollow on sisth.

ample, thomgh kept not an inch hisher than that it the present outlet of the culvert to the south of bindige street. For at is easy somewhat a lower the level al the thot at the Arena.

Torvod danger the deep ditch should, of comrse. be filled uf. A further artrantage of ths dammong is that 11 dows away wht the ome disturbance of the perfect acoustics already referred to-the noise of the stredu at this pont; while yet another is that it gives ws the opportunity of creating not "mly here the beatiful reflection murror, which is all that is noeded to make this butle valley an axcecdingly perfect onte, lut also an opjersdinity of aflording a real climax to the naturalstic heanty of the winding dell below. For, thanks to this dam and its long pool abuve, we can mow arrange a watertall orer th top, of some us wr even Is feet in height in short, with the eflect of a lakeled above we slould also olstain a fall below, thoroushly comparable to that which is the climax of fesmond bene. Whole thes dam is, if course, first of all a lit of substantial emencor. ing, thougly not by any means an expensive one, it need have mone of the ustal engincentrg baldness, but, as the accompanyines llustrabon shows fin.

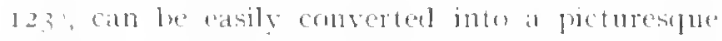
witerfall. The passage desirable here, from one siele of the stream os the other, may be siven

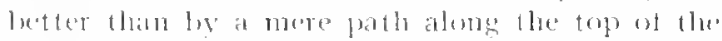

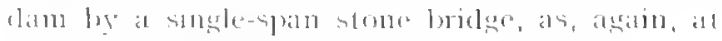
fexmotid line* fig. Sit.

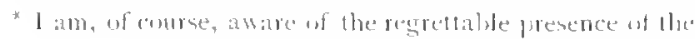

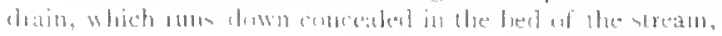

\section{Interior of Arena: Aspects and Accesses}

To complete the Irona we halustrade the terace below the houses, thus attorlang a man access and promenarle, form which would descend ldse low-stepred passages to the tiers of seats. This terrace mulst lre exterded, not only witheut loss to accommodation, lum giving a row of boxes helow. Three otber larger boxes are also easily frovided behind, next the old buldengs: say, one for the Mumerpality to the north, one tor the Trust to the south, un each sicle of a midrlle one for the Donno and his immerlate guests

To the south the needed spacious man entrance and exil staircase comects with the Tower llill drive; while the walening ot this drive upon open arches gives a new set of picturesque ihadoms. recullung thome of the ald arches under the palice kitchems, homuh, ot conrse, bess lofty and well sunnet. To the eatst the eftect of the old builings looking towards the ablues see Frontispiece once more is so fine that hithe nead he done hevond the necessary repair and reharline of these. No donbt even this involves tor the moment a certain loss uf pietnrestpueness, but onc necessary in itself, and whoh weatheng will som make mp tor. On

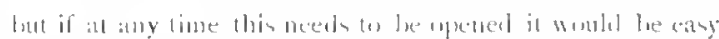

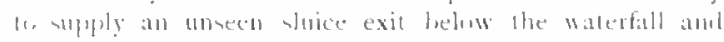
bum run uft ontr lake altergether, and, excasating at any reguired puint the mol with which the preant deep?

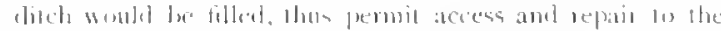

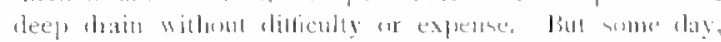

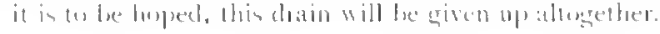




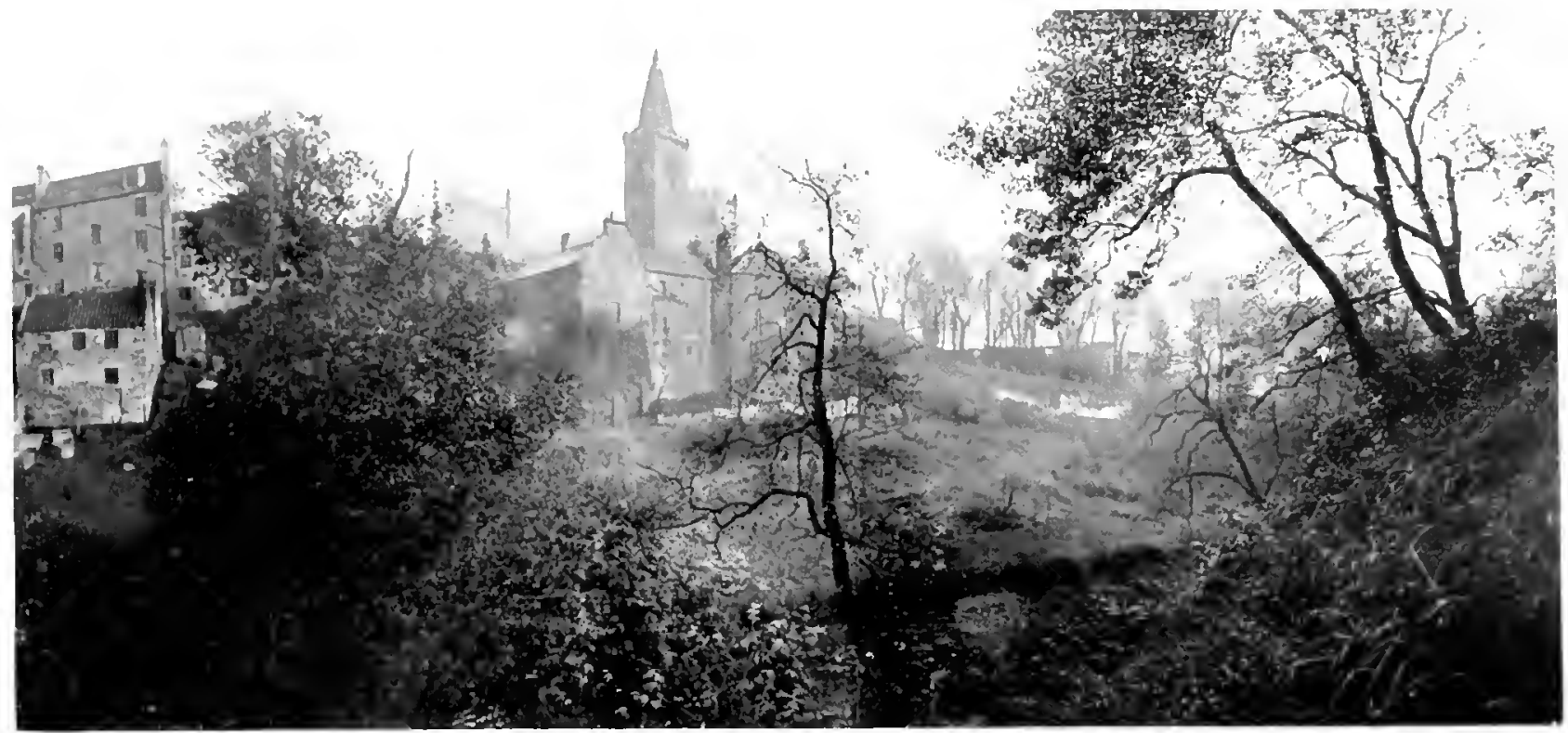

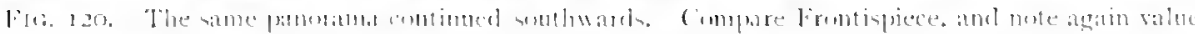

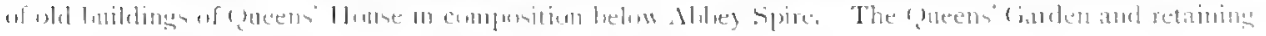

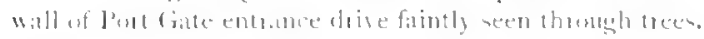

位

$t_{x \rightarrow \infty}=1$

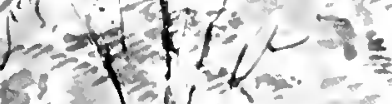

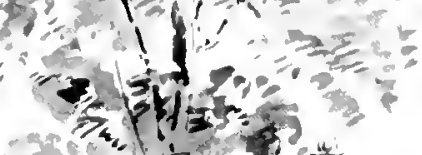

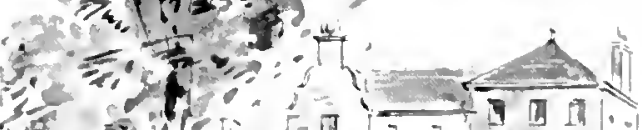

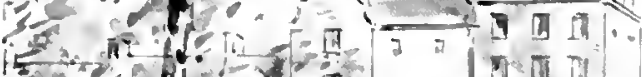

$20.9-1=0$

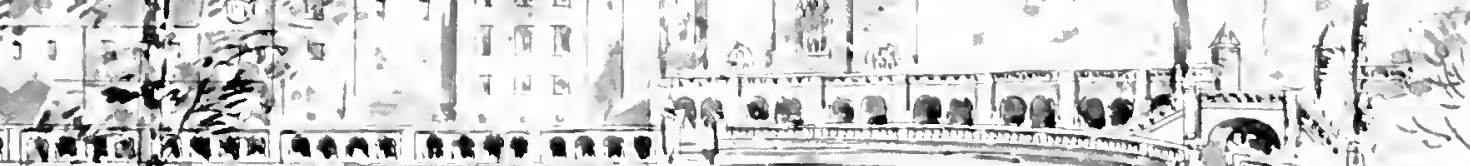

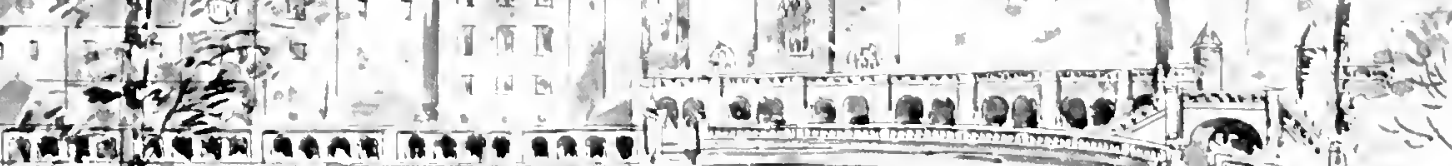

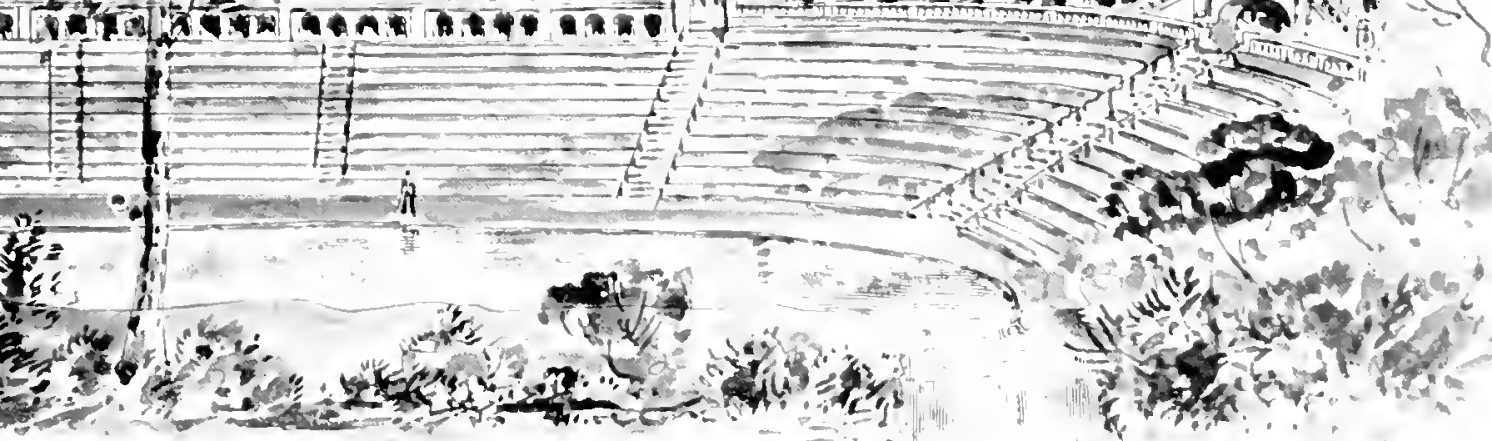




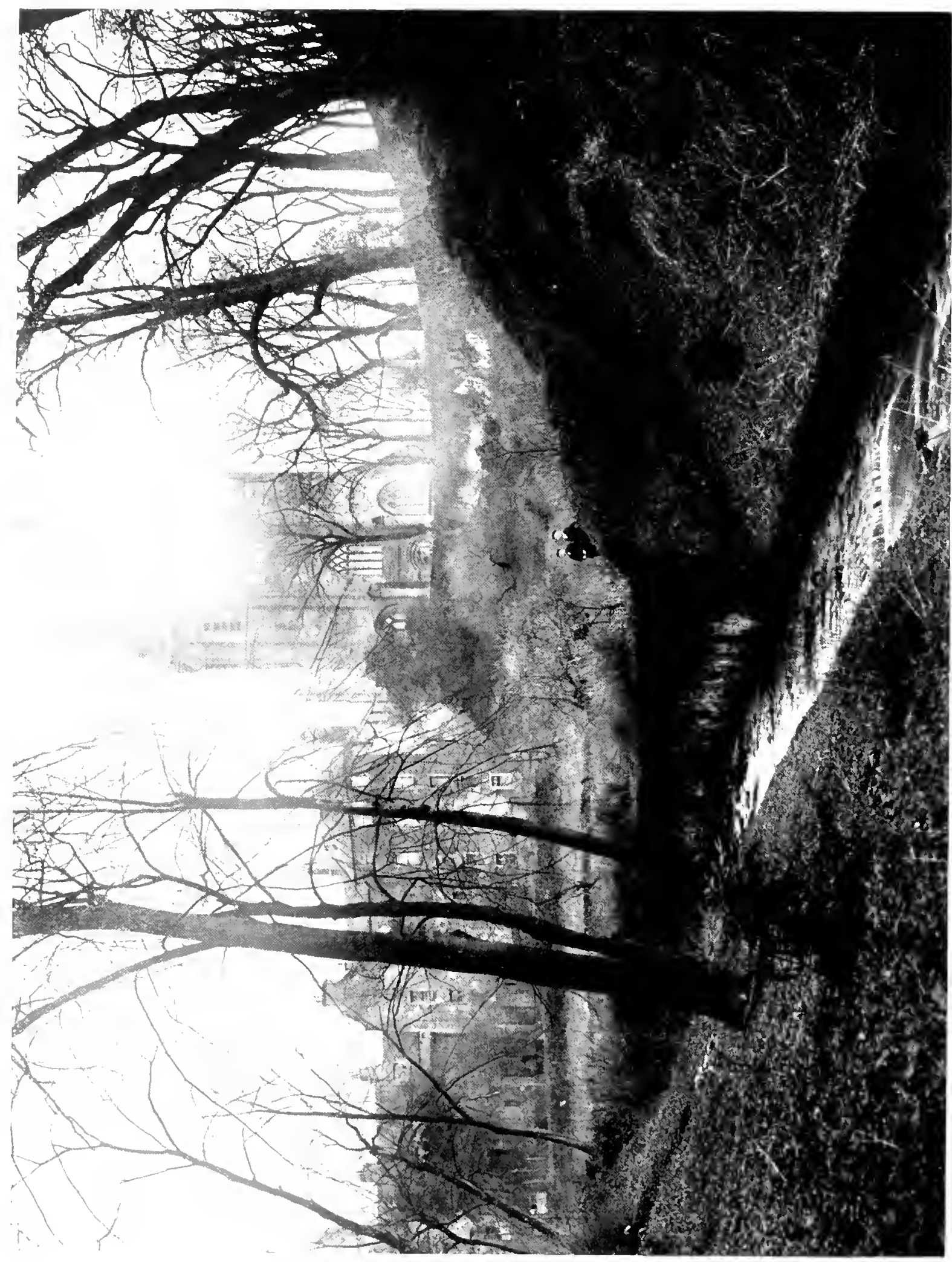




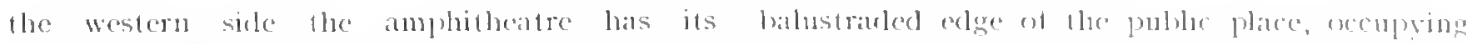

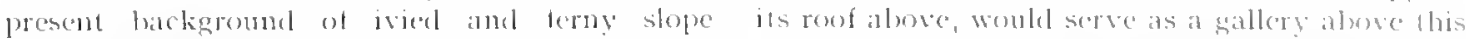

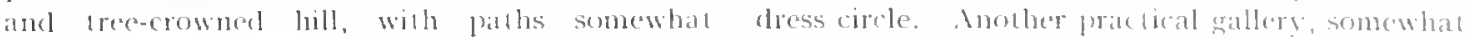

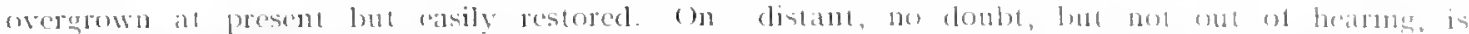

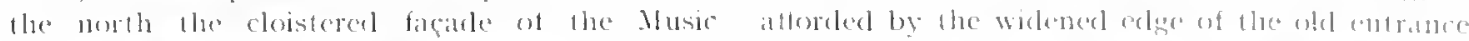

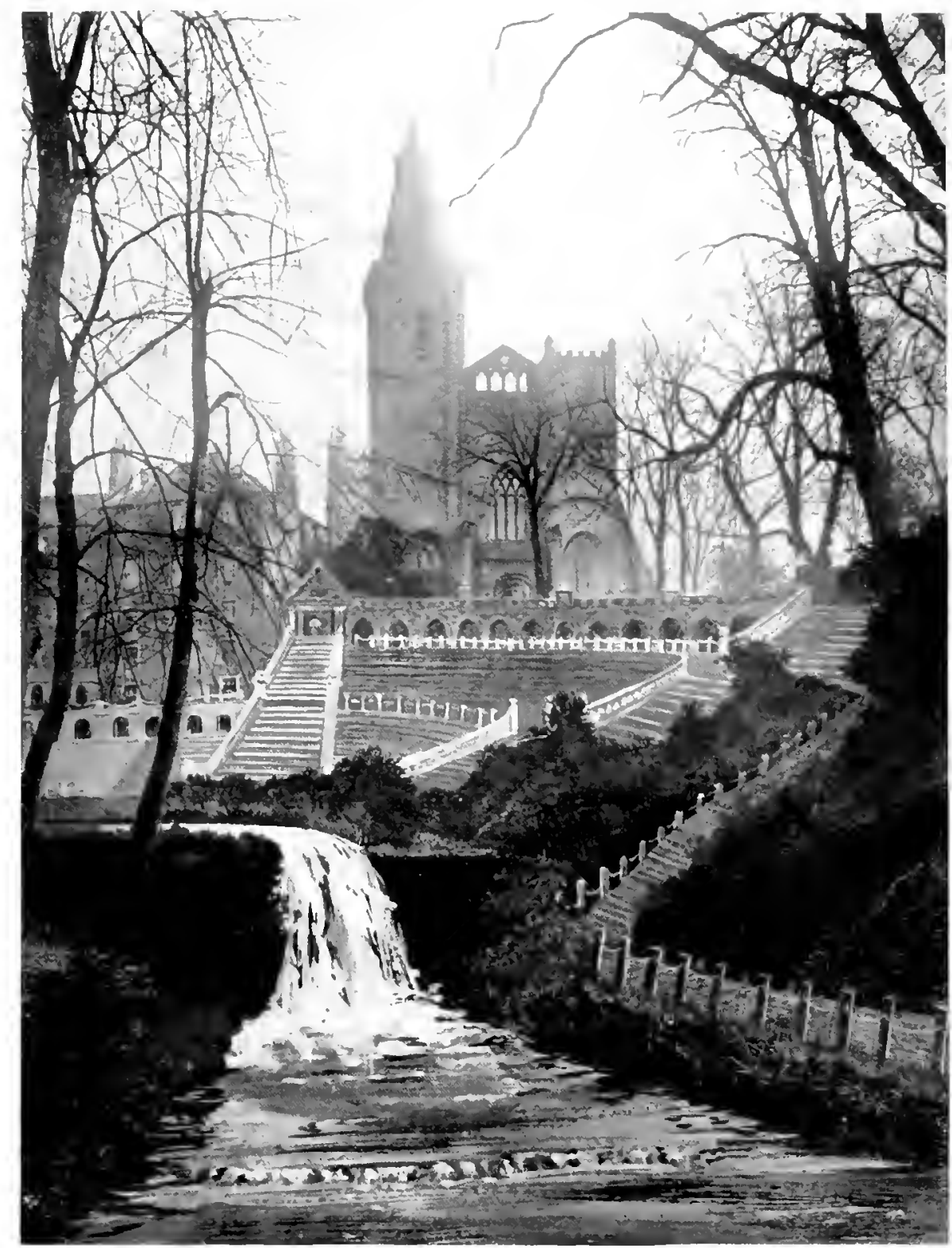

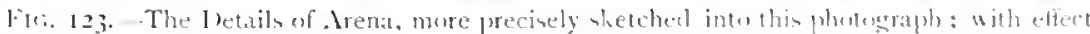

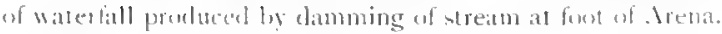

Hall and its halustraded l'lace above enclose our view.

This arena should seat between three and four thousand, and also give accommodation upon its spacions promenade, east and somb, for at least a thousand more. The southward chister of the new Itusic llall Chap, XXYII]. would be the best of situtions, for liearing wpecially, while the drive from lbhey in Tower. In surh wily vers large assemblages can be helel; and open-air functions, oratorical and muscal, historic anol dramatic, may thus arain become common, especially as the current exagerated torror of the climate disappears with a grencration reinvigorated by that open-air treatment, which, as already repeatedly ured, is no mere resoures on medicine 


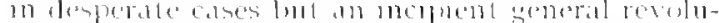
won की

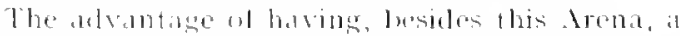

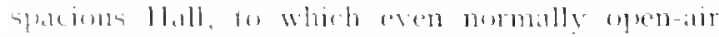

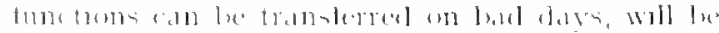

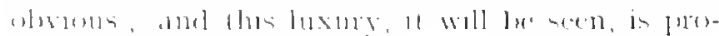

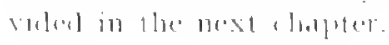

\section{E. Stage}

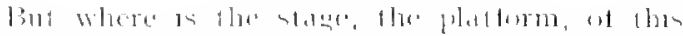

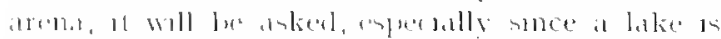
thesu

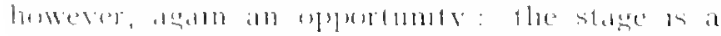

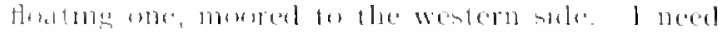

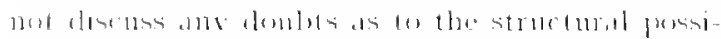

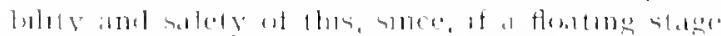

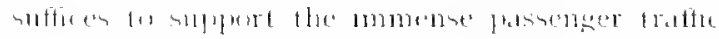

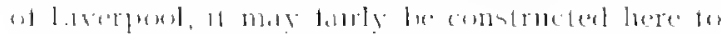

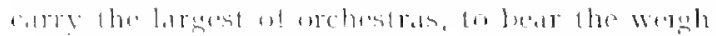

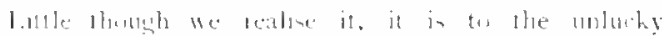

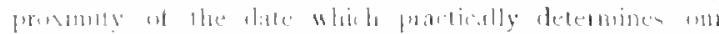

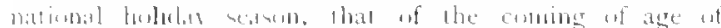

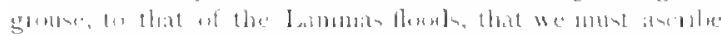

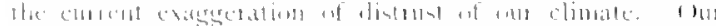

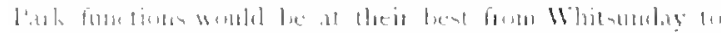

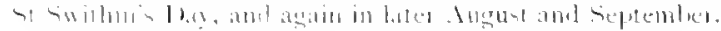

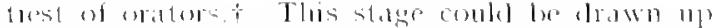

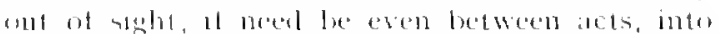

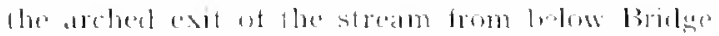

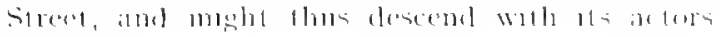
reituly.

\section{F. Garden Details, etc,}

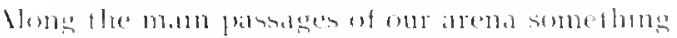

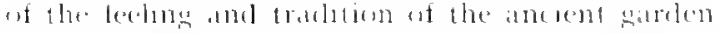

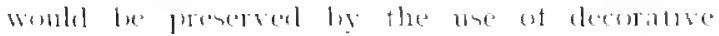

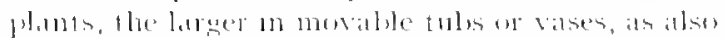

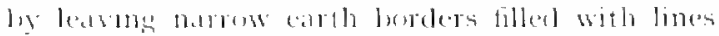

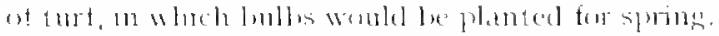

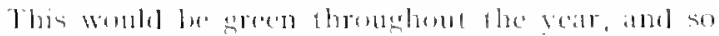

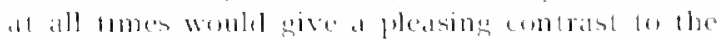

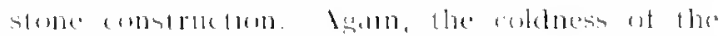

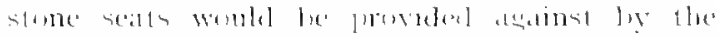
sil]ply at a

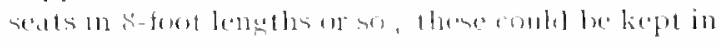

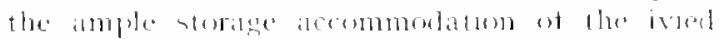

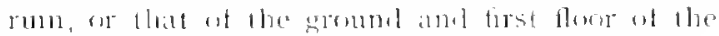

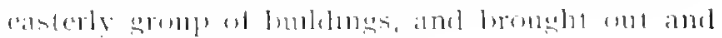

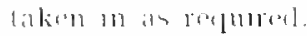

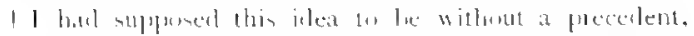

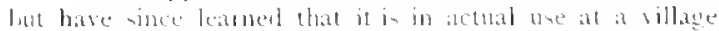

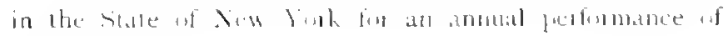
"Hianathis." 


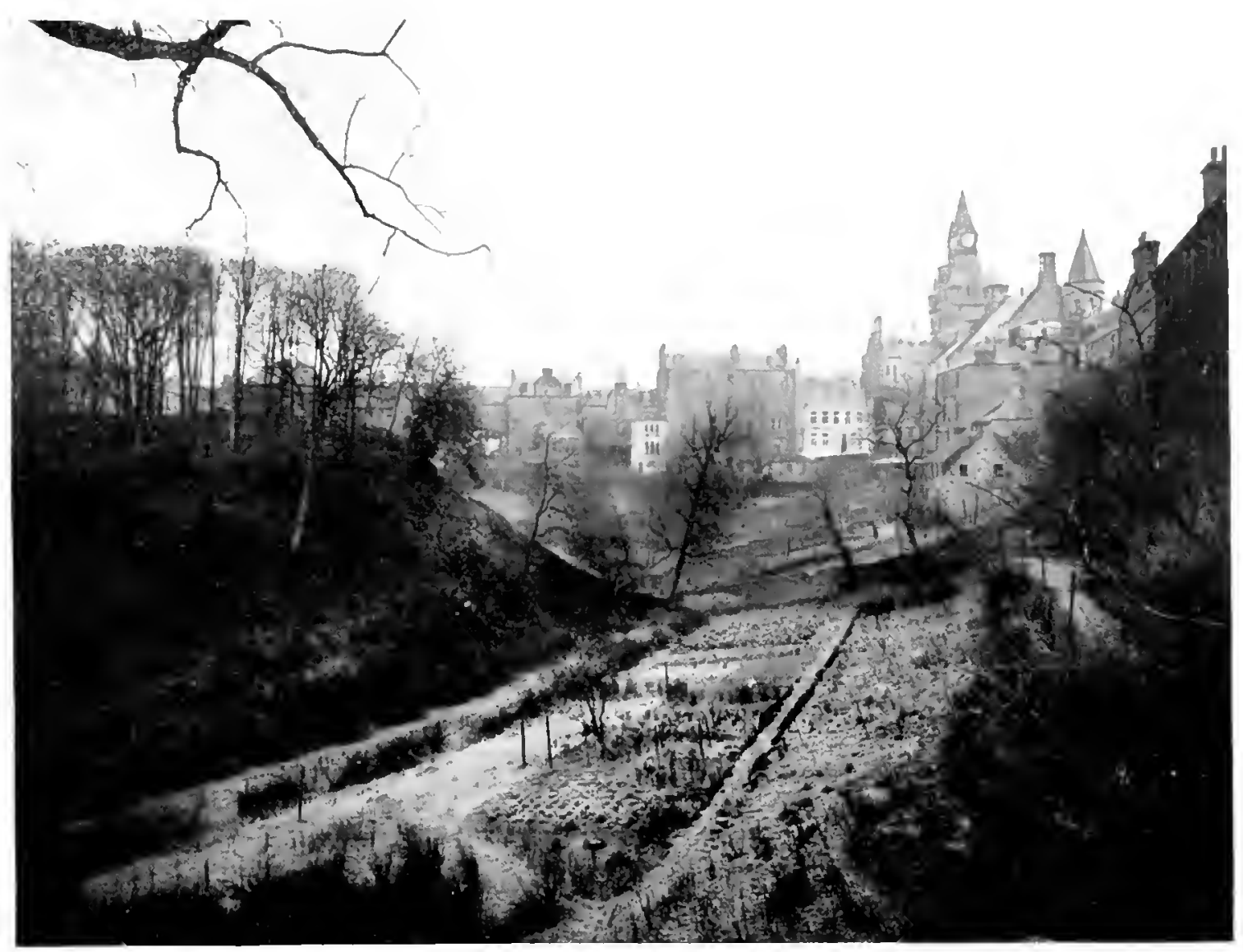

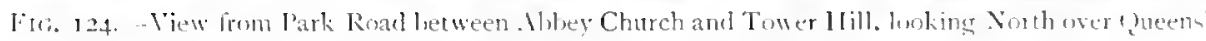
Farten. Ninte laark Itill on left, bach of houses in tridge Street, and Town thouse on right.

\section{CIAPTER XXYII}

\section{MUSIC HALL}

\section{A. Accommodation, Sile, and Plan}

Wr: have now provided most, vet not all, the buildings required by the work of the Trust. M least one, and that in some wars the most important of all, still remains the great Music Hall. It is peculiarly difficult to determine the proper size and dimensions for such a hall, since here anthorities ditter. After prolonged and varied incuiries there is little doubt on my mind that from, 30x 103500 is the maximum size compatible with full enjoyment of the best music, since berond this mannitude the subtler effects both of voice and instrumentation begin to be host.

Where in Dunformline we can find a site for so large a building without cutting up a ifuarter of the park has leen mo easy matter to answer. But, again, after very tull consideration I helieve that the following proposal will not only be found workable but will gradually overpowe the varions oljections which may at fust sight be urged against it
While regretting the great injury both to the glen and town of the building up of Bridge Street I frankly regard this as irreparable. Even had the Trust the enormous sum which would to necessary now fo remove these buildings, to re npen the slen, and proside a suitalle brige, the moner might be more isetully emploved in other ways. The sollhward view this would yeld is maloubledly of the greatest beauty, far excelling almost all dse in Dunfermline, hence chosen as my frontispices: but I venture to say that this can be fally displayed, and at its hest, al tar less expense than that of the wholesale demolition which all first sight one feels templext to wish for.

The startling beatsy of llus view to no small extent depends upon its mexpectedness and upon the contrast which the present commonplace little street affords. Ilere, then, is one of those artistio disasters and present diffieulties which ofler cpportunity to the designer. We stuly and photograjh this view trom the thece best stamel 
points trom the west, mieldle, and cast ot the biak

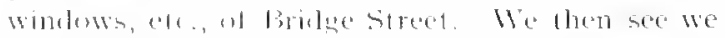

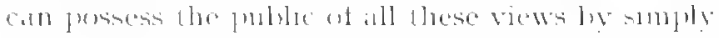

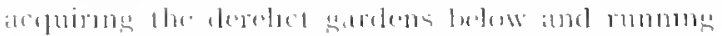

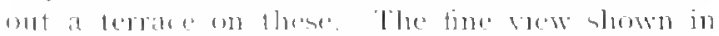

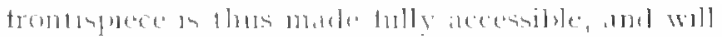

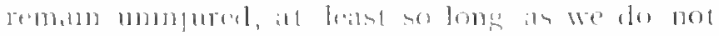

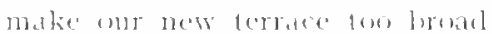

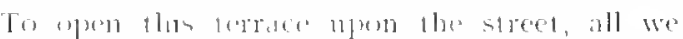

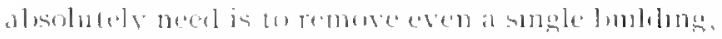

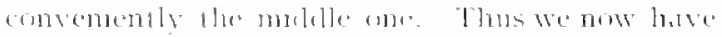

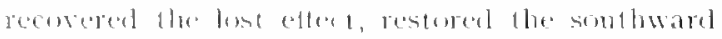

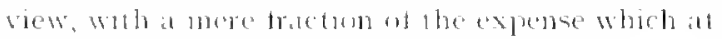

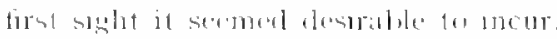

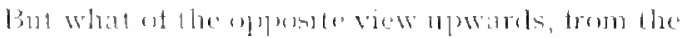

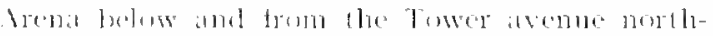

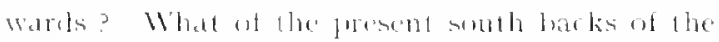

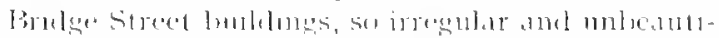

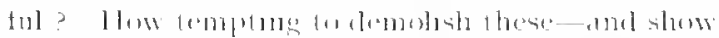

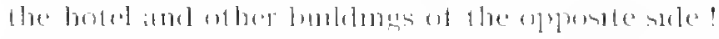

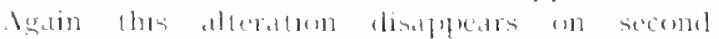

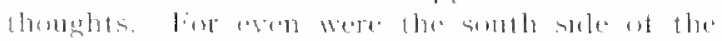

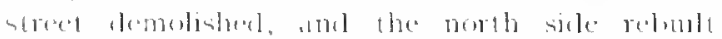

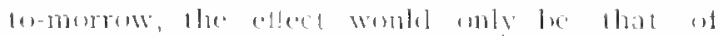

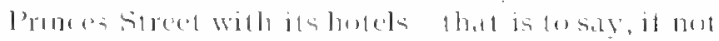

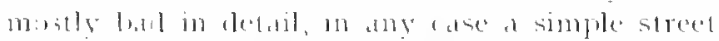

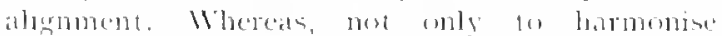

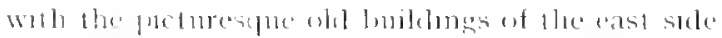

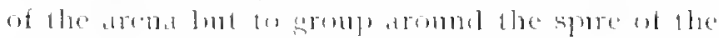

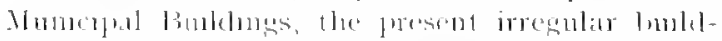

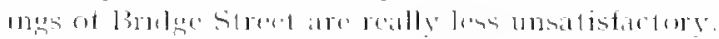

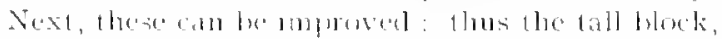

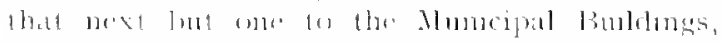

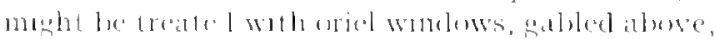

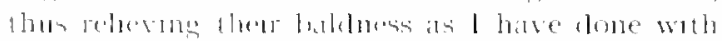

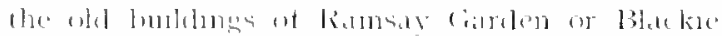

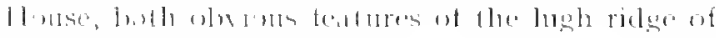

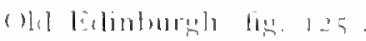

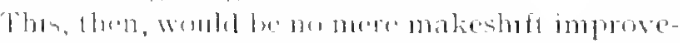

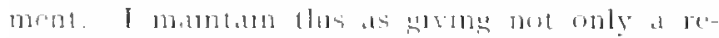

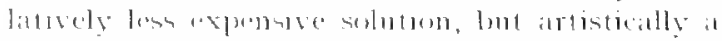

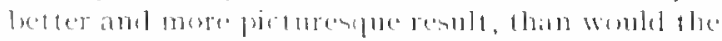

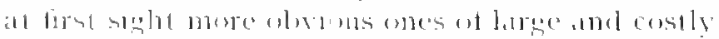

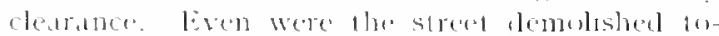

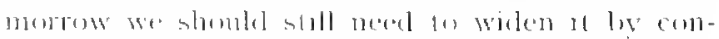

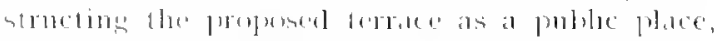

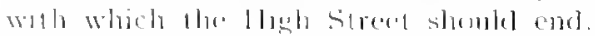

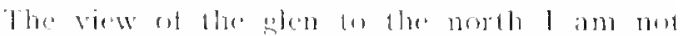

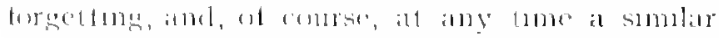

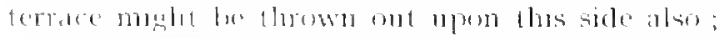

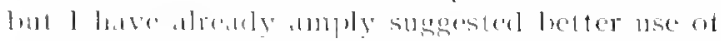

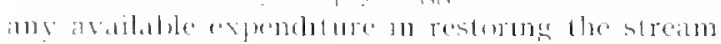
and corrying epen speres amel walks alome its

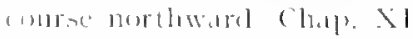

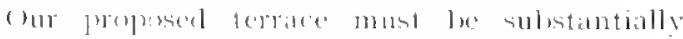

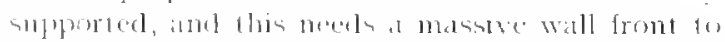

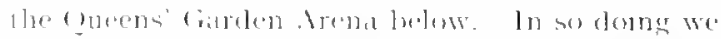

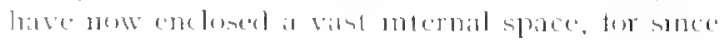

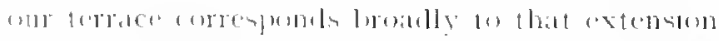

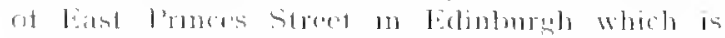

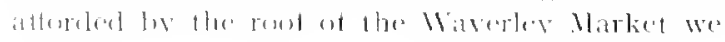

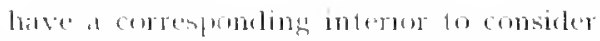

INhol use now shall we make of the vast space

Here is all Wusc Hall. I crowel ot oljoctions

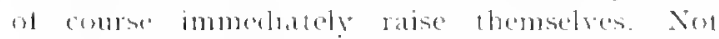

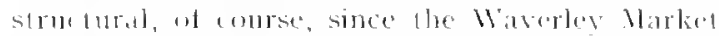

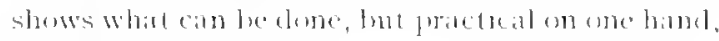
arlitic (נ) the ahere.

Takum the pratelical matters, here sis the noeded

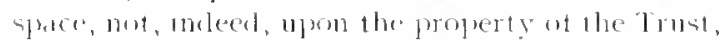
lome 11 yon mosily distised gardens, surely tar more

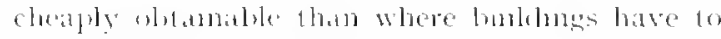
lie clemolisted I lase portion of the proposed

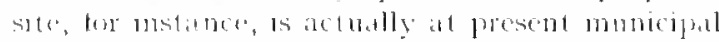

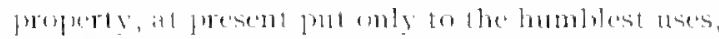

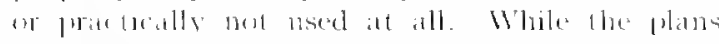

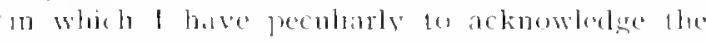

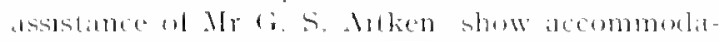

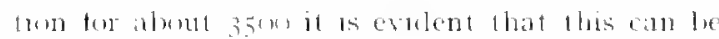
to some extent moreased, at regured, lwoth in leneth and breadth, I partioulaty press, however, that

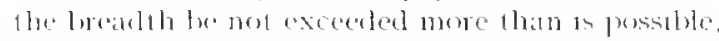
suce the turther we encrouch mpon the arenat

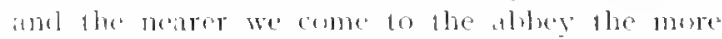

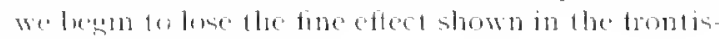
juece

It is posishle somembit to lengthen the lasll, it regulded, beyond the stimensions indicaled. To

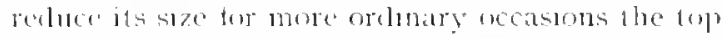

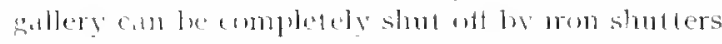

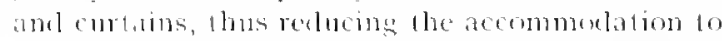

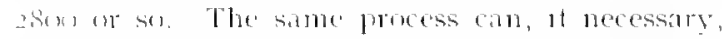
be alpled below the sallery, st waing only the

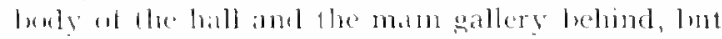

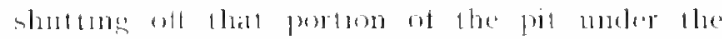
pillery.

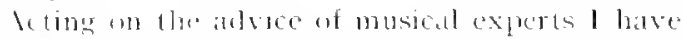

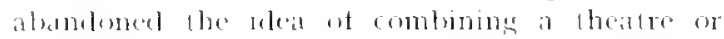

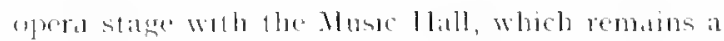

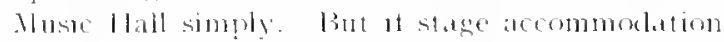

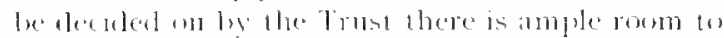

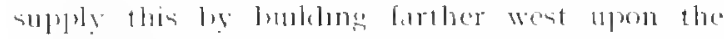

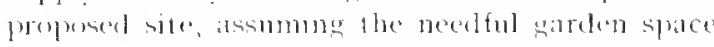

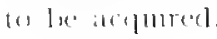

\section{B. Accesses and Exits}

The yuestum of alecesses and exils has, of course, presented consideralle difficulties, lune that it has

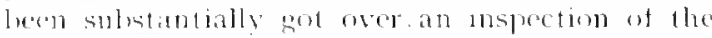
plin whll show. Thus the new otoluphe drove from

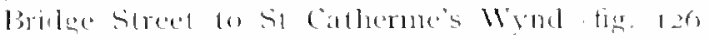

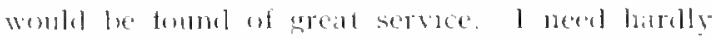
say that the deatening of the rond ot the hall is ath easy mallur, its protect cemtral lightimg and

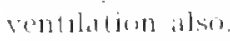

latu wedl abue that perple do not easily think

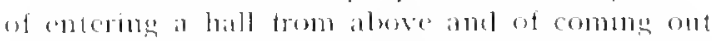
al top, and that such associations are nowalals

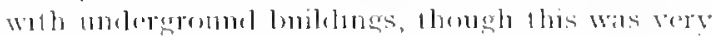

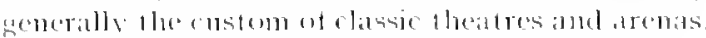




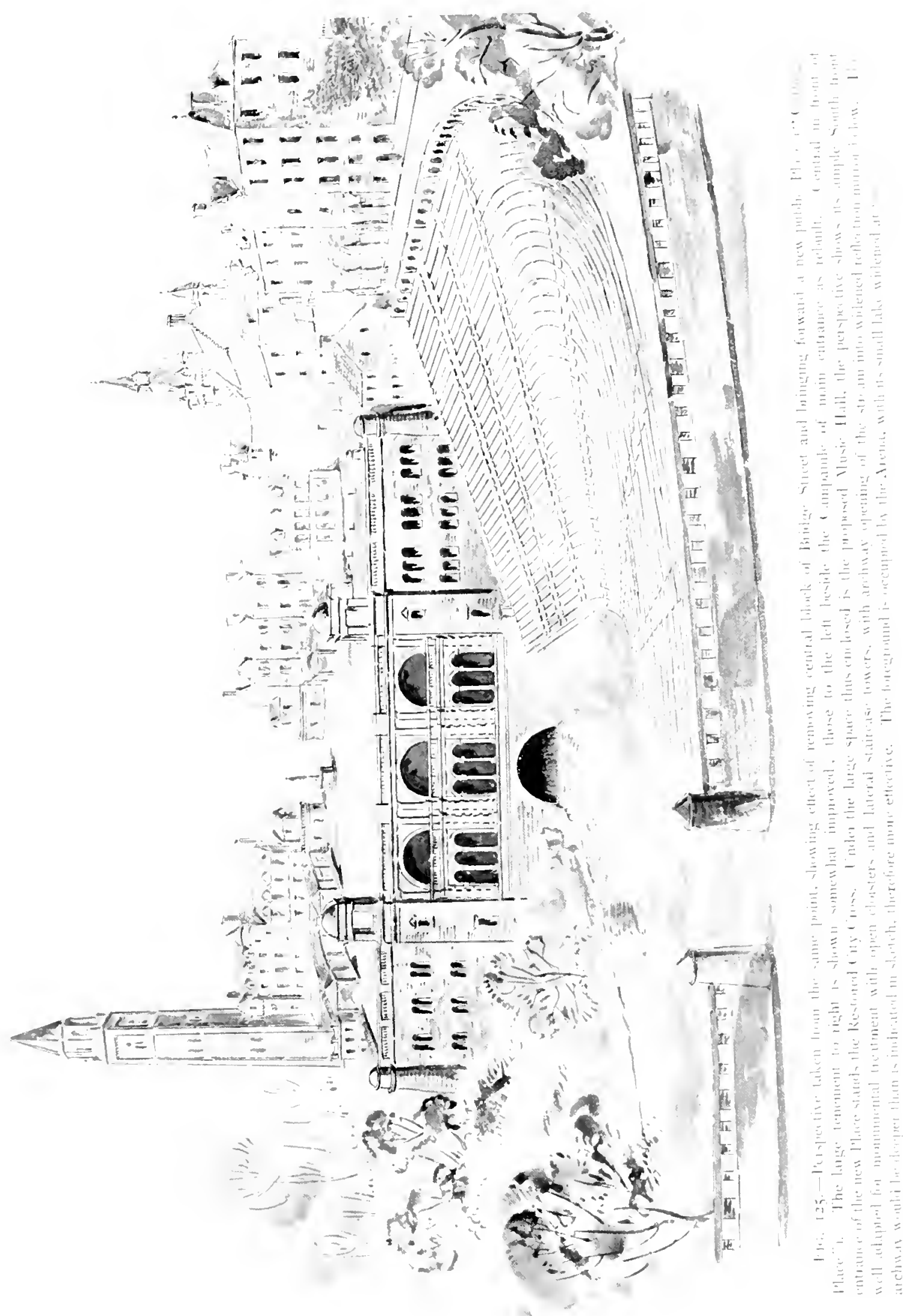




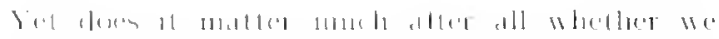

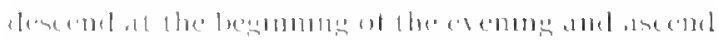

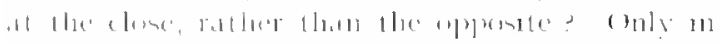

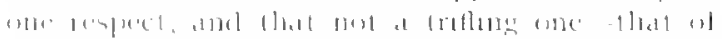

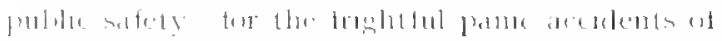

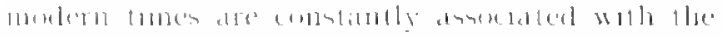

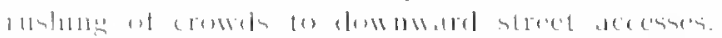

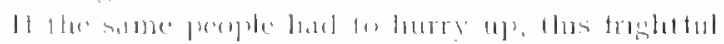

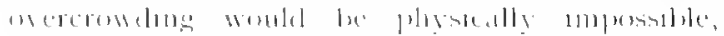

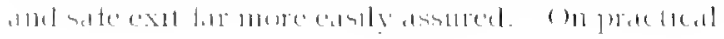

\section{Facade}

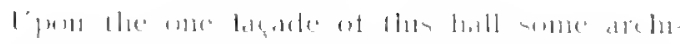

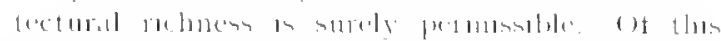

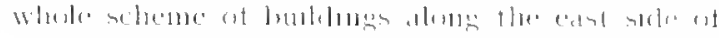

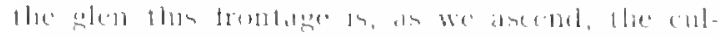

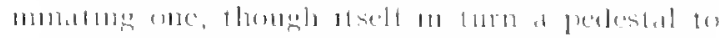

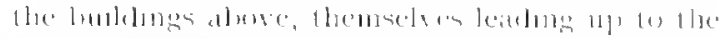

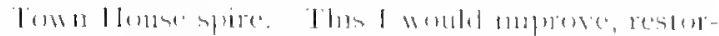

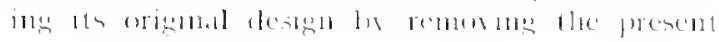

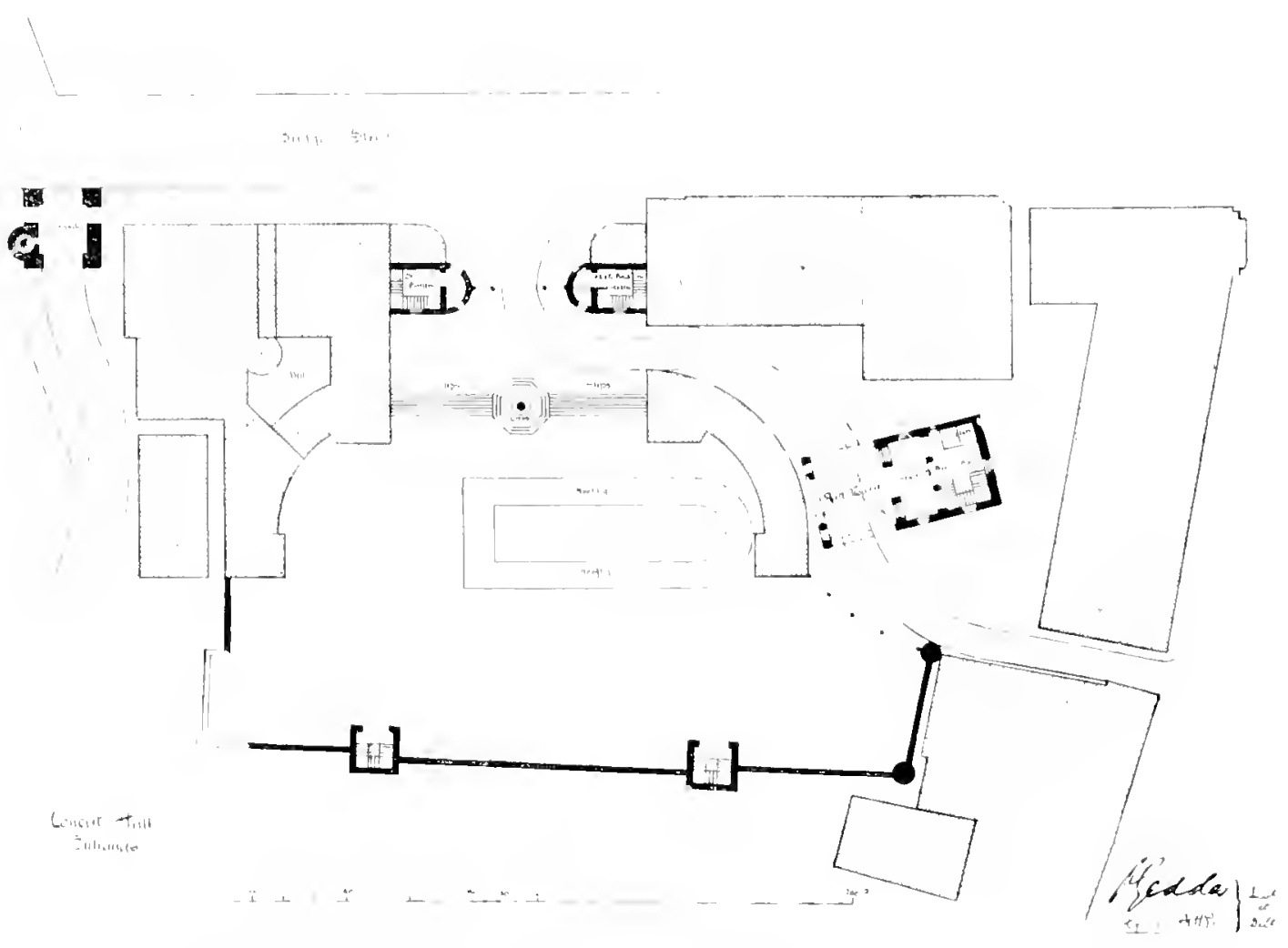

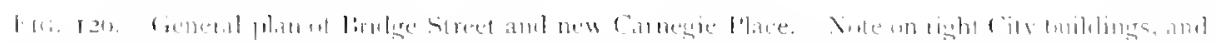

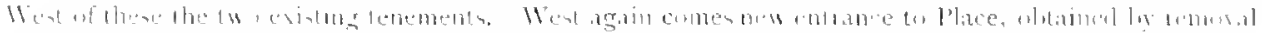

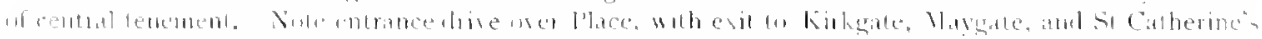

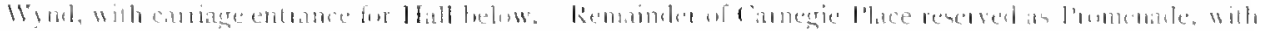

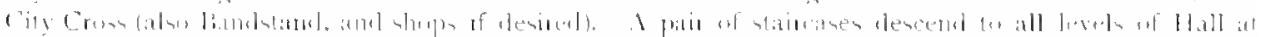

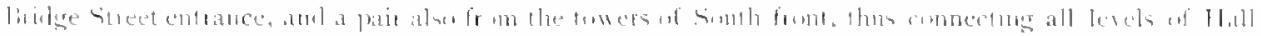

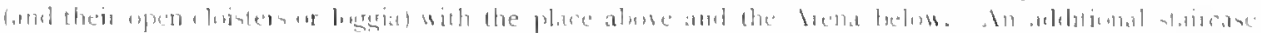

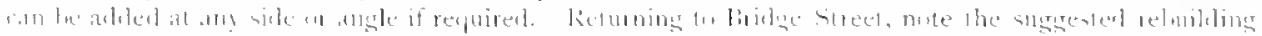

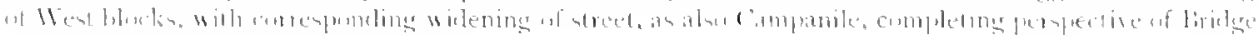

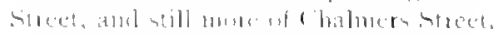

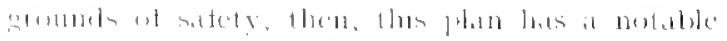

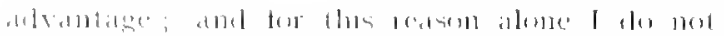

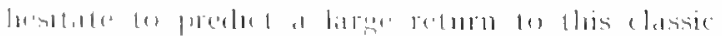

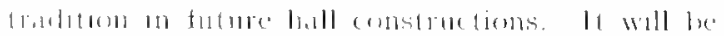

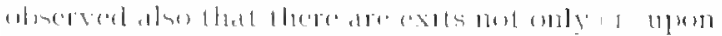

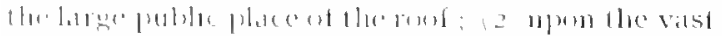

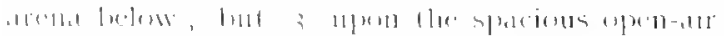

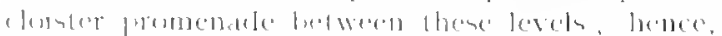

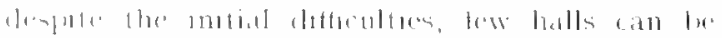

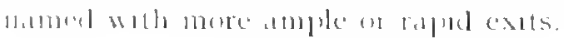

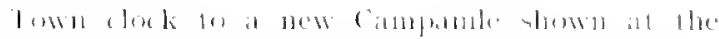

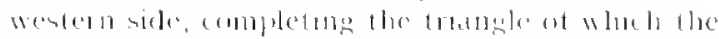

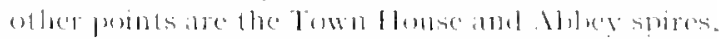

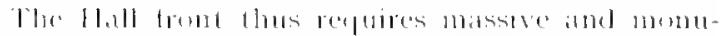

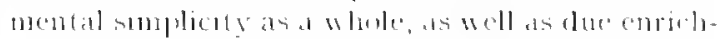

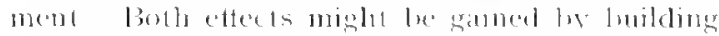

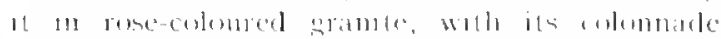

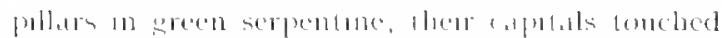

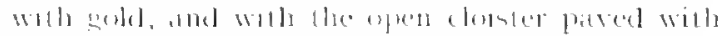

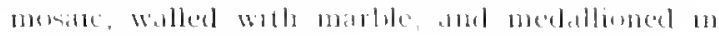




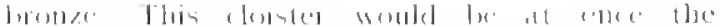

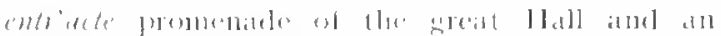

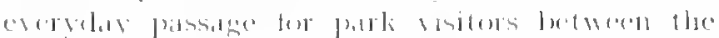

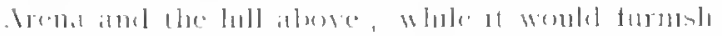

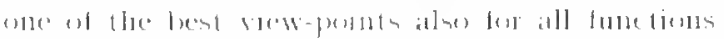

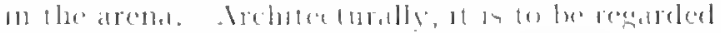

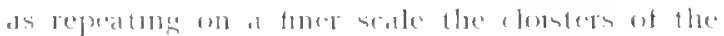

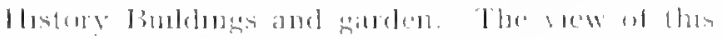

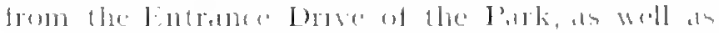

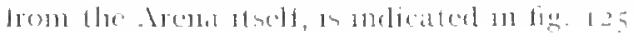

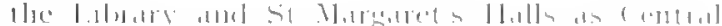

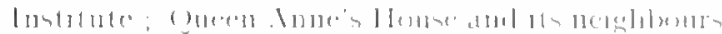

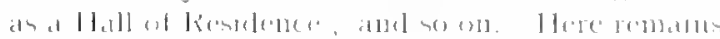

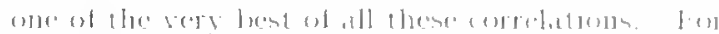

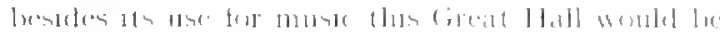

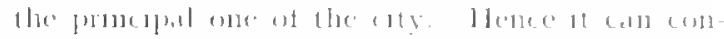

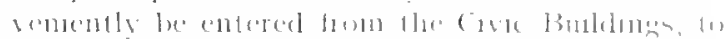

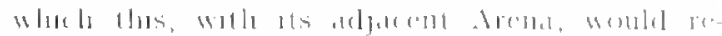

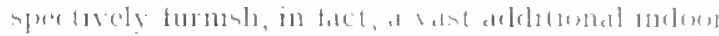
amel anteleme apartment

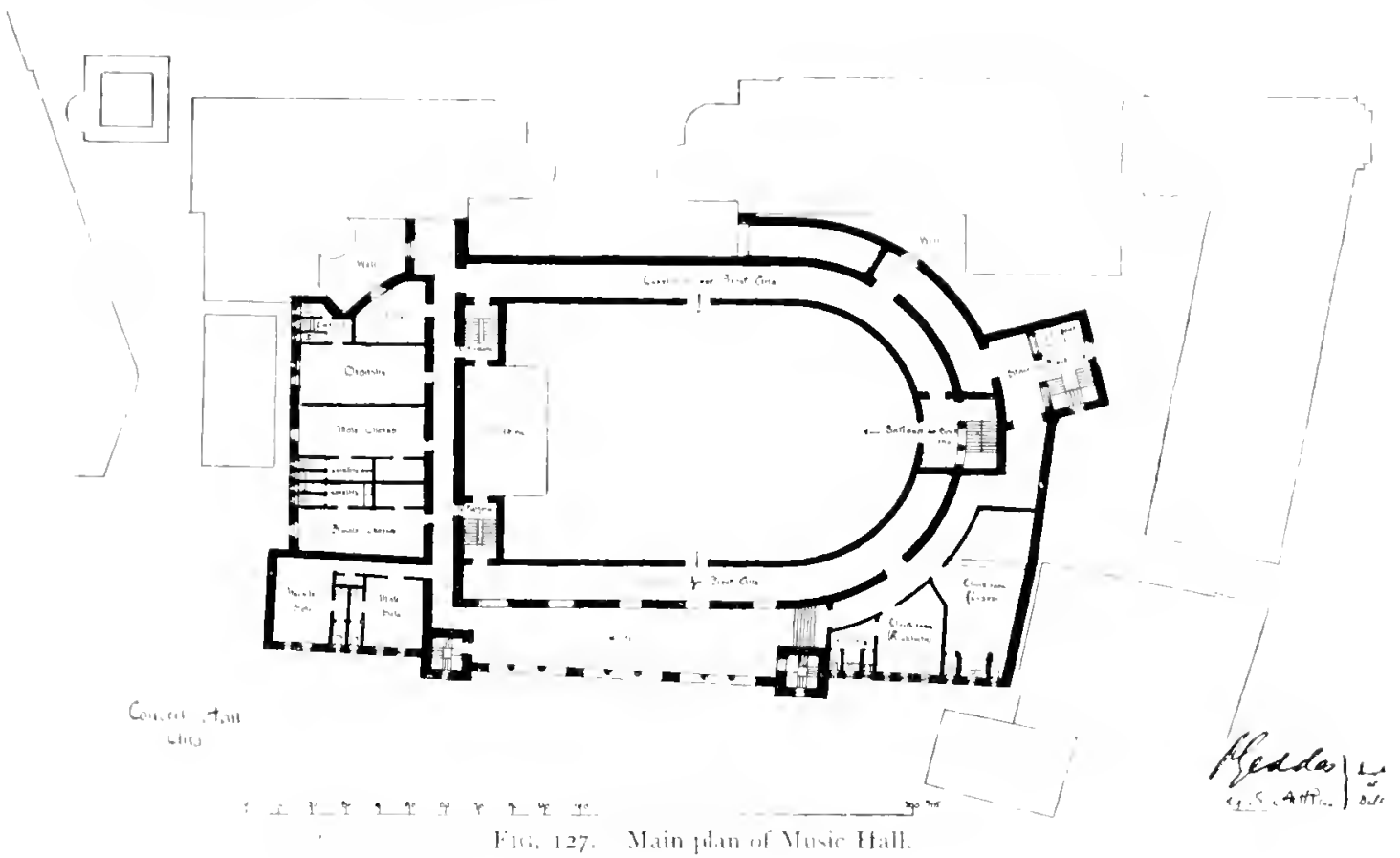

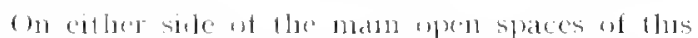

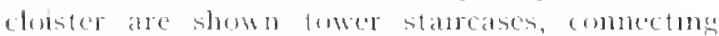
the arena ledure and the place abose with all the

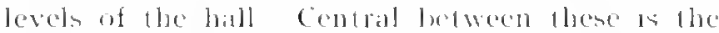

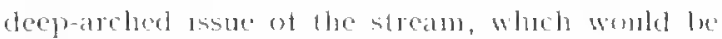
lotter than as shown an the perspectuce Into

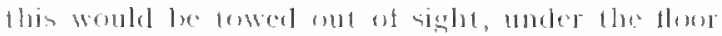

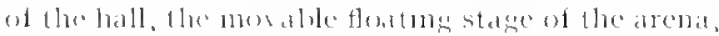

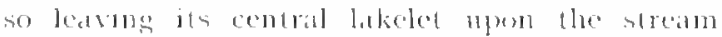

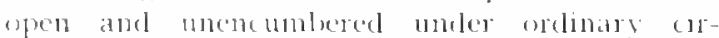
cullustances

\section{Cily Hall}

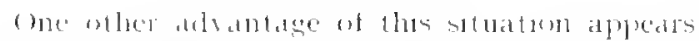

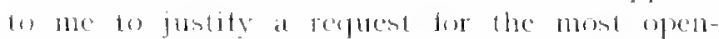

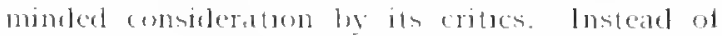

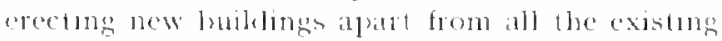
smes we lave al each point reintorecel the old ones, ant this for looth artistic and practical purposeswitness the Mulls as Labuul Muscum; the Mbley and l'alace Bublengs with the History Buildings

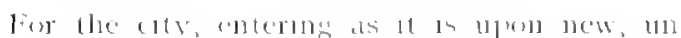

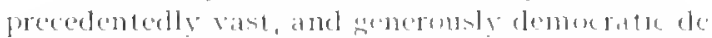

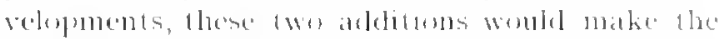

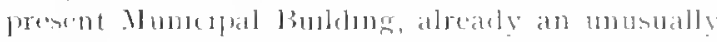
palatial ane, one ot the bastest ind completent

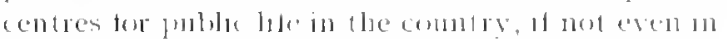

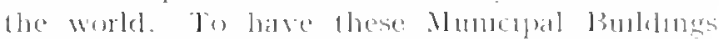

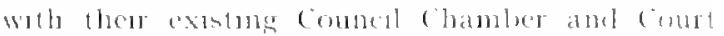

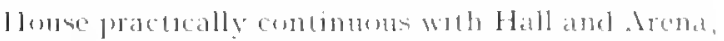

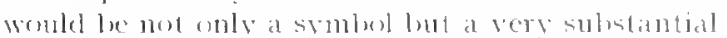

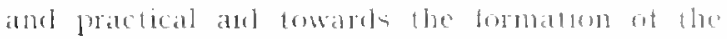

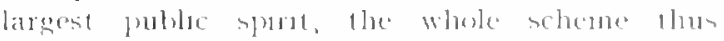

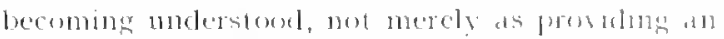

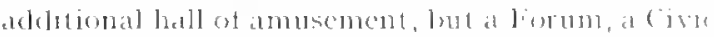
Cathedral. Within such an envmonnent. Such al prowing cente of cisic activity and mexlerte

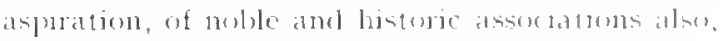
the mustab shoulel surely surpass lamself.

This union, then, at buce material and noral.

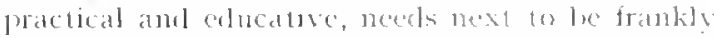
symbolic in its supteme atdornment. Nibat sym. frol shall we use, deep contgh tor any, simplo 


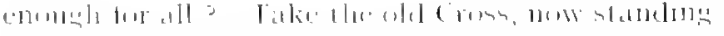

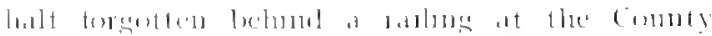

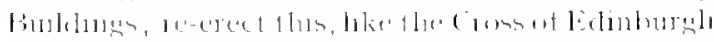

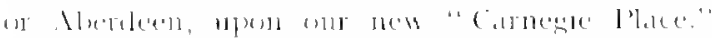

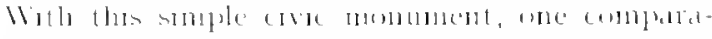

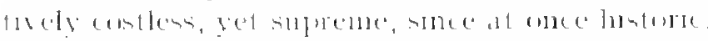

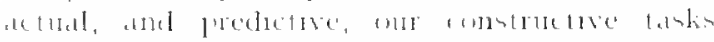

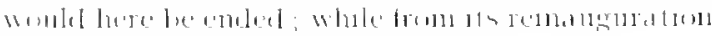

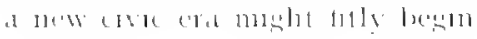

\section{E. Music and Drama}

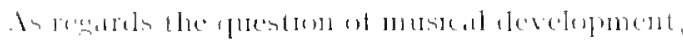

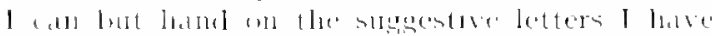

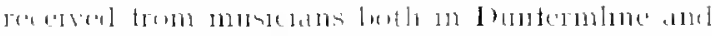

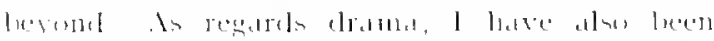

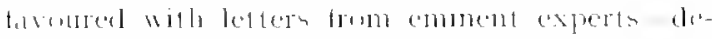

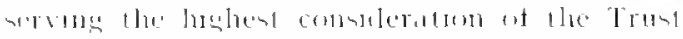

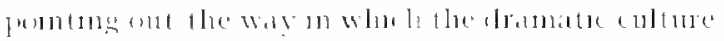

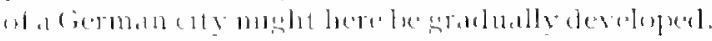

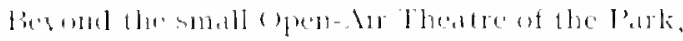

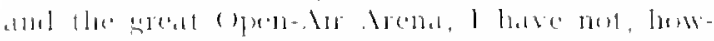

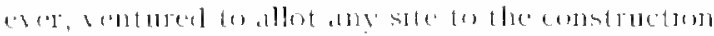

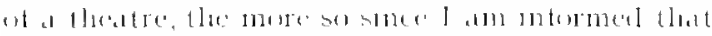

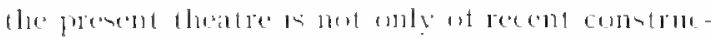

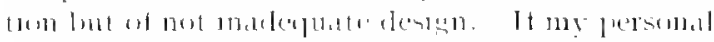

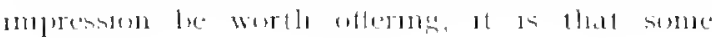

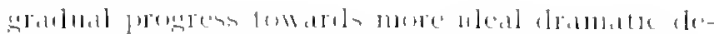

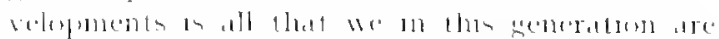

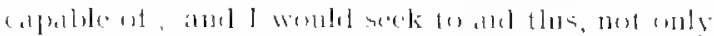

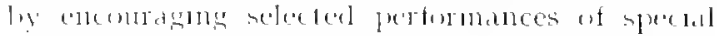

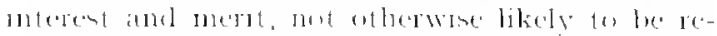

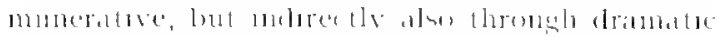

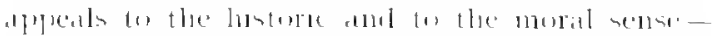

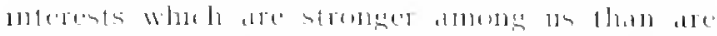

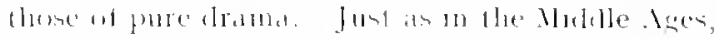

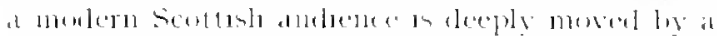

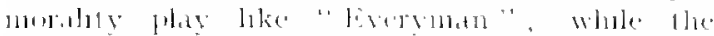

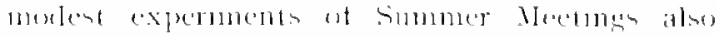

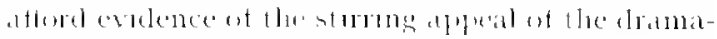

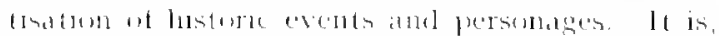

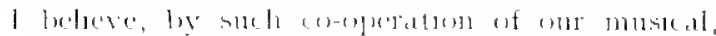

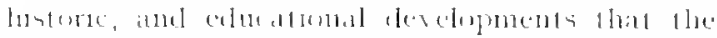

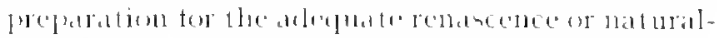

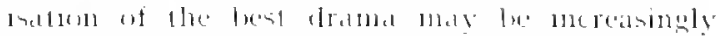
posinglile.

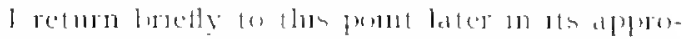

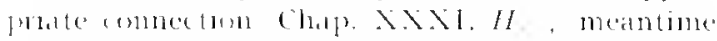

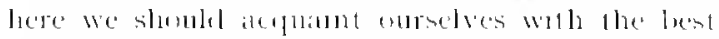

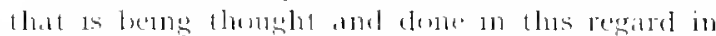

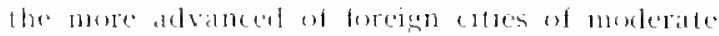

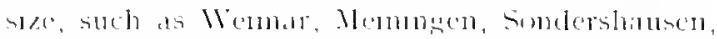
.11ul berenen. The example ol Stratlonel-upun-

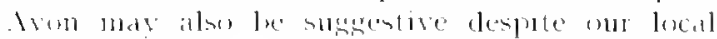
dradchantage. 


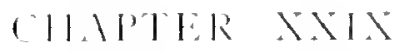 \\ THE GRAND ENTRANCE}

\section{A. Bridge Street}

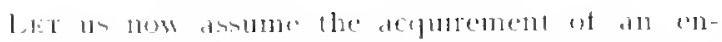
trance from brulge Street. "This nateway should, of coutere, be clestened an a numumental leature on low aly, concluding the perspee the of hluh street.

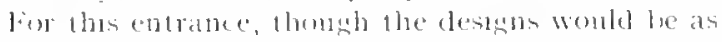

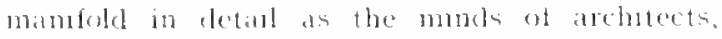
they must all, notwehstanding, tall ante the (we matin alsses which we find everywere the mote formal amel the mone naturalistuc-the are hitede of

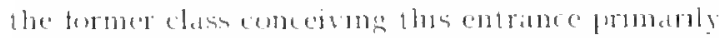
ats an oppentunity of statedy archlectural completion lo the prespective of the llath sitreet, the

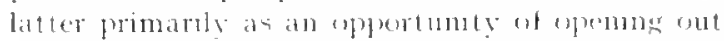
a croweled street vew thto a pledsant mass of

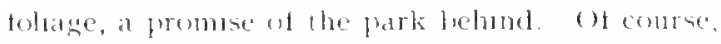
all designs must have something of louts, hut the proportans will vary greatly.

\section{B. Buildings in Park: Pros and Cons}

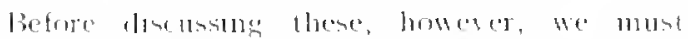
deede on the interior treatment. The sery first

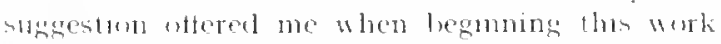
in October list wat to continue Bridge street right throment the park to the coal kowl, and the

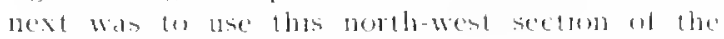
park ats the site of the musemms and other huildinges.

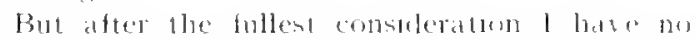

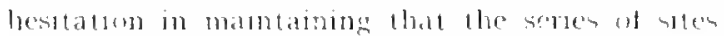
I have selected alonge the lown wele of the freth rasme are greatly preterable, and the on many

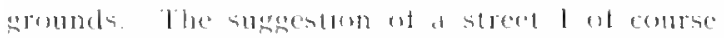

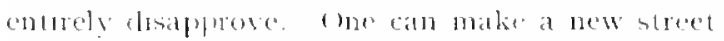
anywhere clie, hol mos a new park. As regads

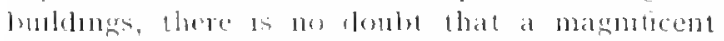

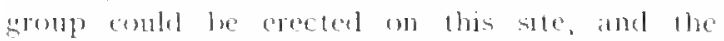
economes and adrantages of centralisation make this polacy worthy at comideration, (me thes subject I have comsulted not a few leadms atuthorities, and am rebereel for find that whth a smogle exception, that of an admunstrator, not an arclutect they all decide against mificaturn, and this for very valded reasons.

Besides all their arguments, a knowledge of the

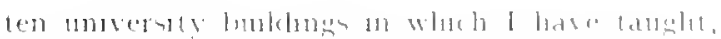

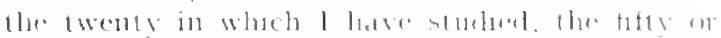

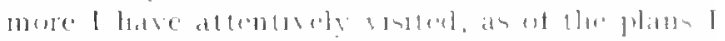

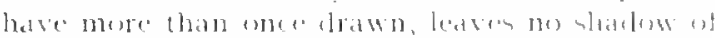

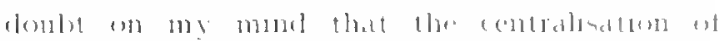

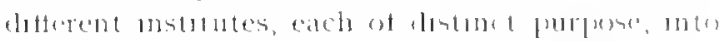

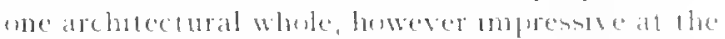

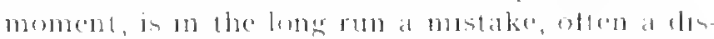
astrous one. for each lublong senter or later

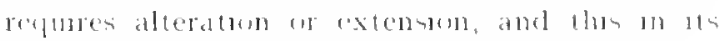
umn way and at ats wh rate of erowth.

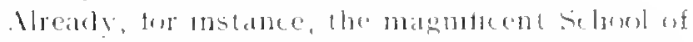

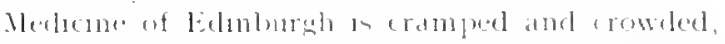

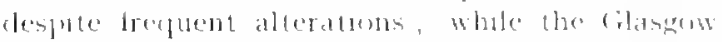

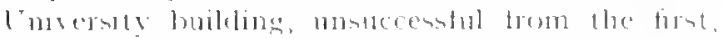

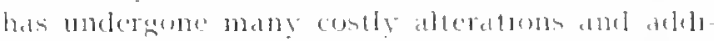

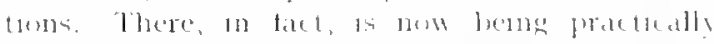

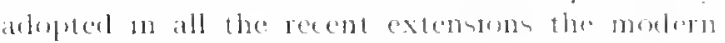

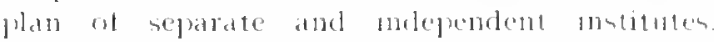
The pan elaracterses the great magonty of the

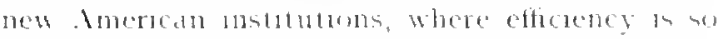
groatly resterbt, and in all length previlling in

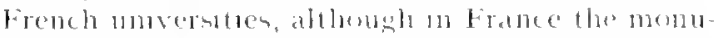
mental and contralionge trablum in ses extrd-

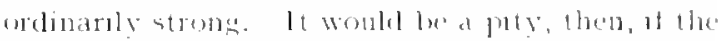

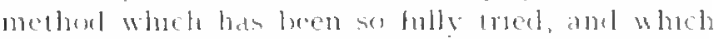

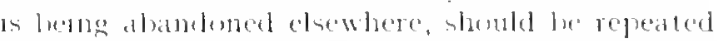
anew here: rot flum an a comblatut langer ot

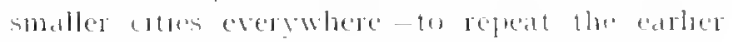
expertmonts of the greate centres metedel of profirme ly lacem.

The real reason at the attratedreness at the bled ot a monumental prle wh the lane of bridge street

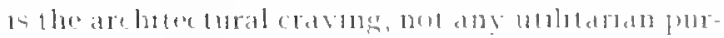

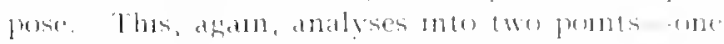

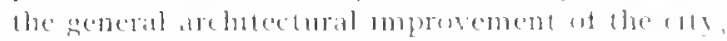
(1) wheth these new huldings, it they were all

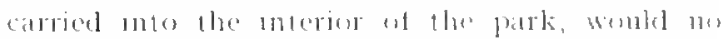

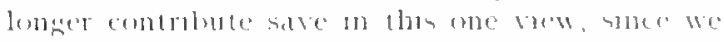

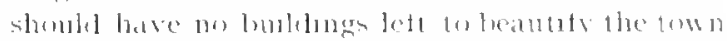
wath berond the monumental gatewats these new bubling would practlcally remaln ungerts,

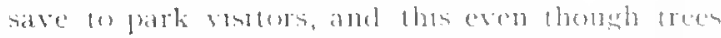
were sreatly sacrificed, so spoilung th present seduled character, an comtrast whth the bury street.

Morener, is the parte an very large that we can afford to gare up thas quarter of 16 , and this one 


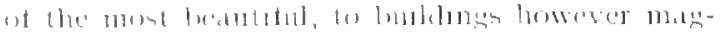

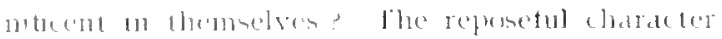

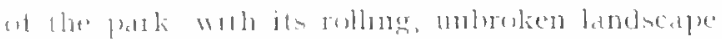

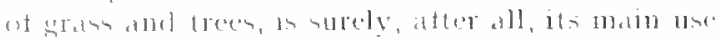

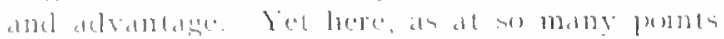

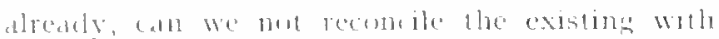

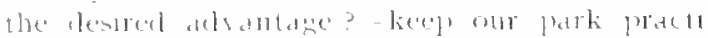

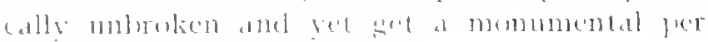
-pectere trom lindige street.

\section{Harmony of Advantage: Gateway and Fountain}

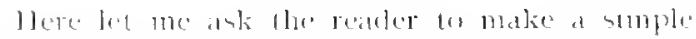
experment forking trom a moderate destance

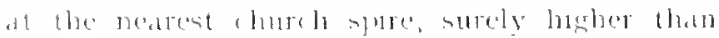

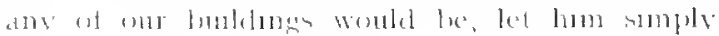

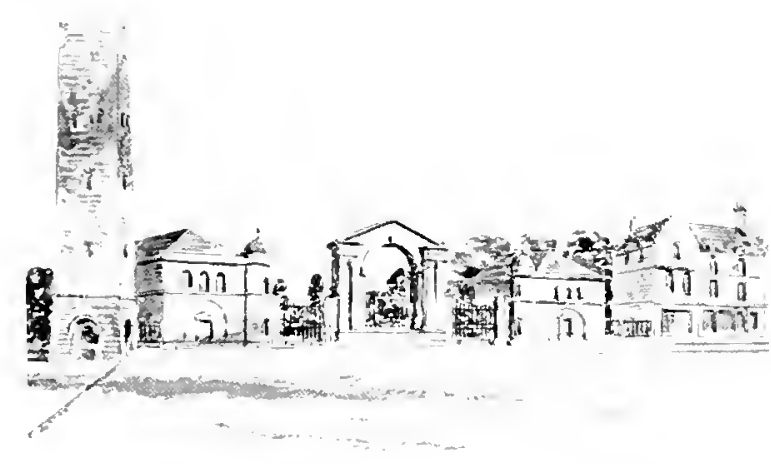

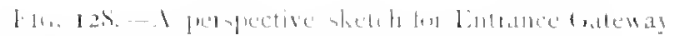

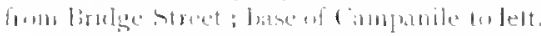

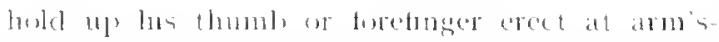

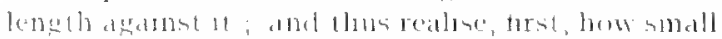

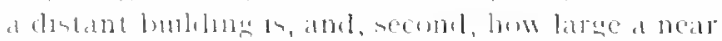

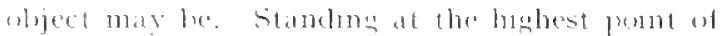
the Heg street, and lexking down to the Town

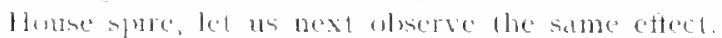

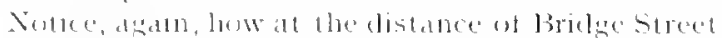
the preant heruses, where this new elstranee would

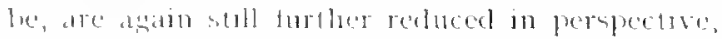
and low mall are exen the trees lwhmel them

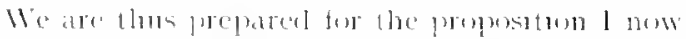
make, that a suffelently mommental gatewas at

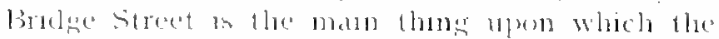

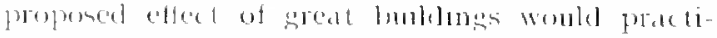

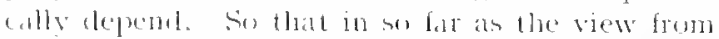
the lown in comernerl, there as no such sreat

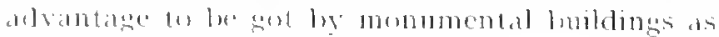
at first ane is templed lo think

bint bow suppose we have our gateway, and (nter 11 -shomld we mot then see the monumental

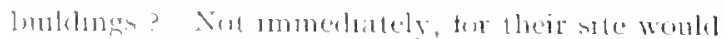

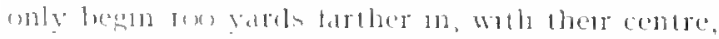
say, fex foet tather. Here, agdin, perspective womb greatly refluce ther masnitule. But now

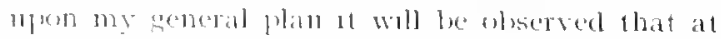

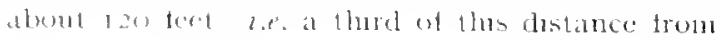

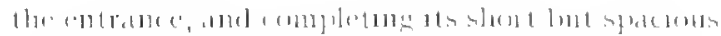

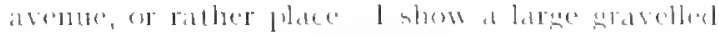

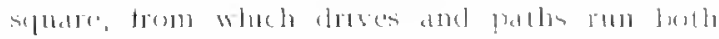

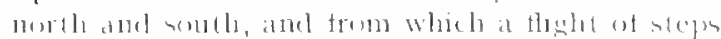

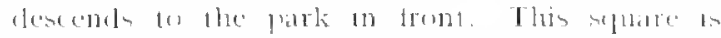

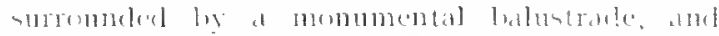
leate

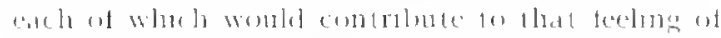

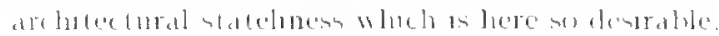

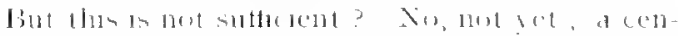

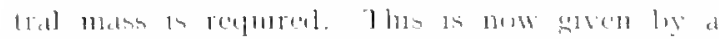

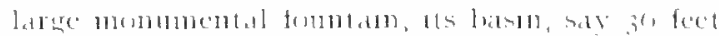

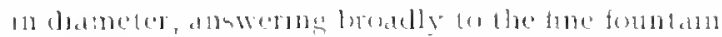

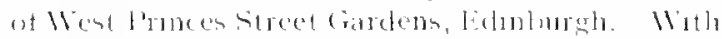

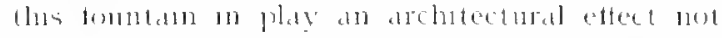

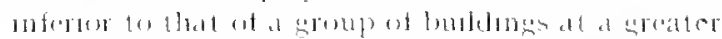

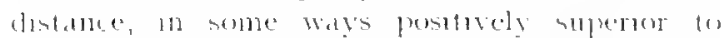
this, wombl be oldanded, and all thes practically whlumt enereaching upen the park at all.

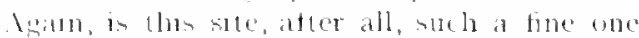

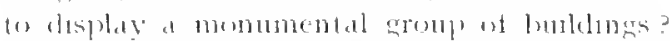
freme where weuld at he seen? Fom this, the

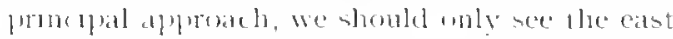
skle at lle profuned group-but this is in shadow atfer mideddy: while tor is southern and weofen vew, as the park paths and levels hom, we hate no aldeptate wew ponds at all.

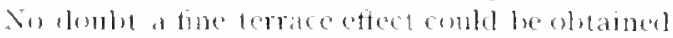
from below, hat omly for a destatece of a comple of hunded teet, whole the atceess to this low druxe is mecesondyly a sonsewhat steell and an-

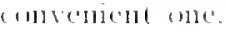

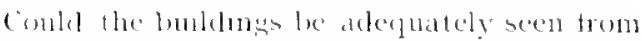

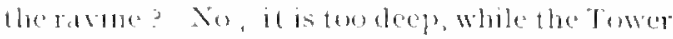

I bll woukl ent ot the vewot them trom the other

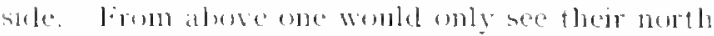
siele, Whach as emolletely sunless, anel from the

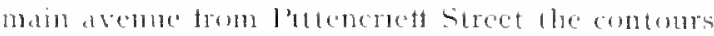

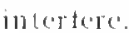

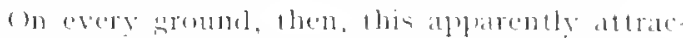

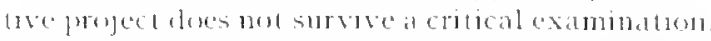

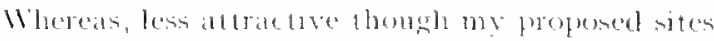

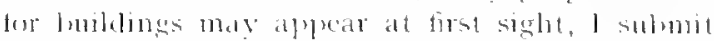
that the mole alde the homere thes ate critically exammed the leeter lisey will appeat, and the from every jumb of vew, monumental and predeical. Thus is especially the case when we licele in

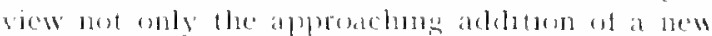
fown lint the reactom of all these clatreres upon he mopresement at the old one.

lians and perspectises show that we liave mol

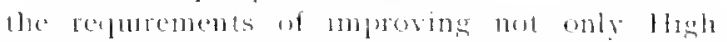

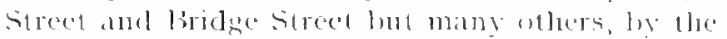
aleption of the maternal sites-those "alomin the

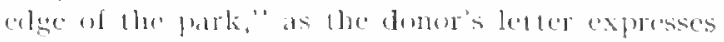

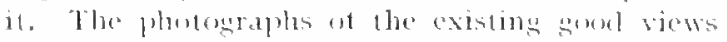

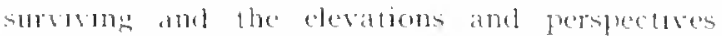
of the propered hmblungs show a tar more sabied range of eftects than combl be pusbly obuaned from any single central mass, nobly desinned llowgh the night le. 


\section{Conclusion as regards Sites of Buildings}

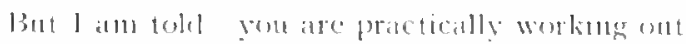
thas whole schene ol a park without putling mu

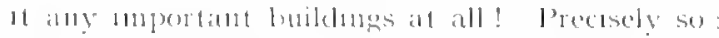

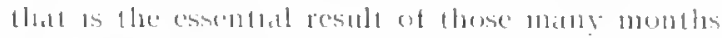
of platumng the essential mest on and clam tor the present selicue that it improses the park ats park, the lown ats town. The park, thougly now filled fhrenghout its range whth new and vatticed

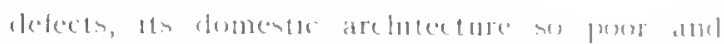

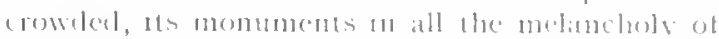
lleor rum, Whereas, the supreme argument in

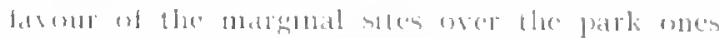

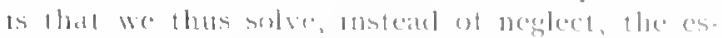
sential problem of preserving the rate combunat

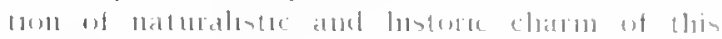

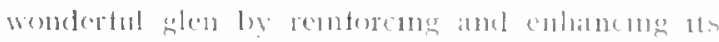

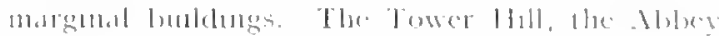

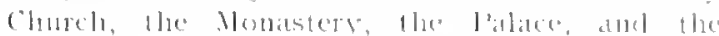

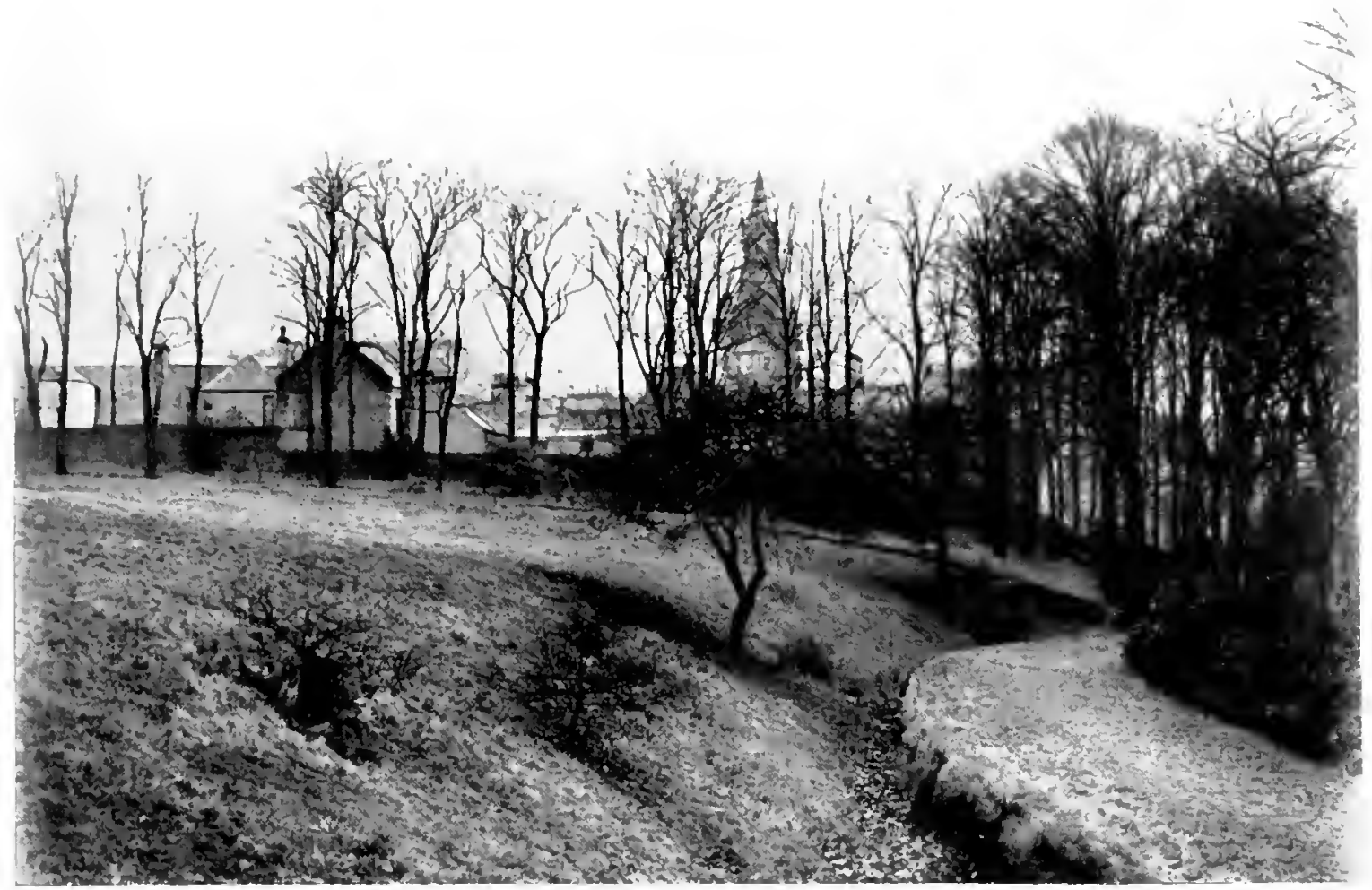

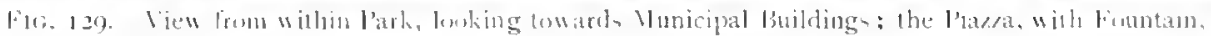

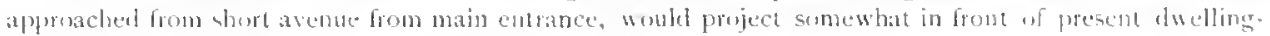
house seen miduay hetween Tom llouse spite and left side uf figure.

mlerests and beatules, has vet the same restful expanses of prass and trees as crer, the same shaty and sepuestered tell, and this allhough all reasenuble monmmental demamels, as of al stately approach from lhe lligh street, of an daborate lormal giteden within, have been fully met. But this is very difterent from cuthing up the park for buidenge, and thus also practically leaving the town unimprosed by them; in fact. bringing out be lhis sharp contratst all its present
Mills, decalyed thometh they all are, still constutue one of the most remarkable gromps of cubure assets to be tound in seotland or clewhere; upord the present plan cach and all of thene are preserved, supprorted, displated, developed] ; whereas to athanion all these and set up our new culture apparatus pactically in a new yuater out of sight, for the silke of a little greater proximity to the lusiness street of the like, would be at trate misunderstanding, an irreparable disaster. 


\section{CHAPTER XXX}

\section{MANSION-HOUSE AND QUEENS' HOUSE}

\section{A. Mansion-House: its possible Utilisation}

Sixce my previous references to the MansmonHonse in Chapter $V$. were written l have hecome atware of that final act of senerosity wheh rounds off this magnficent froperty.

What now from the prinde froint of rew is the hest use we can make of hlus central and notable loulding? A moseum is but of lomeled appeal, though such use misht le temporars: 11 is not large cnough, now accessilite enough at nogt and in all wealluers, a become d central Institute, eren if we hat not found that elsewhere Chau, III. B...

After the fullest conseleration, must we not come lack to the itea that the Mansion-House lad best remann a Mansion-House still? l3ut whose? follow once more that method of historic retrospect whels, as no mere antmalreading but as the reviow of the stages of soctal development, has heren of service an prevous chapters. Here, ats the lniblings of our openair museum remind us, wre many sucesssucentres of power and sucial leadership. This has passed from the Celac and early saxum fower to the mediatal dbres, from this to the lienalssince l'aldee With the demolition of the roval power by the commonweallh and the re-estahbshment of squireately at the Restoration this Larrel's House lecame the natual apex of Dunfermine soesety : Whate with the industrial revolution of the late eighteenth and nineteenth centuries the prosferons burgens snceedes the ancient tambles, to establish a more closely walleal-in exclustreness in turn. Here, them, are, as it were stratified betore us, all the man formatums of the socal frast, just as are the geologic ones m the glen or in war propmed roxk sarten.

Nor ate the lecent proprosils for lts use any lese hufortc in then regular successiom. First the acqumement he the captain of industry (1) whom we are here so peculiarly indebted, then the adea of using this as a temponary home, of which the position and sumonndings unite noble tradituons and cric sympathes. Next came the proposal that this shonld become the Mansion-Hunse in the curic sense no longer the rustic one, and, as the official dwelling of the chef magmatrate express the utmost crite dignty, the utmost popular accesslitity elso later sugnestons have been from the standfornt of the teehnical anel se ientific oreler of thingss as for temperaty museum acermmoslation led the last word cannot be whth arte and sciences: a louse must he a house. To living, non to ledrning, let us cledeate this buildum.

lowking at lite, then, ats smply and generally as we cann, at our wn lives dnd amlotwons along with others, what do we work lor leyond the mere continuance of exstence? - Lowarils a sucters of some sort. Ancl on whatever plane of sulcess, $1 t$ is the simple lact that however hish the goal of on ambition, even conchudng the arandest perspectives, we think of a little tume ol pleasant retirement whlum a bome more resttul and spatcious than our present one, and commonly whth gatclen, srass, and tree, with kindly hrol-nete, and, it it may he, a somel of running water.*

Hence that matusum-house magnaficence wheh has so specially dommated the three lingdoms tor centuries: hence that growth of suburban villas, each with its miniature park and worel and garden. Ineleed, as Mr Wells hat spectally. pented out, the poorest tragment of iron railing upon the steps of a town house represents alike in history and an imagnatuon the park lesundaties at that rustic lowme, to realue whald is the ambition and mstinet eren of the coly-born. Inel that reghty, tor, more than rich tome ant sous chothmg, a bome with some rustic condituons is the first organic need of healthy indovidual lite and uphringing. The contemporaty lats movement, and the meipent Gaten city one, are recegnitions of this, which must lectore long transform the map of caties anew

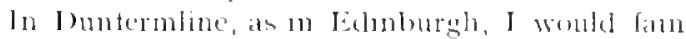

" We hase umpathised tow longe with the orelinatry criti.

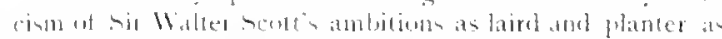

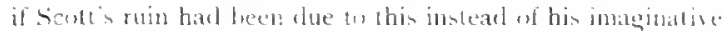

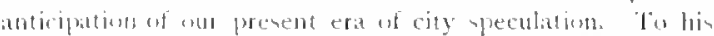

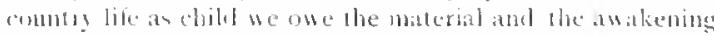

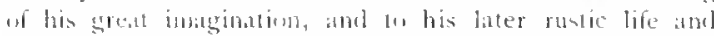

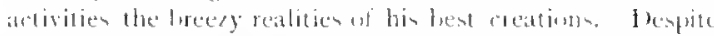

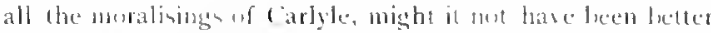
for the latter' work and teaching had he falkused in his

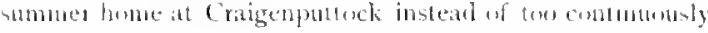

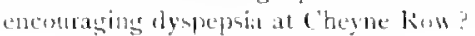




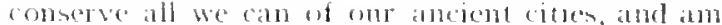
llum no over-sentmental alvocate of a garelen its, least of all as a new kind of gond beneath

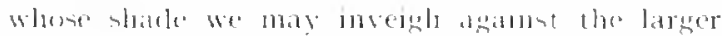

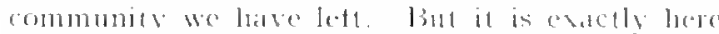
and now in buffermline, with its many apposteds. 11m: improvements and extensioms, that this

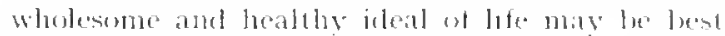
renewed and flemosatised.

So that the return lobalde the ensentlals of

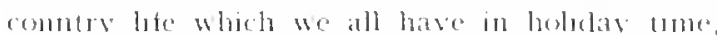
or in convalesenese, slumbl tully re-conter the conception of success in life-success in loving. a foothole in comble comblitoms as woll als in mwn ones-a country house, in shopt.*

\section{$B$. Specific Uses recommended}

for lus one commeryouse, which is our present problem, my propesal is that not wnly the common use of our park and culture huildugs but the occasional molivelual enjorment which goes with the ordmaty idea of property, be centred here in this buse, hencetoth revy man's, still more, therefore, every woman's. it is with the actual possession and enjovment of his henses that the hoir louls and fully comes into hise estate amel the fortune which acompanies it lleres is the very centre of all this wealth of recreations and of culture resources, wh their betterins of healli, bolly and memal, moral and social After the denuty of kimg, alloot, ant lestel, of laird and millomare, of provost and Trust, there thes not only arrives the day ly which all these hate to tre judecel, in proportion as they have helped or hindered the development of the people. ther rompleteness, efficiency, and culture, but even the day when their personal dignity passes to the people in their turn.

With this ideal cleat we are nuw and onty now, in a position to come down to plans, to enter the house and see how it can be best atapted to subserve ths widest popular, vet highest induidual, usefulness. To plan could well be simpler. Ifoum the groumel and first fluor is a single moderate-sized a partment 10 cast and west, the latter whth a room opening from it

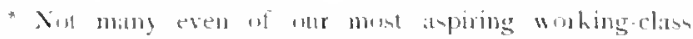
leater are an are that there are already many cities where the ordinarily pouperous working man has hiv condery house an well ac his town une. amd thinks of thene an his stamdard of comfun as naturally ardies laird ur Vlember ul l'arliament

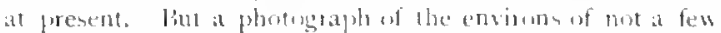
comtinental cities, lange and small-sas Marseillen for a smaller filangow, or Nimes for a larerer I)tonfermbine

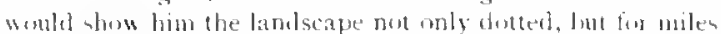
composed, of small lut real country buthes and sineyards. whith are mol only the possensiom lant the regilar sumber 11 stutum homes of the wating families of the town. Is mat this a fir esample of the ned of concrete and gengtaph. ical knowledge to give reality and encouragement even to

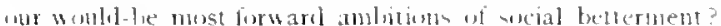

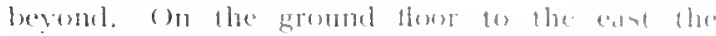
klteben with litte change wonld become it peduresplue oldfashomed kituben once more, with two allernathes for use a plarromen for

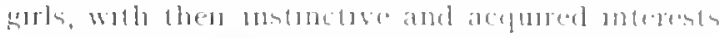

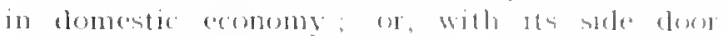
apened fo the east, 11 womlit make it suluking rom tor men

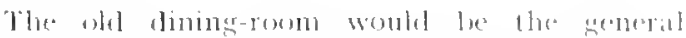
folding-roum, the withlrawnerom bevont,

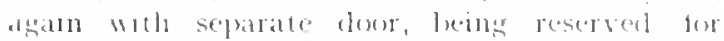
women.

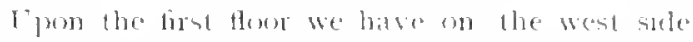
the drawing-roums proper, and these two thrown moto one wrold gire a long resem tor entertain-

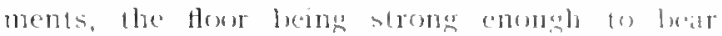
even dancing the panelled walls should be pinted whth decorature plotures, such as they once probathly possessed, or at any rate were intended for. With such decoratmon litule furniture is repuned, chetly wall solds and light chatrs a latrge table being at any lime extemponard upon trestles kept in the adfacent hall store The room to the eant would be rearranged ats kitchen and pantry, ete. Woll pas and sonk, foxl being easily sent in from town.

Whale the ground-flero rooms would be com stantly opren, and thes drawing-roun also on ardinary occastoms, at sombl be jermithed fo any and every stazen, on the smplest comblions of appluation to the loust, te be able to obutan the use wh this for a short perect of homs, morning, aftermon, or moht, there fo entertan at her or hus own pleasure, and in their own way, instead of un then own homes Ind for the hours concerned, with the sime privacy tor themselven and their invited sulests, smply for the tume shutling oft this first tloor by its hall doese, whth a bibel "lingaged till biclek"- the entertamer thus becommes tor the moment the tenant of a privale flat mpon the common taurease.

Ascending this slantase we come to the loret room and garret foors. Is suggested in a recent

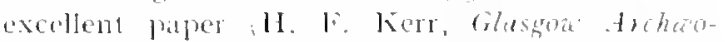
logical society lene the whole set of partitions and intervenim floor should bere be demolshed, thus furnishing one lomg and stately gallery, its tolty rool adorned witly that magnificent plaster-work, so characteristic of our beat old Scottish mansions and town houres, of this perond espectally, and which in benu successtully rerived The nse of this gallery in a way worthy ot its central and culminating position in the whole park may he discussed more fitly in the followng chapter.

\section{External Improvements}

The corresponding external mprosement would restore the lost seventeenth-century wmelow pediments, and, perhaps, open out the stair turut- 


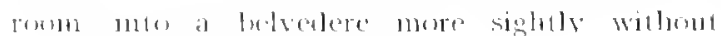

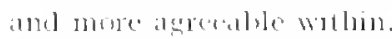

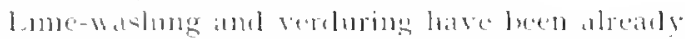

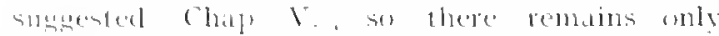

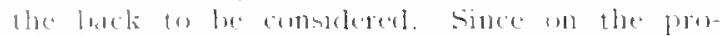

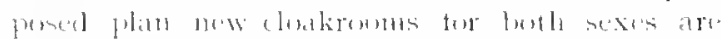

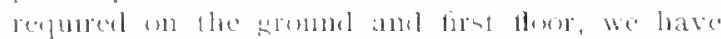

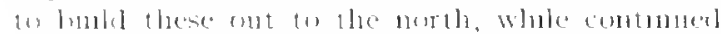

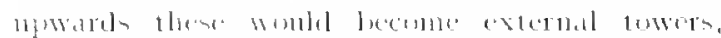

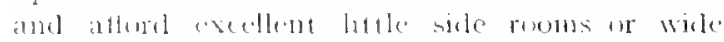
bays to the matre erallery. Were this dome with the smoplicaly get sense of proportion at an

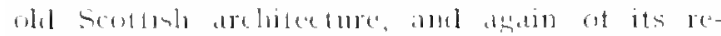

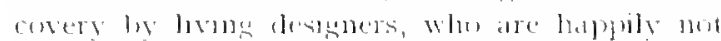

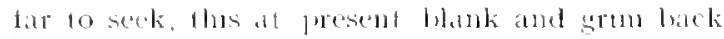
wall would stedenty beome the picturespene

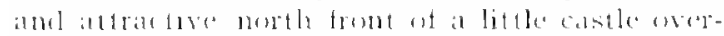
lowkmls its rovme see fig. - 5

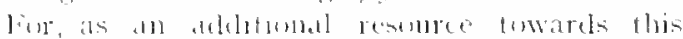

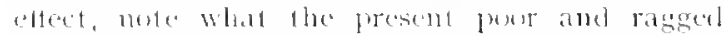
hedge comerals- a mussive retainng wall upon the stogly tencending bank. Regularise and batustrate thes, butress it betow the two new

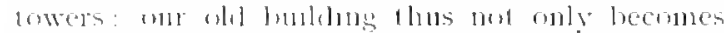

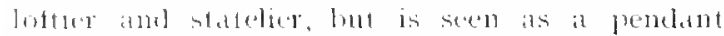
and contrast fo the stroking and massive domble

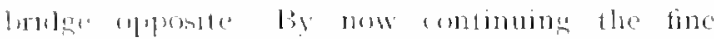

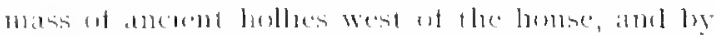

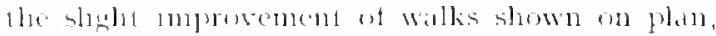
13. liouse wall have been all onee consersed, yet fransformed and inporeded, l trust to the permanent reomeblation of all partics, both comsorvatives ant whlom icomodasts.

The present reproberes of the exterion and

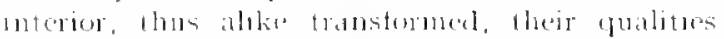

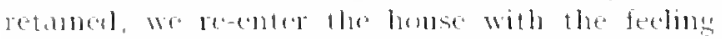
ot an anciont ree impresed bume tre we in

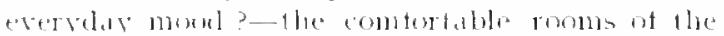

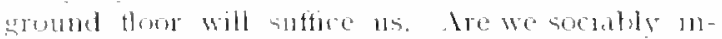
clinet to make mert whi our trends? - let us

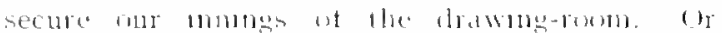
as, atter all, 11 womblaten be vacant, we mat rest

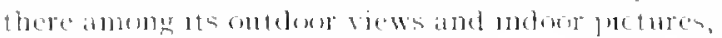
alone ur in the frectom on a c loh

\section{$D$. Theory underlying proposed Use}

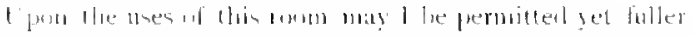

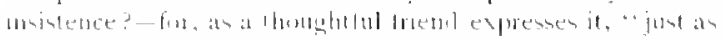

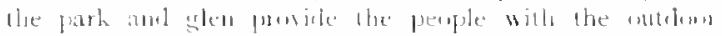

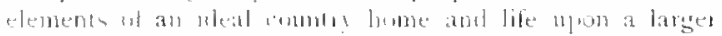

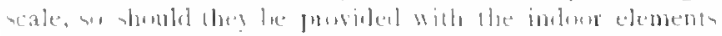

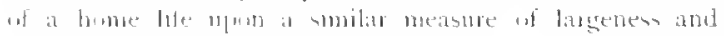
lecanty:

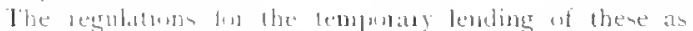

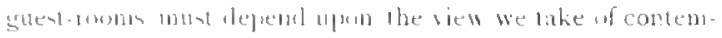

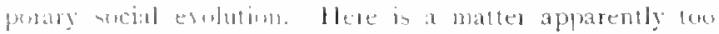

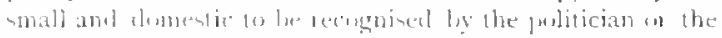

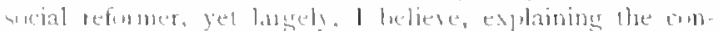

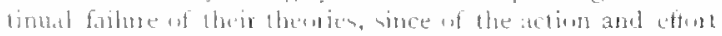

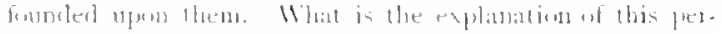

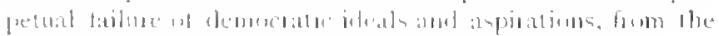

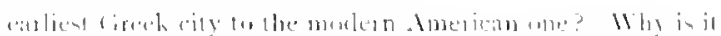

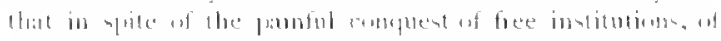

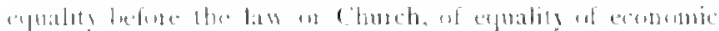

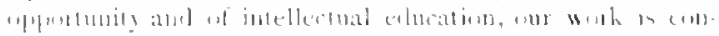

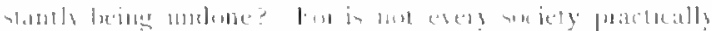

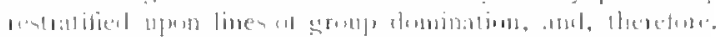

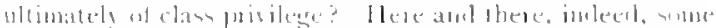

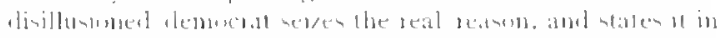

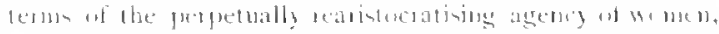

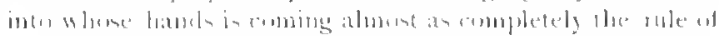

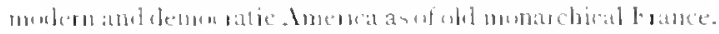

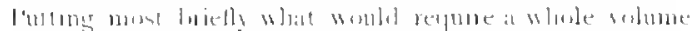

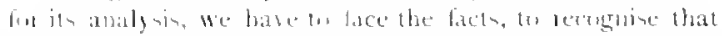

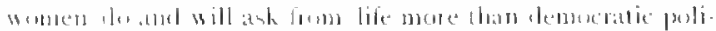

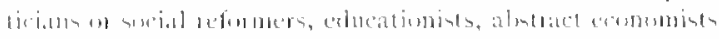

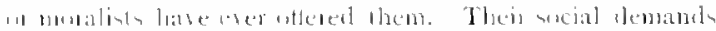

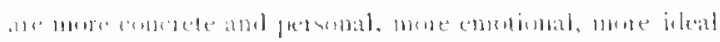

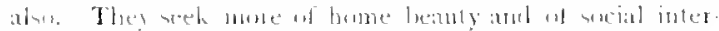

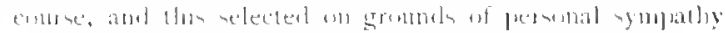

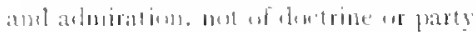

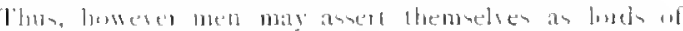

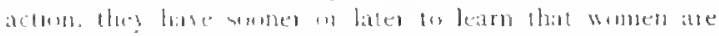

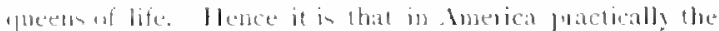

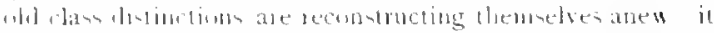

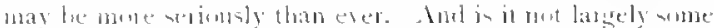

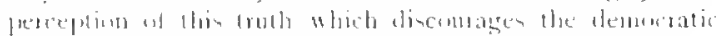

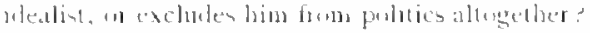

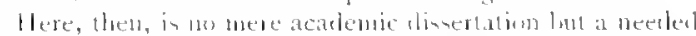

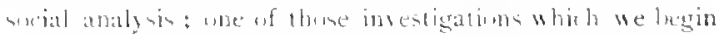

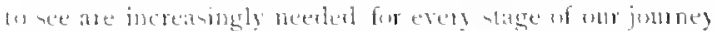

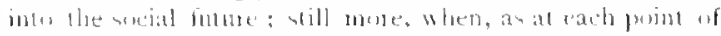

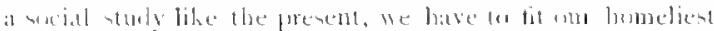

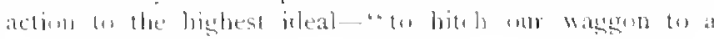
पlair."

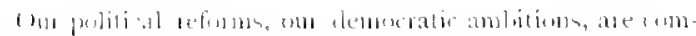

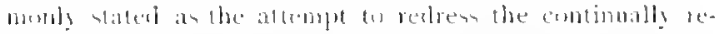

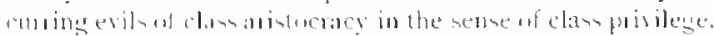

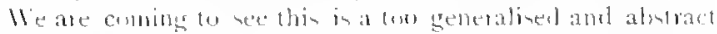

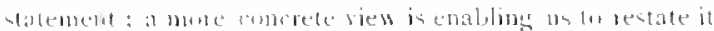

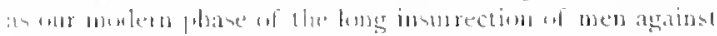

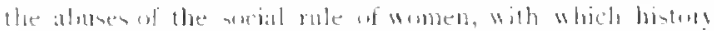

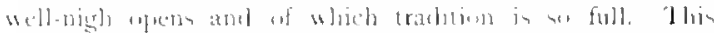

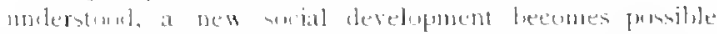

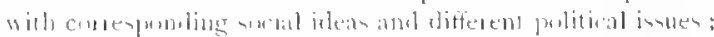

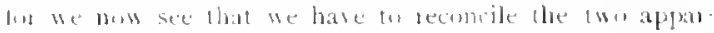

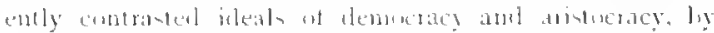

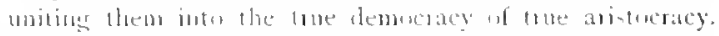

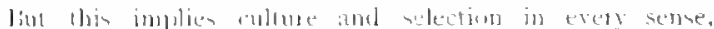

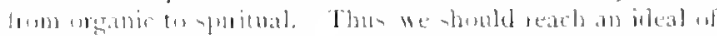

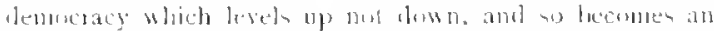

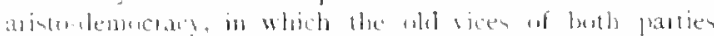

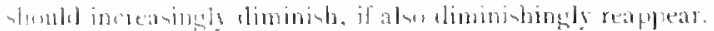

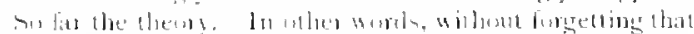

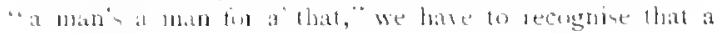

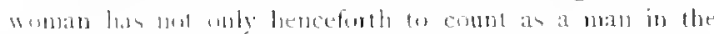

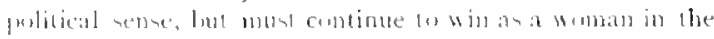

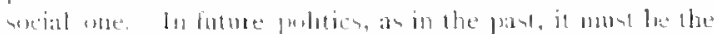

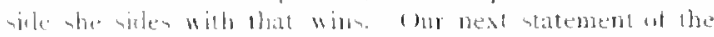

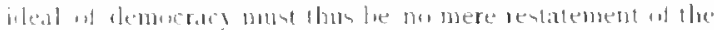

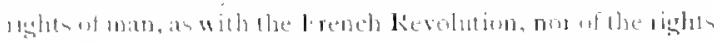

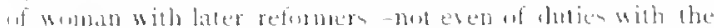

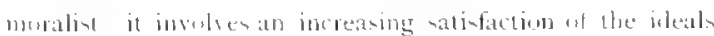

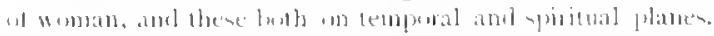

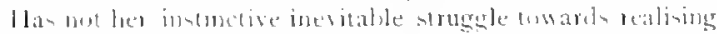

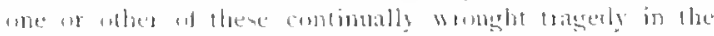

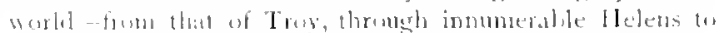

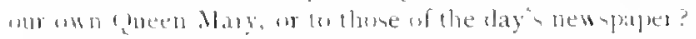

In arial, as in hatural science, we ate lont frecoming

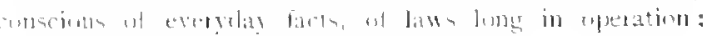




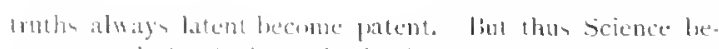
comes rearly for tetinn: ble leggins tw claim the adaptation

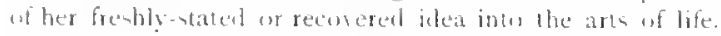

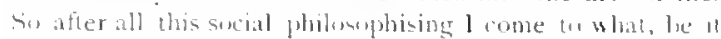
at firat sight pleaving an no, I believe w he the mont vital and llefal wit the varium sonthetic insentions, the wactat

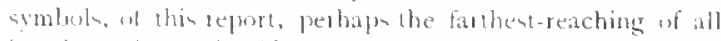
its pionering. scientitic or social. Fin the whole cuncep. tion of this park, with it bumely and wately garlems, ik leivureand pleanure groumsls, ils learned nuseuns, its palaces of art. its bally of numic and drama, its civic eampus and formm, and all as the theate of an enmobled civic and social life, han hal it practical startine-print, from the humble

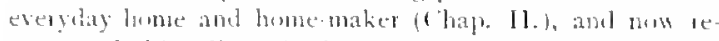
turns tu fiud its climas in the same conception, thush mus ujum a higher youal.

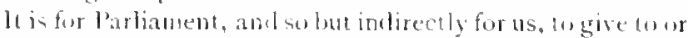

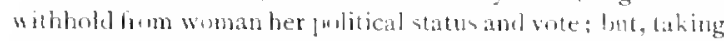
the political amd the wcial urder as we find then. we can at once give ber what, an we hase seen, she valueseven moresomething of her social and ideal status.

\section{$E$. Use in further Detail}

Each flan working woman in Duntermline who choose to clam her turn of this drawingroom and urganise her little social function, thus for the time Jeing, takes for 11 socual precedence ot all elsce in Dunfermline. She thereby becomes for the time being the Larly of the Mansion-House, the first lady of the aty, representing unt only trustees and donor but her own long line of predecessors to yucen and saint.

That before long the demand might exceed the limiled accommodition is no ohjection to these proposals, but the recugnition of them expeliency. The Mansion-llouse will hear such enlargements and developments as have heen proposed for it by various architects, and even where such new wings are daily and nightly overerowded by their happy circles there is room, on the lawn or hard by, for a new matnon altogether, such as has, indeed, been planned already.

Here, ton, is a use for the gardens and gardenhouses and for the many and stately open-air apartments of our formal gardens, for our wondland nooks. Each may have its fite champithe. and each of these shoukl reconcle the "Iualities of olel aristocracs and new democracy, and thus avoid their dectects, so noiting courtesy and grace with the hospitalities of home. Each such bright experience of thue merry-making would thus be an education $m$ bettered social living.

of the common-sense regulations which would naturally arise for all this the possible trifling registration or cleaning fee, the order of priority of application or ballot, and so on-l need not here speak. Let me in conclusion plead that sperial preference be here given tor wedehng applications, since in no resifect is the spacionsness and beauty of the Mansion-House more at advantage wer the ordmarily too narrow and small-roomed home. To mitke the ald Mansion-
Honse al wedelung-house is also surcly speelally fittm: in a coty whose essential history dates Irom at haply wedehng fig. 1,31.

\section{F. Queens' House}

Thompt the Hanson-House thus becomes of more value and significance to these sehenes than at first appeared, wheh wise by angone must. after all, he but eccasional and temporary. It is the everyaly home which is the true contre, in which woman centralises the arts into that of lumg, and thus, heside our people's mansion, we need a correspontingly ideal and representatwe home. (bace more our openoair musem of hustory is chuat to the necasion. I mansionlunbe to entertam an is much for any liely, lunt a queents lune to lave in would he more; and this is now actlably arablable between fower and Ibrey, Queen inne's House replacing gueen innatidla's. Below us, too, is the Queens' Garden, its atrena pared and terraced, yet no longer hower. less.

Within this precinct is the ivied Chapel-ruin of Si Catherine, herself no mere shaclow or plaster satut, lut a noble memory, an immortal simbol.

Where now un any city, even the greatest, the sacrelest, shomll we find a home more nol in asstretatums, more environed with beauty, more smply practical and homely as well? Here, then, let woman worker, nurse, student, leacher come tugether and renew tor themselves. in and from and around this recovered historic centre, the sisterly tellowhip, the queenty service, of olel.

For and whth one such eroup, which woukl soon srom and divide, as with all active life, Dunfermbne would be agan in this respect of the culture and career of women no longer a mere provincial city, far from the resources of Elonburgl and london, of firton or Newnham, ot Boston or l'aris. Ilere is an available home and centre of which any one of these greatcr cities might well he proud-one readily in tull com. munion with all their characteristic actrantages.

The intimate lile of such a community cannot, and need not, be planned ont here, any more than the detail of th furnishing or decoration. Its manysided interests, its social learning, would gradually aljust themsolves, and find their vaned expression lwth $m$ a villening corporate life and in individual developments.

The establishment and spread of such residences for women and tor men is one of the most encombaging and edncative features of our time. I have been too long and intimately connected with this movement from its earliest years to share all its illusions and an tully aware, for instance, that the main result of most enclearours it "sending out university men to educate the people" 
in that the people are someltumes not withoul

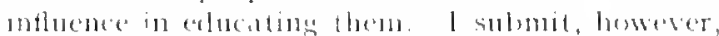

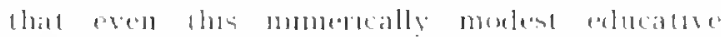

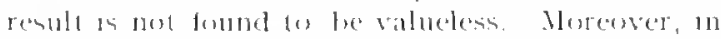
Dunfermber the moversity element womlel not

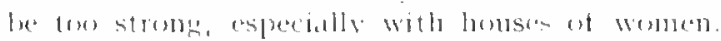

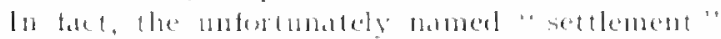
meed not arine, but something of more oralinaly atul alomeratic type

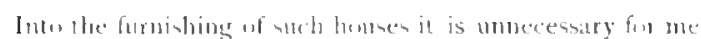

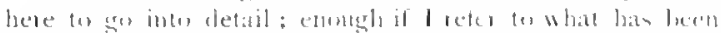
said in carlice chapters (II and II I) of I lomsing impureensed

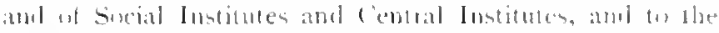

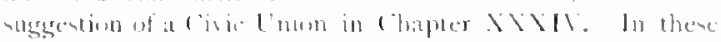

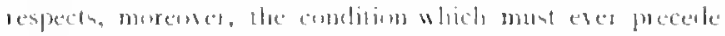

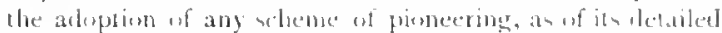

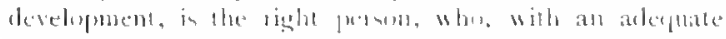

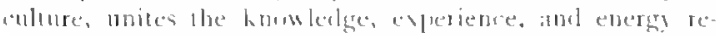

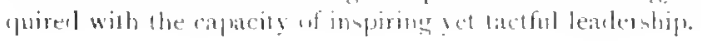

\section{$G$. The Working Women of Dunfermline}

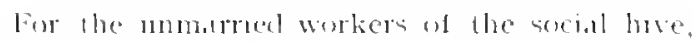
here profortunally so many, ther are also grent problems of he worked oul, mowhere easy, yel here less doffomlt than alsewhore lor whont disrespert the humbler industries of cotton and jute, it is no hattery to cham tor this more refined linen imbustry a more refined puality of workes also; one more ready, theretore, tor all that an enriching culture can aflesel

Ot all contemporary progress and ponetring in Dunfermline may not this turn out to be one of

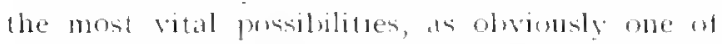
the largest ones? Wi!honl presumnog to entor upon the development of an inclustry lo wheh I am a strallerer, I mas ret rectll one or 1 wo eximples of kindred rise or transtomation ot whole occupations whlin our own lifetimes. First, that of Nitrsing. If fifts rears age Satrey Gamp had nol heen a common purtrait, or at any rate a tair caricature, her mame woult not have hecome a homsehold word. much less lasted to this day Yet about that very tume arose Florence Vightingale: and now we have a whole protession many thousands strong, whose rengresentative type is sister Dura.

Again recall the lames schod, the "atcomplishments" at the "finishing Aratemy," of the immortal Mrs squeers, llese types and bywords of pognlar illiteracy, of gented fullity, of debased commercialsan. Next hee how, withn the same periol, the wnen teathers wer beginning of le- velop what are now .11 this momem the leatrline

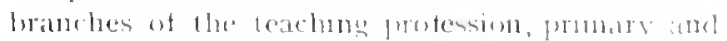

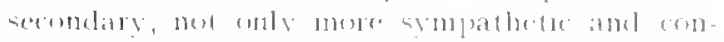

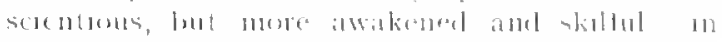
shest, more eftecent- hath are we at the helerte

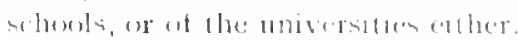

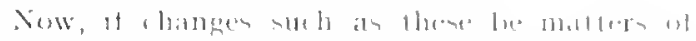

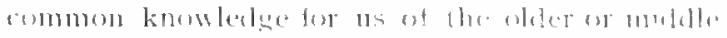
generatun, why mat non smolar rhanges talix.

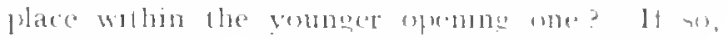
why not lace, first and most of all, in lombermline. thes representature Bntend centre at the woking aristeraty of the textile melustrese

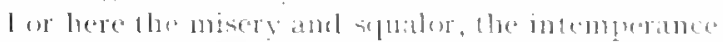

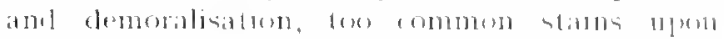

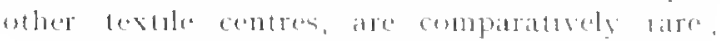
purity of life and ilignily of charicter are constantly maintained; why not, therefore, espectally at this time of opening and cxtending cullureresources, a turther movement of practical ideal irm? that is, of life practical in larper ways hiln lefure.

The paint sencration has attoredel more aximples than does the present or mening and of "m-

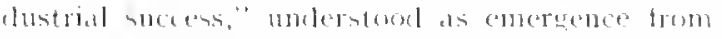
the ratuks of lalwers; and there areweightr reason-

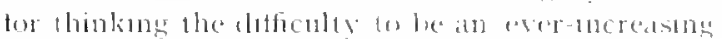
one. But, if so, there is also fullex apuortunity and hepe for the utilisateon of the spected talents

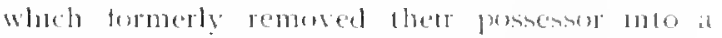
wealther class, comarels the help and beterment wf the working community as a whole

(1) the development of the dealuate yel firatical vew of the posible progress of the workers uf bur staple industry I offer no sugerestions 11 detail, hut lester this sulpert with a final symlul - that of the llstory Fountan, whth thead cover spinning around the pedestal ot Tame. Fer the laread of history is ever beginning anew: and here is a new movement mor hastory. In his heral everviay thead of working hands, there les at renewed possibility of tuture derelopments, mots vidual and social, cive amil natomal, indeed international ats labour and capital themselves. For, wh the opening tuture, as in the early past, the luture of civilisation lies not with the destrongng sword, hut wits the patent, the nuremembered detiil of life-matnaning tonl. Ance more, llen, the refrain of so many of these proponale rowatre pioncering. that whe would ree or shere or aid the progress of labour muly alsi come lo Duntermber For though much olvionsty remans w le lone. here suely a the plater, here the preste, to do it. 


\section{CIIPIER XXXI}

\section{THE GENERAL VIEW: ITS ASPECTS AND INTERPRETATIONS}

\section{A. General Perspective Views}

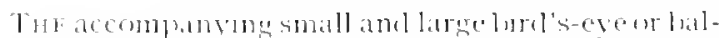

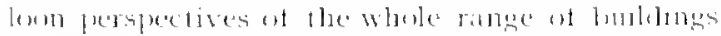
alome the east morem of the elen, lor which l must

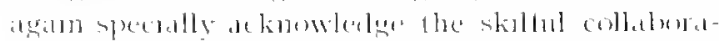

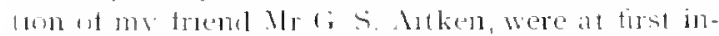

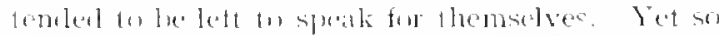

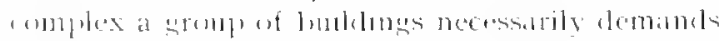

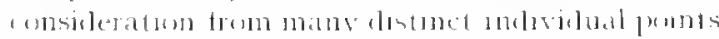
of biew and lleer crate must, therefore, place limselt at earle of thene in lump for lis the

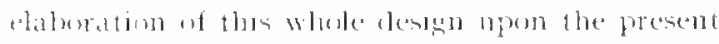

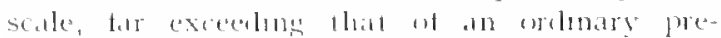

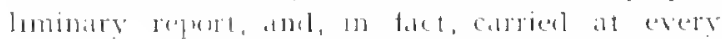

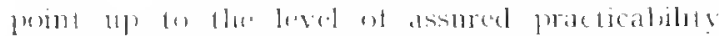

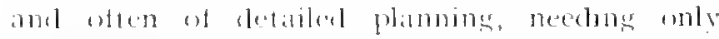

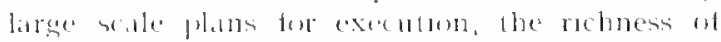
detald and low vanedy of appeal maty readily

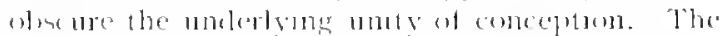

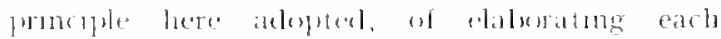
department of butsculture, ateh erreat periont

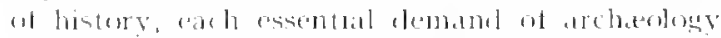

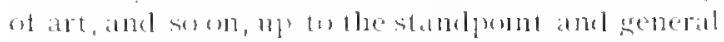

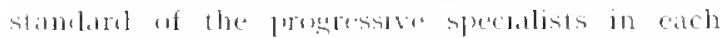

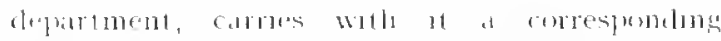

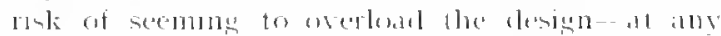
rate for peaters mot spectully interented in this

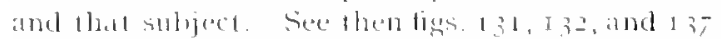

let il is whb a design of thes kmel, as whth the bulling of a shy -momlesis each and exery

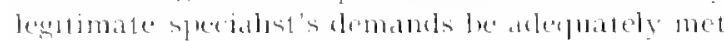
the resultant whale will mat he seawnthy.

letarong, huwever, girclener amel archited,

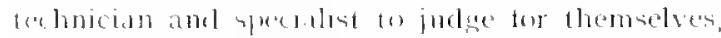
let not mow ale als amele thromeb this labrinth (1) representatures of the vartens clesses of the more gencral publor, so ats, if pussible, for satusty them that an ablematme the redgutements of

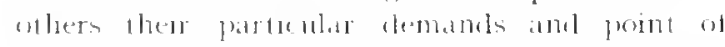

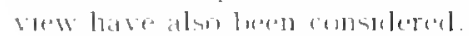

Whe generally, any comprebenste latk desinn, such as the present, has lo satesty ats fur ats may be beit inly all sorts and comelotoms of mon, all

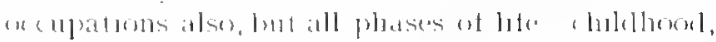

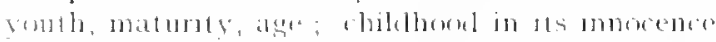
and platy, on that atmoralom and that questom-

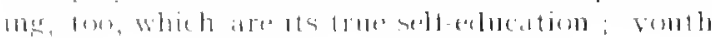

in lis lope atmel aspratuon, its ambutum and

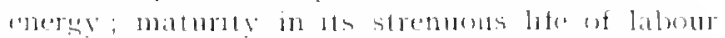

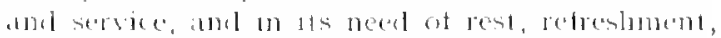
and repuse; age an ats power and intlutence, its

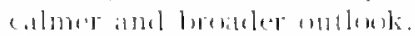

\section{B. The Processional Ways}

1.0 ar arompang representatues of eate of

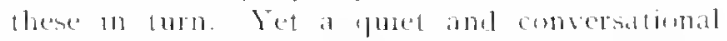
ramble se not in otself sufficient: in almost all

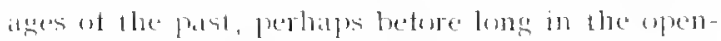
ing foture, we see the larger serial verw, the cove

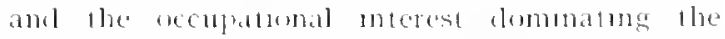
individual one. Ilence ant designs must be

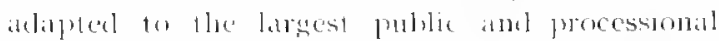
nse ats well ats to the evervelay molovelual rambler. firt as the mulern park ts heconning the Cathedral of the leople it must express, as this diel in its warous chapels and thes atlars, the various ideals

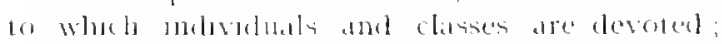
must le aldpled to their group mberests amb

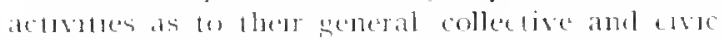
functions, In shurt, then, our laving out of roads and paths is alles one of routes for visitors, and these not only practical and comvenicut hut suggestive and educative, and even indiviclually emotional and collettively dramatio : it rises an the desisumg of the courses and the stations of the indivilual meditative pilgrimage, and even heyond this to the renewal of that greatest and molbes of all the teatures of an ancient crly-its romles of symbul, festival, and trimph, its Proansionul kowel, its sacred Way.

\section{The Child and the Naturalist}

Wilh whom, then, shall we legom? Surdy first ot all whth the little children. large and

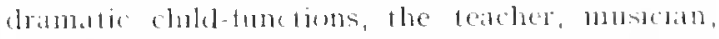

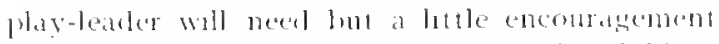
to organne. (r, lett to themselves, the chuldren will naturally hurry past all atr great huldhogs and preter the gardens. They seon leave these for the open park and playgrounds, nest to be tempted lown thes little dell into the stupentums 
and mystrions ghen below, and once there

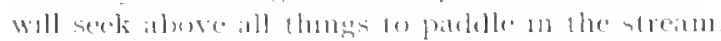

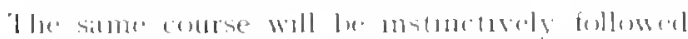

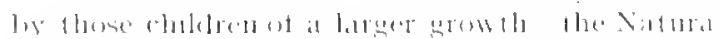

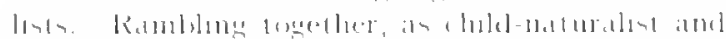

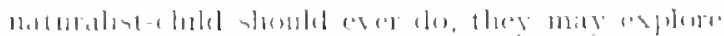

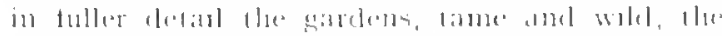

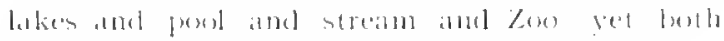

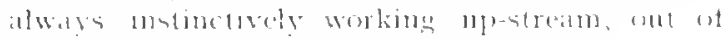

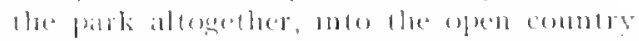

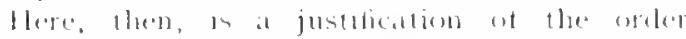

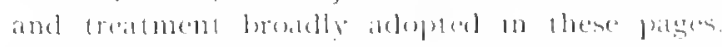

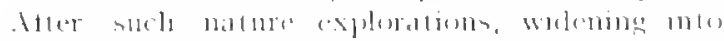

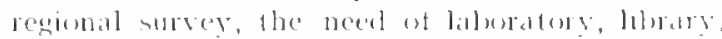

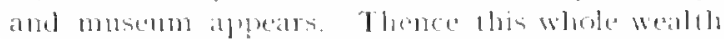

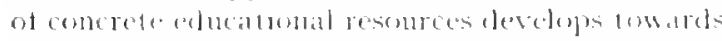
that larger conception of the natural werlel, that ot Lyell and Datwor, of llumblell and lieclus which is expressed an the Nillure lablere, ith

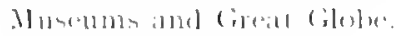

\section{Youth and Labour}

With devebpung youth the fluy inatum

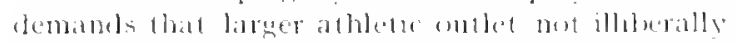
provuled low foth soxes, but nest also seme initiation into the dawning responsibilites, the opening work, of lite. Here, then, is a main justificattion of the Primtive Village and the Cratte Villatge.

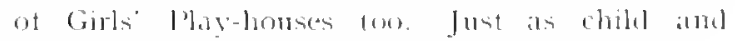
maturalist weme naturally roumme fogether, so now mar Youth and labour

L." them start somelimes trom the buldumg.

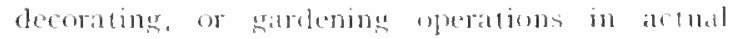
progress, somedmites woth the masterpueces of the Art Musenm, and thence pass through llus

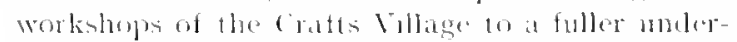
stameling and share in the devedoped activbles of the industral cily and the correspending - meles of tes technical sehools

At times, ton, they will work back qugether to the earlese begmongs of all these indretries in that smpler comtact with nature whach the fromitive village commemorates and attorts: and lous, like lle noturaliet in his wat, lavong here touched bottom-that is, returned fo con-

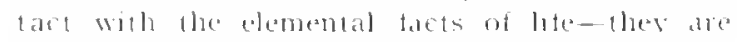

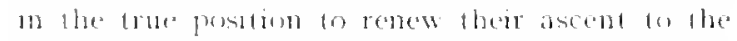
mastepleces of molem ar or ansentom. I camol for, stronely emplasise the remmoles that it a prectsely the pactical and moentue spinte of Chicago wheh heads the pioncerung of at trues techmeal aluation by this recovery ot ifs elemental industral basts. Ind not anly is it the diblogardener who lecomes the borticulturist, the child-bubler the arebited, the

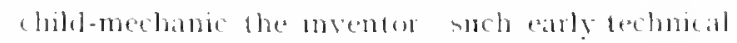
experience offers also a real means of moralentur and socialiong industry, onte far in arlvance of

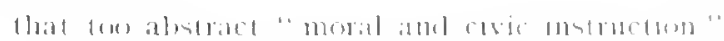

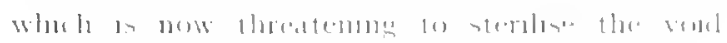

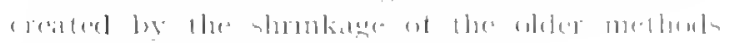

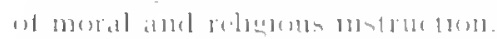

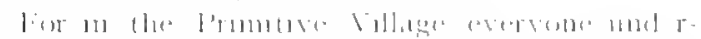

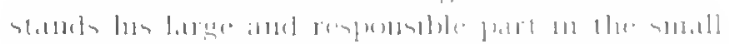

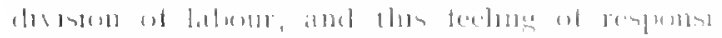

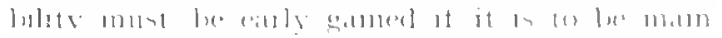

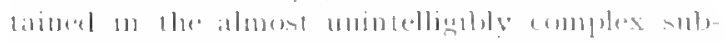

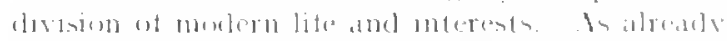

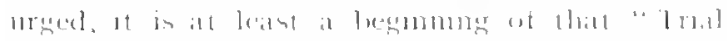

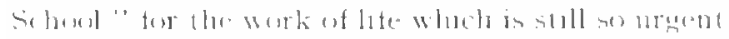

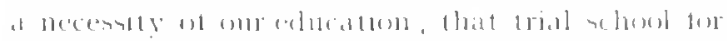

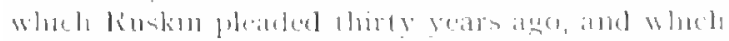

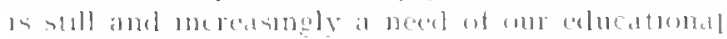

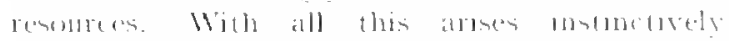

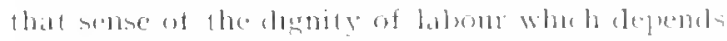

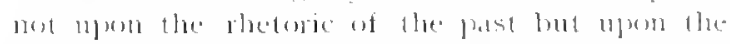

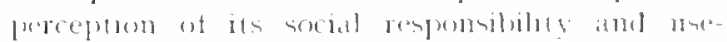

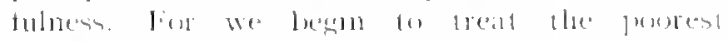

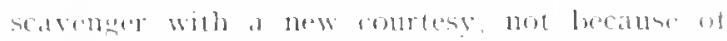

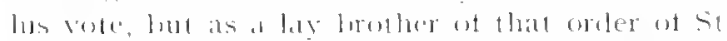

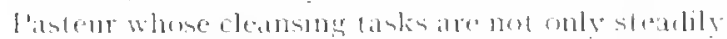

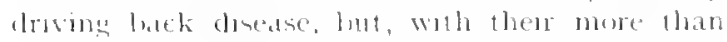

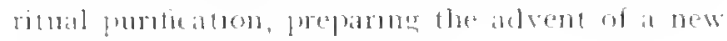
personal and socald dedealism.

so on for arere cratl. We have fo express in ferms of its se jentifie and leshrical realitien edements of at new denty exceedlones that of

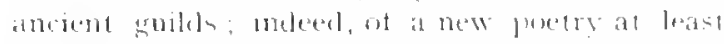

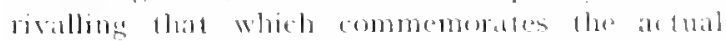

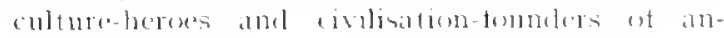
tupuity.

lor miller and blakemotic espectally, the same

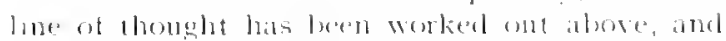

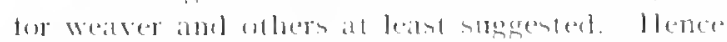

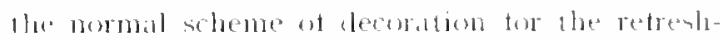

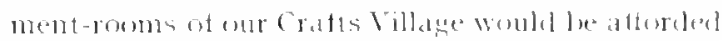

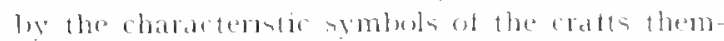
atives.

The J'rumbtice Village, Crats Village, atul

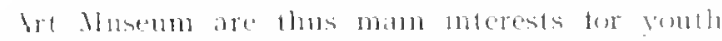
and worker, lut the detaled progress of then respetive arts will be found expresised wath

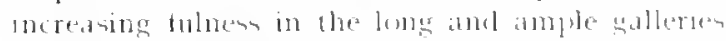
of the Historic Mrienm llere, lhen, we have at least a glimpe of the develuping ratt procestions of the future, with ther ceremomes of initution, their graduaton dass of mastership, as alreaty ot those exhlbtions of ther masterpieces wheh are alrealy the most magnficent of ciric functions. and even of internatimal ones. Our l'atk Roaln. then, 10 and through these varioms centres are the processional romes of funte feutuals - the lia sionand lia Triamphalis of labour.

\section{E. The Historian}

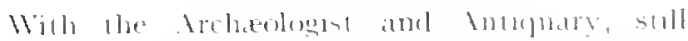
more with the llistorian, we lase alreatly hat 
whle chapters. Suftee it, then, to recall hm as a grurle of all whom we have as yet consideredGhlol and naturalist, youth and wotker, watels a completer conceptuon of man, trom lis emergence trom nature to his htghest developments, with therr present confusion of promise and elecay.

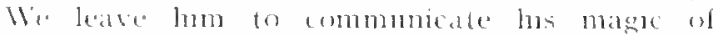
erocation for every phase of the long procession of the past, his deeper spirit of interpretatem of its mart forces, louth spiritual and temporal Wi" thus aploreciate more fully his conception of our gorlly enviromment-the parts, the cils, the werlel itsely-a a d rast open-ar museum of socid development. Thus emancipated from our petty modern insistence mom the present, and with mulds thus opened to the vist perspectives of the pant, we may look whth new hope and courage to that ipenong perspective of the future to which "the specious prestent" leares its devorees so bind.

For it is in great thingse as in small: it is mot the chald lo whom torlay is as yet all, who can make much whe even of hos tuny garden, but only Hoat older one who has larnesl trom the experience al fast satsons to prepare for commen ones. 1 . is the lover of ancome trees who is most ready to plant the new ones whose fruit he mat newer eat, whose tull expansion he can never see. So any whe mas have feared a fow acalemic conservatism on my pleadnus 10 preserve our despent traments of antiquity may surely now admit that I have not hesilated to develop them, no to meed what I believe to b" the tresh needs of the fresent upon a new and sometimes unprece bented sale.

\section{F. The Citizen}

But it is time to leave the historian for the Cilizen, or rather to pass with the historian into the cituzen, prosent though bis interests rightly ant primarily are. Of betered housing even beyond his arerage demands, witness a repeated msistence $" 1 w n$ open-air tratment, which he may as yet tou commonly comsider exaggerated thrugh of suggestions for the briglutening of famuly life some, I trust, may he found not uncongenial. sugrestions towards terhnical as well as general ellucation have been pushed beyond the secondary aluration resources of a munor city or those of mntersity extension His immamental requirements at regards fown and sehool have thus not been formotten Fren if our institutes of wilter ambition do not so strongly appeal, he may let lhem pass, as oftering, m their molern way, some reconstultion of the ancient Ables some cloisters at the meditative lile, in which, apart fom his ordinary range of lite and thought, he may some day alsi finul retreat, and even now some truttul suggestion or inendly counsel. Hos natural distrust of the speculative lite, with its cultured weakness, its shrinking trom action, may be abated as the sees lhe increasing weallh of practical application to lite which comes forth from ench true dotstering of thonght. But without detainims him amid our musenus and studies, our parabline of nature and art, its wealth of literal blossom on the present, let us set upon his restored City Cross Chap XXVIII. What may serbe as a simple signpost and map to all these labyrinths of thought and action. The mason at least will hear with this; I irust even approve its renewal of his ancient simholism.

On one of the sis wides ofith arcated lase, from which its pillar whafe should rise, lad un arse the ymbold of the Mechanical lodustries, yet mark mohtrusively lehind, the ymbulsof the l"hyical Sciences on which these industries in. creasingly deguend. On the next side let us carse in full day. light the plough and yade of Arriculture, the mortar and pertle uf Wedicine, yet its wimesed setpent-rod as wedt. The froum of hemely and puldic llygiente must have due place of honsur ; yet lehind all these, in shathw, must be set the seal of fiolugic acience, the scarabs'lls with alt it manifold signili-

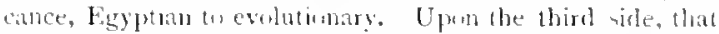

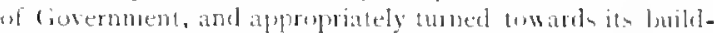

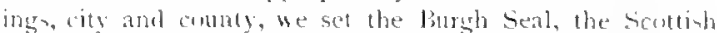

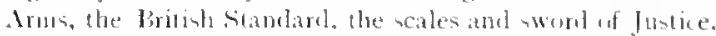

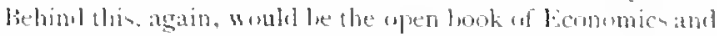
law. Sis far the three sides twward the street: mon all

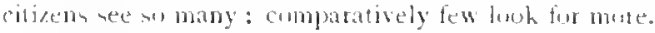

let some will note upun the side towards the Alobey the crumier aud crom of antigue and modern suidance, and in the shatow lehind these the Celtic eros renascent, with it unjun of spiritual and cosmic symlutism.

somtlwad, towardis the drena, we carve the symbols of Elucation-the hosoric wal aml the pesent three lis ant. it may lese hoped, newer and hecter anes. For again, lethind these, cones the winged l'syche of puchologic science : and with this, her gemelric youlwil.

Finally, upon the uisth side, twwals theatre amd sarden. we carve the symbils if the Fine Irts the paletle and chine? with rfuate and complamen alwe. () ver all these the daclianl

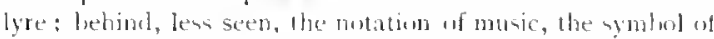
listhetics.

From the side of Art we thus come round to fudustay again: it may le with a fuller wggestion of their kinship. a fuller perception if this whole unity of meaning. Our civic fecoration in thu civie indeed, since a view of all its forms of work and thomght, a Clasuification of the fres and their related sciences, in thu plainly populatised. The inter. comnection of all the activities of the city, of all its divisins of laturu, is simply et forth; and with this alw that int mate reartion of theng and practice, which it is the foulish fashion of the moment on dery, is reathrmed to the simplest listander.

from thin central hesagen a corresponding sixfold pavement design (rencwing, therefore, the ancient stas pattem of interecting equilateral ubaglen) larliates over the whole Place. The l'iblar of the rom is nom seen as the gromon of a colomal dial, and at its whole trueture anda for the renareent and ideal cits, so its trastling shadow is the litting symbel of sweh imliviclual life. Alence this travel from the side of beauty and art at dawn, thrumgh that of labur with morning. towards citisendip and wole as the lay sears late, and linally lenglhens eastwat fuwads the ancient spire of loftice contemplation with the fallings nislut. 
(Har new l'lates is thus nos mere return (1) the pieturestue view-point of mor trontisplece, but ine al which 10 recover and (1) express that cre feeting which is our noblest and most endurnge inberitanee from the past, llere, then, onfe dive processions will sometimes muster, sometomes disperser, and trem thes pont of bew lhe developed City Buldums, whth then great ball lecew, then vast Arenat heshle, will all he neederl

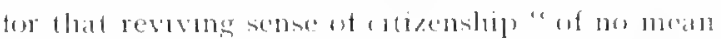

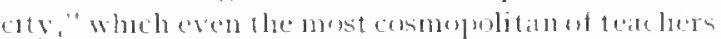
was pond to attrm.

\section{G. The Politician}

Gur sereat Hall and open Mrend, our loublic Pace and city Coss, onr Campme and l'ark ways are now surely a sery paralise for the bolitecian, who canmot hencetorth grulge 14 hostoric treasure or naturalistic paradise, since his fiedel of action las been so fully recoumsed, hin expression so tully provederl for.

Epon every phane the selemes abore sugerested can but when hus appeal and unefulness rivic, regond, national, internatomal, all are eonsidered. So our hestory buildung culmunater with no retropective survey, but with an outlock wer the widening world.

Conservative and Radical mat thus meet here 1un less amicably than behund the seenes at Westminster. Indeed nore su, tor the respeet of all that is rital in the past, the burial of what is eleat on evil in it, has heen more fully aceomplsshed. The chisaltrue memories, the fore in lite and nature, whele are the strenglh and lite of the calcatied party, are all represented here, lut no less are the stern ancl alsstract intellectuality, the tath an ideals, which have chatateresed the luritan. for these are still our two streat pertes howerer legenerate they may secm to each other, towards potman or huckster respeetively ; and that reconciliation ot erder and progress, fowards which the best spirts of froth parties ever lexk, must surely the some stech synthesis of these ats is materiallacel in these designs. Hence the deeper meatming of the two statues proposed in (hatp. I'

\section{H. Woman}

We mat now come to Woman. (1) ber spectat interests within this scheme I have alreaty spolien, first and last Chaps. II. and XXIX. tron the bettererl homes of the nemphlourng street and city (1) the manson-house, with its expression of that levelling up hoth of her sex and the other, in which the idcals of democracy and aristocracy remnite. Fet for her also other ways in this labyrinthme design will be seen to open. What park-maker can torget that not the least real, if tacit, of his instructions-in

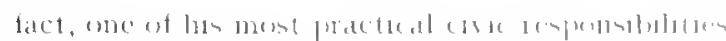

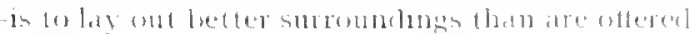

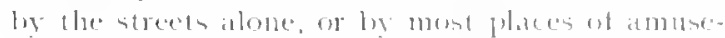
mont, tor the meethes and resert of voung men

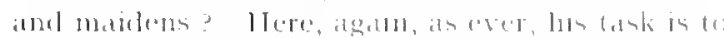

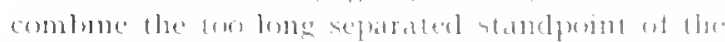
pwetry anel the remmance of lite with that of its

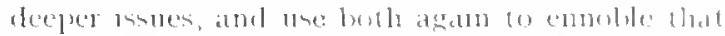
of the everveldy world. Here least of all catl we

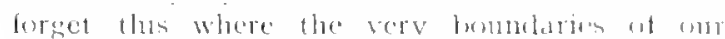
listone glen and park run. like the refram ot at ballarl, "Irom Wimers" Dller to lasers" Lamo." Here, surely, we hase justincition and wothy

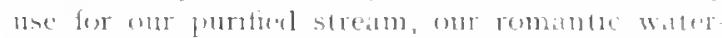

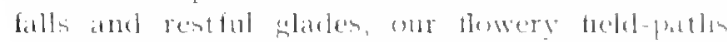

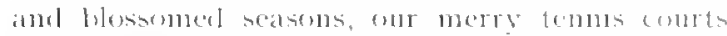

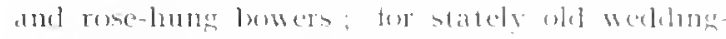

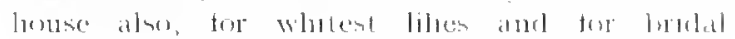

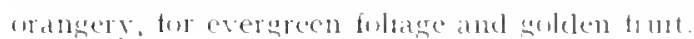

fir the mans momatreel women of the ents

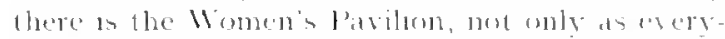

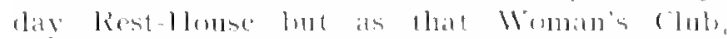
wheh would stall remain one of the most solil

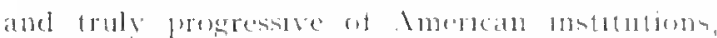

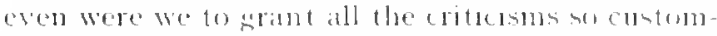

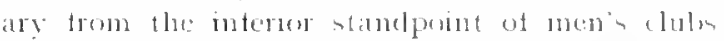
aenerally. Ilenee, tom, num Mlamsion-1lumse and oncens House Chat XXIX. Hence, lest of all, in hrealta and pleasure, an play, in lignety, and an

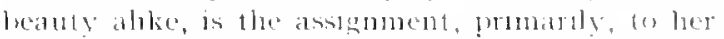
uses of the lawns and terrates of ont contral

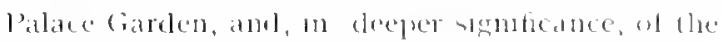

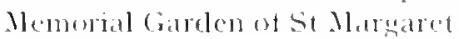

\section{The Artist}

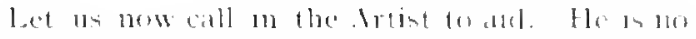
lomger, as through his nineteenth-century coreer, th the man the amuser of wealth. Agan, he lexpms to see, that, ats at worker ot skill, foncherl will im-

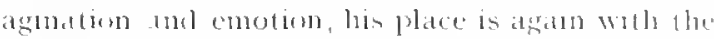
penple, his work agan tor them. Here, meleed, is the interpretation of any soul there may les in

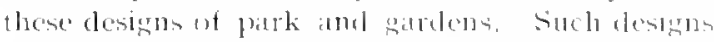

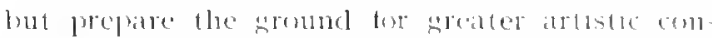
structions, lay ont the pathe of more than theral prexessons, prepare the theatres of at dedmo streater that the seasumal one. Amomin the speetators of the recent openne procestion atud " $11 \mathrm{n}$ feftment ceremony" were artists who misht bave cloubled its artistic effect, and this not ly musmme their own knowlerge, their own fancus and dreams, but be atolng this and that partaculat cratt to mprove the part it telt its alue m the whole social procession. Cratt-ideallism, crattsymbolism were compicuns at almost esery punt in this, sometinses sn the forms of old art nu longer living, sometimes in forms fresly but still crude. These are what the artist is now espectally ready 


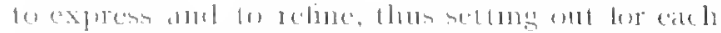

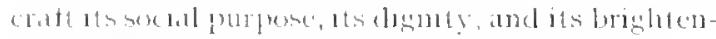
1119 tulure

(1) the endlest, the mfonite detenl of all thes art servece from the sered chald-games of ome play

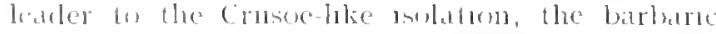
recaptulaten of bur l'rumbure Village, or, agdon,

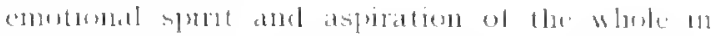
Mllsic

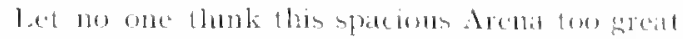

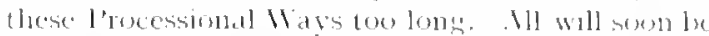

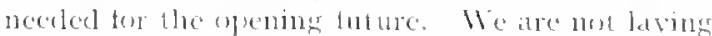

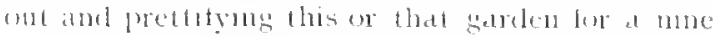
lays womer, not retting up this or thet muscoun

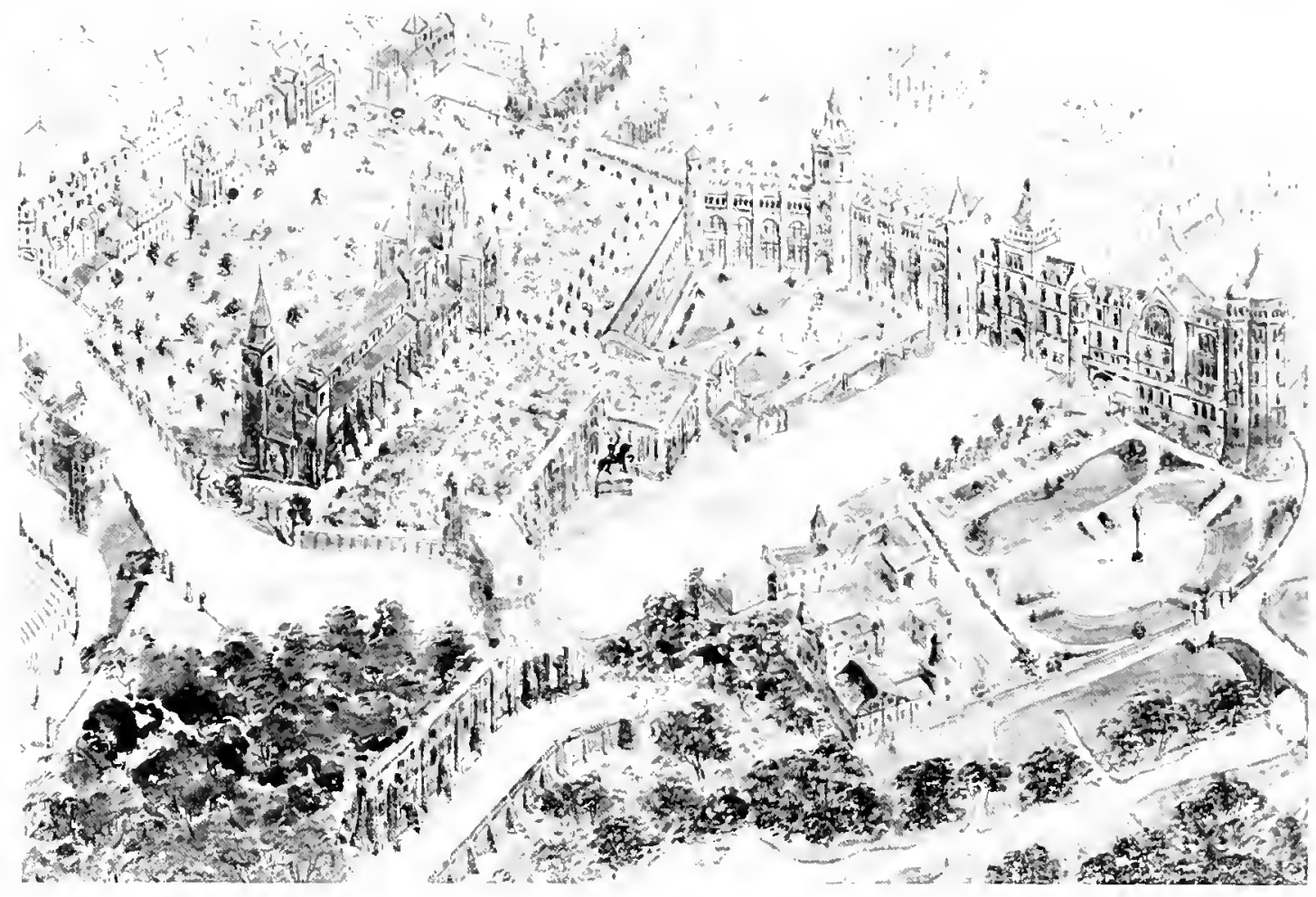

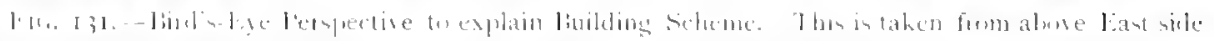

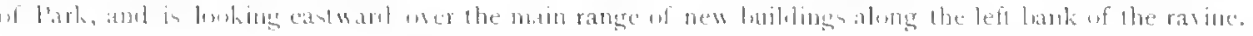

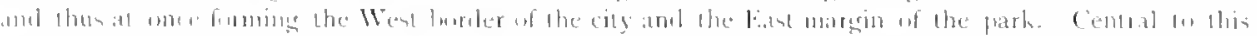

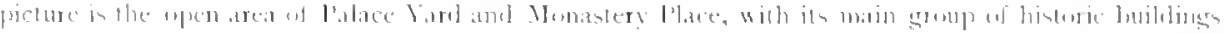

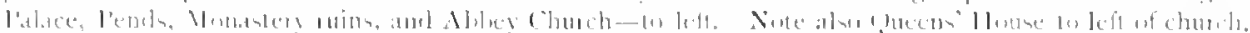

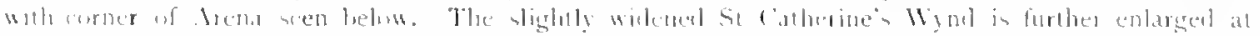

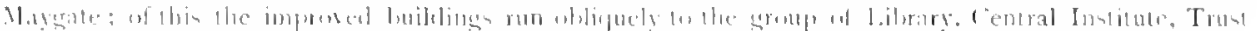

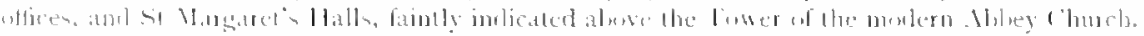

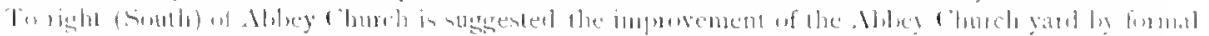

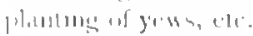

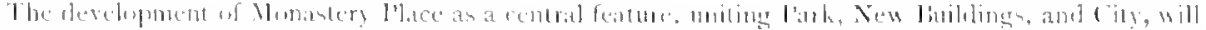

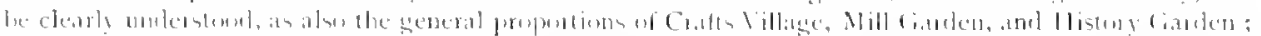

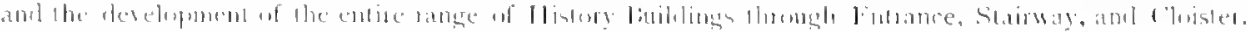

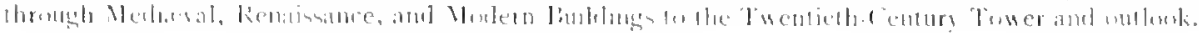

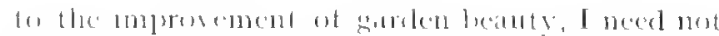

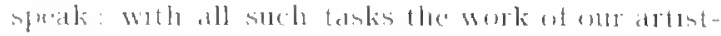

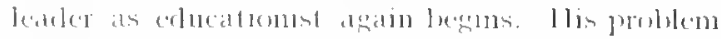

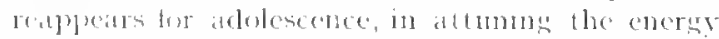
of athlete voutle fowates a more than linerotly

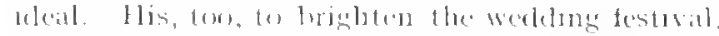

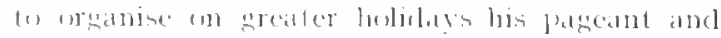

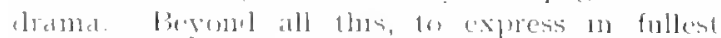
Wealth of sense inuprestem, 113 most strenturus

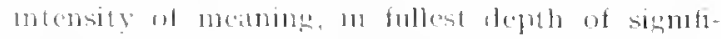
cance, the whole possibihtus of collure, and thence, when worl and imagery fail, to express the

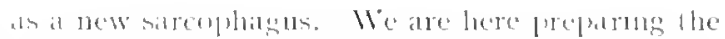

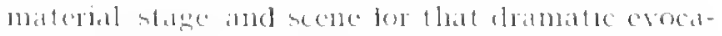

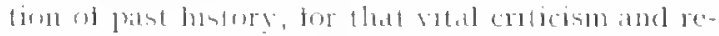

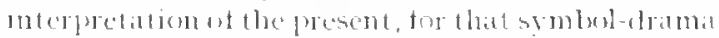

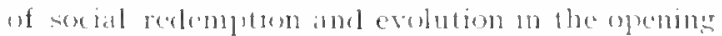
future which are the true divisons of the trology of twentleth-eentury art. Withon seme divisim

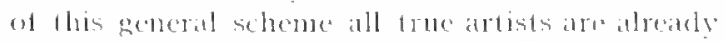

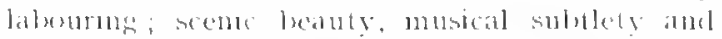

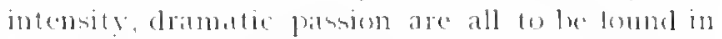
therr works. What these need is but the weatson. one of social purpose, if popular aspiration, of 
cisic mity, and at is mow tor the enty lo ufter all

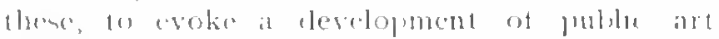
wortle wt the oceasion and of the opsurtunty.

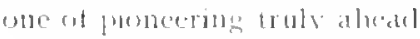

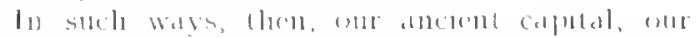

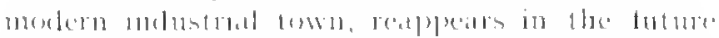

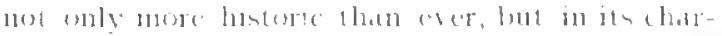

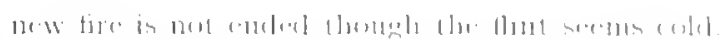

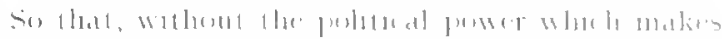

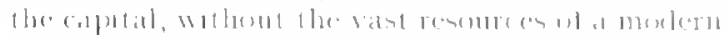

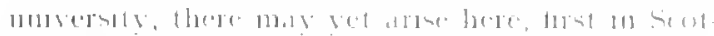

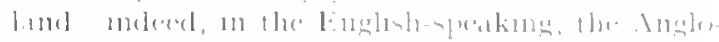

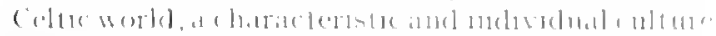

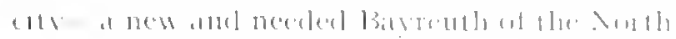

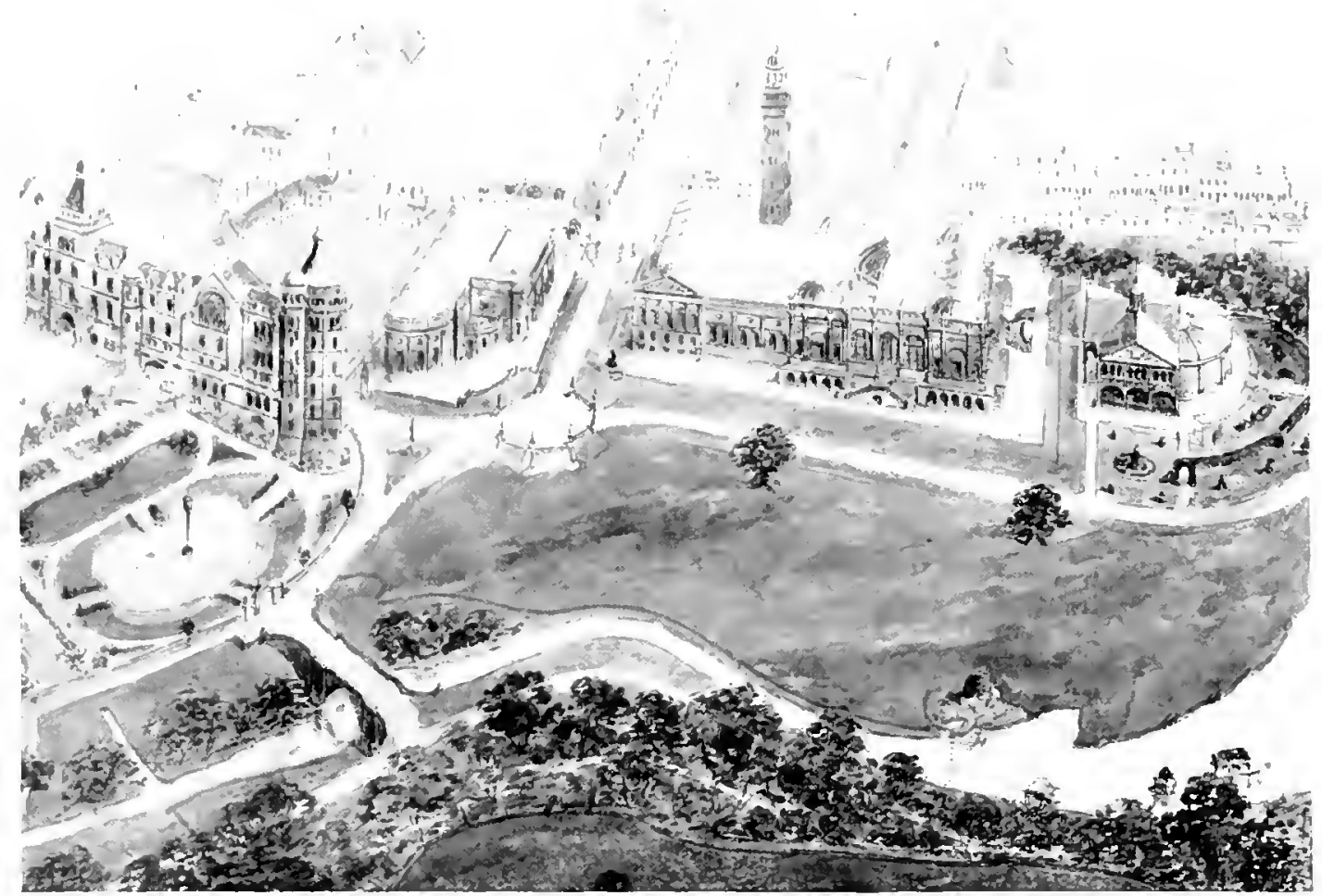

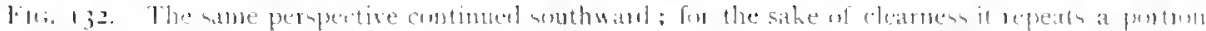

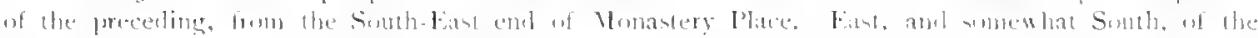

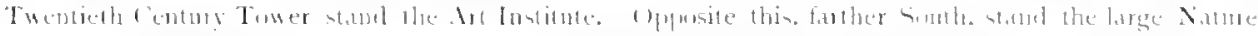

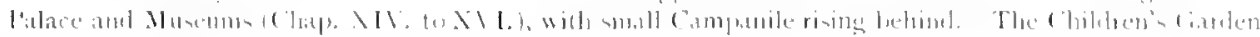

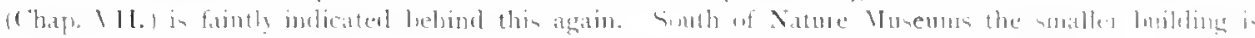

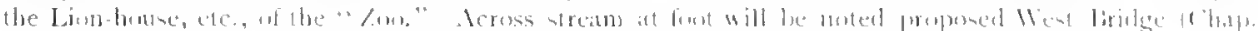

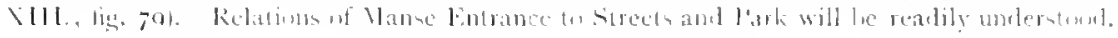

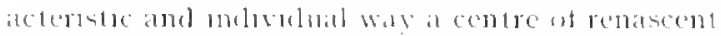
at. The contemporaty l rish kenatsence has mow phosed the prolininaty stakes of soldaty study

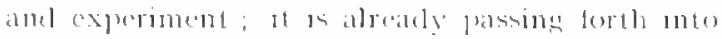
artiste and solat expression. Where lietle an

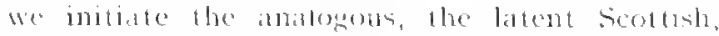
development than here? I an well analse how such suggestions delight and motgorate the soutert

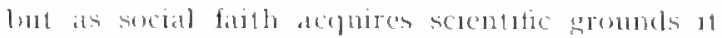
is mot shaken ly sncers. Sald a bremen sociolugist linty sweeping his finger over the Seotlish map w Classow and libnlumbs si Indrews and foundee to Aberdeen: "Sitrange so many great

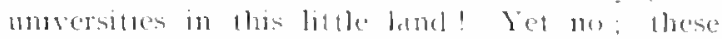
we but the spatlis struck from the contact of the colte and the saxom genuts along their racial trontier." Where nure m the past have such

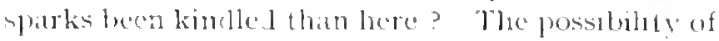

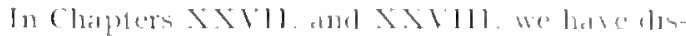

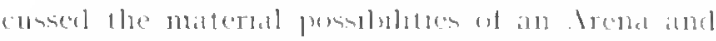

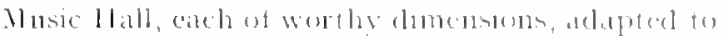

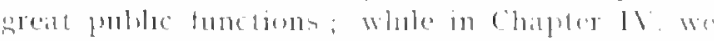

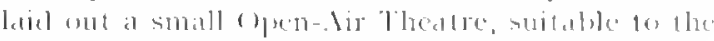

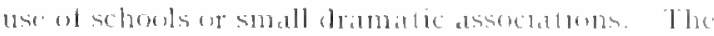
fuller development at these resourcen is alike beyonel my lask and puwers, hut it in plan that

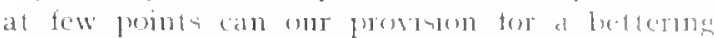
tuture be more lestlumate or more destralles. The

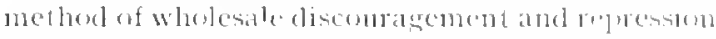

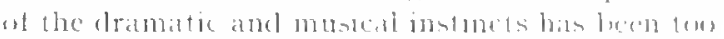

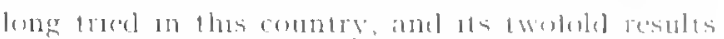

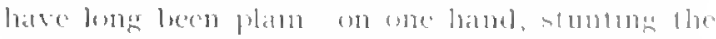

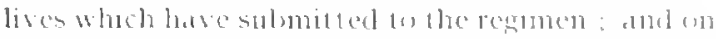

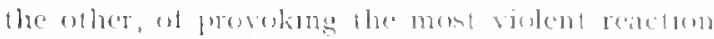
lowards debased and debasing fleasures in these who hase resolted from such control. It is m 


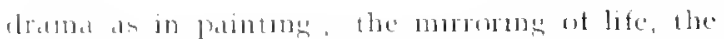

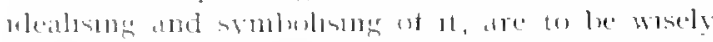
surded, then generously enconteded, and here in

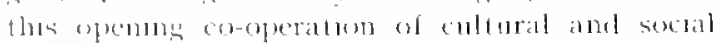
agencles is surety the opportunte of worthy ant

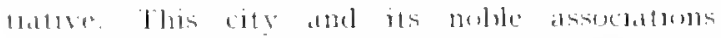

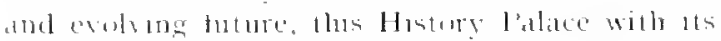

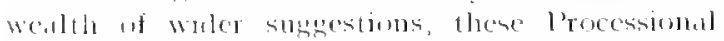

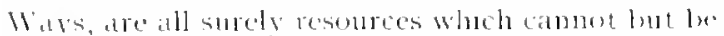

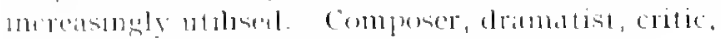
eath is reaty with his creatude or lus commel

\section{$K$. Thought-Ways and Thinking-House}

In Jena, and, it I mustalie not, in ather Gorman Emoersty towns, there is a "l'lilusophenweg." al quet path fraldimally assodated with the detily "constlutional" by which some noted branworker was wont fo rencw bis forces, and now more or less well worn by litter stutents. for un thought tul rantulers there in here ample chosec ;

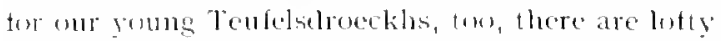

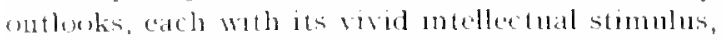

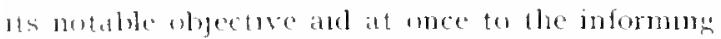
and the inspirns, the calmung and the lsoatenmer al the inner veson. This seret of education. hlerally upm the herghts, the ald worlit knew well,

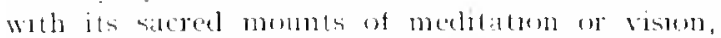
(1) the "high plikes" of old patganjems, ar lorm

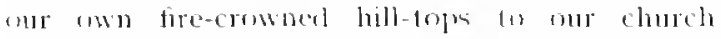
and castle towers. Exerywere aml all at tumes the sirerning spints, spiritual and temporal, in peace als in wat, bave elmbed the heeglits and raned themsdies towers. So drubl this dea is nowdays largely lorgutten, ar coen popularty

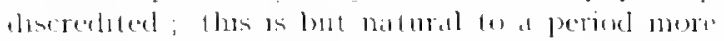

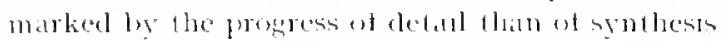
in selence, and ly devesom of lalkour in invention

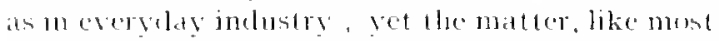

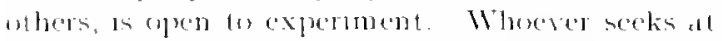

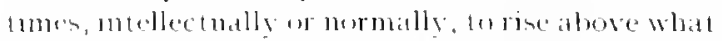
he reghty calls his " "sergilay flane" may well

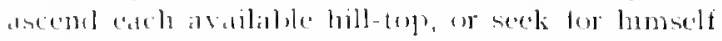
some engemal molook fower. for cach way of

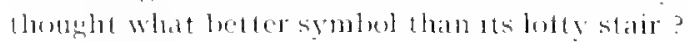

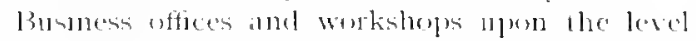

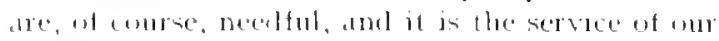

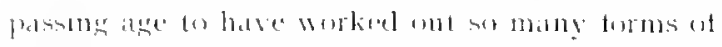

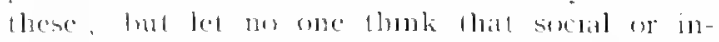
douthal evolution enels wall these, Here and

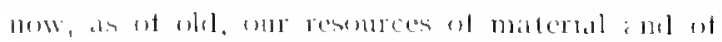
immitrial coldure canmol be completerl without

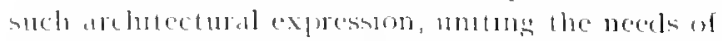
freplate culture and of probate meditaturn: and this not only in cathedral and an closistered retreatl but in pealing belfry and an lofty towes.

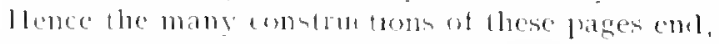

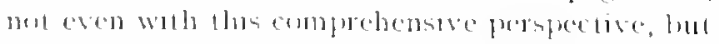

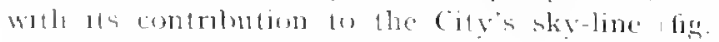
13t, and by this it whll 11 every sense he judgend. firat and list

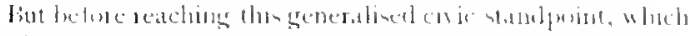

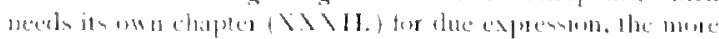
purely infellectual a tupece of the present schene may nom ln

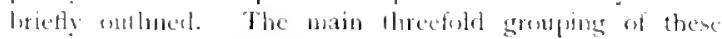

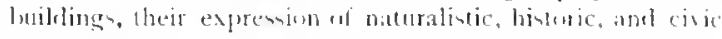

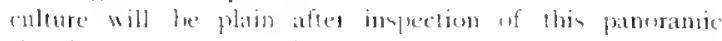

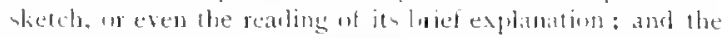

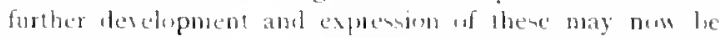

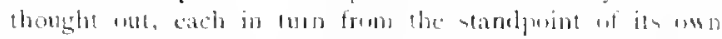

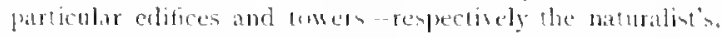

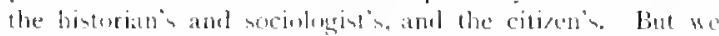

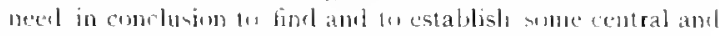

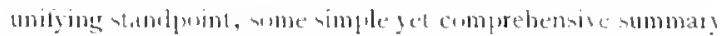
of thomble. The problem thus, ar already stoften, becmes that of expessing and emberly ing a tually mercly intel.

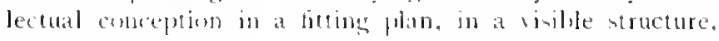
and a pratical use. Is ang sub unitied view withings in

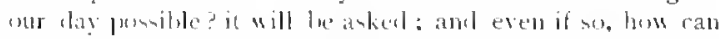

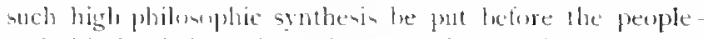
and this in their park, their place of recreation and enjoy ment: Vet the answer is aluplain. In the high recreative arts of ull neither priest nur singer, neither artint-buider nor planter forgen that upon the joynus note of la Allegro the graver mo of 11 l'encerm mus strely follow, were it even for the decpening al jus:

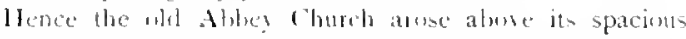
park, it whemon are, an wur inisial and still supreme culture. inslituse since the perpetual reminder of the mystery from which we enne, if the contranter ideals towarts which we gur: for tuwarals ane or other the resultant of every thought and action temots. Neat, there followed thome more personal treatments of the great fuestions which make up literature: and witl thin the -nccessive liluaries af the city, so notably histurical. lecalle each in ils day a forerunner-unce that of the monks of Ioma and of Cantelduty then of the sclondars and pretw of the kenainsance, and num of that more democratic

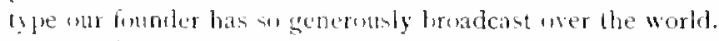

bevond the chureh with ith many general questions and awmers. beyoul the libraries with their many individual ores-in hist, lesond the Keligisn and Ieemong of the fast-there las come the fluetioning and anwering of sicience, and henes we need it musetim and its schools. lantly follawing thin, party anticifaling it have come also the urgent ancotions of Industy, am this buth in its simplet

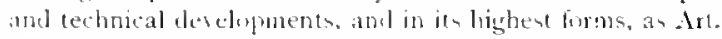
bet une more there press forwart other questions, whes answers, liom the interrugation of nature we relurn to the history of 11 umanity as the 4 apreme problem af evalution. and, correspendingly, from imlustry controlling nature we

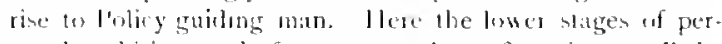
wonal ambition and of party winggles at first olscure all the

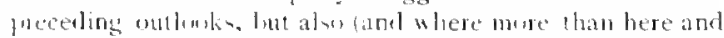

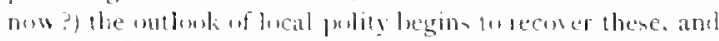

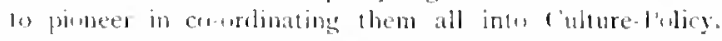
lint any such practical cu-ndinatom of our public life and

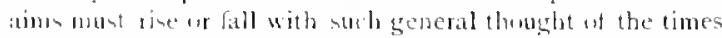

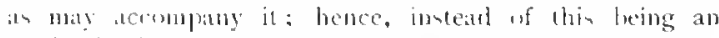
acalemic divertation. Foreign lo the practioal prothlem of this volume, an a weary an a linjel cealer mas kar, we now

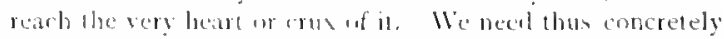
to construet umme central thinking-house, chat rusm, and conning-tower, in which intellertual clearness of conception and fritctical etficiency in excution most meet. An actual

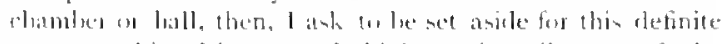
purpore, this ulsimate and highent (inncil-rum of the

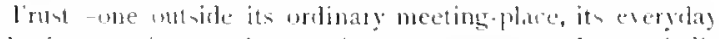

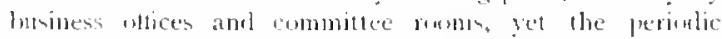
meting place of its bromlest exerutive policy with its most seneral investigatins and pionecring functions. 


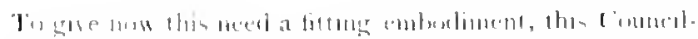

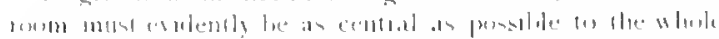

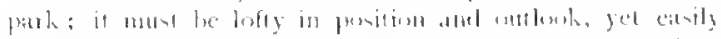

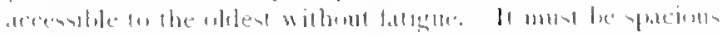

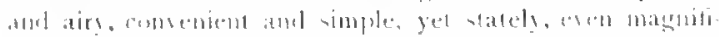

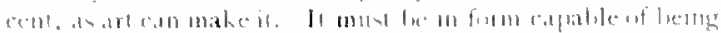

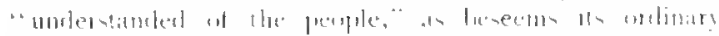

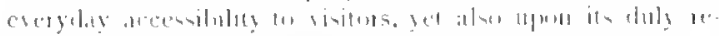

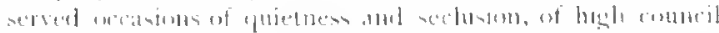

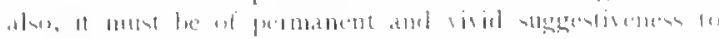

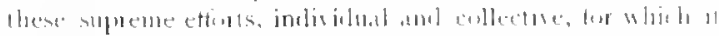

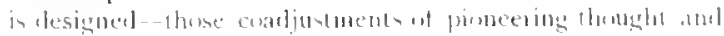

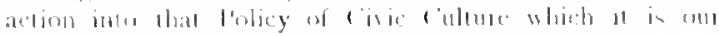
moblem loce fitly to initiate.

Ilere all lengh is the right 11 se for that 4 lolly gallew

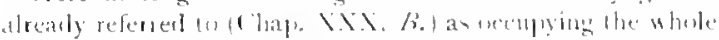

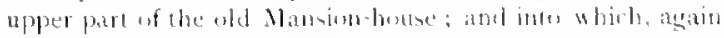

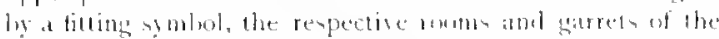

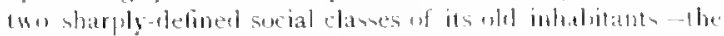

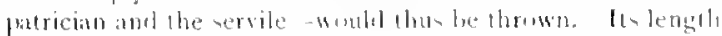

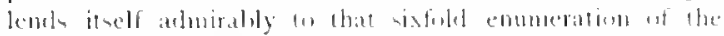

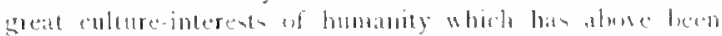

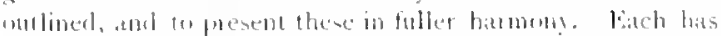

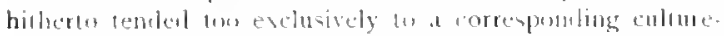

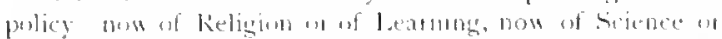

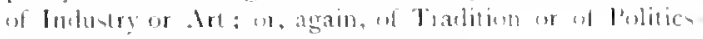

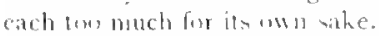

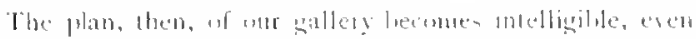

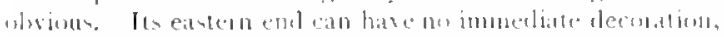

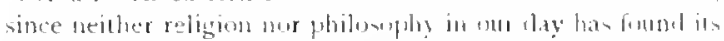

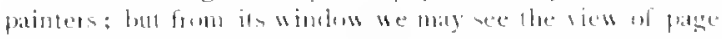

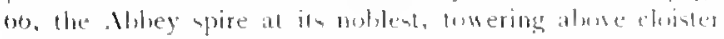

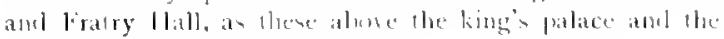
milere mill alike.

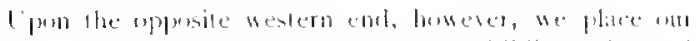

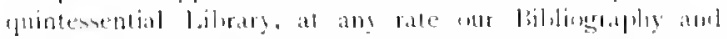

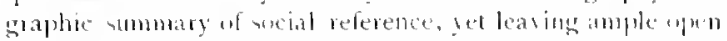

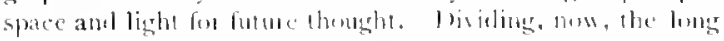

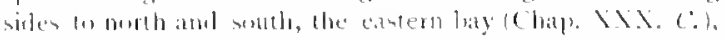

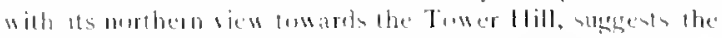

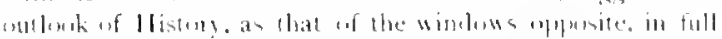

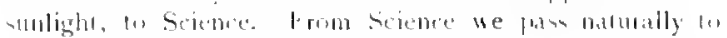

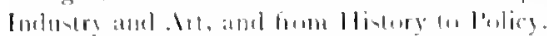

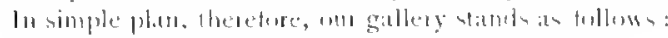

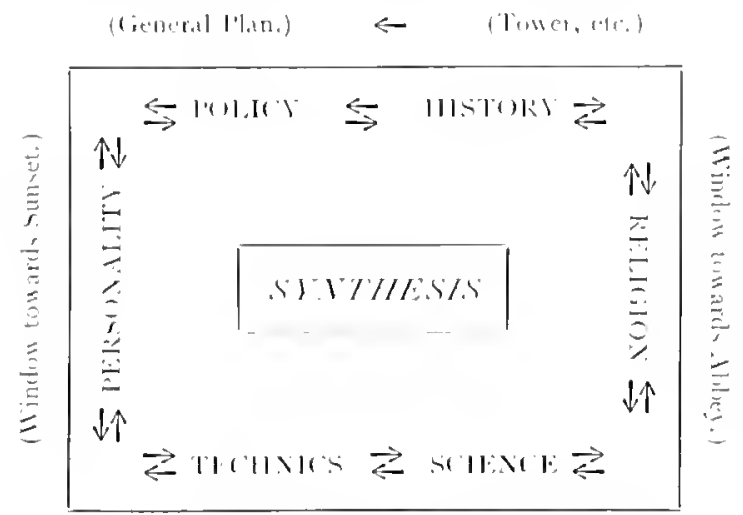

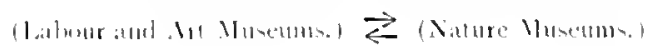

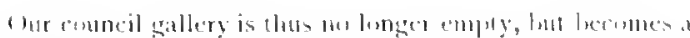

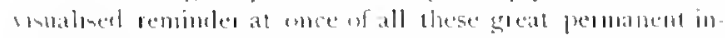
terest and print of vien ambl which all life ham lo he lised,

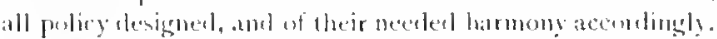

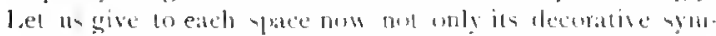

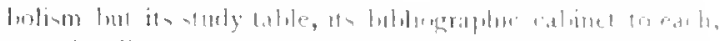

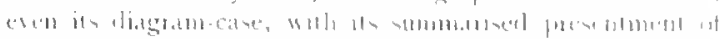

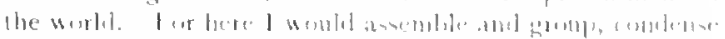

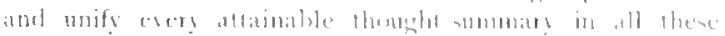

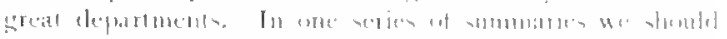

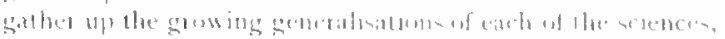

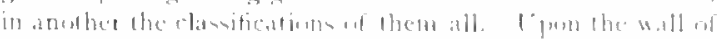

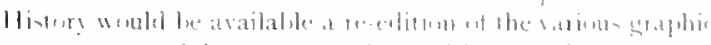

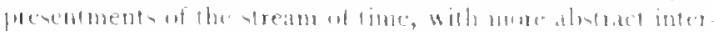

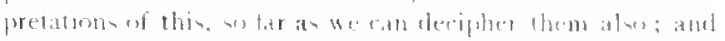

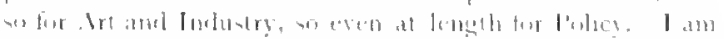

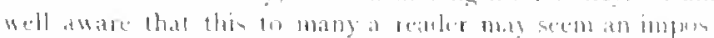

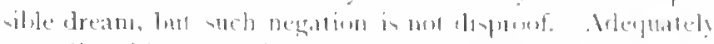

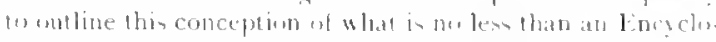

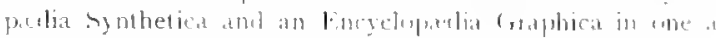

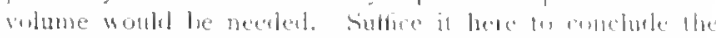

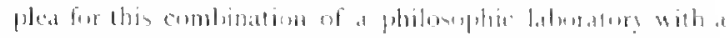

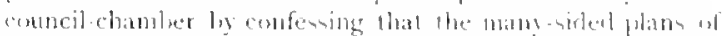

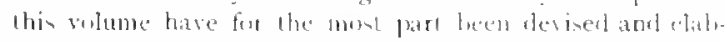

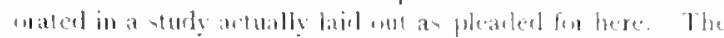

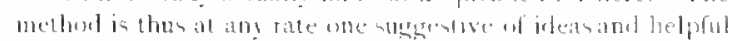
in the arrangement of them. Why mol, theretores give it a |rial?

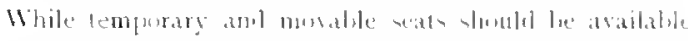

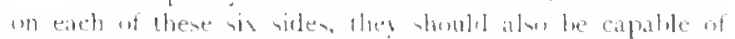

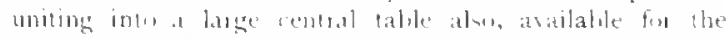

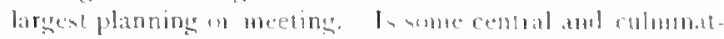

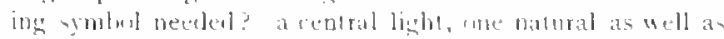
whe allificial may suttice with, fur ingle ardernument of the

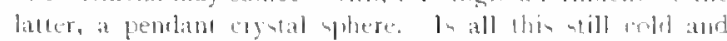

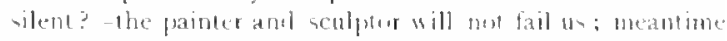

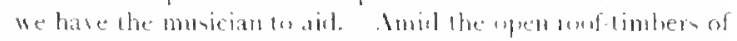

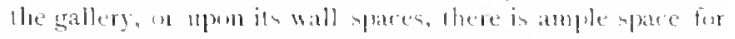

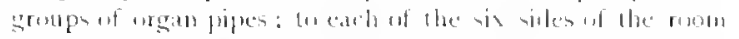

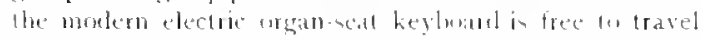

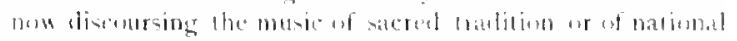

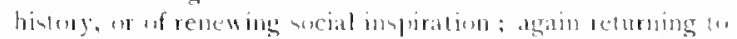

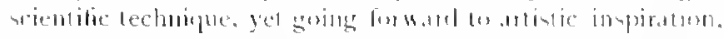

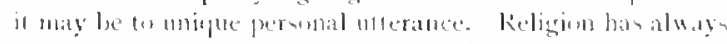

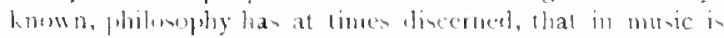

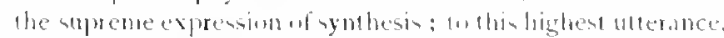

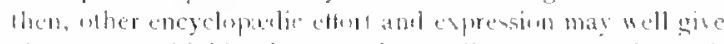

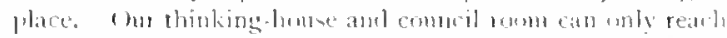

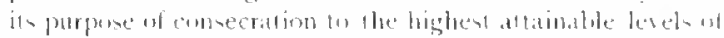

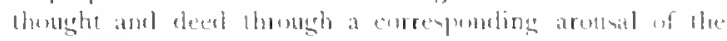

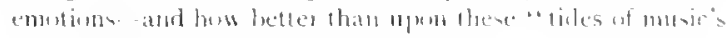
melden verit"

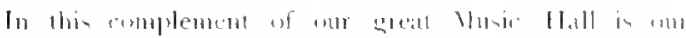

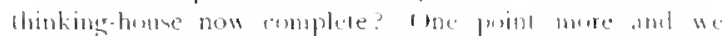

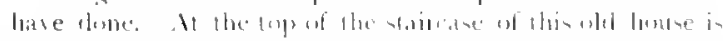

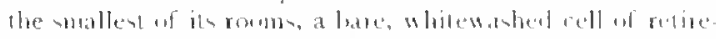

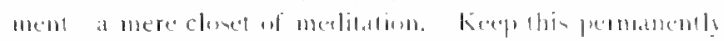

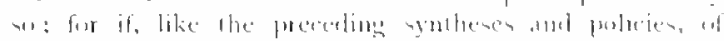

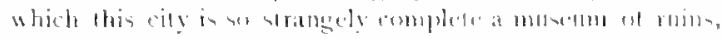

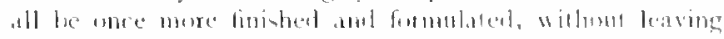

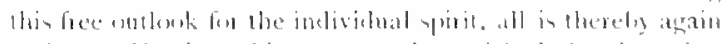

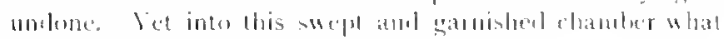

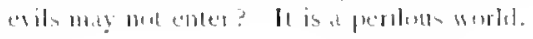

\section{The Last Procession}

Enownh now of these peregrundtions, these varied upprouches and groupings of our culture-pulaces. our renewing city of the body and of the spirit.

To leave this labyrinth, then, one path remains, one final processional way. With ehildhond we begin with the nature playgromols by the stream; 


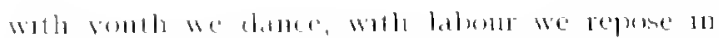
lie cheertal garden hedween the workadaly erats

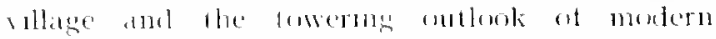

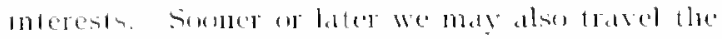

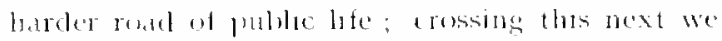

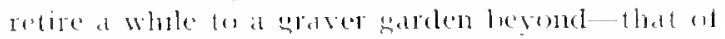
ut tmine, at sorrow, and memory. Beyond there.

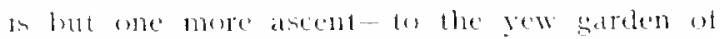
prater, whele ont ratoms lalumes comelude, for

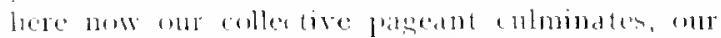

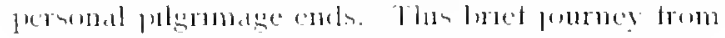

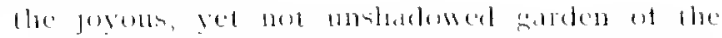

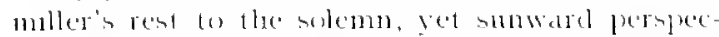

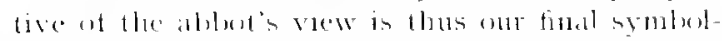

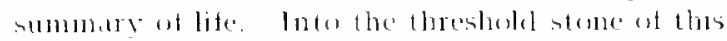

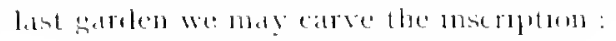

lial lile, lial Laberis

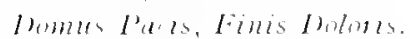

I. this all? Salnt and here have sume the

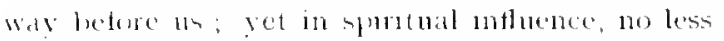

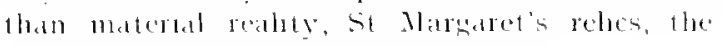
Bruces leart, aban have travelled tar. 


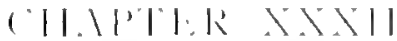

\section{CITIES AND CIVIC PROBLEMS}

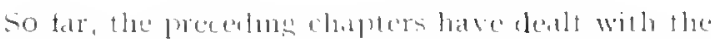
specitic problem and stluatrom - that of inproser-

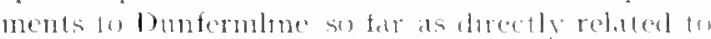

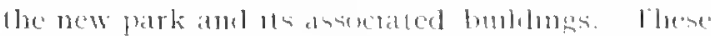
popmals have, it is true, been retated to more

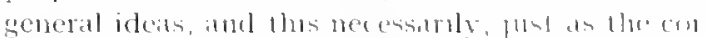

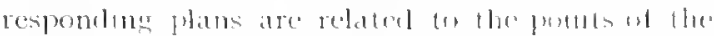

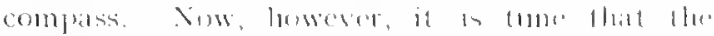

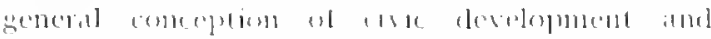

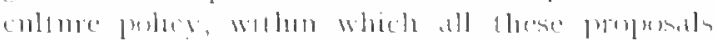

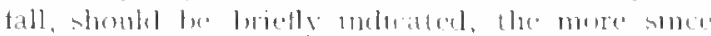
some at the prepmeste abme made depatre trom comsentumal hmes.

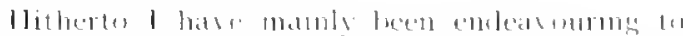

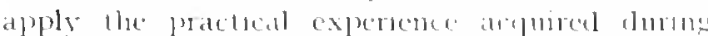

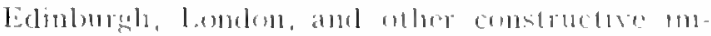

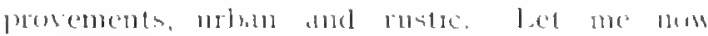

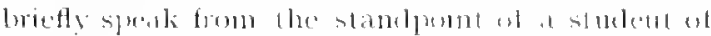

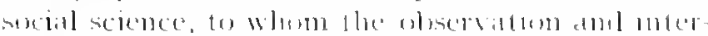

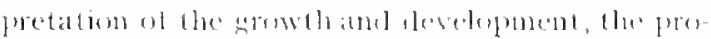

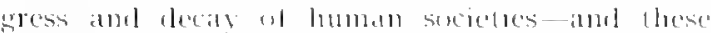
espectally as fresentert in listoric and conterm perary chtes - comstilute the centril froblem le

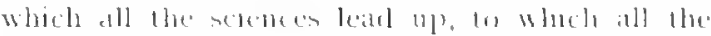

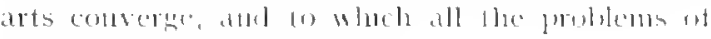
the indisislual ater redelted.

\section{A. Significance of Historic Citics}

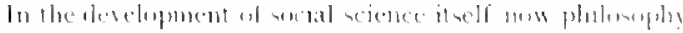

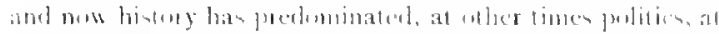

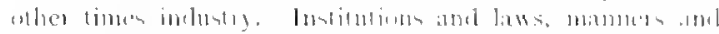

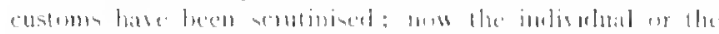

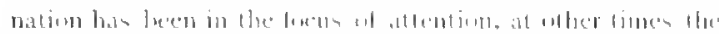

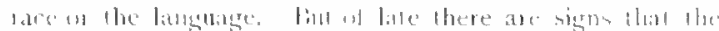

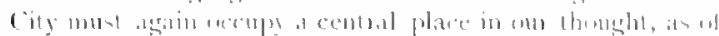

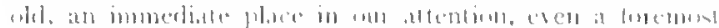

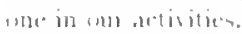

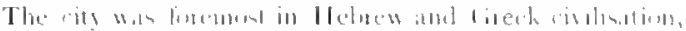

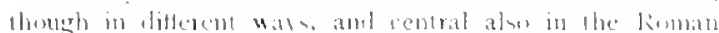

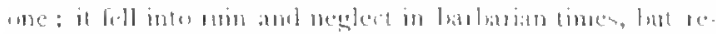

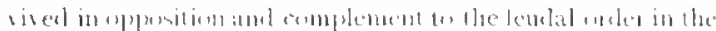

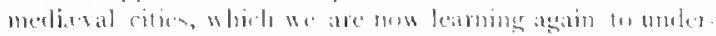

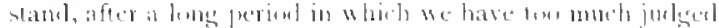

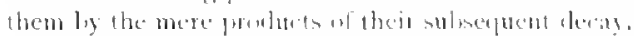

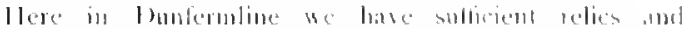

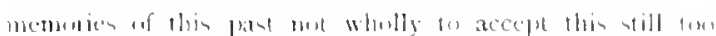

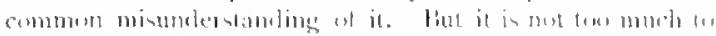

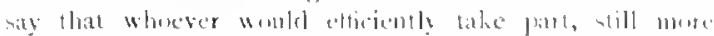

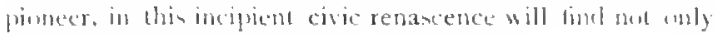

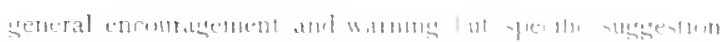

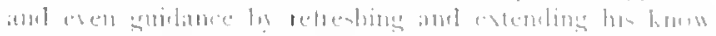

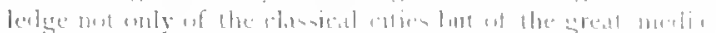

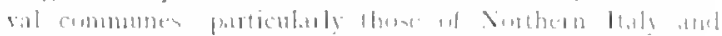

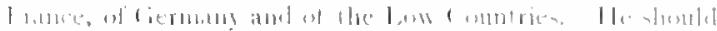

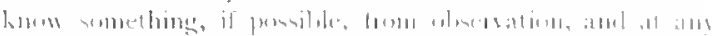

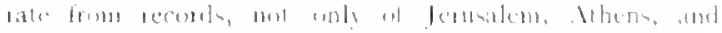

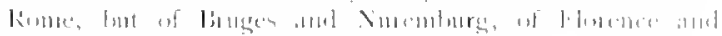
liarin.

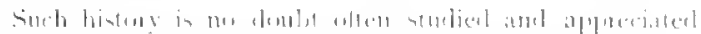

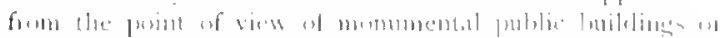

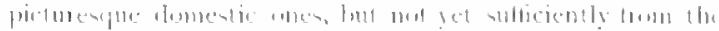

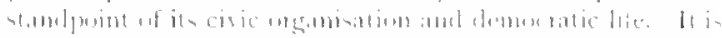

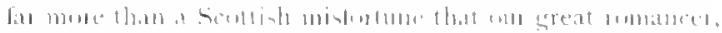

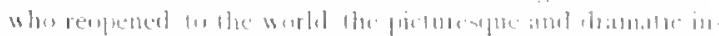

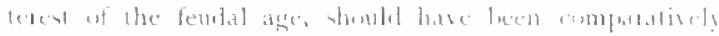

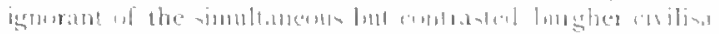

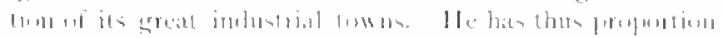

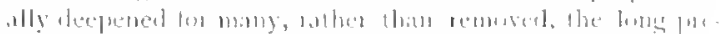

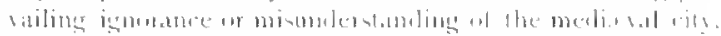

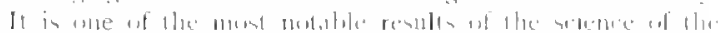

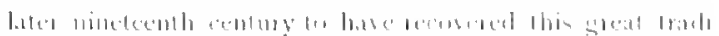

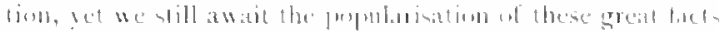

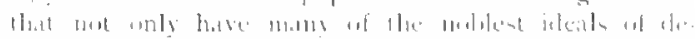

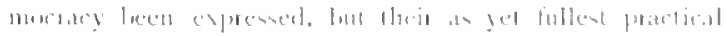

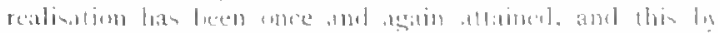

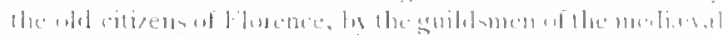

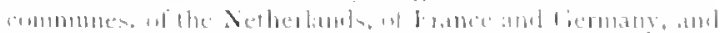

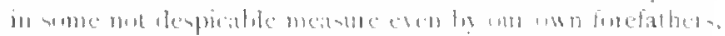

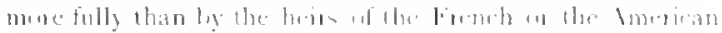

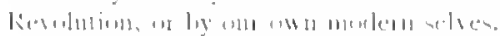

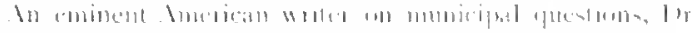

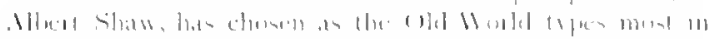

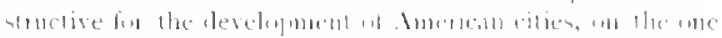

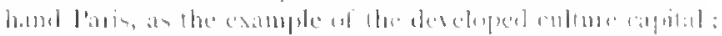

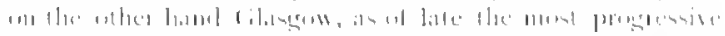

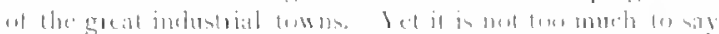

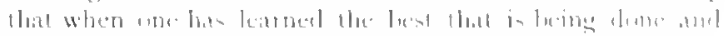

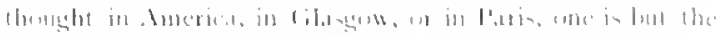

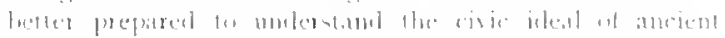

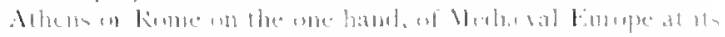

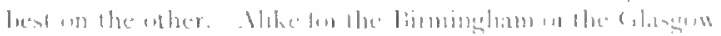

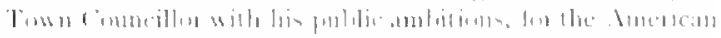

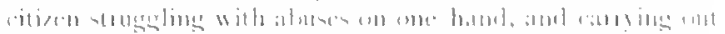

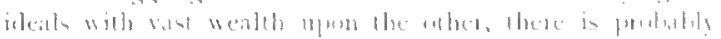

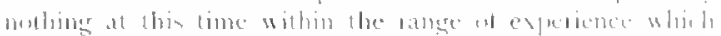

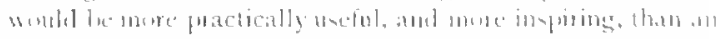

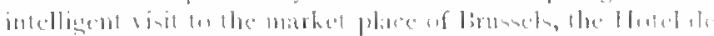

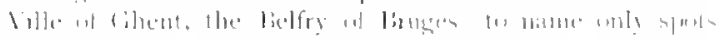

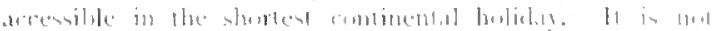

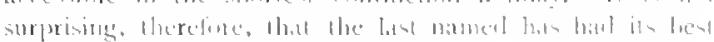

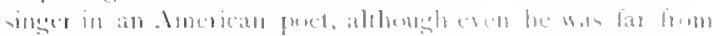
realising it rull cisic signilitance.

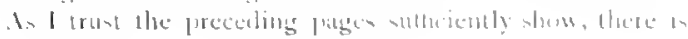




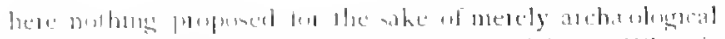

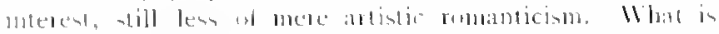

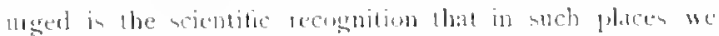

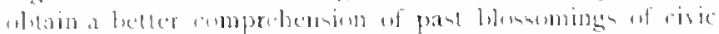

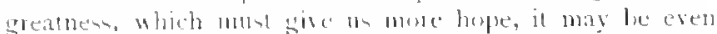
muse skill. in tealing with much of what in with ontedres agaill in the lute. I am lan muse seeking los return to the

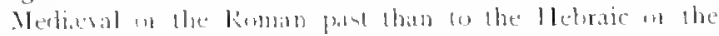
llellenic mes if bings. On the contrary, I mainatin

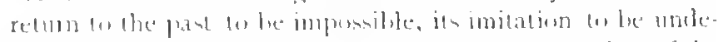

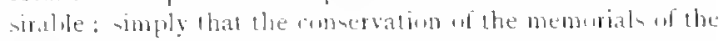

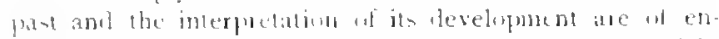

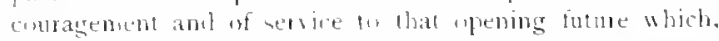

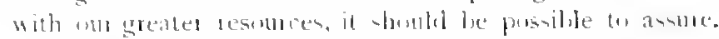

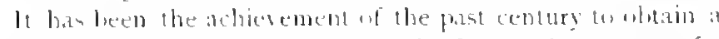

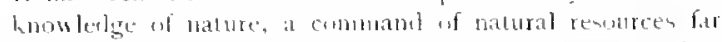

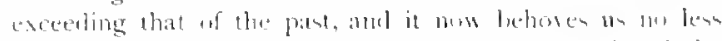

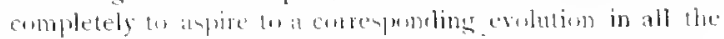

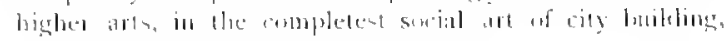
therefore, mol at all.

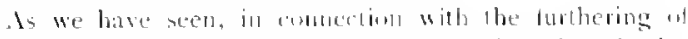
matmal handerlen and of technicat ethoaliem, that the in-

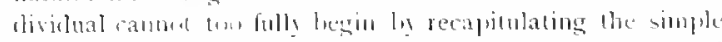

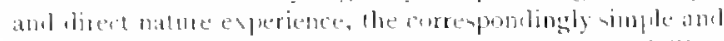

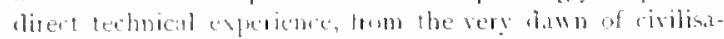

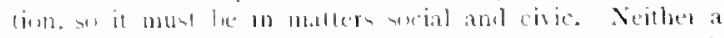

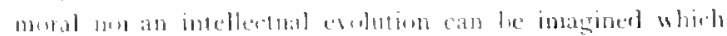

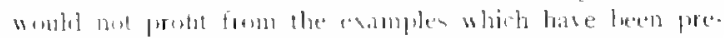

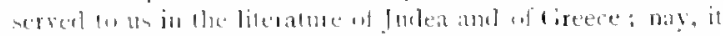

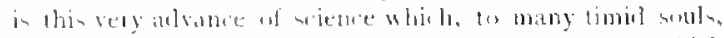

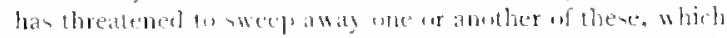
munt now mont folly pust ly their ysirit. whatever in erateipation from the letter.

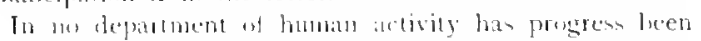

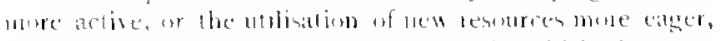

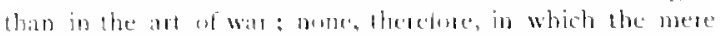
savish imiation of the past can let muse completely futile.

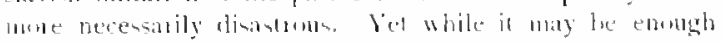

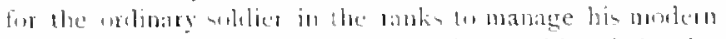

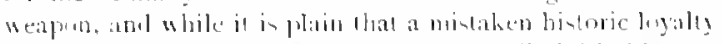

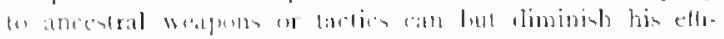
ciessy, the fact remains that it bas been preately the greated

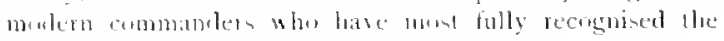

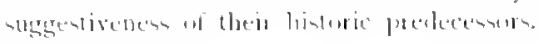

\section{B. The Civic Problem: its Various Statements}

As suspestave fo the fuller sturly and more effecture grasp al corr problesus, it may be ot service here lo alpernal at few examples of tranments ot lobe aly trom representature points of

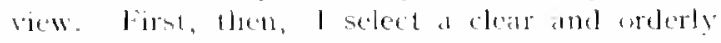

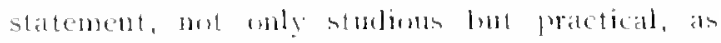

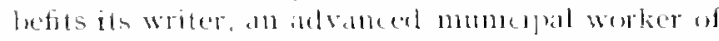

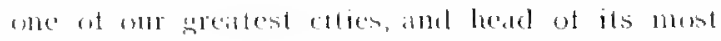
chective munsersily settenent.

\section{Municipalities at Work:}

\section{In meredution to the study of Municipal Idministration \\ l: T. K. . . $1 \mathrm{kK}$}

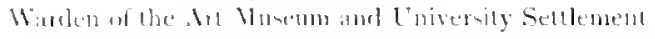

In this class the am wall be to explatin simply fecal government. So tar as possible illustrations wall be dawn trem Manchester, Salfmel, and destrict.

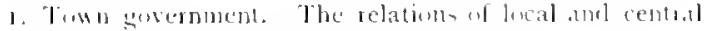

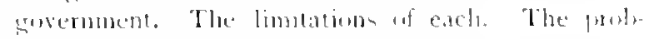
lem of ғомл atdministration.

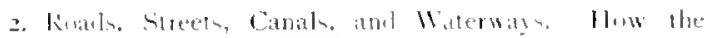

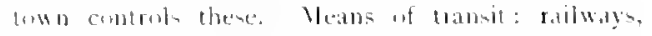
tramalay and otber services. Sereet comblurtions.

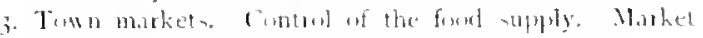
dights. Funl invection. Vilk -

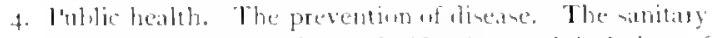
corle. life blatiutise. Notifiontion and inolation of infectionm liseanes. Iloppitals.

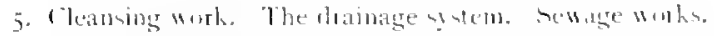
The dicponal if wefuse and dirt. The supply it water. The anmesploce and anoke presention.

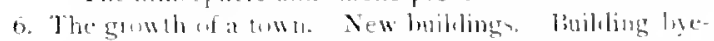

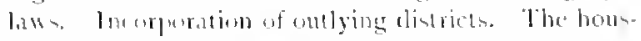
ingerf tle working clasen.

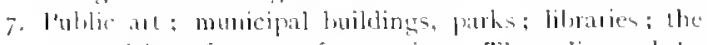
provision of meane if recreation. The prolice and the licensing yotem.

$\therefore$ Inllic utititien. lias and electic light umertakings. The provinem of pomer. Bathe and washbouses. lire piterention and salvage.

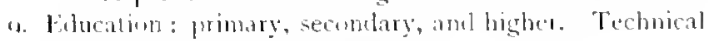
culucation. Sprecial uhusls.

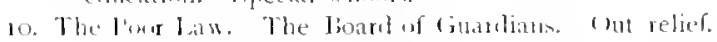

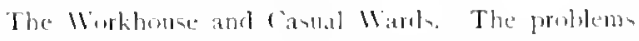
of persely ant pauperiom.

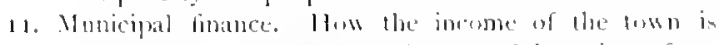

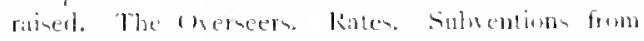
the contral sereanment. Municipal luane The contmol uf municipal finance.

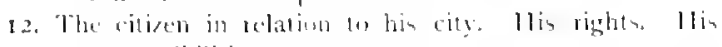
répumitilitien.

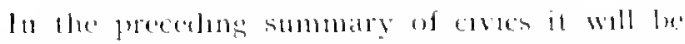
secul that the froblems essenthally constalered in the preceding report oceupe a very molest shate ut atfention-mainly that in a portion of uts see[un; and 10 the the majority of civic tratuses Iroatly atslee, the stand point of british muncipalitles also.

I therefore select a sery difterent statement of

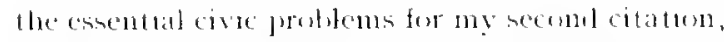
the chapter heabmes of Mr C. W. Robinsem's "Mulern civic Ant ar, The city Mate beanth111." l'nlnam, and, a representalive expressum al amore amblums cive pont uf view now rapully sprealing thromgh American cotes. Here the stimulunt of material betferment is man-

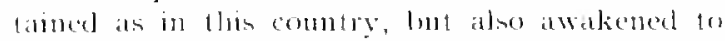

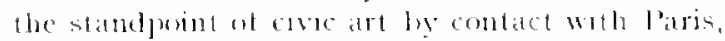
Berlin, and other momumental cities of the contment, the elass to which Washngem, al course.

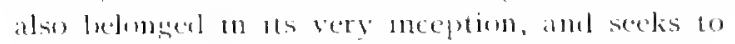

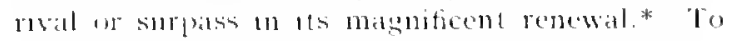
"funte theme :

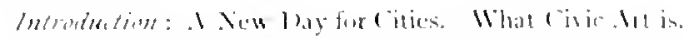

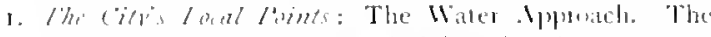

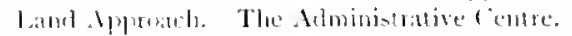

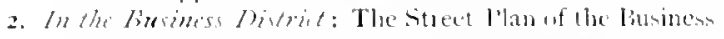
bistrict. Arehitecture in the businew bistiet. The

* l'ark keport, l bintrice of Columbiat, 1900. 
Fumishings of the Street. Mlom ning with foumtain and sioulpure.

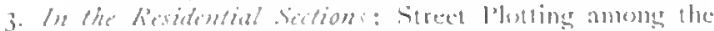

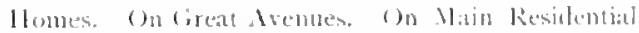
sirectar Anung the Tenements

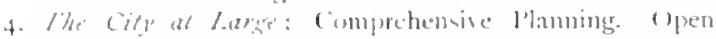
spaces. lathwass. Distribution and locattisas of

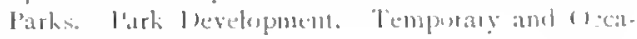
simall] [)ecoration.

llere we have the archifect as again the literal "chict workman" his name implies. Long lett asile in the rush of industrial expansion, and with his opportunities so rare as to make his success witl them still rarer, he is here claiming, and justitying his claim, to the high offece of civic edile, charged with the wradual redress and transformation of the disorder of the past, and with the immediate better remalation of the expansion of the future. Such American civic improvers "are not asking the town to help) art but art to belp the town; the artists not to ghorty their ant but be their art to glorify the city." From this outline, and still more from the inspirtng volume itselt, it will be plain that such associated teity improsements ats I bave ventured to suggest from the sicles of park approaches or of stream purtication are but modest anticipations of that largeness and rigour with which Dunfermline, ats henceforth the cynosure for American as well as British cities, may he expected soon tu grapple with its various improvement problems.

Finally, the thurd statement of the eivio problem I select is that more general and comparative treatment sutable to the initial course of applied sociology in the Lniversity of london which I havelat dy been prwileged to dodver. This is submitted here, partly as induating the lines of a fuller comparison of towns and cities, great and small; as stating in general hnes those nnversal prohlems and tasks of culture develonment 10wards which the plans and proposals of the preceding pages ofter particular and local solutions; and, further, as indicating more fully the high significance of Dunfermline in the past of ciric history, its ypical interest in the present, and now in the oprening future its renewing cultureintiative, its extending example and influence among the cities of the world.

\footnotetext{
Introductory Course in Sociology

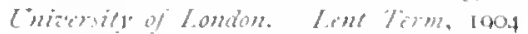

\section{Cities and their Culture-Resources Aclual and Incipient}

\section{Studv in Ciric Development}

1. (a) 1, (1) w w

Comtinerial cities and their resources: Anerican cities and their anditions. Great lint lewn deseloped resuurces and leas awakened icleale of loonden, and of mom, if not all, Lritannic (British and Colunial) cities. Symptom of awakening.

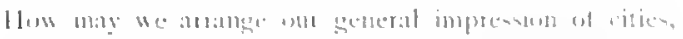

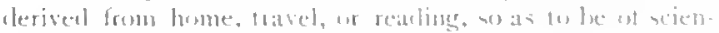

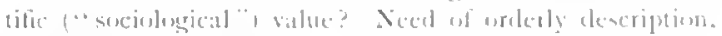

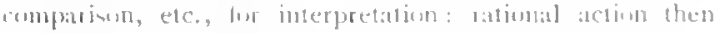
lxcomen more powitle.

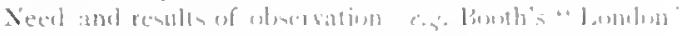

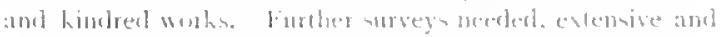
intemise.

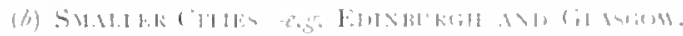
sualler national as provincial capilate, with their ats-

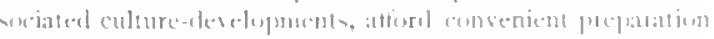

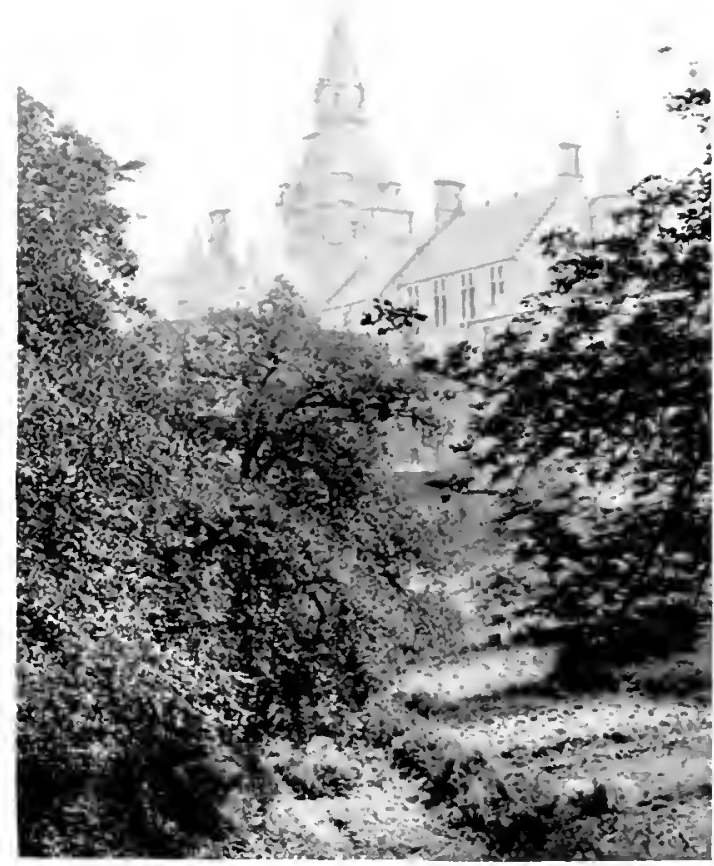

Fu. 13. Sipire of Toun llouse fum Park, near last entrance to Timer 1lill.

for aturly of Ionden and Westmimet, Eamples: lidinlurgh, Inulermline. Winchenter.

similarly, lew enormums commercial and imlundrial cities are more convenient to legin with than lomklom, the City and the kast-r.y. Gakgum and hindred cities. Simpler are minor ports and lourghs c.p. of fife, levem, ete. In short, we must vuly tww from their gengraphical origine mwark.

Comparison w Eithomgh and (ilangus in contemproaty and hivionic avelopment: suggentiveness on this.

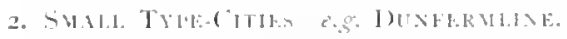

The smallest igpe neeterl, in which hinturic, actual, and incipient develuments mure eavily llacenthe. I must com. venient iype at present lounfermlibe: medichal capilal and abbey, and modern manufacturing toss nus heginning

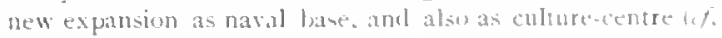
NI Carnegie"s initiative). 


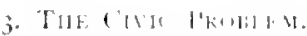

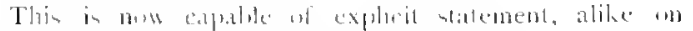

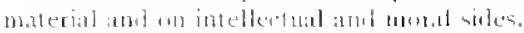

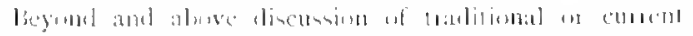

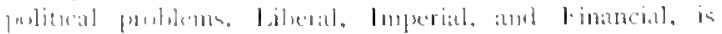

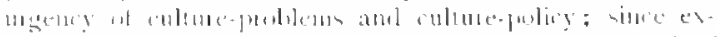

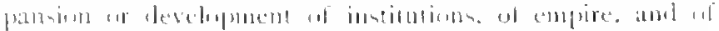

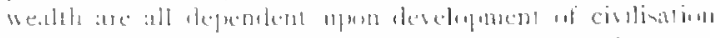

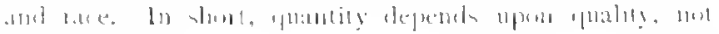
consteraty.

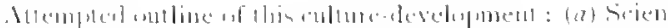

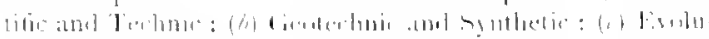
litisint.

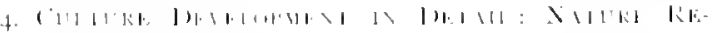

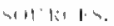

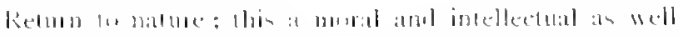

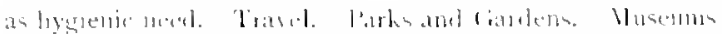

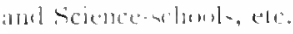

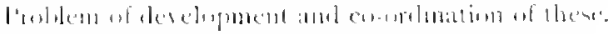

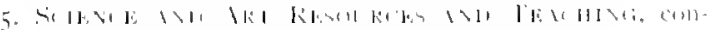
limeter.

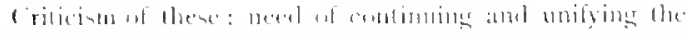

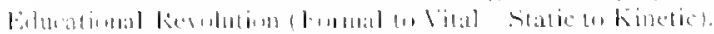

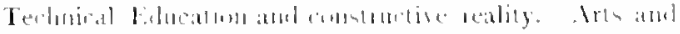

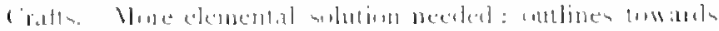
linin.

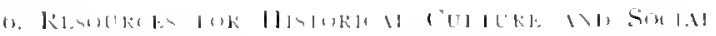
CiTluir E.

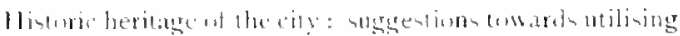

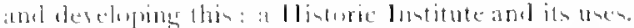

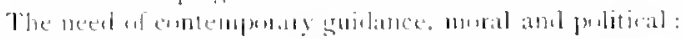

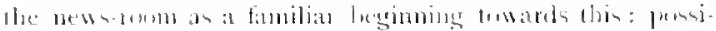

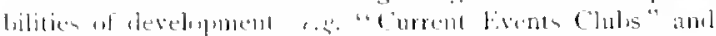

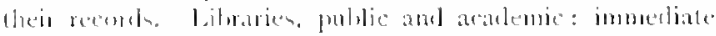

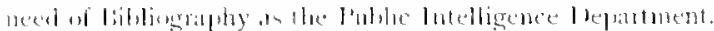

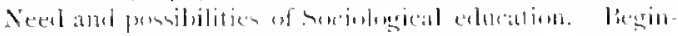

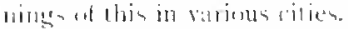

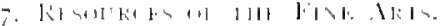

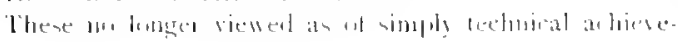

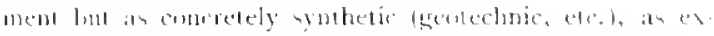

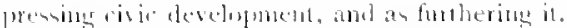

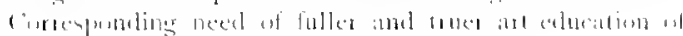

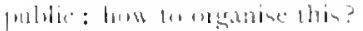

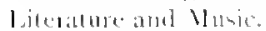

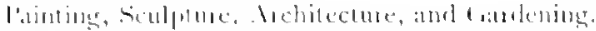

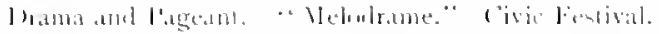

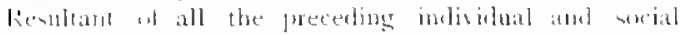

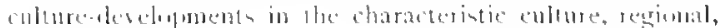

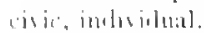

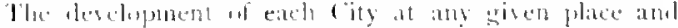

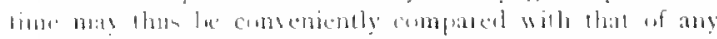

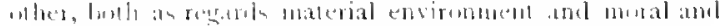

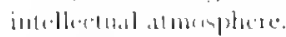

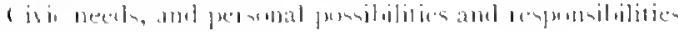
acolangly.

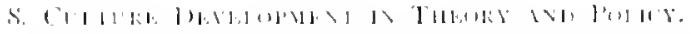

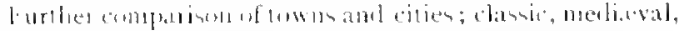

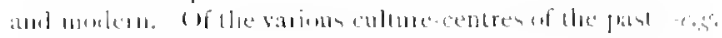

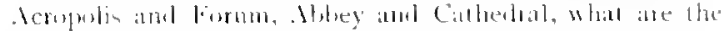

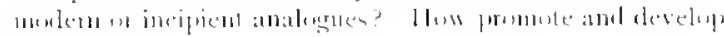
Ihene?

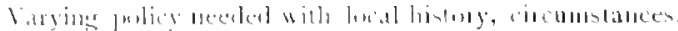

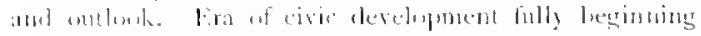

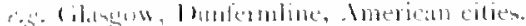

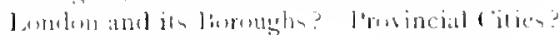

(iilumbal c'alutals?

Thal wher and higher siatements ot the coric

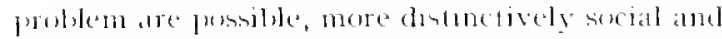

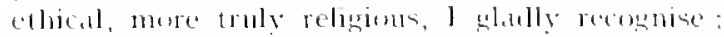

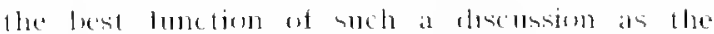

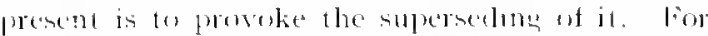
lhe presind, however, it may seres as a sime matrised melication al the stantprint al the present velume, and as an intsuluction of the

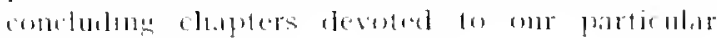
ene reveluphent. 


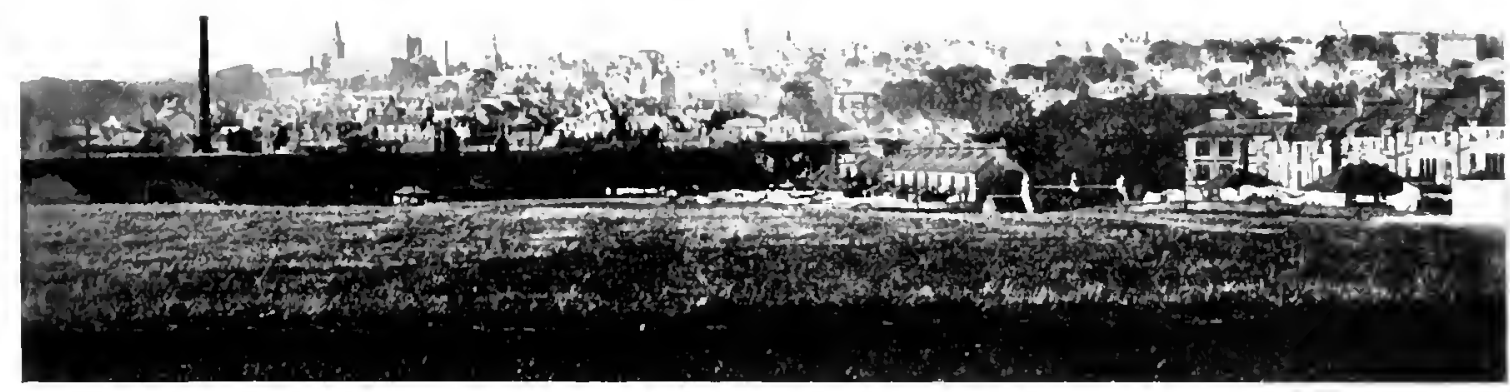

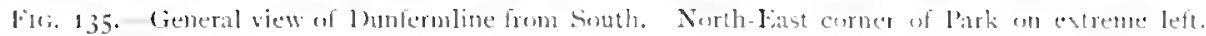
Note old West tower and spire, and modewn stuare tower of new Abbe Church. Spine of Toun Honse

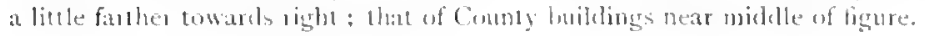

\section{CHAPTR NXXII}

\section{DUNFERMLINE AS TOWN AND AS CITY}

\section{A. The Town}

So far, then, the study of the city in general Suppose the concrete sugrestions of the preceling report discussed ancl improved upon as fully as may be, and the Trust then to carry out a scheme of ciric improvements satisfactory alike to themsetves, the city, and the worke, fully expressing the best attaiment of our time, even the highest it has been alle 10 toresee. Were all this accomplished we should have legitimate cause for a daly of civic festivity, such as that which recently matred the public opening of the scheme.

What then? Not only the larger worls hut our awn city woukt thereafter live on in its accustomed wav, leaving our series of new institutions, once completed, to "settle town," which ton commonty" neans to frecze or degenerate. ()nty an aim and conception of ever-extending, exer-expanding individual and social culure can protect them and us from this.

Why at this day is on Mediaral Abley ruined, our Renaissance Palace fallen in? Because from these the great stream of national and of world life which once animated thom mored away. teaving their dignified exteriors, at first apparently" unchinged, to fall steadily and inevitably into ruin.

How, then, shall we safeguard these new heginnings? Though civic renascence seems fully hegun, who can proted our schemes and institutions and buiklings from falling into decay in their turn it may not be into picturesque ruin, as of old, but with that far subtler dry rot which has befallen so many of our lately most hopeful molern constructions, educational and other?

$110 w$ are Dunfermline and its Trust-presumably at this moment the most eagerly progressive community and body in scotland-lo escape sink- ing in time, albeit distant, to the frozen conventionality of Edinburgh, the hopeless paralysis of its happily disappearing Board of Manufactures? For when such things have befallen our national capital - still with all its frosts one of the greater culture cities of Europe-what is to be hoped for this little Dunfermbine? Jlas it any huture heyond that of provincial mediocrity at best? Hust not its young ability be creaned for larger centreseach "lad o' pairts" leaving us just as we have reared him? Nlust not the mniversities, as they revive, search out more and more keenly each individual of intcllectual gift or moral glow? Must not the larger worlet-Glasgow, London, Americamore and more call away our vigorous youth to ever-enlarging lut increasingly distant carcers? Derelop local and civic patriotism as we may, the linger call of nation and empire can but the more largely predominate. We have seen this in our own generation; we see, too, that the next will he yet more open to the call of the common language - nay, of the larger humanity begond. And must we not lovally accept this? The little grey old mother cily will still take pricle in the soms whom she has sent out, well schonted and nohly inspired, to battle in the larger workl; ever and anon mav welcome one who returns, as in nur own day her most successful child has done, to rise up) and call her blessed

But all this does not wholly content us. It cannot, it need not. Let us consider, then, what larger possibilities of civic life may also lie before us here. But what principle is there to guide us in this rast question, what che?

Here, as in all true progress, we must not only comprehend and transform the environment without but develop our life within. Onr inevitable and permanent provincialism must be accepted as one of the facts of life. Dnnfermline will and may 


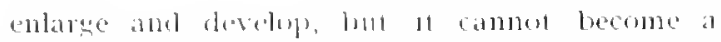
citason or Edinbugh. What is the rital dement which must complement our provincialism? In at single word, it is Regionaliom-an icleat and movement which is alrealy prolucing in other combtries

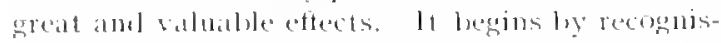
ing that while centralisation (1) the great capitals was inevitable, and is in some meatsure permanent, this is no lometer so completely necessiry als when they practically atome pussessed a momopoly ot the resources ot justice and ot arministratuon, al pratetical monopuly also of the resources of culture in almost all its holuer forms. The moreasmp complexily of loumatu altatis, with rathaty, tele araple, and busmess organisation, has enabled the

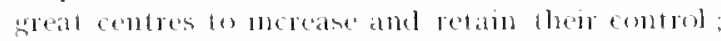

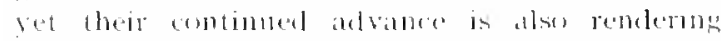
decentrallsitem, with local goreroment of all kimls, moreasmoly pessilse. Simblaty for culture

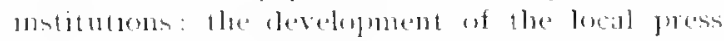

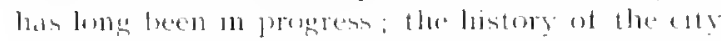

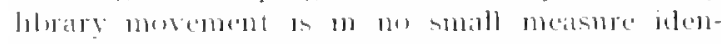

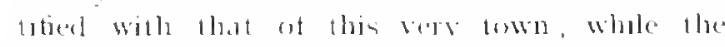

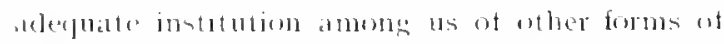

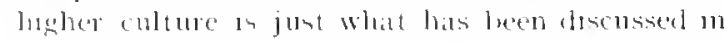

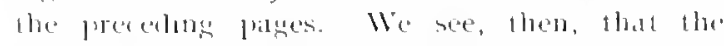
unall aty is thas in sume meatsure esciplong from the exclusar antellectud demination of the greater ones, and is tending ar rederedeps, not,

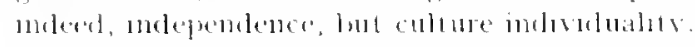

There alfe more ammedatte reasoms for the development ot smaller coties. They he in the

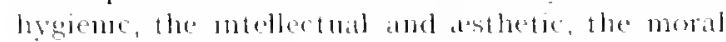

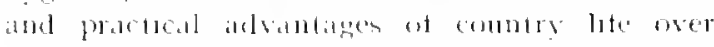
city life, partedulaty for the poums. The ent-

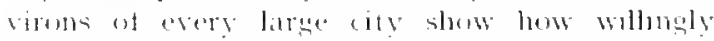
fotertamilats taces a lome and tatiguing double

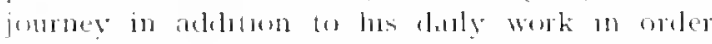

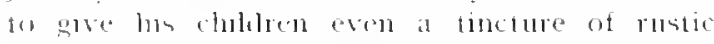

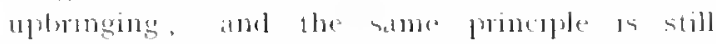
more monitestly at work 13 the Gaten rats morement

ta personally a stong comservative in thas matter-that in as lomg more acturely mterested in the renascence of om ancient and historic cules than 1 the creation of new ones, however delightul-my awn testimony must yet be guren to the side with which l personally least sympathise. Having hat the exceptional treelom among busy men of choosing and varying my home tor tour-tithles of each of the last five and twenty fears, I have made large use of thes to famblorise myself practically with the special and reglonal arluantages of clty and of country life, both in northern and sonthern Lumpe, and, indecol, from the fiast to America. Ant hoping that the present trightul inferiority

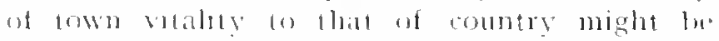
adeguately treated hy holy of apen spaces, heter atmosphere, ind so on, I experimentally built my city home on at spent seowedy surpassable

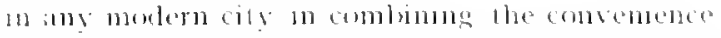
of central position with that of adjacent bast open spaces and almost of hill ati-the lotty and

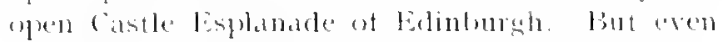

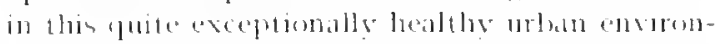
ment it mexter but latte observation of ane's own or neighlouring fomilies or see that utally still dromps, and that, to ensute the full vital derelopunent which is the mente estentsul to the artefuatle uphringing of choldren, at tar tuller

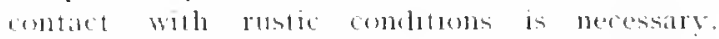
Still more when, with the alvince of lnological

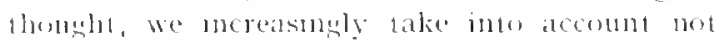

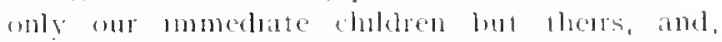

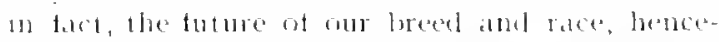
torwatal no longer an be thoughtlessly sateriticent th the immerliate strugere tor wealth of daily breat, lout to be considered with that long and more than statesmanlike patrence with whols we select and fllant the torest, wh b wheh we tent, select, and muprose the humbler amimal breeds.

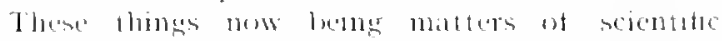
cortitule, ats of ereryday fact, alte now begmong

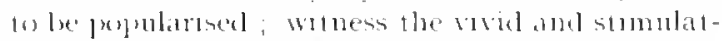

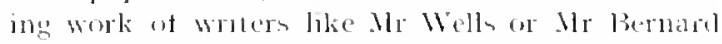

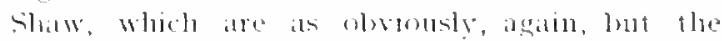

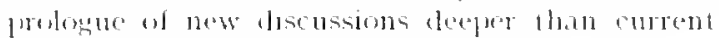
pollinall or soctial ones

fowking, then, at the position of truntermbine ujun the mat, so combentently situited upon sereal hores of communcation also, we see that it may reatlily combine the artvantiges of an ancent and revived culture city with those of a modern fincen Cits, and these independently "ren of the new matrime city and garden eity forected in the immediate neirhbourhous.

Here, in fact, al Dunfermine especially assuming some tuture lowering of ralway fares, of whold the llungarian zone sytem and other improvements give promme. We hate the most convenient resikentul centre withon eass reach of Eelinburgh. Fin the large class of retired preople, and for lluse whose main concern 11 is 10 cilucate their chulden, Duntermbne, especially in view of the progtess and tmitiative of 1 ts schonls now beng frovided lor, should be able to exercise a permanent attraction

The lark is but the centre trom which must mereasingly radidte the lunes of an enlarging web of civic imporement, not only extending ww1 mote combly but fully diffusing country into tomn. With its chammg and sheltered walks, and those afforded by the naturat extension of the frati, Lhomgln and heyomel St Margaret's Glen, aml gratually for miles leyond, we have deal comblums fon the invaliu, the convalescent, as woll ats tor the rourist and holutaryeker, woll sulstintuld eromomic import to the rity.

* francis Calfom, "Viagenics: it I letinition and hoope." sixciulogical suciely. Way 1904 


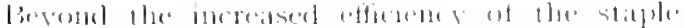

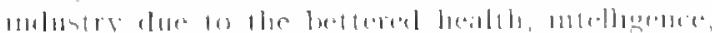

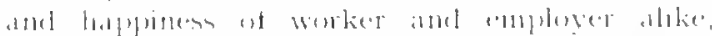

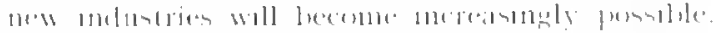

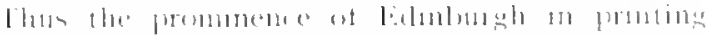

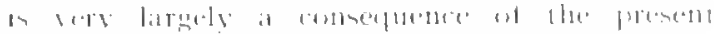

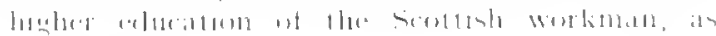

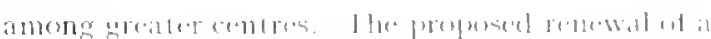

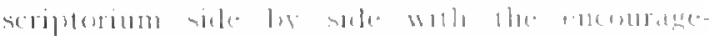

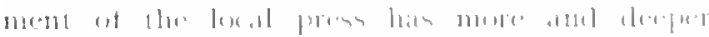

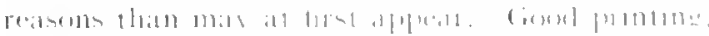

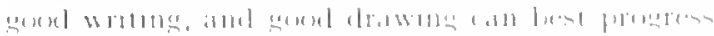
ligectiner

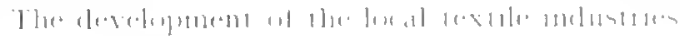

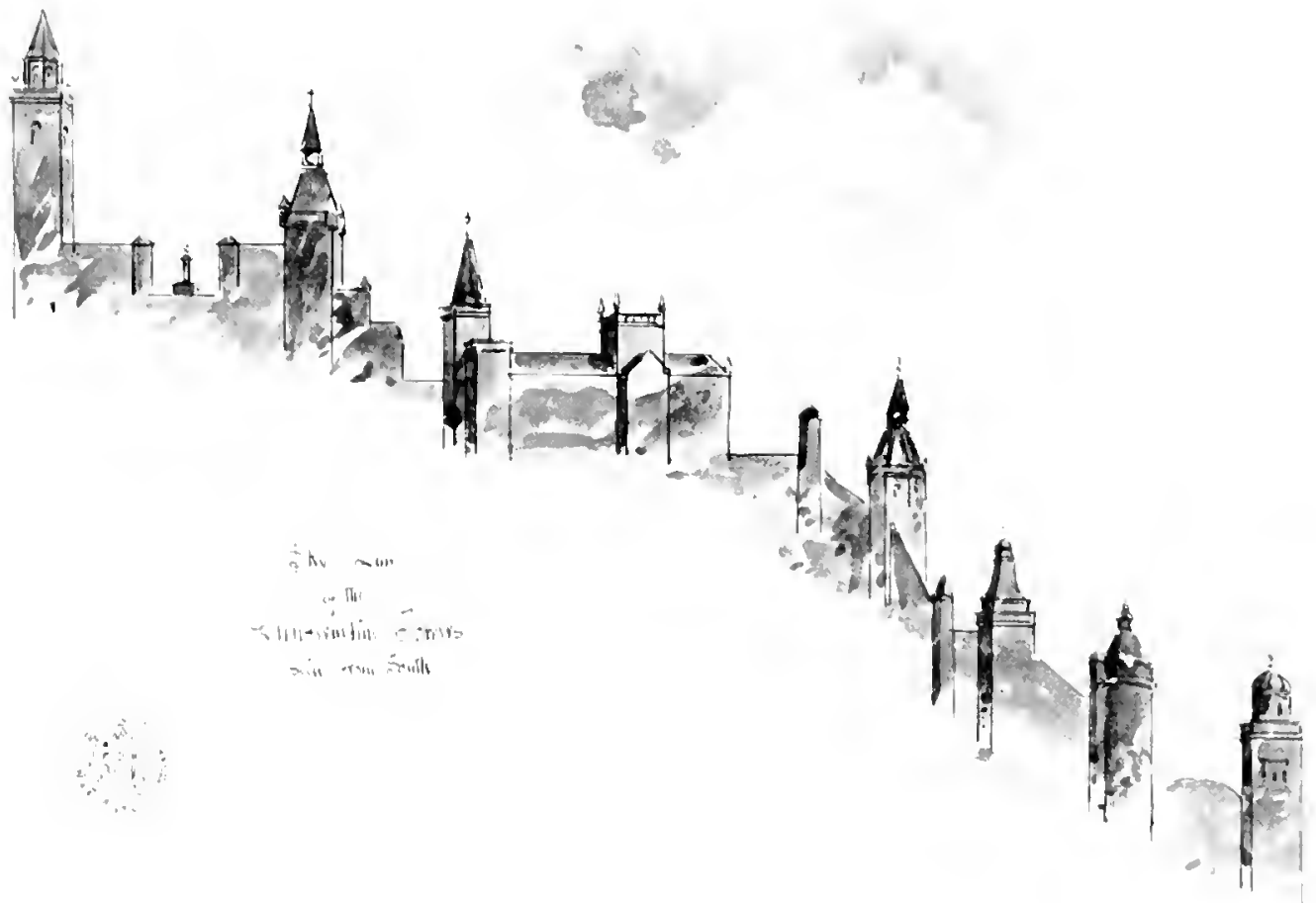

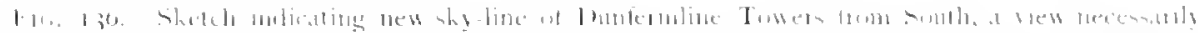

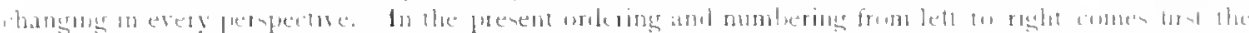

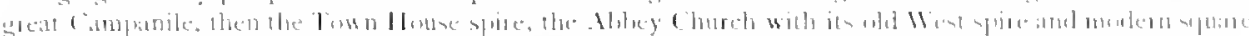

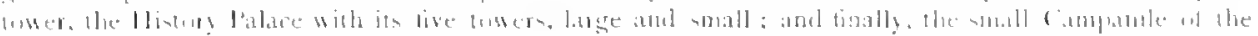

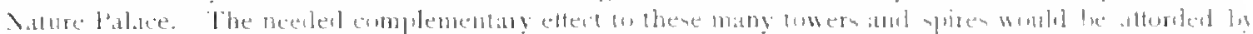

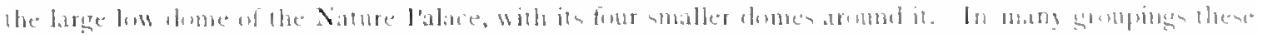

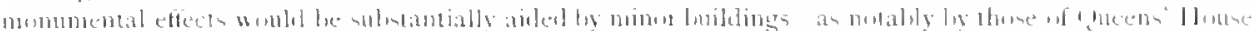

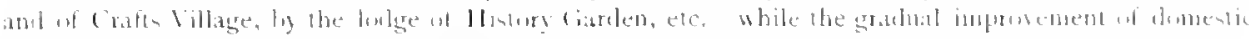

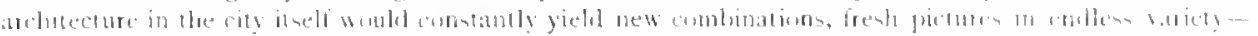

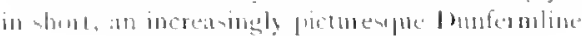

well ats of the prost artivity of sontish writers,

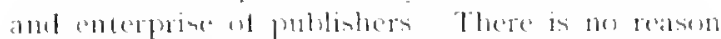
whe lomtermline should not obtan some sul stand1,1 shase ot this. The city whels in the

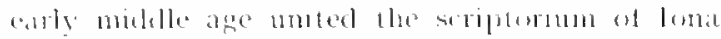
with that at rantertunt, whele at the Renaissance sent bramme ter Italy, and where the modern Libars Inorement has an such latge measure bexun, cambot think itself to have ented

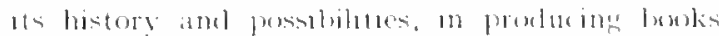
as well as using llem, at the ver moment whell ils culture tacilues ate beng revised, and when

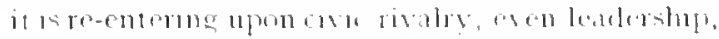

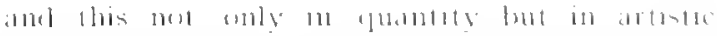

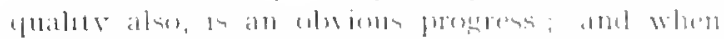

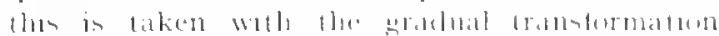

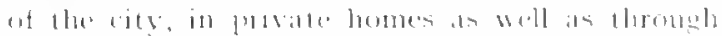

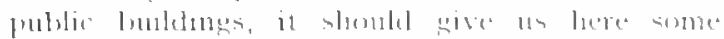

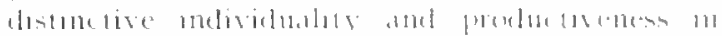
art imlustries of all kinds. Iml, as lats alleaty

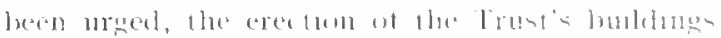

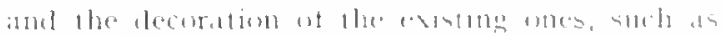

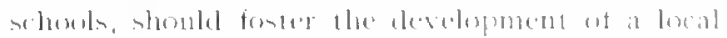

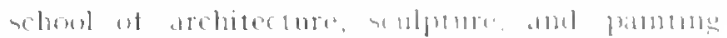

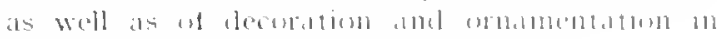

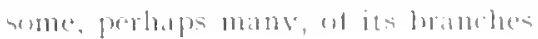


With the bettermg of homes, as of the larerer emironment, there are here all the comblitions, and flese in anusilal and ever-inereasing proportum, for those conditions of luklyly and mental beallh which are needed tor tull industrial and commercial effetency ancl artistic pertomance, amel, ferhaps, enpecitly for that mental alertucis in the atpplication of seience 40 intustry buen which the opening future of hut combles so lowgely depents. Is a single speestic instance, 11 is a vere small ferman efly, not halt the size of lomfomline, dhat lias defeloper what is at mace the best and the sreatert socontific instrumont-mationg husmess in the world: amel wolle

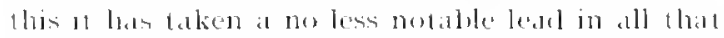
concerns the conditions of housing, insurance. and general werl-being it lhe workers, in techneal and higher education, in eity amel moversily improsements also.* "There is surely reatson and

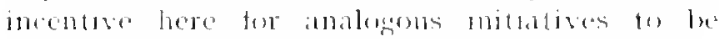
fursilse and truiltul.

such are many ways, therefore, in wheth a miner eity like Dontermbe may open new careers for its more gifted chullen, in wheh. incledel. it may not only retain many of its best, but attrat high ability from other filaces, with all the mutual adrantage, the perpetual tertalisation which such interchange inverlecs.

In this respect, as in so many others, the strangely chequered history of our cun holle combly is at no small sionfieance. It has been fixed in our minds, chetly by the tratition of achol geography looks, that arery combry, erery kinglom, for that matter every connty, late ils "calpital." Vet we do nol bere very seriously fect the governmental yolite of Cuparfite, nor even lum exelusucly to the educational anturity ot the ancient and once metropolitan miversty af si Andrews. We hope freely in ulstise not only this but the acarlemic resources

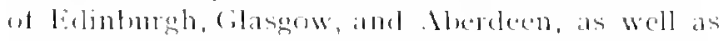
remoter ones it noed be. Edinluargh was only created the capital in 1437 and, ot comrec laredy reabed fo be so in fous, and tor most purposes in 170; while in earlier limes we find lerth. stirlumg, and buntermline all rivallins, indeed sometimes execeding. Edinturgh in mportance

lispend these indin we find at network of -malier regional capitals; witness the traditional

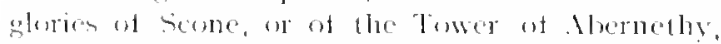
still more that wealth of folk-lore and tration which pions memory has prescrved trom amomg the roums of lons. Aromel the almost lorgotten yed bong inclependent capital of the lord of the

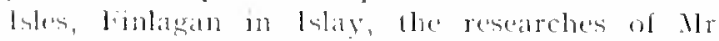
Camplyell of Islay and rethers have diselosed a wealth of tratedion eren strpissing these disdemed ly lierman tolk-lorists and philologists, at level ot alture almost loclandic

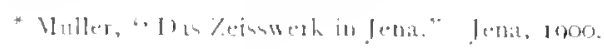

But it is not necessary 10 go back to this remote and shadowy antiputy. One has only to (2) north to the thrising regional metropolis of

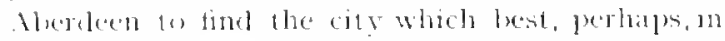
all the british lsles combines an corr-widening development of manufactures and commerese national, amperald, and international, with intense lewal lile and pougressive culure, populat and alcalemic allike. It is this mfensise melividual and regional development which presents tor us the truent tree and torecast of our seottish cities; and purticuluty in lite, where Scottish melowludle has always moloriondy leen pushed to its rery furthest, and which hat produced sach worlit representaldives of individuelism in pholosephy, in personal lite, and in praterical aflares as delam smith, Robinson crusoc, and Anelorw cornegie, we hase evielently litele to feirn exen from the Alerelonian.

Wie have thus reviewed not only the regional develepunent of this place lut the corresponding and extemeling possblitites of tis regional work, with a glance at the correspombling development w the life and conditions of tamily, and even with that improvine "social selection," not only as regateds melustry lut tamily, which is increasingly seen to lie a vital comdelion of all human progeress. For the romantic tales, of which our tom sorions oritics ot libtaries are apt monfficiently of appectite the populat use, cven these of Edwin and Angelina, of Cinderella and her l'rince, or of rustic lad transformed by

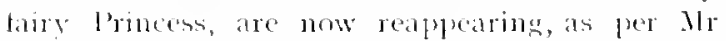
Cralumis and other works alled above, in the very forefromt of twentienth-century science, which las now to poprularise elegenies, as the last decdrle has diftured the idea of hysene.

l'lace, work, fomily-region, ocempation, liteseovraphic, industrial, and social well-beingthese are but varied wordings at the threetold undy of like, work, and surfomdungs organism, function, and ensionment - whicl we are areking la realine in this one wan goos town.

\section{B. The City: its Schools}

Butt lus dele of the Town, its Place, ats llork, 1ts familes, is as yet ton purely material and objectise: we must more anel more tully take into acome its deeper and subjective desclopments. To rise from the conception of Town to that of city we need far more than better laying ont, better organisation of industrial and resielential eonditions, fuller aecess 60 nalure and so on, neceltul though all these are. We must tirst now complement material "Town," "xen "Garlen Town" thomgh it thas become, by the no loss undispensable developments of its non- 


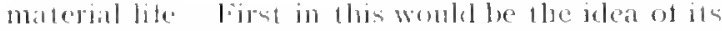

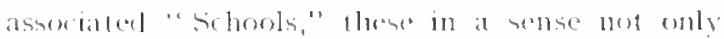
inchelume the evervelat one, yet with all the

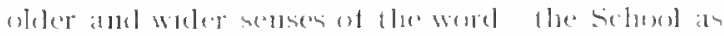

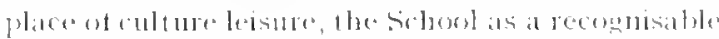
frand of all, as a lowal colesur in loleralure, and so soll. fer 10 be really conscions al ont where-

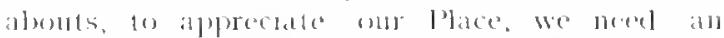

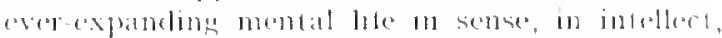

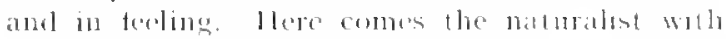
all has resoureses of regiomal survers; the artist

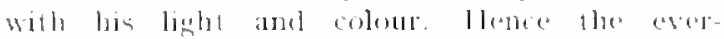
continued, ever-vital usedulnese of thuse nialusabistic and arlistic lesoluces whels we have abose ondlinerl.

Again commer to the next great conception of Work, here the derelopment of the indiviclual must recapitulate the essential development of

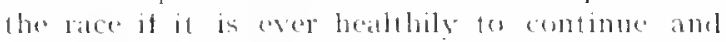
to surpass it. Henere the neerl of that prespetnal renewal of priminue acompations, that village of prinitive life which we have pleaded that the children should have the oppertunity of actually constructime, of mantainuge, reconstruction also. generation alter generation.

Ilere, tor, is the plea for the forese, the mill; anel here agdin the arement for recapitulating the whole development of the loum, and this trom its most primitive legrinminss, ceen tor the very sake of mastering its complexity and alsancing this

In the same way the chims of rustic lalune, in cvery form from the simplest plonghing for the most complex gardening or most skilful fruit-rowing, have their place and their correspondung scientific disciplines. The technical sefuent thus escapes trom the mechanical lromblage of art (1) science, and wlilises a living and progressive experimental science in the actual pustut of industry ancl art. The eurent Iiducation of Exercises ton tarhly applied in practice, thus gives place to an insigorating Elucation of lixperience, a cliscipline of widenng responsibility. in which scientific reflection and muestigation are combined. At present a loy wten learms geometry tor years before he comes lo landsurvering; whereas, starting anew will tho primitive tope-stretching of the legption, his practical efticiency and bis mathematical power switly inctease logether.

seientitic research has nothing to fear from this intimate relation witl practice: the great chemical factories of Cermany surpass in their research activities the university laboratories; while that extraorsinary focus it medienl progress, the lasteur Institute, is at the same time a centre of advance of many other kimls, from pure chemistry to sochal science.

Social science amd the corresponding efficiency of social service thus hegin essentially will the sludy of place and of work, with gengrapher

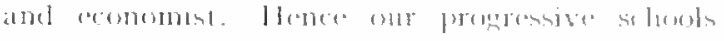

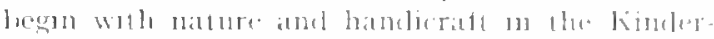

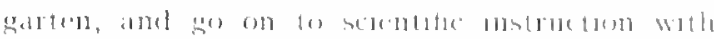

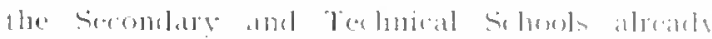

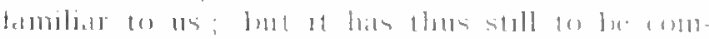

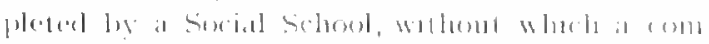

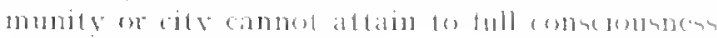

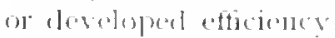

form it is the development of the past, inters

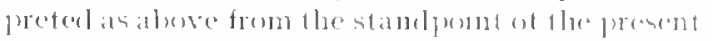

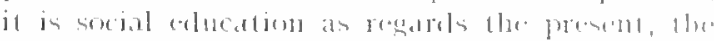

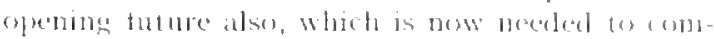

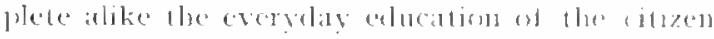

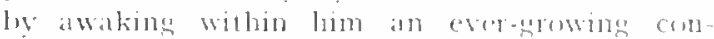

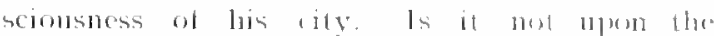
freor and imperfeet deredepment of this hish clement of enlucation that we must explatin the weakness of the modern city in these respects ats comprared wilh the great historio cities, not fome anly, but others betore and smee? on

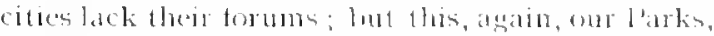
nut arema, maty increasindy smplyly, the remewal city cross at any rate stand ar a comtere.

In this way we kee develuphe from the place, the work, the family of our Town, not mly the welsof aceupation and the organisation of industry.

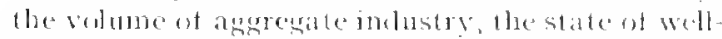
being and heath, the varmos institutions, lut also the School-iet. the sed of reats connectert with each of these, and needful for their efficient exercise. Fom elementary geography and otloes

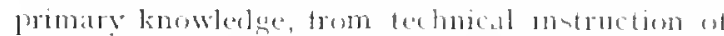
the simpler sort, we mat thus rise fo higher and higher schools, ancl an sperial cities lo institutions

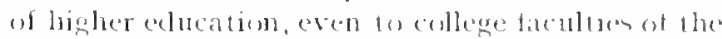
old pofessions, such as medicine or law, as webl ats to the new protesusms of engineering, agricul

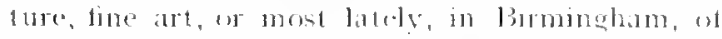
commerce, Ilere, m fact, we have the usual deleat

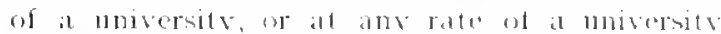
college. This type of development, howerer Dunfermline does nest repuire to follow to the full, since (o) her completion of her own schorst system In utulisation of the tive mejubbourin: Univasity Cities, as an laer uschul reatetion mpon thesc, there se evidently nolmit.

\section{The City: its Cloister}

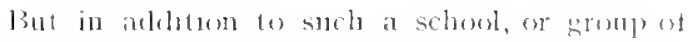
schools, a new derelopment may arise, that whel retires from the practical everyelay tote ot a city, or even its everyday elluational dotum, mots the meditative life-in antique phrase, therefore, into "the closter," the " Hber" in laterplids" into "intellectual retirement"; "hile in more modern tumes this mental attituele is largely re placed by that of "original research." The 
common character of atl these cloistered orelers, as 1 maly call them, is that them members are mo lomger manly concerned with the town's worting hife or

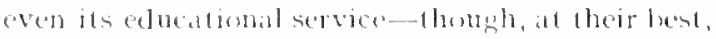
they hase always laten a not inconsiderable part in theres. It is that theil essential relutum and responsilitity anc now with the highent ansects of truth, as they understand it, and with the deepening of their whe combet and that of others with this Ab]M-fombling, as I mave all all turtherance ot instintums desoted to the comtemplatue life. whesher of redrous deat in the medieval past. ot phitowophe systems in Greets or in recent times

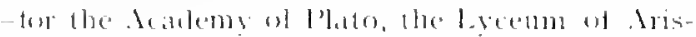
folle were the dointers of thens in their daly, m nowaters of the seientifie orter it the moversehas of late geass leen biberally atranced, indeed,

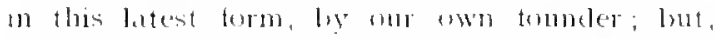
blsously and righaly, in our universily cities, in Wabhimeng and the loke, net here. It is thas union of sehool aml keseateh closister which in

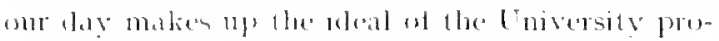
frer, and we see that present conditions do not

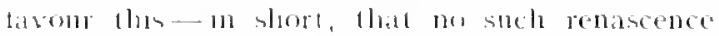

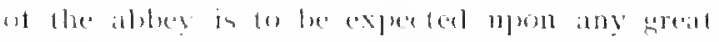
seale here. An aceasomal yreculative hermit may

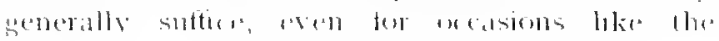
preatent.*

\section{The City: its Calhedral}

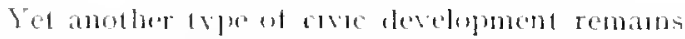
and this the buhest, dhation andugue phrase 11

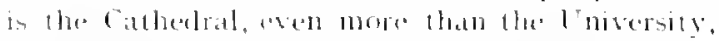
the Cloister, or the selood, which ratses the con-

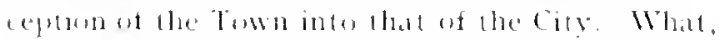
then, was the cathedeal? What was its contrast

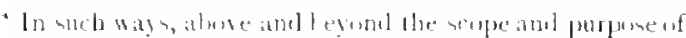

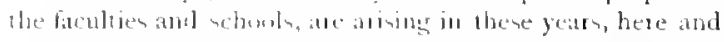

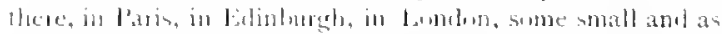

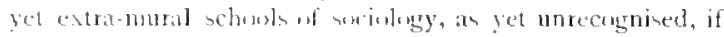

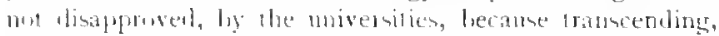
alihe in scientific level, in intellertual range, and in sucial atud moral anditions, their tratitional facoltien, Vet, nune

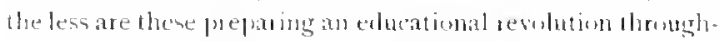
wht the miversity system no len impuntant than that which

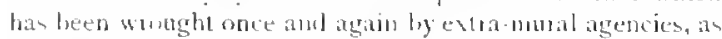

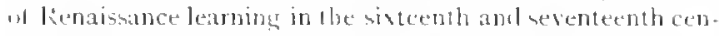

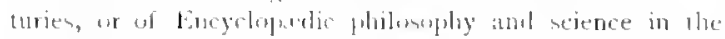

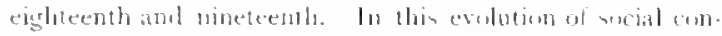

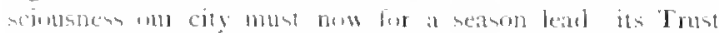

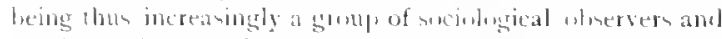

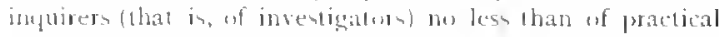

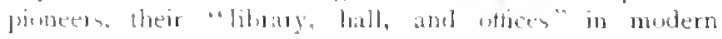

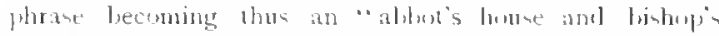

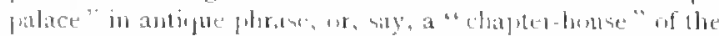

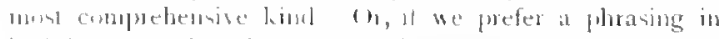

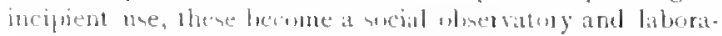
tosy, a cente at unce uf social wurvey and sosial service, a schoul and example of civic life and diry. with the dhbey? Howionsly this: that while the ablut and his monke were a "regular sergy"whese whole proneiple and reason of existence wat

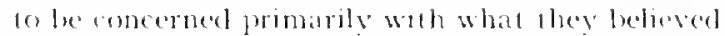

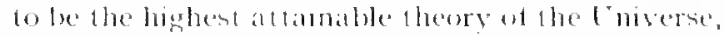
11s highest order and law- the bishop and puests were a "secular clerey," less hoghly learned, as a

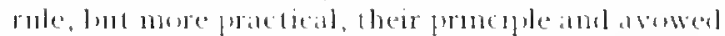

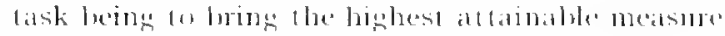

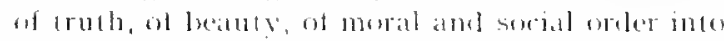

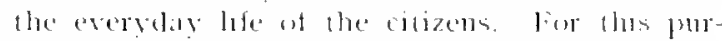
prose they grablually exolved the matrelloms art syatheas of the rathedral, $m$ its waly the rastest

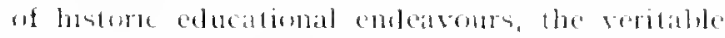

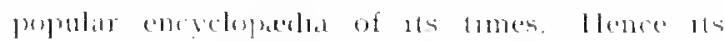
astronomic symbelism, its maturalistic detall, its fresentment at the ereation, of the oregin and tall of man, of netional hesory also, woth its kings and heroes, of orio hustory and interests atso exen to the dreest crotedsm on cancature of the citizens of the time. Withon, too, the same enevelopedre presentment alpeats: from les many chapels of

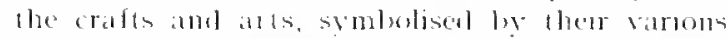
pettrons, for lis presentment of the unity of these

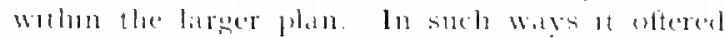
not only a relonums anel a philoserphie sysem, but

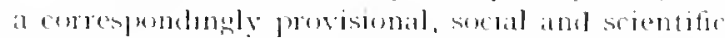

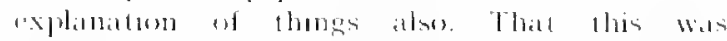
suftectent is tor trom sugesterl; it has lomg heen

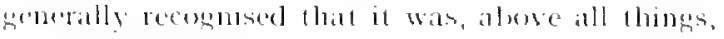

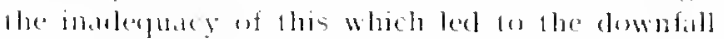

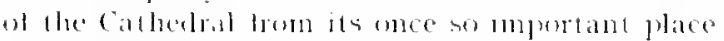
in the resulation and the development of core and regural lite. But what is nowadays m-

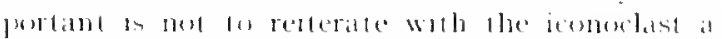

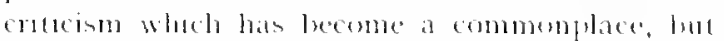
to recogmese with historian and soenaliser that just ats we hate seen fown and sehool and Cloister of

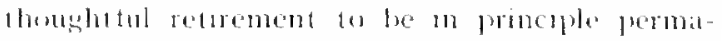
nent, so, almese all, must the Catherlyal le angun consulered. In princolle, in veleal, this was the haghest ageney of the tomes fowarde the bringing te bear apen the community the best cultural resources, the synthests of ideals and of knowledge, in then working theories, the methestation of all the arts-pantong, seulpture, and archocture, music and symbeletrama. The meorpmation of the whole boty at citizens, was here an essential idea, promanly, 3 their personal capacity, nrespective st age, sex, rank, or wealth, lut coftering " to tach man all that is humaln," fel secomalurily in their social capacily also,

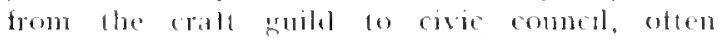
exen a more or less molependent cily-state. Jorum this lugh sere ot lite it is litfle wonder that the fown took a new aspect-place architecturally

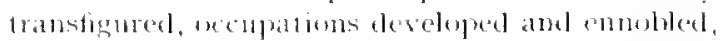
melividual and tamily suided and momalised.

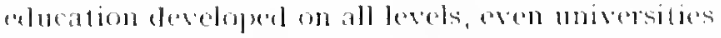
tomndal - in short, the whole crele ot teveloprments, material and ideat, temporat ans spiritual, 


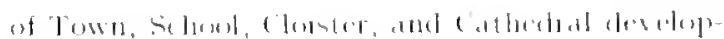
111 anders

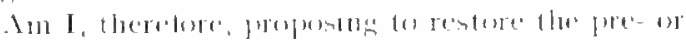

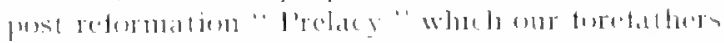

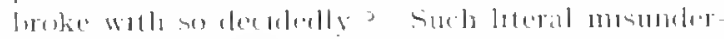

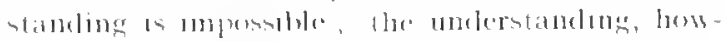

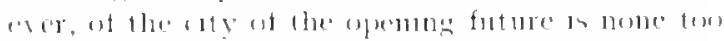

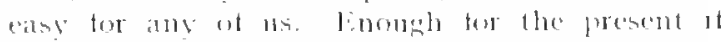
we see that as molustres and asper th of Town

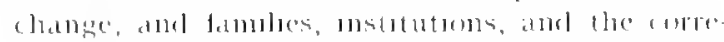

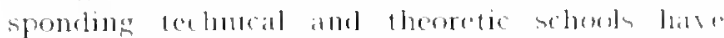
changer whth the tmones, and eser need to be

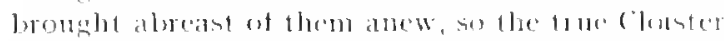
of thought and meditation, of obstritan ant experimental labeur must exer be restored m appropriate form; and so, finally, the trae Cialle dral estaldished. Where shall thes be? Mhere better shatl we thel oms modern Covid Cathedral Close than 13 the leople's l'ark- with lls vatht places of assembly, its halls of musk, itsexperesterns of symbel? The fresentment ot nature in 1 ts leatuty

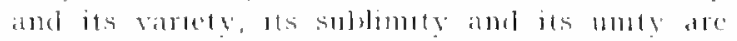
again bere. The presentment of history and its untolding meanung are aram set forth to be platuly understoot of the perple, and this an every level.

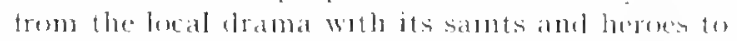
that of the laterer worle- contemperary inel cwelised-indeal, to that on homan origins. It the old emplatic boctrine of human destmy la in some respeets less clearly expressed, there is at

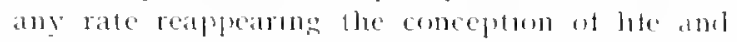
babour towatels the fuller realeatuon of the moldest deals which, in ont tome and onr phatse of evelution, we can discern, even if never tully attan, the preceshendal way of ont park anel city Cathe-

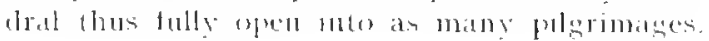

\section{E. Summary}

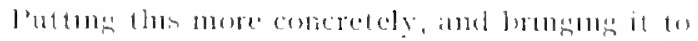
fouticulars, 11 is, I trust, apparem that the purpuse of the present volume has been more than to

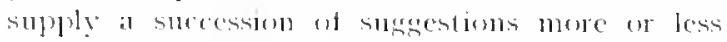
attractare, ar simply for criticion pieceneal. flurough all the comerete plans and perspectives. these gencralised discussoms of their respectue purpuses, flace runs a unuly of thomphe amb of design, le thes stecessiful or no. It is not only that of neetung general needs, more or less folt everywhere at present, but also of expressing the character and melumblitg of the city betore us. of conservong all that is essential or worthily representatue an th past and present developinent. ret of beldly comtuntung this into the entarging inture. This conception of the City is ats at necessarily unipue social personality, a defimte regional and racial development, yet one capable of increasingly consciom evolution, ant this

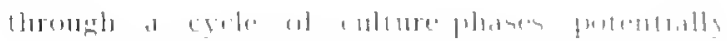

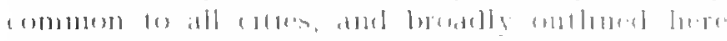

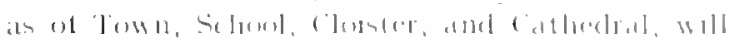

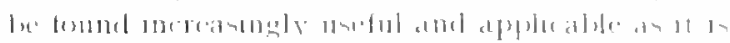

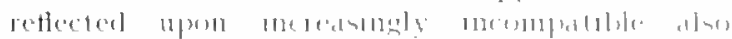

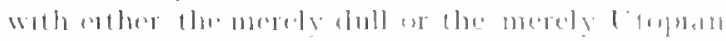

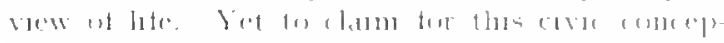

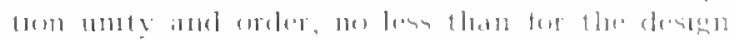

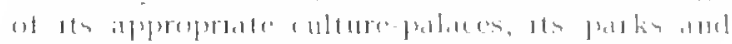

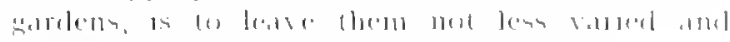
1)

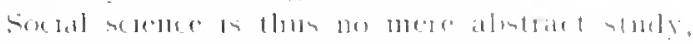

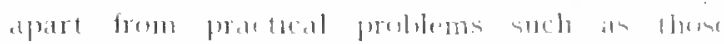

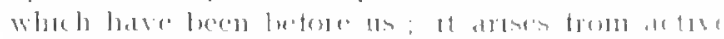

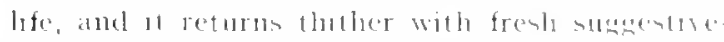
nest, new mention. What melatume of

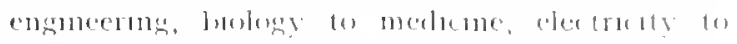

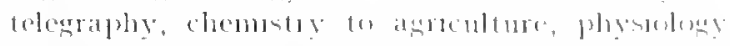

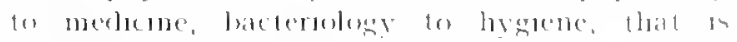
secology to rive lifo and well-being. Thet thes

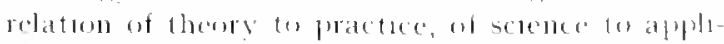
cation, is mose cemplux than ang ot the procerbug

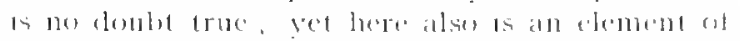
lupe, sonce with fuller knowledge we mate ted

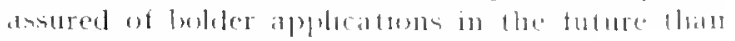

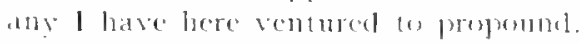

The sturly of the bxiy not anmated in the

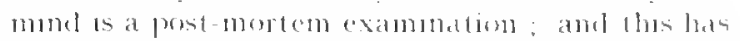
been fors much the case with the olde exmonten and polites, whels are cres secking to dommente most of that whel makes socety hring. (Jur

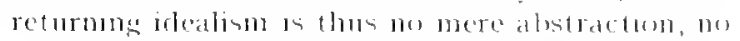
mere altair of semtment, at is the recosery, an new and erolutenary torm, wh that erestent of all trabtions that recosentern of the compreliensise. molelectual and moral oreler which ever underben and conclutums any honh level of serall acturn.

Amain, the varmes propresals of park and ell! momovement, whed I have abose submeted, mas now be reen to conform to the varume toleses of art. First came that of lescriptum, ot simple.

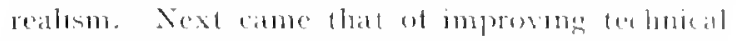

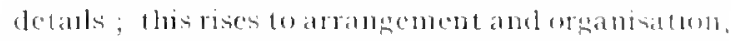

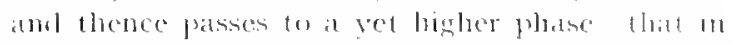

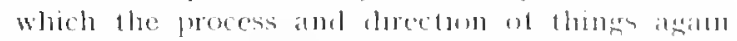

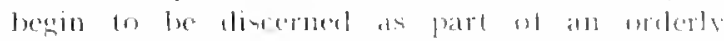

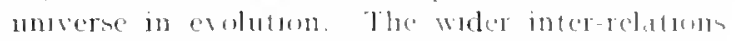
ot social life and of molural lath thus andme ut

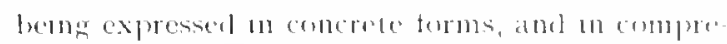
henswe symbols, so that to the religious youtt these molern selentic matitutes may asum bo expressed in hu termumblesy no less than m then awn.*

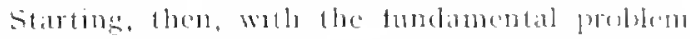

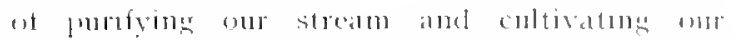

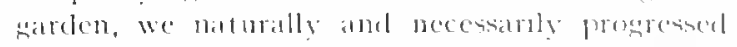

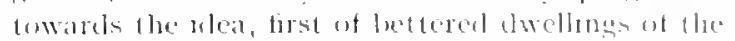

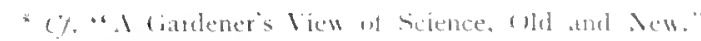

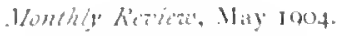




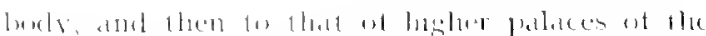

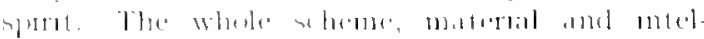

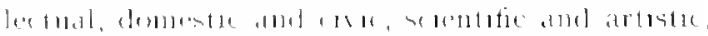

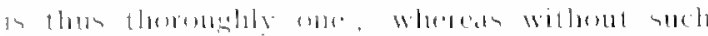

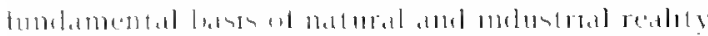

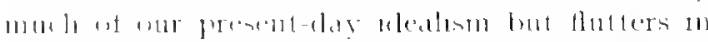

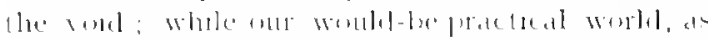

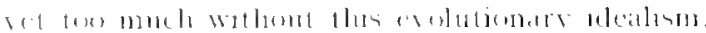

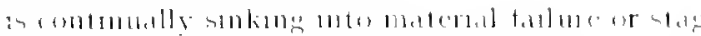

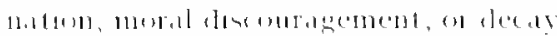

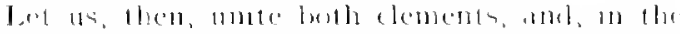

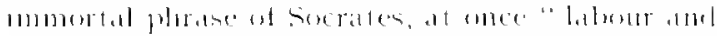

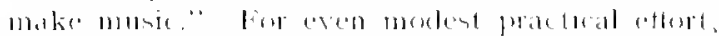

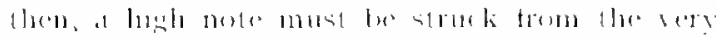

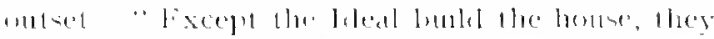

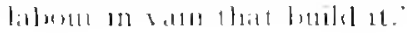




\section{CHATER XXXIV THE CIVIC UNION}

\section{$A$. Introductory}

I worn may be permitted of alut to the citizen. The mercenary view of the Trust ats something

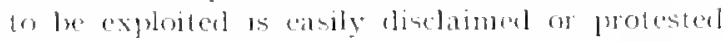
ardinst; fut whth false deats, as whth bat institulions, "we can ondy destroy whalt we replace." I 10uw submit, then, as the esentlal sughestion one lating precelence even of fork and huddings recreation or elucation, "sweetnese or light," hois social and moral proposal that, as the cily is anly to tre clevated in proportion as the citizens plevate themselses, it is tor then to work in and with the interests of the Trust rather than for their own. To pleat for the seting uj of defunte and well-organised agencies towates this is thus 11) principle my innal recommendation, as here actually my final ane.

l'utling this matter yet more concretely, is nut the truster tow often comblered as an exceptumel aml isolited individual on me sirle, with all Dnutermbine on the other? Vet, desple the unparalleled magnitude of his gifts, and the rare devilion of his purpose, he is a vowedly and truly but the foremost of his felfow-citzens; in laking

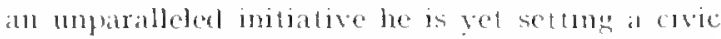
example. He calls upom whers to follow thes: amed thomgh no other may contribute dollars ly mullons, nor acres by sceres, at substantial increment to the lrust, or at any rate do lts purpeses and their accomplishment, as contemplated in the truster's tetter, maty thus he increasingly hoped for. Stoll more mat we he assured of this when the penple thembelves awake to this particupatum, and surpass the generosity of the rich with thent adfed mites, renewng that principle of whutary taxition for culture purposes so notalde in the listery of Scotland.

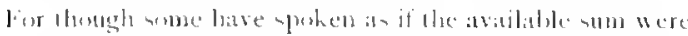

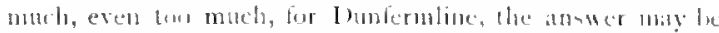
simply expressed, that affer all even this large inconte atser-

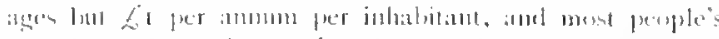

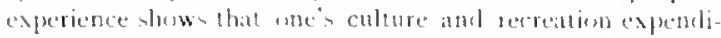

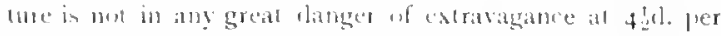

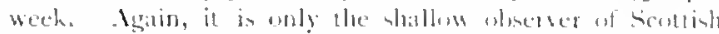
chatracter and lemperament whe thinks it me:an and patron : the mos critiol of all perplen, fommling upon six centurie of pultical and economic alliance mute intimate than modern

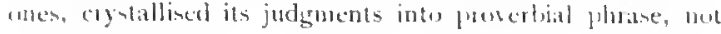

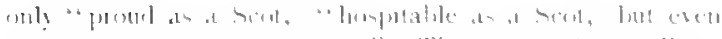

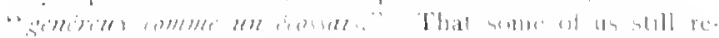

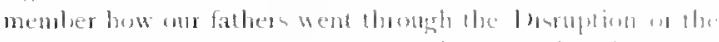

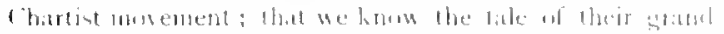

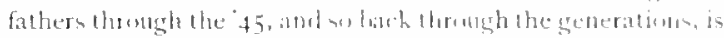

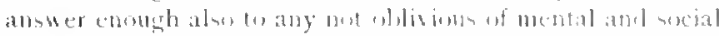

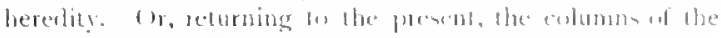

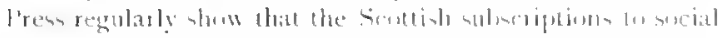

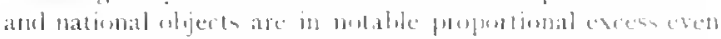

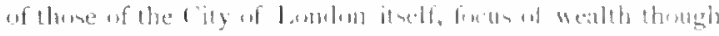
it be.

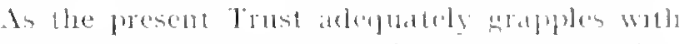
this second great meject of the fomnder, that

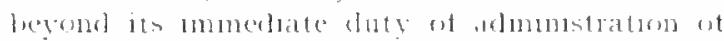
hus gifte, and patsecs on the tark of awakenme and

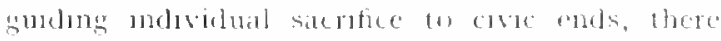
need be nu fear but liat the seottish cities may again rise, 11 maly le even lead; as bohnturgh, for instance, was wont fo do m architecture, or ats Chaspow now does an some ofluer respects. Ibere then, in ow two oly - in somerespects esen mort richly colowed than either by nature and by tralituns, as well as ly larger proportonal " amamon goonl, and now asan by generous atizensing

a new lade ol cive mithtive maly and must be erolied, unless all concerncal are on hall liomentably shert of there mitratue impulse.

In mating a repert af thes kind, whet of te uscdul must be definite, and to be detinte must advere spectic froperties tor atrumememt, and sugrest operations which tend to inhance the villue of otlers, I senture to hepe that sweth

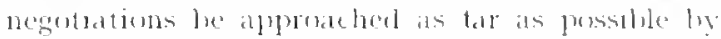
all farties from the stamelenint promarily not of the interest of the privale enteres expertung alvantage or gencrosity from the loust, lut from that of the Trust, whech, as refresenting the common weal, has a right to explect always reatsonable and, when pussilde, generous treat

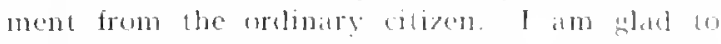
hate toube tistinct encouragerment in such very tentative inpuiries ats I hatre sentureal to matae at several specific prints: the owner somotimes freely pomisine lo value lis property, if redured, as a willing seller-ide at mo more than orellnary

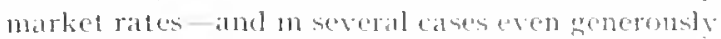
sttering the ground or access reyuired whout payment altogether

I lake upon me to matie this apjecal in assurcel 


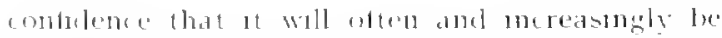

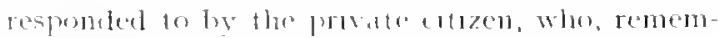

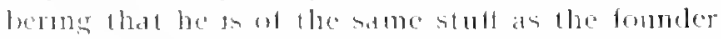
and trustees themelocs, must also increasmels

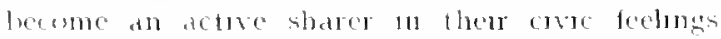
and therr practical senerosty of means, or time.

ledm, it must be anked, hus in each new cultureagency, such as the present, fo cheape graclually rekling to the tur common tate of human mslututurse-1 the entalual omeome ut routhe and semithy. It not death and fosslisatum? How is each eommunus, for ats part, 10 protect itself from mulacorporate degeneraly, meled, from a measure of indivdual pauperisatum? How are such easy donenty of good mtontuns an he pevented?

Amoumly in ane way only: Wy defining the breetoon of "progress," hy organtsing it inte an "the and resulute ascent. But this imolves the

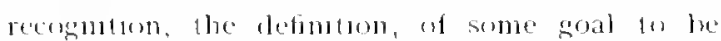
ascenderl to, 11 imples orme well-matured and clearly malntained folley and pronciple, alleeil

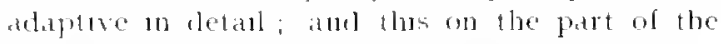
clazens as well as therr representatues and leaters. What we thun first of all requare is some sear conception af meneral polscy ly wheh to select among the many aleserving biatung agencres, and the almost innumerablo lesualle new projects which are put torward on all lunds. In such ways. then, Trust and ciluzens must mereasingly find themselves commited fo comprehenswe and contmmos me pury on the one hamd, to mo less man-

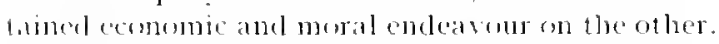

Ilavos cluscossed many reereature, edncatonal, and wher problems, their treatment in workins

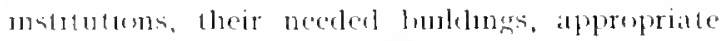
stuatuon, aspect, and final actung of gardens, etc. I nuy now be premited to stm up that concepfoun of the Trust and the purpore whel 1 have lept in verw-that of the city, and catizens ilises.

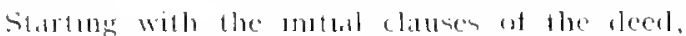
atul woth the armurable letles which aceompanies 11,1 note m cach the emphosis mpon experimental

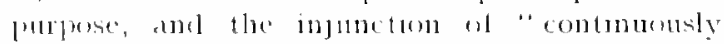
poneerong endeasour." l pete the demor's inslateme upen not reluesugr Ibuntermbne of any

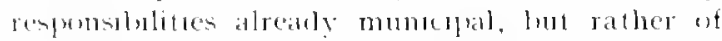

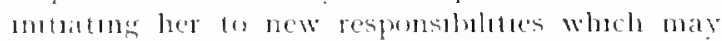
thereafter be municubally atropted. 1 note that

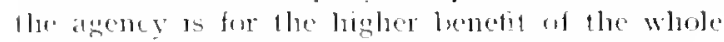
frople, rich and pore moving onwards logether in mutual touch-" all pioneers, always ahead."

In these times, when not only minor seottish

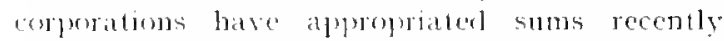

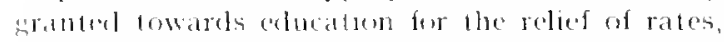
but are in this anly tollowing the example of lelonhurgh, once an educational metreprolis, it will be areally to the eredit of Imntermline if no atcmpt be mate to transfer ritcable burdens to the slouklers of the Trust.

\section{B. Potential Auxiliaries of Trust: the Civic Union}

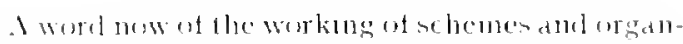

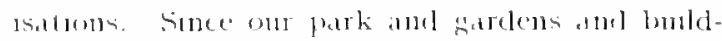
unge ale lout a stage on whels the men and women are the platyers, what is le be their part? vere passive receptivity, whether of immaterial

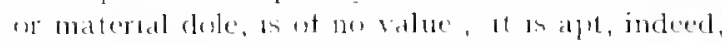

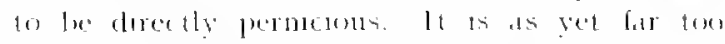

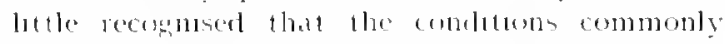

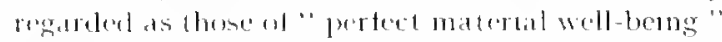

rest, security, wamth, ford, abmelance-are dles the wrante conditions for degeneration far more latn for progress. They are only realosed in nature ly the most degraderl formo of tife, the

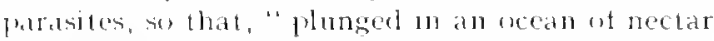
and ambrosa, men would cume not only to muluplo as fast as the parasite but to clegenctate as far."

It is the pereeption of this truth wheh explans

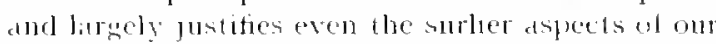

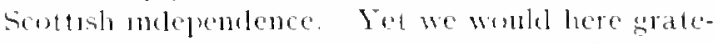
fully acept all that generous and intlative

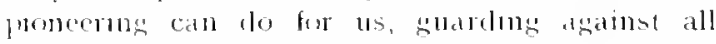
these langers ly ating on the simple reflection that the letter the pionecring the more surely the ment bely maty adrance. But how secure the adrance? Some organisitum is required for this generd atrance, no less than tor the puncering Trust abl its atmiostratum. What form shoulel thes nore popular organisation take?

This is, of eourse, at matter lor the most full and anxums consideration. Fet party 11 is string itself in practice. The varums enture activtles of the tuwn, the institutions of learnugg, like the schools and hbraries, the asson iations atnd societles naturalistle, horticulturat, artiste, musical, and flamalue, are all stirroner 40 renewed activity : and the public are increasmoty learning 10 atp-

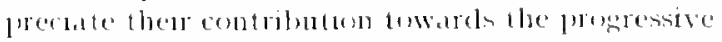
whole.

The nuturalists, the mustems, and the like ate

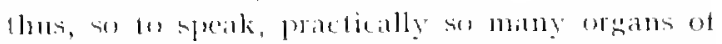

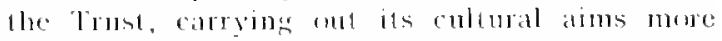
intimately than its central bedy could posstily de. and developing lhers own areanisations, flom the leest members of which, me the natural contere of erents, the Trust will recruit itselt. In the meanfume, maty not the Trust comster the expediency

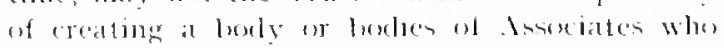

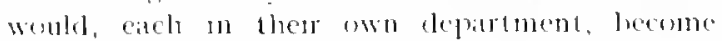
increastugly helpful to the Trust, and who might

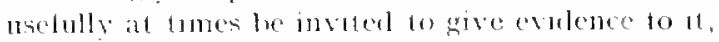
even to join deliberations of its special (inm-

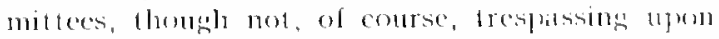
its powers? In this way the Trust would liave at opportunity of judgung potential members betore dection, and its own reerutitment be more thatn ever assured.

Fien without going so far as thas at the outset, this democratic principle is worth dotfusing. Liery 


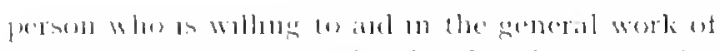

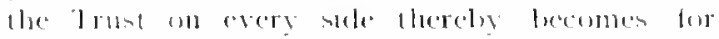
practual purposes as associale. In al very true

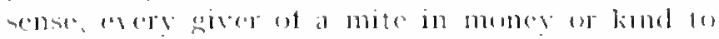

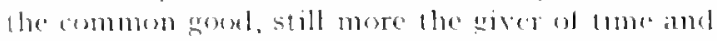
prons, is so falr at true co-rperator watlo the foundere

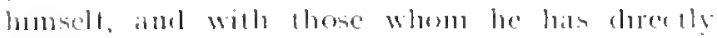
interetated, and is fulfilling and extemelong the

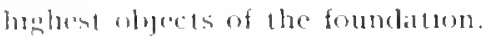

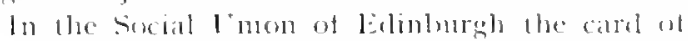
momberabip bears, or nsed lo bear, a design lor the domer's subcriptiom in four columns; not, an ulstial, in one- the first marked, indeed, with the puste, tor a moneve column: the next whth a plin of the elly for gifts of benses or lands; the next will at bale of geruls for gifts in kind; the last with an hourstiss, for what may at once be the castest, yet the moxit precions gift of all-time generustr applicel.

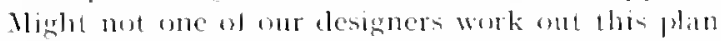
afresh in his own way for the memiership card of these proposed lsinociales?

Such a somp would he worthy of a rel more (listinguished and ambitious title: lley would practloally comstinte a civic lonom. Sinch at l non woulel naturally have many and increasuly bunches, which canmot he fully antrepated liere. The principle, in fact, of immensely uncreanng the culture statt, and, therefore, the culture resources and culture efficiency of the Trust, ly urganising the voluntary labonr, and developing the varied aptitudes of an mereasing number al associates from among the orelinary citizens is no doubl difficult, but is practicahle. Such work, morearer, is not less educative 10 its volumary leaders and its coffeces of all ranks than to its roungest memirets.

If fuller conception of the Civic Lomon maty he stated brecalling the treatment I have slagested for the City Cross, wh its siele temarels catel grealt group of practical interests, with its groul of occupittons, its correspouding seiences. Inother presentment, yet more synthetic in its way, is that alove smogested for the dispustion of the Comncil (iallery ill the Mansion-House; while a lhird is suggested in that interpretation of the four platses of the evolution of the cits set forth mathe periosts chapter. Nt the initial meeting ut the Civic l'nion, with its representatives of all its compoment oxianistlions, led us place on the lable and arclutecturat melel of the city coss, with its graphic reminder of the clams and fluties of the division of lateno withn the cive whole - the natualists with their survers, the physicians with their licalth promamine, the horticulumists, no less ambitions, with lheirs of "Flowers I nlimited," and so onthe educalionst, no doubt, most active of all.

lhese respective organisations, eatch acture in its own field, would meet periodically in eneral commitce or general meeting, and might thereafter brms their resultant ideas betore the linst, which wonlel accept one proposal, reject another,

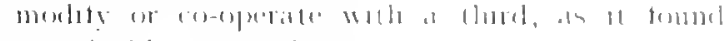
practicable or expreluent.

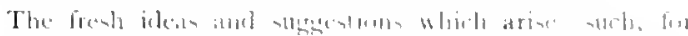

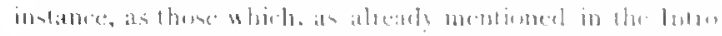

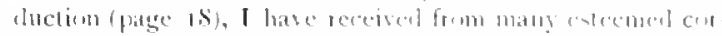

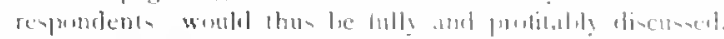

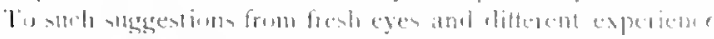

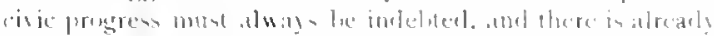

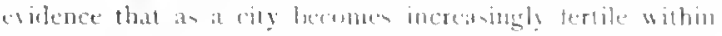

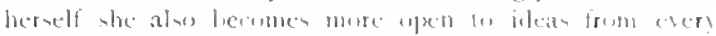

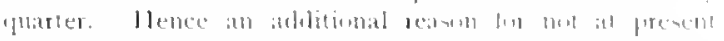

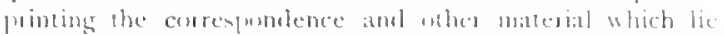

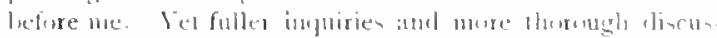

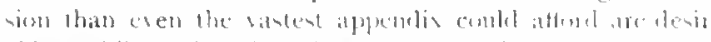
able: while such unity of treatment at the grovent volume

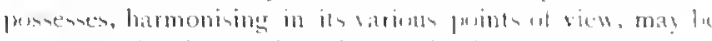
ixest apprecialed apart from further detail.

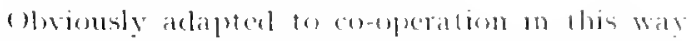

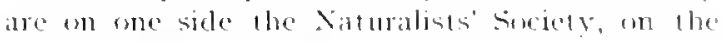

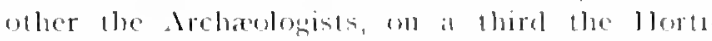
collurists, on a foumb the fhoterraphic sireiely. and ser 011 .

\section{City Improvement Associations}

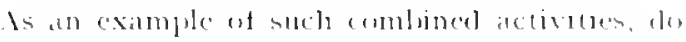
we not require in Donfermbure some andengue le lluse "Improvement soctetes" whoch are now springing up though lown and villaces, of the lnited siates especially, but whols bave been m active work an German cilies, espectally for a enencrition, wath the larsest resulta upon them lowns?

Thus the remathable natural and homere at

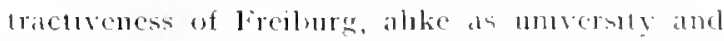
residential city, has been rery ereatly increated

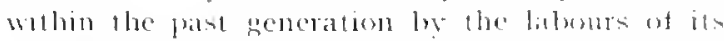
"Verachonerungsteren" ar lmprosement 1sose cration. This, for motance has lait ent probuthly not fess than a hundred miles of pathes, woth the necessary seats. througheme the magnifiecnt ciry forest wheh strefeles from the cathedral plice to the mommtain tops. besules all this, it hat corried om many impromenents in the tomn. as well als exereised a most useful combervalure

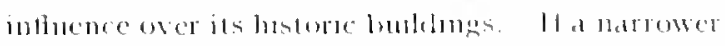

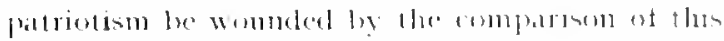

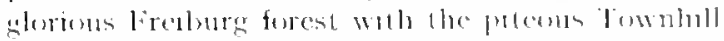
warel, all the more need for a lareser patriestem which arlmits the lessen and applies it

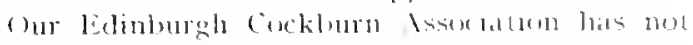
been withont smolar anms, homgh the crutucal rather than the construetive atmosplate of

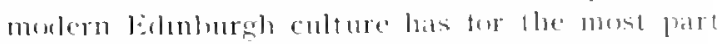
pratralyed its usefulness. (1) lith yeats a more

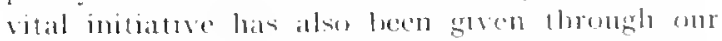

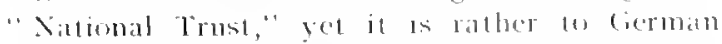
and American examples lant we must stull manly rely tor eximple ane pratetical incenture. That the Dresden fowns lixhilntion of last stmmer 


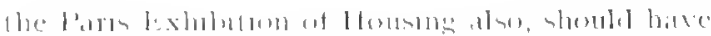

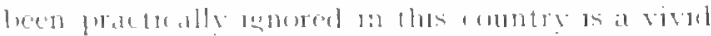

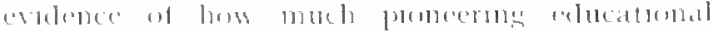

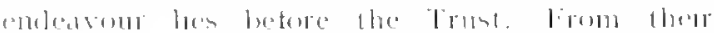

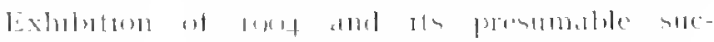

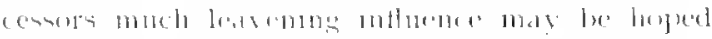
firs

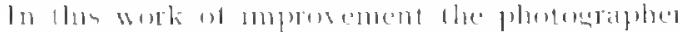

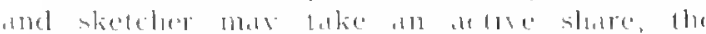

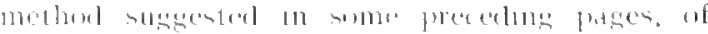

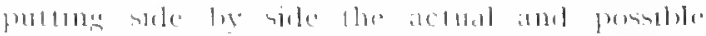

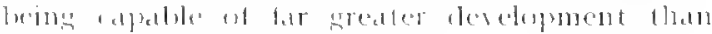
that whate I hate here elven.

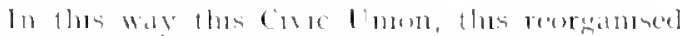

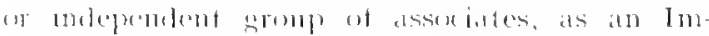

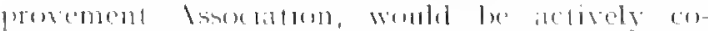

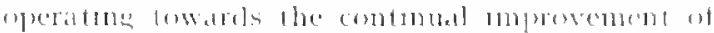

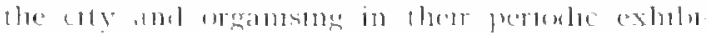

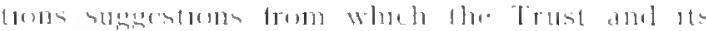

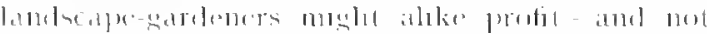

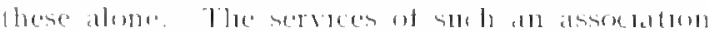

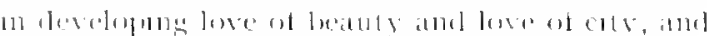

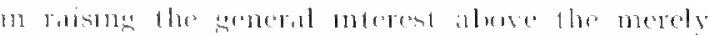

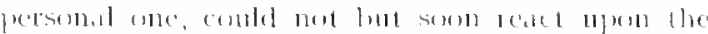

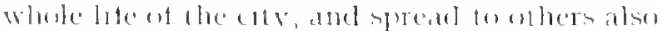

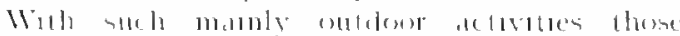

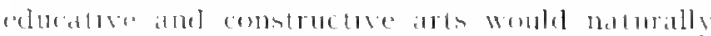

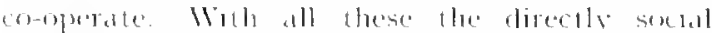

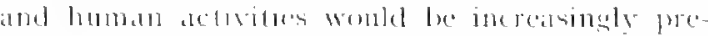

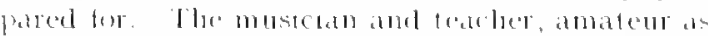
wedl as offecid, hate hore also a limitless freld.

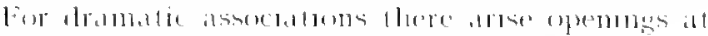

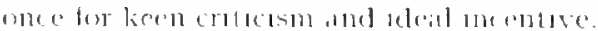

\section{Teachers and Clergy}

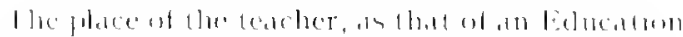

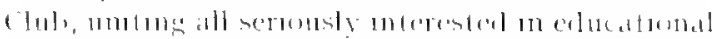

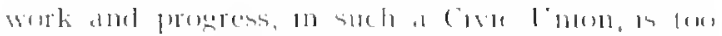

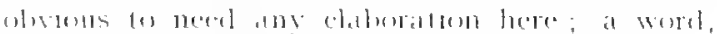

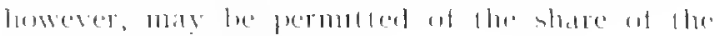
mas kmedred profession.

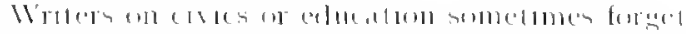

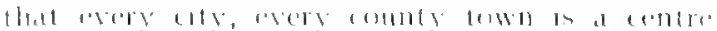

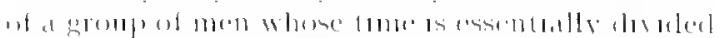

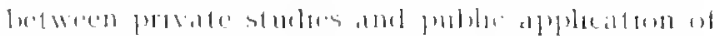

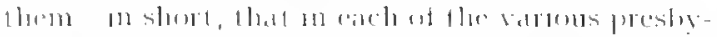

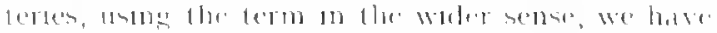

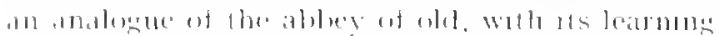

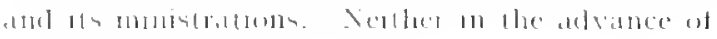

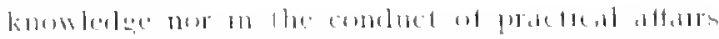

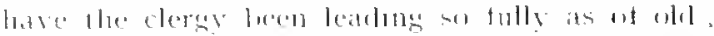

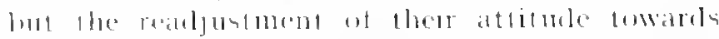

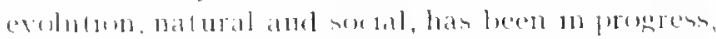

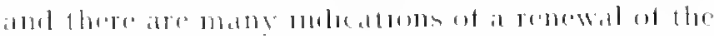

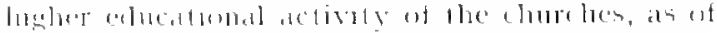

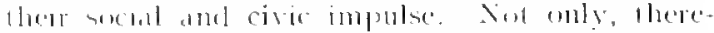
fore, wo the seneral lexty of the chome hess. hut to

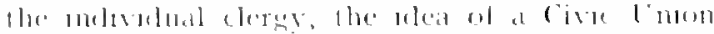

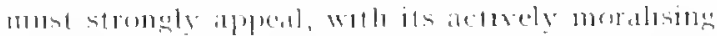

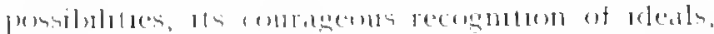

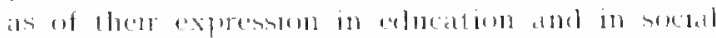
lite. To them of all men, as to therr predecesione of old, such of plea als that for material purticatem woll carry its fullest stomlulism alsos, and them

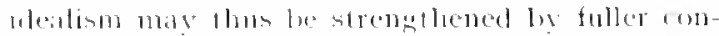

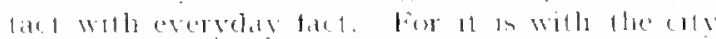

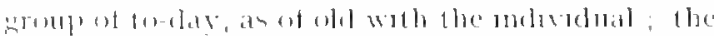

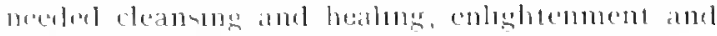
awakemong are all best ablaneed together

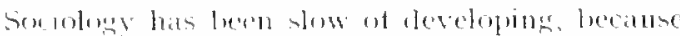

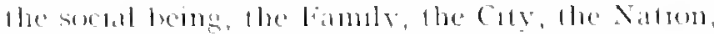
must fust come mto existence, ant even develof

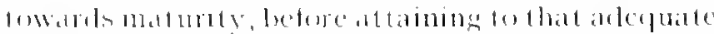

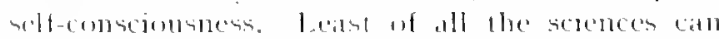

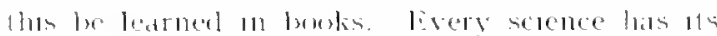

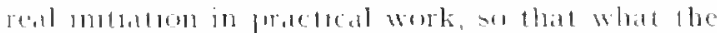
fulwrildory and the warks ire lo the chemust, the hespreal and pratedere to the phosiction, that the

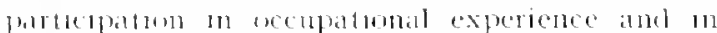

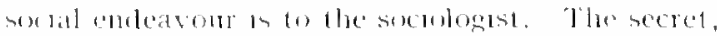

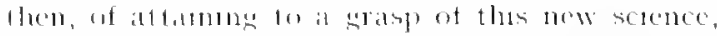

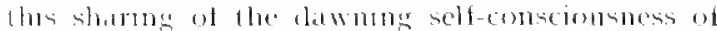

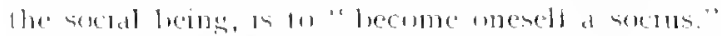
This, at comroce, in loul a recent technted way of

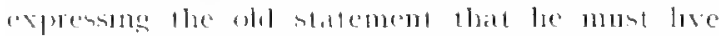
the lefe whe would know the dextrine. The

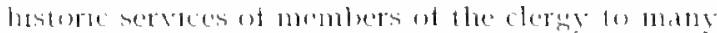

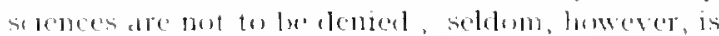

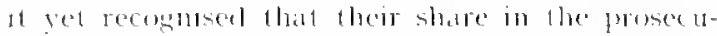

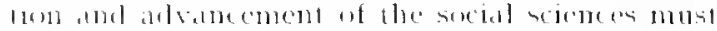
soun become an increastan one, and still mere their

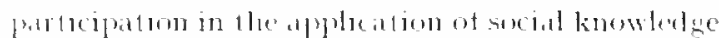

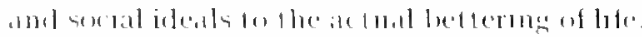

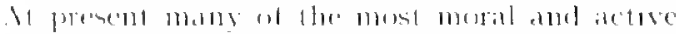

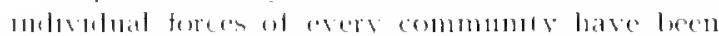

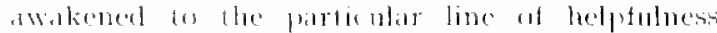

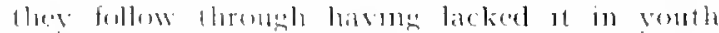

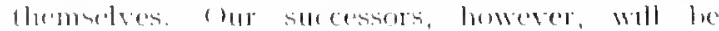

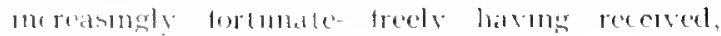
flory maly dhot more treely aive 


\section{FNI 11}

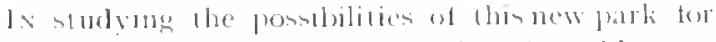

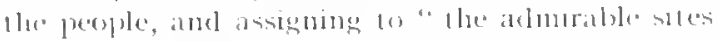

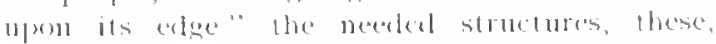

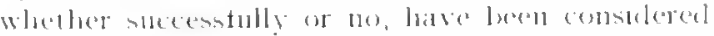

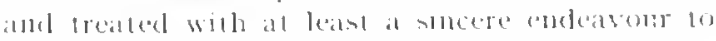

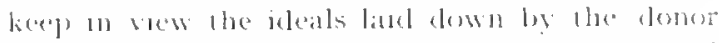
In his deed of trust and accompanying letter, and mambancel in the chatrman's matugural atdeless,

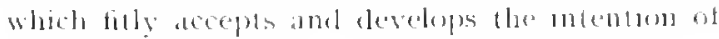
the linust.

Iowerer inatequate, the prenent repunt is lons "s sysematic endeavour w think ont into the neadtul details the general principles latid doun in the three dexuments reterred to-an orsantsed allempll lo ouline a comprehensive treatment a) lle malertal clements of parle and lumldings. and of lheir uses and all this upon a seale suffici"moly large to ocempe the avalable resourees and the activity of years 10 come, vel destere enough to testerand stimulate, not limi, fouthel dexelopment.

I am tully prepared for some ot the precedung propusals benter comsidered at first sight $(x)$ simple, too democratic, for juremile an them purpose, character, and pesint of vew; whle? olluers, again, whll to many at first sight seem for ambitsons, l'topian, since certanly" "seckng to introduce into the lises of the people pleatsures and empoments at present bevend their reach."

It so, I have only one request on make- that is. lhat the three intial douments abese retered to be repead before my proponals atre regectad for

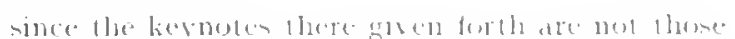

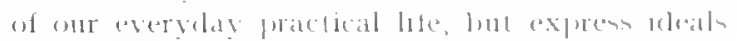

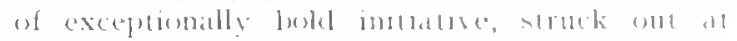
moments of hehent tuskght atme enthusasm, the

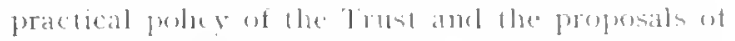
the present report must anm at, must be attuneel to, the correspondmp height. 11 is not simply 111

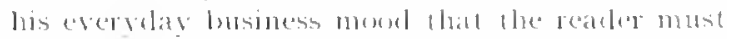
judge at them, laut in las highest moments of bope and resolve. It is for him to surpass the we-matk of these chapters, mon wo julge it trom aserylay aserage, much lesis trom the low watce-

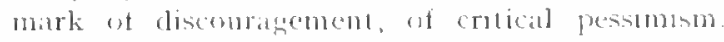
The higher lowe unce laken, lis praelicaloility may become clearer. lin "lasks in homrs of insight willed maty be fhromgh hours of glom tulfilled

The members of thas lows, then, are mo mere buely of ascentors or abmoners. They are, or shoulet be, tor the tme the worlat's foremost councal of seciolugacil and soctal pionecers, and their present deluberatuons upon map, plan at campatinn, and war chest are preliminary at campaign pledged to the molest initiative. Thus viewed, the creation of than latut may be considered as at move ot the highest mportance on that cuve evolutoon of the wotel which claims locaring amul the political chamour of the limes 11 may lue ere long precedence of this. Jlere then. once more in sentland, as in the sturing times of wh, we see opentm before $u$ " actions of a very high nature, leabng w umbolden frathe.
Floruit.

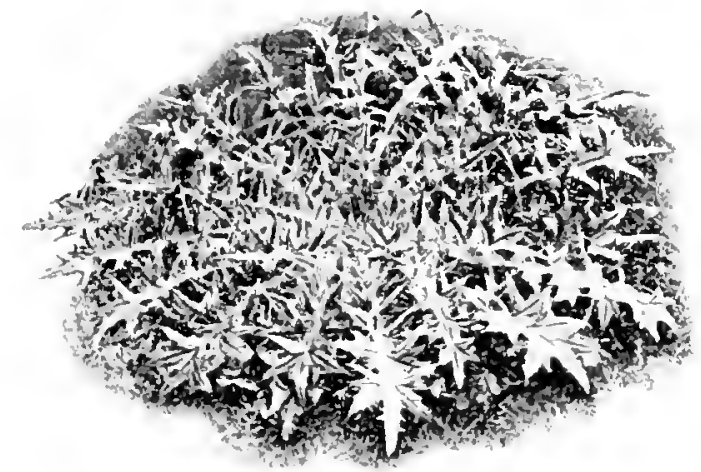





\section{N D EX}

Nolies, $4+210$

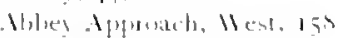

Alber Chomband, 15 "

Alam (Arithlecel), 11 )

Adler, I tr, an ( tulture, 125

litken, 1i. S., 15S, 202

America, leanuracy in, los

American Cisy Imburasment, 212

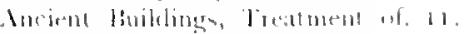
12

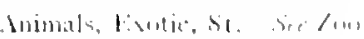

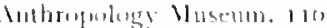

Approbititen, 21

Ayuturium, 7"

M140 1 1.19, 17, 1.5

Arhatury, 20;

Arena, 1si-1si

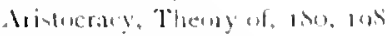

blt and lrints, ots

Arl Appreviation, 104

Arl Cillection, izl

Arl lincalion, 104, 173, 175

A1P Evhibitioum, 170

Int lastitute, mon

Irt Jibrary, 171

Ant llatum, I il

Artuand indle, 1 it

Allist, 205

Ant18)

Mintien, 7n

Pritelilunate, (2)

Basin, $+3,+4,+5$

Bayreull, 1 So, 207

Beasel lomm, si

liee- Alley lianden, 13

Peveridge 11 ell, $9 ;$

liiloliograpty. 41

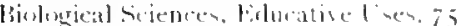

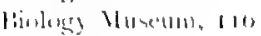

lirul life, in

likatsmilh. 135. 20;

lisulb, Ihalles, at, i.

lindante ciardem, $73 ;$

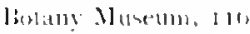

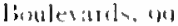

lam ling lireate by

lim Activitian, 122

liranch liluaries, 40

Pridge sitreel, 187,103

Bitge. Tutrul, fo

liridge, West Iake, 51, 50

Bromonhead, 91

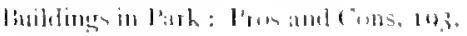
101

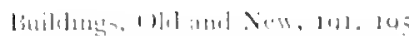

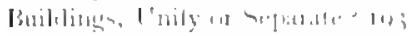

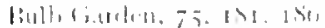

I impmile, 11,4

I

(:incerlus), $20 k$

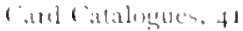

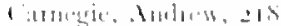

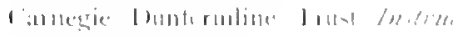
(isin, s

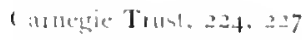

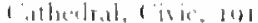

cilluerine (4), (hagel, sor

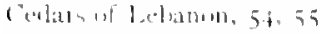

lellic llintur, 145,155

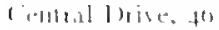

1'0113,1 Instilule, fis

'hirat', $1,32,20$;

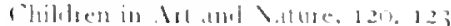

Chilelenv loebl, 102

"likbeñ l'alace. 110

Chilekellis lark, t?

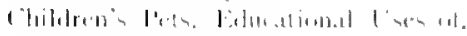
is

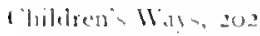

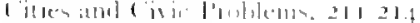

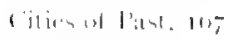

(i1iken. 204

( ilizenthi]", 1;u

till and allectral, 220

ar Closinter, zal

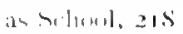

an lim 13,215

(imas, 142, 204

- Imprimentint, 225

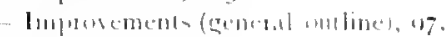

(3), ase

l'erumblits. 220

(is ite Fxlitilitom, 225

kenancente, It)

I'nimn, 222

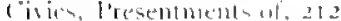

leley. $25 \mathrm{~h}$

Cial, triginal Minhing n, 101

(iol lisul, 2u

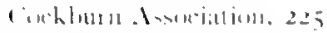

1 inservaturien, 63.6\%

("imtourioges, 9

Cintelation uf sturliten, 150

cincespondents, is

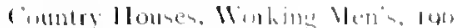

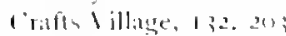

inhet, cte.. of

a ilute lising

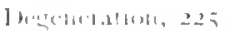

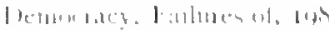

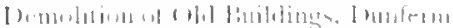
linke, 11, 12, \$

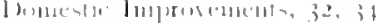

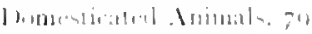

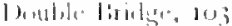

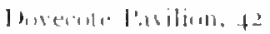

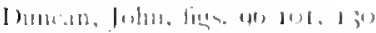

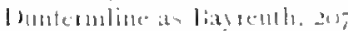

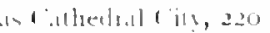

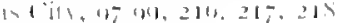

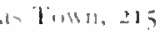

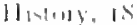

in lesile luelunlu, 201

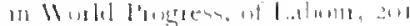

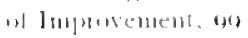

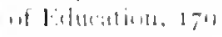

its (indere 210

>ten, (h)

ahem, 1 the 21s

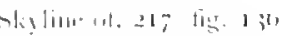

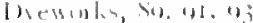

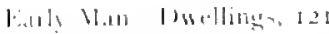

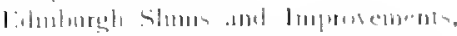
$11,11 \%, 17,80$

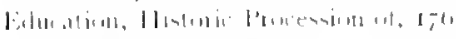

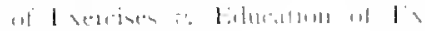
proternce, 132

i, 11 (n)ten, $2(x)$

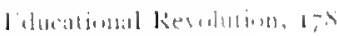
quhome, 17i

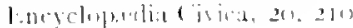

Craphlicix, 210

tynthelina, 210

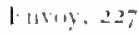

lingenis -216

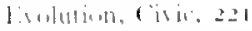

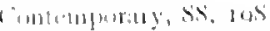

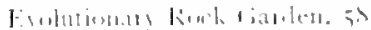

Tumblymets it

l.itt. $21 \mathrm{~s}$

1,11601), 7.1, 10;

lite, lodis ulualum in. 21

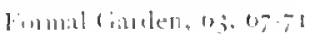

Jintom. (1)1

lintulatins, I 20

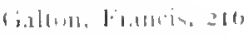

lidulen, $17 .+1$

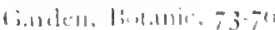




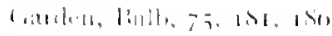
chilinenes, 155 ("its, 188, 94, 1(x), 1ens, 197

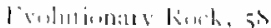

latmel. 0507,7

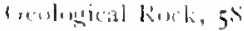

Ilinems, 155

lam, 5

I.1pantence, 1.4. 5-

Iatiril's, $200-0.4$

Minurentyledom, sit

macems", Bis

kinct, 50, 5x, 10?

sheme. 30, 64, sin

siracle, 103

spring, 10 i

St Walgdet So St.

lelance, it

Tial, 125

W.atur. 5h

livile, 7 :

Hinter. [on

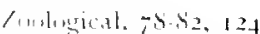

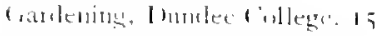

kight unew 11. 75, 7\%

Si!lea, 13,14

liblemas, Vhmmmertial, rot

fieneral Ham, Nine In, 20

Shethe, Cits Inumurementa, a7

surber, firite, ate, 11)

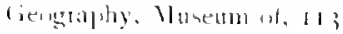

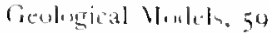

kisch fimblen, 5s

lieulugy, Murnum, I 1n

Cirls Flay-houmen, 42, 121, 203

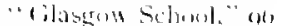

Gitex, Ixlutions al, 22

Gilen, st

ciliste, liteat, 117

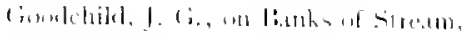
IOI

Giand lintance, dut

bieenhomses, 1,2

Grottu, kustir, los

(ivmuania, 3: 4.4

llinturic linildinges, 204

llistury. Incient. Ith

and . Ir. 130,104

lonilinge 16;

lighlenth lintury, 16u

1. Shiloition, 153

Gitulit11, 155

in lousteruline, 14 ;

in Future, tots

in ficotluml, 14;

[nutitule in, Iti

Vetli, ial, 1 f', 151

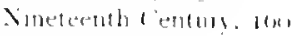

1, Citich, 211

l'alatice, 203 .

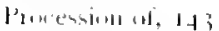

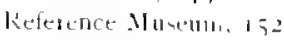

kicnajisaller. Irus

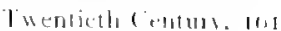

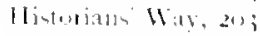

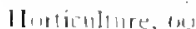

11 minter, it

llursfall, T. 1 , is

llomine llane, 103

IJoning, Ilealihy, 217

lmurnemenis, i1, 32, 35

Litertate of, 35.41

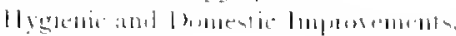
i2, it

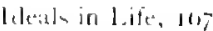

lonagination, I0

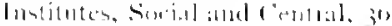

luna, 20 is

Irin lidadell. $5 \%$

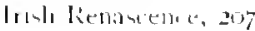

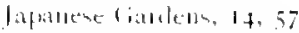

Talkatese Teallanlac, 50

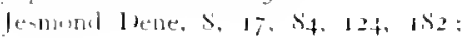
lige is

kerr, 11. 1.. 10

lienwick. I it

Kitchen, 32

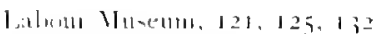
it 111034,203

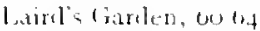

latie, East, 24, 107: Hish. 14-10

lake, simall, +5

l,emling Manemman, 171

l, lli, ar , to, +1

Brancl, to

lite, Sitges $n$, 201

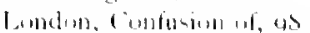

lancer lowall, 25: ling. 20, 21

IInne, 104

Jiance bente. 105

bun-mintlluse, 52, is

Alleralimb, I07, 195

Improvement, 104

Utilisatum, fou-200

Wan, T. K., 35, 212

Mill I bene, Io?

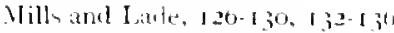

lill in llistuls, 12S, 130

Jethud and l'oint of liew. Is

Jorle of Finecution, I7

Womantery streed and l'lat s." I 2m, I in

Widening of, $135,1,31513$

bunsonvledund tarden, it

Nunicipal liublinge, 191

Wumicipalitien at Mork, 212

Vuseuma, 100

Anthropolige. I11

Irtu, Ios

lintians, 110

Biislegy, 110

leograply, i1;

(iestogy , 110

I Iistury (wee)

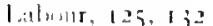

Husemme, lending, Iz

Mnkel, 173

Nature, 100

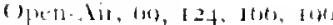

I'cllh, 112, 1111

lunic, 204

ami 1)1.1mat, 192

|1:all. 184. 157.112

Xittunal Truat, 225

Niture l'atlace in liemelal, Ion-113

in kixeanim, 114-11

in W: orking, 11S. 120

N.tuldint" theiels, 5s, 115

Way, 202

Xival liale, 47

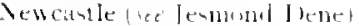

Nen 1 hantermline, os

Woth bullatice. i2

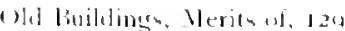

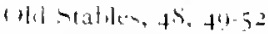

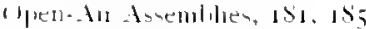

liduation, 177

(i) mulsium, 4

- Vlavellm, 64, 124, 100, lox

Vureum diardering, oy

Hunemm, Mrdel, 125

l'eldumances, ISo

Thealxe, 45, 142

- Tientmens,

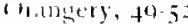

incluarl, ol

cutlowh Timer, 2us, 200

l'allichs, S'

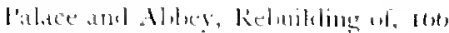
lialitec loenc, 105

l'alace lianden, $07-7$

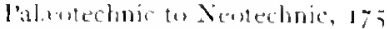

l'anoraman, $11+-110$

J'aris, Uld and Xen, 11

l'ath a l'athedral it the l'enple, at

lask livension Junthwark, t;

- Sisuthands, o7, 95

Sinuthern, 77

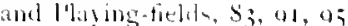

l'athw:4y, 22, 98

l'anteur, 20 ;

latilinn, kefientument, f's

Wrmenis, 44

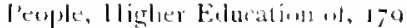

l'ermpecticen, lieneral, 202, 200, 207, 220 ; ligr, 131, 132, 13

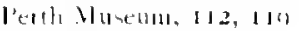

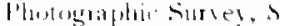

l'isulda, 37

l'inetum, ; ;

lolan of buildingess s

fieneral. 20, tigs. 13

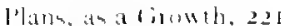

l'lay laschers, +3

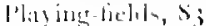

l'olitician, 215

lende and lakech, fol 


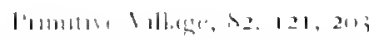

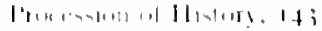

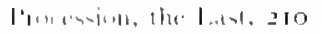

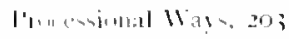

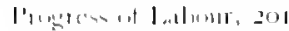

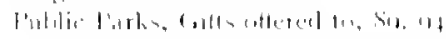

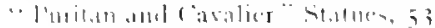

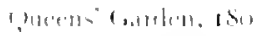

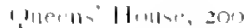

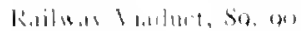
keforoment Jasition. fo K⿺⿻上丨子, 132

Relief Iorlet, lisen if, is

lieplor, 1 10

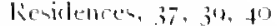

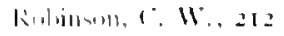

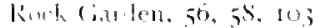

lismatrec. 17, 35

liwhin, 1 it, 203

Silced 115y, 202, 203

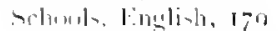
rindera, jo, nt. So

sciemee on detion, 200

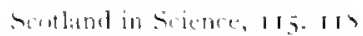

lmportance of, $14 ; 154$

Genllish Character, 222

Seltemenl. 36. 32. 39

Sharle Ciarten, 103

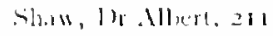

Shank, 1i. Jernuml, 217

Siles al Enildinger 10, 105

simitly in llintus, 130

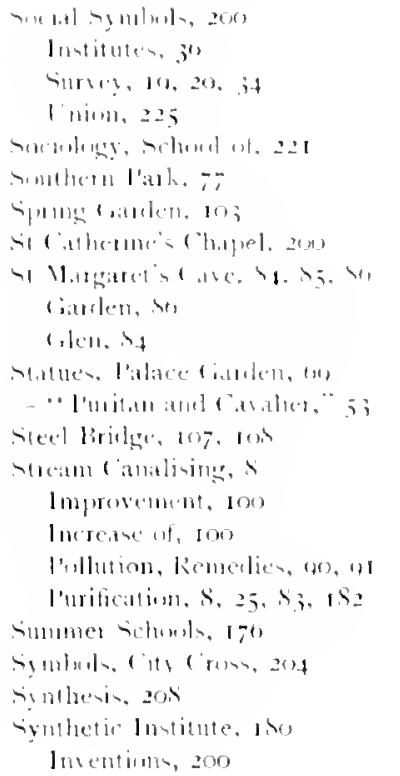

Thelder, 2at

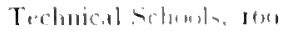

lemativerimats, nz

Tembere liardentme

Thente, topen-111, 45, 1112

lhinking-llumes, 200

Timught Mas m, 20k

"Iixm," Str, So

linser lkene, 100, 102

Tumer llill. 12

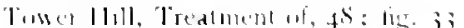

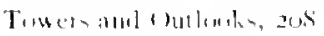

Timnlach, of

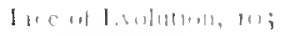

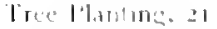

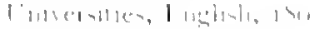

1 anthe a-1

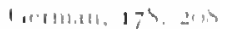

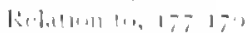

Kevilutim 11, 2.

$4111,1,170,141,2,7,21>$

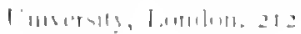

(1.111:11)(1)! in, ir, in

$11,11,160 \times 11,11,115$

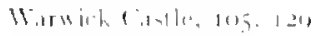

11:

Materey Valkel, I I

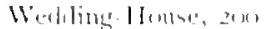

Will, (i, I1, 211

Ment bintiance, fle, ti

Ment Iathe, 55

Milel lianlerr, 7

Minter rindells. Ion

Mimutul. 205

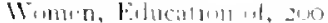
and social lastitulen in statlum (1), 104, 2101

Teacheras 201

$11+11,11 \%, 211$

Mimen - las iliom, ts

Mimea: Nlly, wh

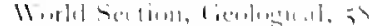

Innth- i1 - 11.11-20;

$1(1,1,24,7)$

/onlrugeal rimblen, 124

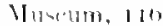




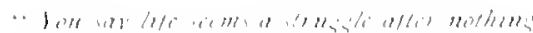

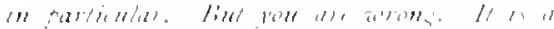

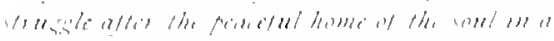

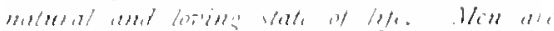

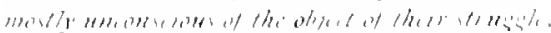

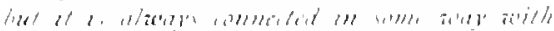
hil..

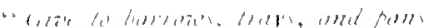

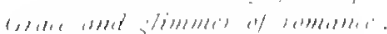

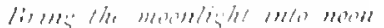

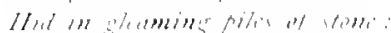
1) the ritgit feriel blet

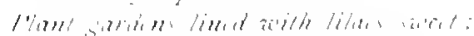

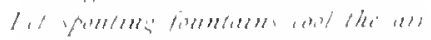

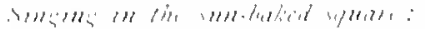

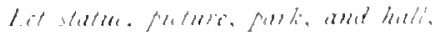

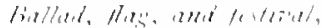

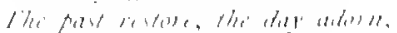

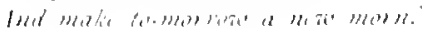

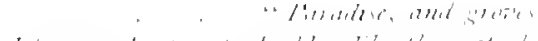

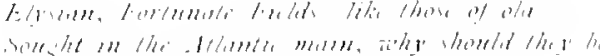
1 hiverel onle al tefertid thens'.

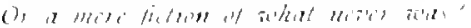

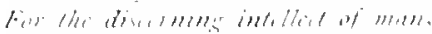

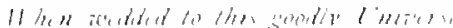

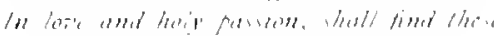

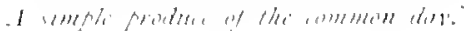

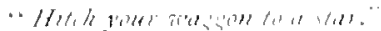




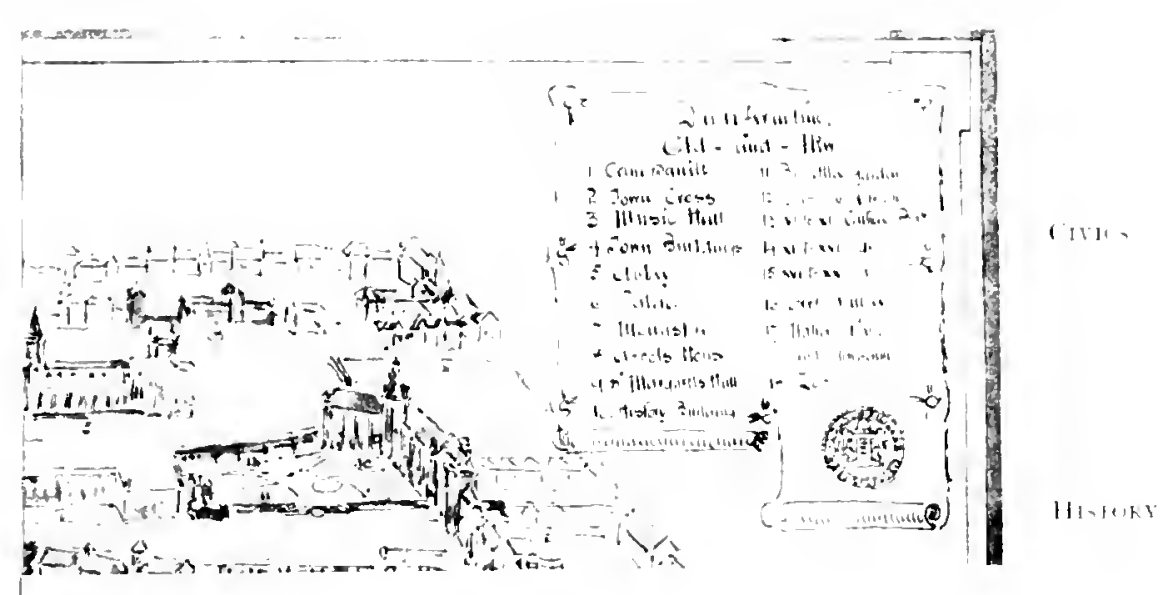




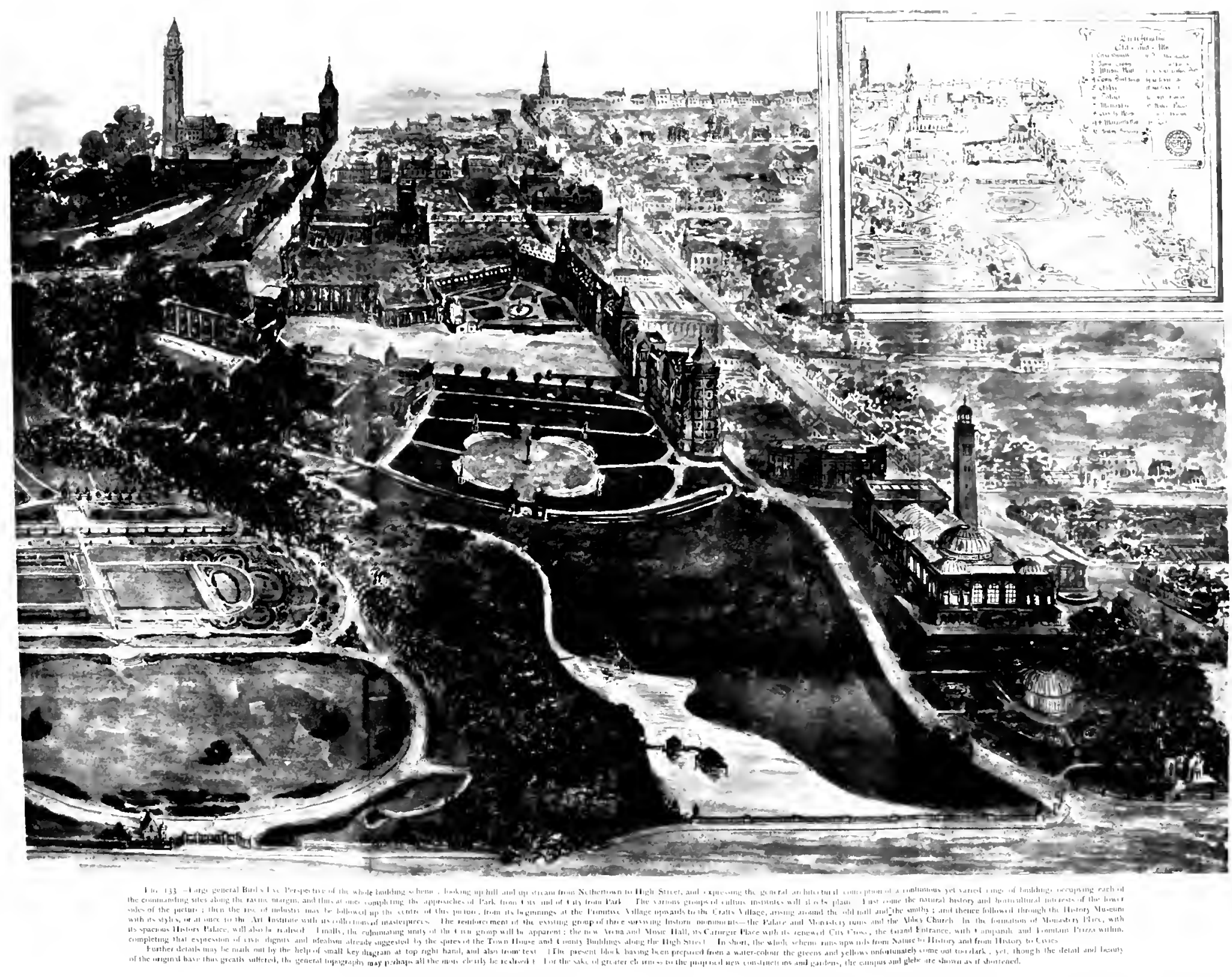





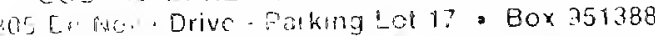

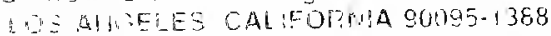

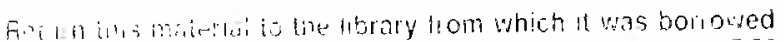

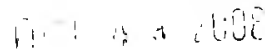




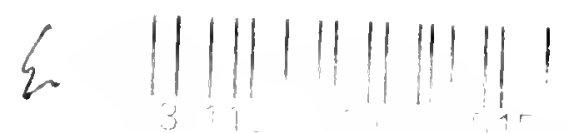

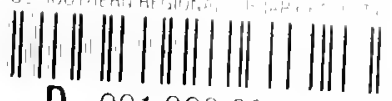
D 001068384 
;alifornia agional

acility 